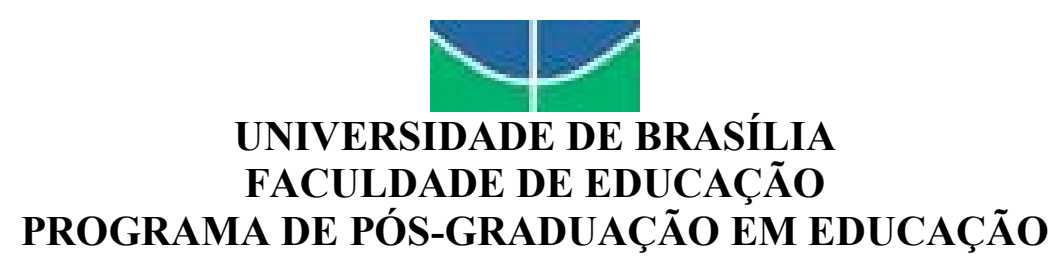

MICHELE MIRANDA DE AZEVEDO

A ORIENTAÇÃO EDUCACIONAL NAS REDES DE ENSINO ESTADUAIS PÚBLICAS DO BRASIL: concursos e funções

Brasília 
MICHELE MIRANDA DE AZEVEDO

\section{A ORIENTAÇÃO EDUCACIONAL NAS REDES DE ENSINO ESTADUAIS PÚBLICAS DO BRASIL: concursos e funções}

Dissertação apresentada ao Programa de Pós-Graduação em Educação da Universidade de Brasília, como exigência parcial para obtenção do Título de Mestre em Educação, na linha de pesquisa Profissão Docente, Currículo e Avaliação, sob orientação da Prof. ${ }^{a}$ Dr $^{\mathrm{a}}$ Shirleide Pereira da Silva Cruz.

\section{Brasília}


MICHELE MIRANDA DE AZEVEDO

\title{
A ORIENTAÇÃO EDUCACIONAL NAS REDES DE ENSINO ESTADUAIS PÚBLICAS DO BRASIL: concursos e funções
}

Defesa de Dissertação de Mestrado apresentada à seguinte Banca Examinadora

Brasília, 15 de abril de 2016.

Prof. ${ }^{\mathrm{a}}$ Dr $^{\mathrm{a}}$. Shirleide Pereira da Silva Cruz - Orientadora Faculdade de Educação - UnB

\author{
Prof. $^{\mathrm{a}}$ Dr$^{\mathrm{a}}$ Ranilce Mascarenhas Guimaraes-Iosif - Membro Externo \\ Universidade Católica de Brasília
}

Prof. ${ }^{a}$. Dra . Kátia Augusta Curado Pinheiro Cordeiro da Silva - Membro Interno Faculdade de Educação - UnB 
Às vezes eu falo com a vida Às vezes é ela quem diz Qual a paz que eu não quero conservar pra tentar ser feliz?

Marcelo Yuka

Proletarier aller Länder, vereinigt euch! (Proletários de todos os países, uni-vos!)

Karl Marx e Friedrich Engels. 


\section{RESUMO}

A pesquisa analisa e discute as relações e contradições entre a legislação nacional vigente referente ao Serviço de Orientação Educacional e as demandas dos sistemas de ensino estaduais públicos do Brasil em seus editais de concurso. Para alcançar esse objetivo geral de pesquisa, outros três objetivos específicos foram traçados: identificar e analisar a legislação nacional vigente a respeito da Orientação Educacional no Brasil; analisar e discutir as bases e perspectivas epistemológicas para a Orientação Educacional; e identificar e analisar as demandas dos sistemas de ensino estaduais públicos referente a Orientação Educacional contidas nos editais de concurso que preveem o Serviço de Orientação Educacional. A pesquisa seguiu a ontologia materialista-histórica-dialética enfatizando assim a dimensão do movimento histórico dos processos sociais, que constituem o objeto a ser estudado. No que se refere aos procedimentos de pesquisa, foi desenvolvida pesquisa bibliográfica e documental. Os documentos legais analisados serão: Lei $\mathrm{n}^{0}$ 5.564/68, Decreto $n^{\circ}$ 72.846/73; LDB 9394/96; e Resolução CNE/CP n ${ }^{\circ} 1$ de 15 de maio de 2006; editais de concurso público para preenchimento de cargo que prevê serviços de orientação educacional, tendo como recorte temporal e geográfico editais dos estados da federação que abriram concurso posteriores ao ano de 2010. Os eixos da pesquisa são: Fundamentação legal, Perspectivas epistemológicas para Orientação Educacional e Demandas das redes estaduais. A pesquisa contribui para o campo da Orientação Educacional tanto nos aspectos exploratórios da pesquisa quanto nos aspectos conceituais da área. Concluiu que as redes estaduais demandam pela orientação educacional considerando, em sua maioria, a atividade inerente ao Pedagogo. A maior contradição entre a legislação vigente e as demandas dos sistemas estaduais consiste no fato de que a orientação educacional não é privativa a uma profissão.

Palavras-chave: Orientação Educacional, Legislação, Rede Pública de ensino. 


\begin{abstract}
The research analyzes and discusses the relations and contradictions between existing national legislation concerning the Educational Guidance Service and the demands of the public state education systems of Brazil in their tender notices. To achieve this overall objective research, three other specific objectives were set: to identify and analyze existing national legislation regarding the Educational Guidance in Brazil; analyze and discuss the basis and epistemological perspectives for Educational Guidance; and identify and analyze the demands of the public state education systems related to Educational Guidance contained in tender notices which provide the Educational Guidance Service. The research followed the historical-materialistdialectical ontology thus emphasizing the size of the historical movement of social processes that constitute the object being studied. With regard to research procedures, bibliographic and documentary research was conducted. Analyzed legal documents are: Law No. 5,564 / 68, Decree No. 72,846 / 73; LDB 9394/96; and CNE / CP No. 1 of May 15, 2006; tender notices for job of filling that provides educational guidance services, with the temporal and geographic cut edicts of the federation states that opened later contest to 2010. The axes of research are: Legal Grounds, epistemological perspective for Educational Guidance and demands of the state networks. The research contributes to the field of Educational Guidance in both the exploratory aspects of research as the conceptual aspects of the area. It concluded that the state networks demand for educational guidance considering, in most cases, the activity inherent in the pedagogue. The greatest contradiction between the legislation and the demands of state systems is the fact that the educational guidance is not private to a profession.
\end{abstract}

Keywords: Educational Guidance, Legislation, Public Network education. 


\section{LISTA DE QUADROS}

Quadro 1 - Modulação dos Orientadores Educacionais na SEEDF.................................11

Quadro 2 - Defasagem do número de Orientadores Educacionais na SEEDF.............. 12

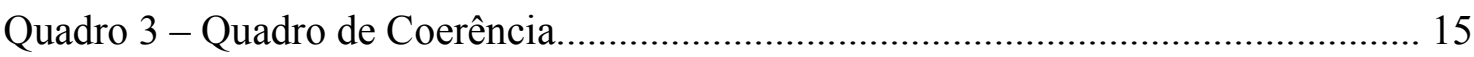

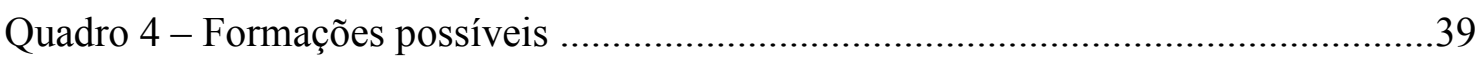

Quadro 5 - Cargos encontrados nos Editais dos sistemas estaduais de educação 2010-

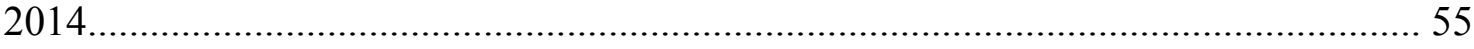

Quadro 6 - Formações exigidas nos editais .................................................................. 56

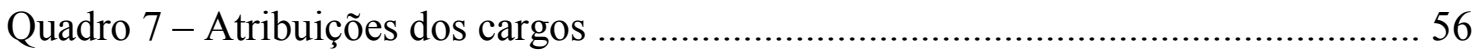

Quadro 8 - Ações previstas pelos editais referentes a Orientação Educacional ....................... 57 


\section{LISTA DE SIGLAS E ABREVIATURAS}

$\begin{array}{ll}\text { ABE } & \text { - Associação Brasileira de Educação } \\ \text { ANFOPE } & \text { - Associação Nacional pela Formação dos Profissionais da Educação } \\ \text { BDBT } & \text { - Biblioteca Digital Brasileira de Teses e Dissertações } \\ \text { CAPES } & \text { - Coordenação de Aperfeiçoamento de Pessoal de Nível Superior } \\ \text { CFE } & \text { - Conselho Federal de Educação } \\ \text { CFESP } & \text { - Centro Ferroviário de Ensino e Seleção Profissional } \\ \text { CNE } & \text { - Conselho Nacional de Educação } \\ \text { CNPq } & \text { - Conselho Nacional de Desenvolvimento Científico e Tecnológico } \\ \text { CONARCFE } & \text { - Comissão Nacional pela Reformulação dos Cursos de Formação de } \\ \text { DCNs } & \text { Educadores } \\ \text { IDORT } & \text { - Diretrizes Curriculares Nacionais } \\ \text { LDBEN } & \text { - Instituto de Organização Racional do Trabalho } \\ \text { OE } & \text { - Orientação Educacional } \\ \text { Or.E } & \text { - Orientador Educacional } \\ \text { PUC } & \text { - Pontífice Universidade Católica } \\ \text { Res. } & \text { - Resolução } \\ \text { SEEDF } & \text { - Secretaria de Estado de Educação do Distrito Federal } \\ \text { SESP } & \text { - Serviço de Ensino e Seleção Profissional } \\ \text { SPA } & \text { - Serviço de Psicologia Aplicada }\end{array}$


SUMÁRIO

INTRODUÇÃO

CAPÍTULO 1- ORIENTAÇÃO EDUCACIONAL NO BRASIL

CAPÍTULO 2- PERSPECTIVAS EPISTEMOLÓGICAS PARA ORIENTAÇÃO EDUCACIONAL: análise e proposições 43

2.1 TRABALHO DE ORIENTAÇÃO EDUCACIONAL, ORIENTAÇÃO EDUCACIONAL E ORIENTADOR EDUCACIONAL: algumas diferenciações. .43

2.2 A BASE DOCENTE NA FORMAÇÃO EM ORIENTAÇÃO EDUCACIONAL: alguns apontamentos .48

2.3 ORIENTAÇÃO EDUCACIONAL NA PERSPECTIVA DA PEDAgOGIA HISTÓRICO-CRÍTICA. .52

CAPítulo 3- ORIENTAÇÃo EDUCACIONAL NAS REDES PÚbliCAS ESTADUAIS DE ENSINO NO BRASIL 


\section{INTRODUÇÃO}

Esta pesquisa foi realizada no curso de Mestrado em Educação do programa de pós-graduação da Faculdade de Educação da Universidade de Brasília, dentro da linha de pesquisa "Profissão Docente, Currículo e Avaliação".

Com a justificativa de que a Orientação Educacional é uma área da Educação, inserida nas dimensões sociais, culturais, políticas e econômicas onde ela ocorre, “[...] deve buscar os subsídios, a fundamentação teórica específica de sua área, bem como os conhecimentos necessários para o entendimento desse novo tempo que vivemos na sociedade e, portanto, na própria Educação." (GRINSPUN, 2011, p. 37).

Acredita-se que a importância da Orientação Educacional se faz quando ela está investida de uma prática-social fundamentada solidamente em uma formação teórico-crítica. O campo de atuação desse profissional é o cotidiano escolar e engloba todas as dimensões nele presentes (sociais, culturais, políticas, econômicas) e todas as relações entre seus atores (alunos, professores, demais profissionais, família, comunidade e sociedade).

Segundo Pascoal (2008) a Orientação Educacional no Brasil está presente na rede pública escolar estadual de treze dos vinte e seis estados brasileiros, mais o Distrito Federal. Contudo, o estado da arte especificamente na temática da Orientação Educacional sofre com a escassez de pesquisas.

Em busca balizada pelas palavras chave: Orientação Educacional, Orientador Educacional, foram encontradas na Biblioteca Digital Brasileira de Teses e Dissertações - BDBT apenas três produções dentro da temática Orientação Educacional, elaboradas nos últimos cinco anos (2011-2016). Sendo estas: "Interrogações e exclamações no cotidiano escolar da orientação educacional" defendida por Arlete Steil Kumm em 2009, na Universidade do Vale do Itajaí; “A práxis do serviço de orientação educacional revisitada sob a perspectiva da teoria sistêmica e do desenvolvimento moral" defendida por Anita Maria Lins da Silva, em 2012, como Trabalho Final de Mestrado Profissional para obtenção do grau de Mestre em Teologia na Escola Superior de Teologia, e; "A contribuição do orientador educacional na política da educação um estudo na rede municipal de ensino de Pelotas 
- RS" defendida por Margarete Hirdes Antunes na Universidade Católica de Pelotas, também em 2009. Em consulta ao Banco de Teses da Coordenação de Aperfeiçoamento de Pessoal de Nível Superior - CAPES, encontrou-se apenas uma pesquisa realizada nos últimos cinco anos, já publicada também na BDBT.

Quanto aos artigos e aos periódicos, encontra-se uma publicação nos últimos cinco anos dentro da temática: "O orientador educacional no Brasil" publicado na Educação em Revista de Belo Horizonte no ano de 2008, encontrado na base de dados da Scielo.

No repositório da UnB, universidade onde se produziu esta pesquisa, encontrase uma única publicação nos últimos cinco anos sobre a temática, uma dissertação de mestrado defendida no ano de 2013, denominada "Orientação educacional na atualidade: possibilidades de atuação", defendida pela pesquisadora Thaiane Ferreira, "teve como foco a prática dos orientadores educacionais, inserida no Serviço de Orientação Educacional em escolas públicas[...] (FERREIRA, 2013, p.6).

A falta de pesquisas na área trouxe inquietações que despertaram ainda mais o interesse pelo tema. Esse interesse é oriundo da experiência da pesquisadora que é Orientadora Educacional na rede pública de ensino do Distrito Federal desde 2008. Seu percurso formativo começa no curso de Pedagogia da Universidade de Brasília, que na época, antes das Diretrizes Curriculares Nacionais do Curso de Pedagogia (BRASIL,2006) oferecia-o com a habilitação em Orientação Educacional, entre outras habilitações.

O concurso pelo qual se deu o ingresso da pesquisadora na Secretaria de Estado de Educação do Distrito Federal - SEEDF como Orientadora Educacional, aconteceu em 2004, mas os aprovados somente tomaram posse, parte em 2007, parte em 2008, já próximo à data final de validade do concurso.

Esse dado parece indicar que a Orientação Educacional na escola pública do DF não se apresentou como uma prioridade, somada a outras questões que não entraram numa linha de priorização nos últimos governos do DF para a educação pública. Questões que não serão aqui tratadas, mas que são o cenário para se problematizar a orientação educacional nos diferentes sistemas de ensino estaduais no país. Além disso, o último concurso para Orientador Educacional da SEEDF havia ocorrido aproximadamente dez anos antes. E um novo concurso ocorreu dez anos 
depois, em 2014, sendo os aprovados ainda não nomeados ${ }^{1}$. Contudo, mostrou-se um grande avanço em comparação à década anterior como espaço de trabalho para a orientação educacional.

A realização muito esparsada de concursos tendeu a não suprir a carência das escolas. Por exemplo, com base nos dados apresentados no sítio oficial da SEEDF, identifica-se que do número total de escolas da educação básica da rede pública estadual do DF, e o número total de alunos matriculados, obtém-se uma média simples que representa a proporção de alunos por escola. Mesmo que esta proporção seja por estimativa, pois se deve considerar que cada escola atende diferentes níveis e modalidades, em diferentes turnos, com diferentes propostas, o que influencia em seu número matrículas. E a partir do número de Orientadores Educacionais ativos, não aposentados, e o número total de escolas, também foi feita uma média simples para representar a proporção de orientadores por escola. O que se apresenta, comparado ao número previsto na Portaria $n^{\circ} 32 / 2013^{2}$, que trata da modulação por escola do número de orientadores educacionais, observa-se, então, uma defasagem de pelo menos $50 \%$ no número de Orientadores na rede. Nas tabelas a seguir ${ }^{3}$, apresentamos de forma resumida esse percentual discutido e a proeminência de defasagem de orientadores na rede do DF.

\section{Quadro 1 - Modulação dos Orientadores Educacionais na SEEDF}

\begin{tabular}{|l|l|}
\hline \multicolumn{2}{|c|}{ Modulação dos Orientadores Educacionais na SEEDF } \\
\hline De 100 a 499 alunos matriculados & 1 Orientador Educacional \\
\hline De 500 a 999 alunos matriculados & 2 Orientadores Educacionais \\
\hline Acima de 1000 alunos matriculados & 3 Orientadores Educacionais \\
\hline
\end{tabular}

\footnotetext{
${ }^{1}$ Existe um movimento dos candidatos aprovados neste concurso que luta por suas nomeações. O movimento realiza reuniões e se articula politicamente estando presente em audiências junto a Câmara dos Deputados Distrital e a negociação com o Governo do Distrito Federal.

${ }^{2}$ Dispõe sobre as atribuições, os critérios para modulação e distribuição dos Especialistas de Educação - Orientador Educacional, da Carreira Magistério Público do Distrito Federal em exercício nas unidades escolares da rede pública de ensino do Distrito Federal.

3 Elaboradas a partir do censo escolar de 2013 encontrado no sítio virtual da SEEDF, o www.se.df.gov.br, e da modulação prevista na Portaria nº 32, de 4 de fevereiro de 2013.
} 


\section{Quadro 2 - Defasagem do número de Orientadores Educacionais na SEEDF}

\begin{tabular}{|c|c|c|c|c|c|}
\hline \multicolumn{6}{|c|}{$\begin{array}{l}\text { Exemplificação da defasagem do quadro d } \\
\text { SEEDF }\end{array}$} \\
\hline Escolas & Alunos & Alunos por escola & OEs & OEs / escola & $\begin{array}{l}\text { OEs / escola na } \\
\text { modulação }\end{array}$ \\
\hline 651 & 471.724 & 724,61 & 748 & 1,15 & 2 \\
\hline
\end{tabular}

Quando tomamos posse e fomos designada para uma escola pública, sentimos os reflexos dessa defasagem. Vivenciamos uma série de dificuldades na atuação profissional, ora por parte das condições de trabalho, ora devido a uma formação que não atendia mais às demandas da escola. Nessas condições dadas às necessidades concretas da escola, sentimos que, pela formação fragmentada obtida pelo modelo das habilitações que corroborava com uma divisão social do trabalho no faltava alguns elementos para enxergamos o trabalho da orientação educacional como um todo a ser desenvolvido na escola. Nesse sentido, buscamos alternativas para resistir e executar um trabalho que desconfigurasse a ideia de um Orientador estanque do processo educativo docente.

Foi aproximando-se do trabalho dos professores que buscamos nos aproximar de uma Orientação Educacional que permitisse um olhar ampliado para a escola, de modo que as tensões, as relações e contradições foram aparecendo e tornando possível uma práxis que ainda está em construção.

A partir disso, uma série de inquietações fez parte do nosso trabalho. E muitas delas não encontraram na literatura algo que as satisfizesse devido à precariedade das informações atualizadas tanto em termos de quantidade, quanto em termos de qualidade.

Onde estão os Orientadores Educacionais? Nas redes públicas ou privadas de ensino? Na educação básica? Ou no ensino superior também? Quais os espaços de atuação do Orientador Educacional? A função de orientação educacional é inerente ao trabalho pedagógico na escola? O que diz a legislação? Qual a carreira do Orientador? 
O orientador educacional é o único que pode atuar na função de orientação educacional? Qual a demanda de atuação desse profissional nos sistemas de ensino?

Dada precariedade já citada das informações, julgou-se prudente primeiro, eleger uma questão central para iniciar nossa investigação: Qual a demanda de atuação para a Orientação Educacional nos sistemas de ensino?

Essa demanda pode refletir as problemáticas quanto à Orientação Educacional, em termos legais e epistemológicos. Em termos legais, o aspecto da formação do profissional para exercício do serviço nas escolas é controverso, e permite que a orientação seja exercida a partir de bases bem diversas.

A regulamentação da profissão é prevista pelo Decreto $\mathrm{n}^{\mathrm{o}} 72.846 / 73$ que regulamenta a Lei $n^{0} 5.564 / 68$, que prevê sobre o exercício da profissão de orientador educacional (BRASIL, 1968). O decreto autoriza o exercício àqueles que portarem diploma ou certificação em Orientação Educacional, ou seja, podemos inferir que hoje, estes seriam: bacharéis e ou/licenciados habilitados ou pós-graduados na área. A Lei de Diretrizes e Bases da Educação Nacional (LDBEN), Lei 9394/96 (BRASIL, 1996) prevê para o exercício da Orientação a formação a partir de uma licenciatura acompanhada de uma pós-graduação na área, ou na Pedagogia com ou sem habilitação ou pós-graduação específica. Já a Resolução do Conselho Nacional de Educação, Resolução CNE/CP n ${ }^{\circ} 1$ de 15 de maio de 2006 que institui suas Diretrizes Curriculares Nacionais para os cursos de Pedagogia- DCNPs (BRASIL, 2006) extingue as habilitações dos cursos de Pedagogia. Sendo assim, não há mais formação específica para o Orientador Educacional dentro da Pedagogia, e em seu artigo 14 a Resolução ratifica a LDBEN autorizando a formação profissional em cursos de pósgraduação abertos a todos os licenciados.

Grinspun (2011, p. 207) compreende "que até o presente momento a discussão em torno da temática não se encerrou, pois, o Orientador poderá eventualmente formar-se na graduação e com certeza na pós-graduação".

A preocupação com uma formação delegada a esse nível de ensino é que como resultado de políticas públicas de expansão da educação superior que impulsionaram seu crescimento indiscriminado, e em grande parte oferecida na modalidade a distância e por instituições privadas, existe uma conversão da promessa da democracia em consumo. A flexibilidade, a oferta, as vantagens financeiras em fazer um curso, visto por alguns como o acesso democrático à educação, na verdade está a serviço de 
interesses econômicos, que buscam a lucratividade desse tipo de oferta, sem preocupação e compromisso com a legitimidade do conhecimento (CHAVES, 2010).

Segundo levantamento realizado em 2010, 80,48\% das matrículas em educação distância foram realizadas em instituições privadas (MANCEBO, VALE; MARTINS, 2015, p.40). O dado refere-se às matrículas na graduação, entretanto, foi tomada como ilustração para sustentar a ideia da demanda cada vez mais crescente por essa modalidade de curso na administração do ensino superior privado. No último censo da educação superior produzido e divulgado pelo Inep em 2013 a matrícula em cursos de licenciatura a distância se elevou e o curso de Pedagogia capitaneou essa elevação, embora tenha havido um aumento da presença de universidades públicas neste cenário, principalmente via Programa Universidade Aberta do Brasil- UAB. Esse número pode ainda aumentar com a proposta da Rede de Universidade do Professor. ${ }^{4}$

Em relação à pós-graduação em Orientação educacional localizamos no sítio institucional do MEC a oferta de 158 cursos ativos, dentre eles, 24 são ofertados na modalidade a distância, em todo o Brasil denotando assim que existe um mercado consolidado da orientação educacional em nível de pós-graduação. No Distrito Federal, ainda segundo os dados do MEC são 33 cursos ativos sendo ofertados aos profissionais para a qualificação em orientação educacional ${ }^{5}$. O destaque dado aqui pela modalidade à distância tenta fazer a crítica de que após as reformas do ensino superior em escala mundial efetuadas desde os anos 1990, tem-se apresentado o princípio da diversificação das instituições utilizando-se também da educação a distância tendendo a se apresentar a educação muito mais como mercadoria do que como direito social (FREITAS, 2007).

Acredita-se que a formação em Orientação Educacional, assim como de todo docente, deve se posicionar diante de três questões: que sujeito se pretende formar, para que trabalho e para que sociedade? Respondendo a essas três questões com

\footnotetext{
${ }^{4}$ Anunciada pelo MEC, a Rede de Universidade do Professor será um programa que oferecerá 105 mil vagas para formação de professores efetivos das redes estaduais e municipais que não atuam em sua área de formação. Sendo destas, 24 mil presenciais em universidades e institutos federais e 81 mil na modalidade educação a distância, por meio da Universidade Aberta do Brasil. ( Fonte: Sítio do MEC, 2016)

5 Dados retirados da base de dados denominada "e-MEC", onde ficaram registrados todos os cursos credenciados e reconhecidos pelo Ministério da Educação. Ressalva-se que nesta base que dentre os 33 cursos ativos no DF apenas teria um curso sendo ofertado à distância, contudo, em consulta superficial em sítios de buscas sobre a oferta de cursos de especialização em Orientação profissional, localizamos quase uma dezena de cursos ofertados por diferentes instituições e em sua maioria na modalidade à distância.
} 
coerência ideológica e intencionalidade objetivada. Assim, em relação ao espaço de formação para a orientação educacional problematizado nestes parágrafos anteriores vemos que o modelo de instituições predominante mostra a contradição de se ter uma perspectiva mais mercadológica do que emancipatória, contudo, podendo, ao mesmo tempo, desvelar as possibilidades da orientação educacional.

Bernstein (1977, apud BORGES, 2010)) propõe um currículo integrado, que deve ser "estruturado com base em uma ideia relacional". Refletindo o objetivo da Orientação Educacional, arrisca-se propor que a ideia relacional para um curso que se proponha formar Orientadores seria o desenvolvimento social humano. Com essa proposta se quer dizer que ao pensar uma formação em Orientação Educacional, o sujeito que se pretende formar é aquele que tenha condições de emancipação numa sociedade de classes para a superação da mesma por meio de uma prática social pela unidade não linear teoria- prática-reflexão.

Diante desse cenário, as reflexões que seguiram, levaram ao seguinte quadro que ilustra sinteticamente a pesquisa: 


\section{Quadro 3 - Quadro de Coerência}

\begin{tabular}{|c|c|c|c|}
\hline Tema & \multicolumn{3}{|c|}{ Orientação Educacional } \\
\hline Objeto & \multicolumn{3}{|c|}{ Orientação Educacional no Brasil } \\
\hline Problemática: & \multicolumn{3}{|c|}{$\begin{array}{l}\text { - A profissão de Orientador Educacional é regulamentada, não havendo } \\
\text { expressamente revogação da lei, e ela diz que a função é privativa do } \\
\text { Orientador Educacional, e ainda que todo aquele que tiver curso em } \\
\text { Orientação Educacional pode exercer a profissão. } \\
\text { - A LDB 9394/96, sobre a questão da formação para o profissional, deixa } \\
\text { diferentes perspectivas como possibilidades de formação inicial. Da } \\
\text { mesma forma, não se pode afirmar juridicamente que a LDB revoga a lei } \\
\text { de regulamentação da profissão. } \\
\text { - As redes estaduais públicas de ensino do Brasil demandam pela } \\
\text { Orientação Educacional, mas cada uma define quem irá executá-lo e que } \\
\text { atribuições serão delegadas. }\end{array}$} \\
\hline $\begin{array}{l}\text { Questão } \\
\text { central }\end{array}$ & \multicolumn{3}{|c|}{$\begin{array}{l}\text { Quais as demandas dos sistemas de ensino estaduais público brasileiro em } \\
\text { seus editais de concurso? }\end{array}$} \\
\hline $\begin{array}{l}\text { Objetivo } \\
\text { Geral }\end{array}$ & \multicolumn{3}{|c|}{$\begin{array}{l}\text { Analisar a formação da Orientação Educacional e as demandas dos } \\
\text { sistemas de ensino estaduais públicos do Brasil em seus editais de } \\
\text { concurso. }\end{array}$} \\
\hline \multicolumn{4}{|c|}{ Ouestões específicas: } \\
\hline \multicolumn{2}{|c|}{$\begin{array}{l}\text { Quais as bases legais } \\
\text { nacionais vigentes a respeito } \\
\text { da Orientação Educacional } \\
\text { no Brasil? }\end{array}$} & $\begin{array}{l}\text { Quais as atividades da } \\
\text { Orientação Educacional? } \\
\text { Sob quais bases } \\
\text { epistemológicas podem ser } \\
\text { analisadas? E, quais } \\
\text { perspectivas podem ser } \\
\text { apontadas? }\end{array}$ & $\begin{array}{l}\text { Qual a demanda dos sistemas } \\
\text { de ensino estaduais público } \\
\text { referente a Orientação } \\
\text { Educacional? }\end{array}$ \\
\hline \multicolumn{4}{|c|}{ Objetivos Específicos } \\
\hline \multicolumn{2}{|c|}{$\begin{array}{l}\text { Identificar e analisar a } \\
\text { legislação nacional vigente a } \\
\text { respeito da Orientação } \\
\text { Educacional no Brasil }\end{array}$} & $\begin{array}{l}\text { Analisar e discutir as bases e } \\
\text { perspectivas epistemológicas } \\
\text { para a Orientação } \\
\text { Educacional. }\end{array}$ & $\begin{array}{l}\text { Identificar e analisar as } \\
\text { demandas dos sistemas de } \\
\text { ensino estaduais públicos } \\
\text { referente a Orientação } \\
\text { Educacional previstas nos } \\
\text { editais de concurso que } \\
\text { preveem a Orientação } \\
\text { Educacional }\end{array}$ \\
\hline \multicolumn{4}{|c|}{ Eixos } \\
\hline \multicolumn{2}{|c|}{ Fundamentação legal } & \multicolumn{2}{|c|}{$\begin{array}{l}\text { Historicidade da Orientação Educacional. Aspectos legais da } \\
\text { Orientação Educacional }\end{array}$} \\
\hline \multicolumn{2}{|c|}{$\begin{array}{l}\text { Perspectivas } \\
\text { epistemológicas }\end{array}$} & \multicolumn{2}{|c|}{$\begin{array}{l}\text { Orientador Educacional, Orientação Educacional e o } \\
\text { processo de Orientação Educacional. A Orientação } \\
\text { Educacional na perspectiva da Pedagogia histórico crítica }\end{array}$} \\
\hline \multicolumn{2}{|c|}{$\begin{array}{l}\text { Demandas das redes } \\
\text { estaduais }\end{array}$} & \multicolumn{2}{|c|}{$\begin{array}{l}\text { Onde está o orientação educacional? Quem atua nela? } \\
\text { Quais ações compõem o trabalho da orientação educacional? }\end{array}$} \\
\hline
\end{tabular}

A pesquisa contemplou o referencial bibliográfico que fez análises numa perspectiva que dialogará com os seguintes autores: Antunes (2009), Grinspun (2011, 
2012), Cunha (2000), Saviani (2007, 2012a, 2012b), Pascoal \&Honorato (2008), entre outros.

Quanto ao percurso teórico-metodológico, entendendo que método é indissociável de uma teoria, a pesquisa seguiu uma abordagem dialética de natureza qualitativa (TRIVIÑOS, 1987). Para explicar o objeto enfatizar-se-á a dimensão histórica dos processos sociais e partir do modo de produção e de sua relação com as superestruturas é que se dará a interpretação dos dados (GIL, 2009). Ou seja, a partir da historicidade e demais mediações do objeto Serviço de Orientação Educacional e suas determinações no modo de produção capitalista brasileiro, e sua relação com os sistemas estaduais de ensino público brasileiros, que será realizada a análise dos fenômenos a serem investigados. Historicidade está sendo admitida como a história que desvela as contradições, políticas, fillosofias, intenções e pressupostos; como o movimento das múltiplas determinações que constitui o objeto de estudo. (NETTO, 2011).

Fazendo aproximações com a ontologia materialista-histórico-dialética, importa partir da aparência para a essência, pois, segundo Netto (2011, p.25), para Marx, cabe ao pesquisador apreender não só a aparência ou a forma dada ao objeto, mas a sua essência, que corresponde a sua estrutura e a sua dinâmica, como um processo.

A aparência dada ao objeto desta pesquisa está em muito na ausência de reflexão da sua história contemporaneamente, no fato do campo da Orientação Educacional estar subsumido nas pesquisas educacionais apesar de existirem profissionais atuando na área e defenderem sua existência no trabalho cotidiano que realizam.

A materialidade deu-se pela análise de documentos importantes para a compreensão do processo de orientação educacional na contemporaneidade. Uma análise para além do documento, em que este foi o ponto de partida para buscar a historicidade do objeto, que mediou as relações que o constituíram. Nesse processo dialético de investigação foram considerados a legalidade do objeto, a demanda concreta, as contradições e aproximações entre eles.

As categorias a priori elencadas para a investigação são: contradição, mediação e trabalho. Categorias inerentes ao materialismo histórico dialético. Tais 
categorias ajudaram a olhar os elementos que foram investigados constituintes do objeto, de modo que da análise do objeto em si possa emergir sua essência.

Com relação a contradição ela é central na metodologia proposta, pois, segundo Cury (1989, p. 31):

A contradição, pois, ao interpretar o real, capta-o como sendo o resultado de uma inadequação pugnativa entre $o$ que é e o que ainda não é, numa síntese contraditória. Por isso, todo real é um processo que contém, sem encerrar, o possível numa unidade de contrários.

A mediação, não sendo uma coisa em si, mas o que permite expressar a concreticidade, numa relação entre a teoria e a prática, estabelece criticamente quais as relações contraditórias entre os fenômenos do objeto de modo que não sejam vistos isoladamente.

O trabalho entendido como princípio ontológico, é a categoria que permitirá, indissoluvelmente imbricada com a mediação e contradição, desvelar as objetivações relativas aos elementos do processo de orientação educacional.

O processo de orientação educacional é contraditório em vários aspectos desde sua origem até a contemporaneidade, desde as leis que ainda vigoram a respeito, que convergem e em certa medida divergem, até a demanda exigida pelas escolas. As contradições no objeto são reflexo de relações com outros fenômenos, como por exemplo o das políticas de e para a educação. As mediações que fazem parte do movimento do objeto desvelaram qual a realidade concreta do campo da orientação educacional hoje. A análise a partir da categoria trabalho pretende alcançar quais as condições de trabalho previstas já no recrutamento para a orientação educacional, sendo, portanto, balizador da compreensão de que o trabalho é o processo de objetivação humana e assim, buscou-se identificar quais as objetivações que constituem o fazer do orientador educacional, destacando-se, portanto, os editais dos concursos. Editais esses que guardam contradições, mediações e objetivações sobre essa atividade laboral.

No que se refere aos procedimentos técnicos, além da pesquisa bibliográfica comum às pesquisas acadêmicas, optou-se pela análise de documentos a partir do materialismo histórico dialético. Essa formulação se fundamenta a partir dos estudos de Shiroma, Campos e Garcia (2005) que consideram o documento como uma fonte de evidência histórica, social e única, produzido no tempo e movida por uma intencionalidade. 
A partir do materialismo-histórico-dialético foi possível realizar uma análise documental que inquirisse a realidade, a conjuntura, desconstruindo a aparência para poder realizar uma interpretação da realidade dentro de um tempo/espaço contextualizado.

Assim, foram analisados documentos legais vigentes de abrangência nacional relacionados à Orientação Educacional, uma vez que a pesquisa teve abrangência nacional. Como também editais de concursos para cargo efetivo das redes públicas estaduais de ensino que tenham sido realizados a partir de 2010, com exigência para a função de Orientação Educacional, sendo este o conceito adotado nesta pesquisa para definir as atividades relativas ao campo de Orientação Educacional.

Os editais foram selecionados para a pesquisa porque são eles os documentos que regem a seleção de mão-de-obra, contendo o perfil de entrada para o serviço público no Brasil, e a pesquisa se ateve ao serviço público para contribuir com o estado do conhecimento no campo da educação pública. A partir do perfil de entrada contido nos editais, no período de (2010-2015), foi possível identificar o panorama, respondendo quem entra para o serviço de orientação educacional, qual a formação exigida, quais as atribuições designadas, e qual a carreira inicial na escola pública estadual. O edital traça raízes elementares do perfil profissional para o campo da orientação nesse caso.

O recorte temporal relativo aos editais de concurso foi assim elegido por considerar o ano de 2010 como o suposto ano de término das últimas turmas dos cursos de Pedagogia com as habilitações, sendo uma delas a Orientação Educacional, uma vez que no ano de 2006, ano que passa a vigorar as Diretrizes Curriculares Nacionais do curso de Pedagogia, as habilitações deveriam ser extintas. O que a pesquisa pretendeu revelar relaciona-se ao fato da formação em Orientação Educacional não estar mais abrigada no curso de Pedagogia, deixando a identidade do da Orientação Educacional à decisão dos sistemas de ensino, de acordo com a problemática da legislação vigente.

O recorte geográfico relativo aos editais justifica-se pela pretensão de avançar na investigação sobre o tema, abordando as redes estaduais de ensino por se tratarem de objeto de pesquisa divulgada na Educação em Revista de Belo Horizonte no ano de 2008, elaborada por Miriam Pascoal, Eliane Costa Honorato e Fabiana Aparecida de 
Albuquerque $^{6}$. Tal pesquisa ainda é a única referência em quantitativo de OE no Brasil. Sabe-se que há demanda pelo Serviço de Orientação Educacional em sistemas de ensino públicos municipais, porém, devido ao volume de dados, para efeito deste trabalho considerou-se que a investigação junto aos estados seria uma contribuição importante para continuidade de pesquisas na área.

Os documentos legais analisados foram: Lei $n^{0} 5.564 / 68$ ( BRASIL, 1968), que prevê sobre o exercício da profissão de orientador educacional, Decreto $n^{0} 72.846 / 73$ que regulamenta a lei anterior; Lei de Diretrizes e Bases da Educação NacionalLDBEN 9394/96 (BRASIL, 1996); e a Resolução do Conselho Nacional de Educação, Resolução CNE/CP n ${ }^{\circ} 1$ de 15 de maio de 2006 que institui as Diretrizes Curriculares Nacionais do curso de Pedagogia ( BRASIL,2006).

Os editais dos concursos analisados foram dos seguintes sistemas de ensino estaduais: Amazonas, Distrito Federal, Espírito Santo, Minas Gerais, Paraná, Rio Grande do Sul e Rondônia. Editais que atenderam ao recorte temporal elegido.

\footnotetext{
${ }^{6}$ Dados das autoras a época da publicação do artigo: Mirian Pascoal - Doutora em Educação pela Faculdade de Educação da Unicamp e professora da Faculdade de Educação da PUC-Campinas. Eliane Costa Honorato - Aluna do $6^{\circ}$ período do curso de Pedagogia da PUC-Campinas e orientanda de Iniciação Científica. Fabiana Aparecida de Albuquerque - Aluna do $8^{\circ}$ período do curso de Pedagogia da PUC-Campinas e orientanda de Iniciação Científica
} 


\section{CAPÍTULO 1 - ORIENTAÇÃO EDUCACIONAL NO BRASIL}

O capítulo pretende identificar e analisar a legislação nacional vigente a respeito da Orientação Educacional no Brasil. Para alcançar tal objetivo fez-se necessário recorrer a historicidade da orientação educacional no Brasil, pois entende-se que as mediações inerentes ao objeto poderão dessa forma emergir a partir do desvelamento das contradições históricas.

\section{1 - Histórico}

No início do século XX o Brasil sofria com um aumento populacional e os problemas sociais derivados de uma urbanização precária e uma industrialização atípica comparada a outros modelos de desenvolvimento industrial. O modo de produção escravista veio sendo substituído por outras relações de produção provocadas principalmente pela abolição da escravatura e a imigração de estrangeiros desde o século XIX.

A prosperidade da exportação do café desencadeou uma elevação da população com concentração em algumas cidades e também a implantação de uma malha ferroviária importante em São Paulo (SAVIANI, 2012a).

Neste contexto, o ensino profissional foi visto pelas classes dirigentes como um antídoto contra a "inoculação de ideias exóticas" no proletariado brasileiro (CUNHA, 2000, p. 94). Além desse pensamento conservador, havia outra ideologia, a industrialista, que via na indústria a resolução dos problemas econômicos, pois, atribuía à indústria o progresso, a emancipação econômica, a independência política, a democracia e civilização (CUNHA, 2000). São as bases capitalistas se solidificando em solo brasileiro.

Com base nessa ideologia, destacam-se dois tipos de escolas industriais que surgem na primeira década do século XX: as atividades de ensino de ofícios das empresas ferroviárias, para a formação de operários destinados à manutenção de seus equipamentos, veículos e instalações; e as escolas de aprendizes e artífices. Estas últimas criadas por Nilo Peçanha, em 1909, como presidente da República através do decreto 7.566, de 23 de setembro.

As Escolas de aprendizes e artífices cunhavam-se como instituições beneficentes que deveriam oferecer cuidados aos filhos do proletariado, e incutir ideias 
de combate ao ócio, ao vício e ao crime, além de oferecer formação técnica e profissional numa perspectiva com forte marca assistencialista.

Foram criadas 19 escolas desse tipo, distribuídas entre as capitais dos estados, com exceção do Rio de Janeiro que se instalou em Campos. Segundo Cunha (2000, p. 95), as escolas, além de legitimarem a ideologia industrialista, também eram estratégicas politicamente, pois,

[...] constituíram uma presença do governo federal nos estados, oferecendo cargos aos indicados pelos políticos locais e vagas para alunos a serem preenchidas com os encaminhados por eles. A contrapartida não seria difícil de imaginar: o apoio político ao bloco dominante no plano federal. (CUNHA, 2000, p.95).

De acordo com Cunha (2000) após a década de 20 a maior parte dessas escolas entrou em decadência, pois os cursos ofertados e suas instalações não atendiam aos ofícios propriamente industriais, não indo, portanto, ao encontro dos propósitos industrialistas. Em São Paulo, porém, "as condições de crescimento da produção industrial, aliadas à emulação do Liceu de Artes e Ofícios, levaram a um maior esforço de adaptação das oficinas às exigências da produção fabril” (CUNHA, 2000, p.96).

Em 1924, as intenções das escolas ferroviárias e das escolas de aprendizes e artífices encontram subsídios uma na outra com a criação da Escola Profissional Mecânica no Liceu de Artes e Ofícios de São Paulo. As escolas ferroviárias se apresentavam descentralizadas e assistematizadas, e o Liceu se adaptava a produção fabril e buscava a ratificação de suas atividades. Com a criação da escola de mecânica, quatro empresas ferroviárias que operavam em São Paulo "fizeram um acordo com o Liceu, pelo qual enviariam cada um dois aprendizes para frequentarem um curso de quatro anos, realizando estágio nas oficinas de uma delas, situadas na capital."(CUNHA, 2000, p. 97).

Na criação da Escola Profissional Mecânica teve papel destacado o engenheiro suíço Roberto Mange, professor da Escola Politécnica de São Paulo que inicia um trabalho de Orientação Profissional, considerado pela literatura, a primeira experiência em Orientação Educacional no Brasil (GRINSPUN, 2011). Claramente, essa experiência nada tem de educacional, uma vez que a função de orientação educacional oferecida pela escola se tratava de aplicação de testes psicotécnicos para seleção e orientação dos candidatos aos diversos cursos. Porém, ela denuncia as origens dessa função e remete a compreensão dos interesses em trazer esse tipo d e trabalho para o 
Brasil: selecionar trabalhadores para a continuidade eficiente do processo de industrialização e modernização do país. Influenciado pelas ideias de Frederick Taylor, Mange divulga a doutrina da Organização Racional do Trabalho e com outros engenheiros adeptos fundam em 1931 o Instituto de Organização Racional do Trabalho - IDORT, ele apresentava o taylorismo como solução para a gestão eficiente da produção.

Para essa gestão eficiente da produção se fazia necessária a gestão do trabalho dos operários, nesse sentido o serviço de Orientação Profissional fundamentado na psicologia tinha relevante função de escalonar, selecionar e direcionar:

[...] para que a produtividade geral se elevasse, seria necessário, também, aumentar a produtividade dos trabalhadores em termos físicos, para o que seriam indispensáveis os exames psicotécnicos, permitindo colocar "o homem certo no lugar certo" e selecionar os mais capazes; e o ensino sistemático de ofícios, apressando e barateando a formação profissional. [...] Os exames psicotécnicos serviriam, também, para evitar a contratação de "agitadores", medida convergente com a adoção de fichas de identificação datiloscópica destinadas a evitar a reentrada nos quadros das empresas de trabalhadores despedidos por razões político-ideológicas ou outras" (CUNHA, 2000, p. 97)

Com vistas à melhoria dos resultados econômicos, a experiência do Liceu provocou a empresa estatal Estrada de Ferro Sorocabana a criar o "Serviço de Ensino e Seleção Profissional - SESP, em 1930, incorporando as práticas pedagógicas e psicotécnicas que se divulgavam e se aplicavam" (CUNHA, 2000, p. 97). A exemplo do Liceu verifica-se a presença de profissionais que exerciam a função de orientadores realizando a seleção profisssional.

Paralelamente a essas experiências em orientação, em 27 de outubro de 1930, Lourenço Filho, assumindo a Diretoria Geral da Instrução Pública de São Paulo e nela permanecendo até 23 de novembro de 1931 cria o Serviço de Psicologia Aplicada (SPA), subordinada à Secretaria de Educação e Saúde Pública do Estado de São Paulo. Para dirigir o serviço foi designada a psicóloga Noemy Marques da Silveira Rudolfer. A psicóloga teve formação nos Estados Unidos no Teacher's College da Universidade de Columbia, onde "frequentou cursos de Psicologia Educacional, Estatística Aplicada à Psicologia, Filosofia da Educação, Sociologia Educacional e Construção Social” (MONARCHA, 2009, p. 8). Essa experiência também é citada como pioneira para a 
Orientação Educacional, apesar de suas características profissionais e vocacionais (GRINSPUN, 2011). O referido serviço ocupou-se de avaliar e escalonar alunos considerando que se a associação entre idade mental e maturidade para o aprendizado fosse sempre ou fortemente positiva, seria fácil selecionar os alunos (MONARCHA, 2009).

Lourenço Filho e Noemy Silveira também se envolveram com os trabalhos do IDORT, o que corroborou para a difusão das ideias psicologizantes na educação que se preocupavam em selecionar, escalonar e imputar vocações ao interesse do bom desenvolvimento das instituições escolares e, por conseguinte, o desenvolvimento do país. Aqui cabe ressaltar que esse desenvolvimento se daria para uma sociedade fundamentada em pressupostos liberais, em que cada indivíduo é responsável e responsabilizado por suas conquistas e/ou fracassos.

Em 1932, como tentativa de traçar diretrizes de uma política nacional de educação e ensino foi lançado o Manifesto dos Pioneiros da Educação. O texto redigido por Fernando de Azevedo e assinado por vários pensadores da época, retratou as forças dominantes no ideário da educação do Estado Novo:

[...] se a evolução orgânica do sistema cultural de um país depende de suas condições econômicas, é impossível desenvolver as forças econômicas ou de produção, sem o preparo intensivo das forças culturais e o desenvolvimento das aptidões à invenção e à iniciativa que são os fatores fundamentais do acréscimo de riqueza de uma sociedade. (AZEVEDO, 2010)

O trecho revela que se via na educação a resposta para o desenvolvimento econômico do país. Os pressupostos da Escola Nova, difundidos no Brasil, principalmente por intermédio de Anísio Teixeira, um dos signatários do manifesto, pregavam a democratização da sociedade por meio da educação como se ela tivesse o papel de equalizar as oportunidades, como se não houvesse mais desigualdades tanto dentro como fora da escola (FARIAS, 1990).

Ainda que o Manifesto tenha sido uma importante reação para a educação, ele estava impregnado de um ideário dos pressupostos liberais e, portanto, a busca de uma educação integral com base nas aptidões naturais (GRINSPUN, 2011). O trecho a seguir exemplifica bem isso: 
A educação nova, alargando a sua finalidade para além dos limites das classes, assume, com uma feição mais humana, a sua verdadeira função social, preparando-se para formar "a hierarquia democrática" pela "hierarquia das capacidades", recrutadas em todos os grupos sociais, a que se abrem as mesmas oportunidades de educação. (AZEVEDO, 2010, p. 40)

Por meio do manifesto pode-se depreender também as perspectivas de atuação que se configurariam para a Orientação Educacional: aquela que fornecerá dentro da escola justificativas para uma divisão social do trabalho, a partir da psicometria, do recrutamento, seleção e nivelamento dos indivíduos.

Segundo Grinspun (2011), dois anos após a divulgação do manifesto, em 1934, a Associação Brasileira de Educação - ABE ofereceu um curso de Extensão sobre Orientação Educacional. O curso teve como um de seus professores o aqui já citado Lourenço Filho e também o então Ministro da Educação e Saúde Pública, Gustavo Capanema Filho, ambos responsáveis pela conceituação de Orientação que aparece nas Leis Orgânicas, que serão abordadas adiante. Então se conclui que a concepção que circundou o curso foi também aquela relacionada à Orientação Profissional de base psicologizante. O problema dessa base é que ela responsabiliza o indivíduo sem considerar suas condições objetivas, dadas não apenas por sua capacidade de responder a questionários, mas sim pela sua materialidade histórica. Não permite que se avance nas questões sociais para uma Orientação Educacional que se envolva efetivamente com a transformação da sociedade.

Ainda segundo Grinspun (2011) também em 1934, “[...] em termos de tentativas isoladas de Orientação, [...] experiência pioneira é de Aracy Muniz Freire e de Maria Junqueira Schmidt, no Colégio Amaro Cavalcanti, no Rio de Janeiro". Apesar dessa experiência ter se dado fora do contexto das escolas industriais, os pressupostos teórico-filosóficos e metodológicos, nada diferem um do outro. Todos servindo a manutenção de uma classe hegemônica, pois Schmidt em seu livro intitulado 'Orientação Educacional', de 1942, um dos primeiros a respeito do assunto, a autora deixa claro que o objetivo da orientação nada tem com a mudança da sociedade, princípio que denuncia a intenção da manutenção do status quo: "Educar e orientar constituem, em essência, uma função coletiva, que tem por fim adaptar a criança ao meio social a que se destina" (SCHMIDT, 1942, p. 18). 
Nesse ínterim, em 1934, foi criado por meio de decreto o Centro Ferroviário de Ensino e Seleção Profissional - CFESP, que passou a ser modelo para outras ferrovias. O CFESP tinha nas séries metódicas a espinha dorsal de uma pedagogia que se mostrou eficaz no atendimento dos objetivos almejados (CUNHA, 2000). Entre seus princípios, “[...] encontra-se a seleção profissional baseada no conhecimento das características individuais e nas aptidões funcionais para determinadas funções e ocupações” (GRINSPUN, 2011, p. 26) "[...] a clientela restrita e selecionada (filhos de ferroviários, principalmente) e a formação para utilização também restrita (as estradas de ferro)" (CUNHA, 2000, p.98).

O modelo de aprendizagem sistemática do CFESP se generalizou em âmbito nacional com a adoção de um projeto industrialista de desenvolvimento, pelo Estado Novo. A Constituição de 1937 instituiu o ensino profissionalizante e o artigo 129 da mesma faz referência à sua destinação às classes menos favorecidas, dispõe ainda que, é obrigação das indústrias e dos sindicatos criarem escolas de aprendizagem na área de sua especialização para os filhos de seus empregados e membros.

O Ministério da Educação, através da Divisão de Ensino Industrial, elaborou, em 1938, um projeto de regulamentação desse dispositivo constitucional. A partir daí ocorre "[...] um intenso conflito de bastidores entre o Ministério da Educação e Saúde e o do Trabalho, Indústria e Comércio, que tinha por detrás, principalmente, a Federação Nacional da Indústria e a Federação das Indústrias de são Paulo" (SCHWARTZMAN, 2000, p. 1). De um lado o Ministério da Educação defendia que as escolas seriam mantidas com recursos do imposto sindical, geridos conjuntamente por representantes dos sindicatos e dos Ministérios da Educação e do Trabalho, e de outro os líderes industriais contrários por temerem as despesas oriundas desse sistema (CUNHA, 2000, p. 99).

Essa disputa culminou na promulgação de dois decretos quase que simultâneos: o Decreto $\mathrm{n}^{\circ} 4.048$ (BRASIL,1942) que criou o Serviço Nacional da Aprendizagem Industrial, o SENAI, conforme as aspirações da indústria e do Ministério do Trabalho; e outro, o Decreto 4.073 (BRASIL,1942a) que definia a Lei Orgânica do Ensino Industrial. Tais decretos integraram a chamada Reforma de Capanema, então Ministro da Educação e Saúde.

O Decreto 4.073 (BRASIL,1942a) tornou-se um marco para a Orientação Educacional, pois se trata da primeira lei a utilizar essa expressão e a institucionalizar 
o serviço. A referência ao serviço aparece no capítulo XIII, intitulado 'Da Orientação

Educacional':

Art. 50. Instituir-se-á, em cada escola industrial ou escola técnica, a orientação educacional, que busque, mediante a aplicação de processos pedagógicos adequados, e em face da personalidade de cada aluno, e de seus problemas, não só a necessária correção e encaminhamento, mas ainda a elevação das qualidades morais.

Art. 51. lncumbe também à orientação educacional, nas escolas industriais e escolas técnicas, promover, com o auxílio da direção escolar, a organização e o desenvolvimento, entre os alunos, de instituições escolares, tais como as cooperativas, as revistas e jornais, os clubes ou grêmios, criando, na vida dessas instituições, num regime de autonomia, as condições favoráveis à educação social dos escolares.

Art. 52. Cabe ainda à orientação educacional velar no sentido de que o estudo e o descanso dos alunos decorram em termos da maior conveniência pedagógica. (BRASIL, 1942)

Analisando o conteúdo retirado dos artigos acima, pode-se constatar alguns fundamentos contraditórios da orientação que se pretendia nas escolas: individualizante "em face da personalidade de cada aluno, e de seus problemas"; responsabilizadora "a necessária correção e encaminhamento"; moralista "elevação das qualidades morais" "educação social dos escolares"; e conservadora "conveniência pedagógica".

No mesmo ano, como integrante do conjunto de leis que compuseram a Reforma Capanema, foi decretada a Lei Orgânica do Ensino Secundário no 4424 de 9 de abril. Esta lei oferece um pouco mais de esclarecimento quanto ao serviço de Orientação Educacional. No capítulo VI, artigos 80 a 82 a Lei determina a obrigatoriedade do serviço no ensino secundário, qual a função do Orientador e, os meios para sua execução:

Art. 80. Far-se-á, nos estabelecimentos de ensino secundária, a orientação educacional. Art. 81. E' função da orientação educacional, mediante as necessárias observações, cooperar no sentido de que cada aluno se encaminhe convenientemente nos estudos e na escolha da sua profissão, ministrando-lhe esclarecimentos e conselhos, sempre em entendimento com a sua família. Art. 82. Cabe ainda à orientação educacional cooperar com os professores no sentido da boa execução, por parte dos alunos, dos trabalhos escolares, buscar imprimir segurança e atividade aos trabalhos complementares e velar por que o estudo, a recreação e o descanso dos alunos decorram em condições da maior conveniência pedagógica. (BRASIL, 1942b) 
Apoiada então na fundamentação psicológica de conhecer melhor o aluno, visando o seu acompanhamento, a Orientação foi caminhando em sua trajetória no Brasil, agora fortificada por ser legalmente instituída (GRINSPUN, 2011, p. 29). Assim, a Orientação Educacional chega às escolas, pelo viés do autoritarismo com que é imposta através de um discurso liberal, reforçando a ideologia das aptidões naturais, como se o esforço individual fosse o único responsável pelo fracasso ou sucesso do indivíduo independente e suas condições sociais e, o Orientador Educacional fosse o profissional que desvelaria as aptidões individuais e apontaria o futuro para cada um (MAIA e GARCIA, 1984).

Concordando com Giacaglia e Penteado (2010) a Orientação foi implantada de forma bastante artificial, o que viria acarretar uma série de problemas, muitos dos quais se fazem presentes ainda hoje.

Fica então evidente que a origem da função de Orientação Educacional no Serviço de Orientação Profissional, revela interesses políticos e econômicos que fundamentam a sedimentação do capitalismo no Brasil e fortalecem a burguesia como a ideologia hegemônica.

No contexto da Reforma Capanema o conjunto de leis implantadas tinham caráter
centralista, fortemente burocratizado; dualista, separando o ensino secundário, destinado às elites condutoras, do ensino profissional, destinado ao povo conduzido e concedendo apenas ao ramo secundário a prerrogativa de acesso a qualquer carreira de nível superior; corporativista, pois vinculava estreitamente cada ramo ou tipo de ensino às profissões $\mathrm{e}$ aos ofícios requeridos pela organização social. (SAVIANI, 2012a, P. 269)

As reformas também denunciavam, segundo Saviani (2012a), um equilíbrio entre católicos - que se ofenderam com as propostas do Manifesto dos Pioneiros da Educação de 1932 - e os renovadores - aqueles que defendiam o movimento da Escola Nova fundamentado em pressupostos que, entre outros, apoiavam a ideia das aptidões naturais independentes das condições concretas do indivíduo e da sociedade. Com esse equilíbrio, ainda segundo Saviani (2012a) entre o final da década de 40 e início da década de 60 houve predominância da pedagogia nova na educação brasileira. 
Assim o Orientador Educacional era a figura que na escola deveria buscar ferramentas para adaptar o aluno a sociedade de classes, ajustando suas aptidões às necessidades dos pressupostos políticos que se vislumbrava para o país. Era papel do Orientador Educacional aconselhar os alunos para a escolha de acordo com sua condição individual, camuflando suas condições objetivas de classe.

Ainda tratando da Lei Orgânica do Ensino Secundário, essa foi a primeira lei que tratou da formação do Orientador Educacional no Brasil. A Lei Orgânica do Ensino Secundário faz referência à formação necessária para atuação como Orientador Educacional no ensino secundário. No artigo 83 da Lei encontramos que eram aplicáveis aos orientadores os preceitos do artigo 79 , relativo aos professores:

Art. 79. A constituição do corpo docente, em cada estabelecimento de ensino secundário, far-se-á com observância dos seguintes preceitos: 1. Deverão os professores do ensino secundário receber conveniente formação, em cursos apropriados, em regra de ensino superior. 2. O provimento, em caráter efetivo, dos professores dos estabelecimentos de ensino secundário federais e equiparados dependerá da prestação de concurso. 3. Dos candidatos ao exercício do magistério nos estabelecimentos de ensino secundário reconhecidos exigir-se-á prévia inscrição, que se fará mediante prova de habilitação, no competente registro do Ministério da Educação. 4. Aos professores do ensino secundário será assegurada remuneração condigna, que se pagará pontualmente.(BRASIL, 1942b)

Ou seja, para exercer a função de Orientador Educacional nas escolas secundárias do Brasil, o candidato deveria passar por concurso público, ter formação preferencialmente no ensino superior, em curso congênere e obter registro junto ao Ministério da Educação. Apesar dessa referência, o texto não definiu qual a formação específica para o Orientador, o que então não regulamentou sua formação.

O primeiro curso específico para formar Orientadores Educacionais em nível superior no Brasil somente foi oferecido em 1945, pela Universidade Católica de Campinas - PUC - no estado de São Paulo, intitulado 'Curso de Formação de Orientador Educacional'. O curso foi destinado aos que realizaram o curso de didática e portadores de diplomas de normalistas. A PUC Campinas seguia o modelo institucional da época, determinado pelo Decreto $\mathrm{n}^{\circ} 1190$ de 4 de abril de 1939, que organizou a Faculdade Nacional de Filosofia, a qual foi dada um caráter de modelo padrão a ser seguido por todas as Universidades do país. O modelo instituía duas 
modalidades: o bacharelado, com duração de três anos e a licenciatura, composta pelo curso de didática, com duração de um ano (SAVIANI, 2012a, p. 35).

Segue-se até 1958, quando a Portaria no 105 de 12 de março do Ministério da Educação e Cultura, regulamentou o exercício da função de orientador educacional no ensino secundário. A Portaria admitia a seguinte formação para o orientador do ensino secundário:

Art. $4^{\circ}(\ldots)$ a) Diploma de Licenciado por Faculdade de Filosofia; b) diploma de bacharelado na seção de Pedagogia, expedido por Faculdade de Filosofia; $c$ ) titulo de Técnico de Educação, obtido em concurso oficial; $d$ ) registro definitivo de professor, expedido pela Diretoria do Ensino Secundário. $\S 1^{\circ}$ Além de um destes títulos acima requeridos, deve apresentar certificado que comprove ter o candidato realizado, com eficiência, durante um ano no mínimo, curso de especialização em Orientação Educacional e respectivo estágio supervisionado, promovido por Faculdade de Filosofia ou, em caráter supletivo, por uma das Diretorias de Ensino deste Ministério com a colaboração de professores universitários. (BRASIL, 1958)

Em 1959, o Decreto $\mathrm{n}^{\circ} 47.038$, de 16 de outubro, que aprovou o Regulamento do Ensino Industrial, apenas citava que o orientador deverá ser devidamente habilitado para o exercício do cargo, porém não especifica nenhuma formação.

Somente em 1961, com a promulgação da Lei n ${ }^{\circ} 4.024$, de 20 de dezembro, nossa primeira Lei de Diretrizes e Bases da Educação Nacional - LDB, é que se teve a normatização para a formação do Orientador Educacional:

Art. 62. A formação do orientador de educação será feita em cursos especiais que atendam às condições do grau do tipo de ensino e do meio social a que se destinam. Art. 63. Nas faculdades de filosofia será criado, para a formação de orientadores de educação do ensino médio, curso especial a que terão acesso os licenciados em pedagogia, filosofia, psicologia ou ciências sociais, bem como os diplomados em Educação Física pelas Escolas Superiores de Educação Física e os inspetores federais de ensino, todos com estágio mínimo de três anos no magistério. Art. 64. Os orientadores de educação do ensino primário serão formados nos institutos de educação em curso especial a que terão acesso os diplomados em escolas normais de grau colegial e em institutos de educação, com estágio mínimo de três anos no magistério primário." (BRASIL, 1961)

Percebe-se que a nomenclatura variou desde a instituição da Orientação, apontando que não havia consenso entre os legisladores, quiçá quanto às funções do orientador e seu papel na escola e na educação. 
Embora a inclusão do atendimento da Orientação Educacional no ensino primário tenha parecido um avanço, a diferença entre a formação para atuação no primário e secundário apresenta uma dualidade que desqualifica o trabalho no ensino primário. Pois “[...] não há razão de natureza teórica para que se devesse exigir nível superior apenas dos Orientadores que trabalhariam com alunos o ensino secundário." (GIACAGLIA e PENTEADO, p. 28, 2010). Mas como à época o entendimento era de que a formação para atuação no primário deveria ser realizada nas escolas normais, a orientação educacional acabou por se incluir nesse entendimento, assim o orientador do ensino primário poderia ter sua base formativa no ensino secundário, e o orientador do secundário deveria ter sua base formativa no ensino superior.

As políticas de educação no Estado Novo foram marcadas por dualidades. Além dessa consideração que para atuar no ensino primário bastava o ensino secundário, o ensino secundário marcava a dualidade entre as elites e as classes mais desfavorecidas. Até então, havia dois ramos de ensino secundário: o propedêutico e o profissional. O propedêutico destinava-se as elites pois era aquele que permitia o acesso à universidade, e o profissional era para a classe trabalhadora e não dava acesso ao ensino superior. O papel do orientador educacional nessa dualidade era conformar os estudantes e propicia-los a escolha dentro dessas limitações.

Com a Lei de Diretrizes e Bases da Educação nacional de 1961, foi garantida a equivalência de todos os ramos do ensino secundário para o acesso ao ensino superior com a introdução das disciplinas necessárias. Entretanto, apesar da normatização apontar para a equidade de acesso, a prática na orientação permanecia sob as bases dualistas. A orientação ainda era profissional, e uma orientação profissional tendenciosa.

Em busca de um conceito para a orientação, os orientadores da época buscavam fundamentos na orientação americana, que era prioritariamente profissional. Porém, quando em 1962 veio a regulamentação da profissão de psicólogo, e com ela a reserva de mercado da utilização de muitos testes que eram utilizados nas orientações, principalmente vocacionais, o orientador educacional sofre com a indefinição de suas atribuições.

Segundo Giacaglia e Penteado (2010) nesse momento tem importância as associações. Em 1967, o MEC promoveu no Rio de Janeiro, um encontro para discussão da Orientação Educacional. Ao fim do encontro os orientadores cogitavam a 
formação de associações. A primeira delas foi a Rio Grande do Sul, que existe até o presente momento.

Em 1968, foi promulgada a Lei $\mathrm{n}^{\mathrm{o}} 5564$ de 21 de dezembro que regulamentou a profissão, e em 1973, já por força das associações geradas no final da década de 60, foi promulgado o Decreto 72.846 de 26 de setembro, que regulamentou a Lei 5564/68. Tido como vitória profissional, o Decreto $72.846 / 73$ "determinou as atribuições do orientador educacional, confirmou o caráter psicológico da Orientação, mantendo a conceituação de tal área, mais uma vez em uma visão individualizada e pessoal" (GRINSPUN, p.31, 2011). Portanto, não há o que se comemorar na regulamentação de uma profissão que nasce com o objetivo de ratificar a divisão social, promovendo educacionalmente ideias que, se valendo de psicologias e teorias preconceituosas, excludentes serve diretamente a interesses hegemônicos.

Do ponto de vista da formação, a regulamentação da profissão também não foi feliz ao passo que não define qual a base formativa desse profissional, pois em síntese considera que todo aquele que realize um curso em orientação educacional está apto a exercer a função. Tornando assim o serviço sem identidade conceitual em sua base.

A Lei 5.564/68 que prevê sobre o exercício da profissão de orientador ainda está em vigor, apesar de pouco conhecida por quem não pertence a área da orientação, e não citada nos editais de concurso quando da seleção para o serviço. Seu conteúdo se resume a oito artigos:

Art. $1^{\circ}$ A orientação educacional se destina a assistir ao educando, individualmente ou em grupo, no âmbito das escolas e sistemas escolares de nível médio e primário visando ao desenvolvimento integral e harmonioso de sua personalidade, ordenando e integrando os elementos que exercem influência em sua formação e preparandoo para o exercício das opções básicas. Art. $2^{\circ} \mathrm{A}$ orientação educacional será atribuição exclusiva dos profissionais de que trata a presente Lei. Art. $3^{\circ}$ A formação de orientador educacional obedecerá ao disposto nos arts. 62, 63 e 64 da Lei no 4.024, de 20 de dezembro de 1961 e aos outros diplomas legais vigentes. Art. $4^{\circ}$ Os diplomas de orientador educacional serão registrados em órgão próprio do Ministério da Educação e Cultura. Art. $5^{\circ}$ Constituem atribuições do orientador educacional além do aconselhamento dos alunos e outras que the são peculiares, lecionar as disciplinas das áreas da orientação educacional. Art. $6^{\circ}$ As disposições desta Lei serão regulamentadas pelo Poder Executivo, inclusive para definição do código de ética dos orientadores educacionais. Art. $7^{\circ}$ Esta Lei entra em vigor na data de sua publicação. Art. $8^{\circ}$ Revogam-se as disposições em contrário. (BRASIL, 1968) 
Algumas contradições no próprio âmbito jurídico podem ser encontradas se a lei for considerada vigente: 1 - a referência à formação do orientador que deverá se fazer de acordo com a Lei 4.024/61, que não vigora mais; 2 - registro do diploma de orientador junto ao Ministério, que não se faz mais necessário; 3 - o magistério de disciplinas na orientação educacional, que se referia a lecionar no ensino normal para a formação de orientadores em nível médio.

Os elementos elencados, que não fazem mais sentido na atualidade, não revogam a lei por si somente. No campo jurídico é necessário observar o Decreto-lei $n^{\text {o }} 4.657$, de 4 de setembro de 1942, Lei de Introdução às normas do Direito Brasileiro, com ementa de redação dada pela Lei $n^{0} 12.376$, de 30/12/2010, que prevê em seu artigo $2^{\circ}$ os elementos que revogam ou não uma lei:

Art. $2^{\circ}$ Não se destinando à vigência temporária, a lei terá vigor até
que outra a modifique ou revogue. $\S 1^{\circ}$ A lei posterior revoga a
anterior quando expressamente o declare, quando seja com ela
incompatível ou quando regule inteiramente a matéria de que tratava
a lei anterior. $\S 2^{\circ}$ A lei nova, que estabeleça disposições gerais ou
especiais a par das já existentes, não revoga nem modifica a lei
anterior. $\S 3^{\circ}$ Salvo disposição em contrário, a lei revogada não se
restaura por ter a lei revogadora perdido a vigência. (BRASIL, 1942)

Analisando os elementos revogadores nota-se que não há justificativa para encerrar a matéria como revogada como justifica-se a seguir: em primeiro lugar a Lei 5.564/68 não apresenta vigência temporária; e segundo a LDB vigente, que é a lei maior de abrangência da educação brasileira, não a revoga expressamente, não é incompatível e não regula inteiramente a matéria da lei 5.564/68 ${ }^{7}$. Portanto, não há como indubitavelmente declarar a Lei 5.564/68 revogada expressamente.

Ainda no âmbito jurídico, existe a possibilidade de revogação tácita, que ocorre quando uma lei posterior e de maior abrangência possa contrariá-la. Como foi

\footnotetext{
${ }^{7}$ Um exemplo disso pode ser encontrado no sítio oficial JUSBRASIL que reuni várias matérias dos Tribunais de Justiça do Brasil no qual localizamos uma Apelação Cível no Estado do Paraná tendo como matéria a acumulação de cargos de professor e de orientação educacionais em turnos distintos e a interpretação jurídica foi de que, em sendo tendo o diploma Pedagogo, com base docente, o requerente poderia acumular sem que haja incompatibilidade de carga horória. Disponível em http://www.jusbrasil.com.br/jurisprudencia/busca?q=ORIENTADOR+EDUCACIONAL. Acesso abril de 2016.

${ }^{8}$ Inclusive encontra-se acessível no endereço http://www2.camara.leg.br/legin/fed/lei/1960-1969/lei5564-21-dezembro-1968358617-norma-pl.html, sítio virtual da Câmara dos Deputados Federais, onde observa-se em sua situação que não consta revogação expressa.
} 
observado não aconteceu no caso. Entretanto, em última instância dependerá da doutrina de interpretação jurídica para que se decida por uma revogação tácita caso assim seja demandada a matéria no contexto judicial.

O Decreto $\mathrm{n}^{\mathrm{o}} 72.846 / 73$ que regulamenta a lei anterior, também é encontrado no sítio virtual da Câmara dos Deputados Federais com situação em que não consta revogação expressa. O decreto é mais específico e detalhado posicionando a profissão como privativa ao Orientador Educacional, que deverá ter em sua formação curso específico em Orientação Educacional, na forma de habilitação, certificado ou diploma.

O decreto não define uma formação inicial única, podendo o profissional ser licenciado ou bacharel desde que apresente terminalidade específica. Em seu segundo artigo encontra-se a formação necessária ao exercício da profissão:

Art. $2^{\circ}$. O exercício da profissão de Orientador Educacional é
privativo:
I. Dos licenciados em pedagogia, habilitados em orientação
educacional, possuidores de diplomas expedidos por
estabelecimentos de ensino superior oficiais ou reconhecidos. II Dos
portadores de diplomas ou certificados de orientador educacional
obtidos em cursos de pós-graduação, ministrados por
estabelecimentos oficiais ou reconhecidos, devidamente
credenciados pelo Conselho Federal de Educação. III. Dos
diplomados em orientação educacional por escolas estrangeiras,
cujos títulos sejam revalidados na forma da legislação em vigor.
(BRASIL, 1973)

Ou seja, o decreto autoriza o exercício àqueles que portarem diploma ou certificação em Orientação Educacional, sendo estes hoje: bacharéis e ou/licenciados habilitados ou pós-graduados na área.

Continuando a trajetória cronológica da orientação educacional no Brasil, em 1968, outra lei que teve um impacto relevante para a orientação educacional foi a Lei da reforma universitária 5.540 (BRASIL, 1968). Essa reforma acabou por levar a uma nova regulamentação do curso de Pedagogia, que culminou na Resolução do Conselho Federal de Educação $\mathrm{n}^{\mathrm{o}} 2$ de 1969, onde nascem as habilitações do curso de Pedagogia, e uma delas a Orientação Educacional. As habilitações permaneceram e assim a orientação abrigada no curso de Pedagogia, até a homologação das novas Diretrizes Curriculares Nacionais do curso de Pedagogia em 2006.

A década de 70 foi a mais movimentada para a Orientação Educacional. Com encontros e congressos para o fortalecimento do campo, e com a regulamentação da 
profissão, a partir da lei já citada, a orientação educacional parecia ter encontrado sua identidade.

Nesse mesmo contexto dos anos de 1970, a reforma da LDBN de 1961, a Lei 5692/71, que instituiu obrigatoriamente a orientação educacional nos estabelecimentos de ensino de $1^{\circ}$ e $2^{\circ}$ graus, aparentemente trouxe uma decisão importante que conferia destaque a $\mathrm{OE}$, contudo, apenas confirmava a intenção do governo militar em profissionalizar o maior número possível de estudantes para que estes se inserissem no mercado de trabalho que servia aos interesses de industrialização mais uma vez, e limitasse o acesso ao ensino superior. Assim, a orientação educacional viria a servir novamente aos interesses do mercado, ratificando as escolhas dos alunos, por meio de técnicas de aconselhamento profissional preferencialmente individualizadas.

A partir da década de 80, com a democratização do país, as discussões educacionais e lutas por uma educação mais crítica, política e reflexiva; o orientador questiona suas atribuições definidas ou não, e seu papel social. Com as tendências educacionais que se comprometiam mais com o político e social, amplia-se o debate e as contradições da profissão vão aos poucos sendo levantadas. "Há uma discussão muito grande do papel do orientador educacional, como trabalhador, desvelando seu compromisso político e pedagógico" (GRINPUN, 2012).

As discussões da década de 80 foram comuns ao campo da Educação. Quanto a formação dos profissionais da educação, em especial a de Pedagogos, incluindo a do Orientador Educacional, a década viu nascer o Comitê Pró Participação na Reformulação dos cursos de Pedagogia e Licenciatura, que "transformou-se em 1983 em CONARCFE, que por sua vez, em 1990, se constituiu na ANFOPE, que continua em atividade." (SAVIANI, 2012a, p. 51).

A Associação Nacional pela formação dos Profissionais da Educação ANFOPE teve papel decisivo no futuro da formação em Orientação Educacional. Discutindo a formação em Pedagogia, a ANFOPE e seus autores associados defendia que a formação do Pedagogo e de todo educador deveria ser fundamentada na base docente. A ideia de docência defendida pela ANFOPE não se restringia e não se restringe a uma docência relacionada apenas a didática e a sala de aula, mas enfatiza uma concepção ampliada de docência em que esta seria o próprio trabalho docente. Esta concepção ganhou força nas décadas de 90 e início de 2000 e teve sua vitória expressa na homologação das novas Diretrizes Curriculares Nacionais do curso de 
Pedagogia em 2006, que extingue as habilitações e com isso acaba por desabrigar a Orientação Educacional de uma habilitação para exercício, porém podia ainda fornecer elementos para sua atuação dependendo da base docente trabalhada nos cursos de Pedagogia.

O artigo 64 da LDB 9394/96, que foi promulgada contemporaneamente a toda essa discussão, deixa em aberto base legal do Orientador Educacional quando propõe que a formação seja dada nos cursos de Pedagogia ou na Pós-graduação.

Assim, o serviço de orientação educacional continua a contemporaneidade num limbo identitário. A discussão não se encerrou até hoje, mas o campo da Orientação Educacional não encontrando legitimidade legal nacional que o obrigue ou que defina sua posição formativa, foi sendo subsumido por outros campos da educação, sendo isso refletido nas poucas produções acadêmicas que são encontradas hoje, e na falta de adesão de pouco mais da metade dos sistemas públicos estaduais de ensino do país.

Então, a legislação nacional vigente a respeito da orientação educacional no Brasil são as seguintes: Lei $n^{0} 5.564 / 68$, que prevê sobre o exercício da profíssão de orientador educacional, Decreto $\mathrm{n}^{\mathrm{o}} 72.846 / 73$ que regulamenta a lei anterior; Lei de Diretrizes e Bases da Educação Brasileira - LDB 9394/96; e a Resolução do Conselho Nacional de Educação, Resolução CNE/CP n ${ }^{\circ} 1$ de 15 de maio de 2006 que institui as Diretrizes Curriculares Nacionais do curso de Pedagogia.

A atual Lei de Diretrizes e Bases da Educação Nacional - LDBEN 9394/96 trata da Orientação Educacional no Título VI, intitulado "Dos Profissionais da Educação". Na LDB não há previsão de obrigatoriedade da Orientação Educacional no ensino. Fica a critério de cada sistema de ensino do país, estaduais e municipais, definir em seus projetos e legislação específica a presença da função de orientação nas escolas, assim como será e por quem será executada.

As referências diretas a Orientação Educacional aparecem: no artigo 61 que define quem são os profissionais da educação e; no artigo 64, que apresenta as possibilidades de formação para o orientador educacional, citado como um dos profissionais da educação. De modo indireto, se faz relevante para este estudo a referência do artigo 67, parágrafo primeiro, que prevê a experiência docente para o exercício das funções do magistério.

No artigo 61, que define os profissionais da educação, destaca-se o inciso II: 
II - trabalhadores em educação portadores de diploma de pedagogia, com habilitação em administração, planejamento, supervisão, inspeção e orientação educacional, bem como com títulos de mestrado ou doutorado nas mesmas áreas; (Redação dada pela Lei ${ }^{\circ}$ 12.014, de 2009). (BRASIL, 1996)

$\mathrm{O}$ artigo 61 diferencia terminologicamente os profissionais da educação entre professores e trabalhadores em educação. Interessante observar que os orientadores então são denominados trabalhadores. Mas questiona-se porque os professores também não recebem tal denominação?

Considerando trabalhador aquele que vive do trabalho, pertencente a "classeque-vive-do-trabalho" (ANTUNES, 2009, p. 101), pode-se considerar todos os profissionais da educação como trabalhadores. Tratando especificamente do objeto de estudo desta pesquisa, a orientação educacional, é ímpar admitir que aquele que exerce as atividades relativas ao serviço pertence à classe trabalhadora. Pois segundo Antunes (2009, p. 102) "a classe-que-vive-do-trabalho engloba também os trabalhadores improdutivos, aqueles cujas formas de trabalho são utilizadas como serviço, seja para uso público ou para o capitalista [...]”. Portanto, a função de orientação educacional é designada um trabalhador.

O artigo 64 referente à formação, não avança na delimitação da base inicial do orientador educacional:

Art. 64. A formação de profissionais de educação para administração, planejamento, inspeção, supervisão e orientação educacional para a educação básica, será feita em cursos de graduação em pedagogia ou em nível de pós-graduação, a critério da instituição de ensino, garantida, nesta formação, a base comum nacional. (BRASIL, 1996)

Como se observa, prevê para o exercício da Orientação Educacional a formação na graduação em Pedagogia, que atualmente não abriga mais habilitação específica em orientação educacional, ficando a critério das instituições incluir ou não conteúdo referente; e formação na pós-graduação, que é aberta a todos formados no ensino superior, inclusive bacharéis.

Uma interpretação possível, na tentativa de limitar o exercício da função de orientação educacional aqueles que ao menos tenham uma base docente em sua formação, poderá se dar a partir da seguinte reflexão: além do artigo 64 da LDBN que 
trata da "formação de profissionais da educação", o artigo 67 nos parágrafos primeiro e segundo esclarece que é necessário ter experiência docente para o exercício da profissão, e a formação desse docente para a educação básica está prevista nos artigos 62 e 65, conforme podemos observar nas transcrições dos artigos supracitados da LDBEN:

\begin{abstract}
Art. 62. A formação de docentes para atuar na educação básica far-seá em nível superior, em curso de licenciatura, de graduação plena, em universidades e institutos superiores de educação, admitida, como formação mínima para o exercício do magistério na educação infantil e nos 5 (cinco) primeiros anos do ensino fundamental, a oferecida em nível médio na modalidade normal. [...]Art. 65. A formação docente, exceto para a educação superior, incluirá prática de ensino de, no mínimo, trezentas horas. [...] Art. 67 [...] § 1o A experiência docente é pré-requisito para o exercício profissional de quaisquer outras funções de magistério, nos termos das normas de cada sistema de ensino. § 20 [...] são consideradas funções de magistério as exercidas por professores e especialistas em educação no desempenho de atividades educativas, quando exercidas em estabelecimento de educação básica em seus diversos níveis e modalidades, incluídas, além do exercício da docência, as de direção de unidade escolar e as de coordenação e assessoramento pedagógico. (BRASIL, 1996).
\end{abstract}

Assim, pode-se inferir que para atuar na educação básica, com a exigência de experiência docente, e a formação para a docência nesse nível de ensino ter que se dar necessariamente nos cursos de licenciatura, o serviço de orientação educacional também deva ser apenas exercido a partir da formação em base docente. Logo, excluise aqui os bacharéis sem licenciatura.

Apesar dessa interpretação possível, juridicamente, a luz da LDBEN 9394/96, ainda assim não se pode afirmar indubitavelmente que a lei limita o exercício apenas aos licenciados. Mais uma vez dependerá da doutrina jurídica da avaliação caso seja demandada, conforme comentamos anteriormente.

A Resolução do Conselho Nacional de Educação, Resolução CNE/CP $n^{\circ} 1$ de 15 de maio de 2006 que institui suas Diretrizes Curriculares Nacionais - DCNs, extingue as habilitações dos cursos de Pedagogia: “Art.10. As habilitações em cursos de Pedagogia atualmente existentes entrarão em regime de extinção, a partir do período letivo seguinte à publicação desta Resolução.” (BRASIL, 2006).

Sendo assim, não há mais formação específica para o Orientador Educacional dentro da Pedagogia, contudo em seu artigo 14 a Resolução ratifica a LDBEN 9394/96 autorizando a formação profissional em cursos de pós-graduação abertos a todos os 
licenciados e, assegura a formação para a Orientação na Licenciatura em Pedagogia, ou seja, conforme indica a legislação citada o Pedagogo não precisa de pós-graduação para exercer a função, desde que obedecido o disposto a seguir:

Art.14. A Licenciatura em Pedagogia, nos termos dos Pareceres CNE/CP n. 5/2005 e 3/2006 e desta Resolução, assegura a formação de profissionais da educação prevista no art. 64 , em conformidade com o inciso VIII do art. $3^{\circ}$ da Lei n. $9394 / 96$. § $1^{\circ}$ Esta formação profissional também poderá ser realizada em cursos de pósgraduação, especialmente estruturados para esse fim e abertos a todos os licenciados. [...] (BRASIL, 2006)

Apreende-se, então, dentre as legislações observadas, a resolução, é a que melhor define uma formação para o orientador educacional: licenciados com pósgraduação específica e Pedagogos com ou sem pós-graduação.

Em síntese, de acordo com a legislação estudada no capítulo e em vigor no Brasil hoje são admitidas as seguintes formações para o exercício da função de Orientação Educacional:

\section{Quadro 4 - Formações possíveis}

\begin{tabular}{|c|c|}
\multicolumn{1}{|c|}{ Formação Inicial } & $\begin{array}{c}\text { Formação } \\
\text { Continuada }\end{array}$ \\
\hline Bacharel & Pós-graduação em OE \\
\hline Licenciatura em qualquer área & Pós-graduação em OE \\
\hline Pedagogia & Pós-graduação em OE \\
\hline Pedagogia & Habilitação em OE \\
\hline Pedagogia & - \\
\hline
\end{tabular}

Fonte: Elaborado pela pesquisadora a partir do estudo da legislação vigente, 2015

Também faz essa análise, Spricigo (2012), entretanto sugere que medidas devem ser tomadas para superar a problemática em relação à formação do orientador 
educacional, defendendo o curso de Pedagogia como formação inicial e básica para essa função.

Mesmo com todas as possibilidades legais acima levantadas, a orientação educacional no Brasil hoje, mostra-se prioritariamente exercida pelos Pedagogos, como será apresentado no capítulo 3 desta pesquisa. Apesar de ter perdido o status de profissão, com a lei que a regulamenta em desuso, considera-se um avanço que a base docente tem sido adotada para a atividade, entretanto, as funções da orientação estão sendo acumuladas a outras funções dentro da escola, sendo executadas por um único profissional, o Pedagogo. Quando o número de profissionais atuando na escola não equivale ao número de atribuições, funções e atividades demandadas pelo trabalho inerentemente escolar, a intensificação do trabalho desses profissionais é praticamente inevitável.

Em síntese a formação/profissão do orientador educacional hoje apresenta vários elementos e contradições:

a) Existe uma posição legal em que as atuais Diretrizes Curriculares Nacionais de Pedagogia (DCNs), bem como o Parecer CNE/CP N 3/2006, asseveram que a Licenciatura em Pedagogia (sem habilitações específicas) realiza a formação para administração, planejamento, inspeção, supervisão e orientação educacional, em organizações (escolas e órgãos dos sistemas de ensino) da Educação Básica e também estabelece que devem ser observadas igualmente as disposições do Parágrafo Único do art. 67 da Lei $n^{\circ}$ 9.394/96, no sentido de que a experiência docente é pré-requisito para o exercício profissional de quaisquer outras funções de magistério, nos termos das normas de cada sistema de ensino. Sendo a organização escolar eminentemente colegiada, cabe prever que todos os licenciados em educação possam ter oportunidade de ulterior aprofundamento da formação pertinente, ao longo de sua vida profissional.

b) De acordo com a nova legislação, não mais cabe, como outrora (na vigência da legislação anterior - Lei $\mathrm{n}^{\mathrm{o}} 5.540 / 1968$ e currículos mínimos), conceber a formação para as funções supracitadas como privativas dos Licenciados em Pedagogia. (PARECER CNE/CP No 3/2006) As Novas Diretrizes Curriculares Nacionais de Pedagogia não têm por objetivo abolir a Orientação Educacional das Unidades Educativas. O que se aborda são a formação e o fim das habilitações na 
graduação em Pedagogia. Mas como consequência, abriu a possibilidade para todos os licenciados em Educação trabalharem na área, com uma formação em menor tempo que o Pedagogo Escolar (que possui uma formação plena).

Nesse contexto, percebe-se a falta de clareza, de definição e de significância socioeducacional-político-cultural da orientação educacional e, para culminar com as certezas e as incertezas, surge a nova Lei de Diretrizes e Bases da Educação. Com princípios e objetivos embasados na globalização, instrumentalizada por uma política educacional globalizante, a lei exclui veladamente a orientação educacional e demais profissionais. Embora cite em artigos a formação desses profissionais da educação, percebe-se nas ações programáticas sua exclusão, com isso, um profissional tão necessário parece tornar-se desnecessário.

c) A orientação educacional é vista como profissão, entretanto, não há curso específico de formação, considerando os aspectos que envolvem o fim das habilitações em pedagogia. A sua formação específica acontece em pós-graduação para qualquer licenciado e este aspecto contradiz com o conceito de profissão, mas ao mesmo tempo contêm outros elementos. A Sociologia das Profissões sustenta que uma profissão é instituída socialmente, interpretando as modalidades de organização social e de divisão social do trabalho como um processo de interação social que tem a organização como um limite.

d) Lemosse (1989) identificou as seguintes características de uma profissão: (a) uma atividade intelectual que acarreta a responsabilidade individual daquele que a exerce; (b) é científica, e não de natureza rotineira, mecânica ou repetitiva; (c) é, no entanto, prática, pois se define pelo exercício duma arte mais do que puramente teórica ou especulativa; (d) a sua técnica aprende-se após uma longa formação e em ensino superior; (e) o grupo que exerce determinada atividade caracteriza-se por possuir uma forte organização e uma grande coesão internas; e (f) é uma atividade de natureza altruísta, que presta um serviço à sociedade.

e) Entendemos que há um exercício da função de orientação, ou seja, existe a atividade de orientação. É extremamente válido lembrar que o trabalho do orientador educacional, é um trabalho pedagógico, portanto de base docente e que necessita estar revestido pelo comportamento ético, estético, político e técnico o que exige uma formação específica tendo como referência o trabalho pedagógico, portanto, a docência. 
f) Entendemos que há um exercício da função de orientação, ou seja, existe a atividade de orientação. É extremamente válido lembrar que o trabalho do orientador educacional, é um trabalho pedagógico, portanto de base docente e que necessita estar revestido pelo comportamento ético, estético, político e técnico o que exige uma formação específica tendo como referência o trabalho pedagógico, portanto a docência. 


\section{CAPÍTULO 2 - PERSPECTIVAS EPISTEMOLÓGICAS PARA ORIENTAÇÃO EDUCACIONAL: análise e proposições}

Este capítulo aborda diferentes perspectivas sob as quais a Orientação Educacional pode ser analisada e descreve princípios básicos para numa nova perspectiva teórica de atuação e de trabalho. Dessa forma considerou-se necessário redefinir conceitualmente as terminologias Serviço, Orientação e Orientador. Discutir a questão da base docente na formação em orientação educacional articulando essa compreensão de modo a propor uma pedagogia que seja seu fundamento, adotando-se seus pressupostos políticos e filosóficos. Entendendo, portanto, que a docência como atividade intencional que balizaria uma orientação educacional precisa ter clareza da tendência pedagógica que assume. A concepção pedagógica adotada para tal problematização é a Pedagogia Histórico-crítica, por considerá-la coerente com o mundo concreto e as possiblidades reais de transformação da sociedade e por meio da formação de sujeitos históricos.

\subsection{TRABALHO DE ORIENTAÇÃO EDUCACIONAL, ORIENTAÇÃO EDUCACIONAL E ORIENTADOR EDUCACIONAL: algumas diferenciações}

Os três termos - serviço, orientação e orientador - recebem na literatura ora diferentes conceitos de acordo com diferentes autores, ou apenas não aparecem diferenciados. A Orientação Educacional foi conceituado como um serviço do qual o Orientador Educacional é titular como um espaço físico, local, sala, onde ocorrem as atividades do Orientador (GIACAGLIA e PENTEADO, 2010). Já a Orientação Educacional como um conceito que apresenta três dimensões, a legalista, a funcionalista e a realista (GRINSPUN, 2001), ou um processo complexo (GIACAGLIA e PENTEADO, 2010). E o Orientador como o agente que executa a orientação.

Para efeito desta pesquisa considerar-se-á a diferença entre eles, a partir da problemática dos aspectos legais referentes ao exercício da Orientação Educacional 
hoje e as demandas para esse trabalho nas redes estaduais públicas expressadas nos editais de recrutamento do profissional.

A pesquisa apontou, sendo melhor explicitado no próximo capítulo, que o trabalho de Orientação Educacional é solicitado nas redes estaduais públicas a serem pesquisadas, porém, esta função na escola não é exercida por profissional exclusivamente Orientador Educacional, uma vez que a demanda analisada e discutida em relação ao editais dos concursos públicos estaduais que serão adiante mais detalhadas, aponta para a necessidade de um profissional que execute atividades para além do campo da Orientação Educacional, incluindo atividades do campo da Coordenação Educacional, Supervisão Educacional e outras. Cabe então, uma explicação a respeito da diferenciação, proposta para este trabalho, entre o processo de Orientação Educacional, a Orientação Educacional e o Orientador Educacional, baseadas em sínteses realizadas a partir dessa pesquisa.

Orientação Educacional é um campo da Educação que prevê processos de Orientação Educacional. O conceito de campo é uma "categoria que devemos a Bourdieu" (Saviani, 2012b, p.116). Considerando o caráter materialista-históricodialético deste trabalho, fazer referência a um autor crítico-reprodutivista pode parecer incoerente, entretanto, sua menção deve-se ao fato de que, concordando com Saviani (2012b), essas teorias trouxeram elementos importantes para se entender a prática educativa.

Nesse sentido o conceito de campo intelectual adotado pode ser expressado a partir da seguinte citação:

Recordar que el campo intelectual como sistema autónomo o que pretende la autonomía es el producto de un proceso histórico de autonomización y de diferenciación interna, es legitimar la autonomización metodológica que permite la investigación de la lógica específica de las relaciones que se establecen en el seno de este sistema y lo integran como tal; [...] (BOURDIEU, 2002, p.17).

A aproximação com o conceito de campo intelectual de Bourdieu está vinculado à compreensão de que a Orientação Educacional sendo histórica e relativamente autônoma em seus fundamentos, conseguiu se estabelecer com um escopo teórico próprio em determinado momento, dentro da Educação. A intenção aqui é fomentar a especificidade teórica da Orientação Educacional. 
O campo da Orientação Educacional - OE está fundamentado em diferentes perspectivas e epistemologias (GRINSPUN, 2011). Numa síntese quanto aos fundamentos epistemológicos da Orientação Educacional pode-se propor o seguinte: Orientação Educacional positivista, Orientação Educacional fenomenológica e Orientação Educacional histórico-dialética. É valido ressaltar que apesar de apontar para uma orientação educacional histórico-dialética com base na pedagogia históricocrítica, entendemos que esta não seria a única via de proposição para a ação da orientação educacional no contexto mais amplo de diferentes tendências pedagógicas consideradas progressistas.

Dado os limites desse trabalho não iremos nos aprofundar em cada uma das diferentes frentes que podem ser pensadas para a atividade de OE, apenas destacamos que as duas primeiras tendências, positivistas e fenomenológicas, parecem referendar a realidade concreta sob a qual a orientação educacional em sua historicidade foi sendo constituída com forte incidência dos seus elementos e que a perspectiva de orientação histórico-dialética, além de apresentar sua concentricidade, principalmente no movimento crítico empreendido em diferentes momentos históricos da OE, abre-se como via de reflexão-ação como um ato educativo cada vez mais intencional.

Uma Orientação Educacional positivista (SCHEEFFER, 1976; GRINSPUN, 1992) tem seus pressupostos teóricos apoiados na psicometria. Esta perspectiva se posiciona pragmática e a partir de experiências, busca resultados que aloquem os educandos em suas devidas posições na sociedade. O conhecimento a ser elaborado no campo deve olhar para a harmonização da sociedade de classes, sem considerar as contradições existentes. O sujeito não é encarado como protagonista, mas como um expectador do que está posto.

A Orientação Educacional fenomenológica (GRINSPUN, 1992, 2011; LOFREDI, 1976) rompe com a positivista, quando volta seu olhar para o sujeito e partir dele constrói os conhecimentos fundantes da sua prática. A construção do conhecimento no campo da Orientação nessa perspectiva deve considerar a especificidade dos fenômenos, delimitando o olhar para o que está sendo apresentado, sem a necessidade de se considerar uma conjuntura. A partir da necessidade imediata, dos problemas que se apresentam, é que a Orientação busca seus subsídios teóricos.

$\mathrm{Na}$ Orientação Educacional histórico-dialética o conhecimento advém da análise da estrutura e suas superestruturas (GRINSPUN, 2011; VIEIRA, 2015; 
SILVA, 2015; SAVIANI, 1991, GARCIA, 1991; SCALCON,2002). Rompe-se com a fenomenologia e com o positivismo. A orientação constrói seus conhecimentos a partir da investigação da realidade material, concreta, histórica e pelo movimento dialético que pressupõe que a essência dos fenômenos não está dada, sendo imprescindível as mediações que realizem movimento entre as redes de relações que circundam, perpassam e integram os fenômenos.

A Orientação Educacional na perspectiva histórico-crítica também deve compreender que "trabalho educativo é o ato de produzir, direta e intencionalmente, em cada indivíduo singular, a humanidade que é produzida histórica e coletivamente pelo conjunto dos homens" (SAVIANI, 2012b, p.13). Assim o movimento da atividade de orientação educacional que se ampare nessa concepção deverá ter a prática social como ponto de partida e de chegada. Valendo-se da epistemologia da pedagogia histórico-crítica, "pela mediação do trabalho pedagógico, a compreensão e a vivência da prática social passam por uma alteração qualitativa" (SAVIANI, 2012b, p. 113)

O Orientador Educacional é o profissional que atua exclusivamente no campo da Orientação Educacional e no processo de Orientação Educacional. Como já foi analisado, este profissional tem seu reconhecimento legal. Cabe aqui o termo 'exclusivamente' porque o campo da orientação educacional não é mais privilégio de um profissional habilitado unicamente para o exercício no serviço. Como aponta este trabalho, outros profissionais trabalham executando funções inerentes à orientação educacional.

O trabalho da Orientação Educacional pode ser conceituado como um conjunto de ações pedagógicas que integram os diversos sujeitos da escola à sociedade com o objetivo de emancipar os seres humanos nela envolvidos. Trata-se das atividades a serem desenvolvidas no sentido da práxis, a partir dos pressupostos epistemológicos do campo da orientação educacional que se for adotar.

Abandona-se aqui qualquer conceito de Serviço de Orientação Educacional que se aproxime de um local, uma sala, onde o profissional realiza intervenções junto aos indivíduos. A ideia de trabalho de Orientação Educacional se amplia para um conjunto de ações que abrange toda a escola. Placco (1994, p. 30) conceitua a orientação educacional como 
um processo social desencadeado dentro da escola, mobilizando todos os educadores que nela atuam - especialmente os professores para que, na formação desse homem coletivo, auxiliem cada aluno a se construir, a identificar o processo de escolha por que passam, os fatores socioeconômico-político-ideológicos e éticos que o permeiam e os mecanismos por meio dos quais ele possa superar a alienação proveniente de nossa organização social, tornando-se, assim, um elemento consciente e atuante dentro da organização social, contribuindo para sua transformação.

As ações previstas para o trabalho de orientação educacional envolvem atividades de cunho práxico ${ }^{9}$, na perspectiva da unidade entre teoria e prática. Tais atividades devem permear todos os âmbitos da escola, o pedagógico e o administrativo.

Nessa perspectiva, as atividades previstas para a orientação educacional deverão considerar a prática social, assim cada realidade demandará quais elas serão. Para tanto, teria a Pedagogia histórico-crítica (SAVIANI, 2007) como princípio, fundamento e metodologia para as ações de Orientação Educacional. Mais adiante aprofundaremos essa proposição.

Assim, postas as diferenças entre os termos orientação educacional, processo/trabalho de orientação educacional e orientador educacional, espera-se uma melhor compreensão das análises dos editais públicos que foram realizadas neste estudo, assim como das perspectivas que possam ser desenvolvidas para o campo, considerando as demandas escolares e uma prática revolucionária na atuação pedagógica.

\subsection{A BASE DOCENTE NA FORMAÇÃO EM ORIENTAÇÃO EDUCACIONAL: alguns apontamentos}

Como campo intelectual dentro da educação é importante considerar quais pressupostos são defendidos para formação em Orientação Educacional. Sendo assim, neste trabalho, a posição adotada, inclusive para a análise dos dados no próximo capítulo, é a de que a orientação educacional, assim como os demais campos dos

\footnotetext{
${ }^{9}$ Ser humano práxico é aquele que faz movimentar a História com sentido e com significado; é ser humano que faz cultura, é ser humano ativo no exercício da criação, da expressão e da busca da liberdade; é ser humano que se revela crítico na tomada de decisão e de oposição.
} 
chamados especialistas que eram formados no curso de Pedagogia, supervisão, administração, coordenação, etc., devem ter uma base docente, sendo esta hoje no Brasil melhor representada pelo próprio curso de Pedagogia.

Significa dizer que o que se defende é que, estes campos, devem ser aprofundados após um curso de Pedagogia, que é o curso que, segundo a legislação atual, deve garantir uma ampla formação docente.

Cabe ressaltar que a defesa pelo curso de Pedagogia como base da formação para os outros campos da educação citados, incluindo o da orientação educacional, se faz por considerar que as demais licenciaturas na atual conjuntura político-educativa do país, não permitem o aprofundamento dos pressupostos essencialmente pedagógicos.

A Pedagogia tem papel primoroso junto à Orientação Educacional porque na função é preciso compreender como se dá o processo de ensino e aprendizagem para realizar uma análise consistente e compreender os sujeitos envolvidos no processo pedagógico. É fundamental que procuremos saber como as pessoas aprendem e se desenvolvem. A Pedagogia leva em conta as dificuldades e os problemas que os alunos encontram quando estão diante de novas aprendizagens. Ela nos apresenta as intervenções que necessitam ser dirigidas aos alunos para superação de suas dificuldades por meio de atividades especialmente pensadas, planejadas executadas, permitindo que os alunos aprendam mais e melhor, ou seja, como a Pedagogia tema a educação como objeto torna-se central na formação do orientador educacional. (KUMM, 2009, p. 23)

Além da especificidade do campo, há o ‘bacharelismo’ das licenciaturas é tema de produções acadêmicas que criticam o modelo de formação de professores das chamadas disciplinas específicas da educação básica. Em síntese, a crítica se faz, principalmente em relação aos padrões curriculares das licenciaturas que tendem a subsumir com os conteúdos das disciplinas pedagógicas:

É nesse cenário, enraizado em nossa tradição enciclopédica, aliada à concepção tecnicista de educação, que podemos interpretar um forte estereótipo presente em nossas universidades: o de que formar professores se reduz ao cumprimento de certas disciplinas de natureza educacional (as chamadas "disciplinas pedagógicas"), voltadas à disseminação de alguma teoria de natureza educacional e 
sua "aplicação" na elaboração e/ou execução do processo ensinoaprendizagem. (DIAS-DA-SILVA ET AL., 2008)

Até o ano de $2015^{10}$ a Resolução do Conselho Nacional de Educação ${ }^{\circ}$ 1, de 18 de fevereiro de 2002 é a que instituía as Diretrizes Curriculares Nacionais para a Formação de Professores da Educação Básica, em nível superior, curso de licenciatura, de graduação plena. Pode-se inferir então que todos os professores formandos e formados hoje, estão sob as características legais previstas pela resolução de 2002. Isso significa que a matriz curricular de seus cursos de graduação deve respeitar o seguinte, previsto no artigo 11, parágrafo único:

Parágrafo único. Nas licenciaturas em educação infantil e anos iniciais do ensino fundamental deverão preponderar os tempos dedicados à constituição de conhecimento sobre os objetos de ensino e nas demais licenciaturas o tempo dedicado às dimensões pedagógicas não será inferior à quinta parte da carga horária total. (BRASIL, 2002)

Então, nos cursos de licenciatura, exceto Pedagogia, a carga horária mínima prevista para as dimensões pedagógicas equivale a 560 horas, pois a Resolução CNE/CP 2, de 19 de fevereiro de 2002, lançada no dia seguinte, propunha uma carga horária de no mínimo 2800 horas para os cursos de licenciatura. Mesmo se tratando de carga horária mínima, há uma desproporção grande entre o que o curso de Pedagogia garante, inerentemente imerso nas dimensões pedagógicas, e o que os cursos de licenciatura oferecem. O que, por uma questão de natureza do curso, os difere e qualifica melhor o Pedagogo para os demais campos pedagógicos.

Diferentemente do que eram as habilitações do antigo curso de Pedagogia, que em determinado período do curso dividia os estudantes de acordo com a especialidade que desejavam como carreira, a proposta aqui é formar professores aptos a lecionarem na educação infantil e anos iniciais do ensino fundamental com o título de Pedagogo, e de acordo com a Resolução $\mathrm{n}^{\mathrm{o}} 2$, de $1^{\mathrm{o}}$ de julho de 2015 do Conselho Nacional de

\footnotetext{
10 As atuais diretrizes promulgadas em junho de 2015, Resolução $\mathrm{n}^{\mathrm{o}} 02$ do Conselho Nacional de Educação deram destaque exatamente para uma clara concepção de docência para formar o profissional do magistério incluindo também a visão de que os processos de gestão são inerentes ao trabalho educativo em sua totalidade.
} 
Educação, em cursos de no mínimo quatro anos. Após essa diplomação em Pedagogia, estariam aptos a realizarem uma especialização no campo desejado.

A partir dessa ideia, teria que ser revisto o quadro atual dos programas de pósgraduação lato sensu. Considerado um grande mercado, os cursos de especialização não se submetem a nenhuma avaliação para que sejam considerados de qualidade ou não, bastando serem oferecidos por instituições de nível superior devidamente credenciadas, de acordo com a Resolução ${ }^{\circ} 1$, de 8 de junho de $2007^{11}$.

Além de uma regulamentação mais incisiva sobre a qualidade dos cursos, mesmo não contando com a mesma, a produção epistemológica sobre o campo deve ser revista e atualizada para atender não somente as demandas da sociedade capitalista, mas acima de tudo uma nova sociedade que se pretende. Isso implica em rever os históricos pressupostos políticos e filosóficos da orientação educacional apresentados no capítulo 1 deste trabalho.

Quanto à base docente, entende-se que ela é imprescindível para atuação na educação básica. Os pressupostos da base docente defendida aqui são os mesmos defendidos pela ANFOPE - Associação Nacional pela Formação dos Profissionais da Educação, quando da reestruturação do curso de Pedagogia.

Entretanto, arrisca-se, concordando com o posicionamento de Saviani (2012a), que o curso de Pedagogia tal como está estruturado hoje de acordo com suas diretrizes curriculares, atua para formar o Pedagogo polivalente, e faz-se aqui a defesa pelo Pedagogo politécnico.

O conceito de politecnia é amplamente abordado por Demerval Saviani no livro "Sobre a concepção de politecnia" (Saviani, 1989), e para efeito deste trabalho considerar-se-á o seguinte trecho para representar a ideia de politecnia proposta:

\footnotetext{
A ideia de politecnia envolve a articulação entre trabalho intelectual e trabalho manual e envolve uma formação a partir do próprio trabalho social, que desenvolve os fundamentos, os princípios, que estão na base da organização do trabalho na nossa sociedade e que, portanto, nos permitem compreender o seu funcionamento. (SAVIANI, 1989, p. 19)
}

\footnotetext{
${ }^{11}$ Encontram-se em discussão no Conselho Nacional de Educação portaria que normatiza os cursos de especialização lato sensu apresentando subsídios para a avaliação destes.
} 
Ou seja, a formação de um Pedagogo estaria aportada nesse conceito, o de politecnia, no pressuposto de que a base, o curso de Pedagogia, deva ser fundamentada no que as escolas como instituições sociais, tem como dever e papel na formação, sendo aqui defendido que o papel da escola e seu dever é desenvolver a humanidade na perspectiva da materialidade histórica e dialética.

O Pedagogo teria na base docente a unidade entre teoria e prática e os conhecimentos necessários para lecionar, refletir a realidade concreta da educação, propor transformações da mesma, antes de todas as outras funções do magistério, para somente após essa experiência ter condições concretas de desempenhar as demais funções.

A docência como base da formação do pedagogo que irá desempenhar as funções de orientação educacional é um pressuposto defendido pela ANFOPE desde as primeiras lutas pela reestruturação do curso de Pedagogia. A superação da dualidade entre trabalho intelectual e trabalho manual, teoria e prática, especialistas e professores, é uma reinvindicação para formação dos trabalhadores do magistério desde que este conceito de magistério encontrou na docência o ponto comum de todos os educadores.

Entre outros princípios destaca-se, então, para a formação docente os seguintes aspectos: unidade teoria e prática, visão de totalidade do conhecimento socialmente produzido, sólida formação teórica, política, cultural e técnica. Com isso se quer dizer que o docente deve ser formado pela práxis e para a práxis, para que seja possível alcançar a essência dos fenômenos educativos, percebendo as relações e contradições entre o sistema educativo e demais sistemas sociais, e assim encontrar alternativas para a superação das desigualdades, com apropriação do seu fazer.

Em síntese, entendemos que o orientador educacional deve ter como formação inicial o curso de Pedagogia com sólida fundamentação sobre a compreensão da própria organização educacional, suas raízes históricas e as concepções políticas, ideológicas e filosóficas que as embasam, assim como o conhecimento da legislação que determina as funções e o funcionamento da Instituição Educativa e na formação continuada lato sensu aprofundar as especificidades do trabalho de orientação. 


\subsection{ORIENTAÇÃO EDUCACIONAL NA PERSPECTIVA DA PEDAGOGIA HISTÓRICO-CRÍTICA}

A Pedagogia histórico-crítica tem como marco, segundo Saviani (2012b), o final da década de 70, mais precisamente o ano de 1979. Neste ano as recém-criadas entidades da área de educação: Associação Nacional de Pesquisa e Pós-graduação em Educação - ANPED, Centro de Estudos Educação e Sociedade - CEDES e, a Associação Nacional de Educação - ANDE, se articulam para a promoção das conferências de educação.

A década é marcada pelas teorias crítico-reprodutivistas, originadas na França, que muito contribuíram para pensar o capitalismo na educação e a educação no capitalismo, fazendo críticas importantes ao papel da escola no sistema. Essas teorias apresentam limites e passam a ser criticadas por não apontarem uma proposta educativa, e não afirmarem a possibilidade de a escola desempenhar papeis transformadores, não apontam saídas no campo educacional, pois defendem que toda proposta pedagógica desempenhará papel reprodutor da sociedade.

Pensando em alternativas a tais ideias, que chegam ao Brasil e são apropriadas pelos educadores, em 1980 a união das três grandes entidades educacionais, ANPED, CEDES e ANDES, realiza a I Conferência Brasileira de Educação, onde a temática se fez presente. Na política brasileira é o momento de luta pelas eleições diretas e oposição ao regime militar e suas políticas, incluindo as educacionais, assim como da emergência de propostas para a educação brasileira que se afirmassem como oposição ao regime. As alternativas às teorias crítico-reprodutivistas tornam-se, então, proeminentes, pois não se podia conceber a educação apenas para a reprodução, mas também como entidade de possibilidades, que trabalhasse para desvelar as contradições e a partir delas oferecer saídas.

Na ocasião, Saviani (2012b) participa da conferência e sua exposição dá origem ao artigo que trata da" Teoria da curvatura da vara", publicado no número 1 da Revista da ANDE. Depois desse artigo surge a necessidade de continuação da temática e no ano de 1982, no número 3 da Revista do ANDES é publicado o artigo "Para além da curvatura da vara," em que estão, segundo o próprio Saviani (2012b), esboçadas as linhas básicas do que seria a Pedagogia Histórico-crítica. 
Teoricamente, a Pedagogia Histórico-crítica é marxista. Como explica Saviani (2012b, p. 119,120):

Quando se pensam os fundamentos teóricos, observa-se que, de um lado, está a questão da dialética, essa relação dos movimentos das transformações; e, de outro, que não se trata de uma dialética idealista, uma dialética entre conceitos, mas de uma dialética de movimento real. Portanto, trata-se de uma dialética histórica expressa no materialismo histórico, que é justamente a concepção que procura compreender e explicar o todo desse processo, abrangendo desde a forma como são produzidas as relações sociais e suas condições de existência até a inserção da educação nesse processo. (SAVIANI, 2012b, p.119,120).

Então, uma vez que sua base é materialista histórico-dialética, a Pedagogia Histórico-crítica tem como um de seus princípios, a unidade teoria e prática. A esse princípio Saviani (2012b, p.120) procurou elaborar o significado de práxis a partir de Vázquez (1968), conceituando práxis como uma prática fundamentada teoricamente.

A partir desse princípio uma proposta teórica metodológica foi estruturada no campo da didática por João Luiz Gasparin (2005) a partir de cinco passos: Prática social inicial, Problematização, Instrumentalização, Catarse e Prática social final. Saviani (2012a) a inclui na edição de 2007 do livro 'Escola e democracia'.

Os cinco passos são, então, adotados como o método histórico-critico, os quais Saviani (2007) assemelham aos esquemas propostos por Herbart na Pedagogia tradicional, e Dewey na Pedagogia nova, para facilitar a compreensão da nova proposta pedagógica.

Gasparin (2005) explica que o primeiro passo, a Prática Social Inicial, é o ponto de partida em que o professor e o aluno devem explicitar seus conhecimentos prévios a respeito do conteúdo. Conteúdo que, nesse caso, deve ser emergente prioritariamente de uma necessidade social, sem que se deixe subsumido os conhecimentos científicos necessários ao crescimento intelectual. Pode-se dizer que o ponto de partida é, então, a Prática social concreta.

O segundo passo, a Problematização, é o levantamento dos principais problemas da prática social, de modo que o máximo de questões, considerando seus múltiplos aspectos sejam referidas a luz do conteúdo científico. Tais questões serão então trabalhadas no próximo passo, a Instrumentalização.

$\mathrm{Na}$ Instrumentalização, o papel docente se destaca, pois é ele o profissional habilitado para o trabalho. Aqui trata-se do momento para a aprendizagem. Quando 
deverão ser adotados todos as técnicas e procedimentos pedagógicos necessários para que os alunos se apropriem de novos conteúdos.

O passo seguinte, a Catarse, é a expressão da apropriação desses novos conteúdos. Os alunos aqui devem ser capazes de lançar um novo olhar para a prática social inicial, uma síntese que una o conhecimento científico ao conhecimento cotidiano.

Por fim, a Prática Social final, é o resultado esperado em que os novos conhecimentos sejam apropriados de tal forma que a partir deles uma nova postura social diante dos objetos aprendidos seja incorporada. É a prática dos novos conhecimentos para além da sala de aula. Diante de novos saberes, o aluno então adota novas ações transformadoras em seu cotidiano. Lembrando que, quando se refere ao termo transformador no materialismo-histórico-dialético, trata-se de cunho revolucionário, portanto na perspectiva coletiva e não individual, uma transformação não apenas para que o aluno alcance novo status social a partir da apropriação de conhecimentos, mas para que ele seja um novo agente promotor de uma mudança social coletiva.

A partir desse método histórico-critico, é possível pensar uma proposta para Orientação Educacional também revolucionária. Considerando a complexidade teórica de proposição para um campo intelectual, mas também o caráter material do serviço de orientação educacional que já acontece nas escolas, para efeito deste trabalho e para compreensão das análises realizadas no capítulo posterior, serão apresentadas aqui as propostas de atividades para o serviço de orientação nas escolas.

A proposta de orientação educacional como campo intelectual tem em sua especificidade a promoção de relações dialéticas entre os sujeitos da escola, e entre eles e a sociedade, através de ações que privilegiem o coletivo, e sejam fundamentadas na unidade teoria e prática.

As relações dialéticas de que se trata, seriam as relações construídas pelo desvelamento da realidade. As ações que privilegiam o coletivo são aquelas que em detrimento do individualismo, busquem o desenvolvimento humano. E a unidade teoria e prática é a práxis, em as atividades são construídas a partir da realidade social para sua transformação.

Como proposta de atuação para a função de orientador educacional, como já foi explicitado neste trabalho, a orientação educacional deve ocorrer junto aos âmbitos 
pedagógico e administrativo da escola. Em ambos, as ações podem ser institucionais, junto ao corpo docente, discente, a redes sociais que circundam as instituições escolares na defesa dos direitos das crianças e adolescentes e a família.

A Secretaria de Educação de Estado do Distrito Federal apresenta um documento intitulado "Orientações Pedagógicas da Orientação Educacional” que tem como objetivo nortear a prática dos orientadores educacionais da rede pública do DF. O documento lançado em 2010, foi resultante de elaboração coletiva que envolveu os orientadores educacionais das escolas públicas atuantes na época. Ele representa a materialidade da atuação nas escolas do Distrito Federal. Ainda que não esteja aportado claramente em uma concepção pedagógica, serve aqui como base para o desenvolvimento dessa proposta, uma vez que é importante a compreensão de como a Pedagogia Histórico-crítica pode ser apropriada no campo.

As atividades a serem descritas tem então como inspiração as Orientações Pedagógicas para a Orientação Educacional do Distrito Federal, no que diz respeito as atribuições do cargo e os procedimentos específicos.

No âmbito pedagógico as ações institucionais da orientação educacional dizem respeito àquelas que viabilizem o trabalho pedagógico. A atividade aqui demanda o conhecimento da realidade da escola e as devidas intervenções. Dentro do método histórico-crítico, os procedimentos adotados para se conhecer a realidade da escola devem considerar quais são as concepções de educação que escola elegeu para seu trabalho, mais precisamente, qual a concepção de mundo, sociedade, homem e escola que é adotado pelo coletivo desde a equipe gestora escolar até aquela que é praticada em sala de aula pelo coletivo dos professores. A partir desse olhar, o orientador educacional, ou aquele que estiver exercendo a atividade, terá como desafio desvelar as contradições inerentes ao cotidiano. Como procedimento específico de trabalho, ele deverá elaborar coletas de dados, observar o cotidiano da escola, participar de todos os momentos coletivos, por exemplo. Em suas intervenções expor dialeticamente o que foi analisado, observado, buscando fazer com que o coletivo escolar possa contribuir nas soluções institucionais que viabilizem o trabalho pedagógico, inclusive no que disser respeito as condições de trabalho.

As ações junto ao corpo docente são aquelas que fomentam as atividades em sala de aula com o objetivo de se alcançar um fazer consciente do sujeito que a escola quer formar para uma nova sociedade mais humanizada. $\mathrm{O}$ trabalho orientador junto 
aos professores consiste em apresentar propostas em que as relações entre eles e especialmente os educandos sejam as mais dialéticas possíveis. Sendo assim, a atividade da orientação educacional nesse contexto deve se encarregar de desvelar as condições materiais dos professores e educandos e as relações destas com o processo de ensino e de aprendizagem.

Junto aos discentes, tradicionalmente a orientação educacional teve um papel de aconselhamento, muitas vezes individualizada. Para essa nova proposta de orientação, as ações junto aos alunos na escola devem priorizar o coletivo e as condições materiais dos ambientes que circundam esses estudantes. Ações que promovam o conhecimento dos alunos quanto a realidade que os cercam devem ser prioritárias em relação a qualquer tipo de atendimento individual e individualizante.

As redes sociais de atendimento e promoção dos direitos da criança e do adolescente devem ser de conhecimento de todos os agentes da escola. Entretanto, quem executa o serviço de orientação educacional, por incumbência do cargo, uma vez que cada agente na escola pode estar mais focado em determinadas atribuições, deve estar atento as necessidades de se acionar a rede.

Assim, a orientação educacional na perspectiva da Pedagogia Histórico-crítica se apropriar das contradições existentes no sistema educacional e nos demais sistemas em que ele está inserido do micro ao macro, para que se empenhe em oferecer as devidas orientações aos sujeitos das escolas considerando a perspectiva de uma educação para uma transformação revolucionária. 


\section{CAPÍTULO 3 - ORIENTAÇÃO EDUCACIONAL NAS REDES PÚBLICAS ESTADUAIS DE ENSINO NO BRASIL}

Este capítulo tem como objetivo identificar e analisar as demandas dos sistemas de ensino estaduais públicos referente à Orientação Educacional previstas nos editais de concurso que preveem a Orientação Educacional.

\section{1 - Conhecendo a Orientação Educacional nas Redes Públicas de Ensino}

As questões que orientaram esta análise foram: Onde está prevista a presença da Orientação Educacional? Quem atua? Quais são as atividades? Qual a formação exigida? Qual a carreira que abriga o Serviço de Orientação Educacional?

Para começar a responder, serão apresentados primeiramente os resultados de uma pesquisa divulgada na Educação em Revista de Belo Horizonte no ano de 2008, elaborada por Miriam Pascoal, Eliane Costa Honorato e Fabiana Aparecida de Albuquerque. O motivo desta apresentação deve-se ao fato de esta ser ainda a última pesquisa em termos quantitativos a respeito da presença do orientador educacional nas redes estaduais do Brasil.

A pesquisa partiu de um "levantamento, tipo survey, que é a pesquisa que busca informação diretamente com um grupo de interesse a respeito dos dados que se deseja obter" (PASCOAL, p.113, 2008). O levantamento foi realizado via telefone e o objetivo foi

[...] fazer um mapeamento sobre a existência da Orientação Educacional nos diferentes estados brasileiros. Para isso, dividimos a busca por regiões: Região Norte: Acre, Amapá, Amazonas, Pará, Rondônia, Roraima, Tocantins. Região Nordeste: Maranhão, Piauí, Ceará, Rio Grande do Norte, Paraíba, Pernambuco, Alagoas, Sergipe, Bahia. Região Centro-Oeste: Mato Grosso, Mato Grosso do Sul, Goiás, Distrito Federal. Região Sul: Rio Grande do Sul, Santa Catarina, Paraná Região Sudeste: São Paulo, Rio de Janeiro, Espírito Santo, Minas Gerais. (PASCOAL, p.114, 2008)

Os resultados apontaram que dos 26 estados mais o Distrito Federal, 13 possuem o orientador educacional na sua rede escolar estadual, o que significa dizer que há presença do profissional em $48,14 \%$ das redes estaduais brasileiras. 
Segundo a pesquisa, os estados que contam com Orientador Educacional na rede pública estadual de ensino são:

1. Região Norte: Amazonas, Roraima, Rondônia, Amapá, Tocantins;

2. Região Nordeste: Maranhão, Piauí, Paraíba;

3. Região Centro-Oeste: Distrito Federal;

4. Região Sudeste: Minas Gerais, Rio de Janeiro, Espírito Santo;

5. Região Sul: Paraná e Rio Grande do Sul.

Contudo, percebe-se que apesar da relevância dessa pesquisa esta não abrangeu os sistemas de ensino municipais no Brasil, pois nesta pesquisa não se incluíram as redes municipais de ensino e a as redes particulares. Muito há que pesquisar quanto a esse campo de atuação e nossa pesquisa também não pode verificar os municípios dado o limite temporal do mestrado para o estudo.

A partir da verificação de editais de concursos públicos para atuação em Orientação Educacional realizados entre os anos de 2010 até a presente data, encontrados a partir de levantamento junto aos sítios virtuais das respectivas secretarias de educação e, o sítio virtual do jornal de circulação nacional "Folha Dirigida" que tem como objetivo principais divulgar concursos públicos realizados em todo o Brasil, identificou-se que, dos treze sistemas de ensino citados na pesquisa de Pascoal, sete apresentaram uma certa regularidade na realização de concurso público nos últimos cinco anos para preenchimento de vaga para cargo que executa funções relativas a função de Orientação Educacional.

No percurso da pesquisa, primeiramente foram buscados editais das redes estaduais que estivessem recrutando Orientadores Educacionais a partir das palavras chaves: Orientador Educacional, Orientação Educacional. Tais buscas não tiveram retorno diretamente equivalente às palavras citadas, entretanto, foram encontrados editais gerais de recrutamento para composição de quadros de pessoal para as secretarias de educação. Ao analisar tais editais é que foram encontradas vagas para atuação em cargos que inferimos existir o requerimento de conhecimentos que seriam imprescindíveis no campo da Orientação Educacional. 
Considerando então a diferença entre, orientação e orientador, significa que essas redes estaduais, em sua maioria, não têm orientador educacional em suas escolas, mas apresentaram a demanda para a função de orientação.

Os estados que realizaram concurso para essa demanda são: Amazonas, Rondônia, Distrito Federal, Minas Gerais, Espírito Santo, Paraná e Rio Grande do Sul. Apenas dois deles contrataram Orientadores Educacionais, ou seja, aquele que irá exercer somente o Serviço de Orientação Educacional: Distrito Federal e Minas Gerais; os demais contrataram para o Serviço e outras atribuições geralmente facultadas ao Pedagogo.

O quadro a seguir apresenta as nomenclaturas dos cargos expressos nos editais de cada estado, que exigem conhecimentos do campo da Orientação Educacional:

\section{Quadro 5 - Cargos encontrados nos Editais dos sistemas estaduais de educação} 2010-2014

\begin{tabular}{|c|c|c|}
\hline REGIÃO & $\begin{array}{c}\text { DATA DO } \\
\text { EDITAL }\end{array}$ & NOMENCLATURA DO CARGO \\
\hline $\begin{array}{c}\text { NORTE } \\
\text { Amazonas }\end{array}$ & 2011 & Pedagogo \\
\hline $\begin{array}{c}\text { Rondônia } \\
\text { CENTRO- } \\
\text { OESTE }\end{array}$ & 2013 & \\
\hline $\begin{array}{c}\text { Distrito Federal } \\
\text { SUDESTE }\end{array}$ & 2014 & Pedagogo-Orientador Escolar \\
\hline Minas Gerais & 2011 & Especialista em educação Orientação Educacional \\
\hline Espírito Santo & 2010 & Pedagogo \\
\hline $\begin{array}{c}\text { SUL } \\
\text { Paraná }\end{array}$ & 2013 & Professor - Pedagogo \\
\hline $\begin{array}{c}\text { Rio Grande do } \\
\text { Sul }\end{array}$ & 2013 & Matérias Pedagógicas \\
\hline
\end{tabular}

Fonte: Editais dos concursos. Elaboração da autora (2015). 
Os estados que realizaram recrutamento para Pedagogos, incluindo Rondônia, foram selecionados para esta pesquisa porque na descrição das atribuições dos cargos ou no "requisito" e "exigência" para o cargo, apontam atividades inerentes ao serviço de orientação educacional ou requereram alguma formação específica área de orientação educacional.

Quanto à formação então, os editais apontam para as seguintes exigências, expressando a graduação, para qual foi usado o termo 'base' (formação inicial) e utilizando o termo 'terminalidade' (formação continuada) para apresentar a complementação necessária, assim como veio descrito nos editais que exigiram pósgraduação ou habilitação específica.

\section{Quadro 6 - Formações exigidas nos editais}

\begin{tabular}{|c|c|c|}
\hline Estado & $\begin{array}{c}\text { Formação } \\
\text { Inicial }\end{array}$ & Formação Continuada \\
\hline Amazonas e Paraná & Pedagogia & - \\
\hline Distrito Federal & Pedagogia & Habilitação ou pós-graduação em $\mathrm{OE}$ \\
\hline Espírito Santo & Pedagogia & $\begin{array}{l}\text { Habilitação em Supervisão ou OE ou } \\
\text { administração escolar, ou inspeção } \\
\text { escolar, ou pós-graduação lato sensu } \\
\text { nas mesmas áreas. }\end{array}$ \\
\hline \multirow[t]{2}{*}{ Minas Gerais } & Pedagogia & Habilitação ou pós-graduação em OE \\
\hline & Licenciatura & Pós-graduação em OE \\
\hline Rio Grande do Sul & Pedagogia & Pós-graduação em Supervisão ou OE \\
\hline \multirow[t]{2}{*}{ Rondônia } & Pedagogia & Habilitação ou pós-graduação em $\mathrm{OE}$ \\
\hline & Bacharel & Complementação Pedagógica \\
\hline
\end{tabular}

Fonte: Editais de concurso. Elaborado pela pesquisadora, 2015

Verifica-se que, com exceção de dois estados, há uma prevalência da exigência de pós-graduação. Apesar dos editais admitirem a habilitação em Orientação Educacional, antes abrigada nos cursos de Pedagogia, a pós-graduação em Orientação Educacional é o curso que forma em última instância para o exercício das atividades 
em Orientação Educacional, segundo demanda da maioria dos sistemas de ensino público estaduais do país.

Descrevemos sumariamente a seguir as registradas nos editais de cada estado:

Quadro 7 - Atribuições dos cargos

\begin{tabular}{|c|c|}
\hline ESTADO & ATRIBUIÇÕES DOS CARGOS \\
\hline $\begin{array}{l}\text { Amazonas } \\
\text { (E1) }\end{array}$ & $\begin{array}{l}\text { Formular, orientar, acompanhar, fiscalizar e executar propostas pedagógicas, } \\
\text { no ensino público estadual. Atuar nas áreas de administração, supervisão e } \\
\text { inspeção escolar. Atuar nas áreas de planejamento, orientação e psicopedagogia } \\
\text { educacional. Cooperar com as atividades docentes. Participar na elaboração } \\
\text { da proposta pedagógica das unidades escolares, objetivando garantir o } \\
\text { efetivo desempenho das ações e da qualidade do ensino. }\end{array}$ \\
\hline $\begin{array}{l}\text { Rondônia } \\
\text { (E2) }\end{array}$ & $\begin{array}{l}\text { Direção escolar, a administração, a avaliação, o planejamento, a pesquisa, a } \\
\text { orientação, a supervisão, a inspeção, a assistência técnica, o assessoramento em } \\
\text { assuntos educacionais, chefia, coordenação, acompanhamento e controle de } \\
\text { resultados educacionais e outras similares na área de educação, compreendendo } \\
\text { as seguintes especificações: I - no âmbito escolar: a) administrar, planejar, } \\
\text { organizar, coordenar, controlar e avaliar atividades educacionais junto ao } \\
\text { corpo técnico - pedagógico, docente e discente, fora da sala de aula, } \\
\text { desenvolvidas na unidade escolar; b) planejar, orientar, acompanhar e avaliar } \\
\text { atividades pedagógicas nas unidades escolares, promovendo a integração } \\
\text { entre as atividades, áreas de estudos e/ou disciplinas que compõem o } \\
\text { currículo, bem como o contínuo aperfeiçoamento do processo de } \\
\text { ensino/aprendizagem, propondo treinamento e aperfeiçoamento do pessoal, } \\
\text { aprimoramento dos recursos de ensino/aprendizagem e melhoria dos } \\
\text { currículos; e c) planejar, acompanhar e avaliar a participação do aluno no } \\
\text { processo ensino/aprendizagem envolvendo a comunidade escolar e a família } \\
\text { nesse acompanhamento; }\end{array}$ \\
\hline $\begin{array}{l}\text { Distrito } \\
\text { Federal } \\
\text { (E3) }\end{array}$ & $\begin{array}{l}\text { Planejar, coordenar, implementar e avaliar o desenvolvimento de projetos } \\
\text { pedagógicos/institucionais, aplicando metodologias e técnicas para facilitar o } \\
\text { processo de ensino-aprendizagem e desenvolvimento integral dos estudantes; } \\
\text { atuar em todas as etapas/modalidades da Educação Básica para atender as } \\
\text { necessidades dos estudantes, acompanhando e avaliando os processes } \\
\text { educacionais, viabilizar o trabalho coletivo, criando e organizando mecanismos } \\
\text { de participação em programas e projetos educacionais, facilitando o processo } \\
\text { comunicativo entre a comunidade escolar e as associações a ela vinculadas, } \\
\text { participar de programas de desenvolvimento que envolvam conteúdos relativos à } \\
\text { área de atuação ou neles atuar; executar outras atividades de interesse da área. } \\
\text { Descrição detalhada: Participar do processo de elaboração do Projeto Político } \\
\text { Pedagógico da unidade escolar; elaborar, anualmente, plano de ação das } \\
\text { atividades do Serviço de Orientação Educacional; participar das coordenações } \\
\text { pedagógicas visando à organização do trabalho pedagógico da unidade escolar; } \\
\text { implantar e implementar o Serviço de Orientação Educacional na unidade } \\
\text { escolar; identificar os fatores que interferem no processo de ensino- } \\
\text { aprendizagem; assessorar a equipe técnico-pedagógica no que se refere ao }\end{array}$ \\
\hline
\end{tabular}




\begin{tabular}{|c|c|}
\hline & $\begin{array}{l}\text { processo de ensino-aprendizagem; coordenar o processo de informação } \\
\text { educacional e profissional visando à inserção para o mundo do trabalho; } \\
\text { coordenar ações voltadas para a orientação sexual e para a prevenção ao uso } \\
\text { indevido de drogas; integrar a comunidade no processo educativo; supervisionar } \\
\text { estágio na área de orientação educacional; articular as ações vinculadas à saúde } \\
\text { do educando; participar da identificação e/ou encaminhamento de estudantes que } \\
\text { apresentem dificuldades no processo de ensino e aprendizagem; apoiar } \\
\text { segmentos escolares, conselho de classe, grêmio estudantil, conselho de } \\
\text { segurança e Associação de Pais e Mestres; planejar e executar projetos que visem } \\
\text { à melhoria do contexto escolar e o processo de desenvolvimento humano, na } \\
\text { perspectiva do Projeto Político Pedagógico da unidade escolar; articular ações em } \\
\text { parceria com as Redes Sociais e outros setores da SEDF, favorecendo o } \\
\text { desenvolvimento integral do estudante; cumprir as normas de segurança do } \\
\text { trabalho, de forma a evitar acidentes no ambiente laboral; participar de programas } \\
\text { de formação continuada, como aluno ou como formador, com o objetivo de } \\
\text { reelaborar os saberes iniciais da formação docente e de fomentar práticas } \\
\text { educativas para a melhoria da qualidade social do ensino; estimular o respeito aos } \\
\text { valores, às instituições e às práticas políticas do país; elaborar e apresentar } \\
\text { relatórios periódicos; fornecer dados estatísticos de suas atividades; emitir } \\
\text { parecer técnico sobre assuntos de sua competência; assessorar atividades } \\
\text { específicas da especialidade; observar normas de higiene e segurança do trabalho; } \\
\text { zelar pela guarda, conservação e manutenção de materiais e equipamentos; } \\
\text { executar outras atividades de mesma natureza e nível de complexidade. }\end{array}$ \\
\hline $\begin{array}{l}\text { Minas } \\
\text { Gerais } \\
\text { (E4) }\end{array}$ & $\begin{array}{l}\text { Exercer em unidade escolar a supervisão do processo didático como elemento } \\
\text { articulador no planejamento, no acompanhamento, no controle e na avaliação das } \\
\text { atividades pedagógicas, conforme o plano de desenvolvimento pedagógico e } \\
\text { institucional da unidade escolar; - atuar como elemento articulador das relações } \\
\text { interpessoais internas e externas da escola que envolvam os profissionais, os } \\
\text { alunos e seus pais e a comunidade; - planejar, executar e coordenar cursos, } \\
\text { atividades e programas internos de capacitação profissional e treinamento em } \\
\text { serviço; - participar da elaboração do calendário escolar; - participar das } \\
\text { atividades do Conselho de Classe ou coordená-las; - exercer, em trabalho } \\
\text { individual ou em grupo, a orientação, o aconselhamento e o encaminhamento de } \\
\text { alunos em sua formação geral e na sondagem de suas aptidões específicas; - atuar } \\
\text { como elemento articulador das relações internas na escola e externas com as } \\
\text { famílias dos alunos, comunidade e entidades de apoio psicopedagógicos e como } \\
\text { ordenador das influências que incidam sobre a formação do educando; - exercer } \\
\text { atividades de apoio à docência; - exercer outras atividades integrantes do plano } \\
\text { de desenvolvimento pedagógico e institucional da escola, previstas no } \\
\text { regulamento desta lei e no regimento escolar. }\end{array}$ \\
\hline $\begin{array}{l}\text { Espírito } \\
\text { Santo } \\
\text { (E5) }\end{array}$ & $\begin{array}{l}\text { Administrar, planejar, organizar, coordenar, controlar e avaliar atividades } \\
\text { educacionais, junto ao corpo técnico - pedagógico, docente e discente, fora da } \\
\text { sala de aula, desenvolvidas na unidade escolar; planejar, orientar, acompanhar e } \\
\text { avaliar atividades pedagógicas nas unidades escolares, promovendo a integração } \\
\text { entre as atividades, áreas de estudos e/ou disciplinas que o compõem o currículo, } \\
\text { bem como o contínuo aperfeiçoamento do processo ensino - aprendizagem, } \\
\text { propondo treinamento e aperfeiçoamento do pessoal, aprimoramento dos recursos } \\
\text { de ensino-aprendizagem e melhoria dos currículos; planejar, acompanhar e } \\
\text { avaliar a participação do aluno no processo ensino - aprendizagem envolvendo a }\end{array}$ \\
\hline
\end{tabular}


comunidade escolar, e a família nesse acompanhamento; desenvolver outras atividades correlatas.

Paraná Atividades de Suporte Pedagógico direto à docência na Educação Básica, (E6) voltadas para planejamento, administração, supervisão e orientação educacional, incluindo, entre outras, as seguintes atribuições: coordenar a elaboração e execução da proposta pedagógica da escola; administrar o pessoal e os recursos materiais e financeiros da escola, tendo em vista o atingimento de seus objetivos pedagógicos; assegurar o cumprimento dos dias letivos e horasaula estabelecidas; zelar pelo cumprimento do plano de trabalho dos docentes; prover meios para a recuperação dos alunos de menor rendimento; promover a articulação com as famílias e a comunidade, criando processos de integração da sociedade com a escola; informar os pais ou responsáveis sobre a frequência e o rendimento dos alunos, bem como sobre a execução da proposta pedagógica da escola; coordenar, no âmbito da escola, as atividades de planejamento, avaliação e desenvolvimento profissional; acompanhar e orientar o processo de desenvolvimento dos estudantes, em colaboração com os docentes e as famílias; elaborar estudos, levantamentos qualitativos e quantitativos indispensáveis ao desenvolvimento do sistema ou rede de ensino ou da escola; elaborar, implementar, acompanhar e avaliar planos, programas e projetos voltados para o desenvolvimento do sistema e/ou rede de ensino e da escola, em relação a aspectos pedagógicos, administrativos, financeiros, de pessoal e de recursos materiais; acompanhar e supervisionar o funcionamento das escolas, zelando pelo cumprimento da legislação e normas educacionais e pelo padrão de qualidade de ensino.

Rio Grande Não apresentou atribuições específicas para o cargo. do Sul

(E7)

Ao cruzar as informações quanto à formação exigida, nomenclatura dos cargos e atribuições, encontramos diferentes situações. Os estados do Amazonas e do Espírito Santo e Paraná apresentaram similaridades quanto ao elenco de uma diversidade de atribuições para um único profissional tendendo à intensificação. Apesar destes apresentarem as atribuições e indicar a formação de base parece considerar que o curso de Pedagogia forma o profissional apto a desenvolver todas as atividades de magistério na instituição escolar, questiona-se se a base docente está garantida para o exercício das funções descritas uma vez que de acordo com a legislação vigente o curso de Pedagogia e demais licenciaturas habilitam para a docência, porém, apresenta ainda limitações quanto ao trato curricular com o campo pedagógico e, principalmente, relativos aos conteúdos da gestão escolar e educacional, aspectos já debatidos neste trabalho. Esses conteúdos aparecem fortemente nos respectivos editais interligados ao serviço de orientação. 
Nessa mesma linha o apontamento para o exercício de tantas atribuições ("Formular, orientar, acompanhar, fiscalizar e executar propostas pedagógicas, no ensino público estadual. Atuar nas áreas de administração, supervisão e inspeção escolar “- E1, por exemplo) e atividades pode levar a intensificação do trabalho, e revelar também a tendência do sistema educacional em delegar a apenas um profissional uma série de funções para que não haja a necessidade de contratar mais profissionais para a escola, deixando a cargo de apenas uma pessoa todo o trabalho, economizando em mão-de-obra e explorando o trabalho. No edital referente ao estado do Paraná verifica-se agravante do acúmulo de atividades administrativo-financeiras e não pedagógicas como as seguintes informações a respeito das atribuições revelam: administrar o pessoal e os recursos materiais e financeiros da escola, tendo em vista o atingimento de seus objetivos pedagógicos, elaborar, implementar, acompanhar e avaliar planos, programas e projetos voltados para o desenvolvimento do sistema e/ou rede de ensino e da escola, em relação a aspectos pedagógicos, administrativos, financeiros, de pessoal e de recursos materiais. Ainda que essas atividades tenham sido descritas como voltadas aos aspectos pedagógicos e para seu objetivo, é redundante afirmá-las assim, pois todo trabalho na escola é necessariamente com fins pedagógicos. Por mais que atinjam os objetivos pedagógicos e assim possam ser desempenhadas por pedagogos, a questão é o número de atribuições que se acumula para um único profissional executar. Essas características parecem indicar ainda este Pedagogo para atuar no serviço de orientação educacional nos sistemas de ensino como na escola.

Já em Rondônia o estado não considera imprescindível a formação em uma base docente, acreditando que uma formação complementar, mesmo para um bacharel, seja o suficiente para alocar o profissional na educação básica. De acordo com a legislação vigente, por exemplo, a lei da regulamentação da profissão de orientador e a própria LDBEN em seu artigo.64, é direito do estado fazer essa opção. A complementação pedagógica de que trata o edital, apresentado no quadro 6 no campo "terminalidade" é a segunda graduação, legalmente ela habilita para o exercício da docência, quando essa segunda graduação se tratar de cursos de licenciatura. Depreende-se ainda que este estado prevê a presença do serviço educacional realizado por um orientador do qual se exige a formação específica em pós-graduação, contudo 
ele não será contratado como orientador enquanto cargo claramente denominado como tal e, consequentemente, para uma carreira proposta definida também de forma clara.

O ente federado que pareceu estar atento às mudanças na legislação e opta pelo profissional com formação na base docente, por meio do curso de Pedagogia, que historicamente abrigou a orientação educacional, foi o do Distrito Federal. O profissional é chamado para desempenhar atividades específicas da orientação educacional. Este, então, parece ter um local claro de atuação prevista pelo edital, uma vez que no Regimento Geral da Secretaria de Estado da Educação do Distrito Federal as escolas podem contar ainda com supervisores e coordenadores pedagógicos pertencentes ao quadro do magistério. O recrutamento de supervisores e coordenadores não se dá por concurso específico. Eles assumem os cargos pela via da docência em sala de aula. Em todos os níveis os supervisores são escolhidos dentro do quadro de professores pela direção da escola. Os coordenadores são eleitos anualmente pela equipe de professores que elege um colega professor para exercer a função. Não é exigida formação complementar à licenciatura que esses professores já apresentaram quando do concurso para sua área específica. A questão aqui é: por que orientadores educacionais são recrutados por concurso específico? Uma resposta possível se dá pela tradição historicamente estabelecida pelo estado, em que nem sempre os orientadores educacionais pertenceram ao quadro do magistério, e sim ao quadro da carreira de assistência a educação, sendo eles profissionais com reconhecimento legal de suas profissões.

O estado de Minas Gerais seleciona profissionais com base docente, pedagogos, entretanto, a nomenclatura ainda o afirma como especialista. Essa denominação foi duramente criticada, durante os anos de 1980 nas discussões a respeito da reformulação dos cursos de Pedagogia por caracterizar a divisão técnica do trabalho considerando então, o trabalho dos especialistas como o trabalho intelectual e o dos professores como trabalho manual ressaltando assim, uma dualidade entre teoria e prática. Essa questão é amplamente discutida principalmente desde a luta contra o regime militar e suas políticas educacionais aqui no Brasil. È, então, muito problemático esse sentido de especialista ainda permear um edital publicado em pleno século XXI no qual tanto já se debateu e se propôs a unidade teoria-prática na formação dos profissionais da educação. 
O edital do Rio Grande do Sul - estado que abriga a primeira Associação de Orientadores Educacionais do país -, não apontou nomenclatura que explicitasse a demanda por Pedagogos com pós-graduação em orientação ou supervisão educacional. Também não apresentou descrição do cargo. No anexo do edital em que deveriam ser descritas as atividades dos cargos, encontra-se apenas a descrição do cargo de professor que atuará em sala de aula. O que denuncia a atividade de supervisão e de orientação educacional é a demanda pela formação específica e os conteúdos exigidos para as provas objetivas do concurso.

Quanto à carreira que abriga a de orientação educacional todos os sete estados o posicionam na carreira do magistério, mesmo Rondônia que também admite bacharéis para o serviço. Apesar de quase óbvio, pelo fato de todos admitirem Pedagogos, e hoje o curso de Pedagogia ter uma base docente e, portanto, ser inequivocamente pertencente ao magistério, esse dado quanto a carreira merece ser citado, pois nem sempre o orientador educacional foi considerado pertencente a mesma carreira dos professores. Entretanto, o salário inicial pode variar em função da carga horária e da formação exigida.

Essa mudança nos planos de carreira do magistério das redes de ensino está prevista na a LDB 9394/96 que considera como funções de magistério também as exercidas por especialistas em educação, como eram chamados os orientadores educacionais:

\footnotetext{
Art. 67. Os sistemas de ensino promoverão a valorização dos profissionais da educação, assegurando-lhes, inclusive nos termos dos estatutos e dos planos de carreira do magistério público: [...] $\S 2^{\circ}$ Para os efeitos do disposto no $\S 5^{\circ}$ do art. 40 e no $\S 80$ do art. 201 da Constituição Federal, são consideradas funções de magistério as exercidas por professores e especialistas em educação no desempenho de atividades educativas, quando exercidas em estabelecimento de educação básica em seus diversos níveis e modalidades, incluídas, além do exercício da docência, as de direção de unidade escolar e as de coordenação e assessoramento pedagógico. (Incluído pela Lei no 11.301, de 2006). (BRASIL, 1996)
}

Quanto ao trabalho propriamente dito e as atribuições designadas ao profissional pretendido pelos editais, as análises a seguir buscaram identificar quais os pressupostos teóricos e filosóficos subjacentes às demandas específicas da orientação educacional. O quadro abaixo apresenta os elementos chaves referentes a atuação no campo da Orientação Educacional e junto à instituição escolar, aos docentes, aos 
discentes, à família e a redes sociais. Os elementos chaves elencados foram selecionados para condensar o quadro de atribuições e direcionar a análise para este trabalho. As palavras foram recortadas tal qual estão nos editais.

Quadro 8 - Ações previstas pelos editais referentes à Orientação Educacional

\begin{tabular}{|c|c|c|c|c|c|}
\hline ESTADO & INSTITUIÇÃO & DOCENTE & DISCENTE & FAMÍLIA & REDES \\
\hline AM & $\begin{array}{l}\text { Propostas } \\
\text { pedagógicas. }\end{array}$ & Cooperar & & & \\
\hline RO & Assessoramento & $\begin{array}{l}\text { Atividades } \\
\text { educacionais. } \\
\text { Treinamento } \\
\text { aperfeiçoamento. }\end{array}$ & $\begin{array}{l}\text { Processo } \\
\text { ensino/aprendizagem }\end{array}$ & Envolver & \\
\hline DF & $\begin{array}{l}\text { Projeto Político } \\
\text { Pedagógico }\end{array}$ & $\begin{array}{l}\text { Coordenações } \\
\text { pedagógicas. } \\
\text { Assessorar } \\
\text { processo de ensino- } \\
\text { aprendizagem. } \\
\text { Formação } \\
\text { continuada. }\end{array}$ & $\begin{array}{l}\text { Processo de ensino- } \\
\text { aprendizagem. } \\
\text { Informação } \\
\text { educacional } \\
\text { profissional. } \\
\text { Orientação sexual. } \\
\text { Prevenção ao uso } \\
\text { indevido de drogas. } \\
\text { Saúde do educando. } \\
\text { Dificuldades no } \\
\text { processo de ensino e } \\
\text { aprendizagem. }\end{array}$ & Integrar & $\begin{array}{ll}\text { Articular } & \\
\text { ações } & \text { em } \\
\text { parceria }\end{array}$ \\
\hline MG & $\begin{array}{l}\begin{array}{l}\text { Supervisionar o } \\
\text { processo didático. }\end{array} \\
\text { Articulador. } \\
\text { Atividades } \\
\text { pedagógicas. }\end{array}$ & $\begin{array}{l}\begin{array}{l}\text { Articulador } \\
\text { relações }\end{array} \\
\text { interpessoais. } \\
\text { Capacitação } \\
\text { profissional } \\
\text { treinamento } \\
\text { serviço. } \\
\text { Conselho de Classe }\end{array}$ & $\begin{array}{l}\text { Aconselhamento e o } \\
\text { encaminhamento. } \\
\text { Sondagem de } \\
\text { aptidões específicas. } \\
\text { Ordenar as } \\
\text { influências que } \\
\text { incidam sobre a } \\
\text { formação. }\end{array}$ & $\begin{array}{l}\text { Articular as } \\
\text { relações da } \\
\text { escola com a } \\
\text { família. }\end{array}$ & $\begin{array}{l}\text { Articular as } \\
\text { relações com } \\
\text { a } \\
\text { comunidade } \\
\text { e entidades } \\
\text { de apoio } \\
\text { psicopedagó } \\
\text { gicos. }\end{array}$ \\
\hline ES & & $\begin{array}{l}\text { Atividades } \\
\text { educacionais. } \\
\text { Treinamento } \\
\text { aperfeiçoamento do }\end{array}$ & $\begin{array}{l}\text { Processo ensino - } \\
\text { aprendizagem }\end{array}$ & $\begin{array}{l}\text { Envolver } \\
\text { comunidade } \\
\text { escolar, e a } \\
\text { família no } \\
\text { acompanham }\end{array}$ & \\
\hline
\end{tabular}




\begin{tabular}{|l|l|l|l|l|l|}
\hline PR & $\begin{array}{l}\text { Elaborar estudos, } \\
\text { levantamentos } \\
\text { qualitativos } \\
\text { quantitativos } \\
\text { indispensáveis ao } \\
\text { desenvolvimento } \\
\text { do sistema ou rede } \\
\text { de ensino ou da } \\
\text { escola. }\end{array}$ & $\begin{array}{l}\text { Desenvolvimento } \\
\text { dos estudantes. }\end{array}$ & Articulação & Articulação \\
\hline
\end{tabular}

Fonte: Editais de concurso. Elaborado pela pesquisadora, 2015

$\mathrm{O}$ estado do Amazonas é o mais sucinto quanto a atividades do campo da orientação. Os elementos selecionados indicam ações relacionadas a atuação institucional e junto aos docentes. O título da vaga e a formação corresponde diretamente a suas atribuições. Entretanto ao incluir a orientação educacional na descrição sumária das atribuições no edital, o conjunto de ações previstas indica que de fato a formação em Pedagogia é legalmente suficiente para o cargo, porém questiona-se mais uma vez se o curso de Pedagogia realmente seria suficiente para atender essas atribuições.

Sendo este também o caso do Paraná. O edital do estado ainda inclui a necessidade de articulação com a família e redes sociais, sendo estas atividades caracteristicamente desempenhadas na orientação educacional.

Rondônia apresenta maior especificidade do campo de orientação educacional. O assessoramento institucional, suporte aos professores, inclusive formativo, acompanhamento do processo de aprendizagem dos alunos e a demanda por envolver a família nesse processo, são atividades da orientação educacional. A formação exigida para o cargo inclui a possibilidade de um bacharel assumir a vaga. Ainda que com a devida complementação pedagógica, como já foi defendido neste trabalho, não se julga suficiente para uma atuação comprometida com a especificidade pedagógica. A descrição das atividades não é coerente com essa possibilidade. Um profissional que assuma o cargo tendo sua formação inicial no bacharelado, tenderá a ter dificuldades no seu fazer pedagógico.

O Distrito Federal apresenta uma descrição detalhada das atribuições. O recorte da tabela ainda que sucinto, indica a previsão de atuação em todos os contextos, desde o institucional até as redes sociais. A formação exigida e o cargo são coerentes com as 
atividades previstas. Entretanto, chamamos a atenção para o fato de que numa nova proposta de orientação educacional, as atividades junto aos discentes podem não ser preponderantes, pois acredita-se que intervenções junto a instituição, docentes, família, e rede social, numa perspectiva coletiva, integradora, podem ser mais efetivas para a vida do educando do que necessariamente intervenções pontuais junto aos mesmos.

Minas Gerais, estado que ainda neste edital chama de os" especialistas”, e admite licenciados para o cargo, também aponta a atuação junto a todas as instâncias aqui consideradas como contextos de atuação da orientação educacional. As ações junto aos discentes indica um caráter tradicional na proposta de orientação, quando ainda considera a sondagem de aptidões, e cita o ordenamento das influências sobre a formação dos alunos, elementos tão criticados neste trabalho. De fato, que a nomenclatura do cargo, a exigência formativa e as atividades propostas, estão coerentes entre elas neste edital, contudo, não se faz coerente a emergência de uma nova proposta de orientação educacional como foi defendido neste trabalho.

O Espírito Santo admite o Pedagogo com especialização diversa: supervisão, orientação, administração ou inspeção. Quanto a formação exigida, as atribuições, e a nomenclatura do cargo, o edital é coerente. Apenas quanto a atividade de envolver a comunidade e a família no acompanhamento escolar, é questionável uma formação fora da orientação educacional que se refira diretamente a essa atividade.

A análise dos editais permitiu-nos elaborar uma síntese a partir de quatro categorias que emergiram a partir do objeto e da questão central:

1- Há uma dispersão da tarefa do orientador educacional nas demandas do edital

A dispersão nas atividades do profissional escolar, na perspectiva aqui apresentada, é pouco conhecida. Não tem aparecido nas pautas dos debates ou críticas nos eventos sobre educação, entretanto, há, na área da educação, uma considerável literatura sobre a ação docente e o cotidiano escolar. Essas contribuições, embora se refiram às diferentes e múltiplas atividades que integram o campo de atuação dos professores, não mencionam como o fazemos, o caso da dispersão no trabalho docente. Para tanto, oportuno se faz iniciarmos este estudo conceituando dispersão. Nos dicionários e outras fontes, os significados atribuídos ao termo dispersão remetem à ideia de fragmentação, divisão, desvio. Dispersivo é aquele que não se concentra no que faz (Dicionário Aurélio). 
Assim, dispersão no trabalho docente além de fragmentação, significa também, gerir vários desafios/tarefas ao mesmo tempo. É como um modo de vida e trabalho. Nessa perspectiva, diz respeito a uma condição do trabalho docente. A dispersão, assim, entendida é uma condição negativa do trabalho docente, em que o sujeito desempenha várias atividades. Sua intensidade dá ao sujeito um sentimento de cansaço e fragiliza seu trabalho.

A visão de orientação exposta nas demandas dos editais acumula as funções desempenhadas por esse profissional no passado e outras do processo educativo e da gestão escolar. Indica novamente uma função de "apagar o fogo" de "faz tudo", como, historicamente, fazia o orientador educacional, chamado nas ocasiões em que havia problema a ser solucionado ou para abafar os casos de indisciplina e agora de gestão e coordenação pedagógica, outras vezes de inspetor de alunos e de psicólogo. Hoje, além de conhecer o contexto socioeconômico e cultural da comunidade, bem como a realidade social mais ampla, o orientador educacional pode ser um profissional da educação encarregado de desvelar as forças e contradições presentes no cotidiano escolar e que podem interferir na aprendizagem. O que poderia significar avanço sobrecarrega a função e deixa o profissional sem foco de trabalho.

2- Nesse sentido também pode se inferir sobre a intensificação do trabalho do orientador educacional

O ensino público vem sofrendo os efeitos da precarização e intensificação do trabalho docente ao longo dos anos e pouco tem mudado nesse aspecto a realidade das escolas públicas. Hypólito, Vieira e Pizzi (2009 p. 105) explicam o processo de intensificação no trabalho docente

implica uma sensação crônica e persistente de sobrecarga de trabalho que sempre parece estar aumentando, mais e mais tem para ser feito e menos tempo existe para fazer o que deve ser feito. Isso reduz áreas de decisão pessoal, inibe envolvimento e controle sobre planejamento de longo prazo, aumentando a dependência a materiais externos e a técnicos especialistas também externos ao trabalho, o que provoca um aumento da separação entre concepção e execução, entre planejamento e desenvolvimento; 
As condições nas quais os orientadores educacionais docentes desenvolvem suas atividades é amplamente precária devido a diversificação das funções e também em relação aos recursos físicos, financeiros, materiais e sobre o corpo docente que atua nas escolas públicas, constata-se inexoravelmente uma distribuição regressiva dos recursos e um estado precaríssimo das condições de funcionamento destas escolas.

A análise dos editais em questão mostra uma intensificação pelo número e diversificação de tarefas, além disso, o número de vagas para a rede é reduzido, demostrando que um profissional irá atender diversas escolas.

3- A especialidade: confusão entre o específico da orientação e outras atividades/trabalhos na escola.

O Orientador Educacional, muitas vezes, não tem condições de realizar todas as tarefas que lhes são pertinentes, correndo o risco de tornar-se generalista, ou de esvaziar sua ação, a ponto de torná-la irrelevante na escola. A especialidade no campo educacional, como toda especialidade, só faz sentido na medida em que a área básica não seja perdida de vista. Entendemos que orientadores Educacionais são antes de tudo, professores, e a finalidade de toda e qualquer ação orientadora é educativa. Se a escola é uma instituição que tem por finalidade ensinar bem à totalidade dos alunos que a procuram, a orientação educacional tem por função fundamental mobilizar os diferentes saberes dos profissionais que atuam na escola, para que a escola cumpra a sua função: que os alunos aprendam. Partindo da condição comum de educadores, cada um desempenha tarefas específicas, capacitado pela habilitação específica, cujo sentido é dado pelos fins comuns.

Os editais trazem aspectos de outras funções como: supervisor, gestor e coordenador pedagógico atribuindo tarefas a um profissional específico. Referindo-se ao papel do Orientador Educacional, Silva (1981), relaciona, a partir da posição de diversos autores, alguns dos papéis a ele atribuídos, tais como: Especialista - prioridade ao aconselhamento psicopedagógico. • Generalista orientação de grupo, registro de alunos, sessões de aula, aplicação de testes, organização de classes, fichas cumulativas, etc. • Monitor - orientação centrada no aluno. • Assessor - orientação centrada no contexto. • Consultor e assessor - 
Assessoramento de pessoas e pequenos grupos, consultando professores, diretores, pais e outros. • Agente de mudança - revisão crítica. • Profissional de ajuda ajuda, assessoramento. • Catalizador - o indivíduo realizando seu próprio papel. • Conselheiro e guia pessoal do aluno. • Agente de informações sobre oportunidades educacionais e ocupacionais. • Orientador da vocação do aluno. • Mediador entre comunidade escolar e familiar. $\bullet$ Membro do grupo profissional.

\section{4- Identidade profissional}

A identidade social é "a representação que um indivíduo dá a si mesmo por pertencer a um grupo" (TAJFEL, 1972). Nesse sentido, ela é o fruto da interação dos mecanismos psicológicos e dos fatores sociais. Trata-se de processo social dinâmico, em contínua evolução, que se constrói por semelhança e oposição.

A identidade de um grupo repousa sobre uma representação social construída, sobre a qual uma coletividade toma consciência de sua unidade pela diferenciação dos outros (DUBAR, 1998), pois a vida no grupo cria um imaginário social. Dessa forma, a identidade social é constituída não somente pela representação que o indivíduo faz dele mesmo no seu ambiente social, referindo-se a diferentes grupos aos quais ele pertence, mas também aos grupos de oposição, aos quais ele não pertence, pois essa identidade é guiada pela necessidade do indivíduo de ser no mundo, assim como pela sua necessidade de pertencer a grupos sociais. Isso ocorre porque a definição do outro e de si mesmo é largamente relacional e comparativa.

Assim, a identidade não é algo que se possua, mas sim algo que se desenvolve durante a vida. A identidade não é um atributo fixo para uma pessoa, e sim um fenômeno relacional. O desenvolvimento da identidade acontece no terreno do intersubjetivo e se caracteriza como um processo evolutivo, um processo de interpretação de si mesmo como pessoa dentro de um determinado contexto. Sendo assim, a identidade pode ser entendida como uma resposta à pergunta "quem sou eu neste momento? " A identidade profissional não é uma identidade estável, inerente ou fixa. É resultado de um complexo e dinâmico equilíbrio onde a própria imagem como profissional tem que se harmonizar com uma variedade de papéis que os 
professores sentem que devem desempenhar. (BEIJAARD, MEIJER, \& VERLOOP, 2004).

A identidade do Orientador Educacional como um profissional, e o seu posicionamento frente à vida são fatores que caracterizam o desencadeamento do processo de Orientação. Se toda identificação profissional pressupõe reforço de valoração, supõe-se que o Orientador Educacional vivencie valores pessoais na sua atuação. Crenças, valores, atitudes da pessoa, ao serem associados com elementos comportamentais comuns a uma determinada profissão, delineiam um perfil profissional. O levantamento dos editais não demonstra essa identidade, pois estabelece funções não específicas e muitas vezes fora do contexto do trabalho do orientador educacional.

O Orientador Educacional, por sua vez, pode ficar confuso, principalmente em relação ao trabalho do coordenador pedagógico, como descrito nos diferentes editais. Talvez essa confusão se deva às razões históricas de seu surgimento ou razões funcionais pelo fato de sua categoria ser considerada uma semi-profissão assim como magistério, gerando conflitos de papéis e identidade. Dá-se o conflito de papéis quando o Orientador Educacional não consegue realizar o que é de sua competência e realiza atividades incompatíveis com sua formação.

Em síntese, dessa forma, após tecer algumas considerações e (re)flexões a partir desse estudo da orientação educacional a partir de suas demandas e funções analisadas a partir dos editais de concurso modificou-se com o tempo, mas não se modificou a essência da Orientação, que é ajudar o outro no seu projeto de vir- $a$ ser. Esse outro não é um indivíduo qualquer, mas uma pessoa, um ser humano real, concreto, histórico que se move na teia de relações que o sujeito e o pedagogo orientador educacional estão contextualizados, ou seja, a orientação educacional colabora com o individual, mas não deixando, em momento algum, de olhar para o individual inserido no coletivo, no político e no social.

Neste contexto, cabe ao trabalho do Pedagogo - orientador educacional, numa perspectiva crítica de atuação, viabilizar a discussão das relações entre educação e trabalho, tendo presente um projeto de educação que possibilite a formação para o trabalhador consciente, crítico, participativo, autônomo e apropriado do saber e do controle do seu trabalho. Nessa perspectiva, espera-se do profissional Orientador Educacional um trabalho que possibilite a formação da consciência crítica do 
aluno, considerando suas as experiências de vida e de trabalho nas discussões dos problemas sociais e culturais. A dimensão atual do trabalho do pedagogo orientador educacional tem apontado para a construção de um espaço coletivo junto aos demais profissionais da escola, na busca por desenvolver conjuntamente o estudo e a reflexão sistemática do fenômeno educativo. Nesta premissa, a gestão escolar que visa à emancipação necessita de apoio e trabalho conjunto de diferentes profissionais da educação, em suas diferentes frentes de atuação.

Com essas análises foi possível concluir que a orientação educacional ainda se faz presente na demanda dos sistemas de ensino, ainda que não necessariamente exercida por um orientador educacional. A maior contradição entre a legislação vigente e as demandas dos sistemas estaduais consiste no fato de que a orientação educacional atualmente não é relacionada a uma profissão, apesar de ser uma das duas profissões da educação oficialmente reconhecidas (a outra é de educador físico), pois todos licenciados podem exercer a função. A maior relação entre a legislação e a demanda, é que os estados pesquisados, em sua maioria, aderiram ao perfil do Pedagogo como aquele que detém conhecimento para exercer as funções do magistério. 


\section{CONSIDERAÇÕES}

A partir de uma prática social integrante dos processos de formação da pesquisadora, foi possível pensar em uma investigação que pretende trazer de volta um olhar para o Serviço de Orientação Educacional.

Olhar para o trabalho de Orientação Educacional não significa ratificá-lo dentro da tradição teórica que o introduziu no Brasil, nem a que o ainda o mantém no entendimento de uma perspectiva da divisão social do trabalho.

A elaboração do presente estudpo foi permeada por um movimento constante de revisão de seus objetivos até que as leituras puderam esclarecer o que de fato instiga este processo de pesquisa dentro de tantas inquietações: o 'o que é e o que ainda não é'. O que é o Serviço de Orientação Educacional? O que ele ainda não é? Para responder a estas questões foi necessário recorrer a mediações que desvelam, identificam e desconstroem elementos da aparência, e alcancem uma essência capaz de transformar o atual quadro de conhecimento no campo da Orientação Educacional, atentando para a condição concreta sob a qual a orientação educacional está submetida por expressar uma divisão entre trabalho intelectual e trabalho manual. O Serviço de Orientação Educacional pode se diferenciar, em muito, contemporaneamente para que não seja mais um agente de promoção do status quo.

Ao propor um novo olhar para a orientação educacional na perspectiva da Pedagogia histórico-crítica, está se pretendendo lançar uma perspectiva mais atualizada para a luta da escola pública. As desigualdades sociais que cercam os estudantes especialmente da escola pública, não são atuais, mas a imersão histórica no capitalismo cada mais desenvolvido sugere que essa luta está apenas começando, e que as forças contra-hegemônicas não podem deixar de pensar alternativas a essa sociedade, ainda que imbricadas nela.

A orientação educacional foi uma das marcas educacionais históricas do desenvolvimento do capitalismo no Brasil, entretanto, antes de julgá-la fadada a submeter-se a ele, seja por sua origem ou pelo que ainda vem sendo praticado, é possível fazer diferente. Assim como a escola foi considerada fadada a servir invariavelmente ao capital, e ainda assim conseguir forças para alcançar propostas subversivas a ele, a orientação educacional pode e deve ser ressignificada. 
Sua ressignificação demanda um esforço de reconceituação plena, para que a escola pública não perca determinados elementos que podem ser de importante relevância para o fazer pedagógico.

Também para ratificar a necessidade de trabalhadores do magistério que integrem o processo de ensino e de aprendizagem, a docência, e que não necessariamente estarão em sala de aula. Tais trabalhadores estarão a dar suporte para a sala de aula, para que as condições de trabalho do professor regente sejam cada vez mais favoráveis, e que os educandos tenham também o suporte devido da escola em seu desenvolvimento.

A pesquisa mostrou que há demanda para as atividades do magistério fora da sala de aula, e que as atribuições não são poucas nem simples. Exigem uma formação completa na docência. Essa formação ainda deverá ser questionada, pois as licenciaturas não a contemplam, a Pedagogia, apesar do avanço das suas diretrizes curriculares, pode ainda não contemplar, e as especializações que poderiam complementar o trabalho docente, estão imersas numa condição de mercado que não as permite avançar epistemologicamente para cumprirem seu papel.

Toda a historicidade, apresentada no capítulo 1, aponta que na orientação educacional o consenso era de que ela servia a interesses hegemônicos. Como ela serviria foi sendo adaptado conforme as necessidades, e foi sendo instituído legalmente seu papel. Quando as discussões educacionais tiveram alguma representação contra-hegemônica, o papel da orientação foi sendo subsumido embora o estudo demonstre que a função da orientação ainda é está muito presente e aponta para a totalidade do trabalho docente na escola.

Nesse sentido, apresentamos no capítulo 2 uma proposta de reformulação da orientação educacional por considerar que seu papel é importante desde que não sirva mais para dividir e sim para transformar.

As análises dos editais, endossa que a atividade existe e é demandada pelo sistema educacional. Ainda que, com interpretações diversas sobre a legislação e o papel da orientação educacional nas escolas, e a não definição de um cargo específico registra-se que as ações relativas ao trabalho do orientador ainda são exigidas e aponta para uma dispersão e intensificação deste trabalho.

Nesse contexto, a orientação educacional pode traduzir-se num campo intelectual e não necessariamente uma profissão com regulamentações rígidas a partir 
de uma única perspectiva. Esse campo intelectual ganharia força epistemológica a partir da compreensão da proposição da base docente que sustentaria uma formação ulterior que aprofundasse nas questões inerentes ao trabalho de orientação educacional na escola pública e reconhecesse a educação como prática social em sua totalidade tendo-se clareza de sua função social na formação e humanização dos sujeitos. 


\section{REFERÊNCIAS BIBLIOGRÁFICAS}

AMAZONAS. Secretaria de Estado de Educação e Qualidade do Ensino (SEDUC) Concurso Público para Provimento de Vagas em Cargos de Nível Superior, de Nível Médio e Nível Fundamental. Edital No 1/2010 - SEDUC/AM, de 6 de janeiro de 2011.

APPLE, M. Ideologia e Currículo. 3ª ed.Porto Alegre: Artmed. 2008.

ANTUNES, Ricardo. Os sentidos do trabalho: ensaio sobre a formação e a negação do trabalho. 2 Ed. revista e ampliada. Editora Boitempo. São Paulo, 2009.

AZEVEDO, Fernando O Manifesto dos Pioneiros da Educação Nova. Coleção

Educadores. Recife: Fundação Joaquim Nabuco, Editora Massangana, 2010.

Beijaard, D., Meijer, P., \& Verloop, N. (2004). Reconsidering research on teachers' professional identity. Teaching and Teacher Education, 20, 107-128.

BOURDIEU, Pierre. Campo de poder, campo intelectual: itinerario de um concepto. Colección: Jungla Simbólica. Editorial Montressor. Argentina, 2002.

BORGES, L. F. F. Um currículo para a formação de professores. In: VEIGA, I. P. A; SILVA, E. F. (Orgs.). A escola mudou. Que mude a formação de professores! Campinas, SP: Papirus, 2010.

BRASIL. Decreto 4.048, de 22 de janeiro de 1942. Cria o Serviço Nacional da Aprendizagem Industrial - SENAI.

BRASIL. Decreto 4.073, de 30 de janeiro de 1942a. Define a Lei Orgânica do Ensino Industrial.

BRASIL. Lei no 4424 de 9 de abril de 1942b. Lei Orgânica do Ensino Secundário.

BRASIL, Decreto-lei 4.657, de 4 de setembro de 1942c. Lei de Introdução às normas do Direito Brasileiro.

BRASIL. Lei $\mathbf{n}^{0}$ 4.024, de 20 de dezembro de 1961. Lei de Diretrizes e Bases da Educação Nacional.

BRASIL. Lei $\mathbf{n}^{0}$ 5.564, de 21 de dezembro de 1968. Prevê sobre o exercício da profissão de orientador educacional.

BRASIL. Decreto $\mathbf{n}^{\mathbf{0}} \mathbf{7 2 . 8 4 6}$, de 26 de setembro de 1973. Regulamentada a Lei n. $^{\mathbf{o}}$ 5.564 , de 21 de dezembro de 1968, que prevê sobre o exercício da profissão de orientador educacional. 
BRASIL. Lei $\mathbf{n}^{\circ}$ 9.394, de 20 de dezembro de 1996. Estabelece as Diretrizes e Bases da Educação Nacional.

BRASIL. Ministério da Educação. Conselho Nacional de Educação- Conselho Pleno. Resolução CNE/CP $\mathbf{n}^{0}$ 1, de 15 de maio de 2006. Institui Diretrizes Curriculares Nacionais para o Curso de Graduação em Pedagogia, licenciatura.

BRASIL. Ministério da Educação. Conselho Nacional de Educação. Resolução $\mathbf{n}^{\circ} \mathbf{1}$, de 8 de junho de 2007. Estabelece normas para o funcionamento de cursos de pósgraduação lato sensu, em nível de especialização.

CHAVES, Vera Lúcia Jacob. Expansão da privatização/mercantilização do ensino superior brasileiro: a formação dos oligopólios. Educ. Soc., Campinas, v. 31, n. 111, p. 481-500, abr.-jun. 2010485 Disponível em http://www.cedes.unicamp.br.

CUNHA, Luiz Antonio. O ensino industrial-manufatureiro no Brasil In: Revista Brasileira de Educação. Mai/Jun/Jul/Ago $2000 \quad \mathrm{~N}^{\mathrm{o}}$ 14. Disponível em: http://www.anped.org.br/rbe/rbedigital/RBDE14/RBDE14_07_LUIZ_ANTONIO_CU NHA.pdf

DIAS-DA-SILVA, Maria Helena G. F et al. A reestruturação das licenciaturas: alguns princípios, propostas e (pré) condições institucionais. Revista Diálogo Educ. Curitiba, v. 8, n. 23, p. 15-37, jan. /abr. 2008.

DISTRITO FEDERAL. Secretaria de Estado de Administração Pública do Distrito Federal. Concurso Público para provimento de vagas e formação de cadastro reserva para o cargo de Pedagogo-Orientador Educacional, da carreira magistério público do quadro de pessoal do Distrito Federal. Edital $\mathrm{N}^{\circ} 1$, de 06 de agosto de 2014.

Secretaria de Estado de Educação do Distrito Federal. PORTARIA No 32, DE 4 DE FEVEREIRO DE 2013. Dispõe sobre as atribuições, os critérios para modulação e distribuição dos Especialistas de Educação - Orientador Educacional, da Carreira Magistério Público do Distrito Federal em exercício nas unidades escolares da rede pública de ensino do Distrito Federal.

DUBAR, C. Trajetórias sociais e formas identitárias: alguns esclarecimentos conceituais e metodológicos. Educação \& Sociedade, ano XIX, n 62, abril/ 98.

ESPÍRITO SANTO. Secretaria de Estado da Educação (SEDU). Concurso público para provimento de vagas no cargo de professor $b$ - ensino fundamental e médio e professor p - pedagogo. Edital no 14/2010 - SEDU, de 10 de fevereiro de 2010.

FARIAS, Itamar Mazza. A Orientação Educacional, seus pressupostos e sua evolução no sistema escolar Brasileiro. In: Educação e Filosofia. Uberlândia: 5 (9): 79-95. Jul./dez. $1990 . \quad$ Disponível em: http://www.seer.ufu.br/index.php/EducacaoFilosofia/article/view/1231. 
FREITAS, HELENA Costa Lopes de . A (nova) política de formação de professores a prioridade postergada. Educação e Sociedade. Campinas, vol. 28, n. 100 - Especial, p. 1203-1230, out. 2007.

GARCIA, Regina Leite. Orientação Educacional: afinal a quem serve. In: Cadernos Cedes. São Paulo: Cortez, n. 6, p. 28-36, jun. 1982.

GARCIA, Regina Leite (org.). Orientação Educacional: o trabalho na escola. 2 ed. São Paulo: Edições Loyola, 1991

GASPARIN, J. L. Uma Didática para a Pedagogia Histórico-Crítica. 3. ed. Campinas: Autores Associados, 2005.

GIL, Antônio Carlos. Métodos e Técnicas de Pesquisa social. 6a.Ed. São Paulo: Atlas, 2009.

GRINSPUN, Mírian Paura. O espaço filosófico da orientação educacional na realidade brasileira. Rio de Janeiro: Rio Fundo, 1992.

GRINSPUN, Mírian P.S.Z. A Orientação Educacional: conflito de paradigmas e alternativas para a escola. $5^{\text {a }}$ ed. São Paulo: Cortez, 2011.

GRINSPUN, Mírian P.S.Z. (org.) A prática dos orientadores educacionais. $7^{\mathrm{a}}$ ed. São Paulo: Cortez, 2012.

KUMM, A. S. Interrogações e exclamações no cotidiano escolar da orientação educacional. Dissertação (Mestrado) Universidade do Vale do Itajaí, Curso de PósGraduação Stricto Sensu,Programa de Mestrado Acadêmico em Educação, 2009.

LOFREDI, L. E. - Paradigma de orientação educacional; baseado no modelo de relação de ajuda de Cark-huff. Rio de Janeiro, F. Alves, 1976.

MAIA, Eny Marisa \& GARCIA, Regina L. Uma orientação educacional nova para uma nova escola. São Paulo, Loyola, 1984.

MANCEBO, Deise; VALE, Andréa Araujo; MARTINS, Tânia Barbosa. Políticas de expansão da Educação superior no Brasil 1995-2010. In: Revista Brasileira de educação. V.20, n. 60 jan - mar. 2015.

MINAYO, Maria Cecília de Souza. Pesquisa Social: Teoria, método e criatividade. Petrópolis: Vozes, $19^{\circ}$ edição, 1994.

MINAS GERAIS. Secretaria de estado de planejamento e gestão - SEPLAG e secretaria de estado de educação - SEE. Concurso público para provimento de cargos das carreiras de professor de educação básica, analista educacional, especialista em educação básica, assistente técnico educacional e assistente técnico de educação básica. Edital seplag/see nº 01 /2011, de 11 de julho de 2011. 
MONARCHA, Carlos. Lourenço Filho. Coleção Educadores. Recife: Fundação Joaquim Nabuco, Editora Massangana, 2010.

MONARCHA, Carlos. Notas sobre a Institucionalização da Psicologia em São Paulo: o serviço de Psicologia Aplicada (1930-1938). In: Boletim Academia Paulista de Psicologia. Volume XXIX, $\mathrm{n}^{\mathrm{o}}$ 01, 2009. Disponível em: http://www.redalyc.org/pdf/946/94611474002.pdf.

NETTO, José Paulo. Introdução ao Estudo do Método de Marx. São Paulo: Expressão Popular, 2010.

PARANÁ. Secretaria de Estado da Administração e da Previdência Departamento de Recursos Humanos. Concurso Público de Provas e Títulos para provimento no cargo de Professor, nas disciplinas da matriz curricular e pedagogo, do Quadro Próprio do Magistério - QPM, da Secretaria de Estado da Educação - SEED. Edital no 017/2013.

PASCOAL, M. A orientação educacional no Brasil: uma discussão crítica. In: Poíesis pedagógica Revista do Curso de Pedagogia da Universidade Federal de Goiás. V.3, N. 3 e 4, 2005 e 2006. Disponível em: http://www.revistas.ufg.br/index.php/poesis/article/view/10549/7019.

PASCOAL, Miriam; HONORATO, Eliane Costa; ALBUQUERQUE, Fabiana Aparecida de. O orientador educacional no Brasil. Educ. rev. Belo Horizonte, n. 47, junho 2008. Disponível em: http://www.scielo.br/scielo.php?script=sci_arttext\&pid=S010246982008000100006\&1 $\mathrm{ng}=\mathrm{en} \& \mathrm{nrm}=\mathrm{iso}$.

PLACCO, V. M. N. S. Formação e prática do educador e do orientador. Campinas, SP: Papirus, 1994.

RIO GRANDE DO SUL. Concurso Público para Secretaria de Estado da Educação. SEDUC/RS - 2013. Edital de concurso nº 01/2013.

RONDÔNIA. Secretaria de Estado da Administração. Concurso Público para provimento vagas do cargo de Professor Classe "C", (áreas específicas), pertencentes ao Quadro de Pessoal Efetivo da Secretaria de Estado da Educação de Rondônia. Edital de concurso público n.006, de 10 de janeiro de 2013.

SAVIANI, Dermeval. Escola e democracia. 39 Ed. Campinas, SP: Editora Autores Associados, 2007.

SAVIANI, Dermeval. História da Pedagogia no Brasil. $3^{\text {a }}$ Ed. Campinas, SP: Editora Autores Associados, 2012a.

SAVIANI, Dermeval. Pedagogia histórico-crítica: primeiras aproximações. Campinas, SP: Editora Autores Associados, 2012b. 
SACRISTÁN, J.G. O currículo: uma reflexão sobre a prática. $3^{\mathrm{a}}$ ed. Porto Alegre: Artmed. 2008.

SANTOMÉ, Jurjo Torres. Globalização e interdisciplinariedade: o currículo integrado. Porto Alegre: Artmed. 2008.

SCALCON, S. À procura da unidade psicopedagógica: articulando a psicologia históricocultural com a pedagogia histórico-crítica. Campinas: Autores Associados, 2002.

SCHWARTZMAN, Simon; BOMENY, Helena Maria Bousquet; COSTA, Vanda Maria Ribeiro. O Ensino Industrial In: TEMPOS DE CAPANEMA. Capítulo 8, $2^{\mathrm{a}}$ edição, Fundação Getúlio Vargas e Editora Paz e Terra, 2000. Disponível em: http://www.schwartzman.org.br/simon/capanema/capit8.htm

SCHEEFFER, Ruth. Teorias de aconselhamento. São Paulo: Atlas, 1976.

SILVA, Nara Rúbia Miranda. A práxis do orientador educacional como agente importante da equipe gestora democrática e o seu papel frente o desenvolvimento de aprendizagem significativa do cidadão crítico reflexivo. Educação. Revista P@rtes. São Paulo, Setembro de 2010. Disponível em $<$ www.partes.com.br/educacao/praxisdorientador.asp>. Acesso em 08 jan. 2015.

SILVA, Tomaz T. da. Documentos de identidade: uma introdução às teorias do currículo. $3^{\mathrm{a}}$ ed. Belo Horizonte: Autêntica. 2011.

SPRICIGO, Fabricio. O Orientador Educacional: Atuação, formação profissional e dilemas enfrentados pelo Pedagogo Escolar com o fim das habilitações em Pedagogia. Florianópolis, v. 13, n. 01, p. 187 - 205, jan. / jun. 2012.

TAJFEL, H. La catégorisation sociale. In: MOSCOVICI, S. Introduction à la psychologie sociale. Paris: Larousse, 1972. v. 1.

TRIVIÑOS, Augusto N. S. Introdução à Pesquisa em Ciências Sociais. A Pesquisa Qualitativa em Educação. São Paulo: Atlas, 1987.

VÁZQUEZ, A. Filosofia da práxis. Rio de Janeiro, Paz e Terra. 1968.

VIEIRA, Aline Silva. O orientador educacional como facilitador do processo de aprendizagem de história nos anos iniciais. P@artes. V. 00. P. Eletrônica. Junho de 2015. Disponível em: <www.partes.com.br>. Acesso em: 25/06/2015 


\section{ANEXOS}

ANEXO A - EDITAL DO ESTADO DO AMAZONAS

ANEXO B - EDITAL DO ESTADO DE RONDÔNIA

ANEXO C - EDITAL DO DISTRITO FEDERAL

ANEXO D - EDITAL DO ESTADO DE MINAS GERAIS

ANEXO E - EDITAL DO ESTADO DO ESPÍRITO SANTO

ANEXO F - EDITAL DO ESTADO DO PARANÁ

ANEXO G - EDITAL DO ESTADO DO RIO GRANDE DO SUL 


\section{GOVERNO DO ESTADO DO AMAZONAS \\ SECRETARIA DE ESTADO DE EDUCAÇÃO E QUALIDADE DO ENSINO (SEDUC) \\ CONCURSO PÚBLICO PARA PROVIMENTO DE VAGAS EM CARGOS DE NÍVEL SUPERIOR, \\ DE NÍVEL MÉDIO E DE NÍVEL FUNDAMENTAL \\ EDITAL № 1/2010 - SEDUC/AM, DE 6 DE JANEIRO DE 2011}

A SECRETARIA DE ESTADO DE EDUCAÇÃO E QUALIDADE DO ENSINO (SEDUC), nos termos do Decreto no 5.626, de 22 de dezembro de 2005, publicado no Diário Oficial da União, da Lei Ordinária no 2.871, de 5 de janeiro de 2004, da Lei Ordinária no 3.088, de 25 de outubro de 2006, da Lei no 3.510, de 21 de maio de 2010, da Lei no 3.566, de 26 de outubro de 2010, publicadas no Diário Oficial do Estado do Amazonas, da Resolução no 155/2002 - CEE/AM, de 3 de dezembro de 2002, e da Resolução no 97/2010 - CEE/AM, aprovada em 21 de setembro de 2010, torna pública a realização de concurso público para provimento de vagas em cargos de nível superior, de nível médio e de nível fundamental, mediante as condições estabelecidas neste edital.

\section{DAS DISPOSIÇÕES PRELIMINARES}

1.10 concurso público será regido por este edital e executado pelo Centro de Seleção e de Promoção de Eventos da Universidade de Brasília (CESPE/UnB).

1.2 A seleção para os cargos/disciplinas de que trata este edital compreenderá as seguintes fases:

a) exame de habilidades e conhecimentos, mediante aplicação de provas objetivas, de caráter eliminatório e classificatório, para todos os cargos;

b) prova discursiva, de caráter eliminatório e classificatório, somente para os cargos de nível superior;

c) prova prática, de caráter eliminatório e classificatório, somente para o cargo de Merendeiro.

1.3 As provas serão realizadas nos 62 municípios do Estado do Amazonas, listados no Anexo I deste edital.

1.3.1 Havendo indisponibilidade de locais suficientes ou adequados nos municípios de realização das provas, estas poderão ser realizadas em outros municípios.

\section{DOS CARGOS}

\subsection{NÍVEL SUPERIOR}

\section{CARGO: PROFESSOR}

DESCRIÇÃO SUMÁRIA DAS ATIVIDADES: Atuar no nível pré-escolar, educação especial, programa de educação básica e na realização de um conjunto de atividades didático-pedagógicas nos níveis de ensino fundamental e médio. Realizar estudos e pesquisas científicas no âmbito educacional. Prestar assessoramento técnico especializado no âmbito do sistema educacional de Estado. Participar na elaboração da proposta pedagógica do estabelecimento do ensino. Participar na elaboração e execução do plano de trabalho docente. Atuar com zelo e responsabilidade na aprendizagem do aluno. Colaborar diretamente nas atividades de articulação da escola com as famílias e a comunidade, objetivando garantir o efetivo desempenho das ações de ensino em prol do desenvolvimento social, da cidadania e do bom conceito de qualidade da educação pública estadual.

JORNADA DE TRABALHO: 20 horas semanais e 40 horas semanais.

REMUNERAÇÃO: R\$ $1.174,89$ para Professor 20 horas semanais e $2.349,78$ para Professor 40 horas semanais.

\section{CARGO 1: PROFESSOR - ARTES}

REQUISITO: diploma, devidamente registrado, de conclusão de curso de nível superior de licenciatura plena em Artes, fornecido por instituição de ensino superior reconhecida pelo MEC.

\section{CARGO 2: PROFESSOR - BIOLOGIA}

REQUISITO: diploma, devidamente registrado, de conclusão de curso de nível superior de licenciatura plena em Biologia, fornecido por instituição de ensino superior reconhecida pelo MEC. 
CARGO 3: PROFESSOR - PRIMEIRO CICLO - ANOS INICIAIS DO ENSINO FUNDAMENTAL

REQUISITO: diploma, devidamente registrado, de conclusão de curso de nível superior de licenciatura em Normal Superior ou em Pedagogia com habilitação em Magistério, fornecido por instituição de ensino superior reconhecida pelo MEC.

\section{CARGO 4: PROFESSOR - CIÊNCIAS}

REQUISITO: diploma, devidamente registrado, de conclusão de curso de nível superior de licenciatura plena em Ciências Naturais ou em Ciências Biológicas, fornecido por instituição de ensino superior reconhecida pelo MEC.

\section{CARGO 5: PROFESSOR - EDUCAÇÃO ESPECIAL 1 (Professor 10 ao 5o ano do Ensino Fundamental)}

REQUISITO: diploma, devidamente registrado, de conclusão de curso de nível superior de Licenciatura Plena em Pedagogia ou Normal Superior e curso de Educação Especial nas áreas de deficiência auditiva, visual ou mental reconhecido pelo MEC.

CARGO 6: PROFESSOR - EDUCAÇÃO ESPECIAL 2 (Professor 6 ao 9o ano do Ensino Fundamental e Ensino Médio - Português)

REQUISITO: diploma, devidamente registrado, de conclusão de curso de nível superior de Licenciatura Plena em Letras com habilitação em Língua Portuguesa ou Licenciatura Plena em Letras com habilitação em Língua Brasileira de Sinais - LIBRAS e curso de Educação Especial nas áreas de deficiência auditiva, visual ou mental reconhecido pelo MEC

CARGO 7: PROFESSOR - EDUCAÇÃO ESPECIAL 3 (Professor 60 ao 9o ano do Ensino Fundamental e Ensino Médio - Matemática)

REQUISITO: diploma, devidamente registrado, fornecido por instituição de ensino superior reconhecida pelo MEC de conclusão de curso de nível superior de Licenciatura Plena em Matemática e curso de Educação Especial nas áreas de deficiência auditiva, visual ou mental reconhecido pelo MEC.

CARGO 8: PROFESSOR - EDUCAÇÃO ESPECIAL 4 (Professor Intérprete LIBRAS 60 ao 9o ano do Ensino Fundamental e Ensino Médio)

REQUISITO: diploma, devidamente registrado, de conclusão de curso de nível superior de Licenciatura Plena em qualquer área do conhecimento, fornecido por instituição de ensino superior reconhecida pelo MEC, e comprovação de formação em Língua Brasileira de Sinais - LIBRAS expedida pelo PROLIBRAS do MEC ou pelo Centro de Apoio ao Surdo do Amazonas.

\section{CARGO 9: PROFESSOR - EDUCAÇÃO FÍSICA}

REQUISITO: diploma, devidamente registrado, de conclusão de curso de nível superior de licenciatura plena em Educação Física, fornecido por instituição de ensino superior reconhecida pelo MEC.

CARGO 10: PROFESSOR - ESPANHOL

REQUISITO: diploma, devidamente registrado, de conclusão de curso de nível superior de licenciatura plena em Letras com habilitação em Espanhol, fornecido por instituição de ensino superior reconhecida pelo MEC.

CARGO 11: PROFESSOR - FILOSOFIA

REQUISITO: diploma, devidamente registrado, de conclusão de curso de nível superior de licenciatura plena em Filosofia, fornecido por instituição de ensino superior reconhecida pelo MEC.

CARGO 12: PROFESSOR - FÍSICA

REQUISITO: diploma, devidamente registrado, de conclusão de curso de nível superior de licenciatura plena em Física, fornecido por instituição de ensino superior reconhecida pelo MEC.

\section{CARGO 13: PROFESSOR - GEOGRAFIA}

REQUISITO: diploma, devidamente registrado, de conclusão de curso de nível superior de licenciatura plena em Geografia, fornecido por instituição de ensino superior reconhecida pelo MEC.

\section{CARGO 14: PROFESSOR - HISTÓRIA}

REQUISITO: diploma, devidamente registrado, de conclusão de curso de nível superior de licenciatura plena em História, fornecido por instituição de ensino superior reconhecida pelo MEC. 


\section{CARGO 15: PROFESSOR - INGLÊS}

REQUISITO: diploma, devidamente registrado, de conclusão de curso de nível superior de licenciatura plena em Letras com habilitação em Inglês, fornecido por instituição de ensino superior reconhecida pelo MEC.

\section{CARGO 16: PROFESSOR - MATEMÁTICA}

REQUISITO: diploma, devidamente registrado, de conclusão de curso de nível superior de licenciatura plena em Matemática, fornecido por instituição de ensino superior reconhecida pelo MEC.

\section{CARGO 17: PROFESSOR - PORTUGUÊS}

REQUISITO: diploma, devidamente registrado, de conclusão de curso de nível superior de licenciatura plena em Letras com habilitação em Português, fornecido por instituição de ensino superior reconhecida pelo MEC.

\section{CARGO 18: PROFESSOR - QUÍMICA}

REQUISITO: diploma, devidamente registrado, de conclusão de curso de nível superior de licenciatura plena em Química, fornecido por instituição de ensino superior reconhecida pelo MEC.

\section{CARGO 19: PROFESSOR - ENSINO RELIGIOSO}

REQUISITO: diploma, devidamente registrado, de conclusão de curso de nível superior de licenciatura em qualquer área do conhecimento, fornecido por instituição de ensino superior reconhecida pelo MEC, e formação em Religião oferecida por instituição de ensino superior reconhecida pelo MEC sendo: curso de atualização ou aperfeiçoamento de pelo menos 180 horas; ou curso de extensão universitária, de pelo menos 180 horas; ou curso em nível de pós-graduação, de pelo menos 360 horas, ministrados por instituição de ensino superior reconhecida pelo MEC.

\section{CARGO 20: PROFESSOR - SOCIOLOGIA}

REQUISITO: diploma, devidamente registrado, de conclusão de curso de nível superior de licenciatura plena em Sociologia, fornecido por instituição de ensino superior reconhecida pelo MEC.

\section{CARGO 21: PEDAGOGO}

REQUISITO: diploma, devidamente registrado, de conclusão de curso de nível superior de licenciatura plena em Pedagogia, fornecido por instituição de ensino superior reconhecida pelo MEC.

DESCRIÇÃO SUMÁRIA DAS ATIVIDADES: Formular, orientar, acompanhar, fiscalizar e executar propostas pedagógicas, no ensino público estadual. Atuar nas áreas de administração, supervisão e inspeção escolar. Atuar nas áreas de planejamento, orientação e psicopedagogia educacional. Cooperar com as atividades docentes. Participar na elaboração da proposta pedagógica das unidades escolares, objetivando garantir o efetivo desempenho das ações e da qualidade do ensino.

JORNADA DE TRABALHO: 40 horas semanais.

REMUNERAÇÃO: R\$ 2.348,06.

\section{CARGO 22: ASSISTENTE SOCIAL}

REQUISITO: diploma, devidamente registrado, de conclusão de curso de nível superior de em serviço social, fornecido por instituição de ensino superior reconhecida pelo MEC, acrescido de registro no Conselho Regional de Serviço Social.

DESCRIÇÃO SUMÁRIA DAS ATIVIDADES: Planejar, coordenar, executar e avaliar pesquisas e projetos sociais no âmbito educacional. Visitas domiciliares e institucionais. Atendimento e acompanhamento da comunidade escolar. Orientação à comunidade escolar quanto aos seus direitos e deveres de cidadão. Elaboração de pareceres técnicos. Desenvolver programas e projetos de prevenção e promoção da qualidade de vida.

JORNADA DE TRABALHO: 30 horas semanais.

REMUNERAÇÃO: R\$ 994,51.

\section{CARGO 23: BIBLIOTECÁRIO}

REQUISITO: diploma, devidamente registrado, de conclusão de curso de nível superior de bacharelado em biblioteconomia, fornecido por instituição de ensino superior reconhecida pelo MEC, acrescido de registro no Conselho Regional de Biblioteconomia. 
DESCRIÇÃO SUMÁRIA DAS ATIVIDADES: Dirigir, orientar, organizar, coordenar e controlar serviços de bibliotecas. Selecionar e adquirir material destinado ao acervo da biblioteca. Providenciar a aquisição de obras bibliográficas do interesse da biblioteca. Catalogar e classificar as peças bibliográficas, promovendo sua conservação e recuperação. Manter organizados os catálogos para uso do público, prestando as informações e orientações que forem solicitadas. Manter organizado o acervo de publicações oficiais, estaduais, nacionais e estrangeiras. Distribuir serviço entre os auxiliares.

JORNADA DE TRABALHO: 30 horas semanais.

REMUNERAÇÃO: R\$ 994,51.

\section{CARGO 24: CONTADOR}

REQUISITO: diploma, devidamente registrado, de conclusão de curso de nível superior de bacharelado em contabilidade, fornecido por instituição de ensino superior reconhecida pelo MEC, acrescido de registro no Conselho Regional de Contabilidade.

DESCRIÇÃO SUMÁRIA DAS ATIVIDADES: Avaliação de acervos patrimoniais e verificação de haveres e obrigações, para quaisquer finalidades, inclusive de natureza fiscal. Reavaliações e medição dos efeitos das variações do poder aquisitivo da moeda sobre o patrimônio e o resultado periódicos de quaisquer entidades. Implantação e aplicação dos planos de depreciação, amortização e diferimento, bem como de correções monetárias e reavaliações. Regulações judiciais ou extrajudiciais, de avarias grossas ou comuns. Escrituração regular, oficial ou não, de todos os fatos relativos aos patrimônios das entidades, por quaisquer métodos, técnicas ou processos. Classificação dos fatos para registros contábeis, por qualquer processo, inclusive computação eletrônica, e respectiva validação dos registros e demonstrações. Abertura e encerramento de escrituras contábeis. Controle e avaliação da gestão econômica, financeira e patrimonial das empresas e demais entidades. Determinação da capacidade econômico-financeira das entidades, inclusive nos conflitos trabalhistas e de tarifa. Elaboração de orçamentos de qualquer tipo, tais como econômicos, financeiros, patrimoniais e de investimento. Análise das variações orçamentárias. Organização dos processos de prestação de contas das entidades e órgãos da administração pública federal, estadual e municipal, a serem julgados pelos Tribunais, Conselhos de Contas ou órgãos similares.

JORNADA DE TRABALHO: 30 horas semanais.

REMUNERAÇÃO: R\$ 994,51.

\section{CARGO 25: ESTATÍSTICO}

REQUISITO: diploma, devidamente registrado, de conclusão de curso de nível superior em estatística, fornecido por instituição de ensino superior reconhecida pelo MEC.

DESCRIÇÃO SUMÁRIA DAS ATIVIDADES: Planejar e dirigir a execução de pesquisas ou levantamentos estatísticos. Executar o controle estatístico de produção e de qualidade. Efetuar pesquisas, análises estatísticas, perícias em matéria de estatística e assinar os laudos respectivos. Responsabilizar-se pela escrituração de livros de registro de controle estatístico criados em Lei. Emitir pareceres no campo da estatística.

JORNADA DE TRABALHO: 30 horas semanais.

REMUNERAÇÃO: R\$ 994,51.

\section{CARGO 26: NUTRICIONISTA}

REQUISITO: diploma, devidamente registrado, de conclusão de curso de nível superior em nutrição, fornecido por instituição de ensino superior reconhecida pelo MEC.

DESCRIÇÃO SUMÁRIA DAS ATIVIDADES: Planejar, organizar, administrar e avaliar unidades de alimentação e nutrição. Efetuar controle higiênico-sanitário. Executar a elaboração de cardápios normais e especiais, inclusive dietas, aplicando os princípios da nutrição a pessoas e grupos, adequando o valor nutritivo dos alimentos às necessidades dos mesmos. Participar de programas de educação nutricional. Planejar e coordenar estudos dietéticos. Elaborar informe técnico-científico.

JORNADA DE TRABALHO: 30 horas semanais.

REMUNERAÇÃO: R\$ 994,51. 


\section{CARGO 27: PSICÓLOGO}

REQUISITO: diploma, devidamente registrado, de conclusão de curso de nível superior em psicologia, fornecido por instituição de ensino superior reconhecida pelo MEC, acrescido de registro no Conselho Profissional.

DESCRIÇÃO SUMÁRIA DAS ATIVIDADES: Prevenção, orientação e acompanhamento na área de psicologia a servidores e estudantes. Elaboração e avaliação de desempenho, aprendizagem e de nível intelectual. Realização de exames psicológicos com diagnóstico específico. Atendimento, acompanhamento e controle da evolução clínica da comunidade escolar. Realizar psicoterapia. Diagnosticar, planejar e executar intervenção psicopedagógica no âmbito educacional.

JORNADA DE TRABALHO: 30 horas semanais.

REMUNERAÇÃO: R\$ 994,51.

\subsection{NÍVEL MÉDIO}

\section{CARGO 28: ASSISTENTE ADMINISTRATIVO}

REQUISITO: certificado, devidamente registrado, de conclusão de curso de ensino médio (antigo segundo grau) ou de curso técnico equivalente, expedido por instituição de ensino reconhecida pelo Ministério da Educação (MEC).

DESCRIÇÃO SUMÁRIA DAS ATIVIDADES: Trabalho administrativo que consiste em executar tarefas burocráticas de apoio operacional. Redigir qualquer modalidade de expediente administrativo. Coletar e fornecer elementos para relatórios. Escriturar livros. Fazer o levantamento e controle de bens materiais. Controlar a frequência dos servidores. Executar tarefas de rotina administrativa, propondo a adoção de medidas que visem a sua racionalização. Digitar e conferir expedientes diversos.

JORNADA DE TRABALHO: 30 horas semanais.

REMUNERAÇÃO: R\$ 746,71.

\subsection{NÍVEL FUNDAMENTAL}

\section{CARGO 29: MERENDEIRO}

REQUISITO: ensino fundamental incompleto, mediante comprovação de conclusão de no mínimo a primeira série do 1 o grau, e conhecimento elementar em culinária.

DESCRIÇÃO SUMÁRIA DAS ATIVIDADES: Trabalho simples que consiste em preparar e distribuir merenda escolar, executar serviços de copa e refeitório. Preparar e distribuir merenda escolar. Responsabilizar-se pela copa. Lavar os utensílios e objetos utilizados nas mesas de refeições, responsabilizando-se por sua higiene e conservação. Servir à mesa, após arrumá-la convenientemente. Preparar café e alimentos de rápido cozimento. Zelar pela conservação e limpeza do material e do local de trabalho. Executar tarefas afins.

JORNADA DE TRABALHO: 30 horas semanais.

REMUNERAÇÃO: R\$ 623,36.

2.4 As vagas ofertadas por este edital estão distribuídas por jornada, disciplina, município e zona de vaga, para o cargo de Professor, e por cargo e município de vaga, para os demais cargos, de acordo com o Anexo II.

\section{DAS VAGAS DESTINADAS AOS CANDIDATOS PORTADORES DE DEFICIÊNCIA}

3.1 Das vagas destinadas a cada cargo/disciplina/município/zona de vaga, para o cargo de Professor, e por cargo/município de vaga, para os demais cargos, $5 \%$ serão providas na forma do § 20 do artigo 5 da Lei no 8.112, de 11 de dezembro de 1990, e do Decreto no 3.298, de 20 de dezembro de 1999, e suas alterações.

3.1.1 Caso a aplicação do percentual de que trata o subitem 3.1 deste edital resulte em número fracionado, este deverá ser elevado até o primeiro número inteiro subsequente, desde que não ultrapasse a $20 \%$ das vagas oferecidas, nos termos do § 2ㅇ do artigo 5으 da Lei no 8.112/1990.

3.1.2 O candidato que se declarar portador de deficiência concorrerá em igualdade de condições com os demais candidatos.

3.2 Para concorrer a uma dessas vagas, o candidato deverá:

a) no ato da inscrição, declarar-se portador de deficiência; 
b) encaminhar cópia simples do CPF e laudo médico original ou cópia simples autenticada em cartório, emitido nos últimos doze meses, atestando a espécie e o grau ou nível da deficiência, com expressa referência ao código correspondente da Classificação Internacional de Doença (CID-10), bem como à provável causa da deficiência, na forma do subitem 3.2.1.

c) o candidato portador de deficiência que necessitar de tempo adicional para a realização das provas deverá indicar a necessidade na solicitação de inscrição e encaminhar ou entregar, até 2 de março de 2011, na forma dos subitens 5.6.9 ou 5.6.9.1, justificativa acompanhada de laudo e parecer emitido por especialista da área de sua deficiência que ateste a necessidade de tempo adicional, conforme prevê o parágrafo 20 do artigo 40 do Decreto no 3.298, de 20 de dezembro de 1999, e suas alterações.

3.2.1 O candidato portador de deficiência deverá enviar a cópia simples do CPF e o laudo médico original ou cópia autenticada em cartório a que se refere a alínea " $b$ " do subitem 3.2 deste edital, via SEDEX ou carta registrada com aviso de recebimento, postado impreterivelmente até $\mathbf{2}$ de março de 2011, para a Central de Atendimento do CESPE/UnB - Concurso SEDUC/AM 2011 (laudo médico), Caixa Postal 4488, CEP 70904-970, Brasília/DF.

3.2.1.1 O candidato poderá, ainda, entregar, até $\mathbf{2}$ de março de 2011, das 8 horas às 19 horas (exceto sábado, domingo e feriado), pessoalmente ou por terceiro, a cópia simples do CPF e o laudo médico original ou cópia autenticada em cartório a que se refere à alínea " $b$ " do subitem 3.2 deste edital, na Central de Atendimento do CESPE/UnB, Universidade de Brasília (UnB), Campus Universitário Darcy Ribeiro, Sede do CESPE/UnB, Asa Norte, Brasília/DF.

3.2.2 O fornecimento do laudo médico original ou cópia autenticada em cartório e da cópia simples do CPF, por qualquer via, é de responsabilidade exclusiva do candidato. O CESPE/UnB não se responsabiliza por qualquer tipo de extravio que impeça a chegada dessa documentação a seu destino.

3.3 O candidato portador de deficiência poderá requerer, na forma do subitem 5.6.9 deste edital, atendimento especial, no ato da inscrição, para o dia de realização das provas, indicando as condições de que necessita para a sua realização, conforme previsto no artigo 40, §§ 1으 e 2으, do Decreto n ․ 3.298/1999 e suas alterações.

3.4 O laudo médico original ou cópia autenticada em cartório e a cópia simples do CPF terão validade somente para este concurso público e não serão devolvidos, assim como não serão fornecidas cópias dessa documentação.

3.4.1 A relação dos candidatos que tiveram a inscrição deferida para concorrer na condição de portadores de deficiência será divulgada na Internet, no endereço eletrônico http://www.cespe.unb.br/concursos/seduc_am2011, na ocasião da divulgação do edital de locais e horário de realização das provas.

3.4.1.1 O candidato disporá de um dia a partir da data de divulgação da relação citada no subitem anterior para contestar o indeferimento na Central de Atendimento do CESPE/UnB, Universidade de Brasília (UnB), Campus Universitário Darcy Ribeiro, Sede do CESPE/UnB, Asa Norte, Brasília/DF, pessoalmente ou por terceiro, ou pelo e-mail atendimentoespecial@cespe.unb.br. Após esse período, não serão aceitos pedidos de revisão.

3.5 A inobservância do disposto no subitem 3.2 deste edital acarretará a perda do direito ao pleito das vagas reservadas aos candidatos em tal condição e o não atendimento às condições especiais necessárias.

\subsection{DA PERÍCIA MÉDICA}

3.6.1 Os candidatos que se declararem portadores de deficiência, se não eliminados no concurso, serão convocados para se submeter à perícia médica oficial, a ser realizada no mesmo município em que o candidato realizou as provas objetivas, promovida por equipe multiprofissional de responsabilidade do CESPE/UnB, formada por seis profissionais, que verificará sobre a sua qualificação como deficiente ou não, nos termos do artigo 43 do Decreto no 3.298/1999 e suas alterações.

3.6.2 Os candidatos deverão comparecer à perícia médica munidos de documento de identidade original e de laudo médico original ou cópia autenticada em cartório que ateste a espécie e o grau ou nível de deficiência, com expressa referência ao código correspondente da Classificação Internacional de Doenças 
(CID-10), conforme especificado no Decreto no 3.298/1999 e suas alterações, bem como à provável causa da deficiência.

3.6.3 O laudo médico original ou cópia autenticada em cartório será retido pelo CESPE/UnB por ocasião da realização da perícia médica.

3.6.4 Os candidatos convocados para a perícia médica deverão comparecer com uma hora de antecedência do horário marcado para o seu início, conforme edital de convocação.

3.6.5 Perderá o direito de concorrer às vagas reservadas aos portadores de deficiência o candidato que, por ocasião da perícia médica de que trata o subitem 3.6, não apresentar laudo médico original ou cópia autenticada em cartório ou que apresentar laudo que não tenha sido emitido nos últimos doze meses, bem como que não for qualificado na perícia médica como portador de deficiência ou, ainda, que não comparecer à perícia.

3.6.6 O candidato que não for considerado portador de deficiência na perícia médica, caso seja aprovado no concurso, figurará na lista de classificação geral por cargo/disciplina/município/zona de vaga, para o cargo de Professor, e por cargo/município de vaga, para os demais cargos.

3.6.7 A compatibilidade entre as atribuições do cargo e a deficiência apresentada pelo candidato será avaliada durante o estágio probatório, na forma estabelecida no § 2ำ do artigo 43 do Decreto no 3.298/1999 e suas alterações.

3.6.8 O candidato portador de deficiência que no decorrer do estágio probatório apresentar incompatibilidade da deficiência com as atribuições do cargo será exonerado.

3.70 candidato que, no ato da inscrição, se declarar portador de deficiência, se for qualificado na perícia médica e não for eliminado do concurso, terá seu nome publicado em lista à parte e figurará também na lista de classificação geral por cargo/disciplina/município/zona de vaga, para o cargo de Professor, e por cargo/município de vaga, para os demais cargos.

3.8 As vagas definidas no subitem 3.1 deste edital que não forem providas por falta de candidatos portadores de deficiência aprovados serão preenchidas pelos demais candidatos, observada a ordem geral de classificação por cargo/disciplina/município/zona de vaga, para o cargo de Professor, e por cargo/município de vaga, para os demais cargos.

\section{DOS REQUISITOS PARA A INVESTIDURA NO CARGO}

4.1 Ter nacionalidade brasileira ou portuguesa e, em caso de nacionalidade portuguesa, estar amparado pelo estatuto de igualdade entre brasileiros e portugueses, com reconhecimento de gozo de direitos políticos, nos termos do parágrafo 1ำ, artigo 12, da Constituição Federal.

4.2 Estar em dia com as obrigações eleitorais.

4.3 Ter certificado de reservista ou de dispensa de incorporação, em caso de candidato do sexo masculino.

4.4 Possuir os requisitos exigidos para o exercício do cargo, constantes do item 2 deste edital.

4.5 Ter idade mínima de dezoito anos completos na data da posse.

4.6 Ter aptidão física e mental para o exercício das atribuições do cargo.

4.7 Não ter sofrido, no exercício de função pública, penalidade incompatível com nova investidura em cargo público.

4.8 Apresentar documentação pessoal, necessária na ocasião da posse.

4.9 Cumprir as determinações deste edital e ser aprovado no concurso público.

\section{DAS INSCRIÇÕES NO CONCURSO PÚBLICO}

\subsection{TAXAS:}

a) nível superior: $\mathrm{R} \$ 70,00$;

b) nível médio: $\mathrm{R} \$ 55,00$;

c) nível fundamental: $R \$ 40,00$.

5.2 Será admitida a inscrição exclusivamente via Internet, no endereço eletrônico http://www.cespe.unb.br/concursos/seduc_am2011, solicitada no período entre 10 horas do dia 10 de janeiro de 2011 e 23 horas e 59 minutos do dia 3 de fevereiro de 2011, observado o horário oficial de Brasília/DF. 
5.2.1 O CESPE/UnB não se responsabiliza por solicitação de inscrição não recebida por motivos de ordem técnica dos computadores, falhas de comunicação, congestionamento das linhas de comunicação, bem como outros fatores que impossibilitem a transferência de dados.

5.3 O candidato poderá efetuar o pagamento da taxa de inscrição por meio da Guia de Recolhimento da União (GRU Cobrança).

5.3.1 A GRU Cobrança estará disponível no endereço eletrônico http://www.cespe.unb.br/concursos/seduc_am2011 e deverá ser impressa para o pagamento da taxa de inscrição imediatamente após a conclusão do preenchimento da ficha de solicitação de inscrição online.

5.3.2 A GRU Cobrança pode ser paga em qualquer banco, bem como nas lotéricas e Correios, obedecendo aos critérios estabelecidos nesses correspondentes bancários.

5.3.3 O pagamento da taxa de inscrição deverá ser efetuado até o dia 10 de março de 2011.

5.3.4 As inscrições somente serão acatadas após a comprovação de pagamento da taxa de inscrição.

5.40 comprovante de inscrição do candidato estará disponível no endereço eletrônico http://www.cespe.unb.br/concursos/seduc_am2011, por meio da página de acompanhamento, após o acatamento da inscrição, sendo de responsabilidade exclusiva do candidato a obtenção desse documento.

5.5 Para os candidatos que não dispuserem de acesso à Internet, o CESPE/UnB disponibilizará locais com acesso à internet, localizados nos endereços listados no Anexo III deste edital, no período entre 10 horas do dia 10 de janeiro de 2011 e 23 horas e 59 minutos do dia 3 de fevereiro de 2011, observado o horário de funcionamento de cada estabelecimento.

\subsection{DAS DISPOSIÇÕES GERAIS SOBRE A INSCRIÇÃO NO CONCURSO PÚBLICO}

5.6.1 Antes de efetuar a inscrição, o candidato deverá conhecer o edital e certificar-se de que preenche todos os requisitos exigidos. No momento da inscrição, os candidatos ao cargo de Professor deverão optar pela disciplina e pelo município/zona de vaga (se sede do município ou zona rural). Os candidatos aos demais cargos deverão optar pelo cargo e pelo município de vaga. Todos os candidatos deverão optar, ainda, pelo município de realização das provas.

5.6.2 É vedada a transferência do valor pago a título de taxa para terceiros, para outro cargo ou para outros concursos públicos.

5.6.3 É vedada inscrição condicional, extemporânea, via postal, via fax ou via correio eletrônico.

5.6.4 Para efetuar a inscrição, é imprescindível o número de Cadastro de Pessoa Física (CPF) do candidato.

5.6.5 As informações prestadas na solicitação de inscrição via Internet serão de inteira responsabilidade do candidato, dispondo o CESPE/UnB do direito de excluir do concurso público aquele que não preencher o formulário de forma completa e correta.

5.6.6 0 valor referente ao pagamento da taxa de inscrição não será devolvido em hipótese alguma, salvo em caso de cancelamento do certame por conveniência da Administração.

5.6.7 Não haverá isenção total ou parcial do valor da taxa de inscrição, exceto nos casos previstos na Lei Estadual no 3.088, de 27 de outubro de 2006, conforme procedimentos descritos a seguir.

5.6.7.1 0 interessado que preencher os requisitos do dispositivo citado no item anterior e desejar isenção de pagamento da taxa de inscrição neste concurso público deverá, no período de 10 de janeiro a 4 de fevereiro de 2011 (inclusive sábado, domingo e feriado), das 10 às 17 horas, entregar, pessoalmente ou por procurador, em um dos endereços listados no Anexo III deste edital, o requerimento de isenção, devidamente preenchido, conferido e assinado, disponibilizado no endereço eletrônico http://www.cespe.unb.br/concursos/seduc_am2011, por intermédio do aplicativo de inscrição, instruindo-o com cópia autenticada ou acompanhada dos originais dos seguintes documentos:

a) os trabalhadores que estejam regularmente empregados deverão juntar a cópia de seu contracheque ou de documento similar, o qual comprove pagamento para fazer prova de sua renda mensal;

b) os trabalhadores ambulantes, prestadores de serviços e os que exerçam qualquer tipo de atividade autônoma, desde que não cumulada com outra atividade cuja remuneração, somada, faça exceder a três salários mínimos, deverão fazer prova de sua renda mensal, por meio de declaração de renda 
expedida por Contador devidamente registrado no seu órgão de classe.

c) os trabalhadores que se encontram desempregados, para poder fruir o direito da presente Lei, deverão fazer prova de sua condição, por meio da juntada, no ato da inscrição, de cópia autenticada de sua Carteira de Trabalho ou, não tendo, da Declaração Pessoal de tal situação.

5.6.7.2 As informações prestadas no formulário, bem como a documentação apresentada, serão de inteira responsabilidade do candidato, respondendo este, por qualquer falsidade.

5.6.7.3 Não será concedida isenção de pagamento de taxa de inscrição ao candidato que:

a) omitir informações e/ou torná-las inverídicas;

b) fraudar e/ou falsificar documentação;

c) pleitear a isenção, sem apresentar cópia de todos os documentos previstos no subitem 5.6.7.2;

d) não observar o local, a forma e o prazo estabelecidos no subitem 5.6.7.2 deste edital.

5.6.7.4 Não será permitida, após a entrega do requerimento de isenção e dos documentos comprobatórios, a complementação da documentação bem como revisão e/ou recurso.

5.6.7.6 Não será aceita solicitação de isenção de pagamento em desacordo com o estipulado no presente edital.

5.6.7.7 Cada pedido de isenção será analisado e julgado pelo CESPE/UnB.

5.6.7.8 A relação dos pedidos de isenção deferidos será divulgada na data provável de $\mathbf{1 6}$ de fevereiro de 2011, no endereço eletrônico http://www.cespe.unb.br/concursos/seduc_am2011.

5.6.7.9.1 O candidato disporá de dois dias, após a divulgação da relação, para interpor recurso contra o resultado do pedido de isenção de taxa.

5.6.7.9.2 O candidato que tiver seu pedido de isenção indeferido deverá acessar o endereço eletrônico http://www.cespe.unb.br/concursos/seduc_am2011 e imprimir a GRU Cobrança por meio da página de acompanhamento para pagamento até o dia 10 de março de 2011, conforme procedimentos descritos neste edital.

5.6.7.10 O interessado que não tiver seu pedido de isenção deferido e que não efetuar o pagamento da taxa de inscrição na forma e no prazo estabelecido no item anterior estará automaticamente excluído do concurso público.

5.6.8 O comprovante de inscrição ou o comprovante de pagamento da inscrição deverá ser mantido em poder do candidato e apresentado nos locais de realização das provas.

5.6.9 o candidato, portador de deficiência ou não, que necessitar de atendimento especial para a realização das provas deverá indicar, na solicitação de inscrição, os recursos especiais necessários e, ainda, enviar, até o dia 2 de março de 2011, impreterivelmente, via SEDEX ou carta registrada com aviso de recebimento, para a Central de Atendimento do CESPE/UnB - Concurso SEDUC/AM 2011 (laudo médico), Caixa Postal 4488, CEP 70904-970, Brasília/DF, cópia simples do CPF e laudo médico (original ou cópia autenticada em cartório) que justifique o atendimento especial solicitado. Após esse período, a solicitação será indeferida, salvo nos casos de força maior e nos que forem de interesse da Administração Pública.

5.6.9.1 O laudo médico (original ou cópia autenticada em cartório) e a cópia simples do CPF referidos no subitem 5.6.9 poderão, ainda, ser entregues, até o dia 2 de março de 2011, das 8 horas às 19 horas, pessoalmente ou por terceiro, na Central de Atendimento do CESPE/UnB, na Universidade de Brasília (UnB), Campus Universitário Darcy Ribeiro, Sede do CESPE/UnB - Asa Norte, Brasília/DF.

5.6.9.2 A candidata que tiver necessidade de amamentar durante a realização das provas, além de solicitar atendimento especial para tal fim, deverá encaminhar, para a Central de Atendimento do CESPE/UnB, cópia da certidão de nascimento da criança, até o dia $\mathbf{2}$ de março de 2011, e levar um acompanhante, que ficará em sala reservada e será o responsável pela guarda da criança. A candidata que não levar acompanhante no dia de realização da prova não poderá permanecer com a criança no local de realização das provas.

5.6.9.2.1 O CESPE/UnB não disponibilizará acompanhante para guarda de criança.

5.6.9.3 O laudo médico (original ou cópia autenticada em cartório) e a cópia simples do CPF terão 
validade somente para este concurso público e não serão devolvidos, assim como não serão fornecidas cópias dessa documentação.

5.6.9.4 A relação dos candidatos que tiveram o seu atendimento especial deferido será divulgada no endereço eletrônico http://www.cespe.unb.br/concursos/seduc_am2011, na ocasião de divulgação do edital de locais e horários de realização das provas.

5.6.9.4.1 O candidato disporá de dois dias a partir da data de divulgação da relação citada no subitem anterior para contestar o indeferimento, na Central de Atendimento do CESPE/UnB, Universidade de Brasília (UnB), Campus Universitário Darcy Ribeiro, Sede do CESPE/UnB, Asa Norte, Brasília/DF, pessoalmente ou por terceiro, ou pelo e-mail atendimentoespecial@cespe.unb.br. Após esse período, não serão aceitos pedidos de revisão.

5.6.9.5 A solicitação de condições ou recursos especiais será atendida, em qualquer caso, segundo os critérios de viabilidade e de razoabilidade.

5.6.10 o candidato deverá declarar, na solicitação de inscrição, que tem ciência e aceita que, caso aprovado, deverá entregar os documentos comprobatórios dos requisitos exigidos para o cargo por ocasião da posse.

\section{DO EXAME DE HABILIDADES E CONHECIMENTOS}

6.1 Será aplicado exame de habilidades e de conhecimentos, mediante provas objetivas, de caráter eliminatório e classificatório, para todos os cargos, prova discursiva, de caráter eliminatório e classificatório, para os cargos de nível superior, abrangendo os objetos de avaliação constantes do item 15 deste edital, e prova prática, de caráter eliminatório, para o cargo de Merendeiro, conforme os quadros a seguir.

6.1.1 NÍVEL SUPERIOR - SOMENTE PARA O CARGO DE PROFESSOR

\begin{tabular}{|l|l|c|c|}
\hline \multicolumn{1}{|c|}{ PROVAS/TIPO } & \multicolumn{1}{c|}{ ÁREA DE CONHECIMENTO } & NÚMERO DE ITENS & CARÁTER \\
\hline$\left(P_{1}\right)$ Objetiva & Conhecimentos Básicos & 50 & \multirow{2}{*}{ ELIMINATÓRIO } \\
\hline$\left(P_{2}\right)$ Objetiva & Conhecimentos Complementares & 30 & E \\
\hline$\left(P_{3}\right)$ Objetiva & Conhecimentos Específicos & 40 & \\
\hline$\left(P_{4}\right)$ Discursiva & - & - & \\
\hline
\end{tabular}

\subsubsection{NÍVEL SUPERIOR - EXCETO PARA O CARGO DE PROFESSOR}

\begin{tabular}{|l|l|c|c|}
\hline \multicolumn{1}{|c|}{ PROVAS/TIPO } & ÁREA DE CONHECIMENTO & NÚMERO DE ITENS & CARÁTER \\
\hline$\left(P_{1}\right)$ Objetiva & Conhecimentos Básicos & 50 & \multirow{2}{*}{ ELIMINATÓRIO } \\
\cline { 1 - 2 }$\left(P_{2}\right)$ Objetiva & Conhecimentos Específicos & 70 & E \\
\cline { 1 - 2 }$\left(P_{3}\right)$ Discursiva & - & - & CLASSIFICATÓRIO \\
\hline
\end{tabular}

6.1.3 NÍVEL MÉDIO

\begin{tabular}{|l|l|c|c|}
\hline \multicolumn{1}{|c|}{ PROVAS/TIPO } & \multicolumn{1}{|c|}{ ÁREA DE CONHECIMENTO } & NÚMERO DE ITENS & CARÁTER \\
\hline$\left(P_{1}\right)$ Objetiva & Conhecimentos Básicos & 40 & \multirow{2}{*}{ ELIMINATÓRIO E } \\
\hline$\left(P_{2}\right)$ Objetiva & Conhecimentos Específicos & 60 & CLASSIFICATÓRIO \\
\hline
\end{tabular}

6.1.4 NÍVEL FUNDAMENTAL - MERENDEIRO

\begin{tabular}{|l|c|c|c|}
\hline \multicolumn{1}{|c|}{ PROVAS/TIPO } & ÁREA DE CONHECIMENTO & NÚMERO DE ITENS & CARÁTER \\
\hline$\left(P_{1}\right)$ Objetiva & Conhecimentos Básicos & 100 & \multirow{2}{*}{ ELIMINATÓRIO E } \\
\hline$\left(P_{2}\right)$ Prova prática & - & - & CLASSIFICATÓRIO \\
\hline
\end{tabular}

6.2 As provas objetivas e a prova discursiva para os cargos de nível superior terão a duração de 4 horas e 30 minutos e serão aplicadas na data provável de 17 de abril de 2011, no turno da manhã.

6.3 As provas objetivas para os cargos de nível médio e de nível fundamental terão a duração de 3 horas e $\mathbf{3 0}$ minutos e serão aplicadas na data provável de 17 de abril de 2011, no turno da tarde.

6.40 edital de locais e horários de realização das provas objetivas, para todos os cargos, e da prova discursiva, para os cargos de nível superior, será publicado no Diário Oficial do Estado do Amazonas e divulgado na Internet, no endereço eletrônico http://www.cespe.unb.br/concursos/seduc_am2011, na data provável de 7 de abril de 2011. É de responsabilidade exclusiva do candidato a identificação correta de seu local de realização das provas e o comparecimento no horário determinado. 
6.4.1 O CESPE/UnB poderá enviar, como complemento às informações citadas no subitem anterior, comunicação pessoal dirigida ao candidato, por e-mail ou pelos Correios, sendo de sua exclusiva responsabilidade a manutenção/atualização de seu correio eletrônico e a informação de seu endereço completo e correto na solicitação de inscrição, o que não o desobriga do dever de observar o edital a ser publicado, consoante o que dispõe o subitem 6.4 deste edital.

6.5 O resultado final nas provas objetivas, para todos os cargos, o resultado provisório na prova discursiva, para os cargos de nível superior, e a convocação para a prova prática, para o cargo de Merendeiro, serão publicados no Diário Oficial do Estado do Amazonas e divulgados na Internet, no endereço eletrônico http://www.cespe.unb.br/concursos/seduc_am2011, na data provável de 13 de maio de 2011.

\section{DAS PROVAS OBJETIVAS}

7.1 As provas objetivas para os cargos de nível superior valerão 120,00 pontos e as provas objetivas para os cargos de nível médio e de nível fundamental valerão 100,00 pontos. As provas objetivas serão constituídas de itens para julgamento, agrupados por comandos que deverão ser respeitados. $\mathrm{O}$ julgamento de cada item será CERTO ou ERRADO, de acordo com o(s) comando(s) a que se refere o item. Haverá, na folha de respostas, para cada item, dois campos de marcação: o campo designado com o código $\mathbf{C}$, que deverá ser preenchido pelo candidato caso julgue o item CERTO, e o designado com o código $\mathrm{E}$, que deverá ser preenchido pelo candidato caso julgue o item ERRADO.

7.2 Para obter pontuação no item, o candidato deverá marcar um, e somente um, dos dois campos da folha de respostas.

7.3 O candidato deverá transcrever as respostas das provas objetivas para a folha de respostas, que será o único documento válido para a correção das provas. O preenchimento da folha de respostas será de inteira responsabilidade do candidato, que deverá proceder em conformidade com as instruções específicas contidas neste edital, e, se for o caso, em edital complementar, na capa do caderno de provas e na folha de respostas. Em hipótese alguma haverá substituição da folha de respostas por erro do candidato.

7.4 Serão de inteira responsabilidade do candidato os prejuízos advindos do preenchimento indevido da folha de respostas. Serão consideradas marcações indevidas as que estiverem em desacordo com este edital e/ou com a folha de respostas, tais como marcação rasurada ou emendada e/ou campo de marcação não preenchido integralmente.

7.5 O candidato não deverá amassar, molhar, dobrar, rasgar, manchar ou, de qualquer modo, danificar a sua folha de respostas, sob pena de arcar com os prejuízos advindos da impossibilidade de realização da leitura óptica.

7.6 o candidato é responsável pela conferência de seus dados pessoais, em especial seu nome, seu número de inscrição e o número de seu documento de identidade.

7.7 Não será permitido que as marcações na folha de respostas sejam feitas por outras pessoas, salvo em caso de candidato a quem tenha sido deferido atendimento especial para esse fim. Nesse caso, 0 candidato será acompanhado por um fiscal do CESPE/UnB devidamente treinado.

7.8 O CESPE/UnB divulgará a imagem da folha de respostas dos candidatos que realizaram as provas objetivas, exceto dos candidatos eliminados na forma do subitem 14.11, no endereço eletrônico http://www.cespe.unb.br/concursos/seduc_am2011, após a data de divulgação do resultado final das provas objetivas. A referida imagem ficará disponível até quinze dias corridos da data de publicação do resultado final do concurso público.

7.8.1 Após o prazo determinado no subitem anterior, não serão aceitos pedidos de disponibilização da imagem da folha de respostas.

8 DA PROVA DISCURSIVA (somente para os cargos de nível superior)

8.1 A prova discursiva para os cargos de nível superior valerá 30,00 pontos e consistirá de redação de texto, de até 30 linhas, acerca dos conhecimentos específicos de cada cargo constantes do subitem 14.2.1.3 deste edital. 
8.2 A prova discursiva deverá ser manuscrita, em letra legível, com caneta esferográfica de tinta preta, fabricada em material transparente, não sendo permitida a interferência ou a participação de outras pessoas, salvo em caso de candidato a quem tenha sido deferido atendimento especial para a realização das provas quanto a esse aspecto. Nesse caso, o candidato será acompanhado por fiscal do CESPE/UnB devidamente treinado, para o qual deverá ditar os textos, especificando oralmente a grafia das palavras e os sinais gráficos de pontuação.

8.3 A folha de texto definitivo da prova discursiva não poderá ser assinada, rubricada nem conter, em outro local que não o apropriado, qualquer palavra ou marca que a identifique, sob pena de anulação da prova discursiva. Assim, a detecção de qualquer marca identificadora no espaço destinado à transcrição dos textos definitivos acarretará a anulação da prova discursiva.

8.4 A folha de texto definitivo será o único documento válido para avaliação da prova discursiva. A folha para rascunho no caderno de provas é de preenchimento facultativo e não valerá para tal finalidade.

8.5 A folha de texto definitivo não será substituída por erro de preenchimento do candidato.

8.6 A prova discursiva tem o objetivo de avaliar o conteúdo - conhecimento do tema, a capacidade de expressão na modalidade escrita e o uso das normas do registro formal culto da Língua Portuguesa. $O$ candidato deverá produzir, com base em temas formulados pela banca examinadora, texto dissertativo, primando pela coerência e pela coesão.

\section{DA PROVA PRÁTICA (somente para o cargo de Merendeiro)}

9.1 A prova prática, de caráter eliminatório e classificatório, versará sobre conhecimentos técnicos referentes às atividades do cargo de Merendeiro e valerá 100,00 pontos.

9.2 A prova prática de Merendeiro consistirá no preparo de uma receita disponibilizada em fichas técnicas de preparação, que será definida pela banca avaliadora.

9.3 Caberá ao candidato manipular os ingredientes, bem como utilizar, adequadamente, os equipamentos e utensílios de cozinha, além de ter de preparar o prato de acordo com a medida prescrita na ficha técnica e o tempo estabelecido neste edital.

9.4 A prova prática terá a duração de até $\mathbf{3 0}$ minutos por candidato.

9.50 candidato, quando necessário, deverá responder a questionamentos, de cunho técnico, acerca dos procedimentos empregados.

9.6 A banca avaliadora será composta por 2 (dois) profissionais.

9.7 Serão fornecidos os produtos e utensílios necessários para a realização da prova prática.

9.80 desempenho do candidato será avaliado com base nos critérios abaixo:

a) Postura e apresentação adequadas.

b) Conhecimentos técnicos: capacidade de lidar com utensílios e correto manuseio dos equipamentos.

c) Criatividade e originalidade: habilidade em oferecer alternativas e soluções criativas ou originais que reduzam o período de execução das tarefas.

d) Tempo de Execução: o cumprimento das tarefas não poderá exceder o tempo limite de prova.

e) Produção Final: o resultado do produto será avaliado em relação à apresentação e aos procedimentos referentes ao adequado preparo do cardápio solicitado.

9.9 Para o dia da prova, o candidato deverá respeitar os seguintes aspectos: ter unhas curtas, limpas e sem esmalte; não usar quaisquer tipos de acessórios, tais como: anéis, brincos, pulseiras etc.; estar com os cabelos presos; estar com a barba aparada, no caso de candidatos do sexo masculino; utilizar calçado fechado e sem salto, além de vestuário devidamente asseado.

9.10 Será eliminado do certame o candidato que obtiver nota na prova prática menor que $\mathbf{5 0 , 0 0}$ pontos. 9.11 Os candidatos não aprovados na prova prática serão eliminados do concurso e não terão classificação alguma no certame.

9.12 Demais informações a respeito da prova prática constarão de edital de convocação para essa fase.

\section{DOS CRITÉRIOS DE AVALIAÇÃO E DE CLASSIFICAÇÃO}

10.1 Todos os candidatos terão suas provas objetivas corrigidas por meio de processamento eletrônico.

10.1.1 A nota em cada item das provas objetivas, feita com base nas marcações da folha de respostas, 
será igual a: 1,00 ponto, caso a resposta do candidato esteja em concordância com o gabarito oficial definitivo da prova; 0,50 ponto negativo, caso a resposta do candidato esteja em discordância com o gabarito oficial definitivo da prova; 0,00, caso não haja marcação ou caso haja marcação dupla (C e E). 10.1.2 O cálculo da pontuação em cada prova objetiva, comum a todos os candidatos, será igual à soma algébrica das notas obtidas em todos os itens que a compõem.

10.1.3 Será reprovado nas provas objetivas e eliminado do concurso público o candidato ao cargo de Professor que se enquadrar em pelo menos um dos itens a seguir:

a) obtiver nota inferior a 10,00 pontos na prova objetiva de Conhecimentos Básicos $\left(P_{1}\right)$;

b) obtiver nota inferior a 6,00 pontos na prova objetiva de Conhecimentos Complementares $\left(P_{2}\right)$;

c) obtiver nota inferior a 12,00 pontos na prova objetiva de Conhecimentos Específicos $\left(P_{3}\right)$.

d) obtiver nota inferior a 36,00 pontos no somatório das provas objetivas.

10.1.4 Será reprovado nas provas objetivas e eliminado do concurso público o candidato aos cargos de nível superior, exceto de Professor, que se enquadrar em pelo menos um dos itens a seguir:

a) obtiver nota inferior a 10,00 pontos na prova objetiva de Conhecimentos Básicos $\left(P_{1}\right)$;

b) obtiver nota inferior a 21,00 pontos na prova objetiva de Conhecimentos Específicos $\left(P_{2}\right)$.

c) obtiver nota inferior a 36,00 pontos no somatório das provas objetivas.

10.1.5 Será reprovado nas provas objetivas e eliminado do concurso público o candidato ao cargo de nível médio que se enquadrar em pelo menos um dos itens a seguir:

a) obtiver nota inferior a 8,00 pontos na prova objetiva de Conhecimentos Básicos $\left(P_{1}\right)$;

b) obtiver nota inferior a 18,00 pontos na prova objetiva de Conhecimentos Específicos $\left(P_{2}\right)$.

c) obtiver nota inferior a 30,00 pontos no somatório das provas objetivas.

10.1.6 Será reprovado na prova objetiva e eliminado do concurso público o candidatos ao cargo de nível fundamental que obtiver nota inferior a 30,00 pontos na prova objetiva.

10.1.7 Os candidatos eliminados na forma dos subitens 10.1.3, 10.1.4, 10.1 .5 e 10.1 .6 deste edital não terão classificação alguma no concurso público.

10.1.8 Os candidatos ao cargo de Professor não eliminados na forma do subitem 10.1 .3 serão ordenados por cargo/disciplina/município/zona de vaga, de acordo com os valores decrescentes da nota final nas provas objetivas (NFPO), que será igual à soma algébrica das notas obtidas em $P_{1}, P_{2}$ e $P_{3}$.

10.1.9 Os candidatos aos cargos de nível superior, exceto para Professor, e de nível médio não eliminados na forma dos subitens 10.1 .4 e 10.1.5 serão ordenados por cargo/município de vaga, de acordo com os valores decrescentes da nota final nas provas objetivas (NFPO), que será igual à soma algébrica das notas obtidas em $P_{1}$ e $P_{2}$.

10.1.10 Os candidatos ao cargo de nível fundamental não eliminados na forma do subitem 10.1 .6 serão ordenados por cargo/município de vaga, de acordo com os valores decrescentes da nota final na prova objetiva (NFPO).

10.2 Com base na lista organizada na forma dos subitens 10.1.8, 10.1 .9 e 10.1.10 deste edital, respeitados os empates na última posição e a reserva de vagas para os candidatos portadores de deficiência, serão corrigidas as provas discursivas dos candidatos aos cargos de nível superior aprovados nas provas objetivas e classificados em até três vezes o número de vagas.

10.3 A prova discursiva será corrigida conforme critérios a seguir, ressaltando-se que em atendimento ao que está estabelecido no Decreto no 6.583, de 29 de setembro de 2008, serão aceitas como corretas, até 31 de dezembro de 2012, ambas as ortografias, isto é, a forma de grafar e de acentuar as palavras vigente até 31 de dezembro de 2008 e a que entrou em vigor em 10 de janeiro de 2009:

a) a apresentação e a estrutura textuais e o desenvolvimento do tema totalizarão a nota relativa ao domínio do conteúdo (NC), cuja pontuação máxima será limitada ao valor de 30,00 pontos;

b) a avaliação do domínio da modalidade escrita totalizará o número de erros (NE) do candidato, considerando-se aspectos tais como: grafia/acentuação, pontuação/morfossintaxe, propriedade vocabular;

c) será computado o número total de linhas ( $T L$ ) efetivamente escritas pelo candidato; 
d) será desconsiderado, para efeito de avaliação, qualquer fragmento de texto que for escrito fora do local apropriado e(ou) que ultrapassar a extensão máxima estabelecida no caderno de provas;

e) será calculada, então, para cada candidato, a nota na prova discursiva (NPD), como sendo igual a NC menos o resultado do quociente $N E / T L$;

f) se NPD for menor que zero, então considerar-se-á NPD = zero.

10.3.1 Será eliminado do concurso público e não terá classificação alguma o candidato que obtiver NPD $<15,00$ pontos

10.3.2 Os candidatos aos cargos de nível superior que não tiverem as provas discursivas avaliadas estarão automaticamente eliminados e não terão classificação alguma no concurso público.

10.4 Com base na lista organizada no subitem 10.1.10 deste edital, respeitados os empates na última posição e a reserva de vagas para os candidatos portadores de deficiência, serão convocados para a prova prática os candidatos ao cargo de Merendeiro aprovados na prova objetiva e classificados em até três vezes o número de vagas.

10.5 Será eliminado do certame e não terá classificação alguma o candidato que obtiver nota na prova prática (NPP) menor que $\mathbf{5 0 , 0 0}$ pontos

10.5.1 Os candidatos ao cargo de Merendeiro que não forem convocados para a prova prática estarão automaticamente eliminados e não terão classificação alguma no concurso público.

10.6 Todos os cálculos citados neste edital serão considerados até a segunda casa decimal, arredondando-se o número para cima, se o algarismo da terceira casa decimal for igual ou superior a cinco.

\section{DOS CRITÉRIOS DE DESEMPATE NO CONCURSO}

11.1 Em caso de empate na nota final do concurso, terá preferência o candidato aos cargos de nível superior e de nível médio que, na seguinte ordem:

a) tiver idade igual ou superior a sessenta anos, até o último dia de inscrição neste concurso, conforme artigo 27, parágrafo único, do Estatuto do Idoso;

b) obtiver a maior nota na prova objetiva de Conhecimentos Específicos;

c) obtiver o maior número de acertos na prova objetiva de Conhecimentos Específicos;

11.2 Em caso de empate na nota final do concurso, terá preferência o candidato ao cargo de nível fundamental que, na seguinte ordem:

a) tiver idade igual ou superior a sessenta anos, até o último dia de inscrição neste concurso, conforme artigo 27, parágrafo único, do Estatuto do Idoso;

b) obtiver o maior número de acertos na prova objetiva de Conhecimentos Básicos.

11.3 Persistindo o empate, terá preferência o candidato mais idoso.

\section{DA NOTA FINAL NO CONCURSO PÚBLICO}

12.1 A nota final no concurso público para os candidatos aos cargos de nível superior será a soma algébrica das notas obtidas nas provas objetivas (NPFO) e na prova discursiva (NPD).

12.2 A nota final no concurso público para os candidatos ao cargo de nível médio será a nota obtida na prova objetiva (NPFO).

12.3 A nota final no concurso público para os candidatos ao cargo de Merendeiro será a soma algébrica das notas obtidas na prova objetiva (NPFO) e na prova prática (NPP).

12.4 Os candidatos ao cargo de Professor serão ordenados por cargo/disciplina/município/zona de vaga, de acordo com os valores decrescentes da nota final no concurso público.

12.5 Os candidatos aos demais cargos serão ordenados por cargo/município de vaga, de acordo com os valores decrescentes da nota final no concurso público.

12.6 O candidato que, no ato da inscrição, se declarar portador de deficiência, se for considerado portador de deficiência e não for eliminado do concurso, terá seu nome publicado em lista à parte e figurará também na lista de classificação geral por cargo/disciplina/município/zona de vaga, para o cargo de Professor, e por cargo/município de vaga, para os demais cargos.

\section{DOS RECURSOS}


13.1 Os gabaritos oficiais preliminares das provas objetivas serão divulgados na Internet, no endereço eletrônico http://www.cespe.unb.br/concursos/seduc_am2011, a partir das 19 horas da data provável de $\mathbf{2 0}$ de abril de 2011, observado o horário oficial de Brasília/DF.

13.20 candidato que desejar interpor recursos contra os gabaritos oficiais preliminares das provas objetivas disporá de dois dias corridos para fazê-lo, a contar do dia subsequente ao da divulgação desses gabaritos, a partir das 9 horas do primeiro dia até às 18 horas do segundo dia, ininterruptamente.

13.3 Para recorrer contra os gabaritos oficiais preliminares das provas objetivas, o candidato deverá utilizar o Sistema Eletrônico de Interposição de Recurso, no endereço eletrônico http://www.cespe.unb.br/concursos/seduc_am2011, e seguir as instruções ali contidas.

13.4 Todos os recursos serão analisados, e as justificativas das alterações/anulações de gabarito serão divulgadas no endereço eletrônico http://www.cespe.unb.br/concursos/seduc_am2011 quando da divulgação do gabarito definitivo. Não serão encaminhadas respostas individuais aos candidatos.

13.50 candidato que desejar interpor recursos contra os resultados provisórios nas demais fases do concurso disporá de dois dias corridos para fazê-lo, a contar do dia subsequente ao da divulgação desses resultados, conforme procedimentos disciplinados nos respectivos editais de resultados provisórios.

\subsection{DAS DISPOSIÇÕES GERAIS SOBRE OS RECURSOS}

13.6.1 O candidato deverá ser claro, consistente e objetivo em seu pleito. Recurso inconsistente ou intempestivo será preliminarmente indeferido.

13.6.2 O recurso não poderá conter, em outro local que não o apropriado, qualquer palavra ou marca que o identifique, sob pena de ser preliminarmente indeferido.

13.6.3 Se do exame de recursos resultar anulação de item ou de quesito integrante de prova, a pontuação correspondente a esse item ou quesito será atribuída a todos os candidatos, independentemente de terem recorrido.

13.6.4 Se houver alteração, por força de impugnações, de gabarito oficial preliminar de item integrante de prova, essa alteração valerá para todos os candidatos, independentemente de terem recorrido.

13.6.5 Não será aceito recurso via postal, via fax, via correio eletrônico ou, ainda, fora do prazo.

13.6.6 Em nenhuma hipótese serão aceitos pedidos de revisão de recursos ou recurso de gabarito oficial definitivo, bem como contra os resultados finais nas demais etapas.

13.6.7 Recursos cujo teor desrespeite a banca serão preliminarmente indeferidos.

\section{DAS DISPOSIÇÕES FINAIS}

14.1 A inscrição do candidato implicará a aceitação das normas para o concurso público contidas nos comunicados, neste edital e em outros a serem publicados.

14.2 É de inteira responsabilidade do candidato acompanhar a publicação de todos os atos, editais e comunicados referentes a este concurso público no Diário Oficial do Estado do Amazonas e divulgados na Internet, no endereço eletrônico http://www.cespe.unb.br/concursos/seduc_am2011.

14.30 candidato poderá obter informações referentes ao concurso público na Central de Atendimento do CESPE/UnB, localizada na Universidade de Brasília (UnB), Campus Universitário Darcy Ribeiro, Asa Norte, Brasília/DF, por meio do telefone (61) 3448-0100 ou via Internet, no endereço eletrônico http://www.cespe.unb.br/concursos/seduc_am2011, ressalvado o disposto no subitem 14.5 deste edital.

14.4 O candidato que desejar relatar ao CESPE/UnB fatos ocorridos durante a realização do concurso deverá fazê-lo à Central de Atendimento do CESPE/UnB, podendo postar correspondência para a Caixa Postal 4488, CEP 70904-970, encaminhar mensagem pelo fax de número (61) 3448-0110 ou enviar para o endereço eletrônico sac@cespe.unb.br.

14.5 Não serão dadas, por telefone, informações a respeito de datas, locais e horários de realização das provas. O candidato deverá observar rigorosamente os editais e os comunicados a serem divulgados na forma do subitem 14.2 . 
14.60 candidato deverá comparecer ao local designado para a realização das provas com antecedência mínima de uma hora do horário fixado para o seu início, munido de caneta esferográfica de tinta preta, fabricada em material transparente, do comprovante de inscrição e do documento de identidade original. Não será permitido o uso de lápis, lapiseira/grafite e/ou borracha durante a realização das provas.

14.7 Serão considerados documentos de identidade: carteiras expedidas pelos Comandos Militares, pelas Secretarias de Segurança Pública, pelos Institutos de Identificação e pelos Corpos de Bombeiros Militares; carteiras expedidas pelos órgãos fiscalizadores de exercício profissional (ordens, conselhos etc.); passaporte brasileiro; certificado de reservista; carteiras funcionais do Ministério Público; carteiras funcionais expedidas por órgão público que, por lei federal, valham como identidade; carteira de trabalho; carteira nacional de habilitação (somente o modelo com foto).

14.7.1 Não serão aceitos como documentos de identidade: certidões de nascimento, CPF, títulos eleitorais, carteiras de motorista (modelo sem foto), carteiras de estudante, carteiras funcionais sem valor de identidade, nem documentos ilegíveis, não identificáveis e/ou danificados.

14.7.2 Não será aceita cópia do documento de identidade, ainda que autenticada, nem protocolo do documento.

14.8 Por ocasião da realização das provas, o candidato que não apresentar documento de identidade original, na forma definida no subitem 14.7 deste edital, não poderá fazer as provas e será automaticamente eliminado do concurso público.

14.9 Caso o candidato esteja impossibilitado de apresentar, no dia de realização das provas, documento de identidade original, por motivo de perda, roubo ou furto, deverá ser apresentado documento que ateste o registro da ocorrência em órgão policial, expedido há, no máximo, noventa dias, ocasião em que será submetido à identificação especial, compreendendo coleta de dados, de assinaturas e de impressão digital em formulário próprio.

14.9.1 A identificação especial será exigida, também, ao candidato cujo documento de identificação apresente dúvidas relativas à fisionomia ou à assinatura do portador.

14.10 No dia de realização das provas, o CESPE/UnB poderá submeter os candidatos ao sistema de detecção de metal.

14.11 Terá suas provas anuladas e será automaticamente eliminado do concurso público o candidato que durante a sua realização:

a) for surpreendido dando ou recebendo auxílio para a execução das provas;

b) utilizar-se de livros, máquinas de calcular ou equipamento similar, dicionário, notas ou impressos que não forem expressamente permitidos ou que se comunicar com outro candidato;

c) for surpreendido portando aparelhos eletrônicos, tais como bip, telefone celular, walkman, agenda eletrônica, notebook, palmtop, receptor, gravador, máquina de calcular, máquina fotográfica, controle de alarme de carro etc., bem como relógio de qualquer espécie, óculos escuros ou quaisquer acessórios de chapelaria, tais como chapéu, boné, gorro, protetor auricular etc. e, ainda, lápis, lapiseira/grafite e/ou borracha;

d) faltar com o devido respeito para com qualquer membro da equipe de aplicação das provas, com as autoridades presentes ou com os demais candidatos;

e) fizer anotação de informações relativas às suas respostas no comprovante de inscrição provisória ou em qualquer outro meio que não os permitidos;

f) não entregar o material das provas ao término do tempo destinado para a sua realização;

g) afastar-se da sala, a qualquer tempo, sem o acompanhamento de fiscal;

h) ausentar-se da sala, a qualquer tempo, portando a folha de respostas ou o caderno de texto definitivo;

i) descumprir as instruções contidas no caderno de provas, na folha de respostas ou no caderno de texto definitivo;

j) perturbar, de qualquer modo, a ordem dos trabalhos, incorrendo em comportamento indevido; 
k) utilizar ou tentar utilizar meios fraudulentos ou ilegais para obter aprovação própria ou de terceiros em qualquer etapa do concurso público;

I) não permitir a coleta de sua assinatura;

m) for surpreendido portando caneta fabricada em material não transparente;

n) for surpreendido portando anotações em papéis que não os permitidos;

o) for surpreendido portando qualquer tipo de arma e/ou se negar a entregar a arma à Coordenação;

p) recusar-se a ser submetido ao detector de metal;

q) não transcrever o texto apresentado durante a aplicação das provas para posterior exame grafológico.

14.12 Não serão aplicadas provas em local, data ou horário diferentes dos predeterminados em edital ou em comunicado.

14.13 Não será admitido ingresso de candidato no local de realização das provas após o horário fixado para o seu início.

14.14 O candidato deverá permanecer obrigatoriamente no local de realização das provas por, no mínimo, uma hora após o seu início.

14.14.1 A inobservância do subitem anterior acarretará a não correção das provas e, consequentemente, a eliminação do candidato no concurso público.

14.15 O CESPE/UnB manterá um marcador de tempo em cada sala de provas para fins de acompanhamento pelos candidatos.

14.160 candidato que se retirar do ambiente de provas não poderá retornar em hipótese alguma.

14.170 candidato somente poderá se retirar do local de realização das provas levando o caderno de provas no decurso dos últimos quinze minutos anteriores ao horário determinado para o término das provas.

14.18 Não haverá, por qualquer motivo, prorrogação do tempo previsto para a aplicação das provas em razão do afastamento de candidato da sala de provas.

14.19 Não haverá segunda chamada para a realização das provas. O não comparecimento a estas implicará a eliminação automática do candidato.

14.20 Não será permitida, durante a realização das provas, a comunicação entre os candidatos nem a utilização de máquinas calculadoras e/ou similares, livros, anotações, réguas de cálculo, impressos ou qualquer outro material de consulta, inclusive códigos e/ou legislação.

14.21 Será eliminado do concurso o candidato que, durante a realização das provas, for surpreendido portando aparelhos eletrônicos, tais como bip, telefone celular, walkman, agenda eletrônica, notebook, palmtop, receptor, gravador, máquina de calcular, máquina fotográfica, controle de alarme de carro etc. bem como relógio de qualquer espécie, óculos escuros ou quaisquer acessórios de chapelaria, tais como chapéu, boné, gorro, protetor auricular etc. e, ainda, lápis, lapiseira/grafite e/ou borracha.

14.21.1 O CESPE/UnB recomenda que, no dia de realização das provas, o candidato não leve nenhum dos objetos citados no subitem anterior.

14.21.2 O CESPE/UnB não se responsabilizará por perdas ou extravios de objetos ou de equipamentos eletrônicos ocorridos durante a realização das provas, nem por danos neles causados.

14.21.3 Não será permitida a entrada de candidatos no ambiente de provas portando armas. 0 candidato que estiver armado será encaminhado à Coordenação.

14.22 No dia de realização das provas, não serão fornecidas, por qualquer membro da equipe de aplicação destas e/ou pelas autoridades presentes, informações referentes ao seu conteúdo e/ou aos critérios de avaliação e de classificação.

14.23 Se, a qualquer tempo, for constatado, por meio eletrônico, estatístico, visual, grafológico ou por investigação policial, ter o candidato se utilizado de processo ilícito, suas provas serão anuladas e ele será automaticamente eliminado do concurso público.

14.24 O descumprimento de quaisquer das instruções supracitadas implicará a eliminação do candidato, constituindo tentativa de fraude. 
14.25 O prazo de validade do concurso é de um ano, contado a partir da data de publicação da homologação do resultado final, podendo ser prorrogado, uma única vez, por igual período, a critério da Secretaria de Estado de Educação.

14.26 O resultado final do concurso será homologado pelo Secretário de Estado de Educação, publicado no Diário Oficial do Estado do Amazonas e divulgado no endereço eletrônico http://www.cespe.unb.br/concursos/seduc_am2011.

14.27 O candidato deverá manter atualizado seu endereço perante o CESPE/UnB, enquanto estiver participando do concurso público, por meio de requerimento a ser enviado à Central de Atendimento do CESPE/UnB, e perante a SEDUC/AM, se selecionado. São de exclusiva responsabilidade do candidato os prejuízos advindos da não atualização de seu endereço.

14.28 Os casos omissos serão resolvidos pelo CESPE/UnB junto com a SEDUC/AM.

14.29 Legislação com entrada em vigor após a data de publicação deste edital, exceto a listada nos objetos de avaliação constantes deste edital, bem como alterações em dispositivos legais e normativos a ele posteriores não serão objeto de avaliação nas provas do concurso.

14.30 Quaisquer alterações nas regras fixadas neste edital só poderão ser feitas por meio de outro edital.

\section{DOS OBJETOS DE AVALIAÇÃO (HABILIDADES E CONHECIMENTOS) 15.1 HABILIDADES}

15.1.1 Os itens das provas objetivas poderão avaliar habilidades que vão além de mero conhecimento memorizado, abrangendo compreensão, aplicação, análise, síntese e avaliação, valorizando a capacidade de raciocínio.

15.1.2 Cada item das provas objetivas poderá contemplar mais de uma habilidade e conhecimentos relativos a mais de uma área de conhecimento.

\subsection{CONHECIMENTOS}

15.2.1 Nas provas objetivas, serão avaliados, além das habilidades, conhecimentos, conforme especificação a seguir.

\subsubsection{CONHECIMENTOS BÁSICOS (para os cargos de nível superior e de nível médio)}

LÍNGUA PORTUGUESA: 1 Compreensão e interpretação de textos de gêneros variados. 2 Reconhecimento de tipos e gêneros textuais. 3 Domínio da ortografia oficial: emprego das letras; emprego da acentuação gráfica. 4 Domínio dos mecanismos de coesão textual: emprego de elementos de referenciação, substituição e repetição, de conectores e outros elementos de sequenciação textual; emprego/correlação de tempos e modos verbais. 5 Domínio da estrutura morfossintática do período: relações de coordenação entre orações e entre termos da oração; relações de subordinação entre orações e entre termos da oração; emprego dos sinais de pontuação; concordâncias verbal e nominal; emprego do sinal indicativo de crase; colocação dos pronomes átonos. 6 Reescritura de frases e parágrafos do texto: substituição de palavras ou de trechos de texto; retextualização de diferentes gêneros e níveis de formalidade. 7 Correspondência oficial: adequação da linguagem ao tipo de documento; adequação do formato do texto ao gênero.

RACIOCÍNIO LÓGICO: 1 Lógica sentencial e de primeira ordem. 2 Contagem: princípio aditivo e multiplicativo. 3 Arranjo. 4 Permutação. 5 Combinação simples e com repetição.

NOÇÕES DE INFORMÁTICA: 1 Conceitos e modos de utilização de aplicativos para edição de textos, planilhas e apresentações: ambiente Microsoft Office. 2 Sistema operacional Windows. 3 Conceitos básicos e modos de utilização de tecnologias, ferramentas, aplicativos e procedimentos associados a internet e intranet. 4 Conceitos de organização, de segurança e de gerenciamento de informações, arquivos, pastas e programas.

\subsubsection{CONHECIMENTOS COMPLEMENTARES PARA O CARGO DE PROFESSOR} EDUCAÇÃO BRASILEIRA: TEMAS EDUCACIONAIS E PEDAGÓGICOS: 1 História do pensamento pedagógico brasileiro: teoria da educação, diferentes correntes do pensamento pedagógico brasileiro. Projeto político pedagógico. 2 A didática e o processo de ensino e aprendizagem: Organização do 
processo didático: planejamento, estratégias e metodologias, avaliação. A sala de aula como espaço de aprendizagem e interação. A didática como fundamento epistemológico do fazer docente. 3 Principais teorias da aprendizagem: inatismo, comportamentalismo, behaviorismo, interacionismo; cognitivismo. As bases empíricas, metodológicas e epistemológicas das diversas teorias de aprendizagem; contribuições de Piaget, Vygotsky e Wallon para a psicologia e pedagogia; teoria das inteligências múltiplas de Gardner. Psicologia do desenvolvimento: aspectos históricos e biopsicossociais; temas contemporâneos: bullying, o papel da escola, a escolha da profissão, transtornos alimentares na adolescência, família, escolhas sexuais. 4 Teorias do currículo: acesso, permanência e sucesso do aluno na escola. Planejamento e gestão educacional. Avaliação institucional, de desempenho e de aprendizagem. O Professor: formação e profissão. A pesquisa na prática docente. A dimensão ética da profissão. 5 Aspectos legais e políticos da organização da educação brasileira. 6 Políticas educacionais para a educação básica: Ensino Médio - Diretrizes, Parâmetros Curriculares, currículo e avaliação. Interdisciplinaridade e contextualização. Educação Inclusiva. Educação, trabalho, formação profissional e as transformações do Ensino Médio. Protagonismo Juvenil e Cidadania. 7 Aspectos filosóficos, históricos e sociológicos da educação. 8 Normas federais sobre educação. 9 Níveis e modalidades de ensino - estrutura e funcionamento. 9.1 Educação infantil. 9.2 Ensino fundamental. 9.3 Ensino médio. 9.4 Educação de jovens e adultos. 9.5 Educação especial. 9.6 Educação indígena. 9.7 Educação a distância. 10 Planejamento e estatísticas educacionais. O Plano Nacional de Educação. 11 Políticas de avaliação educacional. 12 Financiamento da educação. 13 Princípios de educação comparada. 14 Educação no contexto da modernidade.

\subsubsection{CONHECIMENTOS ESPECÍFICOS}

CARGO 1: PROFESSOR - ARTES: $1 \mathrm{~A}$ arte na Educação para todos - LDB/PCN/RCB. 2 Fundamentos da Arte-Educação. 3 A arte e o processo de construção da cidadania. 4 As diversas linguagens artísticas: estética - conceitos e contextos. 5 A cultura popular brasileira: formação histórica, multiculturalismo. 6 A arte da pré-história brasileira e amazonense. 7 As artes visuais no Brasil e no Amazonas: do barroco colonial brasileiro aos dias atuais. 8 As artes audiovisuais: TV, cinema, fotografia, multimídia - novos recursos/novas linguagens. 9 A música no Brasil e a contribuição amazonense, partindo do período colonial aos nossos dias. 100 teatro no Brasil e na Região Norte: história e movimentos. 11 A dança no Brasil e na Região Norte: dramática e folclórica, popular e erudita. 12 Principais movimentos artísticos do século XX no Brasil.

CARGO 2: PROFESSOR - BIOLOGIA: 1 Identidade dos seres vivos: aspectos físicos, químicos e estruturais da célula; as organelas; a organização celular: seres procariontes, eucariontes e sem organização celular; funções celulares: síntese, transporte, eliminação de substâncias e processos de obtenção de energia: fermentação, fotossíntese e respiração celular; ciclo celular. 2 Noções básicas de microscopia. 3 Origem e evolução da vida: hipóteses sobre a origem da vida; teoria de Lamarck e teoria de Darwin; origem do homem. 4 Diversidade da vida: principais características dos representantes de cada domínio e de cada reino da natureza; regras de nomenclatura; biodiversidade no planeta e no Brasil. 5 Espécies ameaçadas. 6 Características anatômicas e fisiológicas do homem: fisiologia dos sistemas biológicos (digestório, respiratório, cardiovascular, urinário, nervoso, endócrino, imunológico, reprodutor e locomotor). 7 Transmissão da vida: fundamentos da hereditariedade - gene e código genético, cálculos com probabilidade; primeira e segunda lei de Mendel; aplicações da engenharia genética: clonagem, transgênicos. 8 Interação entre os seres vivos: conceitos básicos em ecologia; relações tróficas (cadeias e teias alimentares; distribuição natural da matéria e da energia e concentração de pesticidas e de subprodutos radiativos); relações ecológicas limitadoras do crescimento populacional; ecossistemas do Brasil.

CARGO 3: PROFESSOR - PRIMEIRO CICLO - ANOS INICIAIS DO ENSINO FUNDAMENTAL: 1 Alfabetização nos diferentes momentos históricos. 2 A função social da alfabetização atual. 3 Alfabetização e letramento. 4 As práticas da Língua Portuguesa: a leitura, a produção e escrita do texto, a análise linguística e a sistematização do código. $5 \mathrm{~A}$ intencionalidade da avaliação no processo de apropriação e 
produção do conhecimento. 6 Educação infantil na perspectiva histórica. 70 papel social da educação infantil. 8 Educar e cuidar. 9 A organização do tempo e do espaço na educação infantil (escola organizada por ciclos de formação - teoria e desafios). 10 A documentação pedagógica (planejamento, registro, avaliação). 11 Princípios que fundamentam a prática na educação infantil: pedagogia da infância, dimensões humanas; direitos da infância e relação creche família. 12 As instituições de educação infantil como espaço de produção das culturas infantis.

CARGO 4: PROFESSOR - CIÊNCIAS: 1 Seres vivos e ambiente: características morfofisiológicas dos grupos de vírus aos mamíferos e de algas a gimnospermas e suas relações entre si e com o meio. 2 Citologia e histologia; organização das células; divisão celular - características dos tecidos básicos animais e vegetais. 3 Reprodução: tipos de reprodução - reprodução humana - características hereditárias: sexualidade e DST. 4 Evolução: origem da vida; evolução humana. 5 Misturas e substâncias: propriedades e processos de separação; átomos, moléculas e substâncias; reações químicas; átomo e eletricidade; gases e líquidos. 6 Ondas e energia: ondas eletromagnéticas - luz, visão, espectro eletromagnético; óptica e suas leis; problemas da visão; ondas e comunicação; tipos de energia e suas transformações; propagação da energia. 7 Terra - energia e vida; a terra e a luz no espaço, seus movimentos e suas consequências; atmosfera e pressão; a vida na terra e suas relações com a energia solar; camadas da terra; condições ambientais e condições de sobrevivência. 8 Metodologia de ensino de Ciências: organização didático-pedagógica e suas implicações na construção do conhecimento em sala de aula; organização didático-pedagógica e o ensino integrado de ciências frente às exigências metodológicas do ensino-aprendizagem: o ensino globalizado e formação da cidadania. 9 Educação ambiental. 100 Projeto Genoma.

CARGOS 5, 6, 7 e 8 - PROFESSOR DE EDUCAÇÃO ESPECIAL: I EDUCAÇÃO ESPECIAL: 1 Função social, cidadania e comunidade escolar pública. 2 Pedagogia dos projetos. 3 Relações entre acesso e permanência, reprovação e evasão no ensino público. 4 Teorias psicogenéticas e suas implicações na prática pedagógica de ensino especial. 5 Psicologia do desenvolvimento humano. 6 Relação professoraluno. 70 processo ensino-aprendizagem. 8 Planejamento de ensino. 9 Avaliação da aprendizagem. 10 Representação e alteridade da pessoa com deficiência na sociedade. 11 Atendimentos educacionais especializados. 12 Política Nacional de Educação Especial na perspectiva da Educação inclusiva. II LEGISLAÇÃO: 1 Lei de Diretrizes e Bases da Educação Nacional e suas atualizações. 2 Parecer CNE/CEB no 17/2001 e Resolução CNE/CEB no 2/2001 (institui as Diretrizes Curriculares Nacionais para a Educação Especial). 3 Convenção Interamericana para a eliminação de todas as formas de discriminação contra a pessoa portadora de deficiência. 4 Lei Federal no 10.098/2000, que estabelece normas gerais e critérios básicos para a promoção da acessibilidade das pessoas portadoras de deficiência ou com mobilidade reduzida. 5 Estatuto da criança e do adolescente (ECA).

CARGO 9: PROFESSOR - EDUCAÇÃO FÍSICA: 1 Histórico da Educação Física. 2 A Educação Física enquanto linguagem. $3 \mathrm{O}$ Processo ensino-aprendizagem na Educação Física. 4 Construindo competências e habilidades em Educação Física. 5 Avaliação em Educação Física. 6 Educação Física e sociedade. 7 Fundamentos didático-pedagógicos da educação física. 8 Atividade física e saúde. 9 Crescimento e desenvolvimento. 10 Aspectos da aprendizagem motora. 11 Aspectos sócio-históricos da educação física. 12 Política educacional e educação física. 13 Cultura e educação física. 14 Aspectos da competição e cooperação no cenário escolar.

CARGO 10: PROFESSOR - ESPANHOL: 1 Interpretação e compreensão dos diversos aspectos textuais; uso e domínio das Estratégias de Leitura: compreensão geral do texto; reconhecimento de informações específicas; inferência e predição; palavras cognatas e falsos cognatos; abordagem da linguagem sob novos enfoques. 2 Vocabulário: domínio de vocabulário compatível com a interpretação e elaboração de texto, dentro do conteúdo exigido. 3 Aspectos gramaticais: el alfabeto gráfico y oral; artículos; pronombres; personales de tratamiento; presente de indicativo: ser, estar y tener; adjetivos posesivos, la familia; contracciones; combinaciones; perífrasis de futuro; lugares y medios de transporte; los numerales; el articulo neutro LO; objetos variados; los colores; adverbios y expresiones de tiempo; 
verbos; pronombres demostrativos; adverbios y pronombres interrogativos; formación del plural. 4 Aprendizagens em língua estrangeira. 5 Relação entre Língua, cultura e sociedade.

CARGO 11: PROFESSOR - FILOSOFIA: 1 Filosofia e conhecimento: Pré-Socráticos; Sofistas; Sócrates, Platão e Aristóteles; Patrística (Santo Agostinho); Escolástica (Santo Tomás de Aquino); Racionalismo (Descartes); Empirismo (Bacon e Locke); o Criticismo Kantiano; o Idealismo Hegeliano; Materialismo Histórico e Dialético; Fenomenologia; a Escola de Frankfurt e a Teoria Crítica (Razão Instrumental e Razão Crítica). 2 Filosofia da Arte; Filosofia da Moral; Filosofia da Ciência; as Ciências da Natureza e as Ciências Humanas; a Epistemologia Contemporânea (Popper, Bachelard, Feyerabend, Lakatos e Kuhn). 3 Filosofia Política: pensamento político grego e medieval; o pensamento político em Maquiavel, Hobbes, Locke, Montesquieu, Rousseau, Kant, Hegel e Marx; Filosofia da Linguagem (Wittgenstein, John Searle) a Pós-modernidade: Lyotard, Foucault, Deleuze, Derrida. 4 O Ensino de Filosofia no Ensino Médio: Determinações Legais; As reflexões acerca do ensino de Filosofia no Ensino Médio; as estratégias didáticas e a seleção de conteúdos; Competências e Habilidades propostas pelos Parâmetros Curriculares Nacionais para a Disciplina de Filosofia.

CARGO 12: PROFESSOR - FÍSICA: 1 História e Evolução das Idéias da Física: cosmologia antiga; a física de Aristóteles; origens da mecânica; surgimento da teoria da relatividade e da teoria quântica. 2 Mecânica: cinemática escalar, cinemática vetorial; movimento circular; leis de Newton e suas aplicações; trabalho; potência; energia, conservação e suas transformações, impulso; quantidade de movimento, conservação da quantidade de movimento; gravitação universal; estática dos corpos rígidos; estática dos fluidos; princípios de Pascal, Arquimedes e Stevin. 3 Termodinâmica: calor e temperatura; temperatura e dilatação térmica; calor específico; trocas de calor; mudança de fase e diagramas de fases; propagação do calor; teoria cinética dos gases; energia interna; lei de Joule; transformações gasosas; leis da termodinâmica: entropia e entalpia; máquinas térmicas; ciclo de Carnot. 4 Eletromagnetismo: introdução à eletricidade; campo elétrico; lei de Gauss; potencial elétrico; corrente elétrica; potência elétrica e resistores; circuitos elétricos; campo magnético; lei de Ampère; lei de Faraday; propriedades elétricas e magnéticas dos materiais; equações de Maxwell; radiação. 5 Ondulatória: movimento harmônico simples; oscilações livres, amortecidas e forçadas; ondas; ondas sonoras e eletromagnéticas; frequências naturais e ressonância; Ótica Geométrica: reflexão e refração da luz; instrumentos ópticos - características e aplicações. 6 Ótica Física: interferência; difração; polarização. 7 Física Moderna: introdução a Relatividade Especial, transformação de Lorentz; equivalência Massa-Energia; natureza ondulatória-corpuscular da matéria; teoria quântica da matéria e da radiação; modelo do átomo de hidrogênio; núcleo atômico; energia nuclear. 8 Ensino de Física: conhecimento científico e habilidade didática no ensino de Física; A construção do conhecimento no ensino da Física: abordagens metodológicas; Avaliação de aprendizagem.

CARGO 13: PROFESSOR - GEOGRAFIA: 1 Introdução: tratamento didático para o ensino da Geografia; o sentido do aprendizado da geografia; competências/habilidades em geografia. 2 Geopolítica e Econômica: o espaço como produto do homem; capitalismo; desenvolvimento e subdesenvolvimento; economia do pós-guerra; o Brasil, a nova ordem mundial e a globalização; o comércio internacional; o MERCOSUL; a economia mundial e do Brasil; o problema da dívida externa; energia e transporte; a agropecuária; o comércio; a indústria; os serviços; as relações de trabalho; as desigualdades sociais e a exploração humana; a revolução técnico-científica. 3 Geografia da população: a população e as formas de ocupação do espaço; os contrastes regionais do Brasil; urbanização e metropolização. 4 Ecologia: ecossistemas naturais; impactos ambientais; recursos naturais e devastação histórica; política ambiental.

CARGO 14: PROFESSOR - HISTÓRIA: 1 Introdução aos estudos históricos: historicidade do conhecimento histórico; metodologias e conceitos da ciência história; periodização e tempo; o historiador e seu trabalho; conhecimento e verdade em história. 2 Pré-história: primórdios da humanidade no continente: Americano (Brasil), África, Ásia, Europa. Idade Antiga: Organização sócio, política, econômica e cultural (Egito, Mesopotâmia, Palestina, Fenícia, Pérsia e África). 3 Antiguidade 
Clássica: organização sócio, política, econômica e cultural das Civilizações Greco Romana. 4 Idade Média: a sociedade européia (do séc. $V$ ao XV); o império bizantino; o islamismo; os reinos africanos no século $V$ ao XV. 5 Idade Moderna: o renascimento comercial a estruturação da escravidão africana e a diáspora dos povos africanos e o declínio do feudalismo; os grandes estados nacionais; a revolução cultural do renascimento; o humanismo; a reforma e a contra reforma; as grandes navegações; o absolutismo monárquico. 6 Idade Contemporânea: a revolução francesa; revolução industrial; o liberalismo, o socialismo, o sindicalismo, o anarquismo e o catolicismo social; as independências na América espanhola; Imperialismo europeu e norte-americano no séc. XIX; a 1a guerra mundial; a revolução russa; a crise de 1929; o nazi-facismo; a 2a Guerra Mundial; o bloco capitalista e o bloco socialista; a Guerra Fria; a nova ordem mundial; América Latina e as lutas sociais; o socialismo em Cuba e na China; integração e conflito em um mundo globalizado. 7 História do Brasil: organização sócio, política, econômica e cultural no Brasil Colonial; escravidão e resistência negra e indígena; cultura e religiosidade africana e indígena; a crise do sistema colonial, movimento de independência; a família real no Brasil; independência; Primeiro Império; Período Regencial e as revoluções sociais Cabanagem, Balaiada, Farroupilha, Sabinada, Revolta dos Malês, Quebra Quilo Segundo Império, a proclamação da república; da republica oligárquica à revolução de 30; a ditadura de 1930 a 1945, redemocracia; a ditadura de 1960 a 1985; redemocratização e globalização. 8 História do Amazonas: o processo de ocupação e produção no espaço amazonense; a sociedade amazonense no período colonial; a escravidão no Amazonas; o negro e o índio nos modos de produção econômica; a luta e resistência de negros e índios; Amazonas no processo de Independência; Revolução de 1817, 1824, Sedição de Pinto Madeira (1831), as lutas fratricidas, a dizimação das nações indígenas; Amazonas no período regencial; o binômino couro e algodão e o processo de urbanização; resistência e abolição no Amazonas; a sociedade amazonense nos contextos sócio, político, econômico e cultural dos séculos XX e XXI.

CARGO 15: PROFESSOR - INGLÊS: 1 Interpretação e compreensão dos diversos aspectos textuais; uso e domínio das Estratégias de Leitura: compreensão geral do texto; reconhecimento de informações específicas; inferência e predição; palavras cognatas e falsos cognatos; abordagem da linguagem sob novos enfoques. 2 Vocabulário: domínio de vocabulário compatível com a interpretação e elaboração de texto, dentro do conteúdo exigido. 3 Aspectos gramaticais: conhecimento dos tempos e modos verbais. 4 Verb "to be", regular/irregular verbs (simple present and simple past). 5 Present continuous. 6 Past continuous. 7 Present perfect and past perfect. 8 Present perfect continuous. 9 Future tense: will; going to - nas diversas formas (afirmativa, negativa e interrogativa). 10 Imperative. 11 Modals: can, could, should, must, have, may. 12 Passive voice. 13 Uso de preposições e conjunções. 14 Formação e classe de palavras; pronomes: personal pronouns (object pronouns, subject pronouns); possessive pronouns; possessive adjectives; relative clauses: who/that/which/whose/whom/where. 15 Comparatives and superlatives: possessive case. 16 Aprendizagens em língua estrangeira; relação entre Língua, cultura e sociedade.

CARGO 16: PROFESSOR - MATEMÁTICA: 1 Números: números inteiros; divisibilidade; números racionais; números irracionais e reais. 2 Funções: igualdade de funções; determinação do domínio de uma função; funções injetivas, sobrejetivas e bijetivas; função inversa; composição de funções; funções crescentes, decrescentes, pares e impares; os zeros e os sinais de uma função; funções lineares, constantes, do 10 e do 2 o graus, modulares, polinomiais, logarítmicas e exponenciais. 3 Equações, desigualdades e inequações. 4 Geometria: plana,espacial e analítica. 5 Trigonometria: triângulo retângulo; estudo do seno, cosseno, tangente, cotangente, secante e cossecante. 6 Sequências: sequências de Fibonacci, sequências numéricas; progressão aritmética e geométrica. 7 Matrizes: determinantes; sistemas lineares. 8 Noções de Estatística: medidas de tendência central; medidas de dispersão distribuição de frequência; gráficos; tabelas. 9 Matemática Financeira: proporção; porcentagem; juros e taxas de juros; juro exato e juro comercial; sistemas de capitalização; descontos simples; desconto racional; desconto bancário; taxa efetiva; equivalência de capitais. 10 Cálculo de probabilidade. 11 Números Complexos. 12 Cálculo diferencial e integral das funções de uma variável. 13 
Noções de História da Matemática. 14 Avaliação e Educação Matemática: formas e instrumentos. 15 Metodologia do Ensino de Matemática: uso de material concreto e aplicativos digitais.

CARGO 17: PROFESSOR - PORTUGUÊS: I LITERATURA. 1 A linguagem literária. 20 Barroco no Brasil. 30 Arcadismo no Brasil. 40 Romantismo - a prosa no Brasil. 50 Realismo-Naturalismo no Brasil. 60 Parnasianismo no Brasil. 70 Simbolismo no Brasil. 8 A revolução artística do inicio do século XX. 9 O PréModernismo no Brasil. 10 O Modernismo no Brasil: poesia e prosa. 11 O Pós-Modernismo. II LEITURA. 1 Compreensão literal - relações de coerência: ideia de coerência; ideia principal detalhes de apoio, relações de causa e efeito, sequência temporal, sequência espacial, relações de comparação e contraste. 2 Relações coesivas: referência, substituição, elipse, repetição. 3 Indícios contextuais: definição, exemplo modificadores, recolocação, estruturas paralelas, conectivos, repetição de palavras chave. 4 Relações de sentido entre palavras: sinonímia/antonímia/hiperonímia/hiponímia/campo semântico. 5 Compreensão interpretativa: propósito do autor, informações implícitas, distinção entre fato e opinião. 6 Organização retórica: generalização, exemplificação, descrição, definição, exemplificação/ especificação, explanação, classificação, elaboração. 7 Seleção de inferência: compreensão crítica. III PRODUÇÃO DE TEXTOS: Recursos estilísticos e estruturais (aspectos textuais, gramaticais e convenções da escrita ). Fatores constitutivos de relevância - coerência e coesão. IV ANÁLISE LINGUÍSTICA (aspectos gramaticais). 1 Estrutura da frase: modos de construção de orações segundo diferentes perspectivas de ordenação. 2 Estrutura do vocábulo: flexão dos vocábulos, seu valor e significação dentro de frases. 3 Aspectos normativos: regras padrão de concordância, regência e colocação. 4 Emprego de certas formas e palavras: modos verbais, aspectos verbais, pronome relativo, conjunção etc., formas-padrão de expressar o tratamento, pontuação, ortografia. 5 Descrição linguística: unidades linguísticas: orações, sintagmas, palavras, morfemas. 6 Categorias semânticas: gênero, número, tempo, modo, aspectos, classificação dos vocábulos, processos de subordinação e coordenação, funções sintáticas e papéis semânticos.

CARGO 18: PROFESSOR - QUÍMICA: 10 mundo e suas transformações: História da Química, Ensino da Química: concepções e metodologias, leis ponderais (Lavoisier, Proust, Dalton, Richter); leis das reações gasosas de Gay Lussac; hipótese de Avogadro, mole, molécula; Cálculos estequiométricos; natureza elétrica da matéria (os trabalhos de Faraday). 2 Ligações químicas: iônica, covalente, eletronegatividade; repulsão de pares eletrônicos, geometria molecular; teoria da ligação de valência e a sobreposição de orbitais; orbitais híbridos e moleculares. 3 A tabela periódica: histórico da tabela e sua construção; o problema da classificação (metais, não metais e semimetais), gases nobres e química do carbono. 4 Sólidos, líquidos e gases no universo da Química: evolução do conceito de matéria; características e propriedades; líquidos e sólidos ideais, ligações químicas nos sólidos e líquidos. 5 Matéria e mudança de estado: sólidos, líquidos e gases reais; mudança de estado, diagrama de fase. 60 modelo atômico: evolução dos conceitos de átomo; propriedades dos átomos (eletronegatividade, afinidade eletrônica e suas dimensões). 7 Soluções: misturas, tipos de solução, concentração e solubilidade; propriedades coligativas, eletrólitos, íons em solução aquosa. 8 Funções químicas e aplicações: ácidos; bases; sais; óxidos; reações em solução aquosa de ácido-base, precipitação e complexação; equilíbrio das soluções aquosas de ácido-base, dissociação, hidrólise, indicadores ácido-base de titulação, tampões, estequiometria de soluções. 9 Cinética e equilíbrio químico: velocidades e mecanismos de reação; equação de velocidade, teoria de colisões, complexo ativado, catálise. 10 Química Orgânica: princípios básicos da nomenclatura orgânica; funções orgânicas, reações e mecanismos de reação.

CARGO 19: PROFESSOR - ENSINO RELIGIOSO: 1 Elementos históricos do ensino religioso. 2 o ensino religioso e a participação social, cultura e transferência. 3 Culturas e tradições religiosas. 4 As escrituras sagradas. $5 \mathrm{O}$ ensino religioso/teologias. $6 \mathrm{~A}$ origem do fenômeno religioso. $7 \mathrm{O}$ ensino religioso e a escola a partir da Lei $\mathrm{n}$ - 9.394/96. 8 Objetivos do ensino religioso para o ensino fundamental. 9 Metodologia de ensino religioso.

CARGO 20: PROFESSOR - SOCIOLOGIA: 1 Contexto histórico do surgimento da Sociologia. 2 Sociologia e sociedade: conceitos, desenvolvimento da Sociologia. 3 Pensamento sociológico: conceitos básicos da 
Teoria de Durkheim, Marx e Weber. 4 Condicionamentos sócio-culturais da personalidade do indivíduo. 5 Cultura e sociedade: o Estado, a família, a religião, as instituições sociais e o processo de socialização. 60 novo mundo do trabalho. 7 Meios de comunicação de massa: ideologia, a indústria cultural. 80 Problema das gerações: exclusão social e cidadania; escola juventude e violência; a escola e o tratamento das diferenças sociais. 9 A globalização e os novos desafios da sociedade. 10 A História do sindicalismo no Brasil. 11 Os novos movimentos sociais. 12 Sociologia no Brasil: cultura e identidade. 13 Sociologia no Nordeste: cultura, identidade, religiosidade.

CARGO 21: PEDAGOGO: I Fundamentos teóricos metodológicos legais do currículo. 1 Fundamentos da educação. 1.1 A relação educação e sociedade: dimensões filosófica, sociocultural e pedagógica. 1.2 Desenvolvimento histórico das concepções pedagógicas. 20 currículo e a construção do conhecimento. II Gestão e organização do trabalho pedagógico. 1 A supervisão: concepção e prática. 1.1 Funções e responsabilidades do supervisor escolar: pedagógicas, administrativas, técnicas e político-sociais. 1.2 Liderança e relações humanas no trabalho: tipos de liderança, mecanismos de participação; normas e formas organizativas facilitadoras da integração grupal. 1.3 Organização do trabalho na escola pública: articulação da ação supervisora com as diferentes instâncias e agentes educativos na construção da cidadania e na melhoria da qualidade do ensino. 1.4 A pesquisa participante como instrumento de inovação e de avaliação do ensinar e aprender. 20 papel político pedagógico e a organicidade do ensinar, aprender e pesquisar. 2.1 A função sociocultural da escola. 2.2 A escola: a comunidade escolar e o contexto institucional e sociocultural. 2.30 processo de planejamento: concepção, importância, dimensões e níveis. 2.4 Projeto político-pedagógico da escola: concepção, princípios e eixos norteadores. 3 A gestão educacional decorrente da concepção do projeto político-pedagógico. 3.1 Planejamento participativo: concepção, construção, acompanhamento e avaliação. 3.2 A comunicação e a interação grupal no processo de planejamento: constituição de equipes, encontros e avaliações sistemáticas, capacitação de pessoal para o planejamento, constituição de grupos de estudo, aplicação de critérios na distribuição de tarefas, articulação com outros grupos sociais. 40 processo de ensinoaprendizagem. 4.1 Relação professor-aluno. 4.2 Bases psicológicas da aprendizagem. 4.3 Planejamento de ensino em seus elementos constitutivos: objetivos e conteúdos de ensino; métodos e técnicas e a multimídia educativa e a avaliação educacional. 4.4 Análise de dificuldades, problemas e potencialidades no cotidiano escolar em sua relação com a sociedade concreta.

CARGO 22: ASSISTENTE SOCIAL: 1 Fundamentos históricos e teórico-metodológicos do Serviço Social. 1.1 Da institucionalização do Serviço Social ao movimento de reconceituação na América Latina, em particular no Brasil. 1.2 Análise crítica das influências teórico-metodológicas e as formas de intervenção construídas pela profissão em seus distintos contextos históricos. 1.3 Redimensionamento da profissão ante as transformações societárias: condições e relações de trabalho, espaços sócio-ocupacionais, atribuições. 20 projeto ético-político do Serviço Social: construção e desafios. 3 Fundamentos éticos, ética profissional e legislação específica: lei de regulamentação da profissão, código de ética profissional, diretrizes curriculares do curso de Serviço Social, Resoluções do Conselho Federal de Serviço Social. 5- A dimensão investigativa, processos de planejamento e de intervenção profissional: 5.1 Formulação de projeto de intervenção profissional: aspectos teóricos e metodológicos. 5.2 Fundamentos, instrumentos e técnicas de pesquisa social. $5.3 \mathrm{O}$ planejamento como processo técnicopolítico: concepção, operacionalização e avaliação de planos, programas e projetos. 5.4 Assessoria, consultoria e supervisão em Serviço Social. 6 A dimensão técnico-operativa do serviço social. 6.1 Concepções e debates sobre instrumentos e técnicas. 6.2 Entrevista, visita domiciliar, visita institucional, reunião, mobilização social, trabalho em rede, ação socioeducativa com indivíduos, grupos e família, abordagens individual e coletiva. 6.3 Estudo social, perícia social, relatório social, laudo social, parecer social. 6.4 Atuação em equipe multiprofissional e interdisciplinar. 7 Questão social e direitos de cidadania. 7.1 Formas de expressão, enfrentamento e Serviço Social. 8 Política Social: fundamentos, história e políticas. 8.1 Seguridade Social no Brasil. Relação Estado/Sociedade. Contexto atual e o neoliberalismo. 8.2 Política de Saúde, de Assistência Social e de Previdência Social e respectivas 
legislações. 8.3 Políticas Sociais setoriais: educação, habitação, trabalho, urbana, rural, e meio ambiente e respectivas legislações. 8.4 Políticas e programas sociais dirigidas aos segmentos: criança, adolescentes, jovens, idosos, mulheres, homens, afro-descendentes, indígenas, pessoas com deficiência, pessoas com transtorno mental, pessoas vítimas de violência, população em situação de rua, usuário de álcool e outras drogas, portadores do HIV e, respectivas legislações. 8.5 Políticas, diretrizes, ações e desafios na área da família, da criança e do adolescente; concepções e modalidades de família; estratégias de atendimento e acompanhamento; estatuto da Criança e do Adolescente (ECA); a defesa de direitos da criança e do adolescente; o papel dos conselhos; centros de defesa e delegacias; adoção e guarda; violência contra crianças e adolescentes; prostituição infanto-juvenil; extermínio, sequestro e tráfico de crianças; exploração sexual no trabalho e no tráfico de drogas; sexo turismo; meninos e meninas de rua; trabalho infanto-juvenil. 9 Legislação Social: 9.1 Constituição Federativa do Brasil e Leis da Seguridade Social (LOS, LOPS, LOAS): Lei Orgânica da Seguridade Social (Lei no 8.212/1991); Lei Orgânica da Saúde (Lei no 8.080/1990); Lei que dispõe sobre planos de benefícios da Previdência Social (Lei no 8.213/1991); Lei Orgânica da Assistência Social (Lei no 8.742/1993) e respectivas atualizações. 9.2 Legislação social para áreas/segmentos específicos: Lei de Diretrizes e Bases da Educação Brasileira (LDB); Estatuto da Criança e do Adolescente (ECA), Estatuto do Idoso, Lei Maria da Penha, Programa Nacional de Direitos Humanos - PNDH. 9.3 Sistema Nacional de Atendimento Socioeducativo (Sinase), Sistema Nacional de Políticas Públicas sobre Drogas (Sisnad). Normativas Internacionais (Declaração de Beijing, Princípios Orientadores das Nações Unidas para a Prevenção da Delinquência Juvenil (Princípios Orientadores de Riad), Normas Mínimas para a Proteção de Adolescentes Privados de Liberdade, Regras Mínimas para a Administração da Justiça da Infância e da Juventude). 10 Legislação profissional: Lei no 8.662/1993 - Lei de regulamentação da profissão de Assistente Social; Código de Ética Profissional do Assistente Social (Resolução CFESS no 273/1993 e alterações); Resoluções do Conselho Federal de Serviço Social - CFESS.

CARGO 23: BIBLIOTECÁRIO: 1 Documentação: conceitos básicos e finalidades da documentação geral e jurídica. 2 Biblioteconomia e ciência da informação: conceitos básicos e finalidades. 3 Noções de informática para bibliotecas: dispositivos de memória, de entrada e saída de dados. 4 Normas técnicas para a área de documentação: referência bibliográfica (de acordo com as normas da ABNT - NBR 6023/2002), resumos, abreviação de títulos de periódicos e publicações seriadas, sumário, preparação de índices de publicações, preparação de guias de bibliotecas, centros de informação e de documentação. 5 Indexação: conceito, definição, linguagens, descritores, processos e tipos de indexação. 6 Resumos e índices: tipos e funções. 7 Classificação decimal universal (CDU): estrutura, princípios e índices principais e emprego das tabelas auxiliares. 8 Catalogação (AACR-2): catalogação descritiva, entradas e cabeçalhos; catalogação de multimeios: CD-ROM, fitas de vídeos e fitas cassetes. 9 Catálogo: tipos e funções. 10 Organização e administração de bibliotecas: princípios e funções administrativas em bibliotecas, estrutura organizacional, as grandes áreas funcionais da biblioteca, marketing. 11 Centros de documentação e serviços de informação: planejamento, redes e sistemas. 12 Desenvolvimento de coleções: políticas de seleção e de aquisição, avaliação de coleções; fontes de informação. 13 Estrutura e características das publicações: Diário Oficial da União - DOU. 14 Serviço de referência: organização de serviços de notificação corrente (serviços de alerta), disseminação seletiva da informação (DSI): estratégia de busca de informação, planejamento e etapas de elaboração, atendimento ao usuário. 15 Estudo de usuário - entrevista. 16 Automação: formato de intercâmbio, formato US MARC, banco de dados, base de dados, planejamento da automação, principais sistemas de informação automatizados nacionais e internacionais. 17 Bibliografia: conceituação, teorias, classificação, histórico e objetivos.

CARGO 24: CONTADOR: I Contabilidade geral. 1 Princípios Contábeis Fundamentais (aprovados pela Resolução CFC no 750/1993, DOU de 31/12/1993). 2 Patrimônio - componentes patrimoniais: ativo, passivo e situação líquida (ou patrimônio líquido). 3 Diferenciação entre capital e patrimônio. 4 Equação fundamental do patrimônio. 5 Representação gráfica dos estados patrimoniais. 6 Fatos contábeis e 
respectivas variações patrimoniais. 7 Conta: conceito; débito, crédito e saldo; teorias, função e estruturas das contas; contas patrimoniais e de resultado. 8 Apuração de resultados; controle de estoques e do custo das vendas. 9 Sistema de contas; plano de contas. 10 Provisões em geral. 11 Escrituração; conceito e métodos; lançamento contábil: rotinas e fórmulas; processos de escrituração; escrituração de operações financeiras; escrituração de operações típicas. 12 Livros de escrituração: obrigatoriedade, funções, formas de escrituração; erros de escrituração e su0as correções. 13 Sistema de partidas dobradas. 14 Balancete de verificação. 15 Balanço patrimonial: obrigatoriedade e apresentação; conteúdo dos grupos e subgrupos. 16 Classificação das contas; critérios de avaliação do ativo e do passivo; avaliação de investimentos; levantamento do balanço de acordo com a Lei no 6.404/1976 (Lei das Sociedades por Ações). 17 Demonstração do resultado do exercício: estrutura, características e elaboração de acordo com a Lei no 6.404/1976. 18 Apuração da receita líquida; apuração do lucro bruto e do lucro líquido; destinação do lucro: participações, imposto de renda e absorção de prejuízos. 19 Demonstração de lucros ou prejuízos acumulados: forma de apresentação de acordo com a Lei $n$ - 6.404/1976. 20 Transferência do lucro líquido para reservas; dividendo mínimo obrigatório. 21 Capital de giro: origens e aplicações. II Contabilidade pública. 1 Conceito, objeto e regime. 2 Campo de aplicação. 3 Legislação básica (Lei no 4.320/1964 e Decreto no 93.872/1986). 4 Receita e despesa pública: conceito, classificação econômica e estágios. 5 Receitas e despesas orçamentárias e extra-orçamentárias: interferências e mutações. 6 Plano de contas da administração federal: conceito, estrutura e contas do ativo, passivo, despesa, receita, resultado e compensação. 7 Tabela de eventos: conceito, estrutura e fundamentos lógicos. 8 Sistema Integrado de Administração Financeira do Governo Federal - SIAFI: conceito, objetivos, principais documentos. 9 Balanços financeiro, patrimonial, orçamentário e demonstrativo das variações, de acordo com a Lei no 4.320/1964. 10 Lei no 8.666/1993 e suas alterações posteriores. 11 Lei Complementar no 101/2000 (Lei de Responsabilidade Fiscal). III AUDITORIA. 1 Normas brasileiras para o exercício da auditoria interna: independência, competência profissional, âmbito do trabalho, execução do trabalho e administração do órgão de auditoria interna. 2 Auditoria no setor público federal; finalidades e objetivos da auditoria governamental; abrangência de atuação; formas e tipos; normas relativas à execução dos trabalhos; normas relativas à opinião do auditor; relatórios e pareceres de auditoria; operacionalidade. 3 Objetivos, técnicas e procedimentos de auditoria: planejamento dos trabalhos; programas de auditoria; papéis de trabalho; testes de auditoria; amostragem estatística em auditoria; eventos ou transações subsequentes; revisão analítica; entrevista; conferência de cálculo; confirmação; interpretação das informações; observações; procedimentos de auditoria em áreas específicas das demonstrações contábeis. IV Legislação tributária aplicada à administração pública: INSRF/no 480/2004 e suas alterações; INSRP/no 003/2005 e alterações.

CARGO 25: ESTATÍSTICO: 1 Cálculos de probabilidades. 2 Cálculos com geometria analítica. 3 Inferência estatística. 4 Estatística computacional. 5 Análise matemática. 6 Demografia. 7 Métodos numéricos. 8 Pesquisa operacional. 9 Técnica de amostragem. 10 Análise de correlação e regressão. 11 Controle estatístico de qualidade. 12 Processos estocásticos. 13 Análise de dados discretos. 14 Análise multivariada. 15 Análise das séries temporais. 16 Análise exploratória de dados. 17 Medidas de tendência central. 18 Medidas de dispersão. 19 Medidas de assimetria. 20 Medidas de curtose. 21 Distribuições conjuntas.

CARGO 26: NUTRICIONISTA: 1 Noções de anatomia e fisiologia do aparelho digestório. 2 Conceitos de nutrição e dietética. Nutrição humana básica: metabolismo energético e nutricional, biodisponiblidade, classificação, função, fontes, carências e toxicidade de macro e micronutrientes, água, eletrólitos e fibras. 3 Noções de avaliação do estado nutricional do indivíduo saudável nos ciclos da vida: métodos, indicadores antropométricos e características da alimentação. Aleitamento materno. Sistema de vigilância alimentar e nutricional (SISVAN). 4 Alimentos: conceito, características e qualidade. Enfermidades transmitidas por alimentos (ETA) e microbiologia dos alimentos: fatores que influenciam a multiplicação dos microorganismos; microrganismos patogênicos de importância em alimento. 5 Técnica 
Dietética: conceito, classificação e características dos alimentos, pré-preparo e preparo de alimentos,metodologia para pesos e medidas de alimentos, processos básicos de coç̧ão e técnicas de armazenamento e transporte, propriedades sensoriais e testes de degustação. Cardápios: Leis da Nutrição e tipos de cardápios. Ficha técnicas de preparação. 6 Unidades de alimentação e nutrição objetivos, características físicas, recursos humanos, abastecimento e armazenamento, tipos de serviços e distribuição. Custos, higiene e sanitização. Noções de organização e gestão do processo de trabalho. Vigilância sanitária e controle de qualidade dos grupos de alimentos. Análise de perigos e pontos críticos de controle (APPCC) e manual de boas práticas. Noções de saúde e segurança no trabalho. 7 Banco de leite, lactário e sondário hospitalar, cozinha dietética: características físicas, normas, procedimentos, equipamentos. 8 Guia alimentar para a população brasileira, modificações da dieta normal e noções de dietas especiais com finalidades terapêuticas. Noções de educação nutricional. 9 Ética e legislação profissional.

CARGO 27: PSICóLOGO: 1 Teorias da aprendizagem: processo de ensino-aprendizagem, elação professor e aluno, bases psicológicas da aprendizagem. Planejamento de ensino em seus elementos constitutivos: objetivos e conteúdos de ensino, métodos e técnicas, multimídia educativa e avaliação educacional. Metodologia de projetos, interdisciplinaridade e globalização do conhecimento, análise de dificuldades, problemas e potencialidades no cotidiano escolar em sua relação com a sociedade concreta. 2 Educação continuada dos profissionais da escola: o trabalho do psicólogo com os professores e funcionários, planejamento de políticas educacionais. Educação corporativa, educação à distância, projeto pedagógico. 3 Psicologia da aprendizagem: teorias da aprendizagem, princípios básicos do Behavorismo e implicações educacionais, epistemologia genética de Jean Piaget, perspectiva sócio-interacionista de Vigotsky, a teoria da complexidade de Edgar Morin, a clínica psicanalítica da criança e do adolescente com dificuldades de aprendizagem. 4 Dificuldade de aprendizagem: 0 papel do psicólogo na identificação das causas de evasão e repetência; o fracasso escolar: abordagens atuais.

\subsubsection{CONHECIMENTOS ESPECÍFICOS PARA O CARGO DE NÍVEL MÉDIO}

CARGO 28: ASSISTENTE ADMINISTRATIVO: 1 Noções de arquivamento e outros procedimentos administrativos. 2 Noções de administração financeira, de recursos humanos e de material. 3 Ética no serviço público: comportamento profissional; atitudes no serviço; organização do trabalho; prioridade em serviço. 4 Qualidade no atendimento ao público: comunicabilidade; apresentação; atenção; cortesia; interesse; presteza; eficiência; tolerância; discrição; conduta; objetividade. 5 Trabalho em equipe: personalidade e relacionamento; eficácia no comportamento interpessoal; servidor e opinião pública; fatores positivos do relacionamento; comportamento receptivo e defensivo; empatia; compreensão mútua. 6 Noções de matemática financeira: proporcionalidade, regras de três simples e composta, divisão de grandezas em partes diretamente e inversamente proporcionais, médias aritmética e geométrica, porcentagem, capital, tempo, juros, taxa de juros e montante, juros simples, juros compostos.

\subsubsection{CONHECIMENTOS GERAIS PARA O CARGO DE NÍVEL FUNDAMENTAL}

CARGO 29: MERENDEIRO: I LÍNGUA PORTUGUESA: 1 Compreensão e interpretação de textos. 2 Tipologia textual. 3 Ortografia oficial. 4 Acentuação gráfica. 5 Emprego das classes de palavras. 6 Emprego do sinal indicativo de crase. 7 Sintaxe da oração e do período. 8 Pontuação. 9 Concordância nominal e verbal. 10 Regências nominal e verbal. 11 Significação das palavras. 12 Redação de correspondências oficiais. II MATEMÁTICA: 1 Conjuntos numéricos. 2 Números naturais, inteiros, racionais e reais. 3 Operações com conjuntos. 4 Fatoração e números primos - divisibilidade, máximo divisor comum e mínimo múltiplo comum. 5 Razões e proporções - regras de três simples e composta. 6 Percentagem, juros simples e compostos, divisão proporcional. II NOÇÕES DE HIGIENE: grupos de alimentos, critérios e aplicabilidade; métodos de avaliação e efeitos das diversas modalidades de armazenamento, pré-preparo, preparo e conservação da qualidade nutricional; aquisição, seleção, armazenamento, conservação e destino final; conversão, correção e absorção; higiene e sanitização dos alimentos, utensílios e equipamentos; doenças veiculadas por alimentos; dietoterapia nas doenças 
nutricionais; saúde coletiva e nutrição. III Noções de relações humanas.

\section{GEDEÃO TIMÓTEO AMORIM}

Secretaria de Estado de Educação e Qualidade do Ensino 


\title{
GOVERNO DO DISTRITO FEDERAL \\ SECRETARIA DE ESTADO DE ADMINISTRAÇÃO PÚBLICA DO DISTRITO FEDERAL \\ CONCURSO PÚBLICO PARA PROVIMENTO DE VAGAS E FORMAÇÃO DE CADASTRO RESERVA PARA O CARGO DE \\ PEDAGOGO-ORIENTADOR EDUCACIONAL, DA CARREIRA MAGISTÉRIO PÚBLICO DO QUADRO DE PESSOAL DO DISTRITO \\ FEDERAL \\ EDITAL № 1, DE 06 DE AGOSTO DE 2014.
}

\begin{abstract}
Edital no 1 publicado no Diário Oficial do Distrito Federal no 159, de 6 de agosto de 2014, páginas 51 a 57
Atualização: Edital no 2 publicado no Diário Oficial do Distrito Federal no 166, de 14 de agosto de 2014, página 107

Atualização: Edital no 3 publicado no Diário Oficial do Distrito Federal no 194, de 17 de setembro de 2014, página 96

Atualização: Edital no 5 publicado no Diário Oficial do Distrito Federal no 272, de 30 de dezembro de 2014, página 53
\end{abstract}

O SECRETÁRIO DE ESTADO DE ADMINISTRAÇÃO PÚBLICA DO DISTRITO FEDERAL, no uso de suas atribuições legais, o disposto na Lei no 4.949, de 15 de outubro de 2012, na Lei Complementar no 840, de 23 de dezembro de 2011, na Lei no 5.105, de 03 de maio de 2013, bem como a autorização do Conselho de Política de Recursos Humanos publicada no Diário Oficial do Distrito Federal no 45, de 04 de março de 2013, torna pública a realização de concurso público para provimento de 50 (cinquenta) vagas e formação de cadastro de reserva para o cargo de Pedagogo-Orientador educacional, da carreira Magistério Público do Quadro de Pessoal do Distrito Federal, e estabelece as normas contidas no presente edital e seus anexos.

\section{DAS DISPOSIÇÕES PRELIMINARES}

1.10 concurso público será realizado pela Secretaria de Estado de Administração Pública do Distrito Federal (SEAP-DF), regulado pelas normas contidas no presente edital e seus anexos e será executado pelo INSTITUTO QUADRIX.

1.20 concurso público destina-se a selecionar candidatos para provimento de 50 (cinquenta) vagas e formação de cadastro de reserva para o cargo de Pedagogo-Orientador educacional, da carreira Magistério Público do quadro de pessoal do Distrito Federal.

1.30 concurso público compreenderá as seguintes etapas:

a) provas objetivas, de caráter eliminatório e classificatório; e

b) avaliação de títulos, de caráter classificatório.

1.4 As provas referentes ao concurso público serão aplicadas no Distrito Federal.

1.5 Os candidatos aprovados e nomeados realizarão procedimentos pré-admissionais e exames médicos complementares, de caráter unicamente eliminatório, em conformidade com a legislação vigente e de responsabilidade da Secretaria de Educação do Distrito Federal.

1.6 Os candidatos que ingressarem no Quadro de Pessoal do Distrito Federal estarão sujeitos ao Regime Jurídico dos Servidores Públicos Civis do Distrito Federal, das Autarquias e das Fundações Públicas Distritais, instituído pela Lei Complementar no 840, de 23 de dezembro de 2011; e às normas internas do órgão de lotação.

1.7 Os horários mencionados no presente edital e nos demais editais a serem publicados para o concurso público obedecerão ao horário oficial de Brasília.

\subsection{DA IMPUGNAÇÃO DO EDITAL}

1.8.1 É facultado a qualquer cidadão apresentar solicitação de impugnação ao presente edital e(ou) eventuais retificações, no período de 07 a 13 de agosto de 2014.

1.8.2 O pedido de impugnação deverá ser protocolado na Central de Atendimento ao Candidato do INSTITUTO QUADRIX (ver item 16) e indicar o(s) item(ns) a ser(em) impugnado(s).

1.8.3 Os eventuais pedidos de impugnação serão analisados e julgados pela SEAP-DF e o INSTITUTO QUADRIX.

1.8.4 Ao término da apreciação das solicitações de impugnação, do que trata o subitem anterior, o INSTITUTO QUADRIX divulgará em seu endereço eletrônico http://www.quadrix.org.br, na data provável de $\mathbf{1 5}$ de agosto de 2014, relatório contendo a análise e o julgamento dos eventuais pedidos de impugnação.

1.8.5 Não caberá, sob nenhuma hipótese, recurso administrativo sobre o resultado do julgamento dos pedidos de impugnação.

\section{DOS CARGOS}

\subsection{NÍVEL SUPERIOR - PEDAGOGO-ORIENTADOR EDUCACIONAL, DA CARREIRA MAGISTÉRIO PÚBLICO}

Vagas: 50 (cinquenta).

Remuneração: $\mathrm{R} \$ 3.579,42$ (três mil, quinhentos e setenta e nove reais e quarenta e dois centavos), para ingresso no padrão inicial da Etapa III da Carreira Magistério Público.

Carga horária: 40 (quarenta) horas semanais. 
Requisitos: Diploma, devidamente registrado, de conclusão de curso de nível superior em Pedagogia, com habilitação específica ou pós-graduação em Orientação Educacional, nas seguintes áreas de atuação: anos iniciais e finais do Ensino Fundamental, Ensino Especial, Educação Infantil, 1으, 2ㅇe 3ㅇs segmentos da Educação de Jovens e Adultos, Ensino Médio e Educação Profissional.

Descrição sumária das atividades: Planejar, coordenar, implementar e avaliar o desenvolvimento de projetos pedagógicos/institucionais, aplicando metodologias e técnicas para facilitar o processo de ensino-aprendizagem e desenvolvimento integral dos estudantes; atuar em todas as etapas/modalidades da Educação Básica para atender as necessidades dos estudantes, acompanhando e avaliando os processes educacionais, viabilizar o trabalho coletivo, criando e organizando mecanismos de participação em programas e projetos educacionais, facilitando o processo comunicativo entre a comunidade escolar e as associações a ela vinculadas, participar de programas de desenvolvimento que envolvam conteúdos relativos à área de atuação ou neles atuar; executar outras atividades de interesse da área.

Descrição detalhada: Participar do processo de elaboração do Projeto Político Pedagógico da unidade escolar; elaborar, anualmente, plano de ação das atividades do Serviço de Orientação Educacional; participar das coordenações pedagógicas visando à organização do trabalho pedagógico da unidade escolar; implantar e implementar o Serviço de Orientação Educacional na unidade escolar; identificar os fatores que interferem no processo de ensino-aprendizagem; assessorar a equipe técnico-pedagógica no que se refere ao processo de ensino-aprendizagem; coordenar o processo de informação educacional e profissional visando à inserção para o mundo do trabalho; coordenar ações voltadas para a orientação sexual e para a prevenção ao uso indevido de drogas; integrar a comunidade no processo educativo; supervisionar estágio na área de orientação educacional; articular as ações vinculadas à saúde do educando; participar da identificação e/ou encaminhamento de estudantes que apresentem dificuldades no processo de ensino e aprendizagem; apoiar segmentos escolares, conselho de classe, grêmio estudantil, conselho de segurança e Associação de Pais e Mestres; planejar e executar projetos que visem à melhoria do contexto escolar e o processo de desenvolvimento humano, na perspectiva do Projeto Político Pedagógico da unidade escolar; articular ações em parceria com as Redes Sociais e outros setores da SEDF, favorecendo o desenvolvimento integral do estudante; cumprir as normas de segurança do trabalho, de forma a evitar acidentes no ambiente laboral; participar de programas de formação continuada, como aluno ou como formador, com o objetivo de reelaborar os saberes iniciais da formação docente e de fomentar práticas educativas para a melhoria da qualidade social do ensino; estimular o respeito aos valores, às instituições e às práticas políticas do país; elaborar e apresentar relatórios periódicos; fornecer dados estatísticos de suas atividades; emitir parecer técnico sobre assuntos de sua competência; assessorar atividades específicas da especialidade; observar normas de higiene e segurança do trabalho; zelar pela guarda, conservação e manutenção de materiais e equipamentos; executar outras atividades de mesma natureza e nível de complexidade.

Habilidades e atitudes pessoais: Paciência; afetividade; organização; trabalhar em equipe; iniciativa; liderança; dinamismo; capacidade de decisão; contornar situações adversas; sensibilidade; solidariedade; criatividade; senso crítico; cooperação; senso de justiça; versatilidade; flexibilidade.

\section{DAS VAGAS}

\begin{tabular}{|c|c|c|c|c|c|}
\hline CóD & CARGO & $\begin{array}{c}\text { VAGAS } \\
\text { EFETIVAS }\end{array}$ & $\begin{array}{c}\text { JORNADA DE } \\
\text { TRABALHO } \\
\text { SEMANAL }\end{array}$ & SALÁRIO & TAXA DE INSCRIÇÃO \\
\hline 300 & $\begin{array}{c}\text { PEDAGOGO-ORIENTADOR } \\
\text { EDUCACIONAL }\end{array}$ & 50 & 40 horas & $\mathrm{R} \$ 3.579,42$ & $\mathrm{R} \$ 41,50$ \\
\hline
\end{tabular}

\section{DOS REQUISITOS MÍNIMOS PARA A POSSE}

4.1. O candidato aprovado no concurso público de que trata esse Edital será investido no cargo, se atendidas todas as exigências a seguir:

4.2 Cumprir as determinações deste edital e ter sido aprovado e classificado no concurso público, dentro do número de vagas.

4.3 Ter nacionalidade brasileira ou portuguesa e, em caso de nacionalidade portuguesa, estar amparado pelo estatuto de igualdade entre brasileiros e portugueses, com reconhecimento de gozo de direitos políticos, nos termos do parágrafo 1으, artigo 12, da Constituição da República Federativa do Brasil.

4.4 Ter idade mínima de 18 (dezoito) anos completos, na data da posse.

4.5 Apresentar os documentos comprobatórios dos requisitos exigidos para o exercício do cargo, constantes do item 2 deste edital, bem como outros documentos que se fizerem necessários, à época da posse.

4.6 Estar em dia com as obrigações eleitorais e em pleno gozo dos direitos políticos.

4.7 Apresentar certificado de reservista ou de dispensa de incorporação, em caso de candidato do sexo masculino.

4.8 Apresentar declaração de bens que constituem o seu patrimônio.

4.9 Apresentar declaração de que não acumula cargo, emprego ou função pública, ou proventos de inatividade; ressalvadas as possibilidades de acumulação lícita previstas no inciso XVI do art. 37 da Constituição Federal. 
4.10 Não ter sofrido, no exercício de função pública, penalidade incompatível com a nomeação de cargo público.

4.11 Não estar cumprindo sanção por inidoneidade, aplicada por qualquer órgão público ou entidade das esferas federal, estadual, municipal ou do Distrito Federal.

4.12 Ter aptidão física e mental para o exercício das atribuições correspondentes ao cargo.

\section{DA INSCRIÇÃO NO CONCURSO PUBLICO}

5.10 valor da taxa de inscrição é de $R \$ 41,50$ (quarenta e um reais e cinquenta centavos).

5.1.1 Será admitida a inscrição exclusivamente via internet, no endereço eletrônico http://www.quadrix.org.br, solicitada no período entre 10 horas do dia 12 de setembro de 2014 e 23 horas e 59 minutos do dia 13 de outubro de 2014, observado o horário oficial de Brasília/DF.

5.1.2 O INSTITUTO QUADRIX não se responsabiliza por solicitação de inscrição via internet não recebida por motivos de ordem técnica dos computadores, falhas de comunicação, congestionamento das linhas de comunicação, por erro ou atraso dos bancos ou entidades conveniadas no que se refere ao processamento do pagamento da taxa de inscrição, bem como por outros fatores que impossibilitem a transferência de dados.

5.1.3 O INSTITUTO QUADRIX disponibiliza computadores com acesso a internet (ver item 16), para uso pelos candidatos.

5.1.3 O candidato poderá efetuar o pagamento da taxa de inscrição por meio de boleto bancário.

5.1.4 O boleto bancário estará disponível no endereço eletrônico http://www.quadrix.org.br e deverá ser impresso para o pagamento da taxa de inscrição imediatamente após a conclusão do preenchimento do formulário de inscrição.

5.1.4.1 O candidato poderá reimprimir o boleto bancário acessando novamente o sistema de inscrição.

5.1.5 O boleto bancário poderá ser pago, preferencialmente, em qualquer agência bancária, bem como nas lotéricas e outros estabelecimentos, obedecendo aos critérios estabelecidos nesses correspondentes bancários.

5.1.6 O pagamento da taxa de inscrição deverá ser efetuado até o dia $\mathbf{1 4}$ de outubro de 2014.

5.1.6.1 O INSTITUTO QUADRIX, em nenhuma hipótese, processará qualquer registro de pagamento com data posterior ao dia 14 de outubro de 2014.

5.1.7 As inscrições somente serão acatadas após a comprovação de pagamento da taxa de inscrição.

\subsection{DO COMPROVANTE DEFINITIVO DE INSCRIÇÃO E LOCAL DE PROVA}

5.2.1 No comprovante definitivo de inscrição constarão as informações de dia, horário, local e sala de prova.

5.2.2 O comprovante definitivo de inscrição do candidato estará disponível no endereço eletrônico http://www.quadrix.org.br, após o acatamento da inscrição, na data provável de 14 de novembro de 2014.

5.2.2.1 O candidato deverá, obrigatoriamente, acessar o referido endereço eletrônico para verificar o seu local de provas, por meio de busca individual, devendo, para tanto, informar os dados solicitados.

5.2.3 É de responsabilidade exclusiva do candidato a identificação correta de seu local de realização das provas e o comparecimento no horário determinado.

5.2.4 O INSTITUTO QUADRIX poderá enviar como complemento às informações citadas no item anterior, comunicação pessoal dirigida ao candidato, por e-mail, sendo de sua exclusiva responsabilidade a manutenção/atualização de seu correio eletrônico correto no formulário de inscrição, o que não o desobriga do dever de observar o edital de convocação a ser publicado.

5.2.5 O INSTITUTO QUADRIX não enviará correspondência ao endereço dos candidatos informando os locais de aplicação de provas.

5.2.6 Em caso de não confirmação de inscrição, o candidato deverá entrar em contato com o INSTITUTO QUADRIX por meio dos telefones ou e-mail informados no item 16.

5.2.7 O comprovante definitivo de inscrição terá a informação do local e do horário de realização das provas, o que não desobriga o candidato do dever de observar o edital de convocação a ser publicado no endereço eletrônico http://www.quadrix.org.br e publicado no Diário Oficial do Distrito Federal.

\subsection{DAS DISPOSIÇÕES GERAIS SOBRE A INSCRIÇÃO NO CONCURSO PÚBLICO}

5.3.1 Antes de efetuar a inscrição, o candidato deverá conhecer este edital e certificar-se de que preenche todos os requisitos exigidos. Uma vez efetivada a inscrição e confirmado o respectivo pagamento do boleto bancário, não será permitida, em hipótese alguma, a sua alteração.

5.3.2 É vedada a inscrição condicional, fora do prazo de inscrições, via postal, via fax e(ou) via correio eletrônico.

5.3.3 Para efetuar a inscrição, é imprescindível o número de Cadastro de Pessoa Física (CPF) do candidato.

5.3.3.1 O candidato que não possuir CPF deverá solicitá-lo nos postos credenciados, localizados em qualquer agência do Banco do Brasil, da Caixa Econômica Federal e dos Correios, ou na Receita Federal, em tempo hábil, isto é, de forma que consiga obter o respectivo número antes do término do período de inscrição.

5.3.4 As informações prestadas no formulário de inscrição serão de inteira responsabilidade do candidato, dispondo o INSTITUTO QUADRIX do direito de excluir do concurso público aquele que não preencher a solicitação de forma completa e correta. 
5.3.5 O valor referente ao pagamento da taxa de inscrição não será devolvido em hipótese alguma, salvo nas condições legalmente previstas.

5.3.6 No caso do pagamento da taxa de inscrição ser efetuado com cheque bancário que, porventura, venha a ser devolvido, por qualquer motivo, o INSTITUTO QUADRIX reserva-se o direito de tomar as medidas legais cabíveis, inclusive a não efetivação da inscrição.

5.3.7 É vedada a transferência para terceiros do valor pago da taxa de inscrição.

5.3.8 O candidato deverá declarar, no formulário de inscrição, que tem ciência e que aceita que, caso aprovado, deverá entregar, por ocasião da posse, os documentos comprobatórios dos requisitos exigidos para o respectivo cargo.

\section{DAS CONDIÇÕES PARA ISENÇÃO DA TAXA DE INSCRIÇÃO}

6.1 Em conformidade com a Lei Distrital no 4.949, de 15 de outubro de 2012, a isenção da taxa de inscrição será concedida apenas para doadores de sangue a instituições públicas de saúde e beneficiários de programa social de complementação ou suplementação de renda instituído pelo Governo do Distrito Federal.

6.2 Nesses casos, o candidato deverá dirigir-se a Central de Atendimento ao Candidato do INSTITUTO QUADRIX (ver item 16), entre os dias 18 a 20 de agosto de 2014, preencher um requerimento, entregar cópia do documento de identidade (ver subitem 11.7) e os seguintes documentos:

a) para doadores de sangue a instituições públicas de saúde: certificado, outorgado pela Fundação Hemocentro ou outra instituição pública de saúde, que o qualifica como doador de sangue e que comprova no mínimo 3 (três) doações de sangue realizadas nos últimos 12 (doze) meses antes do período de inscrições;

b) para beneficiário de programa social de complementação ou suplementação de renda instituído pelo Governo do Distrito Federal: comprovante oficial de inscrição em plena validade em programa social de complementação ou suplementação de renda instituído pelo Governo do Distrito Federal.

6.3 O candidato deverá entregar cópias autenticadas ou cópia simples acompanhadas dos originais dos documentos previstos no subitem 6.2.

6.4 Será considerada nula a isenção de pagamento de taxa de inscrição ao candidato que:

a) omitir informações e(ou) apresentar informações inverídicas; e(ou)

b) fraudar e(ou) falsificar documentação.

6.4.1 Nesse caso, o candidato terá sua situação informada à autoridade policial competente para as providências cabíveis.

6.4.2 Não será concedida isenção de taxa de inscrição ao candidato que:

a) não possuir condição contemplada no subitem 6.1;

b) pleitear a isenção sem apresentar os documentos previstos no subitem 6.2 deste edital;

c) não observar o período, o local e o horário estabelecido para a solicitação de isenção.

6.5 Não será aceita solicitação de isenção de taxa de inscrição via postal e(ou) via fax, tampouco por procuração.

6.6 Não será permitida, após a entrega do requerimento de isenção de taxa de inscrição e dos documentos comprobatórios citados no subitem 6.2 deste edital, complementação da documentação, bem como revisão e(ou) recurso.

6.7 Ao término da apreciação dos requerimentos de isenção de taxa de inscrição e dos respectivos documentos, o INSTITUTO QUADRIX divulgará, no endereço eletrônico http://www.quadrix.org.br, na data provável de 26 de agosto de 2014, a listagem contendo o resultado de tais requerimentos.

6.8 Do resultado preliminar dos requerimentos de isenção de taxa de inscrição caberá recurso, que deverá ser preenchido e entregue pelo candidato na Central de Atendimento ao Candidato do INSTITUTO QUADRIX (ver item 16) no período e forma estabelecidos no item 14.

6.9 Ao término da apreciação dos recursos contra o resultado preliminar do requerimento de isenção de taxa de inscrição, o INSTITUTO QUADRIX divulgará, no endereço eletrônico http://www.quadrix.org.br, na data provável de $\mathbf{1 1}$ de setembro de 2014, a listagem contendo o resultado final de tais requerimentos.

6.100 candidato que não tiver seu pedido de isenção de taxa de inscrição deferido e que não efetuar a inscrição na forma estabelecida no item 5 deste edital estará automaticamente excluído do concurso público.

\section{DAS VAGAS DESTINADAS AOS CANDIDATOS COM DEFICIÊNCIA}

7.1 As vagas destinadas aos candidatos com deficiência serão providas na forma do art. 8, da Lei Distrital no 4.949 , de 15 de outubro de 2012.

7.2 Ficam reservados $20 \%$ (vinte por cento) das vagas a serem preenchidas por pessoas com deficiência, desprezada a parte decimal, conforme quadro do item 3.

7.2.1 Na hipótese da aplicação do disposto no subitem anterior resultar em fração inferior a 1 (um), será desconsiderada a reserva em questão, conforme Decisão no 156/2005 do Tribunal de Contas do Distrito Federal.

7.30 candidato que, no ato de inscrição, se declarar com deficiência, se aprovado e classificado no concurso público, terá seu nome publicado em lista à parte e, caso obtenha a classificação necessária, figurará também na lista de classificação geral. 
7.4 As vagas definidas no subitem 7.2 deste edital que não forem providas por falta de candidatos com deficiência ou por reprovação no concurso público ou na perícia médica serão preenchidas pelos demais candidatos, observada a ordem de classificação do cargo.

7.50 candidato que se declarar com deficiência concorrerá em igualdade de condições com os demais candidatos.

7.6 As atividades dos cargos não serão modificadas para se adaptarem à(às) condição(ões) especial(is) dos candidatos com deficiência.

7.7 Para concorrer a uma das vagas para candidatos com deficiência, o candidato deverá:

a) no ato de inscrição, declarar-se com deficiência;

b) entregar laudo médico original, ou cópia autenticada, emitido nos últimos 12 (doze) meses, contados até o último dia do período de inscrição, atestando o nome da doença, a espécie e o grau ou o nível da deficiência, com expressa referência ao código correspondente da Classificação Estatística Internacional de Doenças e Problemas Relacionados à Saúde (CID), bem como a provável causa da deficiência, na forma do subitem 7.8 deste edital, e o requerimento constante no Anexo II deste edital.

7.80 candidato com deficiência deverá, encaminhar, impreterivelmente até o dia $\mathbf{1 4}$ de outubro de 2014, o referido laudo médico e o requerimento constante do Anexo II devidamente preenchido e assinado, via postal (exclusivamente via SEDEX), para o INSTITUTO QUADRIX (CONCURSO PÚBLICO - PEDAGOGO/O.E.), Caixa Postal 3646, CEP 70.089-970, Brasília/DF, desde que cumprida a formalidade de inscrição dentro dos prazos citados no item 5 deste edital.

7.8.1 O candidato com deficiência poderá também entregar pessoalmente, ou por terceiro (mediante procuração simples), na Central de Atendimento ao Candidato do INSTITUTO QUADRIX (ver item 16), a documentação indicada no subitem 7.7 acima, mantendo-se o prazo máximo já indicado.

7.9 O INSTITUTO QUADRIX divulgará, no endereço eletrônico http://www.quadrix.org.br, na data provável de 27 de outubro de 2014, a listagem contendo o resultado da apreciação das solicitações para concorrer às vagas especiais.

7.10 Do resultado preliminar das solicitações para concorrer às vagas especiais caberá recurso, que deverá ser preenchido e entregue pelo candidato na Central de Atendimento ao Candidato do INSTITUTO QUADRIX (ver item 16) no período e forma estabelecidos no item 14.

7.11 Ao término da apreciação dos recursos contra o resultado preliminar das solicitações para concorrer às vagas especiais, o INSTITUTO QUADRIX divulgará, no endereço eletrônico http://www.quadrix.org.br, na data provável de $\mathbf{1 3}$ de novembro de 2014, a listagem contendo o resultado final de tais solicitações.

\subsection{DA PERÍCIA MÉDICA}

7.12.1 O candidato que, no ato de inscrição, se declarar com deficiência e tiver a sua documentação para concorrer às vagas especiais deferida, caso aprovado e classificado no concurso público, quando nomeado deverá submeter-se à perícia médica promovida pela SEAP-DF, que verificará a sua qualificação como candidato com deficiência, o grau da deficiência e a capacidade para o exercício do respectivo cargo, nos termos da Lei Distrital no 4.317/2009, do Decreto Federal $n$ o 3.298/1999 e da Lei Complementar no 840/2011.

7.12.2 O candidato deverá comparecer à perícia médica munido de laudo médico original, ou de cópia autenticada em cartório, que ateste a espécie e o grau ou o nível de deficiência, com expressa referência ao código correspondente da (CID) e a provável causa da deficiência.

7.12.3 O laudo médico original ou sua cópia autenticada em cartório serão retidos pela SEAP-DF por ocasião da realização da perícia médica.

7.12.4 Perderá o direito de concorrer às vagas reservadas às pessoas com deficiência o candidato que, por ocasião da perícia médica, não apresentar laudo médico original ou cópia autenticada em cartório, ou que apresentar laudo que não tenha sido emitido nos últimos 12 (doze) meses, bem como o que não for qualificado na perícia médica como pessoa com deficiência, ou, ainda, que não comparecer à perícia.

7.12.5 Será garantido prazo de 2 (dois) dias úteis de recurso ao candidato que não for qualificado na perícia médica como pessoa com deficiência.

\section{DA SOLICITAÇÃO DE ATENDIMENTO ESPECIAL}

8.10 candidato que necessitar de atendimento especial para a realização das provas deverá indicar a sua opção no formulário eletrônico de inscrição e protocolar na Central de Atendimento ao Candidato do INSTITUTO QUADRIX (ver item 16), impreterivelmente até o dia 14 de outubro de 2014, requerimento indicando os recursos especiais necessários (ver Anexo III) e laudo médico, original ou cópia simples, que justifique o atendimento especial solicitado, se for o caso. Após esse período, a solicitação será indeferida, salvo nos casos de força maior.

8.20 laudo médico referido no subitem 8.1 deste edital valerá somente para este concurso público e não será devolvido. 8.2.1 Não será fornecida cópia do laudo.

8.3 A candidata que tiver necessidade de amamentar durante a realização das provas deverá, ainda, levar um acompanhante maior de idade, que ficará em sala reservada para essa finalidade e que será responsável pela guarda da criança. A candidata que não levar acompanhante não fará a prova. 
8.40 candidato que fizer uso de aparelho auditivo por orientação médica, deverá solicitar permissão para uso do referido aparelho, de acordo com as instruções contidas no subitem 8.1.

8.5 Todas as solicitações de atendimento especial serão atendidas segundo os critérios de viabilidade e de razoabilidade.

8.6 Ao término da apreciação dos requerimentos de atendimento especial e dos respectivos documentos, o INSTITUTO QUADRIX divulgará, no endereço eletrônico http://www.quadrix.org.br, na data provável de 27 de outubro de 2014, a listagem contendo o resultado da apreciação dos pedidos de atendimento especial.

8.7 Do resultado preliminar dos requerimentos de atendimento especial caberá recurso, que deverá ser preenchido e entregue pelo candidato na Central de Atendimento ao Candidato do INSTITUTO QUADRIX (ver item 16) no período e forma estabelecidos no item 14.

8.8 Ao término da apreciação dos recursos contra o resultado preliminar do requerimento de atendimento especial, o INSTITUTO QUADRIX divulgará, no endereço eletrônico http://www.quadrix.org.br, na data provável de 13 de novembro de 2014, a listagem contendo o resultado final de tais requerimentos.

\section{DA PROVA OBJETIVA}

9.1 A prova objetiva, de caráter eliminatório e classificatório, será composta de 50 (cinquenta) questões, de múltipla escolha, com 5 (cinco) alternativas em cada questão, para escolha de 1 (uma) única resposta correta, e pontuação total variando entre o mínimo de 0,00 (zero) ponto e o máximo de 100,00 (cem) pontos, de acordo com os conteúdos programáticos definidos no Anexo l e o número de questões e os pesos definidos a seguir:

\begin{tabular}{|c|c|c|c|c|c|}
\hline $\begin{array}{c}\text { ÁREA DE } \\
\text { CONHECIMENTO }\end{array}$ & DISCIPLINA & $\begin{array}{c}\text { № DE } \\
\text { QUESTÕES }\end{array}$ & PESO & $\begin{array}{l}\text { TOTAL DE } \\
\text { PONTOS }\end{array}$ & $\begin{array}{l}\text { PONTUAÇÃO } \\
\text { MÍNIMA PARA } \\
\text { APROVAÇÃO }\end{array}$ \\
\hline \multirow{5}{*}{$\begin{array}{l}\text { CONHECIMENTOS } \\
\text { BÁSICOS }\end{array}$} & Língua Portuguesa & 10 & 2 & 20 & \multirow{5}{*}{20} \\
\hline & Raciocínio Lógico & 5 & 1 & 5 & \\
\hline & Atualidades & 5 & 1 & 5 & \\
\hline & Noções de Direito Administrativo & 5 & 1 & 5 & \\
\hline & Lei Orgânica do Distrito Federal & 5 & 1 & 5 & \\
\hline $\begin{array}{l}\text { CONHECIMENTOS } \\
\text { ESPECÍ́FICOS }\end{array}$ & Conhecimentos Específicos do cargo & 20 & 3 & 60 & 30 \\
\hline \multicolumn{2}{|l|}{ TOTAL } & 50 & & 100 & \\
\hline
\end{tabular}

9.2 As provas objetivas serão corrigidas por meio de processamento eletrônico, a partir das marcações feitas pelos candidatos no cartão-resposta.

9.3 A nota de cada candidato na prova objetiva será obtida pela multiplicação da quantidade de questões acertadas pelo candidato, conforme o gabarito oficial definitivo, pelo peso de cada questão, conforme subitem 9.1.

9.4 Serão considerados aprovados na prova objetiva os candidatos que acertarem o mínimo de $50 \%$ para cada um dos conhecimentos avaliados, ou seja, 50\% de conhecimentos básicos (correspondente a 20 pontos) e $50 \%$ de conhecimentos específicos (correspondente a 30 pontos).

9.4.1 O candidato não poderá, sob pena de eliminação do certame, obter pontuação igual a 0 (zero) nas questões de Língua Portuguesa.

9.5 Serão convocados para a Avaliação de Títulos, os candidatos aprovados e classificados na prova objetiva, em ordem decrescente, até a classificação correspondente a $\mathbf{2 0}$ (vinte) vezes o número de vagas ofertadas neste Edital, incluindo os empatados na última posição e a reserva de vagas para os candidatos com deficiência, ficando os demais candidatos não convocados, reprovados e eliminados do concurso, para todos os efeitos.

9.6 O candidato não aprovado na prova objetiva será automaticamente considerado eliminado, para todos os efeitos, e não terá classificação alguma no concurso público.

\section{DA AVALIAÇÃO DE TÍTULOS}

10.1 A Avaliação de Títulos será aplicada somente para os candidatos habilitados de acordo com o subitem 9.5.

10.1.1 Serão avaliados os títulos de todos os candidatos habilitados, de acordo com o exposto no subitem 10.11.

10.2 O INSTITUTO QUADRIX será o responsável pelo recebimento e verificação dos documentos.

10.3 A Avaliação de Títulos terá caráter classificatório e consistirá na valorização de cursos, conforme os pontos que constam no subitem 10.11 deste edital.

10.4 Constatada, a qualquer tempo, irregularidade e/ou ilegalidade na obtenção de títulos e documentos, o candidato terá anulada a pontuação e, comprovada a culpa do mesmo, este será excluído do concurso público. 


\subsection{PERÍODO PARA ENTREGA DOS DOCUMENTOS}

10.5.1 A entrega dos documentos será no período previsto entre os dias $\mathbf{2 8}$ a $\mathbf{3 0}$ de janeiro de $\mathbf{2 0 1 5}$.

10.5.2 A data de entrega é sujeita a alteração.

\subsection{FORMA DE ENVIO DOS DOCUMENTOS}

10.6.1 Os documentos deverão ser postados impreterivelmente, via SEDEX, para a Central de Atendimento do INSTITUTO QUADRIX (CONCURSO PÚBLICO - PEDAGOGO/O.E.), Caixa Postal 3646, CEP 70.089-970, Brasília/DF.

11.6.2 Não serão aceitos documentos entregues via fax, via correio eletrônico ou por qualquer outro meio que não seja o estabelecido no subitem anterior.

\subsection{FORMA DE APRESENTAÇÃO DOS DOCUMENTOS}

10.7.1 Os documentos deverão ser entregues juntamente com 2 (duas) vias preenchidas do Formulário de Protocolo de Entrega da Avaliação de Títulos , que será disponibilizado no endereço eletrônico http://www.quadrix.org.br no momento da publicação do edital de convocação desta fase, e dentro de envelope fechado (tamanho aproximado de $30 \mathrm{~cm} \times 22 \mathrm{~cm}$ ), devidamente identificado com o nome (CONCURSO PÚBLICO - PEDAGOGO/O.E.), e nome do candidato.

10.7.2 O candidato deverá preencher, assinar e enviar o Formulário de Protocolo de Entrega da Avaliação de Títulos, no qual indicará os títulos e documentos apresentados.

10.7.3 Juntamente com esse formulário o candidato deverá apresentar 1 (uma) cópia, autenticada em cartório, de cada título declarado.

10.7.4 Não serão aceitos documentos originais.

\subsection{NÃO SERÃO CONSIDERADOS}

10.8.1 Documentos apresentados fora do prazo, forma e local estabelecidos neste edital.

10.8.2 Documentos sem assinatura, ou em desacordo com o disposto neste edital.

10.8.3 Cópias não autenticadas em cartório, bem como documentos gerados por via eletrônica que não estejam acompanhados do respectivo mecanismo de autenticação.

10.8.4 Documentos originais.

10.8.5 Documentos ilegíveis.

\subsection{INFORMAÇÕES SOBRE OS TÍTULOS E DOCUMENTOS}

10.9.1 Se o nome do candidato, nos documentos apresentados na Avaliação de Títulos, for diferente do nome que consta no cadastro de inscritos, deverá ser anexado o comprovante de alteração de nome (Certidão de Casamento, de Divórcio ou outro).

10.9.2 As cópias apresentadas não serão devolvidas em hipótese alguma.

10.9.3 Uma vez encaminhados os títulos e documentos, não serão aceitos acréscimos de outros documentos fora do prazo. Por ocasião dos recursos, poderão ser encaminhados somente documentos que sirvam para esclarecer ou complementar dados de títulos e documentos apresentados no período de entrega estipulado no anexo IV.

\subsection{CRITÉRIOS DE JULGAMENTO DOS TÍTULOS}

10.10.1 Serão considerados os títulos e documentos conforme o subitem 10.11 deste edital, limitados ao valor máximo de 5 (cinco) pontos, sendo desconsiderados os pontos excedentes.

10.10.2 Serão considerados apenas os títulos e documentos emitidos até a data da entrega.

10.10.3 Cada título será considerado uma única vez.

10.10.4 A pontuação alcançada na Avaliação de Títulos será considerada apenas para efeito de classificação.

\subsection{DA AVALIAÇÃO DE TÍTULOS}

\subsubsection{TÍTULO DE DOUTOR}

Em área relacionada ao respectivo cargo, concluído até a data da apresentação dos títulos, obtido em curso recomendado pela CAPES na ocasião da obtenção do título, e expedido por instituição oficial de ensino devidamente reconhecida pelo Ministério da Educação.

\begin{tabular}{|l|c|c|c|}
\hline COMPROVAÇÃO & $\begin{array}{c}\text { VALOR } \\
\text { UNITÁRIO }\end{array}$ & $\begin{array}{c}\text { QUANTIDADE } \\
\text { MÁXIMA }\end{array}$ & VALOR MÁXIMO \\
\hline $\begin{array}{l}\text { Diploma ou certificado, devidamente registrado e expedido por } \\
\text { instituição oficial de ensino devidamente reconhecida pelo } \\
\text { MEC. }\end{array}$ & $\begin{array}{c}2,5 \\
\text { pontos }\end{array}$ & 1 & 2,5 pontos \\
\hline
\end{tabular}


Em área relacionada ao respectivo cargo, concluído até a data da apresentação dos títulos, obtido em curso recomendado pela CAPES na ocasião da obtenção do título, e expedido por instituição oficial de ensino devidamente reconhecida pelo Ministério da Educação.

\begin{tabular}{|l|c|c|c|}
\hline COMPROVAÇÃO & $\begin{array}{c}\text { VALOR } \\
\text { UNITÁRIO }\end{array}$ & $\begin{array}{c}\text { QUANTIDADE } \\
\text { MÁXIMA }\end{array}$ & VALOR MÁXIMO \\
\hline $\begin{array}{l}\text { Diploma ou certificado, devidamente registrado e expedido } \\
\text { por instituição oficial de ensino devidamente reconhecida pelo } \\
\text { MEC. }\end{array}$ & $\begin{array}{c}1,5 \\
\text { pontos }\end{array}$ & 1 & 1,5 pontos \\
\hline
\end{tabular}

\subsubsection{TÍTULO DE PÓS-GRADUAÇão LATO SENSU}

Em área relacionada ao respectivo cargo, concluído até a data da apresentação dos títulos e expedido por instituição oficial de ensino devidamente reconhecida pelo Ministério da Educação.

\begin{tabular}{|l|c|c|c|}
\hline COMPROVAÇÃO & $\begin{array}{c}\text { VALOR } \\
\text { UNITÁRIO }\end{array}$ & $\begin{array}{c}\text { QUANTIDADE } \\
\text { MÁXIMA }\end{array}$ & VALOR MÁXIMO \\
\hline $\begin{array}{l}\text { Certificado de curso de pós-graduação Lato Sensu, com carga } \\
\text { horária mínima de } 360 \text { horas, devidamente registrado, } \\
\text { expedido por instituição oficial reconhecida pelo MEC. }\end{array}$ & 0,5 ponto & 2 & 1 ponto \\
\hline
\end{tabular}

\subsection{DOS DOCUMENTOS NECESSÁRIOS À COMPROVAÇÃO DOS TíTULOS}

10.12.1 Para a comprovação de curso de pós-graduação, em nível de especialização, conforme estabelecido no subitem 10.11.3 deste edital, será aceito certificado atestando que o curso possui o mínimo de 360 horas e que atende às normas da Lei no 9.394/96 - Lei de Diretrizes e Bases da Educação, ou do Conselho Nacional de Educação (CNE) ou está de acordo com as normas do extinto Conselho Federal de Educação (CFE). Também será aceita declaração de conclusão de pósgraduação em nível de especialização acompanhada do respectivo histórico escolar no qual conste a carga horária do curso, as disciplinas cursadas com as respectivas menções e a comprovação da apresentação e aprovação da monografia, atestando que o curso atende às normas da Lei no 9.394/96 - Lei de Diretrizes e Bases da Educação, ou do Conselho Nacional de Educação (CNE) ou está de acordo com as normas do extinto Conselho Federal de Educação (CFE).

10.12.1.1 Caso o certificado não ateste as exigências acima, o candidato deverá incluir uma declaração da instituição responsável pelo curso atestando a carga horária e o cumprimento de uma das normas citadas no subitem anterior.

10.12.2 Para a comprovação de curso de pós-graduação em nível de mestrado e doutorado será aceito o diploma de conclusão, devidamente registrado, expedido por instituição reconhecida pelo Ministério da Educação (MEC). Também será aceito certificado/declaração de conclusão de curso de mestrado ou doutorado, expedido por instituição reconhecida pelo Ministério da Educação (MEC), desde que acompanhado do histórico escolar do candidato, no qual conste o número de créditos obtidos, as áreas em que foi aprovado e as respectivas menções, o resultado dos exames e do julgamento da tese ou da dissertação. Caso o histórico ateste a existência de alguma pendência ou falta de requisito de conclusão do curso, o certificado/declaração não será aceito.

10.12.2.1 Outros comprovantes de conclusão de curso ou disciplina não serão aceitos como títulos referentes a curso de mestrado e doutorado.

10.12.3 Todo diploma, certificado ou declaração expedido em língua estrangeira somente será considerado se traduzido para a Língua Portuguesa por tradutor juramentado.

\section{DAS INSTRUÇõES PARA APLICAÇÃO DAS PROVAS OBJETIVAS}

11.1 As provas objetivas serão aplicadas na data provável de $\mathbf{2 3}$ de novembro de $\mathbf{2 0 1 4}$, no turno da tarde, e com a duração de 4 (quatro) horas.

11.2 Os locais de aplicação das provas objetivas serão divulgados no endereço eletrônico http://www.quadrix.org.br e no Diário Oficial do Distrito Federal, na data provável de 14 de novembro de 2014.

11.3 São de responsabilidade exclusiva do candidato a identificação correta de seu local de realização das provas e o comparecimento no dia e no horário determinados, conforme disposto no subitem 5.2.

11.4 Não serão dadas, por telefone, fax ou correio eletrônico, informações a respeito de data, de local e de horário de aplicação de provas. O candidato deverá observar rigorosamente os editais e os comunicados a serem publicados.

11.50 candidato deverá comparecer ao local designado para a realização da prova com antecedência mínima de 1 (uma) hora do horário fixado para o seu início, munido de caneta esferográfica de tinta preta, de comprovante de inscrição e de documento de identidade original.

11.6 Não será admitido ingresso de candidato no local de realização das provas após o horário fixado para o seu início.

11.7 Serão considerados documentos de identidade: carteiras expedidas pelos Comandos Militares, pelas Secretarias de Segurança Pública, pelos Institutos de Identificação e pelos Corpos de Bombeiros Militares; carteiras expedidas pelos 
órgãos fiscalizadores de exercício profissional (ordens, conselhos, entre outros); passaporte brasileiro; certificado de reservista; carteiras funcionais do Ministério Público; carteiras funcionais expedidas por órgão público que, por lei federal, valham como identidade; carteira de trabalho; carteira nacional de habilitação (somente o modelo aprovado pelo artigo 159으 da Lei $n^{\circ}$ 9.503, de 23 de setembro de 1997, publicada no Diário Oficial da União de 24 de setembro de 1997).

11.7.1 Não serão aceitos como documentos de identidade: certidão de nascimento, CPF, título eleitoral, carteira nacional de habilitação (modelo antigo), carteira de estudante, carteira funcional sem valor de identidade nem documentos ilegíveis, não-identificáveis e(ou) danificados.

11.7.2 Não será aceita cópia de documento de identidade, ainda que autenticada, bem como protocolo de documento de identidade.

11.7.3 À exceção da situação prevista no subitem 11.8 deste edital, o candidato que não apresentar documento de identidade original, na forma definida no subitem 11.7 deste edital, não poderá fazer as provas e será automaticamente eliminado do concurso público.

11.8 Caso o candidato esteja impossibilitado de apresentar, no dia de aplicação das provas, documento de identidade original, por motivo de perda, furto ou roubo, deverá ser apresentado documento que ateste o registro da ocorrência em órgão policial, expedido há, no máximo, 30 (trinta) dias, ocasião em que será submetido à identificação especial, que compreenderá coleta de dados, de assinaturas e de impressão digital em formulário próprio.

11.8.1 A identificação especial será exigida, também, ao candidato cujo documento de identificação apresente dúvidas relativas à fisionomia e(ou) à assinatura do portador.

11.9 Não serão aplicadas provas, em hipótese alguma, em local, em data e(ou) em horário diferente dos predeterminados em edital ou em comunicado.

11.10 o candidato deverá transcrever as respostas da prova objetiva para o cartão-resposta, que será o único documento válido para a correção da prova. O preenchimento do cartão-resposta será de inteira responsabilidade do candidato, que deverá proceder em conformidade com as instruções específicas contidas neste edital, no caderno de prova e no cartãoresposta. Em hipótese alguma haverá substituição do cartão-resposta por erro do candidato.

11.11 Serão de inteira responsabilidade do candidato os prejuízos advindos do preenchimento indevido do cartão-resposta. Serão consideradas marcações indevidas as que estiverem em desacordo com este edital e(ou) com o cartão-resposta, tais como: marcação rasurada ou emendada, campo de marcação não-preenchido integralmente e(ou) mais de uma marcação por questão.

$11.12 \mathrm{O}$ candidato não deverá amassar, molhar, dobrar, rasgar ou, de qualquer modo, danificar o seu cartão-resposta, sob pena de arcar com os prejuízos advindos da impossibilidade de realização da leitura óptica.

11.13 Não será permitido que as marcações no cartão-resposta sejam feitas por outras pessoas, salvo em caso de candidato a quem tenha sido deferido atendimento especial para realização das provas. Nesse caso, se necessário, o candidato será acompanhado por fiscal do INSTITUTO QUADRIX devidamente treinado, para o qual deverá ditar suas marcações.

11.140 candidato que se retirar da sala de aplicação de provas não poderá retornar a ela, em hipótese alguma, exceto se sua saída for acompanhada, durante todo o tempo de ausência, de fiscal ou de membro da coordenação do INSTITUTO QUADRIX.

11.15 Não será permitida, durante a realização das provas, a comunicação entre os candidatos nem a utilização de máquinas calculadoras e(ou) similares, livros, anotações, réguas de cálculo, impressos ou qualquer outro material de consulta.

11.16 No dia de realização das provas, não será permitido ao candidato permanecer com armas ou aparelhos eletrônicos bipe, telefone celular, smartphones, relógio, walkman $^{\circledR}$, aparelho portátil de armazenamento e de reprodução de músicas, vídeos e outros arquivos digitais, máquinas calculadoras, agendas eletrônicas ou similares, notebook, tablets, iPod ${ }^{\circledR}$, palmtop, gravadores, pendrive, $m p 3$ player ou similar, qualquer receptor ou transmissor de dados e mensagens, máquina fotográfica, controle de alarme de carro, entre outros).

11.16.1 No ambiente de provas, ou seja, nas dependências físicas em que serão realizadas as provas, não será permitido o uso pelo candidato de quaisquer dispositivos eletrônicos relacionados no subitem 11.16 deste edital.

11.16.1.1 Antes de entrar na sala de provas, o candidato deverá guardar, em embalagem porta-objetos fornecida pelo INSTITUTO QUADRIX, telefone celular desligado ou quaisquer outros equipamentos eletrônicos desligados relacionados no subitem 11.16 deste edital, sob pena de ser eliminado do concurso público.

11.16.2 A embalagem porta-objetos devidamente lacrada e identificada pelo candidato deverá ser mantida embaixo da carteira até o término das suas provas. A embalagem porta-objetos somente poderá ser deslacrada fora do ambiente de provas.

11.16.2.1 O INSTITUTO QUADRIX recomenda que o candidato não leve nenhum dos objetos citados no subitem 11.16 no dia de realização das provas.

11.16.2.2 O INSTITUTO QUADRIX não ficará responsável pela guarda de quaisquer dos objetos supracitados.

11.16.3 O INSTITUTO QUADRIX não se responsabilizará por perdas ou extravios de objetos ou de equipamentos eletrônicos ocorridos durante a realização das provas nem por danos neles causados. 
11.17 Não será permitida a entrada de candidatos no ambiente de provas portando armas. 0 candidato que estiver armado deverá se encaminhar à Coordenação antes do início das provas para o acautelamento da arma.

11.18 Não será admitido, durante a realização das provas, o uso de boné, lenço, chapéu, gorro ou qualquer outro acessório que cubra as orelhas do candidato.

11.19 Não haverá segunda chamada para a aplicação das provas, em hipótese alguma. O não comparecimento às provas implicará a eliminação automática do candidato.

11.200 candidato somente poderá retirar-se definitivamente da sala de aplicação das provas após 1 (uma) hora de seu início. Nessa ocasião, o candidato não levará, em hipótese alguma, o caderno de provas.

11.210 candidato somente poderá retirar-se do local de aplicação das provas levando o caderno de provas no decurso dos últimos 60 (sessenta) minutos anteriores ao término do tempo destinado à realização das provas

11.22 A inobservância dos subitens 11.20 e 11.21 deste edital acarretarão a não-correção das provas e, consequentemente, a eliminação do candidato do concurso público.

11.23 Terá suas provas anuladas e será automaticamente eliminado do concurso o candidato que durante a realização das provas:

a) for surpreendido dando ou recebendo auxílio para a execução das provas;

b) utilizar-se de livros, máquinas de calcular ou equipamento similar, dicionário, notas ou impressos que não forem expressamente permitidos ou que se comunicar com outro candidato;

c) for surpreendido portando aparelhos eletrônicos ou outros objetos, tais como os listados no subitem 11.16 deste edital;

d) faltar com o devido respeito para com qualquer membro da equipe de aplicação das provas, com as autoridades presentes ou com os demais candidatos;

e) fizer anotação de informações relativas às suas respostas no comprovante de inscrição ou em qualquer outro meio que não os permitidos;

f) não entregar o material das provas ao término do tempo destinado para a sua realização;

g) afastar-se da sala, a qualquer tempo, sem o acompanhamento de fiscal;

h) ausentar-se da sala, a qualquer tempo, portando o cartão-resposta da prova objetiva;

i) descumprir as instruções contidas no caderno de provas e no cartão-resposta;

j) perturbar, de qualquer modo, a ordem dos trabalhos, causando comportamento indevido;

k) utilizar ou tentar utilizar meios fraudulentos ou ilegais para obter aprovação própria ou de terceiros em qualquer etapa do concurso;

I) não permitir a coleta de sua assinatura;

m) for surpreendido portando caneta fabricada em material não transparente;

n) for surpreendido portando anotações em papéis que não os permitidos;

11.24 Nos casos de eventual falta de prova/material personalizado de aplicação de provas, em razão de falha de impressão ou de equívoco na distribuição de prova/material, o INSTITUTO QUADRIX tem a prerrogativa para entregar ao candidato prova/material reserva não personalizado eletronicamente, o que será registrado em atas de sala e de coordenação.

$11.25 \mathrm{Se}$, a qualquer tempo, for constatado, por meio eletrônico, estatístico, visual, grafológico ou por investigação policial, ter o candidato se utilizado de processo ilícito, suas provas serão anuladas e ele será automaticamente eliminado do concurso público.

11.260 descumprimento de quaisquer das instruções supracitadas constituirá tentativa de fraude e implicará a eliminação do candidato.

11.27 Não haverá, por qualquer motivo, prorrogação do tempo previsto para a aplicação das provas em razão do afastamento de candidato da sala de provas.

11.280 candidato é responsável pela devolução do cartão-resposta da prova objetiva devidamente preenchida ao final da prova. Em hipótese alguma o candidato poderá sair da sala de aplicação de prova com esse documento.

11.29 No dia de aplicação das provas, não serão fornecidas, por nenhum membro da equipe de aplicação das provas e(ou) pelas autoridades presentes, informações referentes ao conteúdo das provas e(ou) aos critérios de avaliação e de classificação.

\section{DOS CRITÉRIOS DE AVALIAÇÃO E DE CLASSIFICAÇÃO}

12.1 A nota final no concurso público será igual à soma das notas finais obtidas na prova objetiva e na avaliação de títulos.

12.2 Após a aplicação dos critérios de desempate dispostos no item 13, estarão classificados os candidatos que se encontrarem dentro do número de vagas estabelecidas, e os candidatos habilitados de acordo com o subitem 9.5 deste edital. Os demais candidatos serão considerados eliminados, para todos os efeitos, e não terão classificação alguma no concurso público.

12.3 Todos os cálculos citados neste edital serão considerados até a segunda casa decimal. 


\section{DOS CRITÉRIOS DE DESEMPATE}

13.1 No caso de igualdade de pontuação na classificação final, serão considerados os seguintes critérios para efeito de desempate, sucessivamente:

a) tiver idade igual ou superior a 60 (sessenta) anos conforme estabelece o parágrafo único do art. 27 da Lei Federal no 10.741/2003 (Estatuto do Idoso);

b) acertar o maior número de questões de Conhecimentos Específicos;

c) acertar o maior número de questões de Conhecimentos Básicos;

d) acertar o maior número de questões de Língua Portuguesa;

e) acertar o maior número de questões de Lei Orgânica do Distrito Federal;

f) acertar o maior número de questões de Noções de Direito Administrativo;

g) acertar o maior número de questões de Noções de Raciocínio Lógico;

h) acertar o maior número de questões de Noções de Atualidades;

i) tiver a maior pontuação na prova de títulos;

j) tiver a idade mais avançada.

\section{DOS RECURSOS}

14.10 candidato que desejar interpor recurso contra o gabarito preliminar da prova objetiva e(ou) resultado preliminar das provas objetivas e da avaliação de títulos; disporá de 10 (dez) dias úteis para fazê-lo, a contar do dia subsequente ao da divulgação do gabarito oficial preliminar ou resultado preliminar da fase, conforme o modelo correspondente de formulário, que será disponibilizado no ato da divulgação de cada uma dessas fases.

14.1.1 O candidato que desejar interpor recurso contra o resultado preliminar das seguintes fases: dos requerimentos de isenção de taxa de inscrição, das solicitações para concorrer às vagas especiais e(ou) dos requerimentos de atendimento especial, disporá de 5 (cinco) dias úteis para fazê-lo, a contar do dia subsequente ao da divulgação do resultado preliminar da fase, conforme o modelo correspondente de formulário para cada uma dessas fases.

14.2 Os recursos poderão ser entregues pessoalmente ou por procurador, mediante procuração do interessado, com reconhecimento de firma, no horário das 10 (dez) horas às 16 (dezesseis) horas, ininterrupto, no INSTITUTO QUADRIX (ver item 16).

14.3 Não será aceito recurso por via fax, via internet e(ou) via correio eletrônico, ou qualquer outro meio que não seja o estabelecido no subitem anterior.

14.4 O candidato deverá entregar 2 (dois) conjuntos idênticos de recursos - original e 1 (uma) cópia -, sendo que cada conjunto deverá ter todos os recursos e apenas 1 (uma) capa.

14.5 Cada conjunto de recursos deverá ser apresentado com as seguintes especificações:

a) folhas separadas para questões diferentes;

b) em cada folha, indicação do número da questão, da resposta marcada pelo candidato e da resposta divulgada pelo INSTITUTO QUADRIX;

c) para cada questão, argumentação lógica e consistente;

d) capa única constando: nome, assinatura e número de inscrição do candidato; nome do emprego a que está concorrendo; e) sem identificação do candidato no corpo do recurso e

f) recurso datilografado ou digitado em formulário próprio, de acordo com o modelo a ser disponibilizado na internet, sob pena de ser preliminarmente indeferido.

14.6 O candidato deverá ser claro, consistente e objetivo em seu pleito. Recursos inconsistentes, em formulário diferente do exigido e(ou) fora das especificações estabelecidas neste edital e em outros editais relativos a este concurso serão indeferidos.

14.7 Se do exame de recursos da prova objetiva resultar anulação de questão(ões), a pontuação correspondente a essa(s) questão(ões) será atribuída a todos os candidatos, independentemente de terem recorrido. Se houver alteração do gabarito oficial preliminar, por força de impugnações, a prova será corrigida de acordo com o gabarito oficial definitivo. Essa alteração valerá para todos os candidatos, independentemente de terem recorrido. Em hipótese alguma, o quantitativo de questões da prova objetiva sofrerá alterações.

14.7.1 Caso haja procedência de recurso interposto dentro das especificações isso poderá, eventualmente, alterar a classificação inicial obtida pelo candidato para uma classificação superior ou inferior ou, ainda, poderá acarretar a desclassificação do candidato que não obtiver nota mínima exigida para aprovação.

14.8 Todos os recursos serão julgados e as justificativas das alterações de gabarito serão divulgadas no endereço eletrônico http://www.quadrix.org.br, quando da divulgação do gabarito oficial definitivo/resultado definitivo, não sendo possível o conhecimento do resultado via telefone, fax ou correio eletrônico.

14.8.1 Não serão encaminhadas respostas individuais aos candidatos.

14.9 Em nenhuma hipótese será aceito pedido de revisão de recurso, tampouco recurso de recurso. Somente serão aceitos recursos contra o gabarito oficial preliminar da prova objetiva e o resultado preliminar das fases e etapas do certame.

14.10 Recursos cujo teor desrespeite a banca examinadora serão preliminarmente indeferidos. 
14.11 A banca examinadora constitui última instância para recurso, sendo soberana em suas decisões, razão pela qual não caberão recursos adicionais.

\section{DA NOMEAÇÃO}

15.1 A aprovação e a classificação de candidatos em número excedente ao número de vagas estabelecido neste Edital geram para o candidato apenas a expectativa de direito à nomeação, limitada ao prazo de validade do presente concurso público e observada rigorosamente a ordem de classificação dos candidatos.

15.2 o prazo de validade do presente concurso público é de 2 (dois) anos, contados a partir da data de publicação da homologação do resultado final do concurso no Diário Oficial do Distrito Federal, podendo ser prorrogado, 1 (uma) única vez, por igual período, por conveniência administrativa.

15.3 O candidato aprovado no presente concurso público, quando nomeado, além da publicação no Diário Oficial do Distrito Federal, será comunicado por meio de telegrama, enviado para o endereço constante na sua ficha de inscrição.

15.40 envio de telegramas tem caráter meramente supletivo, independendo de publicação no Diário Oficial do Distrito Federal, e o não recebimento da correspondência não invalida, em hipótese alguma, o concurso público ou qualquer de suas etapas.

15.50 candidato aprovado no presente concurso público, quando nomeado, deverá submeter-se à avaliação médica préadmissional e apresentar-se munido dos documentos exigidos em Edital a ser oportunamente publicado. A posse do candidato dependerá de prévia inspeção médica, e a inobservância do disposto neste subitem implicará impedimento ao ato de posse, nos termos da legislação vigente.

15.6 A avaliação médica pré-admissional citada no subitem 15.5 deste Edital é obrigatória, nos termos da legislação vigente.

15.7 Os candidatos empossados estarão sujeitos ao regime jurídico dos servidores públicos civis do Distrito Federal, das autarquias e das fundações públicas distritais, instituído pela Lei Complementar no 840, de 23 de dezembro de 2011, e às normas internas do órgão de lotação.

15.80 candidato aprovado no presente concurso público, quando convocado para a posse, deverá apresentar-se munido dos documentos relacionados no item 2 deste Edital.

15.8.1 De acordo com a Lei complementar no 840/2011, art. 13, § 20, o candidato aprovado, no prazo de cinco dias contados da publicação do ato de nomeação, poderá solicitar seu reposicionamento para o final da lista de classificação.

15.9 O cronograma de nomeações dos candidatos aprovados no certame, objeto deste edital, prevê as nomeações de 20 (vinte) candidatos no ano de 2015 e 30 (trinta) candidatos no ano de 2016, totalizando as 50 (cinquenta) vagas prevista neste edital.

\section{DA CENTRAL DE ATENDIMENTO AO CANDIDATO DO INSTITUTO QUADRIX}

16.1 Durante todo o período de realização do certame, a Central de Atendimento ao Candidato do INSTITUTO QUADRIX funcionará na SHN Quadra 02 Bloco F Número 87, Loja 167 e Sala 1605 - Edifício Executive Office Tower - Asa Norte Brasília-DF - CEP 70.763-530, em dias úteis e no horário compreendido entre 10 (dez) horas e 16 (dezesseis) horas.

16.2 A Central de Atendimento ao Candidato do INSTITUTO QUADRIX disponibiliza atendimento para entrega e protocolo de documentos e solicitações, protocolo de recursos administrativos e pedagógicos, esclarecimento de dúvidas e apoio às inscrições.

16.3 O candidato poderá obter informações, manter contato ou relatar fatos ocorridos referentes ao concurso público, por meio dos seguintes telefones: Brasília (61) 3550-0000 e São Paulo (11) 3198-0000. Por e-mail (contato@quadrix.org.br) ou via internet, no endereço eletrônico http://www.quadrix.org.br.

16.4 Não serão dadas, por telefone, informações a respeito de datas, locais e horários de realização das provas objetiva e demais etapas do concurso público. O candidato deverá observar rigorosamente os editais e os comunicados a serem divulgados na forma do subitem 17.2.

\section{DAS DISPOSIÇÕES FINAIS}

$17.1 \mathrm{~A}$ inscrição do candidato implicará a aceitação das normas para o concurso público contidas nos comunicados, neste edital e em outros a serem publicados.

17.2 São de inteira responsabilidade o candidato acompanhar a publicação de todos os atos, editais e comunicados referentes a este concurso público no Diário Oficial do Distrito Federal e na internet, no endereço eletrônico http://www.quadrix.org.br.

17.3 Não serão fornecidos ao candidato nenhum documento comprobatório de aprovação e(ou) classificação no concurso público, valendo para esse fim a homologação do resultado final no Diário Oficial do Distrito Federal.

17.4 Os candidatos convocados para a posse serão lotados nas Unidades da Secretaria de Educação do Distrito Federal.

17.5 O resultado final do concurso público será homologado pela SEAP-DF, publicado no Diário Oficial do Distrito Federal, e divulgado na internet, no endereço eletrônico http://www.quadrix.org.br. 
17.6 O candidato deverá manter atualizado seu endereço e seu telefone no INSTITUTO QUADRIX, enquanto estiver participando do concurso público, e perante a Secretaria de Educação, após a homologação do resultado final, desde que aprovado. São de exclusiva responsabilidade do candidato os prejuízos advindos da não atualização de seus dados pessoais. 17.7 Acarretará a eliminação sumária do candidato do concurso público, sem prejuízo das sanções penais cabíveis, a burla ou a tentativa de burla a quaisquer das normas estipuladas neste edital.

17.8 Os casos omissos serão resolvidos pelo INSTITUTO QUADRIX em conjunto com a SEAP-DF.

17.9 Legislações com entrada em vigor após a data de publicação deste edital, bem como alterações em dispositivos legais e normativos a ele posteriores, não será objeto de avaliação nas provas do concurso público.

17.10 Quaisquer alterações nas regras estabelecidas neste edital somente poderão ser feitas por meio de outro edital.

WILMAR LACERDA

Secretário de Estado de Administração Pública do Distrito Federal 


\section{ANEXO I - CONTEÚDO PROGRAMÁTICO}

\section{CONHECIMENTOS BÁSICOS}

1.1 LíNGUA PORTUGUESA: 1. Compreensão e interpretação de textos, com domínio das relações morfossintáticas, semânticas, discursivas e argumentativas. 2. Tipologia textual. 3. Coesão e coerência. 4. Ortografia oficial. 5. Fonética e fonologia. 6. Acentuação gráfica. 7. Pontuação. 8. Formação e emprego das classes de palavras. 9. Significação de palavras. 10. Sintaxe da oração e do período. 11. Concordância nominal e verbal. 12. Regência nominal e verbal. 13. Emprego do sinal indicativo de crase. 14. Funções da Linguagem.

1.2 NOÇÕES DE DIREITO ADMINISTRATIVO: 1. Estado, governo e administração pública: conceitos, elementos, poderes e organização; natureza, fins e princípios. 2. Organização administrativa do Estado. 3. Administração direta e indireta. 4. Agentes públicos: espécies e classificação, poderes, deveres e prerrogativas, cargo, emprego e função públicos. 5 . Poderes administrativos. 6. Atos administrativos: conceitos, requisitos, atributos, classificação, espécies e invalidação. 7. Controle e responsabilização da administração: controle administrativo, controle judicial, controle legislativo, responsabilidade civil do Estado. 8. Lei Complementar no 840 de 23 de Dezembro de 2011.

1.3 LEI ORGÂNICA DO DISTRITO FEDERAL: 1. Dos Fundamentos da Organização dos Poderes e do Distrito Federal. 2. Da organização do Distrito Federal. 3. Da Organização Administrativa do Distrito Federal. 4. Dos Servidores Públicos.

1.4 RACIOCÍNIO LÓGICO E MATEMÁTICO: 1. Operações, propriedades e aplicações (soma, subtração, multiplicação, divisão, potenciação e radiciação). 2. Princípios de contagem e probabilidade. 3. Arranjos e permutações. 4. Combinações. 5. Conjuntos numéricos (números naturais, inteiros, racionais e reais) e operações com conjuntos. 6. Razões e proporções (grandezas diretamente proporcionais, grandezas inversamente proporcionais, porcentagem, regras de três simples e compostas). 7. Equações e inequações. 8. Sistemas de medidas. 9. Volumes. 10. Compreensão de estruturas lógicas. 11. Lógica de argumentação (analogias, inferências, deduções e conclusões). 12. Diagramas lógicos.

1.5 ATUALIDADES: 1. Brasil: política, cultura, economia, saúde, educação, sociedade e atualidades. 2. Políticas públicas. 3. Direitos sociais. 4. Ética e cidadania. 5. Qualidade de vida. 6. Meio Ambiente. 7. Ecologia. 8. Proteção e preservação ambiental. 9. Mundo: continentes, divisão política e geográfica. 10. Cenário internacional: cultura, economia, política, ambiente. 11. Tecnologia, avanços e descobertas científicas e tecnológicas. 12. Globalização. 13. Interesse geral: assuntos nacionais ou internacionais, amplamente veiculados nos últimos dois anos, suas inter-relações e suas vinculações históricas. 14. Atualidades e contextos históricos, geográficos, sociais, políticos, econômicos e culturais referentes ao Distrito Federal.

\section{CONHECIMENTOS ESPECÍFICOS}

2.1 CONHECIMENTOS ESPECÍfICOS DO CARGO: A - Conhecimentos Pedagógicos: 1. Aspectos pedagógicos e sociais da prática educativa, segundo as tendências pedagógicas. 2. Currículo em Movimento da Educação Básica da SEEDF cadernos (2014). Site da SEEDF. 2.1. Pedagogia Histórico-Crítica. 2.2. Psicologia Histórico-Cultural. 2.3. Eixos transversais: educação para a diversidade, educação para a sustentabilidade e educação em e para os direitos humanos. 3. Educação Integral: concepções teórico-metodológicas. (Caderno Cidade Escola Candanga: Educação Integral). Site da SEEDF. Teoria Crítica e Pós-Crítica. 4. Planejamento Educacional: Projeto Político-Pedagógico. 5. Avaliação Educacional: aprendizagem, institucional e em larga escala. Funções da Avaliação: diagnóstica, somativa, classificatória e formativa. 6. Escolarização na Socioeducação. 7. Organização do trabalho pedagógico e da gestão escolar: projeto político-pedagógico da escola e coordenação pedagógica na educação básica. (Orientação Pedagógica para elaboração do Projeto Político-Pedagógico na escola). Site da SEEDF. 7.1. A orientação educacional e a construção do projeto político-pedagógico na escola: concepção, princípios e eixos norteadores; a gestão educacional decorrente do projeto político-pedagógico; o processo de planejamento, importância, dimensões, componentes e instrumentos. 8. Gestão Democrática - Lei 4.751/2012.

B - Conhecimentos Específicos: 1. Origem, evolução e contextualização da orientação educacional no Brasil: conceituação, evolução histórica, fundamentos legais, pressupostos teóricos, o profissional de orientação educacional e a ética. 2. A orientação educacional como mediadora do sucesso na aprendizagem e permanência do aluno na escola. Meios para a apropriação crítica dos conhecimentos dos diversos campos disciplinares e transversais, a interdisciplinaridade, a multidisciplinaridade e a transdisciplinaridade; a inclusão educacional, a evasão escolar e estudo das causas fundamentais; o problema da repetência e como vencê-la: as dificuldades de aprendizagem. 3. Psicologia do desenvolvimento: aspectos biopsicossociais da criança, do adolescente e ou juventude, do adulto e do idoso. 4. Prática da orientação educacional no processo de avaliação: limites e possibilidades para medir e avaliar, conceitos básicos; instrumentos de medida e avaliação como subsídios no trabalho de orientação educacional: observação, análise de cenário, entrevistas, 
questionário, testes sociométricos, testes vocacionais, o projeto de pesquisa como caminho para elaboração de instrumentos de medida. 5. Perspectivas de atuação na área vocacional frente às características dos alunos das escolas brasileiras: trajetória da orientação vocacional, proposições teóricas e suas aplicações à prática da orientação e visão crítica. 6. A orientação educacional e a construção de processos solidários e engajamento normativo: o orientador educacional como mediador das relações escola-família-comunidade. Conselho escolar e grêmio estudantil. Alunos e pais representantes de turma, conselho de classe. 7. Plano de convivência escolar/mediação de conflitos no contexto escolar. 
$\mathrm{Eu}$,

CPF no inscrito(a) no Concurso Público para provimento de vagas para o cargo de PedagogoOrientador educacional, da carreira Magistério Público do Quadro de Pessoal do Distrito Federal, DECLARO, com a finalidade de concorrer a vaga especial, ser pessoa com deficiência e estar ciente das atribuições do emprego para o qual me inscrevo.

Nessa ocasião, apresento laudo médico com a respectiva Classificação Estatística Internacional de Doenças e Problemas Relacionados à Saúde (CID), no qual constam os seguintes dados:

Tipo de deficiência que possuo:

Código correspondente da (CID):

Nome e número de registro no Conselho Regional de Medicina (CRM) do médico responsável pelo laudo:

Observação: não serão considerados como deficiência os distúrbios de acuidade visual passíveis de correção simples, tais como, miopia, astigmatismo, estrabismo e congêneres.

Ao assinar este requerimento, o(a) candidato(a) declara sua expressa concordância em relação ao enquadramento de sua situação, nos termos do Decreto Federal no 5.296, de 2 de dezembro de 2004, publicado no Diário Oficial da União de 3 de dezembro de 2004, sujeitando-se à perda dos direitos requeridos em caso de não homologação de sua situação, por ocasião da realização da perícia médica.

\section{REQUERIMENTO DE PROVA ESPECIAL E(OU) DE TRATAMENTO ESPECIAL}

Dados para aplicação de prova especial: marcar com um X no quadrado, caso necessite, ou não, de prova especial e(ou) tratamento especial. Em caso positivo, discriminar o tipo de prova e(ou) necessidade.

NÃO HÁ NECESSIDADE DE PROVA ESPECIAL E(OU) DE TRATAMENTO ESPECIAL.

HÁ NECESSIDADE DE PROVA ESPECIAL E(OU) DE TRATAMENTO ESPECIAL.

Todas as solicitações de atendimento especial serão atendidas segundo os critérios de viabilidade e de razoabilidade.

de de 2014. 
$\mathrm{Eu}$,

CPF no inscrito(a) no Concurso Público para provimento de vagas para o cargo de PedagogoOrientador educacional, da carreira Magistério Público do Quadro de Pessoal do Distrito Federal, SOLICITO, conforme laudo médico em anexo $(*)$, atendimento especial no dia da aplicação da prova conforme descrito a seguir:

\begin{tabular}{|l|}
\hline \\
\hline 2 \\
\hline 2 \\
\hline 2 \\
\hline \\
\hline
\end{tabular}

${ }^{*}$ ) Nessa ocasião, apresento laudo médico com a respectiva Classificação Estatística Internacional de Doenças e Problemas Relacionados à Saúde (CID), no qual constam os seguintes dados:

Tipo de deficiência que possuo:

Código correspondente da (CID):

Nome e número de registro no Conselho Regional de Medicina (CRM) do médico responsável pelo laudo:

Todas as solicitações de atendimento especial serão atendidas segundo os critérios de viabilidade e de razoabilidade.

de de 2014.

Assinatura do(a) Candidato(a) 


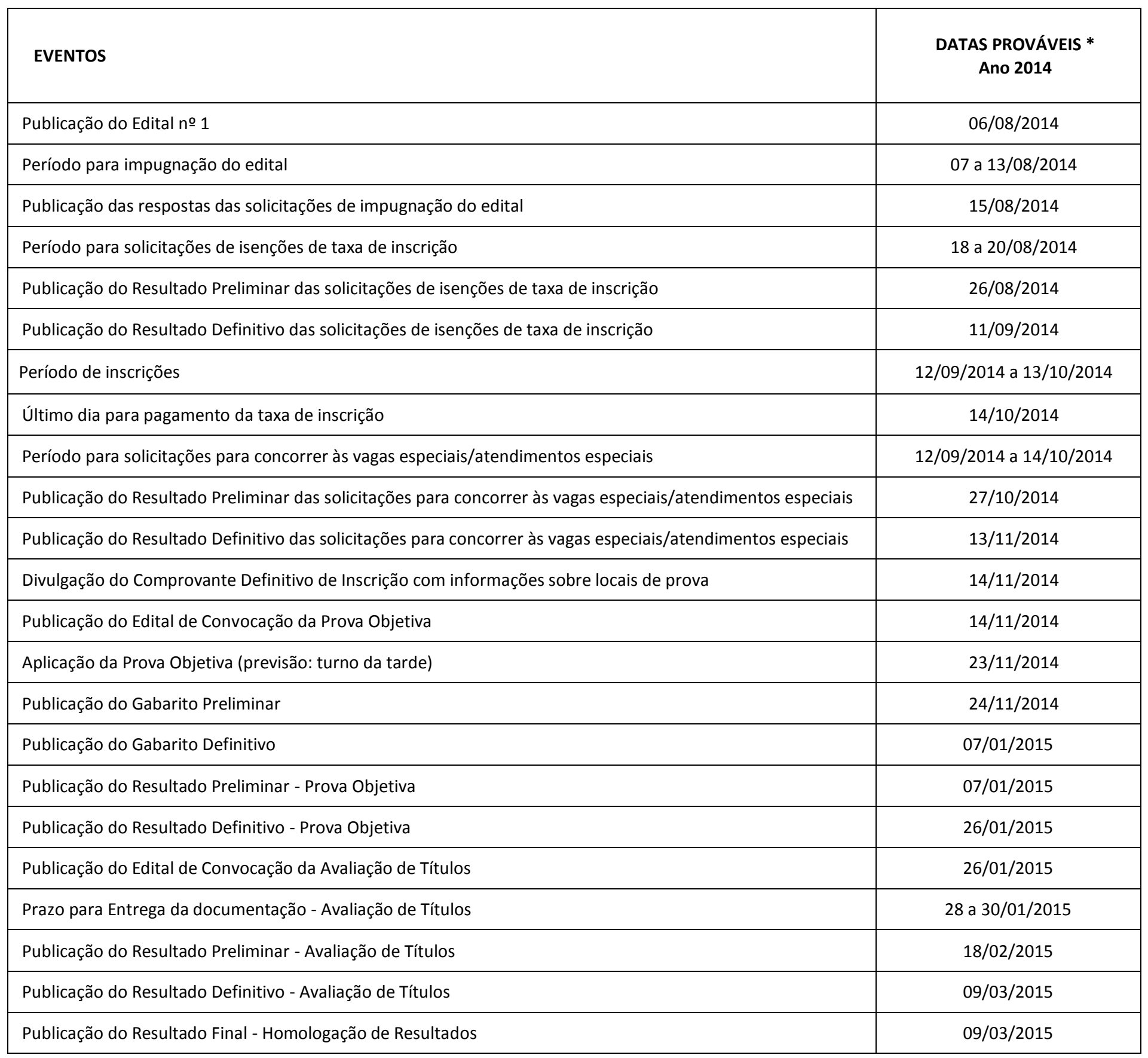

* Datas prováveis de realização. Qualquer alteração no cronograma será divulgada por meio de comunicado oficial no endereço eletrônico http://www.quadrix.org.br 


\section{CONCURSO PÚBLICO \\ SECRETARIA DE ESTADO DA EDUCAÇÃO - SEDUC/RS - 2013 EDITAL DE CONCURSO $\mathrm{N}^{\circ} 01 / 2013$}

O Secretário de Estado da Educação, no uso de suas atribuições, torna público por este Edital que realizará Concurso Público, através de provas seletivas de caráter competitivo, sob a coordenação técnico-administrativa da Fundação para o Desenvolvimento de Recursos Humanos - FDRH, para o provimento de cargo de Professor do Quadro de Carreira do Magistério Público do Estado do Rio Grande do Sul, de acordo com a Lei Estadual no 6.672/74, com alterações posteriores, sob o regime estatutário.

O Concurso reger-se-á pelas disposições contidas no Decreto Estadual $n^{\circ} 48.724$, de 22/12/2011, que regulamenta os Concursos Públicos do Magistério Público do Estado do Rio Grande do Sul, e pelas disposições contidas na Lei Complementar $n^{\mathbf{0}}$ 13.763/2011, que disciplina o acesso dos estrangeiros aos cargos públicos, na Lei 13.694/2011 (Estatuto da Igualdade Racial), na Lei $n^{\circ} 10.228 / 94$, na Lei $n^{\circ} 13.320 / 2009$ e no Decreto $n^{\circ} 44.300 / 2006$, alterado através do Decreto n. ${ }^{\circ} 46.656 / 2009$, que regram a participação da pessoa com deficiência em Concursos Públicos, na Lei Federal no 9.394/96 e, subsidiariamente, naquilo que não é contrário, no Decreto Estadual nº 43.911 de 13 de julho de 2005, bem como pelas normas estabelecidas neste Edital.

\section{DAS DISPOSIÇÕES PRELIMINARES:}

1.1. O Concurso Público destina-se ao provimento de 10.000 (dez mil) vagas para o cargo de professor, para as áreas do conhecimento e habilitação relacionadas no Anexo 1 deste Edital.

1.1.1. O concurso destina-se ao preenchimento das vagas relacionadas no Anexo 2 para o provimento do cargo de professor do Quadro de Carreira do Magistério Público do Estado do Rio Grande do Sul e dos que vierem a vagar.

1.2. De acordo com as necessidades da Secretaria da Educação, os candidatos nomeados poderão ser designados para exercer suas atribuições em qualquer um dos municípios que integram a jurisdição da respectiva Coordenadoria Regional de Educação (CRE) onde se inscreverem.

1.2.1. Não havendo mais candidatos classificados na região, poderá ser nomeado candidato de região diversa, devidamente habilitado para a vaga a ser preenchida com sua anuência, conforme item 12.1.4, deste Edital.

1.3. O candidato será nomeado no nível 1 ou 5, conforme a sua habilitação, na forma do Anexo 1 deste Edital, combinado com o Art. $7^{\circ}$ da Lei $n^{\circ}$. 6.672/74, regulamentado pelo Decreto $\mathrm{n}^{\circ}$ $25.182 / 76$.

1.4. No ato da inscrição, o candidato deverá optar pela Coordenadoria Regional de Educação (CRE). Antes de efetuar sua inscrição, o candidato deverá verificar no Anexo 2 deste Edital se está prevista vaga na CRE para a área de conhecimento em que deseja se inscrever.

\section{DA DIVULGAÇÃO:}

2.1. A divulgação oficial das informações referentes a este Concurso, editais ou avisos, até a homologação de seus resultados finais, dar-se-á por meio de publicações no Diário Oficial do Estado. 
2.1.1. Essas informações estarão à disposição dos candidatos nos seguintes endereços:

a) Secretaria de Estado da Educação (SEDUC) - localizada na Avenida Borges de Medeiros, $\mathrm{n}^{\circ}$ 1501, Plataforma - Porto Alegre - RS e no site www.educacao.rs.gov.br;

b) Fundação para o Desenvolvimento de Recursos Humanos - FDRH, situada na Avenida Praia de Belas n. ${ }^{\circ}$ 1595, Bairro Menino Deus - Porto Alegre/RS e no site www.fdrh.rs.gov.br

2.2. O acompanhamento da divulgação das informações referentes a este Concurso Público é de inteira responsabilidade do candidato.

\section{DAS INSCRIÇÕES E SUAS CONDIÇÕES:}

3.1. As inscrições serão efetuadas exclusivamente pela Internet, no período de $\mathbf{2 7}$ de fevereiro a 13 de março de 2013, no Formulário Eletrônico de Inscrição específico, disponível no endereço www.fdrh.rs.gov.br.

3.2. Ao efetuar a inscrição, o candidato deverá certificar-se dos requisitos exigidos para a posse, previstos no item 12 deste Edital.

3.3. O Formulário Eletrônico de Inscrição deverá ser preenchido com as seguintes informações:

3.3.1. Nome completo do candidato;

3.3.2. Número do CPF;

3.3.3. Número do documento de identidade que tenha fé pública;

3.3.3.1. Serão aceitos como documentos de identidade, dentre outros que tenham fé pública, desde que com foto e assinatura do candidato:

a) carteiras e/ou cédulas de identidade expedidas pelas Secretarias de Segurança Pública de qualquer dos Estados Brasileiros, pelas Forças Armadas, pelas Polícias Militares, pelo Ministério das Relações Exteriores;

b) cédulas de identidade fornecidas por Ordens ou Conselhos de Classe que, por Lei Federal, valem como documento de identidade, como as do Conselho Regional de Engenharia e Arquitetura (CREA), da Ordem dos Advogados do Brasil (OAB), do Conselho Regional de Química (CRQ) ou outros de mesma equivalência;

c) Carteira de Trabalho e Previdência Social;

d) Carteira Nacional de Habilitação com fotografia e assinatura, na forma da Lei Federal $n^{\circ}$ 9.503/97;

e) Registro Nacional de Estrangeiro - RNE, com visto permanente.

3.3.3.2. O documento cujo número constar no Formulário Eletrônico de Inscrição deverá ser, preferencialmente, apresentado no momento da realização das provas objetivas.

3.3.4. Endereço completo;

3.3.5. E-mail;

3.3.6. Nacionalidade;

3.3.7. Atendimento Especial para a prova;

3.3.8. Cotista (racial ou deficiente);

3.3.9. Área; e

3.3.10. Habilitação. 
3.4. Após o preenchimento do Formulário Eletrônico de Inscrição, o candidato deverá imprimir o registro provisório de inscrição para o pagamento da respectiva taxa de inscrição.

3.5. Para concorrer à reserva de vagas, o candidato negro e o candidato com deficiência deverá assinalar a sua opção no Formulário Eletrônico de Inscrição.

3.5.1. O candidato negro e o candidato com deficiência que não indicar a sua opção no Formulário Eletrônico de Inscrição, preenchendo as outras exigências deste Edital, terá a sua inscrição homologada sem direito à reserva de vagas.

3.5.2. O candidato negro e com deficiência deverá optar por apenas uma das categorias de reserva de vagas.

3.6. O pagamento da taxa de inscrição deverá ser efetuado em instituição bancária, preferencialmente no BANRISUL, ou em outros meios de arrecadação disponibilizados. $\mathrm{O}$ candidato deverá observar o horário de recebimento do meio a ser utilizado para fins de pagamento.

3.6.1. O pagamento da taxa de inscrição deverá ser feito, impreterivelmente, até o dia $\mathbf{1 4}$ de março de 2013, por meio de boleto bancário.

3.6.2. Conforme regulamentado pela Lei $n^{\circ} 8.109 / 85$, alterada pelo inciso II da Lei $n^{\circ}$ 14.108/2012, na forma do artigo $1^{\circ}$, inciso I, da Lei $\mathrm{n}^{\circ} 10.909 / 96$, o valor da taxa de inscrição será de:

a) $\mathrm{R} \$ 129,70$ para o cargo de professor que exija nível de escolaridade superior;

b) $\mathrm{R} \$ 56,87$ para o cargo de professor que exija nível de escolaridade médio (curso normal/magistério, pós-médio do curso normal/magistério, inclusive magistério indígena).

3.7. O candidato terá sua inscrição efetivada somente quando a FDRH receber do BANRISUL a confirmação do pagamento de sua taxa de inscrição.

3.8. A FDRH não se responsabiliza por inscrições e pagamentos não recebidos por motivos de ordem técnica dos computadores, falhas de comunicação, congestionamento das linhas de comunicação, bem como por outros fatores que impossibilitem a transferência de dados e valores.

3.9. A pessoa com deficiência deverá indicar, no formulário de inscrição, a sua opção de concorrer à reserva de vagas para pessoas com deficiência. Deverá também providenciar e encaminhar um Atestado Médico indicando a espécie e o grau ou o nível de deficiência com a expressa referência ao Código Internacional de Doença - CID, bem como a provável causa da deficiência, no período de 27 de fevereiro a 04 de março de 2013 (o modelo de Laudo Médico se encontra no Anexo 4 deste Edital), conforme subitem 4.3.1.

3.9.1. O Atestado Médico a ser entregue, que comprove a deficiência do candidato, deverá ser original ou cópia autenticada e deverá ter sido expedido no máximo 60 (sessenta) dias antes da publicação deste Edital, conter a assinatura do médico e número do registro no Conselho Regional de Medicina. 
3.9.1.1. Caso necessite de condições especiais para a realização das provas, no ato da inscrição o candidato deverá declarar, conforme Anexo 3, para que sejam tomadas as providências cabíveis com antecedência.

3.9.2. A viabilidade dessa solicitação será examinada pela Comissão de Concurso da FDRH.

3.9.3. Ao candidato cego será disponibilizada, exclusivamente, prova com auxílio de fiscal ledor, em sala separada.

3.9.4. A candidata lactante que necessite amamentar durante a realização da prova deverá encaminhar antecipadamente a solicitação e, no dia da prova, apresentar à Coordenação do Concurso o acompanhante, o qual ficará em sala reservada e será responsável pela guarda da criança.

3.9.4.1. Não será permitida a permanência da criança na sala de prova.

3.9.4.2. O tempo de amamentação não será acrescido ao final da prova.

3.10. O candidato poderá inscrever-se para concorrer somente a um cargo.

3.10.1. Caso o candidato efetue o pagamento da taxa para mais de uma inscrição, valerá a inscrição com a data mais recente (a última inscrição paga), ficando ciente de que não haverá devolução da outra taxa paga.

3.11. Os requisitos para a inscrição quanto à escolaridade e habilitação legal para o exercício do cargo estão previstos no Anexo 1 deste Edital.

3.12. O candidato é responsável pelas informações prestadas no Formulário Eletrônico de Inscrição, arcando com as consequências de eventuais erros no preenchimento do documento.

3.13. Não haverá devolução do valor da taxa de inscrição paga, mesmo que o candidato, por qualquer motivo, não tenha sua inscrição homologada.

3.14. O candidato, ao preencher o Formulário Eletrônico de Inscrição declara, automaticamente, que está de acordo com as normas e condições previstas neste Edital e na legislação pertinente.

3.15. A homologação do pedido de inscrição será divulgada por meio de Edital, no qual constará o motivo de indeferimento.

3.16. Cabe pedido de revisão da não homologação da inscrição, nos termos do item 9 deste Edital.

\section{DAS VAGAS RESERVADAS A CANDIDATOS COM DEFICIÊNCIA:}

4.1. Aos candidatos com deficiência é assegurada a inscrição no concurso público de que trata este Edital, nos termos da Lei $\mathrm{n}^{\mathrm{o}} 13.320$, de 21 de dezembro de 2009, atualizada pela Lei 13.519, de 16 de setembro de 2010, desde que haja compatibilidade com as atribuições do cargo, nos termos do Decreto $n^{\circ} 44.300$, de 20 de fevereiro de 2006, do Decreto $n^{\circ} 46.656$, de $1^{\circ}$ de outubro de 2009 e do Decreto ${ }^{\circ} 48.724$, de 22 de dezembro de 2011. 
4.2. Nos termos da legislação em vigor, $10 \%$ (dez por cento) dos cargos a serem preenchidos por meio deste concurso público serão reservados a candidatos com deficiência, sendo esse percentual observado ao longo do período de validade do concurso, inclusive em relação às vagas que surgirem ou que forem criadas.

4.3. A comprovação da condição de pessoa com deficiência, para fins de isenção de taxa, se dará no ato da inscrição, conforme Lei $\mathrm{n}^{\circ}$ 13.153, de 16 de abril de 2009, mediante apresentação dos seguintes documentos:

a) Carteira de Identidade;

b) Atestado Médico fornecido por profissional cadastrado no respectivo Conselho (original ou cópia autenticada) esclarecendo o tipo e grau da deficiência, a especificação da CID, o número do registro do médico no Conselho Regional de Medicina, nome e assinatura do mesmo, devendo ter sido expedido no máximo 60 (sessenta) dias antes da publicação deste Edital (Modelo Anexo 4);

c) Comprovação de renda mensal do candidato igual ou inferior a 1,5 (um e meio) salário mínimo nacionalmente fixado per capita e certidão de nascimento/casamento dos dependentes. Caso o candidato dependa financeiramente de outra pessoa, deverá apresentar o comprovante de renda mensal atualizado dessa pessoa.

4.3.1. Os Atestados Médicos devem ser entregues no Protocolo da Fundação para o Desenvolvimento de Recursos Humanos, no horário das $9 \mathrm{~h}$ às $11 \mathrm{~h} 30 \mathrm{~min}$ e das $14 \mathrm{~h}$ às $17 \mathrm{~h}$, no período de 27 de fevereiro a 13 de março de 2013 (subitem 3.9) e de 27 de fevereiro a 04 de março de 2013, no caso de isenção de taxa (subitem 4.3) do Edital nº 01/2013.

4.3.1.1. Se o candidato o desejar, poderá encaminhar o laudo médico pelos Correios, somente por meio de SEDEX, à Divisão de Concursos Públicos da FDRH, nos prazos acima estabelecidos, para o seguinte endereço:

Divisão de Concursos Públicos da FDRH
Concurso Público da SEDUC - 2013
Avenida Praia de Belas, 1595
Bairro Menino Deus
Porto Alegre/RS - CEP. 90.110-001

4.3.2. No caso de remessa por SEDEX, a data que consta no carimbo de postagem do Correio deve estar dentro do prazo acima determinado.

4.3.3. Os nomes dos candidatos isentos do pagamento da taxa de inscrição serão divulgados nos sites www.fdrh.rs.gov.br e www.educacao.rs.gov.br, em Concursos da SEDUC, até o dia 08/03/2013.

4.4. As pessoas com deficiência participarão da seleção em igualdade de condições com os demais candidatos no que se refere ao conteúdo, à avaliação, à duração, ao horário e ao local de realização das provas.

4.5. Não ocorrendo aprovação de candidatos com deficiência em número suficiente para ocupar os $10 \%$ (dez por cento) dos cargos reservados, estes serão preenchidos pelos demais candidatos aprovados neste concurso. 
4.6. Em face da reserva legal de $10 \%$ das vagas aos candidatos com deficiência, tem-se que, dentre cada 10 (dez) candidatos nomeados, deverá ser nomeado 1 (um) candidato com deficiência.

4.7. A verificação da condição de pessoa com deficiência dar-se-á no período da inscrição, a partir da opção declarada:

4.7.1. O laudo ou atestado médico com a espécie, grau ou nível de deficiência deverá ser apresentado no prazo determinado no item 3.9 e subitem 4.3.1;

4.7.2. Para a homologação preliminar da inscrição que possibilita ao candidato a realização da prova, o atestado deverá ser encaminhado na forma do subitem 4.3, letra b, combinado com os subitens 4.3.1 e 4.3.1.1 conforme o previsto no artigo 41, $\S 1^{\circ}$ do Decreto $n^{\circ} 48.724 / 2011$.

4.8. No curso dos procedimentos, até a nomeação, o candidato com deficiência aprovado será submetido à avaliação médica, pelo Departamento Médico do Estado e Saúde do Trabalhador (DMEST), para verificar a compatibilidade da deficiência com o exercício das atribuições do cargo.

4.9. Caso a avaliação prevista no item 4.7 conclua pela incompatibilidade entre a deficiência e o exercício das atribuições do cargo, o candidato será eliminado do Concurso.

\section{DAS VAGAS DESTINADAS A CANDIDATOS NEGROS:}

5.1. Nos termos da diretriz estabelecida pelo art. 17 da Lei n. ${ }^{\circ} 13.694$, de 19 de janeiro de 2011 e Lei $\mathrm{n}^{\circ} 14.147 / 2012$, aos candidatos negros serão reservadas $16 \%$ (dezesseis por cento) das vagas (IBGE/Censo Demográfico 2010).

5.2. Para efeitos do previsto neste Edital, considerar-se-á negro aquele que assim se declare expressamente no momento da inscrição.

5.3. Não ocorrendo aprovação de candidatos negros em número suficiente para ocupar os $16 \%$ (dezesseis por cento) dos cargos reservados, estes serão preenchidos pelos demais candidatos aprovados neste concurso.

5.4. O percentual de $16 \%$ das vagas reservadas aos candidatos negros será observado ao longo do período de validade do concurso público, inclusive em relação às vagas que surgirem ou que forem criadas.

5.5. Em face da reserva legal de $16 \%$ das vagas aos candidatos negros, tem-se que, dentre cada 07 (sete) candidatos nomeados, deverá ser nomeado 1 (um) candidato negro.

5.6. O candidato negro participará do Concurso Público em igualdade de condições com os demais candidatos, no que se refere ao conteúdo, à avaliação, à duração, ao equipamento, à data, ao horário e ao local de realização das provas do concurso.

5.7. As informações fornecidas pelos candidatos são de sua responsabilidade e ficarão nos registros cadastrais de ingresso. 


\section{DOS CANDIDATOS À EDUCAÇÃO INDÌGENA:}

6.1. As vagas mencionadas no Anexo 2 são exclusivas para candidatos integrantes de Povos Indígenas com vínculo de pertencimento a comunidades indígenas reconhecidas nos âmbitos federal e/ou estadual.

6.2. Os candidatos indígenas a essas vagas devem obrigatoriamente apresentar Declaração atualizada de Pertencimento a uma comunidade indígena reconhecida, fornecida pela liderança instituída da comunidade (cacique ou conselho) com chancela da FUNAI ou do CEPI Conselho Estadual dos Povos Indígenas (conforme Anexo 5), devendo ser apresentada no ato da posse. A não apresentação deste documento, ou cujas informações, dados e autenticações sejam inverídicas ou contenham vício de origem, excluirá o candidato do certame.

\section{DA JORNADA DE TRABALHO:}

7.1. A jornada de trabalho é de 20 horas semanais e os vencimentos constam no Anexo 6 deste Edital.

7.2. A jornada de trabalho será exercida da seguinte maneira:

I -13 (treze) horas $=$ setecentos e oitenta minutos $(13$ horas $=780$ minutos $)$ a serem cumpridas na escola, em atividades letivas, incluindo o período de recreio;

II -7 (sete) horas $=$ quatrocentos e vinte minutos $(7$ horas $=420$ minutos $)$ de atividades, distribuídas a critério da SEDUC.

7.3. A descrição das atribuições do cargo consta no Anexo 7 deste Edital.

\section{DAS PROVAS:}

8.1. O Concurso será constituído de uma prova objetiva, de caráter eliminatório, e de uma prova de títulos, de caráter classificatório.

8.2. A prova objetiva será composta por dois módulos, conforme descrição dos itens a seguir:

8.2.1. Aos candidatos ao cargo de Professor Anos Finais do Ensino Fundamental e Ensino Médio, a prova será constituída de dois módulos, sendo o primeiro composto de 10 questões de Língua Portuguesa, 15 questões de Conhecimentos Pedagógicos e 10 questões de Legislação da Educação e, o segundo módulo, de 15 questões de Conhecimentos da Área e 10 questões da Habilitação do professor.

8.2.2. Aos candidatos ao cargo de Professor Anos Iniciais do Ensino Fundamental e, da Educação Especial, a prova será constituída de dois módulos, sendo o primeiro composto de 10 questões de Língua Portuguesa, 10 questões de Conhecimentos Pedagógicos e 5 questões de Legislação, e o segundo módulo composto de 35 questões, relativa à Área de Conhecimento e Habilitação do Professor.

8.2.3. Aos candidatos na Educação Indígena: 
a) Anos Iniciais do Ensino Fundamental / Língua Guarani, a prova terá apenas um módulo, constituído de $90 \%$ na Língua Guarani e 10\% na Língua Portuguesa, sendo 25 questões de proficiência na Língua Guarani e conhecimentos da Língua Portuguesa, 25 questões de Conhecimentos Pedagógicos da modalidade Educação Escolar Indígena e 10 questões de Legislação da Educação Indígena;

b) Anos Iniciais do Ensino Fundamental / Língua Kaingang, a prova terá apenas um módulo, constituído de $70 \%$ na Língua Kaingang e 30\% na Língua Portuguesa, sendo 25 questões de proficiência em Língua Kaingang e conhecimentos de Língua Portuguesa, 25 questões de Conhecimentos Pedagógicos da modalidade Educação Escolar Indígena e 10 questões de Legislação da Educação Indígena;

c) Anos Iniciais do Ensino Fundamental / Língua Portuguesa com conhecimento de Língua Kaingang, a prova terá apenas um módulo, constituído de 30\% na Língua Kaingang e 70\% na Língua Portuguesa, sendo 25 questões de proficiência em Língua Portuguesa e conhecimentos de Língua Kaingang, 25 questões de Conhecimentos Pedagógicos da modalidade Educação Escolar Indígena e 10 questões de Legislação da Educação Indígena;

d) Anos Finais do Ensino Fundamental e Ensino Médio /Educação Indígena, a prova será constituída de dois módulos, escritos em Língua Portuguesa, sendo o primeiro com 10 questões de proficiência em Língua Portuguesa e conhecimentos da Língua Indígena Kaingang, com 50\% das questões para cada língua, 15 questões de Conhecimentos Pedagógicos da modalidade Educação Escolar Indígena e 10 questões de Legislação da Educação Indígena e, no segundo módulo, 25 questões de Conhecimentos da Área.

8.2.4. Aos candidatos da Educação Profissional, a prova será constituída de dois módulos, sendo o primeiro de 10 questões de Língua Portuguesa, 15 questões de Conhecimentos Pedagógicos e 10 questões de Legislação e, no segundo módulo, de 10 questões da Área de Conhecimento e 15 questões no Eixo Tecnológico da Habilitação do professor.

8.3. A prova objetiva será constituída e avaliada conforme o previsto no Anexo 8 deste Edital.

8.4. A prova objetiva será valorada na escala de 0 (zero) ao máximo de 100 (cem) pontos, equivalente a $80 \%$ da nota final.

8.5. A prova de títulos será valorada na escala de 0 (zero) ao máximo de 100 (cem) pontos, equivalente a $20 \%$ da nota final.

8.5.1. Os títulos para avaliação deverão ser encaminhados conforme modelo constante no Anexo 9 deste Edital.

8.6. Para aprovação no Concurso, o candidato deverá alcançar o percentual mínimo de $60 \%$ do total das questões de cada um dos módulos que compõem a prova objetiva, conforme previsto no Anexo 8 deste Edital, sendo eliminado, automaticamente, caso não alcance tal percentual.

8.6.1. O percentual é calculado multiplicando-se o número de acertos pelo peso da questão, conforme exemplo a seguir:

- no módulo I: 35 questões com peso 2, caso tenha 21(acertos) vezes 2 (peso da questão), é igual a 42 (pontuação), que corresponde à pontuação mínima de $60 \%$ do módulo I - 21 x $2=42$ $\Leftrightarrow 60 \%$ 
- no módulo II: 25 questões com peso 1.2, caso tenha 15(acertos) vezes 1,2 (peso da questão), é igual a 18 (pontuação), que corresponde à pontuação mínima de $60 \%$ do módulo II - 15 x 1,2 $=18 \Leftrightarrow 60 \%$.

8.7. Os programas das provas objetivas e as referências bibliográficas recomendadas encontram-se no Anexo 10 deste Edital.

\subsection{DA PROVA OBJETIVA:}

8.8.1. A prova objetiva será realizada em espaços localizados no município-sede das Coordenadorias Regionais de Educação, conforme Anexo 11. Caso o número de candidatos para prestar provas exceda a oferta de lugares existentes nos estabelecimentos de ensino disponíveis na cidade sede da CRE, a FDRH se reserva o direito de alocá-los em cidades próximas para aplicação da prova, não assumindo qualquer responsabilidade quanto ao transporte e alojamento dos candidatos.

8.8.2. A duração da prova objetiva será de 4 (quatro) horas.

8.8.3. As informações sobre a data, a hora e o local da prova objetiva serão publicadas conforme o previsto no item 2 deste Edital, no mínimo, com 10 (dez) dias de antecedência.

8.8.4. Não serão encaminhados informativos individuais sobre o local, a data e o horário da prova

8.8.5. A critério da Secretaria de Estado da Educação - SEDUC, a prova poderá ser realizada em qualquer dia da semana, inclusive sábado, domingo ou feriado.

8.8.6. O candidato deverá comparecer ao local da prova com 1 (uma) hora de antecedência do horário fixado para início da mesma.

8.8.7. Para o ingresso na sala de provas poderá ser apresentado um dos documentos citados no item 3.3.3.1 deste Edital, devendo estar em boas condições, de forma a permitir, com clareza, a identificação do candidato. Deverá ser apresentado, preferencialmente, o documento cujo número consta no Formulário Eletrônico de Inscrição.

8.8.8. Ao ingressar na sala de provas, o candidato receberá uma embalagem plástica, na qual deverá colocar todos os seus pertences: livros, apostilas, bolsas, boné, gorro, capangas, calculadora, relógio com calculadora, rádio, telefone celular (desligado e sem alarme), bip ou qualquer aparelho receptor de mensagem. A referida embalagem plástica deverá ser colocada no chão, sob a cadeira/classe do candidato.

8.8.9. Após o sinal indicativo do início da prova, não será permitido ao candidato retardatário ingressar na sala de realização da mesma.

8.8.10. Durante a realização da prova, somente será permitido ao candidato portar caneta esferográfica transparente de ponta grossa, com tinta de cor azul ou preta.

8.8.10.1. É vedado ao candidato utilizar óculos escuros, chapéu, boné, touca ou outros acessórios que cubram as orelhas ou parte do rosto durante a realização da prova. 
8.8.10.2. Não será permitida a permanência de acompanhante do candidato, ou de pessoas estranhas ao Concurso, nas dependências do local, salvo a questão relativa ao item 3.9.4.

8.8.11. Durante a realização da prova, não será permitida a comunicação entre os candidatos, nem consultas de qualquer espécie, bem como o uso de qualquer aparelho eletrônico (bip, telefone celular, mobi, relógio do tipo data bank, walkman, agenda eletrônica, notebook, palmtop, tablet, receptor, gravador, fones de ouvido, prótese auditiva, calculadora financeira ou científica).

8.8.12. O candidato com prótese auditiva que não possa ser retirada deverá solicitar atendimento especial. Esta solicitação deverá ser feita previamente, conforme o previsto no subitem 3.9 deste Edital.

8.8.13. O candidato deverá assinalar suas respostas na Folha de Respostas, obrigatoriamente com caneta esferográfica transparente de ponta grossa, com tinta de cor azul ou preta.

8.8.14. Não serão computadas as questões não assinaladas na Folha de Respostas, bem como as questões que contenham mais de uma resposta, emenda ou rasura, ainda que legível.

8.8.15. Será excluído do Concurso o candidato que:

a) For surpreendido, em ato flagrante, durante a realização das provas, comunicando-se com outros candidatos ou pessoas estranhas ao Concurso, bem como se utilizando de consultas de livros, apontamentos, aparelhos celulares, instrumentos digitais ou outro objeto ou equipamento de qualquer natureza;

b) Portar-se inconvenientemente, perturbando, de qualquer forma, o bom andamento dos trabalhos;

c) Utilizar-se de quaisquer recursos ilícitos ou fraudulentos, em qualquer etapa de realização do Concurso.

8.8.16. Os fundamentos da exclusão do candidato serão registrados em Formulário do Termo de Infração.

8.8.17. O candidato somente poderá retirar-se do recinto da prova após 1 (uma) hora do início da mesma.

8.8.18. O candidato que desejar levar o caderno da prova, só poderá fazê-lo após decorridas 2 (duas) horas do início da prova.

8.8.19. O candidato não poderá ausentar-se da sala da prova, a não ser em casos excepcionais, acompanhado do fiscal.

8.8.20. Não será permitido ao candidato entrar ou permanecer com armas na sala da prova.

8.8.21. O candidato que tiver os seus documentos furtados ou roubados deverá apresentar documento que ateste o registro da ocorrência em órgão policial, expedido há, no máximo, 30 (trinta) dias de antecedência da data da prova. 
8.8.22. O candidato, ao terminar a prova, entregará ao fiscal da sala a Folha de Respostas preenchida e assinada. Se assim não proceder, será excluído do Concurso, mediante o preenchimento do Formulário do Termo de Infração.

8.8.23. Em nenhuma hipótese haverá segunda chamada, nem será aplicada prova fora da data, do local e do horário estabelecidos no Edital.

\subsection{DA PROVA DE TÍTULOS:}

8.9.1. Os documentos para a prova de títulos, discriminados no quadro do item 8.9 .5 deste Edital, deverão ser entregues no prazo de 4 (quatro) dias, no período estabelecido em Edital próprio.

8.9.2. Somente serão avaliados os títulos de candidatos aprovados na prova objetiva.

8.9.3. Os envelopes contendo as cópias dos documentos para a prova de títulos poderão ser entregues diretamente no Protocolo da Fundação para o Desenvolvimento de Recursos Humanos, no endereço abaixo, das $9 \mathrm{~h}$ às $11 \mathrm{~h} 30 \mathrm{~min}$ e das $14 \mathrm{~h}$ às $17 \mathrm{~h}$, ou poderão ser encaminhados, somente por SEDEX, para o seguinte endereço:

Divisão de Concursos Públicos da FDRH.

TÍTULOS - Concurso Público da SEDUC - 2013.

Av. Praia de Belas, 1595.

Bairro Menino Deus.

Porto Alegre-RS - CEP 90.110-001.

8.9.4. A FDRH é responsável pelo recebimento dos documentos referentes à prova de títulos.

8.9.5. Para efeitos deste Concurso, serão considerados e pontuados os títulos conforme o estabelecido na tabela abaixo:

\begin{tabular}{|c|l|c|c|c|}
\hline ALÍNEA & \multicolumn{1}{|c|}{ ESPECIFICAÇÃo } & $\begin{array}{c}\text { QUANTIDADE } \\
\text { DE Tí́TULOS } \\
\text { (MÁXIMO) }\end{array}$ & $\begin{array}{c}\text { VALOR } \\
\text { UNITÁRIO } \\
\text { (PONTOS) }\end{array}$ & $\begin{array}{c}\text { MÁXIMO } \\
\text { (PONTOS) }\end{array}$ \\
\hline $\mathbf{A}$ & $\begin{array}{l}\text { Curso Superior em Licenciatura } \\
\text { Plena, ou de outro curso de } \\
\text { graduação, exceto do curso que é } \\
\text { requisito para inscrição no } \\
\text { concurso. }\end{array}$ & $\mathbf{1}$ & $\mathbf{6}$ \\
\hline $\mathbf{B}$ & $\begin{array}{l}\text { Pós-Graduação em nível de } \\
\text { especialização, atualização, } \\
\text { aperfeiçoamento, extensão, ou } \\
\text { outro curso na área da Educação, } \\
\text { com carga horária mínima de 360 } \\
\text { horas. }\end{array}$ & $\mathbf{1}$ & $\mathbf{8}$ & $\mathbf{8}$ \\
\hline $\mathbf{C}$ & $\begin{array}{l}\text { Pós-Graduação em nível de } \\
\text { Mestrado na área da Educação. }\end{array}$ & $\mathbf{1}$ & $\mathbf{1 0}$ & $\mathbf{1 0}$ \\
\hline
\end{tabular}




\begin{tabular}{|c|c|c|c|c|}
\hline $\mathbf{D}$ & $\begin{array}{l}\text { Pós-Graduação em nível de } \\
\text { Doutorado na área da Educação. }\end{array}$ & 1 & 13 & 13 \\
\hline $\mathbf{E}$ & $\begin{array}{l}\text { Participação em cursos de } \\
\text { qualificação em informática, com } \\
\text { o mínimo de } 40 \text { (quarenta) horas. }\end{array}$ & 5 & 2 & 10 \\
\hline $\mathbf{F}$ & $\begin{array}{l}\text { Participação em congressos, } \\
\text { seminários, simpósios ou outros } \\
\text { eventos na área da Educação, com } \\
\text { o mínimo de } 40 \text { (quarenta) horas. }\end{array}$ & 5 & 1 & 5 \\
\hline $\mathbf{G}$ & $\begin{array}{l}\text { Participação como palestrante em } \\
\text { Congresso, Seminários, simpósios } \\
\text { ou outros eventos na área da } \\
\text { Educação. }\end{array}$ & 4 & 2 & 8 \\
\hline $\mathbf{H}$ & $\begin{array}{l}\text { Publicações de artigos, na área da } \\
\text { educação, em revistas, jornais e } \\
\text { livros. }\end{array}$ & 4 & 1 & 4 \\
\hline $\mathbf{I}$ & $\begin{array}{l}\text { Publicações de artigos, na área da } \\
\text { educação, em periódicos } \\
\text { reconhecidos pela CAPES. }\end{array}$ & 4 & 3 & 12 \\
\hline $\mathbf{J}$ & $\begin{array}{l}\text { Tempo anual de experiência } \\
\text { profissional em instituição regular } \\
\text { de ensino como não docente. }\end{array}$ & 4 & 2 & 8 \\
\hline $\mathbf{K}$ & $\begin{array}{l}\text { Tempo anual de experiência } \\
\text { profissional no magistério em } \\
\text { instituição regular de ensino, em } \\
\text { regência de classe. }\end{array}$ & 4 & 4 & 16 \\
\hline & PONTUAÇÃO MÁXIMA & - & & 100 \\
\hline
\end{tabular}

OBS: Somente será contabilizado um título de pós-graduação, valendo o titulo de maior valor.

8.9.6. A comprovação da experiência profissional deverá ser feita por meio das alternativas de documentação abaixo relacionadas:

a) Cópia da Carteira de Trabalho e Previdência Social (CTPS) contendo a parte que identifica o candidato (frente e verso) e a parte do registro do empregador (com a data de início e fim, se for o caso) acrescida de declaração do empregador que informe a espécie do serviço realizado, com a descrição das atividades básicas desenvolvidas;

b) Declaração ou certidão de tempo de serviço que informe o período (com início e fim, se for o caso) e a espécie do serviço realizado, com a descrição das atividades básicas desenvolvidas. A declaração ou certidão deverá ser emitida por órgão de pessoal ou de recursos humanos. Não havendo órgão de pessoal ou de recursos humanos, a autoridade responsável pela emissão do documento deverá declarar/certificar também essa inexistência; 
c) Para as pessoas que possuem ou possuíram vínculo com o Estado, poderá ser apresentado o Resumo Funcional /RHE - Sistema de Gestão de Recursos Humanos, devidamente assinado e carimbado pela Coordenadoria Regional de Educação;

d) A comprovação por meio do recibo de pagamento autônomo (RPA) só será aceita com a apresentação dos meses recebidos; ou

e) Contrato de prestação de serviços ou recibo de pagamento autônomo (RPA) acrescido de declaração do contratante que informe o período (com início e fim, se for o caso) e a espécie do serviço realizado, no caso de serviço prestado como autônomo.

8.9.7. Não serão pontuadas como experiência profissional atividades curriculares desenvolvidas durante o curso que habilita o candidato ao cargo.

8.9.8. Em caso de atividades desenvolvidas em períodos concomitantes será pontuado somente o de maior duração.

8.9.9. O candidato deverá entregar cópias autenticadas de todos os títulos que vier a apresentar, acondicionadas em envelope tamanho ofício. No envelope deverão constar os seguintes dados de identificação:
a)Nome;
b) Número da Inscrição;
c) Área e habilitação;
d) Concurso da SEDUC-2013-Prova de Títulos.

8.9.10. O candidato deverá preencher e assinar o Formulário da Relação de Títulos, em 2 (duas) vias, na forma determinada no Anexo 9 deste Edital.

8.9.11. A escolha dos títulos deve observar a quantidade máxima estipulada na tabela constante no subitem 8.9.5 deste Edital.

8.9.12. O mesmo título não será valorado duas vezes.

8.9.13. Os certificados ou diplomas expedidos por universidades estrangeiras deverão estar revalidados por universidades públicas brasileiras que tenham curso do mesmo nível e área ou equivalente, respeitando-se os acordos internacionais de reciprocidade ou equiparação nos termos do artigo $48, \S \S 2^{\circ}$ e $3^{\circ}$ da Lei Federal n. ${ }^{\circ}$ 9.394/96.

8.9.14. Os documentos apresentados em língua estrangeira deverão vir acompanhados de tradução feita por tradutor juramentado, exceto aqueles apresentados em língua espanhola.

8.9.15. Se o nome do candidato no(s) documento(s) apresentado(s) para a prova de títulos for diferente do nome que consta no Formulário Eletrônico de Inscrição, deverá ser encaminhado, também, um comprovante de alteração de nome, sob pena de esse(s) documento(s) não ser (em) considerado(s).

8.9.16. Os documentos comprobatórios de títulos não podem apresentar rasuras ou emendas.

8.9.17. Após a entrega do envelope não serão aceitos acréscimos de documentos. 
8.9.18. Constatada, em qualquer tempo, irregularidade ou ilegalidade na obtenção dos títulos apresentados, o candidato terá anulada a respectiva pontuação e, comprovado que agiu de máfé, será excluído do Concurso.

8.9.19. As cópias dos comprovantes dos títulos não serão devolvidas ao candidato.

8.9.20. Todos os diplomas e/ou certificados de Curso Normal, de cursos superiores de graduação e de pós-graduação, em todos os níveis, deverão ser expedidos por instituição de ensino cujo curso seja devidamente reconhecido, na forma do artigo 48 da Lei Federal $\mathrm{n}^{\circ}$ 9.394/96.

8.9.20.1. O candidato que estiver aguardando diplomas e/ou certificados de cursos concluídos poderá apresentar certidão de conclusão expedida pela respectiva instituição.

8.9.20.2. Para a comprovação da conclusão de cursos de Pós-Graduação Stricto Sensu em nível de Doutorado ou de Mestrado será aceito o diploma registrado ou certidão de conclusão acompanhada do histórico escolar, expedidos por instituição cujo curso seja reconhecido pela CAPES/MEC ou com validade no Brasil.

8.9.21. Não serão computados os títulos que excederem ao número máximo previsto em cada alínea da Tabela de Pontuação da Prova de Títulos constante no subitem 8.9.5 deste Edital.

8.9.22. Caso, no mesmo documento, conste a comprovação de mais de um título referente ao mesmo evento, será considerado apenas o de maior valoração para fins de pontuação.

8.9.23. Os documentos que não estiverem de acordo com as informações prestadas por ocasião da inscrição e com os critérios estabelecidos neste Edital, ainda que entregues ou encaminhados, não serão considerados.

\section{DOS PEDIDOS DE REVISÃO:}

9.1. A homologação das inscrições, os gabaritos, as listas contendo os resultados das provas objetivas e de títulos e as respostas aos pedidos de revisão, bem como a homologação do Concurso, serão divulgados através de editais ou avisos publicados conforme prevê o item 2 deste Edital.

9.2. O candidato poderá interpor pedido de revisão dirigido ao Secretário de Estado da Educação em relação às inscrições não homologadas, aos gabaritos, aos resultados referentes às provas objetivas e ao resultado obtido na prova de títulos, no prazo de 5 (cinco) dias ininterruptos a contar da publicação dos resultados.

9.2.1. O pedido de revisão deverá ser entregue no protocolo da FDRH, para análise e manifestação da Comissão de Concurso da FDRH, a qual, posteriormente, o encaminhará ao Secretário de Estado da Educação.

9.2.2. No caso de remessa pelo Correio, o pedido de revisão somente poderá ser encaminhado por SEDEX endereçado à FDRH.

9.3. O pedido de revisão deverá conter: 
a) Nome completo e número de inscrição do candidato;

b) Indicação do cargo e da habilitação;

c) Exposição circunstanciada sobre os motivos a respeito da matéria contestada, em face das normas do concurso;

d) Objeto do pedido de revisão claramente especificado e, se for o caso, com o total dos pontos solicitados.

9.4. O deferimento ou indeferimento do pedido de revisão será publicado conforme prevê o item 2 deste Edital.

9.5. Não serão considerados os pedidos de revisão protocolados na FDRH fora do prazo, bem como os pedidos remetidos por SEDEX em que o carimbo de postagem do Correio estiver fora do prazo determinado.

\section{DA APROVAÇÃO E DA CLASSIFICAÇÃO:}

10.1 Será considerado aprovado nas provas objetivas o candidato que obtiver as pontuações mínimas exigidas, conforme os requisitos estabelecidos no Anexo 8 deste Edital.

10.2. As questões que, porventura, vierem a ser anuladas nas provas objetivas serão consideradas como respondidas corretamente por todos os candidatos.

10.3. A nota final será obtida conforme o previsto no Anexo 8 deste Edital.

10.3.1. No presente certame, haverá arredondamento na atribuição de pontos e/ou notas a qualquer prova, ou na apuração dos resultados parciais e ou finais.

10.3.2. Quando as notas resultarem em fração, serão arredondadas para o número inteiro imediatamente superior, em caso de fração igual ou maior a 0,5 (cinco décimos), ou para o número inteiro imediatamente inferior, em caso de fração menor que 0,5 (cinco décimos).

10.4. A classificação dos candidatos aprovados dar-se-á, depois de esgotada a fase recursal, pela ordem decrescente da pontuação obtida na nota final.

10.5. Será publicada uma lista de candidatos classificados que determinará a ordem de nomeação. A lista conterá a região, a área do conhecimento, a habilitação e a identificação de quotas, se for o caso.

10.5.1. Para a área do conhecimento Educação Profissional, a lista publicada dos candidatos classificados conterá a região, o eixo tecnológico, o curso e a habilitação do candidato, na forma do Anexo 12.

\section{DOS CRITÉRIOS DE DESEMPATE PARA A CLASSIFICAÇÃO FINAL:}

11.1. Na hipótese de empate de pontos obtidos na nota final do Concurso objeto deste Edital, entre dois ou mais candidatos, serão utilizados os critérios de desempate a seguir especificados:

11.1.1. acertar o maior número de questões na prova de Língua Portuguesa; 
11.1.1.1. para os candidatos indígenas, acertar o maior número de questões na prova de proficiência em Língua Indígena e conhecimentos da Língua Portuguesa;

11.1.2. acertar o maior número de questões na prova de Conhecimentos Pedagógicos;

11.1.3. acertar o maior número de questões na prova de Legislação.

11.1.4. maior pontuação na prova de títulos;

11.1.5. nacionalidade brasileira;

11.1.6. ter um dos candidatos a idade mais avançada.

11.2. Persistindo o empate entre os candidatos, depois de aplicados todos os critérios acima, o desempate dar-se-á através do sistema de sorteio descrito a seguir:

11.2.1. Os candidatos empatados serão ordenados de acordo com seu número de inscrição, de forma crescente ou decrescente. A ordem crescente ou decrescente do número de inscrição será definida pelo resultado do primeiro prêmio da extração da Loteria Federal imediatamente posterior ao dia da publicação da lista de resultados das provas de títulos antes dos recursos, segundo os critérios a seguir:

a) se a soma dos algarismos do número sorteado no primeiro prêmio da Loteria Federal for par, a ordem será crescente;

b) se a soma dos algarismos da Loteria Federal for ímpar, a ordem será decrescente.

\section{DA NOMEAÇÃO E POSSE}

12.1. A nomeação no cargo, a ser publicada no Diário Oficial do Estado, se dará conforme a necessidade da SEDUC.

12.1.1. A nomeação dos candidatos observará a necessidade da região, área de conhecimento e habilitação, respeitada a região na qual o mesmo se inscreveu, nos termos do Anexo 2.

12.1.2. No momento da posse, para efeito do preenchimento de vagas nas Coordenadorias Regionais de Educação - CRE, a prioridade de designação do professor nomeado é o atendimento das turmas de alunos sem professor.

12.1.3. Quando a nomeação do professor implicar em dispensa de contratos temporários, para efeito de preenchimento das vagas nas CREs, serão utilizados, respectivamente, os critérios abaixo relacionados, conforme a necessidade da Administração:

a) Turma de alunos atendida por professor contratado sem habilitação (curso incompleto), iniciando a dispensa pelo contratado mais antigo que ainda não tenha concluído sua Licenciatura;

b) Turma de alunos atendida por professor contratado atuando fora da sua área de habilitação, iniciando a dispensa pelo contratado com o menor tempo de contrato; 
c) Turma de alunos atendida por professor contratado dentro da sua área de habilitação, iniciando a dispensa pelo contratado com o menor tempo de contrato;

d) Observada a ordem de classificação e a conveniência da Administração Pública, o professor nomeado neste concurso que já estiver atuando como professor contratado na Área para a qual prestou o concurso poderá permanecer na vaga que ocupa.

12.1.4. A nomeação dos candidatos para a Educação Profissional se dará pela necessidade, respeitada a região na qual o mesmo se inscreveu, no eixo tecnológico, curso e habilitação, conforme Anexo 12, e ainda, nos termos dos subitens 12.1.2 e 12.1.3.

12.1.5. A nomeação do candidato habilitado se dará conforme a ordem decrescente da pontuação obtida na nota final.

12.1.6. Não havendo mais candidatos aprovados na região, conforme a área do conhecimento e habilitação pela qual dar-se-á a nomeação, a fim de atender o interesse público e a critério da SEDUC, na forma dos subitens $12.1 .1,12.1 .2$ e 12.1.3, o candidato poderá ser designado para região diversa daquela escolhida no ato de inscrição, aberta a opção a todos os candidatos classificados nas demais regiões, respeitada a respectiva ordem decrescente de classificação.

12.1.6.1. A divulgação se dará na forma do item 2 .

12.1.6.2. Os candidatos já empossados não terão direito à opção prevista no subitem 12.1.6.

12.1.6.3. Em caso de empate, utilizar-se-ão os critérios estabelecidos no item 11.

12.2. O candidato quotista que ostentar classificação superior a de algum dos candidatos que não concorrem a reserva de vagas será nomeado com observância da classificação da região, abrindo a vaga para os demais candidatos quotistas.

12.2.1. Caso o número de vagas oferecidas na região impossibilite atingir o percentual previsto no Edital, no mínimo uma delas será destinada a candidato quotista. Havendo apenas uma vaga, tem preferência o candidato com deficiência.

12.3. São requisitos para a posse:

12.3.1. Ser brasileiro ou gozar das prerrogativas contidas no Art. 12 da Constituição Federal, cujo processo de naturalização tenha sido encerrado dentro do prazo das inscrições;

12.3.2. No caso de estrangeiro, estar em situação regular no território nacional, dentro do prazo das inscrições, e conforme o estabelecido na Lei Estadual Complementar n ${ }^{\circ}$ 13.763/2011;

12.3.3. Estar em dia com o Serviço Militar, quando do sexo masculino, até a data da posse;

12.3.4. Estar em dia com as obrigações eleitorais até a data da posse;

12.3.5. Ter completado 18 (dezoito) anos até a data da posse;

12.3.6. Possuir a escolaridade exigida, comprovando a habilitação legal para o exercício do cargo, e atender aos outros requisitos estabelecidos nos Anexos 1 e 7 deste Edital, na data da posse; 
12.3.7. Ser aprovado em exame admissional realizado pelo Departamento Médico do Estado (DMEST);

12.3.8. Apresentar a documentação que comprove as exigências estabelecidas neste Edital;

12.4. Os candidatos nomeados por meio de Ato do Governador publicado no Diário Oficial do Estado e divulgado no site da SEDUC (www.educacao.rs.gov.br), deverão, a partir da data de publicação, comparecer na respectiva Coordenadoria Regional de Educação para a qual fez a inscrição, no prazo máximo de 15 (quinze) dias, para manifestar o seu interesse em relação à posse, portando a seguinte documentação e/ou outras exigidas pela legislação:

12.4.1. Certificado de regularidade de situação militar, se do sexo masculino (original e cópia);

12.4.2. Carteira de Identidade (original e cópia);

12.4.3. Documento oficial que contenha o CPF (original e cópia);

12.4.4. Certidão de Casamento / União Estável / Divórcio;

12.4.5. Comprovante do PIS/PASEP (se cadastrado);

12.4.5. Título de Eleitor e comprovante de quitação eleitoral (original e cópia);

12.4.6. Comprovação de escolaridade, mediante a apresentação de diploma ou certificado de conclusão emitido pela Instituição de Ensino, contendo a data de conclusão do curso e assinatura do responsável (original e cópia);

12.4.7. Carteira de Trabalho - cópia da $1^{\text {a }}$ página com número, série e foto; qualificação civil e registro do $1^{\mathrm{o}}$ emprego (original e cópia);

12.4.8. Laudo Médico Pericial para ingresso no serviço público fornecido pelo DMEST/SARH - original, conforme encaminhamento feito pela DRH/SEDUC;

12.4.9. Alvará de Folha Corrida expedido pelo Poder Judiciário Estadual;

12.4.10. Comprovante de residência (original e cópia);

12.4.11. Declaração expedida pelo RH do órgão empregador municipal, estadual ou federal, contendo o nome do cargo ou função, número da Portaria, Decreto ou Boletim de nomeação/admissão com data, carga horária semanal, turno e regime previdenciário, se exercer cargo ou função pública (original).

12.4.12. Comprovante de exoneração de cargo público ou protocolo de pedido, no caso de acúmulo de cargo/função pública vedado pela Constituição Federal, Art. 37, Inciso XVI (cópia).

12.5. O candidato que não tenha interesse em assumir a vaga poderá solicitar o remanejamento, uma única vez, para o final da lista de classificação, devendo fazê-lo por escrito. 
12.6. O candidato que não comparecer no prazo estabelecido, não apresentar qualquer um dos documentos citados no subitem 12.4 ou não solicitar o remanejamento por escrito para o final da lista de classificação do respectivo cargo, prevista no subitem 12.5. deste Edital, ficará automaticamente excluído do Concurso Público.

12.7. É de responsabilidade exclusiva do candidato manter atualizado o seu endereço na Coordenadoria Regional de Educação da SEDUC.

12.8. A alteração de endereço deve ser comunicada na forma estabelecida no subitem 12.8.1 e deve conter a identificação do concurso, o nome do candidato, o número de inscrição, o número do documento de identidade, o número do $\mathrm{CPF}$, além da data, assinatura e novo endereço completo.

12.8.1. Se a mudança de endereço tiver acontecido antes da data de publicação da lista de classificação final, o comunicado deve ser encaminhado à Fundação para o Desenvolvimento de Recursos Humanos - Divisão de Concursos Públicos, Av. Praia de Belas, 1595, Porto Alegre - RS, CEP 90.110-001, por Aviso de Recebimento (AR) ou para o e-mail: concursos@fdrh.rs.gov.br.

12.8.2. Se a mudança de endereço tiver acontecido após a publicação dos resultados finais, o comunicado deve ser encaminhado à Coordenadoria Regional de Educação para a qual o candidato fez a inscrição, cujos endereços constam no Anexo 11, pessoalmente, ou, sendo por correspondência, por Aviso de Recebimento (AR).

\section{DA VIGÊNCIA DO CONCURSO PÚBLICO:}

13.1. O prazo da vigência para aproveitamento dos candidatos classificados será de 2 (dois) anos, contados a partir da data de publicação da homologação do resultado final deste Concurso, podendo ser prorrogado por igual período.

\section{DAS DISPOSIÇÕES FINAIS:}

14.1. A FDRH é responsável por constituir a Comissão de Concurso com a competência exclusiva de resolver as questões definidas neste Edital.

14.2. Constatada, a qualquer tempo, inexatidão e/ou irregularidade nas informações e documentos, o candidato será eliminado do concurso, sendo declarados nulos todos os atos daí decorrentes.

14.3. A inobservância, por parte do candidato, de qualquer chamamento ou de prazo estabelecido neste Edital, será considerada como desistência.

14.4. Em caso de anulação de prova(s), não haverá qualquer forma de ressarcimento ao candidato.

14.5. É responsabilidade do candidato acompanhar todas as publicações, avisos, atos, editais e comunicados referentes a este Concurso.

14.5.1. Após o término do certame, as informações ficarão disponíveis no site da Secretaria da Educação (www.educacao.rs.gov.br). 
14.6. A Secretaria de Estado da Educação - SEDUC e a Fundação para o Desenvolvimento de Recursos Humanos - FDRH não se responsabilizam pelas publicações, apostilas e outros materiais elaborados por terceiros relativos a este concurso.

14.7. Os casos omissos serão resolvidos pela Comissão do Concurso da FDRH, observada a legislação pertinente, cabendo recurso ao Secretário de Estado da Educação.

14.8. São partes integrantes deste Edital os seguintes anexos:

Anexo 1 - Quadro demonstrativo das áreas, habilitação legal e requisitos obrigatórios e carga horária;

Anexo 2 - Quadro das Vagas por Coordenadoria Regional de Educação;

Anexo 3 - Requerimento de Condições Especiais para a realização das provas;

Anexo 4 - Modelo de Atestado Médico para Pessoa com Deficiência;

Anexo 5 - Modelo de Declaração de pertencimento a Comunidade Indígena;

Anexo 6 - Tabela de Remuneração e Níveis;

Anexo 7 - Descrição das atribuições do cargo;

Anexo 8 - Quadro demonstrativo das provas objetivas de caráter eliminatório e classificatório, do número e valor das questões;

Anexo 9 - Formulário da relação de títulos entregues;

Anexo 10 - Programas e bibliografias recomendadas;

Anexo 11 - Listagem das Coordenadorias Regionais de Educação - CREs;

Anexo 12 - Quadro dos Eixos, Cursos e Habilitações da Área da Educação Profissional.

Porto Alegre, 06 de fevereiro de 2013.

Jose Clovis de Azevedo

Secretário de Estado da Educação 


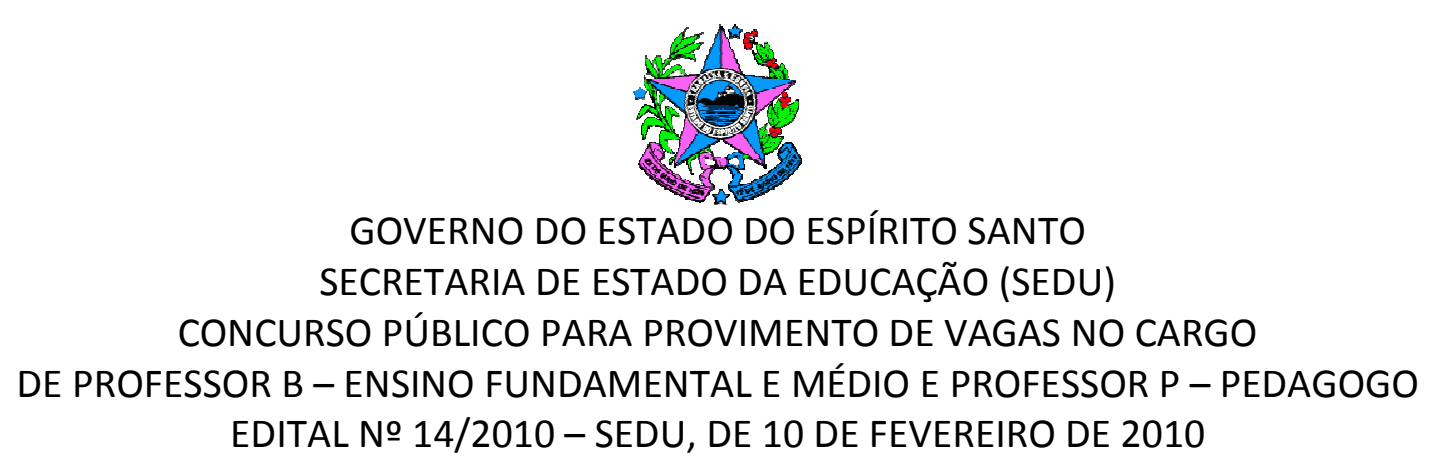

A SECRETARIA DE ESTADO DA EDUCAÇÃO (SEDU), nos termos da Lei Complementar no 115, de 13 de janeiro de 1998, publicada no Diário Oficial do Estado do Espírito Santo de 14 de janeiro de 1998, da Lei no 5.580, de 13 de janeiro de 1998, publicada no Diário Oficial do Estado do Espírito Santo de 14 de janeiro de 1998, Lei Complementar no 428, de 17 de dezembro de 2007, Lei Complementar no 521, publicada no Diário Oficial de 28 de dezembro de 2009 e da Lei Complementar no 46, de 31 de janeiro de 1994 e suas alterações, torna pública a realização de concurso público para provimento de vagas nos cargos de Professor B - Ensino Fundamental e Médio e Professor P - Pedagogo, mediante as condições estabelecidas neste edital.

\section{DAS DISPOSIÇÕES PRELIMINARES}

1.1 O concurso público será regido por este edital e executado pelo Centro de Seleção e de Promoção de Eventos da Universidade de Brasília (CESPE/UnB).

1.2 A seleção para os cargos/disciplinas de que trata este edital compreenderá duas etapas.

1.2.1 A primeira etapa, de responsabilidade do CESPE/UnB, será composta pelas seguintes fases:

a) exame de habilidades e conhecimentos, mediante aplicação de provas objetivas e de prova discursiva, de caráter eliminatório e classificatório;

b) avaliação de títulos, de caráter classificatório.

1.2.2 A segunda etapa, de responsabilidade da SEDU, será composta de curso intensivo de formação, de caráter eliminatório, conforme previsto na Lei Complementar no 521, publicada no Diário Oficial de 28 de dezembro de 2009, com carga horária de até 80 horas, em regime fechado e com exigência de $100 \%$ de frequência e $70 \%$ de aproveitamento ao final da formação, a ser realizado antes da nomeação, posse e exercício para os candidatos aprovados, respeitado o numero de vagas contidas neste edital.

1.3 As provas serão realizadas em Vitória/ES, Colatina/ES, São Mateus/ES, Vila Velha/ES, Linhares/ES e Cachoeiro de Itapemirim/ES.

1.3.1 Havendo indisponibilidade de locais suficientes ou adequados nas cidades de realização das provas, estas poderão ser realizadas em outros municípios.

\section{DO CARGO}

\subsection{CARGO 1: PROFESSOR B - ENSINO FUNDAMENTAL E MÉDIO}

REQUISITO: diploma, devidamente registrado, de conclusão de curso de nível superior de licenciatura plena, observada a área de conhecimento, fornecido por instituição de ensino superior reconhecida pelo $M E C$, e registro no órgão de classe, quando for o caso.

DESCRIÇÃO SUMÁRIA DAS ATIVIDADES: são atribuições do professor em docência preparar e ministrar aulas, avaliar e acompanhar o aproveitamento do corpo discente de ensino médio.

\subsection{CARGO 2: PROFESSOR P - PEDAGOGO}

REQUISITO: diploma, devidamente registrado, de conclusão de curso de nível superior de licenciatura plena em Pedagogia com habilitação em supervisão escolar, orientação educacional, administração escolar, inspeção escolar ou curso de formação de especialista em nível de pós-graduação lato sensu, fornecido por instituição de ensino superior reconhecida pelo MEC, 2 (dois) anos de experiência docente, no mínimo, e registro no órgão de classe, quando for o caso.

DESCRIÇÃO SUMÁRIA DAS ATIVIDADES: administrar, planejar, organizar, coordenar, controlar e avaliar atividades educacionais, junto ao corpo técnico - pedagógico, docente e discente, fora da sala de aula, desenvolvidas na unidade escolar; planejar, orientar, acompanhar e avaliar atividades pedagógicas nas unidades escolares, promovendo a integração entre as atividades, áreas de estudos e/ou disciplinas que 
compõem o currículo, bem como o contínuo aperfeiçoamento do processo ensino - aprendizagem, propondo treinamento e aperfeiçoamento do pessoal, aprimoramento dos recursos de ensinoaprendizagem e melhoria dos currículos; planejar, acompanhar e avaliar a participação do aluno no processo ensino - aprendizagem envolvendo a comunidade escolar, e a família nesse acompanhamento; Desenvolver outras atividades correlatas.

2.3 SUBSÍDIO: O subsídio mensal, para ambos os cargos, será definido em função da escolaridade, conforme quadro a seguir:

\begin{tabular}{|c|c|c|}
\hline NÍVEL & SUBSÍDIO INICIAL & ESCOLARIDADE \\
\hline IV & $R \$ 1.583,40$ & $\begin{array}{l}\text { Formação em nível superior em curso de licenciatura de graduação } \\
\text { plena; em programas de formação pedagógica para portadores de } \\
\text { Educação Superior nos termos da Resolução no 02, de 26/06/1997, } \\
\text { do CNE; ou formação em curso Normal Superior. }\end{array}$ \\
\hline V & $\mathrm{R} \$ 1.692,60$ & $\begin{array}{l}\text { Formação em nível superior em curso de licenciatura de graduação } \\
\text { plena ou em programas de formação pedagógica para portadores } \\
\text { de Educação Superior nos termos da Resolução no 02, de } \\
26 / 06 / 1997 \text {, do CNE; ou formação em curso Normal Superior, } \\
\text { acrescida de pós-graduação obtida em curso de especialização na } \\
\text { área de educação com duração mínima de } 360 \text { (trezentos e } \\
\text { sessenta) horas, com aprovação de monografia. }\end{array}$ \\
\hline VI & $\mathrm{R} \$ 2.184,00$ & $\begin{array}{l}\text { Formação em nível superior ou em curso de licenciatura de } \\
\text { graduação plena ou em programas de formação pedagógica para } \\
\text { portadores de diploma de Educação Superior nos termos da } \\
\text { Resolução no 02, de } 26 / 06 / 1997 \text {, do CNE; ou formação em curso } \\
\text { Normal Superior, acrescida de mestrado em educação com defesa } \\
\text { e aprovação de dissertação. }\end{array}$ \\
\hline VII & $\mathrm{R} \$ 2.839,20$ & $\begin{array}{l}\text { Formação em nível superior ou em curso de licenciatura de } \\
\text { graduação plena ou em programas de formação pedagógica para } \\
\text { portadores de diploma de Educação Superior nos termos da } \\
\text { Resolução no 02, de } 26 / 06 / 1997 \text {, do CNE; ou formação em curso } \\
\text { Normal Superior, acrescida de doutorado em educação com defesa } \\
\text { e aprovação de tese. }\end{array}$ \\
\hline
\end{tabular}

2.4 JORNADA DE TRABALHO PARA AMBOS OS CARGOS: 25 horas semanais.

2.5 REGIME DE TRABALHO PARA AMBOS OS CARGOS: será regido pela Lei Complementar no 46, de 31 de janeiro de 1994 e suas modificações posteriores, que regula o Regime Jurídico Único dos Servidores Públicos Civis do Estado do Espírito Santo.

2.6 As vagas ofertadas por este edital estão distribuídas por cargo, disciplina e município de vaga, de acordo com o Anexo Único.

2.7 Antes de se inscreverem para o presente certame, os candidatos deverão observar atentamente as regras contidas na Constituição Federal em vigor (Art. 37, XVI, e suas alíneas, Inciso XVII e Art. 95, parágrafo único), no que se refere às regras de acumulação de cargos públicos, já que a SEDU observará essa questão antes do candidato iniciar suas atividades.

\section{DAS VAGAS DESTINADAS AOS CANDIDATOS PORTADORES DE DEFICIÊNCIA}

3.1 Do total das vagas destinadas a cada cargo/disciplina/município de vaga e das que vierem a surgir durante o prazo de validade do concurso, 5\% serão providas na forma do Decreto Federal no 3.298, de 20 de dezembro de 1999, e suas alterações. As vagas disponibilizadas para candidatos portadores de deficiência, por disciplina e município, estão detalhadas no Anexo Único.

3.20 candidato que se declarar portador de deficiência concorrerá em igualdade de condições com os demais candidatos.

3.3 Para concorrer a uma dessas vagas, o candidato deverá:

a) no ato da inscrição, declarar-se portador de deficiência; 
b) encaminhar cópia simples do CPF e do laudo médico, original ou cópia autenticada em cartório, emitido nos últimos doze meses, atestando a espécie e o grau ou o nível da deficiência, com expressa referência ao código correspondente da Classificação Internacional de Doenças (CID-10), bem como à provável causa da deficiência, na forma dos subitens 3.4 ou 3.5 deste edital.

3.4 O candidato portador de deficiência deverá encaminhar o laudo médico (original ou cópia autenticada em cartório) referido na alínea " $b$ " do subitem 3.3, via SEDEX ou carta registrada com aviso de recebimento, postado impreterivelmente até o dia $\mathbf{2 3}$ de março de 2010, para a Central de Atendimento do CESPE/UnB - Concurso SEDU/ES Professor (laudo médico) - Caixa Postal 4488, CEP 70904-970, Brasília/DF.

3.50 candidato poderá, ainda, entregar, até o dia $\mathbf{2 3}$ de março de 2010, das 8 horas às 19 horas (exceto sábado, domingo e feriado), pessoalmente ou por terceiro, laudo médico (original ou cópia autenticada em cartório) referido na alínea " $b$ " do subitem 3.3, na Central de Atendimento do CESPE/UnB na Universidade de Brasília (UnB) - Campus Universitário Darcy Ribeiro, Sede do CESPE/UnB - Asa Norte, Brasília/DF.

3.6 O fornecimento do laudo médico (original ou cópia autenticada em cartório) e da cópia simples do CPF, por qualquer via, é de responsabilidade exclusiva do candidato. O CESPE/UnB não se responsabiliza por qualquer tipo de extravio que impeça a chegada dessa documentação.

3.70 candidato portador de deficiência poderá requerer, na forma do subitem 5.6 .9 deste edital, atendimento especial, no ato da inscrição, para o dia de realização das provas, indicando as condições de que necessita para a realização destas, conforme previsto no artigo 40 , parágrafos 10 e $2^{\circ}$, do Decreto no 3.298/99.

3.8 A cópia simples do CPF e o laudo médico (original ou cópia autenticada em cartório) terão validade somente para este concurso público e não serão devolvidos, assim como não serão fornecidas cópias dessa documentação.

3.8.1 A relação dos candidatos que tiveram a inscrição deferida para concorrer na condição de portadores de necessidades especiais será divulgada no endereço eletrônico http://www.cespe.unb.br/concursos/seduprofessor2010, na ocasião de divulgação do edital de locais e horários de realização das provas.

3.8.2 O candidato disporá de um dia a partir da data de divulgação da relação citada no subitem anterior para contestar o indeferimento pessoalmente ou por meio de fax, e-mail ou via SEDEX, observadas as condições do subitem 13.4 deste edital. Após esse período, não serão aceitos pedidos de revisão.

3.9 A inobservância do disposto no subitem 3.3 acarretará a perda do direito ao pleito das vagas reservadas aos candidatos em tal condição e o não-atendimento às condições especiais necessárias.

3.10 Os candidatos que se declararem portadores de deficiência, se não eliminados na primeira etapa do concurso, serão convocados para se submeter à perícia médica promovida por equipe multiprofissional, a ser realizada em Vitória/ES, sob responsabilidade da SEDU/ES, formada por seis profissionais, que verificará sobre a sua qualificação como deficiente ou não, nos termos do artigo 43 do Decreto no 3.298/99 e suas alterações.

3.11 Os candidatos deverão comparecer à perícia médica, munidos de laudo médico que ateste a espécie e o grau ou nível de deficiência, com expressa referência ao código correspondente da Classificação Internacional de Doenças (CID-10), conforme especificado no Decreto no 3.298/99 e suas alterações, bem como à provável causa da deficiência.

3.12 A não observância do disposto no subitem 3.11 deste edital, a reprovação na perícia médica ou o não-comparecimento à perícia acarretará a perda do direito às vagas reservadas aos candidatos em tais condições.

3.130 candidato portador de deficiência reprovado na perícia médica por não ter sido considerado deficiente, caso seja aprovado no concurso, figurará na lista de classificação geral por cargo/disciplina/município de vaga.

$3.14 \mathrm{O}$ candidato portador de deficiência reprovado na perícia médica no decorrer do estágio probatório em virtude de incompatibilidade da deficiência com as atribuições do cargo será exonerado do cargo. 
3.15 Os candidatos que, no ato da inscrição, declararem-se portadores de deficiência, se não eliminados no concurso e considerados portadores de deficiência, terão seus nomes publicados em lista à parte e, caso obtenham classificação, figurarão também na lista de classificação geral por cargo/disciplina/município de vaga.

3.16 As vagas definidas no subitem 2.1 deste edital que não forem providas por falta de candidatos portadores de necessidades especiais aprovados serão preenchidas pelos demais candidatos, observada a ordem geral de classificação por cargo/disciplina/município de vaga.

\section{DOS REQUISITOS PARA A INVESTIDURA NO CARGO}

4.1 Ser aprovado no concurso público e apresentar documentação exigida nos termos da Lei Complementar no 46/1994.

4.2 Ter nacionalidade brasileira ou portuguesa e, no caso de nacionalidade portuguesa, estar amparado pelo estatuto de igualdade entre brasileiros e portugueses, com reconhecimento do gozo dos direitos políticos, nos termos do artigo $12, \S 10$, da Constituição Federal.

4.3 Ter idade mínima de dezoito anos completos na data da posse.

4.4 Estar no gozo de seus direitos políticos.

4.5 Estar em dia com as obrigações eleitorais e, no caso de candidatos do sexo masculino, também militares.

4.6 Ter aptidão física e mental para o exercício das atribuições do cargo/área.

4.7 Possuir os requisitos exigidos para o exercício do cargo/área, na data da posse, conforme item 2 deste edital.

\section{DAS INSCRIÇÕES NO CONCURSO PÚBLICO}

5.1 TAXA: R\$ 50,00.

5.2 Será admitida a inscrição exclusivamente via Internet, no endereço eletrônico http://www.cespe.unb.br/concursos/seduprofessor2010, solicitada no período entre 10 horas do dia 19 de fevereiro de $\mathbf{2 0 1 0}$ e $\mathbf{2 3}$ horas e $\mathbf{5 9}$ minutos do dia $\mathbf{5}$ de março de 2010, observado o horário oficial de Brasília/DF.

5.2.1 O CESPE/UnB não se responsabiliza por solicitação de inscrição não recebida por motivos de ordem técnica dos computadores, falhas de comunicação, congestionamento das linhas de comunicação, bem como outros fatores que impossibilitem a transferência de dados.

5.30 candidato poderá efetuar o pagamento da taxa de inscrição por meio da Guia de Recolhimento da União (GRU).

5.3.1 A GRU Cobrança estará disponível no endereço eletrônico http://www.cespe.unb.br/concursos/seduprofessor2010 e deverá ser impressa para o pagamento da taxa de inscrição imediatamente após a conclusão do preenchimento da ficha de solicitação de inscrição online.

5.3.2 A GRU COBRANÇA pode ser paga em qualquer banco, bem como nas lotéricas e Correios, obedecendo aos critérios estabelecidos nesses correspondentes bancários.

5.3.3 O pagamento da taxa de inscrição deverá ser efetuado até o dia $\mathbf{2 3}$ de março de $\mathbf{2 0 1 0}$.

5.3.4 As inscrições somente serão acatadas após a comprovação de pagamento da taxa de inscrição.

5.40 comprovante de inscrição do candidato estará disponível no endereço eletrônico http://www.cespe.unb.br/concursos/seduprofessor2010, por meio da página de acompanhamento, após o acatamento da inscrição, sendo de responsabilidade exclusiva do candidato a obtenção desse documento.

5.5 Para os candidatos que não dispuserem de acesso à Internet, o CESPE/UnB disponibilizará postos de inscrição com computadores, localizados nos endereços listados a seguir, no período entre $\mathbf{1 0}$ horas do dia $\mathbf{1 9}$ de fevereiro de $\mathbf{2 0 1 0}$ e $\mathbf{2 3}$ horas e $\mathbf{5 9}$ minutos do dia $\mathbf{5}$ de março de 2010, observado o horário de funcionamento de cada estabelecimento.

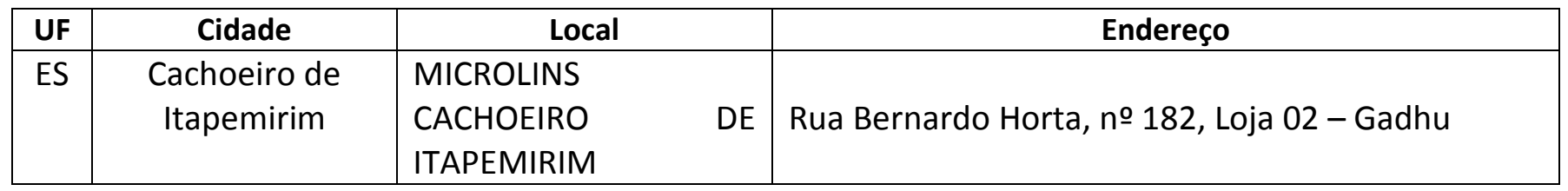




\begin{tabular}{|c|c|l|l|}
\hline ES & Colatina & $\begin{array}{l}\text { EEEFM Geraldo Vargas } \\
\text { Nogueira }\end{array}$ & Avenida Brasil, s/no - Lacê \\
\hline ES & Linhares & MICROLINS LINHARES & Avenida Augusto Pestana, no 1.301 - Centro \\
\hline ES & São Mateus & YES & $\begin{array}{l}\text { Rua Doutor Ademar de Oliveira Neves, } \mathrm{n} \text { - 592 } \\
- \text { Sernambi }\end{array}$ \\
\hline ES & Vila Velha & Fx Lan House & $\begin{array}{l}\text { Avenida Coronel Pedro Maia de Carvalho no } \\
\text { 319 Loja 01 - Praia das Gaivotas }\end{array}$ \\
\hline ES & Vitória & $\begin{array}{l}\text { MICROLINS VITORIA } \\
\text { CENTRO }\end{array}$ & Avenida Jerônimo Monteiro, no 776 - Centro \\
\hline
\end{tabular}

5.6 DAS DISPOSIÇÕES GERAIS SOBRE A INSCRIÇÃO NO CONCURSO PÚBLICO

5.6.1 Antes de efetuar a inscrição, o candidato deverá conhecer o edital e certificar-se de que preenche todos os requisitos exigidos. No momento da inscrição, o candidato deverá optar pelo cargo/disciplina, pelo município onde deseja atuar, se aprovado no concurso, e pela cidade onde deseja realizar as provas. Uma vez efetivada a inscrição não será permitida, em hipótese alguma, a sua alteração.

5.6.2 É vedada a transferência do valor pago a título de taxa para terceiros, para outro cargo/disciplina ou para outros concursos públicos.

5.6.3 É vedada inscrição condicional, extemporânea, via postal, via fax ou via correio eletrônico.

5.6.4 Para efetuar a inscrição, é imprescindível o número de Cadastro de Pessoa Física (CPF) do candidato.

5.6.5 As informações prestadas na solicitação de inscrição via Internet serão de inteira responsabilidade do candidato, dispondo o CESPE/UnB do direito de excluir do concurso público aquele que não preencher o formulário de forma completa e correta.

5.6.6 O valor referente ao pagamento da taxa de inscrição não será devolvido em hipótese alguma, salvo em caso de cancelamento do certame por conveniência da Administração.

5.6.7 Não haverá isenção total ou parcial do valor da taxa de inscrição, exceto nos casos previstos na Lei Estadual no 6.663, de 25 de abril de 2001, conforme procedimentos descritos a seguir.

5.6.7.1 Poderá solicitar a isenção de pagamento da taxa de inscrição neste concurso público o candidato amparado pela Lei Estadual no 6.663, de 25 de abril de 2001.

5.6.7.2 0 interessado que preencher os requisitos dos dispositivos citados no subitem anterior e desejar isenção de pagamento da taxa de inscrição neste concurso público deverá, no período de $\mathbf{2 2}$ a $\mathbf{2 6}$ de fevereiro 2010, das 10 às 17 horas, entregar, pessoalmente ou por procurador, em um dos endereços listados no subitem 5.6.7.6, o requerimento de isenção, devidamente preenchido, conferido e assinado, disponibilizado no endereço eletrônico http://www.cespe.unb.br/concursos/seduprofessor2010, por intermédio do aplicativo de inscrição, instruindo-o com cópia autenticada ou acompanhada dos originais dos seguintes documentos:

a) carteira de trabalho - páginas que contenham fotografia, identificação e contrato de trabalho, inclusive a última página em branco (no caso de desempregados e de trabalhadores que recebem até três salários mínimos);

b) contracheque atual (no caso de empregados);

c) declarar, no requerimento de isenção de taxa de inscrição, que não usufruiu do direito da isenção mais de três vezes no ano de 2009 (no caso de desempregados e de trabalhadores que recebem até três salários mínimos).

5.6.7.3 As informações prestadas no formulário, bem como a documentação apresentada, serão de inteira responsabilidade do candidato, respondendo este, por qualquer falsidade.

5.6.7.4 Não será concedida isenção de pagamento de taxa de inscrição ao candidato que:

a) omitir informações e/ou torná-las inverídicas;

b) fraudar e/ou falsificar documentação;

c) pleitear a isenção, sem apresentar cópia de todos os documentos previstos no subitem 5.6.7.2;

d) não observar o local, a forma e o prazo estabelecidos nos subitens 5.6.7.2 e 5.6.7.6 deste edital.

5.6.7.5 Não será permitida, após a entrega do requerimento de isenção e dos documentos comprobatórios, a complementação da documentação bem como revisão e/ou recurso. 
5.6.7.5.1 O candidato disporá de dois dias, após a divulgação da relação, para interpor recurso contra o resultado do pedido de isenção de taxa.

5.6.7.6 A solicitação de isenção de pagamento de valor da inscrição poderá ser entregue pessoalmente pelo candidato ou por seu procurador, no período de 22 a 26 de fevereiro 2010, das 10 às 17 horas,, em um dos endereços listados abaixo:

\begin{tabular}{|c|c|c|c|}
\hline UF & Cidade & Local & Endereço \\
\hline ES & $\begin{array}{l}\text { Cachoeiro do } \\
\text { Itapemirim }\end{array}$ & Copiadora Galista & Rua Moreira, no 20 - Independência \\
\hline ES & Colatina & $\begin{array}{lll}\text { EEEFM } & \text { Geraldo } & \text { Vargas } \\
\text { Nogueira } & & \end{array}$ & Avenida Brasil, s/no - Lacê \\
\hline ES & Linhares & $\begin{array}{l}\text { EEEFM Emir de Macedo Gomes } \\
\text { Filho }\end{array}$ & Rua Nicola Biacardi no 490 - Shell \\
\hline ES & São Mateus & YES & $\begin{array}{l}\text { Rua Doutor Ademar de Oliveira Neves, no } \\
592 \text { - Sernambi }\end{array}$ \\
\hline ES & Vitória & EEEM Fernando Duarte Rabelo & $\begin{array}{l}\text { Praça Cristovão Jacques, no } 260 \text { - Praia de } \\
\text { Santa Helena }\end{array}$ \\
\hline ES & Vila Velha & Faculdade Novo Milênio & $\begin{array}{l}\text { Avenida Santa Leopoldina, no } 840 \text { - Coqueiral } \\
\text { de Itaparica }\end{array}$ \\
\hline
\end{tabular}

5.6.7.7 Não será aceita solicitação de isenção de pagamento em desarcordo com o estipulado no presente edital.

5.6.7.8 Cada pedido de isenção será analisado e julgado pela SEDU.

5.6.7.9 A relação dos pedidos de isenção deferidos será divulgada até o dia 12 de março de 2010, no endereço eletrônico http://www.cespe.unb.br/concursos/seduprofessor2010.

5.6.7.9.1 O candidato disporá de dois dias para contestar o indeferimento da solicitação de isenção do pagamento da taxa de inscrição a partir da divulgação da relação, conforme disposto na referida relação.

5.6.7.10 Os candidatos que tiverem seus pedidos de isenção indeferidos, para efetivar a sua inscrição no concurso, deverão acessar o endereço etrônico http://www.cespe.unb.br/concursos/seduprofessor2010 e imprimir a GRU COBRANÇA por meio da página de acompanhamento para pagamento até o dia $\mathbf{2 3}$ de março de $\mathbf{2 0 1 0}$, conforme procedimentos descritos neste edital.

5.6.7.11 O interessado que não tiver seu pedido de isenção deferido e que não efetuar o pagamento da taxa de inscrição na forma e no prazo estabelecido no item anterior estará automaticamente excluído do concurso público.

5.6.8 O comprovante de inscrição ou o comprovante de pagamento da inscrição deverá ser mantido em poder do candidato e apresentado nos locais de realização das provas.

5.6.9 O candidato, portador de deficiência ou não, que necessitar de atendimento especial para a realização das provas deverá indicar, na solicitação de inscrição, os recursos especiais necessários e, ainda, enviar, até o dia 23 de março de 2010, impreterivelmente, via SEDEX ou carta registrada com aviso de recebimento, para a Central de Atendimento do CESPE/UnB - Concurso SEDU/Professor (laudo médico), Campus Universitário Darcy Ribeiro, Instituto Central de Ciências (ICC), mezanino, ala norte Asa Norte, Brasília/DF, Caixa Postal 4488, CEP 70904-970, Brasília/DF, cópia simples do CPF e laudo médico (original ou cópia simples) que justifique o atendimento especial solicitado. Após esse período, a solicitação será indeferida, salvo nos casos de força maior e nos que forem de interesse da Administração Pública.

5.6.9.1 O laudo médico (original ou cópia autenticada em cartório) referido no subitem 5.6.9 poderá, ainda, ser entregue, até o dia 23 de março de 2010, das 8 horas às 19 horas, pessoalmente ou por terceiro, na Central de Atendimento do CESPE/UnB na Universidade de Brasília (UnB) - Campus Universitário Darcy Ribeiro, Sede do CESPE/UnB - Asa Norte, Brasília/DF.

5.6.9.2 A candidata que tiver necessidade de amamentar durante a realização das provas, além de solicitar atendimento especial para tal fim, deverá encaminhar, para a Central de Atendimento do 
CESPE/UnB, cópia da certidão de nascimento da criança, até o dia $\mathbf{2 3}$ de março de 2010, e levar um acompanhante, que ficará em sala reservada e será o responsável pela guarda da criança. A candidata que não levar acompanhante no dia de realização da prova não poderá permanecer com a criança no local de realização das provas.

5.6.9.2.1 O CESPE/UnB não disponibilizará acompanhante para guarda de criança.

5.6.9.3 O laudo médico (original ou cópia autenticada em cartório) terá validade somente para este concurso público e não será devolvido, assim como não serão fornecidas cópias desse laudo.

5.6.9.4 A relação dos candidatos que tiveram o seu atendimento especial deferido será divulgada no endereço eletrônico http://www.cespe.unb.br/concursos/seduprofessor2010, na ocasião de divulgação do edital de locais e horários de realização das provas.

5.6.9.4.1 O candidato disporá de um dia a partir da data de divulgação da relação citada no subitem anterior para contestar o indeferimento, pessoalmente ou por meio de fax, e-mail ou via SEDEX, citados no subitem 13.4 deste edital. Após esse período, não serão aceitos pedidos de revisão.

5.6.9.5 A solicitação de condições ou recursos especiais será atendida, em qualquer caso, segundo os critérios de viabilidade e de razoabilidade.

5.6.10 O candidato deverá declarar, na solicitação de inscrição via Internet, que tem ciência e aceita ser submetido a processo de certificação ocupacional no período de estágio probatório, caso aprovado, e que entregará os documentos exigidos como requisitos mínimos para o cargo/área por ocasião de sua posse.

\section{DAS ETAPAS DO CONCURSO}

6.1 Na primeira etapa do concurso, será aplicado exame de habilidades e de conhecimentos mediante aplicação de provas objetivas, de caráter eliminatório e classificatório, abrangendo os objetos de avaliação constantes do item 15 deste edital, e avaliação de títulos, de caráter classificatório, e na segunda etapa, curso intensivo de formação, conforme o quadro a seguir.

\begin{tabular}{|l|l|c|c|}
\hline \multicolumn{1}{|c|}{ PROVAS/TIPO } & \multicolumn{1}{|c|}{ ÁREA DE CONHECIMENTO } & NÚMERO DE ITENS & CARÁTER \\
\hline$\left(P_{1}\right)$ Objetiva & Conhecimentos Básicos & 35 & \multirow{2}{*}{ ELIMINATÓRIO E } \\
CLASSIFICATÓRIO \\
$\left(P_{2}\right)$ Objetiva & $\begin{array}{l}\text { Conhecimentos } \\
\text { Complementares }\end{array}$ & 35 & \multirow{2}{*}{ CLASSIFICATÓRIO } \\
\hline$\left(P_{3}\right)$ Objetiva & Conhecimentos Específicos & 50 & \multirow{2}{*}{ ELIMINATÓRIO } \\
\hline $\begin{array}{l}\left(P_{4}\right) \text { Avaliação de } \\
\text { títulos }\end{array}$ & - & - & \\
\hline $\begin{array}{l}\text { Curso Intensivo de } \\
\begin{array}{l}\text { Formação } \\
\text { Segunda Etapa }\end{array}\end{array}$ & - & - & \\
\hline
\end{tabular}

6.2 As provas objetivas terão a duração de $\mathbf{3}$ horas e $\mathbf{3 0}$ minutos e serão aplicadas na data provável de 11 de abril de 2010, no turno da tarde.

6.3 Os locais e o horário de realização das provas objetivas serão publicados no Diário Oficial do Estado do Espírito Santo e divulgados na Internet, no endereço eletrônico http://www.cespe.unb.br/concursos/seduprofessor2010, na data provável de $\mathbf{2}$ de abril de 2010. São de responsabilidade exclusiva do candidato a identificação correta de seu local de realização das provas e o comparecimento no horário determinado.

6.3.1 O CESPE/UnB poderá enviar, como complemento às informações citadas no subitem anterior, comunicação pessoal dirigida ao candidato, por e-mail ou pelos Correios, sendo de sua exclusiva responsabilidade a manutenção/atualização de seu correio eletrônico e a informação de seu endereço completo e correto na solicitação de inscrição, o que não o desobriga do dever de observar o edital a ser publicado, consoante o que dispõe o subitem 6.3 deste edital.

6.4 O resultado final nas provas objetivas e a convocação para a avaliação de títulos serão publicados no Diário Oficial do Estado do Espírito Santo e divulgados na Internet, no endereço eletrônico http://www.cespe.unb.br/concursos/seduprofessor2010, na data provável de $\mathbf{4}$ de maio de 2010.

\section{DAS PROVAS OBJETIVAS}

7.1 As provas objetivas valerão 120,00 pontos e serão constituídas de itens para julgamento, agrupados 
por comandos que deverão ser respeitados. O julgamento de cada item será CERTO ou ERRADO, de acordo com o(s) comando(s) a que se refere o item. Haverá, na folha de respostas, para cada item, dois campos de marcação: o campo designado com o código $\mathbf{C}$, que deverá ser preenchido pelo candidato caso julgue o item CERTO, e o designado com o código $\mathrm{E}$, que deverá ser preenchido pelo candidato caso julgue o item ERRADO.

7.2 Para obter pontuação no item, o candidato deverá marcar um, e somente um, dos dois campos da folha de respostas.

7.30 candidato deverá transcrever as respostas das provas objetivas para a folha de respostas, que será o único documento válido para a correção das provas. O preenchimento da folha de respostas será de inteira responsabilidade do candidato, que deverá proceder em conformidade com as instruções específicas contidas neste edital, e, se for o caso, em edital complementar, na capa do caderno de provas e na folha de respostas. Em hipótese alguma haverá substituição da folha de respostas por erro do candidato.

7.4 Serão de inteira responsabilidade do candidato os prejuízos advindos do preenchimento indevido da folha de respostas. Serão consideradas marcações indevidas as que estiverem em desacordo com este edital e/ou com a folha de respostas, tais como marcação rasurada ou emendada e/ou campo de marcação não preenchido integralmente.

7.5 O candidato não deverá amassar, molhar, dobrar, rasgar, manchar ou, de qualquer modo, danificar a sua folha de respostas, sob pena de arcar com os prejuízos advindos da impossibilidade de realização da leitura óptica.

7.6 O candidato é responsável pela conferência de seus dados pessoais, em especial seu nome, seu número de inscrição e o número de seu documento de identidade.

7.7 Não será permitido que as marcações na folha de respostas sejam feitas por outras pessoas, salvo em caso de candidato a quem tenha sido deferido atendimento especial para esse fim. Nesse caso, se necessário, o candidato será acompanhado por um agente do CESPE/UnB devidamente treinado.

7.8 O CESPE/UnB divulgará a imagem da folha de respostas dos candidatos que realizaram as provas objetivas, exceto dos candidatos eliminados na forma do subitem 13.11, no endereço eletrônico http://www.cespe.unb.br/concursos/seduprofessor2010, após a data de divulgação do resultado final das provas objetivas. A referida imagem ficará disponível até quinze dias corridos da data de publicação do resultado final do concurso público.

7.8.1 Após o prazo determinado no subitem anterior, não serão aceitos pedidos de disponibilização da imagem da folha de respostas.

\section{DA AVALIAÇÃO DE TÍTULOS}

8.1 A avaliação de títulos, de caráter classificatório, valerá 5,00 pontos, ainda que a soma dos valores dos títulos apresentados seja superior a esse valor.

8.2 Somente serão aceitos os títulos abaixo relacionados, expedidos até a data da entrega, observados os limites de pontos do quadro a seguir.

\begin{tabular}{|c|l|c|c|}
\hline \multicolumn{2}{|c|}{ QUADRO DE ATRIBUIÇÃO DE PONTOS PARA A AVALIAÇÃO DE TÍTULOS } \\
\hline ALíNEA & \multicolumn{1}{|c|}{ TíTULO } & $\begin{array}{c}\text { VALOR DE } \\
\text { CADA } \\
\text { TíTULO }\end{array}$ & $\begin{array}{c}\text { VALOR MÁXIMO } \\
\text { DOS TíTULOS }\end{array}$ \\
\hline A & $\begin{array}{l}\text { Diploma, devidamente registrado, de conclusão de } \\
\text { doutorado. Também será aceito certificado/declaração } \\
\text { de conclusão de doutorado, desde que acompanhado do } \\
\text { histórico do curso, na área de educação. }\end{array}$ & 1,30 & 1,30 \\
\hline B & $\begin{array}{l}\text { Diploma, devidamente registrado, de conclusão de } \\
\text { mestrado. Também será aceito certificado/declaração de } \\
\text { conclusão de mestrado, desde que acompanhado do } \\
\text { histórico escolar, na área de educação. }\end{array}$ & 1,10 & 1,10 \\
\hline C & $\begin{array}{l}\text { Certificado/Declaração de conclusão de curso de pós- } \\
\text { graduação, em nível de especialização, acompanhado de }\end{array}$ & 0,80 & 0,80 \\
\hline
\end{tabular}




\begin{tabular}{|c|l|c|c|}
\hline & $\begin{array}{l}\text { histórico escolar, na área de educação, com carga } \\
\text { horária mínima de } 360 \text { horas. }\end{array}$ & 0,60 \\
\hline D & $\begin{array}{l}\text { Certificado/declaração de conclusão, de atualização ou } \\
\text { aperfeiçoamento na área de educação, com carga } \\
\text { horária mínima de } 180 \text { horas. }\end{array}$ & 0,60 & 0,50 \\
\hline E & $\begin{array}{l}\text { Certificado/declaração de conclusão, de atualização ou } \\
\text { aperfeiçoamento na área de educação, com carga } \\
\text { horária mínima de 120 horas. }\end{array}$ & 0,50 & 0,40 \\
\hline F & $\begin{array}{l}\text { Certificado/declaração de conclusão, de atualização ou } \\
\text { aperfeiçoamento na área de educação, com carga } \\
\text { horária mínima de 80 horas. }\end{array}$ & 0,40 \\
\hline G & $\begin{array}{l}\text { Certificado/declaração de conclusão, de atualização ou } \\
\text { aperfeiçoamento na área de educação, com carga } \\
\text { horária mínima de } 30 \text { horas. }\end{array}$ & 0,30 \\
\hline TOTAL & MÁxıMO DE PONTOS & $\mathbf{5 , 0 0}$ \\
\hline
\end{tabular}

8.3 Receberá nota zero o candidato que não entregar os títulos na forma, no prazo, no horário e no local estipulados no edital de convocação para a avaliação de títulos.

8.3.1 Não serão aceitos títulos encaminhados via postal, via fax e/ou via correio eletrônico.

8.4 No ato de entrega dos títulos, o candidato deverá preencher e assinar o formulário a ser fornecido pelo CESPE/UnB, no qual indicará a quantidade de títulos apresentados. Juntamente com esse formulário deverá ser apresentada uma cópia, autenticada em cartório, de cada título declarado. Os documentos apresentados não serão devolvidos.

8.4.1 Não serão recebidos documentos originais.

8.4.2 Não serão aceitos documentos ilegíveis, como também, os emitidos via fax ou outras formas que não aquelas exigidas neste edital.

8.5 Não serão consideradas, para efeito de pontuação, as cópias não autenticadas em cartório, bem como documentos gerados por via eletrônica que não estejam acompanhados com o respectivo mecanismo de autenticação.

8.6 Na impossibilidade de comparecimento do candidato, serão aceitos os títulos entregues por terceiros, mediante apresentação de documento de identidade original do procurador e de procuração simples do interessado, acompanhada de cópia legível do documento de identidade do candidato.

8.6.1 Serão de inteira responsabilidade do candidato as informações prestadas por seu procurador no ato de entrega dos títulos, bem como a entrega dos títulos na data prevista no edital de convocação para essa fase, arcando o candidato com as consequências de eventuais erros de seu representante.

\subsection{DOS DOCUMENTOS NECESSÁRIOS À COMPROVAÇÃO DOS TÍTULOS}

8.7.1 Para a comprovação da conclusão do curso de pós-graduação em nível de doutorado ou de mestrado, será aceito o diploma, devidamente registrado, expedido por instituição reconhecida pelo MEC. Também será aceito certificado/declaração de conclusão de curso de doutorado ou mestrado, expedido por instituição reconhecida pelo MEC, desde que acompanhado do histórico escolar do candidato, no qual conste o número de créditos obtidos, as áreas em que foi aprovado e as respectivas menções, o resultado dos exames e do julgamento da tese ou da dissertação.

8.7.1.1 Para curso de doutorado ou de mestrado concluído no exterior, será aceito apenas o diploma, desde que revalidado por instituição de ensino superior no Brasil.

8.7.1.2 Outros comprovantes de conclusão de curso ou disciplina não serão aceitos como os títulos relacionados nas alíneas $\mathbf{A}$ e $\mathbf{B}$ do quadro de títulos.

8.7.2 Para receber a pontuação relativa ao título relacionado na alínea $\mathbf{C}$ do quadro de títulos, o candidato deverá comprovar, por meio de certificado, que o curso de especialização foi realizado de acordo com as normas do Conselho Nacional de Educação (CNE) ou de acordo com as normas do extinto Conselho Federal de Educação (CFE).

8.7.2.1 Caso o certificado não comprove que o curso de especialização foi realizado de acordo com o solicitado no subitem anterior, deverá ser anexada declaração da instituição, atestando que o curso 
atende às normas do CNE ou está de acordo com as normas do extinto CFE.

8.7.2.2 Não receberá pontuação na alínea $\mathbf{C}$ do quadro de títulos o candidato que apresentar certificado que não comprove que o curso foi realizado de acordo com as normas do CNE ou de acordo com as normas do extinto CFE ou, ainda, sem a declaração da instituição referida no subitem 8.7.2.1.

8.7.2.3 Para receber a pontuação relativa ao título relacionado na alínea $\mathbf{C}$ do quadro de títulos, serão aceitos somente os certificados/declarações em que constem a carga horária.

8.7.2.4 Para receber a pontuação relativa ao título relacionado na alínea $\mathbf{C}$ do quadro de títulos deste edital, será aceito somente o histórico escolar em que constem as disciplinas cursadas, os professores e suas titulações, a carga horária e a menção obtida.

8.7.3 Para receber a pontuação relativa aos títulos relacionados nas alíneas $\mathbf{D}, \mathbf{E}$, F e $\mathbf{G}$ do quadro de títulos, o candidato deverá apresentar certificado/declaração contendo o conteúdo programático e a carga horária do respectivo curso.

8.8 Todo documento expedido em língua estrangeira somente será considerado se traduzido para a Língua Portuguesa por tradutor juramentado.

8.9 Cada título será considerado uma única vez.

8.10 Os pontos que excederem o valor máximo em cada alínea do Quadro de Atribuição de Pontos para a Avaliação de Títulos, bem como os que excederem o limite de pontos estipulados no subitem 9.1 serão desconsiderados.

\section{DOS CRITÉRIOS DE AVALIAÇÃO E DE CLASSIFICAÇÃO NA PRIMEIRA ETAPA DO CONCURSO}

9.1 Todos os candidatos terão suas provas objetivas corrigidas por meio de processamento eletrônico.

9.1.1 A nota em cada item das provas objetivas, feita com base nas marcações da folha de respostas, será igual a: 1,00 ponto, caso a resposta do candidato esteja em concordância com o gabarito oficial definitivo da prova; 1,00 ponto negativo, caso a resposta do candidato esteja em discordância com o gabarito oficial definitivo da prova; 0,00, caso não haja marcação ou caso haja marcação dupla (C e E).

9.1.2 O cálculo da pontuação em cada prova objetiva, comum a todos os candidatos, será igual à soma algébrica das notas obtidas em todos os itens que a compõem.

9.1.3 Será reprovado nas provas objetivas e eliminado do concurso público os candidatos que se enquadrarem em pelo menos um dos itens a seguir:

a) obtiver nota inferior a 10,00 pontos na prova objetiva de Conhecimentos Básicos $\left(P_{1}\right)$;

b) obtiver nota inferior a 10,00 pontos na prova objetiva de Conhecimentos Complementares $\left(P_{2}\right)$;

c) obtiver nota inferior a 12,00 pontos na prova objetiva de Conhecimentos Específicos $\left(P_{3}\right)$;

d) obtiver nota inferior a 36,00 pontos no conjunto das provas objetivas.

9.1.4 O candidato eliminado na forma do subitem 9.1.3 deste edital não terá classificação alguma no concurso público.

9.1.5 Os candidatos não eliminados na forma do subitem 9.1.3 serão ordenados por cargo/disciplina/município de acordo com os valores decrescentes da nota final nas provas objetivas (NFPO), que será igual à soma algébrica das notas obtidas em $P_{1}, P_{2}$ e $P_{3}$.

9.2 Com base na lista organizada na forma do subitem 9.1.5 deste edital, respeitados os empates na última posição e a reserva de vagas para os candidatos portadores de deficiência, serão convocados para a avaliação de títulos os candidatos ao cargo de Professor P - Pedagogo e os candidatos ao cargo de Professor B, disciplinas Física, Matemática e Química, aprovados nas provas objetivas e classificados em até duas vezes o número de vagas.

9.2.1 Com base na lista organizada na forma do subitem 9.1.5 deste edital, respeitados os empates na última posição e a reserva de vagas para os candidatos portadores de deficiência, serão convocados para a avaliação de títulos os candidatos ao cargo de Professor B, disciplinas Arte, Biologia, Educação Física, Espanhol, Filosofia, Geografia, História, Inglês, Língua Portuguesa e Sociologia aprovados nas provas objetivas e classificados em até três vezes o número de vagas.

9.2.2 Para os cargos/disciplinas/municípios para os quais não haverá reserva de vagas para portadores de deficiência para provimento imediato, serão convocados para a avaliação de títulos os candidatos aprovados nas provas objetivas e classificados em até a $\mathbf{2} \mathbf{a}$ posição.

9.2.3 Os candidatos que não forem convocados para a avaliação de títulos estarão automaticamente 
eliminados e não terão classificação alguma no concurso.

9.3 Todos os cálculos citados neste edital serão considerados até a segunda casa decimal, arredondando-se o número para cima, se o algarismo da terceira casa decimal for igual ou superior a cinco.

\section{DOS CRITÉRIOS DE DESEMPATE NA PRIMEIRA ETAPA DO CONCURSO}

10.1 Em caso de empate na nota final da primeira etapa do concurso, terá preferência o candidato que, na seguinte ordem:

a) tiver idade igual ou superior a sessenta anos, até o último dia de inscrição neste concurso, conforme artigo 27, parágrafo único, do Estatuto do Idoso;

b) obtiver a maior nota na prova objetiva de Conhecimentos Específicos $\left(P_{3}\right)$;

c) obtiver o maior número de acertos na prova objetiva de Conhecimentos Específicos $\left(P_{3}\right)$;

d) obtiver a maior nota na prova objetiva de Conhecimentos Complementares $\left(P_{2}\right)$;

e) obtiver o maior número de acertos na prova objetiva de Conhecimentos Complementares $\left(P_{2}\right)$;

f) obtiver o maior número de acertos na prova objetiva de Conhecimentos Básicos $\left(P_{1}\right)$.

10.1.1 Persistindo o empate, terá preferência o candidato mais idoso.

\section{DA NOTA FINAL NA PRIMEIRA ETAPA DO CONCURSO E DA NOTA FINAL NO CONCURSO}

11.1 A nota final na primeira etapa do concurso será a soma algébrica das notas obtidas nas provas objetivas e da pontuação obtida na avaliação de títulos.

11.2 Os candidatos serão ordenados por cargo/disciplina/município de vaga de acordo com os valores decrescentes da nota final no concurso público.

11.3 o candidato que, no ato da inscrição, se declarar portador de deficiência, se for considerado portador de deficiência e não for eliminado do concurso, terá seu nome publicado em lista à parte e figurará também na lista de classificação geral por cargo/disciplina/município de vaga.

11.4 Com base nas listas organizadas na forma dos subitens 11.2 e 11.3 deste edital, serão convocados para inscrição no curso intensivo de formação os candidatos aprovados na primeira etapa do concurso e classificados dentro do número de vagas previsto neste edital.

11.4.1 O candidato convocado para participar do curso intensivo de formação, segunda etapa do concurso, que não se inscrever para participar do mesmo, será automaticamente eliminado do certame.

11.4.2 Demais informações a respeito do curso intensivo de formação serão divulgadas no respectivo edital de convocação para essa etapa.

11.5 A nota final no concurso será a nota final obtida na primeira etapa do concurso, observados, para a classificação, os critérios de desempate previstos no item 10 deste edital.

\section{DOS RECURSOS}

12.1 Os gabaritos oficiais preliminares das provas objetivas serão divulgados na Internet, no endereço eletrônico http://www.cespe.unb.br/concursos/seduprofessor2010, na data provável de $\mathbf{1 3}$ de abril de 2010, observado o horário oficial de Brasília/DF.

12.20 candidato que desejar interpor recursos contra os gabaritos oficiais preliminares das provas objetivas disporá de dois dias, a contar do dia subsequente ao da divulgação desses gabaritos, no horário das 9 horas do primeiro dia às 18 horas do último dia, ininterruptamente, observado o horário oficial de Brasília/DF.

12.3 Para recorrer contra os gabaritos oficiais preliminares das provas objetivas, o candidato deverá utilizar o Sistema Eletrônico de Interposição de Recurso, por meio do endereço eletrônico http://www.cespe.unb.br/concursos/seduprofessor2010, e seguir as instruções ali contidas.

12.40 candidato deverá ser claro, consistente e objetivo em seu pleito. Recurso inconsistente ou intempestivo será preliminarmente indeferido.

12.5 O recurso não poderá conter, em outro local que não o apropriado, qualquer palavra ou marca que o identifique, sob pena de ser preliminarmente indeferido.

12.6 Se do exame de recursos resultar anulação de item integrante de prova, a pontuação correspondente a esse item será atribuída a todos os candidatos, independentemente de terem recorrido. 
12.7 Se houver alteração, por força de impugnações, de gabarito oficial preliminar de item integrante de provas, essa alteração valerá para todos os candidatos, independentemente de terem recorrido.

12.8 Todos os recursos serão analisados e as justificativas das alterações de gabarito serão divulgadas no endereço eletrônico http://www.cespe.unb.br/concursos/seduprofessor2010 quando da divulgação do gabarito definitivo. Não serão encaminhadas respostas individuais aos candidatos.

12.9 Não será aceito recurso via postal, via fax, via correio eletrônico ou, ainda, fora do prazo.

12.10 Em nenhuma hipótese serão aceitos pedidos de revisão de recursos ou recurso de gabarito oficial definitivo, bem como recurso contra o resultado final nas demais fases.

12.11 Recursos cujo teor desrespeite a banca serão preliminarmente indeferidos.

12.12 A forma e o prazo para a interposição de recursos contra o resultado provisório nas demais fases/etapa do concurso serão disciplinados no respectivo edital de resultado provisório.

\section{DAS DISPOSIÇÕES FINAIS}

13.1 A inscrição do candidato implicará a aceitação das normas para o concurso público contidas nos comunicados, neste edital e em outros a serem publicados.

13.2 É de inteira responsabilidade do candidato acompanhar a publicação de todos os atos, editais e comunicados referentes a este concurso público no Diário Oficial do Estado do Espírito Santo e divulgados na Internet, no eletrônico http://www.cespe.unb.br/concursos/seduprofessor2010.

$13.3 \mathrm{O}$ candidato poderá obter informações referentes ao concurso público na Central de Atendimento do CESPE/UnB, localizada na Universidade de Brasília (UnB) - Campus Universitário Darcy Ribeiro - Asa Norte, Brasília/DF, por meio do telefone (61) 34480100 ou via Internet, no endereço eletrônico http://www.cespe.unb.br/concursos/seduprofessor2010, ressalvado o disposto no subitem 13.5 deste edital.

13.40 candidato que desejar relatar ao CESPE/UnB fatos ocorridos durante a realização do concurso deverá fazê-lo à Central de Atendimento do CESPE/UnB, postar correspondência para a Caixa Postal 4488, CEP 70904-970; encaminhar mensagem pelo fax de número (61) 3448 0110; ou enviá-la para o endereço eletrônicosac@cespe.unb.br.

13.5 Não serão dadas, por telefone, informações a respeito de datas, locais e horários de realização das provas. O candidato deverá observar rigorosamente os editais e os comunicados a serem divulgados na forma do subitem 13.2 .

13.6 O candidato deverá comparecer ao local designado para a realização das provas com antecedência mínima de uma hora do horário fixado para o seu início, munido de caneta esferográfica de tinta preta, fabricada em material transparente, do comprovante de inscrição e do documento de identidade original. Não será permitido o uso de lápis, lapiseira/grafite e/ou borracha durante a realização das provas.

13.7 Serão considerados documentos de identidade: carteiras expedidas pelos Comandos Militares, pelas Secretarias de Segurança Pública, pelos Institutos de Identificação e pelos Corpos de Bombeiros Militares; carteiras expedidas pelos órgãos fiscalizadores de exercício profissional (ordens, conselhos etc.); passaporte brasileiro; certificado de reservista; carteiras funcionais do Ministério Público; carteiras funcionais expedidas por órgão público que, por lei federal, valham como identidade; carteira de trabalho; carteira nacional de habilitação (somente o modelo com foto).

13.7.1 Não serão aceitos como documentos de identidade: certidões de nascimento, CPF, títulos eleitorais, carteiras de motorista (modelo sem foto), carteiras de estudante, carteiras funcionais sem valor de identidade, nem documentos ilegíveis, não identificáveis e/ou danificados.

13.7.2 Não será aceita cópia do documento de identidade, ainda que autenticada, nem protocolo do documento.

13.8 Por ocasião da realização das provas, o candidato que não apresentar documento de identidade original, na forma definida no subitem 13.7 deste edital, não poderá fazer as provas e será automaticamente eliminado do concurso público.

13.9 Caso o candidato esteja impossibilitado de apresentar, no dia de realização das provas, documento de identidade original, por motivo de perda, roubo ou furto, deverá ser apresentado documento que 
ateste o registro da ocorrência em órgão policial, expedido há, no máximo, noventa dias, ocasião em que será submetido à identificação especial, compreendendo coleta de dados, de assinaturas e de impressão digital em formulário próprio.

13.9.1 A identificação especial será exigida, também, ao candidato cujo documento de identificação apresente dúvidas relativas à fisionomia ou à assinatura do portador.

13.10 Para a segurança dos candidatos e a garantia da lisura do certame, o CESPE/UnB poderá proceder à coleta da impressão digital de todos os candidatos no dia de realização das provas.

13.11 Terá suas provas anuladas e será automaticamente eliminado do concurso público o candidato que durante a sua realização:

a) for surpreendido dando ou recebendo auxílio para a execução das provas;

b) utilizar-se de livros, máquinas de calcular ou equipamento similar, dicionário, notas ou impressos que não forem expressamente permitidos ou que se comunicar com outro candidato;

c) for surpreendido portando aparelhos eletrônicos, tais como bip, telefone celular, walkman, agenda eletrônica, notebook, palmtop, receptor, gravador, máquina de calcular, máquina fotográfica, controle de alarme de carro etc., bem como relógio de qualquer espécie, óculos escuros ou quaisquer acessórios de chapelaria, tais como chapéu, boné, gorro etc. e, ainda, lápis, lapiseira/grafite e/ou borracha;

d) faltar com o devido respeito para com qualquer membro da equipe de aplicação das provas, com as autoridades presentes ou com os demais candidatos;

e) fizer anotação de informações relativas às suas respostas no comprovante de inscrição provisória ou em qualquer outro meio que não os permitidos;

f) não entregar o material das provas ao término do tempo destinado para a sua realização;

g) afastar-se da sala, a qualquer tempo, sem o acompanhamento de fiscal;

h) ausentar-se da sala, a qualquer tempo, portando a folha de respostas ou os cadernos de textos definitivos;

i) descumprir as instruções contidas no caderno de provas, na folha de respostas ou nos cadernos de textos definitivos;

j) perturbar, de qualquer modo, a ordem dos trabalhos, incorrendo em comportamento indevido;

k) utilizar ou tentar utilizar meios fraudulentos ou ilegais para obter aprovação própria ou de terceiros em qualquer etapa do concurso público;

I) não permitir a coleta de sua assinatura;

m) for surpreendido portando caneta fabricada em material não transparente;

n) for surpreendido portando anotações em papéis que não os permitidos;

o) for surpreendido portando qualquer tipo de arma e/ou se negar a entregar a arma à Coordenação;

p) recusar-se a ser submetido ao detector de metal;

q) não transcrever o texto apresentado durante a aplicação das provas para posterior exame grafológico.

13.12 Não serão aplicadas provas em local, data ou horário diferentes dos predeterminados em edital ou em comunicado.

13.13 Não será admitido ingresso de candidato no local de realização das provas após o horário fixado para o seu início.

13.140 candidato deverá permanecer obrigatoriamente no local de realização das provas por, no mínimo, uma hora após o seu início.

13.14.1 A inobservância do subitem anterior acarretará a não correção das provas e, consequentemente, a eliminação do candidato no concurso público.

13.15 O CESPE/UnB manterá um marcador de tempo em cada sala de provas para fins de acompanhamento pelos candidatos.

13.160 candidato que se retirar do ambiente de provas não poderá retornar em hipótese alguma.

13.17 o candidato somente poderá se retirar do local de realização das provas levando o caderno de provas no decurso dos últimos quinze minutos anteriores ao horário determinado para o término das provas. 
13.18 Não haverá, por qualquer motivo, prorrogação do tempo previsto para a aplicação das provas em razão do afastamento de candidato da sala de provas.

13.19 Não haverá segunda chamada para a realização das provas. O não comparecimento a estas implicará a eliminação automática do candidato.

13.20 Não será permitida, durante a realização das provas, a comunicação entre os candidatos nem a utilização de máquinas calculadoras e/ou similares, livros, anotações, réguas de cálculo, impressos ou qualquer outro material de consulta, inclusive códigos e/ou legislação.

13.21 Será eliminado do concurso o candidato que, durante a realização das provas, for surpreendido portando aparelhos eletrônicos, tais como bip, telefone celular, walkman, agenda eletrônica, notebook, palmtop, receptor, gravador, máquina de calcular, máquina fotográfica, controle de alarme de carro etc. bem como relógio de qualquer espécie, óculos escuros ou quaisquer acessórios de chapelaria, tais como chapéu, boné, gorro etc. e, ainda, lápis, lapiseira/grafite e/ou borracha.

13.21.1 O CESPE/UnB recomenda que, no dia de realização das provas, o candidato não leve nenhum dos objetos citados no subitem anterior.

13.21.2 O CESPE/UnB não se responsabilizará por perdas ou extravios de objetos ou de equipamentos eletrônicos ocorridos durante a realização das provas, nem por danos neles causados.

13.21.3 Não será permitida a entrada de candidatos no ambiente de provas portando armas. $\mathrm{O}$ candidato que estiver armado será encaminhado à Coordenação.

13.21.4 O CESPE/UnB poderá submeter os candidatos ao sistema de detecção de metal no dia de realização das provas.

13.22 No dia de realização das provas, não serão fornecidas, por qualquer membro da equipe de aplicação destas e/ou pelas autoridades presentes, informações referentes ao seu conteúdo e/ou aos critérios de avaliação e de classificação.

13.23 Se, a qualquer tempo, for constatado, por meio eletrônico, estatístico, visual, grafológico ou por investigação policial, ter o candidato se utilizado de processo ilícito, suas provas serão anuladas e ele será automaticamente eliminado do concurso público.

13.24 O descumprimento de quaisquer das instruções supracitadas implicará a eliminação do candidato, constituindo tentativa de fraude.

13.25 O prazo de validade do concurso é de um ano, contados a partir da data de publicação da homologação do resultado final, podendo ser prorrogado, uma única vez, por igual período.

13.26 O resultado final do concurso será homologado pelo Secretário de Estado da Educação, publicado no Diário Oficial do Estado do Espírito Santo e divulgado no endereço eletrônico http://www.cespe.unb.br/concursos/seduprofessor2010.

13.27 O candidato deverá manter atualizado seu endereço perante o CESPE/UnB, enquanto estiver participando do concurso público, por meio de requerimento a ser enviado à Central de Atendimento do CESPE/UnB, e perante a SEDU, se selecionado. São de exclusiva responsabilidade do candidato os prejuízos advindos da não-atualização de seu endereço.

13.28 Os casos omissos serão resolvidos pelo CESPE/UnB junto com a SEDU.

13.29 Legislação com entrada em vigor após a data de publicação deste edital, exceto a listada nos objetos de avaliação constantes deste edital, bem como alterações em dispositivos legais e normativos a ele posteriores não serão objeto de avaliação nas provas do concurso.

13.30 Quaisquer alterações nas regras fixadas neste edital só poderão ser feitas por meio de outro edital.

\section{DOS OBJETOS DE AVALIAÇÃO (HABILIDADES E CONHECIMENTOS)}

\subsection{HABILIDADES}

14.1.1 Os itens das provas objetivas poderão avaliar habilidades que vão além de mero conhecimento memorizado, abrangendo compreensão, aplicação, análise, síntese e avaliação, valorizando a capacidade de raciocínio.

14.1.2 Cada item das provas objetivas poderá contemplar mais de uma habilidade e conhecimentos relativos a mais de uma área de conhecimento.

\subsection{CONHECIMENTOS}


14.2.1 Nas provas objetivas, serão avaliados, além das habilidades, conhecimentos, conforme especificação a seguir.

\subsubsection{CONHECIMENTOS BÁSICOS PARA O CARGO DE PROFESSOR B - ENSINO FUNDAMENTAL E MÉDIO}

LÍNGUA PORTUGUESA: 1 Compreensão e interpretação de textos. 2 Tipologia textual. 3 Ortografia oficial. 4 Acentuação gráfica. 5 Emprego do sinal indicativo de crase. 6 Pontuação. 7 Concordância nominal e verbal. 8 Regência nominal e verbal. 9 Significação das palavras.

ATUALIDADES: Domínio de tópicos atuais e relevantes de diversas áreas, tais como política, economia, sociedade, educação, tecnologia, energia, relações internacionais, desenvolvimento sustentável, segurança, artes e literatura, e suas vinculações históricas.

NOÇÕES DE INFORMÁTICA: 1 Conceito de Internet e Intranet. 2 Principais navegadores para Internet. 3 Correio Eletrônico. 4 Principais aplicativos comerciais para edição de textos e planilhas. 5 Procedimento para a realização de cópias de segurança. 6 Sistema de arquivo, sistema de entrada, saída e armazenamento e métodos de acesso.

\subsubsection{CONHECIMENTOS COMPLEMENTARES PARA O CARGO DE PROFESSOR B - ENSINO FUNDAMENTAL E MÉDIO}

LEGISLAÇÃO BÁSICA: 1 Lei de Diretrizes e Bases da Educação Nacional - Lei no 9.394/96 e suas alterações. 2 Estatuto da Criança e do Adolescente - Lei no 8.069/1990 (ECA). 3 Constituição da República Federativa do Brasil (Art. 205 a 214). 4 Emenda Constitucional no 53, de 19/12/2006, publicada em 20/12/2006. 5 Lei no 11.494, de 20/6/2007, publicada em 21/6/2007. 6 Resolução do Conselho Estadual de Educação no 1.286/2006, que fixa normas para a Educação no Sistema Estadual de Ensino do Estado do Espírito Santo, publicado no Diário Oficial do Estado de 29/5/2006; Diretrizes e Bases da Educação Nacional - Decreto Federal 5.154/2004. 7. Lei 11.114, de 16/05/2005 e Lei no 11.274, de 06/02/2006, que alteram a Lei no 9394/1996, tornando obrigatório o ensino fundamental de 9 anos.

PSICOLOGIA DA APRENDIZAGEM: 1 Teoria da aprendizagem. 2 Princípios básicos do Behavorismo e implicações educacionais. 3 Psicologia da Gestalt e implicações na aprendizagem. 4 Epistemiologia genética de Jean Piaget. 5 Perspectiva sócio-interacionista de Vigotsky. 6 A teoria da complexidade de Edgar Morin. 70 fracasso escolar: abordagens atuais.

AVALIAÇÃO DO PROCESSO ENSINO-APRENDIZAGEM: 1. Concepções de avaliação. 2 Funções da avaliação: diagnóstica, formativa e somativa. 3 Técnicas e instrumentos de avaliação. 4 Usos de resultados avaliação da aprendizagem no planejamento do ensino.

\subsubsection{CONHECIMENTOS ESPECÍFICOS}

CARGO 1: PROFESSOR - DISCIPLINA: ARTE: 1 Teoria da arte: conceitos de arte, funções da arte, estética, crítica. 2 História da arte. 3 Formas de expressão e comunicação artística. 4 Elementos da linguagem artística. 5 Representação e expressão. 6 Estética. 7 Arte e folclore brasileiro. 8 Produção artística: exploração e utilização dos elementos materiais e formais da linguagem. 9 Planejamento na produção artística: instrumentos, metodologias e indicadores de resultados. 10 Influência das culturas indígenas, negras e européias na produção artística brasileira. 11 Importância das manifestações artísticas para a formação da identidade nacional e do patrimônio artístico local, regional e nacional. 12 Aplicação de tecnologias modernas na produção artística. 13 Questões relacionadas ao processo de ensino-aprendizagem de Artes. 14 Metodologia de ensino de artes.

CARGO 2: PROFESSOR - DISCIPLINA: BIOLOGIA: 1 Origem da vida. 1.1 História e filosofia da Biologia. 1.2 Teoria da origem da vida. 1.3 Divisões da Biologia. 2 Citologia. 2.1 Componentes minerais e orgânicos (água, sais minerais, carboidratos, lipídios, proteínas e vitaminas, enzimas, ácidos nucléicos). 2.2 Membrana celular e parede celular. 2.2.1 Estrutura. 2.2.2 Composição química. 2.2.3 Funções: transporte através da membrana plasmática - osmose, difusão simples, difusão facilitada, bomba de sódio e potássio, fagocitose, pinocitose e exocitose. 2.2.4 Diferenciações da membrana. 2.2.5 Reforços externos da membrana. 2.3 Citoplasma. 2.3.1 Fundamental ou hialoplasma. 2.3.2 Elementos figurados (organóides). 2.3.3 Forma, estrutura e função: retículo endoplasmático, ribossomos, complexo de Golgi, vacúolos, centríolos, lisossomos, perixossomos, plastos e fotossíntese, mitocôndrias e respiração celular. 2.4 Núcleo. 2.4.1 Forma, número e função. 2.4.2 Elementos nucleares: envoltório nuclear, 
nucleoplasma, nucléolos, cromatina e cromossomos (estrutura e classificação). 3 Gametas e gametogênese. 3.1 Morfologia dos gametas humanos. 3.2 Espermatogênese. 3.3 Ovulogênese. 4 Embriologia. 4.1 Tipos de ovos animais e clivagem. 4.2 Folhetos embrionários. 4.3 Embriogênese humana. 4.4 Anexos embrionários humanos. 5 Genética. 5.1 Conceitos básicos. 5.2 Leis de Mendel (mono e poliibridismo). 5.3 Noções de probabilidades. 5.4 Genealogia. 5.5 Polialelia. 5.6 Em coelhos. 5.7 Grupos sangüíneos: sistema ABO; fator $\mathrm{RH}$. Interação gênica e pleiotropia. 5.8 Herança ligada ao sexo. 5.9 Hemofilia. 5.10 Daltonismo. 5.11 Heranças influenciadas pelo sexo. 5.12 Calvície. 5.13 Herança parcialmente ligada ao sexo. 5.14 Leituras complementares: projeto Genoma; clonagem. 5.15 Determinação de paternidade através da análise de DNA. 5.16 Atuação da engenharia genética: na cura de doenças, no combate a pragas na lavoura e na criação de espécies transgênicas. 6 Evolução. 6.1 Criacionismo ou fixismo. 6.2 Evolucionismo. 6.2.1 Teoria de Lamarck. 6.2.2 Teoria de Darwin. 6.2.3 Teoria Neodarwinista ou Neodarwinismo. 6.2.4 Mutações cromossômicas: numéricas e estruturais. 6.2.5 Mutações gênicas. 6.2.6 Principais síndromes humanas: Down, Turner e Klinefelter. 6.2.7 Recombinação gênica. 7 Classificação dos seres vivos. 7.1 Sistemas de classificação. 7.2 Regras de nomenclatura. 7.3 As categorias taxonômicas. 7.4 Classificação dos grandes grupos de organismos: Vírus, Monera; Protista; Fungi; Plantae; Animália; Vírus. 8 Anatomia e fisiologia comparada dos seres vivos (zoologia). 8.1 Reprodução humana. 8.2 Aspectos anatomo-fisiológicos dos sistemas reprodutores masculino e feminino. 8.3 Ciclo menstrual e controle hormonal no processo. 8.4 Ciclos biológicos das principais espécies de invertebrados causadores de doenças. 9 Anatomia e fisiologia comparada dos seres vivos demais sistemas. 9.1 Sistema de nutrição e digestão. 9.1.1 Nutrição e etapas. 9.1.2 Tipos de digestão intracelular, extracelular e extracorpórea. 9.1.3 Digestão humana, sistema de trocas gasosas, respiração celular: respiração humana. 9.2 Sistema cardiovascular - circulação humana. 9.2.1 Coração. 9.2.2 Vasos sanguíneos. 9.2.3 Plasma sangüíneo. 9.2.4 Células e fragmentos de células sanguíneas. 9.2.5 Grande e pequena circulação. 9.2.6 Linfa. 9.2.7 Vasos linfáticos. 9.3 Sistema excretor - excreção humana. 9.4 Órgãos constituintes. 9.4.1 Estrutura e fisiologia do néfron. 9.4.2 Sensibilidade, coordenação nervosa e hormonal. 9.5 Sistema nervoso humano. 9.5.1 S.N.C. 9.5.2 S.N.P. 9.6 Sistema endócrino humano. 9.6.1 Glândulas endócrinas. 9.6.2 Glândulas exócrinas. 9.6.3 Órgãos dos sentidos do homem. 9.7 Sistema locomotor humano. 9.8 Sistema de revestimento humano - revestimento e anexos. 10 Anatomia e fisiologia comparada de vegetais. 10.1 Estrutura geral de talófitas, briófitas e traqueófitas. 10.1.1 Sistema de nutrição: fotossíntese. 10.1.2 Sistema de trocas gasosas: respiração; transpiração. 10.1.3 Sistema de transporte: xilema; floema. Sistema de revestimento: epiderme; periderme. 10.1.4 Sistema reprodutor: Briófitas; Pteridófitas; Fanerógamas. 11 Ecologia: conceitos básicos. 11.1 Cadeias e teias alimentares. 11.2 Fluxo de energia. 11.3 Biomas aquáticos. 11.4 Mangues. Biomas terrestres. 11.5 Floresta trópico-equatorial. 11.6 Impacto ambiental. 11.6.1 Zona urbana: poluição do ar; poluição do solo. 11.6.2 Zona rural. 12 Metodologia de ensino de Biologia.

CARGO 3: PROFESSOR - DISCIPLINA: EDUCAÇÃO FÍSICA: 1 A história e as atuais tendências pedagógicas da Educação Física. 2 Processos de ensino e avaliação da Educação Física escolar. 3 Conhecimentos sobre o corpo (anatômicos, fisiológicos, bioquímicos, biomecânicos e afetivos). 4 A cultura modular corporal da Educação Física. 5 Conceitos e procedimentos das danças, jogos (cooperativos, recreativos e competitivos), lutas e ginásticas. 6 Estética, fisiculturismo e consumo. 7 A Educação Física com instrumento de comunicação, expressão, lazer e cultura. 8 A Educação Física: ética, saúde, orientação sexual, pluralidade cultural e meio ambiente. 9 A corporalidade e a ludicidade no ambiente escolar. 10 Linguagem corporal e cultura. 11 Corpo e poder: disciplina e controle. 12 Metodologia de ensino de educação física.

CARGO 4: PROFESSOR - DISCIPLINA: ESPANHOL: 1 Origen, influencias y expansión del espanõl. 2 Interpretación de textos. 3 Gramática contextualizada. 3.1 El alfabeto. 3.2 El acento. 3.3 La división silábica. 3.4 Saludos y formas de tratamiento. 3.5 El artículo y las contracciones. 3.6 El sustantivo (género y número). 3.7 Sinónimos y antônimos. 3.8 Heterosemánticos y heterogenéricos. 3.9 El adjetivo (calificativos y detarminativos). 3.10 El pronombre (personales y determinantes). 3.11 Los numerales (ordinales y cardinales). 3.12 Las preposiciones. 3.13 Las conjunciones. 3.14 Los advérbios. 3.15 El verbo (tiempos y modos). 3.16 Tipos de frase (afirmativa, negativa, interrogativa, exclamativa). 3.17 Discurso 
directo y indirecto. 3.18 Concordancia nominal y verbal. 4 Metodologia de ensino de Espanhol.

CARGO 5: PROFESSOR - DISCIPLINA: FILOSOFIA: 1 Do mito à razão. 1.1 Mito e logos como discursos explicativos sobre a origem do cosmos. 1.2 Características e funções do mito. 1.3 Noções fundamentais à filosofia nascente: Physis, causalidade, cosmos, logos, senso crítico. 2 Filosofia e ciência. 2.1 Relação e distinção entre Filosofia e ciência. 2.2 Surgimento da ciência moderna e as suas características. 2.3 As ciências humanas: a questão do método e da objetividade. 2.4 Ciência e Ideologia. 2.5 Conhecimento e linguagem. 3 Ética e cidadania. 3.10 campo da moral. 3.2 Liberdade e determinismo. 3.3 Felicidade e dever moral. 3.4 Ética e política. 4 Estética. 4.1 Arte e realidade: imitação e representação. 4.20 belo e a questão do gosto. 4.3 Arte e técnica. 4.4 A função social da arte. 5 Metodologia de ensino de filosofia.

CARGO 6: PROFESSOR - DISCIPLINA: FÍSICA: 1 Mecânica. 1.1 Estática. 1.1.1 Sistema de forças. 1.1.2 Equilíbrio de um ponto material. 1.1.3 Momento ou torque de uma força. 1.1.4 Equilíbrio de um corpo extenso. 1.1.5 Centro de gravidade. 1.2 Cinemática. 1.2.1 Referencial. 1.2.2 Posição, deslocamento, velocidade, aceleração. 1.2.3 Movimento retilíneo uniforme. 1.2.4 Movimento retilíneo uniformemente variado. 1.2.5 Vetores. 1.2.6 Movimento circular uniforme. 1.2.7 Lançamento horizontal. 1.2.8 Lançamento oblíquo. 1.3 Dinâmica. 1.3.1 Leis de Newton. 1.3.2. Atrito. 1.3.3 Lei de Hooke. 1.3.4 Gravitação universal. 1.4 Trabalho, potência e energia. 1.4.1 Trabalho. 1.4.2 Potência. 1.4.3 Energia cinética e potencial. 1.4.4 Conservação de Energia. 1.4.5 Impulso e quantidade de movimento. 1.4.6 Conservação da quantidade de movimento. 2 Hidrostática e hidromecânica. 2.1 Densidade. 2.2 Pressão. 2.3 Princípio de Pascal. 2.4 Teorema de Stevin. 2.5 Teorema de Arquimedes. 2.6 Noções sobre escoamento em regime permanente ou estacionário. 2.7 Vazão. 2.8 Equação da continuidade. 2.9 Equação de Bernoulli. 3 Fenômenos térmicos, ópticos e acústicos. 3.1 Calor e temperatura. 3.1.1 Temperatura e calor. 3.1.2 Escalas termométricas. 3.1.3 Dilatação térmica dos sólidos e líquidos (preferencialmente qualitativo). 3.2 Calorimetria. 3.2.1 Capacidade térmica. 3.2.2 Calor específico e calor de combustão. 3.2.3 Calor latente e calor sensível. 3.2.4 Mudança de estado físico. 3.2.5 Processos de transmissão do calor. 3.3 Gases perfeitos. 3.3.1 Transformações gasosas. 3.3.2 Equação de Clapeyron. 3.4 Termodinâmica. 3.4.1 Primeira Lei da Termodinâmica. 3.4.2 Segunda Lei da Termodinâmica. 3.4.3 Máquinas térmicas. 3.5 Movimento ondulatório. 3.5.1 Movimento harmônico simples: pêndulo simples, sistema massa - mola. 3.5.2 Ondas, equação fundamental. 3.5.3 Reflexão, refração, difração, interferência e ressonância. 3.6 Acústica. 3.6.1 Ondas sonoras. 3.6.2 Propagação e velocidade do som. 3.6.3 Infra-som e ultra-som. 3.6.4 Qualidades fisiológicas do som. 3.6.5 Efeito Doppler. 3.7 Óptica. 3.7.1 Natureza e propagação de luz. 3.7.2 Espectro eletromagnético. 3.7.3 Princípios da óptica geométrica. 3.7.4 Leis de reflexão - espelhos planos e esféricos. 3.7.5 Leis da refração - prismas e lentes. 3.7.6 Difração, interferência e polarização da luz. 4 Eletromagnetismo. 4.1 Eletrostática. 4.1.1 Carga elétrica. 4.1.2 Condutores e isolantes. 4.1.3 Processos de eletrização. 4.1.4 Lei de Coulomb. 4.1.5 Campo elétrico. 4.1.6 Potencial elétrico. 4.1.7 Trabalho no campo elétrico. 4.1.8 Capacitores. 4.2 Eletrodinâmica. 4.2.1 Corrente elétrica. 4.2.2 Leis de Ohm. 4.2.3 Efeito Joule. 4.2.4 Instrumentos de medição elétrica. 4.2.5 Geradores e receptores. 4.2.6 Circuitos elétricos simples. 4.2.7 Leis de Kirchof. 4.3 Magnetismo. 4.3.1 Imãs naturais e artificiais. 4.3.2 Campo magnético. 4.3.3 Substâncias magnéticas. 4.4 Eletromagnetismo. 4.4.1 Lei de Ampère. 4.4.2 Vetor campo magnético. 4.4.3 Força magnética. 4.4.4 Fluxo magnético. 4.4.5 Indução magnética. 4.5 Física moderna. 4.5.1 Radiação eletromagnética. 4.5.2 Teoria da Relatividade Restrita. 4.5.3 Teoria dos Quantas. 5 Metodologia de ensino de física.

CARGO 7: PROFESSOR - DISCIPLINA: GEOGRAFIA: 1 Leitura, análise e interpretação de códigos específicos de Geografia: mapas, gráficos, tabelas, escalas. 2 Uso de escalas cartográficas e geográficas como forma de organizar e conhecer a localização, a distribuição e a freqüência dos fenômenos naturais e humanos. 30 conceito geopolítico do espaço. 4 Identificação da unidade espacial: lugar, paisagem e território. 5 Organização de grupos humanos. 6 Apropriação-expropriação do espaço. 7 Exploração e preservação das paisagens. 80 local e o global - jogo de escalas. 9 O espaço como disputa social. 10 Evolução do pensamento geográfico e seus reflexos no contexto escolar de ensino fundamental e médio. 11 Geografia política mundial. Características e contradições da organização sócio-espacial no século XXI. 12 Espaço agroindustrial brasileiro: características e transformações recentes. 13 
Geoecologia global, clima, solo, relevo, hidrografia, vegetação e qualidade de vida da população. 14 Espacialidades rurais e urbanas. 15 Ética e cidadania. 16 Geografia e meio ambiente: nova abordagem. 17 Os espaços e paisagens como construções sociais e luta política. 18 Metodologia de ensino de geografia.

CARGO 8: PROFESSOR - DISCIPLINA: HISTÓRIA: 1 A formação do mundo contemporâneo. 2 O período entre guerras. 3 A Segunda Guerra Mundial. 40 mundo após a Segunda Guerra Mundial. 50 Terceiro Mundo. 6 Brasil - A ocupação inicial do território brasileiro e a questão indígena. 7 A colonização portuguesa no Brasil. 80 Brasil Imperial. 9 A República Velha. 10 A Era Vargas. 11 A República Contemporânea. 12 A Nova República. 13 Datas comemorativas e a figura do herói no ensino de História. 14 A percepção do fato no ensino de História. 15 A interdisciplinaridade e o conceito de "Longa Duração" na História Nova. 16 Metodologia de ensino de história.

CARGO 9: PROFESSOR - DISCIPLINA: INGLÊS: 1 Pronomes (pessoais, demonstrativos, possessivos, interrogativos). 2 Substantivos. 3 Adjetivos. 4 Artigos definidos e indefinidos. 5 Numerais ordinais e cardinais. 6 Verbos: to be; presente simples; presente progressivo; there to be. 7 Horas, dias da semana, meses e estações no ano. 8 Advérbios. 9 Falsos cognatos. 10 Preposições. 11 Conjunções. 12 Verbos; presente $\mathrm{x}$ presente contínuo; passado; passado $\mathrm{x}$ passado contínuo; presente perfeito; presente perfeito x presente perfeito contínuo; passado perfeito; passado perfeito x passado perfeito contínuo; futuro; condicional; modais; voz passiva/ativa; infinitivo e o gerúndio. 13 Question Tag. 14 Discurso indireto. 15 Phrasal verbs. 16 Modo imperativo. 17 Leitura e interpretação de textos em língua inglesa. 18 Metodologia de ensino de Inglês.

CARGO 10: PROFESSOR - DISCIPLINA: MATEMÁTICA: 1 Conjuntos. 1.1 Representação e relação: pertinência, inclusão e igualdade. 1.2 Operações: união, intercessão, diferença e complementar. 1.3 Conjuntos numéricos: naturais, inteiros, racionais, reais e complexos. 2 Funções. 2.1 Definição, domínio, imagem, gráficos, crescimento e decrescimento. 2.2 Funções: afim, quadrática, modular, exponencial, logarítmica e polinomial. 2.3 Operações algébricas com funções polinomiais. 2.4 Tipologia, função injetora, sobrejetora, bijetora, par e ímpar. 2.5 Função composta e inversa. 3 Trigonometria. 3.1 Arcos e ângulos. 3.2 Relações no círculo trigonométrico. 3.3 Redução no 10 quadrante. 3.4 Operações com arcos. 3.5 Relações métricas e trigonométricas no Triângulo. 3.6 Funções trigonométricas diretas. 3.7 Equações trigonométricas. 4 Análise combinatória. 4.1 Teorema fundamentada da contagem. 4.2 Agrupamentos simples: arranjos, combinação e permutação. 4.3 Binômio de Newton. 5 Noções de probabilidade. 5.1 Experiência, espaço amostra e evento. 5.2 Definição, propriedades e operações de probabilidade. 5.3 Probabilidade condicionada. 6 Noções de estatística. 6.1 Conceito, universo estatístico e amostra. 6.2 Freqüência e amplitude. Representação gráfica. 6.3 Medidas de posição e dispersão. 7 Seqüência. 7.1 Progressões aritméticas. 7.2 Progressões geométricas. 8 Matrizes, determinantes e sistemas lineares. 8.1 Conceito, igualdade, tipos, operações e propriedades das matrizes. 8.2 Definição, propriedades e cálculo dos determinantes. 8.3 Definição, classificação, discussão e resolução de sistemas lineares. 8.4 Sistema de inequação linear. 9 Geometria analítica. 9.1 Ponto, reta e circunferência. 9.2 Movimentos no plano: rotação, reflexão e translação. 10 Geometria espacial. 10.1 Ponto, retas e plano no espaço. 10.2 Poliedros convexos. 10.3 Sólidos geométricos: prisma, pirâmide, cilindro, cone e esfera. 11 Noções de matemática financeira. 12 Metodologia de ensino de matemática.

CARGO 11: PROFESSOR - DISCIPLINA: LÍNGUA PORTUGUESA: 1 Fonologia: relação letra e fonema. Separação de sílaba e translineação. Acentuação gráfica e tônica. Ortografia vigente e pontuação. 2 Morfologia: estrutura de palavras. Processo de formação de palavras. Classes gramaticais de palavras. 3 Sintaxe: frase, oração e período. Tipos de períodos: simples e composto. 3.1 Análise morfossintática de período simples. Análise de período composto por coordenação. Análise de período composto por subordinação (orações substantivas, adjetivas e adverbiais). Sintaxe de concordância verbal e nominal. Sintaxe de regência verbal e nominal. Colocação pronominal. 4 Semântica. Sinonímia. Antononímia. Homonímia. Paronímia. Polissemia. Ambigüidade. 5 Linguagem. Funções da linguagem. Denotação e conotação. Figuras de linguagem. Níveis de linguagem. 6 Produção de texto: leitura, compreensão, interpretação e produção de texto. Coesão e coerência. Tipologia textual e gênero textual: narração, descrição, dissertação, carta (argumentativa, familiar, comercial, convite, amorosa etc.). Produção de 
texto em prosa, dissertativo, argumentativo com temas relacionados à questões educacionais. 7 Metodologia de ensino de português.

CARGO 12: PROFESSOR - DISCIPLINA: QUÍMICA: 1 Classificação periódica dos elementos químicos. 2 Radioatividade. 2.1 Natureza das emissões radioativas; leis da radioatividade. 2.2 Fenômenos de fissão nuclear e fusão nuclear. 3 Ligação química. Teoria eletrônica de valência; ligação iônica; ligação covalente; ligação metálica; tipos de fórmula; polaridade das ligações e das moléculas; números de oxidação. 4 Função inorgânica. Conceito; classificação; notação; nomenclatura; conceitos de Arrhenius, Bronsted e Lowry e de Lewis para ácidos e bases. 5 Reação química. Reação química; equação química; tipos de reação química; balanceamento de equação química. 6 Cálculos químicos. Unidade de massa atômica; massas atômica e molecular; Número de Avogadro; Mol; massa molar volume molar; cálculos estequiométricos. 7 Soluções. Conceito; classificação; equivalente-grama; tipos de concentração; diluição; volumetria de neutralização. 8 Termoquímica. Energia e calor; entalpia; reações exotérmica e endotérmica; calor de reação em pressão constante e em volume constante; Entalpias de formação das substâncias, de combustão; Lei de Hess. 9 Cinética química. 9.1 Velocidade de uma reação química; fatores que a influenciam; energia de ativação com ou sem influência de catalisador; lei da ação das massas. 10 Química do carbono. Propriedades fundamentais do átomo de carbono; hibridação; estados de oxidação de carbono; ligação sigma e pi; geometria molecular; classificação do átomo de carbono na cadeia carbônica; notação e nomenclatura dos principais radicais orgânicos. 11 Função orgânica. Conceito; grupamento funcional; fórmulas geral e estrutural; notação e nomenclatura IUPAC das funções orgânicas. 12 Polaridade das moléculas e força intermolecular. Moléculas orgânicas polar e apolar; tipos de força intermolecular; efeitos sobre os pontos de fusão e ebulição nos compostos orgânicos. 13 Acidez e basicidade. Acidez e basicidade de compostos orgânicos. 14 Isomeria. Isomeria plana; isomeria espacial. 15 Intermediário de reação orgânica. Rupturas homolítica e heterolítica; tipo de intermediário. 16 Tipos de mecanismos da reação orgânica. Reação de adição; reação de substituição; reação de eliminação; reação de oxidação; reação de redução; reagentes eletrofílico e radical livre; mecanismo da reação orgânica. 17 Reações de compostos orgânicos. Reação de adição; reação de substituição; reação de eliminação; reação de oxidação. 18 Equilíbrio químico e equilíbrio iônico em soluções aquosas. Reação reversível; equilíbrio químico; constante de equilíbrio; deslocamento de equilíbrio; equilíbrio iônico; ionização da água; ionização dos eletrólitos fracos. 19 Eletroquímica. Potenciais de oxidação e redução; pilhas e acumuladores; eletrólise. 20 Metodologia de ensino de química.

CARGO 13: PROFESSOR - DISCIPLINA: SOCIOLOGIA: 1 A constituição do saber sociológico. $1.1 \mathrm{~A}$ sociologia como ciência. 1.2 A sociologia e as ciências sociais. 1.3 A questão metodológica nas ciências sociais e a pesquisa social. 2 Estrutura e organização social. 2.1 Estrutura da sociedade. 2.2 Instituições sociais. 2.3 Classes sociais/status. 3 Problemas sociais contemporâneos. 3.1 As desigualdades sociais, movimentos, violência e Estado. 3.2 Ética e Cidadania. 3.3 Sociedade, trabalho, relações sociais. 3.4 Os meios de comunicação e a questão ideológica. 3.50 meio ambiente e o desenvolvimento tecnológico. 3.6 A globalização e os Estados nacionais. 3.7 Diversidade cultural e étnicas. 4 Metodologia de ensino de sociologia.

\subsection{CONHECIMENTOS BASICOS PARA O CARGO DE PROFESSOR P - PEDAGOGO}

LÍNGUA PORTUGUESA: 1 Compreensão e interpretação de textos. 2 Tipologia textual. 3 Ortografia oficial. 4 Acentuação gráfica. 5 Emprego do sinal indicativo de crase. 6 Pontuação. 7 Concordância nominal e verbal. 8 Regência nominal e verbal. 9 Significação das palavras.

ATUALIDADES: Domínio de tópicos atuais e relevantes de diversas áreas, tais como política, economia, sociedade, educação, tecnologia, energia, relações internacionais, desenvolvimento sustentável, segurança, artes e literatura, e suas vinculações históricas.

NOÇÕES DE INFORMÁTICA: 1 Conceito de Internet e Intranet. 2 Principais navegadores para Internet. 3 Correio Eletrônico. 4 Principais aplicativos comerciais para edição de textos e planilhas. 5 Procedimento para a realização de cópias de segurança. 6 Sistema de arquivo, sistema de entrada, saída e armazenamento e métodos de acesso.

14.2.1.2 CONHECIMENTOS COMPLEMENTARES PARA O CARGO DE PROFESSOR P - PEDAGOGO 
LEGISLAÇÃO BÁSICA: 1 Lei de Diretrizes e Bases da Educação Nacional - Lei no 9.394/96 e suas alterações. 2 Estatuto da Criança e do Adolescente - Lei no 8.069/1990 (ECA). 3 Constituição da República Federativa do Brasil (Art. 205 a 214). 4 Emenda Constitucional no 53, de 19/12/2006, publicada em 20/12/2006. 5 Lei no 11.494, de 20/6/2007, publicada em 21/6/2007. 6 Resolução do Conselho Estadual de Educação № 1.286/2006, que fixa normas para a Educação no Sistema Estadual de Ensino do Estado do Espírito Santo, publicado no Diário Oficial do Estado de 29/5/2006; Diretrizes e Bases da Educação Nacional - Decreto Federal 5.154/2004. 7. Lei 11.114, de 16/05/2005 e Lei no 11.274, de 06/02/2006, que alteram a Lei no 9394/1996, tornando obrigatório o ensino fundamental de 9 anos.

PSICOLOGIA DA APRENDIZAGEM: 1 Teoria da aprendizagem. 2 Princípios básicos do Behavorismo e implicações educacionais. 3 Psicologia da Gestalt e implicações na aprendizagem. 4 Epistemiologia genética de Jean Piaget. 5 Perspectiva sócio-interacionista de Vigotsky. 6 A teoria da complexidade de Edgar Morin. 70 fracasso escolar: abordagens atuais.

AVALIAÇÃO DO PROCESSO ENSINO-APRENDIZAGEM: 1. Concepções de avaliação. 2 Funções da avaliação: diagnóstica, formativa e somativa. 3 Técnicas e instrumentos de avaliação. 4 Usos dos resultados da avaliação da aprendizagem no planejamento do ensino.

\subsubsection{CONHECIMENTOS ESPECÍFICOS PARA O CARGO DE PROFESSOR P - PEDAGOGO}

1. Fundamentos da Educação: 1.1. Relação educação e sociedade: dimensões filosófica, sociocultural e pedagógica; educação e pobreza; educação e cidadania. 1.2. A educação e a diversidade de contextos culturais: pluralismo e diversidade cultural. 1.3 Desenvolvimento histórico das concepções pedagógicas no Brasil. A educação na perspectiva de Paulo Freire. 1.4 As funções sociais da escola: da reprodução à reconstrução crítica. A escola básica como agente socializador: os desafios atuais. 2. O Pedagogo na Escola: 2.1. Concepção e papel do pedagogo na escola. 2.2 Liderança e relações humanas no trabalho: tipos de liderança; mecanismos de participação; formas organizativas facilitadoras da integração grupal. 2.3. Atuação do pedagogo e sua articulação com os demais profissionais da escola na perspectiva da qualidade da educação. O Conselho Escolar: propósitos e funcionamento. 2.4. Gestão escolar e participação da família na vida escolar. 3 Organização do Trabalho Pedagógico na Escola Pública. 3.10 processo de planejamento: concepção, dimensões, níveis e importância. O ano letivo e o calendário escolar. O planejamento de ensino em seus elementos constitutivos: objetivos e conteúdos de ensino, métodos e técnicas; multimídia educativa e avaliação da aprendizagem. 3.2. A proposta pedagógica da escola: concepção, princípios, eixos norteadores, construção, acompanhamento e avaliação. Os planos de ensino. 3.3. O processo de ensino-aprendizagem: concepções e teorias da aprendizagem. A interação pedagógica na sala de aula: o aluno, o professor, os tempos, os espaços e os conteúdos escolares conceituais, procedimentais e atitudinais. Mapeamento e análise de dificuldades, problemas e potencialidades do cotidiano escolar. 3.4. Comunicação e interação grupal junto aos professores no planejamento, assessoramento, monitoramento e avaliação do processo pedagógico: técnicas e instrumentos. O plano de ação do pedagogo. 4 O Currículo Escolar: 4.1. Currículo e construção do conhecimento. As aprendizagens como foco da ação educativa. 4.2. O currículo como referência para o desenvolvimento do processo pedagógico; a base nacional comum e a parte diversificada; a organização curricular por áreas de conhecimento; interdisciplinaridade e globalização do conhecimento. 4.3 O currículo básico da escola pública estadual do Espírito Santo (www.educacao.es.gov.br). 4.4 A organização curricular nos cursos de educação profissional técnica de nível médio. Os grandes eixos da formação profissional técnica de nível médio. 4.5 Metodologia de projetos: um caminho entre teoria e prática. 5 Educação Inclusiva: 5.1 Educação inclusiva: fundamentos, conceito, princípios, recursos pedagógicos e a adaptação curricular. 6 Educação e Trabalho: 6.1 A formação profissional técnica de nível médio a partir da Lei no 9394/1996-LDB. 7 Análise de indicadores sociais e educacionais- o acesso à educação, a permanência no processo educativo e a qualidade dos resultados escolares.

Vitória/ES, 10 de fevereiro de 2010.

HAROLDO CORRÊA ROCHA

Secretário de Estado da Educação 


\begin{tabular}{|c|c|c|c|c|c|c|c|c|c|c|c|c|c|c|c|c|}
\hline \multicolumn{2}{|c|}{ MUNICÍPIO/DISCIPLINA } & $\underset{\frac{\alpha}{\alpha}}{\frac{w}{\alpha}}$ & $\begin{array}{l}\text { 저 } \\
\text { 어 } \\
\frac{0}{0}\end{array}$ & 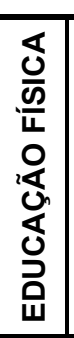 & 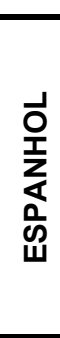 & 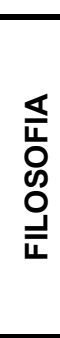 & $\frac{\mathbb{J}}{\frac{0}{L}}$ & 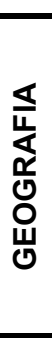 & 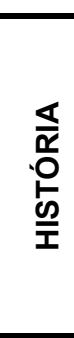 & 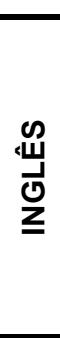 & 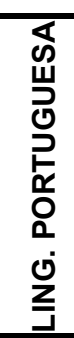 & 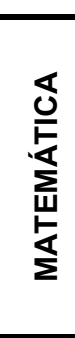 & 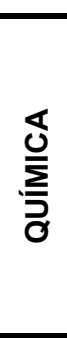 & 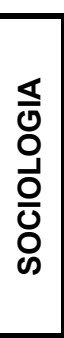 & 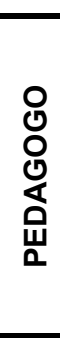 & $\frac{1}{\&}$ \\
\hline \multirow[b]{2}{*}{ Afonso Cláudio } & Geral & - & - & - & - & 1 & 2 & - & - & - & - & - & 1 & - & 2 & 6 \\
\hline & $\mathrm{PD}\left({ }^{*}\right)$ & - & - & - & - & ** & ** & - & - & - & - & - & ** & - & ** & \\
\hline \multirow{2}{*}{$\begin{array}{l}\text { Água Doce do } \\
\text { Norte }\end{array}$} & Geral & - & - & - & - & - & - & - & - & - & 1 & 1 & - & - & 4 & 6 \\
\hline & $\mathrm{PD}$ & - & - & - & - & - & - & - & - & - & $* *$ & ** & - & - & ** & \\
\hline \multirow[b]{2}{*}{ Águia Branca } & Geral & - & 1 & - & - & - & - & 1 & - & - & - & - & 1 & - & - & 3 \\
\hline & $\mathrm{PD}$ & - & $* *$ & - & - & - & - & $* *$ & - & - & - & - & ** & - & - & \\
\hline \multirow[b]{2}{*}{ Alegre } & Geral & - & - & - & - & - & 1 & 1 & - & - & 3 & 2 & 1 & - & - & 8 \\
\hline & PD & - & - & - & - & - & ** & ** & - & - & ** & ** & ** & - & - & \\
\hline \multirow[b]{2}{*}{ Alfredo Chaves } & Geral & - & 1 & - & - & - & 1 & - & - & - & - & 1 & 1 & - & - & 4 \\
\hline & $\mathrm{PD}$ & - & ** & - & - & - & ** & - & - & - & - & ** & $* *$ & - & - & \\
\hline \multirow[b]{2}{*}{ Alto Rio Novo } & Geral & - & 1 & - & - & - & 1 & 1 & 1 & - & 1 & - & 1 & - & - & 6 \\
\hline & PD & - & $* *$ & - & - & - & $* *$ & ** & $* *$ & - & $* *$ & - & ** & - & - & \\
\hline \multirow[b]{2}{*}{ Anchieta } & Geral & - & - & - & - & 1 & - & - & - & - & - & - & 2 & - & - & 3 \\
\hline & PD & - & - & - & - & ** & - & - & - & - & - & - & $* *$ & - & - & \\
\hline \multirow[b]{2}{*}{ Apiacá } & Geral & - & - & - & - & - & - & - & - & - & 1 & - & - & - & - & 1 \\
\hline & PD & - & - & - & - & - & - & - & - & - & ** & - & - & - & - & \\
\hline \multirow[b]{2}{*}{ Aracruz } & Geral & - & - & - & 2 & - & 1 & - & - & - & - & 3 & 1 & - & 4 & 10 \\
\hline & PD & - & - & - & $* *$ & - & ** & - & - & - & - & ** & $* *$ & - & ** & \\
\hline \multirow[b]{2}{*}{ Atílio Vivácqua } & Geral & - & - & - & - & - & 1 & - & - & - & - & - & - & - & - & 1 \\
\hline & PD & - & - & - & - & - & ** & - & - & - & - & - & - & - & - & \\
\hline \multirow[b]{2}{*}{ Baixo Guandú } & Geral & 1 & 2 & - & - & - & 3 & - & - & - & - & 1 & 1 & 1 & 1 & 10 \\
\hline & PD & $* *$ & $* *$ & - & - & - & ** & - & - & - & - & ** & $* *$ & $* *$ & $* *$ & \\
\hline \multirow{2}{*}{$\begin{array}{l}\text { Barra de São } \\
\text { Francisco }\end{array}$} & Geral & 1 & - & - & - & 1 & 4 & - & - & - & - & 3 & 4 & 1 & 4 & 18 \\
\hline & $\mathrm{PD}$ & $* *$ & - & - & - & ** & $* *$ & - & - & - & - & ** & $* *$ & $* *$ & $* *$ & \\
\hline \multirow[b]{2}{*}{ Boa Esperança } & Geral & 1 & - & - & - & - & 1 & - & - & - & - & 1 & 1 & - & 1 & 5 \\
\hline & $\mathrm{PD}$ & ** & - & - & - & - & $* *$ & - & - & - & - & ** & ** & - & $* *$ & \\
\hline \multirow[b]{2}{*}{ Brejetuba } & Geral & - & - & - & - & - & - & - & - & - & - & 3 & - & - & 6 & 9 \\
\hline & $\mathrm{PD}$ & - & - & - & - & - & - & - & - & - & - & ** & - & - & 1 & 1 \\
\hline \multirow{2}{*}{$\begin{array}{l}\text { Cachoeiro de } \\
\text { Itapemirim } \\
\end{array}$} & Geral & - & - & - & 2 & 1 & 5 & 1 & - & 1 & - & - & 4 & - & 4 & 18 \\
\hline & PD & - & - & - & $* *$ & ** & 1 & $* *$ & - & $* *$ & - & - & 1 & - & 1 & 3 \\
\hline \multirow[b]{2}{*}{ Cariacica } & Geral & 4 & - & - & - & - & 7 & - & - & - & - & 43 & 8 & - & 66 & 128 \\
\hline & PD & 1 & - & - & - & - & 1 & - & - & - & - & 3 & 1 & - & 4 & 10 \\
\hline \multirow[b]{2}{*}{ Castelo } & Geral & - & - & - & - & - & 1 & - & - & - & - & - & 1 & 1 & - & 3 \\
\hline & PD & - & - & - & - & - & ** & - & - & - & - & - & $* *$ & $* *$ & - & \\
\hline \multirow[b]{2}{*}{ Colatina } & Geral & 3 & - & - & 1 & - & 6 & - & 3 & - & - & 5 & 5 & 0 & 3 & 26 \\
\hline & PD & ** & - & - & $* *$ & - & 1 & - & $* *$ & - & - & 1 & 1 & $* *$ & $* *$ & 3 \\
\hline
\end{tabular}




\begin{tabular}{|c|c|c|c|c|c|c|c|c|c|c|c|c|c|c|c|c|}
\hline \multirow{2}{*}{$\begin{array}{l}\text { Conceição da } \\
\text { Barra }\end{array}$} & Geral & - & - & - & - & - & 2 & - & - & - & - & - & - & - & 5 & 7 \\
\hline & $\mathrm{PD}$ & - & - & - & - & - & ** & - & - & - & - & - & - & - & 1 & 1 \\
\hline \multirow{2}{*}{$\begin{array}{l}\text { Conceição do } \\
\text { Castelo }\end{array}$} & Geral & - & - & - & - & - & 1 & - & - & - & - & 1 & 1 & - & - & 3 \\
\hline & PD & - & - & - & - & - & ** & - & - & - & - & ** & ** & - & - & \\
\hline \multirow{2}{*}{$\begin{array}{l}\text { Divino de São } \\
\text { Lourenço }\end{array}$} & Geral & - & - & - & - & - & - & - & - & - & 1 & - & - & - & - & 1 \\
\hline & PD & - & - & - & - & - & - & - & - & - & ** & - & - & - & - & \\
\hline \multirow{4}{*}{ Domingos Martins } & Geral & - & - & - & - & - & 1 & 1 & - & - & - & 4 & 1 & - & 3 & 10 \\
\hline & $\mathrm{PD}$ & - & - & - & - & - & ** & ** & - & - & - & ** & ** & - & ** & \\
\hline & Geral & - & 2 & - & - & 1 & 2 & - & - & - & - & 2 & 2 & 2 & 9 & 20 \\
\hline & PD & - & ** & - & - & ** & ** & - & - & - & - & ** & ** & ** & 1 & 1 \\
\hline \multirow[b]{2}{*}{ Fundão } & Geral & - & - & - & - & - & 1 & - & 1 & - & - & - & 1 & - & - & 3 \\
\hline & PD & - & - & - & - & - & ** & - & ** & - & - & - & ** & - & - & \\
\hline \multirow{2}{*}{$\begin{array}{l}\text { Governador } \\
\text { Lindenberg } \\
\end{array}$} & Geral & - & - & - & - & - & - & - & - & - & - & - & - & - & 4 & 4 \\
\hline & PD & - & - & - & - & - & - & - & - & - & - & - & - & - & ** & \\
\hline \multirow[b]{2}{*}{ Guaçuí } & Geral & 1 & - & - & - & - & - & 1 & - & 1 & - & - & 1 & - & - & 4 \\
\hline & $\mathrm{PD}$ & ** & - & - & - & - & - & ** & - & ** & - & - & ** & - & - & \\
\hline \multirow[b]{2}{*}{ Guaraparí } & Geral & - & - & 1 & 1 & 1 & 5 & - & - & - & - & 6 & - & - & 5 & 19 \\
\hline & PD & - & - & ** & ** & ** & 1 & - & - & - & - & 1 & - & - & 1 & 3 \\
\hline \multirow[b]{2}{*}{ Ibatiba } & Geral & 1 & 1 & 1 & - & - & - & - & - & 1 & 2 & - & 1 & - & - & 7 \\
\hline & PD & ** & ** & ** & - & - & - & - & - & ** & ** & - & ** & - & - & \\
\hline \multirow[b]{2}{*}{ Ibiraçú } & Geral & - & 1 & - & - & - & 1 & - & - & - & - & 2 & 1 & - & 1 & 6 \\
\hline & PD & - & ** & - & - & - & ** & - & - & - & - & ** & ** & - & ** & \\
\hline \multirow[b]{2}{*}{ Iconha } & Geral & - & - & - & - & - & 1 & - & - & - & - & - & 1 & - & 1 & 3 \\
\hline & PD & - & - & - & - & - & ** & - & - & - & - & - & ** & - & $* *$ & \\
\hline \multirow[b]{2}{*}{ Irupí } & Geral & - & - & - & - & - & - & - & 1 & - & - & - & - & - & 2 & 3 \\
\hline & $\mathrm{PD}$ & - & - & - & - & - & - & - & ** & - & - & - & - & - & ** & \\
\hline \multirow[b]{2}{*}{ Itaguaçú } & Geral & - & - & - & - & - & 1 & - & - & - & - & - & - & - & 1 & 2 \\
\hline & $\mathrm{PD}$ & - & - & - & - & - & ** & - & - & - & - & - & - & - & ** & \\
\hline \multirow[b]{2}{*}{ Itapemirim } & Geral & - & - & - & - & - & 1 & 1 & - & - & - & 1 & 1 & - & 2 & 6 \\
\hline & $\mathrm{PD}$ & - & - & - & - & - & ** & ** & - & - & - & $* *$ & ** & - & ** & \\
\hline \multirow[b]{2}{*}{ Itarana } & Geral & - & - & - & - & - & 1 & - & - & - & 1 & - & 1 & - & 2 & 5 \\
\hline & $\mathrm{PD}$ & - & - & - & - & - & ** & - & - & - & ** & - & ** & - & ** & \\
\hline \multirow[b]{2}{*}{ lúna } & Geral & - & - & - & 1 & - & - & - & - & - & - & - & - & - & 1 & 2 \\
\hline & PD & - & - & - & ** & - & - & - & - & - & - & - & - & - & ** & \\
\hline \multirow[b]{2}{*}{ Jaguaré } & Geral & - & - & - & - & 1 & 2 & - & - & - & - & - & 2 & 1 & 2 & 8 \\
\hline & PD & - & - & - & - & ** & $* *$ & - & - & - & - & - & ** & ** & ** & \\
\hline \multirow{2}{*}{$\begin{array}{l}\text { Jerônimo } \\
\text { Monteiro } \\
\end{array}$} & Geral & 1 & 1 & - & - & - & 1 & - & 1 & 1 & - & - & 1 & - & - & 6 \\
\hline & PD & ** & ** & - & - & - & ** & - & ** & ** & - & - & ** & - & - & \\
\hline \multirow[b]{2}{*}{ João Neiva } & Geral & - & - & - & - & - & 1 & - & - & - & - & - & - & - & 1 & 2 \\
\hline & PD & - & - & - & - & - & ** & - & - & - & - & - & - & - & ** & \\
\hline & Geral & - & - & - & - & - & - & - & - & - & - & 1 & - & 1 & - & 2 \\
\hline Laranja de Terra & PD & - & - & - & - & - & - & - & - & - & - & ** & - & ** & - & \\
\hline & Geral & 1 & - & 1 & - & - & 8 & - & - & - & - & 13 & 4 & - & - & 27 \\
\hline Linhares & PD & ** & - & ** & - & - & 1 & - & - & - & - & 1 & 1 & - & - & 3 \\
\hline
\end{tabular}




\begin{tabular}{|c|c|c|c|c|c|c|c|c|c|c|c|c|c|c|c|c|}
\hline & Geral & - & 1 & 1 & - & - & 1 & - & - & - & - & 1 & - & - & 3 & 7 \\
\hline Mantenópolis & PD & - & ** & ** & - & - & ** & - & - & - & - & ** & - & - & ** & \\
\hline \multirow[b]{2}{*}{ Marataízes } & Geral & 1 & - & - & - & - & 2 & - & - & 1 & - & 1 & - & - & 1 & 6 \\
\hline & PD & ** & - & - & - & - & ** & - & - & ** & - & ** & - & - & ** & \\
\hline \multirow[b]{2}{*}{ Marechal Floriano } & Geral & - & - & - & - & - & 1 & - & - & - & - & - & 1 & - & 1 & 3 \\
\hline & PD & - & - & - & - & - & ** & - & - & - & - & - & ** & - & ** & \\
\hline \multirow[b]{2}{*}{ Marilândia } & Geral & - & 1 & - & - & - & 1 & - & - & - & - & - & 1 & - & - & 3 \\
\hline & PD & - & ** & - & - & - & ** & - & - & - & - & - & ** & - & - & \\
\hline \multirow[b]{2}{*}{ Montanha } & Geral & - & - & - & - & - & 1 & 1 & - & - & 1 & 1 & 1 & - & - & 5 \\
\hline & PD & - & - & - & - & - & ** & ** & - & - & ** & ** & ** & - & - & \\
\hline \multirow[b]{2}{*}{ Mucurici } & Geral & - & - & - & - & - & - & - & - & - & - & 1 & - & - & - & 1 \\
\hline & PD & - & - & - & - & - & - & - & - & - & - & ** & - & - & - & \\
\hline \multirow[b]{2}{*}{ Muniz Freire } & Geral & - & - & - & - & - & 1 & - & 1 & - & - & - & 1 & - & - & 3 \\
\hline & PD & - & - & - & - & - & ** & - & ** & - & - & - & ** & - & - & \\
\hline \multirow[b]{2}{*}{ Muqui } & Geral & - & - & - & - & - & - & - & - & - & 1 & - & 1 & - & - & 2 \\
\hline & PD & - & - & - & - & - & - & - & - & - & ** & - & ** & - & - & \\
\hline \multirow[b]{2}{*}{ Nova Venécia } & Geral & 1 & - & - & - & - & 1 & 2 & 1 & - & - & - & 1 & - & 4 & 10 \\
\hline & PD & ** & - & - & - & - & ** & ** & ** & - & - & - & ** & - & 1 & 1 \\
\hline \multirow[b]{2}{*}{ Pancas } & Geral & 1 & 1 & 1 & - & - & 1 & - & - & 1 & - & 3 & 1 & - & 3 & 12 \\
\hline & PD & ** & ** & ** & - & - & ** & - & - & ** & - & ** & ** & - & ** & \\
\hline \multirow[b]{2}{*}{ Pedro Canário } & Geral & 1 & 1 & - & - & - & 1 & 1 & 1 & - & - & 4 & 2 & - & 6 & 17 \\
\hline & PD & ** & ** & - & - & - & ** & ** & ** & - & - & $* *$ & ** & - & 1 & 1 \\
\hline \multirow[b]{2}{*}{ Pinheiros } & Geral & - & - & - & - & 1 & 2 & - & 1 & - & - & - & 2 & 1 & 1 & 8 \\
\hline & PD & - & - & - & - & ** & ** & - & ** & - & - & - & ** & ** & $* *$ & \\
\hline \multirow[b]{2}{*}{ Piúma } & Geral & 1 & - & - & - & - & - & - & - & 1 & - & 2 & - & - & - & 4 \\
\hline & PD & ** & - & - & - & - & - & - & - & ** & - & ** & - & - & - & \\
\hline \multirow[b]{2}{*}{ Ponto Belo } & Geral & - & - & - & - & - & - & 1 & - & - & - & - & - & - & - & 1 \\
\hline & PD & - & - & - & - & - & - & ** & - & - & - & - & - & - & - & \\
\hline \multirow{2}{*}{$\begin{array}{l}\text { Presidente } \\
\text { Kennedy } \\
\end{array}$} & Geral & 1 & 1 & - & - & 1 & 2 & - & - & 1 & - & 2 & 2 & 1 & - & 11 \\
\hline & PD & ** & ** & - & - & ** & ** & - & - & ** & - & ** & ** & ** & - & \\
\hline \multirow[b]{2}{*}{ Rio Bananal } & Geral & 1 & - & 1 & - & - & 1 & - & 1 & - & - & - & 1 & - & - & 5 \\
\hline & PD & ** & - & ** & - & - & ** & - & ** & - & - & - & ** & - & - & \\
\hline \multirow[b]{2}{*}{ Rio Novo do Sul } & Geral & - & 1 & - & - & - & - & - & - & 1 & 1 & - & 1 & - & - & 4 \\
\hline & PD & - & ** & - & - & - & - & - & - & ** & ** & - & ** & - & - & \\
\hline \multirow[b]{2}{*}{ Santa Leopoldina } & Geral & - & - & - & - & - & - & - & - & - & - & 1 & - & - & 2 & 3 \\
\hline & PD & - & - & - & - & - & - & - & - & - & - & ** & - & - & ** & \\
\hline \multirow{2}{*}{$\begin{array}{l}\text { Santa Maria de } \\
\text { Jetibá }\end{array}$} & Geral & - & - & - & - & - & - & 1 & - & - & 1 & 1 & 1 & - & 5 & 9 \\
\hline & PD & - & - & - & - & - & - & ** & - & - & ** & ** & ** & - & 1 & 1 \\
\hline \multirow[b]{2}{*}{ Santa Teresa } & Geral & - & - & - & - & - & - & - & - & - & - & - & - & - & 1 & 1 \\
\hline & PD & - & - & - & - & - & - & - & - & - & - & - & - & - & ** & \\
\hline & Geral & - & 1 & - & - & - & 1 & - & - & - & 1 & 1 & 1 & - & 1 & 6 \\
\hline Norte & PD & - & ** & - & - & - & ** & - & - & - & ** & ** & ** & - & ** & \\
\hline & Geral & 1 & - & - & - & - & 2 & - & - & - & - & 3 & 3 & 1 & 2 & 12 \\
\hline Palha & PD & ** & - & - & - & - & ** & - & - & - & - & ** & ** & ** & ** & \\
\hline
\end{tabular}




\begin{tabular}{|c|c|c|c|c|c|c|c|c|c|c|c|c|c|c|c|c|}
\hline \multirow{2}{*}{$\begin{array}{l}\text { São José do } \\
\text { Calçado }\end{array}$} & Geral & - & - & - & - & - & 1 & - & - & - & - & - & - & - & - & 1 \\
\hline & $\mathrm{PD}$ & - & - & - & - & - & ** & - & - & - & - & - & - & - & - & \\
\hline \multirow[b]{2}{*}{ São Mateus } & Geral & 3 & - & - & - & 1 & 6 & - & - & - & - & - & 6 & 1 & 14 & 31 \\
\hline & PD & ** & - & - & - & ** & 1 & - & - & - & - & - & 1 & ** & 1 & 3 \\
\hline \multirow{2}{*}{$\begin{array}{l}\text { São Roque do } \\
\text { Canaã }\end{array}$} & Geral & - & - & - & - & - & - & 1 & 1 & - & - & 1 & - & - & - & 3 \\
\hline & PD & - & - & - & - & - & - & ** & ** & - & - & $* *$ & - & - & - & \\
\hline \multirow[b]{2}{*}{ Serra } & Geral & 5 & - & 2 & 4 & 3 & 7 & - & - & - & - & 40 & 7 & - & 54 & 122 \\
\hline & PD & 1 & - & ** & ** & ** & 1 & - & - & - & - & 2 & 1 & - & 3 & 8 \\
\hline \multirow[b]{2}{*}{ Sooretama } & Geral & 1 & - & 1 & - & - & 1 & - & 1 & - & - & 3 & 1 & - & 5 & 13 \\
\hline & PD & ** & - & ** & - & - & ** & - & ** & - & - & ** & ** & - & 1 & 1 \\
\hline \multirow[b]{2}{*}{ Vargem Alta } & Geral & - & - & - & - & - & - & - & - & - & - & 2 & - & - & 3 & 5 \\
\hline & $\mathrm{PD}$ & - & - & - & - & - & - & - & - & - & - & $* *$ & - & - & $* *$ & \\
\hline \multirow{2}{*}{$\begin{array}{l}\text { Venda Nova do } \\
\text { Imigrante }\end{array}$} & Geral & 1 & - & - & - & - & 1 & - & - & - & 2 & - & 2 & 1 & 1 & 8 \\
\hline & PD & ** & - & - & - & - & ** & - & - & - & ** & - & ** & ** & ** & \\
\hline \multirow[b]{2}{*}{ Viana } & Geral & 3 & 1 & - & - & - & 4 & - & - & - & - & 7 & 2 & - & 8 & 25 \\
\hline & PD & ** & ** & - & - & - & ** & - & - & - & - & 1 & ** & - & 1 & 2 \\
\hline \multirow[b]{2}{*}{ Vila Pavão } & Geral & - & - & - & - & - & 1 & - & - & - & - & 1 & - & - & - & 2 \\
\hline & $\mathrm{PD}$ & - & - & - & - & - & $* *$ & - & - & - & - & $* *$ & - & - & - & \\
\hline \multirow[b]{2}{*}{ Vila Valério } & Geral & - & 1 & - & - & - & 1 & - & - & - & - & 1 & - & 1 & 1 & 5 \\
\hline & $P D$ & - & $* *$ & - & - & - & ** & - & - & - & - & $* *$ & - & ** & ** & \\
\hline \multirow[b]{2}{*}{ Vila Velha } & Geral & 4 & - & 1 & - & 1 & 10 & - & - & - & 1 & 22 & 4 & 2 & 15 & 59 \\
\hline & PD & 1 & - & $* *$ & - & ** & 1 & - & - & - & $* *$ & 2 & $* *$ & ** & 1 & 5 \\
\hline \multirow[b]{2}{*}{ Vitória } & Geral & 3 & - & - & 2 & - & 5 & - & - & - & - & 10 & 5 & 3 & 2 & 30 \\
\hline & $\mathrm{PD}$ & $* *$ & - & - & $* *$ & - & 1 & - & - & - & - & 1 & 1 & ** & $* *$ & 3 \\
\hline \multicolumn{2}{|l|}{ TOTAL } & 45 & 19 & 10 & 12 & 14 & 127 & 14 & 14 & 9 & 18 & 213 & 104 & 18 & 285 & 902 \\
\hline
\end{tabular}

$\left(^{*}\right)$ PD - Portador de Deficiência

$\left({ }^{* *}\right)$ Não sendo reservadas vagas para candidatos portadores de deficiência (PD) para provimento imediato em virtude do quantitativo oferecido. 


\section{GOVERNO DO ESTADO DE MINAS GERAIS}

EDITAL SEPLAG/SEE Nº. 01 /2011, de 11 de julho de 2011

CONCURSO PÚBLICO PARA PROVIMENTO DE CARGOS DAS CARREIRAS DE PROFESSOR DE EDUCAÇÃO BÁSICA, ANALISTA EDUCACIONAL, ESPECIALISTA EM EDUCAÇÃO BÁSICA, ASSISTENTE TÉCNICO EDUCACIONAL E ASSISTENTE TÉCNICO DE EDUCAÇÃO BÁSICA, DO QUADRO DE PESSOAL DA SECRETARIA DE ESTADO DE EDUCAÇÃO.

A Secretaria de Estado de Planejamento e Gestão - SEPLAG, a Secretaria de Estado de Educação - SEE e a Fundação Carlos Chagas - FCC tornam pública a abertura de inscrições e estabelecem normas para a realização de Concurso Público destinado a selecionar candidatos para o provimento de cargos das carreiras de Professor de Educação Básica, Analista Educacional, Especialista em Educação Básica, Assistente Técnico Educacional e Assistente Técnico de Educação Básica do quadro de pessoal da Secretaria de Estado de Educação, observados os termos da Lei Estadual n. ${ }^{\circ}$ 15.293, de 05 de agosto de 2004 (institui as carreiras dos Profissionais de Educação Básica do Estado); Lei Estadual n. ${ }^{\circ}$ 18.975, de 29 de junho de 2010 (fixa o subsídio das carreiras do grupo de atividades de educação básica do Poder Executivo Estadual e do pessoal civil da Polícia Militar do Estado de Minas Gerais); Decreto Estadual n. ${ }^{\circ}$ 42.899, de 17 de setembro de 2002 (Regulamento Geral de Concursos Públicos do Poder Executivo); Decreto Estadual n ${ }^{\circ} .43 .885$, de 4 de outubro de 2004 (dispõe sobre código de conduta ética do servidor público e da Alta Administração Estadual); Lei Estadual no 869, de 05 de julho de 1952 (Dispõe sobre o Estatuto dos Funcionários Públicos Civis do Estado de Minas Gerais), as disposições constitucionais referentes ao assunto; a legislação complementar e demais normas contidas neste Edital.

\section{DAS DISPOSIÇÕES PRELIMINARES}

1.1 O Concurso Público será regido por este Edital, por seus anexos, avisos, atos complementares e eventuais retificações, sendo sua execução de responsabilidade da FCC.

1.2 O Concurso Público de que trata este Edital visa ao provimento de cargos das carreiras de Professor de Educação Básica, Analista Educacional, Especialista em Educação Básica, Assistente Técnico Educacional e Assistente Técnico de Educação Básica, todos no grau inicial do nível I, conforme as áreas de atuação e vagas estabelecidas no Anexo I deste Edital. 
1.3 O Concurso Público de que trata este Edital será de provas e títulos, para todos os cargos, composto das seguintes etapas:

a) Primeira Etapa: Prova Objetiva de Múltipla Escolha, de caráter eliminatório e classificatório;

b) Segunda Etapa: Avaliação de Títulos, de caráter classificatório.

1.4 A legislação e as alterações em dispositivos legais e normativos, com entrada em vigor após a data de publicação deste Edital, não serão objeto de avaliação nas provas deste Concurso Público.

1.5 Este Concurso Público terá validade de 02 (dois) anos, a contar da data da publicação de sua homologação, podendo ser prorrogado por igual período, a critério da Administração Pública.

1.6 O quadro de vagas por Cargo consta do Anexo I deste Edital.

1.7 A distribuição de vagas por Superintendências Regionais de Ensino, Municípios e Órgão Central consta do Anexo II deste Edital.

1.8 As atribuições gerais dos cargos constam do Anexo III deste Edital.

1.9 Os Municípios que compõem as Superintendências Regionais de Ensino e Municípios de Realização das Provas constam do Anexo IV deste Edital.

1.10 As referências de estudo constam do Anexo V deste Edital.

1.11 O quadro contendo os critérios de pontuação para a Segunda Etapa - Avaliação de Títulos consta do Anexo VI deste Edital.

\section{DAS ESPECIFICAÇÕES DOS CARGOS}

2.1 A escolaridade, a carga horária de trabalho, a remuneração inicial, os regimes jurídico e de previdência, a lotação e o local de exercício são os estabelecidos a seguir:

2.2 Escolaridade mínima exigida:

a) Assistente Técnico de Educação Básica - ATB - Nível I Grau A: diploma de curso técnico legalmente reconhecido em Administração, ou Contabilidade, ou Informação e Comunicação (Informática para Internet, Manutenção e Suporte em Informática, Redes de Computadores), ou Secretaria Escolar, ou Gestão e Negócios, ou Magistério/Normal, expedido por instituição de ensino credenciada;

b) Assistente Técnico Educacional - ATE - Nível I Grau A: diploma de curso técnico legalmente reconhecido em Administração, ou Contabilidade, ou Informação e Comunicação (Informática para Internet, Manutenção e Suporte em Informática, Redes de Computadores), ou Gestão e Negócios, ou Magistério/Normal, expedido por instituição de ensino credenciada;

c) Analista Educacional - ANE - Nível I Grau A: diploma devidamente registrado de curso legalmente reconhecido de Bacharelado em Administração, ou Ciência da Computação, ou Ciências Contábeis, ou Ciências Sociais, ou Direito, ou Economia, ou Estatística, ou Gestão Pública, ou Informática; ou Licenciatura Plena em qualquer área de conhecimento, expedido por instituição de ensino superior credenciada;

d) Analista Educacional - ANE - Nível I Grau A - Inspeção Escolar: diploma devidamente registrado de curso legalmente reconhecido de Licenciatura Plena em Pedagogia, com habilitação específica em Inspeção Escolar, ou de Licenciatura Plena em área específica, acrescida de pósgraduação em Inspeção Escolar, expedido por instituição de ensino superior credenciada; 
e) Especialista em Educação Básica - EEB - Nível I Grau A - Orientação Educacional: diploma devidamente registrado de curso legalmente reconhecido de Licenciatura Plena em Pedagogia, com habilitação específica em Orientação Educacional, ou Licenciatura Plena em área específica, acrescida de pós-graduação em Orientação Educacional, expedido por instituição de ensino superior credenciada;

f) Especialista em Educação Básica - EEB - Nível I Grau A - Supervisão Pedagógica: diploma devidamente registrado de curso legalmente reconhecido de Licenciatura Plena em Pedagogia, com habilitação específica em Supervisão Pedagógica, ou Licenciatura Plena em área específica acrescida de pós-graduação em Supervisão Pedagógica, expedido por instituição de ensino superior credenciada;

g) Professor de Educação Básica - PEB - Nível I Grau A - Anos Iniciais do Ensino Fundamental: diploma devidamente registrado de curso legalmente reconhecido de Licenciatura Plena em Pedagogia ou Normal Superior, com habilitação para lecionar nos anos iniciais do Ensino Fundamental, expedido por instituição de ensino superior credenciada;

h) Professor de Educação Básica - PEB - Nível I Grau A:

h.1) Arte/Artes: diploma devidamente registrado de curso legalmente reconhecido de Licenciatura Plena em Educação Artística, expedido por instituição de ensino superior credenciada;

h.2) Biologia: diploma devidamente registrado de curso legalmente reconhecido de Licenciatura Plena em Ciências Biológicas, expedido por instituição de ensino superior credenciada;

h.3) Educação Física: diploma devidamente registrado de curso legalmente reconhecido de Licenciatura Plena em Educação Física, expedido por instituição de ensino superior credenciada;

h.4) Filosofia: diploma devidamente registrado de curso legalmente reconhecido de Licenciatura Plena em Filosofia, expedido por instituição de ensino superior credenciada;

h.5) Física: diploma devidamente registrado de curso legalmente reconhecido de Licenciatura Plena em Física, expedido por instituição de ensino superior credenciada;

h.6) Geografia: diploma devidamente registrado de curso legalmente reconhecido de Licenciatura Plena em Geografia, expedido por instituição de ensino superior credenciada;

h.7) História: diploma devidamente registrado de curso legalmente reconhecido de Licenciatura Plena em História, expedido por instituição de ensino superior credenciada;

h.8) Língua Estrangeira Moderna -- Espanhol: diploma devidamente registrado de curso legalmente reconhecido de Licenciatura Plena em Letras, com habilitação em Espanhol, expedido por instituição de ensino superior credenciada;

h.9) Língua Estrangeira Moderna -- Inglês: diploma devidamente registrado de curso legalmente reconhecido de Licenciatura Plena em Letras, com habilitação em Inglês, expedido por instituição de ensino superior credenciada;

h.10) Língua Portuguesa: diploma devidamente registrado de curso legalmente reconhecido de Licenciatura Plena em Letras, com habilitação em Língua Portuguesa, expedido por instituição de ensino superior credenciada;

h.11) Matemática: diploma devidamente registrado de curso legalmente reconhecido de Licenciatura Plena em Matemática, expedido por instituição de ensino superior credenciada;

h.12) Química: diploma devidamente registrado de curso legalmente reconhecido de Licenciatura Plena em Química, expedido por instituição de ensino superior credenciada; 
h.13) Sociologia: diploma devidamente registrado de curso legalmente reconhecido de Licenciatura Plena em Ciências Sociais, expedido por instituição de ensino superior credenciada.

2.2.1 Caso o candidato ainda não esteja de posse do diploma, este documento poderá ser substituído provisoriamente por certidão de conclusão de curso acompanhada de histórico escolar, emitida pela instituição de ensino credenciada.

2.3 Carga Horária de Trabalho:

a) Assistente Técnico de Educação Básica - ATB - Nível I Grau A: 30 (trinta) horas semanais;

b) Assistente Técnico Educacional - ATE - Nível I Grau A: 40 (quarenta) horas semanais;

c) Analista Educacional - ANE - Nível I Grau A: 40 (quarenta) horas semanais;

d) Analista Educacional - ANE - Nível I Grau A - Inspeção Escolar: 40 (quarenta) horas semanais, com dedicação exclusiva;

e) Especialista em Educação Básica - EEB - Nível I Grau A - Orientação Educacional: 24 (vinte e quatro) horas semanais;

f) Especialista em Educação Básica - EEB - Nível I Grau A - Supervisão Pedagógica: 24 (vinte e quatro) horas semanais;

g) Professor de Educação Básica - PEB - Nível I Grau A - Anos Iniciais do Ensino Fundamental: 24 (vinte e quatro) horas semanais;

h) Professor de Educação Básica - PEB - Nível I Grau A - Arte/Artes, Biologia, Educação Física, Filosofia, Física, Geografia, História, Língua Estrangeira Moderna - Inglês, Língua Estrangeira Moderna - Espanhol, Língua Portuguesa, Matemática, Química, Sociologia: de 8 (oito) até 24 (vinte e quatro) horas semanais;

2.4 Remuneração Inicial, conforme Lei Estadual n. ${ }^{\circ}$ 18.975/2010:

a) O subsídio para o cargo da carreira de Assistente Técnico de Educação Básica - ATB Nível I, Grau A corresponde a R \$ 911,98 (novecentos e onze reais e noventa e oito centavos);

b) O subsídio para o cargo da carreira de Assistente Técnico Educacional - ATE - Nível I, Grau A corresponde a R \$ 1.215,97 (um mil, duzentos e quinze reais e noventa e sete centavos);

c) O subsídio para o cargo da carreira de Analista Educacional - ANE - Nível I, Grau A corresponde a $\mathrm{R} \$ 2.200,00$ (dois mil e duzentos reais);

d) O subsídio para o cargo da carreira de Analista Educacional - ANE - Nível I, Grau A / Inspeção Escolar corresponde a R\$ 3.300,00 (três mil e trezentos reais);

e) O subsídio para o cargo da carreira de Especialista em Educação Básica - EEB - Nível I, Grau A / Orientação Educacional corresponde a R \$ 1.320,00 (um mil, trezentos e vinte reais);

f) O subsídio para o cargo da carreira de Especialista em Educação Básica - EEB - Nível I, Grau A / Supervisão Pedagógica corresponde a R \$ 1.320,00 (um mil, trezentos e vinte reais);

g) O subsídio para o cargo da carreira de Professor de Educação Básica - PEB - Nível I, Grau A corresponde a $\mathrm{R} \$ 1.320,00$ (um mil, trezentos e vinte reais).

2.4.1 A remuneração do cargo de Professor de Educação Básica será proporcional à carga horária, quando for o caso.

2.5 Regime Jurídico: os candidatos nomeados estarão subordinados ao Regime Jurídico Estatutário, em conformidade com as normas estabelecidas na Lei Estadual no. 869/1952, que dispõe sobre o Estatuto dos Funcionários Públicos Civis do Estado de Minas Gerais, bem como legislação federal e estadual pertinente. 
2.6 Regime de Previdência: os candidatos nomeados e empossados estarão subordinados ao Regime Próprio de Previdência Social do Estado de Minas Gerais, instituído pela Lei Complementar Estadual nº. 64/2002, bem como legislação federal e estadual pertinente.

2.7 O candidato que concorrer a cargos cuja habilitação exigida (área de atuação) permita cursos por equivalência/similaridade ao exigido deverá apresentar o respectivo histórico escolar.

2.8 Lotação: as vagas oferecidas neste Edital serão lotadas nas unidades da SEE.

2.9 Local de exercício: o exercício funcional do candidato nomeado dar-se-á, observada a escolha do candidato no ato da inscrição, conforme quadro a seguir:

\begin{tabular}{|l|l|}
\hline \multicolumn{1}{|c|}{ CARGO } & \multicolumn{1}{c|}{ LOCAL DE EXERCíCIO } \\
\hline Assistente Técnico Educacional - ATE & $\begin{array}{l}\text { Superintendência Regional de Ensino (SRE) ou } \\
\text { Órgão Central da SEE - conforme opção de } \\
\text { inscrição }\end{array}$ \\
\hline Assistente Técnico de Educação Básica -- ATB & Escola Estadual do Município de inscrição \\
\hline Analista Educacional - ANE & $\begin{array}{l}\text { Superintendência Regional de Ensino (SRE) ou } \\
\text { Órgão Central da SEE - conforme opção de } \\
\text { inscrição }\end{array}$ \\
\hline Analista Educacional/ Inspeção Escolar - ANE/IE & $\begin{array}{l}\text { Superintendência Regional de Ensino (SRE) } \\
\text { conforme opção de inscrição, com atuação nas } \\
\text { unidades escolares }\end{array}$ \\
\hline $\begin{array}{l}\text { Especialista em Educação Básica/Supervisão } \\
\text { Pedagógica - EEB/SP }\end{array}$ & Escola Estadual do Município de inscrição \\
\hline $\begin{array}{l}\text { Especialista em Educação Básica/Orientação } \\
\text { Educacional - EEB/OE }\end{array}$ & Escola Estadual do Município de inscrição \\
\hline Professor de Educação Básica - PEB & Escola Estadual do Município de inscrição \\
\hline
\end{tabular}

\section{DAS VAGAS}

3.1 O número de vagas por cargo é o constante do Anexo I deste Edital, sendo elas distribuídas por Municípios, Superintendências Regionais de Ensino (SREs) ou Órgão Central da SEE, conforme o caso e disposições do Anexo II deste Edital.

3.2 Em atendimento à Lei Estadual $\mathrm{n}^{\mathrm{o}}$. 11.867/1995, 10\% (dez por cento) do total de vagas oferecidas neste Concurso Público serão reservadas a candidatos portadores de deficiência, de acordo com os critérios definidos pelo artigo $4^{\circ}$ do Decreto Federal $\mathrm{n}^{\mathrm{o}}$. 3.298/1999, observada a exigência de compatibilidade entre a deficiência e as atribuições do cargo.

3.3 O percentual de $10 \%$ de reserva de que trata o item 3.2 deste Edital será aplicado sobre o número total de vagas disponibilizadas por cargo e área de atuação, conforme disposto no Anexo I deste Edital.

3.3.1 Para fins de reserva de vagas para portadores de deficiência, não será admitida inscrição de candidato para município onde não houver vaga prevista, devendo ser observadas as vagas reservadas no Anexo II deste Edital.

3.4 Ao número de vagas estabelecido no Anexo I deste Edital poderão ser acrescidas novas vagas, autorizadas dentro do prazo de validade do Concurso Público. 
3.5 Caso novas vagas sejam oferecidas durante o prazo de validade do Concurso Público, 10\% (dez por cento) delas serão destinadas a candidatos portadores de deficiência.

3.6 O candidato portador de deficiência participará deste Concurso Público em igualdade de condições com os demais candidatos, no que se refere à avaliação, ao conteúdo, ao horário, ao local de aplicação das provas e à nota mínima de aprovação exigida para todos os candidatos.

3.7 O candidato inscrito como portador de deficiência, se aprovado e classificado neste Concurso Público, além de figurar na lista de classificação da ampla concorrência, terá sua classificação em listagem classificatória exclusiva dos candidatos portadores de deficiência.

3.8 Para cumprimento da reserva estabelecida na Lei Estadual $\mathrm{n}^{\mathrm{o}}$. 11.867/95, as vagas reservadas serão providas por candidato portador de deficiência aprovado, classificado, nomeado e submetido à perícia médica, observada a distribuição de vagas constante do Anexo II deste Edital e a ordem de classificação do candidato nessa concorrência.

\section{DOS REQUISITOS PARA A INVESTIDURA NOS CARGOS}

4.1 O candidato aprovado e classificado neste Concurso Público será investido no cargo, se comprovar na data da posse:

a) ser brasileiro nato ou naturalizado ou cidadão português em condição de igualdade de direitos com os brasileiros; no caso de ser português, comprovar a condição de igualdade e gozo dos direitos políticos na forma do art. $12, \S 1^{\circ}$ da Constituição da República;

b) gozar dos direitos políticos;

c) estar quite com as obrigações eleitorais;

d) estar quite com as obrigações do Serviço Militar, quando se tratar de candidato do sexo masculino;

e) ter 18 anos completos até a data de posse;

f) ter aptidão física e mental para o exercício das atribuições do cargo, a ser aferida em perícia médica oficial, realizada por unidade pericial competente, nos termos da legislação vigente;

g) não ter sido demitido, a bem do serviço público, nos últimos 5 (cinco) anos, nos termos do Parágrafo Único do art. 259, da Lei Estadual nº 869/1952.

4.2 O candidato que, na data da posse, não reunir os requisitos enumerados no item 4.1 deste Edital ou que por qualquer motivo não puder comprová-los, perderá o direito à posse no cargo para o qual foi nomeado.

\section{DAS INSCRIÇÕES}

\subsection{Disposições Gerais sobre as inscrições:}

5.1.1 A inscrição do candidato implicará o conhecimento e a tácita aceitação das normas e condições estabelecidas neste Edital, em relação às quais não poderá alegar desconhecimento.

5.1.2 Objetivando evitar ônus desnecessário, o candidato deverá orientar-se no sentido de somente efetuar a inscrição e recolher o valor respectivo após tomar conhecimento do disposto neste Edital e seus anexos, e certificar-se de que preenche todos os requisitos exigidos para o cargo. 
5.1.3 As informações prestadas no Formulário Eletrônico de Inscrição serão de inteira responsabilidade do candidato, reservando-se à SEPLAG, à SEE e à FCC o direito de cancelar a inscrição do candidato que não preenchê-lo de forma completa, correta e legível.

5.1.4 Declarações falsas ou inexatas constantes do Formulário Eletrônico de Inscrição determinarão o cancelamento da inscrição e a anulação de todos os atos dela decorrentes, em qualquer época, sem prejuízo das sanções penais cabíveis.

5.1.5 No ato da inscrição, não se exigirá do candidato cópia de nenhum documento, sendo de sua exclusiva responsabilidade a veracidade dos dados informados no Formulário Eletrônico de Inscrição, sob as penas da lei.

5.1.6 As Tabelas do Anexo II deste Edital apresentam a distribuição de vagas existentes por cargo em Municípios, SREs e Órgão Central da SEE.

5.1.6.1 Não será admitida a inscrição de candidato para município onde não houver vaga prevista, devendo ser observadas as vagas ofertadas no Anexo II deste Edital.

5.1.7 A Tabela constante do Anexo IV deste Edital apresenta os municípios de realização da prova.

5.1.8 Ao inscrever-se no Concurso Público, o candidato deverá indicar no Formulário Eletrônico de Inscrição se pretende concorrer a cargo para Município, SRE ou Órgão Central da SEE e observar se o município para o qual se inscreve está vinculado à SRE em cuja sede realizará a prova, quando for o caso, nas condições previstas nos quadros de vagas constantes do Anexo II deste Edital.

5.1.9 O candidato poderá se inscrever somente para um cargo constante do Anexo I deste Edital.

5.1.10 O candidato que efetivar mais de uma inscrição neste Concurso Público terá confirmada apenas a última inscrição, observado o pagamento do valor respectivo, sendo as demais inscrições canceladas, não havendo devolução da importância paga, ainda que superior ou em duplicidade.

5.1.11 A inscrição e o valor de inscrição pago são pessoais e intransferíveis.

5.1.12 Não serão aceitas as solicitações de inscrição que não atenderem rigorosamente ao estabelecido neste Edital.

5.1.13 Efetivada a inscrição, não serão aceitos pedidos para alteração de cargo ou local de prova.

5.1.14 Não será admitida a restituição da importância paga com a inscrição, salvo nos casos e condições previstos na Lei Estadual nº $13.801 / 2000$.

\subsection{Dos Procedimentos para Inscrição:}

5.2.1 As inscrições para este Concurso Público serão realizadas exclusivamente pela Internet, no endereço eletrônico da FCC www.concursosfcc.com.br, no período de 10 horas do dia 20/09/2011, às 14 horas do dia 19/10/2011, observado o horário de Brasília.

5.2.1.1 A SEE disponibilizará em cada sede das SRE's computadores com acesso à Internet e material para impressão de boleto bancário, sendo de exclusiva responsabilidade do candidato realizar o ato de inscrição nos termos deste Edital.

5.2.2 O período de inscrições poderá ser prorrogado por necessidade técnica e/ou operacional, a critério da SEPLAG, da SEE e/ou da FCC, mediante publicação no Órgão Oficial dos Poderes do Estado - Minas Gerais e comunicação no endereço eletrônico www.concursosfcc.com.br. 
5.2.3 Para inscrever-se neste Concurso Público, o candidato deverá acessar o endereço eletrônico $\boldsymbol{w w w . c o n c u r s o s f c c . c o m . b r}$ durante o período das inscrições e, por meio do link "Inscrição via Internet" correspondente ao Concurso da Secretaria de Estado de Educação de Minas Gerais, efetuar sua inscrição conforme os procedimentos estabelecidos abaixo:

a) ler atentamente este Edital e o Formulário Eletrônico de Inscrição;

b) aceitar o Requerimento de Inscrição, preencher o Formulário Eletrônico de Inscrição e transmitir os dados pela Internet, providenciando a impressão do comprovante de Inscrição Finalizada;

c) imprimir o boleto bancário para pagamento do valor da inscrição correspondente, em qualquer banco do sistema de compensação bancária;

d) efetuar o pagamento da importância referente à inscrição descrita no item 5.2.5 deste Edital, por meio de boleto bancário ou débito em conta corrente de banco(s) conveniado(s) ou em dinheiro ou cheque do próprio candidato, de acordo com as instruções constantes do endereço eletrônico da página de inscrições, até a data limite para o encerramento das inscrições (19/10/2011).

5.2.4 As inscrições somente serão confirmadas após a quitação do pagamento do valor de inscrição.

5.2.5 O candidato deverá, no período das inscrições, pagar a importância indicada a seguir, correspondente ao cargo para o qual se inscreveu, a título de ressarcimento de despesas com material e serviço:

\begin{tabular}{|c|c|c|}
\hline CARGO & ÁREA DE ATUAÇÃO & $\begin{array}{l}\text { VALOR DA } \\
\text { INSCRIÇÃO }\end{array}$ \\
\hline $\begin{array}{l}\text { Assistente Técnico Educacional - ATE - } \\
\text { Nível I Grau A }\end{array}$ & $\begin{array}{l}\text { Técnico / Apoio Técnico em SRE e no Órgão } \\
\text { Central da SEE }\end{array}$ & $\mathrm{R} \$ 37,41$ \\
\hline $\begin{array}{l}\text { Assistente Técnico de Educação Básica - } \\
\text { ATB - Nível I Grau A }\end{array}$ & $\begin{array}{l}\text { Técnico / Apoio Técnico em Escolas } \\
\text { Estaduais }\end{array}$ & $\mathrm{R} \$ 37,41$ \\
\hline $\begin{array}{l}\text { Analista Educacional - ANE - Nível I Grau } \\
\text { A }\end{array}$ & $\begin{array}{l}\text { Atividades Técnicas em SRE e Órgão } \\
\text { Central da SEE }\end{array}$ & $\mathrm{R} \$ 47,41$ \\
\hline $\begin{array}{l}\text { Analista Educacional - ANE - Nível I Grau } \\
\text { A / Inspeção Escolar }\end{array}$ & Inspeção Escolar & $\mathrm{R} \$ 47,41$ \\
\hline \multirow{2}{*}{$\begin{array}{l}\text { Especialista em Educação Básica - EEB - } \\
\text { Nível I Grau A }\end{array}$} & Orientação Educacional & \multirow{2}{*}{$\mathrm{R} \$ 47,41$} \\
\hline & Supervisão Pedagógica & \\
\hline $\begin{array}{l}\text { Professor de Educação Básica - PEB - Nível } \\
\text { I Grau A }\end{array}$ & $\begin{array}{l}\text { Anos Iniciais do Ensino Fundamental } \\
\text { Arte/Artes } \\
\text { Biologia } \\
\text { Educação Física } \\
\text { Filosofia } \\
\text { Física } \\
\text { Geografia } \\
\text { História } \\
\text { Língua Estrangeira Moderna (Espanhol) } \\
\text { Língua Estrangeira Moderna (Inglês) } \\
\text { Língua Portuguesa } \\
\text { Matemática } \\
\text { Química } \\
\text { Sociologia }\end{array}$ & $\mathrm{R} \$ 47,41$ \\
\hline
\end{tabular}

5.2.6 O pagamento efetuado por meio de cheque somente será considerado quitado após a respectiva compensação. 
5.2.7 Em caso de devolução do cheque, qualquer que seja o motivo, considerar-se-á automaticamente sem efeito a inscrição.

5.2.8 Em caso de feriado ou evento que acarrete o fechamento de agências bancárias, o pagamento deverá ser feito antecipadamente.

5.2.9 Não serão aceitas inscrições por depósito em caixa eletrônico, via postal, fac-símile (fax), transferência ou depósito em conta corrente, DOC, ordem de pagamento condicional e extemporânea ou por qualquer outra via que não a especificada neste Edital.

5.2.10 A FCC, a SEPLAG e a SEE não se responsabilizam por solicitações de inscrição via Internet que deixarem de ser concretizadas por motivos externos de ordem técnica dos computadores, falhas de comunicação, congestionamento das linhas de comunicação, ausência de energia elétrica e outros fatores de ordem técnica que impossibilitem a transferência de dados, salvo quando se tratar de falha técnica ou operacional no endereço eletrônico onde serão processadas as inscrições.

5.2.11 Poderá ser cancelada a inscrição com pagamento efetuado por um valor menor do que o estabelecido e as solicitações de inscrição cujos pagamentos forem efetuados após a data de encerramento das inscrições, não sendo devido ao candidato qualquer ressarcimento da importância paga extemporaneamente.

5.2.12 A partir de 26/10/2011 o candidato deverá conferir, no endereço eletrônico da FCC, se os dados da inscrição foram recebidos e o pagamento da inscrição processado. Em caso negativo, o candidato deverá entrar em contato com o Serviço de Atendimento ao Candidato -- SAC da FCC, pelo telefone (0xx11) 3723-4388, de segunda a sexta-feira úteis, das 10 às 16 horas (horário de Brasília), para verificar o ocorrido.

\subsection{Da Isenção do Pagamento do Valor de Inscrição}

5.3.1 O candidato comprovadamente desempregado, amparado pela Lei Estadual $\mathrm{n}^{\circ}$. 13.392/1999, poderá requerer isenção do pagamento do valor de inscrição exclusivamente de 10 horas do dia 08/08/2011 até as 14 horas do dia 12/08/2011, observado o horário de Brasília.

5.3.1.1 É facultada aos interessados em requerer a isenção do pagamento do valor de inscrição a utilização dos computadores disponíveis nas sedes das Superintendências Regionais de Ensino, conforme disposto no subitem 5.2.1.1 deste Edital.

5.3.2 O requerimento de isenção do pagamento do valor de inscrição estará disponível para preenchimento no endereço eletrônico www.concursosfcc.com.br somente no período constante do item 5.3.1 deste Edital.

5.3.3 Para requerer a isenção do pagamento do valor de inscrição o candidato deverá comprovar, cumulativamente:

a) não possuir vínculo empregatício vigente registrado em Carteira de Trabalho e Previdência Social - CTPS;

b) não possuir vínculo estatutário vigente com o poder público nos âmbitos municipal, estadual ou federal;

c) não possuir contrato de prestação de serviços vigente com o poder público nos âmbitos municipal, estadual ou federal;

d) não exercer atividade legalmente reconhecida como autônoma.

5.3.4 Para requerer a isenção do pagamento do valor de inscrição, o candidato deverá obedecer aos seguintes procedimentos: 
a) acessar o endereço eletrônico www.concursosfcc.com.br - por meio do link correspondente ao Concurso da Secretaria de Estado de Educação de Minas Gerais, ler e aceitar o requerimento de isenção do pagamento do valor de inscrição;

b) encaminhar a documentação citada nos itens 5.3.5 a 5.3.9 deste Edital, no período de 08/08/2011 a 12/08/2011, via Sedex ou Aviso de Recebimento (AR), à Fundação Carlos Chagas (Núcleo de Tratamento da Informação - Ref.: Isenção de Pagamento/SEE-MG) - Av. Prof. Francisco Morato, 1565, Jardim Guedala - São Paulo - SP - CEP 05513-900).

5.3.5 No requerimento de isenção do pagamento do valor de inscrição o candidato deverá firmar declaração de que é desempregado, não se encontra em gozo de nenhum benefício previdenciário de prestação continuada, não aufere nenhum tipo de renda - exceto a proveniente de segurodesemprego - e que sua situação econômico-financeira não lhe permite pagar o referido valor sem prejuízo do sustento próprio ou de sua família, respondendo civil e criminalmente pelo inteiro teor de sua declaração.

5.3.6 Para comprovar a situação prevista na alínea "a" do item 5.3.3 deste Edital, o candidato deverá:

a) apresentar declaração de próprio punho, datada e assinada, na qual informará que nunca teve registro em sua Carteira de Trabalho e Previdência Social (CTPS) de vínculo empregatício, quando for o caso; ou

b) apresentar cópia autenticada das páginas da Carteira de Trabalho e Previdência Social (CTPS) que contenham fotografia, qualificação civil, anotações do último contrato de trabalho (com as alterações salariais e registro da saída), e da primeira página em branco subsequente à anotação do último contrato de trabalho ocorrido.

5.3.7 Para comprovar a situação prevista na alínea "b" do item 5.3.3 deste Edital, o candidato deverá:

a) apresentar declaração de próprio punho, datada e assinada, na qual informará que nunca teve vínculo estatutário com o poder público nos âmbitos municipal, estadual ou federal, quando for o caso; ou

b) apresentar certidão expedida por órgão ou entidade competente, em papel timbrado, com identificação e assinatura legível da autoridade emissora do documento, informando o fim do vínculo estatutário, ou a cópia da publicação oficial do ato que determinou a extinção do vínculo.

5.3.8 Para comprovar a situação prevista na alínea "c" do item 5.3.3 deste Edital, o candidato deverá apresentar declaração de próprio punho, datada e assinada, na qual informará que não possui contrato de prestação de serviços vigente com o poder público nos âmbitos municipal, estadual ou federal.

5.3.9 Para comprovar a situação prevista na alínea "d" do item 5.3.3 deste Edital, o candidato deverá:

a) apresentar certidão em que conste a baixa da atividade autônoma; ou

b) apresentar declaração de próprio punho, datada e assinada, na qual informará não auferir qualquer tipo de renda (exceto aquela proveniente de seguro desemprego).

5.3.10 Não será concedida isenção do pagamento do valor de inscrição ao candidato que:

a) deixar de efetuar o requerimento de inscrição pela Internet;

b) omitir informações e/ou torná-las inverídicas;

c) fraudar e/ou falsificar documento;

d) pleitear a isenção, sem apresentar cópia autenticada dos documentos previstos nos itens anteriores; 
e) não observar prazos para postagem dos documentos.

5.3.11 Cada candidato deverá encaminhar individualmente sua documentação, sendo vedado o envio de documentos de mais de um candidato no mesmo envelope.

5.3.12 As informações prestadas no requerimento de isenção do pagamento do valor de inscrição serão de inteira responsabilidade do candidato.

5.3.13 A declaração falsa de dados para fins de isenção do pagamento do valor de inscrição determinará o cancelamento da inscrição e a anulação de todos os atos dela decorrentes, em qualquer época, sem prejuízo das sanções civis e penais cabíveis pelo teor das afirmativas.

5.3.14 Encerrado o prazo de postagem de documentos, não será permitida a complementação da documentação.

5.3.15 Não será aceita solicitação de isenção do pagamento de valor de inscrição via fax, via correio eletrônico ou qualquer outra forma que não seja prevista neste Edital.

5.3.16 A comprovação da tempestividade do requerimento de isenção do pagamento do valor de inscrição será feita pelo registro da data de postagem.

5.3.17 Para fins de isenção do pagamento do valor de inscrição, a documentação comprobatória da condição de desempregado será analisada pela FCC.

5.3.18 O pedido de isenção do pagamento do valor de inscrição que não atender a quaisquer das exigências determinadas neste Edital será indeferido.

5.3.19 A partir de 06/09/2011 o resultado da análise do requerimento de isenção do pagamento do valor de inscrição será publicado no Órgão Oficial dos Poderes do Estado - Minas Gerais e disponibilizado no endereço eletrônico www.concursosfcc.com.br, listando os candidatos por nome em ordem alfabética, número do documento de identidade e apresentando a informação sobre deferimento ou indeferimento.

5.3.20 Ao acessar o endereço eletrônico da FCC, o sistema de inscrição informará ao candidato, automaticamente, se o seu requerimento de isenção do pagamento do valor de inscrição foi deferido, não gerando boleto para pagamento da inscrição.

5.3.21 O candidato que tiver seu requerimento de isenção do pagamento do valor de inscrição deferido deverá retornar ao endereço eletrônico www.concursosfcc.com.br para efetivar sua inscrição no período de 10 horas do dia 20/09/2011 até as 14 horas de 19/10/2011, observado o horário de Brasília.

5.3.21.1 O candidato que não efetivar a sua inscrição após a análise do requerimento de isenção do pagamento do valor de inscrição, será excluído do certame.

5.3.22 O candidato que tiver seu requerimento de isenção do pagamento do valor de inscrição indeferido poderá apresentar recurso no prazo de 2 (dois) dias úteis após a publicação indicada no subitem 5.3.19 deste Edital.

5.3.23 Após a análise dos recursos será divulgada no endereço eletrônico www.concursosfcc.com.br e publicada no Órgão Oficial dos Poderes do Estado - Minas Gerais a relação nominal dos requerimentos de isenção do pagamento do valor de inscrição deferidos e indeferidos.

5.3.24 Os candidatos que tiverem seus pedidos de isenção do pagamento do valor de inscrição indeferidos e que mantiverem interesse em participar do certame deverão efetuar sua inscrição no endereço eletrônico $\boldsymbol{w w w . c o n c u r s o s f c c . c o m . b r}$, no período previsto para inscrições, observando os procedimentos previstos no item 5.2 deste Edital.

5.3.25 Concedida ou não a isenção, poderão ser realizadas diligências relativas à situação declarada pelo candidato. 


\section{DA INSCRIÇÃO DE PESSOA PORTADORA DE DEFICIÊNCIA}

6.1 Para fins de reserva de vagas prevista na Lei Estadual $\mathrm{n}^{\circ} .11 .867 / 1995$, considera-se pessoa portadora de deficiência aquela que se enquadra nas categorias discriminadas no art. $4^{\circ}$ do Decreto Federal $n^{\circ}$. 3.298/1999 combinado com o enunciado da Súmula 377 do Superior Tribunal de Justiça - STJ, assim definidas:

a) Deficiência física: alteração completa ou parcial de um ou mais segmentos do corpo humano, acarretando o comprometimento da função física, apresentando-se sob a forma de paraplegia, paraparesia, monoplegia, monoparesia, tetraplegia, tetraparesia, triplegia, triparesia, hemiplegia, hemiparesia, ostomia, amputação ou ausência de membro, paralisia cerebral, nanismo, membros com deformidade congênita ou adquirida, exceto as deformidades estéticas e as que não produzam dificuldades para o desempenho das funções.

b) Deficiência auditiva: perda bilateral, parcial ou total, de quarenta e um decibéis (dB) ou mais, aferida por audiograma nas frequências de $500 \mathrm{~Hz}, 1.000 \mathrm{~Hz}, 2.000 \mathrm{~Hz}$ e $3.000 \mathrm{~Hz}$.

c) Deficiência visual: cegueira, na qual a acuidade visual é igual ou menor que 0,05 no melhor olho, com a melhor correção óptica; a baixa visão, que significa acuidade visual entre 0,3 e 0,5 no melhor olho, com a melhor correção óptica; casos nos quais a somatória da medida do campo visual em ambos os olhos for igual ou menor que $60^{\circ}$, ou ocorrência simultânea de quaisquer condições anteriores. Visão monocular.

d) Deficiência mental: funcionamento intelectual significativamente inferior à média, com manifestação antes dos dezoito anos e limitações associadas a duas ou mais áreas de habilidades adaptativas, tais como: comunicação, cuidado pessoal, habilidades sociais; utilização dos recursos da comunidade; saúde e segurança; habilidades acadêmicas; lazer e trabalho.

e) Deficiência múltipla: associação de duas ou mais deficiências.

6.2 Às pessoas portadoras de deficiência, que pretendam fazer uso das prerrogativas que lhes são facultadas pela legislação, é assegurado o direito de inscrição para a reserva de vagas em Concurso Público, nos cargos cujas atribuições sejam compatíveis com a deficiência de que são portadoras.

6.3 A utilização de material tecnológico de uso habitual não obsta a inscrição na reserva de vagas; porém, a deficiência do candidato deve permitir o desempenho adequado das atribuições especificadas para o cargo, admitida a correção por equipamentos, adaptações, meios ou recursos especiais.

6.4 No ato da inscrição, o candidato portador de deficiência deverá declarar que está ciente das atribuições do cargo para o qual pretende se inscrever e que, no caso de vir a exercê-lo, estará sujeito à avaliação pelo desempenho dessas atribuições.

6.5 O candidato portador de deficiência, se aprovado e classificado neste Concurso Público, além de figurar na lista de classificação da ampla concorrência, terá seu nome constante da lista específica de portadores de deficiência.

6.6 O candidato portador de deficiência, durante o preenchimento do Formulário Eletrônico de Inscrição, além de observar os procedimentos descritos no item 5 deste Edital, deverá proceder da seguinte forma:

a) informar que é portador de deficiência;

b) especificar a deficiência;

c) manifestar se possui interesse em concorrer às vagas reservadas a portadores de deficiência. 
6.7 O candidato portador de deficiência que não preencher os campos específicos do Formulário Eletrônico de Inscrição e não cumprir o determinado neste Edital terá a sua inscrição processada como candidato de ampla concorrência e não poderá alegar posteriormente essa condição para reivindicar a prerrogativa legal.

6.8 Para solicitar inscrição na reserva de vagas, o candidato portador de deficiência, deverá encaminhar no período de 20/09/2011 a 19/10/2011, via Sedex ou Aviso de Recebimento (AR), à Fundação Carlos Chagas (A/C Departamento de Execução de Projetos - Ref.: Laudo Médico SEE-MG - Av. Professor Francisco Morato, 1565, Jardim Guedala - São Paulo - SP - CEP 05513-900) os documentos a seguir:

a) Laudo Médico original ou cópia autenticada expedido no prazo máximo de 12 (doze) meses da data do término das inscrições, atestando a espécie e o grau de deficiência, com expressa referência ao código correspondente da Classificação Internacional de Doença - CID, bem como a provável causa da deficiência, inclusive para assegurar previsão de adaptação da sua prova, informando, também, o seu nome, documento de identidade (RG), número do CPF e opção de cargo, unidade de exercício, bem como o local onde irá realizar a prova, de acordo com a listagem que consta do Anexo IV deste Edital;

b) O candidato portador de deficiência visual, além do envio da documentação indicada na alínea "a" deste item, deverá solicitar, por escrito, até o término das inscrições, a confecção de prova especial em Braile ou Ampliada ou Software de Leitura de Tela ou leitura de sua prova, especificando o tipo de deficiência;

c) O candidato com deficiência auditiva, além do envio da documentação indicada na alínea "a" deste item, deverá solicitar, por escrito, até o término das inscrições, o Intérprete da Língua Brasileira de Sinais.

d) O candidato portador de deficiência que necessitar de tempo adicional para realização da prova, além do envio da documentação indicada na alínea "a" deste item, deverá encaminhar solicitação, por escrito, até o término das inscrições, com justificativa acompanhada de parecer emitido por especialista da área de sua deficiência.

6.9 A FCC, a SEPLAG e a SEE não se responsabilizam pelo extravio dos documentos encaminhados via Sedex ou Aviso de Recebimento (AR).

6.10 O candidato portador de deficiência, além do envio do Laudo Médico indicado na alínea "a" do item 6.8 deste Edital, deverá assinalar, no Formulário Eletrônico de Inscrição ou no Requerimento de Isenção de Pagamento do Valor de Inscrição, nos respectivos prazos, a condição especial de que necessitar para a realização da prova, quando houver.

6.11 O Laudo Médico de que trata a alínea "a" do item 6.8 deste Edital terá validade somente para este Concurso Público e não será devolvido.

6.12 O candidato com dificuldade de locomoção deverá indicar essa condição, informando no Formulário Eletrônico de Inscrição se utiliza cadeira de rodas e/ou se necessita de local de fácil acesso.

6.13 Aos candidatos com deficiência visual (cegos) que solicitarem prova especial em braile serão oferecidas provas neste sistema e suas respostas deverão ser transcritas também em braile. Os referidos candidatos deverão levar, para este fim, no dia da aplicação da prova, reglete e punção, podendo utilizar-se de soroban.

6.14 Aos deficientes com deficiência visual (baixa visão) que solicitarem prova especial ampliada serão oferecidas provas neste sistema.

6.14.1 O candidato deverá indicar o tamanho da fonte de sua prova ampliada, entre 18, 24 ou 28. Não havendo indicação de tamanho da fonte, a prova será confeccionada em fonte 24 . 
6.15 Os candidatos com deficiência visual (cegos ou baixa visão), que solicitarem prova especial por meio da utilização de software, deverão indicar um dos relacionados a seguir:

6.15.1 Dos Vox (sintetizador de voz);

6.15.2 Jaws (leitor de tela);

\subsubsection{Zoom Text (ampliação e voz).}

6.16 Os candidatos que, dentro do prazo do período das inscrições, não atenderem os dispositivos mencionados no item 6.8 e seus subitens, deste Edital, não serão considerados portadores de deficiência e não terão a prova e/ou condições especiais atendidas, seja qual for o motivo alegado.

6.17 A realização de provas nas condições especiais solicitadas pelo candidato portador de deficiência será condicionada à legislação específica e à possibilidade técnica examinada pela FCC.

6.18 O candidato será comunicado do atendimento de sua solicitação por meio do Cartão Informativo que será encaminhado via e-mail, podendo acessar as referidas informações por meio de consulta no site www.concursosfcc.com.br.

6.19 Será desconsiderado qualquer recurso em favor de candidato portador de deficiência que não seguir as instruções constantes deste Edital para inscrição nesta condição.

6.20 Após a nomeação do candidato, a deficiência não poderá ser arguida para justificar a concessão de aposentadoria.

\section{DA COMPROVAÇÃO DE INSCRIÇÃO}

7.1 A FCC disponibilizará ao candidato, no endereço eletrônico www.concursosfcc.com.br, com antecedência mínima de 5 (cinco) dias úteis da data de realização das provas, o Cartão Informativo, que conterá a indicação do horário e do local de realização das provas, para consulta pelo próprio candidato.

7.2 É de inteira responsabilidade do candidato consultar no endereço eletrônico www.concursosfcc.com.br as informações relativas ao horário e local da prova.

7.3 No caso de o candidato não conseguir visualizar o Informativo no endereço eletrônico da FCC dentro do período fixado, deverá entrar em contato com o Serviço de Atendimento ao Candidato - SAC da FCC, pelo telefone (0xx11) 3723-4388, de segunda a sexta-feira úteis, das 10 às 16 horas (horário de Brasília), para as devidas orientações.

7.4 No Cartão Informativo estarão expressos o nome completo do candidato, o número do documento de identidade, o cargo, a área de atuação, a unidade de exercício do cargo, a data, o horário e o local da realização das provas (escola/prédio/sala) e outras orientações úteis ao candidato, sendo de responsabilidade do candidato conferir todos os dados informados.

7.5 Caso haja inexatidão na informação relativa à opção de cargo, área de atuação, unidade de exercício do cargo, local de realização das provas, ou à condição de portador de deficiência, o candidato deverá entrar em contato com o Serviço de Atendimento ao Candidato - SAC da FCC com, no mínimo, 48 (quarenta e oito) horas de antecedência da data de realização da prova, pelo telefone (0XX11) 3723-4388, de segunda a sexta-feira úteis, das 10 às 16 horas (horário de Brasília).

7.6 Eventuais retificações de erros de digitação verificados no Cartão Informativo, ou erros observados nos documentos impressos entregues ao candidato no dia de realização da prova, quanto a nome, número do documento de identidade, data de nascimento, endereço etc, deverão 
ser corrigidos por meio do endereço eletrônico www.concursosfcc.com.br, até o terceiro dia útil após a aplicação das Provas Objetivas.

7.6.1 O candidato que não solicitar as correções dos dados pessoais nos termos do item 7.6 deste Edital deverá arcar, exclusivamente, com as consequências advindas de sua omissão.

7.7 Em nenhuma hipótese serão efetuadas alterações nos dados informados pelo candidato no Formulário Eletrônico de Inscrição ou no Requerimento de Isenção, relativos ao cargo, à lotação do cargo, ao local de realização das provas e nem quanto à condição em que concorre (vagas de ampla concorrência ou reservadas a portadores de deficiência).

7.8 O candidato não portador de deficiência que, por razões diversas, necessitar de condição especial para realização da prova deverá solicitá-la até o término das inscrições $(\mathbf{1 9} / \mathbf{1 0} / \mathbf{2 0 1 1})$, via Sedex ou Aviso de Recebimento (AR) à FCC (Departamento de Execução de Projetos - Ref.: Solicitação/SEE-MG - Av. Prof. Francisco Morato, 1565, Jardim Guedala - São Paulo - SP CEP 05513-900).

7.9 A candidata lactante que necessitar amamentar durante a realização da prova deverá encaminhar sua solicitação, via Sedex ou Aviso de Recebimento (AR), à Fundação Carlos Chagas (Departamento de Execução de Projetos - Ref.: Solicitação/SEE-MG - Av. Prof. Francisco Morato, 1565, Jardim Guedala - São Paulo - SP - CEP 05513-900), observando os procedimentos a seguir, para a adoção das providências necessárias:

a) a criança ficará sob a guarda do acompanhante (maior responsável por sua guarda, podendo este ser familiar ou terceiro indicado pela candidata) em ambiente reservado para este fim, diferente do local de prova da candidata;

b) nos horários previstos para amamentação, a candidata lactante poderá ausentar-se temporariamente da sala de prova, acompanhada de uma fiscal;

c) a amamentação dar-se-á nos momentos em que se fizerem necessários e na sala reservada para amamentação ficarão somente a candidata lactante, a criança e uma fiscal, sendo vedada a permanência de babás ou quaisquer outras pessoas que tenham grau de parentesco ou de amizade com a candidata;

d) não haverá, em favor da candidata, prorrogação de prazo de duração da prova ou compensação pelo tempo de prova dispensado na amamentação.

\section{DA PRIMEIRA ETAPA DO CONCURSO - PROVA OBJETIVA}

\subsection{Da Prova Objetiva:}

8.1.1 A primeira etapa deste Concurso Público será constituída de Prova Objetiva, de caráter eliminatório e classificatório, que será aplicada a todos os cargos.

8.1.2 A Prova Objetiva constará de um total de 60 (sessenta) questões objetivas de múltipla escolha.

8.1.3 Os conteúdos, o número de questões e o tempo de duração da Prova Objetiva estão definidos no quadro a seguir:

\begin{tabular}{|c|l|c|c|}
\hline PROVA & \multicolumn{1}{|c|}{ CONTEÚDO DA PROVA $^{\text {N. }}{ }^{\mathbf{D}}$ DE QUESTÕES } & DURAÇÃO DA PROVA \\
\hline \multirow{2}{*}{ Objetiva } & Conhecimentos Gerais & 20 & \multirow{2}{*}{4 Horas } \\
\cline { 2 - 3 } & Conhecimentos Específicos & 40 & \\
\hline
\end{tabular}

8.1.4 As questões da Prova Objetiva versarão sobre as Referências de Estudo contidas no Anexo $\mathrm{V}$ deste Edital. 
8.1.5 Cada questão da Prova Objetiva terá 4 (quatro) alternativas de resposta, devendo ser marcada como resposta apenas 1 (uma) alternativa por questão.

8.1.6 A Prova Objetiva será avaliada na escala de 0 (zero) a 60 (sessenta) pontos, por processo eletrônico, sendo atribuído 1 (um) ponto para cada resposta correta.

8.1.7 Será considerado aprovado na Prova Objetiva o candidato que obtiver no mínimo 50\% (cinquenta por cento) de acertos nas questões de Conhecimentos Gerais e no mínimo 50\% (cinquenta por cento) de acertos nas questões de Conhecimentos Específicos.

8.1.8 Será excluído do Concurso Público o candidato que não obtiver o mínimo de acertos exigidos para aprovação nos termos do item 8.1.7 deste Edital.

\subsection{Da data e do local de realização da Prova Objetiva:}

8.2.1 A aplicação da Prova Objetiva está prevista para o dia 08/01/2012, com duração de 4 horas e será realizada no Estado de Minas Gerais, nas cidades sedes das SRE's, constantes do Anexo IV deste Edital.

8.2.2 A confirmação da data de realização da Prova será publicada em aviso no Órgão Oficial dos Poderes do Estado - Minas Gerais, com antecedência mínima de 30 dias.

8.2.3 Havendo alteração da data prevista, as provas poderão ocorrer em domingos ou feriados.

8.2.4 Os candidatos que concorrerem às vagas para a Órgão Central da SEE e SRE's metropolitanas A, B e C realizarão as provas em Belo Horizonte.

8.2.5 Para fins de aplicação das provas, caso o número de candidatos inscritos exceda a oferta de lugares disponíveis nas escolas localizadas nas cidades sedes das SRE's indicadas no Anexo IV deste Edital, a FCC reserva-se o direito de aplicá-las em qualquer das cidades pertencentes às respectivas SRE's, não assumindo qualquer responsabilidade quanto ao transporte e alojamento desses candidatos.

8.2.6 O candidato somente poderá realizar as provas em data, local e horário definidos no Cartão Informativo de que trata o item 7.1 deste Edital.

8.2.7 O candidato não poderá alegar desconhecimento acerca da data, horário e local de realização da prova, para fins de justificativa de sua ausência.

\subsection{Das condições de realização da Prova Objetiva:}

8.3.1 A Prova Objetiva será aplicada em períodos distintos, a depender do cargo, com duração máxima de 4 (quatro) horas, de acordo com o indicado no quadro a seguir:

\begin{tabular}{|c|c|}
\hline $\begin{array}{l}\text { PERÍODO DE } \\
\text { APLICACÃO }\end{array}$ & CARGOS/CARREIRAS \\
\hline MANHÃ & $\begin{array}{l}\text { - Professor de Educação Básica - Anos Iniciais do Ensino Fundamental } \\
\text { - Assistente Técnico Educacional } \\
\text { - Assistente Técnico de Educação Básica }\end{array}$ \\
\hline TARDE & $\begin{array}{l}\text { - Professor de Educação Básica - Arte/Artes, Biologia, Educação Física, Filosofia, Física, } \\
\text { Geografia, História, Língua Estrangeira Moderna (Espanhol), Língua Estrangeira Moderna } \\
\text { (Inglês), Língua Portuguesa, Matemática, Química, Sociologia } \\
\text { - Analista Educacional } \\
\text { - Analista Educacional - Inspeção Escolar } \\
\text { - Especialista em Educação Básica - Orientação Educacional } \\
\text { - Especialista em Educação Básica - Supervisão Pedagógica }\end{array}$ \\
\hline
\end{tabular}

8.3.2 Ao candidato só será permitida a realização da prova na respectiva data, no local e no horário definidos no Cartão Informativo disponibilizado no endereço eletrônico da FCC www.concursosfcc.com.br, ou em eventual Ato Complementar a este Edital, publicado no Órgão Oficial dos Poderes do Estado - Minas Gerais. 
8.3.3 É de exclusiva responsabilidade do candidato tomar ciência do trajeto até o local de realização da Prova Objetiva, a fim de evitar eventuais atrasos, sendo aconselhável ao candidato visitar o local de realização da prova com antecedência.

8.3.4 O não comparecimento às provas, por qualquer motivo, caracterizará a desistência do candidato e resultará em sua eliminação deste Concurso Público.

8.3.5 Em nenhuma hipótese haverá segunda chamada para a Prova Objetiva, seja qual for o motivo alegado pelo candidato.

8.3.6 Somente será admitido à sala de prova o candidato que estiver portando documento de identidade original que bem o identifique, tal como carteira e/ou cédula de identidade expedida por Secretaria de Segurança Pública, pelas Forças Armadas, pela Polícia Militar, pelo Ministério das Relações Exteriores, Cédula de Identidade para Estrangeiros, Cédula de Identidade fornecida por Órgãos ou Conselhos de Classe que, por força de Lei Federal valem como documento de identidade, como, por exemplo, a da OAB, CRM, CREA, CRC etc., Passaporte, Carteira de Trabalho e Previdência Social, bem como Carteira Nacional de Habilitação (com fotografia na forma da Lei Federal nº. 9.503/1997).

8.3.7 O documento oficial de identificação deverá estar em perfeitas condições, de forma a permitir, com clareza, a identificação do candidato.

8.3.8 Caso o candidato esteja impossibilitado de apresentar, no dia de realização das provas, documento de identidade oficial, por motivo de extravio, perda, roubo ou furto, deverá apresentar certidão que ateste o registro da ocorrência em órgão policial expedida há, no máximo, 30 (trinta) dias da data da realização da prova e, ainda, ser submetido à identificação especial, compreendendo a coleta de assinatura e impressão digital em formulário específico.

8.3.9 A identificação especial será exigida, também, do candidato cujo documento de identificação gere dúvidas quanto à fisionomia, à assinatura ou à condição de conservação do documento.

8.3.10 No dia da realização da Prova Objetiva, na hipótese de o nome do candidato não constar das listagens oficiais relativas aos locais de prova estabelecidos no Cartão Informativo, a FCC fará a inclusão do candidato, desde que apresente o boleto bancário com comprovação de pagamento, mediante preenchimento de formulário específico.

8.3.11 Quando ocorrer a inclusão de que trata o item 8.3.10 deste Edital, a pertinência da inscrição será analisada pela FCC, na fase do julgamento da Prova Objetiva.

8.3.11.1 Constatada a improcedência da inscrição, a mesma será automaticamente cancelada, independentemente de qualquer formalidade, considerados nulos todos os atos dela decorrentes.

8.3.12 O candidato deverá comparecer ao local de prova munido de caneta esferográfica de material transparente - tinta preta, lápis preto $\mathrm{n}^{\circ} .2$ e borracha.

8.3.13 Após ser identificado e alocado na sala de prova, o candidato não poderá consultar ou manusear qualquer material de estudo ou leitura, enquanto aguarda o início da aplicação da Prova Objetiva.

8.3.14 Os pertences pessoais dos candidatos, tais como bolsas, sacolas, bonés, chapéus, gorros ou similares, relógio digital, telefone celular, óculos escuros, equipamentos eletrônicos serão lacrados - utilizando saco plástico e etiqueta, a serem fornecidos pela FCC exclusivamente para tal fim e acomodados em local a ser indicado pelos fiscais de sala de prova, onde deverão ser mantidos durante todo o período de permanência dos candidatos no local de prova, até o fim de sua realização.

8.3.14.1 Os aparelhos eletrônicos deverão ser desligados pelo candidato antes de serem lacrados. 
8.3.15 A FCC não se responsabilizará por perda ou extravio de documentos, objetos ou equipamentos eletrônicos ocorridos no local de realização de prova, nem por danos neles causados.

8.3.16 Em nenhuma hipótese será permitido:

a) o candidato prestar prova sem que esteja portando um documento oficial de identificação, contendo no mínimo foto, filiação e assinatura;

b) o candidato prestar prova sem que o seu pedido de inscrição esteja previamente confirmado;

c) o ingresso de candidato na sala de aplicação de prova após o início do exame;

d) o candidato prestar prova fora do horário ou espaço físico predeterminado e informado;

e) o ingresso ou a permanência de pessoa estranha ao certame, em qualquer sala de aplicação de prova, durante a realização do exame.

8.3.17 No ato da realização da Prova Objetiva será fornecido ao candidato o Caderno de Questões e a Folha de Respostas personalizada com os dados do candidato, para aposição da assinatura no campo próprio e transcrição das respostas.

8.3.18 Na Prova Objetiva, o candidato deverá assinalar as respostas das questões na Folha de Respostas personalizada, que será o único documento válido para a correção de sua prova.

8.3.19 O candidato deverá preencher a Folha de Respostas com caneta esferográfica de tinta preta e reforçar com grafite na cor preta, se necessário.

8.3.20 O candidato não deverá fazer nenhuma marca fora do campo reservado às respostas ou à assinatura, pois qualquer marca poderá ser lida pelas leitoras óticas, prejudicando o seu desempenho.

8.3.21 O preenchimento da Folha de Respostas será de inteira responsabilidade do candidato, que deverá proceder em conformidade com as instruções específicas contidas neste Edital e na capa do Caderno de Questões.

8.3.22 Em nenhuma hipótese haverá substituição da Folha de Respostas por erro do candidato, devendo este arcar com os prejuízos advindos de marcações feitas incorretamente.

8.3.23 Não serão computadas questões não assinaladas ou que contenham mais de uma resposta assinalada, emenda ou rasura, ainda que legível.

8.3.24 Objetivando garantir a lisura e a idoneidade do Concurso Público, bem como sua autenticidade, será solicitada aos candidatos, quando da aplicação da Prova Objetiva, a autenticação digital da Folha de Respostas personalizada.

8.3.24.1 Se, por qualquer motivo, não for possível a autenticação digital, o candidato deverá apor sua assinatura, em campo específico, por três vezes.

8.3.24.2 A autenticação digital (ou assinaturas) dos candidatos na Folha de Respostas visa a atender o disposto no item 14.3.2 deste Edital.

8.3.25 O candidato deverá conferir os seus dados pessoais impressos na Folha de Respostas e no Caderno de Questões, em especial seu nome, número de inscrição, número do documento de identidade e opção de cargo.

8.3.26 Caso sejam verificadas falhas de impressão após a distribuição dos Cadernos de Questões aos candidatos, o Coordenador do local de aplicação, antes do início da prova, diligenciará no sentido de:

a) substituição dos Cadernos de Questões defeituosos;

b) em não havendo número suficiente de Cadernos para a devida substituição, proceder-se-á à leitura dos itens onde ocorreram falhas, usando, para tanto, um Caderno de Questões completo; 
c) se a ocorrência se verificar após o início da prova, o Coordenador do local de aplicação, após contato com a $\mathrm{FCC}$, estabelecerá prazo para compensação do tempo usado para regularização do Caderno de Questões.

8.3.27 Por medida de segurança os candidatos deverão deixar as orelhas totalmente descobertas, à observação dos fiscais de sala, durante todo o período de realização da Prova Objetiva.

8.3.28 Motivará a eliminação do candidato deste Concurso Público, sem prejuízo das sanções penais cabíveis, a burla ou a tentativa de burla a quaisquer das normas definidas neste Edital ou a outras relativas a este concurso, aos comunicados, às instruções ao candidato e/ou às instruções constantes da prova, bem como o tratamento incorreto e/ou descortês a qualquer pessoa envolvida na aplicação da prova.

8.3.29 Poderá ser excluído do Concurso Público o candidato que, na Prova Objetiva, além das demais hipóteses previstas neste Edital:

a) apresentar-se em local diferente da convocação oficial;

b) apresentar-se após o horário estabelecido, não sendo admitida qualquer tolerância;

c) não apresentar documento que bem o identifique;

d) ausentar-se da sala de prova sem o acompanhamento do fiscal ou deixar a sala de prova sem a devida autorização;

e) ausentar-se do local de prova antes de decorridos 60 (sessenta) minutos do início da prova;

f) fizer anotação de informações relativas às suas respostas no comprovante de inscrição ou em qualquer outro meio que não o autorizado pela FCC;

g) ausentar-se da sala de prova levando Folha de Respostas, Caderno de Questões ou outros materiais não permitidos, sem autorização;

h) estiver portando armas, mesmo que possua licença para o respectivo porte;

i) utilizar de meios ilícitos para a execução das provas ou obter vantagem para si ou para outros;

j) não devolver integralmente o material recebido;

k) for surpreendido em comunicação com outras pessoas ou utilizando-se de livro, anotação ou impresso não permitidos ou similar;

1) estiver fazendo uso de qualquer tipo de aparelho eletrônico ou de comunicação (bip, telefone celular, relógios digitais, walkman, agenda eletrônica, máquina calculadora, notebook, palmtop, receptor, gravador, smartphones ou outros equipamentos similares), bem como protetores auriculares;

m) perturbar ou tumultuar, de qualquer modo, a ordem dos trabalhos;

n) tratar com falta de urbanidade examinadores, auxiliares, fiscais ou autoridades presentes;

o) estabelecer comunicação com outros candidatos ou com pessoas estranhas, por qualquer meio;

p) deixar de atender às orientações expedidas pelo Coordenador responsável pela aplicação da prova.

8.3.30 Os aparelhos eletrônicos indicados na alínea "l" do item 8.3.29 deste Edital deverão ser desligados pelo candidato, antes de serem lacrados, utilizando saco plástico e etiqueta fornecidos pela FCC exclusivamente para tal fim, devendo permanecer desta forma até a saída do candidato do local após o término de realização da prova.

8.3.31 Ao terminar a prova, o candidato entregará obrigatoriamente ao Fiscal da Sala sua Folha de Respostas assinada, juntamente com o Caderno de Questões. 
8.3.32 O candidato poderá deixar o local de exame somente após 60 (sessenta) minutos do início da prova.

8.3.33 Quando, após a prova, for constatado, por meio eletrônico, estatístico, visual ou grafológico ou por investigação policial, ter o candidato utilizado meios ilícitos, sua prova será anulada e ele será automaticamente eliminado deste Concurso Público.

8.3.34 Por razões de ordem técnica, de segurança e de direitos autorais adquiridos, não serão fornecidos exemplares dos Cadernos de Questões a candidatos ou a instituições de direito público ou privado, mesmo após o encerramento do Concurso Público.

8.3.35 Para fins de consulta do candidato, serão divulgadas no endereço eletrônico www.concursosfcc.com.br, no primeiro dia útil após a aplicação da Prova Objetiva, a(s) data(s) prevista(s) para divulgação das questões da Prova Objetiva, dos gabaritos e/ou dos resultados.

\section{DA SEGUNDA ETAPA DO CONCURSO - AVALIAÇÃO DE TÍTULOS}

9.1 A segunda etapa do Concurso Público será constituída por Avaliação de Títulos, de caráter apenas classificatório.

9.2 Serão convocados para a Avaliação de Títulos todos os candidatos inscritos que lograrem aprovação na Prova Objetiva, na forma do item 8.1.7 deste Edital.

9.3 A convocação do candidato para a apresentação de títulos será realizada mediante publicação de ato no Órgão Oficial dos Poderes do Estado - Minas Gerais, com indicação do local e do período para envio da documentação.

9.3.1 O Ato de Convocação será publicado com antecedência mínima de 20 (vinte) dias da data de início do prazo para entrega da documentação referente a títulos.

9.4 Na Avaliação de Títulos será considerada e pontuada a formação acadêmica do candidato, de acordo com os critérios estabelecidos Anexo VI deste Edital.

9.4.1 Para fins de Avaliação de Títulos, a formação acadêmica a ser pontuada não se confunde com a escolaridade mínima a ser exigida para ingresso no cargo pretendido, escolaridade esta informada no item 2.2 deste Edital.

9.4.2 Para fins de Avaliação de Títulos, não será considerado diploma ou certidão de conclusão de curso que seja requisito para ingresso no cargo concorrido pelo candidato.

9.4.3 O candidato deverá apresentar apenas um título acadêmico válido para o cargo em que se inscreveu, não sendo permitida acumulação de pontuação nesse caso.

9.4.4 Na apresentação do título a que se refere o item 9.4 deste Edital o candidato deverá optar por aquele que corresponda à pontuação mais elevada na forma definida no Anexo VI deste Edital.

9.5 Para o cargo de Professor de Educação Básica, além de observados os critérios definidos no item 9.4 deste Edital, será considerado e pontuado o Tempo de Serviço do candidato em estabelecimentos privados ou públicos (federais, estaduais, municipais) de acordo com os critérios estabelecidos no Anexo VI deste Edital.

9.5.1 Para que seja pontuado o Tempo de Serviço, o candidato deverá comprovar efetivo exercício de atividades correspondentes ao cargo e área de atuação para a qual se inscreveu, mediante apresentação de atestado expedido pela instituição onde exerceu as atividades, conforme modelo disponibilizado no Anexo VI deste Edital.

9.6 Será de responsabilidade exclusiva do candidato a entrega da documentação referente a títulos.

9.7 Serão aceitos os títulos obtidos pelo candidato até a data final do prazo de envio de títulos considerando para tanto a data da postagem indicada no envelope. 
9.8 Somente será avaliada a documentação encaminhada dentro do prazo estabelecido em Ato de Convocação a ser publicado, nos termos do item 9.3 deste Edital.

9.9 Expirado o período de envio da documentação, não serão aceitos pedidos de inclusão, complementação e/ou substituição, sob qualquer hipótese ou alegação.

9.10 Os documentos a serem encaminhados deverão ser rubricados e numerados por página, em ordem sequencial, conforme estiverem listados na Folha de Rosto constante do item 9.11 deste Edital.

9.11 Os títulos a serem avaliados deverão ser encaminhados pelo candidato com uma folha de rosto, obrigatoriamente digitada ou datilografada, conforme modelo a seguir:

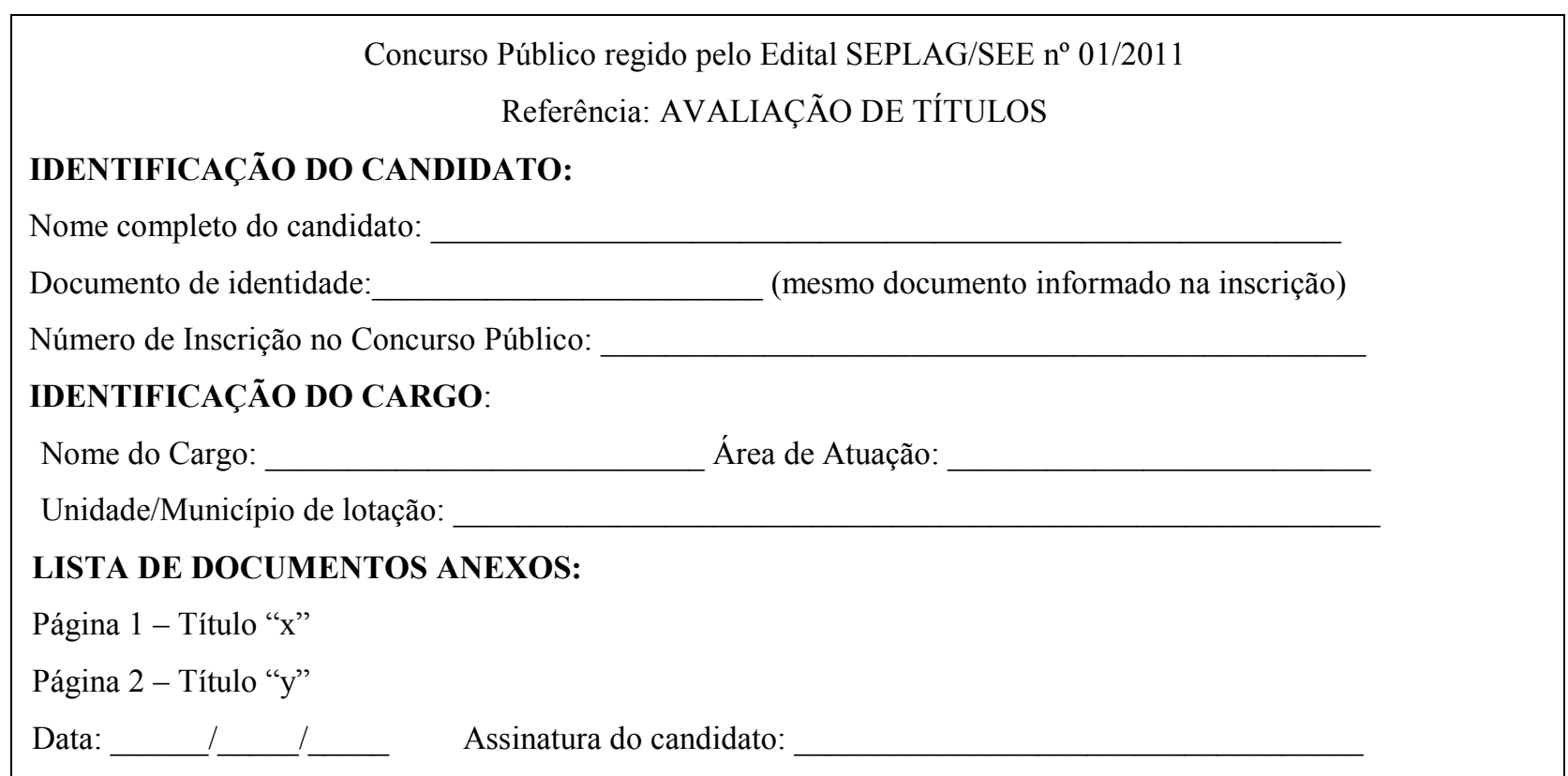

9.12 Caso o candidato não tenha qualquer título válido para o cargo em que se inscreveu, terá atribuída nota 0 (zero) na Avaliação de Títulos.

9.13 A documentação referente aos títulos deverá ser encaminhada por fotocópias - frente e verso - devidamente autenticadas em cartório.

9.14 Quando o nome do candidato for diferente do constante do título apresentado, deverá ser anexado comprovante de alteração do nome (por exemplo: certidão de casamento).

9.15 As certidões ou declarações de conclusão dos cursos mencionados no item 9.4 deste Edital referem-se a cursos comprovadamente concluídos.

9.16 Somente serão aceitas certidões ou declarações de cursos expedidas por instituição de ensino legalmente reconhecida pelo sistema federal ou pelos sistemas estaduais de ensino.

9.17 Caso o candidato ainda não detenha posse de seu diploma de conclusão do bacharelado/licenciatura, poderá apresentar certidão/declaração da conclusão do curso, acompanhada do histórico escolar, documentos expedidos pela Instituição de Ensino responsável pelo curso.

9.18 Caso o candidato ainda não detenha a posse de seu diploma de mestrado ou doutorado, poderá apresentar certidão/declaração da conclusão do curso, acompanhada do histórico escolar e da ata de defesa da dissertação e/ou tese, juntamente com declaração do coordenador do curso, documentos estes expedidos pela Instituição de Ensino responsável pelo curso. 
9.19 O título referente a curso realizado no exterior somente será considerado válido se o documento estiver revalidado conforme legislação vigente.

9.19.1 Os documentos comprobatórios de cursos realizados no exterior somente serão considerados quando traduzidos para a língua portuguesa por tradutor juramentado e devidamente revalidados por Universidades Oficiais credenciadas pelo Ministério da Educação - MEC.

9.20 A Avaliação de Títulos será de responsabilidade da FCC e o resultado será publicado no Órgão Oficial dos Poderes do Estado - Minas Gerais, podendo ainda ser divulgado no endereço eletrônico www.concursosfcc.com.br.

9.21 Não serão considerados documentos de candidatos não convocados para a Avaliação de Títulos.

9.22 Não serão aceitos documentos que não atenderem aos prazos e às exigências deste Edital e/ou suas complementações.

9.23 Em nenhuma hipótese haverá devolução aos candidatos de documentos referentes a títulos.

9.24 Comprovada, em qualquer tempo, irregularidade ou ilegalidade na obtenção dos títulos apresentados, o candidato terá anulada a respectiva pontuação e, comprovada a culpa do mesmo, este será excluído deste Concurso Público, sem prejuízo das medidas penais cabíveis.

\section{DO PROCESSO DE CLASSIFICAÇÃO E DESEMPATE DOS CANDIDATOS}

10.1 Será considerado aprovado neste Concurso Público o candidato que obtiver pontuação mínima exigida para aprovação na Prova Objetiva, nos termos do item 8.1.7 deste Edital.

10.2A nota final dos candidatos aprovados neste Concurso Público será igual ao total de pontos obtidos na Prova Objetiva acrescido dos pontos obtidos na Avaliação de Títulos.

10.2.1 O total de pontos obtido na Prova Objetiva será igual aos pontos obtidos nas questões de Conhecimentos Gerais somados aos pontos obtidos nas questões de Conhecimentos Específicos.

$10.3 \mathrm{Na}$ hipótese de igualdade de nota final entre candidatos, serão aplicados critérios de desempate, tendo preferência, sucessivamente, o candidato que tiver:

a) idade igual ou superior a 60 (sessenta) anos, conforme estabelece o parágrafo único do art. 27 da Lei Federal no ${ }^{\circ}$ 10.741/2003 (Estatuto do Idoso), sendo considerada, para esse fim, a data de realização das provas objetivas;

b) maior número de acertos nas questões de Conhecimentos Específicos da Prova Objetiva;

c) maior número de acertos nas questões de Conhecimentos Gerais da Prova Objetiva;

d) idade maior.

10.4Os candidatos aprovados neste Concurso Público serão classificados em ordem decrescente de nota final, observado o cargo, a área de atuação e a unidade de exercício para os quais concorreram.

10.5A classificação dos candidatos aprovados será feita em duas listas, a saber:

a) a primeira lista conterá a classificação de todos os candidatos (ampla concorrência), respeitados cargo, área de atuação e localidade para os quais se inscreveram, incluindo aqueles inscritos como portadores de deficiência;

b) a segunda lista conterá especificamente a classificação dos candidatos inscritos como portadores de deficiência, respeitados cargo, área de atuação e localidade para os quais se inscreveram. 
10.6 O resultado final deste Concurso Público será publicado no Órgão Oficial dos Poderes do Estado - Minas Gerais, onde constarão as notas finais dos candidatos aprovados, assim como a classificação por eles obtida.

10.7 O candidato não aprovado será excluído do Concurso Público e não constará da lista de classificação.

10.8 Não serão publicados os resultados obtidos pelos candidatos não aprovados neste Concurso Público.

10.8.1 Para os candidatos não aprovados neste Concurso Público, será disponibilizado Boletim de Desempenho nas provas para consulta, por meio do CPF e do número de inscrição do candidato, no endereço eletrônico www.concursosfcc.com.br, após a publicação dos resultados no Órgão Oficial dos Poderes do Estado - Minas Gerais.

\section{DOS RECURSOS}

11.1 Será admitido recurso quanto:

a) ao indeferimento do pedido de isenção do valor de inscrição;

b) indeferimento da inscrição;

c) às questões das provas e gabaritos preliminares;

d) ao resultado da Prova Objetiva;

e) à pontuação atribuída na Avaliação de Títulos;

f) ao somatório das notas atribuídas nas etapas e classificação dos candidatos no Concurso Público.

11.2 O prazo para interposição de recurso será de 2 (dois) dias úteis contados do primeiro dia subsequente da data de publicação oficial do ato objeto do recurso a que se refere o item 11.1 deste Edital, nos termos do artigo 22 do Regulamento Geral de Concurso Público, instituído pelo Decreto Estadual n ${ }^{\circ}$. 42.899/2002.

11.3 O prazo para interposição de recurso é preclusivo e comum a todos os candidatos.

11.4 O recurso contra o indeferimento do pedido de isenção do valor de inscrição, mencionado no item 11.1, na alínea "a" deste Edital, deverá ser interposto à FCC exclusivamente por meio da Internet, no endereço eletrônico www.concursos.fcc.com.br de acordo com as instruções constantes da página do Concurso Público.

11.5 Os recursos mencionados no item 11.1, alíneas " $b$ " a " $\mathrm{f}$ " deste Edital, deverão ser digitados ou datilografados e remetidos via Sedex ou correspondência com Aviso de Recebimento (AR), postado nas agências dos Correios, com custo por conta do candidato, endereçado à Fundação Carlos Chagas (A/C Departamento de Execução de Projetos - Ref.: Recurso - SEE-MG - Av. Professor Francisco Morato, 1565, Jardim Guedala - São Paulo - SP - CEP 05513-900).

11.6 O recurso interposto fora do respectivo prazo não será aceito, sendo considerada, para fins de comprovação da tempestividade do recurso, a data do registro da postagem.

11.7 Não serão aceitos recursos interpostos em prazo destinado a evento diverso do questionado.

11.8Os candidatos deverão enviar o recurso em duas vias (original e cópia).

11.8.1 Os recursos deverão ser digitados ou datilografados. 
11.8.2 Cada questão ou item deverá ser apresentado em folha separada, identificada conforme modelo a seguir:

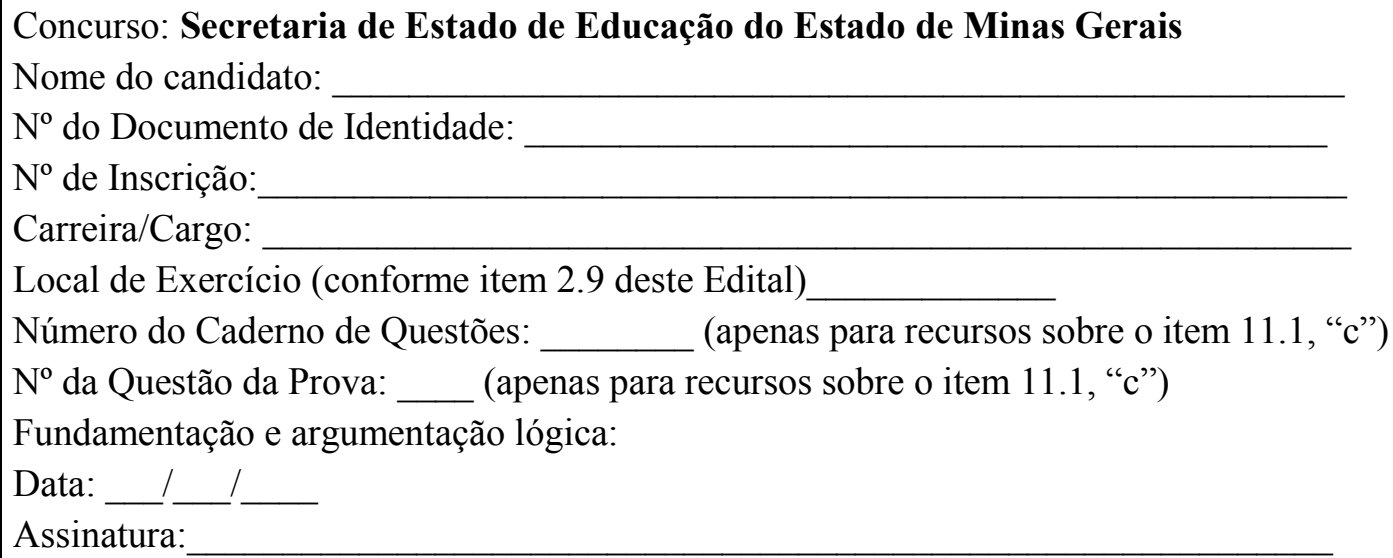

11.9 Admitir-se-á um único recurso por questão, relativamente ao seu conteúdo ou ao gabarito.

11.10 Não será acatado recurso interposto em coletivo.

11.11 Será divulgado o Boletim de Desempenho nas provas para consulta, por meio do CPF e do número de inscrição do candidato, no endereço eletrônico www.concursosfcc.com.br, após a publicação dos resultados no Órgão Oficial dos Poderes do Estado - Minas Gerais.

11.12 Todos os recursos deverão ser fundamentados, devendo o candidato ser claro, consistente e objetivo em seu pleito, sob pena de ter seu recurso indeferido.

11.13 Se, por força de decisão prévia, no período previsto para interposição de recurso, for processada alteração no gabarito anteriormente divulgado, será publicado ato de retificação do gabarito, sendo as provas corrigidas de acordo com a retificação.

11.13.1 Não será admitido recurso contra o ato de retificação de que trata o item 11.13 deste Edital.

11.14 Se da decisão sobre recurso interposto resultar anulação de questão(ões), os pontos a ela correspondentes serão atribuídos a todos os candidatos presentes à prova, independentemente de formulação de recurso.

11.15 Não será permitido ao candidato anexar cópia de qualquer documento quando da interposição de recurso.

11.16 Banca Examinadora constitui última instância para recurso, sendo soberana em suas decisões, razão pela qual não caberão recursos adicionais no âmbito administrativo.

\subsection{Serão indeferidos os recursos:}

a) cujo teor desrespeite a Banca Examinadora;

b) que estejam em desacordo com as especificações contidas neste Edital e com as instruções disponibilizadas no endereço eletrônico www.concursosfcc.com.br ;

c) com fundamentação inconsistente ou incoerente;

d) intempestivos.

11.18 Após análise dos recursos, será publicada no Órgão Oficial dos Poderes do Estado Minas Gerais a listagem daqueles que forem deferidos. 
11.19 As decisões de todos os recursos serão divulgadas no endereço eletrônico da FCC, $\boldsymbol{w w w . c o n c u r s o s f c c . c o m . b r}$, e ficarão disponibilizadas pelo prazo de 7 (sete) dias a contar da data de sua divulgação, com apresentação das razões de indeferimento dos recursos quando for o caso.

11.20 Após análise de todos os recursos interpostos, será publicado o resultado final deste Concurso Público no Órgão Oficial dos Poderes do Estado - Minas Gerais.

\section{DA HOMOLOGAÇÃO DO CONCURSO PÚBLICO}

12.1 A homologação do Concurso Público será processada por meio de ato da Secretária de Estado de Planejamento e Gestão, publicado no Órgão Oficial dos Poderes do Estado - Minas Gerais.

\section{DOS EXAMES MÉDICOS PRÉ-ADMISSIONAIS}

\subsection{Das Disposições Gerais:}

13.1.1 Todos os candidatos nomeados em decorrência de aprovação neste Concurso Público deverão se submeter a Exame Médico Pré-Admissional, sob a responsabilidade da Superintendência Central de Perícia Médica e Saúde Ocupacional da SEPLAG, em unidade central ou unidades regionais, que concluirá quanto à sua aptidão física e mental para o exercício do cargo.

13.1.2 Para a realização do Exame Médico Pré-Admissional o candidato deverá apresentar os seguintes documentos:

a) Boletim de Inspeção Médica - BIM - devidamente preenchido (frente);

b) fotocópia da publicação da nomeação;

c) documento original de identidade, com foto e assinatura;

d) comprovante de inscrição no Cadastro de Pessoa Física - CPF.

13.1.3 Para a realização do Exame Médico Pré-Admissional o candidato deverá apresentar também resultado dos seguintes exames, realizados às suas expensas:

a) hemograma completo;

b) contagem de plaquetas;

c) urina rotina;

d) glicemia de jejum;

e) $\mathrm{TSH}$;

f) glicohemoglobina;

g) creatinina;

h) radiografia de tórax em $\mathrm{PA}$ e perfil;

i) eletrocardiograma;

j) laringoscopia indireta com laudo descritivo e videolaringoscopia com laudo, somente para os candidatos ao cargo de Professor de Educação Básica.

13.1.4 Os exames descritos nas alíneas "a" a "i" do item 13.1.3 deste Edital poderão ser realizados em laboratórios de livre escolha do candidato e somente terão validade se realizados dentro de 30 (trinta) dias anteriores à data de marcação do Exame Pré-Admissional. 
13.1.5 O material de exame de urina de que trata a alínea "c" item 13.1.3 deste Edital deverá ser colhido no próprio laboratório, devendo esta informação constar do resultado do exame.

13.1.6 O exame descrito na alínea "j”" do item 13.1.3 deste Edital somente terá validade se realizado dentro de 90 (noventa) dias anteriores à data de marcação do Exame Pré-Admissional.

13.1.7 Nos resultados dos exames descritos em todas as alíneas do item 13.1.3 deste Edital deverão constar o número de identidade do candidato e a identificação dos profissionais que os realizaram.

13.1.8 Não serão aceitos resultados de exames emitidos pela Internet sem assinatura digital, fotocopiados ou por fax.

13.1.9 Os candidatos nomeados para o cargo de Professor de Educação Básica deverão se submeter ao treinamento de saúde vocal, realizado pela Superintendência Central de Perícia Médica e Saúde Ocupacional da SEPLAG.

13.1.10 No Exame Médico Pré-Admissional todos os candidatos deverão responder ao questionário de antecedentes clínicos.

13.1.11 No Exame Médico Pré-Admissional poderão ser exigidos novos exames e testes complementares que sejam considerados necessários para a conclusão sobre a aptidão física e mental do candidato para exercer o cargo em que foi nomeado.

13.1.12 O candidato que for considerado inapto no Exame Médico Pré-Admissional poderá recorrer da decisão ao Superintendente Central de Perícia Médica e Saúde Ocupacional da SEPLAG, no prazo máximo de 10 (dez) dias corridos, contados da data em que se der ciência do resultado da inaptidão ao candidato.

13.1.13 O recurso referido no item 13.1.12 suspende o prazo legal para a posse do candidato.

13.1.14 O candidato considerado inapto no Exame Médico Pré-Admissional estará impedido de tomar posse e terá seu ato de nomeação tornado sem efeito.

\subsection{Da Inspeção Médica para caracterização de deficiência:}

13.2.1 O candidato inscrito como portador de deficiência, quando nomeado em decorrência de aprovação neste Concurso Público, paralelamente à realização do Exame Médico Pré-Admissional de que trata o item 13.1 deste Edital, será submetido a Inspeção Médica para fins de caracterização de deficiência declarada no momento de inscrição no Concurso Público.

13.2.2 A Inspeção Médica de que trata o item 13.2.1 deste Edital, que será realizada pela Superintendência Central de Perícia Médica e Saúde Ocupacional da SEPLAG, decidirá sobre a caracterização do candidato como portador de deficiência segundo os critérios dispostos no artigo $4^{\circ}$ do Decreto Federal n ${ }^{\circ}$. 3.298/1999.

13.2.3 A utilização de material tecnológico de uso habitual não é fator de incompatibilidade com as atribuições dos cargos.

13.2.4 Após realização da Inspeção Médica, a conclusão será formalizada por meio de Certidão de Caracterização de Deficiência.

13.2.5 A Certidão que caracterize o candidato como não portador de deficiência propiciará ao mesmo a oportunidade de recorrer ao Superintendente Central de Perícia Médica e Saúde Ocupacional da SEPLAG, no prazo máximo de 10 (dez) dias corridos contados da data em que a Inspeção Médica der ciência do resultado ao candidato.

13.2.6 Concluindo a Inspeção Médica pela não caracterização de deficiência do candidato para fins de reserva de vagas, o candidato será excluído da lista de classificação específica de portadores de deficiência e permanecerá na lista de classificação da ampla concorrência. 


\subsection{Da avaliação de candidato portador de deficiência por Equipe Multiprofissional:}

13.3.1 O candidato portador de deficiência aprovado neste Concurso Público, quando nomeado e caracterizado como tal na Inspeção Médica de que trata o item 13.2 deste Edital, será submetido a Avaliação para fins de verificação de compatibilidade entre a sua deficiência e as atribuições do cargo em que foi nomeado.

13.3.2 A Avaliação de que trata o item 13.3.1 deste Edital será realizada por Equipe Multiprofissional da Superintendência Central de Perícia Médica e Saúde Ocupacional da SEPLAG e profissional integrante da carreira para a qual foi nomeado o candidato.

13.3.3 A Equipe Multiprofissional verificará as informações prestadas pelo candidato no ato da inscrição, a natureza das atribuições e tarefas essenciais ao cargo, a viabilidade das condições e acessibilidade, as adequações do ambiente de trabalho na execução das tarefas, a possibilidade de uso de equipamentos ou outros meios que habitualmente utilize, a Classificação Internacional de Doenças (CID) apresentada, e emitirá Parecer fundamentado acerca da compatibilidade da deficiência com as atividades a serem desempenhadas pelo candidato.

13.3.4 A realização da Avaliação prevista no item 13.3.1 deste Edital não dispensa o candidato inscrito como portador de deficiência da realização do Exame Médico Pré-Admissional, previsto no item 13.1 deste Edital.

13.3.5 Verificada a incompatibilidade entre a deficiência e as atribuições do cargo postulado, $\mathrm{o}$ candidato perderá o direito à posse.

\section{DO PROVIMENTO DO CARGO - NOMEAÇÃO, POSSE E EXERCÍCIO}

14.1 Concluído o Concurso Público e homologado o resultado final, a concretização do ato de nomeação dos candidatos aprovados dentro do número de vagas ofertadas neste Edital obedecerá à estrita ordem de classificação, ao prazo de validade do concurso e ao cumprimento das disposições legais pertinentes.

14.2 O candidato nomeado deverá se apresentar para posse no prazo estabelecido pelo art. 66 da Lei Estadual nº. 869/1952, sob pena de ter seu ato de nomeação tornado sem efeito.

14.3 O candidato nomeado deverá apresentar obrigatoriamente, no ato da posse:

a) 02 (duas) fotos $3 \times 4$;

b) fotocópia do documento de identidade com fotografia, acompanhada do original;

c) fotocópia do Título de Eleitor com o comprovante de votação na última eleição, acompanhada do original;

d) fotocópia do Cadastro Nacional de Pessoa Física (CPF), acompanhada do original;

e) fotocópia do Certificado de Reservista ou de Dispensa de Incorporação, para candidatos do sexo masculino, acompanhada do original;

f) fotocópia do comprovante de residência, acompanhada do original;

g) Resultado de Laudo Médico Pericial - REM com conclusão pela aptidão para o cargo;

h) no caso dos portadores de deficiência amparados pela Lei Estadual n ${ }^{0} 11.867 / 95$, Certidão de Caracterização da Deficiência - CADE, emitida pela Superintendência Central de Perícia Médica e Saúde Ocupacional da SEPLAG;

i) declaração de que exerce, ou não, outro cargo, emprego ou função pública nos âmbitos federal, estadual e/ou municipal;

j) declaração de bens atualizada até a data da posse; 
k) cartão de cadastramento no PIS/PASEP, se tiver;

1) declaração de não estar cumprindo sanção por inidoneidade, aplicada por qualquer órgão público ou entidade do âmbito federal, estadual ou municipal;

m) declaração de próprio punho de não ter sido demitido a bem do serviço público, nos últimos cinco anos, nos termos do Parágrafo Único do art. 259, da Lei Estadual n ${ }^{\circ}$. 869/1952;

n) comprovante de escolaridade mínima exigida para o cargo, nas condições especificadas no item 2.2 deste Edital.

14.3.1 O Candidato nomeado será responsabilizado administrativamente por quaisquer informações inverídicas que vier a prestar.

14.3.2 A SEE, no momento de recebimento dos documentos para a posse, afixará 1 (uma) foto $3 \times 4$ do candidato no Cartão de Autenticação Digital - CAD, coletará a assinatura do candidato e procederá à autenticação digital no cartão para confirmação dos dados digitais e/ou assinaturas solicitadas no dia da realização das provas.

14.4 Estará impedido de tomar posse o candidato que deixar de comprovar qualquer um dos requisitos especificados no item 14.3 deste Edital.

14.5 O candidato que concorrer a cargos cuja habilitação exigida (área de atuação) permita cursos por equivalência/similaridade ao exigido deverá apresentar o respectivo histórico escolar.

14.6 A escolha da vaga para a posse será feita pelo candidato de acordo com a ordem de classificação final no Concurso Público e será restrita às vagas especificadas no município de inscrição. Os candidatos nomeados serão convocados pela SEE ou SRE vinculada ao município de inscrição, à exceção dos nomeados para o município de Belo Horizonte que farão a escolha da vaga em local a ser divulgado pela SEE.

14.7 Após tomar posse, o candidato passará à condição de servidor público e deverá entrar em exercício no prazo estabelecido pelo art. 70 da Lei Estadual nº. 869/1952.

$14.8 \mathrm{O}$ candidato que for nomeado na condição de portador de deficiência não poderá arguir ou utilizar essa condição para pleitear ou justificar pedido de relotação, reopção de vaga, alteração de carga horária, alteração de jornada de trabalho e limitação de atribuições para o desempenho da função.

14.9 Durante o período de estágio probatório o servidor não poderá solicitar remoção ou mudança de lotação, sendo desconsiderada qualquer pretensão nesse sentido.

\section{DAS DISPOSIÇÕES FINAIS}

15.1 A SEPLAG, a SEE e a FCC eximem-se das despesas com viagens e estadia dos candidatos para prestar as provas deste Concurso Público.

15.2 Todas as publicações oficiais referentes ao Concurso Público de que trata este Edital serão feitas no Órgão Oficial dos Poderes do Estado - Minas Gerais e providenciadas pela SEPLAG.

15.3 O acompanhamento das publicações, atos complementares, avisos, comunicados e convocações referentes ao Concurso Público é de responsabilidade exclusiva do candidato.

$15.4 \mathrm{O}$ candidato deverá consultar o endereço eletrônico da FCC www.concursosfcc.com. $\boldsymbol{b r}$ frequentemente para verificar as informações que lhe são pertinentes referentes à execução do Concurso Público, até a data de homologação.

15.5 Não serão prestadas, por telefone, informações relativas ao resultado deste Concurso Público. 
15.6 A eventual disponibilização de atos nos endereços eletrônicos da FCC, da SEPLAG e da SEE não isenta o candidato da obrigação de acompanhar as publicações oficiais sobre este Concurso Público.

15.7 Incorporar-se-ão a este Edital, para todos os efeitos, quaisquer atos complementares, avisos, comunicados e convocações, relativos a este Concurso Público, que vierem a ser publicados no Órgão Oficial dos Poderes do Estado - Minas Gerais.

15.8 Não será fornecido qualquer documento comprobatório de aprovação ou classificação ao candidato, valendo, para esse fim, a publicação no Órgão Oficial dos Poderes do Estado - Minas Gerais.

15.9 Os prazos estabelecidos neste Edital são preclusivos, contínuos e comuns a todos os candidatos, não havendo justificativa para o não cumprimento e para a apresentação de documentos após as datas estabelecidas.

15.10 A SEPLAG, a SEE e a FCC não se responsabilizam por quaisquer cursos, textos, apostilas e outras publicações referentes às matérias deste Concurso Público que não sejam oficialmente divulgadas ou por quaisquer informações que estejam em desacordo com o disposto neste Edital.

15.11 Para contagem dos prazos de interposição de recursos, deverá ser observado o disposto no item 11 deste Edital.

15.12 Não serão considerados requerimentos, reclamações, notificações extrajudiciais ou quaisquer outros instrumentos similares, cujo teor seja objeto de recurso apontado neste Edital.

15.13 A qualquer tempo poder-se-á anular a inscrição, prova e/ou tornar sem efeito a nomeação do candidato, em todos os atos relacionados ao Concurso Público, quando constatada a omissão ou declaração falsa de dados ou condições, irregularidade de documentos, ou ainda, irregularidade na realização das provas, com finalidade de prejudicar direito ou criar obrigação.

15.13.1 Comprovada a inexatidão ou irregularidades descritas no item 15.13 deste Edital, o candidato estará sujeito a responder por falsidade ideológica de acordo com o art. 299 do Código Penal.

15.14 Em caso de verificação de incorreção nos dados pessoais (nome, endereço, telefone para contato, data de nascimento, etc.) constantes do Formulário Eletrônico de Inscrição, o candidato deverá atualizar suas informações nas seguintes condições:

a) efetuar a atualização dos dados pessoais até o terceiro dia útil após a aplicação das provas, conforme estabelecido no item 7.6 deste Edital, por meio do site www.concursosfcc.com.br.

b) após o prazo estabelecido no item 15.14 "a" e até a homologação deste Concurso Público, efetuar a atualização junto à FCC via Sedex ou Aviso de Recebimento (AR), endereçado ao Serviço de Atendimento ao Candidato - SAC - Ref.: Atualização de Dados Cadastrais/SEE-MG Av. Prof. Francisco Morato, 1565, Jardim Guedala - São Paulo - SP - CEP 05513-900).

c) após a data de homologação e durante o prazo de validade deste Concurso Público, efetuar a atualização junto à SEPLAG por meio de correspondência registrada, às expensas do candidato, endereçada à Secretaria de Estado de Planejamento e Gestão (A/C Diretoria Central de Provisão Ref.: Atualização de Dados do Concurso SEPLAG/SEE n. ${ }^{\circ}$ 01/2011 - Rodovia Prefeito Américo Gianetti, $\mathrm{s} / \mathrm{n}^{\mathrm{o}}$, Serra Verde - Belo Horizonte - MG - CEP: 31.630-901).

15.15 A SEPLAG, a SEE e a FCC não se responsabilizam por eventuais prejuízos ao candidato decorrentes de:

a) endereço eletrônico errado e/ou desatualizado;

b) endereço residencial desatualizado;

c) correspondência devolvida pelos Correios (ECT) por razões diversas; 
d) correspondência recebida por terceiros.

15.16 As ocorrências não previstas neste Edital, os casos omissos e os casos duvidosos serão resolvidos, pela Comissão de Concurso da SEE, pela SEPLAG e pela FCC, no que a cada um couber.

15.17 Poderão os candidatos valer-se das normas ortográficas vigentes antes ou depois daquelas implementadas pelo Decreto Federal $n^{\circ}$. 6.583, de 29 de setembro de 2008, em decorrência do período de transição previsto no art. $2^{\circ}$, parágrafo único da citada norma que estabeleceu acordo ortográfico da Língua Portuguesa.

15.18 Nos casos em que não for preenchido o número de vagas ofertado em edital por ausência de candidatos aprovados em número suficiente para determinada localidade, a Administração poderá realizar processo de reopção de vagas, a ser definido em edital específico, de forma que candidatos classificados em uma mesma área de atuação possam optar por concorrer a vaga de localidade diversa daquela em que se inscreveram inicialmente.

15.19 Os itens deste Edital poderão sofrer eventuais alterações, atualizações ou acréscimos enquanto não consumada a providência ou evento que lhes disser respeito, circunstância que será comunicada em ato complementar ao Edital ou aviso a ser publicado no Órgão Oficial dos Poderes do Estado - Minas Gerais.

Em Belo Horizonte, aos 11 de julho de 2011.

RENATA MARIA PAES DE VILHENA

Secretária de Estado de Planejamento e Gestão 
ANEXO I

QUADRO GERAL DE VAGAS POR CARGO

\begin{tabular}{|c|c|c|c|}
\hline CARGO & ÁREA DE ATUAÇÃO & $\begin{array}{c}\text { NÚMERO DE } \\
\text { VAGAS - AMPLA } \\
\text { CONCORRENCIA }\end{array}$ & $\begin{array}{l}\text { NÚMERO DE VAGAS } \\
\text { RESERVADAS A } \\
\text { PORTADORES DE } \\
\text { DEFICIÊNCIA(*) }\end{array}$ \\
\hline $\begin{array}{c}\text { Assistente Técnico } \\
\text { Educacional - ATE - nível I } \\
\text { - grau A }\end{array}$ & $\begin{array}{l}\text { Técnico / Apoio Técnico em } \\
\text { SRE e na Órgão Central da SEE }\end{array}$ & 603 & 60 \\
\hline $\begin{array}{c}\text { Assistente Técnico de } \\
\text { Educação Básica - ATB - } \\
\text { nível I - grau A }\end{array}$ & $\begin{array}{c}\text { Técnico / Apoio Técnico em } \\
\text { Escolas Estaduais }\end{array}$ & 4.401 & 440 \\
\hline $\begin{array}{c}\text { Analista Educacional - ANE } \\
\text { - nível I - grau A }\end{array}$ & $\begin{array}{c}\text { Atividades técnicas em SRE e na } \\
\text { Órgão Central da SEE }\end{array}$ & 378 & 38 \\
\hline $\begin{array}{c}\text { Analista Educacional / } \\
\text { Inspeção Escolar - ANE/IE } \\
\text { - nível I - grau A }\end{array}$ & Inspeção Escolar & 133 & 13 \\
\hline Especialista em Educação & Orientação Educacional & 252 & 25 \\
\hline grau A & Supervisão Pedagógica & 1.617 & 162 \\
\hline \multirow{14}{*}{$\begin{array}{c}\text { Professor de Educação } \\
\text { Básica - PEB - nível I - } \\
\text { grau A }\end{array}$} & $\begin{array}{l}\text { Anos Iniciais do Ensino } \\
\text { Fundamental }\end{array}$ & 3.551 & 355 \\
\hline & Arte/Artes & 432 & 43 \\
\hline & Biologia & 1.124 & 112 \\
\hline & Educação Física & 1.377 & 138 \\
\hline & Filosofia & 654 & 65 \\
\hline & Física & 739 & 74 \\
\hline & Geografia & 700 & 70 \\
\hline & História & 730 & 73 \\
\hline & $\begin{array}{l}\text { Língua Estrangeira Moderna: } \\
\text { Espanhol }\end{array}$ & 97 & 10 \\
\hline & $\begin{array}{c}\text { Língua Estrangeira Moderna: } \\
\text { Inglês }\end{array}$ & 542 & 54 \\
\hline & Língua Portuguesa & 1.179 & 118 \\
\hline & Matemática & 1.476 & 148 \\
\hline & Química & 815 & 82 \\
\hline & Sociologia & 577 & 58 \\
\hline
\end{tabular}

(*) O número de vagas reservadas a candidatos portadores de deficiência está contido no total de vagas, conforme item 3.3 deste Edital. 
ANEXO II

DISTRIBUIÇÃO DE VAGAS POR SUPERINTENDÊNCIAS REGIONAIS DE ENSINO/MUNICÍPIOS

\begin{tabular}{|c|c|c|}
\hline SRE & TOTAL DE VAGAS & $\begin{array}{l}\text { VAGAS RESERVADAS - } \\
\text { PORTADORES DE DEFICIÊNCIA }\end{array}$ \\
\hline ÓRGÃO CENTRAL & 106 & 11 \\
\hline METROPOLITANA A & 24 & 2 \\
\hline METROPOLITANA B & 46 & 5 \\
\hline METROPOLITANA C & 32 & 3 \\
\hline ALMENARA & 10 & 1 \\
\hline ARAÇUAÍ & 27 & 3 \\
\hline BARBACENA & 9 & 1 \\
\hline CAMPO BELO & 2 & 0 \\
\hline CARANGOLA & 3 & 0 \\
\hline CARATINGA & 8 & 1 \\
\hline CAXAMBU & 2 & 0 \\
\hline CONSELHEIRO LAFAIETE & 10 & 1 \\
\hline CORONEL FABRICIANO & 7 & 1 \\
\hline CURVELO & 5 & 0 \\
\hline DIAMANTINA & 19 & 2 \\
\hline DIVINÓPOLIS & 17 & 2 \\
\hline GOVERNADOR VALADARES & 9 & 1 \\
\hline GUANHÃES & 6 & 1 \\
\hline ITAJUBÁ & 5 & 0 \\
\hline ITUIUTABA & 3 & 0 \\
\hline JANAÚBA & 11 & 1 \\
\hline JANUÁRIA & 11 & 1 \\
\hline JUIZ DE FORA & 11 & 1 \\
\hline LEOPOLDINA & 9 & 1 \\
\hline MANHUAÇU & 16 & 2 \\
\hline MONTE CARMELO & 4 & 0 \\
\hline MONTES CLAROS & 7 & 1 \\
\hline MURIAÉ & 4 & 0 \\
\hline NOVA ERA & 13 & 1 \\
\hline OURO PRETO & 6 & 1 \\
\hline PARÁ DE MINAS & 15 & 1 \\
\hline PARACATU & 5 & 0 \\
\hline PASSOS & 3 & 0 \\
\hline PATOS DE MINAS & 7 & 1 \\
\hline PATROCÍNIO & 3 & 0 \\
\hline PIRAPORA & 7 & 1 \\
\hline POÇOS DE CALDAS & 7 & 1 \\
\hline
\end{tabular}




\begin{tabular}{|l|c|c|}
\hline PONTE NOVA & 8 & 1 \\
\hline POUSO ALEGRE & 7 & 1 \\
\hline SÃO JOÃO DEL REI & 14 & 0 \\
\hline SÃO SEBASTĨ̃O DO PARAÍSO & 3 & 1 \\
\hline SETE LAGOAS & 6 & 0 \\
\hline TEÓFILO OTONI & 4 & 1 \\
\hline UBÁ & 11 & 1 \\
\hline UBERABA & 10 & 1 \\
\hline UBERLÂNDIA & 9 & 3 \\
\hline UNAÍ & 25 & 2 \\
\hline VARGINHA & 17 & $\mathbf{6 0}$ \\
\hline TOTAL & $\mathbf{6 0 3}$ & \\
\hline
\end{tabular}

CARGO : ASSISTENTE TÉCNICO DE EDUCAÇÃO BÁSICA - ATB

\begin{tabular}{|c|c|c|c|}
\hline S R E & MUNICIPIO & $\begin{array}{l}\text { TOTAL DE } \\
\text { VAGAS }\end{array}$ & $\begin{array}{c}\text { VAGAS } \\
\text { RESERVADAS - } \\
\text { PORTADORES DE } \\
\text { DEFICIÊNCIA } \\
\end{array}$ \\
\hline ALMENARA & AGUAS VERMELHAS & 6 & 1 \\
\hline ALMENARA & ALMENARA & 3 & 0 \\
\hline ALMENARA & BANDEIRA & 1 & 0 \\
\hline ALMENARA & CACHOEIRA DE PAJEU & 2 & 0 \\
\hline ALMENARA & CURRAL DE DENTRO & 4 & 0 \\
\hline ALMENARA & DIVISA ALEGRE & 1 & 0 \\
\hline ALMENARA & DIVISOPOLIS & 0 & 0 \\
\hline ALMENARA & FELISBURGO & 2 & 0 \\
\hline ALMENARA & JACINTO & 1 & 0 \\
\hline ALMENARA & JEQUITINHONHA & 2 & 0 \\
\hline ALMENARA & JOAIMA & 4 & 0 \\
\hline ALMENARA & JORDANIA & 3 & 0 \\
\hline ALMENARA & MATA VERDE & 2 & 0 \\
\hline ALMENARA & MONTE FORMOSO & 1 & 0 \\
\hline ALMENARA & PALMOPOLIS & 1 & 0 \\
\hline ALMENARA & PEDRA AZUL & 2 & 0 \\
\hline ALMENARA & RIO DO PRADO & 1 & 0 \\
\hline ALMENARA & RUBIM & 2 & 0 \\
\hline ALMENARA & SALTO DA DIVISA & 2 & 0 \\
\hline ALMENARA & SANTA MARIA DO SALTO & 1 & 0 \\
\hline ALMENARA & SANTO ANTONIO DO JACINTO & 4 & 0 \\
\hline ARACUAI & ARACUAI & 5 & 1 \\
\hline ARACUAI & BERILO & 9 & 1 \\
\hline ARACUAI & BERIZAL & 1 & 0 \\
\hline ARACUAI & CHAPADA DO NORTE & 6 & 1 \\
\hline ARACUAI & COMERCINHO & 1 & 0 \\
\hline
\end{tabular}




\begin{tabular}{|c|c|c|c|}
\hline ARACUAI & CORONEL MURTA & 0 & 0 \\
\hline ARACUAI & FRANCISCO BADARO & 4 & 0 \\
\hline ARACUAI & FRUTA DE LEITE & 2 & 0 \\
\hline ARACUAI & INDAIABIRA & 4 & 0 \\
\hline ARACUAI & ITAOBIM & 4 & 0 \\
\hline ARACUAI & ITINGA & 7 & 1 \\
\hline ARACUAI & JENIPAPO DE MINAS & 1 & 0 \\
\hline ARACUAI & JOSE GONCALVES DE MINAS & 2 & 0 \\
\hline ARACUAI & MEDINA & 7 & 1 \\
\hline ARACUAI & NINHEIRA & 2 & 0 \\
\hline ARACUAI & NOVORIZONTE & 1 & 0 \\
\hline ARACUAI & RUBELITA & 5 & 1 \\
\hline ARACUAI & SALINAS & 7 & 1 \\
\hline ARACUAI & SANTA CRUZ DE SALINAS & 0 & 0 \\
\hline ARACUAI & TAIOBEIRAS & 8 & 1 \\
\hline ARACUAI & VIRGEM DA LAPA & 3 & 0 \\
\hline BARBACENA & ALFREDO VASCONCELOS & 4 & 0 \\
\hline BARBACENA & ALTO RIO DOCE & 3 & 0 \\
\hline BARBACENA & ANDRELANDIA & 3 & 0 \\
\hline BARBACENA & ANTONIO CARLOS & 5 & 1 \\
\hline BARBACENA & ARACITABA & 0 & 0 \\
\hline BARBACENA & BARBACENA & 14 & 1 \\
\hline BARBACENA & BARROSO & 5 & 1 \\
\hline BARBACENA & BIAS FORTES & 1 & 0 \\
\hline BARBACENA & CAPELA NOVA & 1 & 0 \\
\hline BARBACENA & CARANDAI & 3 & 0 \\
\hline BARBACENA & CIPOTANEA & 4 & 0 \\
\hline BARBACENA & DESTERRO DO MELO & 1 & 0 \\
\hline BARBACENA & IBERTIOGA & 2 & 0 \\
\hline BARBACENA & MADRE DE DEUS DE MINAS & 3 & 0 \\
\hline BARBACENA & MERCES & 1 & 0 \\
\hline BARBACENA & OLIVEIRA FORTES & 0 & 0 \\
\hline BARBACENA & PAIVA & 0 & 0 \\
\hline BARBACENA & PIEDADE DO RIO GRANDE & 1 & 0 \\
\hline BARBACENA & RESSAQUINHA & 0 & 0 \\
\hline BARBACENA & SANTA BARBARA DO TUGURIO & 1 & 0 \\
\hline BARBACENA & SANTA RITA DO IBITIPOCA & 1 & 0 \\
\hline BARBACENA & SANTANA DO GARAMBEU & 0 & 0 \\
\hline BARBACENA & SAO VICENTE DE MINAS & 3 & 0 \\
\hline BARBACENA & SENHORA DOS REMEDIOS & 3 & 0 \\
\hline CAMPO BELO & AGUANIL & 1 & 0 \\
\hline CAMPO BELO & CAMACHO & 1 & 0 \\
\hline CAMPO BELO & CAMPO BELO & 13 & 1 \\
\hline CAMPO BELO & CANA VERDE & 1 & 0 \\
\hline CAMPO BELO & CANDEIAS & 2 & 0 \\
\hline
\end{tabular}




\begin{tabular}{|c|c|c|c|}
\hline CAMPO BELO & CRISTAIS & 0 & 0 \\
\hline CAMPO BELO & LAVRAS & 13 & 1 \\
\hline CAMPO BELO & PERDOES & 3 & 0 \\
\hline CAMPO BELO & RIBEIRAO VERMELHO & 1 & 0 \\
\hline CAMPO BELO & SANTANA DO JACARE & 1 & 0 \\
\hline CAMPO BELO & SANTO ANTONIO DO AMPARO & 4 & 0 \\
\hline CAMPO BELO & SAO FRANCISCO DE PAULA & 1 & 0 \\
\hline CARANGOLA & ALTO CAPARAO & 2 & 0 \\
\hline CARANGOLA & CAIANA & 2 & 0 \\
\hline CARANGOLA & CAPARAO & 4 & 0 \\
\hline CARANGOLA & CARANGOLA & 14 & 1 \\
\hline CARANGOLA & DIVINO & 8 & 1 \\
\hline CARANGOLA & ESPERA FELIZ & 9 & 1 \\
\hline CARANGOLA & FARIA LEMOS & 1 & 0 \\
\hline CARANGOLA & FERVEDOURO & 2 & 0 \\
\hline CARANGOLA & ORIZANIA & 0 & 0 \\
\hline CARANGOLA & PEDRA DOURADA & 0 & 0 \\
\hline CARANGOLA & TOMBOS & 3 & 0 \\
\hline CARATINGA & ALVARENGA & 2 & 0 \\
\hline CARATINGA & BOM JESUS DO GALHO & 2 & 0 \\
\hline CARATINGA & BUGRE & 0 & 0 \\
\hline CARATINGA & CARATINGA & 24 & 3 \\
\hline CARATINGA & CORREGO NOVO & 0 & 0 \\
\hline CARATINGA & DOM CAVATI & 2 & 0 \\
\hline CARATINGA & ENTRE FOLHAS & 1 & 0 \\
\hline CARATINGA & IAPU & 2 & 0 \\
\hline CARATINGA & IMBE DE MINAS & 3 & 0 \\
\hline CARATINGA & INHAPIM & 8 & 1 \\
\hline CARATINGA & IPABA & 4 & 0 \\
\hline CARATINGA & IPANEMA & 6 & 1 \\
\hline CARATINGA & PIEDADE DE CARATINGA & 1 & 0 \\
\hline CARATINGA & PINGO D AGUA & 1 & 0 \\
\hline CARATINGA & POCRANE & 2 & 0 \\
\hline CARATINGA & SANTA BARBARA DO LESTE & 2 & 0 \\
\hline CARATINGA & SANTA RITA DE MINAS & 1 & 0 \\
\hline CARATINGA & SAO DOMINGOS DAS DORES & 2 & 0 \\
\hline CARATINGA & SAO JOAO DO ORIENTE & 0 & 0 \\
\hline CARATINGA & SAO SEBASTIAO DO ANTA & 3 & 0 \\
\hline CARATINGA & TAPARUBA & 0 & 0 \\
\hline CARATINGA & TARUMIRIM & 7 & 1 \\
\hline CARATINGA & UBAPORANGA & 5 & 1 \\
\hline CARATINGA & VARGEM ALEGRE & 0 & 0 \\
\hline CAXAMBU & AIURUOCA & 1 & 0 \\
\hline CAXAMBU & ALAGOA & 0 & 0 \\
\hline CAXAMBU & BAEPENDI & 5 & 1 \\
\hline
\end{tabular}




\begin{tabular}{|c|c|c|c|}
\hline CAXAMBU & BOCAINA DE MINAS & 0 & 0 \\
\hline CAXAMBU & CARVALHOS & 1 & 0 \\
\hline CAXAMBU & CAXAMBU & 3 & 0 \\
\hline CAXAMBU & CONCEICAO DO RIO VERDE & 6 & 1 \\
\hline CAXAMBU & CRUZILIA & 8 & 1 \\
\hline CAXAMBU & ITAMONTE & 3 & 0 \\
\hline CAXAMBU & ITANHANDU & 8 & 1 \\
\hline CAXAMBU & JESUANIA & 2 & 0 \\
\hline CAXAMBU & LIBERDADE & 2 & 0 \\
\hline CAXAMBU & MINDURI & 3 & 0 \\
\hline CAXAMBU & OLIMPIO NORONHA & 0 & 0 \\
\hline CAXAMBU & PASSA QUATRO & 6 & 1 \\
\hline CAXAMBU & PASSA VINTE & 0 & 0 \\
\hline CAXAMBU & POUSO ALTO & 0 & 0 \\
\hline CAXAMBU & SAO LOURENCO & 10 & 1 \\
\hline CAXAMBU & SAO SEBASTIAO DO RIO VERDE & 0 & 0 \\
\hline CAXAMBU & SAO TOME DAS LETRAS & 5 & 1 \\
\hline CAXAMBU & SERITINGA & 0 & 0 \\
\hline CAXAMBU & SERRANOS & 0 & 0 \\
\hline CAXAMBU & SOLEDADE DE MINAS & 2 & 0 \\
\hline CEL. FABRICIANO & ANTONIO DIAS & 4 & 0 \\
\hline CORONEL FABRICIANO & BELO ORIENTE & 3 & 0 \\
\hline CORONEL FABRICIANO & BRAUNAS & 2 & 0 \\
\hline CORONEL FABRICIANO & CORONEL FABRICIANO & 15 & 2 \\
\hline CORONEL FABRICIANO & IPATINGA & 25 & 4 \\
\hline CORONEL FABRICIANO & JAGUARAÇU & 0 & 0 \\
\hline CORONEL FABRICIANO & JOANESIA & 1 & 0 \\
\hline CORONEL FABRICIANO & MARLIERIA & 2 & 0 \\
\hline CORONEL FABRICIANO & MESQUITA & 2 & 0 \\
\hline CORONEL FABRICIANO & SANTANA DO PARAISO & 5 & 1 \\
\hline CORONEL FABRICIANO & TIMOTEO & 15 & 2 \\
\hline CONSELHEIRO LAFAIETE & CARANAIBA & 2 & 0 \\
\hline CONSELHEIRO LAFAIETE & CASA GRANDE & 0 & 0 \\
\hline CONSELHEIRO LAFAIETE & CATAS ALTAS DA NORUEGA & 1 & 0 \\
\hline CONSELHEIRO LAFAIETE & CONGONHAS & 3 & 0 \\
\hline CONSELHEIRO LAFAIETE & CONSELHEIRO LAFAIETE & 8 & 1 \\
\hline CONSELHEIRO LAFAIETE & CRISTIANO OTONI & 0 & 0 \\
\hline CONSELHEIRO LAFAIETE & DESTERRO DE ENTRE RIOS & 2 & 0 \\
\hline CONSELHEIRO LAFAIETE & ENTRE RIOS DE MINAS & 0 & 0 \\
\hline CONSELHEIRO LAFAIETE & ITAVERAVA & 1 & 0 \\
\hline CONSELHEIRO LAFAIETE & JECEABA & 1 & 0 \\
\hline CONSELHEIRO LAFAIETE & LAMIM & 2 & 0 \\
\hline CONSELHEIRO LAFAIETE & OURO BRANCO & 3 & 0 \\
\hline CONSELHEIRO LAFAIETE & PIRANGA & 11 & 1 \\
\hline CONSELHEIRO LAFAIETE & QUELUZITO & 0 & 0 \\
\hline
\end{tabular}




\begin{tabular}{|c|c|c|c|}
\hline CONSELHEIRO LAFAIETE & RIO ESPERA & 4 & 0 \\
\hline CONSELHEIRO LAFAIETE & SANTANA DOS MONTES & 1 & 0 \\
\hline CONSELHEIRO LAFAIETE & SAO BRAS DO SUACUI & 0 & 0 \\
\hline CONSELHEIRO LAFAIETE & SENHORA DE OLIVEIRA & 2 & 0 \\
\hline CURVELO & AUGUSTO DE LIMA & 1 & 0 \\
\hline CURVELO & BUENOPOLIS & 2 & 0 \\
\hline CURVELO & CORINTO & 3 & 0 \\
\hline CURVELO & CURVELO & 11 & 1 \\
\hline CURVELO & FELIXLANDIA & 3 & 0 \\
\hline CURVELO & INIMUTABA & 1 & 0 \\
\hline CURVELO & JOAQUIM FELICIO & 0 & 0 \\
\hline CURVELO & LASSANCE & 4 & 0 \\
\hline CURVELO & MORRO DA GARCA & 0 & 0 \\
\hline CURVELO & PRESIDENTE JUSCELINO & 1 & 0 \\
\hline CURVELO & SANTO HIPOLITO & 0 & 0 \\
\hline CURVELO & TRES MARIAS & 3 & 0 \\
\hline DIAMANTINA & ALVORADA DE MINAS & 3 & 0 \\
\hline DIAMANTINA & ANGELANDIA & 6 & 1 \\
\hline DIAMANTINA & ARICANDUVA & 2 & 0 \\
\hline DIAMANTINA & CAPELINHA & 5 & 1 \\
\hline DIAMANTINA & CARBONITA & 2 & 0 \\
\hline DIAMANTINA & CONCEICAO DO MATO DENTRO & 13 & 1 \\
\hline DIAMANTINA & CONGONHAS DO NORTE & 2 & 0 \\
\hline DIAMANTINA & COUTO DE MAGALHAES DE MINAS & 2 & 0 \\
\hline DIAMANTINA & DATAS & 3 & 0 \\
\hline DIAMANTINA & DIAMANTINA & 15 & 2 \\
\hline DIAMANTINA & FELICIO DOS SANTOS & 4 & 0 \\
\hline DIAMANTINA & GOUVEA & 6 & 1 \\
\hline DIAMANTINA & ITAMARANDIBA & 11 & 1 \\
\hline DIAMANTINA & LEME DO PRADO & 1 & 0 \\
\hline DIAMANTINA & MINAS NOVAS & 18 & 2 \\
\hline DIAMANTINA & MONJOLOS & 0 & 0 \\
\hline DIAMANTINA & PRESIDENTE KUBITSCHEK & 2 & 0 \\
\hline DIAMANTINA & RIO VERMELHO & 5 & 1 \\
\hline DIAMANTINA & SANTO ANTONIO DO ITAMBE & 0 & 0 \\
\hline DIAMANTINA & SAO GONCALO DO RIO PRETO & 1 & 0 \\
\hline DIAMANTINA & SENADOR MODESTINO GONCALVES & 1 & 0 \\
\hline DIAMANTINA & SERRA AZUL DE MINAS & 2 & 0 \\
\hline DIAMANTINA & SERRO & 12 & 1 \\
\hline DIAMANTINA & TURMALINA & 12 & 1 \\
\hline DIAMANTINA & VEREDINHA & 2 & 0 \\
\hline DIVINÓPOLIS & ARAUJOS & 0 & 0 \\
\hline DIVINÓPOLIS & ARCOS & 6 & 1 \\
\hline DIVINÓPOLIS & BAMBUI & 5 & 1 \\
\hline DIVINÓPOLIS & CARMO DA MATA & 1 & 0 \\
\hline
\end{tabular}




\begin{tabular}{|c|c|c|c|}
\hline DIVINÓPOLIS & CARMO DO CAJURU & 3 & 0 \\
\hline DIVINÓPOLIS & CARMOPOLIS DE MINAS & 3 & 0 \\
\hline DIVINÓPOLIS & CLAUDIO & 1 & 0 \\
\hline DIVINÓPOLIS & CORREGO DANTA & 0 & 0 \\
\hline DIVINÓPOLIS & DIVINOPOLIS & 40 & 5 \\
\hline DIVINÓPOLIS & IGUATAMA & 0 & 0 \\
\hline DIVINÓPOLIS & ITAGUARA & 0 & 0 \\
\hline DIVINÓPOLIS & ITAPECERICA & 2 & 0 \\
\hline DIVINÓPOLIS & ITATIAIUCU & 1 & 0 \\
\hline DIVINÓPOLIS & ITAUNA & 14 & 1 \\
\hline DIVINÓPOLIS & JAPARAIBA & 3 & 0 \\
\hline DIVINÓPOLIS & LAGOA DA PRATA & 7 & 1 \\
\hline DIVINÓPOLIS & LUZ & 3 & 0 \\
\hline DIVINÓPOLIS & MEDEIROS & 1 & 0 \\
\hline DIVINÓPOLIS & MOEMA & 2 & 0 \\
\hline DIVINÓPOLIS & NOVA SERRANA & 17 & 2 \\
\hline DIVINÓPOLIS & OLIVEIRA & 2 & 0 \\
\hline DIVINÓPOLIS & PAINS & 0 & 0 \\
\hline DIVINÓPOLIS & PASSA TEMPO & 0 & 0 \\
\hline DIVINÓPOLIS & PEDRA DO INDAIA & 0 & 0 \\
\hline DIVINÓPOLIS & PERDIGAO & 0 & 0 \\
\hline DIVINÓPOLIS & PIRACEMA & 1 & 0 \\
\hline DIVINÓPOLIS & SANTO ANTONIO DO MONTE & 3 & 0 \\
\hline DIVINÓPOLIS & SAO GONCALO DO PARA & 2 & 0 \\
\hline DIVINÓPOLIS & SAO SEBASTIAO DO OESTE & 0 & 0 \\
\hline DIVINÓPOLIS & TAPIRAI & 1 & 0 \\
\hline GOVERNADOR VALADARES & ACUCENA & 7 & 1 \\
\hline GOVERNADOR VALADARES & AIMORES & 9 & 1 \\
\hline GOVERNADOR VALADARES & ALPERCATA & 2 & 0 \\
\hline GOVERNADOR VALADARES & CAPITAO ANDRADE & 3 & 0 \\
\hline GOVERNADOR VALADARES & CENTRAL DE MINAS & 2 & 0 \\
\hline GOVERNADOR VALADARES & CONSELHEIRO PENA & 5 & 1 \\
\hline GOVERNADOR VALADARES & COROACI & 2 & 0 \\
\hline GOVERNADOR VALADARES & CUPARAQUE & 2 & 0 \\
\hline GOVERNADOR VALADARES & DIVINO DAS LARANJEIRAS & 1 & 0 \\
\hline GOVERNADOR VALADARES & ENGENHEIRO CALDAS & 4 & 0 \\
\hline GOVERNADOR VALADARES & FERNANDES TOURINHO & 1 & 0 \\
\hline GOVERNADOR VALADARES & FREI INOCENCIO & 1 & 0 \\
\hline GOVERNADOR VALADARES & GALILEIA & 5 & 1 \\
\hline GOVERNADOR VALADARES & GOIABEIRA & 2 & 0 \\
\hline GOVERNADOR VALADARES & GOVERNADOR VALADARES & 67 & 9 \\
\hline GOVERNADOR VALADARES & ITABIRINHA & 2 & 0 \\
\hline GOVERNADOR VALADARES & ITANHOMI & 2 & 0 \\
\hline GOVERNADOR VALADARES & ITUETA & 2 & 0 \\
\hline GOVERNADOR VALADARES & MANTENA & 5 & 1 \\
\hline
\end{tabular}




\begin{tabular}{|c|c|c|c|}
\hline GOVERNADOR VALADARES & MARILAC & 2 & 0 \\
\hline GOVERNADOR VALADARES & MATHIAS LOBATO & 2 & 0 \\
\hline GOVERNADOR VALADARES & MENDES PIMENTEL & 1 & 0 \\
\hline GOVERNADOR VALADARES & NACIP RAYDAN & 3 & 0 \\
\hline GOVERNADOR VALADARES & NAQUE & 2 & 0 \\
\hline GOVERNADOR VALADARES & NOVA BELEM & 1 & 0 \\
\hline GOVERNADOR VALADARES & NOVA MODICA & 1 & 0 \\
\hline GOVERNADOR VALADARES & PERIQUITO & 2 & 0 \\
\hline GOVERNADOR VALADARES & RESPLENDOR & 1 & 0 \\
\hline GOVERNADOR VALADARES & SANTA EFIGENIA DE MINAS & 1 & 0 \\
\hline GOVERNADOR VALADARES & SANTA RITA DO ITUETO & 5 & 1 \\
\hline GOVERNADOR VALADARES & SAO FELIX DE MINAS & 2 & 0 \\
\hline GOVERNADOR VALADARES & SAO GERALDO DA PIEDADE & 1 & 0 \\
\hline GOVERNADOR VALADARES & SAO GERALDO DO BAIXIO & 1 & 0 \\
\hline GOVERNADOR VALADARES & SAO JOAO DO MANTENINHA & 1 & 0 \\
\hline GOVERNADOR VALADARES & SAO JOSE DA SAFIRA & 6 & 1 \\
\hline GOVERNADOR VALADARES & SAO JOSE DO DIVINO & 1 & 0 \\
\hline GOVERNADOR VALADARES & SARDOA & 4 & 0 \\
\hline GOVERNADOR VALADARES & SOBRALIA & 4 & 0 \\
\hline GOVERNADOR VALADARES & TUMIRITINGA & 3 & 0 \\
\hline GOVERNADOR VALADARES & VIRGOLANDIA & 2 & 0 \\
\hline GUANHÃES & AGUA BOA & 3 & 0 \\
\hline GUANHÃES & CANTAGALO & 2 & 0 \\
\hline GUANHÃES & CARMESIA & 1 & 0 \\
\hline GUANHÃES & COLUNA & 1 & 0 \\
\hline GUANHÃES & DIVINOLANDIA DE MINAS & 0 & 0 \\
\hline GUANHÃES & DOM JOAQUIM & 3 & 0 \\
\hline GUANHÃES & DORES DE GUANHAES & 1 & 0 \\
\hline GUANHÃES & FREI LAGONEGRO & 1 & 0 \\
\hline GUANHÃES & GONZAGA & 2 & 0 \\
\hline GUANHÃES & GUANHAES & 10 & 1 \\
\hline GUANHÃES & JOSE RAYDAN & 0 & 0 \\
\hline GUANHÃES & MATERLANDIA & 2 & 0 \\
\hline GUANHÃES & PAULISTAS & 1 & 0 \\
\hline GUANHÃES & PECANHA & 5 & 1 \\
\hline GUANHÃES & SABINOPOLIS & 3 & 0 \\
\hline GUANHÃES & SANTA MARIA DO SUACUI & 5 & 1 \\
\hline GUANHÃES & SAO JOAO EVANGELISTA & 6 & 1 \\
\hline GUANHÃES & SAO JOSE DO JACURI & 2 & 0 \\
\hline GUANHÃES & SAO PEDRO DO SUACUI & 5 & 1 \\
\hline GUANHÃES & SAO SEBASTIAO DO MARANHAO & 3 & 0 \\
\hline GUANHÃES & SENHORA DO PORTO & 1 & 0 \\
\hline GUANHÃES & VIRGINOPOLIS & 4 & 0 \\
\hline ITAJUBÁ & BRASOPOLIS & 14 & 1 \\
\hline ITAJUBÁ & CARMO DE MINAS & 4 & 0 \\
\hline
\end{tabular}




\begin{tabular}{|c|c|c|c|}
\hline ITAJUBÁ & CONCEICAO DAS PEDRAS & 0 & 0 \\
\hline ITAJUBÁ & CONCEICAO DOS OUROS & 3 & 0 \\
\hline ITAJUBÁ & CONSOLACAO & 0 & 0 \\
\hline ITAJUBÁ & CRISTINA & 2 & 0 \\
\hline ITAJUBÁ & DELFIM MOREIRA & 2 & 0 \\
\hline ITAJUBÁ & DOM VICOSO & 1 & 0 \\
\hline ITAJUBÁ & GONCALVES & 1 & 0 \\
\hline ITAJUBÁ & ITAJUBA & 27 & 4 \\
\hline ITAJUBÁ & MARIA DA FE & 2 & 0 \\
\hline ITAJUBÁ & MARMELOPOLIS & 1 & 0 \\
\hline ITAJUBÁ & NATERCIA & 0 & 0 \\
\hline ITAJUBÁ & PARAISOPOLIS & 5 & 1 \\
\hline ITAJUBÁ & PEDRALVA & 4 & 0 \\
\hline ITAJUBÁ & PIRANGUCU & 1 & 0 \\
\hline ITAJUBÁ & PIRANGUINHO & 3 & 0 \\
\hline ITAJUBÁ & SAO JOSE DO ALEGRE & 2 & 0 \\
\hline ITAJUBÁ & SAPUCAI-MIRIM & 3 & 0 \\
\hline ITAJUBÁ & VIRGINIA & 5 & 1 \\
\hline ITAJUBÁ & WENCESLAU BRAZ & 1 & 0 \\
\hline ITUIUTABA & CACHOEIRA DOURADA & 0 & 0 \\
\hline ITUIUTABA & CANAPOLIS & 0 & 0 \\
\hline ITUIUTABA & CAPINOPOLIS & 2 & 0 \\
\hline ITUIUTABA & CENTRALINA & 0 & 0 \\
\hline ITUIUTABA & GURINHATA & 2 & 0 \\
\hline ITUIUTABA & IPIACU & 2 & 0 \\
\hline ITUIUTABA & ITUIUTABA & 18 & 2 \\
\hline ITUIUTABA & SANTA VITORIA & 4 & 0 \\
\hline JANAUBA & CATUTI & 4 & 0 \\
\hline JANAUBA & ESPINOSA & 13 & 1 \\
\hline JANAUBA & GAMELEIRAS & 2 & 0 \\
\hline JANAUBA & JAIBA & 25 & 4 \\
\hline JANAUBA & JANAUBA & 22 & 3 \\
\hline JANAUBA & MAMONAS & 1 & 0 \\
\hline JANAUBA & MATO VERDE & 3 & 0 \\
\hline JANAUBA & MONTE AZUL & 8 & 1 \\
\hline JANAUBA & MONTEZUMA & 5 & 1 \\
\hline JANAUBA & NOVA PORTEIRINHA & 2 & 0 \\
\hline JANAUBA & PAI PEDRO & 1 & 0 \\
\hline JANAUBA & PORTEIRINHA & 10 & 1 \\
\hline JANAUBA & RIACHO DOS MACHADOS & 1 & 0 \\
\hline JANAUBA & RIO PARDO DE MINAS & 12 & 1 \\
\hline JANAUBA & SANTO ANTONIO DO RETIRO & 1 & 0 \\
\hline JANAUBA & SERRANOPOLIS DE MINAS & 3 & 0 \\
\hline JANAUBA & VERDELANDIA & 5 & 1 \\
\hline JANUARIA & BONITO DE MINAS & 9 & 1 \\
\hline
\end{tabular}




\begin{tabular}{|c|c|c|c|}
\hline JANUARIA & CHAPADA GAUCHA & 8 & 1 \\
\hline JANUARIA & CONEGO MARINHO & 7 & 1 \\
\hline JANUARIA & IBIRACATU & 5 & 1 \\
\hline JANUARIA & ICARAI DE MINAS & 10 & 1 \\
\hline JANUARIA & ITACARAMBI & 8 & 1 \\
\hline JANUARIA & JANUARIA & 29 & 4 \\
\hline JANUARIA & JUVENILIA & 1 & 0 \\
\hline JANUARIA & MANGA & 8 & 1 \\
\hline JANUARIA & MATIAS CARDOSO & 4 & 0 \\
\hline JANUARIA & MIRAVANIA & 1 & 0 \\
\hline JANUARIA & MONTALVANIA & 8 & 1 \\
\hline JANUARIA & PEDRAS DE MARIA DA CRUZ & 3 & 0 \\
\hline JANUARIA & PINTOPOLIS & 2 & 0 \\
\hline JANUARIA & SAO FRANCISCO & 21 & 2 \\
\hline JANUARIA & SAO JOAO DAS MISSOES & 5 & 1 \\
\hline JANUARIA & UBAI & 6 & 1 \\
\hline JANUARIA & URUCUIA & 3 & 0 \\
\hline JANUARIA & VARZELANDIA & 14 & 1 \\
\hline JUIZ DE FORA & ARANTINA & 0 & 0 \\
\hline JUIZ DE FORA & BELMIRO BRAGA & 6 & 1 \\
\hline JUIZ DE FORA & BICAS & 2 & 0 \\
\hline JUIZ DE FORA & BOM JARDIM DE MINAS & 2 & 0 \\
\hline JUIZ DE FORA & CHACARA & 0 & 0 \\
\hline JUIZ DE FORA & CHIADOR & 0 & 0 \\
\hline JUIZ DE FORA & CORONEL PACHECO & 0 & 0 \\
\hline JUIZ DE FORA & DESCOBERTO & 3 & 0 \\
\hline JUIZ DE FORA & EWBANK DA CAMARA & 1 & 0 \\
\hline JUIZ DE FORA & GOIANA & 2 & 0 \\
\hline JUIZ DE FORA & GUARARA & 0 & 0 \\
\hline JUIZ DE FORA & JUIZ DE FORA & 72 & 9 \\
\hline JUIZ DE FORA & LIMA DUARTE & 5 & 1 \\
\hline JUIZ DE FORA & MAR DE ESPANHA & 5 & 1 \\
\hline JUIZ DE FORA & MARIPA DE MINAS & 0 & 0 \\
\hline JUIZ DE FORA & MATIAS BARBOSA & 1 & 0 \\
\hline JUIZ DE FORA & OLARIA & 0 & 0 \\
\hline JUIZ DE FORA & PEDRO TEIXEIRA & 1 & 0 \\
\hline JUIZ DE FORA & PEQUERI & 0 & 0 \\
\hline JUIZ DE FORA & PIAU & 1 & 0 \\
\hline JUIZ DE FORA & RIO NOVO & 0 & 0 \\
\hline JUIZ DE FORA & RIO PRETO & 0 & 0 \\
\hline JUIZ DE FORA & ROCHEDO DE MINAS & 0 & 0 \\
\hline JUIZ DE FORA & SANTA BARBARA DO MONTE VERDE & 1 & 0 \\
\hline JUIZ DE FORA & SANTA RITA DE JACUTINGA & 0 & 0 \\
\hline JUIZ DE FORA & SANTANA DO DESERTO & 0 & 0 \\
\hline JUIZ DE FORA & SANTOS DUMONT & 8 & 1 \\
\hline
\end{tabular}




\begin{tabular}{|c|c|c|c|}
\hline JUIZ DE FORA & SAO JOAO NEPOMUCENO & 4 & 0 \\
\hline JUIZ DE FORA & SENADOR CORTES & 0 & 0 \\
\hline JUIZ DE FORA & SIMAO PEREIRA & 0 & 0 \\
\hline LEOPOLDINA & ALEM PARAIBA & 6 & 1 \\
\hline LEOPOLDINA & ARGIRITA & 0 & 0 \\
\hline LEOPOLDINA & CATAGUASES & 8 & 1 \\
\hline LEOPOLDINA & ESTRELA DALVA & 2 & 0 \\
\hline LEOPOLDINA & ITAMARATI DE MINAS & 0 & 0 \\
\hline LEOPOLDINA & LEOPOLDINA & 19 & 2 \\
\hline LEOPOLDINA & PIRAPETINGA & 2 & 0 \\
\hline LEOPOLDINA & RECREIO & 1 & 0 \\
\hline LEOPOLDINA & SANTO ANTONIO DO AVENTUREIRO & 2 & 0 \\
\hline LEOPOLDINA & VOLTA GRANDE & 2 & 0 \\
\hline MANHUAÇU & ALTO JEQUITIBA & 4 & 0 \\
\hline MANHUAÇU & CAPUTIRA & 2 & 0 \\
\hline MANHUAÇU & CHALE & 3 & 0 \\
\hline MANHUAÇU & CONCEICAO DE IPANEMA & 1 & 0 \\
\hline MANHUAÇU & DURANDE & 6 & 1 \\
\hline MANHUAÇU & LAJINHA & 10 & 1 \\
\hline MANHUAÇU & LUISBURGO & 1 & 0 \\
\hline MANHUAÇU & MANHUACU & 42 & 5 \\
\hline MANHUAÇU & MANHUMIRIM & 5 & 1 \\
\hline MANHUAÇU & MARTINS SOARES & 2 & 0 \\
\hline MANHUAÇU & MATIPO & 15 & 2 \\
\hline MANHUAÇU & MUTUM & 15 & 2 \\
\hline MANHUAÇU & REDUTO & 5 & 1 \\
\hline MANHUAÇU & SANTA MARGARIDA & 9 & 1 \\
\hline MANHUAÇU & SANTANA DO MANHUACU & 4 & 0 \\
\hline MANHUAÇU & SAO JOAO DO MANHUACU & 6 & 1 \\
\hline MANHUAÇU & SAO JOSE DO MANTIMENTO & 0 & 0 \\
\hline MANHUAÇU & SIMONESIA & 11 & 1 \\
\hline METROPOLITANA A & BARAO DE COCAIS & 2 & 0 \\
\hline METROPOLITANA A & BELO HORIZONTE & 117 & 20 \\
\hline METROPOLITANA A & BELO VALE & 1 & 0 \\
\hline METROPOLITANA A & BOM JESUS DO AMPARO & 2 & 0 \\
\hline METROPOLITANA A & BONFIM & 2 & 0 \\
\hline METROPOLITANA A & BRUMADINHO & 2 & 0 \\
\hline METROPOLITANA A & CAETE & 8 & 1 \\
\hline METROPOLITANA A & CATAS ALTAS & 1 & 0 \\
\hline METROPOLITANA A & CRUCILANDIA & 0 & 0 \\
\hline METROPOLITANA A & MOEDA & 1 & 0 \\
\hline METROPOLITANA A & NOVA LIMA & 9 & 1 \\
\hline METROPOLITANA A & NOVA UNIAO & 1 & 0 \\
\hline METROPOLITANA A & PIEDADE DOS GERAIS & 1 & 0 \\
\hline METROPOLITANA A & RAPOSOS & 4 & 0 \\
\hline
\end{tabular}




\begin{tabular}{|c|c|c|c|}
\hline METROPOLITANA A & RIO ACIMA & 0 & 0 \\
\hline METROPOLITANA A & RIO MANSO & 3 & 0 \\
\hline METROPOLITANA A & SABARA & 21 & 2 \\
\hline METROPOLITANA A & SANTA BARBARA & 1 & 0 \\
\hline METROPOLITANA B & BELO HORIZONTE & 84 & 10 \\
\hline METROPOLITANA B & BETIM & 38 & 5 \\
\hline METROPOLITANA B & CONTAGEM & 51 & 6 \\
\hline METROPOLITANA B & ESMERALDAS & 24 & 3 \\
\hline METROPOLITANA B & IBIRITE & 18 & 2 \\
\hline METROPOLITANA B & IGARAPE & 8 & 1 \\
\hline METROPOLITANA B & JUATUBA & 2 & 0 \\
\hline METROPOLITANA B & MARIO CAMPOS & 2 & 0 \\
\hline METROPOLITANA B & MATEUS LEME & 8 & 1 \\
\hline METROPOLITANA B & SAO JOAQUIM DE BICAS & 3 & 0 \\
\hline METROPOLITANA B & SARZEDO & 5 & 1 \\
\hline METROPOLITANA C & BELO HORIZONTE & 75 & 10 \\
\hline METROPOLITANA C & CONFINS & 1 & 0 \\
\hline METROPOLITANA C & JABOTICATUBAS & 4 & 0 \\
\hline METROPOLITANA C & LAGOA SANTA & 5 & 1 \\
\hline METROPOLITANA C & MORRO DO PILAR & 5 & 1 \\
\hline METROPOLITANA C & PEDRO LEOPOLDO & 10 & 1 \\
\hline METROPOLITANA C & RIBEIRAO DAS NEVES & 109 & 16 \\
\hline METROPOLITANA C & SANTA LUZIA & 33 & 4 \\
\hline METROPOLITANA C & SANTANA DO RIACHO & 4 & 0 \\
\hline METROPOLITANA C & SAO JOSE DA LAPA & 2 & 0 \\
\hline METROPOLITANA C & TAQUARACU DE MINAS & 0 & 0 \\
\hline METROPOLITANA C & VESPASIANO & 15 & 2 \\
\hline MONTE CARMELO & ABADIA DOS DOURADOS & 2 & 0 \\
\hline MONTE CARMELO & CASCALHO RICO & 1 & 0 \\
\hline MONTE CARMELO & COROMANDEL & 3 & 0 \\
\hline MONTE CARMELO & DOURADOQUARA & 2 & 0 \\
\hline MONTE CARMELO & ESTRELA DO SUL & 2 & 0 \\
\hline MONTE CARMELO & GRUPIARA & 0 & 0 \\
\hline MONTE CARMELO & MONTE CARMELO & 13 & 1 \\
\hline MONTE CARMELO & ROMARIA & 1 & 0 \\
\hline MONTES CLAROS & BOCAIUVA & 6 & 1 \\
\hline MONTES CLAROS & BOTUMIRIM & 5 & 1 \\
\hline MONTES CLAROS & BRASILIA DE MINAS & 13 & 1 \\
\hline MONTES CLAROS & CAMPO AZUL & 2 & 0 \\
\hline MONTES CLAROS & CAPITAO ENEAS & 8 & 1 \\
\hline MONTES CLAROS & CLARO DOS POCOES & 3 & 0 \\
\hline MONTES CLAROS & CORACAO DE JESUS & 19 & 2 \\
\hline MONTES CLAROS & CRISTALIA & 1 & 0 \\
\hline MONTES CLAROS & ENGENHEIRO NAVARRO & 2 & 0 \\
\hline MONTES CLAROS & FRANCISCO DUMONT & 1 & 0 \\
\hline
\end{tabular}




\begin{tabular}{|c|c|c|c|}
\hline MONTES CLAROS & FRANCISCO SA & 9 & 1 \\
\hline MONTES CLAROS & GLAUCILANDIA & 0 & 0 \\
\hline MONTES CLAROS & GRAO MOGOL & 7 & 1 \\
\hline MONTES CLAROS & GUARACIAMA & 0 & 0 \\
\hline MONTES CLAROS & ITACAMBIRA & 2 & 0 \\
\hline MONTES CLAROS & JAPONVAR & 4 & 0 \\
\hline MONTES CLAROS & JOSENOPOLIS & 0 & 0 \\
\hline MONTES CLAROS & JURAMENTO & 2 & 0 \\
\hline MONTES CLAROS & LONTRA & 6 & 1 \\
\hline MONTES CLAROS & LUISLANDIA & 4 & 0 \\
\hline MONTES CLAROS & MIRABELA & 2 & 0 \\
\hline MONTES CLAROS & MONTES CLAROS & 40 & 5 \\
\hline MONTES CLAROS & OLHOS-D AGUA & 4 & 0 \\
\hline MONTES CLAROS & PADRE CARVALHO & 4 & 0 \\
\hline MONTES CLAROS & PATIS & 3 & 0 \\
\hline MONTES CLAROS & SAO JOAO DA LAGOA & 3 & 0 \\
\hline MONTES CLAROS & SAO JOAO DA PONTE & 5 & 1 \\
\hline MONTES CLAROS & SAO JOAO DO PACUI & 3 & 0 \\
\hline MONTES CLAROS & SAO JOAO DO PARAISO & 14 & 1 \\
\hline MONTES CLAROS & VARGEM GRANDE DO RIO PARDO & 3 & 0 \\
\hline MURIAÉ & ANTONIO PRADO DE MINAS & 0 & 0 \\
\hline MURIAÉ & BARAO DE MONTE ALTO & 1 & 0 \\
\hline MURIAÉ & EUGENOPOLIS & 1 & 0 \\
\hline MURIAÉ & LARANJAL & 1 & 0 \\
\hline MURIAÉ & MIRADOURO & 1 & 0 \\
\hline MURIAÉ & MIRAI & 1 & 0 \\
\hline MURIAÉ & MURIAE & 18 & 2 \\
\hline MURIAÉ & PALMA & 1 & 0 \\
\hline MURIAÉ & PATROCINIO DO MURIAE & 1 & 0 \\
\hline MURIAÉ & ROSARIO DA LIMEIRA & 1 & 0 \\
\hline MURIAÉ & SANTANA DE CATAGUASES & 0 & 0 \\
\hline MURIAÉ & SAO FRANCISCO DO GLORIA & 1 & 0 \\
\hline MURIAÉ & $\begin{array}{l}\text { SAO SEBASTIAO DA VARGEM } \\
\text { ALEGRE }\end{array}$ & 1 & 0 \\
\hline MURIAÉ & VIEIRAS & 1 & 0 \\
\hline NOVA ERA & BELA VISTA DE MINAS & 6 & 1 \\
\hline NOVA ERA & DIONISIO & 2 & 0 \\
\hline NOVA ERA & FERROS & 2 & 0 \\
\hline NOVA ERA & ITABIRA & 20 & 2 \\
\hline NOVA ERA & ITAMBE DO MATO DENTRO & 2 & 0 \\
\hline NOVA ERA & JOAO MONLEVADE & 8 & 1 \\
\hline NOVA ERA & NOVA ERA & 2 & 0 \\
\hline NOVA ERA & PASSABEM & 4 & 0 \\
\hline NOVA ERA & RIO PIRACICABA & 3 & 0 \\
\hline NOVA ERA & SANTA MARIA DE ITABIRA & 6 & 1 \\
\hline
\end{tabular}




\begin{tabular}{|c|c|c|c|}
\hline NOVA ERA & SANTO ANTONIO DO RIO ABAIXO & 3 & 0 \\
\hline NOVA ERA & SAO DOMINGOS DO PRATA & 4 & 0 \\
\hline NOVA ERA & SAO GONCALO DO RIO ABAIXO & 3 & 0 \\
\hline NOVA ERA & SAO JOSE DO GOIABAL & 1 & 0 \\
\hline NOVA ERA & SAO SEBASTIAO DO RIO PRETO & 2 & 0 \\
\hline OURO PRETO & ACAIACA & 2 & 0 \\
\hline OURO PRETO & DIOGO DE VASCONCELOS & 1 & 0 \\
\hline OURO PRETO & ITABIRITO & 13 & 1 \\
\hline OURO PRETO & MARIANA & 10 & 1 \\
\hline OURO PRETO & OURO PRETO & 27 & 4 \\
\hline PARA DE MINAS & ABAETE & 7 & 1 \\
\hline PARA DE MINAS & BIQUINHAS & 0 & 0 \\
\hline PARA DE MINAS & BOM DESPACHO & 9 & 1 \\
\hline PARA DE MINAS & CEDRO DO ABAETE & 0 & 0 \\
\hline PARA DE MINAS & CONCEICAO DO PARA & 1 & 0 \\
\hline PARA DE MINAS & DORES DO INDAIA & 1 & 0 \\
\hline PARA DE MINAS & ESTRELA DO INDAIA & 3 & 0 \\
\hline PARA DE MINAS & FLORESTAL & 3 & 0 \\
\hline PARA DE MINAS & IGARATINGA & 3 & 0 \\
\hline PARA DE MINAS & LEANDRO FERREIRA & 2 & 0 \\
\hline PARA DE MINAS & MARTINHO CAMPOS & 5 & 1 \\
\hline PARA DE MINAS & MORADA NOVA DE MINAS & 2 & 0 \\
\hline PARA DE MINAS & ONCA DE PITANGUI & 2 & 0 \\
\hline PARA DE MINAS & PAINEIRAS & 0 & 0 \\
\hline PARA DE MINAS & PARA DE MINAS & 38 & 5 \\
\hline PARA DE MINAS & PEQUI & 0 & 0 \\
\hline PARA DE MINAS & PITANGUI & 8 & 1 \\
\hline PARA DE MINAS & QUARTEL GERAL & 1 & 0 \\
\hline PARA DE MINAS & SAO JOSE DA VARGINHA & 3 & 0 \\
\hline PARA DE MINAS & SERRA DA SAUDADE & 0 & 0 \\
\hline PARACATU & BRASILANDIA DE MINAS & 3 & 0 \\
\hline PARACATU & GUARDA-MOR & 1 & 0 \\
\hline PARACATU & JOAO PINHEIRO & 13 & 1 \\
\hline PARACATU & PARACATU & 25 & 4 \\
\hline PARACATU & VAZANTE & 6 & 1 \\
\hline PASSOS & ALPINOPOLIS & 5 & 1 \\
\hline PASSOS & BOM JESUS DA PENHA & 4 & 0 \\
\hline PASSOS & CAPITOLIO & 2 & 0 \\
\hline PASSOS & CARMO DO RIO CLARO & 4 & 0 \\
\hline PASSOS & CORREGO FUNDO & 1 & 0 \\
\hline PASSOS & DELFINOPOLIS & 3 & 0 \\
\hline PASSOS & DORESOPOLIS & 0 & 0 \\
\hline PASSOS & FORMIGA & 21 & 2 \\
\hline PASSOS & FORTALEZA DE MINAS & 1 & 0 \\
\hline PASSOS & PASSOS & 21 & 2 \\
\hline
\end{tabular}




\begin{tabular}{|c|c|c|c|}
\hline PASSOS & PIMENTA & 1 & 0 \\
\hline PASSOS & PIUMHI & 12 & 1 \\
\hline PASSOS & SAO JOAO BATISTA DO GLORIA & 2 & 0 \\
\hline PASSOS & SAO JOSE DA BARRA & 4 & 0 \\
\hline PASSOS & SAO ROQUE DE MINAS & 4 & 0 \\
\hline PASSOS & VARGEM BONITA & 0 & 0 \\
\hline PATOS DE MINAS & ARAPUA & 1 & 0 \\
\hline PATOS DE MINAS & CARMO DO PARANAIBA & 11 & 1 \\
\hline PATOS DE MINAS & LAGAMAR & 5 & 1 \\
\hline PATOS DE MINAS & LAGOA FORMOSA & 5 & 1 \\
\hline PATOS DE MINAS & LAGOA GRANDE & 2 & 0 \\
\hline PATOS DE MINAS & MATUTINA & 0 & 0 \\
\hline PATOS DE MINAS & PATOS DE MINAS & 43 & 5 \\
\hline PATOS DE MINAS & PRESIDENTE OLEGARIO & 3 & 0 \\
\hline PATOS DE MINAS & RIO PARANAIBA & 3 & 0 \\
\hline PATOS DE MINAS & SANTA ROSA DA SERRA & 4 & 0 \\
\hline PATOS DE MINAS & SAO GONCALO DO ABAETE & 2 & 0 \\
\hline PATOS DE MINAS & SAO GOTARDO & 14 & 1 \\
\hline PATOS DE MINAS & TIROS & 2 & 0 \\
\hline PATOS DE MINAS & VARJAO DE MINAS & 1 & 0 \\
\hline PATROCÍNIO & CRUZEIRO DA FORTALEZA & 0 & 0 \\
\hline PATROCÍNIO & GUIMARANIA & 0 & 0 \\
\hline PATROCÍNIO & IBIA & 3 & 0 \\
\hline PATROCÍNIO & IRAI DE MINAS & 1 & 0 \\
\hline PATROCÍNIO & PATROCINIO & 12 & 1 \\
\hline PATROCÍNIO & PERDIZES & 1 & 0 \\
\hline PATROCÍNIO & SERRA DO SALITRE & 1 & 0 \\
\hline PIRAPORA & BURITIZEIRO & 18 & 2 \\
\hline PIRAPORA & IBIAI & 7 & 1 \\
\hline PIRAPORA & JEQUITAI & 4 & 0 \\
\hline PIRAPORA & LAGOA DOS PATOS & 1 & 0 \\
\hline PIRAPORA & PIRAPORA & 10 & 1 \\
\hline PIRAPORA & PONTO CHIQUE & 5 & 1 \\
\hline PIRAPORA & SANTA FE DE MINAS & 3 & 0 \\
\hline PIRAPORA & SAO ROMAO & 3 & 0 \\
\hline PIRAPORA & VARZEA DA PALMA & 8 & 1 \\
\hline POÇOS DE CALDAS & ALTEROSA & 3 & 0 \\
\hline POÇOS DE CALDAS & ANDRADAS & 12 & 1 \\
\hline POÇOS DE CALDAS & AREADO & 4 & 0 \\
\hline POÇOS DE CALDAS & BANDEIRA DO SUL & 3 & 0 \\
\hline POÇOS DE CALDAS & BOTELHOS & 6 & 1 \\
\hline POÇOS DE CALDAS & CABO VERDE & 4 & 0 \\
\hline POÇOS DE CALDAS & CALDAS & 2 & 0 \\
\hline POÇOS DE CALDAS & CAMPESTRE & 5 & 1 \\
\hline POÇOS DE CALDAS & CONCEICAO DA APARECIDA & 3 & 0 \\
\hline
\end{tabular}




\begin{tabular}{|c|c|c|c|}
\hline POÇOS DE CALDAS & DIVISA NOVA & 2 & 0 \\
\hline POÇOS DE CALDAS & IBITIURA DE MINAS & 3 & 0 \\
\hline POÇOS DE CALDAS & MONTE BELO & 6 & 1 \\
\hline POÇOS DE CALDAS & MUZAMBINHO & 3 & 0 \\
\hline POÇOS DE CALDAS & NOVA RESENDE & 4 & 0 \\
\hline POÇOS DE CALDAS & POCOS DE CALDAS & 23 & 3 \\
\hline POÇOS DE CALDAS & SANTA RITA DE CALDAS & 2 & 0 \\
\hline POÇOS DE CALDAS & SERRANIA & 2 & 0 \\
\hline PONTE NOVA & ABRE CAMPO & 4 & 0 \\
\hline PONTE NOVA & ALVINOPOLIS & 6 & 1 \\
\hline PONTE NOVA & AMPARO DO SERRA & 1 & 0 \\
\hline PONTE NOVA & ARAPONGA & 6 & 1 \\
\hline PONTE NOVA & BARRA LONGA & 2 & 0 \\
\hline PONTE NOVA & CAJURI & 0 & 0 \\
\hline PONTE NOVA & CANAA & 1 & 0 \\
\hline PONTE NOVA & DOM SILVERIO & 4 & 0 \\
\hline PONTE NOVA & GUARACIABA & 4 & 0 \\
\hline PONTE NOVA & JEQUERI & 7 & 1 \\
\hline PONTE NOVA & ORATORIOS & 0 & 0 \\
\hline PONTE NOVA & PEDRA BONITA & 3 & 0 \\
\hline PONTE NOVA & PEDRA DO ANTA & 5 & 1 \\
\hline PONTE NOVA & PIEDADE DE PONTE NOVA & 1 & 0 \\
\hline PONTE NOVA & PONTE NOVA & 13 & 1 \\
\hline PONTE NOVA & PORTO FIRME & 2 & 0 \\
\hline PONTE NOVA & RAUL SOARES & 7 & 1 \\
\hline PONTE NOVA & RIO CASCA & 0 & 0 \\
\hline PONTE NOVA & RIO DOCE & 1 & 0 \\
\hline PONTE NOVA & SANTA CRUZ DO ESCALVADO & 2 & 0 \\
\hline PONTE NOVA & SANTO ANTONIO DO GRAMA & 1 & 0 \\
\hline PONTE NOVA & SAO MIGUEL DO ANTA & 1 & 0 \\
\hline PONTE NOVA & SAO PEDRO DOS FERROS & 2 & 0 \\
\hline PONTE NOVA & SEM-PEIXE & 2 & 0 \\
\hline PONTE NOVA & SERICITA & 1 & 0 \\
\hline PONTE NOVA & TEIXEIRAS & 3 & 0 \\
\hline PONTE NOVA & URUCANIA & 3 & 0 \\
\hline PONTE NOVA & VERMELHO NOVO & 3 & 0 \\
\hline PONTE NOVA & VICOSA & 21 & 2 \\
\hline POUSO ALEGRE & ALBERTINA & 1 & 0 \\
\hline POUSO ALEGRE & BOM REPOUSO & 1 & 0 \\
\hline POUSO ALEGRE & BORDA DA MATA & 2 & 0 \\
\hline POUSO ALEGRE & BUENO BRANDAO & 0 & 0 \\
\hline POUSO ALEGRE & CACHOEIRA DE MINAS & 2 & 0 \\
\hline POUSO ALEGRE & CAMANDUCAIA & 10 & 1 \\
\hline POUSO ALEGRE & CAMBUI & 9 & 1 \\
\hline POUSO ALEGRE & CAREACU & 0 & 0 \\
\hline
\end{tabular}




\begin{tabular}{|c|c|c|c|}
\hline POUSO ALEGRE & CONGONHAL & 4 & 0 \\
\hline POUSO ALEGRE & CORREGO DO BOM JESUS & 0 & 0 \\
\hline POUSO ALEGRE & ESPIRITO SANTO DO DOURADO & 0 & 0 \\
\hline POUSO ALEGRE & ESTIVA & 4 & 0 \\
\hline POUSO ALEGRE & EXTREMA & 2 & 0 \\
\hline POUSO ALEGRE & HELIODORA & 0 & 0 \\
\hline POUSO ALEGRE & INCONFIDENTES & 2 & 0 \\
\hline POUSO ALEGRE & IPUIUNA & 0 & 0 \\
\hline POUSO ALEGRE & ITAPEVA & 1 & 0 \\
\hline POUSO ALEGRE & JACUTINGA & 2 & 0 \\
\hline POUSO ALEGRE & MONTE SIAO & 2 & 0 \\
\hline POUSO ALEGRE & MUNHOZ & 1 & 0 \\
\hline POUSO ALEGRE & OURO FINO & 11 & 1 \\
\hline POUSO ALEGRE & POUSO ALEGRE & 22 & 3 \\
\hline POUSO ALEGRE & SANTA RITA DO SAPUCAI & 9 & 1 \\
\hline POUSO ALEGRE & SAO JOAO DA MATA & 2 & 0 \\
\hline POUSO ALEGRE & SAO SEBASTIAO DA BELA VISTA & 0 & 0 \\
\hline POUSO ALEGRE & SENADOR AMARAL & 2 & 0 \\
\hline POUSO ALEGRE & SENADOR JOSE BENTO & 1 & 0 \\
\hline POUSO ALEGRE & SILVIANOPOLIS & 1 & 0 \\
\hline POUSO ALEGRE & TOCOS DO MOJI & 1 & 0 \\
\hline POUSO ALEGRE & TOLEDO & 1 & 0 \\
\hline SÃO JOÃO DEL REI & BOM SUCESSO & 1 & 0 \\
\hline SÃO JOÃO DEL REI & CARRANCAS & 1 & 0 \\
\hline SÃO JOÃO DEL REI & CONCEICAO DA BARRA DE MINAS & 0 & 0 \\
\hline SÃO JOÃO DEL REI & CORONEL XAVIER CHAVES & 0 & 0 \\
\hline SÃO JOÃO DEL REI & DORES DE CAMPOS & 1 & 0 \\
\hline SÃO JOÃO DEL REI & IBITURUNA & 2 & 0 \\
\hline SÃO JOÃO DEL REI & IJACI & 1 & 0 \\
\hline SÃO JOÃO DEL REI & INGAI & 0 & 0 \\
\hline SÃO JOÃO DEL REI & ITUMIRIM & 1 & 0 \\
\hline SÃO JOÃO DEL REI & ITUTINGA & 2 & 0 \\
\hline SÃO JOÃO DEL REI & LAGOA DOURADA & 0 & 0 \\
\hline SÃO JOÃO DEL REI & NAZARENO & 0 & 0 \\
\hline SÃO JOÃO DEL REI & PRADOS & 0 & 0 \\
\hline SÃO JOÃO DEL REI & RESENDE COSTA & 1 & 0 \\
\hline SÃO JOÃO DEL REI & RITAPOLIS & 0 & 0 \\
\hline SÃO JOÃO DEL REI & SANTA CRUZ DE MINAS & 1 & 0 \\
\hline SÃO JOÃO DEL REI & SAO JOAO DEL REI & 15 & 2 \\
\hline SÃO JOÃO DEL REI & SAO TIAGO & 2 & 0 \\
\hline SÃO JOÃO DEL REI & TIRADENTES & 2 & 0 \\
\hline SÃO SEBASTIÃO DO PARAÍSO & ARCEBURGO & 1 & 0 \\
\hline SÃO SEBASTIÃO DO PARAÍSO & CAPETINGA & 2 & 0 \\
\hline SÃO SEBASTIÃO DO PARAÍSO & CASSIA & 2 & 0 \\
\hline SÃO SEBASTIÃO DO PARAÍSO & CLARAVAL & 1 & 0 \\
\hline
\end{tabular}




\begin{tabular}{|c|c|c|c|}
\hline SÃO SEBASTIÃO DO PARAÍSO & GUARANESIA & 3 & 0 \\
\hline SÃO SEBASTIÃO DO PARAÍSO & GUAXUPE & 13 & 1 \\
\hline SÃO SEBASTIÃO DO PARAÍSO & IBIRACI & 6 & 1 \\
\hline SÃO SEBASTIÃO DO PARAÍSO & ITAMOGI & 3 & 0 \\
\hline SÃO SEBASTIÃO DO PARAÍSO & ITAU DE MINAS & 1 & 0 \\
\hline SÃO SEBASTIÃO DO PARAÍSO & JACUI & 1 & 0 \\
\hline SÃO SEBASTIÃO DO PARAÍSO & JURUAIA & 3 & 0 \\
\hline SÃO SEBASTIÃO DO PARAÍSO & MONTE SANTO DE MINAS & 4 & 0 \\
\hline SÃO SEBASTIÃO DO PARAÍSO & PRATAPOLIS & 1 & 0 \\
\hline SÃO SEBASTIÃO DO PARAÍSO & SAO PEDRO DA UNIAO & 1 & 0 \\
\hline SÃO SEBASTIÃO DO PARAÍSO & SAO SEBASTIAO DO PARAISO & 19 & 2 \\
\hline SÃO SEBASTIÃO DO PARAÍSO & SAO TOMAS DE AQUINO & 2 & 0 \\
\hline SETE LAGOAS & ARACAI & 0 & 0 \\
\hline SETE LAGOAS & BALDIM & 3 & 0 \\
\hline SETE LAGOAS & CACHOEIRA DA PRATA & 0 & 0 \\
\hline SETE LAGOAS & CAETANOPOLIS & 1 & 0 \\
\hline SETE LAGOAS & CAPIM BRANCO & 2 & 0 \\
\hline SETE LAGOAS & CORDISBURGO & 3 & 0 \\
\hline SETE LAGOAS & FORTUNA DE MINAS & 0 & 0 \\
\hline SETE LAGOAS & FUNILANDIA & 2 & 0 \\
\hline SETE LAGOAS & INHAUMA & 2 & 0 \\
\hline SETE LAGOAS & JEQUITIBA & 1 & 0 \\
\hline SETE LAGOAS & MARAVILHAS & 1 & 0 \\
\hline SETE LAGOAS & MATOZINHOS & 8 & 1 \\
\hline SETE LAGOAS & PAPAGAIOS & 5 & 1 \\
\hline SETE LAGOAS & PARAOPEBA & 8 & 1 \\
\hline SETE LAGOAS & POMPEU & 8 & 1 \\
\hline SETE LAGOAS & PRUDENTE DE MORAIS & 1 & 0 \\
\hline SETE LAGOAS & SANTANA DE PIRAPAMA & 2 & 0 \\
\hline SETE LAGOAS & SETE LAGOAS & 34 & 4 \\
\hline TEOFILO OTONI & AGUAS FORMOSAS & 8 & 1 \\
\hline TEOFILO OTONI & ATALEIA & 5 & 1 \\
\hline TEOFILO OTONI & BERTOPOLIS & 0 & 0 \\
\hline TEOFILO OTONI & CAMPANARIO & 2 & 0 \\
\hline TEOFILO OTONI & CARAI & 4 & 0 \\
\hline TEOFILO OTONI & CARLOS CHAGAS & 4 & 0 \\
\hline TEOFILO OTONI & CATUJI & 1 & 0 \\
\hline TEOFILO OTONI & CRISOLITA & 2 & 0 \\
\hline TEOFILO OTONI & FRANCISCOPOLIS & 1 & 0 \\
\hline TEOFILO OTONI & FREI GASPAR & 2 & 0 \\
\hline TEOFILO OTONI & FRONTEIRA DOS VALES & 1 & $\underline{0}$ \\
\hline TEOFILO OTONI & ITAIPE & 1 & 0 \\
\hline TEOFILO OTONI & ITAMBACURI & 2 & 0 \\
\hline TEOFILO OTONI & JAMPRUCA & 1 & 0 \\
\hline TEOFILO OTONI & LADAINHA & 3 & 0 \\
\hline
\end{tabular}




\begin{tabular}{|c|c|c|c|}
\hline TEOFILO OTONI & MACHACALIS & 1 & 0 \\
\hline TEOFILO OTONI & MALACACHETA & 5 & 1 \\
\hline TEOFILO OTONI & NANUQUE & 8 & 1 \\
\hline TEOFILO OTONI & NOVO CRUZEIRO & 15 & 2 \\
\hline TEOFILO OTONI & NOVO ORIENTE DE MINAS & 3 & 0 \\
\hline TEOFILO OTONI & OURO VERDE DE MINAS & 5 & 1 \\
\hline TEOFILO OTONI & PADRE PARAISO & 3 & 0 \\
\hline TEOFILO OTONI & PAVAO & 4 & 0 \\
\hline TEOFILO OTONI & PESCADOR & 2 & 0 \\
\hline TEOFILO OTONI & PONTO DOS VOLANTES & 1 & 0 \\
\hline TEOFILO OTONI & POTE & 7 & 1 \\
\hline TEOFILO OTONI & SANTA HELENA DE MINAS & 2 & 0 \\
\hline TEOFILO OTONI & SERRA DOS AIMORES & 3 & 0 \\
\hline TEOFILO OTONI & SETUBINHA & 4 & 0 \\
\hline TEOFILO OTONI & TEOFILO OTONI & 20 & 2 \\
\hline TEOFILO OTONI & UMBURATIBA & 2 & 0 \\
\hline UBÁ & ASTOLFO DUTRA & 0 & 0 \\
\hline UBÁ & BRAS PIRES & 1 & 0 \\
\hline UBÁ & COIMBRA & 1 & 0 \\
\hline UBÁ & DIVINESIA & 2 & 0 \\
\hline UBÁ & DONA EUZEBIA & 2 & 0 \\
\hline UBÁ & DORES DO TURVO & 1 & 0 \\
\hline UBÁ & ERVALIA & 3 & 0 \\
\hline UBÁ & GUARANI & 3 & 0 \\
\hline UBÁ & GUIDOVAL & 2 & 0 \\
\hline UBÁ & GUIRICEMA & 1 & 0 \\
\hline UBÁ & PAULA CANDIDO & 5 & 1 \\
\hline UBÁ & PIRAUBA & 1 & 0 \\
\hline UBÁ & PRESIDENTE BERNARDES & 4 & 0 \\
\hline UBÁ & RIO POMBA & 3 & 0 \\
\hline UBÁ & RODEIRO & 1 & 0 \\
\hline UBÁ & SAO GERALDO & 5 & 1 \\
\hline UBÁ & SENADOR FIRMINO & 1 & 0 \\
\hline UBÁ & SILVEIRANIA & 0 & 0 \\
\hline UBÁ & TABULEIRO & 1 & 0 \\
\hline UBÁ & TOCANTINS & 3 & 0 \\
\hline UBÁ & UBA & 24 & 3 \\
\hline UBÁ & VISCONDE DO RIO BRANCO & 10 & 1 \\
\hline UBERABA & AGUA COMPRIDA & 1 & 0 \\
\hline UBERABA & ARAXA & 16 & 2 \\
\hline UBERABA & CAMPO FLORIDO & 1 & 0 \\
\hline UBERABA & CAMPOS ALTOS & 6 & 1 \\
\hline UBERABA & CARNEIRINHO & 4 & 0 \\
\hline UBERABA & COMENDADOR GOMES & 1 & 0 \\
\hline UBERABA & CONCEICAO DAS ALAGOAS & 6 & 1 \\
\hline
\end{tabular}




\begin{tabular}{|c|c|c|c|}
\hline UBERABA & CONQUISTA & 0 & 0 \\
\hline UBERABA & DELTA & 1 & 0 \\
\hline UBERABA & FRONTEIRA & 8 & 1 \\
\hline UBERABA & FRUTAL & 13 & 1 \\
\hline UBERABA & ITAPAGIPE & 4 & 0 \\
\hline UBERABA & ITURAMA & 13 & 1 \\
\hline UBERABA & LIMEIRA DO OESTE & 4 & 0 \\
\hline UBERABA & PEDRINOPOLIS & 1 & 0 \\
\hline UBERABA & PIRAJUBA & 2 & 0 \\
\hline UBERABA & PLANURA & 1 & 0 \\
\hline UBERABA & PRATINHA & 3 & 0 \\
\hline UBERABA & SACRAMENTO & 7 & 1 \\
\hline UBERABA & SANTA JULIANA & 2 & 0 \\
\hline UBERABA & SAO FRANCISCO DE SALES & 0 & 0 \\
\hline UBERABA & TAPIRA & 1 & 0 \\
\hline UBERABA & UBERABA & 65 & 9 \\
\hline UBERABA & UNIAO DE MINAS & 2 & 0 \\
\hline UBERABA & VERISSIMO & 2 & 0 \\
\hline UBERLANDIA & ARAGUARI & 36 & 5 \\
\hline UBERLANDIA & ARAPORA & 1 & 0 \\
\hline UBERLANDIA & CAMPINA VERDE & 7 & 1 \\
\hline UBERLANDIA & INDIANOPOLIS & 1 & 0 \\
\hline UBERLANDIA & MONTE ALEGRE DE MINAS & 4 & 0 \\
\hline UBERLANDIA & NOVA PONTE & 1 & 0 \\
\hline UBERLANDIA & PRATA & 7 & 1 \\
\hline UBERLANDIA & TUPACIGUARA & 5 & 1 \\
\hline UBERLANDIA & UBERLANDIA & 116 & 20 \\
\hline UNAI & ARINOS & 5 & 1 \\
\hline UNAI & BONFINOPOLIS DE MINAS & 3 & 0 \\
\hline UNAI & BURITIS & 11 & 1 \\
\hline UNAI & CABECEIRA GRANDE & 4 & 0 \\
\hline UNAI & DOM BOSCO & 3 & 0 \\
\hline UNAI & FORMOSO & 7 & 1 \\
\hline UNAI & NATALANDIA & 1 & 0 \\
\hline UNAI & RIACHINHO & 2 & 0 \\
\hline UNAI & UNAI & 17 & 2 \\
\hline UNAI & URUANA DE MINAS & 1 & 0 \\
\hline VARGINHA & ALFENAS & 23 & 3 \\
\hline VARGINHA & BOA ESPERANCA & 8 & 1 \\
\hline VARGINHA & CAMBUQUIRA & 4 & 0 \\
\hline VARGINHA & CAMPANHA & 8 & 1 \\
\hline VARGINHA & CAMPO DO MEIO & 3 & 0 \\
\hline VARGINHA & CAMPOS GERAIS & 13 & 1 \\
\hline VARGINHA & CARMO DA CACHOEIRA & 4 & 0 \\
\hline VARGINHA & CARVALHOPOLIS & 0 & 0 \\
\hline
\end{tabular}




\begin{tabular}{|c|c|c|c|}
\hline VARGINHA & COQUEIRAL & 6 & 1 \\
\hline VARGINHA & CORDISLANDIA & 2 & 0 \\
\hline VARGINHA & ELOI MENDES & 5 & 1 \\
\hline VARGINHA & FAMA & 2 & 0 \\
\hline VARGINHA & GUAPE & 4 & 0 \\
\hline VARGINHA & ILICINEA & 2 & 0 \\
\hline VARGINHA & LAMBARI & 6 & 1 \\
\hline VARGINHA & LUMINARIAS & 1 & 0 \\
\hline VARGINHA & MACHADO & 18 & 2 \\
\hline VARGINHA & MONSENHOR PAULO & 5 & 1 \\
\hline VARGINHA & NEPOMUCENO & 15 & 2 \\
\hline VARGINHA & PARAGUACU & 5 & 1 \\
\hline VARGINHA & POCO FUNDO & 6 & 1 \\
\hline VARGINHA & SANTANA DA VARGEM & 3 & 0 \\
\hline VARGINHA & SAO BENTO ABADE & 4 & 0 \\
\hline VARGINHA & SAO GONCALO DO SAPUCAI & 9 & 1 \\
\hline VARGINHA & TRES CORACOES & 24 & 3 \\
\hline VARGINHA & TRES PONTAS & 9 & 1 \\
\hline VARGINHA & TURVOLANDIA & 2 & 0 \\
\hline VARGINHA & VARGINHA & 22 & 3 \\
\hline Total geral & & 4.401 & 440 \\
\hline
\end{tabular}

CARGO - ANALISTA EDUCACIONAL - ANE

\begin{tabular}{|l|c|c|}
\hline \multicolumn{1}{|c|}{ SRE } & TOTAL DE VAGAS & $\begin{array}{c}\text { VAGAS RESERVADAS - } \\
\text { PORTADORES DE DEFICIÊNCIA }\end{array}$ \\
\hline ÓRGÃO CENTRAL & 69 & 1 \\
\hline METROPOLITANA A & 7 & 2 \\
\hline METROPOLITANA B & 16 & 1 \\
\hline METROPOLITANA C & 13 & 1 \\
\hline ALMENARA & 6 & 1 \\
\hline ARAÇUAÍ & 13 & 1 \\
\hline BARBACENA & 6 & 0 \\
\hline CAMPO BELO & 2 & 0 \\
\hline CARANGOLA & 1 & 0 \\
\hline CARATINGA & 5 & 0 \\
\hline CAXAMBU & 2 & 1 \\
\hline CONSELHEIRO LAFAIETE & 6 & 1 \\
\hline CORONEL FABRICIANO & 6 & 1 \\
\hline CURVELO & 11 & 1 \\
\hline DIAMANTINA & 7 & 1 \\
\hline DIVINÓPOLIS & 6 & 1 \\
\hline GOVERNADOR VALADARES & 10 & 1 \\
\hline
\end{tabular}




\begin{tabular}{|c|c|c|}
\hline GUANHÃES & 6 & 1 \\
\hline ITAJUBÁ & 5 & 0 \\
\hline ITUIUTABA & 6 & 1 \\
\hline JANAÚBA & 10 & 1 \\
\hline JANUÁRIA & 11 & 1 \\
\hline JUIZ DE FORA & 10 & 1 \\
\hline LEOPOLDINA & 3 & 0 \\
\hline MANHUAÇU & 6 & 1 \\
\hline MONTE CARMELO & 4 & 0 \\
\hline MONTES CLAROS & 6 & 1 \\
\hline MURIAÉ & 2 & 0 \\
\hline NOVA ERA & 7 & 1 \\
\hline OURO PRETO & 4 & 0 \\
\hline PARÁ DE MINAS & 7 & 1 \\
\hline PARACATU & 8 & 1 \\
\hline PASSOS & 6 & 1 \\
\hline PATOS DE MINAS & 1 & 0 \\
\hline PATROCÍNIO & 5 & 0 \\
\hline PIRAPORA & 5 & 0 \\
\hline POÇOS DE CALDAS & 3 & 0 \\
\hline PONTE NOVA & 3 & 0 \\
\hline POUSO ALEGRE & 9 & 1 \\
\hline SÃO JOÃO DEL REI & 4 & 0 \\
\hline SÃO SEBASTIÃO DO PARAÍSO & 6 & 1 \\
\hline SETE LAGOAS & 4 & 0 \\
\hline TEÓFILO OTONI & 2 & 0 \\
\hline UBÁ & 6 & 1 \\
\hline UBERABA & 10 & 1 \\
\hline UBERLÂNDIA & 11 & 1 \\
\hline UNAÍ & 19 & 2 \\
\hline VARGINHA & 3 & 0 \\
\hline TOTAL & 378 & 38 \\
\hline
\end{tabular}

CARGO: ANALISTA EDUCACIONAL - INSPETOR ESCOLAR - ANE / IE

\begin{tabular}{|l|c|c|}
\hline \multicolumn{1}{c|}{ SRE } & TOTAL DE VAGAS & $\begin{array}{c}\text { VAGAS RESERVADAS - PORTADORES } \\
\text { DE DEFICIÊNCIA }\end{array}$ \\
\hline ÓRGÃO CENTRAL & 0 & 0 \\
\hline METROPOLITANA A & 3 & 0 \\
\hline METROPOLITANA B & 4 & 0 \\
\hline METROPOLITANA C & 9 & 2 \\
\hline ALMENARA & 1 & 0 \\
\hline ARAÇUAÍ & 9 & 2 \\
\hline BARBACENA & 1 & 0 \\
\hline
\end{tabular}




\begin{tabular}{|c|c|c|}
\hline CAMPO BELO & 1 & 0 \\
\hline CARANGOLA & 1 & 0 \\
\hline CARATINGA & 1 & 0 \\
\hline CAXAMBU & 1 & 0 \\
\hline CONSELHEIRO LAFAIETE & 1 & 0 \\
\hline CORONEL FABRICIANO & 4 & 0 \\
\hline CURVELO & 3 & 0 \\
\hline DIAMANTINA & 5 & 1 \\
\hline DIVINÓPOLIS & 4 & 0 \\
\hline GOVERNADOR VALADARES & 1 & 0 \\
\hline GUANHÃES & 1 & 0 \\
\hline ITAJUBÁ & 1 & 0 \\
\hline ITUIUTABA & 1 & 0 \\
\hline JANAÚBA & 7 & 2 \\
\hline JANUÁRIA & 1 & 0 \\
\hline JUIZ DE FORA & 1 & 0 \\
\hline LEOPOLDINA & 3 & 0 \\
\hline MANHUAÇU & 3 & 0 \\
\hline MONTE CARMELO & 4 & 0 \\
\hline MONTES CLAROS & 1 & 0 \\
\hline MURIAÉ & 1 & 0 \\
\hline NOVA ERA & 5 & 1 \\
\hline OURO PRETO & 2 & 0 \\
\hline PARÁ DE MINAS & 5 & 1 \\
\hline PARACATU & 3 & 0 \\
\hline PASSOS & 2 & 0 \\
\hline PATOS DE MINAS & 3 & 0 \\
\hline PATROCÍNIO & 2 & 0 \\
\hline PIRAPORA & 1 & 0 \\
\hline POÇOS DE CALDAS & 1 & 0 \\
\hline PONTE NOVA & 2 & 0 \\
\hline POUSO ALEGRE & 2 & 0 \\
\hline SÃO JOÃO DEL REI & 1 & 0 \\
\hline SÃO SEBASTIÃO DO PARAÍSO & 1 & 0 \\
\hline SETE LAGOAS & 1 & 0 \\
\hline TEÓFILO OTONI & 10 & 2 \\
\hline UBÁ & 3 & 0 \\
\hline UBERABA & 3 & 0 \\
\hline UBERLÂNDIA & 6 & 1 \\
\hline UNAÍ & 1 & 0 \\
\hline VARGINHA & 6 & 1 \\
\hline TOTAL & 133 & 13 \\
\hline
\end{tabular}




\section{CARGO : ESPECIALISTA EM EDUCAÇÃO BÁSICA - EEB/OE -}

ORIENTAÇÃO EDUCACIONAL

\begin{tabular}{|c|c|c|c|}
\hline S R E & MUNICIPIO & $\begin{array}{l}\text { TOTAL DE } \\
\text { VAGAS }\end{array}$ & $\begin{array}{c}\text { VAGAS } \\
\text { RESERVADAS - } \\
\text { PORTADORES DE } \\
\text { DEFICIENNCIA }\end{array}$ \\
\hline ALMENARA & AGUAS VERMELHAS & 1 & 0 \\
\hline ALMENARA & ALMENARA & 0 & 0 \\
\hline ALMENARA & BANDEIRA & 0 & 0 \\
\hline ALMENARA & CACHOEIRA DE PAJEU & 0 & 0 \\
\hline ALMENARA & CURRAL DE DENTRO & 0 & 0 \\
\hline ALMENARA & DIVISA ALEGRE & 0 & 0 \\
\hline ALMENARA & DIVISOPOLIS & 0 & 0 \\
\hline ALMENARA & FELISBURGO & 0 & 0 \\
\hline ALMENARA & JACINTO & 0 & 0 \\
\hline ALMENARA & JEQUITINHONHA & 0 & 0 \\
\hline ALMENARA & JOAIMA & 0 & 0 \\
\hline ALMENARA & JORDANIA & 0 & 0 \\
\hline ALMENARA & MATA VERDE & 0 & 0 \\
\hline ALMENARA & MONTE FORMOSO & 0 & 0 \\
\hline ALMENARA & PALMOPOLIS & 0 & 0 \\
\hline ALMENARA & PEDRA AZUL & 0 & 0 \\
\hline ALMENARA & RIO DO PRADO & 0 & 0 \\
\hline ALMENARA & RUBIM & 0 & 0 \\
\hline ALMENARA & SALTO DA DIVISA & 0 & 0 \\
\hline ALMENARA & SANTA MARIA DO SALTO & 0 & 0 \\
\hline ALMENARA & SANTO ANTONIO DO JACINTO & 0 & 0 \\
\hline ARACUAI & ARACUAI & 0 & 0 \\
\hline ARACUAI & BERILO & 0 & 0 \\
\hline ARACUAI & BERIZAL & 0 & 0 \\
\hline ARACUAI & CHAPADA DO NORTE & 1 & 0 \\
\hline ARACUAI & COMERCINHO & 0 & 0 \\
\hline ARACUAI & CORONEL MURTA & 0 & 0 \\
\hline ARACUAI & FRANCISCO BADARO & 0 & 0 \\
\hline ARACUAI & FRUTA DE LEITE & 0 & 0 \\
\hline ARACUAI & INDAIABIRA & 0 & 0 \\
\hline ARACUAI & ITAOBIM & 0 & 0 \\
\hline ARACUAI & ITINGA & 0 & 0 \\
\hline ARACUAI & JENIPAPO DE MINAS & 0 & 0 \\
\hline ARACUAI & JOSE GONCALVES DE MINAS & 0 & 0 \\
\hline ARACUAI & MEDINA & 0 & 0 \\
\hline ARACUAI & NINHEIRA & 0 & 0 \\
\hline ARACUAI & NOVORIZONTE & 0 & 0 \\
\hline ARACUAI & RUBELITA & 0 & 0 \\
\hline ARACUAI & SALINAS & 0 & 0 \\
\hline
\end{tabular}




\begin{tabular}{|c|c|c|c|}
\hline ARACUAI & SANTA CRUZ DE SALINAS & 0 & 0 \\
\hline ARACUAI & TAIOBEIRAS & 0 & 0 \\
\hline ARACUAI & VIRGEM DA LAPA & 0 & 0 \\
\hline BARBACENA & ALFREDO VASCONCELOS & 1 & 0 \\
\hline BARBACENA & ALTO RIO DOCE & 0 & 0 \\
\hline BARBACENA & ANDRELANDIA & 0 & 0 \\
\hline BARBACENA & ANTONIO CARLOS & 0 & 0 \\
\hline BARBACENA & ARACITABA & 0 & 0 \\
\hline BARBACENA & BARBACENA & 1 & 0 \\
\hline BARBACENA & BARROSO & 1 & 0 \\
\hline BARBACENA & BIAS FORTES & 0 & 0 \\
\hline BARBACENA & CAPELA NOVA & 0 & 0 \\
\hline BARBACENA & CARANDAI & 1 & 0 \\
\hline BARBACENA & CIPOTANEA & 0 & 0 \\
\hline BARBACENA & DESTERRO DO MELO & 0 & 0 \\
\hline BARBACENA & IBERTIOGA & 0 & 0 \\
\hline BARBACENA & MADRE DE DEUS DE MINAS & 0 & 0 \\
\hline BARBACENA & MERCES & 0 & 0 \\
\hline BARBACENA & OLIVEIRA FORTES & 0 & 0 \\
\hline BARBACENA & PAIVA & 0 & 0 \\
\hline BARBACENA & PIEDADE DO RIO GRANDE & 0 & 0 \\
\hline BARBACENA & RESSAQUINHA & 0 & 0 \\
\hline BARBACENA & SANTA BARBARA DO TUGURIO & 0 & 0 \\
\hline BARBACENA & SANTA RITA DO IBITIPOCA & 0 & 0 \\
\hline BARBACENA & SANTANA DO GARAMBEU & 0 & 0 \\
\hline BARBACENA & SAO VICENTE DE MINAS & 1 & 0 \\
\hline BARBACENA & SENHORA DOS REMEDIOS & 0 & 0 \\
\hline CAMPO BELO & AGUANIL & 0 & 0 \\
\hline CAMPO BELO & CAMACHO & 0 & 0 \\
\hline CAMPO BELO & CAMPO BELO & 1 & 0 \\
\hline CAMPO BELO & CANA VERDE & 0 & 0 \\
\hline CAMPO BELO & CANDEIAS & 0 & 0 \\
\hline CAMPO BELO & CRISTAIS & 1 & 0 \\
\hline CAMPO BELO & LAVRAS & 0 & 0 \\
\hline CAMPO BELO & PERDOES & 0 & 0 \\
\hline CAMPO BELO & RIBEIRAO VERMELHO & 0 & 0 \\
\hline CAMPO BELO & SANTANA DO JACARE & 1 & 0 \\
\hline CAMPO BELO & SANTO ANTONIO DO AMPARO & 0 & 0 \\
\hline CAMPO BELO & SAO FRANCISCO DE PAULA & 0 & 0 \\
\hline CARATINGA & ALVARENGA & 0 & 0 \\
\hline CARATINGA & BOM JESUS DO GALHO & 0 & 0 \\
\hline CARATINGA & BUGRE & 0 & 0 \\
\hline CARATINGA & CARATINGA & 1 & 0 \\
\hline CARATINGA & CORREGO NOVO & 0 & 0 \\
\hline CARATINGA & DOM CAVATI & 1 & 0 \\
\hline
\end{tabular}




\begin{tabular}{|c|c|c|c|}
\hline CARATINGA & ENTRE FOLHAS & 0 & 0 \\
\hline CARATINGA & IAPU & 0 & 0 \\
\hline CARATINGA & IMBE DE MINAS & 0 & 0 \\
\hline CARATINGA & INHAPIM & 0 & 0 \\
\hline CARATINGA & IPABA & 1 & 0 \\
\hline CARATINGA & IPANEMA & 0 & 0 \\
\hline CARATINGA & PIEDADE DE CARATINGA & 0 & 0 \\
\hline CARATINGA & PINGO D AGUA & 0 & 0 \\
\hline CARATINGA & POCRANE & 0 & 0 \\
\hline CARATINGA & SANTA BARBARA DO LESTE & 0 & 0 \\
\hline CARATINGA & SANTA RITA DE MINAS & 0 & 0 \\
\hline CARATINGA & SAO DOMINGOS DAS DORES & 0 & 0 \\
\hline CARATINGA & SAO JOAO DO ORIENTE & 0 & 0 \\
\hline CARATINGA & SAO SEBASTIAO DO ANTA & 0 & 0 \\
\hline CARATINGA & TAPARUBA & 1 & 0 \\
\hline CARATINGA & TARUMIRIM & 1 & 0 \\
\hline CARATINGA & UBAPORANGA & 1 & 0 \\
\hline CARATINGA & VARGEM ALEGRE & 0 & 0 \\
\hline CAXAMBU & AIURUOCA & 0 & 0 \\
\hline CAXAMBU & ALAGOA & 0 & 0 \\
\hline CAXAMBU & BAEPENDI & 0 & 0 \\
\hline CAXAMBU & BOCAINA DE MINAS & 0 & 0 \\
\hline CAXAMBU & CARVALHOS & 0 & 0 \\
\hline CAXAMBU & CAXAMBU & 0 & 0 \\
\hline CAXAMBU & CONCEICAO DO RIO VERDE & 0 & 0 \\
\hline CAXAMBU & CRUZILIA & 0 & 0 \\
\hline CAXAMBU & ITAMONTE & 0 & 0 \\
\hline CAXAMBU & ITANHANDU & 0 & 0 \\
\hline CAXAMBU & JESUANIA & 0 & 0 \\
\hline CAXAMBU & LIBERDADE & 1 & 0 \\
\hline CAXAMBU & MINDURI & 0 & 0 \\
\hline CAXAMBU & OLIMPIO NORONHA & 0 & 0 \\
\hline CAXAMBU & PASSA QUATRO & 0 & 0 \\
\hline CAXAMBU & PASSA VINTE & 0 & 0 \\
\hline CAXAMBU & POUSO ALTO & 0 & 0 \\
\hline CAXAMBU & SAO LOURENCO & 0 & 0 \\
\hline CAXAMBU & SAO SEBASTIAO DO RIO VERDE & 0 & 0 \\
\hline CAXAMBU & SAO TOME DAS LETRAS & 0 & 0 \\
\hline CAXAMBU & SERITINGA & 0 & 0 \\
\hline CAXAMBU & SERRANOS & 0 & 0 \\
\hline CAXAMBU & SOLEDADE DE MINAS & 0 & 0 \\
\hline CORONEL FABRICIANO & ANTONIO DIAS & 0 & 0 \\
\hline CORONEL FABRICIANO & BELO ORIENTE & 0 & 0 \\
\hline CORONEL FABRICIANO & BRAUNAS & 0 & 0 \\
\hline CORONEL FABRICIANO & CORONEL FABRICIANO & 1 & 0 \\
\hline
\end{tabular}




\begin{tabular}{|c|c|c|c|}
\hline CORONEL FABRICIANO & IPATINGA & 4 & 1 \\
\hline CORONEL FABRICIANO & JAGUARAÇU & 0 & 0 \\
\hline CORONEL FABRICIANO & JOANESIA & 0 & 0 \\
\hline CORONEL FABRICIANO & MARLIERIA & 0 & 0 \\
\hline CORONEL FABRICIANO & MESQUITA & 0 & 0 \\
\hline CORONEL FABRICIANO & SANTANA DO PARAISO & 0 & 0 \\
\hline CORONEL FABRICIANO & TIMOTEO & 0 & 0 \\
\hline CONSELHEIRO LAFAIETE & CARANAIBA & 0 & 0 \\
\hline CONSELHEIRO LAFAIETE & CASA GRANDE & 0 & 0 \\
\hline CONSELHEIRO LAFAIETE & CATAS ALTAS DA NORUEGA & 0 & 0 \\
\hline CONSELHEIRO LAFAIETE & CONGONHAS & 0 & 0 \\
\hline CONSELHEIRO LAFAIETE & CONSELHEIRO LAFAIETE & 0 & 0 \\
\hline CONSELHEIRO LAFAIETE & CRISTIANO OTONI & 0 & 0 \\
\hline CONSELHEIRO LAFAIETE & DESTERRO DE ENTRE RIOS & 1 & 0 \\
\hline CONSELHEIRO LAFAIETE & ENTRE RIOS DE MINAS & 0 & 0 \\
\hline CONSELHEIRO LAFAIETE & ITAVERAVA & 0 & 0 \\
\hline CONSELHEIRO LAFAIETE & JECEABA & 0 & 0 \\
\hline CONSELHEIRO LAFAIETE & LAMIM & 0 & 0 \\
\hline CONSELHEIRO LAFAIETE & OURO BRANCO & 0 & 0 \\
\hline CONSELHEIRO LAFAIETE & PIRANGA & 0 & 0 \\
\hline CONSELHEIRO LAFAIETE & QUELUZITO & 0 & 0 \\
\hline CONSELHEIRO LAFAIETE & RIO ESPERA & 0 & 0 \\
\hline CONSELHEIRO LAFAIETE & SANTANA DOS MONTES & 0 & 0 \\
\hline CONSELHEIRO LAFAIETE & SAO BRAS DO SUACUI & 0 & 0 \\
\hline CONSELHEIRO LAFAIETE & SENHORA DE OLIVEIRA & 0 & 0 \\
\hline CURVELO & AUGUSTO DE LIMA & 0 & 0 \\
\hline CURVELO & BUENOPOLIS & 0 & 0 \\
\hline CURVELO & CORINTO & 0 & 0 \\
\hline CURVELO & CURVELO & 1 & 0 \\
\hline CURVELO & FELIXLANDIA & 0 & 0 \\
\hline CURVELO & INIMUTABA & 0 & 0 \\
\hline CURVELO & JOAQUIM FELICIO & 0 & 0 \\
\hline CURVELO & LASSANCE & 0 & 0 \\
\hline CURVELO & MORRO DA GARCA & 0 & 0 \\
\hline CURVELO & PRESIDENTE JUSCELINO & 0 & 0 \\
\hline CURVELO & SANTO HIPOLITO & 0 & 0 \\
\hline CURVELO & TRES MARIAS & 2 & 0 \\
\hline DIVINÓPOLIS & ARAUJOS & 0 & 0 \\
\hline DIVINÓPOLIS & $\mathrm{ARCOS}$ & 0 & 0 \\
\hline DIVINÓPOLIS & BAMBUI & 0 & 0 \\
\hline DIVINÓPOLIS & CARMO DA MATA & 0 & 0 \\
\hline DIVINÓPOLIS & CARMO DO CAJURU & 0 & 0 \\
\hline DIVINÓPOLIS & CARMOPOLIS DE MINAS & 0 & 0 \\
\hline DIVINÓPOLIS & CLAUDIO & 2 & 0 \\
\hline DIVINÓPOLIS & CORREGO DANTA & 0 & 0 \\
\hline
\end{tabular}




\begin{tabular}{|c|c|c|c|}
\hline DIVINÓPOLIS & DIVINOPOLIS & 4 & 1 \\
\hline DIVINÓPOLIS & IGUATAMA & 0 & $\underline{0}$ \\
\hline DIVINÓPOLIS & ITAGUARA & 2 & 0 \\
\hline DIVINÓPOLIS & ITAPECERICA & 0 & 0 \\
\hline DIVINÓPOLIS & ITATIAIUCU & 0 & 0 \\
\hline DIVINÓPOLIS & ITAUNA & 2 & 0 \\
\hline DIVINÓPOLIS & JAPARAIBA & 0 & 0 \\
\hline DIVINÓPOLIS & LAGOA DA PRATA & 1 & 0 \\
\hline DIVINÓPOLIS & LUZ & 0 & 0 \\
\hline DIVINÓPOLIS & MEDEIROS & 0 & 0 \\
\hline DIVINÓPOLIS & MOEMA & 0 & 0 \\
\hline DIVINÓPOLIS & NOVA SERRANA & 1 & 0 \\
\hline DIVINÓPOLIS & OLIVEIRA & 0 & 0 \\
\hline DIVINÓPOLIS & PAINS & 0 & 0 \\
\hline DIVINÓPOLIS & PASSA TEMPO & 0 & 0 \\
\hline DIVINÓPOLIS & PEDRA DO INDAIA & 0 & 0 \\
\hline DIVINÓPOLIS & PERDIGAO & 0 & 0 \\
\hline DIVINÓPOLIS & PIRACEMA & 0 & 0 \\
\hline DIVINÓPOLIS & SANTO ANTONIO DO MONTE & 5 & 2 \\
\hline DIVINÓPOLIS & SAO GONCALO DO PARA & 0 & 0 \\
\hline DIVINÓPOLIS & SAO SEBASTIAO DO OESTE & 0 & 0 \\
\hline DIVINÓPOLIS & TAPIRAI & 0 & 0 \\
\hline GOVERNADOR VALADARES & ACUCENA & 0 & 0 \\
\hline GOVERNADOR VALADARES & AIMORES & 0 & 0 \\
\hline GOVERNADOR VALADARES & ALPERCATA & 0 & 0 \\
\hline GOVERNADOR VALADARES & CAPITAO ANDRADE & 0 & 0 \\
\hline GOVERNADOR VALADARES & CENTRAL DE MINAS & 0 & 0 \\
\hline GOVERNADOR VALADARES & CONSELHEIRO PENA & 1 & $\underline{0}$ \\
\hline GOVERNADOR VALADARES & COROACI & 0 & 0 \\
\hline GOVERNADOR VALADARES & CUPARAQUE & 0 & 0 \\
\hline GOVERNADOR VALADARES & DIVINO DAS LARANJEIRAS & 0 & $\underline{0}$ \\
\hline GOVERNADOR VALADARES & ENGENHEIRO CALDAS & 0 & 0 \\
\hline GOVERNADOR VALADARES & FERNANDES TOURINHO & 0 & 0 \\
\hline GOVERNADOR VALADARES & FREI INOCENCIO & 0 & 0 \\
\hline GOVERNADOR VALADARES & GALILEIA & 0 & 0 \\
\hline GOVERNADOR VALADARES & GOIABEIRA & 0 & 0 \\
\hline GOVERNADOR VALADARES & GOVERNADOR VALADARES & 0 & 0 \\
\hline GOVERNADOR VALADARES & ITABIRINHA & 0 & 0 \\
\hline GOVERNADOR VALADARES & ITANHOMI & 2 & 0 \\
\hline GOVERNADOR VALADARES & ITUETA & 0 & $\underline{0}$ \\
\hline GOVERNADOR VALADARES & MANTENA & 0 & 0 \\
\hline GOVERNADOR VALADARES & MARILAC & 0 & 0 \\
\hline GOVERNADOR VALADARES & MATHIAS LOBATO & 0 & $\underline{0}$ \\
\hline GOVERNADOR VALADARES & MENDES PIMENTEL & 2 & 0 \\
\hline GOVERNADOR VALADARES & NACIP RAYDAN & 0 & 0 \\
\hline
\end{tabular}




\begin{tabular}{|c|c|c|c|}
\hline GOVERNADOR VALADARES & NAQUE & 0 & 0 \\
\hline GOVERNADOR VALADARES & NOVA BELEM & 0 & 0 \\
\hline GOVERNADOR VALADARES & NOVA MODICA & 0 & 0 \\
\hline GOVERNADOR VALADARES & PERIQUITO & 0 & 0 \\
\hline GOVERNADOR VALADARES & RESPLENDOR & 2 & 0 \\
\hline GOVERNADOR VALADARES & SANTA EFIGENIA DE MINAS & 0 & 0 \\
\hline GOVERNADOR VALADARES & SANTA RITA DO ITUETO & 0 & 0 \\
\hline GOVERNADOR VALADARES & SAO FELIX DE MINAS & 0 & 0 \\
\hline GOVERNADOR VALADARES & SAO GERALDO DA PIEDADE & 0 & 0 \\
\hline GOVERNADOR VALADARES & SAO GERALDO DO BAIXIO & 1 & 0 \\
\hline GOVERNADOR VALADARES & SAO JOAO DO MANTENINHA & 0 & 0 \\
\hline GOVERNADOR VALADARES & SAO JOSE DA SAFIRA & 0 & 0 \\
\hline GOVERNADOR VALADARES & SAO JOSE DO DIVINO & 0 & 0 \\
\hline GOVERNADOR VALADARES & SARDOA & 0 & 0 \\
\hline GOVERNADOR VALADARES & SOBRALIA & 0 & 0 \\
\hline GOVERNADOR VALADARES & TUMIRITINGA & 0 & 0 \\
\hline GOVERNADOR VALADARES & VIRGOLANDIA & 1 & 0 \\
\hline GUANHÃES & AGUA BOA & 0 & 0 \\
\hline GUANHÃES & CANTAGALO & 0 & 0 \\
\hline GUANHÃES & CARMESIA & 0 & 0 \\
\hline GUANHÃES & COLUNA & 0 & 0 \\
\hline GUANHÃES & DIVINOLANDIA DE MINAS & 0 & 0 \\
\hline GUANHÃES & DOM JOAQUIM & 0 & 0 \\
\hline GUANHÃES & DORES DE GUANHAES & 0 & 0 \\
\hline GUANHÃES & FREI LAGONEGRO & 0 & 0 \\
\hline GUANHÃES & GONZAGA & 0 & 0 \\
\hline GUANHÃES & GUANHAES & 1 & 0 \\
\hline GUANHÃES & JOSE RAYDAN & 0 & 0 \\
\hline GUANHÃES & MATERLANDIA & 0 & 0 \\
\hline GUANHÃES & PAULISTAS & 0 & 0 \\
\hline GUANHÃES & PECANHA & 0 & 0 \\
\hline GUANHÃES & SABINOPOLIS & 1 & 0 \\
\hline GUANHÃES & SANTA MARIA DO SUACUI & 3 & 0 \\
\hline GUANHÃES & SAO JOAO EVANGELISTA & 0 & 0 \\
\hline GUANHÃES & SAO JOSE DO JACURI & 0 & 0 \\
\hline GUANHÃES & SAO PEDRO DO SUACUI & 0 & 0 \\
\hline GUANHÃES & SAO SEBASTIAO DO MARANHAO & 1 & 0 \\
\hline GUANHÃES & SENHORA DO PORTO & 0 & 0 \\
\hline GUANHÃES & VIRGINOPOLIS & 0 & 0 \\
\hline ITAJUBÁ & BRASOPOLIS & 1 & 0 \\
\hline ITAJUBÁ & CARMO DE MINAS & 0 & 0 \\
\hline ITAJUBÁ & CONCEICAO DAS PEDRAS & 0 & 0 \\
\hline ITAJUBÁ & CONCEICAO DOS OUROS & 0 & 0 \\
\hline ITAJUBÁ & CONSOLACAO & 0 & 0 \\
\hline ITAJUBÁ & CRISTINA & 0 & 0 \\
\hline
\end{tabular}




\begin{tabular}{|c|c|c|c|}
\hline ITAJUBÁ & DELFIM MOREIRA & 0 & 0 \\
\hline ITAJUBÁ & DOM VICOSO & 0 & 0 \\
\hline ITAJUBÁ & GONCALVES & 0 & 0 \\
\hline ITAJUBÁ & ITAJUBA & 0 & 0 \\
\hline ITAJUBÁ & MARIA DA FE & 0 & 0 \\
\hline ITAJUBÁ & MARMELOPOLIS & 0 & 0 \\
\hline ITAJUBÁ & NATERCIA & 0 & 0 \\
\hline ITAJUBÁ & PARAISOPOLIS & 1 & 0 \\
\hline ITAJUBÁ & PEDRALVA & 1 & 0 \\
\hline ITAJUBÁ & PIRANGUCU & 1 & 0 \\
\hline ITAJUBÁ & PIRANGUINHO & 0 & 0 \\
\hline ITAJUBÁ & SAO JOSE DO ALEGRE & 0 & 0 \\
\hline ITAJUBÁ & SAPUCAI-MIRIM & 2 & 0 \\
\hline ITAJUBÁ & VIRGINIA & 0 & 0 \\
\hline ITAJUBÁ & WENCESLAU BRAZ & 0 & 0 \\
\hline JANAUBA & CATUTI & 0 & 0 \\
\hline JANAUBA & ESPINOSA & 0 & 0 \\
\hline JANAUBA & GAMELEIRAS & 0 & 0 \\
\hline JANAUBA & JAIBA & 0 & 0 \\
\hline JANAUBA & JANAUBA & 2 & 0 \\
\hline JANAUBA & MAMONAS & 0 & 0 \\
\hline JANAUBA & MATO VERDE & 0 & 0 \\
\hline JANAUBA & MONTE AZUL & 0 & 0 \\
\hline JANAUBA & MONTEZUMA & 0 & 0 \\
\hline JANAUBA & NOVA PORTEIRINHA & 0 & 0 \\
\hline JANAUBA & PAI PEDRO & 0 & 0 \\
\hline JANAUBA & PORTEIRINHA & 0 & 0 \\
\hline JANAUBA & RIACHO DOS MACHADOS & 0 & 0 \\
\hline JANAUBA & RIO PARDO DE MINAS & 0 & 0 \\
\hline JANAUBA & SANTO ANTONIO DO RETIRO & 0 & 0 \\
\hline JANAUBA & SERRANOPOLIS DE MINAS & 0 & 0 \\
\hline JANAUBA & VERDELANDIA & 1 & 0 \\
\hline JANUARIA & BONITO DE MINAS & 1 & 0 \\
\hline JANUARIA & CHAPADA GAUCHA & 0 & 0 \\
\hline JANUARIA & CONEGO MARINHO & 0 & 0 \\
\hline JANUARIA & IBIRACATU & 1 & 0 \\
\hline JANUARIA & ICARAI DE MINAS & 0 & 0 \\
\hline JANUARIA & ITACARAMBI & 1 & 0 \\
\hline JANUARIA & JANUARIA & 0 & 0 \\
\hline JANUARIA & JUVENILIA & 0 & 0 \\
\hline JANUARIA & MANGA & 0 & 0 \\
\hline JANUARIA & MATIAS CARDOSO & 0 & 0 \\
\hline JANUARIA & MIRAVANIA & 0 & 0 \\
\hline JANUARIA & MONTALVANIA & 0 & 0 \\
\hline JANUARIA & PEDRAS DE MARIA DA CRUZ & 1 & 0 \\
\hline
\end{tabular}




\begin{tabular}{|c|c|c|c|}
\hline JANUARIA & PINTOPOLIS & 0 & 0 \\
\hline JANUARIA & SAO FRANCISCO & 1 & 0 \\
\hline JANUARIA & SAO JOAO DAS MISSOES & 0 & 0 \\
\hline JANUARIA & UBAI & 0 & 0 \\
\hline JANUARIA & URUCUIA & 0 & 0 \\
\hline JANUARIA & VARZELANDIA & 0 & 0 \\
\hline JUIZ DE FORA & ARANTINA & 1 & 0 \\
\hline JUIZ DE FORA & BELMIRO BRAGA & 0 & 0 \\
\hline JUIZ DE FORA & BICAS & 0 & 0 \\
\hline JUIZ DE FORA & BOM JARDIM DE MINAS & 1 & 0 \\
\hline JUIZ DE FORA & CHACARA & 0 & 0 \\
\hline JUIZ DE FORA & CHIADOR & 0 & 0 \\
\hline JUIZ DE FORA & CORONEL PACHECO & 0 & 0 \\
\hline JUIZ DE FORA & DESCOBERTO & 0 & 0 \\
\hline JUIZ DE FORA & EWBANK DA CAMARA & 0 & 0 \\
\hline JUIZ DE FORA & GOIANA & 0 & 0 \\
\hline JUIZ DE FORA & GUARARA & 0 & 0 \\
\hline JUIZ DE FORA & JUIZ DE FORA & 4 & 1 \\
\hline JUIZ DE FORA & LIMA DUARTE & 0 & 0 \\
\hline JUIZ DE FORA & MAR DE ESPANHA & 0 & 0 \\
\hline JUIZ DE FORA & MARIPA DE MINAS & 0 & 0 \\
\hline JUIZ DE FORA & MATIAS BARBOSA & 0 & 0 \\
\hline JUIZ DE FORA & OLARIA & 0 & 0 \\
\hline JUIZ DE FORA & PEDRO TEIXEIRA & 0 & 0 \\
\hline JUIZ DE FORA & PEQUERI & 0 & 0 \\
\hline JUIZ DE FORA & PIAU & 0 & 0 \\
\hline JUIZ DE FORA & RIO NOVO & 0 & 0 \\
\hline JUIZ DE FORA & RIO PRETO & 0 & 0 \\
\hline JUIZ DE FORA & ROCHEDO DE MINAS & 0 & 0 \\
\hline JUIZ DE FORA & SANTA BARBARA DO MONTE VERDE & 0 & 0 \\
\hline JUIZ DE FORA & SANTA RITA DE JACUTINGA & 0 & 0 \\
\hline JUIZ DE FORA & SANTANA DO DESERTO & 1 & 0 \\
\hline JUIZ DE FORA & SANTOS DUMONT & 1 & 0 \\
\hline JUIZ DE FORA & SAO JOAO NEPOMUCENO & 0 & 0 \\
\hline JUIZ DE FORA & SENADOR CORTES & 0 & 0 \\
\hline JUIZ DE FORA & SIMAO PEREIRA & 0 & 0 \\
\hline LEOPOLDINA & ALEM PARAIBA & 2 & 0 \\
\hline LEOPOLDINA & ARGIRITA & 0 & 0 \\
\hline LEOPOLDINA & CATAGUASES & 0 & 0 \\
\hline LEOPOLDINA & ESTRELA DALVA & 0 & 0 \\
\hline LEOPOLDINA & ITAMARATI DE MINAS & 0 & 0 \\
\hline LEOPOLDINA & LEOPOLDINA & 1 & 0 \\
\hline LEOPOLDINA & PIRAPETINGA & 0 & 0 \\
\hline LEOPOLDINA & RECREIO & 0 & 0 \\
\hline LEOPOLDINA & SANTO ANTONIO DO AVENTUREIRO & 0 & 0 \\
\hline
\end{tabular}




\begin{tabular}{|c|c|c|c|}
\hline LEOPOLDINA & VOLTA GRANDE & 0 & 0 \\
\hline MANHUAÇU & ALTO JEQUITIBA & 0 & 0 \\
\hline MANHUAÇU & CAPUTIRA & 0 & 0 \\
\hline MANHUAÇU & CHALE & 2 & 0 \\
\hline MANHUAÇU & CONCEICAO DE IPANEMA & 0 & 0 \\
\hline MANHUAÇU & DURANDE & 0 & 0 \\
\hline MANHUAÇU & LAJINHA & 0 & 0 \\
\hline MANHUAÇU & LUISBURGO & 0 & 0 \\
\hline MANHUAÇU & MANHUACU & 6 & 2 \\
\hline MANHUAÇU & MANHUMIRIM & 1 & 0 \\
\hline MANHUAÇU & MARTINS SOARES & 0 & 0 \\
\hline MANHUAÇU & MATIPO & 0 & 0 \\
\hline MANHUAÇU & MUTUM & 1 & 0 \\
\hline MANHUAÇU & REDUTO & 0 & 0 \\
\hline MANHUAÇU & SANTA MARGARIDA & 0 & 0 \\
\hline MANHUAÇU & SANTANA DO MANHUACU & 1 & 0 \\
\hline MANHUAÇU & SAO JOAO DO MANHUACU & 0 & 0 \\
\hline MANHUAÇU & SAO JOSE DO MANTIMENTO & 1 & 0 \\
\hline MANHUAÇU & SIMONESIA & 2 & 0 \\
\hline METROPOLITANA A & BARAO DE COCAIS & 0 & 0 \\
\hline METROPOLITANA A & BELO HORIZONTE & 2 & 0 \\
\hline METROPOLITANA A & BELO VALE & 0 & 0 \\
\hline METROPOLITANA A & BOM JESUS DO AMPARO & 0 & 0 \\
\hline METROPOLITANA A & BONFIM & 0 & 0 \\
\hline METROPOLITANA A & BRUMADINHO & 0 & 0 \\
\hline METROPOLITANA A & CAETE & 3 & 0 \\
\hline METROPOLITANA A & CATAS ALTAS & 0 & 0 \\
\hline METROPOLITANA A & CRUCILANDIA & 0 & 0 \\
\hline METROPOLITANA A & MOEDA & 0 & 0 \\
\hline METROPOLITANA A & NOVA LIMA & 1 & 0 \\
\hline METROPOLITANA A & NOVA UNIAO & 0 & 0 \\
\hline METROPOLITANA A & PIEDADE DOS GERAIS & 0 & 0 \\
\hline METROPOLITANA A & RAPOSOS & 0 & 0 \\
\hline METROPOLITANA A & RIO ACIMA & 0 & 0 \\
\hline METROPOLITANA A & RIO MANSO & 0 & 0 \\
\hline METROPOLITANA A & SABARA & 3 & 0 \\
\hline METROPOLITANA A & SANTA BARBARA & 2 & 0 \\
\hline METROPOLITANA B & BELO HORIZONTE & 16 & 5 \\
\hline METROPOLITANA B & BETIM & 7 & 2 \\
\hline METROPOLITANA B & CONTAGEM & 10 & 3 \\
\hline METROPOLITANA B & ESMERALDAS & 3 & 0 \\
\hline METROPOLITANA B & IBIRITE & 2 & 0 \\
\hline METROPOLITANA B & IGARAPE & 2 & 0 \\
\hline METROPOLITANA B & JUATUBA & 0 & 0 \\
\hline METROPOLITANA B & MARIO CAMPOS & 0 & 0 \\
\hline
\end{tabular}




\begin{tabular}{|c|c|c|c|}
\hline METROPOLITANA B & MATEUS LEME & 0 & 0 \\
\hline METROPOLITANA B & SAO JOAQUIM DE BICAS & 0 & 0 \\
\hline METROPOLITANA B & SARZEDO & 2 & 0 \\
\hline METROPOLITANA C & BELO HORIZONTE & 9 & 2 \\
\hline METROPOLITANA C & CONFINS & 1 & 0 \\
\hline METROPOLITANA C & JABOTICATUBAS & 1 & 0 \\
\hline METROPOLITANA C & LAGOA SANTA & 3 & 0 \\
\hline METROPOLITANA C & MORRO DO PILAR & 0 & 0 \\
\hline METROPOLITANA C & PEDRO LEOPOLDO & 1 & 0 \\
\hline METROPOLITANA C & RIBEIRAO DAS NEVES & 1 & 0 \\
\hline METROPOLITANA C & SANTA LUZIA & 1 & 0 \\
\hline METROPOLITANA C & SANTANA DO RIACHO & 0 & 0 \\
\hline METROPOLITANA C & SAO JOSE DA LAPA & 0 & 0 \\
\hline METROPOLITANA C & TAQUARACU DE MINAS & 0 & 0 \\
\hline METROPOLITANA C & VESPASIANO & 1 & 0 \\
\hline MONTES CLAROS & BOCAIUVA & 0 & 0 \\
\hline MONTES CLAROS & BOTUMIRIM & 0 & 0 \\
\hline MONTES CLAROS & BRASILIA DE MINAS & 0 & 0 \\
\hline MONTES CLAROS & CAMPO AZUL & 0 & 0 \\
\hline MONTES CLAROS & CAPITAO ENEAS & 0 & 0 \\
\hline MONTES CLAROS & CLARO DOS POCOES & 0 & 0 \\
\hline MONTES CLAROS & CORACAO DE JESUS & 0 & 0 \\
\hline MONTES CLAROS & CRISTALIA & 0 & 0 \\
\hline MONTES CLAROS & ENGENHEIRO NAVARRO & 0 & 0 \\
\hline MONTES CLAROS & FRANCISCO DUMONT & 0 & 0 \\
\hline MONTES CLAROS & FRANCISCO SA & 0 & 0 \\
\hline MONTES CLAROS & GLAUCILANDIA & 0 & 0 \\
\hline MONTES CLAROS & GRAO MOGOL & 1 & 0 \\
\hline MONTES CLAROS & GUARACIAMA & 0 & 0 \\
\hline MONTES CLAROS & ITACAMBIRA & 0 & 0 \\
\hline MONTES CLAROS & JAPONVAR & 0 & 0 \\
\hline MONTES CLAROS & JOSENOPOLIS & 0 & 0 \\
\hline MONTES CLAROS & JURAMENTO & 0 & 0 \\
\hline MONTES CLAROS & LONTRA & 0 & 0 \\
\hline MONTES CLAROS & LUISLANDIA & 0 & 0 \\
\hline MONTES CLAROS & MIRABELA & 0 & 0 \\
\hline MONTES CLAROS & MONTES CLAROS & 0 & 0 \\
\hline MONTES CLAROS & OLHOS-D AGUA & 0 & 0 \\
\hline MONTES CLAROS & PADRE CARVALHO & 0 & 0 \\
\hline MONTES CLAROS & PATIS & 0 & 0 \\
\hline MONTES CLAROS & SAO JOAO DA LAGOA & 0 & 0 \\
\hline MONTES CLAROS & SAO JOAO DA PONTE & 0 & 0 \\
\hline MONTES CLAROS & SAO JOAO DO PACUI & 0 & 0 \\
\hline MONTES CLAROS & SAO JOAO DO PARAISO & 0 & 0 \\
\hline MONTES CLAROS & VARGEM GRANDE DO RIO PARDO & 0 & 0 \\
\hline
\end{tabular}




\begin{tabular}{|c|c|c|c|}
\hline MURIAÉ & ANTONIO PRADO DE MINAS & 0 & 0 \\
\hline MURIAÉ & BARAO DE MONTE ALTO & 0 & 0 \\
\hline MURIAÉ & EUGENOPOLIS & 0 & 0 \\
\hline MURIAÉ & LARANJAL & 0 & 0 \\
\hline MURIAÉ & MIRADOURO & 0 & 0 \\
\hline MURIAÉ & MIRAI & 0 & 0 \\
\hline MURIAÉ & MURIAE & 0 & 0 \\
\hline MURIAÉ & PALMA & 0 & 0 \\
\hline MURIAÉ & PATROCINIO DO MURIAE & 1 & 0 \\
\hline MURIAÉ & ROSARIO DA LIMEIRA & 0 & 0 \\
\hline MURIAÉ & SANTANA DE CATAGUASES & 0 & 0 \\
\hline MURIAÉ & SAO FRANCISCO DO GLORIA & 0 & 0 \\
\hline MURIAÉ & SAO SEBASTIAO DA VARGEM ALEGRE & 0 & 0 \\
\hline MURIAÉ & VIEIRAS & 0 & 0 \\
\hline NOVA ERA & BELA VISTA DE MINAS & 0 & 0 \\
\hline NOVA ERA & DIONISIO & 0 & 0 \\
\hline NOVA ERA & FERROS & 1 & 0 \\
\hline NOVA ERA & ITABIRA & 6 & 2 \\
\hline NOVA ERA & ITAMBE DO MATO DENTRO & 0 & 0 \\
\hline NOVA ERA & JOAO MONLEVADE & 0 & 0 \\
\hline NOVA ERA & NOVA ERA & 1 & 0 \\
\hline NOVA ERA & PASSABEM & 0 & 0 \\
\hline NOVA ERA & RIO PIRACICABA & 0 & 0 \\
\hline NOVA ERA & SANTA MARIA DE ITABIRA & 0 & 0 \\
\hline NOVA ERA & SANTO ANTONIO DO RIO ABAIXO & 0 & 0 \\
\hline NOVA ERA & SAO DOMINGOS DO PRATA & 2 & 0 \\
\hline NOVA ERA & SAO GONCALO DO RIO ABAIXO & 0 & 0 \\
\hline NOVA ERA & SAO JOSE DO GOIABAL & 0 & 0 \\
\hline NOVA ERA & SAO SEBASTIAO DO RIO PRETO & 0 & 0 \\
\hline OURO PRETO & ACAIACA & 0 & 0 \\
\hline OURO PRETO & DIOGO DE VASCONCELOS & 0 & 0 \\
\hline OURO PRETO & ITABIRITO & 1 & 0 \\
\hline OURO PRETO & MARIANA & 1 & 0 \\
\hline OURO PRETO & OURO PRETO & 3 & 0 \\
\hline PASSOS & ALPINOPOLIS & 0 & 0 \\
\hline PASSOS & BOM JESUS DA PENHA & 0 & 0 \\
\hline PASSOS & CAPITOLIO & 0 & 0 \\
\hline PASSOS & CARMO DO RIO CLARO & 0 & 0 \\
\hline PASSOS & CORREGO FUNDO & 0 & 0 \\
\hline PASSOS & DELFINOPOLIS & 0 & 0 \\
\hline PASSOS & DORESOPOLIS & 1 & 0 \\
\hline PASSOS & FORMIGA & 2 & 0 \\
\hline PASSOS & FORTALEZA DE MINAS & 0 & 0 \\
\hline PASSOS & PASSOS & 0 & 0 \\
\hline PASSOS & PIMENTA & 0 & 0 \\
\hline
\end{tabular}




\begin{tabular}{|c|c|c|c|}
\hline PASSOS & PIUMHI & 1 & 0 \\
\hline PASSOS & SAO JOAO BATISTA DO GLORIA & 0 & 0 \\
\hline PASSOS & SAO JOSE DA BARRA & 0 & 0 \\
\hline PASSOS & SAO ROQUE DE MINAS & 0 & 0 \\
\hline PASSOS & VARGEM BONITA & 0 & 0 \\
\hline PATOS DE MINAS & ARAPUA & 0 & 0 \\
\hline PATOS DE MINAS & CARMO DO PARANAIBA & 1 & 0 \\
\hline PATOS DE MINAS & LAGAMAR & 0 & 0 \\
\hline PATOS DE MINAS & LAGOA FORMOSA & 0 & 0 \\
\hline PATOS DE MINAS & LAGOA GRANDE & 0 & 0 \\
\hline PATOS DE MINAS & MATUTINA & 0 & 0 \\
\hline PATOS DE MINAS & PATOS DE MINAS & 2 & 0 \\
\hline PATOS DE MINAS & PRESIDENTE OLEGARIO & 1 & 0 \\
\hline PATOS DE MINAS & RIO PARANAIBA & 0 & 0 \\
\hline PATOS DE MINAS & SANTA ROSA DA SERRA & 0 & 0 \\
\hline PATOS DE MINAS & SAO GONCALO DO ABAETE & 2 & 0 \\
\hline PATOS DE MINAS & SAO GOTARDO & 3 & 0 \\
\hline PATOS DE MINAS & TIROS & 0 & 0 \\
\hline PATOS DE MINAS & VARJAO DE MINAS & 0 & 0 \\
\hline PATROCÍNIO & CRUZEIRO DA FORTALEZA & 0 & 0 \\
\hline PATROCÍNIO & GUIMARANIA & 0 & 0 \\
\hline PATROCÍNIO & IBIA & 0 & 0 \\
\hline PATROCÍNIO & IRAI DE MINAS & 0 & 0 \\
\hline PATROCÍNIO & PATROCINIO & 2 & 0 \\
\hline PATROCÍNIO & PERDIZES & 0 & 0 \\
\hline PATROCÍNIO & SERRA DO SALITRE & 0 & 0 \\
\hline PIRAPORA & BURITIZEIRO & 0 & 0 \\
\hline PIRAPORA & IBIAI & 0 & 0 \\
\hline PIRAPORA & JEQUITAI & 0 & 0 \\
\hline PIRAPORA & LAGOA DOS PATOS & 0 & 0 \\
\hline PIRAPORA & PIRAPORA & 0 & 0 \\
\hline PIRAPORA & PONTO CHIQUE & 0 & 0 \\
\hline PIRAPORA & SANTA FE DE MINAS & 0 & 0 \\
\hline PIRAPORA & SAO ROMAO & 0 & 0 \\
\hline PIRAPORA & VARZEA DA PALMA & 1 & 0 \\
\hline PONTE NOVA & ABRE CAMPO & 1 & 0 \\
\hline PONTE NOVA & ALVINOPOLIS & 0 & 0 \\
\hline PONTE NOVA & AMPARO DO SERRA & 0 & 0 \\
\hline PONTE NOVA & ARAPONGA & 0 & 0 \\
\hline PONTE NOVA & BARRA LONGA & 0 & 0 \\
\hline PONTE NOVA & CAJURI & 0 & 0 \\
\hline PONTE NOVA & CANAA & 0 & 0 \\
\hline PONTE NOVA & DOM SILVERIO & 0 & 0 \\
\hline PONTE NOVA & GUARACIABA & 0 & 0 \\
\hline PONTE NOVA & JEQUERI & 1 & 0 \\
\hline
\end{tabular}




\begin{tabular}{|c|c|c|c|}
\hline PONTE NOVA & ORATORIOS & 0 & 0 \\
\hline PONTE NOVA & PEDRA BONITA & 0 & 0 \\
\hline PONTE NOVA & PEDRA DO ANTA & 0 & 0 \\
\hline PONTE NOVA & PIEDADE DE PONTE NOVA & 0 & 0 \\
\hline PONTE NOVA & PONTE NOVA & 0 & 0 \\
\hline PONTE NOVA & PORTO FIRME & 0 & 0 \\
\hline PONTE NOVA & RAUL SOARES & 1 & 0 \\
\hline PONTE NOVA & RIO CASCA & 0 & 0 \\
\hline PONTE NOVA & RIO DOCE & 0 & 0 \\
\hline PONTE NOVA & SANTA CRUZ DO ESCALVADO & 0 & 0 \\
\hline PONTE NOVA & SANTO ANTONIO DO GRAMA & 0 & 0 \\
\hline PONTE NOVA & SAO MIGUEL DO ANTA & 0 & 0 \\
\hline PONTE NOVA & SAO PEDRO DOS FERROS & 0 & 0 \\
\hline PONTE NOVA & SEM-PEIXE & 0 & 0 \\
\hline PONTE NOVA & SERICITA & 0 & 0 \\
\hline PONTE NOVA & TEIXEIRAS & 0 & 0 \\
\hline PONTE NOVA & URUCANIA & 0 & 0 \\
\hline PONTE NOVA & VERMELHO NOVO & 0 & 0 \\
\hline PONTE NOVA & VICOSA & 0 & 0 \\
\hline POUSO ALEGRE & ALBERTINA & 0 & 0 \\
\hline POUSO ALEGRE & BOM REPOUSO & 0 & 0 \\
\hline POUSO ALEGRE & BORDA DA MATA & 0 & 0 \\
\hline POUSO ALEGRE & BUENO BRANDAO & 0 & 0 \\
\hline POUSO ALEGRE & CACHOEIRA DE MINAS & 0 & 0 \\
\hline POUSO ALEGRE & CAMANDUCAIA & 0 & 0 \\
\hline POUSO ALEGRE & CAMBUI & 2 & 0 \\
\hline POUSO ALEGRE & CAREACU & 0 & 0 \\
\hline POUSO ALEGRE & CONGONHAL & 0 & 0 \\
\hline POUSO ALEGRE & CORREGO DO BOM JESUS & 0 & 0 \\
\hline POUSO ALEGRE & ESPIRITO SANTO DO DOURADO & 0 & 0 \\
\hline POUSO ALEGRE & ESTIVA & 0 & 0 \\
\hline POUSO ALEGRE & EXTREMA & 1 & 0 \\
\hline POUSO ALEGRE & HELIODORA & 0 & 0 \\
\hline POUSO ALEGRE & INCONFIDENTES & 0 & 0 \\
\hline POUSO ALEGRE & IPUIUNA & 0 & 0 \\
\hline POUSO ALEGRE & ITAPEVA & 0 & 0 \\
\hline POUSO ALEGRE & JACUTINGA & 0 & 0 \\
\hline POUSO ALEGRE & MONTE SIAO & 0 & 0 \\
\hline POUSO ALEGRE & MUNHOZ & 0 & 0 \\
\hline POUSO ALEGRE & OURO FINO & 0 & 0 \\
\hline POUSO ALEGRE & POUSO ALEGRE & 1 & 0 \\
\hline POUSO ALEGRE & SANTA RITA DO SAPUCAI & 0 & 0 \\
\hline POUSO ALEGRE & SAO JOAO DA MATA & 0 & 0 \\
\hline POUSO ALEGRE & SAO SEBASTIAO DA BELA VISTA & 0 & 0 \\
\hline POUSO ALEGRE & SENADOR AMARAL & 0 & 0 \\
\hline
\end{tabular}




\begin{tabular}{|c|c|c|c|}
\hline POUSO ALEGRE & SENADOR JOSE BENTO & 0 & 0 \\
\hline POUSO ALEGRE & SILVIANOPOLIS & 0 & $\underline{0}$ \\
\hline POUSO ALEGRE & TOCOS DO MOJI & 0 & 0 \\
\hline POUSO ALEGRE & TOLEDO & 0 & 0 \\
\hline SÃO JOÃO DEL REI & BOM SUCESSO & 1 & 0 \\
\hline SÃO JOÃO DEL REI & CARRANCAS & 0 & 0 \\
\hline SÃO JOÃO DEL REI & CONCEICAO DA BARRA DE MINAS & 0 & 0 \\
\hline SÃO JOÃO DEL REI & CORONEL XAVIER CHAVES & 0 & 0 \\
\hline SÃO JOÃO DEL REI & DORES DE CAMPOS & 0 & 0 \\
\hline SÃO JOÃO DEL REI & IBITURUNA & 0 & 0 \\
\hline SÃO JOÃO DEL REI & IJACI & 0 & 0 \\
\hline SÃO JOÃO DEL REI & INGAI & 0 & 0 \\
\hline SÃO JOÃO DEL REI & ITUMIRIM & 0 & 0 \\
\hline SÃO JOÃO DEL REI & ITUTINGA & 0 & 0 \\
\hline SÃO JOÃO DEL REI & LAGOA DOURADA & 0 & 0 \\
\hline SÃO JOÃO DEL REI & NAZARENO & 0 & 0 \\
\hline SÃO JOÃO DEL REI & PRADOS & 0 & 0 \\
\hline SÃO JOÃO DEL REI & RESENDE COSTA & 0 & 0 \\
\hline SÃO JOÃO DEL REI & RITAPOLIS & 0 & 0 \\
\hline SÃO JOÃO DEL REI & SANTA CRUZ DE MINAS & 0 & 0 \\
\hline SÃO JOÃO DEL REI & SAO JOAO DEL REI & 0 & 0 \\
\hline SÃO JOÃO DEL REI & SAO TIAGO & 0 & 0 \\
\hline SÃO JOÃO DEL REI & TIRADENTES & 0 & $\underline{0}$ \\
\hline SÃO SEBASTIÃO DO PARAÍSO & ARCEBURGO & 0 & 0 \\
\hline SÃO SEBASTIÃO DO PARAÍSO & CAPETINGA & 0 & $\underline{0}$ \\
\hline SÃO SEBASTIÃO DO PARAÍSO & CASSIA & 0 & $\underline{0}$ \\
\hline SÃO SEBASTIÃO DO PARAÍSO & CLARAVAL & 0 & 0 \\
\hline SÃO SEBASTIÃO DO PARAÍSO & GUARANESIA & 0 & $\underline{0}$ \\
\hline SÃO SEBASTIÃO DO PARAÍSO & GUAXUPE & 3 & $\underline{0}$ \\
\hline SÃO SEBASTIÃO DO PARAÍSO & IBIRACI & 0 & 0 \\
\hline SÃO SEBASTIÃO DO PARAÍSO & ITAMOGI & 0 & $\underline{0}$ \\
\hline SÃO SEBASTIÃO DO PARAÍSO & ITAU DE MINAS & 0 & $\underline{0}$ \\
\hline SÃO SEBASTIÃO DO PARAÍSO & JACUI & 0 & 0 \\
\hline SÃO SEBASTIÃO DO PARAÍSO & JURUAIA & 0 & 0 \\
\hline SÃO SEBASTIÃO DO PARAÍSO & MONTE SANTO DE MINAS & 2 & $\underline{0}$ \\
\hline SÃO SEBASTIÃO DO PARAÍSO & PRATAPOLIS & 0 & 0 \\
\hline SÃO SEBASTIÃO DO PARAÍSO & SAO PEDRO DA UNIAO & 0 & $\underline{0}$ \\
\hline SÃO SEBASTIÃO DO PARAÍSO & SAO SEBASTIAO DO PARAISO & 2 & 0 \\
\hline SÃO SEBASTIÃO DO PARAÍSO & SAO TOMAS DE AQUINO & 1 & 0 \\
\hline SETE LAGOAS & ARACAI & 0 & $\underline{0}$ \\
\hline SETE LAGOAS & BALDIM & 0 & $\underline{0}$ \\
\hline SETE LAGOAS & CACHOEIRA DA PRATA & 0 & 0 \\
\hline SETE LAGOAS & CAETANOPOLIS & 0 & 0 \\
\hline SETE LAGOAS & CAPIM BRANCO & 0 & $\underline{0}$ \\
\hline SETE LAGOAS & CORDISBURGO & 0 & 0 \\
\hline
\end{tabular}




\begin{tabular}{|c|c|c|c|}
\hline SETE LAGOAS & FORTUNA DE MINAS & 0 & 0 \\
\hline SETE LAGOAS & FUNILANDIA & 1 & 0 \\
\hline SETE LAGOAS & INHAUMA & 1 & 0 \\
\hline SETE LAGOAS & JEQUITIBA & 0 & 0 \\
\hline SETE LAGOAS & MARAVILHAS & 0 & 0 \\
\hline SETE LAGOAS & MATOZINHOS & 1 & 0 \\
\hline SETE LAGOAS & PAPAGAIOS & 2 & 0 \\
\hline SETE LAGOAS & PARAOPEBA & 0 & 0 \\
\hline SETE LAGOAS & POMPEU & 0 & 0 \\
\hline SETE LAGOAS & PRUDENTE DE MORAIS & 0 & 0 \\
\hline SETE LAGOAS & SANTANA DE PIRAPAMA & 1 & 0 \\
\hline SETE LAGOAS & SETE LAGOAS & 5 & 2 \\
\hline TEOFILO OTONI & AGUAS FORMOSAS & 0 & 0 \\
\hline TEOFILO OTONI & ATALEIA & 0 & 0 \\
\hline TEOFILO OTONI & BERTOPOLIS & 0 & 0 \\
\hline TEOFILO OTONI & CAMPANARIO & 0 & 0 \\
\hline TEOFILO OTONI & CARAI & 0 & $\underline{0}$ \\
\hline TEOFILO OTONI & CARLOS CHAGAS & 0 & 0 \\
\hline TEOFILO OTONI & CATUJI & 0 & 0 \\
\hline TEOFILO OTONI & CRISOLITA & 0 & 0 \\
\hline TEOFILO OTONI & FRANCISCOPOLIS & 0 & 0 \\
\hline TEOFILO OTONI & FREI GASPAR & 0 & 0 \\
\hline TEOFILO OTONI & FRONTEIRA DOS VALES & 0 & 0 \\
\hline TEOFILO OTONI & ITAIPE & 0 & 0 \\
\hline TEOFILO OTONI & ITAMBACURI & 0 & 0 \\
\hline TEOFILO OTONI & JAMPRUCA & 0 & 0 \\
\hline TEOFILO OTONI & LADAINHA & 0 & 0 \\
\hline TEOFILO OTONI & MACHACALIS & 0 & 0 \\
\hline TEOFILO OTONI & MALACACHETA & 0 & 0 \\
\hline TEOFILO OTONI & NANUQUE & 0 & 0 \\
\hline TEOFILO OTONI & NOVO CRUZEIRO & 1 & 0 \\
\hline TEOFILO OTONI & NOVO ORIENTE DE MINAS & 0 & 0 \\
\hline TEOFILO OTONI & OURO VERDE DE MINAS & 0 & 0 \\
\hline TEOFILO OTONI & PADRE PARAISO & 0 & 0 \\
\hline TEOFILO OTONI & PAVAO & 0 & $\underline{0}$ \\
\hline TEOFILO OTONI & PESCADOR & 0 & 0 \\
\hline TEOFILO OTONI & PONTO DOS VOLANTES & 0 & 0 \\
\hline TEOFILO OTONI & POTE & 0 & $\underline{0}$ \\
\hline TEOFILO OTONI & SANTA HELENA DE MINAS & 1 & 0 \\
\hline TEOFILO OTONI & SERRA DOS AIMORES & 0 & 0 \\
\hline TEOFILO OTONI & SETUBINHA & 1 & 0 \\
\hline TEOFILO OTONI & TEOFILO OTONI & 0 & 0 \\
\hline TEOFILO OTONI & UMBURATIBA & 0 & 0 \\
\hline UBÁ & ASTOLFO DUTRA & 0 & $\underline{0}$ \\
\hline UBÁ & BRAS PIRES & 0 & 0 \\
\hline
\end{tabular}




\begin{tabular}{|c|c|c|c|}
\hline UBÁ & COIMBRA & 0 & 0 \\
\hline UBÁ & DIVINESIA & 0 & 0 \\
\hline UBÁ & DONA EUZEBIA & 0 & 0 \\
\hline UBÁ & DORES DO TURVO & 0 & 0 \\
\hline UBÁ & ERVALIA & 0 & 0 \\
\hline UBÁ & GUARANI & 0 & 0 \\
\hline UBÁ & GUIDOVAL & 0 & 0 \\
\hline UBÁ & GUIRICEMA & 0 & 0 \\
\hline UBÁ & PAULA CANDIDO & 0 & 0 \\
\hline UBÁ & PIRAUBA & 0 & 0 \\
\hline UBÁ & PRESIDENTE BERNARDES & 0 & 0 \\
\hline UBÁ & RIO POMBA & 0 & 0 \\
\hline UBÁ & RODEIRO & 0 & 0 \\
\hline UBÁ & SAO GERALDO & 0 & 0 \\
\hline UBÁ & SENADOR FIRMINO & 0 & 0 \\
\hline UBÁ & SILVEIRANIA & 0 & 0 \\
\hline UBÁ & TABULEIRO & 1 & 0 \\
\hline UBÁ & TOCANTINS & 0 & 0 \\
\hline UBÁ & UBA & 0 & 0 \\
\hline UBÁ & VISCONDE DO RIO BRANCO & 0 & 0 \\
\hline UBERABA & AGUA COMPRIDA & 0 & 0 \\
\hline UBERABA & ARAXA & 0 & 0 \\
\hline UBERABA & CAMPO FLORIDO & 0 & 0 \\
\hline UBERABA & CAMPOS ALTOS & 0 & 0 \\
\hline UBERABA & CARNEIRINHO & 0 & 0 \\
\hline UBERABA & COMENDADOR GOMES & 0 & 0 \\
\hline UBERABA & CONCEICAO DAS ALAGOAS & 0 & 0 \\
\hline UBERABA & CONQUISTA & 1 & 0 \\
\hline UBERABA & DELTA & 0 & 0 \\
\hline UBERABA & FRONTEIRA & 0 & 0 \\
\hline UBERABA & FRUTAL & 1 & 0 \\
\hline UBERABA & ITAPAGIPE & 0 & 0 \\
\hline UBERABA & ITURAMA & 2 & 0 \\
\hline UBERABA & LIMEIRA DO OESTE & 0 & 0 \\
\hline UBERABA & PEDRINOPOLIS & 0 & 0 \\
\hline UBERABA & PIRAJUBA & 0 & 0 \\
\hline UBERABA & PLANURA & 0 & 0 \\
\hline UBERABA & PRATINHA & 0 & 0 \\
\hline UBERABA & SACRAMENTO & 0 & 0 \\
\hline UBERABA & SANTA JULIANA & 0 & 0 \\
\hline UBERABA & SAO FRANCISCO DE SALES & 0 & 0 \\
\hline UBERABA & TAPIRA & 0 & 0 \\
\hline UBERABA & UBERABA & 4 & 1 \\
\hline UBERABA & UNIAO DE MINAS & 0 & 0 \\
\hline UBERABA & VERISSIMO & 0 & 0 \\
\hline
\end{tabular}




\begin{tabular}{|c|c|c|c|}
\hline UBERLANDIA & ARAGUARI & 0 & 0 \\
\hline UBERLANDIA & ARAPORA & 0 & 0 \\
\hline UBERLANDIA & CAMPINA VERDE & 0 & 0 \\
\hline UBERLANDIA & INDIANOPOLIS & 0 & 0 \\
\hline UBERLANDIA & MONTE ALEGRE DE MINAS & 0 & 0 \\
\hline UBERLANDIA & NOVA PONTE & 0 & 0 \\
\hline UBERLANDIA & PRATA & 0 & 0 \\
\hline UBERLANDIA & TUPACIGUARA & 0 & 0 \\
\hline UBERLANDIA & UBERLANDIA & 1 & 0 \\
\hline UNAI & ARINOS & 0 & 0 \\
\hline UNAI & BONFINOPOLIS DE MINAS & 0 & 0 \\
\hline UNAI & BURITIS & 0 & 0 \\
\hline UNAI & CABECEIRA GRANDE & 0 & 0 \\
\hline UNAI & DOM BOSCO & 0 & 0 \\
\hline UNAI & FORMOSO & 0 & 0 \\
\hline UNAI & NATALANDIA & 1 & 0 \\
\hline UNAI & RIACHINHO & 0 & 0 \\
\hline UNAI & UNAI & 0 & 0 \\
\hline UNAI & URUANA DE MINAS & 1 & 0 \\
\hline VARGINHA & ALFENAS & 1 & 0 \\
\hline VARGINHA & BOA ESPERANCA & 0 & 0 \\
\hline VARGINHA & CAMBUQUIRA & 0 & 0 \\
\hline VARGINHA & CAMPANHA & 0 & 0 \\
\hline VARGINHA & CAMPO DO MEIO & 1 & 0 \\
\hline VARGINHA & CAMPOS GERAIS & 1 & 0 \\
\hline VARGINHA & CARMO DA CACHOEIRA & 0 & 0 \\
\hline VARGINHA & CARVALHOPOLIS & 0 & 0 \\
\hline VARGINHA & COQUEIRAL & 0 & 0 \\
\hline VARGINHA & CORDISLANDIA & 0 & 0 \\
\hline VARGINHA & ELOI MENDES & 0 & 0 \\
\hline VARGINHA & FAMA & 1 & 0 \\
\hline VARGINHA & GUAPE & 0 & 0 \\
\hline VARGINHA & ILICINEA & 0 & 0 \\
\hline VARGINHA & LAMBARI & 0 & 0 \\
\hline VARGINHA & LUMINARIAS & 0 & 0 \\
\hline VARGINHA & MACHADO & 0 & 0 \\
\hline VARGINHA & MONSENHOR PAULO & 0 & 0 \\
\hline VARGINHA & NEPOMUCENO & 0 & 0 \\
\hline VARGINHA & PARAGUACU & 0 & 0 \\
\hline VARGINHA & POCO FUNDO & 0 & 0 \\
\hline VARGINHA & SANTANA DA VARGEM & 0 & 0 \\
\hline VARGINHA & SAO BENTO ABADE & 0 & 0 \\
\hline VARGINHA & SAO GONCALO DO SAPUCAI & 0 & 0 \\
\hline VARGINHA & TRES CORACOES & 0 & 0 \\
\hline VARGINHA & TRES PONTAS & 1 & 0 \\
\hline
\end{tabular}




\begin{tabular}{|l|l|c|c|} 
VARGINHA & TURVOLANDIA & 0 & 0 \\
\hline VARGINHA & VARGINHA & 4 & 1 \\
\hline Total geral & & $\mathbf{2 5 2}$ & $\mathbf{2 5}$ \\
\hline
\end{tabular}

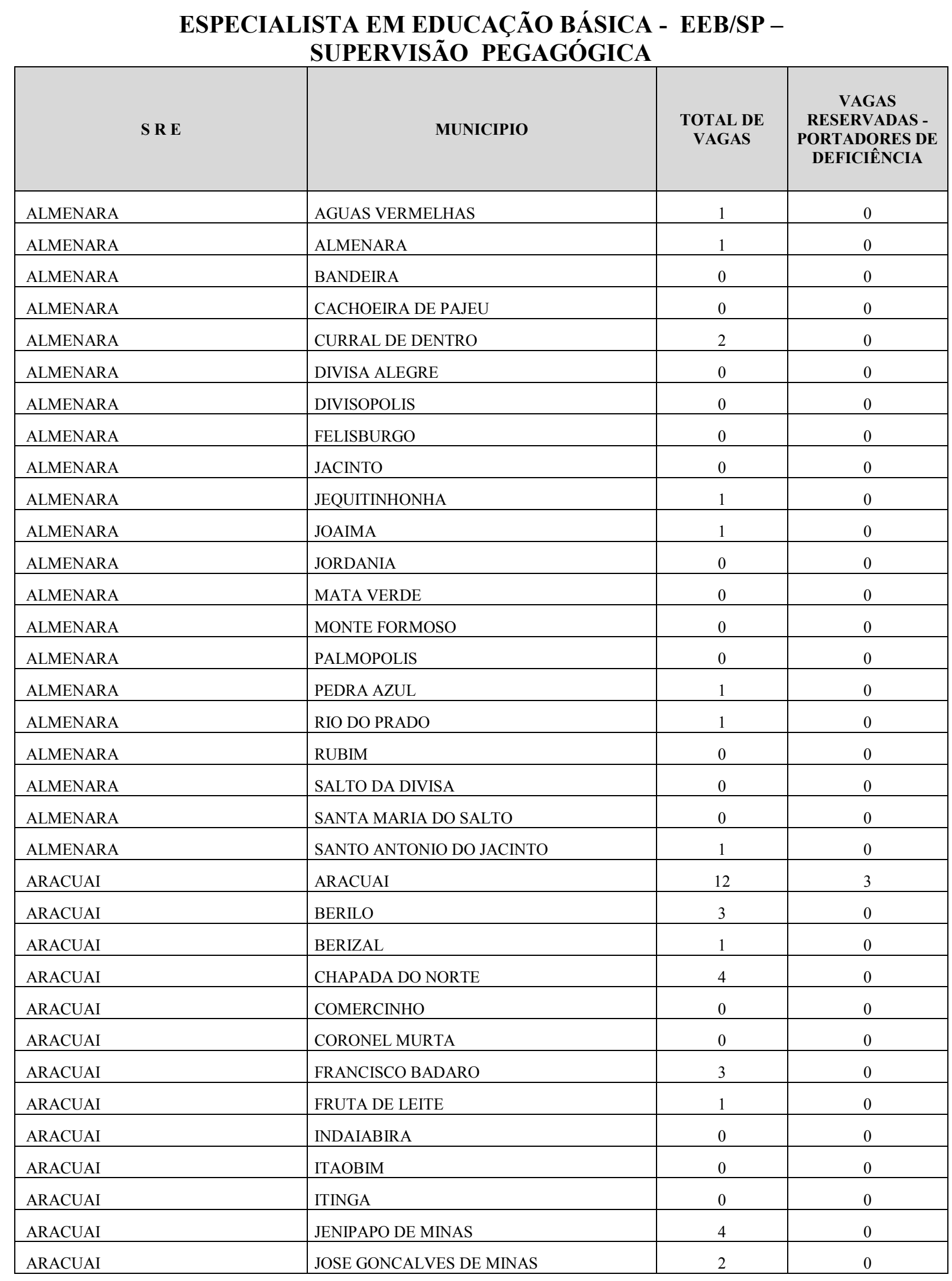




\begin{tabular}{|c|c|c|c|}
\hline ARACUAI & MEDINA & 3 & 0 \\
\hline ARACUAI & NINHEIRA & 2 & 0 \\
\hline ARACUAI & NOVORIZONTE & 0 & 0 \\
\hline ARACUAI & RUBELITA & 0 & 0 \\
\hline ARACUAI & SALINAS & 10 & 2 \\
\hline ARACUAI & SANTA CRUZ DE SALINAS & 2 & 0 \\
\hline ARACUAI & TAIOBEIRAS & 3 & 0 \\
\hline ARACUAI & VIRGEM DA LAPA & 1 & 0 \\
\hline BARBACENA & ALFREDO VASCONCELOS & 0 & 0 \\
\hline BARBACENA & ALTO RIO DOCE & 2 & 0 \\
\hline BARBACENA & ANDRELANDIA & 1 & 0 \\
\hline BARBACENA & ANTONIO CARLOS & 1 & 0 \\
\hline BARBACENA & ARACITABA & 0 & 0 \\
\hline BARBACENA & BARBACENA & 9 & 1 \\
\hline BARBACENA & BARROSO & 0 & 0 \\
\hline BARBACENA & BIAS FORTES & 0 & 0 \\
\hline BARBACENA & CAPELA NOVA & 0 & 0 \\
\hline BARBACENA & CARANDAI & 1 & 0 \\
\hline BARBACENA & CIPOTANEA & 0 & 0 \\
\hline BARBACENA & DESTERRO DO MELO & 0 & 0 \\
\hline BARBACENA & IBERTIOGA & 0 & 0 \\
\hline BARBACENA & MADRE DE DEUS DE MINAS & 0 & 0 \\
\hline BARBACENA & MERCES & 1 & 0 \\
\hline BARBACENA & OLIVEIRA FORTES & 1 & 0 \\
\hline BARBACENA & PAIVA & 0 & 0 \\
\hline BARBACENA & PIEDADE DO RIO GRANDE & 0 & 0 \\
\hline BARBACENA & RESSAQUINHA & 0 & 0 \\
\hline BARBACENA & SANTA BARBARA DO TUGURIO & 2 & 0 \\
\hline BARBACENA & SANTA RITA DO IBITIPOCA & 0 & 0 \\
\hline BARBACENA & SANTANA DO GARAMBEU & 1 & 0 \\
\hline BARBACENA & SAO VICENTE DE MINAS & 1 & 0 \\
\hline BARBACENA & SENHORA DOS REMEDIOS & 0 & 0 \\
\hline CAMPO BELO & AGUANIL & 0 & 0 \\
\hline CAMPO BELO & CAMACHO & 1 & 0 \\
\hline CAMPO BELO & CAMPO BELO & 0 & 0 \\
\hline CAMPO BELO & CANA VERDE & 1 & 0 \\
\hline CAMPO BELO & CANDEIAS & 1 & 0 \\
\hline CAMPO BELO & CRISTAIS & 0 & 0 \\
\hline CAMPO BELO & LAVRAS & 3 & 0 \\
\hline CAMPO BELO & PERDOES & 1 & 0 \\
\hline CAMPO BELO & RIBEIRAO VERMELHO & 0 & 0 \\
\hline CAMPO BELO & SANTANA DO JACARE & 1 & 0 \\
\hline CAMPO BELO & SANTO ANTONIO DO AMPARO & 1 & 0 \\
\hline CAMPO BELO & SAO FRANCISCO DE PAULA & 0 & 0 \\
\hline CARANGOLA & ALTO CAPARAO & 0 & 0 \\
\hline
\end{tabular}




\begin{tabular}{|c|c|c|c|}
\hline CARANGOLA & CAIANA & 1 & 0 \\
\hline CARANGOLA & CAPARAO & 0 & 0 \\
\hline CARANGOLA & CARANGOLA & 8 & 1 \\
\hline CARANGOLA & DIVINO & 5 & 1 \\
\hline CARANGOLA & ESPERA FELIZ & 2 & 0 \\
\hline CARANGOLA & FARIA LEMOS & 1 & 0 \\
\hline CARANGOLA & FERVEDOURO & 5 & 1 \\
\hline CARANGOLA & ORIZANIA & 2 & 0 \\
\hline CARANGOLA & PEDRA DOURADA & 0 & 0 \\
\hline CARANGOLA & TOMBOS & 1 & 0 \\
\hline CARATINGA & ALVARENGA & 1 & 0 \\
\hline CARATINGA & BOM JESUS DO GALHO & 1 & 0 \\
\hline CARATINGA & BUGRE & 1 & 0 \\
\hline CARATINGA & CARATINGA & 5 & 1 \\
\hline CARATINGA & CORREGO NOVO & 2 & 0 \\
\hline CARATINGA & DOM CAVATI & 1 & 0 \\
\hline CARATINGA & ENTRE FOLHAS & 0 & 0 \\
\hline CARATINGA & IAPU & 2 & 0 \\
\hline CARATINGA & IMBE DE MINAS & 1 & 0 \\
\hline CARATINGA & INHAPIM & 6 & 1 \\
\hline CARATINGA & IPABA & 1 & 0 \\
\hline CARATINGA & IPANEMA & 2 & 0 \\
\hline CARATINGA & PIEDADE DE CARATINGA & 0 & 0 \\
\hline CARATINGA & PINGO D AGUA & 1 & 0 \\
\hline CARATINGA & POCRANE & 0 & 0 \\
\hline CARATINGA & SANTA BARBARA DO LESTE & 0 & 0 \\
\hline CARATINGA & SANTA RITA DE MINAS & 0 & 0 \\
\hline CARATINGA & SAO DOMINGOS DAS DORES & 0 & 0 \\
\hline CARATINGA & SAO JOAO DO ORIENTE & 0 & 0 \\
\hline CARATINGA & SAO SEBASTIAO DO ANTA & 2 & 0 \\
\hline CARATINGA & TAPARUBA & 0 & 0 \\
\hline CARATINGA & TARUMIRIM & 4 & 0 \\
\hline CARATINGA & UBAPORANGA & 1 & 0 \\
\hline CARATINGA & VARGEM ALEGRE & 1 & 0 \\
\hline CAXAMBU & AIURUOCA & 1 & 0 \\
\hline CAXAMBU & ALAGOA & 2 & 0 \\
\hline CAXAMBU & BAEPENDI & 3 & 0 \\
\hline CAXAMBU & BOCAINA DE MINAS & 1 & 0 \\
\hline CAXAMBU & CARVALHOS & 0 & 0 \\
\hline CAXAMBU & CAXAMBU & 4 & 0 \\
\hline CAXAMBU & CONCEICAO DO RIO VERDE & 3 & 0 \\
\hline CAXAMBU & CRUZILIA & 0 & 0 \\
\hline CAXAMBU & ITAMONTE & 2 & $\underline{0}$ \\
\hline CAXAMBU & ITANHANDU & 1 & 0 \\
\hline CAXAMBU & JESUANIA & 2 & 0 \\
\hline
\end{tabular}




\begin{tabular}{|c|c|c|c|}
\hline CAXAMBU & LIBERDADE & 1 & 0 \\
\hline CAXAMBU & MINDURI & 2 & 0 \\
\hline CAXAMBU & OLIMPIO NORONHA & 0 & 0 \\
\hline CAXAMBU & PASSA QUATRO & 3 & 0 \\
\hline CAXAMBU & PASSA VINTE & 1 & 0 \\
\hline CAXAMBU & POUSO ALTO & 0 & 0 \\
\hline CAXAMBU & SAO LOURENCO & 0 & 0 \\
\hline CAXAMBU & SAO SEBASTIAO DO RIO VERDE & 1 & 0 \\
\hline CAXAMBU & SAO TOME DAS LETRAS & 2 & 0 \\
\hline CAXAMBU & SERITINGA & 1 & 0 \\
\hline CAXAMBU & SERRANOS & 0 & 0 \\
\hline CAXAMBU & SOLEDADE DE MINAS & 0 & 0 \\
\hline CORONEL FABRICIANO & ANTONIO DIAS & 1 & 0 \\
\hline CORONEL FABRICIANO & BELO ORIENTE & 1 & 0 \\
\hline CORONEL FABRICIANO & BRAUNAS & 0 & 0 \\
\hline CORONEL FABRICIANO & CORONEL FABRICIANO & 6 & 1 \\
\hline CORONEL FABRICIANO & IPATINGA & 8 & 1 \\
\hline CORONEL FABRICIANO & JAGUARAÇU & 0 & 0 \\
\hline CORONEL FABRICIANO & JOANESIA & 0 & 0 \\
\hline CORONEL FABRICIANO & MARLIERIA & 1 & 0 \\
\hline CORONEL FABRICIANO & MESQUITA & 2 & 0 \\
\hline CORONEL FABRICIANO & SANTANA DO PARAISO & 3 & 0 \\
\hline CORONEL FABRICIANO & TIMOTEO & 5 & 1 \\
\hline CONSELHEIRO LAFAIETE & CARANAIBA & 1 & 0 \\
\hline CONSELHEIRO LAFAIETE & CASA GRANDE & 1 & 0 \\
\hline CONSELHEIRO LAFAIETE & CATAS ALTAS DA NORUEGA & 0 & 0 \\
\hline CONSELHEIRO LAFAIETE & CONGONHAS & 1 & 0 \\
\hline CONSELHEIRO LAFAIETE & CONSELHEIRO LAFAIETE & 5 & 1 \\
\hline CONSELHEIRO LAFAIETE & CRISTIANO OTONI & 0 & 0 \\
\hline CONSELHEIRO LAFAIETE & DESTERRO DE ENTRE RIOS & 2 & 0 \\
\hline CONSELHEIRO LAFAIETE & ENTRE RIOS DE MINAS & 1 & 0 \\
\hline CONSELHEIRO LAFAIETE & ITAVERAVA & 1 & 0 \\
\hline CONSELHEIRO LAFAIETE & JECEABA & 0 & 0 \\
\hline CONSELHEIRO LAFAIETE & LAMIM & 1 & 0 \\
\hline CONSELHEIRO LAFAIETE & OURO BRANCO & 2 & $\underline{0}$ \\
\hline CONSELHEIRO LAFAIETE & PIRANGA & 3 & 0 \\
\hline CONSELHEIRO LAFAIETE & QUELUZITO & 0 & 0 \\
\hline CONSELHEIRO LAFAIETE & RIO ESPERA & 1 & 0 \\
\hline CONSELHEIRO LAFAIETE & SANTANA DOS MONTES & 1 & 0 \\
\hline CONSELHEIRO LAFAIETE & SAO BRAS DO SUACUI & 0 & 0 \\
\hline CONSELHEIRO LAFAIETE & SENHORA DE OLIVEIRA & 1 & 0 \\
\hline CURVELO & AUGUSTO DE LIMA & 2 & 0 \\
\hline CURVELO & BUENOPOLIS & 2 & $\underline{0}$ \\
\hline CURVELO & CORINTO & 0 & 0 \\
\hline CURVELO & CURVELO & 9 & 1 \\
\hline
\end{tabular}




\begin{tabular}{|c|c|c|c|}
\hline CURVELO & FELIXLANDIA & 2 & 0 \\
\hline CURVELO & INIMUTABA & 1 & 0 \\
\hline CURVELO & JOAQUIM FELICIO & 0 & 0 \\
\hline CURVELO & LASSANCE & 2 & 0 \\
\hline CURVELO & MORRO DA GARCA & 0 & 0 \\
\hline CURVELO & PRESIDENTE JUSCELINO & 0 & 0 \\
\hline CURVELO & SANTO HIPOLITO & 0 & 0 \\
\hline CURVELO & TRES MARIAS & 2 & 0 \\
\hline DIAMANTINA & ALVORADA DE MINAS & 2 & 0 \\
\hline DIAMANTINA & ANGELANDIA & 0 & 0 \\
\hline DIAMANTINA & ARICANDUVA & 5 & 1 \\
\hline DIAMANTINA & CAPELINHA & 2 & 0 \\
\hline DIAMANTINA & CARBONITA & 2 & $\underline{0}$ \\
\hline DIAMANTINA & CONCEICAO DO MATO DENTRO & 7 & 1 \\
\hline DIAMANTINA & CONGONHAS DO NORTE & 1 & 0 \\
\hline DIAMANTINA & COUTO DE MAGALHAES DE MINAS & 1 & 0 \\
\hline DIAMANTINA & DATAS & 0 & 0 \\
\hline DIAMANTINA & DIAMANTINA & 1 & 0 \\
\hline DIAMANTINA & FELICIO DOS SANTOS & 1 & 0 \\
\hline DIAMANTINA & GOUVEA & 2 & 0 \\
\hline DIAMANTINA & ITAMARANDIBA & 5 & 1 \\
\hline DIAMANTINA & LEME DO PRADO & 3 & 0 \\
\hline DIAMANTINA & MINAS NOVAS & 9 & 1 \\
\hline DIAMANTINA & MONJOLOS & 0 & 0 \\
\hline DIAMANTINA & PRESIDENTE KUBITSCHEK & 0 & 0 \\
\hline DIAMANTINA & RIO VERMELHO & 4 & 0 \\
\hline DIAMANTINA & SANTO ANTONIO DO ITAMBE & 3 & 0 \\
\hline DIAMANTINA & SAO GONCALO DO RIO PRETO & 0 & 0 \\
\hline DIAMANTINA & SENADOR MODESTINO GONCALVES & 0 & 0 \\
\hline DIAMANTINA & SERRA AZUL DE MINAS & 2 & 0 \\
\hline DIAMANTINA & SERRO & 2 & 0 \\
\hline DIAMANTINA & TURMALINA & 2 & 0 \\
\hline DIAMANTINA & VEREDINHA & 1 & 0 \\
\hline DIVINÓPOLIS & ARAUJOS & 1 & 0 \\
\hline DIVINÓPOLIS & ARCOS & 1 & 0 \\
\hline DIVINÓPOLIS & BAMBUI & 0 & 0 \\
\hline DIVINÓPOLIS & CARMO DA MATA & 3 & 0 \\
\hline DIVINÓPOLIS & CARMO DO CAJURU & 5 & 1 \\
\hline DIVINÓPOLIS & CARMOPOLIS DE MINAS & 0 & 0 \\
\hline DIVINÓPOLIS & CLAUDIO & 0 & 0 \\
\hline DIVINÓPOLIS & CORREGO DANTA & 0 & 0 \\
\hline DIVINÓPOLIS & DIVINOPOLIS & 4 & 0 \\
\hline DIVINÓPOLIS & IGUATAMA & 0 & $\underline{0}$ \\
\hline DIVINÓPOLIS & ITAGUARA & 1 & 0 \\
\hline DIVINÓPOLIS & ITAPECERICA & 0 & 0 \\
\hline
\end{tabular}




\begin{tabular}{|c|c|c|c|}
\hline DIVINÓPOLIS & ITATIAIUCU & 0 & 0 \\
\hline DIVINÓPOLIS & ITAUNA & 9 & 1 \\
\hline DIVINÓPOLIS & JAPARAIBA & 1 & 0 \\
\hline DIVINÓPOLIS & LAGOA DA PRATA & 6 & 1 \\
\hline DIVINÓPOLIS & LUZ & 3 & 0 \\
\hline DIVINÓPOLIS & MEDEIROS & 1 & 0 \\
\hline DIVINÓPOLIS & MOEMA & 0 & 0 \\
\hline DIVINÓPOLIS & NOVA SERRANA & 10 & 2 \\
\hline DIVINÓPOLIS & OLIVEIRA & 2 & 0 \\
\hline DIVINÓPOLIS & PAINS & 2 & 0 \\
\hline DIVINÓPOLIS & PASSA TEMPO & 0 & 0 \\
\hline DIVINÓPOLIS & PEDRA DO INDAIA & 1 & 0 \\
\hline DIVINÓPOLIS & PERDIGAO & 0 & 0 \\
\hline DIVINÓPOLIS & PIRACEMA & 1 & 0 \\
\hline DIVINÓPOLIS & SANTO ANTONIO DO MONTE & 2 & 0 \\
\hline DIVINÓPOLIS & SAO GONCALO DO PARA & 2 & 0 \\
\hline DIVINÓPOLIS & SAO SEBASTIAO DO OESTE & 1 & 0 \\
\hline DIVINÓPOLIS & TAPIRAI & 1 & 0 \\
\hline GOVERNADOR VALADARES & ACUCENA & 2 & 0 \\
\hline GOVERNADOR VALADARES & AIMORES & 1 & 0 \\
\hline GOVERNADOR VALADARES & ALPERCATA & 0 & 0 \\
\hline GOVERNADOR VALADARES & CAPITAO ANDRADE & 0 & 0 \\
\hline GOVERNADOR VALADARES & CENTRAL DE MINAS & 1 & 0 \\
\hline GOVERNADOR VALADARES & CONSELHEIRO PENA & 0 & 0 \\
\hline GOVERNADOR VALADARES & COROACI & 3 & 0 \\
\hline GOVERNADOR VALADARES & CUPARAQUE & 2 & 0 \\
\hline GOVERNADOR VALADARES & DIVINO DAS LARANJEIRAS & 2 & 0 \\
\hline GOVERNADOR VALADARES & ENGENHEIRO CALDAS & 2 & 0 \\
\hline GOVERNADOR VALADARES & FERNANDES TOURINHO & 0 & 0 \\
\hline GOVERNADOR VALADARES & FREI INOCENCIO & 1 & 0 \\
\hline GOVERNADOR VALADARES & GALILEIA & 3 & 0 \\
\hline GOVERNADOR VALADARES & GOIABEIRA & 0 & 0 \\
\hline GOVERNADOR VALADARES & GOVERNADOR VALADARES & 17 & 5 \\
\hline GOVERNADOR VALADARES & ITABIRINHA & 0 & 0 \\
\hline GOVERNADOR VALADARES & ITANHOMI & 3 & $\underline{0}$ \\
\hline GOVERNADOR VALADARES & ITUETA & 0 & 0 \\
\hline GOVERNADOR VALADARES & MANTENA & 0 & 0 \\
\hline GOVERNADOR VALADARES & MARILAC & 0 & 0 \\
\hline GOVERNADOR VALADARES & MATHIAS LOBATO & 1 & 0 \\
\hline GOVERNADOR VALADARES & MENDES PIMENTEL & 1 & 0 \\
\hline GOVERNADOR VALADARES & NACIP RAYDAN & 1 & 0 \\
\hline GOVERNADOR VALADARES & NAQUE & 1 & 0 \\
\hline GOVERNADOR VALADARES & NOVA BELEM & 0 & 0 \\
\hline GOVERNADOR VALADARES & NOVA MODICA & 0 & 0 \\
\hline GOVERNADOR VALADARES & PERIQUITO & 0 & 0 \\
\hline
\end{tabular}




\begin{tabular}{|c|c|c|c|}
\hline GOVERNADOR VALADARES & RESPLENDOR & 1 & 0 \\
\hline GOVERNADOR VALADARES & SANTA EFIGENIA DE MINAS & 0 & 0 \\
\hline GOVERNADOR VALADARES & SANTA RITA DO ITUETO & 0 & 0 \\
\hline GOVERNADOR VALADARES & SAO FELIX DE MINAS & 1 & 0 \\
\hline GOVERNADOR VALADARES & SAO GERALDO DA PIEDADE & 0 & 0 \\
\hline GOVERNADOR VALADARES & SAO GERALDO DO BAIXIO & 0 & 0 \\
\hline GOVERNADOR VALADARES & SAO JOAO DO MANTENINHA & 1 & 0 \\
\hline GOVERNADOR VALADARES & SAO JOSE DA SAFIRA & 1 & 0 \\
\hline GOVERNADOR VALADARES & SAO JOSE DO DIVINO & 0 & 0 \\
\hline GOVERNADOR VALADARES & SARDOA & 0 & 0 \\
\hline GOVERNADOR VALADARES & SOBRALIA & 1 & 0 \\
\hline GOVERNADOR VALADARES & TUMIRITINGA & 2 & 0 \\
\hline GOVERNADOR VALADARES & VIRGOLANDIA & 0 & 0 \\
\hline GUANHÃES & AGUA BOA & 8 & 1 \\
\hline GUANHÃES & CANTAGALO & 0 & 0 \\
\hline GUANHÃES & CARMESIA & 1 & 0 \\
\hline GUANHÃES & COLUNA & 1 & 0 \\
\hline GUANHÃES & DIVINOLANDIA DE MINAS & 0 & 0 \\
\hline GUANHÃES & DOM JOAQUIM & 0 & 0 \\
\hline GUANHÃES & DORES DE GUANHAES & 0 & 0 \\
\hline GUANHÃES & FREI LAGONEGRO & 0 & 0 \\
\hline GUANHÃES & GONZAGA & 0 & 0 \\
\hline GUANHÃES & GUANHAES & 3 & 0 \\
\hline GUANHÃES & JOSE RAYDAN & 0 & 0 \\
\hline GUANHÃES & MATERLANDIA & 0 & 0 \\
\hline GUANHÃES & PAULISTAS & 0 & 0 \\
\hline GUANHÃES & PECANHA & 1 & 0 \\
\hline GUANHÃES & SABINOPOLIS & 5 & 1 \\
\hline GUANHÃES & SANTA MARIA DO SUACUI & 1 & 0 \\
\hline GUANHÃES & SAO JOAO EVANGELISTA & 1 & 0 \\
\hline GUANHÃES & SAO JOSE DO JACURI & 1 & 0 \\
\hline GUANHÃES & SAO PEDRO DO SUACUI & 0 & 0 \\
\hline GUANHÃES & SAO SEBASTIAO DO MARANHAO & 0 & 0 \\
\hline GUANHÃES & SENHORA DO PORTO & 1 & 0 \\
\hline GUANHÃES & VIRGINOPOLIS & 0 & 0 \\
\hline ITAJUBÁ & BRASOPOLIS & 1 & 0 \\
\hline ITAJUBÁ & CARMO DE MINAS & 1 & 0 \\
\hline ITAJUBÁ & CONCEICAO DAS PEDRAS & 1 & 0 \\
\hline ITAJUBÁ & CONCEICAO DOS OUROS & 1 & 0 \\
\hline ITAJUBÁ & CONSOLACAO & 0 & 0 \\
\hline ITAJUBÁ & CRISTINA & 0 & 0 \\
\hline ITAJUBÁ & DELFIM MOREIRA & 2 & 0 \\
\hline ITAJUBÁ & DOM VICOSO & 1 & $\underline{0}$ \\
\hline ITAJUBÁ & GONCALVES & 0 & 0 \\
\hline ITAJUBÁ & ITAJUBA & 8 & 1 \\
\hline
\end{tabular}




\begin{tabular}{|c|c|c|c|}
\hline ITAJUBÁ & MARIA DA FE & 3 & 0 \\
\hline ITAJUBÁ & MARMELOPOLIS & 1 & 0 \\
\hline ITAJUBÁ & NATERCIA & 1 & 0 \\
\hline ITAJUBÁ & PARAISOPOLIS & 1 & 0 \\
\hline ITAJUBÁ & PEDRALVA & 3 & 0 \\
\hline ITAJUBÁ & PIRANGUCU & 0 & 0 \\
\hline ITAJUBÁ & PIRANGUINHO & 4 & 0 \\
\hline ITAJUBÁ & SAO JOSE DO ALEGRE & 0 & 0 \\
\hline ITAJUBÁ & SAPUCAI-MIRIM & 0 & 0 \\
\hline ITAJUBÁ & VIRGINIA & 1 & 0 \\
\hline ITAJUBÁ & WENCESLAU BRAZ & 1 & 0 \\
\hline ITUIUTABA & CACHOEIRA DOURADA & 1 & 0 \\
\hline ITUIUTABA & CANAPOLIS & 2 & 0 \\
\hline ITUIUTABA & CAPINOPOLIS & 0 & 0 \\
\hline ITUIUTABA & CENTRALINA & 1 & 0 \\
\hline ITUIUTABA & GURINHATA & 0 & 0 \\
\hline ITUIUTABA & IPIACU & 1 & 0 \\
\hline ITUIUTABA & ITUIUTABA & 14 & 3 \\
\hline ITUIUTABA & SANTA VITORIA & 3 & 0 \\
\hline JANAUBA & CATUTI & 0 & 0 \\
\hline JANAUBA & ESPINOSA & 0 & 0 \\
\hline JANAUBA & GAMELEIRAS & 2 & 0 \\
\hline JANAUBA & JAIBA & 3 & 0 \\
\hline JANAUBA & JANAUBA & 10 & 2 \\
\hline JANAUBA & MAMONAS & 0 & 0 \\
\hline JANAUBA & MATO VERDE & 1 & 0 \\
\hline JANAUBA & MONTE AZUL & 2 & 0 \\
\hline JANAUBA & MONTEZUMA & 1 & 0 \\
\hline JANAUBA & NOVA PORTEIRINHA & 0 & 0 \\
\hline JANAUBA & PAI PEDRO & 0 & 0 \\
\hline JANAUBA & PORTEIRINHA & 0 & 0 \\
\hline JANAUBA & RIACHO DOS MACHADOS & 1 & 0 \\
\hline JANAUBA & RIO PARDO DE MINAS & 7 & 1 \\
\hline JANAUBA & SANTO ANTONIO DO RETIRO & 0 & 0 \\
\hline JANAUBA & SERRANOPOLIS DE MINAS & 0 & 0 \\
\hline JANAUBA & VERDELANDIA & 3 & 0 \\
\hline JANUARIA & BONITO DE MINAS & 1 & 0 \\
\hline JANUARIA & CHAPADA GAUCHA & 0 & 0 \\
\hline JANUARIA & CONEGO MARINHO & 1 & 0 \\
\hline JANUARIA & IBIRACATU & 0 & 0 \\
\hline JANUARIA & ICARAI DE MINAS & 5 & 1 \\
\hline JANUARIA & ITACARAMBI & 1 & 0 \\
\hline JANUARIA & JANUARIA & 13 & 3 \\
\hline JANUARIA & JUVENILIA & 2 & 0 \\
\hline JANUARIA & MANGA & 3 & 0 \\
\hline
\end{tabular}




\begin{tabular}{|c|c|c|c|}
\hline JANUARIA & MATIAS CARDOSO & 1 & 0 \\
\hline JANUARIA & MIRAVANIA & 0 & 0 \\
\hline JANUARIA & MONTALVANIA & 2 & 0 \\
\hline JANUARIA & PEDRAS DE MARIA DA CRUZ & 0 & 0 \\
\hline JANUARIA & PINTOPOLIS & 3 & 0 \\
\hline JANUARIA & SAO FRANCISCO & 12 & 3 \\
\hline JANUARIA & SAO JOAO DAS MISSOES & 2 & 0 \\
\hline JANUARIA & UBAI & 5 & 1 \\
\hline JANUARIA & URUCUIA & 1 & 0 \\
\hline JANUARIA & VARZELANDIA & 5 & 1 \\
\hline JUIZ DE FORA & ARANTINA & 0 & 0 \\
\hline JUIZ DE FORA & BELMIRO BRAGA & 0 & 0 \\
\hline JUIZ DE FORA & BICAS & 0 & 0 \\
\hline JUIZ DE FORA & BOM JARDIM DE MINAS & 1 & 0 \\
\hline JUIZ DE FORA & CHACARA & 0 & 0 \\
\hline JUIZ DE FORA & CHIADOR & 1 & 0 \\
\hline JUIZ DE FORA & CORONEL PACHECO & 0 & 0 \\
\hline JUIZ DE FORA & DESCOBERTO & 1 & 0 \\
\hline JUIZ DE FORA & EWBANK DA CAMARA & 1 & 0 \\
\hline JUIZ DE FORA & GOIANA & 1 & 0 \\
\hline JUIZ DE FORA & GUARARA & 0 & 0 \\
\hline JUIZ DE FORA & JUIZ DE FORA & 21 & 5 \\
\hline JUIZ DE FORA & LIMA DUARTE & 0 & 0 \\
\hline JUIZ DE FORA & MAR DE ESPANHA & 1 & 0 \\
\hline JUIZ DE FORA & MARIPA DE MINAS & 1 & 0 \\
\hline JUIZ DE FORA & MATIAS BARBOSA & 1 & 0 \\
\hline JUIZ DE FORA & OLARIA & 1 & 0 \\
\hline JUIZ DE FORA & PEDRO TEIXEIRA & 1 & 0 \\
\hline JUIZ DE FORA & PEQUERI & 1 & 0 \\
\hline JUIZ DE FORA & PIAU & 0 & 0 \\
\hline JUIZ DE FORA & RIO NOVO & 1 & 0 \\
\hline JUIZ DE FORA & RIO PRETO & 1 & 0 \\
\hline JUIZ DE FORA & ROCHEDO DE MINAS & 1 & 0 \\
\hline JUIZ DE FORA & SANTA BARBARA DO MONTE VERDE & 1 & 0 \\
\hline JUIZ DE FORA & SANTA RITA DE JACUTINGA & 0 & 0 \\
\hline JUIZ DE FORA & SANTANA DO DESERTO & 0 & 0 \\
\hline JUIZ DE FORA & SANTOS DUMONT & 2 & 0 \\
\hline JUIZ DE FORA & SAO JOAO NEPOMUCENO & 1 & 0 \\
\hline JUIZ DE FORA & SENADOR CORTES & 1 & 0 \\
\hline JUIZ DE FORA & SIMAO PEREIRA & 1 & 0 \\
\hline LEOPOLDINA & ALEM PARAIBA & 3 & 0 \\
\hline LEOPOLDINA & ARGIRITA & 0 & 0 \\
\hline LEOPOLDINA & CATAGUASES & 0 & 0 \\
\hline LEOPOLDINA & ESTRELA DALVA & 1 & 0 \\
\hline LEOPOLDINA & ITAMARATI DE MINAS & 0 & 0 \\
\hline
\end{tabular}




\begin{tabular}{|c|c|c|c|}
\hline LEOPOLDINA & LEOPOLDINA & 6 & 1 \\
\hline LEOPOLDINA & PIRAPETINGA & 0 & 0 \\
\hline LEOPOLDINA & RECREIO & 0 & 0 \\
\hline LEOPOLDINA & SANTO ANTONIO DO AVENTUREIRO & 1 & 0 \\
\hline LEOPOLDINA & VOLTA GRANDE & 2 & 0 \\
\hline MANHUAÇU & ALTO JEQUITIBA & 2 & 0 \\
\hline MANHUAÇU & CAPUTIRA & 1 & 0 \\
\hline MANHUAÇU & CHALE & 1 & 0 \\
\hline MANHUAÇU & CONCEICAO DE IPANEMA & 0 & 0 \\
\hline MANHUAÇU & DURANDE & 1 & 0 \\
\hline MANHUAÇU & LAJINHA & 2 & 0 \\
\hline MANHUAÇU & LUISBURGO & 0 & 0 \\
\hline MANHUAÇU & MANHUACU & 5 & 1 \\
\hline MANHUAÇU & MANHUMIRIM & 0 & 0 \\
\hline MANHUAÇU & MARTINS SOARES & 1 & 0 \\
\hline MANHUAÇU & MATIPO & 3 & 0 \\
\hline MANHUAÇU & MUTUM & 3 & 0 \\
\hline MANHUAÇU & REDUTO & 0 & 0 \\
\hline MANHUAÇU & SANTA MARGARIDA & 5 & 1 \\
\hline MANHUAÇU & SANTANA DO MANHUACU & 1 & 0 \\
\hline MANHUAÇU & SAO JOAO DO MANHUACU & 0 & 0 \\
\hline MANHUAÇU & SAO JOSE DO MANTIMENTO & 0 & 0 \\
\hline MANHUAÇU & SIMONESIA & 2 & 0 \\
\hline METROPOLITANA A & BARAO DE COCAIS & 0 & 0 \\
\hline METROPOLITANA A & BELO HORIZONTE & 27 & 6 \\
\hline METROPOLITANA A & BELO VALE & 1 & 0 \\
\hline METROPOLITANA A & BOM JESUS DO AMPARO & 1 & 0 \\
\hline METROPOLITANA A & BONFIM & 1 & 0 \\
\hline METROPOLITANA A & BRUMADINHO & 1 & 0 \\
\hline METROPOLITANA A & CAETE & 2 & 0 \\
\hline METROPOLITANA A & CATAS ALTAS & 0 & 0 \\
\hline METROPOLITANA A & CRUCILANDIA & 0 & 0 \\
\hline METROPOLITANA A & MOEDA & 0 & 0 \\
\hline METROPOLITANA A & NOVA LIMA & 8 & 1 \\
\hline METROPOLITANA A & NOVA UNIAO & 2 & 0 \\
\hline METROPOLITANA A & PIEDADE DOS GERAIS & 0 & 0 \\
\hline METROPOLITANA A & RAPOSOS & 4 & 0 \\
\hline METROPOLITANA A & RIO ACIMA & 0 & 0 \\
\hline METROPOLITANA A & RIO MANSO & 1 & 0 \\
\hline METROPOLITANA A & SABARA & 10 & 2 \\
\hline METROPOLITANA A & SANTA BARBARA & 1 & 0 \\
\hline METROPOLITANA B & BELO HORIZONTE & 30 & 6 \\
\hline METROPOLITANA B & BETIM & 10 & 2 \\
\hline METROPOLITANA B & CONTAGEM & 27 & 6 \\
\hline METROPOLITANA B & ESMERALDAS & 4 & 0 \\
\hline
\end{tabular}




\begin{tabular}{|c|c|c|c|}
\hline METROPOLITANA B & IBIRITE & 7 & 1 \\
\hline METROPOLITANA B & IGARAPE & 2 & 0 \\
\hline METROPOLITANA B & JUATUBA & 0 & 0 \\
\hline METROPOLITANA B & MARIO CAMPOS & 2 & 0 \\
\hline METROPOLITANA B & MATEUS LEME & 2 & 0 \\
\hline METROPOLITANA B & SAO JOAQUIM DE BICAS & 0 & 0 \\
\hline METROPOLITANA B & SARZEDO & 1 & 0 \\
\hline METROPOLITANA C & BELO HORIZONTE & 32 & 6 \\
\hline METROPOLITANA C & CONFINS & 1 & 0 \\
\hline METROPOLITANA C & JABOTICATUBAS & 2 & 0 \\
\hline METROPOLITANA C & LAGOA SANTA & 0 & 0 \\
\hline METROPOLITANA C & MORRO DO PILAR & 1 & 0 \\
\hline METROPOLITANA C & PEDRO LEOPOLDO & 1 & 0 \\
\hline METROPOLITANA C & RIBEIRAO DAS NEVES & 36 & 10 \\
\hline METROPOLITANA C & SANTA LUZIA & 14 & 3 \\
\hline METROPOLITANA C & SANTANA DO RIACHO & 4 & 0 \\
\hline METROPOLITANA C & SAO JOSE DA LAPA & 4 & 0 \\
\hline METROPOLITANA C & TAQUARACU DE MINAS & 0 & 0 \\
\hline METROPOLITANA C & VESPASIANO & 8 & 1 \\
\hline MONTE CARMELO & ABADIA DOS DOURADOS & 1 & 0 \\
\hline MONTE CARMELO & CASCALHO RICO & 0 & 0 \\
\hline MONTE CARMELO & COROMANDEL & 5 & 1 \\
\hline MONTE CARMELO & DOURADOQUARA & 0 & 0 \\
\hline MONTE CARMELO & ESTRELA DO SUL & 1 & 0 \\
\hline MONTE CARMELO & GRUPIARA & 1 & 0 \\
\hline MONTE CARMELO & MONTE CARMELO & 1 & 0 \\
\hline MONTE CARMELO & ROMARIA & 0 & 0 \\
\hline MONTES CLAROS & BOCAIUVA & 2 & 0 \\
\hline MONTES CLAROS & BOTUMIRIM & 2 & 0 \\
\hline MONTES CLAROS & BRASILIA DE MINAS & 6 & 1 \\
\hline MONTES CLAROS & CAMPO AZUL & 1 & 0 \\
\hline MONTES CLAROS & CAPITAO ENEAS & 2 & 0 \\
\hline MONTES CLAROS & CLARO DOS POCOES & 0 & 0 \\
\hline MONTES CLAROS & CORACAO DE JESUS & 5 & 1 \\
\hline MONTES CLAROS & CRISTALIA & 2 & 0 \\
\hline MONTES CLAROS & ENGENHEIRO NAVARRO & 0 & 0 \\
\hline MONTES CLAROS & FRANCISCO DUMONT & 0 & 0 \\
\hline MONTES CLAROS & FRANCISCO SA & 1 & 0 \\
\hline MONTES CLAROS & GLAUCILANDIA & 1 & 0 \\
\hline MONTES CLAROS & GRAO MOGOL & 1 & 0 \\
\hline MONTES CLAROS & GUARACIAMA & 1 & 0 \\
\hline MONTES CLAROS & ITACAMBIRA & 0 & 0 \\
\hline MONTES CLAROS & JAPONVAR & 0 & 0 \\
\hline MONTES CLAROS & JOSENOPOLIS & 2 & 0 \\
\hline MONTES CLAROS & JURAMENTO & 0 & 0 \\
\hline
\end{tabular}




\begin{tabular}{|c|c|c|c|}
\hline MONTES CLAROS & LONTRA & 0 & 0 \\
\hline MONTES CLAROS & LUISLANDIA & 1 & 0 \\
\hline MONTES CLAROS & MIRABELA & 0 & 0 \\
\hline MONTES CLAROS & MONTES CLAROS & 11 & 3 \\
\hline MONTES CLAROS & OLHOS-D AGUA & 0 & 0 \\
\hline MONTES CLAROS & PADRE CARVALHO & 0 & 0 \\
\hline MONTES CLAROS & PATIS & 0 & 0 \\
\hline MONTES CLAROS & SAO JOAO DA LAGOA & 0 & 0 \\
\hline MONTES CLAROS & SAO JOAO DA PONTE & 0 & 0 \\
\hline MONTES CLAROS & SAO JOAO DO PACUI & 1 & 0 \\
\hline MONTES CLAROS & SAO JOAO DO PARAISO & 2 & 0 \\
\hline MONTES CLAROS & VARGEM GRANDE DO RIO PARDO & 0 & 0 \\
\hline MURIAÉ & ANTONIO PRADO DE MINAS & 1 & 0 \\
\hline MURIAÉ & BARAO DE MONTE ALTO & 0 & 0 \\
\hline MURIAÉ & EUGENOPOLIS & 1 & 0 \\
\hline MURIAÉ & LARANJAL & 0 & 0 \\
\hline MURIAÉ & MIRADOURO & 2 & 0 \\
\hline MURIAÉ & MIRAI & 2 & 0 \\
\hline MURIAÉ & MURIAE & 8 & 1 \\
\hline MURIAÉ & PALMA & 0 & 0 \\
\hline MURIAÉ & PATROCINIO DO MURIAE & 0 & 0 \\
\hline MURIAÉ & ROSARIO DA LIMEIRA & 0 & 0 \\
\hline MURIAÉ & SANTANA DE CATAGUASES & 0 & 0 \\
\hline MURIAÉ & SAO FRANCISCO DO GLORIA & 0 & 0 \\
\hline MURIAÉ & SAO SEBASTIAO DA VARGEM ALEGRE & 0 & 0 \\
\hline MURIAÉ & VIEIRAS & 0 & 0 \\
\hline NOVA ERA & BELA VISTA DE MINAS & 0 & 0 \\
\hline NOVA ERA & DIONISIO & 0 & 0 \\
\hline NOVA ERA & FERROS & 3 & 0 \\
\hline NOVA ERA & ITABIRA & 4 & 0 \\
\hline NOVA ERA & ITAMBE DO MATO DENTRO & 2 & 0 \\
\hline NOVA ERA & JOAO MONLEVADE & 6 & 1 \\
\hline NOVA ERA & NOVA ERA & 0 & 0 \\
\hline NOVA ERA & PASSABEM & 1 & 0 \\
\hline NOVA ERA & RIO PIRACICABA & 0 & 0 \\
\hline NOVA ERA & SANTA MARIA DE ITABIRA & 1 & 0 \\
\hline NOVA ERA & SANTO ANTONIO DO RIO ABAIXO & 1 & 0 \\
\hline NOVA ERA & SAO DOMINGOS DO PRATA & 4 & 0 \\
\hline NOVA ERA & SAO GONCALO DO RIO ABAIXO & 1 & 0 \\
\hline NOVA ERA & SAO JOSE DO GOIABAL & 1 & 0 \\
\hline NOVA ERA & SAO SEBASTIAO DO RIO PRETO & 0 & 0 \\
\hline OURO PRETO & ACAIACA & 1 & 0 \\
\hline OURO PRETO & DIOGO DE VASCONCELOS & 2 & 0 \\
\hline OURO PRETO & ITABIRITO & 4 & 0 \\
\hline OURO PRETO & MARIANA & 2 & 0 \\
\hline
\end{tabular}




\begin{tabular}{|c|c|c|c|}
\hline OURO PRETO & OURO PRETO & 9 & 1 \\
\hline PARA DE MINAS & ABAETE & 3 & 0 \\
\hline PARA DE MINAS & BIQUINHAS & 0 & 0 \\
\hline PARA DE MINAS & BOM DESPACHO & 4 & 0 \\
\hline PARA DE MINAS & CEDRO DO ABAETE & 0 & 0 \\
\hline PARA DE MINAS & CONCEICAO DO PARA & 2 & 0 \\
\hline PARA DE MINAS & DORES DO INDAIA & 0 & 0 \\
\hline PARA DE MINAS & ESTRELA DO INDAIA & 2 & 0 \\
\hline PARA DE MINAS & FLORESTAL & 3 & 0 \\
\hline PARA DE MINAS & IGARATINGA & 1 & 0 \\
\hline PARA DE MINAS & LEANDRO FERREIRA & 0 & 0 \\
\hline PARA DE MINAS & MARTINHO CAMPOS & 4 & 0 \\
\hline PARA DE MINAS & MORADA NOVA DE MINAS & 0 & $\underline{0}$ \\
\hline PARA DE MINAS & ONCA DE PITANGUI & 4 & 0 \\
\hline PARA DE MINAS & PAINEIRAS & 0 & 0 \\
\hline PARA DE MINAS & PARA DE MINAS & 5 & 1 \\
\hline PARA DE MINAS & PEQUI & 1 & 0 \\
\hline PARA DE MINAS & PITANGUI & 0 & 0 \\
\hline PARA DE MINAS & QUARTEL GERAL & 0 & 0 \\
\hline PARA DE MINAS & SAO JOSE DA VARGINHA & 0 & 0 \\
\hline PARA DE MINAS & SERRA DA SAUDADE & 0 & 0 \\
\hline PARACATU & BRASILANDIA DE MINAS & 1 & 0 \\
\hline PARACATU & GUARDA-MOR & 0 & 0 \\
\hline PARACATU & JOAO PINHEIRO & 4 & 0 \\
\hline PARACATU & PARACATU & 4 & 0 \\
\hline PARACATU & VAZANTE & 0 & 0 \\
\hline PASSOS & ALPINOPOLIS & 2 & 0 \\
\hline PASSOS & BOM JESUS DA PENHA & 0 & 0 \\
\hline PASSOS & CAPITOLIO & 1 & 0 \\
\hline PASSOS & CARMO DO RIO CLARO & 2 & 0 \\
\hline PASSOS & CORREGO FUNDO & 1 & 0 \\
\hline PASSOS & DELFINOPOLIS & 0 & 0 \\
\hline PASSOS & DORESOPOLIS & 0 & 0 \\
\hline PASSOS & FORMIGA & 1 & 0 \\
\hline PASSOS & FORTALEZA DE MINAS & 1 & $\underline{0}$ \\
\hline PASSOS & PASSOS & 11 & 2 \\
\hline PASSOS & PIMENTA & 0 & 0 \\
\hline PASSOS & PIUMHI & 3 & 0 \\
\hline PASSOS & SAO JOAO BATISTA DO GLORIA & 2 & 0 \\
\hline PASSOS & SAO JOSE DA BARRA & 0 & 0 \\
\hline PASSOS & SAO ROQUE DE MINAS & 1 & 0 \\
\hline PASSOS & VARGEM BONITA & 0 & 0 \\
\hline PATOS DE MINAS & ARAPUA & 0 & 0 \\
\hline PATOS DE MINAS & CARMO DO PARANAIBA & 3 & 0 \\
\hline PATOS DE MINAS & LAGAMAR & 3 & 0 \\
\hline
\end{tabular}




\begin{tabular}{|c|c|c|c|}
\hline PATOS DE MINAS & LAGOA FORMOSA & 1 & 0 \\
\hline PATOS DE MINAS & LAGOA GRANDE & 0 & 0 \\
\hline PATOS DE MINAS & MATUTINA & 0 & 0 \\
\hline PATOS DE MINAS & PATOS DE MINAS & 8 & 1 \\
\hline PATOS DE MINAS & PRESIDENTE OLEGARIO & 4 & 0 \\
\hline PATOS DE MINAS & RIO PARANAIBA & 0 & 0 \\
\hline PATOS DE MINAS & SANTA ROSA DA SERRA & 1 & 0 \\
\hline PATOS DE MINAS & SAO GONCALO DO ABAETE & 0 & 0 \\
\hline PATOS DE MINAS & SAO GOTARDO & 6 & 1 \\
\hline PATOS DE MINAS & TIROS & 0 & 0 \\
\hline PATOS DE MINAS & VARJAO DE MINAS & 0 & 0 \\
\hline PATROCÍNIO & CRUZEIRO DA FORTALEZA & 1 & 0 \\
\hline PATROCÍNIO & GUIMARANIA & 1 & 0 \\
\hline PATROCÍNIO & IBIA & 1 & 0 \\
\hline PATROCÍNIO & IRAI DE MINAS & 0 & 0 \\
\hline PATROCÍNIO & PATROCINIO & 7 & 1 \\
\hline PATROCÍNIO & PERDIZES & 3 & 0 \\
\hline PATROCÍNIO & SERRA DO SALITRE & 0 & 0 \\
\hline PIRAPORA & BURITIZEIRO & 3 & 0 \\
\hline PIRAPORA & IBIAI & 1 & 0 \\
\hline PIRAPORA & JEQUITAI & 1 & 0 \\
\hline PIRAPORA & LAGOA DOS PATOS & 1 & 0 \\
\hline PIRAPORA & PIRAPORA & 0 & 0 \\
\hline PIRAPORA & PONTO CHIQUE & 1 & 0 \\
\hline PIRAPORA & SANTA FE DE MINAS & 1 & 0 \\
\hline PIRAPORA & SAO ROMAO & 1 & 0 \\
\hline PIRAPORA & VARZEA DA PALMA & 1 & 0 \\
\hline POÇOS DE CALDAS & ALTEROSA & 1 & 0 \\
\hline POÇOS DE CALDAS & ANDRADAS & 9 & 1 \\
\hline POÇOS DE CALDAS & AREADO & 1 & 0 \\
\hline POÇOS DE CALDAS & BANDEIRA DO SUL & 2 & 0 \\
\hline POÇOS DE CALDAS & BOTELHOS & 3 & 0 \\
\hline POÇOS DE CALDAS & CABO VERDE & 1 & 0 \\
\hline POÇOS DE CALDAS & CALDAS & 1 & 0 \\
\hline POÇOS DE CALDAS & CAMPESTRE & 0 & $\underline{0}$ \\
\hline POÇOS DE CALDAS & CONCEICAO DA APARECIDA & 0 & 0 \\
\hline POÇOS DE CALDAS & DIVISA NOVA & 2 & 0 \\
\hline POÇOS DE CALDAS & IBITIURA DE MINAS & 1 & 0 \\
\hline POÇOS DE CALDAS & MONTE BELO & 0 & 0 \\
\hline POÇOS DE CALDAS & MUZAMBINHO & 4 & 0 \\
\hline POÇOS DE CALDAS & NOVA RESENDE & 2 & 0 \\
\hline POÇOS DE CALDAS & POCOS DE CALDAS & 4 & 0 \\
\hline POÇOS DE CALDAS & SANTA RITA DE CALDAS & 1 & $\underline{0}$ \\
\hline POÇOS DE CALDAS & SERRANIA & 2 & 0 \\
\hline PONTE NOVA & ABRE CAMPO & 1 & 0 \\
\hline
\end{tabular}




\begin{tabular}{|c|c|c|c|}
\hline PONTE NOVA & ALVINOPOLIS & 4 & 0 \\
\hline PONTE NOVA & AMPARO DO SERRA & 0 & 0 \\
\hline PONTE NOVA & ARAPONGA & 1 & 0 \\
\hline PONTE NOVA & BARRA LONGA & 1 & 0 \\
\hline PONTE NOVA & CAJURI & 2 & 0 \\
\hline PONTE NOVA & CANAA & 2 & 0 \\
\hline PONTE NOVA & DOM SILVERIO & 1 & 0 \\
\hline PONTE NOVA & GUARACIABA & 2 & 0 \\
\hline PONTE NOVA & JEQUERI & 0 & 0 \\
\hline PONTE NOVA & ORATORIOS & 0 & 0 \\
\hline PONTE NOVA & PEDRA BONITA & 0 & 0 \\
\hline PONTE NOVA & PEDRA DO ANTA & 0 & 0 \\
\hline PONTE NOVA & PIEDADE DE PONTE NOVA & 0 & $\underline{0}$ \\
\hline PONTE NOVA & PONTE NOVA & 9 & 1 \\
\hline PONTE NOVA & PORTO FIRME & 2 & 0 \\
\hline PONTE NOVA & RAUL SOARES & 3 & 0 \\
\hline PONTE NOVA & RIO CASCA & 1 & 0 \\
\hline PONTE NOVA & RIO DOCE & 0 & 0 \\
\hline PONTE NOVA & SANTA CRUZ DO ESCALVADO & 0 & 0 \\
\hline PONTE NOVA & SANTO ANTONIO DO GRAMA & 1 & 0 \\
\hline PONTE NOVA & SAO MIGUEL DO ANTA & 3 & 0 \\
\hline PONTE NOVA & SAO PEDRO DOS FERROS & 2 & 0 \\
\hline PONTE NOVA & SEM-PEIXE & 1 & 0 \\
\hline PONTE NOVA & SERICITA & 0 & 0 \\
\hline PONTE NOVA & TEIXEIRAS & 2 & 0 \\
\hline PONTE NOVA & URUCANIA & 0 & 0 \\
\hline PONTE NOVA & VERMELHO NOVO & 0 & 0 \\
\hline PONTE NOVA & VICOSA & 12 & 3 \\
\hline POUSO ALEGRE & ALBERTINA & 1 & 0 \\
\hline POUSO ALEGRE & BOM REPOUSO & 1 & 0 \\
\hline POUSO ALEGRE & BORDA DA MATA & 2 & 0 \\
\hline POUSO ALEGRE & BUENO BRANDAO & 1 & 0 \\
\hline POUSO ALEGRE & CACHOEIRA DE MINAS & 0 & 0 \\
\hline POUSO ALEGRE & CAMANDUCAIA & 5 & 1 \\
\hline POUSO ALEGRE & CAMBUI & 2 & $\underline{0}$ \\
\hline POUSO ALEGRE & CAREACU & 0 & 0 \\
\hline POUSO ALEGRE & CONGONHAL & 1 & 0 \\
\hline POUSO ALEGRE & CORREGO DO BOM JESUS & 0 & 0 \\
\hline POUSO ALEGRE & ESPIRITO SANTO DO DOURADO & 0 & 0 \\
\hline POUSO ALEGRE & ESTIVA & 0 & 0 \\
\hline POUSO ALEGRE & EXTREMA & 0 & 0 \\
\hline POUSO ALEGRE & HELIODORA & 0 & 0 \\
\hline POUSO ALEGRE & INCONFIDENTES & 1 & 0 \\
\hline POUSO ALEGRE & IPUIUNA & 0 & 0 \\
\hline POUSO ALEGRE & ITAPEVA & 1 & 0 \\
\hline
\end{tabular}




\begin{tabular}{|c|c|c|c|}
\hline POUSO ALEGRE & JACUTINGA & 3 & 0 \\
\hline POUSO ALEGRE & MONTE SIAO & 1 & 0 \\
\hline POUSO ALEGRE & MUNHOZ & 0 & 0 \\
\hline POUSO ALEGRE & OURO FINO & 2 & 0 \\
\hline POUSO ALEGRE & POUSO ALEGRE & 10 & 2 \\
\hline POUSO ALEGRE & SANTA RITA DO SAPUCAI & 5 & 1 \\
\hline POUSO ALEGRE & SAO JOAO DA MATA & 1 & 0 \\
\hline POUSO ALEGRE & SAO SEBASTIAO DA BELA VISTA & 0 & 0 \\
\hline POUSO ALEGRE & SENADOR AMARAL & 0 & 0 \\
\hline POUSO ALEGRE & SENADOR JOSE BENTO & 1 & 0 \\
\hline POUSO ALEGRE & SILVIANOPOLIS & 0 & 0 \\
\hline POUSO ALEGRE & TOCOS DO MOJI & 0 & 0 \\
\hline POUSO ALEGRE & TOLEDO & 1 & $\underline{0}$ \\
\hline SÃO JOÃO DEL REI & BOM SUCESSO & 3 & 0 \\
\hline SÃO JOÃO DEL REI & CARRANCAS & 1 & 0 \\
\hline SÃO JOÃO DEL REI & CONCEICAO DA BARRA DE MINAS & 0 & 0 \\
\hline SÃO JOÃO DEL REI & CORONEL XAVIER CHAVES & 2 & 0 \\
\hline SÃO JOÃO DEL REI & DORES DE CAMPOS & 1 & 0 \\
\hline SÃO JOÃO DEL REI & IBITURUNA & 0 & 0 \\
\hline SÃO JOÃO DEL REI & IJACI & 0 & 0 \\
\hline SÃO JOÃO DEL REI & INGAI & 0 & 0 \\
\hline SÃO JOÃO DEL REI & ITUMIRIM & 1 & 0 \\
\hline SÃO JOÃO DEL REI & ITUTINGA & 0 & 0 \\
\hline SÃO JOÃO DEL REI & LAGOA DOURADA & 1 & 0 \\
\hline SÃO JOÃO DEL REI & NAZARENO & 2 & 0 \\
\hline SÃO JOÃO DEL REI & PRADOS & 2 & 0 \\
\hline SÃO JOÃO DEL REI & RESENDE COSTA & 1 & 0 \\
\hline SÃO JOÃO DEL REI & RITAPOLIS & 2 & 0 \\
\hline SÃO JOÃO DEL REI & SANTA CRUZ DE MINAS & 2 & 0 \\
\hline SÃO JOÃO DEL REI & SAO JOAO DEL REI & 6 & 1 \\
\hline SÃO JOÃO DEL REI & SAO TIAGO & 3 & 0 \\
\hline SÃO JOÃO DEL REI & TIRADENTES & 1 & 0 \\
\hline SÃO SEBASTIÃO DO PARAÍSO & ARCEBURGO & 1 & 0 \\
\hline SÃO SEBASTIÃO DO PARAÍSO & CAPETINGA & 3 & 0 \\
\hline SÃO SEBASTIÃO DO PARAÍSO & CASSIA & 1 & 0 \\
\hline SÃO SEBASTIÃO DO PARAÍSO & CLARAVAL & 0 & 0 \\
\hline SÃO SEBASTIÃO DO PARAÍSO & GUARANESIA & 0 & 0 \\
\hline SÃO SEBASTIÃO DO PARAÍSO & GUAXUPE & 3 & 0 \\
\hline SÃO SEBASTIÃO DO PARAÍSO & IBIRACI & 3 & 0 \\
\hline SÃO SEBASTIÃO DO PARAÍSO & ITAMOGI & 1 & 0 \\
\hline SÃO SEBASTIÃO DO PARAÍSO & ITAU DE MINAS & 1 & 0 \\
\hline SÃO SEBASTIÃO DO PARAÍSO & JACUI & 0 & 0 \\
\hline SÃO SEBASTIÃO DO PARAÍSO & JURUAIA & 3 & 0 \\
\hline SÃO SEBASTIÃO DO PARAÍSO & MONTE SANTO DE MINAS & 0 & 0 \\
\hline SÃO SEBASTIÃO DO PARAÍSO & PRATAPOLIS & 2 & 0 \\
\hline
\end{tabular}




\begin{tabular}{|c|c|c|c|}
\hline SÃO SEBASTIÃO DO PARAÍSO & SAO PEDRO DA UNIAO & 1 & 0 \\
\hline SÃO SEBASTIÃO DO PARAÍSO & SAO SEBASTIAO DO PARAISO & 9 & 1 \\
\hline SÃO SEBASTIÃO DO PARAÍSO & SAO TOMAS DE AQUINO & 2 & 0 \\
\hline SETE LAGOAS & ARACAI & 0 & 0 \\
\hline SETE LAGOAS & BALDIM & 1 & 0 \\
\hline SETE LAGOAS & CACHOEIRA DA PRATA & 0 & 0 \\
\hline SETE LAGOAS & CAETANOPOLIS & 0 & 0 \\
\hline SETE LAGOAS & CAPIM BRANCO & 3 & 0 \\
\hline SETE LAGOAS & CORDISBURGO & 0 & 0 \\
\hline SETE LAGOAS & FORTUNA DE MINAS & 0 & 0 \\
\hline SETE LAGOAS & FUNILANDIA & 2 & 0 \\
\hline SETE LAGOAS & INHAUMA & 0 & 0 \\
\hline SETE LAGOAS & JEQUITIBA & 1 & 0 \\
\hline SETE LAGOAS & MARAVILHAS & 0 & 0 \\
\hline SETE LAGOAS & MATOZINHOS & 2 & 0 \\
\hline SETE LAGOAS & PAPAGAIOS & 1 & 0 \\
\hline SETE LAGOAS & PARAOPEBA & 1 & 0 \\
\hline SETE LAGOAS & POMPEU & 0 & 0 \\
\hline SETE LAGOAS & PRUDENTE DE MORAIS & 1 & 0 \\
\hline SETE LAGOAS & SANTANA DE PIRAPAMA & 0 & 0 \\
\hline SETE LAGOAS & SETE LAGOAS & 6 & 1 \\
\hline TEOFILO OTONI & AGUAS FORMOSAS & 5 & 1 \\
\hline TEOFILO OTONI & ATALEIA & 7 & 1 \\
\hline TEOFILO OTONI & BERTOPOLIS & 3 & 0 \\
\hline TEOFILO OTONI & CAMPANARIO & 0 & 0 \\
\hline TEOFILO OTONI & CARAI & 2 & 0 \\
\hline TEOFILO OTONI & CARLOS CHAGAS & 2 & 0 \\
\hline TEOFILO OTONI & CATUJI & 1 & 0 \\
\hline TEOFILO OTONI & CRISOLITA & 0 & 0 \\
\hline TEOFILO OTONI & FRANCISCOPOLIS & 1 & 0 \\
\hline TEOFILO OTONI & FREI GASPAR & 1 & 0 \\
\hline TEOFILO OTONI & FRONTEIRA DOS VALES & 0 & 0 \\
\hline TEOFILO OTONI & ITAIPE & 4 & 0 \\
\hline TEOFILO OTONI & ITAMBACURI & 2 & 0 \\
\hline TEOFILO OTONI & JAMPRUCA & 0 & $\underline{0}$ \\
\hline TEOFILO OTONI & LADAINHA & 4 & 0 \\
\hline TEOFILO OTONI & MACHACALIS & 1 & 0 \\
\hline TEOFILO OTONI & MALACACHETA & 2 & 0 \\
\hline TEOFILO OTONI & NANUQUE & 4 & 0 \\
\hline TEOFILO OTONI & NOVO CRUZEIRO & 8 & 1 \\
\hline TEOFILO OTONI & NOVO ORIENTE DE MINAS & 1 & 0 \\
\hline TEOFILO OTONI & OURO VERDE DE MINAS & 1 & 0 \\
\hline TEOFILO OTONI & PADRE PARAISO & 0 & $\underline{0}$ \\
\hline TEOFILO OTONI & PAVAO & 0 & 0 \\
\hline TEOFILO OTONI & PESCADOR & 1 & 0 \\
\hline
\end{tabular}




\begin{tabular}{|c|c|c|c|}
\hline TEOFILO OTONI & PONTO DOS VOLANTES & 0 & 0 \\
\hline TEOFILO OTONI & POTE & 2 & 0 \\
\hline TEOFILO OTONI & SANTA HELENA DE MINAS & 1 & 0 \\
\hline TEOFILO OTONI & SERRA DOS AIMORES & 2 & 0 \\
\hline TEOFILO OTONI & SETUBINHA & 3 & 0 \\
\hline TEOFILO OTONI & TEOFILO OTONI & 18 & 5 \\
\hline TEOFILO OTONI & UMBURATIBA & 0 & 0 \\
\hline UBÁ & ASTOLFO DUTRA & 4 & 0 \\
\hline UBÁ & BRAS PIRES & 2 & 0 \\
\hline UBÁ & COIMBRA & 1 & 0 \\
\hline UBÁ & DIVINESIA & 1 & 0 \\
\hline UBÁ & DONA EUZEBIA & 1 & 0 \\
\hline UBÁ & DORES DO TURVO & 1 & 0 \\
\hline UBÁ & ERVALIA & 2 & 0 \\
\hline UBÁ & GUARANI & 2 & 0 \\
\hline UBÁ & GUIDOVAL & 1 & 0 \\
\hline UBÁ & GUIRICEMA & 1 & 0 \\
\hline UBÁ & PAULA CANDIDO & 0 & 0 \\
\hline UBÁ & PIRAUBA & 3 & 0 \\
\hline UBÁ & PRESIDENTE BERNARDES & 1 & 0 \\
\hline UBÁ & RIO POMBA & 2 & 0 \\
\hline UBÁ & RODEIRO & 2 & 0 \\
\hline UBÁ & SAO GERALDO & 4 & 0 \\
\hline UBÁ & SENADOR FIRMINO & 0 & 0 \\
\hline UBÁ & SILVEIRANIA & 1 & 0 \\
\hline UBÁ & TABULEIRO & 0 & 0 \\
\hline UBÁ & TOCANTINS & 2 & 0 \\
\hline UBÁ & UBA & 12 & 3 \\
\hline UBÁ & VISCONDE DO RIO BRANCO & 4 & 0 \\
\hline UBERABA & AGUA COMPRIDA & 1 & 0 \\
\hline UBERABA & ARAXA & 2 & 0 \\
\hline UBERABA & CAMPO FLORIDO & 2 & 0 \\
\hline UBERABA & CAMPOS ALTOS & 2 & 0 \\
\hline UBERABA & CARNEIRINHO & 4 & 0 \\
\hline UBERABA & COMENDADOR GOMES & 1 & 0 \\
\hline UBERABA & CONCEICAO DAS ALAGOAS & 1 & 0 \\
\hline UBERABA & CONQUISTA & 1 & 0 \\
\hline UBERABA & DELTA & 1 & 0 \\
\hline UBERABA & FRONTEIRA & 5 & 1 \\
\hline UBERABA & FRUTAL & 3 & 0 \\
\hline UBERABA & ITAPAGIPE & 1 & 0 \\
\hline UBERABA & ITURAMA & 4 & 0 \\
\hline UBERABA & LIMEIRA DO OESTE & 3 & 0 \\
\hline UBERABA & PEDRINOPOLIS & 1 & 0 \\
\hline UBERABA & PIRAJUBA & 1 & 0 \\
\hline
\end{tabular}




\begin{tabular}{|c|c|c|c|}
\hline UBERABA & PLANURA & 3 & 0 \\
\hline UBERABA & PRATINHA & 0 & 0 \\
\hline UBERABA & SACRAMENTO & 3 & 0 \\
\hline UBERABA & SANTA JULIANA & 2 & 0 \\
\hline UBERABA & SAO FRANCISCO DE SALES & 1 & 0 \\
\hline UBERABA & TAPIRA & 1 & 0 \\
\hline UBERABA & UBERABA & 16 & 5 \\
\hline UBERABA & UNIAO DE MINAS & 0 & 0 \\
\hline UBERABA & VERISSIMO & 0 & 0 \\
\hline UBERLANDIA & ARAGUARI & 7 & 1 \\
\hline UBERLANDIA & ARAPORA & 0 & 0 \\
\hline UBERLANDIA & CAMPINA VERDE & 2 & 0 \\
\hline UBERLANDIA & INDIANOPOLIS & 0 & 0 \\
\hline UBERLANDIA & MONTE ALEGRE DE MINAS & 0 & 0 \\
\hline UBERLANDIA & NOVA PONTE & 0 & 0 \\
\hline UBERLANDIA & PRATA & 1 & 0 \\
\hline UBERLANDIA & TUPACIGUARA & 5 & 1 \\
\hline UBERLANDIA & UBERLANDIA & 41 & 10 \\
\hline UNAI & ARINOS & 1 & 0 \\
\hline UNAI & BONFINOPOLIS DE MINAS & 0 & 0 \\
\hline UNAI & BURITIS & 1 & 0 \\
\hline UNAI & CABECEIRA GRANDE & 0 & 0 \\
\hline UNAI & DOM BOSCO & 2 & 0 \\
\hline UNAI & FORMOSO & 1 & 0 \\
\hline UNAI & NATALANDIA & 0 & 0 \\
\hline UNAI & RIACHINHO & 0 & 0 \\
\hline UNAI & UNAI & 4 & 0 \\
\hline UNAI & URUANA DE MINAS & 0 & 0 \\
\hline VARGINHA & ALFENAS & 10 & 2 \\
\hline VARGINHA & BOA ESPERANCA & 6 & 1 \\
\hline VARGINHA & CAMBUQUIRA & 1 & 0 \\
\hline VARGINHA & CAMPANHA & 3 & 0 \\
\hline VARGINHA & CAMPO DO MEIO & 1 & 0 \\
\hline VARGINHA & CAMPOS GERAIS & 6 & 1 \\
\hline VARGINHA & CARMO DA CACHOEIRA & 1 & 0 \\
\hline VARGINHA & CARVALHOPOLIS & 0 & 0 \\
\hline VARGINHA & COQUEIRAL & 0 & 0 \\
\hline VARGINHA & CORDISLANDIA & 0 & 0 \\
\hline VARGINHA & ELOI MENDES & 1 & 0 \\
\hline VARGINHA & FAMA & 0 & 0 \\
\hline VARGINHA & GUAPE & 0 & 0 \\
\hline VARGINHA & ILICINEA & 1 & 0 \\
\hline VARGINHA & LAMBARI & 0 & $\underline{0}$ \\
\hline VARGINHA & LUMINARIAS & 2 & 0 \\
\hline VARGINHA & MACHADO & 4 & 0 \\
\hline
\end{tabular}




\begin{tabular}{|l|l|c|c|}
\hline VARGINHA & MONSENHOR PAULO & 1 & 0 \\
\hline VARGINHA & NEPOMUCENO & 0 & 0 \\
\hline VARGINHA & PARAGUACU & 1 & 0 \\
\hline VARGINHA & POCO FUNDO & 2 & 0 \\
\hline VARGINHA & SANTANA DA VARGEM & 1 & 0 \\
\hline VARGINHA & SAO BENTO ABADE & 1 & 0 \\
\hline VARGINHA & SAO GONCALO DO SAPUCAI & 3 & 0 \\
\hline VARGINHA & TRES CORACOES & 2 & 0 \\
\hline VARGINHA & TRES PONTAS & 1 & 0 \\
\hline VARGINHA & TURVOLANDIA & 10 & 0 \\
\hline VARGINHA & VARGINHA & $\mathbf{1 . 6 1 7}$ & 2 \\
\hline Total geral & & $\mathbf{1 6 2}$ \\
\hline
\end{tabular}

CARGO: PROFESSOR DE EDUCAÇÃO BÁSICA - PEB ANOS INICIAIS DO ENSINO FUNDAMENTAL

\begin{tabular}{|c|c|c|c|}
\hline S R E & MUNICIPIO & $\begin{array}{l}\text { TOTAL DE } \\
\text { VAGAS }\end{array}$ & $\begin{array}{c}\text { VAGAS } \\
\text { RESERVADAS - } \\
\text { PORTADORES DE } \\
\text { DEFICIÊNCIA }\end{array}$ \\
\hline ALMENARA & AGUAS VERMELHAS & 2 & 0 \\
\hline ALMENARA & ALMENARA & 0 & 0 \\
\hline ALMENARA & BANDEIRA & 0 & 0 \\
\hline ALMENARA & CACHOEIRA DE PAJEU & 0 & 0 \\
\hline ALMENARA & CURRAL DE DENTRO & 0 & 0 \\
\hline ALMENARA & DIVISA ALEGRE & 0 & 0 \\
\hline ALMENARA & DIVISOPOLIS & 0 & 0 \\
\hline ALMENARA & FELISBURGO & 0 & 0 \\
\hline ALMENARA & JACINTO & 0 & 0 \\
\hline ALMENARA & JEQUITINHONHA & 4 & 0 \\
\hline ALMENARA & JOAIMA & 1 & 0 \\
\hline ALMENARA & JORDANIA & 3 & 0 \\
\hline ALMENARA & MATA VERDE & 0 & 0 \\
\hline ALMENARA & MONTE FORMOSO & 0 & 0 \\
\hline ALMENARA & PALMOPOLIS & 0 & 0 \\
\hline ALMENARA & PEDRA AZUL & 0 & 0 \\
\hline ALMENARA & RIO DO PRADO & 0 & 0 \\
\hline ALMENARA & RUBIM & 0 & 0 \\
\hline ALMENARA & SALTO DA DIVISA & 1 & 0 \\
\hline ALMENARA & SANTA MARIA DO SALTO & 2 & 0 \\
\hline ALMENARA & SANTO ANTONIO DO JACINTO & 0 & 0 \\
\hline ARACUAI & ARACUAI & 22 & 2 \\
\hline ARACUAI & BERILO & 12 & 1 \\
\hline ARACUAI & BERIZAL & 2 & 0 \\
\hline ARACUAI & CHAPADA DO NORTE & 5 & 1 \\
\hline ARACUAI & COMERCINHO & 0 & 0 \\
\hline
\end{tabular}




\begin{tabular}{|c|c|c|c|}
\hline ARACUAI & CORONEL MURTA & 1 & 0 \\
\hline ARACUAI & FRANCISCO BADARO & 3 & 0 \\
\hline ARACUAI & FRUTA DE LEITE & 0 & 0 \\
\hline ARACUAI & INDAIABIRA & 0 & 0 \\
\hline ARACUAI & ITAOBIM & 0 & 0 \\
\hline ARACUAI & ITINGA & 0 & 0 \\
\hline ARACUAI & JENIPAPO DE MINAS & 2 & 0 \\
\hline ARACUAI & JOSE GONCALVES DE MINAS & 2 & 0 \\
\hline ARACUAI & MEDINA & 10 & 1 \\
\hline ARACUAI & NINHEIRA & 2 & 0 \\
\hline ARACUAI & NOVORIZONTE & 3 & 0 \\
\hline ARACUAI & RUBELITA & 4 & 0 \\
\hline ARACUAI & SALINAS & 28 & 3 \\
\hline ARACUAI & SANTA CRUZ DE SALINAS & 0 & 0 \\
\hline ARACUAI & TAIOBEIRAS & 1 & 0 \\
\hline ARACUAI & VIRGEM DA LAPA & 1 & 0 \\
\hline BARBACENA & ALFREDO VASCONCELOS & 0 & 0 \\
\hline BARBACENA & ALTO RIO DOCE & 2 & 0 \\
\hline BARBACENA & ANDRELANDIA & 8 & 1 \\
\hline BARBACENA & ANTONIO CARLOS & 2 & 0 \\
\hline BARBACENA & ARACITABA & 0 & 0 \\
\hline BARBACENA & BARBACENA & 25 & 3 \\
\hline BARBACENA & BARROSO & 0 & 0 \\
\hline BARBACENA & BIAS FORTES & 0 & 0 \\
\hline BARBACENA & CAPELA NOVA & 0 & 0 \\
\hline BARBACENA & CARANDAI & 3 & 0 \\
\hline BARBACENA & CIPOTANEA & 0 & 0 \\
\hline BARBACENA & DESTERRO DO MELO & 0 & 0 \\
\hline BARBACENA & IBERTIOGA & 0 & 0 \\
\hline BARBACENA & MADRE DE DEUS DE MINAS & 0 & 0 \\
\hline BARBACENA & MERCES & 1 & 0 \\
\hline BARBACENA & OLIVEIRA FORTES & 0 & 0 \\
\hline BARBACENA & PAIVA & 0 & 0 \\
\hline BARBACENA & PIEDADE DO RIO GRANDE & 0 & 0 \\
\hline BARBACENA & RESSAQUINHA & 0 & 0 \\
\hline BARBACENA & SANTA BARBARA DO TUGURIO & 1 & 0 \\
\hline BARBACENA & SANTA RITA DO IBITIPOCA & 1 & 0 \\
\hline BARBACENA & SANTANA DO GARAMBEU & 0 & 0 \\
\hline BARBACENA & SAO VICENTE DE MINAS & 0 & 0 \\
\hline BARBACENA & SENHORA DOS REMEDIOS & 6 & 1 \\
\hline CAMPO BELO & AGUANIL & 1 & 0 \\
\hline CAMPO BELO & CAMACHO & 0 & 0 \\
\hline CAMPO BELO & CAMPO BELO & 8 & 1 \\
\hline CAMPO BELO & CANA VERDE & 0 & 0 \\
\hline CAMPO BELO & CANDEIAS & 0 & 0 \\
\hline
\end{tabular}




\begin{tabular}{|c|c|c|c|}
\hline CAMPO BELO & CRISTAIS & 0 & 0 \\
\hline CAMPO BELO & LAVRAS & 7 & 1 \\
\hline CAMPO BELO & PERDOES & 3 & 0 \\
\hline CAMPO BELO & RIBEIRAO VERMELHO & 0 & 0 \\
\hline CAMPO BELO & SANTANA DO JACARE & 0 & 0 \\
\hline CAMPO BELO & SANTO ANTONIO DO AMPARO & 0 & 0 \\
\hline CAMPO BELO & SAO FRANCISCO DE PAULA & 0 & 0 \\
\hline CARANGOLA & ALTO CAPARAO & 0 & 0 \\
\hline CARANGOLA & CAIANA & 0 & 0 \\
\hline CARANGOLA & CAPARAO & 0 & 0 \\
\hline CARANGOLA & CARANGOLA & 16 & 2 \\
\hline CARANGOLA & DIVINO & 15 & 2 \\
\hline CARANGOLA & ESPERA FELIZ & 3 & 0 \\
\hline CARANGOLA & FARIA LEMOS & 0 & 0 \\
\hline CARANGOLA & FERVEDOURO & 6 & 1 \\
\hline CARANGOLA & ORIZANIA & 1 & 0 \\
\hline CARANGOLA & PEDRA DOURADA & 0 & 0 \\
\hline CARANGOLA & TOMBOS & 1 & 0 \\
\hline CARATINGA & ALVARENGA & 4 & 0 \\
\hline CARATINGA & BOM JESUS DO GALHO & 2 & 0 \\
\hline CARATINGA & BUGRE & 0 & 0 \\
\hline CARATINGA & CARATINGA & 4 & 0 \\
\hline CARATINGA & CORREGO NOVO & 0 & 0 \\
\hline CARATINGA & DOM CAVATI & 0 & 0 \\
\hline CARATINGA & ENTRE FOLHAS & 1 & 0 \\
\hline CARATINGA & IAPU & 0 & 0 \\
\hline CARATINGA & IMBE DE MINAS & 1 & 0 \\
\hline CARATINGA & INHAPIM & 0 & 0 \\
\hline CARATINGA & IPABA & 8 & 1 \\
\hline CARATINGA & IPANEMA & 0 & 0 \\
\hline CARATINGA & PIEDADE DE CARATINGA & 0 & 0 \\
\hline CARATINGA & PINGO D AGUA & 0 & 0 \\
\hline CARATINGA & POCRANE & 0 & 0 \\
\hline CARATINGA & SANTA BARBARA DO LESTE & 3 & 0 \\
\hline CARATINGA & SANTA RITA DE MINAS & 0 & 0 \\
\hline CARATINGA & SAO DOMINGOS DAS DORES & 0 & 0 \\
\hline CARATINGA & SAO JOAO DO ORIENTE & 1 & 0 \\
\hline CARATINGA & SAO SEBASTIAO DO ANTA & 0 & 0 \\
\hline CARATINGA & TAPARUBA & 0 & 0 \\
\hline CARATINGA & TARUMIRIM & 4 & 0 \\
\hline CARATINGA & UBAPORANGA & 0 & 0 \\
\hline CARATINGA & VARGEM ALEGRE & 0 & 0 \\
\hline CAXAMBU & AIURUOCA & 0 & 0 \\
\hline CAXAMBU & ALAGOA & 0 & 0 \\
\hline CAXAMBU & BAEPENDI & 3 & 0 \\
\hline
\end{tabular}




\begin{tabular}{|c|c|c|c|}
\hline CAXAMBU & BOCAINA DE MINAS & 0 & 0 \\
\hline CAXAMBU & CARVALHOS & 0 & 0 \\
\hline CAXAMBU & CAXAMBU & 3 & 0 \\
\hline CAXAMBU & CONCEICAO DO RIO VERDE & 2 & 0 \\
\hline CAXAMBU & CRUZILIA & 4 & 0 \\
\hline CAXAMBU & ITAMONTE & 4 & 0 \\
\hline CAXAMBU & ITANHANDU & 0 & 0 \\
\hline CAXAMBU & JESUANIA & 0 & 0 \\
\hline CAXAMBU & LIBERDADE & 1 & 0 \\
\hline CAXAMBU & MINDURI & 0 & 0 \\
\hline CAXAMBU & OLIMPIO NORONHA & 0 & 0 \\
\hline CAXAMBU & PASSA QUATRO & 6 & 1 \\
\hline CAXAMBU & PASSA VINTE & 0 & 0 \\
\hline CAXAMBU & POUSO ALTO & 0 & 0 \\
\hline CAXAMBU & SAO LOURENCO & 5 & 1 \\
\hline CAXAMBU & SAO SEBASTIAO DO RIO VERDE & 0 & 0 \\
\hline CAXAMBU & SAO TOME DAS LETRAS & 4 & 0 \\
\hline CAXAMBU & SERITINGA & 0 & 0 \\
\hline CAXAMBU & SERRANOS & 0 & 0 \\
\hline CAXAMBU & SOLEDADE DE MINAS & 0 & 0 \\
\hline CORONEL FABRICIANO & ANTONIO DIAS & 8 & 1 \\
\hline CORONEL FABRICIANO & BELO ORIENTE & 0 & 0 \\
\hline CORONEL FABRICIANO & BRAUNAS & 6 & 1 \\
\hline CORONEL FABRICIANO & CORONEL FABRICIANO & 12 & 1 \\
\hline CORONEL FABRICIANO & IPATINGA & 28 & 3 \\
\hline CORONEL FABRICIANO & JAGUARAÇU & 0 & 0 \\
\hline CORONEL FABRICIANO & JOANESIA & 2 & 0 \\
\hline CORONEL FABRICIANO & MARLIERIA & 0 & 0 \\
\hline CORONEL FABRICIANO & MESQUITA & 0 & 0 \\
\hline CORONEL FABRICIANO & SANTANA DO PARAISO & 1 & 0 \\
\hline CORONEL FABRICIANO & TIMOTEO & 18 & 2 \\
\hline CONSELHEIRO LAFAIETE & CARANAIBA & 0 & 0 \\
\hline CONSELHEIRO LAFAIETE & CASA GRANDE & 0 & 0 \\
\hline CONSELHEIRO LAFAIETE & CATAS ALTAS DA NORUEGA & 1 & 0 \\
\hline CONSELHEIRO LAFAIETE & CONGONHAS & 2 & 0 \\
\hline CONSELHEIRO LAFAIETE & CONSELHEIRO LAFAIETE & 15 & 2 \\
\hline CONSELHEIRO LAFAIETE & CRISTIANO OTONI & 0 & 0 \\
\hline CONSELHEIRO LAFAIETE & DESTERRO DE ENTRE RIOS & 1 & 0 \\
\hline CONSELHEIRO LAFAIETE & ENTRE RIOS DE MINAS & 2 & 0 \\
\hline CONSELHEIRO LAFAIETE & ITAVERAVA & 5 & 1 \\
\hline CONSELHEIRO LAFAIETE & JECEABA & 0 & 0 \\
\hline CONSELHEIRO LAFAIETE & LAMIM & 0 & 0 \\
\hline CONSELHEIRO LAFAIETE & OURO BRANCO & 0 & 0 \\
\hline CONSELHEIRO LAFAIETE & PIRANGA & 2 & 0 \\
\hline CONSELHEIRO LAFAIETE & QUELUZITO & 0 & 0 \\
\hline
\end{tabular}




\begin{tabular}{|c|c|c|c|}
\hline CONSELHEIRO LAFAIETE & RIO ESPERA & 3 & 0 \\
\hline CONSELHEIRO LAFAIETE & SANTANA DOS MONTES & 0 & 0 \\
\hline CONSELHEIRO LAFAIETE & SAO BRAS DO SUACUI & 0 & 0 \\
\hline CONSELHEIRO LAFAIETE & SENHORA DE OLIVEIRA & 1 & 0 \\
\hline CURVELO & AUGUSTO DE LIMA & 0 & 0 \\
\hline CURVELO & BUENOPOLIS & 0 & 0 \\
\hline CURVELO & CORINTO & 3 & 0 \\
\hline CURVELO & CURVELO & 3 & 0 \\
\hline CURVELO & FELIXLANDIA & 4 & 0 \\
\hline CURVELO & INIMUTABA & 0 & 0 \\
\hline CURVELO & JOAQUIM FELICIO & 0 & 0 \\
\hline CURVELO & LASSANCE & 0 & 0 \\
\hline CURVELO & MORRO DA GARCA & 0 & 0 \\
\hline CURVELO & PRESIDENTE JUSCELINO & 0 & 0 \\
\hline CURVELO & SANTO HIPOLITO & 0 & 0 \\
\hline CURVELO & TRES MARIAS & 3 & 0 \\
\hline DIAMANTINA & ALVORADA DE MINAS & 4 & 0 \\
\hline DIAMANTINA & ANGELANDIA & 7 & 1 \\
\hline DIAMANTINA & ARICANDUVA & 1 & 0 \\
\hline DIAMANTINA & CAPELINHA & 1 & 0 \\
\hline DIAMANTINA & CARBONITA & 0 & 0 \\
\hline DIAMANTINA & CONCEICAO DO MATO DENTRO & 23 & 2 \\
\hline DIAMANTINA & CONGONHAS DO NORTE & 4 & 0 \\
\hline DIAMANTINA & COUTO DE MAGALHAES DE MINAS & 0 & 0 \\
\hline DIAMANTINA & DATAS & 0 & 0 \\
\hline DIAMANTINA & DIAMANTINA & 16 & 2 \\
\hline DIAMANTINA & FELICIO DOS SANTOS & 0 & 0 \\
\hline DIAMANTINA & GOUVEA & 8 & 1 \\
\hline DIAMANTINA & ITAMARANDIBA & 4 & 0 \\
\hline DIAMANTINA & LEME DO PRADO & 7 & 1 \\
\hline DIAMANTINA & MINAS NOVAS & 14 & 1 \\
\hline DIAMANTINA & MONJOLOS & 0 & 0 \\
\hline DIAMANTINA & PRESIDENTE KUBITSCHEK & 0 & 0 \\
\hline DIAMANTINA & RIO VERMELHO & 6 & 1 \\
\hline DIAMANTINA & SANTO ANTONIO DO ITAMBE & 1 & 0 \\
\hline DIAMANTINA & SAO GONCALO DO RIO PRETO & 0 & 0 \\
\hline DIAMANTINA & SENADOR MODESTINO GONCALVES & 0 & 0 \\
\hline DIAMANTINA & SERRA AZUL DE MINAS & 0 & 0 \\
\hline DIAMANTINA & SERRO & 6 & 1 \\
\hline DIAMANTINA & TURMALINA & 14 & 1 \\
\hline DIAMANTINA & VEREDINHA & 0 & 0 \\
\hline DIVINÓPOLIS & ARAUJOS & 0 & 0 \\
\hline DIVINÓPOLIS & ARCOS & 2 & 0 \\
\hline DIVINÓPOLIS & BAMBUI & 0 & 0 \\
\hline DIVINÓPOLIS & CARMO DA MATA & 0 & 0 \\
\hline
\end{tabular}




\begin{tabular}{|c|c|c|c|}
\hline DIVINÓPOLIS & CARMO DO CAJURU & 5 & 1 \\
\hline DIVINÓPOLIS & CARMOPOLIS DE MINAS & 3 & 0 \\
\hline DIVINÓPOLIS & CLAUDIO & 4 & 0 \\
\hline DIVINÓPOLIS & CORREGO DANTA & 0 & 0 \\
\hline DIVINÓPOLIS & DIVINOPOLIS & 64 & 7 \\
\hline DIVINÓPOLIS & IGUATAMA & 0 & 0 \\
\hline DIVINÓPOLIS & ITAGUARA & 0 & 0 \\
\hline DIVINÓPOLIS & ITAPECERICA & 0 & 0 \\
\hline DIVINÓPOLIS & ITATIAIUCU & 5 & 1 \\
\hline DIVINÓPOLIS & ITAUNA & 20 & 2 \\
\hline DIVINÓPOLIS & JAPARAIBA & 4 & 0 \\
\hline DIVINÓPOLIS & LAGOA DA PRATA & 5 & 1 \\
\hline DIVINÓPOLIS & LUZ & 3 & 0 \\
\hline DIVINÓPOLIS & MEDEIROS & 0 & 0 \\
\hline DIVINÓPOLIS & MOEMA & 2 & 0 \\
\hline DIVINÓPOLIS & NOVA SERRANA & 17 & 2 \\
\hline DIVINÓPOLIS & OLIVEIRA & 7 & 1 \\
\hline DIVINÓPOLIS & PAINS & 0 & 0 \\
\hline DIVINÓPOLIS & PASSA TEMPO & 0 & 0 \\
\hline DIVINÓPOLIS & PEDRA DO INDAIA & 0 & 0 \\
\hline DIVINÓPOLIS & PERDIGAO & 0 & 0 \\
\hline DIVINÓPOLIS & PIRACEMA & 7 & 1 \\
\hline DIVINÓPOLIS & SANTO ANTONIO DO MONTE & 3 & 0 \\
\hline DIVINÓPOLIS & SAO GONCALO DO PARA & 0 & 0 \\
\hline DIVINÓPOLIS & SAO SEBASTIAO DO OESTE & 0 & 0 \\
\hline DIVINÓPOLIS & TAPIRAI & 0 & 0 \\
\hline GOVERNADOR VALADARES & ACUCENA & 6 & 1 \\
\hline GOVERNADOR VALADARES & AIMORES & 20 & 2 \\
\hline GOVERNADOR VALADARES & ALPERCATA & 0 & 0 \\
\hline GOVERNADOR VALADARES & CAPITAO ANDRADE & 0 & 0 \\
\hline GOVERNADOR VALADARES & CENTRAL DE MINAS & 1 & 0 \\
\hline GOVERNADOR VALADARES & CONSELHEIRO PENA & 2 & 0 \\
\hline GOVERNADOR VALADARES & COROACI & 0 & 0 \\
\hline GOVERNADOR VALADARES & CUPARAQUE & 0 & 0 \\
\hline GOVERNADOR VALADARES & DIVINO DAS LARANJEIRAS & 7 & 1 \\
\hline GOVERNADOR VALADARES & ENGENHEIRO CALDAS & 0 & 0 \\
\hline GOVERNADOR VALADARES & FERNANDES TOURINHO & 0 & 0 \\
\hline GOVERNADOR VALADARES & FREI INOCENCIO & 0 & 0 \\
\hline GOVERNADOR VALADARES & GALILEIA & 0 & 0 \\
\hline GOVERNADOR VALADARES & GOIABEIRA & 0 & 0 \\
\hline GOVERNADOR VALADARES & GOVERNADOR VALADARES & 91 & 10 \\
\hline GOVERNADOR VALADARES & ITABIRINHA & 1 & 0 \\
\hline GOVERNADOR VALADARES & ITANHOMI & 0 & 0 \\
\hline GOVERNADOR VALADARES & ITUETA & 5 & 1 \\
\hline GOVERNADOR VALADARES & MANTENA & 0 & 0 \\
\hline
\end{tabular}




\begin{tabular}{|c|c|c|c|}
\hline GOVERNADOR VALADARES & MARILAC & 0 & 0 \\
\hline GOVERNADOR VALADARES & MATHIAS LOBATO & 0 & 0 \\
\hline GOVERNADOR VALADARES & MENDES PIMENTEL & 0 & 0 \\
\hline GOVERNADOR VALADARES & NACIP RAYDAN & 0 & 0 \\
\hline GOVERNADOR VALADARES & NAQUE & 0 & 0 \\
\hline GOVERNADOR VALADARES & NOVA BELEM & 0 & 0 \\
\hline GOVERNADOR VALADARES & NOVA MODICA & 0 & 0 \\
\hline GOVERNADOR VALADARES & PERIQUITO & 0 & 0 \\
\hline GOVERNADOR VALADARES & RESPLENDOR & 0 & 0 \\
\hline GOVERNADOR VALADARES & SANTA EFIGENIA DE MINAS & 0 & 0 \\
\hline GOVERNADOR VALADARES & SANTA RITA DO ITUETO & 0 & 0 \\
\hline GOVERNADOR VALADARES & SAO FELIX DE MINAS & 0 & 0 \\
\hline GOVERNADOR VALADARES & SAO GERALDO DA PIEDADE & 0 & 0 \\
\hline GOVERNADOR VALADARES & SAO GERALDO DO BAIXIO & 0 & 0 \\
\hline GOVERNADOR VALADARES & SAO JOAO DO MANTENINHA & 0 & 0 \\
\hline GOVERNADOR VALADARES & SAO JOSE DA SAFIRA & 0 & 0 \\
\hline GOVERNADOR VALADARES & SAO JOSE DO DIVINO & 0 & 0 \\
\hline GOVERNADOR VALADARES & SARDOA & 0 & 0 \\
\hline GOVERNADOR VALADARES & SOBRALIA & 0 & 0 \\
\hline GOVERNADOR VALADARES & TUMIRITINGA & 0 & 0 \\
\hline GOVERNADOR VALADARES & VIRGOLANDIA & 2 & 0 \\
\hline GUANHÃES & AGUA BOA & 8 & 1 \\
\hline GUANHÃES & CANTAGALO & 0 & 0 \\
\hline GUANHÃES & CARMESIA & 3 & 0 \\
\hline GUANHÃES & COLUNA & 0 & 0 \\
\hline GUANHÃES & DIVINOLANDIA DE MINAS & 0 & 0 \\
\hline GUANHÃES & DOM JOAQUIM & 4 & 0 \\
\hline GUANHÃES & DORES DE GUANHAES & 1 & 0 \\
\hline GUANHÃES & FREI LAGONEGRO & 3 & 0 \\
\hline GUANHÃES & GONZAGA & 0 & 0 \\
\hline GUANHÃES & GUANHAES & 6 & 1 \\
\hline GUANHÃES & JOSE RAYDAN & 0 & 0 \\
\hline GUANHÃES & MATERLANDIA & 0 & 0 \\
\hline GUANHÃES & PAULISTAS & 0 & 0 \\
\hline GUANHÃES & PECANHA & 6 & 1 \\
\hline GUANHÃES & SABINOPOLIS & 11 & 1 \\
\hline GUANHÃES & SANTA MARIA DO SUACUI & 1 & 0 \\
\hline GUANHÃES & SAO JOAO EVANGELISTA & 0 & 0 \\
\hline GUANHÃES & SAO JOSE DO JACURI & 0 & 0 \\
\hline GUANHÃES & SAO PEDRO DO SUACUI & 2 & 0 \\
\hline GUANHÃES & SAO SEBASTIAO DO MARANHAO & 0 & 0 \\
\hline GUANHÃES & SENHORA DO PORTO & 0 & 0 \\
\hline GUANHÃES & VIRGINOPOLIS & 0 & 0 \\
\hline ITAJUBÁ & BRASOPOLIS & 3 & 0 \\
\hline ITAJUBÁ & CARMO DE MINAS & 4 & 0 \\
\hline
\end{tabular}




\begin{tabular}{|c|c|c|c|}
\hline ITAJUBÁ & CONCEICAO DAS PEDRAS & 0 & 0 \\
\hline ITAJUBÁ & CONCEICAO DOS OUROS & 0 & 0 \\
\hline ITAJUBÁ & CONSOLACAO & 0 & 0 \\
\hline ITAJUBÁ & CRISTINA & 0 & 0 \\
\hline ITAJUBÁ & DELFIM MOREIRA & 2 & 0 \\
\hline ITAJUBÁ & DOM VICOSO & 1 & 0 \\
\hline ITAJUBÁ & GONCALVES & 0 & 0 \\
\hline ITAJUBÁ & ITAJUBA & 1 & 0 \\
\hline ITAJUBÁ & MARIA DA FE & 0 & 0 \\
\hline ITAJUBÁ & MARMELOPOLIS & 0 & 0 \\
\hline ITAJUBÁ & NATERCIA & 0 & 0 \\
\hline ITAJUBÁ & PARAISOPOLIS & 0 & 0 \\
\hline ITAJUBÁ & PEDRALVA & 0 & 0 \\
\hline ITAJUBÁ & PIRANGUCU & 0 & 0 \\
\hline ITAJUBÁ & PIRANGUINHO & 0 & 0 \\
\hline ITAJUBÁ & SAO JOSE DO ALEGRE & 0 & 0 \\
\hline ITAJUBÁ & SAPUCAI-MIRIM & 0 & 0 \\
\hline ITAJUBÁ & VIRGINIA & 2 & 0 \\
\hline ITAJUBÁ & WENCESLAU BRAZ & 0 & 0 \\
\hline ITUIUTABA & CACHOEIRA DOURADA & 0 & 0 \\
\hline ITUIUTABA & CANAPOLIS & 5 & 1 \\
\hline ITUIUTABA & CAPINOPOLIS & 5 & 1 \\
\hline ITUIUTABA & CENTRALINA & 0 & 0 \\
\hline ITUIUTABA & GURINHATA & 0 & 0 \\
\hline ITUIUTABA & IPIACU & 0 & 0 \\
\hline ITUIUTABA & ITUIUTABA & 22 & 2 \\
\hline ITUIUTABA & SANTA VITORIA & 15 & 2 \\
\hline JANAUBA & CATUTI & 0 & 0 \\
\hline JANAUBA & ESPINOSA & 1 & 0 \\
\hline JANAUBA & GAMELEIRAS & 0 & 0 \\
\hline JANAUBA & JAIBA & 16 & 2 \\
\hline JANAUBA & JANAUBA & 41 & 4 \\
\hline JANAUBA & MAMONAS & 0 & 0 \\
\hline JANAUBA & MATO VERDE & 1 & 0 \\
\hline JANAUBA & MONTE AZUL & 0 & 0 \\
\hline JANAUBA & MONTEZUMA & 0 & 0 \\
\hline JANAUBA & NOVA PORTEIRINHA & 0 & 0 \\
\hline JANAUBA & PAI PEDRO & 0 & 0 \\
\hline JANAUBA & PORTEIRINHA & 9 & 1 \\
\hline JANAUBA & RIACHO DOS MACHADOS & 0 & 0 \\
\hline JANAUBA & RIO PARDO DE MINAS & 2 & 0 \\
\hline JANAUBA & SANTO ANTONIO DO RETIRO & 0 & 0 \\
\hline JANAUBA & SERRANOPOLIS DE MINAS & 1 & 0 \\
\hline JANAUBA & VERDELANDIA & 16 & 2 \\
\hline JANUARIA & BONITO DE MINAS & 1 & 0 \\
\hline
\end{tabular}




\begin{tabular}{|c|c|c|c|}
\hline JANUARIA & CHAPADA GAUCHA & 2 & 0 \\
\hline JANUARIA & CONEGO MARINHO & 1 & 0 \\
\hline JANUARIA & IBIRACATU & 8 & 1 \\
\hline JANUARIA & ICARAI DE MINAS & 9 & 1 \\
\hline JANUARIA & ITACARAMBI & 4 & 0 \\
\hline JANUARIA & JANUARIA & 35 & 4 \\
\hline JANUARIA & JUVENILIA & 1 & 0 \\
\hline JANUARIA & MANGA & 6 & 1 \\
\hline JANUARIA & MATIAS CARDOSO & 0 & 0 \\
\hline JANUARIA & MIRAVANIA & 0 & 0 \\
\hline JANUARIA & MONTALVANIA & 4 & 0 \\
\hline JANUARIA & PEDRAS DE MARIA DA CRUZ & 2 & 0 \\
\hline JANUARIA & PINTOPOLIS & 3 & 0 \\
\hline JANUARIA & SAO FRANCISCO & 25 & 3 \\
\hline JANUARIA & SAO JOAO DAS MISSOES & 18 & 2 \\
\hline JANUARIA & UBAI & 1 & 0 \\
\hline JANUARIA & URUCUIA & 0 & 0 \\
\hline JANUARIA & VARZELANDIA & 12 & 1 \\
\hline JUIZ DE FORA & ARANTINA & 0 & 0 \\
\hline JUIZ DE FORA & BELMIRO BRAGA & 0 & 0 \\
\hline JUIZ DE FORA & BICAS & 0 & 0 \\
\hline JUIZ DE FORA & BOM JARDIM DE MINAS & 0 & 0 \\
\hline JUIZ DE FORA & CHACARA & 0 & 0 \\
\hline JUIZ DE FORA & CHIADOR & 0 & 0 \\
\hline JUIZ DE FORA & CORONEL PACHECO & 0 & 0 \\
\hline JUIZ DE FORA & DESCOBERTO & 0 & 0 \\
\hline JUIZ DE FORA & EWBANK DA CAMARA & 0 & 0 \\
\hline JUIZ DE FORA & GOIANA & 0 & 0 \\
\hline JUIZ DE FORA & GUARARA & 0 & 0 \\
\hline JUIZ DE FORA & JUIZ DE FORA & 55 & 7 \\
\hline JUIZ DE FORA & LIMA DUARTE & 2 & 0 \\
\hline JUIZ DE FORA & MAR DE ESPANHA & 6 & 1 \\
\hline JUIZ DE FORA & MARIPA DE MINAS & 0 & 0 \\
\hline JUIZ DE FORA & MATIAS BARBOSA & 0 & 0 \\
\hline JUIZ DE FORA & OLARIA & 0 & 0 \\
\hline JUIZ DE FORA & PEDRO TEIXEIRA & 0 & 0 \\
\hline JUIZ DE FORA & PEQUERI & 0 & 0 \\
\hline JUIZ DE FORA & PIAU & 0 & 0 \\
\hline JUIZ DE FORA & RIO NOVO & 0 & 0 \\
\hline JUIZ DE FORA & RIO PRETO & 0 & 0 \\
\hline JUIZ DE FORA & ROCHEDO DE MINAS & 0 & 0 \\
\hline JUIZ DE FORA & SANTA BARBARA DO MONTE VERDE & 0 & 0 \\
\hline JUIZ DE FORA & SANTA RITA DE JACUTINGA & 0 & 0 \\
\hline JUIZ DE FORA & SANTANA DO DESERTO & 0 & 0 \\
\hline JUIZ DE FORA & SANTOS DUMONT & 9 & 1 \\
\hline
\end{tabular}




\begin{tabular}{|c|c|c|c|}
\hline JUIZ DE FORA & SAO JOAO NEPOMUCENO & 3 & 0 \\
\hline JUIZ DE FORA & SENADOR CORTES & 0 & 0 \\
\hline JUIZ DE FORA & SIMAO PEREIRA & 0 & 0 \\
\hline LEOPOLDINA & ALEM PARAIBA & 1 & 0 \\
\hline LEOPOLDINA & ARGIRITA & 0 & 0 \\
\hline LEOPOLDINA & CATAGUASES & 11 & 1 \\
\hline LEOPOLDINA & ESTRELA DALVA & 0 & 0 \\
\hline LEOPOLDINA & ITAMARATI DE MINAS & 0 & 0 \\
\hline LEOPOLDINA & LEOPOLDINA & 9 & 1 \\
\hline LEOPOLDINA & PIRAPETINGA & 2 & 0 \\
\hline LEOPOLDINA & RECREIO & 3 & 0 \\
\hline LEOPOLDINA & SANTO ANTONIO DO AVENTUREIRO & 0 & 0 \\
\hline LEOPOLDINA & VOLTA GRANDE & 0 & 0 \\
\hline MANHUAÇU & ALTO JEQUITIBA & 6 & 1 \\
\hline MANHUAÇU & CAPUTIRA & 0 & 0 \\
\hline MANHUAÇU & CHALE & 2 & 0 \\
\hline MANHUAÇU & CONCEICAO DE IPANEMA & 2 & 0 \\
\hline MANHUAÇU & DURANDE & 2 & 0 \\
\hline MANHUAÇU & LAJINHA & 15 & 2 \\
\hline MANHUAÇU & LUISBURGO & 0 & 0 \\
\hline MANHUAÇU & MANHUACU & 20 & 2 \\
\hline MANHUAÇU & MANHUMIRIM & 0 & 0 \\
\hline MANHUAÇU & MARTINS SOARES & 0 & 0 \\
\hline MANHUAÇU & MATIPO & 3 & 0 \\
\hline MANHUAÇU & MUTUM & 10 & 1 \\
\hline MANHUAÇU & REDUTO & 3 & 0 \\
\hline MANHUAÇU & SANTA MARGARIDA & 12 & 1 \\
\hline MANHUAÇU & SANTANA DO MANHUACU & 0 & 0 \\
\hline MANHUAÇU & SAO JOAO DO MANHUACU & 4 & 0 \\
\hline MANHUAÇU & SAO JOSE DO MANTIMENTO & 0 & 0 \\
\hline MANHUAÇU & SIMONESIA & 10 & 1 \\
\hline METROPOLITANA A & BARAO DE COCAIS & 0 & 0 \\
\hline METROPOLITANA A & BELO HORIZONTE & 48 & 5 \\
\hline METROPOLITANA A & BELO VALE & 0 & 0 \\
\hline METROPOLITANA A & BOM JESUS DO AMPARO & 2 & 0 \\
\hline METROPOLITANA A & BONFIM & 0 & 0 \\
\hline METROPOLITANA A & BRUMADINHO & 0 & 0 \\
\hline METROPOLITANA A & CAETE & 6 & 1 \\
\hline METROPOLITANA A & CATAS ALTAS & 0 & 0 \\
\hline METROPOLITANA A & CRUCILANDIA & 0 & 0 \\
\hline METROPOLITANA A & MOEDA & 0 & 0 \\
\hline METROPOLITANA A & NOVA LIMA & 0 & 0 \\
\hline METROPOLITANA A & NOVA UNIAO & 4 & 0 \\
\hline METROPOLITANA A & PIEDADE DOS GERAIS & 0 & 0 \\
\hline METROPOLITANA A & RAPOSOS & 0 & 0 \\
\hline
\end{tabular}




\begin{tabular}{|c|c|c|c|}
\hline METROPOLITANA A & RIO ACIMA & 0 & 0 \\
\hline METROPOLITANA A & RIO MANSO & 0 & 0 \\
\hline METROPOLITANA A & SABARA & 9 & 1 \\
\hline METROPOLITANA A & SANTA BARBARA & 0 & 0 \\
\hline METROPOLITANA B & BELO HORIZONTE & 108 & 13 \\
\hline METROPOLITANA B & BETIM & 37 & 4 \\
\hline METROPOLITANA B & CONTAGEM & 48 & 5 \\
\hline METROPOLITANA B & ESMERALDAS & 25 & 3 \\
\hline METROPOLITANA B & IBIRITE & 19 & 2 \\
\hline METROPOLITANA B & IGARAPE & 6 & 1 \\
\hline METROPOLITANA B & JUATUBA & 4 & 0 \\
\hline METROPOLITANA B & MARIO CAMPOS & 0 & 0 \\
\hline METROPOLITANA B & MATEUS LEME & 0 & 0 \\
\hline METROPOLITANA B & SAO JOAQUIM DE BICAS & 2 & 0 \\
\hline METROPOLITANA B & SARZEDO & 0 & 0 \\
\hline METROPOLITANA C & BELO HORIZONTE & 60 & 7 \\
\hline METROPOLITANA C & CONFINS & 0 & 0 \\
\hline METROPOLITANA C & JABOTICATUBAS & 0 & 0 \\
\hline METROPOLITANA C & LAGOA SANTA & 0 & 0 \\
\hline METROPOLITANA C & MORRO DO PILAR & 5 & 1 \\
\hline METROPOLITANA C & PEDRO LEOPOLDO & 3 & 0 \\
\hline METROPOLITANA C & RIBEIRAO DAS NEVES & 66 & 8 \\
\hline METROPOLITANA C & SANTA LUZIA & 16 & 2 \\
\hline METROPOLITANA C & SANTANA DO RIACHO & 6 & 1 \\
\hline METROPOLITANA C & SAO JOSE DA LAPA & 0 & 0 \\
\hline METROPOLITANA C & TAQUARACU DE MINAS & 0 & 0 \\
\hline METROPOLITANA C & VESPASIANO & 0 & 0 \\
\hline MONTE CARMELO & ABADIA DOS DOURADOS & 0 & 0 \\
\hline MONTE CARMELO & CASCALHO RICO & 0 & 0 \\
\hline MONTE CARMELO & COROMANDEL & 7 & 1 \\
\hline MONTE CARMELO & DOURADOQUARA & 0 & 0 \\
\hline MONTE CARMELO & ESTRELA DO SUL & 3 & 0 \\
\hline MONTE CARMELO & GRUPIARA & 0 & 0 \\
\hline MONTE CARMELO & MONTE CARMELO & 14 & 1 \\
\hline MONTE CARMELO & ROMARIA & 0 & 0 \\
\hline MONTES CLAROS & BOCAIUVA & 11 & 1 \\
\hline MONTES CLAROS & BOTUMIRIM & 2 & 0 \\
\hline MONTES CLAROS & BRASILIA DE MINAS & 6 & 1 \\
\hline MONTES CLAROS & CAMPO AZUL & 0 & 0 \\
\hline MONTES CLAROS & CAPITAO ENEAS & 0 & 0 \\
\hline MONTES CLAROS & CLARO DOS POCOES & 1 & 0 \\
\hline MONTES CLAROS & CORACAO DE JESUS & 18 & 2 \\
\hline MONTES CLAROS & CRISTALIA & 0 & 0 \\
\hline MONTES CLAROS & ENGENHEIRO NAVARRO & 0 & 0 \\
\hline MONTES CLAROS & FRANCISCO DUMONT & 0 & 0 \\
\hline
\end{tabular}




\begin{tabular}{|c|c|c|c|}
\hline MONTES CLAROS & FRANCISCO AS & 13 & 1 \\
\hline MONTES CLAROS & GLAUCILANDIA & 0 & 0 \\
\hline MONTES CLAROS & GRAO MOGOL & 0 & 0 \\
\hline MONTES CLAROS & GUARACIAMA & 0 & 0 \\
\hline MONTES CLAROS & ITACAMBIRA & 1 & 0 \\
\hline MONTES CLAROS & JAPONVAR & 0 & 0 \\
\hline MONTES CLAROS & JOSENOPOLIS & 0 & 0 \\
\hline MONTES CLAROS & JURAMENTO & 0 & 0 \\
\hline MONTES CLAROS & LONTRA & 1 & 0 \\
\hline MONTES CLAROS & LUISLANDIA & 1 & 0 \\
\hline MONTES CLAROS & MIRABELA & 5 & 1 \\
\hline MONTES CLAROS & MONTES CLAROS & 19 & 2 \\
\hline MONTES CLAROS & OLHOS-D AGUA & 0 & 0 \\
\hline MONTES CLAROS & PADRE CARVALHO & 3 & 0 \\
\hline MONTES CLAROS & PATIS & 4 & 0 \\
\hline MONTES CLAROS & SAO JOAO DA LAGOA & 0 & 0 \\
\hline MONTES CLAROS & SAO JOAO DA PONTE & 1 & 0 \\
\hline MONTES CLAROS & SAO JOAO DO PACUI & 2 & 0 \\
\hline MONTES CLAROS & SAO JOAO DO PARAISO & 3 & 0 \\
\hline MONTES CLAROS & VARGEM GRANDE DO RIO PARDO & 0 & 0 \\
\hline MURIAÉ & ANTONIO PRADO DE MINAS & 0 & 0 \\
\hline MURIAÉ & BARAO DE MONTE ALTO & 0 & 0 \\
\hline MURIAÉ & EUGENOPOLIS & 2 & 0 \\
\hline MURIAÉ & LARANJAL & 0 & 0 \\
\hline MURIAÉ & MIRADOURO & 1 & 0 \\
\hline MURIAÉ & MIRAI & 1 & 0 \\
\hline MURIAÉ & MURIAE & 13 & 1 \\
\hline MURIAÉ & PALMA & 0 & 0 \\
\hline MURIAÉ & PATROCINIO DO MURIAE & 0 & 0 \\
\hline MURIAÉ & ROSARIO DA LIMEIRA & 0 & 0 \\
\hline MURIAÉ & SANTANA DE CATAGUASES & 0 & 0 \\
\hline MURIAÉ & SAO FRANCISCO DO GLORIA & 0 & 0 \\
\hline MURIAÉ & SAO SEBASTIAO DA VARGEM ALEGRE & 0 & 0 \\
\hline MURIAÉ & VIEIRAS & 0 & 0 \\
\hline NOVA ERA & BELA VISTA DE MINAS & 1 & 0 \\
\hline NOVA ERA & DIONISIO & 5 & 1 \\
\hline NOVA ERA & FERROS & 9 & 1 \\
\hline NOVA ERA & ITABIRA & 19 & 2 \\
\hline NOVA ERA & ITAMBE DO MATO DENTRO & 2 & 0 \\
\hline NOVA ERA & JOAO MONLEVADE & 24 & 2 \\
\hline NOVA ERA & NOVA ERA & 0 & 0 \\
\hline NOVA ERA & PASSABEM & 3 & 0 \\
\hline NOVA ERA & RIO PIRACICABA & 4 & 0 \\
\hline NOVA ERA & SANTA MARIA DE ITABIRA & 1 & 0 \\
\hline NOVA ERA & SANTO ANTONIO DO RIO ABAIXO & 0 & 0 \\
\hline
\end{tabular}




\begin{tabular}{|c|c|c|c|}
\hline NOVA ERA & SAO DOMINGOS DO PRATA & 23 & 2 \\
\hline NOVA ERA & SAO GONCALO DO RIO ABAIXO & 0 & 0 \\
\hline NOVA ERA & SAO JOSE DO GOIABAL & 1 & 0 \\
\hline NOVA ERA & SAO SEBASTIAO DO RIO PRETO & 0 & 0 \\
\hline OURO PRETO & ACAIACA & 0 & 0 \\
\hline OURO PRETO & DIOGO DE VASCONCELOS & 0 & 0 \\
\hline OURO PRETO & ITABIRITO & 9 & 1 \\
\hline OURO PRETO & MARIANA & 17 & 2 \\
\hline OURO PRETO & OURO PRETO & 12 & 1 \\
\hline PARA DE MINAS & ABAETE & 5 & 1 \\
\hline PARA DE MINAS & BIQUINHAS & 0 & 0 \\
\hline PARA DE MINAS & BOM DESPACHO & 12 & 1 \\
\hline PARA DE MINAS & CEDRO DO ABAETE & 1 & 0 \\
\hline PARA DE MINAS & CONCEICAO DO PARA & 3 & 0 \\
\hline PARA DE MINAS & DORES DO INDAIA & 4 & 0 \\
\hline PARA DE MINAS & ESTRELA DO INDAIA & 0 & 0 \\
\hline PARA DE MINAS & FLORESTAL & 0 & 0 \\
\hline PARA DE MINAS & IGARATINGA & 0 & 0 \\
\hline PARA DE MINAS & LEANDRO FERREIRA & 1 & 0 \\
\hline PARA DE MINAS & MARTINHO CAMPOS & 4 & 0 \\
\hline PARA DE MINAS & MORADA NOVA DE MINAS & 0 & 0 \\
\hline PARA DE MINAS & ONCA DE PITANGUI & 5 & 1 \\
\hline PARA DE MINAS & PAINEIRAS & 1 & 0 \\
\hline PARA DE MINAS & PARA DE MINAS & 15 & 2 \\
\hline PARA DE MINAS & PEQUI & 0 & 0 \\
\hline PARA DE MINAS & PITANGUI & 5 & 1 \\
\hline PARA DE MINAS & QUARTEL GERAL & 0 & 0 \\
\hline PARA DE MINAS & SAO JOSE DA VARGINHA & 0 & 0 \\
\hline PARA DE MINAS & SERRA DA SAUDADE & 0 & 0 \\
\hline PARACATU & BRASILANDIA DE MINAS & 4 & 0 \\
\hline PARACATU & GUARDA-MOR & 0 & 0 \\
\hline PARACATU & JOAO PINHEIRO & 21 & 2 \\
\hline PARACATU & PARACATU & 31 & 3 \\
\hline PARACATU & VAZANTE & 4 & 0 \\
\hline PASSOS & ALPINOPOLIS & 2 & 0 \\
\hline PASSOS & BOM JESUS DA PENHA & 0 & 0 \\
\hline PASSOS & CAPITOLIO & 7 & 1 \\
\hline PASSOS & CARMO DO RIO CLARO & 3 & 0 \\
\hline PASSOS & CORREGO FUNDO & 0 & 0 \\
\hline PASSOS & DELFINOPOLIS & 0 & 0 \\
\hline PASSOS & DORESOPOLIS & 0 & 0 \\
\hline PASSOS & FORMIGA & 10 & 1 \\
\hline PASSOS & FORTALEZA DE MINAS & 0 & 0 \\
\hline PASSOS & PASSOS & 16 & 2 \\
\hline PASSOS & PIMENTA & 0 & 0 \\
\hline
\end{tabular}




\begin{tabular}{|c|c|c|c|}
\hline PASSOS & PIUMHI & 3 & 0 \\
\hline PASSOS & SAO JOAO BATISTA DO GLORIA & 0 & 0 \\
\hline PASSOS & SAO JOSE DA BARRA & 3 & 0 \\
\hline PASSOS & SAO ROQUE DE MINAS & 0 & 0 \\
\hline PASSOS & VARGEM BONITA & 0 & 0 \\
\hline PATOS DE MINAS & ARAPUA & 0 & 0 \\
\hline PATOS DE MINAS & CARMO DO PARANAIBA & 5 & 1 \\
\hline PATOS DE MINAS & LAGAMAR & 5 & 1 \\
\hline PATOS DE MINAS & LAGOA FORMOSA & 2 & 0 \\
\hline PATOS DE MINAS & LAGOA GRANDE & 1 & 0 \\
\hline PATOS DE MINAS & MATUTINA & 0 & 0 \\
\hline PATOS DE MINAS & PATOS DE MINAS & 52 & 5 \\
\hline PATOS DE MINAS & PRESIDENTE OLEGARIO & 6 & 1 \\
\hline PATOS DE MINAS & RIO PARANAIBA & 3 & 0 \\
\hline PATOS DE MINAS & SANTA ROSA DA SERRA & 4 & 0 \\
\hline PATOS DE MINAS & SAO GONCALO DO ABAETE & 4 & 0 \\
\hline PATOS DE MINAS & SAO GOTARDO & 10 & 1 \\
\hline PATOS DE MINAS & TIROS & 0 & 0 \\
\hline PATOS DE MINAS & VARJAO DE MINAS & 1 & 0 \\
\hline PATROCÍNIO & CRUZEIRO DA FORTALEZA & 0 & 0 \\
\hline PATROCÍNIO & GUIMARANIA & 0 & 0 \\
\hline PATROCÍNIO & IBIA & 1 & 0 \\
\hline PATROCÍNIO & IRAI DE MINAS & 0 & 0 \\
\hline PATROCÍNIO & PATROCINIO & 29 & 3 \\
\hline PATROCÍNIO & PERDIZES & 6 & 1 \\
\hline PATROCÍNIO & SERRA DO SALITRE & 2 & 0 \\
\hline PIRAPORA & BURITIZEIRO & 3 & 0 \\
\hline PIRAPORA & IBIAI & 4 & 0 \\
\hline PIRAPORA & JEQUITAI & 0 & 0 \\
\hline PIRAPORA & LAGOA DOS PATOS & 0 & 0 \\
\hline PIRAPORA & PIRAPORA & 2 & 0 \\
\hline PIRAPORA & PONTO CHIQUE & 0 & 0 \\
\hline PIRAPORA & SANTA FE DE MINAS & 2 & 0 \\
\hline PIRAPORA & SAO ROMAO & 0 & 0 \\
\hline PIRAPORA & VARZEA DA PALMA & 4 & 0 \\
\hline POÇOS DE CALDAS & ALTEROSA & 0 & 0 \\
\hline POÇOS DE CALDAS & ANDRADAS & 4 & 0 \\
\hline POÇOS DE CALDAS & AREADO & 0 & 0 \\
\hline POÇOS DE CALDAS & BANDEIRA DO SUL & 0 & 0 \\
\hline POÇOS DE CALDAS & BOTELHOS & 6 & 1 \\
\hline POÇOS DE CALDAS & CABO VERDE & 5 & 1 \\
\hline POÇOS DE CALDAS & CALDAS & 0 & 0 \\
\hline POÇOS DE CALDAS & CAMPESTRE & 0 & 0 \\
\hline POÇOS DE CALDAS & CONCEICAO DA APARECIDA & 3 & 0 \\
\hline POÇOS DE CALDAS & DIVISA NOVA & 0 & 0 \\
\hline
\end{tabular}




\begin{tabular}{|c|c|c|c|}
\hline POÇOS DE CALDAS & IBITIURA DE MINAS & 0 & 0 \\
\hline POÇOS DE CALDAS & MONTE BELO & 6 & 1 \\
\hline POÇOS DE CALDAS & MUZAMBINHO & 0 & 0 \\
\hline POÇOS DE CALDAS & NOVA RESENDE & 1 & 0 \\
\hline POÇOS DE CALDAS & POCOS DE CALDAS & 18 & 2 \\
\hline POÇOS DE CALDAS & SANTA RITA DE CALDAS & 1 & 0 \\
\hline POÇOS DE CALDAS & SERRANIA & 0 & 0 \\
\hline PONTE NOVA & ABRE CAMPO & 4 & 0 \\
\hline PONTE NOVA & ALVINOPOLIS & 9 & 1 \\
\hline PONTE NOVA & AMPARO DO SERRA & 4 & 0 \\
\hline PONTE NOVA & ARAPONGA & 5 & 1 \\
\hline PONTE NOVA & BARRA LONGA & 5 & 1 \\
\hline PONTE NOVA & CAJURI & 0 & 0 \\
\hline PONTE NOVA & CANAA & 0 & 0 \\
\hline PONTE NOVA & DOM SILVERIO & 0 & 0 \\
\hline PONTE NOVA & GUARACIABA & 7 & 1 \\
\hline PONTE NOVA & JEQUERI & 6 & 1 \\
\hline PONTE NOVA & ORATORIOS & 0 & 0 \\
\hline PONTE NOVA & PEDRA BONITA & 0 & 0 \\
\hline PONTE NOVA & PEDRA DO ANTA & 3 & 0 \\
\hline PONTE NOVA & PIEDADE DE PONTE NOVA & 0 & 0 \\
\hline PONTE NOVA & PONTE NOVA & 28 & 3 \\
\hline PONTE NOVA & PORTO FIRME & 1 & 0 \\
\hline PONTE NOVA & RAUL SOARES & 5 & 1 \\
\hline PONTE NOVA & RIO CASCA & 2 & 0 \\
\hline PONTE NOVA & RIO DOCE & 0 & 0 \\
\hline PONTE NOVA & SANTA CRUZ DO ESCALVADO & 0 & 0 \\
\hline PONTE NOVA & SANTO ANTONIO DO GRAMA & 0 & 0 \\
\hline PONTE NOVA & SAO MIGUEL DO ANTA & 0 & 0 \\
\hline PONTE NOVA & SAO PEDRO DOS FERROS & 2 & 0 \\
\hline PONTE NOVA & SEM-PEIXE & 0 & 0 \\
\hline PONTE NOVA & SERICITA & 0 & 0 \\
\hline PONTE NOVA & TEIXEIRAS & 7 & 1 \\
\hline PONTE NOVA & URUCANIA & 4 & 0 \\
\hline PONTE NOVA & VERMELHO NOVO & 0 & 0 \\
\hline PONTE NOVA & VICOSA & 33 & 3 \\
\hline POUSO ALEGRE & ALBERTINA & 0 & 0 \\
\hline POUSO ALEGRE & BOM REPOUSO & 0 & 0 \\
\hline POUSO ALEGRE & BORDA DA MATA & 7 & 1 \\
\hline POUSO ALEGRE & BUENO BRANDAO & 0 & 0 \\
\hline POUSO ALEGRE & CACHOEIRA DE MINAS & 0 & 0 \\
\hline POUSO ALEGRE & CAMANDUCAIA & 4 & 0 \\
\hline POUSO ALEGRE & CAMBUI & 8 & 1 \\
\hline POUSO ALEGRE & CAREACU & 0 & 0 \\
\hline POUSO ALEGRE & CONGONHAL & 0 & 0 \\
\hline
\end{tabular}




\begin{tabular}{|c|c|c|c|}
\hline POUSO ALEGRE & CORREGO DO BOM JESUS & 0 & 0 \\
\hline POUSO ALEGRE & ESPIRITO SANTO DO DOURADO & 0 & 0 \\
\hline POUSO ALEGRE & ESTIVA & 5 & 1 \\
\hline POUSO ALEGRE & EXTREMA & 0 & 0 \\
\hline POUSO ALEGRE & HELIODORA & 0 & 0 \\
\hline POUSO ALEGRE & INCONFIDENTES & 0 & 0 \\
\hline POUSO ALEGRE & IPUIUNA & 0 & 0 \\
\hline POUSO ALEGRE & ITAPEVA & 0 & 0 \\
\hline POUSO ALEGRE & JACUTINGA & 3 & 0 \\
\hline POUSO ALEGRE & MONTE SIAO & 2 & 0 \\
\hline POUSO ALEGRE & MUNHOZ & 0 & 0 \\
\hline POUSO ALEGRE & OURO FINO & 13 & 1 \\
\hline POUSO ALEGRE & POUSO ALEGRE & 31 & 3 \\
\hline POUSO ALEGRE & SANTA RITA DO SAPUCAI & 22 & 2 \\
\hline POUSO ALEGRE & SAO JOAO DA MATA & 0 & 0 \\
\hline POUSO ALEGRE & SAO SEBASTIAO DA BELA VISTA & 1 & 0 \\
\hline POUSO ALEGRE & SENADOR AMARAL & 5 & 1 \\
\hline POUSO ALEGRE & SENADOR JOSE BENTO & 0 & 0 \\
\hline POUSO ALEGRE & SILVIANOPOLIS & 0 & 0 \\
\hline POUSO ALEGRE & TOCOS DO MOJI & 0 & 0 \\
\hline POUSO ALEGRE & TOLEDO & 0 & 0 \\
\hline SÃO JOÃO DEL REI & BOM SUCESSO & 0 & 0 \\
\hline SÃO JOÃO DEL REI & CARRANCAS & 0 & 0 \\
\hline SÃO JOÃO DEL REI & CONCEICAO DA BARRA DE MINAS & 0 & 0 \\
\hline SÃO JOÃO DEL REI & CORONEL XAVIER CHAVES & 0 & 0 \\
\hline SÃO JOÃO DEL REI & DORES DE CAMPOS & 0 & 0 \\
\hline SÃO JOÃO DEL REI & IBITURUNA & 0 & 0 \\
\hline SÃO JOÃO DEL REI & IJACI & 0 & 0 \\
\hline SÃO JOÃO DEL REI & INGAI & 0 & 0 \\
\hline SÃO JOÃO DEL REI & ITUMIRIM & 6 & 1 \\
\hline SÃO JOÃO DEL REI & ITUTINGA & 3 & 0 \\
\hline SÃO JOÃO DEL REI & LAGOA DOURADA & 0 & 0 \\
\hline SÃO JOÃO DEL REI & NAZARENO & 0 & 0 \\
\hline SÃO JOÃO DEL REI & PRADOS & 0 & 0 \\
\hline SÃO JOÃO DEL REI & RESENDE COSTA & 1 & 0 \\
\hline SÃO JOÃO DEL REI & RITAPOLIS & 0 & 0 \\
\hline SÃO JOÃO DEL REI & SANTA CRUZ DE MINAS & 2 & 0 \\
\hline SÃO JOÃO DEL REI & SAO JOAO DEL REI & 55 & 7 \\
\hline SÃO JOÃO DEL REI & SAO TIAGO & 9 & 1 \\
\hline SÃO JOÃO DEL REI & TIRADENTES & 0 & 0 \\
\hline SÃO SEBASTIÃO DO PARAÍSO & ARCEBURGO & 0 & 0 \\
\hline SÃO SEBASTIÃO DO PARAÍSO & CAPETINGA & 0 & 0 \\
\hline SÃO SEBASTIÃO DO PARAÍSO & CASSIA & 5 & 1 \\
\hline SÃO SEBASTIÃO DO PARAÍSO & CLARAVAL & 0 & 0 \\
\hline SÃO SEBASTIÃO DO PARAÍSO & GUARANESIA & 8 & 1 \\
\hline
\end{tabular}




\begin{tabular}{|c|c|c|c|}
\hline SÃO SEBASTIÃO DO PARAÍSO & GUAXUPE & 12 & 1 \\
\hline SÃO SEBASTIÃO DO PARAÍSO & IBIRACI & 8 & 1 \\
\hline SÃO SEBASTIÃO DO PARAÍSO & ITAMOGI & 0 & 0 \\
\hline SÃO SEBASTIÃO DO PARAÍSO & ITAU DE MINAS & 0 & 0 \\
\hline SÃO SEBASTIÃO DO PARAÍSO & JACUI & 0 & 0 \\
\hline SÃO SEBASTIÃO DO PARAÍSO & JURUAIA & 3 & 0 \\
\hline SÃO SEBASTIÃO DO PARAÍSO & MONTE SANTO DE MINAS & 1 & 0 \\
\hline SÃO SEBASTIÃO DO PARAÍSO & PRATAPOLIS & 1 & 0 \\
\hline SÃO SEBASTIÃO DO PARAÍSO & SAO PEDRO DA UNIAO & 0 & 0 \\
\hline SÃO SEBASTIÃO DO PARAÍSO & SAO SEBASTIAO DO PARAISO & 16 & 2 \\
\hline SÃO SEBASTIÃO DO PARAÍSO & SAO TOMAS DE AQUINO & 0 & 0 \\
\hline SETE LAGOAS & ARACAI & 0 & 0 \\
\hline SETE LAGOAS & BALDIM & 0 & 0 \\
\hline SETE LAGOAS & CACHOEIRA DA PRATA & 0 & 0 \\
\hline SETE LAGOAS & CAETANOPOLIS & 3 & 0 \\
\hline SETE LAGOAS & CAPIM BRANCO & 0 & 0 \\
\hline SETE LAGOAS & CORDISBURGO & 2 & 0 \\
\hline SETE LAGOAS & FORTUNA DE MINAS & 0 & 0 \\
\hline SETE LAGOAS & FUNILANDIA & 1 & 0 \\
\hline SETE LAGOAS & INHAUMA & 0 & 0 \\
\hline SETE LAGOAS & JEQUITIBA & 0 & 0 \\
\hline SETE LAGOAS & MARAVILHAS & 0 & 0 \\
\hline SETE LAGOAS & MATOZINHOS & 7 & 1 \\
\hline SETE LAGOAS & PAPAGAIOS & 0 & 0 \\
\hline SETE LAGOAS & PARAOPEBA & 5 & 1 \\
\hline SETE LAGOAS & POMPEU & 1 & 0 \\
\hline SETE LAGOAS & PRUDENTE DE MORAIS & 3 & 0 \\
\hline SETE LAGOAS & SANTANA DE PIRAPAMA & 2 & 0 \\
\hline SETE LAGOAS & SETE LAGOAS & 19 & 2 \\
\hline TEOFILO OTONI & AGUAS FORMOSAS & 6 & 1 \\
\hline TEOFILO OTONI & ATALEIA & 5 & 1 \\
\hline TEOFILO OTONI & BERTOPOLIS & 1 & 0 \\
\hline TEOFILO OTONI & CAMPANARIO & 0 & 0 \\
\hline TEOFILO OTONI & CARAI & 4 & 0 \\
\hline TEOFILO OTONI & CARLOS CHAGAS & 0 & 0 \\
\hline TEOFILO OTONI & CATUJI & 0 & 0 \\
\hline TEOFILO OTONI & CRISOLITA & 3 & 0 \\
\hline TEOFILO OTONI & FRANCISCOPOLIS & 0 & 0 \\
\hline TEOFILO OTONI & FREI GASPAR & 0 & 0 \\
\hline TEOFILO OTONI & FRONTEIRA DOS VALES & 0 & 0 \\
\hline TEOFILO OTONI & ITAIPE & 5 & 1 \\
\hline TEOFILO OTONI & ITAMBACURI & 8 & 1 \\
\hline TEOFILO OTONI & JAMPRUCA & 0 & 0 \\
\hline TEOFILO OTONI & LADAINHA & 5 & 1 \\
\hline TEOFILO OTONI & MACHACALIS & 1 & 0 \\
\hline
\end{tabular}




\begin{tabular}{|c|c|c|c|}
\hline TEOFILO OTONI & MALACACHETA & 1 & 0 \\
\hline TEOFILO OTONI & NANUQUE & 17 & 2 \\
\hline TEOFILO OTONI & NOVO CRUZEIRO & 7 & 1 \\
\hline TEOFILO OTONI & NOVO ORIENTE DE MINAS & 1 & 0 \\
\hline TEOFILO OTONI & OURO VERDE DE MINAS & 0 & 0 \\
\hline TEOFILO OTONI & PADRE PARAISO & 2 & 0 \\
\hline TEOFILO OTONI & PAVAO & 5 & 1 \\
\hline TEOFILO OTONI & PESCADOR & 0 & 0 \\
\hline TEOFILO OTONI & PONTO DOS VOLANTES & 0 & 0 \\
\hline TEOFILO OTONI & POTE & 3 & 0 \\
\hline TEOFILO OTONI & SANTA HELENA DE MINAS & 1 & 0 \\
\hline TEOFILO OTONI & SERRA DOS AIMORES & 8 & 1 \\
\hline TEOFILO OTONI & SETUBINHA & 4 & 0 \\
\hline TEOFILO OTONI & TEOFILO OTONI & 21 & 2 \\
\hline TEOFILO OTONI & UMBURATIBA & 0 & 0 \\
\hline UBÁ & ASTOLFO DUTRA & 5 & 1 \\
\hline UBÁ & BRAS PIRES & 0 & 0 \\
\hline UBÁ & COIMBRA & 0 & 0 \\
\hline UBÁ & DIVINESIA & 0 & 0 \\
\hline UBÁ & DONA EUZEBIA & 0 & 0 \\
\hline UBÁ & DORES DO TURVO & 0 & 0 \\
\hline UBÁ & ERVALIA & 0 & 0 \\
\hline UBÁ & GUARANI & 0 & 0 \\
\hline UBÁ & GUIDOVAL & 0 & 0 \\
\hline UBÁ & GUIRICEMA & 2 & 0 \\
\hline UBÁ & PAULA CANDIDO & 3 & 0 \\
\hline UBÁ & PIRAUBA & 1 & 0 \\
\hline UBÁ & PRESIDENTE BERNARDES & 2 & 0 \\
\hline UBÁ & RIO POMBA & 0 & 0 \\
\hline UBÁ & RODEIRO & 2 & 0 \\
\hline UBÁ & SAO GERALDO & 1 & 0 \\
\hline UBÁ & SENADOR FIRMINO & 0 & 0 \\
\hline UBÁ & SILVEIRANIA & 0 & 0 \\
\hline UBÁ & TABULEIRO & 1 & 0 \\
\hline UBÁ & TOCANTINS & 4 & 0 \\
\hline UBÁ & UBA & 41 & 4 \\
\hline UBÁ & VISCONDE DO RIO BRANCO & 12 & 1 \\
\hline UBERABA & AGUA COMPRIDA & 0 & 0 \\
\hline UBERABA & ARAXA & 23 & 2 \\
\hline UBERABA & CAMPO FLORIDO & 0 & 0 \\
\hline UBERABA & CAMPOS ALTOS & 5 & 1 \\
\hline UBERABA & CARNEIRINHO & 0 & 0 \\
\hline UBERABA & COMENDADOR GOMES & 0 & 0 \\
\hline UBERABA & CONCEICAO DAS ALAGOAS & 0 & 0 \\
\hline UBERABA & CONQUISTA & 0 & 0 \\
\hline
\end{tabular}




\begin{tabular}{|c|c|c|c|}
\hline UBERABA & DELTA & 0 & 0 \\
\hline UBERABA & FRONTEIRA & 0 & 0 \\
\hline UBERABA & FRUTAL & 10 & 1 \\
\hline UBERABA & ITAPAGIPE & 2 & 0 \\
\hline UBERABA & ITURAMA & 4 & 0 \\
\hline UBERABA & LIMEIRA DO OESTE & 0 & 0 \\
\hline UBERABA & PEDRINOPOLIS & 0 & 0 \\
\hline UBERABA & PIRAJUBA & 0 & 0 \\
\hline UBERABA & PLANURA & 0 & 0 \\
\hline UBERABA & PRATINHA & 0 & 0 \\
\hline UBERABA & SACRAMENTO & 1 & 0 \\
\hline UBERABA & SANTA JULIANA & 0 & 0 \\
\hline UBERABA & SAO FRANCISCO DE SALES & 0 & 0 \\
\hline UBERABA & TAPIRA & 0 & 0 \\
\hline UBERABA & UBERABA & 87 & 10 \\
\hline UBERABA & UNIAO DE MINAS & 0 & 0 \\
\hline UBERABA & VERISSIMO & 0 & 0 \\
\hline UBERLANDIA & ARAGUARI & 44 & 4 \\
\hline UBERLANDIA & ARAPORA & 0 & 0 \\
\hline UBERLANDIA & CAMPINA VERDE & 4 & 0 \\
\hline UBERLANDIA & INDIANOPOLIS & 0 & 0 \\
\hline UBERLANDIA & MONTE ALEGRE DE MINAS & 2 & 0 \\
\hline UBERLANDIA & NOVA PONTE & 0 & 0 \\
\hline UBERLANDIA & PRATA & 4 & 0 \\
\hline UBERLANDIA & TUPACIGUARA & 11 & 1 \\
\hline UBERLANDIA & UBERLANDIA & 180 & 21 \\
\hline UNAI & ARINOS & 12 & 1 \\
\hline UNAI & BONFINOPOLIS DE MINAS & 0 & 0 \\
\hline UNAI & BURITIS & 3 & 0 \\
\hline UNAI & CABECEIRA GRANDE & 0 & 0 \\
\hline UNAI & DOM BOSCO & 4 & 0 \\
\hline UNAI & FORMOSO & 4 & 0 \\
\hline UNAI & NATALANDIA & 0 & 0 \\
\hline UNAI & RIACHINHO & 2 & 0 \\
\hline UNAI & UNAI & 25 & 3 \\
\hline UNAI & URUANA DE MINAS & 0 & 0 \\
\hline VARGINHA & ALFENAS & 12 & 1 \\
\hline VARGINHA & BOA ESPERANCA & 3 & 0 \\
\hline VARGINHA & CAMBUQUIRA & 4 & 0 \\
\hline VARGINHA & CAMPANHA & 0 & 0 \\
\hline VARGINHA & CAMPO DO MEIO & 0 & 0 \\
\hline VARGINHA & CAMPOS GERAIS & 16 & 2 \\
\hline VARGINHA & CARMO DA CACHOEIRA & 0 & 0 \\
\hline VARGINHA & CARVALHOPOLIS & 0 & 0 \\
\hline VARGINHA & COQUEIRAL & 3 & 0 \\
\hline
\end{tabular}




\begin{tabular}{|c|c|c|c|}
\hline VARGINHA & CORDISLANDIA & 0 & 0 \\
\hline VARGINHA & ELOI MENDES & 2 & 0 \\
\hline VARGINHA & FAMA & 0 & 0 \\
\hline VARGINHA & GUAPE & 1 & 0 \\
\hline VARGINHA & ILICINEA & 1 & 0 \\
\hline VARGINHA & LAMBARI & 5 & 1 \\
\hline VARGINHA & LUMINARIAS & 0 & 0 \\
\hline VARGINHA & MACHADO & 3 & 0 \\
\hline VARGINHA & MONSENHOR PAULO & 7 & 1 \\
\hline VARGINHA & NEPOMUCENO & 17 & 2 \\
\hline VARGINHA & PARAGUACU & 1 & 0 \\
\hline VARGINHA & POCO FUNDO & 12 & 1 \\
\hline VARGINHA & SANTANA DA VARGEM & 2 & 0 \\
\hline VARGINHA & SAO BENTO ABADE & 0 & 0 \\
\hline VARGINHA & SAO GONCALO DO SAPUCAI & 6 & 1 \\
\hline VARGINHA & TRES CORACOES & 7 & 1 \\
\hline VARGINHA & TRES PONTAS & 2 & 0 \\
\hline VARGINHA & TURVOLANDIA & 0 & 0 \\
\hline VARGINHA & VARGINHA & 36 & 4 \\
\hline Total geral & & 3.551 & 355 \\
\hline
\end{tabular}

CARGO: PROFESSOR DE EDUCAÇÃO BÁSICA - PEB - ARTE / ARTES

\begin{tabular}{|c|c|c|c|}
\hline S R E & MUNICIPIO & $\begin{array}{l}\text { TOTAL DE } \\
\text { VAGAS }\end{array}$ & $\begin{array}{c}\text { VAGAS } \\
\text { RESERVADAS - } \\
\text { PORTADORES DE } \\
\text { DEFICIÊNCIA }\end{array}$ \\
\hline ALMENARA & AGUAS VERMELHAS & 0 & 0 \\
\hline ALMENARA & ALMENARA & 0 & 0 \\
\hline ALMENARA & BANDEIRA & 0 & 0 \\
\hline ALMENARA & CACHOEIRA DE PAJEU & 0 & 0 \\
\hline ALMENARA & CURRAL DE DENTRO & 2 & 0 \\
\hline ALMENARA & DIVISA ALEGRE & 0 & 0 \\
\hline ALMENARA & DIVISOPOLIS & 0 & 0 \\
\hline ALMENARA & FELISBURGO & 1 & 0 \\
\hline ALMENARA & JACINTO & 0 & 0 \\
\hline ALMENARA & JEQUITINHONHA & 0 & 0 \\
\hline ALMENARA & JOAIMA & 0 & 0 \\
\hline ALMENARA & JORDANIA & 0 & 0 \\
\hline ALMENARA & MATA VERDE & 0 & 0 \\
\hline ALMENARA & MONTE FORMOSO & 0 & 0 \\
\hline ALMENARA & PALMOPOLIS & 0 & 0 \\
\hline ALMENARA & PEDRA AZUL & 1 & 0 \\
\hline ALMENARA & RIO DO PRADO & 0 & 0 \\
\hline ALMENARA & RUBIM & 0 & 0 \\
\hline
\end{tabular}




\begin{tabular}{|c|c|c|c|}
\hline ALMENARA & SALTO DA DIVISA & 0 & 0 \\
\hline ALMENARA & SANTA MARIA DO SALTO & 0 & 0 \\
\hline ALMENARA & SANTO ANTONIO DO JACINTO & 0 & 0 \\
\hline ARACUAI & ARACUAI & 1 & 0 \\
\hline ARACUAI & BERILO & 0 & 0 \\
\hline ARACUAI & BERIZAL & 0 & 0 \\
\hline ARACUAI & CHAPADA DO NORTE & 1 & 0 \\
\hline ARACUAI & COMERCINHO & 0 & 0 \\
\hline ARACUAI & CORONEL MURTA & 0 & 0 \\
\hline ARACUAI & FRANCISCO BADARO & 0 & 0 \\
\hline ARACUAI & FRUTA DE LEITE & 0 & 0 \\
\hline ARACUAI & INDAIABIRA & 0 & 0 \\
\hline ARACUAI & ITAOBIM & 0 & 0 \\
\hline ARACUAI & ITINGA & 0 & 0 \\
\hline ARACUAI & JENIPAPO DE MINAS & 0 & 0 \\
\hline ARACUAI & JOSE GONCALVES DE MINAS & 0 & 0 \\
\hline ARACUAI & MEDINA & 0 & 0 \\
\hline ARACUAI & NINHEIRA & 0 & 0 \\
\hline ARACUAI & NOVORIZONTE & 0 & 0 \\
\hline ARACUAI & RUBELITA & 0 & 0 \\
\hline ARACUAI & SALINAS & 0 & 0 \\
\hline ARACUAI & SANTA CRUZ DE SALINAS & 0 & 0 \\
\hline ARACUAI & TAIOBEIRAS & 1 & 0 \\
\hline ARACUAI & VIRGEM DA LAPA & 1 & 0 \\
\hline BARBACENA & ALFREDO VASCONCELOS & 0 & 0 \\
\hline BARBACENA & ALTO RIO DOCE & 0 & 0 \\
\hline BARBACENA & ANDRELANDIA & 0 & 0 \\
\hline BARBACENA & ANTONIO CARLOS & 0 & 0 \\
\hline BARBACENA & ARACITABA & 0 & 0 \\
\hline BARBACENA & BARBACENA & 5 & 2 \\
\hline BARBACENA & BARROSO & 2 & 0 \\
\hline BARBACENA & BIAS FORTES & 0 & 0 \\
\hline BARBACENA & CAPELA NOVA & 0 & 0 \\
\hline BARBACENA & CARANDAI & 0 & 0 \\
\hline BARBACENA & CIPOTANEA & 0 & 0 \\
\hline BARBACENA & DESTERRO DO MELO & 0 & 0 \\
\hline BARBACENA & IBERTIOGA & 0 & 0 \\
\hline BARBACENA & MADRE DE DEUS DE MINAS & 0 & 0 \\
\hline BARBACENA & MERCES & 0 & 0 \\
\hline BARBACENA & OLIVEIRA FORTES & 0 & 0 \\
\hline BARBACENA & PAIVA & 0 & 0 \\
\hline BARBACENA & PIEDADE DO RIO GRANDE & 0 & 0 \\
\hline BARBACENA & RESSAQUINHA & 0 & 0 \\
\hline BARBACENA & SANTA BARBARA DO TUGURIO & 0 & 0 \\
\hline BARBACENA & SANTA RITA DO IBITIPOCA & 0 & 0 \\
\hline
\end{tabular}




\begin{tabular}{|c|c|c|c|}
\hline BARBACENA & SANTANA DO GARAMBEU & 0 & 0 \\
\hline BARBACENA & SAO VICENTE DE MINAS & 0 & 0 \\
\hline BARBACENA & SENHORA DOS REMEDIOS & 0 & 0 \\
\hline CARANGOLA & ALTO CAPARAO & 0 & 0 \\
\hline CARANGOLA & CAIANA & 0 & 0 \\
\hline CARANGOLA & CAPARAO & 0 & 0 \\
\hline CARANGOLA & CARANGOLA & 0 & 0 \\
\hline CARANGOLA & DIVINO & 0 & 0 \\
\hline CARANGOLA & ESPERA FELIZ & 1 & 0 \\
\hline CARANGOLA & FARIA LEMOS & 0 & 0 \\
\hline CARANGOLA & FERVEDOURO & 0 & 0 \\
\hline CARANGOLA & ORIZANIA & 0 & 0 \\
\hline CARANGOLA & PEDRA DOURADA & 0 & 0 \\
\hline CARANGOLA & TOMBOS & 0 & 0 \\
\hline CARATINGA & ALVARENGA & 0 & 0 \\
\hline CARATINGA & BOM JESUS DO GALHO & 0 & 0 \\
\hline CARATINGA & BUGRE & 1 & 0 \\
\hline CARATINGA & CARATINGA & 0 & 0 \\
\hline CARATINGA & CORREGO NOVO & 0 & 0 \\
\hline CARATINGA & DOM CAVATI & 0 & 0 \\
\hline CARATINGA & ENTRE FOLHAS & 0 & 0 \\
\hline CARATINGA & IAPU & 0 & 0 \\
\hline CARATINGA & IMBE DE MINAS & 1 & 0 \\
\hline CARATINGA & INHAPIM & 0 & 0 \\
\hline CARATINGA & IPABA & 1 & 0 \\
\hline CARATINGA & IPANEMA & 0 & 0 \\
\hline CARATINGA & PIEDADE DE CARATINGA & 0 & 0 \\
\hline CARATINGA & PINGO D AGUA & 0 & 0 \\
\hline CARATINGA & POCRANE & 0 & 0 \\
\hline CARATINGA & SANTA BARBARA DO LESTE & 0 & 0 \\
\hline CARATINGA & SANTA RITA DE MINAS & 0 & 0 \\
\hline CARATINGA & SAO DOMINGOS DAS DORES & 0 & 0 \\
\hline CARATINGA & SAO JOAO DO ORIENTE & 0 & 0 \\
\hline CARATINGA & SAO SEBASTIAO DO ANTA & 0 & 0 \\
\hline CARATINGA & TAPARUBA & 0 & 0 \\
\hline CARATINGA & TARUMIRIM & 0 & 0 \\
\hline CARATINGA & UBAPORANGA & 0 & 0 \\
\hline CARATINGA & VARGEM ALEGRE & 0 & 0 \\
\hline CAXAMBU & AIURUOCA & 0 & 0 \\
\hline CAXAMBU & ALAGOA & 0 & 0 \\
\hline CAXAMBU & BAEPENDI & 0 & 0 \\
\hline CAXAMBU & BOCAINA DE MINAS & 0 & 0 \\
\hline CAXAMBU & CARVALHOS & 0 & 0 \\
\hline CAXAMBU & CAXAMBU & 0 & 0 \\
\hline CAXAMBU & CONCEICAO DO RIO VERDE & 0 & 0 \\
\hline
\end{tabular}




\begin{tabular}{|c|c|c|c|}
\hline CAXAMBU & CRUZILIA & 0 & 0 \\
\hline CAXAMBU & ITAMONTE & 0 & 0 \\
\hline CAXAMBU & ITANHANDU & 0 & 0 \\
\hline CAXAMBU & JESUANIA & 1 & 0 \\
\hline CAXAMBU & LIBERDADE & 2 & 0 \\
\hline CAXAMBU & MINDURI & 0 & 0 \\
\hline CAXAMBU & OLIMPIO NORONHA & 0 & 0 \\
\hline CAXAMBU & PASSA QUATRO & 0 & 0 \\
\hline CAXAMBU & PASSA VINTE & 0 & 0 \\
\hline CAXAMBU & POUSO ALTO & 0 & 0 \\
\hline CAXAMBU & SAO LOURENCO & 0 & 0 \\
\hline CAXAMBU & SAO SEBASTIAO DO RIO VERDE & 0 & 0 \\
\hline CAXAMBU & SAO TOME DAS LETRAS & 0 & 0 \\
\hline CAXAMBU & SERITINGA & 0 & 0 \\
\hline CAXAMBU & SERRANOS & 0 & 0 \\
\hline CAXAMBU & SOLEDADE DE MINAS & 0 & 0 \\
\hline CORONEL FABRICIANO & ANTONIO DIAS & 0 & 0 \\
\hline CORONEL FABRICIANO & BELO ORIENTE & 1 & 0 \\
\hline CORONEL FABRICIANO & BRAUNAS & 0 & 0 \\
\hline CORONEL FABRICIANO & CORONEL FABRICIANO & 5 & 2 \\
\hline CORONEL FABRICIANO & IPATINGA & 1 & 0 \\
\hline CORONEL FABRICIANO & JAGUARAÇU & 0 & 0 \\
\hline CORONEL FABRICIANO & JOANESIA & 0 & 0 \\
\hline CORONEL FABRICIANO & MARLIERIA & 0 & 0 \\
\hline CORONEL FABRICIANO & MESQUITA & 1 & 0 \\
\hline CORONEL FABRICIANO & SANTANA DO PARAISO & 0 & 0 \\
\hline CORONEL FABRICIANO & TIMOTEO & 1 & 0 \\
\hline CONSELHEIRO LAFAIETE & CARANAIBA & 0 & 0 \\
\hline CONSELHEIRO LAFAIETE & CASA GRANDE & 0 & 0 \\
\hline CONSELHEIRO LAFAIETE & CATAS ALTAS DA NORUEGA & 0 & 0 \\
\hline CONSELHEIRO LAFAIETE & CONGONHAS & 0 & 0 \\
\hline CONSELHEIRO LAFAIETE & CONSELHEIRO LAFAIETE & 0 & 0 \\
\hline CONSELHEIRO LAFAIETE & CRISTIANO OTONI & 0 & 0 \\
\hline CONSELHEIRO LAFAIETE & DESTERRO DE ENTRE RIOS & 1 & 0 \\
\hline CONSELHEIRO LAFAIETE & ENTRE RIOS DE MINAS & 0 & 0 \\
\hline CONSELHEIRO LAFAIETE & ITAVERAVA & 0 & 0 \\
\hline CONSELHEIRO LAFAIETE & JECEABA & 0 & 0 \\
\hline CONSELHEIRO LAFAIETE & LAMIM & 0 & 0 \\
\hline CONSELHEIRO LAFAIETE & OURO BRANCO & 0 & 0 \\
\hline CONSELHEIRO LAFAIETE & PIRANGA & 0 & 0 \\
\hline CONSELHEIRO LAFAIETE & QUELUZITO & 0 & 0 \\
\hline CONSELHEIRO LAFAIETE & RIO ESPERA & 0 & 0 \\
\hline CONSELHEIRO LAFAIETE & SANTANA DOS MONTES & 0 & 0 \\
\hline CONSELHEIRO LAFAIETE & SAO BRAS DO SUACUI & 0 & 0 \\
\hline CONSELHEIRO LAFAIETE & SENHORA DE OLIVEIRA & 0 & 0 \\
\hline
\end{tabular}




\begin{tabular}{|c|c|c|c|}
\hline CURVELO & AUGUSTO DE LIMA & 0 & 0 \\
\hline CURVELO & BUENOPOLIS & 1 & 0 \\
\hline CURVELO & CORINTO & 1 & 0 \\
\hline CURVELO & CURVELO & 0 & 0 \\
\hline CURVELO & FELIXLANDIA & 0 & 0 \\
\hline CURVELO & INIMUTABA & 0 & 0 \\
\hline CURVELO & JOAQUIM FELICIO & 0 & 0 \\
\hline CURVELO & LASSANCE & 0 & 0 \\
\hline CURVELO & MORRO DA GARCA & 0 & 0 \\
\hline CURVELO & PRESIDENTE JUSCELINO & 0 & 0 \\
\hline CURVELO & SANTO HIPOLITO & 0 & 0 \\
\hline CURVELO & TRES MARIAS & 0 & 0 \\
\hline DIAMANTINA & ALVORADA DE MINAS & 0 & 0 \\
\hline DIAMANTINA & ANGELANDIA & 2 & 0 \\
\hline DIAMANTINA & ARICANDUVA & 0 & 0 \\
\hline DIAMANTINA & CAPELINHA & 0 & 0 \\
\hline DIAMANTINA & CARBONITA & 1 & 0 \\
\hline DIAMANTINA & CONCEICAO DO MATO DENTRO & 0 & 0 \\
\hline DIAMANTINA & CONGONHAS DO NORTE & 2 & 0 \\
\hline DIAMANTINA & COUTO DE MAGALHAES DE MINAS & 1 & 0 \\
\hline DIAMANTINA & DATAS & 0 & 0 \\
\hline DIAMANTINA & DIAMANTINA & 1 & 0 \\
\hline DIAMANTINA & FELICIO DOS SANTOS & 0 & 0 \\
\hline DIAMANTINA & GOUVEA & 0 & 0 \\
\hline DIAMANTINA & ITAMARANDIBA & 2 & 0 \\
\hline DIAMANTINA & LEME DO PRADO & 0 & 0 \\
\hline DIAMANTINA & MINAS NOVAS & 1 & 0 \\
\hline DIAMANTINA & MONJOLOS & 0 & 0 \\
\hline DIAMANTINA & PRESIDENTE KUBITSCHEK & 0 & 0 \\
\hline DIAMANTINA & RIO VERMELHO & 0 & 0 \\
\hline DIAMANTINA & SANTO ANTONIO DO ITAMBE & 0 & 0 \\
\hline DIAMANTINA & SAO GONCALO DO RIO PRETO & 0 & 0 \\
\hline DIAMANTINA & SENADOR MODESTINO GONCALVES & 0 & 0 \\
\hline DIAMANTINA & SERRA AZUL DE MINAS & 0 & 0 \\
\hline DIAMANTINA & SERRO & 1 & 0 \\
\hline DIAMANTINA & TURMALINA & 0 & 0 \\
\hline DIAMANTINA & VEREDINHA & 0 & 0 \\
\hline DIVINÓPOLIS & ARAUJOS & 0 & 0 \\
\hline DIVINÓPOLIS & ARCOS & 1 & 0 \\
\hline DIVINÓPOLIS & BAMBUI & 0 & 0 \\
\hline DIVINÓPOLIS & CARMO DA MATA & 0 & 0 \\
\hline DIVINÓPOLIS & CARMO DO CAJURU & 3 & 0 \\
\hline DIVINÓPOLIS & CARMOPOLIS DE MINAS & 0 & 0 \\
\hline DIVINÓPOLIS & CLAUDIO & 0 & 0 \\
\hline DIVINÓPOLIS & CORREGO DANTA & 0 & 0 \\
\hline
\end{tabular}




\begin{tabular}{|c|c|c|c|}
\hline DIVINÓPOLIS & DIVINOPOLIS & 2 & 0 \\
\hline DIVINÓPOLIS & IGUATAMA & 0 & 0 \\
\hline DIVINÓPOLIS & ITAGUARA & 0 & 0 \\
\hline DIVINÓPOLIS & ITAPECERICA & 0 & 0 \\
\hline DIVINÓPOLIS & ITATIAIUCU & 0 & 0 \\
\hline DIVINÓPOLIS & ITAUNA & 3 & 0 \\
\hline DIVINÓPOLIS & JAPARAIBA & 0 & 0 \\
\hline DIVINÓPOLIS & LAGOA DA PRATA & 1 & 0 \\
\hline DIVINÓPOLIS & LUZ & 0 & 0 \\
\hline DIVINÓPOLIS & MEDEIROS & 0 & 0 \\
\hline DIVINÓPOLIS & MOEMA & 0 & 0 \\
\hline DIVINÓPOLIS & NOVA SERRANA & 3 & 0 \\
\hline DIVINÓPOLIS & OLIVEIRA & 0 & 0 \\
\hline DIVINÓPOLIS & PAINS & 0 & 0 \\
\hline DIVINÓPOLIS & PASSA TEMPO & 0 & 0 \\
\hline DIVINÓPOLIS & PEDRA DO INDAIA & 0 & 0 \\
\hline DIVINÓPOLIS & PERDIGAO & 1 & 0 \\
\hline DIVINÓPOLIS & PIRACEMA & 0 & 0 \\
\hline DIVINÓPOLIS & SANTO ANTONIO DO MONTE & 4 & 0 \\
\hline DIVINÓPOLIS & SAO GONCALO DO PARA & 0 & 0 \\
\hline DIVINÓPOLIS & SAO SEBASTIAO DO OESTE & 0 & 0 \\
\hline DIVINÓPOLIS & TAPIRAI & 0 & 0 \\
\hline GOVERNADOR VALADARES & ACUCENA & 0 & 0 \\
\hline GOVERNADOR VALADARES & AIMORES & 0 & 0 \\
\hline GOVERNADOR VALADARES & ALPERCATA & 0 & 0 \\
\hline GOVERNADOR VALADARES & CAPITAO ANDRADE & 1 & 0 \\
\hline GOVERNADOR VALADARES & CENTRAL DE MINAS & 0 & 0 \\
\hline GOVERNADOR VALADARES & CONSELHEIRO PENA & 0 & 0 \\
\hline GOVERNADOR VALADARES & COROACI & 0 & 0 \\
\hline GOVERNADOR VALADARES & CUPARAQUE & 0 & 0 \\
\hline GOVERNADOR VALADARES & DIVINO DAS LARANJEIRAS & 0 & 0 \\
\hline GOVERNADOR VALADARES & ENGENHEIRO CALDAS & 0 & 0 \\
\hline GOVERNADOR VALADARES & FERNANDES TOURINHO & 0 & 0 \\
\hline GOVERNADOR VALADARES & FREI INOCENCIO & 0 & 0 \\
\hline GOVERNADOR VALADARES & GALILEIA & 0 & 0 \\
\hline GOVERNADOR VALADARES & GOIABEIRA & 0 & 0 \\
\hline GOVERNADOR VALADARES & GOVERNADOR VALADARES & 4 & 0 \\
\hline GOVERNADOR VALADARES & ITABIRINHA & 0 & 0 \\
\hline GOVERNADOR VALADARES & ITANHOMI & 0 & 0 \\
\hline GOVERNADOR VALADARES & ITUETA & 0 & 0 \\
\hline GOVERNADOR VALADARES & MANTENA & 0 & 0 \\
\hline GOVERNADOR VALADARES & MARILAC & 0 & 0 \\
\hline GOVERNADOR VALADARES & MATHIAS LOBATO & 0 & 0 \\
\hline GOVERNADOR VALADARES & MENDES PIMENTEL & 0 & 0 \\
\hline GOVERNADOR VALADARES & NACIP RAYDAN & 0 & 0 \\
\hline
\end{tabular}




\begin{tabular}{|c|c|c|c|}
\hline GOVERNADOR VALADARES & NAQUE & 0 & 0 \\
\hline GOVERNADOR VALADARES & NOVA BELEM & 0 & 0 \\
\hline GOVERNADOR VALADARES & NOVA MODICA & 0 & 0 \\
\hline GOVERNADOR VALADARES & PERIQUITO & 0 & 0 \\
\hline GOVERNADOR VALADARES & RESPLENDOR & 0 & 0 \\
\hline GOVERNADOR VALADARES & SANTA EFIGENIA DE MINAS & 0 & 0 \\
\hline GOVERNADOR VALADARES & SANTA RITA DO ITUETO & 0 & 0 \\
\hline GOVERNADOR VALADARES & SAO FELIX DE MINAS & 0 & 0 \\
\hline GOVERNADOR VALADARES & SAO GERALDO DA PIEDADE & 0 & 0 \\
\hline GOVERNADOR VALADARES & SAO GERALDO DO BAIXIO & 0 & 0 \\
\hline GOVERNADOR VALADARES & SAO JOAO DO MANTENINHA & 0 & 0 \\
\hline GOVERNADOR VALADARES & SAO JOSE DA SAFIRA & 0 & 0 \\
\hline GOVERNADOR VALADARES & SAO JOSE DO DIVINO & 0 & 0 \\
\hline GOVERNADOR VALADARES & SARDOA & 0 & 0 \\
\hline GOVERNADOR VALADARES & SOBRALIA & 0 & 0 \\
\hline GOVERNADOR VALADARES & TUMIRITINGA & 0 & 0 \\
\hline GOVERNADOR VALADARES & VIRGOLANDIA & 0 & 0 \\
\hline GUANHÃES & AGUA BOA & 1 & 0 \\
\hline GUANHÃES & CANTAGALO & 0 & 0 \\
\hline GUANHÃES & CARMESIA & 0 & 0 \\
\hline GUANHÃES & COLUNA & 0 & 0 \\
\hline GUANHÃES & DIVINOLANDIA DE MINAS & 0 & 0 \\
\hline GUANHÃES & DOM JOAQUIM & 0 & 0 \\
\hline GUANHÃES & DORES DE GUANHAES & 0 & 0 \\
\hline GUANHÃES & FREI LAGONEGRO & 0 & 0 \\
\hline GUANHÃES & GONZAGA & 0 & 0 \\
\hline GUANHÃES & GUANHAES & 0 & 0 \\
\hline GUANHÃES & JOSE RAYDAN & 0 & 0 \\
\hline GUANHÃES & MATERLANDIA & 0 & 0 \\
\hline GUANHÃES & PAULISTAS & 0 & 0 \\
\hline GUANHÃES & PECANHA & 1 & 0 \\
\hline GUANHÃES & SABINOPOLIS & 0 & 0 \\
\hline GUANHÃES & SANTA MARIA DO SUACUI & 0 & 0 \\
\hline GUANHÃES & SAO JOAO EVANGELISTA & 0 & 0 \\
\hline GUANHÃES & SAO JOSE DO JACURI & 1 & 0 \\
\hline GUANHÃES & SAO PEDRO DO SUACUI & 0 & 0 \\
\hline GUANHÃES & SAO SEBASTIAO DO MARANHAO & 0 & 0 \\
\hline GUANHÃES & SENHORA DO PORTO & 0 & 0 \\
\hline GUANHÃES & VIRGINOPOLIS & 0 & 0 \\
\hline ITAJUBÁ & BRASOPOLIS & 0 & 0 \\
\hline ITAJUBÁ & CARMO DE MINAS & 0 & 0 \\
\hline ITAJUBÁ & CONCEICAO DAS PEDRAS & 0 & 0 \\
\hline ITAJUBÁ & CONCEICAO DOS OUROS & 2 & 0 \\
\hline ITAJUBÁ & CONSOLACAO & 0 & 0 \\
\hline ITAJUBÁ & CRISTINA & 1 & 0 \\
\hline
\end{tabular}




\begin{tabular}{|c|c|c|c|}
\hline ITAJUBÁ & DELFIM MOREIRA & 0 & 0 \\
\hline ITAJUBÁ & DOM VICOSO & 0 & 0 \\
\hline ITAJUBÁ & GONCALVES & 0 & 0 \\
\hline ITAJUBÁ & ITAJUBA & 2 & 0 \\
\hline ITAJUBÁ & MARIA DA FE & 0 & 0 \\
\hline ITAJUBÁ & MARMELOPOLIS & 0 & 0 \\
\hline ITAJUBÁ & NATERCIA & 0 & 0 \\
\hline ITAJUBÁ & PARAISOPOLIS & 0 & 0 \\
\hline ITAJUBÁ & PEDRALVA & 1 & 0 \\
\hline ITAJUBÁ & PIRANGUCU & 0 & 0 \\
\hline ITAJUBÁ & PIRANGUINHO & 1 & 0 \\
\hline ITAJUBÁ & SAO JOSE DO ALEGRE & 0 & 0 \\
\hline ITAJUBÁ & SAPUCAI-MIRIM & 1 & 0 \\
\hline ITAJUBÁ & VIRGINIA & 0 & 0 \\
\hline ITAJUBÁ & WENCESLAU BRAZ & 0 & 0 \\
\hline ITUIUTABA & CACHOEIRA DOURADA & 0 & 0 \\
\hline ITUIUTABA & CANAPOLIS & 1 & 0 \\
\hline ITUIUTABA & CAPINOPOLIS & 0 & 0 \\
\hline ITUIUTABA & CENTRALINA & 0 & 0 \\
\hline ITUIUTABA & GURINHATA & 0 & 0 \\
\hline ITUIUTABA & IPIACU & 0 & 0 \\
\hline ITUIUTABA & ITUIUTABA & 1 & 0 \\
\hline ITUIUTABA & SANTA VITORIA & 0 & 0 \\
\hline JANAUBA & CATUTI & 0 & 0 \\
\hline JANAUBA & ESPINOSA & 0 & 0 \\
\hline JANAUBA & GAMELEIRAS & 0 & 0 \\
\hline JANAUBA & JAIBA & 0 & 0 \\
\hline JANAUBA & JANAUBA & 2 & 0 \\
\hline JANAUBA & MAMONAS & 0 & 0 \\
\hline JANAUBA & MATO VERDE & 0 & 0 \\
\hline JANAUBA & MONTE AZUL & 0 & 0 \\
\hline JANAUBA & MONTEZUMA & 0 & 0 \\
\hline JANAUBA & NOVA PORTEIRINHA & 0 & 0 \\
\hline JANAUBA & PAI PEDRO & 0 & 0 \\
\hline JANAUBA & PORTEIRINHA & 0 & 0 \\
\hline JANAUBA & RIACHO DOS MACHADOS & 0 & 0 \\
\hline JANAUBA & RIO PARDO DE MINAS & 0 & 0 \\
\hline JANAUBA & SANTO ANTONIO DO RETIRO & 0 & 0 \\
\hline JANAUBA & SERRANOPOLIS DE MINAS & 0 & 0 \\
\hline JANAUBA & VERDELANDIA & 0 & 0 \\
\hline JANUARIA & BONITO DE MINAS & 1 & 0 \\
\hline JANUARIA & CHAPADA GAUCHA & 0 & 0 \\
\hline JANUARIA & CONEGO MARINHO & 0 & 0 \\
\hline JANUARIA & IBIRACATU & 0 & 0 \\
\hline JANUARIA & ICARAI DE MINAS & 0 & 0 \\
\hline
\end{tabular}




\begin{tabular}{|c|c|c|c|}
\hline JANUARIA & ITACARAMBI & 0 & 0 \\
\hline JANUARIA & JANUARIA & 3 & 0 \\
\hline JANUARIA & JUVENILIA & 0 & 0 \\
\hline JANUARIA & MANGA & 0 & 0 \\
\hline JANUARIA & MATIAS CARDOSO & 1 & 0 \\
\hline JANUARIA & MIRAVANIA & 0 & 0 \\
\hline JANUARIA & MONTALVANIA & 0 & 0 \\
\hline JANUARIA & PEDRAS DE MARIA DA CRUZ & 1 & 0 \\
\hline JANUARIA & PINTOPOLIS & 0 & 0 \\
\hline JANUARIA & SAO FRANCISCO & 2 & 0 \\
\hline JANUARIA & SAO JOAO DAS MISSOES & 0 & 0 \\
\hline JANUARIA & UBAI & 0 & 0 \\
\hline JANUARIA & URUCUIA & 0 & 0 \\
\hline JANUARIA & VARZELANDIA & 0 & 0 \\
\hline JUIZ DE FORA & ARANTINA & 0 & 0 \\
\hline JUIZ DE FORA & BELMIRO BRAGA & 0 & 0 \\
\hline JUIZ DE FORA & BICAS & 0 & 0 \\
\hline JUIZ DE FORA & BOM JARDIM DE MINAS & 0 & 0 \\
\hline JUIZ DE FORA & CHACARA & 0 & 0 \\
\hline JUIZ DE FORA & CHIADOR & 0 & 0 \\
\hline JUIZ DE FORA & CORONEL PACHECO & 0 & 0 \\
\hline JUIZ DE FORA & DESCOBERTO & 0 & 0 \\
\hline JUIZ DE FORA & EWBANK DA CAMARA & 0 & 0 \\
\hline JUIZ DE FORA & GOIANA & 0 & 0 \\
\hline JUIZ DE FORA & GUARARA & 0 & 0 \\
\hline JUIZ DE FORA & JUIZ DE FORA & 10 & 2 \\
\hline JUIZ DE FORA & LIMA DUARTE & 0 & 0 \\
\hline JUIZ DE FORA & MAR DE ESPANHA & 1 & 0 \\
\hline JUIZ DE FORA & MARIPA DE MINAS & 0 & 0 \\
\hline JUIZ DE FORA & MATIAS BARBOSA & 0 & 0 \\
\hline JUIZ DE FORA & OLARIA & 0 & 0 \\
\hline JUIZ DE FORA & PEDRO TEIXEIRA & 0 & 0 \\
\hline JUIZ DE FORA & PEQUERI & 0 & 0 \\
\hline JUIZ DE FORA & PIAU & 0 & 0 \\
\hline JUIZ DE FORA & RIO NOVO & 0 & 0 \\
\hline JUIZ DE FORA & RIO PRETO & 0 & 0 \\
\hline JUIZ DE FORA & ROCHEDO DE MINAS & 0 & 0 \\
\hline JUIZ DE FORA & SANTA BARBARA DO MONTE VERDE & 1 & 0 \\
\hline JUIZ DE FORA & SANTA RITA DE JACUTINGA & 0 & 0 \\
\hline JUIZ DE FORA & SANTANA DO DESERTO & 0 & 0 \\
\hline JUIZ DE FORA & SANTOS DUMONT & 1 & 0 \\
\hline JUIZ DE FORA & SAO JOAO NEPOMUCENO & 0 & 0 \\
\hline JUIZ DE FORA & SENADOR CORTES & 0 & 0 \\
\hline JUIZ DE FORA & SIMAO PEREIRA & 0 & 0 \\
\hline LEOPOLDINA & ALEM PARAIBA & 0 & 0 \\
\hline
\end{tabular}




\begin{tabular}{|c|c|c|c|}
\hline LEOPOLDINA & ARGIRITA & 0 & 0 \\
\hline LEOPOLDINA & CATAGUASES & 1 & 0 \\
\hline LEOPOLDINA & ESTRELA DALVA & 0 & 0 \\
\hline LEOPOLDINA & ITAMARATI DE MINAS & 0 & 0 \\
\hline LEOPOLDINA & LEOPOLDINA & 0 & 0 \\
\hline LEOPOLDINA & PIRAPETINGA & 0 & 0 \\
\hline LEOPOLDINA & RECREIO & 0 & 0 \\
\hline LEOPOLDINA & SANTO ANTONIO DO AVENTUREIRO & 0 & 0 \\
\hline LEOPOLDINA & VOLTA GRANDE & 0 & 0 \\
\hline MANHUAÇU & ALTO JEQUITIBA & 0 & 0 \\
\hline MANHUAÇU & CAPUTIRA & 0 & 0 \\
\hline MANHUAÇU & CHALE & 0 & 0 \\
\hline MANHUAÇU & CONCEICAO DE IPANEMA & 0 & 0 \\
\hline MANHUAÇU & DURANDE & 0 & 0 \\
\hline MANHUAÇU & LAJINHA & 1 & 0 \\
\hline MANHUAÇU & LUISBURGO & 0 & 0 \\
\hline MANHUAÇU & MANHUACU & 0 & 0 \\
\hline MANHUAÇU & MANHUMIRIM & 2 & 0 \\
\hline MANHUAÇU & MARTINS SOARES & 0 & 0 \\
\hline MANHUAÇU & MATIPO & 1 & 0 \\
\hline MANHUAÇU & MUTUM & 1 & 0 \\
\hline MANHUAÇU & REDUTO & 0 & 0 \\
\hline MANHUAÇU & SANTA MARGARIDA & 1 & 0 \\
\hline MANHUAÇU & SANTANA DO MANHUACU & 1 & 0 \\
\hline MANHUAÇU & SAO JOAO DO MANHUACU & 0 & 0 \\
\hline MANHUAÇU & SAO JOSE DO MANTIMENTO & 0 & 0 \\
\hline MANHUAÇU & SIMONESIA & 1 & 0 \\
\hline METROPOLITANA A & BARAO DE COCAIS & 0 & 0 \\
\hline METROPOLITANA A & BELO HORIZONTE & 22 & 5 \\
\hline METROPOLITANA A & BELO VALE & 0 & 0 \\
\hline METROPOLITANA A & BOM JESUS DO AMPARO & 2 & 0 \\
\hline METROPOLITANA A & BONFIM & 1 & 0 \\
\hline METROPOLITANA A & BRUMADINHO & 0 & 0 \\
\hline METROPOLITANA A & CAETE & 2 & 0 \\
\hline METROPOLITANA A & CATAS ALTAS & 0 & 0 \\
\hline METROPOLITANA A & CRUCILANDIA & 0 & 0 \\
\hline METROPOLITANA A & MOEDA & 1 & 0 \\
\hline METROPOLITANA A & NOVA LIMA & 3 & 0 \\
\hline METROPOLITANA A & NOVA UNIAO & 0 & 0 \\
\hline METROPOLITANA A & PIEDADE DOS GERAIS & 0 & 0 \\
\hline METROPOLITANA A & RAPOSOS & 1 & 0 \\
\hline METROPOLITANA A & RIO ACIMA & 0 & 0 \\
\hline METROPOLITANA A & RIO MANSO & 0 & 0 \\
\hline METROPOLITANA A & SABARA & 1 & 0 \\
\hline METROPOLITANA A & SANTA BARBARA & 0 & 0 \\
\hline
\end{tabular}




\begin{tabular}{|c|c|c|c|}
\hline METROPOLITANA B & BELO HORIZONTE & 27 & 6 \\
\hline METROPOLITANA B & BETIM & 15 & 4 \\
\hline METROPOLITANA B & CONTAGEM & 16 & 4 \\
\hline METROPOLITANA B & ESMERALDAS & 4 & 0 \\
\hline METROPOLITANA B & IBIRITE & 4 & 0 \\
\hline METROPOLITANA B & IGARAPE & 0 & 0 \\
\hline METROPOLITANA B & JUATUBA & 0 & 0 \\
\hline METROPOLITANA B & MARIO CAMPOS & 1 & 0 \\
\hline METROPOLITANA B & MATEUS LEME & 1 & 0 \\
\hline METROPOLITANA B & SAO JOAQUIM DE BICAS & 0 & 0 \\
\hline METROPOLITANA B & SARZEDO & 1 & 0 \\
\hline METROPOLITANA C & BELO HORIZONTE & 17 & 4 \\
\hline METROPOLITANA C & CONFINS & 1 & 0 \\
\hline METROPOLITANA C & JABOTICATUBAS & 1 & 0 \\
\hline METROPOLITANA C & LAGOA SANTA & 1 & 0 \\
\hline METROPOLITANA C & MORRO DO PILAR & 0 & 0 \\
\hline METROPOLITANA C & PEDRO LEOPOLDO & 3 & 0 \\
\hline METROPOLITANA C & RIBEIRAO DAS NEVES & 20 & 5 \\
\hline METROPOLITANA C & SANTA LUZIA & 5 & 2 \\
\hline METROPOLITANA C & SANTANA DO RIACHO & 1 & 0 \\
\hline METROPOLITANA C & SAO JOSE DA LAPA & 1 & 0 \\
\hline METROPOLITANA C & TAQUARACU DE MINAS & 0 & 0 \\
\hline METROPOLITANA C & VESPASIANO & 3 & 0 \\
\hline MONTE CARMELO & ABADIA DOS DOURADOS & 0 & 0 \\
\hline MONTE CARMELO & CASCALHO RICO & 0 & 0 \\
\hline MONTE CARMELO & COROMANDEL & 2 & 0 \\
\hline MONTE CARMELO & DOURADOQUARA & 0 & 0 \\
\hline MONTE CARMELO & ESTRELA DO SUL & 0 & 0 \\
\hline MONTE CARMELO & GRUPIARA & 0 & 0 \\
\hline MONTE CARMELO & MONTE CARMELO & 2 & 0 \\
\hline MONTE CARMELO & ROMARIA & 0 & 0 \\
\hline MONTES CLAROS & BOCAIUVA & 2 & 0 \\
\hline MONTES CLAROS & BOTUMIRIM & 0 & 0 \\
\hline MONTES CLAROS & BRASILIA DE MINAS & 0 & 0 \\
\hline MONTES CLAROS & CAMPO AZUL & 0 & 0 \\
\hline MONTES CLAROS & CAPITAO ENEAS & 0 & 0 \\
\hline MONTES CLAROS & CLARO DOS POCOES & 0 & 0 \\
\hline MONTES CLAROS & CORACAO DE JESUS & 0 & 0 \\
\hline MONTES CLAROS & CRISTALIA & 0 & 0 \\
\hline MONTES CLAROS & ENGENHEIRO NAVARRO & 0 & 0 \\
\hline MONTES CLAROS & FRANCISCO DUMONT & 0 & 0 \\
\hline MONTES CLAROS & FRANCISCO SA & 0 & 0 \\
\hline MONTES CLAROS & GLAUCILANDIA & 0 & 0 \\
\hline MONTES CLAROS & GRAO MOGOL & 1 & 0 \\
\hline MONTES CLAROS & GUARACIAMA & 2 & 0 \\
\hline
\end{tabular}




\begin{tabular}{|c|c|c|c|}
\hline MONTES CLAROS & ITACAMBIRA & 0 & 0 \\
\hline MONTES CLAROS & JAPONVAR & 0 & 0 \\
\hline MONTES CLAROS & JOSENOPOLIS & 0 & 0 \\
\hline MONTES CLAROS & JURAMENTO & 2 & 0 \\
\hline MONTES CLAROS & LONTRA & 0 & 0 \\
\hline MONTES CLAROS & LUISLANDIA & 0 & 0 \\
\hline MONTES CLAROS & MIRABELA & 0 & 0 \\
\hline MONTES CLAROS & MONTES CLAROS & 6 & 2 \\
\hline MONTES CLAROS & OLHOS-D AGUA & 0 & 0 \\
\hline MONTES CLAROS & PADRE CARVALHO & 0 & 0 \\
\hline MONTES CLAROS & PATIS & 0 & 0 \\
\hline MONTES CLAROS & SAO JOAO DA LAGOA & 0 & 0 \\
\hline MONTES CLAROS & SAO JOAO DA PONTE & 0 & 0 \\
\hline MONTES CLAROS & SAO JOAO DO PACUI & 0 & 0 \\
\hline MONTES CLAROS & SAO JOAO DO PARAISO & 0 & 0 \\
\hline MONTES CLAROS & VARGEM GRANDE DO RIO PARDO & 0 & 0 \\
\hline NOVA ERA & BELA VISTA DE MINAS & 0 & 0 \\
\hline NOVA ERA & DIONISIO & 0 & 0 \\
\hline NOVA ERA & FERROS & 0 & 0 \\
\hline NOVA ERA & ITABIRA & 3 & 0 \\
\hline NOVA ERA & ITAMBE DO MATO DENTRO & 0 & 0 \\
\hline NOVA ERA & JOAO MONLEVADE & 1 & 0 \\
\hline NOVA ERA & NOVA ERA & 0 & 0 \\
\hline NOVA ERA & PASSABEM & 0 & 0 \\
\hline NOVA ERA & RIO PIRACICABA & 0 & 0 \\
\hline NOVA ERA & SANTA MARIA DE ITABIRA & 1 & 0 \\
\hline NOVA ERA & SANTO ANTONIO DO RIO ABAIXO & 0 & 0 \\
\hline NOVA ERA & SAO DOMINGOS DO PRATA & 0 & 0 \\
\hline NOVA ERA & SAO GONCALO DO RIO ABAIXO & 0 & 0 \\
\hline NOVA ERA & SAO JOSE DO GOIABAL & 0 & 0 \\
\hline NOVA ERA & SAO SEBASTIAO DO RIO PRETO & 0 & 0 \\
\hline OURO PRETO & ACAIACA & 1 & 0 \\
\hline OURO PRETO & DIOGO DE VASCONCELOS & 0 & 0 \\
\hline OURO PRETO & ITABIRITO & 3 & 0 \\
\hline OURO PRETO & MARIANA & 3 & 0 \\
\hline OURO PRETO & OURO PRETO & 3 & 0 \\
\hline PARA DE MINAS & ABAETE & 0 & 0 \\
\hline PARA DE MINAS & BIQUINHAS & 0 & 0 \\
\hline PARA DE MINAS & BOM DESPACHO & 0 & 0 \\
\hline PARA DE MINAS & CEDRO DO ABAETE & 0 & 0 \\
\hline PARA DE MINAS & CONCEICAO DO PARA & 0 & 0 \\
\hline PARA DE MINAS & DORES DO INDAIA & 0 & 0 \\
\hline PARA DE MINAS & ESTRELA DO INDAIA & 2 & 0 \\
\hline PARA DE MINAS & FLORESTAL & 0 & 0 \\
\hline PARA DE MINAS & IGARATINGA & 0 & 0 \\
\hline
\end{tabular}




\begin{tabular}{|c|c|c|c|}
\hline PARA DE MINAS & LEANDRO FERREIRA & 0 & 0 \\
\hline PARA DE MINAS & MARTINHO CAMPOS & 0 & 0 \\
\hline PARA DE MINAS & MORADA NOVA DE MINAS & 0 & 0 \\
\hline PARA DE MINAS & ONCA DE PITANGUI & 0 & 0 \\
\hline PARA DE MINAS & PAINEIRAS & 0 & 0 \\
\hline PARA DE MINAS & PARA DE MINAS & 1 & 0 \\
\hline PARA DE MINAS & PEQUI & 0 & 0 \\
\hline PARA DE MINAS & PITANGUI & 1 & 0 \\
\hline PARA DE MINAS & QUARTEL GERAL & 0 & 0 \\
\hline PARA DE MINAS & SAO JOSE DA VARGINHA & 0 & 0 \\
\hline PARA DE MINAS & SERRA DA SAUDADE & 0 & 0 \\
\hline PARACATU & BRASILANDIA DE MINAS & 0 & 0 \\
\hline PARACATU & GUARDA-MOR & 0 & 0 \\
\hline PARACATU & JOAO PINHEIRO & 0 & 0 \\
\hline PARACATU & PARACATU & 1 & 0 \\
\hline PARACATU & VAZANTE & 0 & 0 \\
\hline PASSOS & ALPINOPOLIS & 2 & 0 \\
\hline PASSOS & BOM JESUS DA PENHA & 0 & 0 \\
\hline PASSOS & CAPITOLIO & 0 & 0 \\
\hline PASSOS & CARMO DO RIO CLARO & 0 & 0 \\
\hline PASSOS & CORREGO FUNDO & 0 & 0 \\
\hline PASSOS & DELFINOPOLIS & 1 & 0 \\
\hline PASSOS & DORESOPOLIS & 0 & 0 \\
\hline PASSOS & FORMIGA & 0 & 0 \\
\hline PASSOS & FORTALEZA DE MINAS & 0 & 0 \\
\hline PASSOS & PASSOS & 0 & 0 \\
\hline PASSOS & PIMENTA & 1 & 0 \\
\hline PASSOS & PIUMHI & 0 & 0 \\
\hline PASSOS & SAO JOAO BATISTA DO GLORIA & 1 & 0 \\
\hline PASSOS & SAO JOSE DA BARRA & 2 & 0 \\
\hline PASSOS & SAO ROQUE DE MINAS & 0 & 0 \\
\hline PASSOS & VARGEM BONITA & 0 & 0 \\
\hline PATOS DE MINAS & ARAPUA & 0 & 0 \\
\hline PATOS DE MINAS & CARMO DO PARANAIBA & 0 & 0 \\
\hline PATOS DE MINAS & LAGAMAR & 0 & 0 \\
\hline PATOS DE MINAS & LAGOA FORMOSA & 0 & 0 \\
\hline PATOS DE MINAS & LAGOA GRANDE & 0 & 0 \\
\hline PATOS DE MINAS & MATUTINA & 0 & 0 \\
\hline PATOS DE MINAS & PATOS DE MINAS & 1 & 0 \\
\hline PATOS DE MINAS & PRESIDENTE OLEGARIO & 0 & 0 \\
\hline PATOS DE MINAS & RIO PARANAIBA & 0 & 0 \\
\hline PATOS DE MINAS & SANTA ROSA DA SERRA & 0 & 0 \\
\hline PATOS DE MINAS & SAO GONCALO DO ABAETE & 0 & 0 \\
\hline PATOS DE MINAS & SAO GOTARDO & 0 & 0 \\
\hline PATOS DE MINAS & TIROS & 0 & 0 \\
\hline
\end{tabular}




\begin{tabular}{|c|c|c|c|}
\hline PATOS DE MINAS & VARJAO DE MINAS & 0 & 0 \\
\hline PATROCÍNIO & CRUZEIRO DA FORTALEZA & 0 & 0 \\
\hline PATROCÍNIO & GUIMARANIA & 0 & 0 \\
\hline PATROCÍNIO & IBIA & 1 & 0 \\
\hline PATROCÍNIO & IRAI DE MINAS & 0 & 0 \\
\hline PATROCÍNIO & PATROCINIO & 1 & 0 \\
\hline PATROCÍNIO & PERDIZES & 2 & 0 \\
\hline PATROCÍNIO & SERRA DO SALITRE & 0 & 0 \\
\hline PIRAPORA & BURITIZEIRO & 1 & 0 \\
\hline PIRAPORA & IBIAI & 0 & 0 \\
\hline PIRAPORA & JEQUITAI & 0 & 0 \\
\hline PIRAPORA & LAGOA DOS PATOS & 0 & 0 \\
\hline PIRAPORA & PIRAPORA & 1 & 0 \\
\hline PIRAPORA & PONTO CHIQUE & 0 & 0 \\
\hline PIRAPORA & SANTA FE DE MINAS & 0 & 0 \\
\hline PIRAPORA & SAO ROMAO & 1 & 0 \\
\hline PIRAPORA & VARZEA DA PALMA & 1 & 0 \\
\hline POÇOS DE CALDAS & ALTEROSA & 0 & 0 \\
\hline POÇOS DE CALDAS & ANDRADAS & 3 & 0 \\
\hline POÇOS DE CALDAS & AREADO & 2 & 0 \\
\hline POÇOS DE CALDAS & BANDEIRA DO SUL & 0 & 0 \\
\hline POÇOS DE CALDAS & BOTELHOS & 0 & 0 \\
\hline POÇOS DE CALDAS & CABO VERDE & 1 & 0 \\
\hline POÇOS DE CALDAS & CALDAS & 0 & 0 \\
\hline POÇOS DE CALDAS & CAMPESTRE & 0 & 0 \\
\hline POÇOS DE CALDAS & CONCEICAO DA APARECIDA & 0 & 0 \\
\hline POÇOS DE CALDAS & DIVISA NOVA & 0 & 0 \\
\hline POÇOS DE CALDAS & IBITIURA DE MINAS & 0 & 0 \\
\hline POÇOS DE CALDAS & MONTE BELO & 1 & 0 \\
\hline POÇOS DE CALDAS & MUZAMBINHO & 0 & 0 \\
\hline POÇOS DE CALDAS & NOVA RESENDE & 0 & 0 \\
\hline POÇOS DE CALDAS & POCOS DE CALDAS & 3 & 0 \\
\hline POÇOS DE CALDAS & SANTA RITA DE CALDAS & 0 & 0 \\
\hline POÇOS DE CALDAS & SERRANIA & 0 & 0 \\
\hline PONTE NOVA & ABRE CAMPO & 0 & 0 \\
\hline PONTE NOVA & ALVINOPOLIS & 0 & 0 \\
\hline PONTE NOVA & AMPARO DO SERRA & 0 & 0 \\
\hline PONTE NOVA & ARAPONGA & 0 & 0 \\
\hline PONTE NOVA & BARRA LONGA & 0 & 0 \\
\hline PONTE NOVA & CAJURI & 0 & 0 \\
\hline PONTE NOVA & CANAA & 0 & 0 \\
\hline PONTE NOVA & DOM SILVERIO & 0 & 0 \\
\hline PONTE NOVA & GUARACIABA & 0 & 0 \\
\hline PONTE NOVA & JEQUERI & 0 & 0 \\
\hline PONTE NOVA & ORATORIOS & 0 & 0 \\
\hline
\end{tabular}




\begin{tabular}{|c|c|c|c|}
\hline PONTE NOVA & PEDRA BONITA & 0 & 0 \\
\hline PONTE NOVA & PEDRA DO ANTA & 0 & 0 \\
\hline PONTE NOVA & PIEDADE DE PONTE NOVA & 0 & 0 \\
\hline PONTE NOVA & PONTE NOVA & 0 & 0 \\
\hline PONTE NOVA & PORTO FIRME & 0 & 0 \\
\hline PONTE NOVA & RAUL SOARES & 1 & 0 \\
\hline PONTE NOVA & RIO CASCA & 0 & 0 \\
\hline PONTE NOVA & RIO DOCE & 0 & 0 \\
\hline PONTE NOVA & SANTA CRUZ DO ESCALVADO & 0 & 0 \\
\hline PONTE NOVA & SANTO ANTONIO DO GRAMA & 0 & 0 \\
\hline PONTE NOVA & SAO MIGUEL DO ANTA & 0 & 0 \\
\hline PONTE NOVA & SAO PEDRO DOS FERROS & 0 & 0 \\
\hline PONTE NOVA & SEM-PEIXE & 0 & 0 \\
\hline PONTE NOVA & SERICITA & 0 & 0 \\
\hline PONTE NOVA & TEIXEIRAS & 0 & 0 \\
\hline PONTE NOVA & URUCANIA & 0 & 0 \\
\hline PONTE NOVA & VERMELHO NOVO & 0 & 0 \\
\hline PONTE NOVA & VICOSA & 1 & 0 \\
\hline POUSO ALEGRE & ALBERTINA & 0 & 0 \\
\hline POUSO ALEGRE & BOM REPOUSO & 0 & 0 \\
\hline POUSO ALEGRE & BORDA DA MATA & 0 & 0 \\
\hline POUSO ALEGRE & BUENO BRANDAO & 2 & 0 \\
\hline POUSO ALEGRE & CACHOEIRA DE MINAS & 0 & 0 \\
\hline POUSO ALEGRE & CAMANDUCAIA & 3 & 0 \\
\hline POUSO ALEGRE & CAMBUI & 2 & 0 \\
\hline POUSO ALEGRE & CAREACU & 0 & 0 \\
\hline POUSO ALEGRE & CONGONHAL & 1 & 0 \\
\hline POUSO ALEGRE & CORREGO DO BOM JESUS & 0 & 0 \\
\hline POUSO ALEGRE & ESPIRITO SANTO DO DOURADO & 0 & 0 \\
\hline POUSO ALEGRE & ESTIVA & 2 & 0 \\
\hline POUSO ALEGRE & EXTREMA & 2 & 0 \\
\hline POUSO ALEGRE & HELIODORA & 0 & 0 \\
\hline POUSO ALEGRE & INCONFIDENTES & 0 & 0 \\
\hline POUSO ALEGRE & IPUIUNA & 0 & 0 \\
\hline POUSO ALEGRE & ITAPEVA & 0 & 0 \\
\hline POUSO ALEGRE & JACUTINGA & 0 & 0 \\
\hline POUSO ALEGRE & MONTE SIAO & 1 & 0 \\
\hline POUSO ALEGRE & MUNHOZ & 0 & 0 \\
\hline POUSO ALEGRE & OURO FINO & 1 & 0 \\
\hline POUSO ALEGRE & POUSO ALEGRE & 1 & 0 \\
\hline POUSO ALEGRE & SANTA RITA DO SAPUCAI & 2 & 0 \\
\hline POUSO ALEGRE & SAO JOAO DA MATA & 0 & 0 \\
\hline POUSO ALEGRE & SAO SEBASTIAO DA BELA VISTA & 0 & 0 \\
\hline POUSO ALEGRE & SENADOR AMARAL & 0 & 0 \\
\hline POUSO ALEGRE & SENADOR JOSE BENTO & 0 & 0 \\
\hline
\end{tabular}




\begin{tabular}{|c|c|c|c|}
\hline POUSO ALEGRE & SILVIANOPOLIS & 0 & 0 \\
\hline POUSO ALEGRE & TOCOS DO MOJI & 0 & 0 \\
\hline POUSO ALEGRE & TOLEDO & 0 & 0 \\
\hline SÃO JOÃO DEL REI & BOM SUCESSO & 0 & 0 \\
\hline SÃO JOÃO DEL REI & CARRANCAS & 0 & 0 \\
\hline SÃO JOÃO DEL REI & CONCEICAO DA BARRA DE MINAS & 0 & 0 \\
\hline SÃO JOÃO DEL REI & CORONEL XAVIER CHAVES & 0 & 0 \\
\hline SÃO JOÃO DEL REI & DORES DE CAMPOS & 0 & 0 \\
\hline SÃO JOÃO DEL REI & IBITURUNA & 1 & 0 \\
\hline SÃO JOÃO DEL REI & IJACI & 0 & 0 \\
\hline SÃO JOÃO DEL REI & INGAI & 0 & 0 \\
\hline SÃO JOÃO DEL REI & ITUMIRIM & 0 & 0 \\
\hline SÃO JOÃO DEL REI & ITUTINGA & 0 & 0 \\
\hline SÃO JOÃO DEL REI & LAGOA DOURADA & 0 & 0 \\
\hline SÃO JOÃO DEL REI & NAZARENO & 0 & 0 \\
\hline SÃO JOÃO DEL REI & PRADOS & 0 & 0 \\
\hline SÃO JOÃO DEL REI & RESENDE COSTA & 0 & 0 \\
\hline SÃO JOÃO DEL REI & RITAPOLIS & 2 & 0 \\
\hline SÃO JOÃO DEL REI & SANTA CRUZ DE MINAS & 0 & 0 \\
\hline SÃO JOÃO DEL REI & SAO JOAO DEL REI & 2 & 0 \\
\hline SÃO JOÃO DEL REI & SAO TIAGO & 0 & 0 \\
\hline SÃO JOÃO DEL REI & TIRADENTES & 0 & 0 \\
\hline SÃO SEBASTIÃO DO PARAÍSO & ARCEBURGO & 0 & 0 \\
\hline SÃO SEBASTIÃO DO PARAÍSO & CAPETINGA & 0 & 0 \\
\hline SÃO SEBASTIÃO DO PARAÍSO & CASSIA & 0 & 0 \\
\hline SÃO SEBASTIÃO DO PARAÍSO & CLARAVAL & 0 & 0 \\
\hline SÃO SEBASTIÃO DO PARAÍSO & GUARANESIA & 0 & 0 \\
\hline SÃO SEBASTIÃO DO PARAÍSO & GUAXUPE & 1 & 0 \\
\hline SÃO SEBASTIÃO DO PARAÍSO & IBIRACI & 0 & 0 \\
\hline SÃO SEBASTIÃO DO PARAÍSO & ITAMOGI & 1 & 0 \\
\hline SÃO SEBASTIÃO DO PARAÍSO & ITAU DE MINAS & 0 & 0 \\
\hline SÃO SEBASTIÃO DO PARAÍSO & JACUI & 0 & 0 \\
\hline SÃO SEBASTIÃO DO PARAÍSO & JURUAIA & 0 & 0 \\
\hline SÃO SEBASTIÃO DO PARAÍSO & MONTE SANTO DE MINAS & 0 & 0 \\
\hline SÃO SEBASTIÃO DO PARAÍSO & PRATAPOLIS & 1 & 0 \\
\hline SÃO SEBASTIÃO DO PARAÍSO & SAO PEDRO DA UNIAO & 0 & 0 \\
\hline SÃO SEBASTIÃO DO PARAÍSO & SAO SEBASTIAO DO PARAISO & 0 & 0 \\
\hline SÃO SEBASTIÃO DO PARAÍSO & SAO TOMAS DE AQUINO & 0 & 0 \\
\hline SETE LAGOAS & ARACAI & 0 & 0 \\
\hline SETE LAGOAS & BALDIM & 0 & 0 \\
\hline SETE LAGOAS & CACHOEIRA DA PRATA & 0 & 0 \\
\hline SETE LAGOAS & CAETANOPOLIS & 0 & 0 \\
\hline SETE LAGOAS & CAPIM BRANCO & 0 & 0 \\
\hline SETE LAGOAS & CORDISBURGO & 0 & 0 \\
\hline SETE LAGOAS & FORTUNA DE MINAS & 0 & 0 \\
\hline
\end{tabular}




\begin{tabular}{|c|c|c|c|}
\hline SETE LAGOAS & FUNILANDIA & 0 & 0 \\
\hline SETE LAGOAS & INHAUMA & 2 & 0 \\
\hline SETE LAGOAS & JEQUITIBA & 0 & 0 \\
\hline SETE LAGOAS & MARAVILHAS & 0 & 0 \\
\hline SETE LAGOAS & MATOZINHOS & 0 & 0 \\
\hline SETE LAGOAS & PAPAGAIOS & 1 & 0 \\
\hline SETE LAGOAS & PARAOPEBA & 0 & 0 \\
\hline SETE LAGOAS & POMPEU & 0 & 0 \\
\hline SETE LAGOAS & PRUDENTE DE MORAIS & 1 & 0 \\
\hline SETE LAGOAS & SANTANA DE PIRAPAMA & 0 & 0 \\
\hline SETE LAGOAS & SETE LAGOAS & 1 & 0 \\
\hline TEOFILO OTONI & AGUAS FORMOSAS & 1 & 0 \\
\hline TEOFILO OTONI & ATALEIA & 0 & 0 \\
\hline TEOFILO OTONI & BERTOPOLIS & 0 & 0 \\
\hline TEOFILO OTONI & CAMPANARIO & 0 & 0 \\
\hline TEOFILO OTONI & CARAI & 0 & 0 \\
\hline TEOFILO OTONI & CARLOS CHAGAS & 1 & 0 \\
\hline TEOFILO OTONI & CATUJI & 0 & 0 \\
\hline TEOFILO OTONI & CRISOLITA & 0 & 0 \\
\hline TEOFILO OTONI & FRANCISCOPOLIS & 0 & 0 \\
\hline TEOFILO OTONI & FREI GASPAR & 0 & 0 \\
\hline TEOFILO OTONI & FRONTEIRA DOS VALES & 0 & 0 \\
\hline TEOFILO OTONI & ITAIPE & 1 & 0 \\
\hline TEOFILO OTONI & ITAMBACURI & 0 & 0 \\
\hline TEOFILO OTONI & JAMPRUCA & 0 & 0 \\
\hline TEOFILO OTONI & LADAINHA & 0 & 0 \\
\hline TEOFILO OTONI & MACHACALIS & 0 & 0 \\
\hline TEOFILO OTONI & MALACACHETA & 3 & 0 \\
\hline TEOFILO OTONI & NANUQUE & 0 & 0 \\
\hline TEOFILO OTONI & NOVO CRUZEIRO & 0 & 0 \\
\hline TEOFILO OTONI & NOVO ORIENTE DE MINAS & 0 & 0 \\
\hline TEOFILO OTONI & OURO VERDE DE MINAS & 1 & 0 \\
\hline TEOFILO OTONI & PADRE PARAISO & 2 & 0 \\
\hline TEOFILO OTONI & PAVAO & 0 & 0 \\
\hline TEOFILO OTONI & PESCADOR & 0 & 0 \\
\hline TEOFILO OTONI & PONTO DOS VOLANTES & 0 & 0 \\
\hline TEOFILO OTONI & POTE & 1 & 0 \\
\hline TEOFILO OTONI & SANTA HELENA DE MINAS & 0 & 0 \\
\hline TEOFILO OTONI & SERRA DOS AIMORES & 0 & 0 \\
\hline TEOFILO OTONI & SETUBINHA & 0 & 0 \\
\hline TEOFILO OTONI & TEOFILO OTONI & 3 & 0 \\
\hline TEOFILO OTONI & UMBURATIBA & 0 & 0 \\
\hline UBÁ & ASTOLFO DUTRA & 0 & 0 \\
\hline UBÁ & BRAS PIRES & 0 & 0 \\
\hline UBÁ & COIMBRA & 0 & 0 \\
\hline
\end{tabular}




\begin{tabular}{|c|c|c|c|}
\hline UBÁ & DIVINESIA & 0 & 0 \\
\hline UBÁ & DONA EUZEBIA & 0 & 0 \\
\hline UBÁ & DORES DO TURVO & 0 & 0 \\
\hline UBÁ & ERVALIA & 0 & 0 \\
\hline UBÁ & GUARANI & 0 & 0 \\
\hline UBÁ & GUIDOVAL & 0 & 0 \\
\hline UBÁ & GUIRICEMA & 0 & 0 \\
\hline UBÁ & PAULA CANDIDO & 0 & 0 \\
\hline UBÁ & PIRAUBA & 0 & 0 \\
\hline UBÁ & PRESIDENTE BERNARDES & 0 & 0 \\
\hline UBÁ & RIO POMBA & 0 & 0 \\
\hline UBÁ & RODEIRO & 1 & 0 \\
\hline UBÁ & SAO GERALDO & 0 & 0 \\
\hline UBÁ & SENADOR FIRMINO & 0 & 0 \\
\hline UBÁ & SILVEIRANIA & 0 & 0 \\
\hline UBÁ & TABULEIRO & 0 & 0 \\
\hline UBÁ & TOCANTINS & 0 & 0 \\
\hline UBÁ & UBA & 3 & 0 \\
\hline UBÁ & VISCONDE DO RIO BRANCO & 0 & 0 \\
\hline UBERABA & AGUA COMPRIDA & 0 & 0 \\
\hline UBERABA & ARAXA & 2 & 0 \\
\hline UBERABA & CAMPO FLORIDO & 0 & 0 \\
\hline UBERABA & CAMPOS ALTOS & 1 & 0 \\
\hline UBERABA & CARNEIRINHO & 0 & 0 \\
\hline UBERABA & COMENDADOR GOMES & 0 & 0 \\
\hline UBERABA & CONCEICAO DAS ALAGOAS & 0 & 0 \\
\hline UBERABA & CONQUISTA & 0 & 0 \\
\hline UBERABA & DELTA & 1 & 0 \\
\hline UBERABA & FRONTEIRA & 1 & 0 \\
\hline UBERABA & FRUTAL & 1 & 0 \\
\hline UBERABA & ITAPAGIPE & 1 & 0 \\
\hline UBERABA & ITURAMA & 3 & 0 \\
\hline UBERABA & LIMEIRA DO OESTE & 2 & 0 \\
\hline UBERABA & PEDRINOPOLIS & 0 & 0 \\
\hline UBERABA & PIRAJUBA & 0 & 0 \\
\hline UBERABA & PLANURA & 0 & 0 \\
\hline UBERABA & PRATINHA & 0 & 0 \\
\hline UBERABA & SACRAMENTO & 2 & 0 \\
\hline UBERABA & SANTA JULIANA & 0 & 0 \\
\hline UBERABA & SAO FRANCISCO DE SALES & 0 & 0 \\
\hline UBERABA & TAPIRA & 0 & 0 \\
\hline UBERABA & UBERABA & 2 & 0 \\
\hline UBERABA & UNIAO DE MINAS & 0 & 0 \\
\hline UBERABA & VERISSIMO & 0 & 0 \\
\hline UBERLANDIA & ARAGUARI & 0 & 0 \\
\hline
\end{tabular}




\begin{tabular}{|c|c|c|c|}
\hline UBERLANDIA & ARAPORA & 0 & 0 \\
\hline UBERLANDIA & CAMPINA VERDE & 0 & 0 \\
\hline UBERLANDIA & INDIANOPOLIS & 0 & 0 \\
\hline UBERLANDIA & MONTE ALEGRE DE MINAS & 0 & 0 \\
\hline UBERLANDIA & NOVA PONTE & 0 & 0 \\
\hline UBERLANDIA & PRATA & 0 & 0 \\
\hline UBERLANDIA & TUPACIGUARA & 2 & 0 \\
\hline UBERLANDIA & UBERLANDIA & 20 & 5 \\
\hline UNAI & ARINOS & 0 & 0 \\
\hline UNAI & BONFINOPOLIS DE MINAS & 0 & 0 \\
\hline UNAI & BURITIS & 1 & 0 \\
\hline UNAI & CABECEIRA GRANDE & 1 & 0 \\
\hline UNAI & DOM BOSCO & 0 & 0 \\
\hline UNAI & FORMOSO & 0 & 0 \\
\hline UNAI & NATALANDIA & 0 & 0 \\
\hline UNAI & RIACHINHO & 0 & 0 \\
\hline UNAI & UNAI & 3 & 0 \\
\hline UNAI & URUANA DE MINAS & 1 & 0 \\
\hline VARGINHA & ALFENAS & 0 & 0 \\
\hline VARGINHA & BOA ESPERANCA & 0 & 0 \\
\hline VARGINHA & CAMBUQUIRA & 0 & 0 \\
\hline VARGINHA & CAMPANHA & 0 & 0 \\
\hline VARGINHA & CAMPO DO MEIO & 0 & 0 \\
\hline VARGINHA & CAMPOS GERAIS & 0 & 0 \\
\hline VARGINHA & CARMO DA CACHOEIRA & 1 & 0 \\
\hline VARGINHA & CARVALHOPOLIS & 0 & 0 \\
\hline VARGINHA & COQUEIRAL & 0 & 0 \\
\hline VARGINHA & CORDISLANDIA & 0 & 0 \\
\hline VARGINHA & ELOI MENDES & 0 & 0 \\
\hline VARGINHA & FAMA & 0 & 0 \\
\hline VARGINHA & GUAPE & 0 & 0 \\
\hline VARGINHA & ILICINEA & 0 & 0 \\
\hline VARGINHA & LAMBARI & 0 & 0 \\
\hline VARGINHA & LUMINARIAS & 0 & 0 \\
\hline VARGINHA & MACHADO & 1 & 0 \\
\hline VARGINHA & MONSENHOR PAULO & 0 & 0 \\
\hline VARGINHA & NEPOMUCENO & 0 & 0 \\
\hline VARGINHA & PARAGUACU & 0 & 0 \\
\hline VARGINHA & POCO FUNDO & 0 & 0 \\
\hline VARGINHA & SANTANA DA VARGEM & 0 & 0 \\
\hline VARGINHA & SAO BENTO ABADE & 0 & 0 \\
\hline VARGINHA & SAO GONCALO DO SAPUCAI & 0 & 0 \\
\hline VARGINHA & TRES CORACOES & 4 & 0 \\
\hline VARGINHA & TRES PONTAS & 0 & 0 \\
\hline VARGINHA & TURVOLANDIA & 0 & 0 \\
\hline
\end{tabular}




\begin{tabular}{|l|l|c|c|} 
VARGINHA & VARGINHA & 2 & 0 \\
\hline Total geral & & $\mathbf{4 3 2}$ & $\mathbf{4 3}$ \\
\hline
\end{tabular}

\section{CARGO: PROFESSOR DE EDUCAÇÃO BÁSICA - PEB - BIOLOGIA / CIÊNCIAS}

\begin{tabular}{|c|c|c|c|}
\hline S R E & MUNICIPIO & $\begin{array}{l}\text { TOTAL DE } \\
\text { VAGAS }\end{array}$ & $\begin{array}{c}\text { VAGAS } \\
\text { RESERVADAS - } \\
\text { PORTADORES DE } \\
\text { DEFICIÊNCIA }\end{array}$ \\
\hline ALMENARA & AGUAS VERMELHAS & 2 & 0 \\
\hline ALMENARA & ALMENARA & 0 & 0 \\
\hline ALMENARA & BANDEIRA & 0 & 0 \\
\hline ALMENARA & CACHOEIRA DE PAJEU & 1 & 0 \\
\hline ALMENARA & CURRAL DE DENTRO & 0 & 0 \\
\hline ALMENARA & DIVISA ALEGRE & 0 & 0 \\
\hline ALMENARA & DIVISOPOLIS & 0 & 0 \\
\hline ALMENARA & FELISBURGO & 0 & 0 \\
\hline ALMENARA & JACINTO & 0 & 0 \\
\hline ALMENARA & JEQUITINHONHA & 1 & 0 \\
\hline ALMENARA & JOAIMA & 0 & 0 \\
\hline ALMENARA & JORDANIA & 1 & 0 \\
\hline ALMENARA & MATA VERDE & 0 & 0 \\
\hline ALMENARA & MONTE FORMOSO & 0 & 0 \\
\hline ALMENARA & PALMOPOLIS & 0 & 0 \\
\hline ALMENARA & PEDRA AZUL & 1 & 0 \\
\hline ALMENARA & RIO DO PRADO & 0 & 0 \\
\hline ALMENARA & RUBIM & 0 & 0 \\
\hline ALMENARA & SALTO DA DIVISA & 2 & 0 \\
\hline ALMENARA & SANTA MARIA DO SALTO & 0 & 0 \\
\hline ALMENARA & SANTO ANTONIO DO JACINTO & 1 & 0 \\
\hline ARACUAI & ARACUAI & 1 & 0 \\
\hline ARACUAI & BERILO & 1 & 0 \\
\hline ARACUAI & BERIZAL & 0 & 0 \\
\hline ARACUAI & CHAPADA DO NORTE & 1 & 0 \\
\hline ARACUAI & COMERCINHO & 0 & 0 \\
\hline ARACUAI & CORONEL MURTA & 0 & 0 \\
\hline ARACUAI & FRANCISCO BADARO & 1 & 0 \\
\hline ARACUAI & FRUTA DE LEITE & 0 & 0 \\
\hline ARACUAI & INDAIABIRA & 1 & 0 \\
\hline ARACUAI & ITAOBIM & 0 & 0 \\
\hline ARACUAI & ITINGA & 1 & 0 \\
\hline ARACUAI & JENIPAPO DE MINAS & 2 & 0 \\
\hline ARACUAI & JOSE GONCALVES DE MINAS & 0 & 0 \\
\hline ARACUAI & MEDINA & 3 & 0 \\
\hline ARACUAI & NINHEIRA & 2 & 0 \\
\hline
\end{tabular}




\begin{tabular}{|c|c|c|c|}
\hline ARACUAI & NOVORIZONTE & 0 & 0 \\
\hline ARACUAI & RUBELITA & 0 & 0 \\
\hline ARACUAI & SALINAS & 5 & 1 \\
\hline ARACUAI & SANTA CRUZ DE SALINAS & 1 & 0 \\
\hline ARACUAI & TAIOBEIRAS & 2 & 0 \\
\hline ARACUAI & VIRGEM DA LAPA & 1 & 0 \\
\hline BARBACENA & ALFREDO VASCONCELOS & 2 & 0 \\
\hline BARBACENA & ALTO RIO DOCE & 0 & 0 \\
\hline BARBACENA & ANDRELANDIA & 0 & 0 \\
\hline BARBACENA & ANTONIO CARLOS & 1 & 0 \\
\hline BARBACENA & ARACITABA & 0 & 0 \\
\hline BARBACENA & BARBACENA & 3 & 0 \\
\hline BARBACENA & BARROSO & 0 & 0 \\
\hline BARBACENA & BIAS FORTES & 0 & 0 \\
\hline BARBACENA & CAPELA NOVA & 2 & 0 \\
\hline BARBACENA & CARANDAI & 1 & 0 \\
\hline BARBACENA & CIPOTANEA & 0 & 0 \\
\hline BARBACENA & DESTERRO DO MELO & 0 & 0 \\
\hline BARBACENA & IBERTIOGA & 1 & 0 \\
\hline BARBACENA & MADRE DE DEUS DE MINAS & 0 & 0 \\
\hline BARBACENA & MERCES & 0 & 0 \\
\hline BARBACENA & OLIVEIRA FORTES & 1 & 0 \\
\hline BARBACENA & PAIVA & 1 & 0 \\
\hline BARBACENA & PIEDADE DO RIO GRANDE & 0 & 0 \\
\hline BARBACENA & RESSAQUINHA & 0 & 0 \\
\hline BARBACENA & SANTA BARBARA DO TUGURIO & 0 & 0 \\
\hline BARBACENA & SANTA RITA DO IBITIPOCA & 0 & 0 \\
\hline BARBACENA & SANTANA DO GARAMBEU & 0 & 0 \\
\hline BARBACENA & SAO VICENTE DE MINAS & 0 & 0 \\
\hline BARBACENA & SENHORA DOS REMEDIOS & 0 & 0 \\
\hline CAMPO BELO & AGUANIL & 0 & 0 \\
\hline CAMPO BELO & CAMACHO & 0 & 0 \\
\hline CAMPO BELO & CAMPO BELO & 1 & 0 \\
\hline CAMPO BELO & CANA VERDE & 0 & 0 \\
\hline CAMPO BELO & CANDEIAS & 1 & 0 \\
\hline CAMPO BELO & CRISTAIS & 1 & 0 \\
\hline CAMPO BELO & LAVRAS & 2 & 0 \\
\hline CAMPO BELO & PERDOES & 1 & 0 \\
\hline CAMPO BELO & RIBEIRAO VERMELHO & 0 & 0 \\
\hline CAMPO BELO & SANTANA DO JACARE & 0 & 0 \\
\hline CAMPO BELO & SANTO ANTONIO DO AMPARO & 0 & 0 \\
\hline CAMPO BELO & SAO FRANCISCO DE PAULA & 0 & 0 \\
\hline CARANGOLA & ALTO CAPARAO & 2 & 0 \\
\hline CARANGOLA & CAIANA & 1 & 0 \\
\hline CARANGOLA & CAPARAO & 0 & 0 \\
\hline
\end{tabular}




\begin{tabular}{|c|c|c|c|}
\hline CARANGOLA & CARANGOLA & 1 & 0 \\
\hline CARANGOLA & DIVINO & 1 & 0 \\
\hline CARANGOLA & ESPERA FELIZ & 0 & 0 \\
\hline CARANGOLA & FARIA LEMOS & 0 & 0 \\
\hline CARANGOLA & FERVEDOURO & 2 & 0 \\
\hline CARANGOLA & ORIZANIA & 0 & 0 \\
\hline CARANGOLA & PEDRA DOURADA & 1 & 0 \\
\hline CARANGOLA & TOMBOS & 2 & 0 \\
\hline CARATINGA & ALVARENGA & 1 & 0 \\
\hline CARATINGA & BOM JESUS DO GALHO & 0 & 0 \\
\hline CARATINGA & BUGRE & 1 & 0 \\
\hline CARATINGA & CARATINGA & 6 & 2 \\
\hline CARATINGA & CORREGO NOVO & 2 & 0 \\
\hline CARATINGA & DOM CAVATI & 0 & 0 \\
\hline CARATINGA & ENTRE FOLHAS & 1 & 0 \\
\hline CARATINGA & IAPU & 0 & 0 \\
\hline CARATINGA & IMBE DE MINAS & 1 & 0 \\
\hline CARATINGA & INHAPIM & 4 & 0 \\
\hline CARATINGA & IPABA & 1 & 0 \\
\hline CARATINGA & IPANEMA & 1 & 0 \\
\hline CARATINGA & PIEDADE DE CARATINGA & 2 & 0 \\
\hline CARATINGA & PINGO D AGUA & 0 & 0 \\
\hline CARATINGA & POCRANE & 0 & 0 \\
\hline CARATINGA & SANTA BARBARA DO LESTE & 1 & 0 \\
\hline CARATINGA & SANTA RITA DE MINAS & 0 & 0 \\
\hline CARATINGA & SAO DOMINGOS DAS DORES & 0 & 0 \\
\hline CARATINGA & SAO JOAO DO ORIENTE & 2 & 0 \\
\hline CARATINGA & SAO SEBASTIAO DO ANTA & 1 & 0 \\
\hline CARATINGA & TAPARUBA & 0 & 0 \\
\hline CARATINGA & TARUMIRIM & 7 & 2 \\
\hline CARATINGA & UBAPORANGA & 2 & 0 \\
\hline CARATINGA & VARGEM ALEGRE & 0 & 0 \\
\hline CAXAMBU & AIURUOCA & 0 & 0 \\
\hline CAXAMBU & ALAGOA & 0 & 0 \\
\hline CAXAMBU & BAEPENDI & 0 & 0 \\
\hline CAXAMBU & BOCAINA DE MINAS & 0 & 0 \\
\hline CAXAMBU & CARVALHOS & 0 & 0 \\
\hline CAXAMBU & CAXAMBU & 0 & 0 \\
\hline CAXAMBU & CONCEICAO DO RIO VERDE & 0 & 0 \\
\hline CAXAMBU & CRUZILIA & 0 & 0 \\
\hline CAXAMBU & ITAMONTE & 0 & 0 \\
\hline CAXAMBU & ITANHANDU & 1 & 0 \\
\hline CAXAMBU & JESUANIA & 0 & 0 \\
\hline CAXAMBU & LIBERDADE & 0 & 0 \\
\hline CAXAMBU & MINDURI & 1 & 0 \\
\hline
\end{tabular}




\begin{tabular}{|c|c|c|c|}
\hline CAXAMBU & OLIMPIO NORONHA & 0 & 0 \\
\hline CAXAMBU & PASSA QUATRO & 2 & 0 \\
\hline CAXAMBU & PASSA VINTE & 0 & 0 \\
\hline CAXAMBU & POUSO ALTO & 0 & 0 \\
\hline CAXAMBU & SAO LOURENCO & 1 & 0 \\
\hline CAXAMBU & SAO SEBASTIAO DO RIO VERDE & 1 & 0 \\
\hline CAXAMBU & SAO TOME DAS LETRAS & 0 & 0 \\
\hline CAXAMBU & SERITINGA & 0 & 0 \\
\hline CAXAMBU & SERRANOS & 1 & 0 \\
\hline CAXAMBU & SOLEDADE DE MINAS & 0 & 0 \\
\hline CORONEL FABRICIANO & ANTONIO DIAS & 1 & 0 \\
\hline CORONEL FABRICIANO & BELO ORIENTE & 1 & 0 \\
\hline CORONEL FABRICIANO & BRAUNAS & 1 & 0 \\
\hline CORONEL FABRICIANO & CORONEL FABRICIANO & 2 & 0 \\
\hline CORONEL FABRICIANO & IPATINGA & 14 & 3 \\
\hline CORONEL FABRICIANO & JAGUARAÇU & 0 & 0 \\
\hline CORONEL FABRICIANO & JOANESIA & 0 & 0 \\
\hline CORONEL FABRICIANO & MARLIERIA & 0 & 0 \\
\hline CORONEL FABRICIANO & MESQUITA & 1 & 0 \\
\hline CORONEL FABRICIANO & SANTANA DO PARAISO & 0 & 0 \\
\hline CORONEL FABRICIANO & TIMOTEO & 1 & 0 \\
\hline CONSELHEIRO LAFAIETE & CARANAIBA & 0 & 0 \\
\hline CONSELHEIRO LAFAIETE & CASA GRANDE & 0 & 0 \\
\hline CONSELHEIRO LAFAIETE & CATAS ALTAS DA NORUEGA & 0 & 0 \\
\hline CONSELHEIRO LAFAIETE & CONGONHAS & 1 & 0 \\
\hline CONSELHEIRO LAFAIETE & CONSELHEIRO LAFAIETE & 4 & 0 \\
\hline CONSELHEIRO LAFAIETE & CRISTIANO OTONI & 0 & 0 \\
\hline CONSELHEIRO LAFAIETE & DESTERRO DE ENTRE RIOS & 1 & 0 \\
\hline CONSELHEIRO LAFAIETE & ENTRE RIOS DE MINAS & 0 & 0 \\
\hline CONSELHEIRO LAFAIETE & ITAVERAVA & 3 & 0 \\
\hline CONSELHEIRO LAFAIETE & JECEABA & 0 & 0 \\
\hline CONSELHEIRO LAFAIETE & LAMIM & 2 & 0 \\
\hline CONSELHEIRO LAFAIETE & OURO BRANCO & 0 & 0 \\
\hline CONSELHEIRO LAFAIETE & PIRANGA & 3 & 0 \\
\hline CONSELHEIRO LAFAIETE & QUELUZITO & 0 & 0 \\
\hline CONSELHEIRO LAFAIETE & RIO ESPERA & 0 & 0 \\
\hline CONSELHEIRO LAFAIETE & SANTANA DOS MONTES & 0 & 0 \\
\hline CONSELHEIRO LAFAIETE & SAO BRAS DO SUACUI & 0 & 0 \\
\hline CONSELHEIRO LAFAIETE & SENHORA DE OLIVEIRA & 1 & 0 \\
\hline CURVELO & AUGUSTO DE LIMA & 0 & 0 \\
\hline CURVELO & BUENOPOLIS & 0 & 0 \\
\hline CURVELO & CORINTO & 1 & 0 \\
\hline CURVELO & CURVELO & 6 & 2 \\
\hline CURVELO & FELIXLANDIA & 0 & 0 \\
\hline CURVELO & INIMUTABA & 1 & 0 \\
\hline
\end{tabular}




\begin{tabular}{|c|c|c|c|}
\hline CURVELO & JOAQUIM FELICIO & 0 & 0 \\
\hline CURVELO & LASSANCE & 1 & 0 \\
\hline CURVELO & MORRO DA GARCA & 0 & 0 \\
\hline CURVELO & PRESIDENTE JUSCELINO & 0 & 0 \\
\hline CURVELO & SANTO HIPOLITO & 2 & 0 \\
\hline CURVELO & TRES MARIAS & 2 & 0 \\
\hline DIAMANTINA & ALVORADA DE MINAS & 1 & 0 \\
\hline DIAMANTINA & ANGELANDIA & 0 & 0 \\
\hline DIAMANTINA & ARICANDUVA & 2 & 0 \\
\hline DIAMANTINA & CAPELINHA & 6 & 2 \\
\hline DIAMANTINA & CARBONITA & 0 & 0 \\
\hline DIAMANTINA & CONCEICAO DO MATO DENTRO & 2 & 0 \\
\hline DIAMANTINA & CONGONHAS DO NORTE & 1 & 0 \\
\hline DIAMANTINA & COUTO DE MAGALHAES DE MINAS & 0 & 0 \\
\hline DIAMANTINA & DATAS & 1 & 0 \\
\hline DIAMANTINA & DIAMANTINA & 1 & 0 \\
\hline DIAMANTINA & FELICIO DOS SANTOS & 0 & 0 \\
\hline DIAMANTINA & GOUVEA & 3 & 0 \\
\hline DIAMANTINA & ITAMARANDIBA & 2 & 0 \\
\hline DIAMANTINA & LEME DO PRADO & 2 & 0 \\
\hline DIAMANTINA & MINAS NOVAS & 3 & 0 \\
\hline DIAMANTINA & MONJOLOS & 0 & 0 \\
\hline DIAMANTINA & PRESIDENTE KUBITSCHEK & 0 & 0 \\
\hline DIAMANTINA & RIO VERMELHO & 3 & 0 \\
\hline DIAMANTINA & SANTO ANTONIO DO ITAMBE & 2 & 0 \\
\hline DIAMANTINA & SAO GONCALO DO RIO PRETO & 1 & 0 \\
\hline DIAMANTINA & SENADOR MODESTINO GONCALVES & 0 & 0 \\
\hline DIAMANTINA & SERRA AZUL DE MINAS & 0 & 0 \\
\hline DIAMANTINA & SERRO & 2 & 0 \\
\hline DIAMANTINA & TURMALINA & 4 & 0 \\
\hline DIAMANTINA & VEREDINHA & 0 & 0 \\
\hline DIVINÓPOLIS & ARAUJOS & 0 & 0 \\
\hline DIVINÓPOLIS & ARCOS & 0 & 0 \\
\hline DIVINÓPOLIS & BAMBUI & 0 & 0 \\
\hline DIVINÓPOLIS & CARMO DA MATA & 0 & 0 \\
\hline DIVINÓPOLIS & CARMO DO CAJURU & 1 & 0 \\
\hline DIVINÓPOLIS & CARMOPOLIS DE MINAS & 0 & 0 \\
\hline DIVINÓPOLIS & CLAUDIO & 1 & 0 \\
\hline DIVINÓPOLIS & CORREGO DANTA & 0 & 0 \\
\hline DIVINÓPOLIS & DIVINOPOLIS & 15 & 4 \\
\hline DIVINÓPOLIS & IGUATAMA & 0 & 0 \\
\hline DIVINÓPOLIS & ITAGUARA & 2 & 0 \\
\hline DIVINÓPOLIS & ITAPECERICA & 0 & 0 \\
\hline DIVINÓPOLIS & ITATIAIUCU & 0 & 0 \\
\hline DIVINÓPOLIS & ITAUNA & 8 & 2 \\
\hline
\end{tabular}




\begin{tabular}{|c|c|c|c|}
\hline DIVINÓPOLIS & JAPARAIBA & 0 & 0 \\
\hline DIVINÓPOLIS & LAGOA DA PRATA & 0 & 0 \\
\hline DIVINÓPOLIS & LUZ & 0 & 0 \\
\hline DIVINÓPOLIS & MEDEIROS & 0 & 0 \\
\hline DIVINÓPOLIS & MOEMA & 0 & 0 \\
\hline DIVINÓPOLIS & NOVA SERRANA & 5 & 1 \\
\hline DIVINÓPOLIS & OLIVEIRA & 0 & 0 \\
\hline DIVINÓPOLIS & PAINS & 1 & 0 \\
\hline DIVINÓPOLIS & PASSA TEMPO & 0 & 0 \\
\hline DIVINÓPOLIS & PEDRA DO INDAIA & 0 & 0 \\
\hline DIVINÓPOLIS & PERDIGAO & 0 & 0 \\
\hline DIVINÓPOLIS & PIRACEMA & 0 & 0 \\
\hline DIVINÓPOLIS & SANTO ANTONIO DO MONTE & 0 & 0 \\
\hline DIVINÓPOLIS & SAO GONCALO DO PARA & 2 & 0 \\
\hline DIVINÓPOLIS & SAO SEBASTIAO DO OESTE & 0 & 0 \\
\hline DIVINÓPOLIS & TAPIRAI & 0 & 0 \\
\hline GOVERNADOR VALADARES & ACUCENA & 1 & 0 \\
\hline GOVERNADOR VALADARES & AIMORES & 3 & 0 \\
\hline GOVERNADOR VALADARES & ALPERCATA & 0 & 0 \\
\hline GOVERNADOR VALADARES & CAPITAO ANDRADE & 0 & 0 \\
\hline GOVERNADOR VALADARES & CENTRAL DE MINAS & 1 & 0 \\
\hline GOVERNADOR VALADARES & CONSELHEIRO PENA & 1 & 0 \\
\hline GOVERNADOR VALADARES & COROACI & 2 & 0 \\
\hline GOVERNADOR VALADARES & CUPARAQUE & 2 & 0 \\
\hline GOVERNADOR VALADARES & DIVINO DAS LARANJEIRAS & 0 & 0 \\
\hline GOVERNADOR VALADARES & ENGENHEIRO CALDAS & 2 & 0 \\
\hline GOVERNADOR VALADARES & FERNANDES TOURINHO & 0 & 0 \\
\hline GOVERNADOR VALADARES & FREI INOCENCIO & 0 & 0 \\
\hline GOVERNADOR VALADARES & GALILEIA & 2 & 0 \\
\hline GOVERNADOR VALADARES & GOIABEIRA & 0 & 0 \\
\hline GOVERNADOR VALADARES & GOVERNADOR VALADARES & 15 & 4 \\
\hline GOVERNADOR VALADARES & ITABIRINHA & 0 & 0 \\
\hline GOVERNADOR VALADARES & ITANHOMI & 5 & 1 \\
\hline GOVERNADOR VALADARES & ITUETA & 1 & 0 \\
\hline GOVERNADOR VALADARES & MANTENA & 3 & 0 \\
\hline GOVERNADOR VALADARES & MARILAC & 0 & 0 \\
\hline GOVERNADOR VALADARES & MATHIAS LOBATO & 2 & 0 \\
\hline GOVERNADOR VALADARES & MENDES PIMENTEL & 0 & 0 \\
\hline GOVERNADOR VALADARES & NACIP RAYDAN & 1 & 0 \\
\hline GOVERNADOR VALADARES & NAQUE & 1 & 0 \\
\hline GOVERNADOR VALADARES & NOVA BELEM & 1 & 0 \\
\hline GOVERNADOR VALADARES & NOVA MODICA & 0 & 0 \\
\hline GOVERNADOR VALADARES & PERIQUITO & 0 & 0 \\
\hline GOVERNADOR VALADARES & RESPLENDOR & 0 & 0 \\
\hline GOVERNADOR VALADARES & SANTA EFIGENIA DE MINAS & 0 & 0 \\
\hline
\end{tabular}




\begin{tabular}{|c|c|c|c|}
\hline GOVERNADOR VALADARES & SANTA RITA DO ITUETO & 0 & 0 \\
\hline GOVERNADOR VALADARES & SAO FELIX DE MINAS & 0 & 0 \\
\hline GOVERNADOR VALADARES & SAO GERALDO DA PIEDADE & 0 & 0 \\
\hline GOVERNADOR VALADARES & SAO GERALDO DO BAIXIO & 0 & 0 \\
\hline GOVERNADOR VALADARES & SAO JOAO DO MANTENINHA & 3 & 0 \\
\hline GOVERNADOR VALADARES & SAO JOSE DA SAFIRA & 1 & 0 \\
\hline GOVERNADOR VALADARES & SAO JOSE DO DIVINO & 0 & 0 \\
\hline GOVERNADOR VALADARES & SARDOA & 0 & 0 \\
\hline GOVERNADOR VALADARES & SOBRALIA & 0 & 0 \\
\hline GOVERNADOR VALADARES & TUMIRITINGA & 0 & 0 \\
\hline GOVERNADOR VALADARES & VIRGOLANDIA & 0 & 0 \\
\hline GUANHÃES & AGUA BOA & 4 & 0 \\
\hline GUANHÃES & CANTAGALO & 0 & 0 \\
\hline GUANHÃES & CARMESIA & 1 & 0 \\
\hline GUANHÃES & COLUNA & 0 & 0 \\
\hline GUANHÃES & DIVINOLANDIA DE MINAS & 0 & 0 \\
\hline GUANHÃES & DOM JOAQUIM & 2 & 0 \\
\hline GUANHÃES & DORES DE GUANHAES & 1 & 0 \\
\hline GUANHÃES & FREI LAGONEGRO & 0 & 0 \\
\hline GUANHÃES & GONZAGA & 1 & 0 \\
\hline GUANHÃES & GUANHAES & 5 & 1 \\
\hline GUANHÃES & JOSE RAYDAN & 0 & 0 \\
\hline GUANHÃES & MATERLANDIA & 0 & 0 \\
\hline GUANHÃES & PAULISTAS & 1 & 0 \\
\hline GUANHÃES & PECANHA & 1 & 0 \\
\hline GUANHÃES & SABINOPOLIS & 3 & 0 \\
\hline GUANHÃES & SANTA MARIA DO SUACUI & 0 & 0 \\
\hline GUANHÃES & SAO JOAO EVANGELISTA & 2 & 0 \\
\hline GUANHÃES & SAO JOSE DO JACURI & 2 & 0 \\
\hline GUANHÃES & SAO PEDRO DO SUACUI & 0 & 0 \\
\hline GUANHÃES & SAO SEBASTIAO DO MARANHAO & 4 & 0 \\
\hline GUANHÃES & SENHORA DO PORTO & 1 & 0 \\
\hline GUANHÃES & VIRGINOPOLIS & 0 & 0 \\
\hline ITAJUBÁ & BRASOPOLIS & 0 & 0 \\
\hline ITAJUBÁ & CARMO DE MINAS & 1 & 0 \\
\hline ITAJUBÁ & CONCEICAO DAS PEDRAS & 2 & 0 \\
\hline ITAJUBÁ & CONCEICAO DOS OUROS & 2 & 0 \\
\hline ITAJUBÁ & CONSOLACAO & 0 & 0 \\
\hline ITAJUBÁ & CRISTINA & 0 & 0 \\
\hline ITAJUBÁ & DELFIM MOREIRA & 0 & 0 \\
\hline ITAJUBÁ & DOM VICOSO & 0 & 0 \\
\hline ITAJUBÁ & GONCALVES & 3 & 0 \\
\hline ITAJUBÁ & ITAJUBA & 0 & 0 \\
\hline ITAJUBÁ & MARIA DA FE & 0 & 0 \\
\hline ITAJUBÁ & MARMELOPOLIS & 0 & 0 \\
\hline
\end{tabular}




\begin{tabular}{|c|c|c|c|}
\hline ITAJUBÁ & NATERCIA & 3 & 0 \\
\hline ITAJUBÁ & PARAISOPOLIS & 0 & 0 \\
\hline ITAJUBÁ & PEDRALVA & 1 & 0 \\
\hline ITAJUBÁ & PIRANGUCU & 0 & 0 \\
\hline ITAJUBÁ & PIRANGUINHO & 0 & 0 \\
\hline ITAJUBÁ & SAO JOSE DO ALEGRE & 0 & 0 \\
\hline ITAJUBÁ & SAPUCAI-MIRIM & 0 & 0 \\
\hline ITAJUBÁ & VIRGINIA & 1 & 0 \\
\hline ITAJUBÁ & WENCESLAU BRAZ & 0 & 0 \\
\hline ITUIUTABA & CACHOEIRA DOURADA & 0 & 0 \\
\hline ITUIUTABA & CANAPOLIS & 0 & 0 \\
\hline ITUIUTABA & CAPINOPOLIS & 1 & 0 \\
\hline ITUIUTABA & CENTRALINA & 0 & 0 \\
\hline ITUIUTABA & GURINHATA & 0 & 0 \\
\hline ITUIUTABA & IPIACU & 2 & 0 \\
\hline ITUIUTABA & ITUIUTABA & 6 & 2 \\
\hline ITUIUTABA & SANTA VITORIA & 2 & 0 \\
\hline JANAUBA & CATUTI & 0 & 0 \\
\hline JANAUBA & ESPINOSA & 1 & 0 \\
\hline JANAUBA & GAMELEIRAS & 1 & 0 \\
\hline JANAUBA & JAIBA & 3 & 0 \\
\hline JANAUBA & JANAUBA & 7 & 2 \\
\hline JANAUBA & MAMONAS & 0 & 0 \\
\hline JANAUBA & MATO VERDE & 1 & 0 \\
\hline JANAUBA & MONTE AZUL & 0 & 0 \\
\hline JANAUBA & MONTEZUMA & 0 & 0 \\
\hline JANAUBA & NOVA PORTEIRINHA & 1 & 0 \\
\hline JANAUBA & PAI PEDRO & 1 & 0 \\
\hline JANAUBA & PORTEIRINHA & 6 & 2 \\
\hline JANAUBA & RIACHO DOS MACHADOS & 0 & 0 \\
\hline JANAUBA & RIO PARDO DE MINAS & 5 & 1 \\
\hline JANAUBA & SANTO ANTONIO DO RETIRO & 0 & 0 \\
\hline JANAUBA & SERRANOPOLIS DE MINAS & 0 & 0 \\
\hline JANAUBA & VERDELANDIA & 1 & 0 \\
\hline JANUARIA & BONITO DE MINAS & 3 & 0 \\
\hline JANUARIA & CHAPADA GAUCHA & 1 & 0 \\
\hline JANUARIA & CONEGO MARINHO & 1 & 0 \\
\hline JANUARIA & IBIRACATU & 1 & 0 \\
\hline JANUARIA & ICARAI DE MINAS & 1 & 0 \\
\hline JANUARIA & ITACARAMBI & 2 & 0 \\
\hline JANUARIA & JANUARIA & 5 & 1 \\
\hline JANUARIA & JUVENILIA & 0 & 0 \\
\hline JANUARIA & MANGA & 0 & 0 \\
\hline JANUARIA & MATIAS CARDOSO & 1 & 0 \\
\hline JANUARIA & MIRAVANIA & 0 & 0 \\
\hline
\end{tabular}




\begin{tabular}{|c|c|c|c|}
\hline JANUARIA & MONTALVANIA & 3 & 0 \\
\hline JANUARIA & PEDRAS DE MARIA DA CRUZ & 2 & 0 \\
\hline JANUARIA & PINTOPOLIS & 0 & 0 \\
\hline JANUARIA & SAO FRANCISCO & 8 & 2 \\
\hline JANUARIA & SAO JOAO DAS MISSOES & 1 & 0 \\
\hline JANUARIA & UBAI & 1 & 0 \\
\hline JANUARIA & URUCUIA & 0 & 0 \\
\hline JANUARIA & VARZELANDIA & 0 & 0 \\
\hline JUIZ DE FORA & ARANTINA & 0 & 0 \\
\hline JUIZ DE FORA & BELMIRO BRAGA & 0 & 0 \\
\hline JUIZ DE FORA & BICAS & 0 & 0 \\
\hline JUIZ DE FORA & BOM JARDIM DE MINAS & 1 & 0 \\
\hline JUIZ DE FORA & CHACARA & 1 & 0 \\
\hline JUIZ DE FORA & CHIADOR & 0 & 0 \\
\hline JUIZ DE FORA & CORONEL PACHECO & 0 & 0 \\
\hline JUIZ DE FORA & DESCOBERTO & 0 & 0 \\
\hline JUIZ DE FORA & EWBANK DA CAMARA & 1 & 0 \\
\hline JUIZ DE FORA & GOIANA & 0 & 0 \\
\hline JUIZ DE FORA & GUARARA & 0 & 0 \\
\hline JUIZ DE FORA & JUIZ DE FORA & 16 & 4 \\
\hline JUIZ DE FORA & LIMA DUARTE & 0 & 0 \\
\hline JUIZ DE FORA & MAR DE ESPANHA & 0 & 0 \\
\hline JUIZ DE FORA & MARIPA DE MINAS & 1 & 0 \\
\hline JUIZ DE FORA & MATIAS BARBOSA & 0 & 0 \\
\hline JUIZ DE FORA & OLARIA & 0 & 0 \\
\hline JUIZ DE FORA & PEDRO TEIXEIRA & 1 & 0 \\
\hline JUIZ DE FORA & PEQUERI & 0 & 0 \\
\hline JUIZ DE FORA & PIAU & 0 & 0 \\
\hline JUIZ DE FORA & RIO NOVO & 0 & 0 \\
\hline JUIZ DE FORA & RIO PRETO & 0 & 0 \\
\hline JUIZ DE FORA & ROCHEDO DE MINAS & 1 & 0 \\
\hline JUIZ DE FORA & SANTA BARBARA DO MONTE VERDE & 0 & 0 \\
\hline JUIZ DE FORA & SANTA RITA DE JACUTINGA & 0 & 0 \\
\hline JUIZ DE FORA & SANTANA DO DESERTO & 0 & 0 \\
\hline JUIZ DE FORA & SANTOS DUMONT & 0 & 0 \\
\hline JUIZ DE FORA & SAO JOAO NEPOMUCENO & 1 & 0 \\
\hline JUIZ DE FORA & SENADOR CORTES & 1 & 0 \\
\hline JUIZ DE FORA & SIMAO PEREIRA & 1 & 0 \\
\hline LEOPOLDINA & ALEM PARAIBA & 0 & 0 \\
\hline LEOPOLDINA & ARGIRITA & 0 & 0 \\
\hline LEOPOLDINA & CATAGUASES & 1 & 0 \\
\hline LEOPOLDINA & ESTRELA DALVA & 2 & 0 \\
\hline LEOPOLDINA & ITAMARATI DE MINAS & 0 & 0 \\
\hline LEOPOLDINA & LEOPOLDINA & 2 & 0 \\
\hline LEOPOLDINA & PIRAPETINGA & 2 & 0 \\
\hline
\end{tabular}




\begin{tabular}{|c|c|c|c|}
\hline LEOPOLDINA & RECREIO & 2 & 0 \\
\hline LEOPOLDINA & SANTO ANTONIO DO AVENTUREIRO & 2 & 0 \\
\hline LEOPOLDINA & VOLTA GRANDE & 2 & 0 \\
\hline MANHUAÇU & ALTO JEQUITIBA & 0 & 0 \\
\hline MANHUAÇU & CAPUTIRA & 0 & 0 \\
\hline MANHUAÇU & CHALE & 0 & 0 \\
\hline MANHUAÇU & CONCEICAO DE IPANEMA & 0 & 0 \\
\hline MANHUAÇU & DURANDE & 1 & 0 \\
\hline MANHUAÇU & LAJINHA & 1 & 0 \\
\hline MANHUAÇU & LUISBURGO & 0 & 0 \\
\hline MANHUAÇU & MANHUACU & 4 & 0 \\
\hline MANHUAÇU & MANHUMIRIM & 1 & 0 \\
\hline MANHUAÇU & MARTINS SOARES & 0 & 0 \\
\hline MANHUAÇU & MATIPO & 0 & 0 \\
\hline MANHUAÇU & MUTUM & 4 & 0 \\
\hline MANHUAÇU & REDUTO & 0 & 0 \\
\hline MANHUAÇU & SANTA MARGARIDA & 1 & 0 \\
\hline MANHUAÇU & SANTANA DO MANHUACU & 1 & 0 \\
\hline MANHUAÇU & SAO JOAO DO MANHUACU & 0 & 0 \\
\hline MANHUAÇU & SAO JOSE DO MANTIMENTO & 1 & 0 \\
\hline MANHUAÇU & SIMONESIA & 1 & 0 \\
\hline METROPOLITANA A & BARAO DE COCAIS & 0 & 0 \\
\hline METROPOLITANA A & BELO HORIZONTE & 27 & 4 \\
\hline METROPOLITANA A & BELO VALE & 0 & 0 \\
\hline METROPOLITANA A & BOM JESUS DO AMPARO & 0 & 0 \\
\hline METROPOLITANA A & BONFIM & 1 & 0 \\
\hline METROPOLITANA A & BRUMADINHO & 0 & 0 \\
\hline METROPOLITANA A & CAETE & 2 & 0 \\
\hline METROPOLITANA A & CATAS ALTAS & 1 & 0 \\
\hline METROPOLITANA A & CRUCILANDIA & 0 & 0 \\
\hline METROPOLITANA A & MOEDA & 0 & 0 \\
\hline METROPOLITANA A & NOVA LIMA & 2 & 0 \\
\hline METROPOLITANA A & NOVA UNIAO & 1 & 0 \\
\hline METROPOLITANA A & PIEDADE DOS GERAIS & 0 & 0 \\
\hline METROPOLITANA A & RAPOSOS & 3 & 0 \\
\hline METROPOLITANA A & RIO ACIMA & 1 & 0 \\
\hline METROPOLITANA A & RIO MANSO & 0 & 0 \\
\hline METROPOLITANA A & SABARA & 11 & 3 \\
\hline METROPOLITANA A & SANTA BARBARA & 3 & 0 \\
\hline METROPOLITANA B & BELO HORIZONTE & 38 & 6 \\
\hline METROPOLITANA B & BETIM & 21 & 4 \\
\hline METROPOLITANA B & CONTAGEM & 31 & 5 \\
\hline METROPOLITANA B & ESMERALDAS & 5 & 1 \\
\hline METROPOLITANA B & IBIRITE & 7 & 2 \\
\hline METROPOLITANA B & IGARAPE & 2 & 0 \\
\hline
\end{tabular}




\begin{tabular}{|c|c|c|c|}
\hline METROPOLITANA B & JUATUBA & 0 & 0 \\
\hline METROPOLITANA B & MARIO CAMPOS & 4 & 0 \\
\hline METROPOLITANA B & MATEUS LEME & 2 & 0 \\
\hline METROPOLITANA B & SAO JOAQUIM DE BICAS & 0 & 0 \\
\hline METROPOLITANA B & SARZEDO & 4 & 0 \\
\hline METROPOLITANA C & BELO HORIZONTE & 33 & 5 \\
\hline METROPOLITANA C & CONFINS & 0 & 0 \\
\hline METROPOLITANA C & JABOTICATUBAS & 1 & 0 \\
\hline METROPOLITANA C & LAGOA SANTA & 3 & 0 \\
\hline METROPOLITANA C & MORRO DO PILAR & 0 & 0 \\
\hline METROPOLITANA C & PEDRO LEOPOLDO & 0 & 0 \\
\hline METROPOLITANA C & RIBEIRAO DAS NEVES & 43 & 6 \\
\hline METROPOLITANA C & SANTA LUZIA & 13 & 3 \\
\hline METROPOLITANA C & SANTANA DO RIACHO & 2 & 0 \\
\hline METROPOLITANA C & SAO JOSE DA LAPA & 4 & 0 \\
\hline METROPOLITANA C & TAQUARACU DE MINAS & 0 & 0 \\
\hline METROPOLITANA C & VESPASIANO & 3 & 0 \\
\hline MONTE CARMELO & ABADIA DOS DOURADOS & 0 & 0 \\
\hline MONTE CARMELO & CASCALHO RICO & 1 & 0 \\
\hline MONTE CARMELO & COROMANDEL & 3 & 0 \\
\hline MONTE CARMELO & DOURADOQUARA & 0 & 0 \\
\hline MONTE CARMELO & ESTRELA DO SUL & 0 & 0 \\
\hline MONTE CARMELO & GRUPIARA & 0 & 0 \\
\hline MONTE CARMELO & MONTE CARMELO & 4 & 0 \\
\hline MONTE CARMELO & ROMARIA & 0 & 0 \\
\hline MONTES CLAROS & BOCAIUVA & 3 & 0 \\
\hline MONTES CLAROS & BOTUMIRIM & 1 & 0 \\
\hline MONTES CLAROS & BRASILIA DE MINAS & 0 & 0 \\
\hline MONTES CLAROS & CAMPO AZUL & 1 & 0 \\
\hline MONTES CLAROS & CAPITAO ENEAS & 1 & 0 \\
\hline MONTES CLAROS & CLARO DOS POCOES & 0 & 0 \\
\hline MONTES CLAROS & CORACAO DE JESUS & 2 & 0 \\
\hline MONTES CLAROS & CRISTALIA & 0 & 0 \\
\hline MONTES CLAROS & ENGENHEIRO NAVARRO & 0 & 0 \\
\hline MONTES CLAROS & FRANCISCO DUMONT & 4 & 0 \\
\hline MONTES CLAROS & FRANCISCO SA & 3 & 0 \\
\hline MONTES CLAROS & GLAUCILANDIA & 1 & 0 \\
\hline MONTES CLAROS & GRAO MOGOL & 4 & 0 \\
\hline MONTES CLAROS & GUARACIAMA & 0 & 0 \\
\hline MONTES CLAROS & ITACAMBIRA & 0 & 0 \\
\hline MONTES CLAROS & JAPONVAR & 1 & 0 \\
\hline MONTES CLAROS & JOSENOPOLIS & 0 & 0 \\
\hline MONTES CLAROS & JURAMENTO & 3 & 0 \\
\hline MONTES CLAROS & LONTRA & 0 & 0 \\
\hline MONTES CLAROS & LUISLANDIA & 0 & 0 \\
\hline
\end{tabular}




\begin{tabular}{|c|c|c|c|}
\hline MONTES CLAROS & MIRABELA & 2 & 0 \\
\hline MONTES CLAROS & MONTES CLAROS & 10 & 3 \\
\hline MONTES CLAROS & OLHOS-D AGUA & 1 & 0 \\
\hline MONTES CLAROS & PADRE CARVALHO & 0 & 0 \\
\hline MONTES CLAROS & PATIS & 0 & 0 \\
\hline MONTES CLAROS & SAO JOAO DA LAGOA & 2 & 0 \\
\hline MONTES CLAROS & SAO JOAO DA PONTE & 2 & 0 \\
\hline MONTES CLAROS & SAO JOAO DO PACUI & 0 & 0 \\
\hline MONTES CLAROS & SAO JOAO DO PARAISO & 0 & 0 \\
\hline MONTES CLAROS & VARGEM GRANDE DO RIO PARDO & 0 & 0 \\
\hline MURIAÉ & ANTONIO PRADO DE MINAS & 0 & 0 \\
\hline MURIAÉ & BARAO DE MONTE ALTO & 0 & 0 \\
\hline MURIAÉ & EUGENOPOLIS & 0 & 0 \\
\hline MURIAÉ & LARANJAL & 0 & 0 \\
\hline MURIAÉ & MIRADOURO & 0 & 0 \\
\hline MURIAÉ & MIRAI & 0 & 0 \\
\hline MURIAÉ & MURIAE & 1 & 0 \\
\hline MURIAÉ & PALMA & 1 & 0 \\
\hline MURIAÉ & PATROCINIO DO MURIAE & 0 & 0 \\
\hline MURIAÉ & ROSARIO DA LIMEIRA & 0 & 0 \\
\hline MURIAÉ & SANTANA DE CATAGUASES & 0 & 0 \\
\hline MURIAÉ & SAO FRANCISCO DO GLORIA & 0 & 0 \\
\hline MURIAÉ & SAO SEBASTIAO DA VARGEM ALEGRE & 0 & 0 \\
\hline MURIAÉ & VIEIRAS & 1 & 0 \\
\hline NOVA ERA & BELA VISTA DE MINAS & 1 & 0 \\
\hline NOVA ERA & DIONISIO & 0 & 0 \\
\hline NOVA ERA & FERROS & 1 & 0 \\
\hline NOVA ERA & ITABIRA & 2 & 0 \\
\hline NOVA ERA & ITAMBE DO MATO DENTRO & 0 & 0 \\
\hline NOVA ERA & JOAO MONLEVADE & 2 & 0 \\
\hline NOVA ERA & NOVA ERA & 1 & 0 \\
\hline NOVA ERA & PASSABEM & 0 & 0 \\
\hline NOVA ERA & RIO PIRACICABA & 0 & 0 \\
\hline NOVA ERA & SANTA MARIA DE ITABIRA & 1 & 0 \\
\hline NOVA ERA & SANTO ANTONIO DO RIO ABAIXO & 0 & 0 \\
\hline NOVA ERA & SAO DOMINGOS DO PRATA & 1 & 0 \\
\hline NOVA ERA & SAO GONCALO DO RIO ABAIXO & 1 & 0 \\
\hline NOVA ERA & SAO JOSE DO GOIABAL & 0 & 0 \\
\hline NOVA ERA & SAO SEBASTIAO DO RIO PRETO & 0 & 0 \\
\hline OURO PRETO & ACAIACA & 1 & 0 \\
\hline OURO PRETO & DIOGO DE VASCONCELOS & 4 & 0 \\
\hline OURO PRETO & ITABIRITO & 6 & 2 \\
\hline OURO PRETO & MARIANA & 13 & 3 \\
\hline OURO PRETO & OURO PRETO & 11 & 3 \\
\hline PARA DE MINAS & ABAETE & 0 & 0 \\
\hline
\end{tabular}




\begin{tabular}{|c|c|c|c|}
\hline PARA DE MINAS & BIQUINHAS & 0 & 0 \\
\hline PARA DE MINAS & BOM DESPACHO & 0 & 0 \\
\hline PARA DE MINAS & CEDRO DO ABAETE & 0 & 0 \\
\hline PARA DE MINAS & CONCEICAO DO PARA & 0 & 0 \\
\hline PARA DE MINAS & DORES DO INDAIA & 0 & 0 \\
\hline PARA DE MINAS & ESTRELA DO INDAIA & 1 & 0 \\
\hline PARA DE MINAS & FLORESTAL & 3 & 0 \\
\hline PARA DE MINAS & IGARATINGA & 2 & 0 \\
\hline PARA DE MINAS & LEANDRO FERREIRA & 0 & 0 \\
\hline PARA DE MINAS & MARTINHO CAMPOS & 0 & 0 \\
\hline PARA DE MINAS & MORADA NOVA DE MINAS & 0 & 0 \\
\hline PARA DE MINAS & ONCA DE PITANGUI & 0 & 0 \\
\hline PARA DE MINAS & PAINEIRAS & 0 & 0 \\
\hline PARA DE MINAS & PARA DE MINAS & 4 & 0 \\
\hline PARA DE MINAS & PEQUI & 0 & 0 \\
\hline PARA DE MINAS & PITANGUI & 1 & 0 \\
\hline PARA DE MINAS & QUARTEL GERAL & 1 & 0 \\
\hline PARA DE MINAS & SAO JOSE DA VARGINHA & 0 & 0 \\
\hline PARA DE MINAS & SERRA DA SAUDADE & 0 & 0 \\
\hline PARACATU & BRASILANDIA DE MINAS & 2 & 0 \\
\hline PARACATU & GUARDA-MOR & 0 & 0 \\
\hline PARACATU & JOAO PINHEIRO & 3 & 0 \\
\hline PARACATU & PARACATU & 3 & 0 \\
\hline PARACATU & VAZANTE & 0 & 0 \\
\hline PASSOS & ALPINOPOLIS & 0 & 0 \\
\hline PASSOS & BOM JESUS DA PENHA & 0 & 0 \\
\hline PASSOS & CAPITOLIO & 1 & 0 \\
\hline PASSOS & CARMO DO RIO CLARO & 2 & 0 \\
\hline PASSOS & CORREGO FUNDO & 0 & 0 \\
\hline PASSOS & DELFINOPOLIS & 1 & 0 \\
\hline PASSOS & DORESOPOLIS & 0 & 0 \\
\hline PASSOS & FORMIGA & 3 & 0 \\
\hline PASSOS & FORTALEZA DE MINAS & 2 & 0 \\
\hline PASSOS & PASSOS & 3 & 0 \\
\hline PASSOS & PIMENTA & 0 & 0 \\
\hline PASSOS & PIUMHI & 3 & 0 \\
\hline PASSOS & SAO JOAO BATISTA DO GLORIA & 0 & 0 \\
\hline PASSOS & SAO JOSE DA BARRA & 1 & 0 \\
\hline PASSOS & SAO ROQUE DE MINAS & 4 & 0 \\
\hline PASSOS & VARGEM BONITA & 0 & 0 \\
\hline PATOS DE MINAS & ARAPUA & 0 & 0 \\
\hline PATOS DE MINAS & CARMO DO PARANAIBA & 1 & 0 \\
\hline PATOS DE MINAS & LAGAMAR & 1 & 0 \\
\hline PATOS DE MINAS & LAGOA FORMOSA & 2 & 0 \\
\hline PATOS DE MINAS & LAGOA GRANDE & 0 & 0 \\
\hline
\end{tabular}




\begin{tabular}{|c|c|c|c|}
\hline PATOS DE MINAS & MATUTINA & 0 & 0 \\
\hline PATOS DE MINAS & PATOS DE MINAS & 3 & 0 \\
\hline PATOS DE MINAS & PRESIDENTE OLEGARIO & 3 & 0 \\
\hline PATOS DE MINAS & RIO PARANAIBA & 1 & 0 \\
\hline PATOS DE MINAS & SANTA ROSA DA SERRA & 0 & 0 \\
\hline PATOS DE MINAS & SAO GONCALO DO ABAETE & 1 & 0 \\
\hline PATOS DE MINAS & SAO GOTARDO & 4 & 0 \\
\hline PATOS DE MINAS & TIROS & 0 & 0 \\
\hline PATOS DE MINAS & VARJAO DE MINAS & 0 & 0 \\
\hline PATROCÍNIO & CRUZEIRO DA FORTALEZA & 0 & 0 \\
\hline PATROCÍNIO & GUIMARANIA & 0 & 0 \\
\hline PATROCÍNIO & IBIA & 0 & 0 \\
\hline PATROCÍNIO & IRAI DE MINAS & 0 & 0 \\
\hline PATROCÍNIO & PATROCINIO & 1 & 0 \\
\hline PATROCÍNIO & PERDIZES & 2 & 0 \\
\hline PATROCÍNIO & SERRA DO SALITRE & 0 & 0 \\
\hline PIRAPORA & BURITIZEIRO & 5 & 1 \\
\hline PIRAPORA & IBIAI & 2 & 0 \\
\hline PIRAPORA & JEQUITAI & 0 & 0 \\
\hline PIRAPORA & LAGOA DOS PATOS & 0 & 0 \\
\hline PIRAPORA & PIRAPORA & 3 & 0 \\
\hline PIRAPORA & PONTO CHIQUE & 0 & 0 \\
\hline PIRAPORA & SANTA FE DE MINAS & 0 & 0 \\
\hline PIRAPORA & SAO ROMAO & 2 & 0 \\
\hline PIRAPORA & VARZEA DA PALMA & 0 & 0 \\
\hline POÇOS DE CALDAS & ALTEROSA & 0 & 0 \\
\hline POÇOS DE CALDAS & ANDRADAS & 2 & 0 \\
\hline POÇOS DE CALDAS & AREADO & 3 & 0 \\
\hline POÇOS DE CALDAS & BANDEIRA DO SUL & 1 & 0 \\
\hline POÇOS DE CALDAS & BOTELHOS & 2 & 0 \\
\hline POÇOS DE CALDAS & CABO VERDE & 2 & 0 \\
\hline POÇOS DE CALDAS & CALDAS & 1 & 0 \\
\hline POÇOS DE CALDAS & CAMPESTRE & 0 & 0 \\
\hline POÇOS DE CALDAS & CONCEICAO DA APARECIDA & 1 & 0 \\
\hline POÇOS DE CALDAS & DIVISA NOVA & 0 & 0 \\
\hline POÇOS DE CALDAS & IBITIURA DE MINAS & 0 & 0 \\
\hline POÇOS DE CALDAS & MONTE BELO & 1 & 0 \\
\hline POÇOS DE CALDAS & MUZAMBINHO & 2 & 0 \\
\hline POÇOS DE CALDAS & NOVA RESENDE & 1 & 0 \\
\hline POÇOS DE CALDAS & POCOS DE CALDAS & 4 & 0 \\
\hline POÇOS DE CALDAS & SANTA RITA DE CALDAS & 0 & 0 \\
\hline POÇOS DE CALDAS & SERRANIA & 0 & 0 \\
\hline PONTE NOVA & ABRE CAMPO & 1 & 0 \\
\hline PONTE NOVA & ALVINOPOLIS & 2 & 0 \\
\hline PONTE NOVA & AMPARO DO SERRA & 1 & 0 \\
\hline
\end{tabular}




\begin{tabular}{|c|c|c|c|}
\hline PONTE NOVA & ARAPONGA & 0 & 0 \\
\hline PONTE NOVA & BARRA LONGA & 1 & 0 \\
\hline PONTE NOVA & CAJURI & 0 & 0 \\
\hline PONTE NOVA & CANAA & 0 & 0 \\
\hline PONTE NOVA & DOM SILVERIO & 0 & 0 \\
\hline PONTE NOVA & GUARACIABA & 0 & 0 \\
\hline PONTE NOVA & JEQUERI & 0 & 0 \\
\hline PONTE NOVA & ORATORIOS & 0 & 0 \\
\hline PONTE NOVA & PEDRA BONITA & 0 & 0 \\
\hline PONTE NOVA & PEDRA DO ANTA & 0 & 0 \\
\hline PONTE NOVA & PIEDADE DE PONTE NOVA & 0 & 0 \\
\hline PONTE NOVA & PONTE NOVA & 0 & 0 \\
\hline PONTE NOVA & PORTO FIRME & 1 & 0 \\
\hline PONTE NOVA & RAUL SOARES & 5 & 1 \\
\hline PONTE NOVA & RIO CASCA & 0 & 0 \\
\hline PONTE NOVA & RIO DOCE & 0 & 0 \\
\hline PONTE NOVA & SANTA CRUZ DO ESCALVADO & 0 & 0 \\
\hline PONTE NOVA & SANTO ANTONIO DO GRAMA & 0 & 0 \\
\hline PONTE NOVA & SAO MIGUEL DO ANTA & 1 & 0 \\
\hline PONTE NOVA & SAO PEDRO DOS FERROS & 0 & 0 \\
\hline PONTE NOVA & SEM-PEIXE & 0 & 0 \\
\hline PONTE NOVA & SERICITA & 0 & 0 \\
\hline PONTE NOVA & TEIXEIRAS & 0 & 0 \\
\hline PONTE NOVA & URUCANIA & 1 & 0 \\
\hline PONTE NOVA & VERMELHO NOVO & 0 & 0 \\
\hline PONTE NOVA & VICOSA & 5 & 1 \\
\hline POUSO ALEGRE & ALBERTINA & 1 & 0 \\
\hline POUSO ALEGRE & BOM REPOUSO & 0 & 0 \\
\hline POUSO ALEGRE & BORDA DA MATA & 0 & 0 \\
\hline POUSO ALEGRE & BUENO BRANDAO & 0 & 0 \\
\hline POUSO ALEGRE & CACHOEIRA DE MINAS & 1 & 0 \\
\hline POUSO ALEGRE & CAMANDUCAIA & 5 & 1 \\
\hline POUSO ALEGRE & CAMBUI & 2 & 0 \\
\hline POUSO ALEGRE & CAREACU & 0 & 0 \\
\hline POUSO ALEGRE & CONGONHAL & 0 & 0 \\
\hline POUSO ALEGRE & CORREGO DO BOM JESUS & 0 & 0 \\
\hline POUSO ALEGRE & ESPIRITO SANTO DO DOURADO & 0 & 0 \\
\hline POUSO ALEGRE & ESTIVA & 0 & 0 \\
\hline POUSO ALEGRE & EXTREMA & 0 & 0 \\
\hline POUSO ALEGRE & HELIODORA & 0 & 0 \\
\hline POUSO ALEGRE & INCONFIDENTES & 1 & 0 \\
\hline POUSO ALEGRE & IPUIUNA & 0 & 0 \\
\hline POUSO ALEGRE & ITAPEVA & 1 & 0 \\
\hline POUSO ALEGRE & JACUTINGA & 0 & 0 \\
\hline POUSO ALEGRE & MONTE SIAO & 0 & 0 \\
\hline
\end{tabular}




\begin{tabular}{|c|c|c|c|}
\hline POUSO ALEGRE & MUNHOZ & 1 & 0 \\
\hline POUSO ALEGRE & OURO FINO & 1 & 0 \\
\hline POUSO ALEGRE & POUSO ALEGRE & 5 & 1 \\
\hline POUSO ALEGRE & SANTA RITA DO SAPUCAI & 1 & 0 \\
\hline POUSO ALEGRE & SAO JOAO DA MATA & 0 & 0 \\
\hline POUSO ALEGRE & SAO SEBASTIAO DA BELA VISTA & 0 & 0 \\
\hline POUSO ALEGRE & SENADOR AMARAL & 0 & 0 \\
\hline POUSO ALEGRE & SENADOR JOSE BENTO & 0 & 0 \\
\hline POUSO ALEGRE & SILVIANOPOLIS & 2 & 0 \\
\hline POUSO ALEGRE & TOCOS DO MOJI & 1 & 0 \\
\hline POUSO ALEGRE & TOLEDO & 0 & 0 \\
\hline SÃO JOÃO DEL REI & BOM SUCESSO & 0 & 0 \\
\hline SÃO JOÃO DEL REI & CARRANCAS & 0 & 0 \\
\hline SÃO JOÃO DEL REI & CONCEICAO DA BARRA DE MINAS & 1 & 0 \\
\hline SÃO JOÃO DEL REI & CORONEL XAVIER CHAVES & 0 & 0 \\
\hline SÃO JOÃO DEL REI & DORES DE CAMPOS & 0 & 0 \\
\hline SÃO JOÃO DEL REI & IBITURUNA & 0 & 0 \\
\hline SÃO JOÃO DEL REI & IJACI & 0 & 0 \\
\hline SÃO JOÃO DEL REI & INGAI & 1 & 0 \\
\hline SÃO JOÃO DEL REI & ITUMIRIM & 0 & 0 \\
\hline SÃO JOÃO DEL REI & ITUTINGA & 0 & 0 \\
\hline SÃO JOÃO DEL REI & LAGOA DOURADA & 0 & 0 \\
\hline SÃO JOÃO DEL REI & NAZARENO & 1 & 0 \\
\hline SÃO JOÃO DEL REI & PRADOS & 0 & 0 \\
\hline SÃO JOÃO DEL REI & RESENDE COSTA & 0 & 0 \\
\hline SÃO JOÃO DEL REI & RITAPOLIS & 0 & 0 \\
\hline SÃO JOÃO DEL REI & SANTA CRUZ DE MINAS & 0 & 0 \\
\hline SÃO JOÃO DEL REI & SAO JOAO DEL REI & 5 & 1 \\
\hline SÃO JOÃO DEL REI & SAO TIAGO & 0 & 0 \\
\hline SÃO JOÃO DEL REI & TIRADENTES & 0 & 0 \\
\hline SÃO SEBASTIÃO DO PARAÍSO & ARCEBURGO & 0 & 0 \\
\hline SÃO SEBASTIÃO DO PARAÍSO & CAPETINGA & 1 & 0 \\
\hline SÃO SEBASTIÃO DO PARAÍSO & CASSIA & 0 & 0 \\
\hline SÃO SEBASTIÃO DO PARAÍSO & CLARAVAL & 0 & 0 \\
\hline SÃO SEBASTIÃO DO PARAÍSO & GUARANESIA & 0 & 0 \\
\hline SÃO SEBASTIÃO DO PARAÍSO & GUAXUPE & 1 & 0 \\
\hline SÃO SEBASTIÃO DO PARAÍSO & IBIRACI & 0 & 0 \\
\hline SÃO SEBASTIÃO DO PARAÍSO & ITAMOGI & 0 & 0 \\
\hline SÃO SEBASTIÃO DO PARAÍSO & ITAU DE MINAS & 0 & 0 \\
\hline SÃO SEBASTIÃO DO PARAÍSO & JACUI & 0 & 0 \\
\hline SÃO SEBASTIÃO DO PARAÍSO & JURUAIA & 1 & 0 \\
\hline SÃO SEBASTIÃO DO PARAÍSO & MONTE SANTO DE MINAS & 1 & 0 \\
\hline SÃO SEBASTIÃO DO PARAÍSO & PRATAPOLIS & 0 & 0 \\
\hline SÃO SEBASTIÃO DO PARAÍSO & SAO PEDRO DA UNIAO & 0 & 0 \\
\hline SÃO SEBASTIÃO DO PARAÍSO & SAO SEBASTIAO DO PARAISO & 3 & 0 \\
\hline
\end{tabular}




\begin{tabular}{|c|c|c|c|}
\hline SÃO SEBASTIÃO DO PARAÍSO & SAO TOMAS DE AQUINO & 0 & 0 \\
\hline SETE LAGOAS & ARACAI & 0 & 0 \\
\hline SETE LAGOAS & BALDIM & 2 & 0 \\
\hline SETE LAGOAS & CACHOEIRA DA PRATA & 0 & 0 \\
\hline SETE LAGOAS & CAETANOPOLIS & 0 & 0 \\
\hline SETE LAGOAS & CAPIM BRANCO & 0 & 0 \\
\hline SETE LAGOAS & CORDISBURGO & 0 & 0 \\
\hline SETE LAGOAS & FORTUNA DE MINAS & 0 & 0 \\
\hline SETE LAGOAS & FUNILANDIA & 3 & 0 \\
\hline SETE LAGOAS & INHAUMA & 2 & 0 \\
\hline SETE LAGOAS & JEQUITIBA & 0 & 0 \\
\hline SETE LAGOAS & MARAVILHAS & 1 & 0 \\
\hline SETE LAGOAS & MATOZINHOS & 2 & 0 \\
\hline SETE LAGOAS & PAPAGAIOS & 1 & 0 \\
\hline SETE LAGOAS & PARAOPEBA & 1 & 0 \\
\hline SETE LAGOAS & POMPEU & 3 & 0 \\
\hline SETE LAGOAS & PRUDENTE DE MORAIS & 1 & 0 \\
\hline SETE LAGOAS & SANTANA DE PIRAPAMA & 0 & 0 \\
\hline SETE LAGOAS & SETE LAGOAS & 9 & 2 \\
\hline TEOFILO OTONI & AGUAS FORMOSAS & 1 & 0 \\
\hline TEOFILO OTONI & ATALEIA & 1 & 0 \\
\hline TEOFILO OTONI & BERTOPOLIS & 1 & 0 \\
\hline TEOFILO OTONI & CAMPANARIO & 1 & 0 \\
\hline TEOFILO OTONI & CARAI & 0 & 0 \\
\hline TEOFILO OTONI & CARLOS CHAGAS & 3 & 0 \\
\hline TEOFILO OTONI & CATUJI & 0 & 0 \\
\hline TEOFILO OTONI & CRISOLITA & 1 & 0 \\
\hline TEOFILO OTONI & FRANCISCOPOLIS & 0 & 0 \\
\hline TEOFILO OTONI & FREI GASPAR & 0 & 0 \\
\hline TEOFILO OTONI & FRONTEIRA DOS VALES & 0 & 0 \\
\hline TEOFILO OTONI & ITAIPE & 0 & 0 \\
\hline TEOFILO OTONI & ITAMBACURI & 0 & 0 \\
\hline TEOFILO OTONI & JAMPRUCA & 1 & 0 \\
\hline TEOFILO OTONI & LADAINHA & 2 & 0 \\
\hline TEOFILO OTONI & MACHACALIS & 0 & 0 \\
\hline TEOFILO OTONI & MALACACHETA & 3 & 0 \\
\hline TEOFILO OTONI & NANUQUE & 4 & 0 \\
\hline TEOFILO OTONI & NOVO CRUZEIRO & 0 & 0 \\
\hline TEOFILO OTONI & NOVO ORIENTE DE MINAS & 2 & 0 \\
\hline TEOFILO OTONI & OURO VERDE DE MINAS & 0 & 0 \\
\hline TEOFILO OTONI & PADRE PARAISO & 0 & 0 \\
\hline TEOFILO OTONI & PAVAO & 1 & 0 \\
\hline TEOFILO OTONI & PESCADOR & 0 & 0 \\
\hline TEOFILO OTONI & PONTO DOS VOLANTES & 1 & 0 \\
\hline TEOFILO OTONI & POTE & 3 & 0 \\
\hline
\end{tabular}




\begin{tabular}{|c|c|c|c|}
\hline TEOFILO OTONI & SANTA HELENA DE MINAS & 1 & 0 \\
\hline TEOFILO OTONI & SERRA DOS AIMORES & 2 & 0 \\
\hline TEOFILO OTONI & SETUBINHA & 0 & 0 \\
\hline TEOFILO OTONI & TEOFILO OTONI & 8 & 2 \\
\hline TEOFILO OTONI & UMBURATIBA & 0 & 0 \\
\hline UBÁ & ASTOLFO DUTRA & 0 & 0 \\
\hline UBÁ & BRAS PIRES & 0 & 0 \\
\hline UBÁ & COIMBRA & 1 & 0 \\
\hline UBÁ & DIVINESIA & 0 & 0 \\
\hline UBÁ & DONA EUZEBIA & 0 & 0 \\
\hline UBÁ & DORES DO TURVO & 0 & 0 \\
\hline UBÁ & ERVALIA & 1 & 0 \\
\hline UBÁ & GUARANI & 0 & 0 \\
\hline UBÁ & GUIDOVAL & 1 & 0 \\
\hline UBÁ & GUIRICEMA & 0 & 0 \\
\hline UBÁ & PAULA CANDIDO & 1 & 0 \\
\hline UBÁ & PIRAUBA & 0 & 0 \\
\hline UBÁ & PRESIDENTE BERNARDES & 1 & 0 \\
\hline UBÁ & RIO POMBA & 0 & 0 \\
\hline UBÁ & RODEIRO & 0 & 0 \\
\hline UBÁ & SAO GERALDO & 3 & 0 \\
\hline UBÁ & SENADOR FIRMINO & 0 & 0 \\
\hline UBÁ & SILVEIRANIA & 0 & 0 \\
\hline UBÁ & TABULEIRO & 0 & 0 \\
\hline UBÁ & TOCANTINS & 1 & 0 \\
\hline UBÁ & UBA & 13 & 3 \\
\hline UBÁ & VISCONDE DO RIO BRANCO & 0 & 0 \\
\hline UBERABA & AGUA COMPRIDA & 0 & 0 \\
\hline UBERABA & ARAXA & 3 & 0 \\
\hline UBERABA & CAMPO FLORIDO & 0 & 0 \\
\hline UBERABA & CAMPOS ALTOS & 0 & 0 \\
\hline UBERABA & CARNEIRINHO & 1 & 0 \\
\hline UBERABA & COMENDADOR GOMES & 0 & 0 \\
\hline UBERABA & CONCEICAO DAS ALAGOAS & 3 & 0 \\
\hline UBERABA & CONQUISTA & 0 & 0 \\
\hline UBERABA & DELTA & 0 & 0 \\
\hline UBERABA & FRONTEIRA & 0 & 0 \\
\hline UBERABA & FRUTAL & 2 & 0 \\
\hline UBERABA & ITAPAGIPE & 2 & 0 \\
\hline UBERABA & ITURAMA & 1 & 0 \\
\hline UBERABA & LIMEIRA DO OESTE & 1 & 0 \\
\hline UBERABA & PEDRINOPOLIS & 0 & 0 \\
\hline UBERABA & PIRAJUBA & 1 & 0 \\
\hline UBERABA & PLANURA & 0 & 0 \\
\hline UBERABA & PRATINHA & 0 & 0 \\
\hline
\end{tabular}




\begin{tabular}{|c|c|c|c|}
\hline UBERABA & SACRAMENTO & 3 & 0 \\
\hline UBERABA & SANTA JULIANA & 2 & 0 \\
\hline UBERABA & SAO FRANCISCO DE SALES & 0 & 0 \\
\hline UBERABA & TAPIRA & 0 & 0 \\
\hline UBERABA & UBERABA & 15 & 4 \\
\hline UBERABA & UNIAO DE MINAS & 0 & 0 \\
\hline UBERABA & VERISSIMO & 0 & 0 \\
\hline UBERLANDIA & ARAGUARI & 2 & 0 \\
\hline UBERLANDIA & ARAPORA & 0 & 0 \\
\hline UBERLANDIA & CAMPINA VERDE & 1 & 0 \\
\hline UBERLANDIA & INDIANOPOLIS & 1 & 0 \\
\hline UBERLANDIA & MONTE ALEGRE DE MINAS & 0 & 0 \\
\hline UBERLANDIA & NOVA PONTE & 0 & 0 \\
\hline UBERLANDIA & PRATA & 1 & 0 \\
\hline UBERLANDIA & TUPACIGUARA & 3 & 0 \\
\hline UBERLANDIA & UBERLANDIA & 35 & 6 \\
\hline UNAI & ARINOS & 1 & 0 \\
\hline UNAI & BONFINOPOLIS DE MINAS & 0 & 0 \\
\hline UNAI & BURITIS & 2 & 0 \\
\hline UNAI & CABECEIRA GRANDE & 0 & 0 \\
\hline UNAI & DOM BOSCO & 1 & 0 \\
\hline UNAI & FORMOSO & 0 & 0 \\
\hline UNAI & NATALANDIA & 0 & 0 \\
\hline UNAI & RIACHINHO & 1 & 0 \\
\hline UNAI & UNAI & 2 & 0 \\
\hline UNAI & URUANA DE MINAS & 1 & 0 \\
\hline VARGINHA & ALFENAS & 3 & 0 \\
\hline VARGINHA & BOA ESPERANCA & 2 & 0 \\
\hline VARGINHA & CAMBUQUIRA & 0 & 0 \\
\hline VARGINHA & CAMPANHA & 0 & 0 \\
\hline VARGINHA & CAMPO DO MEIO & 0 & 0 \\
\hline VARGINHA & CAMPOS GERAIS & 0 & 0 \\
\hline VARGINHA & CARMO DA CACHOEIRA & 0 & 0 \\
\hline VARGINHA & CARVALHOPOLIS & 0 & 0 \\
\hline VARGINHA & COQUEIRAL & 0 & 0 \\
\hline VARGINHA & CORDISLANDIA & 0 & 0 \\
\hline VARGINHA & ELOI MENDES & 1 & 0 \\
\hline VARGINHA & FAMA & 0 & 0 \\
\hline VARGINHA & GUAPE & 1 & 0 \\
\hline VARGINHA & ILICINEA & 1 & 0 \\
\hline VARGINHA & LAMBARI & 2 & 0 \\
\hline VARGINHA & LUMINARIAS & 0 & 0 \\
\hline VARGINHA & MACHADO & 0 & 0 \\
\hline VARGINHA & MONSENHOR PAULO & 0 & 0 \\
\hline VARGINHA & NEPOMUCENO & 1 & 0 \\
\hline
\end{tabular}




\begin{tabular}{|l|l|c|c|} 
VARGINHA & PARAGUACU & 0 & 0 \\
\hline VARGINHA & POCO FUNDO & 1 & 0 \\
\hline VARGINHA & SANTANA DA VARGEM & 0 & 0 \\
\hline VARGINHA & SAO BENTO ABADE & 0 & 0 \\
\hline VARGINHA & SAO GONCALO DO SAPUCAI & 1 & 0 \\
\hline VARGINHA & TRES CORACOES & 0 & 0 \\
\hline VARGINHA & TRES PONTAS & 0 & 0 \\
\hline VARGINHA & TURVOLANDIA & 3 & 0 \\
\hline VARGINHA & VARGINHA & $\mathbf{1 1 2 4}$ & $\mathbf{1 1 2}$ \\
\hline Total geral & & & 0 \\
\hline
\end{tabular}

CARGO: PROFESSOR DE EDUCAÇÃO BÁSICA - PEB -EDUCAÇÃO FÍSICA

\begin{tabular}{|c|c|c|c|}
\hline S R E & MUNICIPIO & $\begin{array}{l}\text { TOTAL DE } \\
\text { VAGAS }\end{array}$ & $\begin{array}{c}\text { VAGAS } \\
\text { RESERVADAS - } \\
\text { PORTADORES DE } \\
\text { DEFICIÊNCIA }\end{array}$ \\
\hline ALMENARA & AGUAS VERMELHAS & 2 & 0 \\
\hline ALMENARA & ALMENARA & 1 & 0 \\
\hline ALMENARA & BANDEIRA & 0 & 0 \\
\hline ALMENARA & CACHOEIRA DE PAJEU & 0 & 0 \\
\hline ALMENARA & CURRAL DE DENTRO & 0 & 0 \\
\hline ALMENARA & DIVISA ALEGRE & 0 & 0 \\
\hline ALMENARA & DIVISOPOLIS & 0 & 0 \\
\hline ALMENARA & FELISBURGO & 1 & 0 \\
\hline ALMENARA & JACINTO & 0 & 0 \\
\hline ALMENARA & JEQUITINHONHA & 1 & 0 \\
\hline ALMENARA & JOAIMA & 0 & 0 \\
\hline ALMENARA & JORDANIA & 0 & 0 \\
\hline ALMENARA & MATA VERDE & 0 & 0 \\
\hline ALMENARA & MONTE FORMOSO & 1 & 0 \\
\hline ALMENARA & PALMOPOLIS & 0 & 0 \\
\hline ALMENARA & PEDRA AZUL & 1 & 0 \\
\hline ALMENARA & RIO DO PRADO & 0 & 0 \\
\hline ALMENARA & RUBIM & 3 & 0 \\
\hline ALMENARA & SALTO DA DIVISA & 0 & 0 \\
\hline ALMENARA & SANTA MARIA DO SALTO & 0 & 0 \\
\hline ALMENARA & SANTO ANTONIO DO JACINTO & 0 & 0 \\
\hline ARACUAI & ARACUAI & 4 & 0 \\
\hline ARACUAI & BERILO & 3 & 0 \\
\hline ARACUAI & BERIZAL & 0 & 0 \\
\hline ARACUAI & CHAPADA DO NORTE & 1 & 0 \\
\hline ARACUAI & COMERCINHO & 0 & 0 \\
\hline ARACUAI & CORONEL MURTA & 1 & 0 \\
\hline ARACUAI & FRANCISCO BADARO & 3 & 0 \\
\hline ARACUAI & FRUTA DE LEITE & 0 & 0 \\
\hline
\end{tabular}




\begin{tabular}{|c|c|c|c|}
\hline ARACUAI & INDAIABIRA & 0 & 0 \\
\hline ARACUAI & ITAOBIM & 0 & 0 \\
\hline ARACUAI & ITINGA & 1 & 0 \\
\hline ARACUAI & JENIPAPO DE MINAS & 0 & 0 \\
\hline ARACUAI & JOSE GONCALVES DE MINAS & 2 & 0 \\
\hline ARACUAI & MEDINA & 1 & 0 \\
\hline ARACUAI & NINHEIRA & 2 & 0 \\
\hline ARACUAI & NOVORIZONTE & 0 & 0 \\
\hline ARACUAI & RUBELITA & 1 & 0 \\
\hline ARACUAI & SALINAS & 9 & 1 \\
\hline ARACUAI & SANTA CRUZ DE SALINAS & 0 & 0 \\
\hline ARACUAI & TAIOBEIRAS & 0 & 0 \\
\hline ARACUAI & VIRGEM DA LAPA & 1 & 0 \\
\hline BARBACENA & ALFREDO VASCONCELOS & 2 & 0 \\
\hline BARBACENA & ALTO RIO DOCE & 0 & 0 \\
\hline BARBACENA & ANDRELANDIA & 0 & 0 \\
\hline BARBACENA & ANTONIO CARLOS & 1 & 0 \\
\hline BARBACENA & ARACITABA & 0 & 0 \\
\hline BARBACENA & BARBACENA & 2 & 0 \\
\hline BARBACENA & BARROSO & 0 & 0 \\
\hline BARBACENA & BIAS FORTES & 0 & 0 \\
\hline BARBACENA & CAPELA NOVA & 0 & 0 \\
\hline BARBACENA & CARANDAI & 0 & 0 \\
\hline BARBACENA & CIPOTANEA & 0 & 0 \\
\hline BARBACENA & DESTERRO DO MELO & 0 & 0 \\
\hline BARBACENA & IBERTIOGA & 0 & 0 \\
\hline BARBACENA & MADRE DE DEUS DE MINAS & 0 & 0 \\
\hline BARBACENA & MERCES & 0 & 0 \\
\hline BARBACENA & OLIVEIRA FORTES & 1 & 0 \\
\hline BARBACENA & PAIVA & 0 & 0 \\
\hline BARBACENA & PIEDADE DO RIO GRANDE & 0 & 0 \\
\hline BARBACENA & RESSAQUINHA & 0 & 0 \\
\hline BARBACENA & SANTA BARBARA DO TUGURIO & 0 & 0 \\
\hline BARBACENA & SANTA RITA DO IBITIPOCA & 0 & 0 \\
\hline BARBACENA & SANTANA DO GARAMBEU & 0 & 0 \\
\hline BARBACENA & SAO VICENTE DE MINAS & 0 & 0 \\
\hline BARBACENA & SENHORA DOS REMEDIOS & 0 & 0 \\
\hline CAMPO BELO & AGUANIL & 0 & 0 \\
\hline CAMPO BELO & CAMACHO & 1 & 0 \\
\hline CAMPO BELO & CAMPO BELO & 0 & 0 \\
\hline CAMPO BELO & CANA VERDE & 0 & 0 \\
\hline CAMPO BELO & CANDEIAS & 0 & 0 \\
\hline CAMPO BELO & CRISTAIS & 0 & 0 \\
\hline CAMPO BELO & LAVRAS & 1 & 0 \\
\hline CAMPO BELO & PERDOES & 0 & 0 \\
\hline
\end{tabular}




\begin{tabular}{|c|c|c|c|}
\hline CAMPO BELO & RIBEIRAO VERMELHO & 1 & 0 \\
\hline CAMPO BELO & SANTANA DO JACARE & 0 & 0 \\
\hline CAMPO BELO & SANTO ANTONIO DO AMPARO & 0 & 0 \\
\hline CAMPO BELO & SAO FRANCISCO DE PAULA & 0 & 0 \\
\hline CARANGOLA & ALTO CAPARAO & 0 & 0 \\
\hline CARANGOLA & CAIANA & 0 & 0 \\
\hline CARANGOLA & CAPARAO & 1 & 0 \\
\hline CARANGOLA & CARANGOLA & 1 & 0 \\
\hline CARANGOLA & DIVINO & 1 & 0 \\
\hline CARANGOLA & ESPERA FELIZ & 7 & 1 \\
\hline CARANGOLA & FARIA LEMOS & 0 & 0 \\
\hline CARANGOLA & FERVEDOURO & 1 & 0 \\
\hline CARANGOLA & ORIZANIA & 0 & 0 \\
\hline CARANGOLA & PEDRA DOURADA & 1 & 0 \\
\hline CARANGOLA & TOMBOS & 0 & 0 \\
\hline CARATINGA & ALVARENGA & 2 & 0 \\
\hline CARATINGA & BOM JESUS DO GALHO & 2 & 0 \\
\hline CARATINGA & BUGRE & 0 & 0 \\
\hline CARATINGA & CARATINGA & 7 & 1 \\
\hline CARATINGA & CORREGO NOVO & 0 & 0 \\
\hline CARATINGA & DOM CAVATI & 0 & 0 \\
\hline CARATINGA & ENTRE FOLHAS & 1 & 0 \\
\hline CARATINGA & IAPU & 1 & 0 \\
\hline CARATINGA & IMBE DE MINAS & 0 & 0 \\
\hline CARATINGA & INHAPIM & 2 & 0 \\
\hline CARATINGA & IPABA & 0 & 0 \\
\hline CARATINGA & IPANEMA & 0 & 0 \\
\hline CARATINGA & PIEDADE DE CARATINGA & 0 & 0 \\
\hline CARATINGA & PINGO D AGUA & 1 & 0 \\
\hline CARATINGA & POCRANE & 2 & 0 \\
\hline CARATINGA & SANTA BARBARA DO LESTE & 0 & 0 \\
\hline CARATINGA & SANTA RITA DE MINAS & 1 & 0 \\
\hline CARATINGA & SAO DOMINGOS DAS DORES & 0 & 0 \\
\hline CARATINGA & SAO JOAO DO ORIENTE & 1 & 0 \\
\hline CARATINGA & SAO SEBASTIAO DO ANTA & 0 & 0 \\
\hline CARATINGA & TAPARUBA & 2 & 0 \\
\hline CARATINGA & TARUMIRIM & 3 & 0 \\
\hline CARATINGA & UBAPORANGA & 1 & 0 \\
\hline CARATINGA & VARGEM ALEGRE & 2 & 0 \\
\hline CAXAMBU & AIURUOCA & 1 & 0 \\
\hline CAXAMBU & ALAGOA & 0 & 0 \\
\hline CAXAMBU & BAEPENDI & 0 & 0 \\
\hline CAXAMBU & BOCAINA DE MINAS & 0 & 0 \\
\hline CAXAMBU & CARVALHOS & 1 & 0 \\
\hline CAXAMBU & CAXAMBU & 0 & 0 \\
\hline
\end{tabular}




\begin{tabular}{|c|c|c|c|}
\hline CAXAMBU & CONCEICAO DO RIO VERDE & 1 & 0 \\
\hline CAXAMBU & CRUZILIA & 3 & 0 \\
\hline CAXAMBU & ITAMONTE & 0 & 0 \\
\hline CAXAMBU & ITANHANDU & 1 & 0 \\
\hline CAXAMBU & JESUANIA & 0 & 0 \\
\hline CAXAMBU & LIBERDADE & 0 & 0 \\
\hline CAXAMBU & MINDURI & 0 & 0 \\
\hline CAXAMBU & OLIMPIO NORONHA & 0 & 0 \\
\hline CAXAMBU & PASSA QUATRO & 1 & 0 \\
\hline CAXAMBU & PASSA VINTE & 0 & 0 \\
\hline CAXAMBU & POUSO ALTO & 0 & 0 \\
\hline CAXAMBU & SAO LOURENCO & 2 & 0 \\
\hline CAXAMBU & SAO SEBASTIAO DO RIO VERDE & 0 & 0 \\
\hline CAXAMBU & SAO TOME DAS LETRAS & 0 & 0 \\
\hline CAXAMBU & SERITINGA & 0 & 0 \\
\hline CAXAMBU & SERRANOS & 1 & 0 \\
\hline CAXAMBU & SOLEDADE DE MINAS & 0 & 0 \\
\hline CEL. FABRICIANO & ANTONIO DIAS & 3 & 0 \\
\hline CEL. FABRICIANO & BELO ORIENTE & 2 & 0 \\
\hline CEL. FABRICIANO & BRAUNAS & 1 & 0 \\
\hline CEL. FABRICIANO & CORONEL FABRICIANO & 4 & 0 \\
\hline CEL. FABRICIANO & IPATINGA & 6 & 1 \\
\hline CEL. FABRICIANO & JAGUARAÇU & 0 & 0 \\
\hline CEL. FABRICIANO & JOANESIA & 0 & 0 \\
\hline CEL. FABRICIANO & MARLIERIA & 0 & 0 \\
\hline CEL. FABRICIANO & MESQUITA & 3 & 0 \\
\hline CEL. FABRICIANO & SANTANA DO PARAISO & 1 & 0 \\
\hline CEL. FABRICIANO & TIMOTEO & 5 & 1 \\
\hline CONSELHEIRO LAFAIETE & CARANAIBA & 0 & 0 \\
\hline CONSELHEIRO LAFAIETE & CASA GRANDE & 1 & 0 \\
\hline CONSELHEIRO LAFAIETE & CATAS ALTAS DA NORUEGA & 0 & 0 \\
\hline CONSELHEIRO LAFAIETE & CONGONHAS & 2 & 0 \\
\hline CONSELHEIRO LAFAIETE & CONSELHEIRO LAFAIETE & 6 & 1 \\
\hline CONSELHEIRO LAFAIETE & CRISTIANO OTONI & 0 & 0 \\
\hline CONSELHEIRO LAFAIETE & DESTERRO DE ENTRE RIOS & 1 & 0 \\
\hline CONSELHEIRO LAFAIETE & ENTRE RIOS DE MINAS & 0 & 0 \\
\hline CONSELHEIRO LAFAIETE & ITAVERAVA & 0 & 0 \\
\hline CONSELHEIRO LAFAIETE & JECEABA & 0 & 0 \\
\hline CONSELHEIRO LAFAIETE & LAMIM & 1 & 0 \\
\hline CONSELHEIRO LAFAIETE & OURO BRANCO & 1 & 0 \\
\hline CONSELHEIRO LAFAIETE & PIRANGA & 3 & 0 \\
\hline CONSELHEIRO LAFAIETE & QUELUZITO & 0 & 0 \\
\hline CONSELHEIRO LAFAIETE & RIO ESPERA & 0 & 0 \\
\hline CONSELHEIRO LAFAIETE & SANTANA DOS MONTES & 0 & 0 \\
\hline CONSELHEIRO LAFAIETE & SAO BRAS DO SUACUI & 0 & 0 \\
\hline
\end{tabular}




\begin{tabular}{|c|c|c|c|}
\hline CONSELHEIRO LAFAIETE & SENHORA DE OLIVEIRA & 0 & 0 \\
\hline CURVELO & AUGUSTO DE LIMA & 0 & 0 \\
\hline CURVELO & BUENOPOLIS & 1 & 0 \\
\hline CURVELO & CORINTO & 6 & 1 \\
\hline CURVELO & CURVELO & 5 & 1 \\
\hline CURVELO & FELIXLANDIA & 0 & 0 \\
\hline CURVELO & INIMUTABA & 1 & 0 \\
\hline CURVELO & JOAQUIM FELICIO & 0 & 0 \\
\hline CURVELO & LASSANCE & 1 & 0 \\
\hline CURVELO & MORRO DA GARCA & 1 & 0 \\
\hline CURVELO & PRESIDENTE JUSCELINO & 0 & 0 \\
\hline CURVELO & SANTO HIPOLITO & 0 & 0 \\
\hline CURVELO & TRES MARIAS & 0 & 0 \\
\hline DIAMANTINA & ALVORADA DE MINAS & 0 & 0 \\
\hline DIAMANTINA & ANGELANDIA & 1 & 0 \\
\hline DIAMANTINA & ARICANDUVA & 1 & 0 \\
\hline DIAMANTINA & CAPELINHA & 4 & 0 \\
\hline DIAMANTINA & CARBONITA & 0 & 0 \\
\hline DIAMANTINA & CONCEICAO DO MATO DENTRO & 4 & 0 \\
\hline DIAMANTINA & CONGONHAS DO NORTE & 0 & 0 \\
\hline DIAMANTINA & COUTO DE MAGALHAES DE MINAS & 1 & 0 \\
\hline DIAMANTINA & DATAS & 1 & 0 \\
\hline DIAMANTINA & DIAMANTINA & 4 & 0 \\
\hline DIAMANTINA & FELICIO DOS SANTOS & 0 & 0 \\
\hline DIAMANTINA & GOUVEA & 0 & 0 \\
\hline DIAMANTINA & ITAMARANDIBA & 4 & 0 \\
\hline DIAMANTINA & LEME DO PRADO & 1 & 0 \\
\hline DIAMANTINA & MINAS NOVAS & 5 & 1 \\
\hline DIAMANTINA & MONJOLOS & 0 & 0 \\
\hline DIAMANTINA & PRESIDENTE KUBITSCHEK & 2 & 0 \\
\hline DIAMANTINA & RIO VERMELHO & 4 & 0 \\
\hline DIAMANTINA & SANTO ANTONIO DO ITAMBE & 1 & 0 \\
\hline DIAMANTINA & SAO GONCALO DO RIO PRETO & 0 & 0 \\
\hline DIAMANTINA & SENADOR MODESTINO GONCALVES & 0 & 0 \\
\hline DIAMANTINA & SERRA AZUL DE MINAS & 0 & 0 \\
\hline DIAMANTINA & SERRO & 3 & 0 \\
\hline DIAMANTINA & TURMALINA & 1 & 0 \\
\hline DIAMANTINA & VEREDINHA & 0 & 0 \\
\hline DIVINÓPOLIS & ARAUJOS & 0 & 0 \\
\hline DIVINÓPOLIS & $\mathrm{ARCOS}$ & 1 & 0 \\
\hline DIVINÓPOLIS & BAMBUI & 0 & 0 \\
\hline DIVINÓPOLIS & CARMO DA MATA & 0 & 0 \\
\hline DIVINÓPOLIS & CARMO DO CAJURU & 7 & 1 \\
\hline DIVINÓPOLIS & CARMOPOLIS DE MINAS & 0 & 0 \\
\hline DIVINÓPOLIS & CLAUDIO & 1 & 0 \\
\hline
\end{tabular}




\begin{tabular}{|c|c|c|c|}
\hline DIVINÓPOLIS & CORREGO DANTA & 0 & 0 \\
\hline DIVINÓPOLIS & DIVINOPOLIS & 18 & 3 \\
\hline DIVINÓPOLIS & IGUATAMA & 0 & 0 \\
\hline DIVINÓPOLIS & ITAGUARA & 2 & 0 \\
\hline DIVINÓPOLIS & ITAPECERICA & 1 & 0 \\
\hline DIVINÓPOLIS & ITATIAIUCU & 0 & 0 \\
\hline DIVINÓPOLIS & ITAUNA & 9 & 1 \\
\hline DIVINÓPOLIS & JAPARAIBA & 1 & 0 \\
\hline DIVINÓPOLIS & LAGOA DA PRATA & 1 & 0 \\
\hline DIVINÓPOLIS & LUZ & 1 & 0 \\
\hline DIVINÓPOLIS & MEDEIROS & 0 & 0 \\
\hline DIVINÓPOLIS & MOEMA & 0 & 0 \\
\hline DIVINÓPOLIS & NOVA SERRANA & 5 & 1 \\
\hline DIVINÓPOLIS & OLIVEIRA & 1 & 0 \\
\hline DIVINÓPOLIS & PAINS & 0 & 0 \\
\hline DIVINÓPOLIS & PASSA TEMPO & 0 & 0 \\
\hline DIVINÓPOLIS & PEDRA DO INDAIA & 1 & 0 \\
\hline DIVINÓPOLIS & PERDIGAO & 1 & 0 \\
\hline DIVINÓPOLIS & PIRACEMA & 0 & 0 \\
\hline DIVINÓPOLIS & SANTO ANTONIO DO MONTE & 4 & 0 \\
\hline DIVINÓPOLIS & SAO GONCALO DO PARA & 0 & 0 \\
\hline DIVINÓPOLIS & SAO SEBASTIAO DO OESTE & 1 & 0 \\
\hline DIVINÓPOLIS & TAPIRAI & 0 & 0 \\
\hline GOVERNADOR VALADARES & ACUCENA & 0 & 0 \\
\hline GOVERNADOR VALADARES & AIMORES & 3 & 0 \\
\hline GOVERNADOR VALADARES & ALPERCATA & 1 & 0 \\
\hline GOVERNADOR VALADARES & CAPITAO ANDRADE & 1 & 0 \\
\hline GOVERNADOR VALADARES & CENTRAL DE MINAS & 1 & 0 \\
\hline GOVERNADOR VALADARES & CONSELHEIRO PENA & 1 & 0 \\
\hline GOVERNADOR VALADARES & COROACI & 0 & 0 \\
\hline GOVERNADOR VALADARES & CUPARAQUE & 1 & 0 \\
\hline GOVERNADOR VALADARES & DIVINO DAS LARANJEIRAS & 0 & 0 \\
\hline GOVERNADOR VALADARES & ENGENHEIRO CALDAS & 0 & 0 \\
\hline GOVERNADOR VALADARES & FERNANDES TOURINHO & 1 & 0 \\
\hline GOVERNADOR VALADARES & FREI INOCENCIO & 0 & 0 \\
\hline GOVERNADOR VALADARES & GALILEIA & 0 & 0 \\
\hline GOVERNADOR VALADARES & GOIABEIRA & 0 & 0 \\
\hline GOVERNADOR VALADARES & GOVERNADOR VALADARES & 16 & 3 \\
\hline GOVERNADOR VALADARES & ITABIRINHA & 1 & 0 \\
\hline GOVERNADOR VALADARES & ITANHOMI & 1 & 0 \\
\hline GOVERNADOR VALADARES & ITUETA & 0 & 0 \\
\hline GOVERNADOR VALADARES & MANTENA & 3 & 0 \\
\hline GOVERNADOR VALADARES & MARILAC & 1 & 0 \\
\hline GOVERNADOR VALADARES & MATHIAS LOBATO & 0 & 0 \\
\hline GOVERNADOR VALADARES & MENDES PIMENTEL & 1 & 0 \\
\hline
\end{tabular}




\begin{tabular}{|c|c|c|c|}
\hline GOVERNADOR VALADARES & NACIP RAYDAN & 0 & 0 \\
\hline GOVERNADOR VALADARES & NAQUE & 0 & 0 \\
\hline GOVERNADOR VALADARES & NOVA BELEM & 0 & 0 \\
\hline GOVERNADOR VALADARES & NOVA MODICA & 0 & 0 \\
\hline GOVERNADOR VALADARES & PERIQUITO & 0 & 0 \\
\hline GOVERNADOR VALADARES & RESPLENDOR & 0 & 0 \\
\hline GOVERNADOR VALADARES & SANTA EFIGENIA DE MINAS & 0 & 0 \\
\hline GOVERNADOR VALADARES & SANTA RITA DO ITUETO & 0 & 0 \\
\hline GOVERNADOR VALADARES & SAO FELIX DE MINAS & 0 & 0 \\
\hline GOVERNADOR VALADARES & SAO GERALDO DA PIEDADE & 0 & 0 \\
\hline GOVERNADOR VALADARES & SAO GERALDO DO BAIXIO & 0 & 0 \\
\hline GOVERNADOR VALADARES & SAO JOAO DO MANTENINHA & 0 & 0 \\
\hline GOVERNADOR VALADARES & SAO JOSE DA SAFIRA & 1 & 0 \\
\hline GOVERNADOR VALADARES & SAO JOSE DO DIVINO & 0 & 0 \\
\hline GOVERNADOR VALADARES & SARDOA & 0 & 0 \\
\hline GOVERNADOR VALADARES & SOBRALIA & 0 & 0 \\
\hline GOVERNADOR VALADARES & TUMIRITINGA & 0 & 0 \\
\hline GOVERNADOR VALADARES & VIRGOLANDIA & 0 & 0 \\
\hline GUANHÃES & AGUA BOA & 1 & 0 \\
\hline GUANHÃES & CANTAGALO & 0 & 0 \\
\hline GUANHÃES & CARMESIA & 0 & 0 \\
\hline GUANHÃES & COLUNA & 0 & 0 \\
\hline GUANHÃES & DIVINOLANDIA DE MINAS & 1 & 0 \\
\hline GUANHÃES & DOM JOAQUIM & 3 & 0 \\
\hline GUANHÃES & DORES DE GUANHAES & 0 & 0 \\
\hline GUANHÃES & FREI LAGONEGRO & 0 & 0 \\
\hline GUANHÃES & GONZAGA & 0 & 0 \\
\hline GUANHÃES & GUANHAES & 2 & 0 \\
\hline GUANHÃES & JOSE RAYDAN & 0 & 0 \\
\hline GUANHÃES & MATERLANDIA & 0 & 0 \\
\hline GUANHÃES & PAULISTAS & 1 & 0 \\
\hline GUANHÃES & PECANHA & 2 & 0 \\
\hline GUANHÃES & SABINOPOLIS & 2 & 0 \\
\hline GUANHÃES & SANTA MARIA DO SUACUI & 1 & 0 \\
\hline GUANHÃES & SAO JOAO EVANGELISTA & 3 & 0 \\
\hline GUANHÃES & SAO JOSE DO JACURI & 1 & 0 \\
\hline GUANHÃES & SAO PEDRO DO SUACUI & 0 & 0 \\
\hline GUANHÃES & SAO SEBASTIAO DO MARANHAO & 0 & 0 \\
\hline GUANHÃES & SENHORA DO PORTO & 1 & 0 \\
\hline GUANHÃES & VIRGINOPOLIS & 0 & 0 \\
\hline ITAJUBÁ & BRASOPOLIS & 2 & 0 \\
\hline ITAJUBÁ & CARMO DE MINAS & 2 & 0 \\
\hline ITAJUBÁ & CONCEICAO DAS PEDRAS & 1 & 0 \\
\hline ITAJUBÁ & CONCEICAO DOS OUROS & 0 & 0 \\
\hline ITAJUBÁ & CONSOLACAO & 1 & 0 \\
\hline
\end{tabular}




\begin{tabular}{|c|c|c|c|}
\hline ITAJUBÁ & CRISTINA & 1 & 0 \\
\hline ITAJUBÁ & DELFIM MOREIRA & 1 & 0 \\
\hline ITAJUBÁ & DOM VICOSO & 1 & 0 \\
\hline ITAJUBÁ & GONCALVES & 2 & 0 \\
\hline ITAJUBÁ & ITAJUBA & 3 & 0 \\
\hline ITAJUBÁ & MARIA DA FE & 1 & 0 \\
\hline ITAJUBÁ & MARMELOPOLIS & 0 & 0 \\
\hline ITAJUBÁ & NATERCIA & 1 & 0 \\
\hline ITAJUBÁ & PARAISOPOLIS & 0 & 0 \\
\hline ITAJUBÁ & PEDRALVA & 3 & 0 \\
\hline ITAJUBÁ & PIRANGUCU & 0 & 0 \\
\hline ITAJUBÁ & PIRANGUINHO & 1 & 0 \\
\hline ITAJUBÁ & SAO JOSE DO ALEGRE & 0 & 0 \\
\hline ITAJUBÁ & SAPUCAI-MIRIM & 2 & 0 \\
\hline ITAJUBÁ & VIRGINIA & 2 & 0 \\
\hline ITAJUBÁ & WENCESLAU BRAZ & 0 & 0 \\
\hline ITUIUTABA & CACHOEIRA DOURADA & 1 & 0 \\
\hline ITUIUTABA & CANAPOLIS & 0 & 0 \\
\hline ITUIUTABA & CAPINOPOLIS & 0 & 0 \\
\hline ITUIUTABA & CENTRALINA & 0 & 0 \\
\hline ITUIUTABA & GURINHATA & 2 & 0 \\
\hline ITUIUTABA & IPIACU & 0 & 0 \\
\hline ITUIUTABA & ITUIUTABA & 5 & 1 \\
\hline ITUIUTABA & SANTA VITORIA & 6 & 1 \\
\hline JANAUBA & CATUTI & 0 & 0 \\
\hline JANAUBA & ESPINOSA & 1 & 0 \\
\hline JANAUBA & GAMELEIRAS & 1 & 0 \\
\hline JANAUBA & JAIBA & 1 & 0 \\
\hline JANAUBA & JANAUBA & 4 & 0 \\
\hline JANAUBA & MAMONAS & 0 & 0 \\
\hline JANAUBA & MATO VERDE & 2 & 0 \\
\hline JANAUBA & MONTE AZUL & 1 & 0 \\
\hline JANAUBA & MONTEZUMA & 1 & 0 \\
\hline JANAUBA & NOVA PORTEIRINHA & 0 & 0 \\
\hline JANAUBA & PAI PEDRO & 0 & 0 \\
\hline JANAUBA & PORTEIRINHA & 0 & 0 \\
\hline JANAUBA & RIACHO DOS MACHADOS & 0 & 0 \\
\hline JANAUBA & RIO PARDO DE MINAS & 2 & 0 \\
\hline JANAUBA & SANTO ANTONIO DO RETIRO & 0 & 0 \\
\hline JANAUBA & SERRANOPOLIS DE MINAS & 0 & 0 \\
\hline JANAUBA & VERDELANDIA & 3 & 0 \\
\hline JANUARIA & BONITO DE MINAS & 2 & 0 \\
\hline JANUARIA & CHAPADA GAUCHA & 5 & 1 \\
\hline JANUARIA & CONEGO MARINHO & 2 & 0 \\
\hline JANUARIA & IBIRACATU & 1 & 0 \\
\hline
\end{tabular}




\begin{tabular}{|c|c|c|c|}
\hline JANUARIA & ICARAI DE MINAS & 1 & 0 \\
\hline JANUARIA & ITACARAMBI & 2 & 0 \\
\hline JANUARIA & JANUARIA & 17 & 3 \\
\hline JANUARIA & JUVENILIA & 3 & 0 \\
\hline JANUARIA & MANGA & 1 & 0 \\
\hline JANUARIA & MATIAS CARDOSO & 0 & 0 \\
\hline JANUARIA & MIRAVANIA & 0 & 0 \\
\hline JANUARIA & MONTALVANIA & 1 & 0 \\
\hline JANUARIA & PEDRAS DE MARIA DA CRUZ & 2 & 0 \\
\hline JANUARIA & PINTOPOLIS & 1 & 0 \\
\hline JANUARIA & SAO FRANCISCO & 9 & 1 \\
\hline JANUARIA & SAO JOAO DAS MISSOES & 1 & 0 \\
\hline JANUARIA & UBAI & 0 & 0 \\
\hline JANUARIA & URUCUIA & 1 & 0 \\
\hline JANUARIA & VARZELANDIA & 2 & 0 \\
\hline JUIZ DE FORA & ARANTINA & 0 & 0 \\
\hline JUIZ DE FORA & BELMIRO BRAGA & 0 & 0 \\
\hline JUIZ DE FORA & BICAS & 0 & 0 \\
\hline JUIZ DE FORA & BOM JARDIM DE MINAS & 0 & 0 \\
\hline JUIZ DE FORA & CHACARA & 1 & 0 \\
\hline JUIZ DE FORA & CHIADOR & 1 & 0 \\
\hline JUIZ DE FORA & CORONEL PACHECO & 0 & 0 \\
\hline JUIZ DE FORA & DESCOBERTO & 1 & 0 \\
\hline JUIZ DE FORA & EWBANK DA CAMARA & 0 & 0 \\
\hline JUIZ DE FORA & GOIANA & 0 & 0 \\
\hline JUIZ DE FORA & GUARARA & 1 & 0 \\
\hline JUIZ DE FORA & JUIZ DE FORA & 16 & 3 \\
\hline JUIZ DE FORA & LIMA DUARTE & 2 & 0 \\
\hline JUIZ DE FORA & MAR DE ESPANHA & 0 & 0 \\
\hline JUIZ DE FORA & MARIPA DE MINAS & 1 & 0 \\
\hline JUIZ DE FORA & MATIAS BARBOSA & 2 & 0 \\
\hline JUIZ DE FORA & OLARIA & 1 & 0 \\
\hline JUIZ DE FORA & PEDRO TEIXEIRA & 1 & 0 \\
\hline JUIZ DE FORA & PEQUERI & 1 & 0 \\
\hline JUIZ DE FORA & PIAU & 0 & 0 \\
\hline JUIZ DE FORA & RIO NOVO & 0 & 0 \\
\hline JUIZ DE FORA & RIO PRETO & 0 & 0 \\
\hline JUIZ DE FORA & ROCHEDO DE MINAS & 0 & 0 \\
\hline JUIZ DE FORA & SANTA BARBARA DO MONTE VERDE & 1 & 0 \\
\hline JUIZ DE FORA & SANTA RITA DE JACUTINGA & 1 & 0 \\
\hline JUIZ DE FORA & SANTANA DO DESERTO & 0 & 0 \\
\hline JUIZ DE FORA & SANTOS DUMONT & 3 & 0 \\
\hline JUIZ DE FORA & SAO JOAO NEPOMUCENO & 0 & 0 \\
\hline JUIZ DE FORA & SENADOR CORTES & 0 & 0 \\
\hline JUIZ DE FORA & SIMAO PEREIRA & 1 & 0 \\
\hline
\end{tabular}




\begin{tabular}{|c|c|c|c|}
\hline LEOPOLDINA & ALEM PARAIBA & 1 & 0 \\
\hline LEOPOLDINA & ARGIRITA & 0 & 0 \\
\hline LEOPOLDINA & CATAGUASES & 5 & 1 \\
\hline LEOPOLDINA & ESTRELA DALVA & 1 & 0 \\
\hline LEOPOLDINA & ITAMARATI DE MINAS & 0 & 0 \\
\hline LEOPOLDINA & LEOPOLDINA & 5 & 1 \\
\hline LEOPOLDINA & PIRAPETINGA & 1 & 0 \\
\hline LEOPOLDINA & RECREIO & 1 & 0 \\
\hline LEOPOLDINA & SANTO ANTONIO DO AVENTUREIRO & 0 & 0 \\
\hline LEOPOLDINA & VOLTA GRANDE & 0 & 0 \\
\hline MANHUAÇU & ALTO JEQUITIBA & 1 & 0 \\
\hline MANHUAÇU & CAPUTIRA & 0 & 0 \\
\hline MANHUAÇU & CHALE & 3 & 0 \\
\hline MANHUAÇU & CONCEICAO DE IPANEMA & 1 & 0 \\
\hline MANHUAÇU & DURANDE & 1 & 0 \\
\hline MANHUAÇU & LAJINHA & 2 & 0 \\
\hline MANHUAÇU & LUISBURGO & 0 & 0 \\
\hline MANHUAÇU & MANHUACU & 16 & 3 \\
\hline MANHUAÇU & MANHUMIRIM & 1 & 0 \\
\hline MANHUAÇU & MARTINS SOARES & 0 & 0 \\
\hline MANHUAÇU & MATIPO & 7 & 1 \\
\hline MANHUAÇU & MUTUM & 7 & 1 \\
\hline MANHUAÇU & REDUTO & 1 & 0 \\
\hline MANHUAÇU & SANTA MARGARIDA & 5 & 1 \\
\hline MANHUAÇU & SANTANA DO MANHUACU & 2 & 0 \\
\hline MANHUAÇU & SAO JOAO DO MANHUACU & 1 & 0 \\
\hline MANHUAÇU & SAO JOSE DO MANTIMENTO & 2 & 0 \\
\hline MANHUAÇU & SIMONESIA & 2 & 0 \\
\hline METROPOLITANA A & BARAO DE COCAIS & 0 & 0 \\
\hline METROPOLITANA A & BELO HORIZONTE & 35 & 7 \\
\hline METROPOLITANA A & BELO VALE & 1 & 0 \\
\hline METROPOLITANA A & BOM JESUS DO AMPARO & 3 & 0 \\
\hline METROPOLITANA A & BONFIM & 0 & 0 \\
\hline METROPOLITANA A & BRUMADINHO & 0 & 0 \\
\hline METROPOLITANA A & CAETE & 2 & 0 \\
\hline METROPOLITANA A & CATAS ALTAS & 1 & 0 \\
\hline METROPOLITANA A & CRUCILANDIA & 0 & 0 \\
\hline METROPOLITANA A & MOEDA & 0 & 0 \\
\hline METROPOLITANA A & NOVA LIMA & 2 & 0 \\
\hline METROPOLITANA A & NOVA UNIAO & 1 & 0 \\
\hline METROPOLITANA A & PIEDADE DOS GERAIS & 0 & 0 \\
\hline METROPOLITANA A & RAPOSOS & 1 & 0 \\
\hline METROPOLITANA A & RIO ACIMA & 0 & 0 \\
\hline METROPOLITANA A & RIO MANSO & 1 & 0 \\
\hline METROPOLITANA A & SABARA & 9 & 1 \\
\hline
\end{tabular}




\begin{tabular}{|c|c|c|c|}
\hline METROPOLITANA A & SANTA BARBARA & 0 & 0 \\
\hline METROPOLITANA B & BELO HORIZONTE & 60 & 12 \\
\hline METROPOLITANA B & BETIM & 29 & 6 \\
\hline METROPOLITANA B & CONTAGEM & 44 & 8 \\
\hline METROPOLITANA B & ESMERALDAS & 7 & 1 \\
\hline METROPOLITANA B & IBIRITE & 12 & 2 \\
\hline METROPOLITANA B & IGARAPE & 4 & 0 \\
\hline METROPOLITANA B & JUATUBA & 1 & 0 \\
\hline METROPOLITANA B & MARIO CAMPOS & 2 & 0 \\
\hline METROPOLITANA B & MATEUS LEME & 2 & 0 \\
\hline METROPOLITANA B & SAO JOAQUIM DE BICAS & 2 & 0 \\
\hline METROPOLITANA B & SARZEDO & 1 & 0 \\
\hline METROPOLITANA C & BELO HORIZONTE & 45 & 8 \\
\hline METROPOLITANA C & CONFINS & 0 & 0 \\
\hline METROPOLITANA C & JABOTICATUBAS & 1 & 0 \\
\hline METROPOLITANA C & LAGOA SANTA & 7 & 1 \\
\hline METROPOLITANA C & MORRO DO PILAR & 0 & 0 \\
\hline METROPOLITANA C & PEDRO LEOPOLDO & 6 & 1 \\
\hline METROPOLITANA C & RIBEIRAO DAS NEVES & 59 & 11 \\
\hline METROPOLITANA C & SANTA LUZIA & 13 & 2 \\
\hline METROPOLITANA C & SANTANA DO RIACHO & 2 & 0 \\
\hline METROPOLITANA C & SAO JOSE DA LAPA & 2 & 0 \\
\hline METROPOLITANA C & TAQUARACU DE MINAS & 0 & 0 \\
\hline METROPOLITANA C & VESPASIANO & 6 & 1 \\
\hline MONTE CARMELO & ABADIA DOS DOURADOS & 0 & 0 \\
\hline MONTE CARMELO & CASCALHO RICO & 1 & 0 \\
\hline MONTE CARMELO & COROMANDEL & 2 & 0 \\
\hline MONTE CARMELO & DOURADOQUARA & 0 & 0 \\
\hline MONTE CARMELO & ESTRELA DO SUL & 0 & 0 \\
\hline MONTE CARMELO & GRUPIARA & 0 & 0 \\
\hline MONTE CARMELO & MONTE CARMELO & 5 & 1 \\
\hline MONTE CARMELO & ROMARIA & 0 & 0 \\
\hline MONTES CLAROS & BOCAIUVA & 1 & 0 \\
\hline MONTES CLAROS & BOTUMIRIM & 1 & 0 \\
\hline MONTES CLAROS & BRASILIA DE MINAS & 3 & 0 \\
\hline MONTES CLAROS & CAMPO AZUL & 0 & 0 \\
\hline MONTES CLAROS & CAPITAO ENEAS & 0 & 0 \\
\hline MONTES CLAROS & CLARO DOS POCOES & 0 & 0 \\
\hline MONTES CLAROS & CORACAO DE JESUS & 2 & 0 \\
\hline MONTES CLAROS & CRISTALIA & 0 & 0 \\
\hline MONTES CLAROS & ENGENHEIRO NAVARRO & 0 & 0 \\
\hline MONTES CLAROS & FRANCISCO DUMONT & 0 & 0 \\
\hline MONTES CLAROS & FRANCISCO SA & 1 & 0 \\
\hline MONTES CLAROS & GLAUCILANDIA & 0 & 0 \\
\hline MONTES CLAROS & GRAO MOGOL & 3 & 0 \\
\hline
\end{tabular}




\begin{tabular}{|c|c|c|c|}
\hline MONTES CLAROS & GUARACIAMA & 1 & 0 \\
\hline MONTES CLAROS & ITACAMBIRA & 0 & 0 \\
\hline MONTES CLAROS & JAPONVAR & 0 & 0 \\
\hline MONTES CLAROS & JOSENOPOLIS & 0 & 0 \\
\hline MONTES CLAROS & JURAMENTO & 2 & 0 \\
\hline MONTES CLAROS & LONTRA & 0 & 0 \\
\hline MONTES CLAROS & LUISLANDIA & 0 & 0 \\
\hline MONTES CLAROS & MIRABELA & 1 & 0 \\
\hline MONTES CLAROS & MONTES CLAROS & 7 & 1 \\
\hline MONTES CLAROS & OLHOS-D AGUA & 0 & 0 \\
\hline MONTES CLAROS & PADRE CARVALHO & 1 & 0 \\
\hline MONTES CLAROS & PATIS & 0 & 0 \\
\hline MONTES CLAROS & SAO JOAO DA LAGOA & 0 & 0 \\
\hline MONTES CLAROS & SAO JOAO DA PONTE & 1 & 0 \\
\hline MONTES CLAROS & SAO JOAO DO PACUI & 0 & 0 \\
\hline MONTES CLAROS & SAO JOAO DO PARAISO & 2 & 0 \\
\hline MONTES CLAROS & VARGEM GRANDE DO RIO PARDO & 0 & 0 \\
\hline MURIAÉ & ANTONIO PRADO DE MINAS & 0 & 0 \\
\hline MURIAÉ & BARAO DE MONTE ALTO & 0 & 0 \\
\hline MURIAÉ & EUGENOPOLIS & 1 & 0 \\
\hline MURIAÉ & LARANJAL & 0 & 0 \\
\hline MURIAÉ & MIRADOURO & 0 & 0 \\
\hline MURIAÉ & MIRAI & 0 & 0 \\
\hline MURIAÉ & MURIAE & 1 & 0 \\
\hline MURIAÉ & PALMA & 1 & 0 \\
\hline MURIAÉ & PATROCINIO DO MURIAE & 0 & 0 \\
\hline MURIAÉ & ROSARIO DA LIMEIRA & 1 & 0 \\
\hline MURIAÉ & SANTANA DE CATAGUASES & 0 & 0 \\
\hline MURIAÉ & SAO FRANCISCO DO GLORIA & 0 & 0 \\
\hline MURIAÉ & SAO SEBASTIAO DA VARGEM ALEGRE & 0 & 0 \\
\hline MURIAÉ & VIEIRAS & 1 & 0 \\
\hline NOVA ERA & BELA VISTA DE MINAS & 1 & 0 \\
\hline NOVA ERA & DIONISIO & 0 & 0 \\
\hline NOVA ERA & FERROS & 2 & 0 \\
\hline NOVA ERA & ITABIRA & 6 & 1 \\
\hline NOVA ERA & ITAMBE DO MATO DENTRO & 0 & 0 \\
\hline NOVA ERA & JOAO MONLEVADE & 7 & 1 \\
\hline NOVA ERA & NOVA ERA & 1 & 0 \\
\hline NOVA ERA & PASSABEM & 1 & 0 \\
\hline NOVA ERA & RIO PIRACICABA & 2 & 0 \\
\hline NOVA ERA & SANTA MARIA DE ITABIRA & 1 & 0 \\
\hline NOVA ERA & SANTO ANTONIO DO RIO ABAIXO & 0 & 0 \\
\hline NOVA ERA & SAO DOMINGOS DO PRATA & 3 & 0 \\
\hline NOVA ERA & SAO GONCALO DO RIO ABAIXO & 0 & 0 \\
\hline NOVA ERA & SAO JOSE DO GOIABAL & 0 & 0 \\
\hline
\end{tabular}




\begin{tabular}{|c|c|c|c|}
\hline NOVA ERA & SAO SEBASTIAO DO RIO PRETO & 0 & 0 \\
\hline OURO PRETO & ACAIACA & 1 & 0 \\
\hline OURO PRETO & DIOGO DE VASCONCELOS & 0 & 0 \\
\hline OURO PRETO & ITABIRITO & 2 & 0 \\
\hline OURO PRETO & MARIANA & 9 & 1 \\
\hline OURO PRETO & OURO PRETO & 8 & 1 \\
\hline PARA DE MINAS & ABAETE & 0 & 0 \\
\hline PARA DE MINAS & BIQUINHAS & 0 & 0 \\
\hline PARA DE MINAS & BOM DESPACHO & 1 & 0 \\
\hline PARA DE MINAS & CEDRO DO ABAETE & 0 & 0 \\
\hline PARA DE MINAS & CONCEICAO DO PARA & 0 & 0 \\
\hline PARA DE MINAS & DORES DO INDAIA & 0 & 0 \\
\hline PARA DE MINAS & ESTRELA DO INDAIA & 2 & 0 \\
\hline PARA DE MINAS & FLORESTAL & 2 & 0 \\
\hline PARA DE MINAS & IGARATINGA & 1 & 0 \\
\hline PARA DE MINAS & LEANDRO FERREIRA & 1 & 0 \\
\hline PARA DE MINAS & MARTINHO CAMPOS & 0 & 0 \\
\hline PARA DE MINAS & MORADA NOVA DE MINAS & 1 & 0 \\
\hline PARA DE MINAS & ONCA DE PITANGUI & 2 & 0 \\
\hline PARA DE MINAS & PAINEIRAS & 0 & 0 \\
\hline PARA DE MINAS & PARA DE MINAS & 12 & 2 \\
\hline PARA DE MINAS & PEQUI & 0 & 0 \\
\hline PARA DE MINAS & PITANGUI & 2 & 0 \\
\hline PARA DE MINAS & QUARTEL GERAL & 0 & 0 \\
\hline PARA DE MINAS & SAO JOSE DA VARGINHA & 1 & 0 \\
\hline PARA DE MINAS & SERRA DA SAUDADE & 0 & 0 \\
\hline PARACATU & BRASILANDIA DE MINAS & 1 & 0 \\
\hline PARACATU & GUARDA-MOR & 0 & 0 \\
\hline PARACATU & JOAO PINHEIRO & 2 & 0 \\
\hline PARACATU & PARACATU & 5 & 1 \\
\hline PARACATU & VAZANTE & 0 & 0 \\
\hline PASSOS & ALPINOPOLIS & 0 & 0 \\
\hline PASSOS & BOM JESUS DA PENHA & 0 & 0 \\
\hline PASSOS & CAPITOLIO & 2 & 0 \\
\hline PASSOS & CARMO DO RIO CLARO & 0 & 0 \\
\hline PASSOS & CORREGO FUNDO & 0 & 0 \\
\hline PASSOS & DELFINOPOLIS & 0 & 0 \\
\hline PASSOS & DORESOPOLIS & 0 & 0 \\
\hline PASSOS & FORMIGA & 3 & 0 \\
\hline PASSOS & FORTALEZA DE MINAS & 0 & 0 \\
\hline PASSOS & PASSOS & 5 & 1 \\
\hline PASSOS & PIMENTA & 0 & 0 \\
\hline PASSOS & PIUMHI & 0 & 0 \\
\hline PASSOS & SAO JOAO BATISTA DO GLORIA & 0 & 0 \\
\hline PASSOS & SAO JOSE DA BARRA & 1 & 0 \\
\hline
\end{tabular}




\begin{tabular}{|c|c|c|c|}
\hline PASSOS & SAO ROQUE DE MINAS & 3 & 0 \\
\hline PASSOS & VARGEM BONITA & 1 & 0 \\
\hline PATOS DE MINAS & ARAPUA & 0 & 0 \\
\hline PATOS DE MINAS & CARMO DO PARANAIBA & 1 & 0 \\
\hline PATOS DE MINAS & LAGAMAR & 3 & 0 \\
\hline PATOS DE MINAS & LAGOA FORMOSA & 0 & 0 \\
\hline PATOS DE MINAS & LAGOA GRANDE & 0 & 0 \\
\hline PATOS DE MINAS & MATUTINA & 0 & 0 \\
\hline PATOS DE MINAS & PATOS DE MINAS & 3 & 0 \\
\hline PATOS DE MINAS & PRESIDENTE OLEGARIO & 2 & 0 \\
\hline PATOS DE MINAS & RIO PARANAIBA & 2 & 0 \\
\hline PATOS DE MINAS & SANTA ROSA DA SERRA & 1 & 0 \\
\hline PATOS DE MINAS & SAO GONCALO DO ABAETE & 0 & 0 \\
\hline PATOS DE MINAS & SAO GOTARDO & 7 & 1 \\
\hline PATOS DE MINAS & TIROS & 0 & 0 \\
\hline PATOS DE MINAS & VARJAO DE MINAS & 0 & 0 \\
\hline PATROCÍNIO & CRUZEIRO DA FORTALEZA & 0 & 0 \\
\hline PATROCÍNIO & GUIMARANIA & 0 & 0 \\
\hline PATROCÍNIO & IBIA & 2 & 0 \\
\hline PATROCÍNIO & IRAI DE MINAS & 0 & 0 \\
\hline PATROCÍNIO & PATROCINIO & 9 & 1 \\
\hline PATROCÍNIO & PERDIZES & 2 & 0 \\
\hline PATROCÍNIO & SERRA DO SALITRE & 0 & 0 \\
\hline PIRAPORA & BURITIZEIRO & 3 & 0 \\
\hline PIRAPORA & IBIAI & 1 & 0 \\
\hline PIRAPORA & JEQUITAI & 1 & 0 \\
\hline PIRAPORA & LAGOA DOS PATOS & 1 & 0 \\
\hline PIRAPORA & PIRAPORA & 3 & 0 \\
\hline PIRAPORA & PONTO CHIQUE & 1 & 0 \\
\hline PIRAPORA & SANTA FE DE MINAS & 0 & 0 \\
\hline PIRAPORA & SAO ROMAO & 1 & 0 \\
\hline PIRAPORA & VARZEA DA PALMA & 2 & 0 \\
\hline POÇOS DE CALDAS & ALTEROSA & 0 & 0 \\
\hline POÇOS DE CALDAS & ANDRADAS & 4 & 0 \\
\hline POÇOS DE CALDAS & AREADO & 1 & 0 \\
\hline POÇOS DE CALDAS & BANDEIRA DO SUL & 1 & 0 \\
\hline POÇOS DE CALDAS & BOTELHOS & 0 & 0 \\
\hline POÇOS DE CALDAS & CABO VERDE & 0 & 0 \\
\hline POÇOS DE CALDAS & CALDAS & 0 & 0 \\
\hline POCOS DE CALDAS & CAMPESTRE & 2 & 0 \\
\hline POÇOS DE CALDAS & CONCEICAO DA APARECIDA & 0 & 0 \\
\hline POÇOS DE CALDAS & DIVISA NOVA & 0 & 0 \\
\hline POÇOS DE CALDAS & IBITIURA DE MINAS & 0 & 0 \\
\hline POÇOS DE CALDAS & MONTE BELO & 1 & 0 \\
\hline POÇOS DE CALDAS & MUZAMBINHO & 0 & 0 \\
\hline
\end{tabular}




\begin{tabular}{|c|c|c|c|}
\hline POÇOS DE CALDAS & NOVA RESENDE & 1 & 0 \\
\hline POÇOS DE CALDAS & POCOS DE CALDAS & 3 & 0 \\
\hline POÇOS DE CALDAS & SANTA RITA DE CALDAS & 1 & 0 \\
\hline POÇOS DE CALDAS & SERRANIA & 1 & 0 \\
\hline PONTE NOVA & ABRE CAMPO & 0 & 0 \\
\hline PONTE NOVA & ALVINOPOLIS & 2 & 0 \\
\hline PONTE NOVA & AMPARO DO SERRA & 0 & 0 \\
\hline PONTE NOVA & ARAPONGA & 2 & 0 \\
\hline PONTE NOVA & BARRA LONGA & 1 & 0 \\
\hline PONTE NOVA & CAJURI & 0 & 0 \\
\hline PONTE NOVA & CANAA & 0 & 0 \\
\hline PONTE NOVA & DOM SILVERIO & 0 & 0 \\
\hline PONTE NOVA & GUARACIABA & 0 & 0 \\
\hline PONTE NOVA & JEQUERI & 2 & 0 \\
\hline PONTE NOVA & ORATORIOS & 0 & 0 \\
\hline PONTE NOVA & PEDRA BONITA & 1 & 0 \\
\hline PONTE NOVA & PEDRA DO ANTA & 1 & 0 \\
\hline PONTE NOVA & PIEDADE DE PONTE NOVA & 0 & 0 \\
\hline PONTE NOVA & PONTE NOVA & 1 & 0 \\
\hline PONTE NOVA & PORTO FIRME & 0 & 0 \\
\hline PONTE NOVA & RAUL SOARES & 2 & 0 \\
\hline PONTE NOVA & RIO CASCA & 0 & 0 \\
\hline PONTE NOVA & RIO DOCE & 1 & 0 \\
\hline PONTE NOVA & SANTA CRUZ DO ESCALVADO & 0 & 0 \\
\hline PONTE NOVA & SANTO ANTONIO DO GRAMA & 0 & 0 \\
\hline PONTE NOVA & SAO MIGUEL DO ANTA & 0 & 0 \\
\hline PONTE NOVA & SAO PEDRO DOS FERROS & 0 & 0 \\
\hline PONTE NOVA & SEM-PEIXE & 0 & 0 \\
\hline PONTE NOVA & SERICITA & 0 & 0 \\
\hline PONTE NOVA & TEIXEIRAS & 1 & 0 \\
\hline PONTE NOVA & URUCANIA & 1 & 0 \\
\hline PONTE NOVA & VERMELHO NOVO & 0 & 0 \\
\hline PONTE NOVA & VICOSA & 4 & 0 \\
\hline POUSO ALEGRE & ALBERTINA & 1 & 0 \\
\hline POUSO ALEGRE & BOM REPOUSO & 0 & 0 \\
\hline POUSO ALEGRE & BORDA DA MATA & 2 & 0 \\
\hline POUSO ALEGRE & BUENO BRANDAO & 0 & 0 \\
\hline POUSO ALEGRE & CACHOEIRA DE MINAS & 1 & 0 \\
\hline POUSO ALEGRE & CAMANDUCAIA & 3 & 0 \\
\hline POUSO ALEGRE & CAMBUI & 1 & 0 \\
\hline POUSO ALEGRE & CAREACU & 0 & 0 \\
\hline POUSO ALEGRE & CONGONHAL & 0 & 0 \\
\hline POUSO ALEGRE & CORREGO DO BOM JESUS & 0 & 0 \\
\hline POUSO ALEGRE & ESPIRITO SANTO DO DOURADO & 0 & 0 \\
\hline POUSO ALEGRE & ESTIVA & 2 & 0 \\
\hline
\end{tabular}




\begin{tabular}{|c|c|c|c|}
\hline POUSO ALEGRE & EXTREMA & 1 & 0 \\
\hline POUSO ALEGRE & HELIODORA & 0 & 0 \\
\hline POUSO ALEGRE & INCONFIDENTES & 0 & 0 \\
\hline POUSO ALEGRE & IPUIUNA & 0 & 0 \\
\hline POUSO ALEGRE & ITAPEVA & 2 & 0 \\
\hline POUSO ALEGRE & JACUTINGA & 1 & 0 \\
\hline POUSO ALEGRE & MONTE SIAO & 2 & 0 \\
\hline POUSO ALEGRE & MUNHOZ & 0 & 0 \\
\hline POUSO ALEGRE & OURO FINO & 3 & 0 \\
\hline POUSO ALEGRE & POUSO ALEGRE & 3 & 0 \\
\hline POUSO ALEGRE & SANTA RITA DO SAPUCAI & 5 & 1 \\
\hline POUSO ALEGRE & SAO JOAO DA MATA & 0 & 0 \\
\hline POUSO ALEGRE & SAO SEBASTIAO DA BELA VISTA & 0 & 0 \\
\hline POUSO ALEGRE & SENADOR AMARAL & 1 & 0 \\
\hline POUSO ALEGRE & SENADOR JOSE BENTO & 0 & 0 \\
\hline POUSO ALEGRE & SILVIANOPOLIS & 0 & 0 \\
\hline POUSO ALEGRE & TOCOS DO MOJI & 0 & 0 \\
\hline POUSO ALEGRE & TOLEDO & 2 & 0 \\
\hline SÃO JOÃO DEL REI & BOM SUCESSO & 0 & 0 \\
\hline SÃO JOÃO DEL REI & CARRANCAS & 0 & 0 \\
\hline SÃO JOÃO DEL REI & CONCEICAO DA BARRA DE MINAS & 0 & 0 \\
\hline SÃO JOÃO DEL REI & CORONEL XAVIER CHAVES & 0 & 0 \\
\hline SÃO JOÃO DEL REI & DORES DE CAMPOS & 0 & 0 \\
\hline SÃO JOÃO DEL REI & IBITURUNA & 0 & 0 \\
\hline SÃO JOÃO DEL REI & IJACI & 1 & 0 \\
\hline SÃO JOÃO DEL REI & INGAI & 0 & 0 \\
\hline SÃO JOÃO DEL REI & ITUMIRIM & 0 & 0 \\
\hline SÃO JOÃO DEL REI & ITUTINGA & 1 & 0 \\
\hline SÃO JOÃO DEL REI & LAGOA DOURADA & 0 & 0 \\
\hline SÃO JOÃO DEL REI & NAZARENO & 0 & 0 \\
\hline SÃO JOÃO DEL REI & PRADOS & 0 & 0 \\
\hline SÃO JOÃO DEL REI & RESENDE COSTA & 2 & 0 \\
\hline SÃO JOÃO DEL REI & RITAPOLIS & 0 & 0 \\
\hline SÃO JOÃO DEL REI & SANTA CRUZ DE MINAS & 0 & 0 \\
\hline SÃO JOÃO DEL REI & SAO JOAO DEL REI & 5 & 1 \\
\hline SÃO JOÃO DEL REI & SAO TIAGO & 1 & 0 \\
\hline SÃO JOÃO DEL REI & TIRADENTES & 0 & 0 \\
\hline SÃO SEBASTIÃO DO PARAÍSO & ARCEBURGO & 0 & 0 \\
\hline SÃO SEBASTIÃO DO PARAÍSO & CAPETINGA & 0 & 0 \\
\hline SÃO SEBASTIÃO DO PARAIISO & CASSIA & 2 & 0 \\
\hline SÃO SEBASTIÃO DO PARAÍSO & CLARAVAL & 0 & 0 \\
\hline SÃO SEBASTIÃO DO PARAÍSO & GUARANESIA & 0 & 0 \\
\hline SÃO SEBASTIÃO DO PARAÍSO & GUAXUPE & 3 & 0 \\
\hline SÃO SEBASTIÃO DO PARAÍSO & IBIRACI & 3 & 0 \\
\hline SÃO SEBASTIÃO DO PARAÍSO & ITAMOGI & 0 & 0 \\
\hline
\end{tabular}




\begin{tabular}{|c|c|c|c|}
\hline SÃO SEBASTIÃO DO PARAÍSO & ITAU DE MINAS & 0 & 0 \\
\hline SÃO SEBASTIÃO DO PARAÍSO & JACUI & 0 & 0 \\
\hline SÃO SEBASTIÃO DO PARAÍSO & JURUAIA & 2 & 0 \\
\hline SÃO SEBASTIÃO DO PARAÍSO & MONTE SANTO DE MINAS & 1 & 0 \\
\hline SÃO SEBASTIÃO DO PARAÍSO & PRATAPOLIS & 0 & 0 \\
\hline SÃO SEBASTIÃO DO PARAÍSO & SAO PEDRO DA UNIAO & 1 & 0 \\
\hline SÃO SEBASTIÃO DO PARAÍSO & SAO SEBASTIAO DO PARAISO & 3 & 0 \\
\hline SÃO SEBASTIÃO DO PARAÍSO & SAO TOMAS DE AQUINO & 0 & 0 \\
\hline SETE LAGOAS & ARACAI & 0 & 0 \\
\hline SETE LAGOAS & BALDIM & 1 & 0 \\
\hline SETE LAGOAS & CACHOEIRA DA PRATA & 0 & 0 \\
\hline SETE LAGOAS & CAETANOPOLIS & 1 & 0 \\
\hline SETE LAGOAS & CAPIM BRANCO & 1 & 0 \\
\hline SETE LAGOAS & CORDISBURGO & 1 & 0 \\
\hline SETE LAGOAS & FORTUNA DE MINAS & 1 & 0 \\
\hline SETE LAGOAS & FUNILANDIA & 0 & 0 \\
\hline SETE LAGOAS & INHAUMA & 1 & 0 \\
\hline SETE LAGOAS & JEQUITIBA & 0 & 0 \\
\hline SETE LAGOAS & MARAVILHAS & 0 & 0 \\
\hline SETE LAGOAS & MATOZINHOS & 2 & 0 \\
\hline SETE LAGOAS & PAPAGAIOS & 1 & 0 \\
\hline SETE LAGOAS & PARAOPEBA & 2 & 0 \\
\hline SETE LAGOAS & POMPEU & 2 & 0 \\
\hline SETE LAGOAS & PRUDENTE DE MORAIS & 2 & 0 \\
\hline SETE LAGOAS & SANTANA DE PIRAPAMA & 0 & 0 \\
\hline SETE LAGOAS & SETE LAGOAS & 16 & 3 \\
\hline TEOFILO OTONI & AGUAS FORMOSAS & 5 & 1 \\
\hline TEOFILO OTONI & ATALEIA & 0 & 0 \\
\hline TEOFILO OTONI & BERTOPOLIS & 0 & 0 \\
\hline TEOFILO OTONI & CAMPANARIO & 1 & 0 \\
\hline TEOFILO OTONI & CARAI & 0 & 0 \\
\hline TEOFILO OTONI & CARLOS CHAGAS & 1 & 0 \\
\hline TEOFILO OTONI & CATUJI & 0 & 0 \\
\hline TEOFILO OTONI & CRISOLITA & 2 & 0 \\
\hline TEOFILO OTONI & FRANCISCOPOLIS & 1 & 0 \\
\hline TEOFILO OTONI & FREI GASPAR & 1 & 0 \\
\hline TEOFILO OTONI & FRONTEIRA DOS VALES & 0 & 0 \\
\hline TEOFILO OTONI & ITAIPE & 2 & 0 \\
\hline TEOFILO OTONI & ITAMBACURI & 5 & 1 \\
\hline TEOFILO OTONI & JAMPRUCA & 0 & 0 \\
\hline TEOFILO OTONI & LADAINHA & 0 & 0 \\
\hline TEOFILO OTONI & MACHACALIS & 0 & 0 \\
\hline TEOFILO OTONI & MALACACHETA & 3 & 0 \\
\hline TEOFILO OTONI & NANUQUE & 7 & 1 \\
\hline TEOFILO OTONI & NOVO CRUZEIRO & 4 & 0 \\
\hline
\end{tabular}




\begin{tabular}{|c|c|c|c|}
\hline TEOFILO OTONI & NOVO ORIENTE DE MINAS & 3 & 0 \\
\hline TEOFILO OTONI & OURO VERDE DE MINAS & 2 & 0 \\
\hline TEOFILO OTONI & PADRE PARAISO & 0 & 0 \\
\hline TEOFILO OTONI & PAVAO & 1 & 0 \\
\hline TEOFILO OTONI & PESCADOR & 0 & 0 \\
\hline TEOFILO OTONI & PONTO DOS VOLANTES & 1 & 0 \\
\hline TEOFILO OTONI & POTE & 1 & 0 \\
\hline TEOFILO OTONI & SANTA HELENA DE MINAS & 0 & 0 \\
\hline TEOFILO OTONI & SERRA DOS AIMORES & 2 & 0 \\
\hline TEOFILO OTONI & SETUBINHA & 2 & 0 \\
\hline TEOFILO OTONI & TEOFILO OTONI & 19 & 3 \\
\hline TEOFILO OTONI & UMBURATIBA & 0 & 0 \\
\hline UBÁ & ASTOLFO DUTRA & 0 & 0 \\
\hline UBÁ & BRAS PIRES & 0 & 0 \\
\hline UBÁ & COIMBRA & 1 & 0 \\
\hline UBÁ & DIVINESIA & 0 & 0 \\
\hline UBÁ & DONA EUZEBIA & 0 & 0 \\
\hline UBÁ & DORES DO TURVO & 0 & 0 \\
\hline UBÁ & ERVALIA & 0 & 0 \\
\hline UBÁ & GUARANI & 0 & 0 \\
\hline UBÁ & GUIDOVAL & 0 & 0 \\
\hline UBÁ & GUIRICEMA & 0 & 0 \\
\hline UBÁ & PAULA CANDIDO & 0 & 0 \\
\hline UBÁ & PIRAUBA & 0 & 0 \\
\hline UBÁ & PRESIDENTE BERNARDES & 0 & 0 \\
\hline UBÁ & RIO POMBA & 0 & 0 \\
\hline UBÁ & RODEIRO & 0 & 0 \\
\hline UBÁ & SAO GERALDO & 1 & 0 \\
\hline UBÁ & SENADOR FIRMINO & 0 & 0 \\
\hline UBÁ & SILVEIRANIA & 0 & 0 \\
\hline UBÁ & TABULEIRO & 0 & 0 \\
\hline UBÁ & TOCANTINS & 2 & 0 \\
\hline UBÁ & UBA & 10 & 2 \\
\hline UBÁ & VISCONDE DO RIO BRANCO & 1 & 0 \\
\hline UBERABA & AGUA COMPRIDA & 0 & 0 \\
\hline UBERABA & ARAXA & 1 & 0 \\
\hline UBERABA & CAMPO FLORIDO & 1 & 0 \\
\hline UBERABA & CAMPOS ALTOS & 0 & 0 \\
\hline UBERABA & CARNEIRINHO & 0 & 0 \\
\hline UBERABA & COMENDADOR GOMES & 0 & 0 \\
\hline UBERABA & CONCEICAO DAS ALAGOAS & 0 & 0 \\
\hline UBERABA & CONQUISTA & 0 & 0 \\
\hline UBERABA & DELTA & 1 & 0 \\
\hline UBERABA & FRONTEIRA & 0 & 0 \\
\hline UBERABA & FRUTAL & 5 & 1 \\
\hline
\end{tabular}




\begin{tabular}{|c|c|c|c|}
\hline UBERABA & ITAPAGIPE & 0 & 0 \\
\hline UBERABA & ITURAMA & 1 & 0 \\
\hline UBERABA & LIMEIRA DO OESTE & 0 & 0 \\
\hline UBERABA & PEDRINOPOLIS & 0 & 0 \\
\hline UBERABA & PIRAJUBA & 0 & 0 \\
\hline UBERABA & PLANURA & 1 & 0 \\
\hline UBERABA & PRATINHA & 0 & 0 \\
\hline UBERABA & SACRAMENTO & 4 & 0 \\
\hline UBERABA & SANTA JULIANA & 1 & 0 \\
\hline UBERABA & SAO FRANCISCO DE SALES & 0 & 0 \\
\hline UBERABA & TAPIRA & 0 & 0 \\
\hline UBERABA & UBERABA & 18 & 3 \\
\hline UBERABA & UNIAO DE MINAS & 0 & 0 \\
\hline UBERABA & VERISSIMO & 1 & 0 \\
\hline UBERLANDIA & ARAGUARI & 7 & 1 \\
\hline UBERLANDIA & ARAPORA & 0 & 0 \\
\hline UBERLANDIA & CAMPINA VERDE & 2 & 0 \\
\hline UBERLANDIA & INDIANOPOLIS & 0 & 0 \\
\hline UBERLANDIA & MONTE ALEGRE DE MINAS & 0 & 0 \\
\hline UBERLANDIA & NOVA PONTE & 0 & 0 \\
\hline UBERLANDIA & PRATA & 4 & 0 \\
\hline UBERLANDIA & TUPACIGUARA & 5 & 1 \\
\hline UBERLANDIA & UBERLANDIA & 29 & 6 \\
\hline UNAI & ARINOS & 3 & 0 \\
\hline UNAI & BONFINOPOLIS DE MINAS & 0 & 0 \\
\hline UNAI & BURITIS & 0 & 0 \\
\hline UNAI & CABECEIRA GRANDE & 0 & 0 \\
\hline UNAI & DOM BOSCO & 0 & 0 \\
\hline UNAI & FORMOSO & 1 & 0 \\
\hline UNAI & NATALANDIA & 0 & 0 \\
\hline UNAI & RIACHINHO & 0 & 0 \\
\hline UNAI & UNAI & 5 & 1 \\
\hline UNAI & URUANA DE MINAS & 1 & 0 \\
\hline VARGINHA & ALFENAS & 13 & 2 \\
\hline VARGINHA & BOA ESPERANCA & 3 & 0 \\
\hline VARGINHA & CAMBUQUIRA & 0 & 0 \\
\hline VARGINHA & CAMPANHA & 1 & 0 \\
\hline VARGINHA & CAMPO DO MEIO & 1 & 0 \\
\hline VARGINHA & CAMPOS GERAIS & 4 & 0 \\
\hline VARGINHA & CARMO DA CACHOEIRA & 0 & 0 \\
\hline VARGINHA & CARVALHOPOLIS & 1 & 0 \\
\hline VARGINHA & COQUEIRAL & 2 & 0 \\
\hline VARGINHA & CORDISLANDIA & 0 & 0 \\
\hline VARGINHA & ELOI MENDES & 0 & 0 \\
\hline VARGINHA & FAMA & 0 & 0 \\
\hline
\end{tabular}




\begin{tabular}{|l|l|c|c|}
\hline VARGINHA & GUAPE & 1 & 0 \\
\hline VARGINHA & ILICINEA & 0 & 0 \\
\hline VARGINHA & LAMBARI & 3 & 0 \\
\hline VARGINHA & LUMINARIAS & 0 & 0 \\
\hline VARGINHA & MACHADO & 3 & 0 \\
\hline VARGINHA & MONSENHOR PAULO & 1 & 0 \\
\hline VARGINHA & NEPOMUCENO & 1 & 0 \\
\hline VARGINHA & PARAGUACU & 0 & 0 \\
\hline VARGINHA & POCO FUNDO & 1 & 0 \\
\hline VARGINHA & SANTANA DA VARGEM & 1 & 0 \\
\hline VARGINHA & SAO BENTO ABADE & 1 & 0 \\
\hline VARGINHA & SAO GONCALO DO SAPUCAI & 4 & 0 \\
\hline VARGINHA & TRES CORACOES & 0 & 0 \\
\hline VARGINHA & TRES PONTAS & 0 & $\mathbf{1 3 8}$ \\
\hline VARGINHA & TURVOLANDIA & 7 & 0 \\
\hline VARGINHA & VARGINHA & & 0 \\
\hline Total geral & & 1 & 0 \\
\hline
\end{tabular}

CARGO: PROFESSOR DE EDUCAÇÃO BÁSICA - PEB -F I L O S O F I A

\begin{tabular}{|c|c|c|c|}
\hline S R E & MUNICIPIO & $\begin{array}{l}\text { TOTAL DE } \\
\text { VAGAS }\end{array}$ & $\begin{array}{c}\text { VAGAS } \\
\text { RESERVADAS - } \\
\text { PORTADORES DE } \\
\text { DEFICIÊNCIA }\end{array}$ \\
\hline ALMENARA & AGUAS VERMELHAS & 1 & 0 \\
\hline ALMENARA & ALMENARA & 0 & 0 \\
\hline ALMENARA & BANDEIRA & 0 & 0 \\
\hline ALMENARA & CACHOEIRA DE PAJEU & 0 & 0 \\
\hline ALMENARA & CURRAL DE DENTRO & 0 & 0 \\
\hline ALMENARA & DIVISA ALEGRE & 0 & 0 \\
\hline ALMENARA & DIVISOPOLIS & 1 & 0 \\
\hline ALMENARA & FELISBURGO & 1 & 0 \\
\hline ALMENARA & JACINTO & 0 & 0 \\
\hline ALMENARA & JEQUITINHONHA & 2 & 0 \\
\hline ALMENARA & JOAIMA & 0 & 0 \\
\hline ALMENARA & JORDANIA & 0 & 0 \\
\hline ALMENARA & MATA VERDE & 0 & 0 \\
\hline ALMENARA & MONTE FORMOSO & 1 & 0 \\
\hline ALMENARA & PALMOPOLIS & 1 & 0 \\
\hline ALMENARA & PEDRA AZUL & 2 & 0 \\
\hline ALMENARA & RIO DO PRADO & 0 & 0 \\
\hline ALMENARA & RUBIM & 0 & 0 \\
\hline ALMENARA & SALTO DA DIVISA & 1 & 0 \\
\hline ALMENARA & SANTA MARIA DO SALTO & 0 & 0 \\
\hline ALMENARA & SANTO ANTONIO DO JACINTO & 0 & 0 \\
\hline ARACUAI & ARACUAI & 2 & 0 \\
\hline
\end{tabular}




\begin{tabular}{|c|c|c|c|}
\hline ARACUAI & BERILO & 0 & 0 \\
\hline ARACUAI & BERIZAL & 0 & 0 \\
\hline ARACUAI & CHAPADA DO NORTE & 3 & 0 \\
\hline ARACUAI & COMERCINHO & 0 & 0 \\
\hline ARACUAI & CORONEL MURTA & 0 & 0 \\
\hline ARACUAI & FRANCISCO BADARO & 0 & 0 \\
\hline ARACUAI & FRUTA DE LEITE & 0 & 0 \\
\hline ARACUAI & INDAIABIRA & 1 & 0 \\
\hline ARACUAI & ITAOBIM & 1 & 0 \\
\hline ARACUAI & ITINGA & 1 & 0 \\
\hline ARACUAI & JENIPAPO DE MINAS & 1 & 0 \\
\hline ARACUAI & JOSE GONCALVES DE MINAS & 0 & 0 \\
\hline ARACUAI & MEDINA & 1 & 0 \\
\hline ARACUAI & NINHEIRA & 0 & 0 \\
\hline ARACUAI & NOVORIZONTE & 1 & 0 \\
\hline ARACUAI & RUBELITA & 0 & 0 \\
\hline ARACUAI & SALINAS & 4 & 0 \\
\hline ARACUAI & SANTA CRUZ DE SALINAS & 0 & 0 \\
\hline ARACUAI & TAIOBEIRAS & 3 & 0 \\
\hline ARACUAI & VIRGEM DA LAPA & 0 & 0 \\
\hline BARBACENA & ALFREDO VASCONCELOS & 0 & 0 \\
\hline BARBACENA & ALTO RIO DOCE & 0 & 0 \\
\hline BARBACENA & ANDRELANDIA & 0 & 0 \\
\hline BARBACENA & ANTONIO CARLOS & 0 & 0 \\
\hline BARBACENA & ARACITABA & 0 & 0 \\
\hline BARBACENA & BARBACENA & 5 & 2 \\
\hline BARBACENA & BARROSO & 1 & 0 \\
\hline BARBACENA & BIAS FORTES & 0 & 0 \\
\hline BARBACENA & CAPELA NOVA & 0 & 0 \\
\hline BARBACENA & CARANDAI & 0 & 0 \\
\hline BARBACENA & CIPOTANEA & 0 & 0 \\
\hline BARBACENA & DESTERRO DO MELO & 0 & 0 \\
\hline BARBACENA & IBERTIOGA & 0 & 0 \\
\hline BARBACENA & MADRE DE DEUS DE MINAS & 0 & 0 \\
\hline BARBACENA & MERCES & 1 & 0 \\
\hline BARBACENA & OLIVEIRA FORTES & 0 & 0 \\
\hline BARBACENA & PAIVA & 0 & 0 \\
\hline BARBACENA & PIEDADE DO RIO GRANDE & 0 & 0 \\
\hline BARBACENA & RESSAQUINHA & 0 & 0 \\
\hline BARBACENA & SANTA BARBARA DO TUGURIO & 0 & 0 \\
\hline BARBACENA & SANTA RITA DO IBITIPOCA & 1 & 0 \\
\hline BARBACENA & SANTANA DO GARAMBEU & 0 & 0 \\
\hline BARBACENA & SAO VICENTE DE MINAS & 0 & 0 \\
\hline BARBACENA & SENHORA DOS REMEDIOS & 0 & 0 \\
\hline CAMPO BELO & AGUANIL & 1 & 0 \\
\hline
\end{tabular}




\begin{tabular}{|c|c|c|c|}
\hline CAMPO BELO & CAMACHO & 0 & 0 \\
\hline CAMPO BELO & CAMPO BELO & 1 & 0 \\
\hline CAMPO BELO & CANA VERDE & 0 & 0 \\
\hline CAMPO BELO & CANDEIAS & 1 & 0 \\
\hline CAMPO BELO & CRISTAIS & 0 & 0 \\
\hline CAMPO BELO & LAVRAS & 1 & 0 \\
\hline CAMPO BELO & PERDOES & 1 & 0 \\
\hline CAMPO BELO & RIBEIRAO VERMELHO & 0 & 0 \\
\hline CAMPO BELO & SANTANA DO JACARE & 0 & 0 \\
\hline CAMPO BELO & SANTO ANTONIO DO AMPARO & 0 & 0 \\
\hline CAMPO BELO & SAO FRANCISCO DE PAULA & 0 & 0 \\
\hline CARANGOLA & ALTO CAPARAO & 0 & 0 \\
\hline CARANGOLA & CAIANA & 1 & 0 \\
\hline CARANGOLA & CAPARAO & 0 & 0 \\
\hline CARANGOLA & CARANGOLA & 0 & 0 \\
\hline CARANGOLA & DIVINO & 0 & 0 \\
\hline CARANGOLA & ESPERA FELIZ & 1 & 0 \\
\hline CARANGOLA & FARIA LEMOS & 0 & 0 \\
\hline CARANGOLA & FERVEDOURO & 0 & 0 \\
\hline CARANGOLA & ORIZANIA & 0 & 0 \\
\hline CARANGOLA & PEDRA DOURADA & 0 & 0 \\
\hline CARANGOLA & TOMBOS & 0 & 0 \\
\hline CARATINGA & ALVARENGA & 0 & 0 \\
\hline CARATINGA & BOM JESUS DO GALHO & 0 & 0 \\
\hline CARATINGA & BUGRE & 0 & 0 \\
\hline CARATINGA & CARATINGA & 2 & 0 \\
\hline CARATINGA & CORREGO NOVO & 0 & 0 \\
\hline CARATINGA & DOM CAVATI & 0 & 0 \\
\hline CARATINGA & ENTRE FOLHAS & 0 & 0 \\
\hline CARATINGA & IAPU & 0 & 0 \\
\hline CARATINGA & IMBE DE MINAS & 0 & 0 \\
\hline CARATINGA & INHAPIM & 0 & 0 \\
\hline CARATINGA & IPABA & 1 & 0 \\
\hline CARATINGA & IPANEMA & 1 & 0 \\
\hline CARATINGA & PIEDADE DE CARATINGA & 0 & 0 \\
\hline CARATINGA & PINGO D AGUA & 0 & 0 \\
\hline CARATINGA & POCRANE & 0 & 0 \\
\hline CARATINGA & SANTA BARBARA DO LESTE & 0 & 0 \\
\hline CARATINGA & SANTA RITA DE MINAS & 1 & 0 \\
\hline CARATINGA & SAO DOMINGOS DAS DORES & 0 & 0 \\
\hline CARATINGA & SAO JOAO DO ORIENTE & 0 & 0 \\
\hline CARATINGA & SAO SEBASTIAO DO ANTA & 0 & 0 \\
\hline CARATINGA & TAPARUBA & 0 & 0 \\
\hline CARATINGA & TARUMIRIM & 0 & 0 \\
\hline CARATINGA & UBAPORANGA & 0 & 0 \\
\hline
\end{tabular}




\begin{tabular}{|c|c|c|c|}
\hline CARATINGA & VARGEM ALEGRE & 1 & 0 \\
\hline CAXAMBU & AIURUOCA & 1 & 0 \\
\hline CAXAMBU & ALAGOA & 1 & 0 \\
\hline CAXAMBU & BAEPENDI & 0 & 0 \\
\hline CAXAMBU & BOCAINA DE MINAS & 1 & 0 \\
\hline CAXAMBU & CARVALHOS & 0 & 0 \\
\hline CAXAMBU & CAXAMBU & 0 & 0 \\
\hline CAXAMBU & CONCEICAO DO RIO VERDE & 0 & 0 \\
\hline CAXAMBU & CRUZILIA & 0 & 0 \\
\hline CAXAMBU & ITAMONTE & 0 & 0 \\
\hline CAXAMBU & ITANHANDU & 1 & 0 \\
\hline CAXAMBU & JESUANIA & 1 & 0 \\
\hline CAXAMBU & LIBERDADE & 0 & 0 \\
\hline CAXAMBU & MINDURI & 0 & 0 \\
\hline CAXAMBU & OLIMPIO NORONHA & 0 & 0 \\
\hline CAXAMBU & PASSA QUATRO & 0 & 0 \\
\hline CAXAMBU & PASSA VINTE & 0 & 0 \\
\hline CAXAMBU & POUSO ALTO & 0 & 0 \\
\hline CAXAMBU & SAO LOURENCO & 2 & 0 \\
\hline CAXAMBU & SAO SEBASTIAO DO RIO VERDE & 0 & 0 \\
\hline CAXAMBU & SAO TOME DAS LETRAS & 0 & 0 \\
\hline CAXAMBU & SERITINGA & 0 & 0 \\
\hline CAXAMBU & SERRANOS & 0 & 0 \\
\hline CAXAMBU & SOLEDADE DE MINAS & 0 & 0 \\
\hline CORONEL FABRICIANO & ANTONIO DIAS & 0 & 0 \\
\hline CORONEL FABRICIANO & BELO ORIENTE & 1 & 0 \\
\hline CORONEL FABRICIANO & BRAUNAS & 0 & 0 \\
\hline CORONEL FABRICIANO & CORONEL FABRICIANO & 2 & 0 \\
\hline CORONEL FABRICIANO & IPATINGA & 10 & 2 \\
\hline CORONEL FABRICIANO & JAGUARAÇU & 0 & 0 \\
\hline CORONEL FABRICIANO & JOANESIA & 0 & 0 \\
\hline CORONEL FABRICIANO & MARLIERIA & 0 & 0 \\
\hline CORONEL FABRICIANO & MESQUITA & 0 & 0 \\
\hline CORONEL FABRICIANO & SANTANA DO PARAISO & 0 & 0 \\
\hline CORONEL FABRICIANO & TIMOTEO & 3 & 0 \\
\hline CONSELHEIRO LAFAIETE & CARANAIBA & 0 & 0 \\
\hline CONSELHEIRO LAFAIETE & CASA GRANDE & 0 & 0 \\
\hline CONSELHEIRO LAFAIETE & CATAS ALTAS DA NORUEGA & 0 & 0 \\
\hline CONSELHEIRO LAFAIETE & CONGONHAS & 3 & 0 \\
\hline CONSELHEIRO LAFAIETE & CONSELHEIRO LAFAIETE & 1 & 0 \\
\hline CONSELHEIRO LAFAIETE & CRISTIANO OTONI & 0 & 0 \\
\hline CONSELHEIRO LAFAIETE & DESTERRO DE ENTRE RIOS & 0 & 0 \\
\hline CONSELHEIRO LAFAIETE & ENTRE RIOS DE MINAS & 2 & 0 \\
\hline CONSELHEIRO LAFAIETE & ITAVERAVA & 0 & 0 \\
\hline CONSELHEIRO LAFAIETE & JECEABA & 1 & 0 \\
\hline
\end{tabular}




\begin{tabular}{|c|c|c|c|}
\hline CONSELHEIRO LAFAIETE & LAMIM & 1 & 0 \\
\hline CONSELHEIRO LAFAIETE & OURO BRANCO & 0 & 0 \\
\hline CONSELHEIRO LAFAIETE & PIRANGA & 2 & 0 \\
\hline CONSELHEIRO LAFAIETE & QUELUZITO & 0 & 0 \\
\hline CONSELHEIRO LAFAIETE & RIO ESPERA & 0 & 0 \\
\hline CONSELHEIRO LAFAIETE & SANTANA DOS MONTES & 0 & 0 \\
\hline CONSELHEIRO LAFAIETE & SAO BRAS DO SUACUI & 0 & 0 \\
\hline CONSELHEIRO LAFAIETE & SENHORA DE OLIVEIRA & 1 & 0 \\
\hline CURVELO & AUGUSTO DE LIMA & 0 & 0 \\
\hline CURVELO & BUENOPOLIS & 1 & 0 \\
\hline CURVELO & CORINTO & 0 & 0 \\
\hline CURVELO & CURVELO & 2 & 0 \\
\hline CURVELO & FELIXLANDIA & 0 & 0 \\
\hline CURVELO & INIMUTABA & 1 & 0 \\
\hline CURVELO & JOAQUIM FELICIO & 0 & 0 \\
\hline CURVELO & LASSANCE & 0 & 0 \\
\hline CURVELO & MORRO DA GARCA & 1 & 0 \\
\hline CURVELO & PRESIDENTE JUSCELINO & 0 & 0 \\
\hline CURVELO & SANTO HIPOLITO & 1 & 0 \\
\hline CURVELO & TRES MARIAS & 0 & 0 \\
\hline DIAMANTINA & ALVORADA DE MINAS & 0 & 0 \\
\hline DIAMANTINA & ANGELANDIA & 0 & 0 \\
\hline DIAMANTINA & ARICANDUVA & 1 & 0 \\
\hline DIAMANTINA & CAPELINHA & 4 & 0 \\
\hline DIAMANTINA & CARBONITA & 0 & 0 \\
\hline DIAMANTINA & CONCEICAO DO MATO DENTRO & 0 & 0 \\
\hline DIAMANTINA & CONGONHAS DO NORTE & 1 & 0 \\
\hline DIAMANTINA & COUTO DE MAGALHAES DE MINAS & 1 & 0 \\
\hline DIAMANTINA & DATAS & 0 & 0 \\
\hline DIAMANTINA & DIAMANTINA & 6 & 2 \\
\hline DIAMANTINA & FELICIO DOS SANTOS & 1 & 0 \\
\hline DIAMANTINA & GOUVEA & 0 & 0 \\
\hline DIAMANTINA & ITAMARANDIBA & 4 & 0 \\
\hline DIAMANTINA & LEME DO PRADO & 1 & 0 \\
\hline DIAMANTINA & MINAS NOVAS & 4 & 0 \\
\hline DIAMANTINA & MONJOLOS & 0 & 0 \\
\hline DIAMANTINA & PRESIDENTE KUBITSCHEK & 0 & 0 \\
\hline DIAMANTINA & RIO VERMELHO & 1 & 0 \\
\hline DIAMANTINA & SANTO ANTONIO DO ITAMBE & 1 & 0 \\
\hline DIAMANTINA & SAO GONCALO DO RIO PRETO & 0 & 0 \\
\hline DIAMANTINA & SENADOR MODESTINO GONCALVES & 0 & 0 \\
\hline DIAMANTINA & SERRA AZUL DE MINAS & 0 & 0 \\
\hline DIAMANTINA & SERRO & 2 & 0 \\
\hline DIAMANTINA & TURMALINA & 1 & 0 \\
\hline DIAMANTINA & VEREDINHA & 0 & 0 \\
\hline
\end{tabular}




\begin{tabular}{|c|c|c|c|}
\hline DIVINÓPOLIS & ARAUJOS & 0 & 0 \\
\hline DIVINÓPOLIS & $\mathrm{ARCOS}$ & 1 & 0 \\
\hline DIVINÓPOLIS & BAMBUI & 1 & 0 \\
\hline DIVINÓPOLIS & CARMO DA MATA & 1 & 0 \\
\hline DIVINÓPOLIS & CARMO DO CAJURU & 2 & 0 \\
\hline DIVINÓPOLIS & CARMOPOLIS DE MINAS & 0 & 0 \\
\hline DIVINÓPOLIS & CLAUDIO & 1 & 0 \\
\hline DIVINÓPOLIS & CORREGO DANTA & 0 & 0 \\
\hline DIVINÓPOLIS & DIVINOPOLIS & 9 & 2 \\
\hline DIVINÓPOLIS & IGUATAMA & 0 & 0 \\
\hline DIVINÓPOLIS & ITAGUARA & 0 & 0 \\
\hline DIVINÓPOLIS & ITAPECERICA & 0 & 0 \\
\hline DIVINÓPOLIS & ITATIAIUCU & 0 & 0 \\
\hline DIVINÓPOLIS & ITAUNA & 2 & 0 \\
\hline DIVINÓPOLIS & JAPARAIBA & 1 & 0 \\
\hline DIVINÓPOLIS & LAGOA DA PRATA & 2 & 0 \\
\hline DIVINÓPOLIS & LUZ & 0 & 0 \\
\hline DIVINÓPOLIS & MEDEIROS & 1 & 0 \\
\hline DIVINÓPOLIS & MOEMA & 0 & 0 \\
\hline DIVINÓPOLIS & NOVA SERRANA & 5 & 2 \\
\hline DIVINÓPOLIS & OLIVEIRA & 0 & 0 \\
\hline DIVINÓPOLIS & PAINS & 0 & 0 \\
\hline DIVINÓPOLIS & PASSA TEMPO & 0 & 0 \\
\hline DIVINÓPOLIS & PEDRA DO INDAIA & 0 & 0 \\
\hline DIVINÓPOLIS & PERDIGAO & 0 & 0 \\
\hline DIVINÓPOLIS & PIRACEMA & 0 & 0 \\
\hline DIVINÓPOLIS & SANTO ANTONIO DO MONTE & 1 & 0 \\
\hline DIVINÓPOLIS & SAO GONCALO DO PARA & 0 & 0 \\
\hline DIVINÓPOLIS & SAO SEBASTIAO DO OESTE & 0 & 0 \\
\hline DIVINÓPOLIS & TAPIRAI & 0 & 0 \\
\hline GOVERNADOR VALADARES & ACUCENA & 0 & 0 \\
\hline GOVERNADOR VALADARES & AIMORES & 1 & 0 \\
\hline GOVERNADOR VALADARES & ALPERCATA & 0 & 0 \\
\hline GOVERNADOR VALADARES & CAPITAO ANDRADE & 1 & 0 \\
\hline GOVERNADOR VALADARES & CENTRAL DE MINAS & 1 & 0 \\
\hline GOVERNADOR VALADARES & CONSELHEIRO PENA & 1 & 0 \\
\hline GOVERNADOR VALADARES & COROACI & 0 & 0 \\
\hline GOVERNADOR VALADARES & CUPARAQUE & 0 & 0 \\
\hline GOVERNADOR VALADARES & DIVINO DAS LARANJEIRAS & 0 & 0 \\
\hline GOVERNADOR VALADARES & ENGENHEIRO CALDAS & 0 & 0 \\
\hline GOVERNADOR VALADARES & FERNANDES TOURINHO & 0 & 0 \\
\hline GOVERNADOR VALADARES & FREI INOCENCIO & 1 & 0 \\
\hline GOVERNADOR VALADARES & GALILEIA & 0 & 0 \\
\hline GOVERNADOR VALADARES & GOIABEIRA & 0 & 0 \\
\hline GOVERNADOR VALADARES & GOVERNADOR VALADARES & 13 & 3 \\
\hline
\end{tabular}




\begin{tabular}{|c|c|c|c|}
\hline GOVERNADOR VALADARES & ITABIRINHA & 1 & 0 \\
\hline GOVERNADOR VALADARES & ITANHOMI & 0 & 0 \\
\hline GOVERNADOR VALADARES & ITUETA & 0 & 0 \\
\hline GOVERNADOR VALADARES & MANTENA & 1 & 0 \\
\hline GOVERNADOR VALADARES & MARILAC & 1 & 0 \\
\hline GOVERNADOR VALADARES & MATHIAS LOBATO & 1 & 0 \\
\hline GOVERNADOR VALADARES & MENDES PIMENTEL & 0 & 0 \\
\hline GOVERNADOR VALADARES & NACIP RAYDAN & 0 & 0 \\
\hline GOVERNADOR VALADARES & NAQUE & 0 & 0 \\
\hline GOVERNADOR VALADARES & NOVA BELEM & 0 & 0 \\
\hline GOVERNADOR VALADARES & NOVA MODICA & 0 & 0 \\
\hline GOVERNADOR VALADARES & PERIQUITO & 0 & 0 \\
\hline GOVERNADOR VALADARES & RESPLENDOR & 0 & 0 \\
\hline GOVERNADOR VALADARES & SANTA EFIGENIA DE MINAS & 0 & 0 \\
\hline GOVERNADOR VALADARES & SANTA RITA DO ITUETO & 0 & 0 \\
\hline GOVERNADOR VALADARES & SAO FELIX DE MINAS & 0 & 0 \\
\hline GOVERNADOR VALADARES & SAO GERALDO DA PIEDADE & 0 & 0 \\
\hline GOVERNADOR VALADARES & SAO GERALDO DO BAIXIO & 0 & 0 \\
\hline GOVERNADOR VALADARES & SAO JOAO DO MANTENINHA & 1 & 0 \\
\hline GOVERNADOR VALADARES & SAO JOSE DA SAFIRA & 0 & 0 \\
\hline GOVERNADOR VALADARES & SAO JOSE DO DIVINO & 1 & 0 \\
\hline GOVERNADOR VALADARES & SARDOA & 0 & 0 \\
\hline GOVERNADOR VALADARES & SOBRALIA & 0 & 0 \\
\hline GOVERNADOR VALADARES & TUMIRITINGA & 0 & 0 \\
\hline GOVERNADOR VALADARES & VIRGOLANDIA & 0 & 0 \\
\hline GUANHÃES & AGUA BOA & 0 & 0 \\
\hline GUANHÃES & CANTAGALO & 0 & 0 \\
\hline GUANHÃES & CARMESIA & 0 & 0 \\
\hline GUANHÃES & COLUNA & 0 & 0 \\
\hline GUANHÃES & DIVINOLANDIA DE MINAS & 0 & 0 \\
\hline GUANHÃES & DOM JOAQUIM & 1 & 0 \\
\hline GUANHÃES & DORES DE GUANHAES & 0 & 0 \\
\hline GUANHÃES & FREI LAGONEGRO & 0 & 0 \\
\hline GUANHÃES & GONZAGA & 0 & 0 \\
\hline GUANHÃES & GUANHAES & 2 & 0 \\
\hline GUANHÃES & JOSE RAYDAN & 0 & 0 \\
\hline GUANHÃES & MATERLANDIA & 1 & 0 \\
\hline GUANHÃES & PAULISTAS & 0 & 0 \\
\hline GUANHÃES & PECANHA & 0 & 0 \\
\hline GUANHÃES & SABINOPOLIS & 1 & 0 \\
\hline GUANHÃES & SANTA MARIA DO SUACUI & 0 & 0 \\
\hline GUANHÃES & SAO JOAO EVANGELISTA & 0 & 0 \\
\hline GUANHÃES & SAO JOSE DO JACURI & 0 & 0 \\
\hline GUANHÃES & SAO PEDRO DO SUACUI & 0 & 0 \\
\hline GUANHÃES & SAO SEBASTIAO DO MARANHAO & 0 & 0 \\
\hline
\end{tabular}




\begin{tabular}{|c|c|c|c|}
\hline GUANHÃES & SENHORA DO PORTO & 0 & 0 \\
\hline GUANHÃES & VIRGINOPOLIS & 0 & 0 \\
\hline ITAJUBÁ & BRASOPOLIS & 0 & 0 \\
\hline ITAJUBÁ & CARMO DE MINAS & 1 & 0 \\
\hline ITAJUBÁ & CONCEICAO DAS PEDRAS & 0 & 0 \\
\hline ITAJUBÁ & CONCEICAO DOS OUROS & 1 & 0 \\
\hline ITAJUBÁ & CONSOLACAO & 0 & 0 \\
\hline ITAJUBÁ & CRISTINA & 0 & 0 \\
\hline ITAJUBÁ & DELFIM MOREIRA & 0 & 0 \\
\hline ITAJUBÁ & DOM VICOSO & 0 & 0 \\
\hline ITAJUBÁ & GONCALVES & 1 & 0 \\
\hline ITAJUBÁ & ITAJUBA & 2 & 0 \\
\hline ITAJUBÁ & MARIA DA FE & 0 & 0 \\
\hline ITAJUBÁ & MARMELOPOLIS & 0 & 0 \\
\hline ITAJUBÁ & NATERCIA & 0 & 0 \\
\hline ITAJUBÁ & PARAISOPOLIS & 0 & 0 \\
\hline ITAJUBÁ & PEDRALVA & 1 & 0 \\
\hline ITAJUBÁ & PIRANGUCU & 0 & 0 \\
\hline ITAJUBÁ & PIRANGUINHO & 1 & 0 \\
\hline ITAJUBÁ & SAO JOSE DO ALEGRE & 0 & 0 \\
\hline ITAJUBÁ & SAPUCAI-MIRIM & 1 & 0 \\
\hline ITAJUBÁ & VIRGINIA & 1 & 0 \\
\hline ITAJUBÁ & WENCESLAU BRAZ & 1 & 0 \\
\hline ITUIUTABA & CACHOEIRA DOURADA & 0 & 0 \\
\hline ITUIUTABA & CANAPOLIS & 0 & 0 \\
\hline ITUIUTABA & CAPINOPOLIS & 0 & 0 \\
\hline ITUIUTABA & CENTRALINA & 0 & 0 \\
\hline ITUIUTABA & GURINHATA & 0 & 0 \\
\hline ITUIUTABA & IPIACU & 0 & 0 \\
\hline ITUIUTABA & ITUIUTABA & 3 & 0 \\
\hline ITUIUTABA & SANTA VITORIA & 1 & 0 \\
\hline JANAUBA & CATUTI & 0 & 0 \\
\hline JANAUBA & ESPINOSA & 1 & 0 \\
\hline JANAUBA & GAMELEIRAS & 0 & 0 \\
\hline JANAUBA & JAIBA & 1 & 0 \\
\hline JANAUBA & JANAUBA & 3 & 0 \\
\hline JANAUBA & MAMONAS & 1 & 0 \\
\hline JANAUBA & MATO VERDE & 0 & 0 \\
\hline JANAUBA & MONTE AZUL & 0 & 0 \\
\hline JANAUBA & MONTEZUMA & 0 & 0 \\
\hline JANAUBA & NOVA PORTEIRINHA & 0 & 0 \\
\hline JANAUBA & PAI PEDRO & 1 & 0 \\
\hline JANAUBA & PORTEIRINHA & 2 & 0 \\
\hline JANAUBA & RIACHO DOS MACHADOS & 0 & 0 \\
\hline JANAUBA & RIO PARDO DE MINAS & 3 & 0 \\
\hline
\end{tabular}




\begin{tabular}{|c|c|c|c|}
\hline JANAUBA & SANTO ANTONIO DO RETIRO & 0 & 0 \\
\hline JANAUBA & SERRANOPOLIS DE MINAS & 0 & 0 \\
\hline JANAUBA & VERDELANDIA & 0 & 0 \\
\hline JANUARIA & BONITO DE MINAS & 1 & 0 \\
\hline JANUARIA & CHAPADA GAUCHA & 1 & 0 \\
\hline JANUARIA & CONEGO MARINHO & 1 & 0 \\
\hline JANUARIA & IBIRACATU & 0 & 0 \\
\hline JANUARIA & ICARAI DE MINAS & 0 & 0 \\
\hline JANUARIA & ITACARAMBI & 0 & 0 \\
\hline JANUARIA & JANUARIA & 2 & 0 \\
\hline JANUARIA & JUVENILIA & 0 & 0 \\
\hline JANUARIA & MANGA & 1 & 0 \\
\hline JANUARIA & MATIAS CARDOSO & 0 & 0 \\
\hline JANUARIA & MIRAVANIA & 0 & 0 \\
\hline JANUARIA & MONTALVANIA & 0 & 0 \\
\hline JANUARIA & PEDRAS DE MARIA DA CRUZ & 0 & 0 \\
\hline JANUARIA & PINTOPOLIS & 0 & 0 \\
\hline JANUARIA & SAO FRANCISCO & 0 & 0 \\
\hline JANUARIA & SAO JOAO DAS MISSOES & 0 & 0 \\
\hline JANUARIA & UBAI & 0 & 0 \\
\hline JANUARIA & URUCUIA & 0 & 0 \\
\hline JANUARIA & VARZELANDIA & 1 & 0 \\
\hline JUIZ DE FORA & ARANTINA & 0 & 0 \\
\hline JUIZ DE FORA & BELMIRO BRAGA & 0 & 0 \\
\hline JUIZ DE FORA & BICAS & 0 & 0 \\
\hline JUIZ DE FORA & BOM JARDIM DE MINAS & 0 & 0 \\
\hline JUIZ DE FORA & CHACARA & 0 & 0 \\
\hline JUIZ DE FORA & CHIADOR & 0 & 0 \\
\hline JUIZ DE FORA & CORONEL PACHECO & 0 & 0 \\
\hline JUIZ DE FORA & DESCOBERTO & 0 & 0 \\
\hline JUIZ DE FORA & EWBANK DA CAMARA & 1 & 0 \\
\hline JUIZ DE FORA & GOIANA & 0 & 0 \\
\hline JUIZ DE FORA & GUARARA & 1 & 0 \\
\hline JUIZ DE FORA & JUIZ DE FORA & 14 & 3 \\
\hline JUIZ DE FORA & LIMA DUARTE & 1 & 0 \\
\hline JUIZ DE FORA & MAR DE ESPANHA & 1 & 0 \\
\hline JUIZ DE FORA & MARIPA DE MINAS & 0 & 0 \\
\hline JUIZ DE FORA & MATIAS BARBOSA & 0 & 0 \\
\hline JUIZ DE FORA & OLARIA & 0 & 0 \\
\hline JUIZ DE FORA & PEDRO TEIXEIRA & 0 & 0 \\
\hline JUIZ DE FORA & PEQUERI & 1 & 0 \\
\hline JUIZ DE FORA & PIAU & 0 & 0 \\
\hline JUIZ DE FORA & RIO NOVO & 0 & 0 \\
\hline JUIZ DE FORA & RIO PRETO & 0 & 0 \\
\hline JUIZ DE FORA & ROCHEDO DE MINAS & 0 & 0 \\
\hline
\end{tabular}




\begin{tabular}{|c|c|c|c|}
\hline JUIZ DE FORA & SANTA BARBARA DO MONTE VERDE & 1 & 0 \\
\hline JUIZ DE FORA & SANTA RITA DE JACUTINGA & 0 & 0 \\
\hline JUIZ DE FORA & SANTANA DO DESERTO & 0 & 0 \\
\hline JUIZ DE FORA & SANTOS DUMONT & 0 & 0 \\
\hline JUIZ DE FORA & SAO JOAO NEPOMUCENO & 1 & 0 \\
\hline JUIZ DE FORA & SENADOR CORTES & 0 & 0 \\
\hline JUIZ DE FORA & SIMAO PEREIRA & 0 & 0 \\
\hline MANHUAÇU & ALTO JEQUITIBA & 0 & 0 \\
\hline MANHUAÇU & CAPUTIRA & 1 & 0 \\
\hline MANHUAÇU & CHALE & 0 & 0 \\
\hline MANHUAÇU & CONCEICAO DE IPANEMA & 0 & 0 \\
\hline MANHUAÇU & DURANDE & 0 & 0 \\
\hline MANHUAÇU & LAJINHA & 0 & 0 \\
\hline MANHUAÇU & LUISBURGO & 1 & 0 \\
\hline MANHUAÇU & MANHUACU & 2 & 0 \\
\hline MANHUAÇU & MANHUMIRIM & 2 & 0 \\
\hline MANHUAÇU & MARTINS SOARES & 0 & 0 \\
\hline MANHUAÇU & MATIPO & 0 & 0 \\
\hline MANHUAÇU & MUTUM & 0 & 0 \\
\hline MANHUAÇU & REDUTO & 0 & 0 \\
\hline MANHUAÇU & SANTA MARGARIDA & 1 & 0 \\
\hline MANHUAÇU & SANTANA DO MANHUACU & 1 & 0 \\
\hline MANHUAÇU & SAO JOAO DO MANHUACU & 0 & 0 \\
\hline MANHUAÇU & SAO JOSE DO MANTIMENTO & 0 & 0 \\
\hline MANHUAÇU & SIMONESIA & 0 & 0 \\
\hline METROPOLITANA A & BARAO DE COCAIS & 1 & 0 \\
\hline METROPOLITANA A & BELO HORIZONTE & 29 & 6 \\
\hline METROPOLITANA A & BELO VALE & 0 & 0 \\
\hline METROPOLITANA A & BOM JESUS DO AMPARO & 1 & 0 \\
\hline METROPOLITANA A & BONFIM & 1 & 0 \\
\hline METROPOLITANA A & BRUMADINHO & 1 & 0 \\
\hline METROPOLITANA A & CAETE & 0 & 0 \\
\hline METROPOLITANA A & CATAS ALTAS & 0 & 0 \\
\hline METROPOLITANA A & CRUCILANDIA & 0 & 0 \\
\hline METROPOLITANA A & MOEDA & 0 & 0 \\
\hline METROPOLITANA A & NOVA LIMA & 2 & 0 \\
\hline METROPOLITANA A & NOVA UNIAO & 0 & 0 \\
\hline METROPOLITANA A & PIEDADE DOS GERAIS & 0 & 0 \\
\hline METROPOLITANA A & RAPOSOS & 1 & 0 \\
\hline METROPOLITANA A & RIO ACIMA & 0 & 0 \\
\hline METROPOLITANA A & RIO MANSO & 1 & 0 \\
\hline METROPOLITANA A & SABARA & 1 & 0 \\
\hline METROPOLITANA A & SANTA BARBARA & 0 & 0 \\
\hline METROPOLITANA B & BELO HORIZONTE & 28 & 6 \\
\hline METROPOLITANA B & BETIM & 18 & 4 \\
\hline
\end{tabular}




\begin{tabular}{|c|c|c|c|}
\hline METROPOLITANA B & CONTAGEM & 20 & 5 \\
\hline METROPOLITANA B & ESMERALDAS & 1 & 0 \\
\hline METROPOLITANA B & IBIRITE & 5 & 2 \\
\hline METROPOLITANA B & IGARAPE & 3 & 0 \\
\hline METROPOLITANA B & JUATUBA & 2 & 0 \\
\hline METROPOLITANA B & MARIO CAMPOS & 0 & 0 \\
\hline METROPOLITANA B & MATEUS LEME & 1 & 0 \\
\hline METROPOLITANA B & SAO JOAQUIM DE BICAS & 0 & 0 \\
\hline METROPOLITANA B & SARZEDO & 1 & 0 \\
\hline METROPOLITANA C & BELO HORIZONTE & 23 & 5 \\
\hline METROPOLITANA C & CONFINS & 1 & 0 \\
\hline METROPOLITANA C & JABOTICATUBAS & 1 & 0 \\
\hline METROPOLITANA C & LAGOA SANTA & 1 & 0 \\
\hline METROPOLITANA C & MORRO DO PILAR & 0 & 0 \\
\hline METROPOLITANA C & PEDRO LEOPOLDO & 4 & 0 \\
\hline METROPOLITANA C & RIBEIRAO DAS NEVES & 15 & 3 \\
\hline METROPOLITANA C & SANTA LUZIA & 5 & 2 \\
\hline METROPOLITANA C & SANTANA DO RIACHO & 1 & 0 \\
\hline METROPOLITANA C & SAO JOSE DA LAPA & 1 & 0 \\
\hline METROPOLITANA C & TAQUARACU DE MINAS & 0 & 0 \\
\hline METROPOLITANA C & VESPASIANO & 3 & 0 \\
\hline MONTE CARMELO & ABADIA DOS DOURADOS & 0 & 0 \\
\hline MONTE CARMELO & CASCALHO RICO & 1 & 0 \\
\hline MONTE CARMELO & COROMANDEL & 1 & 0 \\
\hline MONTE CARMELO & DOURADOQUARA & 0 & 0 \\
\hline MONTE CARMELO & ESTRELA DO SUL & 0 & 0 \\
\hline MONTE CARMELO & GRUPIARA & 0 & 0 \\
\hline MONTE CARMELO & MONTE CARMELO & 1 & 0 \\
\hline MONTE CARMELO & ROMARIA & 0 & 0 \\
\hline MONTES CLAROS & BOCAIUVA & 1 & 0 \\
\hline MONTES CLAROS & BOTUMIRIM & 1 & 0 \\
\hline MONTES CLAROS & BRASILIA DE MINAS & 1 & 0 \\
\hline MONTES CLAROS & CAMPO AZUL & 1 & 0 \\
\hline MONTES CLAROS & CAPITAO ENEAS & 0 & 0 \\
\hline MONTES CLAROS & CLARO DOS POCOES & 0 & 0 \\
\hline MONTES CLAROS & CORACAO DE JESUS & 1 & 0 \\
\hline MONTES CLAROS & CRISTALIA & 0 & 0 \\
\hline MONTES CLAROS & ENGENHEIRO NAVARRO & 0 & 0 \\
\hline MONTES CLAROS & FRANCISCO DUMONT & 0 & 0 \\
\hline MONTES CLAROS & FRANCISCO SA & 1 & 0 \\
\hline MONTES CLAROS & GLAUCILANDIA & 0 & 0 \\
\hline MONTES CLAROS & GRAO MOGOL & 1 & 0 \\
\hline MONTES CLAROS & GUARACIAMA & 0 & 0 \\
\hline MONTES CLAROS & ITACAMBIRA & 0 & 0 \\
\hline MONTES CLAROS & JAPONVAR & 0 & 0 \\
\hline
\end{tabular}




\begin{tabular}{|c|c|c|c|}
\hline MONTES CLAROS & JOSENOPOLIS & 0 & 0 \\
\hline MONTES CLAROS & JURAMENTO & 0 & 0 \\
\hline MONTES CLAROS & LONTRA & 0 & 0 \\
\hline MONTES CLAROS & LUISLANDIA & 0 & 0 \\
\hline MONTES CLAROS & MIRABELA & 1 & 0 \\
\hline MONTES CLAROS & MONTES CLAROS & 4 & 0 \\
\hline MONTES CLAROS & OLHOS-D AGUA & 0 & 0 \\
\hline MONTES CLAROS & PADRE CARVALHO & 0 & 0 \\
\hline MONTES CLAROS & PATIS & 0 & 0 \\
\hline MONTES CLAROS & SAO JOAO DA LAGOA & 1 & 0 \\
\hline MONTES CLAROS & SAO JOAO DA PONTE & 2 & 0 \\
\hline MONTES CLAROS & SAO JOAO DO PACUI & 1 & 0 \\
\hline MONTES CLAROS & SAO JOAO DO PARAISO & 0 & 0 \\
\hline MONTES CLAROS & VARGEM GRANDE DO RIO PARDO & 0 & 0 \\
\hline MURIAÉ & ANTONIO PRADO DE MINAS & 0 & 0 \\
\hline MURIAÉ & BARAO DE MONTE ALTO & 0 & 0 \\
\hline MURIAÉ & EUGENOPOLIS & 0 & 0 \\
\hline MURIAÉ & LARANJAL & 0 & 0 \\
\hline MURIAÉ & MIRADOURO & 0 & 0 \\
\hline MURIAÉ & MIRAI & 0 & 0 \\
\hline MURIAÉ & MURIAE & 0 & 0 \\
\hline MURIAÉ & PALMA & 0 & 0 \\
\hline MURIAÉ & PATROCINIO DO MURIAE & 1 & 0 \\
\hline MURIAÉ & ROSARIO DA LIMEIRA & 0 & 0 \\
\hline MURIAÉ & SANTANA DE CATAGUASES & 0 & 0 \\
\hline MURIAÉ & SAO FRANCISCO DO GLORIA & 0 & 0 \\
\hline MURIAÉ & SAO SEBASTIAO DA VARGEM ALEGRE & 1 & 0 \\
\hline MURIAÉ & VIEIRAS & 0 & 0 \\
\hline NOVA ERA & BELA VISTA DE MINAS & 1 & 0 \\
\hline NOVA ERA & DIONISIO & 0 & 0 \\
\hline NOVA ERA & FERROS & 0 & 0 \\
\hline NOVA ERA & ITABIRA & 5 & 2 \\
\hline NOVA ERA & ITAMBE DO MATO DENTRO & 1 & 0 \\
\hline NOVA ERA & JOAO MONLEVADE & 2 & 0 \\
\hline NOVA ERA & NOVA ERA & 0 & 0 \\
\hline NOVA ERA & PASSABEM & 0 & 0 \\
\hline NOVA ERA & RIO PIRACICABA & 1 & 0 \\
\hline NOVA ERA & SANTA MARIA DE ITABIRA & 0 & 0 \\
\hline NOVA ERA & SANTO ANTONIO DO RIO ABAIXO & 0 & 0 \\
\hline NOVA ERA & SAO DOMINGOS DO PRATA & 0 & 0 \\
\hline NOVA ERA & SAO GONCALO DO RIO ABAIXO & 1 & 0 \\
\hline NOVA ERA & SAO JOSE DO GOIABAL & 0 & 0 \\
\hline NOVA ERA & SAO SEBASTIAO DO RIO PRETO & 0 & 0 \\
\hline OURO PRETO & ACAIACA & 1 & 0 \\
\hline OURO PRETO & DIOGO DE VASCONCELOS & 1 & 0 \\
\hline
\end{tabular}




\begin{tabular}{|c|c|c|c|}
\hline OURO PRETO & ITABIRITO & 3 & 0 \\
\hline OURO PRETO & MARIANA & 3 & 0 \\
\hline OURO PRETO & OURO PRETO & 2 & 0 \\
\hline PARA DE MINAS & ABAETE & 1 & 0 \\
\hline PARA DE MINAS & BIQUINHAS & 0 & 0 \\
\hline PARA DE MINAS & BOM DESPACHO & 0 & 0 \\
\hline PARA DE MINAS & CEDRO DO ABAETE & 0 & 0 \\
\hline PARA DE MINAS & CONCEICAO DO PARA & 0 & 0 \\
\hline PARA DE MINAS & DORES DO INDAIA & 0 & 0 \\
\hline PARA DE MINAS & ESTRELA DO INDAIA & 0 & 0 \\
\hline PARA DE MINAS & FLORESTAL & 1 & 0 \\
\hline PARA DE MINAS & IGARATINGA & 0 & 0 \\
\hline PARA DE MINAS & LEANDRO FERREIRA & 0 & 0 \\
\hline PARA DE MINAS & MARTINHO CAMPOS & 0 & 0 \\
\hline PARA DE MINAS & MORADA NOVA DE MINAS & 0 & 0 \\
\hline PARA DE MINAS & ONCA DE PITANGUI & 0 & 0 \\
\hline PARA DE MINAS & PAINEIRAS & 0 & 0 \\
\hline PARA DE MINAS & PARA DE MINAS & 2 & 0 \\
\hline PARA DE MINAS & PEQUI & 0 & 0 \\
\hline PARA DE MINAS & PITANGUI & 1 & 0 \\
\hline PARA DE MINAS & QUARTEL GERAL & 0 & 0 \\
\hline PARA DE MINAS & SAO JOSE DA VARGINHA & 0 & 0 \\
\hline PARA DE MINAS & SERRA DA SAUDADE & 0 & 0 \\
\hline PARACATU & BRASILANDIA DE MINAS & 0 & 0 \\
\hline PARACATU & GUARDA-MOR & 0 & 0 \\
\hline PARACATU & JOAO PINHEIRO & 3 & 0 \\
\hline PARACATU & PARACATU & 3 & 0 \\
\hline PARACATU & VAZANTE & 0 & 0 \\
\hline PASSOS & ALPINOPOLIS & 0 & 0 \\
\hline PASSOS & BOM JESUS DA PENHA & 0 & 0 \\
\hline PASSOS & CAPITOLIO & 0 & 0 \\
\hline PASSOS & CARMO DO RIO CLARO & 2 & 0 \\
\hline PASSOS & CORREGO FUNDO & 0 & 0 \\
\hline PASSOS & DELFINOPOLIS & 0 & 0 \\
\hline PASSOS & DORESOPOLIS & 0 & 0 \\
\hline PASSOS & FORMIGA & 0 & 0 \\
\hline PASSOS & FORTALEZA DE MINAS & 0 & 0 \\
\hline PASSOS & PASSOS & 1 & 0 \\
\hline PASSOS & PIMENTA & 0 & 0 \\
\hline PASSOS & PIUMHI & 0 & 0 \\
\hline PASSOS & SAO JOAO BATISTA DO GLORIA & 1 & 0 \\
\hline PASSOS & SAO JOSE DA BARRA & 1 & 0 \\
\hline PASSOS & SAO ROQUE DE MINAS & 0 & 0 \\
\hline PASSOS & VARGEM BONITA & 0 & 0 \\
\hline PATOS DE MINAS & ARAPUA & 0 & 0 \\
\hline
\end{tabular}




\begin{tabular}{|c|c|c|c|}
\hline PATOS DE MINAS & CARMO DO PARANAIBA & 1 & 0 \\
\hline PATOS DE MINAS & LAGAMAR & 0 & 0 \\
\hline PATOS DE MINAS & LAGOA FORMOSA & 0 & 0 \\
\hline PATOS DE MINAS & LAGOA GRANDE & 0 & 0 \\
\hline PATOS DE MINAS & MATUTINA & 0 & 0 \\
\hline PATOS DE MINAS & PATOS DE MINAS & 4 & 0 \\
\hline PATOS DE MINAS & PRESIDENTE OLEGARIO & 1 & 0 \\
\hline PATOS DE MINAS & RIO PARANAIBA & 1 & 0 \\
\hline PATOS DE MINAS & SANTA ROSA DA SERRA & 0 & 0 \\
\hline PATOS DE MINAS & SAO GONCALO DO ABAETE & 0 & 0 \\
\hline PATOS DE MINAS & SAO GOTARDO & 2 & 0 \\
\hline PATOS DE MINAS & TIROS & 0 & 0 \\
\hline PATOS DE MINAS & VARJAO DE MINAS & 0 & 0 \\
\hline PATROCÍNIO & CRUZEIRO DA FORTALEZA & 0 & 0 \\
\hline PATROCÍNIO & GUIMARANIA & 0 & 0 \\
\hline PATROCÍNIO & IBIA & 1 & 0 \\
\hline PATROCÍNIO & IRAI DE MINAS & 0 & 0 \\
\hline PATROCÍNIO & PATROCINIO & 2 & 0 \\
\hline PATROCÍNIO & PERDIZES & 1 & 0 \\
\hline PATROCÍNIO & SERRA DO SALITRE & 0 & 0 \\
\hline PIRAPORA & BURITIZEIRO & 3 & 0 \\
\hline PIRAPORA & IBIAI & 0 & 0 \\
\hline PIRAPORA & JEQUITAI & 0 & 0 \\
\hline PIRAPORA & LAGOA DOS PATOS & 1 & 0 \\
\hline PIRAPORA & PIRAPORA & 3 & 0 \\
\hline PIRAPORA & PONTO CHIQUE & 1 & 0 \\
\hline PIRAPORA & SANTA FE DE MINAS & 0 & 0 \\
\hline PIRAPORA & SAO ROMAO & 1 & 0 \\
\hline PIRAPORA & VARZEA DA PALMA & 2 & 0 \\
\hline POÇOS DE CALDAS & ALTEROSA & 0 & 0 \\
\hline POÇOS DE CALDAS & ANDRADAS & 1 & 0 \\
\hline POÇOS DE CALDAS & AREADO & 1 & 0 \\
\hline POÇOS DE CALDAS & BANDEIRA DO SUL & 1 & 0 \\
\hline POÇOS DE CALDAS & BOTELHOS & 0 & 0 \\
\hline POÇOS DE CALDAS & CABO VERDE & 0 & 0 \\
\hline POÇOS DE CALDAS & CALDAS & 0 & 0 \\
\hline POÇOS DE CALDAS & CAMPESTRE & 0 & 0 \\
\hline POÇOS DE CALDAS & CONCEICAO DA APARECIDA & 0 & 0 \\
\hline POÇOS DE CALDAS & DIVISA NOVA & 0 & 0 \\
\hline POÇOS DE CALDAS & IBITIURA DE MINAS & 1 & 0 \\
\hline POÇOS DE CALDAS & MONTE BELO & 0 & 0 \\
\hline POÇOS DE CALDAS & MUZAMBINHO & 0 & 0 \\
\hline POÇOS DE CALDAS & NOVA RESENDE & 1 & 0 \\
\hline POÇOS DE CALDAS & POCOS DE CALDAS & 5 & 2 \\
\hline POÇOS DE CALDAS & SANTA RITA DE CALDAS & 0 & 0 \\
\hline
\end{tabular}




\begin{tabular}{|c|c|c|c|}
\hline POÇOS DE CALDAS & SERRANIA & 0 & 0 \\
\hline PONTE NOVA & ABRE CAMPO & 1 & 0 \\
\hline PONTE NOVA & ALVINOPOLIS & 0 & 0 \\
\hline PONTE NOVA & AMPARO DO SERRA & 1 & 0 \\
\hline PONTE NOVA & ARAPONGA & 1 & 0 \\
\hline PONTE NOVA & BARRA LONGA & 0 & 0 \\
\hline PONTE NOVA & CAJURI & 0 & 0 \\
\hline PONTE NOVA & CANAA & 0 & 0 \\
\hline PONTE NOVA & DOM SILVERIO & 0 & 0 \\
\hline PONTE NOVA & GUARACIABA & 0 & 0 \\
\hline PONTE NOVA & JEQUERI & 0 & 0 \\
\hline PONTE NOVA & ORATORIOS & 0 & 0 \\
\hline PONTE NOVA & PEDRA BONITA & 1 & 0 \\
\hline PONTE NOVA & PEDRA DO ANTA & 0 & 0 \\
\hline PONTE NOVA & PIEDADE DE PONTE NOVA & 0 & 0 \\
\hline PONTE NOVA & PONTE NOVA & 1 & 0 \\
\hline PONTE NOVA & PORTO FIRME & 0 & 0 \\
\hline PONTE NOVA & RAUL SOARES & 0 & 0 \\
\hline PONTE NOVA & RIO CASCA & 0 & 0 \\
\hline PONTE NOVA & RIO DOCE & 0 & 0 \\
\hline PONTE NOVA & SANTA CRUZ DO ESCALVADO & 0 & 0 \\
\hline PONTE NOVA & SANTO ANTONIO DO GRAMA & 0 & 0 \\
\hline PONTE NOVA & SAO MIGUEL DO ANTA & 0 & 0 \\
\hline PONTE NOVA & SAO PEDRO DOS FERROS & 0 & 0 \\
\hline PONTE NOVA & SEM-PEIXE & 1 & 0 \\
\hline PONTE NOVA & SERICITA & 1 & 0 \\
\hline PONTE NOVA & TEIXEIRAS & 1 & 0 \\
\hline PONTE NOVA & URUCANIA & 1 & 0 \\
\hline PONTE NOVA & VERMELHO NOVO & 0 & 0 \\
\hline PONTE NOVA & VICOSA & 5 & 2 \\
\hline POUSO ALEGRE & ALBERTINA & 1 & 0 \\
\hline POUSO ALEGRE & BOM REPOUSO & 1 & 0 \\
\hline POUSO ALEGRE & BORDA DA MATA & 0 & 0 \\
\hline POUSO ALEGRE & BUENO BRANDAO & 1 & 0 \\
\hline POUSO ALEGRE & CACHOEIRA DE MINAS & 1 & 0 \\
\hline POUSO ALEGRE & CAMANDUCAIA & 3 & 0 \\
\hline POUSO ALEGRE & CAMBUI & 2 & 0 \\
\hline POUSO ALEGRE & CAREACU & 1 & 0 \\
\hline POUSO ALEGRE & CONGONHAL & 1 & 0 \\
\hline POUSO ALEGRE & CORREGO DO BOM JESUS & 0 & 0 \\
\hline POUSO ALEGRE & ESPIRITO SANTO DO DOURADO & 1 & 0 \\
\hline POUSO ALEGRE & ESTIVA & 1 & 0 \\
\hline POUSO ALEGRE & EXTREMA & 2 & 0 \\
\hline POUSO ALEGRE & HELIODORA & 0 & 0 \\
\hline POUSO ALEGRE & INCONFIDENTES & 1 & 0 \\
\hline
\end{tabular}




\begin{tabular}{|c|c|c|c|}
\hline POUSO ALEGRE & IPUIUNA & 0 & 0 \\
\hline POUSO ALEGRE & ITAPEVA & 1 & 0 \\
\hline POUSO ALEGRE & JACUTINGA & 0 & 0 \\
\hline POUSO ALEGRE & MONTE SIAO & 0 & 0 \\
\hline POUSO ALEGRE & MUNHOZ & 0 & 0 \\
\hline POUSO ALEGRE & OURO FINO & 1 & 0 \\
\hline POUSO ALEGRE & POUSO ALEGRE & 3 & 0 \\
\hline POUSO ALEGRE & SANTA RITA DO SAPUCAI & 1 & 0 \\
\hline POUSO ALEGRE & SAO JOAO DA MATA & 0 & 0 \\
\hline POUSO ALEGRE & SAO SEBASTIAO DA BELA VISTA & 0 & 0 \\
\hline POUSO ALEGRE & SENADOR AMARAL & 0 & 0 \\
\hline POUSO ALEGRE & SENADOR JOSE BENTO & 0 & 0 \\
\hline POUSO ALEGRE & SILVIANOPOLIS & 0 & 0 \\
\hline POUSO ALEGRE & TOCOS DO MOJI & 0 & 0 \\
\hline POUSO ALEGRE & TOLEDO & 0 & 0 \\
\hline SÃO JOÃO DEL REI & BOM SUCESSO & 0 & 0 \\
\hline SÃO JOÃO DEL REI & CARRANCAS & 0 & 0 \\
\hline SÃO JOÃO DEL REI & CONCEICAO DA BARRA DE MINAS & 0 & 0 \\
\hline SÃO JOÃO DEL REI & CORONEL XAVIER CHAVES & 0 & 0 \\
\hline SÃO JOÃO DEL REI & DORES DE CAMPOS & 0 & 0 \\
\hline SÃO JOÃO DEL REI & IBITURUNA & 1 & 0 \\
\hline SÃO JOÃO DEL REI & IJACI & 0 & 0 \\
\hline SÃO JOÃO DEL REI & INGAI & 0 & 0 \\
\hline SÃO JOÃO DEL REI & ITUMIRIM & 0 & 0 \\
\hline SÃO JOÃO DEL REI & ITUTINGA & 1 & 0 \\
\hline SÃO JOÃO DEL REI & LAGOA DOURADA & 0 & 0 \\
\hline SÃO JOÃO DEL REI & NAZARENO & 0 & 0 \\
\hline SÃO JOÃO DEL REI & PRADOS & 1 & 0 \\
\hline SÃO JOÃO DEL REI & RESENDE COSTA & 0 & 0 \\
\hline SÃO JOÃO DEL REI & RITAPOLIS & 1 & 0 \\
\hline SÃO JOÃO DEL REI & SANTA CRUZ DE MINAS & 0 & 0 \\
\hline SÃO JOÃO DEL REI & SAO JOAO DEL REI & 1 & 0 \\
\hline SÃO JOÃO DEL REI & SAO TIAGO & 0 & 0 \\
\hline SÃO JOÃO DEL REI & TIRADENTES & 0 & 0 \\
\hline SÃO SEBASTIÃO DO PARAÍSO & ARCEBURGO & 0 & 0 \\
\hline SÃO SEBASTIÃO DO PARAÍSO & CAPETINGA & 0 & 0 \\
\hline SÃO SEBASTIÃO DO PARAÍSO & CASSIA & 0 & 0 \\
\hline SÃO SEBASTIÃO DO PARAÍSO & CLARAVAL & 0 & 0 \\
\hline SÃO SEBASTIÃO DO PARAÍSO & GUARANESIA & 0 & 0 \\
\hline SÃO SEBASTIÃO DO PARAÍSO & GUAXUPE & 1 & 0 \\
\hline SÃO SEBASTIÃO DO PARAÍSO & IBIRACI & 0 & 0 \\
\hline SÃO SEBASTIÃO DO PARAÍSO & ITAMOGI & 0 & 0 \\
\hline SÃO SEBASTIÃO DO PARAÍSO & ITAU DE MINAS & 0 & 0 \\
\hline SÃO SEBASTIÃO DO PARAÍSO & JACUI & 0 & 0 \\
\hline SÃO SEBASTIÃO DO PARAÍSO & JURUAIA & 0 & 0 \\
\hline
\end{tabular}




\begin{tabular}{|c|c|c|c|}
\hline SÃO SEBASTIÃO DO PARAÍSO & MONTE SANTO DE MINAS & 0 & 0 \\
\hline SÃO SEBASTIÃO DO PARAÍSO & PRATAPOLIS & 0 & 0 \\
\hline SÃO SEBASTIÃO DO PARAÍSO & SAO PEDRO DA UNIAO & 0 & 0 \\
\hline SÃO SEBASTIÃO DO PARAÍSO & SAO SEBASTIAO DO PARAISO & 4 & 0 \\
\hline SÃO SEBASTIÃO DO PARAÍSO & SAO TOMAS DE AQUINO & 1 & 0 \\
\hline SETE LAGOAS & ARACAI & 0 & 0 \\
\hline SETE LAGOAS & BALDIM & 3 & 0 \\
\hline SETE LAGOAS & CACHOEIRA DA PRATA & 0 & 0 \\
\hline SETE LAGOAS & CAETANOPOLIS & 0 & 0 \\
\hline SETE LAGOAS & CAPIM BRANCO & 0 & 0 \\
\hline SETE LAGOAS & CORDISBURGO & 0 & 0 \\
\hline SETE LAGOAS & FORTUNA DE MINAS & 0 & 0 \\
\hline SETE LAGOAS & FUNILANDIA & 0 & 0 \\
\hline SETE LAGOAS & INHAUMA & 0 & 0 \\
\hline SETE LAGOAS & JEQUITIBA & 1 & 0 \\
\hline SETE LAGOAS & MARAVILHAS & 0 & 0 \\
\hline SETE LAGOAS & MATOZINHOS & 2 & 0 \\
\hline SETE LAGOAS & PAPAGAIOS & 0 & 0 \\
\hline SETE LAGOAS & PARAOPEBA & 1 & 0 \\
\hline SETE LAGOAS & POMPEU & 1 & 0 \\
\hline SETE LAGOAS & PRUDENTE DE MORAIS & 1 & 0 \\
\hline SETE LAGOAS & SANTANA DE PIRAPAMA & 1 & 0 \\
\hline SETE LAGOAS & SETE LAGOAS & 6 & 2 \\
\hline TEOFILO OTONI & AGUAS FORMOSAS & 1 & 0 \\
\hline TEOFILO OTONI & ATALEIA & 0 & 0 \\
\hline TEOFILO OTONI & BERTOPOLIS & 0 & 0 \\
\hline TEOFILO OTONI & CAMPANARIO & 0 & 0 \\
\hline TEOFILO OTONI & CARAI & 1 & 0 \\
\hline TEOFILO OTONI & CARLOS CHAGAS & 1 & 0 \\
\hline TEOFILO OTONI & CATUJI & 0 & 0 \\
\hline TEOFILO OTONI & CRISOLITA & 1 & 0 \\
\hline TEOFILO OTONI & FRANCISCOPOLIS & 1 & 0 \\
\hline TEOFILO OTONI & FREI GASPAR & 0 & 0 \\
\hline TEOFILO OTONI & FRONTEIRA DOS VALES & 0 & 0 \\
\hline TEOFILO OTONI & ITAIPE & 0 & 0 \\
\hline TEOFILO OTONI & ITAMBACURI & 0 & 0 \\
\hline TEOFILO OTONI & JAMPRUCA & 0 & 0 \\
\hline TEOFILO OTONI & LADAINHA & 1 & 0 \\
\hline TEOFILO OTONI & MACHACALIS & 1 & 0 \\
\hline TEOFILO OTONI & MALACACHETA & 1 & 0 \\
\hline TEOFILO OTONI & NANUQUE & 0 & 0 \\
\hline TEOFILO OTONI & NOVO CRUZEIRO & 3 & 0 \\
\hline TEOFILO OTONI & NOVO ORIENTE DE MINAS & 1 & 0 \\
\hline TEOFILO OTONI & OURO VERDE DE MINAS & 0 & 0 \\
\hline TEOFILO OTONI & PADRE PARAISO & 0 & 0 \\
\hline
\end{tabular}




\begin{tabular}{|c|c|c|c|}
\hline TEOFILO OTONI & PAVAO & 1 & 0 \\
\hline TEOFILO OTONI & PESCADOR & 0 & 0 \\
\hline TEOFILO OTONI & PONTO DOS VOLANTES & 1 & 0 \\
\hline TEOFILO OTONI & POTE & 0 & 0 \\
\hline TEOFILO OTONI & SANTA HELENA DE MINAS & 0 & 0 \\
\hline TEOFILO OTONI & SERRA DOS AIMORES & 0 & 0 \\
\hline TEOFILO OTONI & SETUBINHA & 1 & 0 \\
\hline TEOFILO OTONI & TEOFILO OTONI & 4 & 0 \\
\hline TEOFILO OTONI & UMBURATIBA & 0 & 0 \\
\hline UBÁ & ASTOLFO DUTRA & 0 & 0 \\
\hline UBÁ & BRAS PIRES & 0 & 0 \\
\hline UBÁ & COIMBRA & 1 & 0 \\
\hline UBÁ & DIVINESIA & 0 & 0 \\
\hline UBÁ & DONA EUZEBIA & 0 & 0 \\
\hline UBÁ & DORES DO TURVO & 0 & 0 \\
\hline UBÁ & ERVALIA & 0 & 0 \\
\hline UBÁ & GUARANI & 0 & 0 \\
\hline UBÁ & GUIDOVAL & 0 & 0 \\
\hline UBÁ & GUIRICEMA & 0 & 0 \\
\hline UBÁ & PAULA CANDIDO & 1 & 0 \\
\hline UBÁ & PIRAUBA & 0 & 0 \\
\hline UBÁ & PRESIDENTE BERNARDES & 0 & 0 \\
\hline UBÁ & RIO POMBA & 0 & 0 \\
\hline UBÁ & RODEIRO & 1 & 0 \\
\hline UBÁ & SAO GERALDO & 0 & 0 \\
\hline UBÁ & SENADOR FIRMINO & 0 & 0 \\
\hline UBÁ & SILVEIRANIA & 0 & 0 \\
\hline UBÁ & TABULEIRO & 0 & 0 \\
\hline UBÁ & TOCANTINS & 0 & 0 \\
\hline UBÁ & UBA & 2 & 0 \\
\hline UBÁ & VISCONDE DO RIO BRANCO & 0 & 0 \\
\hline UBERABA & AGUA COMPRIDA & 0 & 0 \\
\hline UBERABA & ARAXA & 1 & 0 \\
\hline UBERABA & CAMPO FLORIDO & 0 & 0 \\
\hline UBERABA & CAMPOS ALTOS & 0 & 0 \\
\hline UBERABA & CARNEIRINHO & 1 & 0 \\
\hline UBERABA & COMENDADOR GOMES & 0 & 0 \\
\hline UBERABA & CONCEICAO DAS ALAGOAS & 1 & 0 \\
\hline UBERABA & CONQUISTA & 0 & 0 \\
\hline UBERABA & DELTA & 1 & 0 \\
\hline UBERABA & FRONTEIRA & 0 & 0 \\
\hline UBERABA & FRUTAL & 1 & 0 \\
\hline UBERABA & ITAPAGIPE & 1 & 0 \\
\hline UBERABA & ITURAMA & 2 & 0 \\
\hline UBERABA & LIMEIRA DO OESTE & 1 & 0 \\
\hline
\end{tabular}




\begin{tabular}{|c|c|c|c|}
\hline UBERABA & PEDRINOPOLIS & 1 & 0 \\
\hline UBERABA & PIRAJUBA & 0 & 0 \\
\hline UBERABA & PLANURA & 0 & 0 \\
\hline UBERABA & PRATINHA & 0 & 0 \\
\hline UBERABA & SACRAMENTO & 0 & 0 \\
\hline UBERABA & SANTA JULIANA & 1 & 0 \\
\hline UBERABA & SAO FRANCISCO DE SALES & 1 & 0 \\
\hline UBERABA & TAPIRA & 0 & 0 \\
\hline UBERABA & UBERABA & 7 & 2 \\
\hline UBERABA & UNIAO DE MINAS & 0 & 0 \\
\hline UBERABA & VERISSIMO & 0 & 0 \\
\hline UBERLANDIA & ARAGUARI & 3 & 0 \\
\hline UBERLANDIA & ARAPORA & 0 & 0 \\
\hline UBERLANDIA & CAMPINA VERDE & 0 & 0 \\
\hline UBERLANDIA & INDIANOPOLIS & 0 & 0 \\
\hline UBERLANDIA & MONTE ALEGRE DE MINAS & 0 & 0 \\
\hline UBERLANDIA & NOVA PONTE & 0 & 0 \\
\hline UBERLANDIA & PRATA & 0 & 0 \\
\hline UBERLANDIA & TUPACIGUARA & 1 & 0 \\
\hline UBERLANDIA & UBERLANDIA & 18 & 4 \\
\hline UNAI & ARINOS & 0 & 0 \\
\hline UNAI & BONFINOPOLIS DE MINAS & 0 & 0 \\
\hline UNAI & BURITIS & 0 & 0 \\
\hline UNAI & CABECEIRA GRANDE & 1 & 0 \\
\hline UNAI & DOM BOSCO & 1 & 0 \\
\hline UNAI & FORMOSO & 0 & 0 \\
\hline UNAI & NATALANDIA & 0 & 0 \\
\hline UNAI & RIACHINHO & 0 & 0 \\
\hline UNAI & UNAI & 5 & 2 \\
\hline UNAI & URUANA DE MINAS & 0 & 0 \\
\hline VARGINHA & ALFENAS & 4 & 0 \\
\hline VARGINHA & BOA ESPERANCA & 1 & 0 \\
\hline VARGINHA & CAMBUQUIRA & 0 & 0 \\
\hline VARGINHA & CAMPANHA & 0 & 0 \\
\hline VARGINHA & CAMPO DO MEIO & 0 & 0 \\
\hline VARGINHA & CAMPOS GERAIS & 0 & 0 \\
\hline VARGINHA & CARMO DA CACHOEIRA & 1 & 0 \\
\hline VARGINHA & CARVALHOPOLIS & 1 & 0 \\
\hline VARGINHA & COQUEIRAL & 0 & 0 \\
\hline VARGINHA & CORDISLANDIA & 0 & 0 \\
\hline VARGINHA & ELOI MENDES & 1 & 0 \\
\hline VARGINHA & FAMA & 0 & 0 \\
\hline VARGINHA & GUAPE & 0 & 0 \\
\hline VARGINHA & ILICINEA & 0 & 0 \\
\hline VARGINHA & LAMBARI & 1 & 0 \\
\hline
\end{tabular}




\begin{tabular}{|l|l|c|c|} 
VARGINHA & LUMINARIAS & 0 & 0 \\
\hline VARGINHA & MACHADO & 1 & 0 \\
\hline VARGINHA & MONSENHOR PAULO & 0 & 0 \\
\hline VARGINHA & NEPOMUCENO & 0 & 0 \\
\hline VARGINHA & PARAGUACU & 0 & 0 \\
\hline VARGINHA & POCO FUNDO & 1 & 0 \\
\hline VARGINHA & SANTANA DA VARGEM & 0 & 0 \\
\hline VARGINHA & SAO BENTO ABADE & 0 & 0 \\
\hline VARGINHA & SAO GONCALO DO SAPUCAI & 4 & 0 \\
\hline VARGINHA & TRES CORACOES & 1 & 0 \\
\hline VARGINHA & TRES PONTAS & 0 & 0 \\
\hline VARGINHA & TURVOLANDIA & 3 & $\mathbf{6 5}$ \\
\hline VARGINHA & VARGINHA & $\mathbf{6 5 4}$ & 0 \\
\hline Total geral & & & 0 \\
\hline
\end{tabular}

CARGO: PROFESSOR DE EDUCAÇÃO BÁSICA - PEB -F I S I C A

\begin{tabular}{|c|c|c|c|}
\hline S R E & MUNICIPIO & $\begin{array}{l}\text { TOTAL DE } \\
\text { VAGAS }\end{array}$ & $\begin{array}{c}\text { VAGAS } \\
\text { RESERVADAS - } \\
\text { PORTADORES DE } \\
\text { DEFICIÊNCIA } \\
\end{array}$ \\
\hline ALMENARA & AGUAS VERMELHAS & 1 & 0 \\
\hline ALMENARA & ALMENARA & 2 & 0 \\
\hline ALMENARA & BANDEIRA & 0 & 0 \\
\hline ALMENARA & CACHOEIRA DE PAJEU & 1 & 0 \\
\hline ALMENARA & CURRAL DE DENTRO & 0 & 0 \\
\hline ALMENARA & DIVISA ALEGRE & 0 & 0 \\
\hline ALMENARA & DIVISOPOLIS & 0 & 0 \\
\hline ALMENARA & FELISBURGO & 0 & 0 \\
\hline ALMENARA & JACINTO & 1 & 0 \\
\hline ALMENARA & JEQUITINHONHA & 0 & 0 \\
\hline ALMENARA & JOAIMA & 0 & 0 \\
\hline ALMENARA & JORDANIA & 1 & 0 \\
\hline ALMENARA & MATA VERDE & 0 & 0 \\
\hline ALMENARA & MONTE FORMOSO & 0 & 0 \\
\hline ALMENARA & PALMOPOLIS & 0 & 0 \\
\hline ALMENARA & PEDRA AZUL & 0 & 0 \\
\hline ALMENARA & RIO DO PRADO & 0 & 0 \\
\hline ALMENARA & RUBIM & 0 & 0 \\
\hline ALMENARA & SALTO DA DIVISA & 0 & 0 \\
\hline ALMENARA & SANTA MARIA DO SALTO & 1 & 0 \\
\hline ALMENARA & SANTO ANTONIO DO JACINTO & 0 & 0 \\
\hline ARACUAI & ARACUAI & 2 & 0 \\
\hline ARACUAI & BERILO & 1 & 0 \\
\hline ARACUAI & BERIZAL & 0 & 0 \\
\hline ARACUAI & CHAPADA DO NORTE & 1 & 0 \\
\hline ARACUAI & COMERCINHO & 2 & 0 \\
\hline
\end{tabular}




\begin{tabular}{|c|c|c|c|}
\hline ARACUAI & CORONEL MURTA & 0 & 0 \\
\hline ARACUAI & FRANCISCO BADARO & 2 & 0 \\
\hline ARACUAI & FRUTA DE LEITE & 0 & 0 \\
\hline ARACUAI & INDAIABIRA & 0 & 0 \\
\hline ARACUAI & ITAOBIM & 1 & 0 \\
\hline ARACUAI & ITINGA & 1 & 0 \\
\hline ARACUAI & JENIPAPO DE MINAS & 0 & 0 \\
\hline ARACUAI & JOSE GONCALVES DE MINAS & 0 & 0 \\
\hline ARACUAI & MEDINA & 1 & 0 \\
\hline ARACUAI & NINHEIRA & 3 & 0 \\
\hline ARACUAI & NOVORIZONTE & 0 & 0 \\
\hline ARACUAI & RUBELITA & 0 & 0 \\
\hline ARACUAI & SALINAS & 1 & 0 \\
\hline ARACUAI & SANTA CRUZ DE SALINAS & 1 & 0 \\
\hline ARACUAI & TAIOBEIRAS & 1 & 0 \\
\hline ARACUAI & VIRGEM DA LAPA & 1 & 0 \\
\hline BARBACENA & ALFREDO VASCONCELOS & 0 & 0 \\
\hline BARBACENA & ALTO RIO DOCE & 1 & 0 \\
\hline BARBACENA & ANDRELANDIA & 1 & 0 \\
\hline BARBACENA & ANTONIO CARLOS & 0 & 0 \\
\hline BARBACENA & ARACITABA & 1 & 0 \\
\hline BARBACENA & BARBACENA & 5 & 2 \\
\hline BARBACENA & BARROSO & 1 & 0 \\
\hline BARBACENA & BIAS FORTES & 0 & 0 \\
\hline BARBACENA & CAPELA NOVA & 0 & 0 \\
\hline BARBACENA & CARANDAI & 0 & 0 \\
\hline BARBACENA & CIPOTANEA & 0 & 0 \\
\hline BARBACENA & DESTERRO DO MELO & 0 & 0 \\
\hline BARBACENA & IBERTIOGA & 0 & 0 \\
\hline BARBACENA & MADRE DE DEUS DE MINAS & 0 & 0 \\
\hline BARBACENA & MERCES & 0 & 0 \\
\hline BARBACENA & OLIVEIRA FORTES & 1 & 0 \\
\hline BARBACENA & PAIVA & 0 & 0 \\
\hline BARBACENA & PIEDADE DO RIO GRANDE & 0 & 0 \\
\hline BARBACENA & RESSAQUINHA & 0 & 0 \\
\hline BARBACENA & SANTA BARBARA DO TUGURIO & 0 & 0 \\
\hline BARBACENA & SANTA RITA DO IBITIPOCA & 0 & 0 \\
\hline BARBACENA & SANTANA DO GARAMBEU & 0 & 0 \\
\hline BARBACENA & SAO VICENTE DE MINAS & 1 & 0 \\
\hline BARBACENA & SENHORA DOS REMEDIOS & 0 & 0 \\
\hline CAMPO BELO & AGUANIL & 0 & 0 \\
\hline CAMPO BELO & САMACHO & 0 & 0 \\
\hline CAMPO BELO & CAMPO BELO & 1 & 0 \\
\hline CAMPO BELO & CANA VERDE & 0 & 0 \\
\hline CAMPO BELO & CANDEIAS & 0 & 0 \\
\hline
\end{tabular}




\begin{tabular}{|c|c|c|c|}
\hline CAMPO BELO & CRISTAIS & 1 & 0 \\
\hline CAMPO BELO & LAVRAS & 3 & 0 \\
\hline CAMPO BELO & PERDOES & 0 & 0 \\
\hline CAMPO BELO & RIBEIRAO VERMELHO & 1 & 0 \\
\hline CAMPO BELO & SANTANA DO JACARE & 0 & 0 \\
\hline CAMPO BELO & SANTO ANTONIO DO AMPARO & 0 & 0 \\
\hline CAMPO BELO & SAO FRANCISCO DE PAULA & 0 & 0 \\
\hline CARANGOLA & ALTO CAPARAO & 0 & 0 \\
\hline CARANGOLA & CAIANA & 0 & 0 \\
\hline CARANGOLA & CAPARAO & 0 & 0 \\
\hline CARANGOLA & CARANGOLA & 1 & 0 \\
\hline CARANGOLA & DIVINO & 4 & 0 \\
\hline CARANGOLA & ESPERA FELIZ & 2 & 0 \\
\hline CARANGOLA & FARIA LEMOS & 0 & 0 \\
\hline CARANGOLA & FERVEDOURO & 1 & 0 \\
\hline CARANGOLA & ORIZANIA & 0 & 0 \\
\hline CARANGOLA & PEDRA DOURADA & 0 & 0 \\
\hline CARANGOLA & TOMBOS & 0 & 0 \\
\hline CARATINGA & ALVARENGA & 0 & 0 \\
\hline CARATINGA & BOM JESUS DO GALHO & 0 & 0 \\
\hline CARATINGA & BUGRE & 0 & 0 \\
\hline CARATINGA & CARATINGA & 6 & 2 \\
\hline CARATINGA & CORREGO NOVO & 1 & 0 \\
\hline CARATINGA & DOM CAVATI & 0 & 0 \\
\hline CARATINGA & ENTRE FOLHAS & 0 & 0 \\
\hline CARATINGA & IAPU & 0 & 0 \\
\hline CARATINGA & IMBE DE MINAS & 0 & 0 \\
\hline CARATINGA & INHAPIM & 3 & 0 \\
\hline CARATINGA & IPABA & 0 & 0 \\
\hline CARATINGA & IPANEMA & 0 & 0 \\
\hline CARATINGA & PIEDADE DE CARATINGA & 1 & 0 \\
\hline CARATINGA & PINGO D AGUA & 0 & 0 \\
\hline CARATINGA & POCRANE & 0 & 0 \\
\hline CARATINGA & SANTA BARBARA DO LESTE & 0 & 0 \\
\hline CARATINGA & SANTA RITA DE MINAS & 0 & 0 \\
\hline CARATINGA & SAO DOMINGOS DAS DORES & 0 & 0 \\
\hline CARATINGA & SAO JOAO DO ORIENTE & 0 & 0 \\
\hline CARATINGA & SAO SEBASTIAO DO ANTA & 0 & 0 \\
\hline CARATINGA & TAPARUBA & 0 & 0 \\
\hline CARATINGA & TARUMIRIM & 4 & 0 \\
\hline CARATINGA & UBAPORANGA & 1 & 0 \\
\hline CARATINGA & VARGEM ALEGRE & 1 & 0 \\
\hline CAXAMBU & AIURUOCA & 1 & 0 \\
\hline CAXAMBU & ALAGOA & 0 & 0 \\
\hline CAXAMBU & BAEPENDI & 3 & 0 \\
\hline
\end{tabular}




\begin{tabular}{|c|c|c|c|}
\hline CAXAMBU & BOCAINA DE MINAS & 0 & 0 \\
\hline CAXAMBU & CARVALHOS & 1 & 0 \\
\hline CAXAMBU & CAXAMBU & 0 & 0 \\
\hline CAXAMBU & CONCEICAO DO RIO VERDE & 0 & 0 \\
\hline CAXAMBU & CRUZILIA & 0 & 0 \\
\hline CAXAMBU & ITAMONTE & 0 & 0 \\
\hline CAXAMBU & ITANHANDU & 0 & 0 \\
\hline CAXAMBU & JESUANIA & 0 & 0 \\
\hline CAXAMBU & LIBERDADE & 0 & 0 \\
\hline CAXAMBU & MINDURI & 0 & 0 \\
\hline CAXAMBU & OLIMPIO NORONHA & 0 & 0 \\
\hline CAXAMBU & PASSA QUATRO & 0 & 0 \\
\hline CAXAMBU & PASSA VINTE & 0 & 0 \\
\hline CAXAMBU & POUSO ALTO & 1 & 0 \\
\hline CAXAMBU & SAO LOURENCO & 4 & 0 \\
\hline CAXAMBU & SAO SEBASTIAO DO RIO VERDE & 0 & 0 \\
\hline CAXAMBU & SAO TOME DAS LETRAS & 0 & 0 \\
\hline CAXAMBU & SERITINGA & 0 & 0 \\
\hline CAXAMBU & SERRANOS & 0 & 0 \\
\hline CAXAMBU & SOLEDADE DE MINAS & 0 & 0 \\
\hline CORONEL FABRICIANO & ANTONIO DIAS & 1 & 0 \\
\hline CORONEL FABRICIANO & BELO ORIENTE & 1 & 0 \\
\hline CORONEL FABRICIANO & BRAUNAS & 0 & 0 \\
\hline CORONEL FABRICIANO & CORONEL FABRICIANO & 4 & 0 \\
\hline CORONEL FABRICIANO & IPATINGA & 4 & 0 \\
\hline CORONEL FABRICIANO & JAGUARAÇU & 0 & 0 \\
\hline CORONEL FABRICIANO & JOANESIA & 0 & 0 \\
\hline CORONEL FABRICIANO & MARLIERIA & 1 & 0 \\
\hline CORONEL FABRICIANO & MESQUITA & 0 & 0 \\
\hline CORONEL FABRICIANO & SANTANA DO PARAISO & 1 & 0 \\
\hline CORONEL FABRICIANO & TIMOTEO & 1 & 0 \\
\hline CONSELHEIRO LAFAIETE & CARANAIBA & 0 & 0 \\
\hline CONSELHEIRO LAFAIETE & CASA GRANDE & 1 & 0 \\
\hline CONSELHEIRO LAFAIETE & CATAS ALTAS DA NORUEGA & 0 & 0 \\
\hline CONSELHEIRO LAFAIETE & CONGONHAS & 0 & 0 \\
\hline CONSELHEIRO LAFAIETE & CONSELHEIRO LAFAIETE & 2 & 0 \\
\hline CONSELHEIRO LAFAIETE & CRISTIANO OTONI & 0 & 0 \\
\hline CONSELHEIRO LAFAIETE & DESTERRO DE ENTRE RIOS & 0 & 0 \\
\hline CONSELHEIRO LAFAIETE & ENTRE RIOS DE MINAS & 0 & 0 \\
\hline CONSELHEIRO LAFAIETE & ITAVERAVA & 0 & 0 \\
\hline CONSELHEIRO LAFAIETE & JECEABA & 0 & 0 \\
\hline CONSELHEIRO LAFAIETE & LAMIM & 0 & 0 \\
\hline CONSELHEIRO LAFAIETE & OURO BRANCO & 1 & 0 \\
\hline CONSELHEIRO LAFAIETE & PIRANGA & 1 & 0 \\
\hline CONSELHEIRO LAFAIETE & QUELUZITO & 1 & 0 \\
\hline
\end{tabular}




\begin{tabular}{|c|c|c|c|}
\hline CONSELHEIRO LAFAIETE & RIO ESPERA & 1 & 0 \\
\hline CONSELHEIRO LAFAIETE & SANTANA DOS MONTES & 0 & 0 \\
\hline CONSELHEIRO LAFAIETE & SAO BRAS DO SUACUI & 0 & 0 \\
\hline CONSELHEIRO LAFAIETE & SENHORA DE OLIVEIRA & 2 & 0 \\
\hline CURVELO & AUGUSTO DE LIMA & 0 & 0 \\
\hline CURVELO & BUENOPOLIS & 0 & 0 \\
\hline CURVELO & CORINTO & 2 & 0 \\
\hline CURVELO & CURVELO & 6 & 2 \\
\hline CURVELO & FELIXLANDIA & 1 & 0 \\
\hline CURVELO & INIMUTABA & 1 & 0 \\
\hline CURVELO & JOAQUIM FELICIO & 0 & 0 \\
\hline CURVELO & LASSANCE & 1 & 0 \\
\hline CURVELO & MORRO DA GARCA & 0 & 0 \\
\hline CURVELO & PRESIDENTE JUSCELINO & 1 & 0 \\
\hline CURVELO & SANTO HIPOLITO & 0 & 0 \\
\hline CURVELO & TRES MARIAS & 1 & 0 \\
\hline DIAMANTINA & ALVORADA DE MINAS & 1 & 0 \\
\hline DIAMANTINA & ANGELANDIA & 1 & 0 \\
\hline DIAMANTINA & ARICANDUVA & 1 & 0 \\
\hline DIAMANTINA & CAPELINHA & 4 & 0 \\
\hline DIAMANTINA & CARBONITA & 1 & 0 \\
\hline DIAMANTINA & CONCEICAO DO MATO DENTRO & 1 & 0 \\
\hline DIAMANTINA & CONGONHAS DO NORTE & 0 & 0 \\
\hline DIAMANTINA & COUTO DE MAGALHAES DE MINAS & 1 & 0 \\
\hline DIAMANTINA & DATAS & 0 & 0 \\
\hline DIAMANTINA & DIAMANTINA & 1 & 0 \\
\hline DIAMANTINA & FELICIO DOS SANTOS & 1 & 0 \\
\hline DIAMANTINA & GOUVEA & 1 & 0 \\
\hline DIAMANTINA & ITAMARANDIBA & 3 & 0 \\
\hline DIAMANTINA & LEME DO PRADO & 1 & 0 \\
\hline DIAMANTINA & MINAS NOVAS & 4 & 0 \\
\hline DIAMANTINA & MONJOLOS & 0 & 0 \\
\hline DIAMANTINA & PRESIDENTE KUBITSCHEK & 0 & 0 \\
\hline DIAMANTINA & RIO VERMELHO & 2 & 0 \\
\hline DIAMANTINA & SANTO ANTONIO DO ITAMBE & 0 & 0 \\
\hline DIAMANTINA & SAO GONCALO DO RIO PRETO & 0 & 0 \\
\hline DIAMANTINA & SENADOR MODESTINO GONCALVES & 0 & 0 \\
\hline DIAMANTINA & SERRA AZUL DE MINAS & 0 & 0 \\
\hline DIAMANTINA & SERRO & 3 & 0 \\
\hline DIAMANTINA & TURMALINA & 2 & 0 \\
\hline DIAMANTINA & VEREDINHA & 0 & 0 \\
\hline DIVINÓPOLIS & ARAUJOS & 0 & 0 \\
\hline DIVINÓPOLIS & ARCOS & 0 & 0 \\
\hline DIVINÓPOLIS & BAMBUI & 0 & 0 \\
\hline DIVINÓPOLIS & CARMO DA MATA & 0 & 0 \\
\hline
\end{tabular}




\begin{tabular}{|c|c|c|c|}
\hline DIVINÓPOLIS & CARMO DO CAJURU & 0 & 0 \\
\hline DIVINÓPOLIS & CARMOPOLIS DE MINAS & 1 & 0 \\
\hline DIVINÓPOLIS & CLAUDIO & 2 & 0 \\
\hline DIVINÓPOLIS & CORREGO DANTA & 0 & 0 \\
\hline DIVINÓPOLIS & DIVINOPOLIS & 4 & 0 \\
\hline DIVINÓPOLIS & IGUATAMA & 0 & 0 \\
\hline DIVINÓPOLIS & ITAGUARA & 2 & 0 \\
\hline DIVINÓPOLIS & ITAPECERICA & 2 & 0 \\
\hline DIVINÓPOLIS & ITATIAIUCU & 1 & 0 \\
\hline DIVINÓPOLIS & ITAUNA & 1 & 0 \\
\hline DIVINÓPOLIS & JAPARAIBA & 0 & 0 \\
\hline DIVINÓPOLIS & LAGOA DA PRATA & 3 & 0 \\
\hline DIVINÓPOLIS & LUZ & 0 & 0 \\
\hline DIVINÓPOLIS & MEDEIROS & 1 & 0 \\
\hline DIVINÓPOLIS & MOEMA & 0 & 0 \\
\hline DIVINÓPOLIS & NOVA SERRANA & 6 & 2 \\
\hline DIVINÓPOLIS & OLIVEIRA & 1 & 0 \\
\hline DIVINÓPOLIS & PAINS & 0 & 0 \\
\hline DIVINÓPOLIS & PASSA TEMPO & 0 & 0 \\
\hline DIVINÓPOLIS & PEDRA DO INDAIA & 0 & 0 \\
\hline DIVINÓPOLIS & PERDIGAO & 1 & 0 \\
\hline DIVINÓPOLIS & PIRACEMA & 0 & 0 \\
\hline DIVINÓPOLIS & SANTO ANTONIO DO MONTE & 0 & 0 \\
\hline DIVINÓPOLIS & SAO GONCALO DO PARA & 0 & 0 \\
\hline DIVINÓPOLIS & SAO SEBASTIAO DO OESTE & 0 & 0 \\
\hline DIVINÓPOLIS & TAPIRAI & 0 & 0 \\
\hline GOVERNADOR VALADARES & ACUCENA & 1 & 0 \\
\hline GOVERNADOR VALADARES & AIMORES & 0 & 0 \\
\hline GOVERNADOR VALADARES & ALPERCATA & 0 & 0 \\
\hline GOVERNADOR VALADARES & CAPITAO ANDRADE & 0 & 0 \\
\hline GOVERNADOR VALADARES & CENTRAL DE MINAS & 0 & 0 \\
\hline GOVERNADOR VALADARES & CONSELHEIRO PENA & 1 & 0 \\
\hline GOVERNADOR VALADARES & COROACI & 2 & 0 \\
\hline GOVERNADOR VALADARES & CUPARAQUE & 0 & 0 \\
\hline GOVERNADOR VALADARES & DIVINO DAS LARANJEIRAS & 0 & 0 \\
\hline GOVERNADOR VALADARES & ENGENHEIRO CALDAS & 0 & 0 \\
\hline GOVERNADOR VALADARES & FERNANDES TOURINHO & 0 & 0 \\
\hline GOVERNADOR VALADARES & FREI INOCENCIO & 0 & 0 \\
\hline GOVERNADOR VALADARES & GALILEIA & 0 & 0 \\
\hline GOVERNADOR VALADARES & GOIABEIRA & 0 & 0 \\
\hline GOVERNADOR VALADARES & GOVERNADOR VALADARES & 9 & 2 \\
\hline GOVERNADOR VALADARES & ITABIRINHA & 0 & 0 \\
\hline GOVERNADOR VALADARES & ITANHOMI & 2 & 0 \\
\hline GOVERNADOR VALADARES & ITUETA & 0 & 0 \\
\hline GOVERNADOR VALADARES & MANTENA & 0 & 0 \\
\hline
\end{tabular}




\begin{tabular}{|c|c|c|c|}
\hline GOVERNADOR VALADARES & MARILAC & 1 & 0 \\
\hline GOVERNADOR VALADARES & MATHIAS LOBATO & 0 & 0 \\
\hline GOVERNADOR VALADARES & MENDES PIMENTEL & 0 & 0 \\
\hline GOVERNADOR VALADARES & NACIP RAYDAN & 0 & 0 \\
\hline GOVERNADOR VALADARES & NAQUE & 0 & 0 \\
\hline GOVERNADOR VALADARES & NOVA BELEM & 0 & 0 \\
\hline GOVERNADOR VALADARES & NOVA MODICA & 0 & 0 \\
\hline GOVERNADOR VALADARES & PERIQUITO & 0 & 0 \\
\hline GOVERNADOR VALADARES & RESPLENDOR & 1 & 0 \\
\hline GOVERNADOR VALADARES & SANTA EFIGENIA DE MINAS & 0 & 0 \\
\hline GOVERNADOR VALADARES & SANTA RITA DO ITUETO & 0 & 0 \\
\hline GOVERNADOR VALADARES & SAO FELIX DE MINAS & 0 & 0 \\
\hline GOVERNADOR VALADARES & SAO GERALDO DA PIEDADE & 0 & 0 \\
\hline GOVERNADOR VALADARES & SAO GERALDO DO BAIXIO & 0 & 0 \\
\hline GOVERNADOR VALADARES & SAO JOAO DO MANTENINHA & 1 & 0 \\
\hline GOVERNADOR VALADARES & SAO JOSE DA SAFIRA & 0 & 0 \\
\hline GOVERNADOR VALADARES & SAO JOSE DO DIVINO & 1 & 0 \\
\hline GOVERNADOR VALADARES & SARDOA & 0 & 0 \\
\hline GOVERNADOR VALADARES & SOBRALIA & 0 & 0 \\
\hline GOVERNADOR VALADARES & TUMIRITINGA & 0 & 0 \\
\hline GOVERNADOR VALADARES & VIRGOLANDIA & 1 & 0 \\
\hline GUANHÃES & AGUA BOA & 1 & 0 \\
\hline GUANHÃES & CANTAGALO & 1 & 0 \\
\hline GUANHÃES & CARMESIA & 0 & 0 \\
\hline GUANHÃES & COLUNA & 1 & 0 \\
\hline GUANHÃES & DIVINOLANDIA DE MINAS & 0 & 0 \\
\hline GUANHÃES & DOM JOAQUIM & 1 & 0 \\
\hline GUANHÃES & DORES DE GUANHAES & 1 & 0 \\
\hline GUANHÃES & FREI LAGONEGRO & 0 & 0 \\
\hline GUANHÃES & GONZAGA & 0 & 0 \\
\hline GUANHÃES & GUANHAES & 3 & 0 \\
\hline GUANHÃES & JOSE RAYDAN & 0 & 0 \\
\hline GUANHÃES & MATERLANDIA & 0 & 0 \\
\hline GUANHÃES & PAULISTAS & 0 & 0 \\
\hline GUANHÃES & PECANHA & 0 & 0 \\
\hline GUANHÃES & SABINOPOLIS & 1 & 0 \\
\hline GUANHÃES & SANTA MARIA DO SUACUI & 1 & 0 \\
\hline GUANHÃES & SAO JOAO EVANGELISTA & 2 & 0 \\
\hline GUANHÃES & SAO JOSE DO JACURI & 0 & 0 \\
\hline GUANHÃES & SAO PEDRO DO SUACUI & 0 & 0 \\
\hline GUANHÃES & SAO SEBASTIAO DO MARANHAO & 1 & 0 \\
\hline GUANHÃES & SENHORA DO PORTO & 1 & 0 \\
\hline GUANHÃES & VIRGINOPOLIS & 0 & 0 \\
\hline ITAJUBÁ & BRASOPOLIS & 1 & 0 \\
\hline ITAJUBÁ & CARMO DE MINAS & 1 & 0 \\
\hline
\end{tabular}




\begin{tabular}{|c|c|c|c|}
\hline ITAJUBÁ & CONCEICAO DAS PEDRAS & 0 & 0 \\
\hline ITAJUBÁ & CONCEICAO DOS OUROS & 2 & 0 \\
\hline ITAJUBÁ & CONSOLACAO & 0 & 0 \\
\hline ITAJUBÁ & CRISTINA & 0 & 0 \\
\hline ITAJUBÁ & DELFIM MOREIRA & 0 & 0 \\
\hline ITAJUBÁ & DOM VICOSO & 0 & 0 \\
\hline ITAJUBÁ & GONCALVES & 0 & 0 \\
\hline ITAJUBÁ & ITAJUBA & 1 & 0 \\
\hline ITAJUBÁ & MARIA DA FE & 2 & 0 \\
\hline ITAJUBÁ & MARMELOPOLIS & 0 & 0 \\
\hline ITAJUBÁ & NATERCIA & 0 & 0 \\
\hline ITAJUBÁ & PARAISOPOLIS & 1 & 0 \\
\hline ITAJUBÁ & PEDRALVA & 3 & 0 \\
\hline ITAJUBÁ & PIRANGUCU & 0 & 0 \\
\hline ITAJUBÁ & PIRANGUINHO & 0 & 0 \\
\hline ITAJUBÁ & SAO JOSE DO ALEGRE & 1 & 0 \\
\hline ITAJUBÁ & SAPUCAI-MIRIM & 2 & 0 \\
\hline ITAJUBÁ & VIRGINIA & 0 & 0 \\
\hline ITAJUBÁ & WENCESLAU BRAZ & 1 & 0 \\
\hline ITUIUTABA & CACHOEIRA DOURADA & 0 & 0 \\
\hline ITUIUTABA & CANAPOLIS & 0 & 0 \\
\hline ITUIUTABA & CAPINOPOLIS & 0 & 0 \\
\hline ITUIUTABA & CENTRALINA & 0 & 0 \\
\hline ITUIUTABA & GURINHATA & 0 & 0 \\
\hline ITUIUTABA & IPIACU & 0 & 0 \\
\hline ITUIUTABA & ITUIUTABA & 2 & 0 \\
\hline ITUIUTABA & SANTA VITORIA & 1 & 0 \\
\hline JANAUBA & CATUTI & 0 & 0 \\
\hline JANAUBA & ESPINOSA & 0 & 0 \\
\hline JANAUBA & GAMELEIRAS & 1 & 0 \\
\hline JANAUBA & JAIBA & 0 & 0 \\
\hline JANAUBA & JANAUBA & 7 & 2 \\
\hline JANAUBA & MAMONAS & 0 & 0 \\
\hline JANAUBA & MATO VERDE & 1 & 0 \\
\hline JANAUBA & MONTE AZUL & 0 & 0 \\
\hline JANAUBA & MONTEZUMA & 0 & 0 \\
\hline JANAUBA & NOVA PORTEIRINHA & 0 & 0 \\
\hline JANAUBA & PAI PEDRO & 1 & 0 \\
\hline JANAUBA & PORTEIRINHA & 3 & 0 \\
\hline JANAUBA & RIACHO DOS MACHADOS & 0 & 0 \\
\hline JANAUBA & RIO PARDO DE MINAS & 1 & 0 \\
\hline JANAUBA & SANTO ANTONIO DO RETIRO & 0 & 0 \\
\hline JANAUBA & SERRANOPOLIS DE MINAS & 0 & 0 \\
\hline JANAUBA & VERDELANDIA & 0 & 0 \\
\hline JANUARIA & BONITO DE MINAS & 1 & 0 \\
\hline
\end{tabular}




\begin{tabular}{|c|c|c|c|}
\hline JANUARIA & CHAPADA GAUCHA & 2 & 0 \\
\hline JANUARIA & CONEGO MARINHO & 1 & 0 \\
\hline JANUARIA & IBIRACATU & 1 & 0 \\
\hline JANUARIA & ICARAI DE MINAS & 2 & 0 \\
\hline JANUARIA & ITACARAMBI & 1 & 0 \\
\hline JANUARIA & JANUARIA & 3 & 0 \\
\hline JANUARIA & JUVENILIA & 0 & 0 \\
\hline JANUARIA & MANGA & 0 & 0 \\
\hline JANUARIA & MATIAS CARDOSO & 1 & 0 \\
\hline JANUARIA & MIRAVANIA & 1 & 0 \\
\hline JANUARIA & MONTALVANIA & 2 & 0 \\
\hline JANUARIA & PEDRAS DE MARIA DA CRUZ & 1 & 0 \\
\hline JANUARIA & PINTOPOLIS & 0 & 0 \\
\hline JANUARIA & SAO FRANCISCO & 5 & 2 \\
\hline JANUARIA & SAO JOAO DAS MISSOES & 1 & 0 \\
\hline JANUARIA & UBAI & 0 & 0 \\
\hline JANUARIA & URUCUIA & 0 & 0 \\
\hline JANUARIA & VARZELANDIA & 0 & 0 \\
\hline JUIZ DE FORA & ARANTINA & 0 & 0 \\
\hline JUIZ DE FORA & BELMIRO BRAGA & 0 & 0 \\
\hline JUIZ DE FORA & BICAS & 0 & 0 \\
\hline JUIZ DE FORA & BOM JARDIM DE MINAS & 1 & 0 \\
\hline JUIZ DE FORA & CHACARA & 0 & 0 \\
\hline JUIZ DE FORA & CHIADOR & 0 & 0 \\
\hline JUIZ DE FORA & CORONEL PACHECO & 0 & 0 \\
\hline JUIZ DE FORA & DESCOBERTO & 0 & 0 \\
\hline JUIZ DE FORA & EWBANK DA CAMARA & 0 & 0 \\
\hline JUIZ DE FORA & GOIANA & 0 & 0 \\
\hline JUIZ DE FORA & GUARARA & 1 & 0 \\
\hline JUIZ DE FORA & JUIZ DE FORA & 4 & 0 \\
\hline JUIZ DE FORA & LIMA DUARTE & 1 & 0 \\
\hline JUIZ DE FORA & MAR DE ESPANHA & 0 & 0 \\
\hline JUIZ DE FORA & MARIPA DE MINAS & 1 & 0 \\
\hline JUIZ DE FORA & MATIAS BARBOSA & 0 & 0 \\
\hline JUIZ DE FORA & OLARIA & 0 & 0 \\
\hline JUIZ DE FORA & PEDRO TEIXEIRA & 1 & 0 \\
\hline JUIZ DE FORA & PEQUERI & 1 & 0 \\
\hline JUIZ DE FORA & PIAU & 0 & 0 \\
\hline JUIZ DE FORA & RIO NOVO & 0 & 0 \\
\hline JUIZ DE FORA & RIO PRETO & 0 & 0 \\
\hline JUIZ DE FORA & ROCHEDO DE MINAS & 0 & 0 \\
\hline JUIZ DE FORA & SANTA BARBARA DO MONTE VERDE & 0 & 0 \\
\hline JUIZ DE FORA & SANTA RITA DE JACUTINGA & 0 & 0 \\
\hline JUIZ DE FORA & SANTANA DO DESERTO & 0 & 0 \\
\hline JUIZ DE FORA & SANTOS DUMONT & 4 & 0 \\
\hline
\end{tabular}




\begin{tabular}{|c|c|c|c|}
\hline JUIZ DE FORA & SAO JOAO NEPOMUCENO & 1 & 0 \\
\hline JUIZ DE FORA & SENADOR CORTES & 0 & 0 \\
\hline JUIZ DE FORA & SIMAO PEREIRA & 1 & 0 \\
\hline LEOPOLDINA & ALEM PARAIBA & 0 & 0 \\
\hline LEOPOLDINA & ARGIRITA & 0 & 0 \\
\hline LEOPOLDINA & CATAGUASES & 1 & 0 \\
\hline LEOPOLDINA & ESTRELA DALVA & 0 & 0 \\
\hline LEOPOLDINA & ITAMARATI DE MINAS & 0 & 0 \\
\hline LEOPOLDINA & LEOPOLDINA & 1 & 0 \\
\hline LEOPOLDINA & PIRAPETINGA & 0 & 0 \\
\hline LEOPOLDINA & RECREIO & 0 & 0 \\
\hline LEOPOLDINA & SANTO ANTONIO DO AVENTUREIRO & 0 & 0 \\
\hline LEOPOLDINA & VOLTA GRANDE & 0 & 0 \\
\hline MANHUAÇU & ALTO JEQUITIBA & 1 & 0 \\
\hline MANHUAÇU & CAPUTIRA & 0 & 0 \\
\hline MANHUAÇU & CHALE & 0 & 0 \\
\hline MANHUAÇU & CONCEICAO DE IPANEMA & 0 & 0 \\
\hline MANHUAÇU & DURANDE & 0 & 0 \\
\hline MANHUAÇU & LAJINHA & 1 & 0 \\
\hline MANHUAÇU & LUISBURGO & 0 & 0 \\
\hline MANHUAÇU & MANHUACU & 2 & 0 \\
\hline MANHUAÇU & MANHUMIRIM & 1 & 0 \\
\hline MANHUAÇU & MARTINS SOARES & 0 & 0 \\
\hline MANHUAÇU & MATIPO & 0 & 0 \\
\hline MANHUAÇU & MUTUM & 2 & 0 \\
\hline MANHUAÇU & REDUTO & 0 & 0 \\
\hline MANHUAÇU & SANTA MARGARIDA & 1 & 0 \\
\hline MANHUAÇU & SANTANA DO MANHUACU & 1 & 0 \\
\hline MANHUAÇU & SAO JOAO DO MANHUACU & 1 & 0 \\
\hline MANHUAÇU & SAO JOSE DO MANTIMENTO & 0 & 0 \\
\hline MANHUAÇU & SIMONESIA & 0 & 0 \\
\hline METROPOLITANA A & BARAO DE COCAIS & 1 & 0 \\
\hline METROPOLITANA A & BELO HORIZONTE & 17 & 5 \\
\hline METROPOLITANA A & BELO VALE & 0 & 0 \\
\hline METROPOLITANA A & BOM JESUS DO AMPARO & 0 & 0 \\
\hline METROPOLITANA A & BONFIM & 1 & 0 \\
\hline METROPOLITANA A & BRUMADINHO & 1 & 0 \\
\hline METROPOLITANA A & CAETE & 1 & 0 \\
\hline METROPOLITANA A & CATAS ALTAS & 1 & 0 \\
\hline METROPOLITANA A & CRUCILANDIA & 0 & 0 \\
\hline METROPOLITANA A & MOEDA & 1 & 0 \\
\hline METROPOLITANA A & NOVA LIMA & 7 & 2 \\
\hline METROPOLITANA A & NOVA UNIAO & 0 & 0 \\
\hline METROPOLITANA A & PIEDADE DOS GERAIS & 0 & 0 \\
\hline METROPOLITANA A & RAPOSOS & 0 & 0 \\
\hline
\end{tabular}




\begin{tabular}{|c|c|c|c|}
\hline METROPOLITANA A & RIO ACIMA & 0 & 0 \\
\hline METROPOLITANA A & RIO MANSO & 0 & 0 \\
\hline METROPOLITANA A & SABARA & 1 & 0 \\
\hline METROPOLITANA A & SANTA BARBARA & 3 & 0 \\
\hline METROPOLITANA B & BELO HORIZONTE & 23 & 7 \\
\hline METROPOLITANA B & BETIM & 17 & 5 \\
\hline METROPOLITANA B & CONTAGEM & 21 & 5 \\
\hline METROPOLITANA B & ESMERALDAS & 1 & 0 \\
\hline METROPOLITANA B & IBIRITE & 4 & 0 \\
\hline METROPOLITANA B & IGARAPE & 1 & 0 \\
\hline METROPOLITANA B & JUATUBA & 0 & 0 \\
\hline METROPOLITANA B & MARIO CAMPOS & 2 & 0 \\
\hline METROPOLITANA B & MATEUS LEME & 1 & 0 \\
\hline METROPOLITANA B & SAO JOAQUIM DE BICAS & 1 & 0 \\
\hline METROPOLITANA B & SARZEDO & 1 & 0 \\
\hline METROPOLITANA C & BELO HORIZONTE & 24 & 7 \\
\hline METROPOLITANA C & CONFINS & 0 & 0 \\
\hline METROPOLITANA C & JABOTICATUBAS & 1 & 0 \\
\hline METROPOLITANA C & LAGOA SANTA & 1 & 0 \\
\hline METROPOLITANA C & MORRO DO PILAR & 0 & 0 \\
\hline METROPOLITANA C & PEDRO LEOPOLDO & 5 & 2 \\
\hline METROPOLITANA C & RIBEIRAO DAS NEVES & 10 & 2 \\
\hline METROPOLITANA C & SANTA LUZIA & 9 & 2 \\
\hline METROPOLITANA C & SANTANA DO RIACHO & 0 & 0 \\
\hline METROPOLITANA C & SAO JOSE DA LAPA & 3 & 0 \\
\hline METROPOLITANA C & TAQUARACU DE MINAS & 0 & 0 \\
\hline METROPOLITANA C & VESPASIANO & 6 & 2 \\
\hline MONTE CARMELO & ABADIA DOS DOURADOS & 0 & 0 \\
\hline MONTE CARMELO & CASCALHO RICO & 0 & 0 \\
\hline MONTE CARMELO & COROMANDEL & 1 & 0 \\
\hline MONTE CARMELO & DOURADOQUARA & 0 & 0 \\
\hline MONTE CARMELO & ESTRELA DO SUL & 1 & 0 \\
\hline MONTE CARMELO & GRUPIARA & 0 & 0 \\
\hline MONTE CARMELO & MONTE CARMELO & 3 & 0 \\
\hline MONTE CARMELO & ROMARIA & 0 & 0 \\
\hline MONTES CLAROS & BOCAIUVA & 0 & 0 \\
\hline MONTES CLAROS & BOTUMIRIM & 2 & 0 \\
\hline MONTES CLAROS & BRASILIA DE MINAS & 0 & 0 \\
\hline MONTES CLAROS & CAMPO AZUL & 0 & 0 \\
\hline MONTES CLAROS & CAPITAO ENEAS & 0 & 0 \\
\hline MONTES CLAROS & CLARO DOS POCOES & 0 & 0 \\
\hline MONTES CLAROS & CORACAO DE JESUS & 1 & 0 \\
\hline MONTES CLAROS & CRISTALIA & 2 & 0 \\
\hline MONTES CLAROS & ENGENHEIRO NAVARRO & 0 & 0 \\
\hline MONTES CLAROS & FRANCISCO DUMONT & 0 & 0 \\
\hline
\end{tabular}




\begin{tabular}{|c|c|c|c|}
\hline MONTES CLAROS & FRANCISCO SA & 2 & 0 \\
\hline MONTES CLAROS & GLAUCILANDIA & 0 & 0 \\
\hline MONTES CLAROS & GRAO MOGOL & 1 & 0 \\
\hline MONTES CLAROS & GUARACIAMA & 0 & 0 \\
\hline MONTES CLAROS & ITACAMBIRA & 0 & 0 \\
\hline MONTES CLAROS & JAPONVAR & 0 & 0 \\
\hline MONTES CLAROS & JOSENOPOLIS & 0 & 0 \\
\hline MONTES CLAROS & JURAMENTO & 1 & 0 \\
\hline MONTES CLAROS & LONTRA & 0 & 0 \\
\hline MONTES CLAROS & LUISLANDIA & 1 & 0 \\
\hline MONTES CLAROS & MIRABELA & 1 & 0 \\
\hline MONTES CLAROS & MONTES CLAROS & 11 & 2 \\
\hline MONTES CLAROS & OLHOS-D AGUA & 0 & 0 \\
\hline MONTES CLAROS & PADRE CARVALHO & 1 & 0 \\
\hline MONTES CLAROS & PATIS & 0 & 0 \\
\hline MONTES CLAROS & SAO JOAO DA LAGOA & 0 & 0 \\
\hline MONTES CLAROS & SAO JOAO DA PONTE & 1 & 0 \\
\hline MONTES CLAROS & SAO JOAO DO PACUI & 0 & 0 \\
\hline MONTES CLAROS & SAO JOAO DO PARAISO & 0 & 0 \\
\hline MONTES CLAROS & VARGEM GRANDE DO RIO PARDO & 0 & 0 \\
\hline MURIAÉ & ANTONIO PRADO DE MINAS & 1 & 0 \\
\hline MURIAÉ & BARAO DE MONTE ALTO & 0 & 0 \\
\hline MURIAÉ & EUGENOPOLIS & 1 & 0 \\
\hline MURIAÉ & LARANJAL & 0 & 0 \\
\hline MURIAÉ & MIRADOURO & 0 & 0 \\
\hline MURIAÉ & MIRAI & 0 & 0 \\
\hline MURIAÉ & MURIAE & 3 & 0 \\
\hline MURIAÉ & PALMA & 0 & 0 \\
\hline MURIAÉ & PATROCINIO DO MURIAE & 0 & 0 \\
\hline MURIAÉ & ROSARIO DA LIMEIRA & 0 & 0 \\
\hline MURIAÉ & SANTANA DE CATAGUASES & 0 & 0 \\
\hline MURIAÉ & SAO FRANCISCO DO GLORIA & 0 & 0 \\
\hline MURIAÉ & SAO SEBASTIAO DA VARGEM ALEGRE & 0 & 0 \\
\hline MURIAÉ & VIEIRAS & 1 & 0 \\
\hline NOVA ERA & BELA VISTA DE MINAS & 1 & 0 \\
\hline NOVA ERA & DIONISIO & 0 & 0 \\
\hline NOVA ERA & FERROS & 0 & 0 \\
\hline NOVA ERA & ITABIRA & 2 & 0 \\
\hline NOVA ERA & ITAMBE DO MATO DENTRO & 0 & 0 \\
\hline NOVA ERA & JOAO MONLEVADE & 0 & 0 \\
\hline NOVA ERA & NOVA ERA & 1 & 0 \\
\hline NOVA ERA & PASSABEM & 1 & 0 \\
\hline NOVA ERA & RIO PIRACICABA & 1 & 0 \\
\hline NOVA ERA & SANTA MARIA DE ITABIRA & 0 & 0 \\
\hline NOVA ERA & SANTO ANTONIO DO RIO ABAIXO & 0 & 0 \\
\hline
\end{tabular}




\begin{tabular}{|c|c|c|c|}
\hline NOVA ERA & SAO DOMINGOS DO PRATA & 1 & 0 \\
\hline NOVA ERA & SAO GONCALO DO RIO ABAIXO & 1 & 0 \\
\hline NOVA ERA & SAO JOSE DO GOIABAL & 0 & 0 \\
\hline NOVA ERA & SAO SEBASTIAO DO RIO PRETO & 0 & 0 \\
\hline OURO PRETO & ACAIACA & 0 & 0 \\
\hline OURO PRETO & DIOGO DE VASCONCELOS & 0 & 0 \\
\hline OURO PRETO & ITABIRITO & 2 & 0 \\
\hline OURO PRETO & MARIANA & 5 & 2 \\
\hline OURO PRETO & OURO PRETO & 1 & 0 \\
\hline PARA DE MINAS & ABAETE & 0 & 0 \\
\hline PARA DE MINAS & BIQUINHAS & 1 & 0 \\
\hline PARA DE MINAS & BOM DESPACHO & 0 & 0 \\
\hline PARA DE MINAS & CEDRO DO ABAETE & 0 & 0 \\
\hline PARA DE MINAS & CONCEICAO DO PARA & 0 & 0 \\
\hline PARA DE MINAS & DORES DO INDAIA & 1 & 0 \\
\hline PARA DE MINAS & ESTRELA DO INDAIA & 1 & 0 \\
\hline PARA DE MINAS & FLORESTAL & 3 & 0 \\
\hline PARA DE MINAS & IGARATINGA & 0 & 0 \\
\hline PARA DE MINAS & LEANDRO FERREIRA & 0 & 0 \\
\hline PARA DE MINAS & MARTINHO CAMPOS & 0 & 0 \\
\hline PARA DE MINAS & MORADA NOVA DE MINAS & 0 & 0 \\
\hline PARA DE MINAS & ONCA DE PITANGUI & 0 & 0 \\
\hline PARA DE MINAS & PAINEIRAS & 1 & 0 \\
\hline PARA DE MINAS & PARA DE MINAS & 4 & 0 \\
\hline PARA DE MINAS & PEQUI & 0 & 0 \\
\hline PARA DE MINAS & PITANGUI & 0 & 0 \\
\hline PARA DE MINAS & QUARTEL GERAL & 0 & 0 \\
\hline PARA DE MINAS & SAO JOSE DA VARGINHA & 1 & 0 \\
\hline PARA DE MINAS & SERRA DA SAUDADE & 0 & 0 \\
\hline PARACATU & BRASILANDIA DE MINAS & 2 & 0 \\
\hline PARACATU & GUARDA-MOR & 0 & 0 \\
\hline PARACATU & JOAO PINHEIRO & 2 & 0 \\
\hline PARACATU & PARACATU & 4 & 0 \\
\hline PARACATU & VAZANTE & 1 & 0 \\
\hline PASSOS & ALPINOPOLIS & 2 & 0 \\
\hline PASSOS & BOM JESUS DA PENHA & 0 & 0 \\
\hline PASSOS & CAPITOLIO & 1 & 0 \\
\hline PASSOS & CARMO DO RIO CLARO & 0 & 0 \\
\hline PASSOS & CORREGO FUNDO & 0 & 0 \\
\hline PASSOS & DELFINOPOLIS & 1 & 0 \\
\hline PASSOS & DORESOPOLIS & 0 & 0 \\
\hline PASSOS & FORMIGA & 3 & 0 \\
\hline PASSOS & FORTALEZA DE MINAS & 0 & 0 \\
\hline PASSOS & PASSOS & 2 & 0 \\
\hline PASSOS & PIMENTA & 0 & 0 \\
\hline
\end{tabular}




\begin{tabular}{|c|c|c|c|}
\hline PASSOS & PIUMHI & 0 & 0 \\
\hline PASSOS & SAO JOAO BATISTA DO GLORIA & 1 & 0 \\
\hline PASSOS & SAO JOSE DA BARRA & 0 & 0 \\
\hline PASSOS & SAO ROQUE DE MINAS & 3 & 0 \\
\hline PASSOS & VARGEM BONITA & 0 & 0 \\
\hline PATOS DE MINAS & ARAPUA & 0 & 0 \\
\hline PATOS DE MINAS & CARMO DO PARANAIBA & 1 & 0 \\
\hline PATOS DE MINAS & LAGAMAR & 1 & 0 \\
\hline PATOS DE MINAS & LAGOA FORMOSA & 1 & 0 \\
\hline PATOS DE MINAS & LAGOA GRANDE & 0 & 0 \\
\hline PATOS DE MINAS & MATUTINA & 0 & 0 \\
\hline PATOS DE MINAS & PATOS DE MINAS & 6 & 2 \\
\hline PATOS DE MINAS & PRESIDENTE OLEGARIO & 1 & 0 \\
\hline PATOS DE MINAS & RIO PARANAIBA & 0 & 0 \\
\hline PATOS DE MINAS & SANTA ROSA DA SERRA & 0 & 0 \\
\hline PATOS DE MINAS & SAO GONCALO DO ABAETE & 0 & 0 \\
\hline PATOS DE MINAS & SAO GOTARDO & 4 & 0 \\
\hline PATOS DE MINAS & TIROS & 0 & 0 \\
\hline PATOS DE MINAS & VARJAO DE MINAS & 0 & 0 \\
\hline PATROCÍNIO & CRUZEIRO DA FORTALEZA & 0 & 0 \\
\hline PATROCÍNIO & GUIMARANIA & 0 & 0 \\
\hline PATROCÍNIO & IBIA & 0 & 0 \\
\hline PATROCÍNIO & IRAI DE MINAS & 0 & 0 \\
\hline PATROCÍNIO & PATROCINIO & 2 & 0 \\
\hline PATROCÍNIO & PERDIZES & 1 & 0 \\
\hline PATROCÍNIO & SERRA DO SALITRE & 1 & 0 \\
\hline PIRAPORA & BURITIZEIRO & 3 & 0 \\
\hline PIRAPORA & IBIAI & 1 & 0 \\
\hline PIRAPORA & JEQUITAI & 0 & 0 \\
\hline PIRAPORA & LAGOA DOS PATOS & 1 & 0 \\
\hline PIRAPORA & PIRAPORA & 4 & 0 \\
\hline PIRAPORA & PONTO CHIQUE & 0 & 0 \\
\hline PIRAPORA & SANTA FE DE MINAS & 0 & 0 \\
\hline PIRAPORA & SAO ROMAO & 1 & 0 \\
\hline PIRAPORA & VARZEA DA PALMA & 0 & 0 \\
\hline POÇOS DE CALDAS & ALTEROSA & 0 & 0 \\
\hline POÇOS DE CALDAS & ANDRADAS & 1 & 0 \\
\hline POÇOS DE CALDAS & AREADO & 1 & 0 \\
\hline POÇOS DE CALDAS & BANDEIRA DO SUL & 1 & 0 \\
\hline POÇOS DE CALDAS & BOTELHOS & 0 & 0 \\
\hline POÇOS DE CALDAS & CABO VERDE & 0 & 0 \\
\hline POÇOS DE CALDAS & CALDAS & 0 & 0 \\
\hline POÇOS DE CALDAS & CAMPESTRE & 0 & 0 \\
\hline POÇOS DE CALDAS & CONCEICAO DA APARECIDA & 0 & 0 \\
\hline POÇOS DE CALDAS & DIVISA NOVA & 0 & 0 \\
\hline
\end{tabular}




\begin{tabular}{|c|c|c|c|}
\hline POÇOS DE CALDAS & IBITIURA DE MINAS & 1 & 0 \\
\hline POÇOS DE CALDAS & MONTE BELO & 0 & 0 \\
\hline POÇOS DE CALDAS & MUZAMBINHO & 0 & 0 \\
\hline POÇOS DE CALDAS & NOVA RESENDE & 0 & 0 \\
\hline POÇOS DE CALDAS & POCOS DE CALDAS & 4 & 0 \\
\hline POÇOS DE CALDAS & SANTA RITA DE CALDAS & 0 & 0 \\
\hline POÇOS DE CALDAS & SERRANIA & 0 & 0 \\
\hline PONTE NOVA & ABRE CAMPO & 2 & 0 \\
\hline PONTE NOVA & ALVINOPOLIS & 0 & 0 \\
\hline PONTE NOVA & AMPARO DO SERRA & 0 & 0 \\
\hline PONTE NOVA & ARAPONGA & 0 & 0 \\
\hline PONTE NOVA & BARRA LONGA & 0 & 0 \\
\hline PONTE NOVA & CAJURI & 0 & 0 \\
\hline PONTE NOVA & CANAA & 1 & 0 \\
\hline PONTE NOVA & DOM SILVERIO & 0 & 0 \\
\hline PONTE NOVA & GUARACIABA & 0 & 0 \\
\hline PONTE NOVA & JEQUERI & 0 & 0 \\
\hline PONTE NOVA & ORATORIOS & 0 & 0 \\
\hline PONTE NOVA & PEDRA BONITA & 1 & 0 \\
\hline PONTE NOVA & PEDRA DO ANTA & 0 & 0 \\
\hline PONTE NOVA & PIEDADE DE PONTE NOVA & 0 & 0 \\
\hline PONTE NOVA & PONTE NOVA & 2 & 0 \\
\hline PONTE NOVA & PORTO FIRME & 0 & 0 \\
\hline PONTE NOVA & RAUL SOARES & 0 & 0 \\
\hline PONTE NOVA & RIO CASCA & 0 & 0 \\
\hline PONTE NOVA & RIO DOCE & 0 & 0 \\
\hline PONTE NOVA & SANTA CRUZ DO ESCALVADO & 0 & 0 \\
\hline PONTE NOVA & SANTO ANTONIO DO GRAMA & 0 & 0 \\
\hline PONTE NOVA & SAO MIGUEL DO ANTA & 1 & 0 \\
\hline PONTE NOVA & SAO PEDRO DOS FERROS & 1 & 0 \\
\hline PONTE NOVA & SEM-PEIXE & 0 & 0 \\
\hline PONTE NOVA & SERICITA & 0 & 0 \\
\hline PONTE NOVA & TEIXEIRAS & 0 & 0 \\
\hline PONTE NOVA & URUCANIA & 2 & 0 \\
\hline PONTE NOVA & VERMELHO NOVO & 0 & 0 \\
\hline PONTE NOVA & VICOSA & 3 & 0 \\
\hline POUSO ALEGRE & ALBERTINA & 1 & 0 \\
\hline POUSO ALEGRE & BOM REPOUSO & 1 & 0 \\
\hline POUSO ALEGRE & BORDA DA MATA & 1 & 0 \\
\hline POUSO ALEGRE & BUENO BRANDAO & 0 & 0 \\
\hline POUSO ALEGRE & CACHOEIRA DE MINAS & 0 & 0 \\
\hline POUSO ALEGRE & CAMANDUCAIA & 2 & 0 \\
\hline POUSO ALEGRE & CAMBUI & 0 & 0 \\
\hline POUSO ALEGRE & CAREACU & 0 & 0 \\
\hline POUSO ALEGRE & CONGONHAL & 0 & 0 \\
\hline
\end{tabular}




\begin{tabular}{|c|c|c|c|}
\hline POUSO ALEGRE & CORREGO DO BOM JESUS & 0 & 0 \\
\hline POUSO ALEGRE & ESPIRITO SANTO DO DOURADO & 0 & 0 \\
\hline POUSO ALEGRE & ESTIVA & 1 & 0 \\
\hline POUSO ALEGRE & EXTREMA & 1 & 0 \\
\hline POUSO ALEGRE & HELIODORA & 0 & 0 \\
\hline POUSO ALEGRE & INCONFIDENTES & 0 & 0 \\
\hline POUSO ALEGRE & IPUIUNA & 0 & 0 \\
\hline POUSO ALEGRE & ITAPEVA & 1 & 0 \\
\hline POUSO ALEGRE & JACUTINGA & 0 & 0 \\
\hline POUSO ALEGRE & MONTE SIAO & 1 & 0 \\
\hline POUSO ALEGRE & MUNHOZ & 0 & 0 \\
\hline POUSO ALEGRE & OURO FINO & 3 & 0 \\
\hline POUSO ALEGRE & POUSO ALEGRE & 8 & 2 \\
\hline POUSO ALEGRE & SANTA RITA DO SAPUCAI & 0 & 0 \\
\hline POUSO ALEGRE & SAO JOAO DA MATA & 1 & 0 \\
\hline POUSO ALEGRE & SAO SEBASTIAO DA BELA VISTA & 0 & 0 \\
\hline POUSO ALEGRE & SENADOR AMARAL & 0 & 0 \\
\hline POUSO ALEGRE & SENADOR JOSE BENTO & 1 & 0 \\
\hline POUSO ALEGRE & SILVIANOPOLIS & 0 & 0 \\
\hline POUSO ALEGRE & TOCOS DO MOJI & 0 & 0 \\
\hline POUSO ALEGRE & TOLEDO & 0 & 0 \\
\hline SÃO JOÃO DEL REI & BOM SUCESSO & 0 & 0 \\
\hline SÃO JOÃO DEL REI & CARRANCAS & 0 & 0 \\
\hline SÃO JOÃO DEL REI & CONCEICAO DA BARRA DE MINAS & 0 & 0 \\
\hline SÃO JOÃO DEL REI & CORONEL XAVIER CHAVES & 0 & 0 \\
\hline SÃO JOÃO DEL REI & DORES DE CAMPOS & 1 & 0 \\
\hline SÃO JOÃO DEL REI & IBITURUNA & 0 & 0 \\
\hline SÃO JOÃO DEL REI & IJACI & 0 & 0 \\
\hline SÃO JOÃO DEL REI & INGAI & 0 & 0 \\
\hline SÃO JOÃO DEL REI & ITUMIRIM & 0 & 0 \\
\hline SÃO JOÃO DEL REI & ITUTINGA & 0 & 0 \\
\hline SÃO JOÃO DEL REI & LAGOA DOURADA & 0 & 0 \\
\hline SÃO JOÃO DEL REI & NAZARENO & 0 & 0 \\
\hline SÃO JOÃO DEL REI & PRADOS & 0 & 0 \\
\hline SÃO JOÃO DEL REI & RESENDE COSTA & 0 & 0 \\
\hline SÃO JOÃO DEL REI & RITAPOLIS & 1 & 0 \\
\hline SÃO JOÃO DEL REI & SANTA CRUZ DE MINAS & 0 & 0 \\
\hline SÃO JOÃO DEL REI & SAO JOAO DEL REI & 4 & 0 \\
\hline SÃO JOÃO DEL REI & SAO TIAGO & 1 & 0 \\
\hline SÃO JOÃO DEL REI & TIRADENTES & 0 & 0 \\
\hline SÃO SEBASTIÃO DO PARAÍSO & ARCEBURGO & 0 & 0 \\
\hline SÃO SEBASTIÃO DO PARAÍSO & CAPETINGA & 0 & 0 \\
\hline SÃO SEBASTIÃO DO PARAÍSO & CASSIA & 0 & 0 \\
\hline SÃO SEBASTIÃO DO PARAÍSO & CLARAVAL & 0 & 0 \\
\hline SÃO SEBASTIÃO DO PARAÍSO & GUARANESIA & 2 & 0 \\
\hline
\end{tabular}




\begin{tabular}{|c|c|c|c|}
\hline SÃO SEBASTIÃO DO PARAÍSO & GUAXUPE & 0 & 0 \\
\hline SÃO SEBASTIÃO DO PARAÍSO & IBIRACI & 1 & 0 \\
\hline SÃO SEBASTIÃO DO PARAÍSO & ITAMOGI & 1 & 0 \\
\hline SÃO SEBASTIÃO DO PARAÍSO & ITAU DE MINAS & 0 & 0 \\
\hline SÃO SEBASTIÃO DO PARAÍSO & JACUI & 0 & 0 \\
\hline SÃO SEBASTIÃO DO PARAÍSO & JURUAIA & 1 & 0 \\
\hline SÃO SEBASTIÃO DO PARAÍSO & MONTE SANTO DE MINAS & 1 & 0 \\
\hline SÃO SEBASTIÃO DO PARAÍSO & PRATAPOLIS & 1 & 0 \\
\hline SÃO SEBASTIÃO DO PARAÍSO & SAO PEDRO DA UNIAO & 1 & 0 \\
\hline SÃO SEBASTIÃO DO PARAÍSO & SAO SEBASTIAO DO PARAISO & 1 & 0 \\
\hline SÃO SEBASTIÃO DO PARAÍSO & SAO TOMAS DE AQUINO & 1 & 0 \\
\hline SETE LAGOAS & ARACAI & 0 & 0 \\
\hline SETE LAGOAS & BALDIM & 0 & 0 \\
\hline SETE LAGOAS & CACHOEIRA DA PRATA & 0 & 0 \\
\hline SETE LAGOAS & CAETANOPOLIS & 0 & 0 \\
\hline SETE LAGOAS & CAPIM BRANCO & 1 & 0 \\
\hline SETE LAGOAS & CORDISBURGO & 0 & 0 \\
\hline SETE LAGOAS & FORTUNA DE MINAS & 1 & 0 \\
\hline SETE LAGOAS & FUNILANDIA & 0 & 0 \\
\hline SETE LAGOAS & INHAUMA & 0 & 0 \\
\hline SETE LAGOAS & JEQUITIBA & 0 & 0 \\
\hline SETE LAGOAS & MARAVILHAS & 0 & 0 \\
\hline SETE LAGOAS & MATOZINHOS & 2 & 0 \\
\hline SETE LAGOAS & PAPAGAIOS & 2 & 0 \\
\hline SETE LAGOAS & PARAOPEBA & 0 & 0 \\
\hline SETE LAGOAS & POMPEU & 1 & 0 \\
\hline SETE LAGOAS & PRUDENTE DE MORAIS & 0 & 0 \\
\hline SETE LAGOAS & SANTANA DE PIRAPAMA & 0 & 0 \\
\hline SETE LAGOAS & SETE LAGOAS & 9 & 2 \\
\hline TEOFILO OTONI & AGUAS FORMOSAS & 1 & 0 \\
\hline TEOFILO OTONI & ATALEIA & 2 & 0 \\
\hline TEOFILO OTONI & BERTOPOLIS & 1 & 0 \\
\hline TEOFILO OTONI & CAMPANARIO & 0 & 0 \\
\hline TEOFILO OTONI & CARAI & 1 & 0 \\
\hline TEOFILO OTONI & CARLOS CHAGAS & 3 & 0 \\
\hline TEOFILO OTONI & CATUJI & 0 & 0 \\
\hline TEOFILO OTONI & CRISOLITA & 0 & 0 \\
\hline TEOFILO OTONI & FRANCISCOPOLIS & 1 & 0 \\
\hline TEOFILO OTONI & FREI GASPAR & 2 & 0 \\
\hline TEOFILO OTONI & FRONTEIRA DOS VALES & 0 & 0 \\
\hline TEOFILO OTONI & ITAIPE & 2 & 0 \\
\hline TEOFILO OTONI & ITAMBACURI & 1 & 0 \\
\hline TEOFILO OTONI & JAMPRUCA & 0 & 0 \\
\hline TEOFILO OTONI & LADAINHA & 1 & 0 \\
\hline TEOFILO OTONI & MACHACALIS & 1 & 0 \\
\hline
\end{tabular}




\begin{tabular}{|c|c|c|c|}
\hline TEOFILO OTONI & MALACACHETA & 3 & 0 \\
\hline TEOFILO OTONI & NANUQUE & 1 & 0 \\
\hline TEOFILO OTONI & NOVO CRUZEIRO & 4 & 0 \\
\hline TEOFILO OTONI & NOVO ORIENTE DE MINAS & 2 & 0 \\
\hline TEOFILO OTONI & OURO VERDE DE MINAS & 0 & 0 \\
\hline TEOFILO OTONI & PADRE PARAISO & 0 & 0 \\
\hline TEOFILO OTONI & PAVAO & 1 & 0 \\
\hline TEOFILO OTONI & PESCADOR & 1 & 0 \\
\hline TEOFILO OTONI & PONTO DOS VOLANTES & 1 & 0 \\
\hline TEOFILO OTONI & POTE & 3 & 0 \\
\hline TEOFILO OTONI & SANTA HELENA DE MINAS & 0 & 0 \\
\hline TEOFILO OTONI & SERRA DOS AIMORES & 0 & 0 \\
\hline TEOFILO OTONI & SETUBINHA & 0 & 0 \\
\hline TEOFILO OTONI & TEOFILO OTONI & 5 & 2 \\
\hline TEOFILO OTONI & UMBURATIBA & 0 & 0 \\
\hline UBÁ & ASTOLFO DUTRA & 0 & 0 \\
\hline UBÁ & BRAS PIRES & 0 & 0 \\
\hline UBÁ & COIMBRA & 1 & 0 \\
\hline UBÁ & DIVINESIA & 0 & 0 \\
\hline UBÁ & DONA EUZEBIA & 0 & 0 \\
\hline UBÁ & DORES DO TURVO & 0 & 0 \\
\hline UBÁ & ERVALIA & 0 & 0 \\
\hline UBÁ & GUARANI & 0 & 0 \\
\hline UBÁ & GUIDOVAL & 0 & 0 \\
\hline UBÁ & GUIRICEMA & 0 & 0 \\
\hline UBÁ & PAULA CANDIDO & 0 & 0 \\
\hline UBÁ & PIRAUBA & 0 & 0 \\
\hline UBÁ & PRESIDENTE BERNARDES & 0 & 0 \\
\hline UBÁ & RIO POMBA & 1 & 0 \\
\hline UBÁ & RODEIRO & 0 & 0 \\
\hline UBÁ & SAO GERALDO & 0 & 0 \\
\hline UBÁ & SENADOR FIRMINO & 0 & 0 \\
\hline UBÁ & SILVEIRANIA & 0 & 0 \\
\hline UBÁ & TABULEIRO & 0 & 0 \\
\hline UBÁ & TOCANTINS & 0 & 0 \\
\hline UBÁ & UBA & 0 & 0 \\
\hline UBÁ & VISCONDE DO RIO BRANCO & 0 & 0 \\
\hline UBERABA & AGUA COMPRIDA & 0 & 0 \\
\hline UBERABA & ARAXA & 0 & 0 \\
\hline UBERABA & CAMPO FLORIDO & 1 & 0 \\
\hline UBERABA & CAMPOS ALTOS & 0 & 0 \\
\hline UBERABA & CARNEIRINHO & 1 & 0 \\
\hline UBERABA & COMENDADOR GOMES & 0 & 0 \\
\hline UBERABA & CONCEICAO DAS ALAGOAS & 1 & 0 \\
\hline UBERABA & CONQUISTA & 0 & 0 \\
\hline
\end{tabular}




\begin{tabular}{|c|c|c|c|}
\hline UBERABA & DELTA & 0 & 0 \\
\hline UBERABA & FRONTEIRA & 0 & 0 \\
\hline UBERABA & FRUTAL & 0 & 0 \\
\hline UBERABA & ITAPAGIPE & 0 & 0 \\
\hline UBERABA & ITURAMA & 2 & 0 \\
\hline UBERABA & LIMEIRA DO OESTE & 0 & 0 \\
\hline UBERABA & PEDRINOPOLIS & 0 & 0 \\
\hline UBERABA & PIRAJUBA & 0 & 0 \\
\hline UBERABA & PLANURA & 0 & 0 \\
\hline UBERABA & PRATINHA & 0 & 0 \\
\hline UBERABA & SACRAMENTO & 2 & 0 \\
\hline UBERABA & SANTA JULIANA & 1 & 0 \\
\hline UBERABA & SAO FRANCISCO DE SALES & 0 & 0 \\
\hline UBERABA & TAPIRA & 1 & 0 \\
\hline UBERABA & UBERABA & 2 & 0 \\
\hline UBERABA & UNIAO DE MINAS & 0 & 0 \\
\hline UBERABA & VERISSIMO & 0 & 0 \\
\hline UBERLANDIA & ARAGUARI & 4 & 0 \\
\hline UBERLANDIA & ARAPORA & 0 & 0 \\
\hline UBERLANDIA & CAMPINA VERDE & 1 & 0 \\
\hline UBERLANDIA & INDIANOPOLIS & 1 & 0 \\
\hline UBERLANDIA & MONTE ALEGRE DE MINAS & 0 & 0 \\
\hline UBERLANDIA & NOVA PONTE & 0 & 0 \\
\hline UBERLANDIA & PRATA & 0 & 0 \\
\hline UBERLANDIA & TUPACIGUARA & 1 & 0 \\
\hline UBERLANDIA & UBERLANDIA & 18 & 5 \\
\hline UNAI & ARINOS & 3 & 0 \\
\hline UNAI & BONFINOPOLIS DE MINAS & 0 & 0 \\
\hline UNAI & BURITIS & 3 & 0 \\
\hline UNAI & CABECEIRA GRANDE & 1 & 0 \\
\hline UNAI & DOM BOSCO & 0 & 0 \\
\hline UNAI & FORMOSO & 1 & 0 \\
\hline UNAI & NATALANDIA & 0 & 0 \\
\hline UNAI & RIACHINHO & 0 & 0 \\
\hline UNAI & UNAI & 5 & 2 \\
\hline UNAI & URUANA DE MINAS & 0 & 0 \\
\hline VARGINHA & ALFENAS & 2 & 0 \\
\hline VARGINHA & BOA ESPERANCA & 1 & 0 \\
\hline VARGINHA & CAMBUQUIRA & 0 & 0 \\
\hline VARGINHA & CAMPANHA & 0 & 0 \\
\hline VARGINHA & CAMPO DO MEIO & 0 & 0 \\
\hline VARGINHA & CAMPOS GERAIS & 1 & 0 \\
\hline VARGINHA & CARMO DA CACHOEIRA & 0 & 0 \\
\hline VARGINHA & CARVALHOPOLIS & 0 & 0 \\
\hline VARGINHA & COQUEIRAL & 0 & 0 \\
\hline
\end{tabular}




\begin{tabular}{|l|l|c|c|}
\hline VARGINHA & CORDISLANDIA & 0 & 0 \\
\hline VARGINHA & ELOI MENDES & 0 & 0 \\
\hline VARGINHA & FAMA & 0 & 0 \\
\hline VARGINHA & GUAPE & 0 & 0 \\
\hline VARGINHA & ILICINEA & 0 & 0 \\
\hline VARGINHA & LAMBARI & 1 & 0 \\
\hline VARGINHA & LUMINARIAS & 0 & 0 \\
\hline VARGINHA & MACHADO & 1 & 0 \\
\hline VARGINHA & MONSENHOR PAULO & 0 & 0 \\
\hline VARGINHA & NEPOMUCENO & 0 & 0 \\
\hline VARGINHA & PARAGUACU & 2 & 0 \\
\hline VARGINHA & POCO FUNDO & 0 & 0 \\
\hline VARGINHA & SANTANA DA VARGEM & 1 & 0 \\
\hline VARGINHA & SAO BENTO ABADE & 0 & 0 \\
\hline VARGINHA & SAOGONCALO DO SAPUCAI & 1 & 0 \\
\hline VARGINHA & TRES CORACOES & $\mathbf{7 3 9}$ & 0 \\
\hline VARGINHA & TRES PONTAS & TURVOLANDIA & \\
\hline VARGINHA & VARGINHA & & 0 \\
\hline VARGINHA & & 0 & 0 \\
\hline Total geral & & & 0 \\
\hline
\end{tabular}

CARGO: PROFESSOR DE EDUCAÇÃO BÁSICA - PEB -G E O G R A F I A

\begin{tabular}{|c|c|c|c|}
\hline S R E & MUNICIPIO & $\begin{array}{l}\text { TOTAL DE } \\
\text { VAGAS }\end{array}$ & $\begin{array}{c}\text { VAGAS } \\
\text { RESERVADAS - } \\
\text { PORTADORES DE } \\
\text { DEFICIÊNCIA } \\
\end{array}$ \\
\hline ALMENARA & AGUAS VERMELHAS & 0 & 0 \\
\hline ALMENARA & ALMENARA & 0 & 0 \\
\hline ALMENARA & BANDEIRA & 0 & 0 \\
\hline ALMENARA & CACHOEIRA DE PAJEU & 0 & 0 \\
\hline ALMENARA & CURRAL DE DENTRO & 0 & 0 \\
\hline ALMENARA & DIVISA ALEGRE & 0 & 0 \\
\hline ALMENARA & DIVISOPOLIS & 0 & 0 \\
\hline ALMENARA & FELISBURGO & 0 & 0 \\
\hline ALMENARA & JACINTO & 0 & 0 \\
\hline ALMENARA & JEQUITINHONHA & 2 & 0 \\
\hline ALMENARA & JOAIMA & 2 & 0 \\
\hline ALMENARA & JORDANIA & 0 & 0 \\
\hline ALMENARA & MATA VERDE & 0 & 0 \\
\hline ALMENARA & MONTE FORMOSO & 0 & 0 \\
\hline ALMENARA & PALMOPOLIS & 0 & 0 \\
\hline ALMENARA & PEDRA AZUL & 0 & 0 \\
\hline ALMENARA & RIO DO PRADO & 0 & 0 \\
\hline ALMENARA & RUBIM & 0 & 0 \\
\hline ALMENARA & SALTO DA DIVISA & 0 & 0 \\
\hline ALMENARA & SANTA MARIA DO SALTO & 1 & 0 \\
\hline
\end{tabular}




\begin{tabular}{|c|c|c|c|}
\hline ALMENARA & SANTO ANTONIO DO JACINTO & 0 & 0 \\
\hline ARACUAI & ARACUAI & 2 & 0 \\
\hline ARACUAI & BERILO & 1 & 0 \\
\hline ARACUAI & BERIZAL & 0 & 0 \\
\hline ARACUAI & CHAPADA DO NORTE & 0 & 0 \\
\hline ARACUAI & COMERCINHO & 0 & 0 \\
\hline ARACUAI & CORONEL MURTA & 0 & 0 \\
\hline ARACUAI & FRANCISCO BADARO & 1 & 0 \\
\hline ARACUAI & FRUTA DE LEITE & 0 & 0 \\
\hline ARACUAI & INDAIABIRA & 1 & 0 \\
\hline ARACUAI & ITAOBIM & 0 & 0 \\
\hline ARACUAI & ITINGA & 1 & 0 \\
\hline ARACUAI & JENIPAPO DE MINAS & 1 & 0 \\
\hline ARACUAI & JOSE GONCALVES DE MINAS & 0 & 0 \\
\hline ARACUAI & MEDINA & 1 & 0 \\
\hline ARACUAI & NINHEIRA & 0 & 0 \\
\hline ARACUAI & NOVORIZONTE & 0 & 0 \\
\hline ARACUAI & RUBELITA & 1 & 0 \\
\hline ARACUAI & SALINAS & 0 & 0 \\
\hline ARACUAI & SANTA CRUZ DE SALINAS & 1 & 0 \\
\hline ARACUAI & TAIOBEIRAS & 1 & 0 \\
\hline ARACUAI & VIRGEM DA LAPA & 0 & 0 \\
\hline BARBACENA & ALFREDO VASCONCELOS & 1 & 0 \\
\hline BARBACENA & ALTO RIO DOCE & 0 & 0 \\
\hline BARBACENA & ANDRELANDIA & 0 & 0 \\
\hline BARBACENA & ANTONIO CARLOS & 1 & 0 \\
\hline BARBACENA & ARACITABA & 0 & 0 \\
\hline BARBACENA & BARBACENA & 1 & 0 \\
\hline BARBACENA & BARROSO & 2 & 0 \\
\hline BARBACENA & BIAS FORTES & 0 & 0 \\
\hline BARBACENA & CAPELA NOVA & 0 & 0 \\
\hline BARBACENA & CARANDAI & 0 & 0 \\
\hline BARBACENA & CIPOTANEA & 0 & 0 \\
\hline BARBACENA & DESTERRO DO MELO & 1 & 0 \\
\hline BARBACENA & IBERTIOGA & 0 & 0 \\
\hline BARBACENA & MADRE DE DEUS DE MINAS & 1 & 0 \\
\hline BARBACENA & MERCES & 0 & 0 \\
\hline BARBACENA & OLIVEIRA FORTES & 1 & 0 \\
\hline BARBACENA & PAIVA & 0 & 0 \\
\hline BARBACENA & PIEDADE DO RIO GRANDE & 0 & 0 \\
\hline BARBACENA & RESSAQUINHA & 0 & 0 \\
\hline BARBACENA & SANTA BARBARA DO TUGURIO & 0 & 0 \\
\hline BARBACENA & SANTA RITA DO IBITIPOCA & 1 & 0 \\
\hline BARBACENA & SANTANA DO GARAMBEU & 0 & 0 \\
\hline BARBACENA & SAO VICENTE DE MINAS & 0 & 0 \\
\hline
\end{tabular}




\begin{tabular}{|c|c|c|c|}
\hline BARBACENA & SENHORA DOS REMEDIOS & 0 & 0 \\
\hline CAMPO BELO & AGUANIL & 0 & 0 \\
\hline CAMPO BELO & CAMACHO & 1 & 0 \\
\hline CAMPO BELO & CAMPO BELO & 3 & 0 \\
\hline CAMPO BELO & CANA VERDE & 0 & 0 \\
\hline CAMPO BELO & CANDEIAS & 0 & 0 \\
\hline CAMPO BELO & CRISTAIS & 0 & 0 \\
\hline CAMPO BELO & LAVRAS & 0 & 0 \\
\hline CAMPO BELO & PERDOES & 0 & 0 \\
\hline CAMPO BELO & RIBEIRAO VERMELHO & 0 & 0 \\
\hline CAMPO BELO & SANTANA DO JACARE & 0 & 0 \\
\hline CAMPO BELO & SANTO ANTONIO DO AMPARO & 1 & 0 \\
\hline CAMPO BELO & SAO FRANCISCO DE PAULA & 0 & 0 \\
\hline CARANGOLA & ALTO CAPARAO & 0 & 0 \\
\hline CARANGOLA & CAIANA & 0 & 0 \\
\hline CARANGOLA & CAPARAO & 1 & 0 \\
\hline CARANGOLA & CARANGOLA & 0 & 0 \\
\hline CARANGOLA & DIVINO & 0 & 0 \\
\hline CARANGOLA & ESPERA FELIZ & 0 & 0 \\
\hline CARANGOLA & FARIA LEMOS & 0 & 0 \\
\hline CARANGOLA & FERVEDOURO & 2 & 0 \\
\hline CARANGOLA & ORIZANIA & 0 & 0 \\
\hline CARANGOLA & PEDRA DOURADA & 0 & 0 \\
\hline CARANGOLA & TOMBOS & 0 & 0 \\
\hline CARATINGA & ALVARENGA & 1 & 0 \\
\hline CARATINGA & BOM JESUS DO GALHO & 0 & 0 \\
\hline CARATINGA & BUGRE & 0 & 0 \\
\hline CARATINGA & CARATINGA & 2 & 0 \\
\hline CARATINGA & CORREGO NOVO & 0 & 0 \\
\hline CARATINGA & DOM CAVATI & 0 & 0 \\
\hline CARATINGA & ENTRE FOLHAS & 0 & 0 \\
\hline CARATINGA & IAPU & 1 & 0 \\
\hline CARATINGA & IMBE DE MINAS & 0 & 0 \\
\hline CARATINGA & INHAPIM & 0 & 0 \\
\hline CARATINGA & IPABA & 0 & 0 \\
\hline CARATINGA & IPANEMA & 0 & 0 \\
\hline CARATINGA & PIEDADE DE CARATINGA & 0 & 0 \\
\hline CARATINGA & PINGO D AGUA & 0 & 0 \\
\hline CARATINGA & POCRANE & 1 & 0 \\
\hline CARATINGA & SANTA BARBARA DO LESTE & 0 & 0 \\
\hline CARATINGA & SANTA RITA DE MINAS & 0 & 0 \\
\hline CARATINGA & SAO DOMINGOS DAS DORES & 0 & 0 \\
\hline CARATINGA & SAO JOAO DO ORIENTE & 0 & 0 \\
\hline CARATINGA & SAO SEBASTIAO DO ANTA & 0 & 0 \\
\hline CARATINGA & TAPARUBA & 0 & 0 \\
\hline
\end{tabular}




\begin{tabular}{|c|c|c|c|}
\hline CARATINGA & TARUMIRIM & 1 & 0 \\
\hline CARATINGA & UBAPORANGA & 0 & 0 \\
\hline CARATINGA & VARGEM ALEGRE & 0 & 0 \\
\hline CAXAMBU & AIURUOCA & 1 & 0 \\
\hline CAXAMBU & ALAGOA & 1 & 0 \\
\hline CAXAMBU & BAEPENDI & 0 & 0 \\
\hline CAXAMBU & BOCAINA DE MINAS & 0 & 0 \\
\hline CAXAMBU & CARVALHOS & 0 & 0 \\
\hline CAXAMBU & CAXAMBU & 1 & 0 \\
\hline CAXAMBU & CONCEICAO DO RIO VERDE & 0 & 0 \\
\hline CAXAMBU & CRUZILIA & 0 & 0 \\
\hline CAXAMBU & ITAMONTE & 0 & 0 \\
\hline CAXAMBU & ITANHANDU & 1 & 0 \\
\hline CAXAMBU & JESUANIA & 0 & 0 \\
\hline CAXAMBU & LIBERDADE & 0 & 0 \\
\hline CAXAMBU & MINDURI & 0 & 0 \\
\hline CAXAMBU & OLIMPIO NORONHA & 0 & 0 \\
\hline CAXAMBU & PASSA QUATRO & 0 & 0 \\
\hline CAXAMBU & PASSA VINTE & 0 & 0 \\
\hline CAXAMBU & POUSO ALTO & 0 & 0 \\
\hline CAXAMBU & SAO LOURENCO & 3 & 0 \\
\hline CAXAMBU & SAO SEBASTIAO DO RIO VERDE & 0 & 0 \\
\hline CAXAMBU & SAO TOME DAS LETRAS & 0 & 0 \\
\hline CAXAMBU & SERITINGA & 0 & 0 \\
\hline CAXAMBU & SERRANOS & 0 & 0 \\
\hline CAXAMBU & SOLEDADE DE MINAS & 0 & 0 \\
\hline CORONEL FABRICIANO & ANTONIO DIAS & 1 & 0 \\
\hline CORONEL FABRICIANO & BELO ORIENTE & 0 & 0 \\
\hline CORONEL FABRICIANO & BRAUNAS & 0 & 0 \\
\hline CORONEL FABRICIANO & CORONEL FABRICIANO & 1 & 0 \\
\hline CORONEL FABRICIANO & IPATINGA & 4 & 0 \\
\hline CORONEL FABRICIANO & JAGUARAÇU & 0 & 0 \\
\hline CORONEL FABRICIANO & JOANESIA & 1 & 0 \\
\hline CORONEL FABRICIANO & MARLIERIA & 0 & 0 \\
\hline CORONEL FABRICIANO & MESQUITA & 1 & 0 \\
\hline CORONEL FABRICIANO & SANTANA DO PARAISO & 2 & 0 \\
\hline CORONEL FABRICIANO & TIMOTEO & 1 & 0 \\
\hline CONSELHEIRO LAFAIETE & CARANAIBA & 0 & 0 \\
\hline CONSELHEIRO LAFAIETE & CASA GRANDE & 0 & 0 \\
\hline CONSELHEIRO LAFAIETE & CATAS ALTAS DA NORUEGA & 0 & 0 \\
\hline CONSELHEIRO LAFAIETE & CONGONHAS & 2 & 0 \\
\hline CONSELHEIRO LAFAIETE & CONSELHEIRO LAFAIETE & 4 & 0 \\
\hline CONSELHEIRO LAFAIETE & CRISTIANO OTONI & 0 & 0 \\
\hline CONSELHEIRO LAFAIETE & DESTERRO DE ENTRE RIOS & 1 & 0 \\
\hline CONSELHEIRO LAFAIETE & ENTRE RIOS DE MINAS & 0 & 0 \\
\hline
\end{tabular}




\begin{tabular}{|c|c|c|c|}
\hline CONSELHEIRO LAFAIETE & ITAVERAVA & 0 & 0 \\
\hline CONSELHEIRO LAFAIETE & JECEABA & 0 & 0 \\
\hline CONSELHEIRO LAFAIETE & LAMIM & 1 & 0 \\
\hline CONSELHEIRO LAFAIETE & OURO BRANCO & 1 & 0 \\
\hline CONSELHEIRO LAFAIETE & PIRANGA & 4 & 0 \\
\hline CONSELHEIRO LAFAIETE & QUELUZITO & 0 & 0 \\
\hline CONSELHEIRO LAFAIETE & RIO ESPERA & 1 & 0 \\
\hline CONSELHEIRO LAFAIETE & SANTANA DOS MONTES & 3 & 0 \\
\hline CONSELHEIRO LAFAIETE & SAO BRAS DO SUACUI & 0 & 0 \\
\hline CONSELHEIRO LAFAIETE & SENHORA DE OLIVEIRA & 0 & 0 \\
\hline CURVELO & AUGUSTO DE LIMA & 1 & 0 \\
\hline CURVELO & BUENOPOLIS & 1 & 0 \\
\hline CURVELO & CORINTO & 0 & 0 \\
\hline CURVELO & CURVELO & 0 & 0 \\
\hline CURVELO & FELIXLANDIA & 0 & 0 \\
\hline CURVELO & INIMUTABA & 0 & 0 \\
\hline CURVELO & JOAQUIM FELICIO & 0 & 0 \\
\hline CURVELO & LASSANCE & 0 & 0 \\
\hline CURVELO & MORRO DA GARCA & 1 & 0 \\
\hline CURVELO & PRESIDENTE JUSCELINO & 0 & 0 \\
\hline CURVELO & SANTO HIPOLITO & 0 & 0 \\
\hline CURVELO & TRES MARIAS & 0 & 0 \\
\hline DIAMANTINA & ALVORADA DE MINAS & 0 & 0 \\
\hline DIAMANTINA & ANGELANDIA & 0 & 0 \\
\hline DIAMANTINA & ARICANDUVA & 1 & 0 \\
\hline DIAMANTINA & CAPELINHA & 5 & 2 \\
\hline DIAMANTINA & CARBONITA & 0 & 0 \\
\hline DIAMANTINA & CONCEICAO DO MATO DENTRO & 1 & 0 \\
\hline DIAMANTINA & CONGONHAS DO NORTE & 0 & 0 \\
\hline DIAMANTINA & COUTO DE MAGALHAES DE MINAS & 0 & 0 \\
\hline DIAMANTINA & DATAS & 0 & 0 \\
\hline DIAMANTINA & DIAMANTINA & 1 & 0 \\
\hline DIAMANTINA & FELICIO DOS SANTOS & 0 & 0 \\
\hline DIAMANTINA & GOUVEA & 0 & 0 \\
\hline DIAMANTINA & ITAMARANDIBA & 3 & 0 \\
\hline DIAMANTINA & LEME DO PRADO & 0 & 0 \\
\hline DIAMANTINA & MINAS NOVAS & 4 & 0 \\
\hline DIAMANTINA & MONJOLOS & 0 & 0 \\
\hline DIAMANTINA & PRESIDENTE KUBITSCHEK & 0 & 0 \\
\hline DIAMANTINA & RIO VERMELHO & 0 & 0 \\
\hline DIAMANTINA & SANTO ANTONIO DO ITAMBE & 0 & 0 \\
\hline DIAMANTINA & SAO GONCALO DO RIO PRETO & 0 & 0 \\
\hline DIAMANTINA & SENADOR MODESTINO GONCALVES & 0 & 0 \\
\hline DIAMANTINA & SERRA AZUL DE MINAS & 0 & 0 \\
\hline DIAMANTINA & SERRO & 2 & 0 \\
\hline
\end{tabular}




\begin{tabular}{|c|c|c|c|}
\hline DIAMANTINA & TURMALINA & 0 & 0 \\
\hline DIAMANTINA & VEREDINHA & 0 & 0 \\
\hline DIVINÓPOLIS & ARAUJOS & 2 & 0 \\
\hline DIVINÓPOLIS & ARCOS & 0 & 0 \\
\hline DIVINÓPOLIS & BAMBUI & 0 & 0 \\
\hline DIVINÓPOLIS & CARMO DA MATA & 1 & 0 \\
\hline DIVINÓPOLIS & CARMO DO CAJURU & 1 & 0 \\
\hline DIVINÓPOLIS & CARMOPOLIS DE MINAS & 0 & 0 \\
\hline DIVINÓPOLIS & CLAUDIO & 0 & 0 \\
\hline DIVINÓPOLIS & CORREGO DANTA & 0 & 0 \\
\hline DIVINÓPOLIS & DIVINOPOLIS & 7 & 2 \\
\hline DIVINÓPOLIS & IGUATAMA & 0 & 0 \\
\hline DIVINÓPOLIS & ITAGUARA & 0 & 0 \\
\hline DIVINÓPOLIS & ITAPECERICA & 0 & 0 \\
\hline DIVINÓPOLIS & ITATIAIUCU & 0 & 0 \\
\hline DIVINÓPOLIS & ITAUNA & 2 & 0 \\
\hline DIVINÓPOLIS & JAPARAIBA & 0 & 0 \\
\hline DIVINÓPOLIS & LAGOA DA PRATA & 4 & 0 \\
\hline DIVINÓPOLIS & LUZ & 0 & 0 \\
\hline DIVINÓPOLIS & MEDEIROS & 1 & 0 \\
\hline DIVINÓPOLIS & MOEMA & 0 & 0 \\
\hline DIVINÓPOLIS & NOVA SERRANA & 3 & 0 \\
\hline DIVINÓPOLIS & OLIVEIRA & 1 & 0 \\
\hline DIVINÓPOLIS & PAINS & 0 & 0 \\
\hline DIVINÓPOLIS & PASSA TEMPO & 0 & 0 \\
\hline DIVINÓPOLIS & PEDRA DO INDAIA & 1 & 0 \\
\hline DIVINÓPOLIS & PERDIGAO & 1 & 0 \\
\hline DIVINÓPOLIS & PIRACEMA & 0 & 0 \\
\hline DIVINÓPOLIS & SANTO ANTONIO DO MONTE & 1 & 0 \\
\hline DIVINÓPOLIS & SAO GONCALO DO PARA & 0 & 0 \\
\hline DIVINÓPOLIS & SAO SEBASTIAO DO OESTE & 0 & 0 \\
\hline DIVINÓPOLIS & TAPIRAI & 0 & 0 \\
\hline GOVERNADOR VALADARES & ACUCENA & 0 & 0 \\
\hline GOVERNADOR VALADARES & AIMORES & 1 & 0 \\
\hline GOVERNADOR VALADARES & ALPERCATA & 1 & 0 \\
\hline GOVERNADOR VALADARES & CAPITAO ANDRADE & 1 & 0 \\
\hline GOVERNADOR VALADARES & CENTRAL DE MINAS & 1 & 0 \\
\hline GOVERNADOR VALADARES & CONSELHEIRO PENA & 1 & 0 \\
\hline GOVERNADOR VALADARES & COROACI & 0 & 0 \\
\hline GOVERNADOR VALADARES & CUPARAQUE & 0 & 0 \\
\hline GOVERNADOR VALADARES & DIVINO DAS LARANJEIRAS & 0 & 0 \\
\hline GOVERNADOR VALADARES & ENGENHEIRO CALDAS & 0 & 0 \\
\hline GOVERNADOR VALADARES & FERNANDES TOURINHO & 0 & 0 \\
\hline GOVERNADOR VALADARES & FREI INOCENCIO & 0 & 0 \\
\hline GOVERNADOR VALADARES & GALILEIA & 0 & 0 \\
\hline
\end{tabular}




\begin{tabular}{|c|c|c|c|}
\hline GOVERNADOR VALADARES & GOIABEIRA & 0 & 0 \\
\hline GOVERNADOR VALADARES & GOVERNADOR VALADARES & 13 & 3 \\
\hline GOVERNADOR VALADARES & ITABIRINHA & 1 & 0 \\
\hline GOVERNADOR VALADARES & ITANHOMI & 1 & 0 \\
\hline GOVERNADOR VALADARES & ITUETA & 0 & 0 \\
\hline GOVERNADOR VALADARES & MANTENA & 1 & 0 \\
\hline GOVERNADOR VALADARES & MARILAC & 0 & 0 \\
\hline GOVERNADOR VALADARES & MATHIAS LOBATO & 0 & 0 \\
\hline GOVERNADOR VALADARES & MENDES PIMENTEL & 1 & 0 \\
\hline GOVERNADOR VALADARES & NACIP RAYDAN & 0 & 0 \\
\hline GOVERNADOR VALADARES & NAQUE & 0 & 0 \\
\hline GOVERNADOR VALADARES & NOVA BELEM & 0 & 0 \\
\hline GOVERNADOR VALADARES & NOVA MODICA & 0 & 0 \\
\hline GOVERNADOR VALADARES & PERIQUITO & 0 & 0 \\
\hline GOVERNADOR VALADARES & RESPLENDOR & 0 & 0 \\
\hline GOVERNADOR VALADARES & SANTA EFIGENIA DE MINAS & 0 & 0 \\
\hline GOVERNADOR VALADARES & SANTA RITA DO ITUETO & 0 & 0 \\
\hline GOVERNADOR VALADARES & SAO FELIX DE MINAS & 0 & 0 \\
\hline GOVERNADOR VALADARES & SAO GERALDO DA PIEDADE & 0 & 0 \\
\hline GOVERNADOR VALADARES & SAO GERALDO DO BAIXIO & 0 & 0 \\
\hline GOVERNADOR VALADARES & SAO JOAO DO MANTENINHA & 0 & 0 \\
\hline GOVERNADOR VALADARES & SAO JOSE DA SAFIRA & 2 & 0 \\
\hline GOVERNADOR VALADARES & SAO JOSE DO DIVINO & 1 & 0 \\
\hline GOVERNADOR VALADARES & SARDOA & 0 & 0 \\
\hline GOVERNADOR VALADARES & SOBRALIA & 0 & 0 \\
\hline GOVERNADOR VALADARES & TUMIRITINGA & 1 & 0 \\
\hline GOVERNADOR VALADARES & VIRGOLANDIA & 2 & 0 \\
\hline GUANHÃES & AGUA BOA & 2 & 0 \\
\hline GUANHÃES & CANTAGALO & 0 & 0 \\
\hline GUANHÃES & CARMESIA & 2 & 0 \\
\hline GUANHÃES & COLUNA & 0 & 0 \\
\hline GUANHÃES & DIVINOLANDIA DE MINAS & 0 & 0 \\
\hline GUANHÃES & DOM JOAQUIM & 0 & 0 \\
\hline GUANHÃES & DORES DE GUANHAES & 1 & 0 \\
\hline GUANHÃES & FREI LAGONEGRO & 0 & 0 \\
\hline GUANHÃES & GONZAGA & 0 & 0 \\
\hline GUANHÃES & GUANHAES & 0 & 0 \\
\hline GUANHÃES & JOSE RAYDAN & 0 & 0 \\
\hline GUANHÃES & MATERLANDIA & 1 & 0 \\
\hline GUANHÃES & PAULISTAS & 0 & 0 \\
\hline GUANHÃES & PECANHA & 1 & 0 \\
\hline GUANHÃES & SABINOPOLIS & 1 & 0 \\
\hline GUANHÃES & SANTA MARIA DO SUACUI & 1 & 0 \\
\hline GUANHÃES & SAO JOAO EVANGELISTA & 0 & 0 \\
\hline GUANHÃES & SAO JOSE DO JACURI & 0 & 0 \\
\hline
\end{tabular}




\begin{tabular}{|c|c|c|c|}
\hline GUANHÃES & SAO PEDRO DO SUACUI & 0 & 0 \\
\hline GUANHÃES & SAO SEBASTIAO DO MARANHAO & 1 & 0 \\
\hline GUANHÃES & SENHORA DO PORTO & 1 & 0 \\
\hline GUANHÃES & VIRGINOPOLIS & 2 & 0 \\
\hline ITAJUBÁ & BRASOPOLIS & 0 & 0 \\
\hline ITAJUBÁ & CARMO DE MINAS & 0 & 0 \\
\hline ITAJUBÁ & CONCEICAO DAS PEDRAS & 0 & 0 \\
\hline ITAJUBÁ & CONCEICAO DOS OUROS & 0 & 0 \\
\hline ITAJUBÁ & CONSOLACAO & 0 & 0 \\
\hline ITAJUBÁ & CRISTINA & 0 & 0 \\
\hline ITAJUBÁ & DELFIM MOREIRA & 1 & 0 \\
\hline ITAJUBÁ & DOM VICOSO & 0 & 0 \\
\hline ITAJUBÁ & GONCALVES & 0 & 0 \\
\hline ITAJUBÁ & ITAJUBA & 0 & 0 \\
\hline ITAJUBÁ & MARIA DA FE & 0 & 0 \\
\hline ITAJUBÁ & MARMELOPOLIS & 0 & 0 \\
\hline ITAJUBÁ & NATERCIA & 0 & 0 \\
\hline ITAJUBÁ & PARAISOPOLIS & 0 & 0 \\
\hline ITAJUBÁ & PEDRALVA & 0 & 0 \\
\hline ITAJUBÁ & PIRANGUCU & 0 & 0 \\
\hline ITAJUBÁ & PIRANGUINHO & 1 & 0 \\
\hline ITAJUBÁ & SAO JOSE DO ALEGRE & 0 & 0 \\
\hline ITAJUBÁ & SAPUCAI-MIRIM & 1 & 0 \\
\hline ITAJUBÁ & VIRGINIA & 1 & 0 \\
\hline ITAJUBÁ & WENCESLAU BRAZ & 0 & 0 \\
\hline ITUIUTABA & CACHOEIRA DOURADA & 0 & 0 \\
\hline ITUIUTABA & CANAPOLIS & 0 & 0 \\
\hline ITUIUTABA & CAPINOPOLIS & 1 & 0 \\
\hline ITUIUTABA & CENTRALINA & 0 & 0 \\
\hline ITUIUTABA & GURINHATA & 0 & 0 \\
\hline ITUIUTABA & IPIACU & 1 & 0 \\
\hline ITUIUTABA & ITUIUTABA & 6 & 2 \\
\hline ITUIUTABA & SANTA VITORIA & 0 & 0 \\
\hline JANAUBA & CATUTI & 0 & 0 \\
\hline JANAUBA & ESPINOSA & 1 & 0 \\
\hline JANAUBA & GAMELEIRAS & 0 & 0 \\
\hline JANAUBA & JAIBA & 1 & 0 \\
\hline JANAUBA & JANAUBA & 3 & 0 \\
\hline JANAUBA & MAMONAS & 0 & 0 \\
\hline JANAUBA & MATO VERDE & 0 & 0 \\
\hline JANAUBA & MONTE AZUL & 0 & 0 \\
\hline JANAUBA & MONTEZUMA & 0 & 0 \\
\hline JANAUBA & NOVA PORTEIRINHA & 0 & 0 \\
\hline JANAUBA & PAI PEDRO & 1 & 0 \\
\hline JANAUBA & PORTEIRINHA & 2 & 0 \\
\hline
\end{tabular}




\begin{tabular}{|c|c|c|c|}
\hline JANAUBA & RIACHO DOS MACHADOS & 0 & 0 \\
\hline JANAUBA & RIO PARDO DE MINAS & 1 & 0 \\
\hline JANAUBA & SANTO ANTONIO DO RETIRO & 0 & 0 \\
\hline JANAUBA & SERRANOPOLIS DE MINAS & 0 & 0 \\
\hline JANAUBA & VERDELANDIA & 1 & 0 \\
\hline JANUARIA & BONITO DE MINAS & 2 & 0 \\
\hline JANUARIA & CHAPADA GAUCHA & 0 & 0 \\
\hline JANUARIA & CONEGO MARINHO & 1 & 0 \\
\hline JANUARIA & IBIRACATU & 0 & 0 \\
\hline JANUARIA & ICARAI DE MINAS & 2 & 0 \\
\hline JANUARIA & ITACARAMBI & 1 & 0 \\
\hline JANUARIA & JANUARIA & 3 & 0 \\
\hline JANUARIA & JUVENILIA & 2 & 0 \\
\hline JANUARIA & MANGA & 3 & 0 \\
\hline JANUARIA & MATIAS CARDOSO & 1 & 0 \\
\hline JANUARIA & MIRAVANIA & 0 & 0 \\
\hline JANUARIA & MONTALVANIA & 1 & 0 \\
\hline JANUARIA & PEDRAS DE MARIA DA CRUZ & 1 & 0 \\
\hline JANUARIA & PINTOPOLIS & 1 & 0 \\
\hline JANUARIA & SAO FRANCISCO & 5 & 2 \\
\hline JANUARIA & SAO JOAO DAS MISSOES & 0 & 0 \\
\hline JANUARIA & UBAI & 0 & 0 \\
\hline JANUARIA & URUCUIA & 0 & 0 \\
\hline JANUARIA & VARZELANDIA & 1 & 0 \\
\hline JUIZ DE FORA & ARANTINA & 0 & 0 \\
\hline JUIZ DE FORA & BELMIRO BRAGA & 0 & 0 \\
\hline JUIZ DE FORA & BICAS & 0 & 0 \\
\hline JUIZ DE FORA & BOM JARDIM DE MINAS & 0 & 0 \\
\hline JUIZ DE FORA & CHACARA & 0 & 0 \\
\hline JUIZ DE FORA & CHIADOR & 0 & 0 \\
\hline JUIZ DE FORA & CORONEL PACHECO & 0 & 0 \\
\hline JUIZ DE FORA & DESCOBERTO & 0 & 0 \\
\hline JUIZ DE FORA & EWBANK DA CAMARA & 0 & 0 \\
\hline JUIZ DE FORA & GOIANA & 0 & 0 \\
\hline JUIZ DE FORA & GUARARA & 0 & 0 \\
\hline JUIZ DE FORA & JUIZ DE FORA & 7 & 2 \\
\hline JUIZ DE FORA & LIMA DUARTE & 0 & 0 \\
\hline JUIZ DE FORA & MAR DE ESPANHA & 1 & 0 \\
\hline JUIZ DE FORA & MARIPA DE MINAS & 0 & 0 \\
\hline JUIZ DE FORA & MATIAS BARBOSA & 1 & 0 \\
\hline JUIZ DE FORA & OLARIA & 0 & 0 \\
\hline JUIZ DE FORA & PEDRO TEIXEIRA & 1 & 0 \\
\hline JUIZ DE FORA & PEQUERI & 0 & 0 \\
\hline JUIZ DE FORA & PIAU & 0 & 0 \\
\hline JUIZ DE FORA & RIO NOVO & 1 & 0 \\
\hline
\end{tabular}




\begin{tabular}{|c|c|c|c|}
\hline JUIZ DE FORA & RIO PRETO & 0 & 0 \\
\hline JUIZ DE FORA & ROCHEDO DE MINAS & 0 & 0 \\
\hline JUIZ DE FORA & SANTA BARBARA DO MONTE VERDE & 1 & 0 \\
\hline JUIZ DE FORA & SANTA RITA DE JACUTINGA & 0 & 0 \\
\hline JUIZ DE FORA & SANTANA DO DESERTO & 0 & 0 \\
\hline JUIZ DE FORA & SANTOS DUMONT & 0 & 0 \\
\hline JUIZ DE FORA & SAO JOAO NEPOMUCENO & 1 & 0 \\
\hline JUIZ DE FORA & SENADOR CORTES & 0 & 0 \\
\hline JUIZ DE FORA & SIMAO PEREIRA & 1 & 0 \\
\hline LEOPOLDINA & ALEM PARAIBA & 0 & 0 \\
\hline LEOPOLDINA & ARGIRITA & 0 & 0 \\
\hline LEOPOLDINA & CATAGUASES & 2 & 0 \\
\hline LEOPOLDINA & ESTRELA DALVA & 0 & 0 \\
\hline LEOPOLDINA & ITAMARATI DE MINAS & 0 & 0 \\
\hline LEOPOLDINA & LEOPOLDINA & 0 & 0 \\
\hline LEOPOLDINA & PIRAPETINGA & 0 & 0 \\
\hline LEOPOLDINA & RECREIO & 0 & 0 \\
\hline LEOPOLDINA & SANTO ANTONIO DO AVENTUREIRO & 1 & 0 \\
\hline LEOPOLDINA & VOLTA GRANDE & 0 & 0 \\
\hline MANHUAÇU & ALTO JEQUITIBA & 0 & 0 \\
\hline MANHUAÇU & CAPUTIRA & 0 & 0 \\
\hline MANHUAÇU & CHALE & 0 & 0 \\
\hline MANHUAÇU & CONCEICAO DE IPANEMA & 0 & 0 \\
\hline MANHUAÇU & DURANDE & 0 & 0 \\
\hline MANHUAÇU & LAJINHA & 2 & 0 \\
\hline MANHUAÇU & LUISBURGO & 1 & 0 \\
\hline MANHUAÇU & MANHUACU & 1 & 0 \\
\hline MANHUAÇU & MANHUMIRIM & 2 & 0 \\
\hline MANHUAÇU & MARTINS SOARES & 1 & 0 \\
\hline MANHUAÇU & MATIPO & 1 & 0 \\
\hline MANHUAÇU & MUTUM & 2 & 0 \\
\hline MANHUAÇU & REDUTO & 0 & 0 \\
\hline MANHUAÇU & SANTA MARGARIDA & 1 & 0 \\
\hline MANHUAÇU & SANTANA DO MANHUACU & 2 & 0 \\
\hline MANHUAÇU & SAO JOAO DO MANHUACU & 0 & 0 \\
\hline MANHUAÇU & SAO JOSE DO MANTIMENTO & 0 & 0 \\
\hline MANHUAÇU & SIMONESIA & 1 & 0 \\
\hline METROPOLITANA A & BARAO DE COCAIS & 1 & 0 \\
\hline METROPOLITANA A & BELO HORIZONTE & 26 & 6 \\
\hline METROPOLITANA A & BELO VALE & 0 & 0 \\
\hline METROPOLITANA A & BOM JESUS DO AMPARO & 0 & 0 \\
\hline METROPOLITANA A & BONFIM & 2 & 0 \\
\hline METROPOLITANA A & BRUMADINHO & 0 & 0 \\
\hline METROPOLITANA A & CAETE & 1 & 0 \\
\hline METROPOLITANA A & CATAS ALTAS & 0 & 0 \\
\hline
\end{tabular}




\begin{tabular}{|c|c|c|c|}
\hline METROPOLITANA A & CRUCILANDIA & 0 & 0 \\
\hline METROPOLITANA A & MOEDA & 0 & 0 \\
\hline METROPOLITANA A & NOVA LIMA & 4 & 0 \\
\hline METROPOLITANA A & NOVA UNIAO & 0 & 0 \\
\hline METROPOLITANA A & PIEDADE DOS GERAIS & 1 & 0 \\
\hline METROPOLITANA A & RAPOSOS & 1 & 0 \\
\hline METROPOLITANA A & RIO ACIMA & 0 & 0 \\
\hline METROPOLITANA A & RIO MANSO & 0 & 0 \\
\hline METROPOLITANA A & SABARA & 5 & 2 \\
\hline METROPOLITANA A & SANTA BARBARA & 0 & 0 \\
\hline METROPOLITANA B & BELO HORIZONTE & 18 & 4 \\
\hline METROPOLITANA B & BETIM & 13 & 3 \\
\hline METROPOLITANA B & CONTAGEM & 13 & 3 \\
\hline METROPOLITANA B & ESMERALDAS & 4 & 0 \\
\hline METROPOLITANA B & IBIRITE & 2 & 0 \\
\hline METROPOLITANA B & IGARAPE & 5 & 2 \\
\hline METROPOLITANA B & JUATUBA & 1 & 0 \\
\hline METROPOLITANA B & MARIO CAMPOS & 1 & 0 \\
\hline METROPOLITANA B & MATEUS LEME & 3 & 0 \\
\hline METROPOLITANA B & SAO JOAQUIM DE BICAS & 0 & 0 \\
\hline METROPOLITANA B & SARZEDO & 3 & 0 \\
\hline METROPOLITANA C & BELO HORIZONTE & 11 & 3 \\
\hline METROPOLITANA C & CONFINS & 1 & 0 \\
\hline METROPOLITANA C & JABOTICATUBAS & 3 & 0 \\
\hline METROPOLITANA C & LAGOA SANTA & 1 & 0 \\
\hline METROPOLITANA C & MORRO DO PILAR & 0 & 0 \\
\hline METROPOLITANA C & PEDRO LEOPOLDO & 0 & 0 \\
\hline METROPOLITANA C & RIBEIRAO DAS NEVES & 25 & 6 \\
\hline METROPOLITANA C & SANTA LUZIA & 7 & 2 \\
\hline METROPOLITANA C & SANTANA DO RIACHO & 0 & 0 \\
\hline METROPOLITANA C & SAO JOSE DA LAPA & 0 & 0 \\
\hline METROPOLITANA C & TAQUARACU DE MINAS & 0 & 0 \\
\hline METROPOLITANA C & VESPASIANO & 2 & 0 \\
\hline MONTE CARMELO & ABADIA DOS DOURADOS & 0 & 0 \\
\hline MONTE CARMELO & CASCALHO RICO & 0 & 0 \\
\hline MONTE CARMELO & COROMANDEL & 4 & 0 \\
\hline MONTE CARMELO & DOURADOQUARA & 0 & 0 \\
\hline MONTE CARMELO & ESTRELA DO SUL & 0 & 0 \\
\hline MONTE CARMELO & GRUPIARA & 0 & 0 \\
\hline MONTE CARMELO & MONTE CARMELO & 0 & 0 \\
\hline MONTE CARMELO & ROMARIA & 0 & 0 \\
\hline MONTES CLAROS & BOCAIUVA & 0 & 0 \\
\hline MONTES CLAROS & BOTUMIRIM & 1 & 0 \\
\hline MONTES CLAROS & BRASILIA DE MINAS & 2 & 0 \\
\hline MONTES CLAROS & CAMPO AZUL & 1 & 0 \\
\hline
\end{tabular}




\begin{tabular}{|c|c|c|c|}
\hline MONTES CLAROS & CAPITAO ENEAS & 2 & 0 \\
\hline MONTES CLAROS & CLARO DOS POCOES & 0 & 0 \\
\hline MONTES CLAROS & CORACAO DE JESUS & 4 & 0 \\
\hline MONTES CLAROS & CRISTALIA & 1 & 0 \\
\hline MONTES CLAROS & ENGENHEIRO NAVARRO & 0 & 0 \\
\hline MONTES CLAROS & FRANCISCO DUMONT & 0 & 0 \\
\hline MONTES CLAROS & FRANCISCO SA & 3 & 0 \\
\hline MONTES CLAROS & GLAUCILANDIA & 1 & 0 \\
\hline MONTES CLAROS & GRAO MOGOL & 5 & 2 \\
\hline MONTES CLAROS & GUARACIAMA & 0 & 0 \\
\hline MONTES CLAROS & ITACAMBIRA & 1 & 0 \\
\hline MONTES CLAROS & JAPONVAR & 1 & 0 \\
\hline MONTES CLAROS & JOSENOPOLIS & 0 & 0 \\
\hline MONTES CLAROS & JURAMENTO & 2 & 0 \\
\hline MONTES CLAROS & LONTRA & 0 & 0 \\
\hline MONTES CLAROS & LUISLANDIA & 0 & 0 \\
\hline MONTES CLAROS & MIRABELA & 1 & 0 \\
\hline MONTES CLAROS & MONTES CLAROS & 4 & 0 \\
\hline MONTES CLAROS & OLHOS-D AGUA & 1 & 0 \\
\hline MONTES CLAROS & PADRE CARVALHO & 1 & 0 \\
\hline MONTES CLAROS & PATIS & 0 & 0 \\
\hline MONTES CLAROS & SAO JOAO DA LAGOA & 0 & 0 \\
\hline MONTES CLAROS & SAO JOAO DA PONTE & 2 & 0 \\
\hline MONTES CLAROS & SAO JOAO DO PACUI & 0 & 0 \\
\hline MONTES CLAROS & SAO JOAO DO PARAISO & 0 & 0 \\
\hline MONTES CLAROS & VARGEM GRANDE DO RIO PARDO & 0 & 0 \\
\hline MURIAÉ & ANTONIO PRADO DE MINAS & 0 & 0 \\
\hline MURIAÉ & BARAO DE MONTE ALTO & 0 & 0 \\
\hline MURIAÉ & EUGENOPOLIS & 0 & 0 \\
\hline MURIAÉ & LARANJAL & 0 & 0 \\
\hline MURIAÉ & MIRADOURO & 0 & 0 \\
\hline MURIAÉ & MIRAI & 0 & 0 \\
\hline MURIAÉ & MURIAE & 4 & 0 \\
\hline MURIAÉ & PALMA & 1 & 0 \\
\hline MURIAÉ & PATROCINIO DO MURIAE & 0 & 0 \\
\hline MURIAÉ & ROSARIO DA LIMEIRA & 0 & 0 \\
\hline MURIAÉ & SANTANA DE CATAGUASES & 0 & 0 \\
\hline MURIAÉ & SAO FRANCISCO DO GLORIA & 0 & 0 \\
\hline MURIAÉ & SAO SEBASTIAO DA VARGEM ALEGRE & 0 & 0 \\
\hline MURIAÉ & VIEIRAS & 1 & 0 \\
\hline NOVA ERA & BELA VISTA DE MINAS & 0 & 0 \\
\hline NOVA ERA & DIONISIO & 0 & 0 \\
\hline NOVA ERA & FERROS & 0 & 0 \\
\hline NOVA ERA & ITABIRA & 0 & 0 \\
\hline NOVA ERA & ITAMBE DO MATO DENTRO & 0 & 0 \\
\hline
\end{tabular}




\begin{tabular}{|c|c|c|c|}
\hline NOVA ERA & JOAO MONLEVADE & 0 & 0 \\
\hline NOVA ERA & NOVA ERA & 1 & 0 \\
\hline NOVA ERA & PASSABEM & 0 & 0 \\
\hline NOVA ERA & RIO PIRACICABA & 1 & 0 \\
\hline NOVA ERA & SANTA MARIA DE ITABIRA & 0 & 0 \\
\hline NOVA ERA & SANTO ANTONIO DO RIO ABAIXO & 0 & 0 \\
\hline NOVA ERA & SAO DOMINGOS DO PRATA & 2 & 0 \\
\hline NOVA ERA & SAO GONCALO DO RIO ABAIXO & 1 & 0 \\
\hline NOVA ERA & SAO JOSE DO GOIABAL & 0 & 0 \\
\hline NOVA ERA & SAO SEBASTIAO DO RIO PRETO & 1 & 0 \\
\hline OURO PRETO & ACAIACA & 0 & 0 \\
\hline OURO PRETO & DIOGO DE VASCONCELOS & 1 & 0 \\
\hline OURO PRETO & ITABIRITO & 3 & 0 \\
\hline OURO PRETO & MARIANA & 0 & 0 \\
\hline OURO PRETO & OURO PRETO & 6 & 2 \\
\hline PARA DE MINAS & ABAETE & 0 & 0 \\
\hline PARA DE MINAS & BIQUINHAS & 0 & 0 \\
\hline PARA DE MINAS & BOM DESPACHO & 0 & 0 \\
\hline PARA DE MINAS & CEDRO DO ABAETE & 0 & 0 \\
\hline PARA DE MINAS & CONCEICAO DO PARA & 0 & 0 \\
\hline PARA DE MINAS & DORES DO INDAIA & 0 & 0 \\
\hline PARA DE MINAS & ESTRELA DO INDAIA & 0 & 0 \\
\hline PARA DE MINAS & FLORESTAL & 3 & 0 \\
\hline PARA DE MINAS & IGARATINGA & 1 & 0 \\
\hline PARA DE MINAS & LEANDRO FERREIRA & 0 & 0 \\
\hline PARA DE MINAS & MARTINHO CAMPOS & 0 & 0 \\
\hline PARA DE MINAS & MORADA NOVA DE MINAS & 1 & 0 \\
\hline PARA DE MINAS & ONCA DE PITANGUI & 1 & 0 \\
\hline PARA DE MINAS & PAINEIRAS & 1 & 0 \\
\hline PARA DE MINAS & PARA DE MINAS & 2 & 0 \\
\hline PARA DE MINAS & PEQUI & 0 & 0 \\
\hline PARA DE MINAS & PITANGUI & 1 & 0 \\
\hline PARA DE MINAS & QUARTEL GERAL & 0 & 0 \\
\hline PARA DE MINAS & SAO JOSE DA VARGINHA & 0 & 0 \\
\hline PARA DE MINAS & SERRA DA SAUDADE & 0 & 0 \\
\hline PARACATU & BRASILANDIA DE MINAS & 0 & 0 \\
\hline PARACATU & GUARDA-MOR & 0 & 0 \\
\hline PARACATU & JOAO PINHEIRO & 3 & 0 \\
\hline PARACATU & PARACATU & 4 & 0 \\
\hline PARACATU & VAZANTE & 0 & 0 \\
\hline PASSOS & ALPINOPOLIS & 0 & 0 \\
\hline PASSOS & BOM JESUS DA PENHA & 0 & 0 \\
\hline PASSOS & CAPITOLIO & 1 & 0 \\
\hline PASSOS & CARMO DO RIO CLARO & 1 & 0 \\
\hline PASSOS & CORREGO FUNDO & 0 & 0 \\
\hline
\end{tabular}




\begin{tabular}{|c|c|c|c|}
\hline PASSOS & DELFINOPOLIS & 2 & 0 \\
\hline PASSOS & DORESOPOLIS & 0 & 0 \\
\hline PASSOS & FORMIGA & 1 & 0 \\
\hline PASSOS & FORTALEZA DE MINAS & 1 & 0 \\
\hline PASSOS & PASSOS & 2 & 0 \\
\hline PASSOS & PIMENTA & 0 & 0 \\
\hline PASSOS & PIUMHI & 0 & 0 \\
\hline PASSOS & SAO JOAO BATISTA DO GLORIA & 0 & 0 \\
\hline PASSOS & SAO JOSE DA BARRA & 1 & 0 \\
\hline PASSOS & SAO ROQUE DE MINAS & 3 & 0 \\
\hline PASSOS & VARGEM BONITA & 1 & 0 \\
\hline PATOS DE MINAS & ARAPUA & 0 & 0 \\
\hline PATOS DE MINAS & CARMO DO PARANAIBA & 1 & 0 \\
\hline PATOS DE MINAS & LAGAMAR & 0 & 0 \\
\hline PATOS DE MINAS & LAGOA FORMOSA & 0 & 0 \\
\hline PATOS DE MINAS & LAGOA GRANDE & 0 & 0 \\
\hline PATOS DE MINAS & MATUTINA & 0 & 0 \\
\hline PATOS DE MINAS & PATOS DE MINAS & 0 & 0 \\
\hline PATOS DE MINAS & PRESIDENTE OLEGARIO & 0 & 0 \\
\hline PATOS DE MINAS & RIO PARANAIBA & 0 & 0 \\
\hline PATOS DE MINAS & SANTA ROSA DA SERRA & 0 & 0 \\
\hline PATOS DE MINAS & SAO GONCALO DO ABAETE & 0 & 0 \\
\hline PATOS DE MINAS & SAO GOTARDO & 5 & 2 \\
\hline PATOS DE MINAS & TIROS & 0 & 0 \\
\hline PATOS DE MINAS & VARJAO DE MINAS & 0 & 0 \\
\hline PATROCÍNIO & CRUZEIRO DA FORTALEZA & 0 & 0 \\
\hline PATROCÍNIO & GUIMARANIA & 0 & 0 \\
\hline PATROCÍNIO & IBIA & 0 & 0 \\
\hline PATROCÍNIO & IRAI DE MINAS & 0 & 0 \\
\hline PATROCÍNIO & PATROCINIO & 3 & 0 \\
\hline PATROCÍNIO & PERDIZES & 1 & 0 \\
\hline PATROCÍNIO & SERRA DO SALITRE & 0 & 0 \\
\hline PIRAPORA & BURITIZEIRO & 4 & 0 \\
\hline PIRAPORA & IBIAI & 1 & 0 \\
\hline PIRAPORA & JEQUITAI & 1 & 0 \\
\hline PIRAPORA & LAGOA DOS PATOS & 0 & 0 \\
\hline PIRAPORA & PIRAPORA & 2 & 0 \\
\hline PIRAPORA & PONTO CHIQUE & 0 & 0 \\
\hline PIRAPORA & SANTA FE DE MINAS & 1 & 0 \\
\hline PIRAPORA & SAO ROMAO & 2 & 0 \\
\hline PIRAPORA & VARZEA DA PALMA & 0 & 0 \\
\hline POÇOS DE CALDAS & ALTEROSA & 1 & 0 \\
\hline POÇOS DE CALDAS & ANDRADAS & 1 & 0 \\
\hline POÇOS DE CALDAS & AREADO & 1 & 0 \\
\hline POÇOS DE CALDAS & BANDEIRA DO SUL & 0 & 0 \\
\hline
\end{tabular}




\begin{tabular}{|c|c|c|c|}
\hline POÇOS DE CALDAS & BOTELHOS & 2 & 0 \\
\hline POÇOS DE CALDAS & CABO VERDE & 0 & 0 \\
\hline POÇOS DE CALDAS & CALDAS & 1 & 0 \\
\hline POÇOS DE CALDAS & CAMPESTRE & 0 & 0 \\
\hline POÇOS DE CALDAS & CONCEICAO DA APARECIDA & 1 & 0 \\
\hline POÇOS DE CALDAS & DIVISA NOVA & 0 & 0 \\
\hline POÇOS DE CALDAS & IBITIURA DE MINAS & 0 & 0 \\
\hline POÇOS DE CALDAS & MONTE BELO & 0 & 0 \\
\hline POÇOS DE CALDAS & MUZAMBINHO & 1 & 0 \\
\hline POÇOS DE CALDAS & NOVA RESENDE & 2 & 0 \\
\hline POÇOS DE CALDAS & POCOS DE CALDAS & 9 & 2 \\
\hline POÇOS DE CALDAS & SANTA RITA DE CALDAS & 1 & 0 \\
\hline POÇOS DE CALDAS & SERRANIA & 0 & 0 \\
\hline PONTE NOVA & ABRE CAMPO & 2 & 0 \\
\hline PONTE NOVA & ALVINOPOLIS & 1 & 0 \\
\hline PONTE NOVA & AMPARO DO SERRA & 0 & 0 \\
\hline PONTE NOVA & ARAPONGA & 0 & 0 \\
\hline PONTE NOVA & BARRA LONGA & 0 & 0 \\
\hline PONTE NOVA & CAJURI & 0 & 0 \\
\hline PONTE NOVA & CANAA & 0 & 0 \\
\hline PONTE NOVA & DOM SILVERIO & 0 & 0 \\
\hline PONTE NOVA & GUARACIABA & 1 & 0 \\
\hline PONTE NOVA & JEQUERI & 1 & 0 \\
\hline PONTE NOVA & ORATORIOS & 0 & 0 \\
\hline PONTE NOVA & PEDRA BONITA & 0 & 0 \\
\hline PONTE NOVA & PEDRA DO ANTA & 0 & 0 \\
\hline PONTE NOVA & PIEDADE DE PONTE NOVA & 0 & 0 \\
\hline PONTE NOVA & PONTE NOVA & 1 & 0 \\
\hline PONTE NOVA & PORTO FIRME & 0 & 0 \\
\hline PONTE NOVA & RAUL SOARES & 0 & 0 \\
\hline PONTE NOVA & RIO CASCA & 0 & 0 \\
\hline PONTE NOVA & RIO DOCE & 0 & 0 \\
\hline PONTE NOVA & SANTA CRUZ DO ESCALVADO & 0 & 0 \\
\hline PONTE NOVA & SANTO ANTONIO DO GRAMA & 0 & 0 \\
\hline PONTE NOVA & SAO MIGUEL DO ANTA & 0 & 0 \\
\hline PONTE NOVA & SAO PEDRO DOS FERROS & 0 & 0 \\
\hline PONTE NOVA & SEM-PEIXE & 0 & 0 \\
\hline PONTE NOVA & SERICITA & 0 & 0 \\
\hline PONTE NOVA & TEIXEIRAS & 0 & 0 \\
\hline PONTE NOVA & URUCANIA & 0 & 0 \\
\hline PONTE NOVA & VERMELHO NOVO & 0 & 0 \\
\hline PONTE NOVA & VICOSA & 2 & 0 \\
\hline POUSO ALEGRE & ALBERTINA & 0 & 0 \\
\hline POUSO ALEGRE & BOM REPOUSO & 0 & 0 \\
\hline POUSO ALEGRE & BORDA DA MATA & 0 & 0 \\
\hline
\end{tabular}




\begin{tabular}{|c|c|c|c|}
\hline POUSO ALEGRE & BUENO BRANDAO & 2 & 0 \\
\hline POUSO ALEGRE & CACHOEIRA DE MINAS & 0 & 0 \\
\hline POUSO ALEGRE & CAMANDUCAIA & 2 & 0 \\
\hline POUSO ALEGRE & CAMBUI & 0 & 0 \\
\hline POUSO ALEGRE & CAREACU & 0 & 0 \\
\hline POUSO ALEGRE & CONGONHAL & 0 & 0 \\
\hline POUSO ALEGRE & CORREGO DO BOM JESUS & 0 & 0 \\
\hline POUSO ALEGRE & ESPIRITO SANTO DO DOURADO & 0 & 0 \\
\hline POUSO ALEGRE & ESTIVA & 0 & 0 \\
\hline POUSO ALEGRE & EXTREMA & 0 & 0 \\
\hline POUSO ALEGRE & HELIODORA & 0 & 0 \\
\hline POUSO ALEGRE & INCONFIDENTES & 0 & 0 \\
\hline POUSO ALEGRE & IPUIUNA & 0 & 0 \\
\hline POUSO ALEGRE & ITAPEVA & 2 & 0 \\
\hline POUSO ALEGRE & JACUTINGA & 0 & 0 \\
\hline POUSO ALEGRE & MONTE SIAO & 0 & 0 \\
\hline POUSO ALEGRE & MUNHOZ & 0 & 0 \\
\hline POUSO ALEGRE & OURO FINO & 3 & 0 \\
\hline POUSO ALEGRE & POUSO ALEGRE & 3 & 0 \\
\hline POUSO ALEGRE & SANTA RITA DO SAPUCAI & 1 & 0 \\
\hline POUSO ALEGRE & SAO JOAO DA MATA & 0 & 0 \\
\hline POUSO ALEGRE & SAO SEBASTIAO DA BELA VISTA & 0 & 0 \\
\hline POUSO ALEGRE & SENADOR AMARAL & 1 & 0 \\
\hline POUSO ALEGRE & SENADOR JOSE BENTO & 1 & 0 \\
\hline POUSO ALEGRE & SILVIANOPOLIS & 0 & 0 \\
\hline POUSO ALEGRE & TOCOS DO MOJI & 0 & 0 \\
\hline POUSO ALEGRE & TOLEDO & 1 & 0 \\
\hline SÃO JOÃO DEL REI & BOM SUCESSO & 0 & 0 \\
\hline SÃO JOÃO DEL REI & CARRANCAS & 0 & 0 \\
\hline SÃO JOÃO DEL REI & CONCEICAO DA BARRA DE MINAS & 0 & 0 \\
\hline SÃO JOÃO DEL REI & CORONEL XAVIER CHAVES & 0 & 0 \\
\hline SÃO JOÃO DEL REI & DORES DE CAMPOS & 0 & 0 \\
\hline SÃO JOÃO DEL REI & IBITURUNA & 0 & 0 \\
\hline SÃO JOÃO DEL REI & IJACI & 2 & 0 \\
\hline SÃO JOÃO DEL REI & INGAI & 0 & 0 \\
\hline SÃO JOÃO DEL REI & ITUMIRIM & 0 & 0 \\
\hline SÃO JOÃO DEL REI & ITUTINGA & 0 & 0 \\
\hline SÃO JOÃO DEL REI & LAGOA DOURADA & 0 & 0 \\
\hline SÃO JOÃO DEL REI & NAZARENO & 0 & 0 \\
\hline SÃO JOÃO DEL REI & PRADOS & 0 & 0 \\
\hline SÃO JOÃO DEL REI & RESENDE COSTA & 2 & 0 \\
\hline SÃO JOÃO DEL REI & RITAPOLIS & 0 & 0 \\
\hline SÃO JOÃO DEL REI & SANTA CRUZ DE MINAS & 0 & 0 \\
\hline SÃO JOÃO DEL REI & SAO JOAO DEL REI & 3 & 0 \\
\hline SÃO JOÃO DEL REI & SAO TIAGO & 0 & 0 \\
\hline
\end{tabular}




\begin{tabular}{|c|c|c|c|}
\hline SÃO JOÃO DEL REI & TIRADENTES & 0 & 0 \\
\hline SÃO SEBASTIÃO DO PARAÍSO & ARCEBURGO & 0 & 0 \\
\hline SÃO SEBASTIÃO DO PARAÍSO & CAPETINGA & 1 & 0 \\
\hline SÃO SEBASTIÃO DO PARAÍSO & CASSIA & 0 & 0 \\
\hline SÃO SEBASTIÃO DO PARAÍSO & CLARAVAL & 0 & 0 \\
\hline SÃO SEBASTIÃO DO PARAÍSO & GUARANESIA & 0 & 0 \\
\hline SÃO SEBASTIÃO DO PARAÍSO & GUAXUPE & 0 & 0 \\
\hline SÃO SEBASTIÃO DO PARAÍSO & IBIRACI & 0 & 0 \\
\hline SÃO SEBASTIÃO DO PARAÍSO & ITAMOGI & 0 & 0 \\
\hline SÃO SEBASTIÃO DO PARAÍSO & ITAU DE MINAS & 0 & 0 \\
\hline SÃO SEBASTIÃO DO PARAÍSO & JACUI & 0 & 0 \\
\hline SÃO SEBASTIÃO DO PARAÍSO & JURUAIA & 0 & 0 \\
\hline SÃO SEBASTIÃO DO PARAÍSO & MONTE SANTO DE MINAS & 2 & 0 \\
\hline SÃO SEBASTIÃO DO PARAÍSO & PRATAPOLIS & 0 & 0 \\
\hline SÃO SEBASTIÃO DO PARAÍSO & SAO PEDRO DA UNIAO & 0 & 0 \\
\hline SÃO SEBASTIÃO DO PARAÍSO & SAO SEBASTIAO DO PARAISO & 2 & 0 \\
\hline SÃO SEBASTIÃO DO PARAÍSO & SAO TOMAS DE AQUINO & 0 & 0 \\
\hline SETE LAGOAS & ARACAI & 0 & 0 \\
\hline SETE LAGOAS & BALDIM & 1 & 0 \\
\hline SETE LAGOAS & CACHOEIRA DA PRATA & 0 & 0 \\
\hline SETE LAGOAS & CAETANOPOLIS & 0 & 0 \\
\hline SETE LAGOAS & CAPIM BRANCO & 0 & 0 \\
\hline SETE LAGOAS & CORDISBURGO & 1 & 0 \\
\hline SETE LAGOAS & FORTUNA DE MINAS & 0 & 0 \\
\hline SETE LAGOAS & FUNILANDIA & 0 & 0 \\
\hline SETE LAGOAS & INHAUMA & 0 & 0 \\
\hline SETE LAGOAS & JEQUITIBA & 0 & 0 \\
\hline SETE LAGOAS & MARAVILHAS & 0 & 0 \\
\hline SETE LAGOAS & MATOZINHOS & 0 & 0 \\
\hline SETE LAGOAS & PAPAGAIOS & 0 & 0 \\
\hline SETE LAGOAS & PARAOPEBA & 0 & 0 \\
\hline SETE LAGOAS & POMPEU & 1 & 0 \\
\hline SETE LAGOAS & PRUDENTE DE MORAIS & 0 & 0 \\
\hline SETE LAGOAS & SANTANA DE PIRAPAMA & 0 & 0 \\
\hline SETE LAGOAS & SETE LAGOAS & 3 & 0 \\
\hline TEOFILO OTONI & AGUAS FORMOSAS & 0 & 0 \\
\hline TEOFILO OTONI & ATALEIA & 0 & 0 \\
\hline TEOFILO OTONI & BERTOPOLIS & 1 & 0 \\
\hline TEOFILO OTONI & CAMPANARIO & 1 & 0 \\
\hline TEOFILO OTONI & CARAI & 0 & 0 \\
\hline TEOFILO OTONI & CARLOS CHAGAS & 2 & 0 \\
\hline TEOFILO OTONI & CATUJI & 0 & 0 \\
\hline TEOFILO OTONI & CRISOLITA & 0 & 0 \\
\hline TEOFILO OTONI & FRANCISCOPOLIS & 1 & 0 \\
\hline TEOFILO OTONI & FREI GASPAR & 0 & 0 \\
\hline
\end{tabular}




\begin{tabular}{|c|c|c|c|}
\hline TEOFILO OTONI & FRONTEIRA DOS VALES & 0 & 0 \\
\hline TEOFILO OTONI & ITAIPE & 1 & 0 \\
\hline TEOFILO OTONI & ITAMBACURI & 0 & 0 \\
\hline TEOFILO OTONI & JAMPRUCA & 0 & 0 \\
\hline TEOFILO OTONI & LADAINHA & 0 & 0 \\
\hline TEOFILO OTONI & MACHACALIS & 0 & 0 \\
\hline TEOFILO OTONI & MALACACHETA & 1 & 0 \\
\hline TEOFILO OTONI & NANUQUE & 0 & 0 \\
\hline TEOFILO OTONI & NOVO CRUZEIRO & 1 & 0 \\
\hline TEOFILO OTONI & NOVO ORIENTE DE MINAS & 2 & 0 \\
\hline TEOFILO OTONI & OURO VERDE DE MINAS & 0 & 0 \\
\hline TEOFILO OTONI & PADRE PARAISO & 0 & 0 \\
\hline TEOFILO OTONI & PAVAO & 1 & 0 \\
\hline TEOFILO OTONI & PESCADOR & 0 & 0 \\
\hline TEOFILO OTONI & PONTO DOS VOLANTES & 1 & 0 \\
\hline TEOFILO OTONI & POTE & 0 & 0 \\
\hline TEOFILO OTONI & SANTA HELENA DE MINAS & 1 & 0 \\
\hline TEOFILO OTONI & SERRA DOS AIMORES & 0 & 0 \\
\hline TEOFILO OTONI & SETUBINHA & 2 & 0 \\
\hline TEOFILO OTONI & TEOFILO OTONI & 5 & 2 \\
\hline TEOFILO OTONI & UMBURATIBA & 0 & 0 \\
\hline UBÁ & ASTOLFO DUTRA & 2 & 0 \\
\hline UBÁ & BRAS PIRES & 1 & 0 \\
\hline UBÁ & COIMBRA & 1 & 0 \\
\hline UBÁ & DIVINESIA & 0 & 0 \\
\hline UBÁ & DONA EUZEBIA & 0 & 0 \\
\hline UBÁ & DORES DO TURVO & 0 & 0 \\
\hline UBÁ & ERVALIA & 1 & 0 \\
\hline UBÁ & GUARANI & 0 & 0 \\
\hline UBÁ & GUIDOVAL & 0 & 0 \\
\hline UBÁ & GUIRICEMA & 0 & 0 \\
\hline UBÁ & PAULA CANDIDO & 2 & 0 \\
\hline UBÁ & PIRAUBA & 1 & 0 \\
\hline UBÁ & PRESIDENTE BERNARDES & 0 & 0 \\
\hline UBÁ & RIO POMBA & 0 & 0 \\
\hline UBÁ & RODEIRO & 1 & 0 \\
\hline UBÁ & SAO GERALDO & 0 & 0 \\
\hline UBÁ & SENADOR FIRMINO & 0 & 0 \\
\hline UBÁ & SILVEIRANIA & 0 & 0 \\
\hline UBÁ & TABULEIRO & 0 & 0 \\
\hline UBÁ & TOCANTINS & 1 & 0 \\
\hline UBÁ & UBA & 6 & 2 \\
\hline UBÁ & VISCONDE DO RIO BRANCO & 0 & 0 \\
\hline UBERABA & AGUA COMPRIDA & 1 & 0 \\
\hline UBERABA & ARAXA & 1 & 0 \\
\hline
\end{tabular}




\begin{tabular}{|c|c|c|c|}
\hline UBERABA & CAMPO FLORIDO & 0 & 0 \\
\hline UBERABA & CAMPOS ALTOS & 0 & 0 \\
\hline UBERABA & CARNEIRINHO & 2 & 0 \\
\hline UBERABA & COMENDADOR GOMES & 1 & 0 \\
\hline UBERABA & CONCEICAO DAS ALAGOAS & 1 & 0 \\
\hline UBERABA & CONQUISTA & 0 & 0 \\
\hline UBERABA & DELTA & 0 & 0 \\
\hline UBERABA & FRONTEIRA & 1 & 0 \\
\hline UBERABA & FRUTAL & 2 & 0 \\
\hline UBERABA & ITAPAGIPE & 1 & 0 \\
\hline UBERABA & ITURAMA & 1 & 0 \\
\hline UBERABA & LIMEIRA DO OESTE & 3 & 0 \\
\hline UBERABA & PEDRINOPOLIS & 1 & 0 \\
\hline UBERABA & PIRAJUBA & 0 & 0 \\
\hline UBERABA & PLANURA & 0 & 0 \\
\hline UBERABA & PRATINHA & 1 & 0 \\
\hline UBERABA & SACRAMENTO & 1 & 0 \\
\hline UBERABA & SANTA JULIANA & 1 & 0 \\
\hline UBERABA & SAO FRANCISCO DE SALES & 0 & 0 \\
\hline UBERABA & TAPIRA & 0 & 0 \\
\hline UBERABA & UBERABA & 10 & 3 \\
\hline UBERABA & UNIAO DE MINAS & 0 & 0 \\
\hline UBERABA & VERISSIMO & 0 & 0 \\
\hline UBERLANDIA & ARAGUARI & 1 & 0 \\
\hline UBERLANDIA & ARAPORA & 0 & 0 \\
\hline UBERLANDIA & CAMPINA VERDE & 0 & 0 \\
\hline UBERLANDIA & INDIANOPOLIS & 1 & 0 \\
\hline UBERLANDIA & MONTE ALEGRE DE MINAS & 0 & 0 \\
\hline UBERLANDIA & NOVA PONTE & 0 & 0 \\
\hline UBERLANDIA & PRATA & 1 & 0 \\
\hline UBERLANDIA & TUPACIGUARA & 1 & 0 \\
\hline UBERLANDIA & UBERLANDIA & 39 & 7 \\
\hline UNAI & ARINOS & 2 & 0 \\
\hline UNAI & BONFINOPOLIS DE MINAS & 0 & 0 \\
\hline UNAI & BURITIS & 1 & 0 \\
\hline UNAI & CABECEIRA GRANDE & 0 & 0 \\
\hline UNAI & DOM BOSCO & 2 & 0 \\
\hline UNAI & FORMOSO & 0 & 0 \\
\hline UNAI & NATALANDIA & 0 & 0 \\
\hline UNAI & RIACHINHO & 0 & 0 \\
\hline UNAI & UNAI & 5 & 2 \\
\hline UNAI & URUANA DE MINAS & 0 & 0 \\
\hline VARGINHA & ALFENAS & 3 & 0 \\
\hline VARGINHA & BOA ESPERANCA & 1 & 0 \\
\hline VARGINHA & CAMBUQUIRA & 0 & 0 \\
\hline
\end{tabular}




\begin{tabular}{|c|c|c|c|}
\hline VARGINHA & CAMPANHA & 0 & 0 \\
\hline VARGINHA & CAMPO DO MEIO & 0 & 0 \\
\hline VARGINHA & CAMPOS GERAIS & 0 & 0 \\
\hline VARGINHA & CARMO DA CACHOEIRA & 0 & 0 \\
\hline VARGINHA & CARVALHOPOLIS & 1 & 0 \\
\hline VARGINHA & COQUEIRAL & 0 & 0 \\
\hline VARGINHA & CORDISLANDIA & 0 & 0 \\
\hline VARGINHA & ELOI MENDES & 1 & 0 \\
\hline VARGINHA & FAMA & 0 & 0 \\
\hline VARGINHA & GUAPE & 0 & 0 \\
\hline VARGINHA & ILICINEA & 0 & 0 \\
\hline VARGINHA & LAMBARI & 0 & 0 \\
\hline VARGINHA & LUMINARIAS & 0 & 0 \\
\hline VARGINHA & MACHADO & 1 & 0 \\
\hline VARGINHA & MONSENHOR PAULO & 0 & 0 \\
\hline VARGINHA & NEPOMUCENO & 0 & 0 \\
\hline VARGINHA & PARAGUACU & 0 & 0 \\
\hline VARGINHA & POCO FUNDO & 2 & 0 \\
\hline VARGINHA & SANTANA DA VARGEM & 1 & 0 \\
\hline VARGINHA & SAO BENTO ABADE & 1 & 0 \\
\hline VARGINHA & SAO GONCALO DO SAPUCAI & 0 & 0 \\
\hline VARGINHA & TRES CORACOES & 2 & 0 \\
\hline VARGINHA & TRES PONTAS & 1 & 0 \\
\hline VARGINHA & TURVOLANDIA & 0 & 0 \\
\hline VARGINHA & VARGINHA & 6 & 2 \\
\hline Total geral & & 700 & 70 \\
\hline
\end{tabular}

CARGO: PROFESSOR DE EDUCAÇÃO BÁSICA - PEB - H I S T Ó R I A

\begin{tabular}{|l|l|c|c|}
\hline \multicolumn{1}{|c|}{ S R E } & \multicolumn{1}{|c|}{ MUNICIPIO } & $\begin{array}{c}\text { VAGAS } \\
\text { TOTAL DE } \\
\text { VAGAS } \\
\text { RESERVADAS - } \\
\text { PORTADORES DE } \\
\text { DEFICIENCIA }\end{array}$ \\
\hline ALMENARA & AGUAS VERMELHAS & 0 & 0 \\
\hline ALMENARA & ALMENARA & 0 & 0 \\
\hline ALMENARA & BANDEIRA & 0 & 0 \\
\hline ALMENARA & CACHOEIRA DE PAJEU & 0 & 0 \\
\hline ALMENARA & CURRAL DE DENTRO & 0 & 0 \\
\hline ALMENARA & DIVISA ALEGRE & 0 & 0 \\
\hline ALMENARA & DIVISOPOLIS & 0 & 0 \\
\hline ALMENARA & FELISBURGO & 0 & 0 \\
\hline ALMENARA & JACINTO & 1 & 0 \\
\hline ALMENARA & JEQUITINHONHA & 0 & 0 \\
\hline ALMENARA & JOAIMA & 0 & 0 \\
\hline ALMENARA & JORDANIA & 0 & 0 \\
\hline ALMENARA & MATA VERDE & 1 & 0 \\
\hline ALMENARA & MONTE FORMOSO & 0 \\
\hline
\end{tabular}




\begin{tabular}{|c|c|c|c|}
\hline ALMENARA & PALMOPOLIS & 0 & 0 \\
\hline ALMENARA & PEDRA AZUL & 1 & 0 \\
\hline ALMENARA & RIO DO PRADO & 0 & 0 \\
\hline ALMENARA & RUBIM & 2 & 0 \\
\hline ALMENARA & SALTO DA DIVISA & 0 & 0 \\
\hline ALMENARA & SANTA MARIA DO SALTO & 0 & 0 \\
\hline ALMENARA & SANTO ANTONIO DO JACINTO & 0 & 0 \\
\hline ARACUAI & ARACUAI & 2 & 0 \\
\hline ARACUAI & BERILO & 3 & 0 \\
\hline ARACUAI & BERIZAL & 1 & 0 \\
\hline ARACUAI & CHAPADA DO NORTE & 1 & 0 \\
\hline ARACUAI & COMERCINHO & 0 & 0 \\
\hline ARACUAI & CORONEL MURTA & 0 & 0 \\
\hline ARACUAI & FRANCISCO BADARO & 0 & 0 \\
\hline ARACUAI & FRUTA DE LEITE & 0 & 0 \\
\hline ARACUAI & INDAIABIRA & 0 & 0 \\
\hline ARACUAI & ITAOBIM & 0 & 0 \\
\hline ARACUAI & ITINGA & 0 & 0 \\
\hline ARACUAI & JENIPAPO DE MINAS & 2 & 0 \\
\hline ARACUAI & JOSE GONCALVES DE MINAS & 0 & 0 \\
\hline ARACUAI & MEDINA & 1 & 0 \\
\hline ARACUAI & NINHEIRA & 2 & 0 \\
\hline ARACUAI & NOVORIZONTE & 0 & 0 \\
\hline ARACUAI & RUBELITA & 0 & 0 \\
\hline ARACUAI & SALINAS & 0 & 0 \\
\hline ARACUAI & SANTA CRUZ DE SALINAS & 0 & 0 \\
\hline ARACUAI & TAIOBEIRAS & 3 & 0 \\
\hline ARACUAI & VIRGEM DA LAPA & 1 & 0 \\
\hline BARBACENA & ALFREDO VASCONCELOS & 0 & 0 \\
\hline BARBACENA & ALTO RIO DOCE & 0 & 0 \\
\hline BARBACENA & ANDRELANDIA & 0 & 0 \\
\hline BARBACENA & ANTONIO CARLOS & 0 & 0 \\
\hline BARBACENA & ARACITABA & 0 & 0 \\
\hline BARBACENA & BARBACENA & 1 & 0 \\
\hline BARBACENA & BARROSO & 1 & 0 \\
\hline BARBACENA & BIAS FORTES & 0 & 0 \\
\hline BARBACENA & CAPELA NOVA & 0 & 0 \\
\hline BARBACENA & CARANDAI & 0 & 0 \\
\hline BARBACENA & CIPOTANEA & 0 & 0 \\
\hline BARBACENA & DESTERRO DO MELO & 1 & 0 \\
\hline BARBACENA & IBERTIOGA & 0 & 0 \\
\hline BARBACENA & MADRE DE DEUS DE MINAS & 0 & 0 \\
\hline BARBACENA & MERCES & 0 & 0 \\
\hline BARBACENA & OLIVEIRA FORTES & 1 & 0 \\
\hline BARBACENA & PAIVA & 0 & 0 \\
\hline
\end{tabular}




\begin{tabular}{|c|c|c|c|}
\hline BARBACENA & PIEDADE DO RIO GRANDE & 0 & 0 \\
\hline BARBACENA & RESSAQUINHA & 0 & 0 \\
\hline BARBACENA & SANTA BARBARA DO TUGURIO & 0 & 0 \\
\hline BARBACENA & SANTA RITA DO IBITIPOCA & 0 & 0 \\
\hline BARBACENA & SANTANA DO GARAMBEU & 0 & 0 \\
\hline BARBACENA & SAO VICENTE DE MINAS & 0 & 0 \\
\hline BARBACENA & SENHORA DOS REMEDIOS & 0 & 0 \\
\hline CAMPO BELO & AGUANIL & 0 & 0 \\
\hline CAMPO BELO & САMACHO & 0 & 0 \\
\hline CAMPO BELO & CAMPO BELO & 2 & 0 \\
\hline CAMPO BELO & CANA VERDE & 0 & 0 \\
\hline CAMPO BELO & CANDEIAS & 0 & 0 \\
\hline CAMPO BELO & CRISTAIS & 0 & 0 \\
\hline CAMPO BELO & LAVRAS & 2 & 0 \\
\hline CAMPO BELO & PERDOES & 2 & 0 \\
\hline CAMPO BELO & RIBEIRAO VERMELHO & 0 & 0 \\
\hline CAMPO BELO & SANTANA DO JACARE & 0 & 0 \\
\hline CAMPO BELO & SANTO ANTONIO DO AMPARO & 0 & 0 \\
\hline CAMPO BELO & SAO FRANCISCO DE PAULA & 1 & 0 \\
\hline CARATINGA & ALVARENGA & 1 & 0 \\
\hline CARATINGA & BOM JESUS DO GALHO & 0 & 0 \\
\hline CARATINGA & BUGRE & 0 & 0 \\
\hline CARATINGA & CARATINGA & 2 & 0 \\
\hline CARATINGA & CORREGO NOVO & 0 & 0 \\
\hline CARATINGA & DOM CAVATI & 0 & 0 \\
\hline CARATINGA & ENTRE FOLHAS & 0 & 0 \\
\hline CARATINGA & IAPU & 0 & 0 \\
\hline CARATINGA & IMBE DE MINAS & 0 & 0 \\
\hline CARATINGA & INHAPIM & 2 & 0 \\
\hline CARATINGA & IPABA & 0 & 0 \\
\hline CARATINGA & IPANEMA & 1 & 0 \\
\hline CARATINGA & PIEDADE DE CARATINGA & 0 & 0 \\
\hline CARATINGA & PINGO D AGUA & 0 & 0 \\
\hline CARATINGA & POCRANE & 0 & 0 \\
\hline CARATINGA & SANTA BARBARA DO LESTE & 0 & 0 \\
\hline CARATINGA & SANTA RITA DE MINAS & 0 & 0 \\
\hline CARATINGA & SAO DOMINGOS DAS DORES & 0 & 0 \\
\hline CARATINGA & SAO JOAO DO ORIENTE & 0 & 0 \\
\hline CARATINGA & SAO SEBASTIAO DO ANTA & 0 & 0 \\
\hline CARATINGA & TAPARUBA & 1 & 0 \\
\hline CARATINGA & TARUMIRIM & 1 & 0 \\
\hline CARATINGA & UBAPORANGA & 0 & 0 \\
\hline CARATINGA & VARGEM ALEGRE & 0 & 0 \\
\hline CAXAMBU & AIURUOCA & 0 & 0 \\
\hline CAXAMBU & ALAGOA & 1 & 0 \\
\hline
\end{tabular}




\begin{tabular}{|c|c|c|c|}
\hline CAXAMBU & BAEPENDI & 1 & 0 \\
\hline CAXAMBU & BOCAINA DE MINAS & 0 & 0 \\
\hline CAXAMBU & CARVALHOS & 0 & 0 \\
\hline CAXAMBU & CAXAMBU & 1 & 0 \\
\hline CAXAMBU & CONCEICAO DO RIO VERDE & 0 & 0 \\
\hline CAXAMBU & CRUZILIA & 1 & 0 \\
\hline CAXAMBU & ITAMONTE & 0 & 0 \\
\hline CAXAMBU & ITANHANDU & 5 & 2 \\
\hline CAXAMBU & JESUANIA & 1 & 0 \\
\hline CAXAMBU & LIBERDADE & 0 & 0 \\
\hline CAXAMBU & MINDURI & 0 & 0 \\
\hline CAXAMBU & OLIMPIO NORONHA & 0 & 0 \\
\hline CAXAMBU & PASSA QUATRO & 1 & 0 \\
\hline CAXAMBU & PASSA VINTE & 0 & 0 \\
\hline CAXAMBU & POUSO ALTO & 0 & 0 \\
\hline CAXAMBU & SAO LOURENCO & 0 & 0 \\
\hline CAXAMBU & SAO SEBASTIAO DO RIO VERDE & 1 & 0 \\
\hline CAXAMBU & SAO TOME DAS LETRAS & 0 & 0 \\
\hline CAXAMBU & SERITINGA & 0 & 0 \\
\hline CAXAMBU & SERRANOS & 0 & 0 \\
\hline CAXAMBU & SOLEDADE DE MINAS & 0 & 0 \\
\hline CORONEL FABRICIANO & ANTONIO DIAS & 0 & 0 \\
\hline CORONEL FABRICIANO & BELO ORIENTE & 0 & 0 \\
\hline CORONEL FABRICIANO & BRAUNAS & 2 & 0 \\
\hline CORONEL FABRICIANO & CORONEL FABRICIANO & 1 & 0 \\
\hline CORONEL FABRICIANO & IPATINGA & 5 & 2 \\
\hline CORONEL FABRICIANO & JAGUARAÇU & 0 & 0 \\
\hline CORONEL FABRICIANO & JOANESIA & 0 & 0 \\
\hline CORONEL FABRICIANO & MARLIERIA & 0 & 0 \\
\hline CORONEL FABRICIANO & MESQUITA & 1 & 0 \\
\hline CORONEL FABRICIANO & SANTANA DO PARAISO & 1 & 0 \\
\hline CORONEL FABRICIANO & TIMOTEO & 2 & 0 \\
\hline CONSELHEIRO LAFAIETE & CARANAIBA & 0 & 0 \\
\hline CONSELHEIRO LAFAIETE & CASA GRANDE & 0 & 0 \\
\hline CONSELHEIRO LAFAIETE & CATAS ALTAS DA NORUEGA & 1 & 0 \\
\hline CONSELHEIRO LAFAIETE & CONGONHAS & 0 & 0 \\
\hline CONSELHEIRO LAFAIETE & CONSELHEIRO LAFAIETE & 1 & 0 \\
\hline CONSELHEIRO LAFAIETE & CRISTIANO OTONI & 0 & 0 \\
\hline CONSELHEIRO LAFAIETE & DESTERRO DE ENTRE RIOS & 0 & 0 \\
\hline CONSELHEIRO LAFAIETE & ENTRE RIOS DE MINAS & 0 & 0 \\
\hline CONSELHEIRO LAFAIETE & ITAVERAVA & 0 & 0 \\
\hline CONSELHEIRO LAFAIETE & JECEABA & 1 & 0 \\
\hline CONSELHEIRO LAFAIETE & LAMIM & 0 & 0 \\
\hline CONSELHEIRO LAFAIETE & OURO BRANCO & 0 & 0 \\
\hline CONSELHEIRO LAFAIETE & PIRANGA & 4 & 0 \\
\hline
\end{tabular}




\begin{tabular}{|c|c|c|c|}
\hline CONSELHEIRO LAFAIETE & QUELUZITO & 0 & 0 \\
\hline CONSELHEIRO LAFAIETE & RIO ESPERA & 0 & 0 \\
\hline CONSELHEIRO LAFAIETE & SANTANA DOS MONTES & 0 & 0 \\
\hline CONSELHEIRO LAFAIETE & SAO BRAS DO SUACUI & 0 & 0 \\
\hline CONSELHEIRO LAFAIETE & SENHORA DE OLIVEIRA & 0 & 0 \\
\hline CURVELO & AUGUSTO DE LIMA & 0 & 0 \\
\hline CURVELO & BUENOPOLIS & 0 & 0 \\
\hline CURVELO & CORINTO & 1 & 0 \\
\hline CURVELO & CURVELO & 0 & 0 \\
\hline CURVELO & FELIXLANDIA & 0 & 0 \\
\hline CURVELO & INIMUTABA & 0 & 0 \\
\hline CURVELO & JOAQUIM FELICIO & 0 & 0 \\
\hline CURVELO & LASSANCE & 0 & 0 \\
\hline CURVELO & MORRO DA GARCA & 0 & 0 \\
\hline CURVELO & PRESIDENTE JUSCELINO & 0 & 0 \\
\hline CURVELO & SANTO HIPOLITO & 0 & 0 \\
\hline CURVELO & TRES MARIAS & 0 & 0 \\
\hline DIAMANTINA & ALVORADA DE MINAS & 1 & 0 \\
\hline DIAMANTINA & ANGELANDIA & 0 & 0 \\
\hline DIAMANTINA & ARICANDUVA & 2 & 0 \\
\hline DIAMANTINA & CAPELINHA & 3 & 0 \\
\hline DIAMANTINA & CARBONITA & 0 & 0 \\
\hline DIAMANTINA & CONCEICAO DO MATO DENTRO & 2 & 0 \\
\hline DIAMANTINA & CONGONHAS DO NORTE & 0 & 0 \\
\hline DIAMANTINA & COUTO DE MAGALHAES DE MINAS & 0 & 0 \\
\hline DIAMANTINA & DATAS & 0 & 0 \\
\hline DIAMANTINA & DIAMANTINA & 1 & 0 \\
\hline DIAMANTINA & FELICIO DOS SANTOS & 0 & 0 \\
\hline DIAMANTINA & GOUVEA & 2 & 0 \\
\hline DIAMANTINA & ITAMARANDIBA & 1 & 0 \\
\hline DIAMANTINA & LEME DO PRADO & 0 & 0 \\
\hline DIAMANTINA & MINAS NOVAS & 1 & 0 \\
\hline DIAMANTINA & MONJOLOS & 1 & 0 \\
\hline DIAMANTINA & PRESIDENTE KUBITSCHEK & 0 & 0 \\
\hline DIAMANTINA & RIO VERMELHO & 3 & 0 \\
\hline DIAMANTINA & SANTO ANTONIO DO ITAMBE & 0 & 0 \\
\hline DIAMANTINA & SAO GONCALO DO RIO PRETO & 0 & 0 \\
\hline DIAMANTINA & SENADOR MODESTINO GONCALVES & 0 & 0 \\
\hline DIAMANTINA & SERRA AZUL DE MINAS & 0 & 0 \\
\hline DIAMANTINA & SERRO & 4 & 0 \\
\hline DIAMANTINA & TURMALINA & 0 & 0 \\
\hline DIAMANTINA & VEREDINHA & 0 & 0 \\
\hline DIVINÓPOLIS & ARAUJOS & 2 & 0 \\
\hline DIVINÓPOLIS & ARCOS & 0 & 0 \\
\hline DIVINÓPOLIS & BAMBUI & 1 & 0 \\
\hline
\end{tabular}




\begin{tabular}{|c|c|c|c|}
\hline DIVINÓPOLIS & CARMO DA MATA & 0 & 0 \\
\hline DIVINÓPOLIS & CARMO DO CAJURU & 3 & 0 \\
\hline DIVINÓPOLIS & CARMOPOLIS DE MINAS & 0 & 0 \\
\hline DIVINÓPOLIS & CLAUDIO & 2 & 0 \\
\hline DIVINÓPOLIS & CORREGO DANTA & 0 & 0 \\
\hline DIVINÓPOLIS & DIVINOPOLIS & 9 & 2 \\
\hline DIVINÓPOLIS & IGUATAMA & 2 & 0 \\
\hline DIVINÓPOLIS & ITAGUARA & 0 & 0 \\
\hline DIVINÓPOLIS & ITAPECERICA & 0 & 0 \\
\hline DIVINÓPOLIS & ITATIAIUCU & 0 & 0 \\
\hline DIVINÓPOLIS & ITAUNA & 1 & 0 \\
\hline DIVINÓPOLIS & JAPARAIBA & 0 & 0 \\
\hline DIVINÓPOLIS & LAGOA DA PRATA & 1 & 0 \\
\hline DIVINÓPOLIS & LUZ & 0 & 0 \\
\hline DIVINÓPOLIS & MEDEIROS & 0 & 0 \\
\hline DIVINÓPOLIS & MOEMA & 0 & 0 \\
\hline DIVINÓPOLIS & NOVA SERRANA & 6 & 2 \\
\hline DIVINÓPOLIS & OLIVEIRA & 1 & 0 \\
\hline DIVINÓPOLIS & PAINS & 0 & 0 \\
\hline DIVINÓPOLIS & PASSA TEMPO & 0 & 0 \\
\hline DIVINÓPOLIS & PEDRA DO INDAIA & 1 & 0 \\
\hline DIVINÓPOLIS & PERDIGAO & 2 & 0 \\
\hline DIVINÓPOLIS & PIRACEMA & 0 & 0 \\
\hline DIVINÓPOLIS & SANTO ANTONIO DO MONTE & 0 & 0 \\
\hline DIVINÓPOLIS & SAO GONCALO DO PARA & 1 & 0 \\
\hline DIVINÓPOLIS & SAO SEBASTIAO DO OESTE & 0 & 0 \\
\hline DIVINÓPOLIS & TAPIRAI & 0 & 0 \\
\hline GOVERNADOR VALADARES & ACUCENA & 0 & 0 \\
\hline GOVERNADOR VALADARES & AIMORES & 1 & 0 \\
\hline GOVERNADOR VALADARES & ALPERCATA & 0 & 0 \\
\hline GOVERNADOR VALADARES & CAPITAO ANDRADE & 0 & 0 \\
\hline GOVERNADOR VALADARES & CENTRAL DE MINAS & 0 & 0 \\
\hline GOVERNADOR VALADARES & CONSELHEIRO PENA & 1 & 0 \\
\hline GOVERNADOR VALADARES & COROACI & 0 & 0 \\
\hline GOVERNADOR VALADARES & CUPARAQUE & 0 & 0 \\
\hline GOVERNADOR VALADARES & DIVINO DAS LARANJEIRAS & 0 & 0 \\
\hline GOVERNADOR VALADARES & ENGENHEIRO CALDAS & 0 & 0 \\
\hline GOVERNADOR VALADARES & FERNANDES TOURINHO & 0 & 0 \\
\hline GOVERNADOR VALADARES & FREI INOCENCIO & 1 & 0 \\
\hline GOVERNADOR VALADARES & GALILEIA & 0 & 0 \\
\hline GOVERNADOR VALADARES & GOIABEIRA & 0 & 0 \\
\hline GOVERNADOR VALADARES & GOVERNADOR VALADARES & 8 & 2 \\
\hline GOVERNADOR VALADARES & ITABIRINHA & 1 & 0 \\
\hline GOVERNADOR VALADARES & ITANHOMI & 1 & 0 \\
\hline GOVERNADOR VALADARES & ITUETA & 0 & 0 \\
\hline
\end{tabular}




\begin{tabular}{|c|c|c|c|}
\hline GOVERNADOR VALADARES & MANTENA & 2 & 0 \\
\hline GOVERNADOR VALADARES & MARILAC & 1 & 0 \\
\hline GOVERNADOR VALADARES & MATHIAS LOBATO & 2 & 0 \\
\hline GOVERNADOR VALADARES & MENDES PIMENTEL & 0 & 0 \\
\hline GOVERNADOR VALADARES & NACIP RAYDAN & 0 & 0 \\
\hline GOVERNADOR VALADARES & NAQUE & 0 & 0 \\
\hline GOVERNADOR VALADARES & NOVA BELEM & 0 & 0 \\
\hline GOVERNADOR VALADARES & NOVA MODICA & 0 & 0 \\
\hline GOVERNADOR VALADARES & PERIQUITO & 0 & 0 \\
\hline GOVERNADOR VALADARES & RESPLENDOR & 0 & 0 \\
\hline GOVERNADOR VALADARES & SANTA EFIGENIA DE MINAS & 0 & 0 \\
\hline GOVERNADOR VALADARES & SANTA RITA DO ITUETO & 0 & 0 \\
\hline GOVERNADOR VALADARES & SAO FELIX DE MINAS & 0 & 0 \\
\hline GOVERNADOR VALADARES & SAO GERALDO DA PIEDADE & 0 & 0 \\
\hline GOVERNADOR VALADARES & SAO GERALDO DO BAIXIO & 0 & 0 \\
\hline GOVERNADOR VALADARES & SAO JOAO DO MANTENINHA & 1 & 0 \\
\hline GOVERNADOR VALADARES & SAO JOSE DA SAFIRA & 2 & 0 \\
\hline GOVERNADOR VALADARES & SAO JOSE DO DIVINO & 1 & 0 \\
\hline GOVERNADOR VALADARES & SARDOA & 0 & 0 \\
\hline GOVERNADOR VALADARES & SOBRALIA & 1 & 0 \\
\hline GOVERNADOR VALADARES & TUMIRITINGA & 0 & 0 \\
\hline GOVERNADOR VALADARES & VIRGOLANDIA & 0 & 0 \\
\hline GUANHÃES & AGUA BOA & 1 & 0 \\
\hline GUANHÃES & CANTAGALO & 0 & 0 \\
\hline GUANHÃES & CARMESIA & 1 & 0 \\
\hline GUANHÃES & COLUNA & 0 & 0 \\
\hline GUANHÃES & DIVINOLANDIA DE MINAS & 0 & 0 \\
\hline GUANHÃES & DOM JOAQUIM & 0 & 0 \\
\hline GUANHÃES & DORES DE GUANHAES & 0 & 0 \\
\hline GUANHÃES & FREI LAGONEGRO & 0 & 0 \\
\hline GUANHÃES & GONZAGA & 0 & 0 \\
\hline GUANHÃES & GUANHAES & 0 & 0 \\
\hline GUANHÃES & JOSE RAYDAN & 0 & 0 \\
\hline GUANHÃES & MATERLANDIA & 0 & 0 \\
\hline GUANHÃES & PAULISTAS & 0 & 0 \\
\hline GUANHÃES & PECANHA & 0 & 0 \\
\hline GUANHÃES & SABINOPOLIS & 4 & 0 \\
\hline GUANHÃES & SANTA MARIA DO SUACUI & 0 & 0 \\
\hline GUANHÃES & SAO JOAO EVANGELISTA & 0 & 0 \\
\hline GUANHÃES & SAO JOSE DO JACURI & 0 & 0 \\
\hline GUANHÃES & SAO PEDRO DO SUACUI & 0 & 0 \\
\hline GUANHÃES & SAO SEBASTIAO DO MARANHAO & 1 & 0 \\
\hline GUANHÃES & SENHORA DO PORTO & 1 & 0 \\
\hline GUANHÃES & VIRGINOPOLIS & 1 & 0 \\
\hline ITAJUBÁ & BRASOPOLIS & 0 & 0 \\
\hline
\end{tabular}




\begin{tabular}{|c|c|c|c|}
\hline ITAJUBÁ & CARMO DE MINAS & 1 & 0 \\
\hline ITAJUBÁ & CONCEICAO DAS PEDRAS & 0 & 0 \\
\hline ITAJUBÁ & CONCEICAO DOS OUROS & 0 & 0 \\
\hline ITAJUBÁ & CONSOLACAO & 0 & 0 \\
\hline ITAJUBÁ & CRISTINA & 1 & 0 \\
\hline ITAJUBÁ & DELFIM MOREIRA & 1 & 0 \\
\hline ITAJUBÁ & DOM VICOSO & 0 & 0 \\
\hline ITAJUBÁ & GONCALVES & 0 & 0 \\
\hline ITAJUBÁ & ITAJUBA & 2 & 0 \\
\hline ITAJUBÁ & MARIA DA FE & 0 & 0 \\
\hline ITAJUBÁ & MARMELOPOLIS & 0 & 0 \\
\hline ITAJUBÁ & NATERCIA & 0 & 0 \\
\hline ITAJUBÁ & PARAISOPOLIS & 0 & 0 \\
\hline ITAJUBÁ & PEDRALVA & 0 & 0 \\
\hline ITAJUBÁ & PIRANGUCU & 0 & 0 \\
\hline ITAJUBÁ & PIRANGUINHO & 0 & 0 \\
\hline ITAJUBÁ & SAO JOSE DO ALEGRE & 0 & 0 \\
\hline ITAJUBÁ & SAPUCAI-MIRIM & 0 & 0 \\
\hline ITAJUBÁ & VIRGINIA & 0 & 0 \\
\hline ITAJUBÁ & WENCESLAU BRAZ & 0 & 0 \\
\hline ITUIUTABA & CACHOEIRA DOURADA & 0 & 0 \\
\hline ITUIUTABA & CANAPOLIS & 0 & 0 \\
\hline ITUIUTABA & CAPINOPOLIS & 0 & 0 \\
\hline ITUIUTABA & CENTRALINA & 0 & 0 \\
\hline ITUIUTABA & GURINHATA & 0 & 0 \\
\hline ITUIUTABA & IPIACU & 1 & 0 \\
\hline ITUIUTABA & ITUIUTABA & 4 & 0 \\
\hline ITUIUTABA & SANTA VITORIA & 0 & 0 \\
\hline JANAUBA & CATUTI & 0 & 0 \\
\hline JANAUBA & ESPINOSA & 1 & 0 \\
\hline JANAUBA & GAMELEIRAS & 0 & 0 \\
\hline JANAUBA & JAIBA & 5 & 2 \\
\hline JANAUBA & JANAUBA & 4 & 0 \\
\hline JANAUBA & MAMONAS & 0 & 0 \\
\hline JANAUBA & MATO VERDE & 0 & 0 \\
\hline JANAUBA & MONTE AZUL & 0 & 0 \\
\hline JANAUBA & MONTEZUMA & 2 & 0 \\
\hline JANAUBA & NOVA PORTEIRINHA & 1 & 0 \\
\hline JANAUBA & PAI PEDRO & 1 & 0 \\
\hline JANAUBA & PORTEIRINHA & 1 & 0 \\
\hline JANAUBA & RIACHO DOS MACHADOS & 0 & 0 \\
\hline JANAUBA & RIO PARDO DE MINAS & 2 & 0 \\
\hline JANAUBA & SANTO ANTONIO DO RETIRO & 0 & 0 \\
\hline JANAUBA & SERRANOPOLIS DE MINAS & 1 & 0 \\
\hline JANAUBA & VERDELANDIA & 0 & 0 \\
\hline
\end{tabular}




\begin{tabular}{|c|c|c|c|}
\hline JANUARIA & BONITO DE MINAS & 7 & 2 \\
\hline JANUARIA & CHAPADA GAUCHA & 0 & 0 \\
\hline JANUARIA & CONEGO MARINHO & 2 & 0 \\
\hline JANUARIA & IBIRACATU & 1 & 0 \\
\hline JANUARIA & ICARAI DE MINAS & 2 & 0 \\
\hline JANUARIA & ITACARAMBI & 2 & 0 \\
\hline JANUARIA & JANUARIA & 4 & 0 \\
\hline JANUARIA & JUVENILIA & 1 & 0 \\
\hline JANUARIA & MANGA & 4 & 0 \\
\hline JANUARIA & MATIAS CARDOSO & 0 & 0 \\
\hline JANUARIA & MIRAVANIA & 1 & 0 \\
\hline JANUARIA & MONTALVANIA & 0 & 0 \\
\hline JANUARIA & PEDRAS DE MARIA DA CRUZ & 2 & 0 \\
\hline JANUARIA & PINTOPOLIS & 0 & 0 \\
\hline JANUARIA & SAO FRANCISCO & 4 & 0 \\
\hline JANUARIA & SAO JOAO DAS MISSOES & 0 & 0 \\
\hline JANUARIA & UBAI & 1 & 0 \\
\hline JANUARIA & URUCUIA & 0 & 0 \\
\hline JANUARIA & VARZELANDIA & 1 & 0 \\
\hline JUIZ DE FORA & ARANTINA & 0 & 0 \\
\hline JUIZ DE FORA & BELMIRO BRAGA & 0 & 0 \\
\hline JUIZ DE FORA & BICAS & 0 & 0 \\
\hline JUIZ DE FORA & BOM JARDIM DE MINAS & 0 & 0 \\
\hline JUIZ DE FORA & CHACARA & 0 & 0 \\
\hline JUIZ DE FORA & CHIADOR & 0 & 0 \\
\hline JUIZ DE FORA & CORONEL PACHECO & 0 & 0 \\
\hline JUIZ DE FORA & DESCOBERTO & 0 & 0 \\
\hline JUIZ DE FORA & EWBANK DA CAMARA & 0 & 0 \\
\hline JUIZ DE FORA & GOIANA & 0 & 0 \\
\hline JUIZ DE FORA & GUARARA & 1 & 0 \\
\hline JUIZ DE FORA & JUIZ DE FORA & 8 & 2 \\
\hline JUIZ DE FORA & LIMA DUARTE & 2 & 0 \\
\hline JUIZ DE FORA & MAR DE ESPANHA & 2 & 0 \\
\hline JUIZ DE FORA & MARIPA DE MINAS & 0 & 0 \\
\hline JUIZ DE FORA & MATIAS BARBOSA & 2 & 0 \\
\hline JUIZ DE FORA & OLARIA & 0 & 0 \\
\hline JUIZ DE FORA & PEDRO TEIXEIRA & 0 & 0 \\
\hline JUIZ DE FORA & PEQUERI & 0 & 0 \\
\hline JUIZ DE FORA & PIAU & 0 & 0 \\
\hline JUIZ DE FORA & RIO NOVO & 0 & 0 \\
\hline JUIZ DE FORA & RIO PRETO & 0 & 0 \\
\hline JUIZ DE FORA & ROCHEDO DE MINAS & 0 & 0 \\
\hline JUIZ DE FORA & SANTA BARBARA DO MONTE VERDE & 0 & 0 \\
\hline JUIZ DE FORA & SANTA RITA DE JACUTINGA & 0 & 0 \\
\hline JUIZ DE FORA & SANTANA DO DESERTO & 1 & 0 \\
\hline
\end{tabular}




\begin{tabular}{|c|c|c|c|}
\hline JUIZ DE FORA & SANTOS DUMONT & 0 & 0 \\
\hline JUIZ DE FORA & SAO JOAO NEPOMUCENO & 0 & 0 \\
\hline JUIZ DE FORA & SENADOR CORTES & 0 & 0 \\
\hline JUIZ DE FORA & SIMAO PEREIRA & 1 & 0 \\
\hline LEOPOLDINA & ALEM PARAIBA & 2 & 0 \\
\hline LEOPOLDINA & ARGIRITA & 0 & 0 \\
\hline LEOPOLDINA & CATAGUASES & 0 & 0 \\
\hline LEOPOLDINA & ESTRELA DALVA & 0 & 0 \\
\hline LEOPOLDINA & ITAMARATI DE MINAS & 0 & 0 \\
\hline LEOPOLDINA & LEOPOLDINA & 0 & 0 \\
\hline LEOPOLDINA & PIRAPETINGA & 0 & 0 \\
\hline LEOPOLDINA & RECREIO & 0 & 0 \\
\hline LEOPOLDINA & SANTO ANTONIO DO AVENTUREIRO & 0 & 0 \\
\hline LEOPOLDINA & VOLTA GRANDE & 0 & 0 \\
\hline MANHUAÇU & ALTO JEQUITIBA & 0 & 0 \\
\hline MANHUAÇU & CAPUTIRA & 0 & 0 \\
\hline MANHUAÇU & CHALE & 0 & 0 \\
\hline MANHUAÇU & CONCEICAO DE IPANEMA & 0 & 0 \\
\hline MANHUAÇU & DURANDE & 0 & 0 \\
\hline MANHUAÇU & LAJINHA & 1 & 0 \\
\hline MANHUAÇU & LUISBURGO & 0 & 0 \\
\hline MANHUAÇU & MANHUACU & 3 & 0 \\
\hline MANHUAÇU & MANHUMIRIM & 1 & 0 \\
\hline MANHUAÇU & MARTINS SOARES & 0 & 0 \\
\hline MANHUAÇU & MATIPO & 0 & 0 \\
\hline MANHUAÇU & MUTUM & 6 & 2 \\
\hline MANHUAÇU & REDUTO & 0 & 0 \\
\hline MANHUAÇU & SANTA MARGARIDA & 2 & 0 \\
\hline MANHUAÇU & SANTANA DO MANHUACU & 2 & 0 \\
\hline MANHUAÇU & SAO JOAO DO MANHUACU & 0 & 0 \\
\hline MANHUAÇU & SAO JOSE DO MANTIMENTO & 0 & 0 \\
\hline MANHUAÇU & SIMONESIA & 0 & 0 \\
\hline METROPOLITANA A & BARAO DE COCAIS & 1 & 0 \\
\hline METROPOLITANA A & BELO HORIZONTE & 24 & 6 \\
\hline METROPOLITANA A & BELO VALE & 0 & 0 \\
\hline METROPOLITANA A & BOM JESUS DO AMPARO & 1 & 0 \\
\hline METROPOLITANA A & BONFIM & 2 & 0 \\
\hline METROPOLITANA A & BRUMADINHO & 0 & 0 \\
\hline METROPOLITANA A & CAETE & 3 & 0 \\
\hline METROPOLITANA A & CATAS ALTAS & 0 & 0 \\
\hline METROPOLITANA A & CRUCILANDIA & 0 & 0 \\
\hline METROPOLITANA A & MOEDA & 0 & 0 \\
\hline METROPOLITANA A & NOVA LIMA & 1 & 0 \\
\hline METROPOLITANA A & NOVA UNIAO & 0 & 0 \\
\hline METROPOLITANA A & PIEDADE DOS GERAIS & 0 & 0 \\
\hline
\end{tabular}




\begin{tabular}{|c|c|c|c|}
\hline METROPOLITANA A & RAPOSOS & 2 & 0 \\
\hline METROPOLITANA A & RIO ACIMA & 0 & 0 \\
\hline METROPOLITANA A & RIO MANSO & 0 & 0 \\
\hline METROPOLITANA A & SABARA & 2 & 0 \\
\hline METROPOLITANA A & SANTA BARBARA & 3 & 0 \\
\hline METROPOLITANA B & BELO HORIZONTE & 33 & 9 \\
\hline METROPOLITANA B & BETIM & 11 & 3 \\
\hline METROPOLITANA B & CONTAGEM & 21 & 5 \\
\hline METROPOLITANA B & ESMERALDAS & 2 & 0 \\
\hline METROPOLITANA B & IBIRITE & 9 & 2 \\
\hline METROPOLITANA B & IGARAPE & 3 & 0 \\
\hline METROPOLITANA B & JUATUBA & 2 & 0 \\
\hline METROPOLITANA B & MARIO CAMPOS & 1 & 0 \\
\hline METROPOLITANA B & MATEUS LEME & 1 & 0 \\
\hline METROPOLITANA B & SAO JOAQUIM DE BICAS & 0 & 0 \\
\hline METROPOLITANA B & SARZEDO & 1 & 0 \\
\hline METROPOLITANA C & BELO HORIZONTE & 13 & 3 \\
\hline METROPOLITANA C & CONFINS & 0 & 0 \\
\hline METROPOLITANA C & JABOTICATUBAS & 1 & 0 \\
\hline METROPOLITANA C & LAGOA SANTA & 2 & 0 \\
\hline METROPOLITANA C & MORRO DO PILAR & 0 & 0 \\
\hline METROPOLITANA C & PEDRO LEOPOLDO & 2 & 0 \\
\hline METROPOLITANA C & RIBEIRAO DAS NEVES & 26 & 7 \\
\hline METROPOLITANA C & SANTA LUZIA & 4 & 0 \\
\hline METROPOLITANA C & SANTANA DO RIACHO & 0 & 0 \\
\hline METROPOLITANA C & SAO JOSE DA LAPA & 1 & 0 \\
\hline METROPOLITANA C & TAQUARACU DE MINAS & 1 & 0 \\
\hline METROPOLITANA C & VESPASIANO & 4 & 0 \\
\hline MONTE CARMELO & ABADIA DOS DOURADOS & 0 & 0 \\
\hline MONTE CARMELO & CASCALHO RICO & 1 & 0 \\
\hline MONTE CARMELO & COROMANDEL & 2 & 0 \\
\hline MONTE CARMELO & DOURADOQUARA & 0 & 0 \\
\hline MONTE CARMELO & ESTRELA DO SUL & 0 & 0 \\
\hline MONTE CARMELO & GRUPIARA & 0 & 0 \\
\hline MONTE CARMELO & MONTE CARMELO & 0 & 0 \\
\hline MONTE CARMELO & ROMARIA & 0 & 0 \\
\hline MONTES CLAROS & BOCAIUVA & 0 & 0 \\
\hline MONTES CLAROS & BOTUMIRIM & 0 & 0 \\
\hline MONTES CLAROS & BRASILIA DE MINAS & 3 & 0 \\
\hline MONTES CLAROS & CAMPO AZUL & 0 & 0 \\
\hline MONTES CLAROS & CAPITAO ENEAS & 3 & 0 \\
\hline MONTES CLAROS & CLARO DOS POCOES & 0 & 0 \\
\hline MONTES CLAROS & CORACAO DE JESUS & 3 & 0 \\
\hline MONTES CLAROS & CRISTALIA & 2 & 0 \\
\hline MONTES CLAROS & ENGENHEIRO NAVARRO & 0 & 0 \\
\hline
\end{tabular}




\begin{tabular}{|c|c|c|c|}
\hline MONTES CLAROS & FRANCISCO DUMONT & 0 & 0 \\
\hline MONTES CLAROS & FRANCISCO SA & 3 & 0 \\
\hline MONTES CLAROS & GLAUCILANDIA & 0 & 0 \\
\hline MONTES CLAROS & GRAO MOGOL & 5 & 2 \\
\hline MONTES CLAROS & GUARACIAMA & 0 & 0 \\
\hline MONTES CLAROS & ITACAMBIRA & 2 & 0 \\
\hline MONTES CLAROS & JAPONVAR & 0 & 0 \\
\hline MONTES CLAROS & JOSENOPOLIS & 0 & 0 \\
\hline MONTES CLAROS & JURAMENTO & 1 & 0 \\
\hline MONTES CLAROS & LONTRA & 0 & 0 \\
\hline MONTES CLAROS & LUISLANDIA & 0 & 0 \\
\hline MONTES CLAROS & MIRABELA & 2 & 0 \\
\hline MONTES CLAROS & MONTES CLAROS & 7 & 2 \\
\hline MONTES CLAROS & OLHOS-D AGUA & 2 & 0 \\
\hline MONTES CLAROS & PADRE CARVALHO & 0 & 0 \\
\hline MONTES CLAROS & PATIS & 0 & 0 \\
\hline MONTES CLAROS & SAO JOAO DA LAGOA & 1 & 0 \\
\hline MONTES CLAROS & SAO JOAO DA PONTE & 4 & 0 \\
\hline MONTES CLAROS & SAO JOAO DO PACUI & 0 & 0 \\
\hline MONTES CLAROS & SAO JOAO DO PARAISO & 0 & 0 \\
\hline MONTES CLAROS & VARGEM GRANDE DO RIO PARDO & 0 & 0 \\
\hline MURIAÉ & ANTONIO PRADO DE MINAS & 0 & 0 \\
\hline MURIAÉ & BARAO DE MONTE ALTO & 0 & 0 \\
\hline MURIAÉ & EUGENOPOLIS & 1 & 0 \\
\hline MURIAÉ & LARANJAL & 0 & 0 \\
\hline MURIAÉ & MIRADOURO & 0 & 0 \\
\hline MURIAÉ & MIRAI & 0 & 0 \\
\hline MURIAÉ & MURIAE & 1 & 0 \\
\hline MURIAÉ & PALMA & 0 & 0 \\
\hline MURIAÉ & PATROCINIO DO MURIAE & 0 & 0 \\
\hline MURIAÉ & ROSARIO DA LIMEIRA & 0 & 0 \\
\hline MURIAÉ & SANTANA DE CATAGUASES & 0 & 0 \\
\hline MURIAÉ & SAO FRANCISCO DO GLORIA & 0 & 0 \\
\hline MURIAÉ & SAO SEBASTIAO DA VARGEM ALEGRE & 0 & 0 \\
\hline MURIAÉ & VIEIRAS & 0 & 0 \\
\hline NOVA ERA & BELA VISTA DE MINAS & 1 & 0 \\
\hline NOVA ERA & DIONISIO & 0 & 0 \\
\hline NOVA ERA & FERROS & 0 & 0 \\
\hline NOVA ERA & ITABIRA & 2 & 0 \\
\hline NOVA ERA & ITAMBE DO MATO DENTRO & 0 & 0 \\
\hline NOVA ERA & JOAO MONLEVADE & 2 & 0 \\
\hline NOVA ERA & NOVA ERA & 1 & 0 \\
\hline NOVA ERA & PASSABEM & 1 & 0 \\
\hline NOVA ERA & RIO PIRACICABA & 1 & 0 \\
\hline NOVA ERA & SANTA MARIA DE ITABIRA & 1 & 0 \\
\hline
\end{tabular}




\begin{tabular}{|c|c|c|c|}
\hline NOVA ERA & SANTO ANTONIO DO RIO ABAIXO & 0 & 0 \\
\hline NOVA ERA & SAO DOMINGOS DO PRATA & 1 & 0 \\
\hline NOVA ERA & SAO GONCALO DO RIO ABAIXO & 0 & 0 \\
\hline NOVA ERA & SAO JOSE DO GOIABAL & 1 & 0 \\
\hline NOVA ERA & SAO SEBASTIAO DO RIO PRETO & 0 & 0 \\
\hline OURO PRETO & ACAIACA & 1 & 0 \\
\hline OURO PRETO & DIOGO DE VASCONCELOS & 2 & 0 \\
\hline OURO PRETO & ITABIRITO & 2 & 0 \\
\hline OURO PRETO & MARIANA & 4 & 0 \\
\hline OURO PRETO & OURO PRETO & 8 & 2 \\
\hline PARA DE MINAS & ABAETE & 1 & 0 \\
\hline PARA DE MINAS & BIQUINHAS & 0 & 0 \\
\hline PARA DE MINAS & BOM DESPACHO & 0 & 0 \\
\hline PARA DE MINAS & CEDRO DO ABAETE & 0 & 0 \\
\hline PARA DE MINAS & CONCEICAO DO PARA & 0 & 0 \\
\hline PARA DE MINAS & DORES DO INDAIA & 0 & 0 \\
\hline PARA DE MINAS & ESTRELA DO INDAIA & 0 & 0 \\
\hline PARA DE MINAS & FLORESTAL & 0 & 0 \\
\hline PARA DE MINAS & IGARATINGA & 1 & 0 \\
\hline PARA DE MINAS & LEANDRO FERREIRA & 1 & 0 \\
\hline PARA DE MINAS & MARTINHO CAMPOS & 1 & 0 \\
\hline PARA DE MINAS & MORADA NOVA DE MINAS & 0 & 0 \\
\hline PARA DE MINAS & ONCA DE PITANGUI & 0 & 0 \\
\hline PARA DE MINAS & PAINEIRAS & 1 & 0 \\
\hline PARA DE MINAS & PARA DE MINAS & 8 & 2 \\
\hline PARA DE MINAS & PEQUI & 0 & 0 \\
\hline PARA DE MINAS & PITANGUI & 0 & 0 \\
\hline PARA DE MINAS & QUARTEL GERAL & 0 & 0 \\
\hline PARA DE MINAS & SAO JOSE DA VARGINHA & 0 & 0 \\
\hline PARA DE MINAS & SERRA DA SAUDADE & 0 & 0 \\
\hline PARACATU & BRASILANDIA DE MINAS & 0 & 0 \\
\hline PARACATU & GUARDA-MOR & 0 & 0 \\
\hline PARACATU & JOAO PINHEIRO & 0 & 0 \\
\hline PARACATU & PARACATU & 2 & 0 \\
\hline PARACATU & VAZANTE & 1 & 0 \\
\hline PASSOS & ALPINOPOLIS & 1 & 0 \\
\hline PASSOS & BOM JESUS DA PENHA & 0 & 0 \\
\hline PASSOS & CAPITOLIO & 1 & 0 \\
\hline PASSOS & CARMO DO RIO CLARO & 1 & 0 \\
\hline PASSOS & CORREGO FUNDO & 0 & 0 \\
\hline PASSOS & DELFINOPOLIS & 1 & 0 \\
\hline PASSOS & DORESOPOLIS & 0 & 0 \\
\hline PASSOS & FORMIGA & 2 & 0 \\
\hline PASSOS & FORTALEZA DE MINAS & 0 & 0 \\
\hline PASSOS & PASSOS & 2 & 0 \\
\hline
\end{tabular}




\begin{tabular}{|c|c|c|c|}
\hline PASSOS & PIMENTA & 0 & 0 \\
\hline PASSOS & PIUMHI & 2 & 0 \\
\hline PASSOS & SAO JOAO BATISTA DO GLORIA & 1 & 0 \\
\hline PASSOS & SAO JOSE DA BARRA & 0 & 0 \\
\hline PASSOS & SAO ROQUE DE MINAS & 1 & 0 \\
\hline PASSOS & VARGEM BONITA & 1 & 0 \\
\hline PATOS DE MINAS & ARAPUA & 0 & 0 \\
\hline PATOS DE MINAS & CARMO DO PARANAIBA & 1 & 0 \\
\hline PATOS DE MINAS & LAGAMAR & 0 & 0 \\
\hline PATOS DE MINAS & LAGOA FORMOSA & 0 & 0 \\
\hline PATOS DE MINAS & LAGOA GRANDE & 0 & 0 \\
\hline PATOS DE MINAS & MATUTINA & 0 & 0 \\
\hline PATOS DE MINAS & PATOS DE MINAS & 1 & 0 \\
\hline PATOS DE MINAS & PRESIDENTE OLEGARIO & 0 & 0 \\
\hline PATOS DE MINAS & RIO PARANAIBA & 0 & 0 \\
\hline PATOS DE MINAS & SANTA ROSA DA SERRA & 0 & 0 \\
\hline PATOS DE MINAS & SAO GONCALO DO ABAETE & 0 & 0 \\
\hline PATOS DE MINAS & SAO GOTARDO & 4 & 0 \\
\hline PATOS DE MINAS & TIROS & 0 & 0 \\
\hline PATOS DE MINAS & VARJAO DE MINAS & 0 & 0 \\
\hline PATROCÍNIO & CRUZEIRO DA FORTALEZA & 0 & 0 \\
\hline PATROCÍNIO & GUIMARANIA & 0 & 0 \\
\hline PATROCÍNIO & IBIA & 0 & 0 \\
\hline PATROCÍNIO & IRAI DE MINAS & 1 & 0 \\
\hline PATROCÍNIO & PATROCINIO & 1 & 0 \\
\hline PATROCÍNIO & PERDIZES & 1 & 0 \\
\hline PATROCÍNIO & SERRA DO SALITRE & 0 & 0 \\
\hline PIRAPORA & BURITIZEIRO & 4 & 0 \\
\hline PIRAPORA & IBIAI & 1 & 0 \\
\hline PIRAPORA & JEQUITAI & 2 & 0 \\
\hline PIRAPORA & LAGOA DOS PATOS & 1 & 0 \\
\hline PIRAPORA & PIRAPORA & 0 & 0 \\
\hline PIRAPORA & PONTO CHIQUE & 0 & 0 \\
\hline PIRAPORA & SANTA FE DE MINAS & 0 & 0 \\
\hline PIRAPORA & SAO ROMAO & 1 & 0 \\
\hline PIRAPORA & VARZEA DA PALMA & 0 & 0 \\
\hline POÇOS DE CALDAS & ALTEROSA & 0 & 0 \\
\hline POÇOS DE CALDAS & ANDRADAS & 1 & 0 \\
\hline POÇOS DE CALDAS & AREADO & 1 & 0 \\
\hline POÇOS DE CALDAS & BANDEIRA DO SUL & 0 & 0 \\
\hline POÇOS DE CALDAS & BOTELHOS & 1 & 0 \\
\hline POÇOS DE CALDAS & CABO VERDE & 0 & 0 \\
\hline POÇOS DE CALDAS & CALDAS & 2 & 0 \\
\hline POÇOS DE CALDAS & CAMPESTRE & 0 & 0 \\
\hline POÇOS DE CALDAS & CONCEICAO DA APARECIDA & 1 & 0 \\
\hline
\end{tabular}




\begin{tabular}{|c|c|c|c|}
\hline POÇOS DE CALDAS & DIVISA NOVA & 1 & 0 \\
\hline POÇOS DE CALDAS & IBITIURA DE MINAS & 0 & 0 \\
\hline POÇOS DE CALDAS & MONTE BELO & 0 & 0 \\
\hline POÇOS DE CALDAS & MUZAMBINHO & 1 & 0 \\
\hline POÇOS DE CALDAS & NOVA RESENDE & 1 & 0 \\
\hline POÇOS DE CALDAS & POCOS DE CALDAS & 0 & 0 \\
\hline POÇOS DE CALDAS & SANTA RITA DE CALDAS & 1 & 0 \\
\hline POÇOS DE CALDAS & SERRANIA & 0 & 0 \\
\hline PONTE NOVA & ABRE CAMPO & 1 & 0 \\
\hline PONTE NOVA & ALVINOPOLIS & 1 & 0 \\
\hline PONTE NOVA & AMPARO DO SERRA & 0 & 0 \\
\hline PONTE NOVA & ARAPONGA & 2 & 0 \\
\hline PONTE NOVA & BARRA LONGA & 0 & 0 \\
\hline PONTE NOVA & CAJURI & 0 & 0 \\
\hline PONTE NOVA & CANAA & 0 & 0 \\
\hline PONTE NOVA & DOM SILVERIO & 0 & 0 \\
\hline PONTE NOVA & GUARACIABA & 0 & 0 \\
\hline PONTE NOVA & JEQUERI & 0 & 0 \\
\hline PONTE NOVA & ORATORIOS & 0 & 0 \\
\hline PONTE NOVA & PEDRA BONITA & 1 & 0 \\
\hline PONTE NOVA & PEDRA DO ANTA & 0 & 0 \\
\hline PONTE NOVA & PIEDADE DE PONTE NOVA & 1 & 0 \\
\hline PONTE NOVA & PONTE NOVA & 1 & 0 \\
\hline PONTE NOVA & PORTO FIRME & 1 & 0 \\
\hline PONTE NOVA & RAUL SOARES & 0 & 0 \\
\hline PONTE NOVA & RIO CASCA & 1 & 0 \\
\hline PONTE NOVA & RIO DOCE & 1 & 0 \\
\hline PONTE NOVA & SANTA CRUZ DO ESCALVADO & 0 & 0 \\
\hline PONTE NOVA & SANTO ANTONIO DO GRAMA & 0 & 0 \\
\hline PONTE NOVA & SAO MIGUEL DO ANTA & 0 & 0 \\
\hline PONTE NOVA & SAO PEDRO DOS FERROS & 0 & 0 \\
\hline PONTE NOVA & SEM-PEIXE & 1 & 0 \\
\hline PONTE NOVA & SERICITA & 0 & 0 \\
\hline PONTE NOVA & TEIXEIRAS & 1 & 0 \\
\hline PONTE NOVA & URUCANIA & 0 & 0 \\
\hline PONTE NOVA & VERMELHO NOVO & 0 & 0 \\
\hline PONTE NOVA & VICOSA & 3 & 0 \\
\hline POUSO ALEGRE & ALBERTINA & 0 & 0 \\
\hline POUSO ALEGRE & BOM REPOUSO & 1 & 0 \\
\hline POUSO ALEGRE & BORDA DA MATA & 1 & 0 \\
\hline POUSO ALEGRE & BUENO BRANDAO & 1 & 0 \\
\hline POUSO ALEGRE & CACHOEIRA DE MINAS & 0 & 0 \\
\hline POUSO ALEGRE & CAMANDUCAIA & 4 & 0 \\
\hline POUSO ALEGRE & CAMBUI & 2 & 0 \\
\hline POUSO ALEGRE & CAREACU & 0 & 0 \\
\hline
\end{tabular}




\begin{tabular}{|c|c|c|c|}
\hline POUSO ALEGRE & CONGONHAL & 0 & 0 \\
\hline POUSO ALEGRE & CORREGO DO BOM JESUS & 0 & 0 \\
\hline POUSO ALEGRE & ESPIRITO SANTO DO DOURADO & 0 & 0 \\
\hline POUSO ALEGRE & ESTIVA & 0 & 0 \\
\hline POUSO ALEGRE & EXTREMA & 2 & 0 \\
\hline POUSO ALEGRE & HELIODORA & 0 & 0 \\
\hline POUSO ALEGRE & INCONFIDENTES & 0 & 0 \\
\hline POUSO ALEGRE & IPUIUNA & 0 & 0 \\
\hline POUSO ALEGRE & ITAPEVA & 1 & 0 \\
\hline POUSO ALEGRE & JACUTINGA & 1 & 0 \\
\hline POUSO ALEGRE & MONTE SIAO & 1 & 0 \\
\hline POUSO ALEGRE & MUNHOZ & 0 & 0 \\
\hline POUSO ALEGRE & OURO FINO & 2 & 0 \\
\hline POUSO ALEGRE & POUSO ALEGRE & 4 & 0 \\
\hline POUSO ALEGRE & SANTA RITA DO SAPUCAI & 3 & 0 \\
\hline POUSO ALEGRE & SAO JOAO DA MATA & 0 & 0 \\
\hline POUSO ALEGRE & SAO SEBASTIAO DA BELA VISTA & 0 & 0 \\
\hline POUSO ALEGRE & SENADOR AMARAL & 0 & 0 \\
\hline POUSO ALEGRE & SENADOR JOSE BENTO & 0 & 0 \\
\hline POUSO ALEGRE & SILVIANOPOLIS & 1 & 0 \\
\hline POUSO ALEGRE & TOCOS DO MOJI & 0 & 0 \\
\hline POUSO ALEGRE & TOLEDO & 0 & 0 \\
\hline SÃO JOÃO DEL REI & BOM SUCESSO & 0 & 0 \\
\hline SÃO JOÃO DEL REI & CARRANCAS & 0 & 0 \\
\hline SÃO JOÃO DEL REI & CONCEICAO DA BARRA DE MINAS & 0 & 0 \\
\hline SÃO JOÃO DEL REI & CORONEL XAVIER CHAVES & 0 & 0 \\
\hline SÃO JOÃO DEL REI & DORES DE CAMPOS & 0 & 0 \\
\hline SÃO JOÃO DEL REI & IBITURUNA & 0 & 0 \\
\hline SÃO JOÃO DEL REI & IJACI & 0 & 0 \\
\hline SÃO JOÃO DEL REI & INGAI & 0 & 0 \\
\hline SÃO JOÃO DEL REI & ITUMIRIM & 0 & 0 \\
\hline SÃO JOÃO DEL REI & ITUTINGA & 0 & 0 \\
\hline SÃO JOÃO DEL REI & LAGOA DOURADA & 0 & 0 \\
\hline SÃO JOÃO DEL REI & NAZARENO & 1 & 0 \\
\hline SÃO JOÃO DEL REI & PRADOS & 1 & 0 \\
\hline SÃO JOÃO DEL REI & RESENDE COSTA & 0 & 0 \\
\hline SÃO JOÃO DEL REI & RITAPOLIS & 0 & 0 \\
\hline SÃO JOÃO DEL REI & SANTA CRUZ DE MINAS & 0 & 0 \\
\hline SÃO JOÃO DEL REI & SAO JOAO DEL REI & 4 & 0 \\
\hline SÃO JOÃO DEL REI & SAO TIAGO & 0 & 0 \\
\hline SÃO JOÃO DEL REI & TIRADENTES & 0 & 0 \\
\hline SÃO SEBASTIÃO DO PARAÍSO & ARCEBURGO & 0 & 0 \\
\hline SÃO SEBASTIÃO DO PARAÍSO & CAPETINGA & 0 & 0 \\
\hline SÃO SEBASTIÃO DO PARAÍSO & CASSIA & 0 & 0 \\
\hline SÃO SEBASTIÃO DO PARAÍSO & CLARAVAL & 0 & 0 \\
\hline
\end{tabular}




\begin{tabular}{|c|c|c|c|}
\hline SÃO SEBASTIÃO DO PARAÍSO & GUARANESIA & 0 & 0 \\
\hline SÃO SEBASTIÃO DO PARAÍSO & GUAXUPE & 0 & 0 \\
\hline SÃO SEBASTIÃO DO PARAÍSO & IBIRACI & 0 & 0 \\
\hline SÃO SEBASTIÃO DO PARAÍSO & ITAMOGI & 0 & 0 \\
\hline SÃO SEBASTIÃO DO PARAÍSO & ITAU DE MINAS & 0 & 0 \\
\hline SÃO SEBASTIÃO DO PARAÍSO & JACUI & 0 & 0 \\
\hline SÃO SEBASTIÃO DO PARAÍSO & JURUAIA & 0 & 0 \\
\hline SÃO SEBASTIÃO DO PARAÍSO & MONTE SANTO DE MINAS & 0 & 0 \\
\hline SÃO SEBASTIÃO DO PARAÍSO & PRATAPOLIS & 0 & 0 \\
\hline SÃO SEBASTIÃO DO PARAÍSO & SAO PEDRO DA UNIAO & 0 & 0 \\
\hline SÃO SEBASTIÃO DO PARAÍSO & SAO SEBASTIAO DO PARAISO & 0 & 0 \\
\hline SÃO SEBASTIÃO DO PARAÍSO & SAO TOMAS DE AQUINO & 1 & 0 \\
\hline SETE LAGOAS & ARACAI & 0 & 0 \\
\hline SETE LAGOAS & BALDIM & 0 & 0 \\
\hline SETE LAGOAS & CACHOEIRA DA PRATA & 0 & 0 \\
\hline SETE LAGOAS & CAETANOPOLIS & 0 & 0 \\
\hline SETE LAGOAS & CAPIM BRANCO & 0 & 0 \\
\hline SETE LAGOAS & CORDISBURGO & 1 & 0 \\
\hline SETE LAGOAS & FORTUNA DE MINAS & 0 & 0 \\
\hline SETE LAGOAS & FUNILANDIA & 0 & 0 \\
\hline SETE LAGOAS & INHAUMA & 1 & 0 \\
\hline SETE LAGOAS & JEQUITIBA & 0 & 0 \\
\hline SETE LAGOAS & MARAVILHAS & 0 & 0 \\
\hline SETE LAGOAS & MATOZINHOS & 0 & 0 \\
\hline SETE LAGOAS & PAPAGAIOS & 1 & 0 \\
\hline SETE LAGOAS & PARAOPEBA & 1 & 0 \\
\hline SETE LAGOAS & POMPEU & 1 & 0 \\
\hline SETE LAGOAS & PRUDENTE DE MORAIS & 0 & 0 \\
\hline SETE LAGOAS & SANTANA DE PIRAPAMA & 0 & 0 \\
\hline SETE LAGOAS & SETE LAGOAS & 4 & 0 \\
\hline TEOFILO OTONI & AGUAS FORMOSAS & 1 & 0 \\
\hline TEOFILO OTONI & ATALEIA & 0 & 0 \\
\hline TEOFILO OTONI & BERTOPOLIS & 0 & 0 \\
\hline TEOFILO OTONI & CAMPANARIO & 1 & 0 \\
\hline TEOFILO OTONI & CARAI & 1 & 0 \\
\hline TEOFILO OTONI & CARLOS CHAGAS & 0 & 0 \\
\hline TEOFILO OTONI & CATUJI & 0 & 0 \\
\hline TEOFILO OTONI & CRISOLITA & 1 & 0 \\
\hline TEOFILO OTONI & FRANCISCOPOLIS & 1 & 0 \\
\hline TEOFILO OTONI & FREI GASPAR & 0 & 0 \\
\hline TEOFILO OTONI & FRONTEIRA DOS VALES & 0 & 0 \\
\hline TEOFILO OTONI & ITAIPE & 0 & 0 \\
\hline TEOFILO OTONI & ITAMBACURI & 0 & 0 \\
\hline TEOFILO OTONI & JAMPRUCA & 0 & 0 \\
\hline TEOFILO OTONI & LADAINHA & 1 & 0 \\
\hline
\end{tabular}




\begin{tabular}{|c|c|c|c|}
\hline TEOFILO OTONI & MACHACALIS & 0 & 0 \\
\hline TEOFILO OTONI & MALACACHETA & 0 & 0 \\
\hline TEOFILO OTONI & NANUQUE & 0 & 0 \\
\hline TEOFILO OTONI & NOVO CRUZEIRO & 2 & 0 \\
\hline TEOFILO OTONI & NOVO ORIENTE DE MINAS & 3 & 0 \\
\hline TEOFILO OTONI & OURO VERDE DE MINAS & 1 & 0 \\
\hline TEOFILO OTONI & PADRE PARAISO & 1 & 0 \\
\hline TEOFILO OTONI & PAVAO & 1 & 0 \\
\hline TEOFILO OTONI & PESCADOR & 0 & 0 \\
\hline TEOFILO OTONI & PONTO DOS VOLANTES & 1 & 0 \\
\hline TEOFILO OTONI & POTE & 1 & 0 \\
\hline TEOFILO OTONI & SANTA HELENA DE MINAS & 0 & 0 \\
\hline TEOFILO OTONI & SERRA DOS AIMORES & 1 & 0 \\
\hline TEOFILO OTONI & SETUBINHA & 0 & 0 \\
\hline TEOFILO OTONI & TEOFILO OTONI & 2 & 0 \\
\hline TEOFILO OTONI & UMBURATIBA & 0 & 0 \\
\hline UBÁ & ASTOLFO DUTRA & 1 & 0 \\
\hline UBÁ & BRAS PIRES & 1 & 0 \\
\hline UBÁ & COIMBRA & 0 & 0 \\
\hline UBÁ & DIVINESIA & 0 & 0 \\
\hline UBÁ & DONA EUZEBIA & 0 & 0 \\
\hline UBÁ & DORES DO TURVO & 0 & 0 \\
\hline UBÁ & ERVALIA & 1 & 0 \\
\hline UBÁ & GUARANI & 2 & 0 \\
\hline UBÁ & GUIDOVAL & 0 & 0 \\
\hline UBÁ & GUIRICEMA & 0 & 0 \\
\hline UBÁ & PAULA CANDIDO & 1 & 0 \\
\hline UBÁ & PIRAUBA & 0 & 0 \\
\hline UBÁ & PRESIDENTE BERNARDES & 0 & 0 \\
\hline UBÁ & RIO POMBA & 1 & 0 \\
\hline UBÁ & RODEIRO & 0 & 0 \\
\hline UBÁ & SAO GERALDO & 0 & 0 \\
\hline UBÁ & SENADOR FIRMINO & 0 & 0 \\
\hline UBÁ & SILVEIRANIA & 0 & 0 \\
\hline UBÁ & TABULEIRO & 0 & 0 \\
\hline UBÁ & TOCANTINS & 0 & 0 \\
\hline UBÁ & UBA & 2 & 0 \\
\hline UBÁ & VISCONDE DO RIO BRANCO & 1 & 0 \\
\hline UBERABA & AGUA COMPRIDA & 1 & 0 \\
\hline UBERABA & ARAXA & 3 & 0 \\
\hline UBERABA & CAMPO FLORIDO & 1 & 0 \\
\hline UBERABA & CAMPOS ALTOS & 0 & 0 \\
\hline UBERABA & CARNEIRINHO & 2 & 0 \\
\hline UBERABA & COMENDADOR GOMES & 0 & 0 \\
\hline UBERABA & CONCEICAO DAS ALAGOAS & 2 & 0 \\
\hline
\end{tabular}




\begin{tabular}{|c|c|c|c|}
\hline UBERABA & CONQUISTA & 0 & 0 \\
\hline UBERABA & DELTA & 0 & 0 \\
\hline UBERABA & FRONTEIRA & 0 & 0 \\
\hline UBERABA & FRUTAL & 1 & 0 \\
\hline UBERABA & ITAPAGIPE & 2 & 0 \\
\hline UBERABA & ITURAMA & 4 & 0 \\
\hline UBERABA & LIMEIRA DO OESTE & 0 & 0 \\
\hline UBERABA & PEDRINOPOLIS & 0 & 0 \\
\hline UBERABA & PIRAJUBA & 0 & 0 \\
\hline UBERABA & PLANURA & 0 & 0 \\
\hline UBERABA & PRATINHA & 1 & 0 \\
\hline UBERABA & SACRAMENTO & 1 & 0 \\
\hline UBERABA & SANTA JULIANA & 1 & 0 \\
\hline UBERABA & SAO FRANCISCO DE SALES & 0 & 0 \\
\hline UBERABA & TAPIRA & 0 & 0 \\
\hline UBERABA & UBERABA & 8 & 2 \\
\hline UBERABA & UNIAO DE MINAS & 0 & 0 \\
\hline UBERABA & VERISSIMO & 0 & 0 \\
\hline UBERLANDIA & ARAGUARI & 8 & 2 \\
\hline UBERLANDIA & ARAPORA & 0 & 0 \\
\hline UBERLANDIA & CAMPINA VERDE & 0 & 0 \\
\hline UBERLANDIA & INDIANOPOLIS & 0 & 0 \\
\hline UBERLANDIA & MONTE ALEGRE DE MINAS & 0 & 0 \\
\hline UBERLANDIA & NOVA PONTE & 0 & 0 \\
\hline UBERLANDIA & PRATA & 2 & 0 \\
\hline UBERLANDIA & TUPACIGUARA & 3 & 0 \\
\hline UBERLANDIA & UBERLANDIA & 28 & 8 \\
\hline UNAI & ARINOS & 1 & 0 \\
\hline UNAI & BONFINOPOLIS DE MINAS & 0 & 0 \\
\hline UNAI & BURITIS & 2 & 0 \\
\hline UNAI & CABECEIRA GRANDE & 0 & 0 \\
\hline UNAI & DOM BOSCO & 0 & 0 \\
\hline UNAI & FORMOSO & 1 & 0 \\
\hline UNAI & NATALANDIA & 0 & 0 \\
\hline UNAI & RIACHINHO & 1 & 0 \\
\hline UNAI & UNAI & 2 & 0 \\
\hline UNAI & URUANA DE MINAS & 0 & 0 \\
\hline VARGINHA & ALFENAS & 1 & 0 \\
\hline VARGINHA & BOA ESPERANCA & 1 & 0 \\
\hline VARGINHA & CAMBUQUIRA & 0 & 0 \\
\hline VARGINHA & CAMPANHA & 2 & 0 \\
\hline VARGINHA & CAMPO DO MEIO & 0 & 0 \\
\hline VARGINHA & CAMPOS GERAIS & 0 & 0 \\
\hline VARGINHA & CARMO DA CACHOEIRA & 1 & 0 \\
\hline VARGINHA & CARVALHOPOLIS & 0 & 0 \\
\hline
\end{tabular}




\begin{tabular}{|c|c|c|c|}
\hline VARGINHA & COQUEIRAL & 0 & 0 \\
\hline VARGINHA & CORDISLANDIA & 0 & 0 \\
\hline VARGINHA & ELOI MENDES & 0 & 0 \\
\hline VARGINHA & FAMA & 0 & 0 \\
\hline VARGINHA & GUAPE & 0 & 0 \\
\hline VARGINHA & ILICINEA & 0 & 0 \\
\hline VARGINHA & LAMBARI & 0 & 0 \\
\hline VARGINHA & LUMINARIAS & 0 & 0 \\
\hline VARGINHA & MACHADO & 0 & 0 \\
\hline VARGINHA & MONSENHOR PAULO & 1 & 0 \\
\hline VARGINHA & NEPOMUCENO & 1 & 0 \\
\hline VARGINHA & PARAGUACU & 0 & 0 \\
\hline VARGINHA & POCO FUNDO & 1 & 0 \\
\hline VARGINHA & SANTANA DA VARGEM & 0 & 0 \\
\hline VARGINHA & SAO BENTO ABADE & 1 & 0 \\
\hline VARGINHA & SAO GONCALO DO SAPUCAI & 1 & 0 \\
\hline VARGINHA & TRES CORACOES & 2 & 0 \\
\hline VARGINHA & TRES PONTAS & 2 & 0 \\
\hline VARGINHA & TURVOLANDIA & 0 & 0 \\
\hline VARGINHA & VARGINHA & 1 & 0 \\
\hline Total geral & & 730 & 73 \\
\hline
\end{tabular}

\section{CARGO: PROFESSOR DE EDUCAÇÃO BÁSICA - PEB - LINGUA ESTRANGEIRA} MODERNA: ESPANHOL

\begin{tabular}{|l|l|c|c|}
\hline \multicolumn{1}{|c|}{ S R E } & \multicolumn{1}{|c|}{ MUNICIPIO } & \multicolumn{1}{c|}{$\begin{array}{c}\text { VAGAS } \\
\text { TOTAL DE } \\
\text { VAGAS }\end{array}$} & $\begin{array}{c}\text { RESERVADAS - } \\
\text { PORTADORES DE } \\
\text { DEFICIENCIA }\end{array}$ \\
\hline ALMENARA & AGUAS VERMELHAS & 0 & 0 \\
\hline ALMENARA & ALMENARA & 0 & 0 \\
\hline ALMENARA & BANDEIRA & 0 & 0 \\
\hline ALMENARA & CACHOEIRA DE PAJEU & 0 & 0 \\
\hline ALMENARA & CURRAL DE DENTRO & 0 & 0 \\
\hline ALMENARA & DIVISA ALEGRE & 0 & 0 \\
\hline ALMENARA & DIVISOPOLIS & 0 & 0 \\
\hline ALMENARA & FELISBURGO & 0 & 0 \\
\hline ALMENARA & JACINTO & 1 & 0 \\
\hline ALMENARA & JEQUITINHONHA & 0 & 0 \\
\hline ALMENARA & JOAIMA & 0 & 0 \\
\hline ALMENARA & JORDANIA & 0 & 0 \\
\hline ALMENARA & MATA VERDE & 0 & 0 \\
\hline ALMENARA & MONTE FORMOSO & 0 & 0 \\
\hline ALMENARA & PALMOPOLIS & & 0 \\
\hline ALMENARA & PEDRA AZUL & & 0 \\
\hline ALMENARA & RIO DO PRADO & RUBIM & 0 \\
\hline ALMENARA & & 0 & 0 \\
\hline
\end{tabular}




\begin{tabular}{|c|c|c|c|}
\hline ALMENARA & SALTO DA DIVISA & 0 & 0 \\
\hline ALMENARA & SANTA MARIA DO SALTO & 0 & 0 \\
\hline ALMENARA & SANTO ANTONIO DO JACINTO & 0 & 0 \\
\hline ARACUAI & ARACUAI & 0 & 0 \\
\hline ARACUAI & BERILO & 0 & 0 \\
\hline ARACUAI & BERIZAL & 0 & 0 \\
\hline ARACUAI & CHAPADA DO NORTE & 0 & 0 \\
\hline ARACUAI & COMERCINHO & 0 & 0 \\
\hline ARACUAI & CORONEL MURTA & 0 & 0 \\
\hline ARACUAI & FRANCISCO BADARO & 0 & 0 \\
\hline ARACUAI & FRUTA DE LEITE & 0 & 0 \\
\hline ARACUAI & INDAIABIRA & 0 & 0 \\
\hline ARACUAI & ITAOBIM & 0 & 0 \\
\hline ARACUAI & ITINGA & 0 & 0 \\
\hline ARACUAI & JENIPAPO DE MINAS & 0 & 0 \\
\hline ARACUAI & JOSE GONCALVES DE MINAS & 0 & 0 \\
\hline ARACUAI & MEDINA & 0 & 0 \\
\hline ARACUAI & NINHEIRA & 0 & 0 \\
\hline ARACUAI & NOVORIZONTE & 0 & 0 \\
\hline ARACUAI & RUBELITA & 0 & 0 \\
\hline ARACUAI & SALINAS & 2 & 0 \\
\hline ARACUAI & SANTA CRUZ DE SALINAS & 0 & 0 \\
\hline ARACUAI & TAIOBEIRAS & 0 & 0 \\
\hline ARACUAI & VIRGEM DA LAPA & 0 & 0 \\
\hline CAMPO BELO & AGUANIL & 0 & 0 \\
\hline CAMPO BELO & CAMACHO & 0 & 0 \\
\hline CAMPO BELO & CAMPO BELO & 0 & 0 \\
\hline CAMPO BELO & CANA VERDE & 0 & 0 \\
\hline CAMPO BELO & CANDEIAS & 0 & 0 \\
\hline CAMPO BELO & CRISTAIS & 0 & 0 \\
\hline CAMPO BELO & LAVRAS & 1 & 0 \\
\hline CAMPO BELO & PERDOES & 0 & 0 \\
\hline CAMPO BELO & RIBEIRAO VERMELHO & 0 & 0 \\
\hline CAMPO BELO & SANTANA DO JACARE & 0 & 0 \\
\hline CAMPO BELO & SANTO ANTONIO DO AMPARO & 1 & 0 \\
\hline CAMPO BELO & SAO FRANCISCO DE PAULA & 0 & 0 \\
\hline CARANGOLA & ALTO CAPARAO & 0 & 0 \\
\hline CARANGOLA & CAIANA & 0 & 0 \\
\hline CARANGOLA & CAPARAO & 0 & 0 \\
\hline CARANGOLA & CARANGOLA & 1 & 0 \\
\hline CARANGOLA & DIVINO & 0 & 0 \\
\hline CARANGOLA & ESPERA FELIZ & 0 & 0 \\
\hline CARANGOLA & FARIA LEMOS & 0 & 0 \\
\hline CARANGOLA & FERVEDOURO & 0 & 0 \\
\hline CARANGOLA & ORIZANIA & 0 & 0 \\
\hline
\end{tabular}




\begin{tabular}{|c|c|c|c|}
\hline CARANGOLA & PEDRA DOURADA & 0 & 0 \\
\hline CARANGOLA & TOMBOS & 0 & 0 \\
\hline CORONEL FABRICIANO & ANTONIO DIAS & 0 & 0 \\
\hline CORONEL FABRICIANO & BELO ORIENTE & 0 & 0 \\
\hline CORONEL FABRICIANO & BRAUNAS & 0 & 0 \\
\hline CORONEL FABRICIANO & CORONEL FABRICIANO & 2 & 0 \\
\hline CORONEL FABRICIANO & IPATINGA & 0 & 0 \\
\hline CORONEL FABRICIANO & JAGUARAÇU & 0 & 0 \\
\hline CORONEL FABRICIANO & JOANESIA & 0 & 0 \\
\hline CORONEL FABRICIANO & MARLIERIA & 0 & 0 \\
\hline CORONEL FABRICIANO & MESQUITA & 0 & 0 \\
\hline CORONEL FABRICIANO & SANTANA DO PARAISO & 1 & 0 \\
\hline CORONEL FABRICIANO & TIMOTEO & 1 & 0 \\
\hline CONSELHEIRO LAFAIETE & CARANAIBA & 0 & 0 \\
\hline CONSELHEIRO LAFAIETE & CASA GRANDE & 0 & 0 \\
\hline CONSELHEIRO LAFAIETE & CATAS ALTAS DA NORUEGA & 0 & 0 \\
\hline CONSELHEIRO LAFAIETE & CONGONHAS & 1 & 0 \\
\hline CONSELHEIRO LAFAIETE & CONSELHEIRO LAFAIETE & 0 & 0 \\
\hline CONSELHEIRO LAFAIETE & CRISTIANO OTONI & 0 & 0 \\
\hline CONSELHEIRO LAFAIETE & DESTERRO DE ENTRE RIOS & 0 & 0 \\
\hline CONSELHEIRO LAFAIETE & ENTRE RIOS DE MINAS & 0 & 0 \\
\hline CONSELHEIRO LAFAIETE & ITAVERAVA & 0 & 0 \\
\hline CONSELHEIRO LAFAIETE & JECEABA & 0 & 0 \\
\hline CONSELHEIRO LAFAIETE & LAMIM & 0 & 0 \\
\hline CONSELHEIRO LAFAIETE & OURO BRANCO & 0 & 0 \\
\hline CONSELHEIRO LAFAIETE & PIRANGA & 0 & 0 \\
\hline CONSELHEIRO LAFAIETE & QUELUZITO & 0 & 0 \\
\hline CONSELHEIRO LAFAIETE & RIO ESPERA & 0 & 0 \\
\hline CONSELHEIRO LAFAIETE & SANTANA DOS MONTES & 0 & 0 \\
\hline CONSELHEIRO LAFAIETE & SAO BRAS DO SUACUI & 0 & 0 \\
\hline CONSELHEIRO LAFAIETE & SENHORA DE OLIVEIRA & 0 & 0 \\
\hline CURVELO & AUGUSTO DE LIMA & 0 & 0 \\
\hline CURVELO & BUENOPOLIS & 0 & 0 \\
\hline CURVELO & CORINTO & 0 & 0 \\
\hline CURVELO & CURVELO & 1 & 0 \\
\hline CURVELO & FELIXLANDIA & 0 & 0 \\
\hline CURVELO & INIMUTABA & 0 & 0 \\
\hline CURVELO & JOAQUIM FELICIO & 0 & 0 \\
\hline CURVELO & LASSANCE & 1 & 0 \\
\hline CURVELO & MORRO DA GARCA & 0 & 0 \\
\hline CURVELO & PRESIDENTE JUSCELINO & 0 & 0 \\
\hline CURVELO & SANTO HIPOLITO & 0 & 0 \\
\hline CURVELO & TRES MARIAS & 0 & 0 \\
\hline DIVINÓPOLIS & ARAUJOS & 0 & 0 \\
\hline DIVINÓPOLIS & ARCOS & 0 & 0 \\
\hline
\end{tabular}




\begin{tabular}{|c|c|c|c|}
\hline DIVINÓPOLIS & BAMBUI & 0 & 0 \\
\hline DIVINÓPOLIS & CARMO DA MATA & 0 & 0 \\
\hline DIVINÓPOLIS & CARMO DO CAJURU & 0 & 0 \\
\hline DIVINÓPOLIS & CARMOPOLIS DE MINAS & 0 & 0 \\
\hline DIVINÓPOLIS & CLAUDIO & 1 & 0 \\
\hline DIVINÓPOLIS & CORREGO DANTA & 0 & 0 \\
\hline DIVINÓPOLIS & DIVINOPOLIS & 0 & 0 \\
\hline DIVINÓPOLIS & IGUATAMA & 0 & 0 \\
\hline DIVINÓPOLIS & ITAGUARA & 0 & 0 \\
\hline DIVINÓPOLIS & ITAPECERICA & 0 & 0 \\
\hline DIVINÓPOLIS & ITATIAIUCU & 0 & 0 \\
\hline DIVINÓPOLIS & ITAUNA & 0 & 0 \\
\hline DIVINÓPOLIS & JAPARAIBA & 0 & 0 \\
\hline DIVINÓPOLIS & LAGOA DA PRATA & 0 & 0 \\
\hline DIVINÓPOLIS & LUZ & 0 & 0 \\
\hline DIVINÓPOLIS & MEDEIROS & 0 & 0 \\
\hline DIVINÓPOLIS & MOEMA & 0 & 0 \\
\hline DIVINÓPOLIS & NOVA SERRANA & 0 & 0 \\
\hline DIVINÓPOLIS & OLIVEIRA & 0 & 0 \\
\hline DIVINÓPOLIS & PAINS & 0 & 0 \\
\hline DIVINÓPOLIS & PASSA TEMPO & 0 & 0 \\
\hline DIVINÓPOLIS & PEDRA DO INDAIA & 0 & 0 \\
\hline DIVINÓPOLIS & PERDIGAO & 0 & 0 \\
\hline DIVINÓPOLIS & PIRACEMA & 1 & 0 \\
\hline DIVINÓPOLIS & SANTO ANTONIO DO MONTE & 0 & 0 \\
\hline DIVINÓPOLIS & SAO GONCALO DO PARA & 0 & 0 \\
\hline DIVINÓPOLIS & SAO SEBASTIAO DO OESTE & 0 & 0 \\
\hline DIVINÓPOLIS & TAPIRAI & 0 & 0 \\
\hline GOVERNADOR VALADARES & ACUCENA & 0 & 0 \\
\hline GOVERNADOR VALADARES & AIMORES & 0 & 0 \\
\hline GOVERNADOR VALADARES & ALPERCATA & 0 & 0 \\
\hline GOVERNADOR VALADARES & CAPITAO ANDRADE & 0 & 0 \\
\hline GOVERNADOR VALADARES & CENTRAL DE MINAS & 0 & 0 \\
\hline GOVERNADOR VALADARES & CONSELHEIRO PENA & 0 & 0 \\
\hline GOVERNADOR VALADARES & COROACI & 0 & 0 \\
\hline GOVERNADOR VALADARES & CUPARAQUE & 0 & 0 \\
\hline GOVERNADOR VALADARES & DIVINO DAS LARANJEIRAS & 0 & 0 \\
\hline GOVERNADOR VALADARES & ENGENHEIRO CALDAS & 0 & 0 \\
\hline GOVERNADOR VALADARES & FERNANDES TOURINHO & 0 & 0 \\
\hline GOVERNADOR VALADARES & FREI INOCENCIO & 0 & 0 \\
\hline GOVERNADOR VALADARES & GALILEIA & 0 & 0 \\
\hline GOVERNADOR VALADARES & GOIABEIRA & 0 & 0 \\
\hline GOVERNADOR VALADARES & GOVERNADOR VALADARES & 1 & 0 \\
\hline GOVERNADOR VALADARES & ITABIRINHA & 0 & 0 \\
\hline GOVERNADOR VALADARES & ITANHOMI & 0 & 0 \\
\hline
\end{tabular}




\begin{tabular}{|c|c|c|c|}
\hline GOVERNADOR VALADARES & ITUETA & 0 & 0 \\
\hline GOVERNADOR VALADARES & MANTENA & 1 & 0 \\
\hline GOVERNADOR VALADARES & MARILAC & 0 & 0 \\
\hline GOVERNADOR VALADARES & MATHIAS LOBATO & 0 & 0 \\
\hline GOVERNADOR VALADARES & MENDES PIMENTEL & 0 & 0 \\
\hline GOVERNADOR VALADARES & NACIP RAYDAN & 0 & 0 \\
\hline GOVERNADOR VALADARES & NAQUE & 0 & 0 \\
\hline GOVERNADOR VALADARES & NOVA BELEM & 0 & 0 \\
\hline GOVERNADOR VALADARES & NOVA MODICA & 0 & 0 \\
\hline GOVERNADOR VALADARES & PERIQUITO & 0 & 0 \\
\hline GOVERNADOR VALADARES & RESPLENDOR & 0 & 0 \\
\hline GOVERNADOR VALADARES & SANTA EFIGENIA DE MINAS & 0 & 0 \\
\hline GOVERNADOR VALADARES & SANTA RITA DO ITUETO & 0 & 0 \\
\hline GOVERNADOR VALADARES & SAO FELIX DE MINAS & 0 & 0 \\
\hline GOVERNADOR VALADARES & SAO GERALDO DA PIEDADE & 0 & 0 \\
\hline GOVERNADOR VALADARES & SAO GERALDO DO BAIXIO & 0 & 0 \\
\hline GOVERNADOR VALADARES & SAO JOAO DO MANTENINHA & 0 & 0 \\
\hline GOVERNADOR VALADARES & SAO JOSE DA SAFIRA & 0 & 0 \\
\hline GOVERNADOR VALADARES & SAO JOSE DO DIVINO & 0 & 0 \\
\hline GOVERNADOR VALADARES & SARDOA & 0 & 0 \\
\hline GOVERNADOR VALADARES & SOBRALIA & 0 & 0 \\
\hline GOVERNADOR VALADARES & TUMIRITINGA & 0 & 0 \\
\hline GOVERNADOR VALADARES & VIRGOLANDIA & 0 & 0 \\
\hline JANAUBA & CATUTI & 0 & 0 \\
\hline JANAUBA & ESPINOSA & 0 & 0 \\
\hline JANAUBA & GAMELEIRAS & 0 & 0 \\
\hline JANAUBA & JAIBA & 0 & 0 \\
\hline JANAUBA & JANAUBA & 0 & 0 \\
\hline JANAUBA & MAMONAS & 0 & 0 \\
\hline JANAUBA & MATO VERDE & 0 & 0 \\
\hline JANAUBA & MONTE AZUL & 0 & 0 \\
\hline JANAUBA & MONTEZUMA & 0 & 0 \\
\hline JANAUBA & NOVA PORTEIRINHA & 0 & 0 \\
\hline JANAUBA & PAI PEDRO & 0 & 0 \\
\hline JANAUBA & PORTEIRINHA & 1 & 0 \\
\hline JANAUBA & RIACHO DOS MACHADOS & 0 & 0 \\
\hline JANAUBA & RIO PARDO DE MINAS & 0 & 0 \\
\hline JANAUBA & SANTO ANTONIO DO RETIRO & 0 & 0 \\
\hline JANAUBA & SERRANOPOLIS DE MINAS & 0 & 0 \\
\hline JANAUBA & VERDELANDIA & 0 & 0 \\
\hline JANUARIA & BONITO DE MINAS & 0 & 0 \\
\hline JANUARIA & CHAPADA GAUCHA & 0 & 0 \\
\hline JANUARIA & CONEGO MARINHO & 0 & 0 \\
\hline JANUARIA & IBIRACATU & 0 & 0 \\
\hline JANUARIA & ICARAI DE MINAS & 0 & 0 \\
\hline
\end{tabular}




\begin{tabular}{|c|c|c|c|}
\hline JANUARIA & ITACARAMBI & 0 & 0 \\
\hline JANUARIA & JANUARIA & 0 & 0 \\
\hline JANUARIA & JUVENILIA & 0 & 0 \\
\hline JANUARIA & MANGA & 1 & 0 \\
\hline JANUARIA & MATIAS CARDOSO & 0 & 0 \\
\hline JANUARIA & MIRAVANIA & 0 & 0 \\
\hline JANUARIA & MONTALVANIA & 0 & 0 \\
\hline JANUARIA & PEDRAS DE MARIA DA CRUZ & 0 & 0 \\
\hline JANUARIA & PINTOPOLIS & 0 & 0 \\
\hline JANUARIA & SAO FRANCISCO & 0 & 0 \\
\hline JANUARIA & SAO JOAO DAS MISSOES & 0 & 0 \\
\hline JANUARIA & UBAI & 0 & 0 \\
\hline JANUARIA & URUCUIA & 0 & 0 \\
\hline JANUARIA & VARZELANDIA & 0 & 0 \\
\hline MANHUAÇU & ALTO JEQUITIBA & 0 & 0 \\
\hline MANHUAÇU & CAPUTIRA & 0 & 0 \\
\hline MANHUAÇU & CHALE & 0 & 0 \\
\hline MANHUAÇU & CONCEICAO DE IPANEMA & 0 & 0 \\
\hline MANHUAÇU & DURANDE & 0 & 0 \\
\hline MANHUAÇU & LAJINHA & 0 & 0 \\
\hline MANHUAÇU & LUISBURGO & 0 & 0 \\
\hline MANHUAÇU & MANHUACU & 0 & 0 \\
\hline MANHUAÇU & MANHUMIRIM & 0 & 0 \\
\hline MANHUAÇU & MARTINS SOARES & 1 & 0 \\
\hline MANHUAÇU & MATIPO & 0 & 0 \\
\hline MANHUAÇU & MUTUM & 0 & 0 \\
\hline MANHUAÇU & REDUTO & 0 & 0 \\
\hline MANHUAÇU & SANTA MARGARIDA & 0 & 0 \\
\hline MANHUAÇU & SANTANA DO MANHUACU & 0 & 0 \\
\hline MANHUAÇU & SAO JOAO DO MANHUACU & 0 & 0 \\
\hline MANHUAÇU & SAO JOSE DO MANTIMENTO & 0 & 0 \\
\hline MANHUAÇU & SIMONESIA & 0 & 0 \\
\hline METROPOLITANA A & BARAO DE COCAIS & 0 & 0 \\
\hline METROPOLITANA A & BELO HORIZONTE & 1 & 0 \\
\hline METROPOLITANA A & BELO VALE & 0 & 0 \\
\hline METROPOLITANA A & BOM JESUS DO AMPARO & 0 & 0 \\
\hline METROPOLITANA A & BONFIM & 0 & 0 \\
\hline METROPOLITANA A & BRUMADINHO & 0 & 0 \\
\hline METROPOLITANA A & CAETE & 0 & 0 \\
\hline METROPOLITANA A & CATAS ALTAS & 0 & 0 \\
\hline METROPOLITANA A & CRUCILANDIA & 0 & 0 \\
\hline METROPOLITANA A & MOEDA & 0 & 0 \\
\hline METROPOLITANA A & NOVA LIMA & 1 & 0 \\
\hline METROPOLITANA A & NOVA UNIAO & 0 & 0 \\
\hline METROPOLITANA A & PIEDADE DOS GERAIS & 0 & 0 \\
\hline
\end{tabular}




\begin{tabular}{|c|c|c|c|}
\hline METROPOLITANA A & RAPOSOS & 0 & 0 \\
\hline METROPOLITANA A & RIO ACIMA & 0 & 0 \\
\hline METROPOLITANA A & RIO MANSO & 0 & 0 \\
\hline METROPOLITANA A & SABARA & 1 & 0 \\
\hline METROPOLITANA A & SANTA BARBARA & 0 & 0 \\
\hline METROPOLITANA B & BELO HORIZONTE & 7 & 4 \\
\hline METROPOLITANA B & BETIM & 3 & 0 \\
\hline METROPOLITANA B & CONTAGEM & 10 & 4 \\
\hline METROPOLITANA B & ESMERALDAS & 0 & 0 \\
\hline METROPOLITANA B & IBIRITE & 1 & 0 \\
\hline METROPOLITANA B & IGARAPE & 0 & 0 \\
\hline METROPOLITANA B & JUATUBA & 0 & 0 \\
\hline METROPOLITANA B & MARIO CAMPOS & 0 & 0 \\
\hline METROPOLITANA B & MATEUS LEME & 1 & 0 \\
\hline METROPOLITANA B & SAO JOAQUIM DE BICAS & 0 & 0 \\
\hline METROPOLITANA B & SARZEDO & 1 & 0 \\
\hline METROPOLITANA C & BELO HORIZONTE & 0 & 0 \\
\hline METROPOLITANA C & CONFINS & 0 & 0 \\
\hline METROPOLITANA C & JABOTICATUBAS & 0 & 0 \\
\hline METROPOLITANA C & LAGOA SANTA & 0 & 0 \\
\hline METROPOLITANA C & MORRO DO PILAR & 0 & 0 \\
\hline METROPOLITANA C & PEDRO LEOPOLDO & 2 & 0 \\
\hline METROPOLITANA C & RIBEIRAO DAS NEVES & 3 & 0 \\
\hline METROPOLITANA C & SANTA LUZIA & 0 & 0 \\
\hline METROPOLITANA C & SANTANA DO RIACHO & 0 & 0 \\
\hline METROPOLITANA C & SAO JOSE DA LAPA & 1 & 0 \\
\hline METROPOLITANA C & TAQUARACU DE MINAS & 0 & 0 \\
\hline METROPOLITANA C & VESPASIANO & 2 & 0 \\
\hline MONTES CLAROS & BOCAIUVA & 1 & 0 \\
\hline MONTES CLAROS & BOTUMIRIM & 1 & 0 \\
\hline MONTES CLAROS & BRASILIA DE MINAS & 0 & 0 \\
\hline MONTES CLAROS & CAMPO AZUL & 0 & 0 \\
\hline MONTES CLAROS & CAPITAO ENEAS & 1 & 0 \\
\hline MONTES CLAROS & CLARO DOS POCOES & 0 & 0 \\
\hline MONTES CLAROS & CORACAO DE JESUS & 1 & 0 \\
\hline MONTES CLAROS & CRISTALIA & 0 & 0 \\
\hline MONTES CLAROS & ENGENHEIRO NAVARRO & 0 & 0 \\
\hline MONTES CLAROS & FRANCISCO DUMONT & 0 & 0 \\
\hline MONTES CLAROS & FRANCISCO SA & 1 & 0 \\
\hline MONTES CLAROS & GLAUCILANDIA & 0 & 0 \\
\hline MONTES CLAROS & GRAO MOGOL & 1 & 0 \\
\hline MONTES CLAROS & GUARACIAMA & 0 & 0 \\
\hline MONTES CLAROS & ITACAMBIRA & 0 & 0 \\
\hline MONTES CLAROS & JAPONVAR & 0 & 0 \\
\hline MONTES CLAROS & JOSENOPOLIS & 0 & 0 \\
\hline
\end{tabular}




\begin{tabular}{|c|c|c|c|}
\hline MONTES CLAROS & JURAMENTO & 0 & 0 \\
\hline MONTES CLAROS & LONTRA & 0 & 0 \\
\hline MONTES CLAROS & LUISLANDIA & 0 & 0 \\
\hline MONTES CLAROS & MIRABELA & 1 & 0 \\
\hline MONTES CLAROS & MONTES CLAROS & 5 & 2 \\
\hline MONTES CLAROS & OLHOS-D AGUA & 0 & 0 \\
\hline MONTES CLAROS & PADRE CARVALHO & 0 & 0 \\
\hline MONTES CLAROS & PATIS & 0 & 0 \\
\hline MONTES CLAROS & SAO JOAO DA LAGOA & 0 & 0 \\
\hline MONTES CLAROS & SAO JOAO DA PONTE & 0 & 0 \\
\hline MONTES CLAROS & SAO JOAO DO PACUI & 0 & 0 \\
\hline MONTES CLAROS & SAO JOAO DO PARAISO & 1 & 0 \\
\hline MONTES CLAROS & VARGEM GRANDE DO RIO PARDO & 0 & 0 \\
\hline NOVA ERA & BELA VISTA DE MINAS & 0 & 0 \\
\hline NOVA ERA & DIONISIO & 0 & 0 \\
\hline NOVA ERA & FERROS & 0 & 0 \\
\hline NOVA ERA & ITABIRA & 0 & 0 \\
\hline NOVA ERA & ITAMBE DO MATO DENTRO & 0 & 0 \\
\hline NOVA ERA & JOAO MONLEVADE & 0 & 0 \\
\hline NOVA ERA & NOVA ERA & 0 & 0 \\
\hline NOVA ERA & PASSABEM & 0 & 0 \\
\hline NOVA ERA & RIO PIRACICABA & 0 & 0 \\
\hline NOVA ERA & SANTA MARIA DE ITABIRA & 0 & 0 \\
\hline NOVA ERA & SANTO ANTONIO DO RIO ABAIXO & 1 & 0 \\
\hline NOVA ERA & SAO DOMINGOS DO PRATA & 0 & 0 \\
\hline NOVA ERA & SAO GONCALO DO RIO ABAIXO & 0 & 0 \\
\hline NOVA ERA & SAO JOSE DO GOIABAL & 0 & 0 \\
\hline NOVA ERA & SAO SEBASTIAO DO RIO PRETO & 0 & 0 \\
\hline PASSOS & ALPINOPOLIS & 0 & 0 \\
\hline PASSOS & BOM JESUS DA PENHA & 0 & 0 \\
\hline PASSOS & CAPITOLIO & 0 & 0 \\
\hline PASSOS & CARMO DO RIO CLARO & 0 & 0 \\
\hline PASSOS & CORREGO FUNDO & 0 & 0 \\
\hline PASSOS & DELFINOPOLIS & 0 & 0 \\
\hline PASSOS & DORESOPOLIS & 0 & 0 \\
\hline PASSOS & FORMIGA & 0 & 0 \\
\hline PASSOS & FORTALEZA DE MINAS & 0 & 0 \\
\hline PASSOS & PASSOS & 1 & 0 \\
\hline PASSOS & PIMENTA & 0 & 0 \\
\hline PASSOS & PIUMHI & 1 & 0 \\
\hline PASSOS & SAO JOAO BATISTA DO GLORIA & 0 & 0 \\
\hline PASSOS & SAO JOSE DA BARRA & 0 & 0 \\
\hline PASSOS & SAO ROQUE DE MINAS & 0 & 0 \\
\hline PASSOS & VARGEM BONITA & 0 & 0 \\
\hline PATOS DE MINAS & ARAPUA & 0 & 0 \\
\hline
\end{tabular}




\begin{tabular}{|c|c|c|c|}
\hline PATOS DE MINAS & CARMO DO PARANAIBA & 1 & 0 \\
\hline PATOS DE MINAS & LAGAMAR & 0 & 0 \\
\hline PATOS DE MINAS & LAGOA FORMOSA & 0 & 0 \\
\hline PATOS DE MINAS & LAGOA GRANDE & 0 & 0 \\
\hline PATOS DE MINAS & MATUTINA & 0 & 0 \\
\hline PATOS DE MINAS & PATOS DE MINAS & 1 & 0 \\
\hline PATOS DE MINAS & PRESIDENTE OLEGARIO & 0 & 0 \\
\hline PATOS DE MINAS & RIO PARANAIBA & 0 & 0 \\
\hline PATOS DE MINAS & SANTA ROSA DA SERRA & 0 & 0 \\
\hline PATOS DE MINAS & SAO GONCALO DO ABAETE & 0 & 0 \\
\hline PATOS DE MINAS & SAO GOTARDO & 0 & 0 \\
\hline PATOS DE MINAS & TIROS & 0 & 0 \\
\hline PATOS DE MINAS & VARJAO DE MINAS & 0 & 0 \\
\hline PATROCÍNIO & CRUZEIRO DA FORTALEZA & 0 & 0 \\
\hline PATROCÍNIO & GUIMARANIA & 0 & 0 \\
\hline PATROCÍNIO & IBIA & 0 & 0 \\
\hline PATROCÍNIO & IRAI DE MINAS & 0 & 0 \\
\hline PATROCÍNIO & PATROCINIO & 1 & 0 \\
\hline PATROCÍNIO & PERDIZES & 0 & 0 \\
\hline PATROCÍNIO & SERRA DO SALITRE & 0 & 0 \\
\hline PIRAPORA & BURITIZEIRO & 1 & 0 \\
\hline PIRAPORA & IBIAI & 0 & 0 \\
\hline PIRAPORA & JEQUITAI & 0 & 0 \\
\hline PIRAPORA & LAGOA DOS PATOS & 0 & 0 \\
\hline PIRAPORA & PIRAPORA & 2 & 0 \\
\hline PIRAPORA & PONTO CHIQUE & 0 & 0 \\
\hline PIRAPORA & SANTA FE DE MINAS & 0 & 0 \\
\hline PIRAPORA & SAO ROMAO & 0 & 0 \\
\hline PIRAPORA & VARZEA DA PALMA & 0 & 0 \\
\hline PONTE NOVA & ABRE CAMPO & 0 & 0 \\
\hline PONTE NOVA & ALVINOPOLIS & 0 & 0 \\
\hline PONTE NOVA & AMPARO DO SERRA & 0 & 0 \\
\hline PONTE NOVA & ARAPONGA & 0 & 0 \\
\hline PONTE NOVA & BARRA LONGA & 0 & 0 \\
\hline PONTE NOVA & CAJURI & 0 & 0 \\
\hline PONTE NOVA & CANAA & 0 & 0 \\
\hline PONTE NOVA & DOM SILVERIO & 0 & 0 \\
\hline PONTE NOVA & GUARACIABA & 0 & 0 \\
\hline PONTE NOVA & JEQUERI & 0 & 0 \\
\hline PONTE NOVA & ORATORIOS & 0 & 0 \\
\hline PONTE NOVA & PEDRA BONITA & 0 & 0 \\
\hline PONTE NOVA & PEDRA DO ANTA & 0 & 0 \\
\hline PONTE NOVA & PIEDADE DE PONTE NOVA & 0 & 0 \\
\hline PONTE NOVA & PONTE NOVA & 0 & 0 \\
\hline PONTE NOVA & PORTO FIRME & 0 & 0 \\
\hline
\end{tabular}




\begin{tabular}{|c|c|c|c|}
\hline PONTE NOVA & RAUL SOARES & 1 & 0 \\
\hline PONTE NOVA & RIO CASCA & 0 & 0 \\
\hline PONTE NOVA & RIO DOCE & 0 & 0 \\
\hline PONTE NOVA & SANTA CRUZ DO ESCALVADO & 0 & 0 \\
\hline PONTE NOVA & SANTO ANTONIO DO GRAMA & 0 & 0 \\
\hline PONTE NOVA & SAO MIGUEL DO ANTA & 0 & 0 \\
\hline PONTE NOVA & SAO PEDRO DOS FERROS & 0 & 0 \\
\hline PONTE NOVA & SEM-PEIXE & 0 & 0 \\
\hline PONTE NOVA & SERICITA & 0 & 0 \\
\hline PONTE NOVA & TEIXEIRAS & 0 & 0 \\
\hline PONTE NOVA & URUCANIA & 0 & 0 \\
\hline PONTE NOVA & VERMELHO NOVO & 0 & 0 \\
\hline PONTE NOVA & VICOSA & 0 & 0 \\
\hline SETE LAGOAS & ARACAI & 0 & 0 \\
\hline SETE LAGOAS & BALDIM & 0 & 0 \\
\hline SETE LAGOAS & CACHOEIRA DA PRATA & 0 & 0 \\
\hline SETE LAGOAS & CAETANOPOLIS & 0 & 0 \\
\hline SETE LAGOAS & CAPIM BRANCO & 0 & 0 \\
\hline SETE LAGOAS & CORDISBURGO & 0 & 0 \\
\hline SETE LAGOAS & FORTUNA DE MINAS & 0 & 0 \\
\hline SETE LAGOAS & FUNILANDIA & 0 & 0 \\
\hline SETE LAGOAS & INHAUMA & 0 & 0 \\
\hline SETE LAGOAS & JEQUITIBA & 0 & 0 \\
\hline SETE LAGOAS & MARAVILHAS & 0 & 0 \\
\hline SETE LAGOAS & MATOZINHOS & 0 & 0 \\
\hline SETE LAGOAS & PAPAGAIOS & 0 & 0 \\
\hline SETE LAGOAS & PARAOPEBA & 0 & 0 \\
\hline SETE LAGOAS & POMPEU & 0 & 0 \\
\hline SETE LAGOAS & PRUDENTE DE MORAIS & 0 & 0 \\
\hline SETE LAGOAS & SANTANA DE PIRAPAMA & 0 & 0 \\
\hline SETE LAGOAS & SETE LAGOAS & 1 & 0 \\
\hline TEOFILO OTONI & AGUAS FORMOSAS & 0 & 0 \\
\hline TEOFILO OTONI & ATALEIA & 0 & 0 \\
\hline TEOFILO OTONI & BERTOPOLIS & 0 & 0 \\
\hline TEOFILO OTONI & CAMPANARIO & 0 & 0 \\
\hline TEOFILO OTONI & CARAI & 0 & 0 \\
\hline TEOFILO OTONI & CARLOS CHAGAS & 0 & 0 \\
\hline TEOFILO OTONI & CATUJI & 0 & 0 \\
\hline TEOFILO OTONI & CRISOLITA & 1 & 0 \\
\hline TEOFILO OTONI & FRANCISCOPOLIS & 0 & 0 \\
\hline TEOFILO OTONI & FREI GASPAR & 0 & 0 \\
\hline TEOFILO OTONI & FRONTEIRA DOS VALES & 0 & 0 \\
\hline TEOFILO OTONI & ITAIPE & 0 & 0 \\
\hline TEOFILO OTONI & ITAMBACURI & 0 & 0 \\
\hline TEOFILO OTONI & JAMPRUCA & 0 & 0 \\
\hline
\end{tabular}




\begin{tabular}{|c|c|c|c|}
\hline TEOFILO OTONI & LADAINHA & 0 & 0 \\
\hline TEOFILO OTONI & MACHACALIS & 0 & 0 \\
\hline TEOFILO OTONI & MALACACHETA & 0 & 0 \\
\hline TEOFILO OTONI & NANUQUE & 0 & 0 \\
\hline TEOFILO OTONI & NOVO CRUZEIRO & 0 & 0 \\
\hline TEOFILO OTONI & NOVO ORIENTE DE MINAS & 0 & 0 \\
\hline TEOFILO OTONI & OURO VERDE DE MINAS & 0 & 0 \\
\hline TEOFILO OTONI & PADRE PARAISO & 0 & 0 \\
\hline TEOFILO OTONI & PAVAO & 0 & 0 \\
\hline TEOFILO OTONI & PESCADOR & 0 & 0 \\
\hline TEOFILO OTONI & PONTO DOS VOLANTES & 0 & 0 \\
\hline TEOFILO OTONI & POTE & 0 & 0 \\
\hline TEOFILO OTONI & SANTA HELENA DE MINAS & 0 & 0 \\
\hline TEOFILO OTONI & SERRA DOS AIMORES & 0 & 0 \\
\hline TEOFILO OTONI & SETUBINHA & 0 & 0 \\
\hline TEOFILO OTONI & TEOFILO OTONI & 1 & 0 \\
\hline TEOFILO OTONI & UMBURATIBA & 0 & 0 \\
\hline UBÁ & ASTOLFO DUTRA & 0 & 0 \\
\hline UBÁ & BRAS PIRES & 0 & 0 \\
\hline UBÁ & COIMBRA & 0 & 0 \\
\hline UBÁ & DIVINESIA & 0 & 0 \\
\hline UBÁ & DONA EUZEBIA & 0 & 0 \\
\hline UBÁ & DORES DO TURVO & 0 & 0 \\
\hline UBÁ & ERVALIA & 0 & 0 \\
\hline UBÁ & GUARANI & 0 & 0 \\
\hline UBÁ & GUIDOVAL & 0 & 0 \\
\hline UBÁ & GUIRICEMA & 0 & 0 \\
\hline UBÁ & PAULA CANDIDO & 0 & 0 \\
\hline UBÁ & PIRAUBA & 0 & 0 \\
\hline UBÁ & PRESIDENTE BERNARDES & 0 & 0 \\
\hline UBÁ & RIO POMBA & 0 & 0 \\
\hline UBÁ & RODEIRO & 0 & 0 \\
\hline UBÁ & SAO GERALDO & 0 & 0 \\
\hline UBÁ & SENADOR FIRMINO & 0 & 0 \\
\hline UBÁ & SILVEIRANIA & 0 & 0 \\
\hline UBÁ & TABULEIRO & 0 & 0 \\
\hline UBÁ & TOCANTINS & 0 & 0 \\
\hline UBÁ & UBA & 2 & 0 \\
\hline UBÁ & VISCONDE DO RIO BRANCO & 0 & 0 \\
\hline UBERABA & AGUA COMPRIDA & 0 & 0 \\
\hline UBERABA & ARAXA & 0 & 0 \\
\hline UBERABA & CAMPO FLORIDO & 0 & 0 \\
\hline UBERABA & CAMPOS ALTOS & 0 & 0 \\
\hline UBERABA & CARNEIRINHO & 0 & 0 \\
\hline UBERABA & COMENDADOR GOMES & 0 & 0 \\
\hline
\end{tabular}




\begin{tabular}{|c|c|c|c|}
\hline UBERABA & CONCEICAO DAS ALAGOAS & 0 & 0 \\
\hline UBERABA & CONQUISTA & 0 & 0 \\
\hline UBERABA & DELTA & 0 & 0 \\
\hline UBERABA & FRONTEIRA & 0 & 0 \\
\hline UBERABA & FRUTAL & 2 & 0 \\
\hline UBERABA & ITAPAGIPE & 0 & 0 \\
\hline UBERABA & ITURAMA & 1 & 0 \\
\hline UBERABA & LIMEIRA DO OESTE & 0 & 0 \\
\hline UBERABA & PEDRINOPOLIS & 0 & 0 \\
\hline UBERABA & PIRAJUBA & 1 & 0 \\
\hline UBERABA & PLANURA & 0 & 0 \\
\hline UBERABA & PRATINHA & 0 & 0 \\
\hline UBERABA & SACRAMENTO & 1 & 0 \\
\hline UBERABA & SANTA JULIANA & 0 & 0 \\
\hline UBERABA & SAO FRANCISCO DE SALES & 0 & 0 \\
\hline UBERABA & TAPIRA & 0 & 0 \\
\hline UBERABA & UBERABA & 3 & 0 \\
\hline UBERABA & UNIAO DE MINAS & 0 & 0 \\
\hline UBERABA & VERISSIMO & 0 & 0 \\
\hline UBERLANDIA & ARAGUARI & 0 & 0 \\
\hline UBERLANDIA & ARAPORA & 0 & 0 \\
\hline UBERLANDIA & CAMPINA VERDE & 0 & 0 \\
\hline UBERLANDIA & INDIANOPOLIS & 0 & 0 \\
\hline UBERLANDIA & MONTE ALEGRE DE MINAS & 0 & 0 \\
\hline UBERLANDIA & NOVA PONTE & 0 & 0 \\
\hline UBERLANDIA & PRATA & 0 & 0 \\
\hline UBERLANDIA & TUPACIGUARA & 0 & 0 \\
\hline UBERLANDIA & UBERLANDIA & 4 & 0 \\
\hline VARGINHA & ALFENAS & 0 & 0 \\
\hline VARGINHA & BOA ESPERANCA & 1 & 0 \\
\hline VARGINHA & CAMBUQUIRA & 0 & 0 \\
\hline VARGINHA & CAMPANHA & 0 & 0 \\
\hline VARGINHA & CAMPO DO MEIO & 0 & 0 \\
\hline VARGINHA & CAMPOS GERAIS & 0 & 0 \\
\hline VARGINHA & CARMO DA CACHOEIRA & 0 & 0 \\
\hline VARGINHA & CARVALHOPOLIS & 0 & 0 \\
\hline VARGINHA & COQUEIRAL & 0 & 0 \\
\hline VARGINHA & CORDISLANDIA & 0 & 0 \\
\hline VARGINHA & ELOI MENDES & 0 & 0 \\
\hline VARGINHA & FAMA & 0 & 0 \\
\hline VARGINHA & GUAPE & 0 & 0 \\
\hline VARGINHA & ILICINEA & 0 & 0 \\
\hline VARGINHA & LAMBARI & 0 & 0 \\
\hline VARGINHA & LUMINARIAS & 0 & 0 \\
\hline VARGINHA & MACHADO & 0 & 0 \\
\hline
\end{tabular}




\begin{tabular}{|l|l|c|c|}
\hline VARGINHA & MONSENHOR PAULO & 0 & 0 \\
\hline VARGINHA & NEPOMUCENO & 0 & 0 \\
\hline VARGINHA & PARAGUACU & 0 & 0 \\
\hline VARGINHA & POCO FUNDO & 0 & 0 \\
\hline VARGINHA & SANTANA DA VARGEM & 0 & 0 \\
\hline VARGINHA & SAO BENTO ABADE & 0 & 0 \\
\hline VARGINHA & SAO GONCALO DO SAPUCAI & 0 & 0 \\
\hline VARGINHA & TRES CORACOES & 2 & 0 \\
\hline VARGINHA & TRES PONTAS & 0 & 0 \\
\hline VARGINHA & TURVOLANDIA & 0 & 0 \\
\hline VARGINHA & VARGINHA & $\mathbf{9 7}$ & 0 \\
\hline Total geral & & & $\mathbf{1 0}$ \\
\hline
\end{tabular}

CARGO: PROFESSOR DE EDUCAÇÃO BÁSICA - PEB - LINGUA ESTRANGEIRA MODERNA: INGLES

\begin{tabular}{|c|c|c|c|}
\hline S R E & MUNICIPIO & $\begin{array}{l}\text { TOTAL DE } \\
\text { VAGAS }\end{array}$ & $\begin{array}{c}\text { VAGAS } \\
\text { RESERVADAS - } \\
\text { PORTADORES DE } \\
\text { DEFICIENCIA } \\
\end{array}$ \\
\hline ALMENARA & AGUAS VERMELHAS & 0 & 0 \\
\hline ALMENARA & ALMENARA & 0 & 0 \\
\hline ALMENARA & BANDEIRA & 0 & 0 \\
\hline ALMENARA & CACHOEIRA DE PAJEU & 0 & 0 \\
\hline ALMENARA & CURRAL DE DENTRO & 0 & 0 \\
\hline ALMENARA & DIVISA ALEGRE & 0 & 0 \\
\hline ALMENARA & DIVISOPOLIS & 0 & 0 \\
\hline ALMENARA & FELISBURGO & 0 & 0 \\
\hline ALMENARA & JACINTO & 0 & 0 \\
\hline ALMENARA & JEQUITINHONHA & 1 & 0 \\
\hline ALMENARA & JOAIMA & 0 & 0 \\
\hline ALMENARA & JORDANIA & 0 & 0 \\
\hline ALMENARA & MATA VERDE & 0 & 0 \\
\hline ALMENARA & MONTE FORMOSO & 0 & 0 \\
\hline ALMENARA & PALMOPOLIS & 0 & 0 \\
\hline ALMENARA & PEDRA AZUL & 0 & 0 \\
\hline ALMENARA & RIO DO PRADO & 0 & 0 \\
\hline ALMENARA & RUBIM & 0 & 0 \\
\hline ALMENARA & SALTO DA DIVISA & 0 & 0 \\
\hline ALMENARA & SANTA MARIA DO SALTO & 0 & 0 \\
\hline ALMENARA & SANTO ANTONIO DO JACINTO & 0 & 0 \\
\hline ARACUAI & ARACUAI & 0 & 0 \\
\hline ARACUAI & BERILO & 1 & 0 \\
\hline ARACUAI & BERIZAL & 1 & 0 \\
\hline ARACUAI & CHAPADA DO NORTE & 0 & 0 \\
\hline ARACUAI & COMERCINHO & 0 & 0 \\
\hline ARACUAI & CORONEL MURTA & 1 & 0 \\
\hline
\end{tabular}




\begin{tabular}{|c|c|c|c|}
\hline ARACUAI & FRANCISCO BADARO & 1 & 0 \\
\hline ARACUAI & FRUTA DE LEITE & 0 & 0 \\
\hline ARACUAI & INDAIABIRA & 1 & 0 \\
\hline ARACUAI & ITAOBIM & 0 & 0 \\
\hline ARACUAI & ITINGA & 1 & 0 \\
\hline ARACUAI & JENIPAPO DE MINAS & 1 & 0 \\
\hline ARACUAI & JOSE GONCALVES DE MINAS & 0 & 0 \\
\hline ARACUAI & MEDINA & 0 & 0 \\
\hline ARACUAI & NINHEIRA & 2 & 0 \\
\hline ARACUAI & NOVORIZONTE & 2 & 0 \\
\hline ARACUAI & RUBELITA & 1 & 0 \\
\hline ARACUAI & SALINAS & 2 & 0 \\
\hline ARACUAI & SANTA CRUZ DE SALINAS & 1 & 0 \\
\hline ARACUAI & TAIOBEIRAS & 2 & 0 \\
\hline ARACUAI & VIRGEM DA LAPA & 1 & 0 \\
\hline BARBACENA & ALFREDO VASCONCELOS & 0 & 0 \\
\hline BARBACENA & ALTO RIO DOCE & 0 & 0 \\
\hline BARBACENA & ANDRELANDIA & 0 & 0 \\
\hline BARBACENA & ANTONIO CARLOS & 1 & 0 \\
\hline BARBACENA & ARACITABA & 0 & 0 \\
\hline BARBACENA & BARBACENA & 3 & 0 \\
\hline BARBACENA & BARROSO & 1 & 0 \\
\hline BARBACENA & BIAS FORTES & 0 & 0 \\
\hline BARBACENA & CAPELA NOVA & 0 & 0 \\
\hline BARBACENA & CARANDAI & 0 & 0 \\
\hline BARBACENA & CIPOTANEA & 0 & 0 \\
\hline BARBACENA & DESTERRO DO MELO & 0 & 0 \\
\hline BARBACENA & IBERTIOGA & 0 & 0 \\
\hline BARBACENA & MADRE DE DEUS DE MINAS & 0 & 0 \\
\hline BARBACENA & MERCES & 0 & 0 \\
\hline BARBACENA & OLIVEIRA FORTES & 0 & 0 \\
\hline BARBACENA & PAIVA & 0 & 0 \\
\hline BARBACENA & PIEDADE DO RIO GRANDE & 0 & 0 \\
\hline BARBACENA & RESSAQUINHA & 0 & 0 \\
\hline BARBACENA & SANTA BARBARA DO TUGURIO & 0 & 0 \\
\hline BARBACENA & SANTA RITA DO IBITIPOCA & 0 & 0 \\
\hline BARBACENA & SANTANA DO GARAMBEU & 0 & 0 \\
\hline BARBACENA & SAO VICENTE DE MINAS & 0 & 0 \\
\hline BARBACENA & SENHORA DOS REMEDIOS & 0 & 0 \\
\hline CAMPO BELO & AGUANIL & 0 & 0 \\
\hline CAMPO BELO & CAMACHO & 0 & 0 \\
\hline CAMPO BELO & CAMPO BELO & 2 & 0 \\
\hline CAMPO BELO & CANA VERDE & 0 & 0 \\
\hline CAMPO BELO & CANDEIAS & 1 & 0 \\
\hline CAMPO BELO & CRISTAIS & 1 & 0 \\
\hline
\end{tabular}




\begin{tabular}{|c|c|c|c|}
\hline CAMPO BELO & LAVRAS & 0 & 0 \\
\hline CAMPO BELO & PERDOES & 1 & 0 \\
\hline CAMPO BELO & RIBEIRAO VERMELHO & 0 & 0 \\
\hline CAMPO BELO & SANTANA DO JACARE & 0 & 0 \\
\hline CAMPO BELO & SANTO ANTONIO DO AMPARO & 1 & 0 \\
\hline CAMPO BELO & SAO FRANCISCO DE PAULA & 0 & 0 \\
\hline CARANGOLA & ALTO CAPARAO & 0 & 0 \\
\hline CARANGOLA & CAIANA & 0 & 0 \\
\hline CARANGOLA & CAPARAO & 1 & 0 \\
\hline CARANGOLA & CARANGOLA & 0 & 0 \\
\hline CARANGOLA & DIVINO & 0 & 0 \\
\hline CARANGOLA & ESPERA FELIZ & 1 & 0 \\
\hline CARANGOLA & FARIA LEMOS & 0 & 0 \\
\hline CARANGOLA & FERVEDOURO & 0 & 0 \\
\hline CARANGOLA & ORIZANIA & 0 & 0 \\
\hline CARANGOLA & PEDRA DOURADA & 0 & 0 \\
\hline CARANGOLA & TOMBOS & 0 & 0 \\
\hline CARATINGA & ALVARENGA & 1 & 0 \\
\hline CARATINGA & BOM JESUS DO GALHO & 1 & 0 \\
\hline CARATINGA & BUGRE & 0 & 0 \\
\hline CARATINGA & CARATINGA & 5 & 2 \\
\hline CARATINGA & CORREGO NOVO & 0 & 0 \\
\hline CARATINGA & DOM CAVATI & 0 & 0 \\
\hline CARATINGA & ENTRE FOLHAS & 0 & 0 \\
\hline CARATINGA & IAPU & 0 & 0 \\
\hline CARATINGA & IMBE DE MINAS & 0 & 0 \\
\hline CARATINGA & INHAPIM & 1 & 0 \\
\hline CARATINGA & IPABA & 1 & 0 \\
\hline CARATINGA & IPANEMA & 0 & 0 \\
\hline CARATINGA & PIEDADE DE CARATINGA & 0 & 0 \\
\hline CARATINGA & PINGO D AGUA & 0 & 0 \\
\hline CARATINGA & POCRANE & 1 & 0 \\
\hline CARATINGA & SANTA BARBARA DO LESTE & 0 & 0 \\
\hline CARATINGA & SANTA RITA DE MINAS & 1 & 0 \\
\hline CARATINGA & SAO DOMINGOS DAS DORES & 0 & 0 \\
\hline CARATINGA & SAO JOAO DO ORIENTE & 0 & 0 \\
\hline CARATINGA & SAO SEBASTIAO DO ANTA & 0 & 0 \\
\hline CARATINGA & TAPARUBA & 0 & 0 \\
\hline CARATINGA & TARUMIRIM & 0 & 0 \\
\hline CARATINGA & UBAPORANGA & 0 & 0 \\
\hline CARATINGA & VARGEM ALEGRE & 0 & 0 \\
\hline CAXAMBU & AIURUOCA & 0 & 0 \\
\hline CAXAMBU & ALAGOA & 0 & 0 \\
\hline CAXAMBU & BAEPENDI & 0 & 0 \\
\hline CAXAMBU & BOCAINA DE MINAS & 0 & 0 \\
\hline
\end{tabular}




\begin{tabular}{|c|c|c|c|}
\hline CAXAMBU & CARVALHOS & 0 & 0 \\
\hline CAXAMBU & CAXAMBU & 0 & 0 \\
\hline CAXAMBU & CONCEICAO DO RIO VERDE & 0 & 0 \\
\hline CAXAMBU & CRUZILIA & 3 & 0 \\
\hline CAXAMBU & ITAMONTE & 0 & 0 \\
\hline CAXAMBU & ITANHANDU & 0 & 0 \\
\hline CAXAMBU & JESUANIA & 0 & 0 \\
\hline CAXAMBU & LIBERDADE & 0 & 0 \\
\hline CAXAMBU & MINDURI & 0 & 0 \\
\hline CAXAMBU & OLIMPIO NORONHA & 0 & 0 \\
\hline CAXAMBU & PASSA QUATRO & 0 & 0 \\
\hline CAXAMBU & PASSA VINTE & 0 & 0 \\
\hline CAXAMBU & POUSO ALTO & 0 & 0 \\
\hline CAXAMBU & SAO LOURENCO & 0 & 0 \\
\hline CAXAMBU & SAO SEBASTIAO DO RIO VERDE & 0 & 0 \\
\hline CAXAMBU & SAO TOME DAS LETRAS & 0 & 0 \\
\hline CAXAMBU & SERITINGA & 0 & 0 \\
\hline CAXAMBU & SERRANOS & 0 & 0 \\
\hline CAXAMBU & SOLEDADE DE MINAS & 0 & 0 \\
\hline CORONEL FABRICIANO & ANTONIO DIAS & 1 & 0 \\
\hline CORONEL FABRICIANO & BELO ORIENTE & 1 & 0 \\
\hline CORONEL FABRICIANO & BRAUNAS & 0 & 0 \\
\hline CORONEL FABRICIANO & CORONEL FABRICIANO & 2 & 0 \\
\hline CORONEL FABRICIANO & IPATINGA & 5 & 2 \\
\hline CORONEL FABRICIANO & JAGUARAÇU & 0 & 0 \\
\hline CORONEL FABRICIANO & JOANESIA & 0 & 0 \\
\hline CORONEL FABRICIANO & MARLIERIA & 0 & 0 \\
\hline CORONEL FABRICIANO & MESQUITA & 0 & 0 \\
\hline CORONEL FABRICIANO & SANTANA DO PARAISO & 2 & 0 \\
\hline CORONEL FABRICIANO & TIMOTEO & 0 & 0 \\
\hline CONSELHEIRO LAFAIETE & CARANAIBA & 0 & 0 \\
\hline CONSELHEIRO LAFAIETE & CASA GRANDE & 0 & 0 \\
\hline CONSELHEIRO LAFAIETE & CATAS ALTAS DA NORUEGA & 0 & 0 \\
\hline CONSELHEIRO LAFAIETE & CONGONHAS & 0 & 0 \\
\hline CONSELHEIRO LAFAIETE & CONSELHEIRO LAFAIETE & 1 & 0 \\
\hline CONSELHEIRO LAFAIETE & CRISTIANO OTONI & 0 & 0 \\
\hline CONSELHEIRO LAFAIETE & DESTERRO DE ENTRE RIOS & 1 & 0 \\
\hline CONSELHEIRO LAFAIETE & ENTRE RIOS DE MINAS & 1 & 0 \\
\hline CONSELHEIRO LAFAIETE & ITAVERAVA & 0 & 0 \\
\hline CONSELHEIRO LAFAIETE & JECEABA & 0 & 0 \\
\hline CONSELHEIRO LAFAIETE & LAMIM & 0 & 0 \\
\hline CONSELHEIRO LAFAIETE & OURO BRANCO & 0 & 0 \\
\hline CONSELHEIRO LAFAIETE & PIRANGA & 2 & 0 \\
\hline CONSELHEIRO LAFAIETE & QUELUZITO & 0 & 0 \\
\hline CONSELHEIRO LAFAIETE & RIO ESPERA & 0 & 0 \\
\hline
\end{tabular}




\begin{tabular}{|c|c|c|c|}
\hline CONSELHEIRO LAFAIETE & SANTANA DOS MONTES & 0 & 0 \\
\hline CONSELHEIRO LAFAIETE & SAO BRAS DO SUACUI & 0 & 0 \\
\hline CONSELHEIRO LAFAIETE & SENHORA DE OLIVEIRA & 1 & 0 \\
\hline CURVELO & AUGUSTO DE LIMA & 0 & 0 \\
\hline CURVELO & BUENOPOLIS & 1 & 0 \\
\hline CURVELO & CORINTO & 2 & 0 \\
\hline CURVELO & CURVELO & 2 & 0 \\
\hline CURVELO & FELIXLANDIA & 0 & 0 \\
\hline CURVELO & INIMUTABA & 3 & 0 \\
\hline CURVELO & JOAQUIM FELICIO & 0 & 0 \\
\hline CURVELO & LASSANCE & 0 & 0 \\
\hline CURVELO & MORRO DA GARCA & 0 & 0 \\
\hline CURVELO & PRESIDENTE JUSCELINO & 0 & 0 \\
\hline CURVELO & SANTO HIPOLITO & 0 & 0 \\
\hline CURVELO & TRES MARIAS & 1 & 0 \\
\hline DIAMANTINA & ALVORADA DE MINAS & 0 & 0 \\
\hline DIAMANTINA & ANGELANDIA & 2 & 0 \\
\hline DIAMANTINA & ARICANDUVA & 1 & 0 \\
\hline DIAMANTINA & CAPELINHA & 3 & 0 \\
\hline DIAMANTINA & CARBONITA & 0 & 0 \\
\hline DIAMANTINA & CONCEICAO DO MATO DENTRO & 0 & 0 \\
\hline DIAMANTINA & CONGONHAS DO NORTE & 0 & 0 \\
\hline DIAMANTINA & COUTO DE MAGALHAES DE MINAS & 0 & 0 \\
\hline DIAMANTINA & DATAS & 1 & 0 \\
\hline DIAMANTINA & DIAMANTINA & 0 & 0 \\
\hline DIAMANTINA & FELICIO DOS SANTOS & 0 & 0 \\
\hline DIAMANTINA & GOUVEA & 0 & 0 \\
\hline DIAMANTINA & ITAMARANDIBA & 3 & 0 \\
\hline DIAMANTINA & LEME DO PRADO & 0 & 0 \\
\hline DIAMANTINA & MINAS NOVAS & 3 & 0 \\
\hline DIAMANTINA & MONJOLOS & 1 & 0 \\
\hline DIAMANTINA & PRESIDENTE KUBITSCHEK & 0 & 0 \\
\hline DIAMANTINA & RIO VERMELHO & 1 & 0 \\
\hline DIAMANTINA & SANTO ANTONIO DO ITAMBE & 0 & 0 \\
\hline DIAMANTINA & SAO GONCALO DO RIO PRETO & 0 & 0 \\
\hline DIAMANTINA & SENADOR MODESTINO GONCALVES & 0 & 0 \\
\hline DIAMANTINA & SERRA AZUL DE MINAS & 0 & 0 \\
\hline DIAMANTINA & SERRO & 1 & 0 \\
\hline DIAMANTINA & TURMALINA & 0 & 0 \\
\hline DIAMANTINA & VEREDINHA & 1 & 0 \\
\hline DIVINÓPOLIS & ARAUJOS & 0 & 0 \\
\hline DIVINÓPOLIS & ARCOS & 0 & 0 \\
\hline DIVINÓPOLIS & BAMBUI & 0 & 0 \\
\hline DIVINÓPOLIS & CARMO DA MATA & 0 & 0 \\
\hline DIVINÓPOLIS & CARMO DO CAJURU & 1 & 0 \\
\hline
\end{tabular}




\begin{tabular}{|c|c|c|c|}
\hline DIVINÓPOLIS & CARMOPOLIS DE MINAS & 0 & 0 \\
\hline DIVINÓPOLIS & CLAUDIO & 0 & 0 \\
\hline DIVINÓPOLIS & CORREGO DANTA & 0 & 0 \\
\hline DIVINÓPOLIS & DIVINOPOLIS & 2 & 0 \\
\hline DIVINÓPOLIS & IGUATAMA & 0 & 0 \\
\hline DIVINÓPOLIS & ITAGUARA & 0 & 0 \\
\hline DIVINÓPOLIS & ITAPECERICA & 0 & 0 \\
\hline DIVINÓPOLIS & ITATIAIUCU & 0 & 0 \\
\hline DIVINÓPOLIS & ITAUNA & 2 & 0 \\
\hline DIVINÓPOLIS & JAPARAIBA & 0 & 0 \\
\hline DIVINÓPOLIS & LAGOA DA PRATA & 0 & 0 \\
\hline DIVINÓPOLIS & LUZ & 1 & 0 \\
\hline DIVINÓPOLIS & MEDEIROS & 0 & 0 \\
\hline DIVINÓPOLIS & MOEMA & 0 & 0 \\
\hline DIVINÓPOLIS & NOVA SERRANA & 2 & 0 \\
\hline DIVINÓPOLIS & OLIVEIRA & 1 & 0 \\
\hline DIVINÓPOLIS & PAINS & 0 & 0 \\
\hline DIVINÓPOLIS & PASSA TEMPO & 0 & 0 \\
\hline DIVINÓPOLIS & PEDRA DO INDAIA & 0 & 0 \\
\hline DIVINÓPOLIS & PERDIGAO & 0 & 0 \\
\hline DIVINÓPOLIS & PIRACEMA & 0 & 0 \\
\hline DIVINÓPOLIS & SANTO ANTONIO DO MONTE & 2 & 0 \\
\hline DIVINÓPOLIS & SAO GONCALO DO PARA & 1 & 0 \\
\hline DIVINÓPOLIS & SAO SEBASTIAO DO OESTE & 0 & 0 \\
\hline DIVINÓPOLIS & TAPIRAI & 0 & 0 \\
\hline GOVERNADOR VALADARES & ACUCENA & 0 & 0 \\
\hline GOVERNADOR VALADARES & AIMORES & 2 & 0 \\
\hline GOVERNADOR VALADARES & ALPERCATA & 2 & 0 \\
\hline GOVERNADOR VALADARES & CAPITAO ANDRADE & 1 & 0 \\
\hline GOVERNADOR VALADARES & CENTRAL DE MINAS & 1 & 0 \\
\hline GOVERNADOR VALADARES & CONSELHEIRO PENA & 1 & 0 \\
\hline GOVERNADOR VALADARES & COROACI & 1 & 0 \\
\hline GOVERNADOR VALADARES & CUPARAQUE & 1 & 0 \\
\hline GOVERNADOR VALADARES & DIVINO DAS LARANJEIRAS & 0 & 0 \\
\hline GOVERNADOR VALADARES & ENGENHEIRO CALDAS & 0 & 0 \\
\hline GOVERNADOR VALADARES & FERNANDES TOURINHO & 0 & 0 \\
\hline GOVERNADOR VALADARES & FREI INOCENCIO & 0 & 0 \\
\hline GOVERNADOR VALADARES & GALILEIA & 1 & 0 \\
\hline GOVERNADOR VALADARES & GOIABEIRA & 0 & 0 \\
\hline GOVERNADOR VALADARES & GOVERNADOR VALADARES & 2 & 0 \\
\hline GOVERNADOR VALADARES & ITABIRINHA & 0 & 0 \\
\hline GOVERNADOR VALADARES & ITANHOMI & 1 & 0 \\
\hline GOVERNADOR VALADARES & ITUETA & 0 & 0 \\
\hline GOVERNADOR VALADARES & MANTENA & 1 & 0 \\
\hline GOVERNADOR VALADARES & MARILAC & 0 & 0 \\
\hline
\end{tabular}




\begin{tabular}{|c|c|c|c|}
\hline GOVERNADOR VALADARES & MATHIAS LOBATO & 0 & 0 \\
\hline GOVERNADOR VALADARES & MENDES PIMENTEL & 0 & 0 \\
\hline GOVERNADOR VALADARES & NACIP RAYDAN & 0 & 0 \\
\hline GOVERNADOR VALADARES & NAQUE & 0 & 0 \\
\hline GOVERNADOR VALADARES & NOVA BELEM & 0 & 0 \\
\hline GOVERNADOR VALADARES & NOVA MODICA & 0 & 0 \\
\hline GOVERNADOR VALADARES & PERIQUITO & 0 & 0 \\
\hline GOVERNADOR VALADARES & RESPLENDOR & 0 & 0 \\
\hline GOVERNADOR VALADARES & SANTA EFIGENIA DE MINAS & 0 & 0 \\
\hline GOVERNADOR VALADARES & SANTA RITA DO ITUETO & 0 & 0 \\
\hline GOVERNADOR VALADARES & SAO FELIX DE MINAS & 1 & 0 \\
\hline GOVERNADOR VALADARES & SAO GERALDO DA PIEDADE & 0 & 0 \\
\hline GOVERNADOR VALADARES & SAO GERALDO DO BAIXIO & 0 & 0 \\
\hline GOVERNADOR VALADARES & SAO JOAO DO MANTENINHA & 0 & 0 \\
\hline GOVERNADOR VALADARES & SAO JOSE DA SAFIRA & 1 & 0 \\
\hline GOVERNADOR VALADARES & SAO JOSE DO DIVINO & 0 & 0 \\
\hline GOVERNADOR VALADARES & SARDOA & 0 & 0 \\
\hline GOVERNADOR VALADARES & SOBRALIA & 0 & 0 \\
\hline GOVERNADOR VALADARES & TUMIRITINGA & 1 & 0 \\
\hline GOVERNADOR VALADARES & VIRGOLANDIA & 0 & 0 \\
\hline GUANHÃES & AGUA BOA & 3 & 0 \\
\hline GUANHÃES & CANTAGALO & 0 & 0 \\
\hline GUANHÃES & CARMESIA & 0 & 0 \\
\hline GUANHÃES & COLUNA & 0 & 0 \\
\hline GUANHÃES & DIVINOLANDIA DE MINAS & 0 & 0 \\
\hline GUANHÃES & DOM JOAQUIM & 0 & 0 \\
\hline GUANHÃES & DORES DE GUANHAES & 0 & 0 \\
\hline GUANHÃES & FREI LAGONEGRO & 0 & 0 \\
\hline GUANHÃES & GONZAGA & 1 & 0 \\
\hline GUANHÃES & GUANHAES & 6 & 2 \\
\hline GUANHÃES & JOSE RAYDAN & 0 & 0 \\
\hline GUANHÃES & MATERLANDIA & 0 & 0 \\
\hline GUANHÃES & PAULISTAS & 0 & 0 \\
\hline GUANHÃES & PECANHA & 0 & 0 \\
\hline GUANHÃES & SABINOPOLIS & 2 & 0 \\
\hline GUANHÃES & SANTA MARIA DO SUACUI & 1 & 0 \\
\hline GUANHÃES & SAO JOAO EVANGELISTA & 1 & 0 \\
\hline GUANHÃES & SAO JOSE DO JACURI & 1 & 0 \\
\hline GUANHÃES & SAO PEDRO DO SUACUI & 0 & 0 \\
\hline GUANHÃES & SAO SEBASTIAO DO MARANHAO & 1 & 0 \\
\hline GUANHÃES & SENHORA DO PORTO & 1 & 0 \\
\hline GUANHÃES & VIRGINOPOLIS & 0 & 0 \\
\hline ITAJUBÁ & BRASOPOLIS & 0 & 0 \\
\hline ITAJUBÁ & CARMO DE MINAS & 0 & 0 \\
\hline ITAJUBÁ & CONCEICAO DAS PEDRAS & 0 & 0 \\
\hline
\end{tabular}




\begin{tabular}{|c|c|c|c|}
\hline ITAJUBÁ & CONCEICAO DOS OUROS & 0 & 0 \\
\hline ITAJUBÁ & CONSOLACAO & 0 & 0 \\
\hline ITAJUBÁ & CRISTINA & 0 & 0 \\
\hline ITAJUBÁ & DELFIM MOREIRA & 0 & 0 \\
\hline ITAJUBÁ & DOM VICOSO & 0 & 0 \\
\hline ITAJUBÁ & GONCALVES & 0 & 0 \\
\hline ITAJUBÁ & ITAJUBA & 1 & 0 \\
\hline ITAJUBÁ & MARIA DA FE & 1 & 0 \\
\hline ITAJUBÁ & MARMELOPOLIS & 1 & 0 \\
\hline ITAJUBÁ & NATERCIA & 0 & 0 \\
\hline ITAJUBÁ & PARAISOPOLIS & 0 & 0 \\
\hline ITAJUBÁ & PEDRALVA & 0 & 0 \\
\hline ITAJUBÁ & PIRANGUCU & 0 & 0 \\
\hline ITAJUBÁ & PIRANGUINHO & 0 & 0 \\
\hline ITAJUBÁ & SAO JOSE DO ALEGRE & 0 & 0 \\
\hline ITAJUBÁ & SAPUCAI-MIRIM & 1 & 0 \\
\hline ITAJUBÁ & VIRGINIA & 0 & 0 \\
\hline ITAJUBÁ & WENCESLAU BRAZ & 0 & 0 \\
\hline ITUIUTABA & CACHOEIRA DOURADA & 0 & 0 \\
\hline ITUIUTABA & CANAPOLIS & 0 & 0 \\
\hline ITUIUTABA & CAPINOPOLIS & 0 & 0 \\
\hline ITUIUTABA & CENTRALINA & 0 & 0 \\
\hline ITUIUTABA & GURINHATA & 0 & 0 \\
\hline ITUIUTABA & IPIACU & 0 & 0 \\
\hline ITUIUTABA & ITUIUTABA & 1 & 0 \\
\hline ITUIUTABA & SANTA VITORIA & 1 & 0 \\
\hline JANAUBA & CATUTI & 0 & 0 \\
\hline JANAUBA & ESPINOSA & 1 & 0 \\
\hline JANAUBA & GAMELEIRAS & 0 & 0 \\
\hline JANAUBA & JAIBA & 3 & 0 \\
\hline JANAUBA & JANAUBA & 1 & 0 \\
\hline JANAUBA & MAMONAS & 0 & 0 \\
\hline JANAUBA & MATO VERDE & 0 & 0 \\
\hline JANAUBA & MONTE AZUL & 0 & 0 \\
\hline JANAUBA & MONTEZUMA & 0 & 0 \\
\hline JANAUBA & NOVA PORTEIRINHA & 1 & 0 \\
\hline JANAUBA & PAI PEDRO & 1 & 0 \\
\hline JANAUBA & PORTEIRINHA & 2 & 0 \\
\hline JANAUBA & RIACHO DOS MACHADOS & 0 & 0 \\
\hline JANAUBA & RIO PARDO DE MINAS & 5 & 2 \\
\hline JANAUBA & SANTO ANTONIO DO RETIRO & 0 & 0 \\
\hline JANAUBA & SERRANOPOLIS DE MINAS & 0 & 0 \\
\hline JANAUBA & VERDELANDIA & 0 & 0 \\
\hline JANUARIA & BONITO DE MINAS & 1 & 0 \\
\hline JANUARIA & CHAPADA GAUCHA & 0 & 0 \\
\hline
\end{tabular}




\begin{tabular}{|c|c|c|c|}
\hline JANUARIA & CONEGO MARINHO & 2 & 0 \\
\hline JANUARIA & IBIRACATU & 0 & 0 \\
\hline JANUARIA & ICARAI DE MINAS & 0 & 0 \\
\hline JANUARIA & ITACARAMBI & 2 & 0 \\
\hline JANUARIA & JANUARIA & 5 & 2 \\
\hline JANUARIA & JUVENILIA & 1 & 0 \\
\hline JANUARIA & MANGA & 1 & 0 \\
\hline JANUARIA & MATIAS CARDOSO & 2 & 0 \\
\hline JANUARIA & MIRAVANIA & 0 & 0 \\
\hline JANUARIA & MONTALVANIA & 1 & 0 \\
\hline JANUARIA & PEDRAS DE MARIA DA CRUZ & 2 & 0 \\
\hline JANUARIA & PINTOPOLIS & 0 & 0 \\
\hline JANUARIA & SAO FRANCISCO & 9 & 2 \\
\hline JANUARIA & SAO JOAO DAS MISSOES & 1 & 0 \\
\hline JANUARIA & UBAI & 0 & 0 \\
\hline JANUARIA & URUCUIA & 0 & 0 \\
\hline JANUARIA & VARZELANDIA & 0 & 0 \\
\hline JUIZ DE FORA & ARANTINA & 0 & 0 \\
\hline JUIZ DE FORA & BELMIRO BRAGA & 0 & 0 \\
\hline JUIZ DE FORA & BICAS & 1 & 0 \\
\hline JUIZ DE FORA & BOM JARDIM DE MINAS & 0 & 0 \\
\hline JUIZ DE FORA & CHACARA & 0 & 0 \\
\hline JUIZ DE FORA & CHIADOR & 0 & 0 \\
\hline JUIZ DE FORA & CORONEL PACHECO & 0 & 0 \\
\hline JUIZ DE FORA & DESCOBERTO & 0 & 0 \\
\hline JUIZ DE FORA & EWBANK DA CAMARA & 0 & 0 \\
\hline JUIZ DE FORA & GOIANA & 1 & 0 \\
\hline JUIZ DE FORA & GUARARA & 0 & 0 \\
\hline JUIZ DE FORA & JUIZ DE FORA & 6 & 2 \\
\hline JUIZ DE FORA & LIMA DUARTE & 0 & 0 \\
\hline JUIZ DE FORA & MAR DE ESPANHA & 0 & 0 \\
\hline JUIZ DE FORA & MARIPA DE MINAS & 0 & 0 \\
\hline JUIZ DE FORA & MATIAS BARBOSA & 0 & 0 \\
\hline JUIZ DE FORA & OLARIA & 0 & 0 \\
\hline JUIZ DE FORA & PEDRO TEIXEIRA & 1 & 0 \\
\hline JUIZ DE FORA & PEQUERI & 0 & 0 \\
\hline JUIZ DE FORA & PIAU & 0 & 0 \\
\hline JUIZ DE FORA & RIO NOVO & 0 & 0 \\
\hline JUIZ DE FORA & RIO PRETO & 0 & 0 \\
\hline JUIZ DE FORA & ROCHEDO DE MINAS & 0 & 0 \\
\hline JUIZ DE FORA & SANTA BARBARA DO MONTE VERDE & 1 & 0 \\
\hline JUIZ DE FORA & SANTA RITA DE JACUTINGA & 0 & 0 \\
\hline JUIZ DE FORA & SANTANA DO DESERTO & 0 & 0 \\
\hline JUIZ DE FORA & SANTOS DUMONT & 1 & 0 \\
\hline JUIZ DE FORA & SAO JOAO NEPOMUCENO & 0 & 0 \\
\hline
\end{tabular}




\begin{tabular}{|c|c|c|c|}
\hline JUIZ DE FORA & SENADOR CORTES & 0 & 0 \\
\hline JUIZ DE FORA & SIMAO PEREIRA & 0 & 0 \\
\hline MANHUAÇU & ALTO JEQUITIBA & 1 & 0 \\
\hline MANHUAÇU & CAPUTIRA & 0 & 0 \\
\hline MANHUAÇU & CHALE & 0 & 0 \\
\hline MANHUAÇU & CONCEICAO DE IPANEMA & 0 & 0 \\
\hline MANHUAÇU & DURANDE & 0 & 0 \\
\hline MANHUAÇU & LAJINHA & 1 & 0 \\
\hline MANHUAÇU & LUISBURGO & 0 & 0 \\
\hline MANHUAÇU & MANHUACU & 4 & 0 \\
\hline MANHUAÇU & MANHUMIRIM & 1 & 0 \\
\hline MANHUAÇU & MARTINS SOARES & 0 & 0 \\
\hline MANHUAÇU & MATIPO & 1 & 0 \\
\hline MANHUAÇU & MUTUM & 3 & 0 \\
\hline MANHUAÇU & REDUTO & 0 & 0 \\
\hline MANHUAÇU & SANTA MARGARIDA & 0 & 0 \\
\hline MANHUAÇU & SANTANA DO MANHUACU & 1 & 0 \\
\hline MANHUAÇU & SAO JOAO DO MANHUACU & 0 & 0 \\
\hline MANHUAÇU & SAO JOSE DO MANTIMENTO & 0 & 0 \\
\hline MANHUAÇU & SIMONESIA & 1 & 0 \\
\hline METROPOLITANA A & BARAO DE COCAIS & 0 & 0 \\
\hline METROPOLITANA A & BELO HORIZONTE & 13 & 3 \\
\hline METROPOLITANA A & BELO VALE & 0 & 0 \\
\hline METROPOLITANA A & BOM JESUS DO AMPARO & 0 & 0 \\
\hline METROPOLITANA A & BONFIM & 0 & 0 \\
\hline METROPOLITANA A & BRUMADINHO & 0 & 0 \\
\hline METROPOLITANA A & CAETE & 1 & 0 \\
\hline METROPOLITANA A & CATAS ALTAS & 0 & 0 \\
\hline METROPOLITANA A & CRUCILANDIA & 0 & 0 \\
\hline METROPOLITANA A & MOEDA & 0 & 0 \\
\hline METROPOLITANA A & NOVA LIMA & 3 & 0 \\
\hline METROPOLITANA A & NOVA UNIAO & 0 & 0 \\
\hline METROPOLITANA A & PIEDADE DOS GERAIS & 1 & 0 \\
\hline METROPOLITANA A & RAPOSOS & 1 & 0 \\
\hline METROPOLITANA A & RIO ACIMA & 0 & 0 \\
\hline METROPOLITANA A & RIO MANSO & 0 & 0 \\
\hline METROPOLITANA A & SABARA & 2 & 0 \\
\hline METROPOLITANA A & SANTA BARBARA & 2 & 0 \\
\hline METROPOLITANA B & BELO HORIZONTE & 20 & 6 \\
\hline METROPOLITANA B & BETIM & 17 & 5 \\
\hline METROPOLITANA B & CONTAGEM & 18 & 5 \\
\hline METROPOLITANA B & ESMERALDAS & 4 & 0 \\
\hline METROPOLITANA B & IBIRITE & 6 & 2 \\
\hline METROPOLITANA B & IGARAPE & 2 & 0 \\
\hline METROPOLITANA B & JUATUBA & 1 & 0 \\
\hline
\end{tabular}




\begin{tabular}{|c|c|c|c|}
\hline METROPOLITANA B & MARIO CAMPOS & 4 & 0 \\
\hline METROPOLITANA B & MATEUS LEME & 2 & 0 \\
\hline METROPOLITANA B & SAO JOAQUIM DE BICAS & 0 & 0 \\
\hline METROPOLITANA B & SARZEDO & 3 & 0 \\
\hline METROPOLITANA C & BELO HORIZONTE & 13 & 3 \\
\hline METROPOLITANA C & CONFINS & 0 & 0 \\
\hline METROPOLITANA C & JABOTICATUBAS & 0 & 0 \\
\hline METROPOLITANA C & LAGOA SANTA & 4 & 0 \\
\hline METROPOLITANA C & MORRO DO PILAR & 0 & 0 \\
\hline METROPOLITANA C & PEDRO LEOPOLDO & 0 & 0 \\
\hline METROPOLITANA C & RIBEIRAO DAS NEVES & 16 & 5 \\
\hline METROPOLITANA C & SANTA LUZIA & 3 & 0 \\
\hline METROPOLITANA C & SANTANA DO RIACHO & 0 & 0 \\
\hline METROPOLITANA C & SAO JOSE DA LAPA & 1 & 0 \\
\hline METROPOLITANA C & TAQUARACU DE MINAS & 0 & 0 \\
\hline METROPOLITANA C & VESPASIANO & 2 & 0 \\
\hline MONTE CARMELO & ABADIA DOS DOURADOS & 0 & 0 \\
\hline MONTE CARMELO & CASCALHO RICO & 0 & 0 \\
\hline MONTE CARMELO & COROMANDEL & 2 & 0 \\
\hline MONTE CARMELO & DOURADOQUARA & 0 & 0 \\
\hline MONTE CARMELO & ESTRELA DO SUL & 1 & 0 \\
\hline MONTE CARMELO & GRUPIARA & 0 & 0 \\
\hline MONTE CARMELO & MONTE CARMELO & 1 & 0 \\
\hline MONTE CARMELO & ROMARIA & 0 & 0 \\
\hline MONTES CLAROS & BOCAIUVA & 0 & 0 \\
\hline MONTES CLAROS & BOTUMIRIM & 0 & 0 \\
\hline MONTES CLAROS & BRASILIA DE MINAS & 1 & 0 \\
\hline MONTES CLAROS & CAMPO AZUL & 0 & 0 \\
\hline MONTES CLAROS & CAPITAO ENEAS & 0 & 0 \\
\hline MONTES CLAROS & CLARO DOS POCOES & 0 & 0 \\
\hline MONTES CLAROS & CORACAO DE JESUS & 1 & 0 \\
\hline MONTES CLAROS & CRISTALIA & 1 & 0 \\
\hline MONTES CLAROS & ENGENHEIRO NAVARRO & 1 & 0 \\
\hline MONTES CLAROS & FRANCISCO DUMONT & 0 & 0 \\
\hline MONTES CLAROS & FRANCISCO SA & 1 & 0 \\
\hline MONTES CLAROS & GLAUCILANDIA & 1 & 0 \\
\hline MONTES CLAROS & GRAO MOGOL & 1 & 0 \\
\hline MONTES CLAROS & GUARACIAMA & 0 & 0 \\
\hline MONTES CLAROS & ITACAMBIRA & 1 & 0 \\
\hline MONTES CLAROS & JAPONVAR & 0 & 0 \\
\hline MONTES CLAROS & JOSENOPOLIS & 0 & 0 \\
\hline MONTES CLAROS & JURAMENTO & 0 & 0 \\
\hline MONTES CLAROS & LONTRA & 1 & 0 \\
\hline MONTES CLAROS & LUISLANDIA & 1 & 0 \\
\hline MONTES CLAROS & MIRABELA & 0 & 0 \\
\hline
\end{tabular}




\begin{tabular}{|c|c|c|c|}
\hline MONTES CLAROS & MONTES CLAROS & 5 & 2 \\
\hline MONTES CLAROS & OLHOS-D AGUA & 1 & 0 \\
\hline MONTES CLAROS & PADRE CARVALHO & 1 & 0 \\
\hline MONTES CLAROS & PATIS & 0 & 0 \\
\hline MONTES CLAROS & SAO JOAO DA LAGOA & 1 & 0 \\
\hline MONTES CLAROS & SAO JOAO DA PONTE & 0 & 0 \\
\hline MONTES CLAROS & SAO JOAO DO PACUI & 1 & 0 \\
\hline MONTES CLAROS & SAO JOAO DO PARAISO & 0 & 0 \\
\hline MONTES CLAROS & VARGEM GRANDE DO RIO PARDO & 0 & 0 \\
\hline MURIAÉ & ANTONIO PRADO DE MINAS & 1 & 0 \\
\hline MURIAÉ & BARAO DE MONTE ALTO & 0 & 0 \\
\hline MURIAÉ & EUGENOPOLIS & 1 & 0 \\
\hline MURIAÉ & LARANJAL & 0 & 0 \\
\hline MURIAÉ & MIRADOURO & 0 & 0 \\
\hline MURIAÉ & MIRAI & 0 & 0 \\
\hline MURIAÉ & MURIAE & 0 & 0 \\
\hline MURIAÉ & PALMA & 0 & 0 \\
\hline MURIAÉ & PATROCINIO DO MURIAE & 0 & 0 \\
\hline MURIAÉ & ROSARIO DA LIMEIRA & 0 & 0 \\
\hline MURIAÉ & SANTANA DE CATAGUASES & 0 & 0 \\
\hline MURIAÉ & SAO FRANCISCO DO GLORIA & 0 & 0 \\
\hline MURIAÉ & SAO SEBASTIAO DA VARGEM ALEGRE & 0 & 0 \\
\hline MURIAÉ & VIEIRAS & 0 & 0 \\
\hline NOVA ERA & BELA VISTA DE MINAS & 0 & 0 \\
\hline NOVA ERA & DIONISIO & 0 & 0 \\
\hline NOVA ERA & FERROS & 0 & 0 \\
\hline NOVA ERA & ITABIRA & 0 & 0 \\
\hline NOVA ERA & ITAMBE DO MATO DENTRO & 0 & 0 \\
\hline NOVA ERA & JOAO MONLEVADE & 0 & 0 \\
\hline NOVA ERA & NOVA ERA & 0 & 0 \\
\hline NOVA ERA & PASSABEM & 0 & 0 \\
\hline NOVA ERA & RIO PIRACICABA & 0 & 0 \\
\hline NOVA ERA & SANTA MARIA DE ITABIRA & 0 & 0 \\
\hline NOVA ERA & SANTO ANTONIO DO RIO ABAIXO & 0 & 0 \\
\hline NOVA ERA & SAO DOMINGOS DO PRATA & 1 & 0 \\
\hline NOVA ERA & SAO GONCALO DO RIO ABAIXO & 0 & 0 \\
\hline NOVA ERA & SAO JOSE DO GOIABAL & 0 & 0 \\
\hline NOVA ERA & SAO SEBASTIAO DO RIO PRETO & 0 & 0 \\
\hline OURO PRETO & ACAIACA & 0 & 0 \\
\hline OURO PRETO & DIOGO DE VASCONCELOS & 1 & 0 \\
\hline OURO PRETO & ITABIRITO & 2 & 0 \\
\hline OURO PRETO & MARIANA & 2 & 0 \\
\hline OURO PRETO & OURO PRETO & 7 & 2 \\
\hline PARA DE MINAS & ABAETE & 1 & 0 \\
\hline PARA DE MINAS & BIQUINHAS & 0 & 0 \\
\hline
\end{tabular}




\begin{tabular}{|c|c|c|c|}
\hline PARA DE MINAS & BOM DESPACHO & 0 & 0 \\
\hline PARA DE MINAS & CEDRO DO ABAETE & 0 & 0 \\
\hline PARA DE MINAS & CONCEICAO DO PARA & 0 & 0 \\
\hline PARA DE MINAS & DORES DO INDAIA & 0 & 0 \\
\hline PARA DE MINAS & ESTRELA DO INDAIA & 0 & 0 \\
\hline PARA DE MINAS & FLORESTAL & 2 & 0 \\
\hline PARA DE MINAS & IGARATINGA & 1 & 0 \\
\hline PARA DE MINAS & LEANDRO FERREIRA & 1 & 0 \\
\hline PARA DE MINAS & MARTINHO CAMPOS & 0 & 0 \\
\hline PARA DE MINAS & MORADA NOVA DE MINAS & 0 & 0 \\
\hline PARA DE MINAS & ONCA DE PITANGUI & 0 & 0 \\
\hline PARA DE MINAS & PAINEIRAS & 0 & 0 \\
\hline PARA DE MINAS & PARA DE MINAS & 3 & 0 \\
\hline PARA DE MINAS & PEQUI & 0 & 0 \\
\hline PARA DE MINAS & PITANGUI & 2 & 0 \\
\hline PARA DE MINAS & QUARTEL GERAL & 0 & 0 \\
\hline PARA DE MINAS & SAO JOSE DA VARGINHA & 0 & 0 \\
\hline PARA DE MINAS & SERRA DA SAUDADE & 0 & 0 \\
\hline PARACATU & BRASILANDIA DE MINAS & 0 & 0 \\
\hline PARACATU & GUARDA-MOR & 0 & 0 \\
\hline PARACATU & JOAO PINHEIRO & 1 & 0 \\
\hline PARACATU & PARACATU & 1 & 0 \\
\hline PARACATU & VAZANTE & 0 & 0 \\
\hline PASSOS & ALPINOPOLIS & 0 & 0 \\
\hline PASSOS & BOM JESUS DA PENHA & 0 & 0 \\
\hline PASSOS & CAPITOLIO & 1 & 0 \\
\hline PASSOS & CARMO DO RIO CLARO & 0 & 0 \\
\hline PASSOS & CORREGO FUNDO & 0 & 0 \\
\hline PASSOS & DELFINOPOLIS & 1 & 0 \\
\hline PASSOS & DORESOPOLIS & 0 & 0 \\
\hline PASSOS & FORMIGA & 2 & 0 \\
\hline PASSOS & FORTALEZA DE MINAS & 0 & 0 \\
\hline PASSOS & PASSOS & 2 & 0 \\
\hline PASSOS & PIMENTA & 0 & 0 \\
\hline PASSOS & PIUMHI & 1 & 0 \\
\hline PASSOS & SAO JOAO BATISTA DO GLORIA & 0 & 0 \\
\hline PASSOS & SAO JOSE DA BARRA & 0 & 0 \\
\hline PASSOS & SAO ROQUE DE MINAS & 1 & 0 \\
\hline PASSOS & VARGEM BONITA & 0 & 0 \\
\hline PATOS DE MINAS & ARAPUA & 0 & 0 \\
\hline PATOS DE MINAS & CARMO DO PARANAIBA & 2 & 0 \\
\hline PATOS DE MINAS & LAGAMAR & 0 & 0 \\
\hline PATOS DE MINAS & LAGOA FORMOSA & 0 & 0 \\
\hline PATOS DE MINAS & LAGOA GRANDE & 0 & 0 \\
\hline PATOS DE MINAS & MATUTINA & 0 & 0 \\
\hline
\end{tabular}




\begin{tabular}{|c|c|c|c|}
\hline PATOS DE MINAS & PATOS DE MINAS & 0 & 0 \\
\hline PATOS DE MINAS & PRESIDENTE OLEGARIO & 0 & 0 \\
\hline PATOS DE MINAS & RIO PARANAIBA & 0 & 0 \\
\hline PATOS DE MINAS & SANTA ROSA DA SERRA & 0 & 0 \\
\hline PATOS DE MINAS & SAO GONCALO DO ABAETE & 0 & 0 \\
\hline PATOS DE MINAS & SAO GOTARDO & 4 & 0 \\
\hline PATOS DE MINAS & TIROS & 0 & 0 \\
\hline PATOS DE MINAS & VARJAO DE MINAS & 0 & 0 \\
\hline PATROCÍNIO & CRUZEIRO DA FORTALEZA & 1 & 0 \\
\hline PATROCÍNIO & GUIMARANIA & 0 & 0 \\
\hline PATROCÍNIO & IBIA & 1 & 0 \\
\hline PATROCÍNIO & IRAI DE MINAS & 0 & 0 \\
\hline PATROCÍNIO & PATROCINIO & 1 & 0 \\
\hline PATROCÍNIO & PERDIZES & 0 & 0 \\
\hline PATROCÍNIO & SERRA DO SALITRE & 0 & 0 \\
\hline PIRAPORA & BURITIZEIRO & 3 & 0 \\
\hline PIRAPORA & IBIAI & 0 & 0 \\
\hline PIRAPORA & JEQUITAI & 0 & 0 \\
\hline PIRAPORA & LAGOA DOS PATOS & 0 & 0 \\
\hline PIRAPORA & PIRAPORA & 0 & 0 \\
\hline PIRAPORA & PONTO CHIQUE & 0 & 0 \\
\hline PIRAPORA & SANTA FE DE MINAS & 0 & 0 \\
\hline PIRAPORA & SAO ROMAO & 1 & 0 \\
\hline PIRAPORA & VARZEA DA PALMA & 0 & 0 \\
\hline POÇOS DE CALDAS & ALTEROSA & 0 & 0 \\
\hline POÇOS DE CALDAS & ANDRADAS & 3 & 0 \\
\hline POÇOS DE CALDAS & AREADO & 0 & 0 \\
\hline POÇOS DE CALDAS & BANDEIRA DO SUL & 1 & 0 \\
\hline POÇOS DE CALDAS & BOTELHOS & 1 & 0 \\
\hline POÇOS DE CALDAS & CABO VERDE & 1 & 0 \\
\hline POÇOS DE CALDAS & CALDAS & 0 & 0 \\
\hline POÇOS DE CALDAS & CAMPESTRE & 0 & 0 \\
\hline POÇOS DE CALDAS & CONCEICAO DA APARECIDA & 0 & 0 \\
\hline POÇOS DE CALDAS & DIVISA NOVA & 0 & 0 \\
\hline POÇOS DE CALDAS & IBITIURA DE MINAS & 0 & 0 \\
\hline POÇOS DE CALDAS & MONTE BELO & 0 & 0 \\
\hline POÇOS DE CALDAS & MUZAMBINHO & 1 & 0 \\
\hline POÇOS DE CALDAS & NOVA RESENDE & 1 & 0 \\
\hline POÇOS DE CALDAS & POCOS DE CALDAS & 2 & 0 \\
\hline POÇOS DE CALDAS & SANTA RITA DE CALDAS & 1 & 0 \\
\hline POÇOS DE CALDAS & SERRANIA & 0 & 0 \\
\hline PONTE NOVA & ABRE CAMPO & 1 & 0 \\
\hline PONTE NOVA & ALVINOPOLIS & 0 & 0 \\
\hline PONTE NOVA & AMPARO DO SERRA & 0 & 0 \\
\hline PONTE NOVA & ARAPONGA & 0 & 0 \\
\hline
\end{tabular}




\begin{tabular}{|c|c|c|c|}
\hline PONTE NOVA & BARRA LONGA & 0 & 0 \\
\hline PONTE NOVA & CAJURI & 0 & 0 \\
\hline PONTE NOVA & CANAA & 0 & 0 \\
\hline PONTE NOVA & DOM SILVERIO & 0 & 0 \\
\hline PONTE NOVA & GUARACIABA & 0 & 0 \\
\hline PONTE NOVA & JEQUERI & 0 & 0 \\
\hline PONTE NOVA & ORATORIOS & 0 & 0 \\
\hline PONTE NOVA & PEDRA BONITA & 0 & 0 \\
\hline PONTE NOVA & PEDRA DO ANTA & 1 & 0 \\
\hline PONTE NOVA & PIEDADE DE PONTE NOVA & 0 & 0 \\
\hline PONTE NOVA & PONTE NOVA & 0 & 0 \\
\hline PONTE NOVA & PORTO FIRME & 1 & 0 \\
\hline PONTE NOVA & RAUL SOARES & 1 & 0 \\
\hline PONTE NOVA & RIO CASCA & 0 & 0 \\
\hline PONTE NOVA & RIO DOCE & 0 & 0 \\
\hline PONTE NOVA & SANTA CRUZ DO ESCALVADO & 0 & 0 \\
\hline PONTE NOVA & SANTO ANTONIO DO GRAMA & 0 & 0 \\
\hline PONTE NOVA & SAO MIGUEL DO ANTA & 0 & 0 \\
\hline PONTE NOVA & SAO PEDRO DOS FERROS & 0 & 0 \\
\hline PONTE NOVA & SEM-PEIXE & 0 & 0 \\
\hline PONTE NOVA & SERICITA & 1 & 0 \\
\hline PONTE NOVA & TEIXEIRAS & 0 & 0 \\
\hline PONTE NOVA & URUCANIA & 0 & 0 \\
\hline PONTE NOVA & VERMELHO NOVO & 0 & 0 \\
\hline PONTE NOVA & VICOSA & 2 & 0 \\
\hline POUSO ALEGRE & ALBERTINA & 1 & 0 \\
\hline POUSO ALEGRE & BOM REPOUSO & 0 & 0 \\
\hline POUSO ALEGRE & BORDA DA MATA & 1 & 0 \\
\hline POUSO ALEGRE & BUENO BRANDAO & 0 & 0 \\
\hline POUSO ALEGRE & CACHOEIRA DE MINAS & 0 & 0 \\
\hline POUSO ALEGRE & CAMANDUCAIA & 1 & 0 \\
\hline POUSO ALEGRE & CAMBUI & 1 & 0 \\
\hline POUSO ALEGRE & CAREACU & 1 & 0 \\
\hline POUSO ALEGRE & CONGONHAL & 0 & 0 \\
\hline POUSO ALEGRE & CORREGO DO BOM JESUS & 0 & 0 \\
\hline POUSO ALEGRE & ESPIRITO SANTO DO DOURADO & 0 & 0 \\
\hline POUSO ALEGRE & ESTIVA & 0 & 0 \\
\hline POUSO ALEGRE & EXTREMA & 1 & 0 \\
\hline POUSO ALEGRE & HELIODORA & 0 & 0 \\
\hline POUSO ALEGRE & INCONFIDENTES & 0 & 0 \\
\hline POUSO ALEGRE & IPUIUNA & 0 & 0 \\
\hline POUSO ALEGRE & ITAPEVA & 1 & 0 \\
\hline POUSO ALEGRE & JACUTINGA & 0 & 0 \\
\hline POUSO ALEGRE & MONTE SIAO & 1 & 0 \\
\hline POUSO ALEGRE & MUNHOZ & 0 & 0 \\
\hline
\end{tabular}




\begin{tabular}{|c|c|c|c|}
\hline POUSO ALEGRE & OURO FINO & 1 & 0 \\
\hline POUSO ALEGRE & POUSO ALEGRE & 2 & 0 \\
\hline POUSO ALEGRE & SANTA RITA DO SAPUCAI & 1 & 0 \\
\hline POUSO ALEGRE & SAO JOAO DA MATA & 0 & 0 \\
\hline POUSO ALEGRE & SAO SEBASTIAO DA BELA VISTA & 0 & 0 \\
\hline POUSO ALEGRE & SENADOR AMARAL & 0 & 0 \\
\hline POUSO ALEGRE & SENADOR JOSE BENTO & 1 & 0 \\
\hline POUSO ALEGRE & SILVIANOPOLIS & 0 & 0 \\
\hline POUSO ALEGRE & TOCOS DO MOJI & 0 & 0 \\
\hline POUSO ALEGRE & TOLEDO & 0 & 0 \\
\hline SÃO JOÃO DEL REI & BOM SUCESSO & 0 & 0 \\
\hline SÃO JOÃO DEL REI & CARRANCAS & 0 & 0 \\
\hline SÃO JOÃO DEL REI & CONCEICAO DA BARRA DE MINAS & 1 & 0 \\
\hline SÃO JOÃO DEL REI & CORONEL XAVIER CHAVES & 0 & 0 \\
\hline SÃO JOÃO DEL REI & DORES DE CAMPOS & 0 & 0 \\
\hline SÃO JOÃO DEL REI & IBITURUNA & 0 & 0 \\
\hline SÃO JOÃO DEL REI & IJACI & 0 & 0 \\
\hline SÃO JOÃO DEL REI & INGAI & 0 & 0 \\
\hline SÃO JOÃO DEL REI & ITUMIRIM & 0 & 0 \\
\hline SÃO JOÃO DEL REI & ITUTINGA & 0 & 0 \\
\hline SÃO JOÃO DEL REI & LAGOA DOURADA & 0 & 0 \\
\hline SÃO JOÃO DEL REI & NAZARENO & 0 & 0 \\
\hline SÃO JOÃO DEL REI & PRADOS & 0 & 0 \\
\hline SÃO JOÃO DEL REI & RESENDE COSTA & 0 & 0 \\
\hline SÃO JOÃO DEL REI & RITAPOLIS & 0 & 0 \\
\hline SÃO JOÃO DEL REI & SANTA CRUZ DE MINAS & 0 & 0 \\
\hline SÃO JOÃO DEL REI & SAO JOAO DEL REI & 1 & 0 \\
\hline SÃO JOÃO DEL REI & SAO TIAGO & 0 & 0 \\
\hline SÃO JOÃO DEL REI & TIRADENTES & 0 & 0 \\
\hline SÃO SEBASTIÃO DO PARAÍSO & ARCEBURGO & 0 & 0 \\
\hline SÃO SEBASTIÃO DO PARAÍSO & CAPETINGA & 0 & 0 \\
\hline SÃO SEBASTIÃO DO PARAÍSO & CASSIA & 0 & 0 \\
\hline SÃO SEBASTIÃO DO PARAÍSO & CLARAVAL & 0 & 0 \\
\hline SÃO SEBASTIÃO DO PARAÍSO & GUARANESIA & 0 & 0 \\
\hline SÃO SEBASTIÃO DO PARAÍSO & GUAXUPE & 1 & 0 \\
\hline SÃO SEBASTIÃO DO PARAÍSO & IBIRACI & 0 & 0 \\
\hline SÃO SEBASTIÃO DO PARAÍSO & ITAMOGI & 0 & 0 \\
\hline SÃO SEBASTIÃO DO PARAÍSO & ITAU DE MINAS & 0 & 0 \\
\hline SÃO SEBASTIÃO DO PARAÍSO & JACUI & 0 & 0 \\
\hline SÃO SEBASTIÃO DO PARAÍSO & JURUAIA & 0 & 0 \\
\hline SÃO SEBASTIÃO DO PARAÍSO & MONTE SANTO DE MINAS & 0 & 0 \\
\hline SÃO SEBASTIÃO DO PARAÍSO & PRATAPOLIS & 0 & 0 \\
\hline SÃO SEBASTIÃO DO PARAÍSO & SAO PEDRO DA UNIAO & 0 & 0 \\
\hline SÃO SEBASTIÃO DO PARAÍSO & SAO SEBASTIAO DO PARAISO & 0 & 0 \\
\hline SÃO SEBASTIÃO DO PARAÍSO & SAO TOMAS DE AQUINO & 0 & 0 \\
\hline
\end{tabular}




\begin{tabular}{|c|c|c|c|}
\hline SETE LAGOAS & ARACAI & 0 & 0 \\
\hline SETE LAGOAS & BALDIM & 0 & 0 \\
\hline SETE LAGOAS & CACHOEIRA DA PRATA & 0 & 0 \\
\hline SETE LAGOAS & CAETANOPOLIS & 0 & 0 \\
\hline SETE LAGOAS & CAPIM BRANCO & 2 & 0 \\
\hline SETE LAGOAS & CORDISBURGO & 0 & 0 \\
\hline SETE LAGOAS & FORTUNA DE MINAS & 0 & 0 \\
\hline SETE LAGOAS & FUNILANDIA & 0 & 0 \\
\hline SETE LAGOAS & INHAUMA & 0 & 0 \\
\hline SETE LAGOAS & JEQUITIBA & 0 & 0 \\
\hline SETE LAGOAS & MARAVILHAS & 0 & 0 \\
\hline SETE LAGOAS & MATOZINHOS & 0 & 0 \\
\hline SETE LAGOAS & PAPAGAIOS & 0 & 0 \\
\hline SETE LAGOAS & PARAOPEBA & 1 & 0 \\
\hline SETE LAGOAS & POMPEU & 0 & 0 \\
\hline SETE LAGOAS & PRUDENTE DE MORAIS & 0 & 0 \\
\hline SETE LAGOAS & SANTANA DE PIRAPAMA & 0 & 0 \\
\hline SETE LAGOAS & SETE LAGOAS & 3 & 0 \\
\hline TEOFILO OTONI & AGUAS FORMOSAS & 0 & 0 \\
\hline TEOFILO OTONI & ATALEIA & 0 & 0 \\
\hline TEOFILO OTONI & BERTOPOLIS & 2 & 0 \\
\hline TEOFILO OTONI & CAMPANARIO & 0 & 0 \\
\hline TEOFILO OTONI & CARAI & 0 & 0 \\
\hline TEOFILO OTONI & CARLOS CHAGAS & 0 & 0 \\
\hline TEOFILO OTONI & CATUJI & 0 & 0 \\
\hline TEOFILO OTONI & CRISOLITA & 1 & 0 \\
\hline TEOFILO OTONI & FRANCISCOPOLIS & 0 & 0 \\
\hline TEOFILO OTONI & FREI GASPAR & 0 & 0 \\
\hline TEOFILO OTONI & FRONTEIRA DOS VALES & 0 & 0 \\
\hline TEOFILO OTONI & ITAIPE & 0 & 0 \\
\hline TEOFILO OTONI & ITAMBACURI & 0 & 0 \\
\hline TEOFILO OTONI & JAMPRUCA & 0 & 0 \\
\hline TEOFILO OTONI & LADAINHA & 1 & 0 \\
\hline TEOFILO OTONI & MACHACALIS & 0 & 0 \\
\hline TEOFILO OTONI & MALACACHETA & 2 & 0 \\
\hline TEOFILO OTONI & NANUQUE & 2 & 0 \\
\hline TEOFILO OTONI & NOVO CRUZEIRO & 0 & 0 \\
\hline TEOFILO OTONI & NOVO ORIENTE DE MINAS & 1 & 0 \\
\hline TEOFILO OTONI & OURO VERDE DE MINAS & 0 & 0 \\
\hline TEOFILO OTONI & PADRE PARAISO & 2 & 0 \\
\hline TEOFILO OTONI & PAVAO & 0 & 0 \\
\hline TEOFILO OTONI & PESCADOR & 0 & 0 \\
\hline TEOFILO OTONI & PONTO DOS VOLANTES & 1 & 0 \\
\hline TEOFILO OTONI & POTE & 1 & 0 \\
\hline TEOFILO OTONI & SANTA HELENA DE MINAS & 0 & 0 \\
\hline
\end{tabular}




\begin{tabular}{|c|c|c|c|}
\hline TEOFILO OTONI & SERRA DOS AIMORES & 1 & 0 \\
\hline TEOFILO OTONI & SETUBINHA & 0 & 0 \\
\hline TEOFILO OTONI & TEOFILO OTONI & 6 & 2 \\
\hline TEOFILO OTONI & UMBURATIBA & 0 & 0 \\
\hline UBÁ & ASTOLFO DUTRA & 1 & 0 \\
\hline UBÁ & BRAS PIRES & 1 & 0 \\
\hline UBÁ & COIMBRA & 0 & 0 \\
\hline UBÁ & DIVINESIA & 0 & 0 \\
\hline UBÁ & DONA EUZEBIA & 0 & 0 \\
\hline UBÁ & DORES DO TURVO & 0 & 0 \\
\hline UBÁ & ERVALIA & 0 & 0 \\
\hline UBÁ & GUARANI & 0 & 0 \\
\hline UBÁ & GUIDOVAL & 0 & 0 \\
\hline UBÁ & GUIRICEMA & 0 & 0 \\
\hline UBÁ & PAULA CANDIDO & 0 & 0 \\
\hline UBÁ & PIRAUBA & 1 & 0 \\
\hline UBÁ & PRESIDENTE BERNARDES & 0 & 0 \\
\hline UBÁ & RIO POMBA & 0 & 0 \\
\hline UBÁ & RODEIRO & 0 & 0 \\
\hline UBÁ & SAO GERALDO & 0 & 0 \\
\hline UBÁ & SENADOR FIRMINO & 0 & 0 \\
\hline UBÁ & SILVEIRANIA & 0 & 0 \\
\hline UBÁ & TABULEIRO & 0 & 0 \\
\hline UBÁ & TOCANTINS & 0 & 0 \\
\hline UBÁ & UBA & 1 & 0 \\
\hline UBÁ & VISCONDE DO RIO BRANCO & 1 & 0 \\
\hline UBERABA & AGUA COMPRIDA & 1 & 0 \\
\hline UBERABA & ARAXA & 3 & 0 \\
\hline UBERABA & CAMPO FLORIDO & 0 & 0 \\
\hline UBERABA & CAMPOS ALTOS & 0 & 0 \\
\hline UBERABA & CARNEIRINHO & 1 & 0 \\
\hline UBERABA & COMENDADOR GOMES & 0 & 0 \\
\hline UBERABA & CONCEICAO DAS ALAGOAS & 0 & 0 \\
\hline UBERABA & CONQUISTA & 0 & 0 \\
\hline UBERABA & DELTA & 0 & 0 \\
\hline UBERABA & FRONTEIRA & 1 & 0 \\
\hline UBERABA & FRUTAL & 1 & 0 \\
\hline UBERABA & ITAPAGIPE & 2 & 0 \\
\hline UBERABA & ITURAMA & 1 & 0 \\
\hline UBERABA & LIMEIRA DO OESTE & 0 & 0 \\
\hline UBERABA & PEDRINOPOLIS & 0 & 0 \\
\hline UBERABA & PIRAJUBA & 0 & 0 \\
\hline UBERABA & PLANURA & 0 & 0 \\
\hline UBERABA & PRATINHA & 0 & 0 \\
\hline UBERABA & SACRAMENTO & 0 & 0 \\
\hline
\end{tabular}




\begin{tabular}{|c|c|c|c|}
\hline UBERABA & SANTA JULIANA & 1 & 0 \\
\hline UBERABA & SAO FRANCISCO DE SALES & 0 & 0 \\
\hline UBERABA & TAPIRA & 0 & 0 \\
\hline UBERABA & UBERABA & 11 & 2 \\
\hline UBERABA & UNIAO DE MINAS & 0 & 0 \\
\hline UBERABA & VERISSIMO & 0 & 0 \\
\hline UBERLANDIA & ARAGUARI & 0 & 0 \\
\hline UBERLANDIA & ARAPORA & 0 & 0 \\
\hline UBERLANDIA & CAMPINA VERDE & 0 & 0 \\
\hline UBERLANDIA & INDIANOPOLIS & 1 & 0 \\
\hline UBERLANDIA & MONTE ALEGRE DE MINAS & 0 & 0 \\
\hline UBERLANDIA & NOVA PONTE & 1 & 0 \\
\hline UBERLANDIA & PRATA & 0 & 0 \\
\hline UBERLANDIA & TUPACIGUARA & 1 & 0 \\
\hline UBERLANDIA & UBERLANDIA & 15 & 3 \\
\hline UNAI & ARINOS & 2 & 0 \\
\hline UNAI & BONFINOPOLIS DE MINAS & 0 & 0 \\
\hline UNAI & BURITIS & 1 & 0 \\
\hline UNAI & CABECEIRA GRANDE & 1 & 0 \\
\hline UNAI & DOM BOSCO & 1 & 0 \\
\hline UNAI & FORMOSO & 1 & 0 \\
\hline UNAI & NATALANDIA & 0 & 0 \\
\hline UNAI & RIACHINHO & 0 & 0 \\
\hline UNAI & UNAI & 1 & 0 \\
\hline UNAI & URUANA DE MINAS & 1 & 0 \\
\hline VARGINHA & ALFENAS & 4 & 0 \\
\hline VARGINHA & BOA ESPERANCA & 1 & 0 \\
\hline VARGINHA & CAMBUQUIRA & 0 & 0 \\
\hline VARGINHA & CAMPANHA & 0 & 0 \\
\hline VARGINHA & CAMPO DO MEIO & 0 & 0 \\
\hline VARGINHA & CAMPOS GERAIS & 0 & 0 \\
\hline VARGINHA & CARMO DA CACHOEIRA & 1 & 0 \\
\hline VARGINHA & CARVALHOPOLIS & 0 & 0 \\
\hline VARGINHA & COQUEIRAL & 0 & 0 \\
\hline VARGINHA & CORDISLANDIA & 0 & 0 \\
\hline VARGINHA & ELOI MENDES & 0 & 0 \\
\hline VARGINHA & FAMA & 0 & 0 \\
\hline VARGINHA & GUAPE & 0 & 0 \\
\hline VARGINHA & ILICINEA & 0 & 0 \\
\hline VARGINHA & LAMBARI & 0 & 0 \\
\hline VARGINHA & LUMINARIAS & 0 & 0 \\
\hline VARGINHA & MACHADO & 0 & 0 \\
\hline VARGINHA & MONSENHOR PAULO & 0 & 0 \\
\hline VARGINHA & NEPOMUCENO & 0 & 0 \\
\hline VARGINHA & PARAGUACU & 0 & 0 \\
\hline
\end{tabular}




\begin{tabular}{|l|l|c|c|} 
VARGINHA & POCO FUNDO & 0 & 0 \\
\hline VARGINHA & SANTANA DA VARGEM & 0 & 0 \\
\hline VARGINHA & SAO BENTO ABADE & 0 & 0 \\
\hline VARGINHA & SAO GONCALO DO SAPUCAI & 0 & 0 \\
\hline VARGINHA & TRES CORACOES & 1 & 0 \\
\hline VARGINHA & TRES PONTAS & 2 & 0 \\
\hline VARGINHA & TURVOLANDIA & 0 & 0 \\
\hline VARGINHA & VARGINHA & 4 & 0 \\
\hline Total geral & & $\mathbf{5 4 2}$ & $\mathbf{5 4}$ \\
\hline
\end{tabular}

CARGO: PROFESSOR DE EDUCAÇÃO BÁSICA - PEB - LÍNGUA PORTUGUESA

\begin{tabular}{|c|c|c|c|}
\hline S R E & MUNICIPIO & $\begin{array}{l}\text { TOTAL DE } \\
\text { VAGAS }\end{array}$ & $\begin{array}{c}\text { VAGAS } \\
\text { RESERVADAS - } \\
\text { PORTADORES DE } \\
\text { DEFICIÊNCIA } \\
\end{array}$ \\
\hline ALMENARA & AGUAS VERMELHAS & 0 & 0 \\
\hline ALMENARA & ALMENARA & 0 & 0 \\
\hline ALMENARA & BANDEIRA & 0 & 0 \\
\hline ALMENARA & CACHOEIRA DE PAJEU & 0 & 0 \\
\hline ALMENARA & CURRAL DE DENTRO & 0 & 0 \\
\hline ALMENARA & DIVISA ALEGRE & 0 & 0 \\
\hline ALMENARA & DIVISOPOLIS & 0 & 0 \\
\hline ALMENARA & FELISBURGO & 3 & 0 \\
\hline ALMENARA & JACINTO & 1 & 0 \\
\hline ALMENARA & JEQUITINHONHA & 3 & 0 \\
\hline ALMENARA & JOAIMA & 2 & 0 \\
\hline ALMENARA & JORDANIA & 0 & 0 \\
\hline ALMENARA & MATA VERDE & 0 & 0 \\
\hline ALMENARA & MONTE FORMOSO & 0 & 0 \\
\hline ALMENARA & PALMOPOLIS & 0 & 0 \\
\hline ALMENARA & PEDRA AZUL & 2 & 0 \\
\hline ALMENARA & RIO DO PRADO & 0 & 0 \\
\hline ALMENARA & RUBIM & 0 & 0 \\
\hline ALMENARA & SALTO DA DIVISA & 0 & 0 \\
\hline ALMENARA & SANTA MARIA DO SALTO & 0 & 0 \\
\hline ALMENARA & SANTO ANTONIO DO JACINTO & 0 & 0 \\
\hline ARACUAI & ARACUAI & 2 & 0 \\
\hline ARACUAI & BERILO & 2 & 0 \\
\hline ARACUAI & BERIZAL & 0 & 0 \\
\hline ARACUAI & CHAPADA DO NORTE & 2 & 0 \\
\hline ARACUAI & COMERCINHO & 0 & 0 \\
\hline ARACUAI & CORONEL MURTA & 0 & 0 \\
\hline ARACUAI & FRANCISCO BADARO & 1 & 0 \\
\hline ARACUAI & FRUTA DE LEITE & 0 & 0 \\
\hline ARACUAI & INDAIABIRA & 0 & 0 \\
\hline ARACUAI & ITAOBIM & 0 & 0 \\
\hline
\end{tabular}




\begin{tabular}{|c|c|c|c|}
\hline ARACUAI & ITINGA & 1 & 0 \\
\hline ARACUAI & JENIPAPO DE MINAS & 3 & 0 \\
\hline ARACUAI & JOSE GONCALVES DE MINAS & 0 & 0 \\
\hline ARACUAI & MEDINA & 2 & 0 \\
\hline ARACUAI & NINHEIRA & 4 & 0 \\
\hline ARACUAI & NOVORIZONTE & 1 & 0 \\
\hline ARACUAI & RUBELITA & 1 & 0 \\
\hline ARACUAI & SALINAS & 5 & 1 \\
\hline ARACUAI & SANTA CRUZ DE SALINAS & 2 & 0 \\
\hline ARACUAI & TAIOBEIRAS & 5 & 1 \\
\hline ARACUAI & VIRGEM DA LAPA & 2 & 0 \\
\hline BARBACENA & ALFREDO VASCONCELOS & 0 & 0 \\
\hline BARBACENA & ALTO RIO DOCE & 0 & 0 \\
\hline BARBACENA & ANDRELANDIA & 0 & 0 \\
\hline BARBACENA & ANTONIO CARLOS & 4 & 0 \\
\hline BARBACENA & ARACITABA & 0 & 0 \\
\hline BARBACENA & BARBACENA & 3 & 0 \\
\hline BARBACENA & BARROSO & 0 & 0 \\
\hline BARBACENA & BIAS FORTES & 0 & 0 \\
\hline BARBACENA & CAPELA NOVA & 0 & 0 \\
\hline BARBACENA & CARANDAI & 0 & 0 \\
\hline BARBACENA & CIPOTANEA & 0 & 0 \\
\hline BARBACENA & DESTERRO DO MELO & 0 & 0 \\
\hline BARBACENA & IBERTIOGA & 0 & 0 \\
\hline BARBACENA & MADRE DE DEUS DE MINAS & 0 & 0 \\
\hline BARBACENA & MERCES & 0 & 0 \\
\hline BARBACENA & OLIVEIRA FORTES & 0 & 0 \\
\hline BARBACENA & PAIVA & 1 & 0 \\
\hline BARBACENA & PIEDADE DO RIO GRANDE & 0 & 0 \\
\hline BARBACENA & RESSAQUINHA & 0 & 0 \\
\hline BARBACENA & SANTA BARBARA DO TUGURIO & 0 & 0 \\
\hline BARBACENA & SANTA RITA DO IBITIPOCA & 0 & 0 \\
\hline BARBACENA & SANTANA DO GARAMBEU & 0 & 0 \\
\hline BARBACENA & SAO VICENTE DE MINAS & 0 & 0 \\
\hline BARBACENA & SENHORA DOS REMEDIOS & 1 & 0 \\
\hline CAMPO BELO & AGUANIL & 0 & 0 \\
\hline CAMPO BELO & CAMACHO & 0 & 0 \\
\hline CAMPO BELO & CAMPO BELO & 5 & 1 \\
\hline CAMPO BELO & CANA VERDE & 1 & 0 \\
\hline CAMPO BELO & CANDEIAS & 1 & 0 \\
\hline CAMPO BELO & CRISTAIS & 2 & 0 \\
\hline CAMPO BELO & LAVRAS & 2 & 0 \\
\hline CAMPO BELO & PERDOES & 0 & 0 \\
\hline CAMPO BELO & RIBEIRAO VERMELHO & 1 & 0 \\
\hline CAMPO BELO & SANTANA DO JACARE & 0 & 0 \\
\hline
\end{tabular}




\begin{tabular}{|c|c|c|c|}
\hline CAMPO BELO & SANTO ANTONIO DO AMPARO & 0 & 0 \\
\hline CAMPO BELO & SAO FRANCISCO DE PAULA & 0 & 0 \\
\hline CARANGOLA & ALTO CAPARAO & 1 & 0 \\
\hline CARANGOLA & CAIANA & 0 & 0 \\
\hline CARANGOLA & CAPARAO & 1 & 0 \\
\hline CARANGOLA & CARANGOLA & 0 & 0 \\
\hline CARANGOLA & DIVINO & 1 & 0 \\
\hline CARANGOLA & ESPERA FELIZ & 0 & 0 \\
\hline CARANGOLA & FARIA LEMOS & 0 & 0 \\
\hline CARANGOLA & FERVEDOURO & 2 & 0 \\
\hline CARANGOLA & ORIZANIA & 0 & 0 \\
\hline CARANGOLA & PEDRA DOURADA & 1 & 0 \\
\hline CARANGOLA & TOMBOS & 0 & 0 \\
\hline CARATINGA & ALVARENGA & 1 & 0 \\
\hline CARATINGA & BOM JESUS DO GALHO & 0 & 0 \\
\hline CARATINGA & BUGRE & 0 & 0 \\
\hline CARATINGA & CARATINGA & 4 & 0 \\
\hline CARATINGA & CORREGO NOVO & 0 & 0 \\
\hline CARATINGA & DOM CAVATI & 0 & 0 \\
\hline CARATINGA & ENTRE FOLHAS & 0 & 0 \\
\hline CARATINGA & IAPU & 0 & 0 \\
\hline CARATINGA & IMBE DE MINAS & 0 & 0 \\
\hline CARATINGA & INHAPIM & 0 & 0 \\
\hline CARATINGA & IPABA & 3 & 0 \\
\hline CARATINGA & IPANEMA & 1 & 0 \\
\hline CARATINGA & PIEDADE DE CARATINGA & 0 & 0 \\
\hline CARATINGA & PINGO D AGUA & 0 & 0 \\
\hline CARATINGA & POCRANE & 1 & 0 \\
\hline CARATINGA & SANTA BARBARA DO LESTE & 0 & 0 \\
\hline CARATINGA & SANTA RITA DE MINAS & 0 & 0 \\
\hline CARATINGA & SAO DOMINGOS DAS DORES & 0 & 0 \\
\hline CARATINGA & SAO JOAO DO ORIENTE & 0 & 0 \\
\hline CARATINGA & SAO SEBASTIAO DO ANTA & 0 & 0 \\
\hline CARATINGA & TAPARUBA & 0 & 0 \\
\hline CARATINGA & TARUMIRIM & 1 & 0 \\
\hline CARATINGA & UBAPORANGA & 1 & 0 \\
\hline CARATINGA & VARGEM ALEGRE & 0 & 0 \\
\hline CAXAMBU & AIURUOCA & 0 & 0 \\
\hline CAXAMBU & ALAGOA & 0 & 0 \\
\hline CAXAMBU & BAEPENDI & 1 & 0 \\
\hline CAXAMBU & BOCAINA DE MINAS & 0 & 0 \\
\hline CAXAMBU & CARVALHOS & 0 & 0 \\
\hline CAXAMBU & CAXAMBU & 1 & 0 \\
\hline CAXAMBU & CONCEICAO DO RIO VERDE & 0 & 0 \\
\hline CAXAMBU & CRUZILIA & 2 & 0 \\
\hline
\end{tabular}




\begin{tabular}{|c|c|c|c|}
\hline CAXAMBU & ITAMONTE & 0 & 0 \\
\hline CAXAMBU & ITANHANDU & 2 & 0 \\
\hline CAXAMBU & JESUANIA & 0 & 0 \\
\hline CAXAMBU & LIBERDADE & 0 & 0 \\
\hline CAXAMBU & MINDURI & 0 & 0 \\
\hline CAXAMBU & OLIMPIO NORONHA & 0 & 0 \\
\hline CAXAMBU & PASSA QUATRO & 1 & 0 \\
\hline CAXAMBU & PASSA VINTE & 0 & 0 \\
\hline CAXAMBU & POUSO ALTO & 0 & 0 \\
\hline CAXAMBU & SAO LOURENCO & 3 & 0 \\
\hline CAXAMBU & SAO SEBASTIAO DO RIO VERDE & 0 & 0 \\
\hline CAXAMBU & SAO TOME DAS LETRAS & 0 & 0 \\
\hline CAXAMBU & SERITINGA & 0 & 0 \\
\hline CAXAMBU & SERRANOS & 1 & 0 \\
\hline CAXAMBU & SOLEDADE DE MINAS & 0 & 0 \\
\hline CORONEL FABRICIANO & ANTONIO DIAS & 1 & 0 \\
\hline CORONEL FABRICIANO & BELO ORIENTE & 0 & 0 \\
\hline CORONEL FABRICIANO & BRAUNAS & 0 & 0 \\
\hline CORONEL FABRICIANO & CORONEL FABRICIANO & 8 & 1 \\
\hline CORONEL FABRICIANO & IPATINGA & 10 & 2 \\
\hline CORONEL FABRICIANO & JAGUARAÇU & 0 & 0 \\
\hline CORONEL FABRICIANO & JOANESIA & 0 & 0 \\
\hline CORONEL FABRICIANO & MARLIERIA & 0 & 0 \\
\hline CORONEL FABRICIANO & MESQUITA & 0 & 0 \\
\hline CORONEL FABRICIANO & SANTANA DO PARAISO & 5 & 1 \\
\hline CORONEL FABRICIANO & TIMOTEO & 2 & 0 \\
\hline CONSELHEIRO LAFAIETE & CARANAIBA & 0 & 0 \\
\hline CONSELHEIRO LAFAIETE & CASA GRANDE & 0 & 0 \\
\hline CONSELHEIRO LAFAIETE & CATAS ALTAS DA NORUEGA & 0 & 0 \\
\hline CONSELHEIRO LAFAIETE & CONGONHAS & 0 & 0 \\
\hline CONSELHEIRO LAFAIETE & CONSELHEIRO LAFAIETE & 4 & 0 \\
\hline CONSELHEIRO LAFAIETE & CRISTIANO OTONI & 0 & 0 \\
\hline CONSELHEIRO LAFAIETE & DESTERRO DE ENTRE RIOS & 0 & 0 \\
\hline CONSELHEIRO LAFAIETE & ENTRE RIOS DE MINAS & 2 & 0 \\
\hline CONSELHEIRO LAFAIETE & ITAVERAVA & 0 & 0 \\
\hline CONSELHEIRO LAFAIETE & JECEABA & 0 & 0 \\
\hline CONSELHEIRO LAFAIETE & LAMIM & 0 & 0 \\
\hline CONSELHEIRO LAFAIETE & OURO BRANCO & 0 & 0 \\
\hline CONSELHEIRO LAFAIETE & PIRANGA & 7 & 1 \\
\hline CONSELHEIRO LAFAIETE & QUELUZITO & 0 & 0 \\
\hline CONSELHEIRO LAFAIETE & RIO ESPERA & 0 & 0 \\
\hline CONSELHEIRO LAFAIETE & SANTANA DOS MONTES & 0 & 0 \\
\hline CONSELHEIRO LAFAIETE & SAO BRAS DO SUACUI & 1 & 0 \\
\hline CONSELHEIRO LAFAIETE & SENHORA DE OLIVEIRA & 1 & 0 \\
\hline CURVELO & AUGUSTO DE LIMA & 0 & 0 \\
\hline
\end{tabular}




\begin{tabular}{|c|c|c|c|}
\hline CURVELO & BUENOPOLIS & 1 & 0 \\
\hline CURVELO & CORINTO & 6 & 1 \\
\hline CURVELO & CURVELO & 3 & 0 \\
\hline CURVELO & FELIXLANDIA & 0 & 0 \\
\hline CURVELO & INIMUTABA & 2 & 0 \\
\hline CURVELO & JOAQUIM FELICIO & 0 & 0 \\
\hline CURVELO & LASSANCE & 1 & 0 \\
\hline CURVELO & MORRO DA GARCA & 0 & 0 \\
\hline CURVELO & PRESIDENTE JUSCELINO & 0 & 0 \\
\hline CURVELO & SANTO HIPOLITO & 0 & 0 \\
\hline CURVELO & TRES MARIAS & 1 & 0 \\
\hline DIAMANTINA & ALVORADA DE MINAS & 0 & 0 \\
\hline DIAMANTINA & ANGELANDIA & 2 & 0 \\
\hline DIAMANTINA & ARICANDUVA & 0 & 0 \\
\hline DIAMANTINA & CAPELINHA & 8 & 1 \\
\hline DIAMANTINA & CARBONITA & 0 & 0 \\
\hline DIAMANTINA & CONCEICAO DO MATO DENTRO & 1 & 0 \\
\hline DIAMANTINA & CONGONHAS DO NORTE & 1 & 0 \\
\hline DIAMANTINA & COUTO DE MAGALHAES DE MINAS & 1 & 0 \\
\hline DIAMANTINA & DATAS & 1 & 0 \\
\hline DIAMANTINA & DIAMANTINA & 3 & 0 \\
\hline DIAMANTINA & FELICIO DOS SANTOS & 0 & 0 \\
\hline DIAMANTINA & GOUVEA & 3 & 0 \\
\hline DIAMANTINA & ITAMARANDIBA & 3 & 0 \\
\hline DIAMANTINA & LEME DO PRADO & 1 & 0 \\
\hline DIAMANTINA & MINAS NOVAS & 5 & 1 \\
\hline DIAMANTINA & MONJOLOS & 1 & 0 \\
\hline DIAMANTINA & PRESIDENTE KUBITSCHEK & 0 & 0 \\
\hline DIAMANTINA & RIO VERMELHO & 1 & 0 \\
\hline DIAMANTINA & SANTO ANTONIO DO ITAMBE & 1 & 0 \\
\hline DIAMANTINA & SAO GONCALO DO RIO PRETO & 0 & 0 \\
\hline DIAMANTINA & SENADOR MODESTINO GONCALVES & 0 & 0 \\
\hline DIAMANTINA & SERRA AZUL DE MINAS & 0 & 0 \\
\hline DIAMANTINA & SERRO & 4 & 0 \\
\hline DIAMANTINA & TURMALINA & 2 & 0 \\
\hline DIAMANTINA & VEREDINHA & 1 & 0 \\
\hline DIVINÓPOLIS & ARAUJOS & 1 & 0 \\
\hline DIVINÓPOLIS & ARCOS & 0 & 0 \\
\hline DIVINÓPOLIS & BAMBUI & 1 & 0 \\
\hline DIVINÓPOLIS & CARMO DA MATA & 1 & 0 \\
\hline DIVINÓPOLIS & CARMO DO CAJURU & 7 & 1 \\
\hline DIVINÓPOLIS & CARMOPOLIS DE MINAS & 0 & 0 \\
\hline DIVINÓPOLIS & CLAUDIO & 1 & 0 \\
\hline DIVINÓPOLIS & CORREGO DANTA & 0 & 0 \\
\hline DIVINÓPOLIS & DIVINOPOLIS & 4 & 0 \\
\hline
\end{tabular}




\begin{tabular}{|c|c|c|c|}
\hline DIVINÓPOLIS & IGUATAMA & 0 & 0 \\
\hline DIVINÓPOLIS & ITAGUARA & 1 & 0 \\
\hline DIVINÓPOLIS & ITAPECERICA & 1 & 0 \\
\hline DIVINÓPOLIS & ITATIAIUCU & 0 & 0 \\
\hline DIVINÓPOLIS & ITAUNA & 2 & 0 \\
\hline DIVINÓPOLIS & JAPARAIBA & 1 & 0 \\
\hline DIVINÓPOLIS & LAGOA DA PRATA & 1 & 0 \\
\hline DIVINÓPOLIS & LUZ & 0 & 0 \\
\hline DIVINÓPOLIS & MEDEIROS & 1 & 0 \\
\hline DIVINÓPOLIS & MOEMA & 0 & 0 \\
\hline DIVINÓPOLIS & NOVA SERRANA & 8 & 1 \\
\hline DIVINÓPOLIS & OLIVEIRA & 2 & 0 \\
\hline DIVINÓPOLIS & PAINS & 0 & 0 \\
\hline DIVINÓPOLIS & PASSA TEMPO & 0 & 0 \\
\hline DIVINÓPOLIS & PEDRA DO INDAIA & 0 & 0 \\
\hline DIVINÓPOLIS & PERDIGAO & 0 & 0 \\
\hline DIVINÓPOLIS & PIRACEMA & 0 & 0 \\
\hline DIVINÓPOLIS & SANTO ANTONIO DO MONTE & 2 & 0 \\
\hline DIVINÓPOLIS & SAO GONCALO DO PARA & 2 & 0 \\
\hline DIVINÓPOLIS & SAO SEBASTIAO DO OESTE & 1 & 0 \\
\hline DIVINÓPOLIS & TAPIRAI & 0 & 0 \\
\hline GOVERNADOR VALADARES & ACUCENA & 0 & 0 \\
\hline GOVERNADOR VALADARES & AIMORES & 2 & 0 \\
\hline GOVERNADOR VALADARES & ALPERCATA & 0 & 0 \\
\hline GOVERNADOR VALADARES & CAPITAO ANDRADE & 1 & 0 \\
\hline GOVERNADOR VALADARES & CENTRAL DE MINAS & 1 & 0 \\
\hline GOVERNADOR VALADARES & CONSELHEIRO PENA & 4 & 0 \\
\hline GOVERNADOR VALADARES & COROACI & 0 & 0 \\
\hline GOVERNADOR VALADARES & CUPARAQUE & 2 & 0 \\
\hline GOVERNADOR VALADARES & DIVINO DAS LARANJEIRAS & 0 & 0 \\
\hline GOVERNADOR VALADARES & ENGENHEIRO CALDAS & 1 & 0 \\
\hline GOVERNADOR VALADARES & FERNANDES TOURINHO & 0 & 0 \\
\hline GOVERNADOR VALADARES & FREI INOCENCIO & 0 & 0 \\
\hline GOVERNADOR VALADARES & GALILEIA & 0 & 0 \\
\hline GOVERNADOR VALADARES & GOIABEIRA & 0 & 0 \\
\hline GOVERNADOR VALADARES & GOVERNADOR VALADARES & 6 & 1 \\
\hline GOVERNADOR VALADARES & ITABIRINHA & 0 & 0 \\
\hline GOVERNADOR VALADARES & ITANHOMI & 2 & 0 \\
\hline GOVERNADOR VALADARES & ITUETA & 0 & 0 \\
\hline GOVERNADOR VALADARES & MANTENA & 1 & 0 \\
\hline GOVERNADOR VALADARES & MARILAC & 0 & 0 \\
\hline GOVERNADOR VALADARES & MATHIAS LOBATO & 0 & 0 \\
\hline GOVERNADOR VALADARES & MENDES PIMENTEL & 1 & 0 \\
\hline GOVERNADOR VALADARES & NACIP RAYDAN & 0 & 0 \\
\hline GOVERNADOR VALADARES & NAQUE & 0 & 0 \\
\hline
\end{tabular}




\begin{tabular}{|c|c|c|c|}
\hline GOVERNADOR VALADARES & NOVA BELEM & 0 & 0 \\
\hline GOVERNADOR VALADARES & NOVA MODICA & 0 & 0 \\
\hline GOVERNADOR VALADARES & PERIQUITO & 0 & 0 \\
\hline GOVERNADOR VALADARES & RESPLENDOR & 0 & 0 \\
\hline GOVERNADOR VALADARES & SANTA EFIGENIA DE MINAS & 0 & 0 \\
\hline GOVERNADOR VALADARES & SANTA RITA DO ITUETO & 0 & 0 \\
\hline GOVERNADOR VALADARES & SAO FELIX DE MINAS & 0 & 0 \\
\hline GOVERNADOR VALADARES & SAO GERALDO DA PIEDADE & 0 & 0 \\
\hline GOVERNADOR VALADARES & SAO GERALDO DO BAIXIO & 0 & 0 \\
\hline GOVERNADOR VALADARES & SAO JOAO DO MANTENINHA & 1 & 0 \\
\hline GOVERNADOR VALADARES & SAO JOSE DA SAFIRA & 1 & 0 \\
\hline GOVERNADOR VALADARES & SAO JOSE DO DIVINO & 0 & 0 \\
\hline GOVERNADOR VALADARES & SARDOA & 1 & 0 \\
\hline GOVERNADOR VALADARES & SOBRALIA & 0 & 0 \\
\hline GOVERNADOR VALADARES & TUMIRITINGA & 1 & 0 \\
\hline GOVERNADOR VALADARES & VIRGOLANDIA & 0 & 0 \\
\hline GUANHÃES & AGUA BOA & 4 & 0 \\
\hline GUANHÃES & CANTAGALO & 0 & 0 \\
\hline GUANHÃES & CARMESIA & 1 & 0 \\
\hline GUANHÃES & COLUNA & 0 & 0 \\
\hline GUANHÃES & DIVINOLANDIA DE MINAS & 0 & 0 \\
\hline GUANHÃES & DOM JOAQUIM & 0 & 0 \\
\hline GUANHÃES & DORES DE GUANHAES & 2 & 0 \\
\hline GUANHÃES & FREI LAGONEGRO & 0 & 0 \\
\hline GUANHÃES & GONZAGA & 0 & 0 \\
\hline GUANHÃES & GUANHAES & 5 & 1 \\
\hline GUANHÃES & JOSE RAYDAN & 0 & 0 \\
\hline GUANHÃES & MATERLANDIA & 2 & 0 \\
\hline GUANHÃES & PAULISTAS & 0 & 0 \\
\hline GUANHÃES & PECANHA & 3 & 0 \\
\hline GUANHÃES & SABINOPOLIS & 4 & 0 \\
\hline GUANHÃES & SANTA MARIA DO SUACUI & 2 & 0 \\
\hline GUANHÃES & SAO JOAO EVANGELISTA & 0 & 0 \\
\hline GUANHÃES & SAO JOSE DO JACURI & 1 & 0 \\
\hline GUANHÃES & SAO PEDRO DO SUACUI & 0 & 0 \\
\hline GUANHÃES & SAO SEBASTIAO DO MARANHAO & 0 & 0 \\
\hline GUANHÃES & SENHORA DO PORTO & 0 & 0 \\
\hline GUANHÃES & VIRGINOPOLIS & 0 & 0 \\
\hline ITAJUBÁ & BRASOPOLIS & 0 & 0 \\
\hline ITAJUBÁ & CARMO DE MINAS & 0 & 0 \\
\hline ITAJUBÁ & CONCEICAO DAS PEDRAS & 0 & 0 \\
\hline ITAJUBÁ & CONCEICAO DOS OUROS & 0 & 0 \\
\hline ITAJUBÁ & CONSOLACAO & 0 & 0 \\
\hline ITAJUBÁ & CRISTINA & 0 & 0 \\
\hline ITAJUBÁ & DELFIM MOREIRA & 2 & 0 \\
\hline
\end{tabular}




\begin{tabular}{|c|c|c|c|}
\hline ITAJUBÁ & DOM VICOSO & 0 & 0 \\
\hline ITAJUBÁ & GONCALVES & 2 & 0 \\
\hline ITAJUBÁ & ITAJUBA & 3 & 0 \\
\hline ITAJUBÁ & MARIA DA FE & 0 & 0 \\
\hline ITAJUBÁ & MARMELOPOLIS & 0 & 0 \\
\hline ITAJUBÁ & NATERCIA & 0 & 0 \\
\hline ITAJUBÁ & PARAISOPOLIS & 1 & 0 \\
\hline ITAJUBÁ & PEDRALVA & 1 & 0 \\
\hline ITAJUBÁ & PIRANGUCU & 0 & 0 \\
\hline ITAJUBÁ & PIRANGUINHO & 0 & 0 \\
\hline ITAJUBÁ & SAO JOSE DO ALEGRE & 1 & 0 \\
\hline ITAJUBÁ & SAPUCAI-MIRIM & 2 & 0 \\
\hline ITAJUBÁ & VIRGINIA & 0 & 0 \\
\hline ITAJUBÁ & WENCESLAU BRAZ & 0 & 0 \\
\hline ITUIUTABA & CACHOEIRA DOURADA & 0 & 0 \\
\hline ITUIUTABA & CANAPOLIS & 1 & 0 \\
\hline ITUIUTABA & CAPINOPOLIS & 0 & 0 \\
\hline ITUIUTABA & CENTRALINA & 0 & 0 \\
\hline ITUIUTABA & GURINHATA & 1 & 0 \\
\hline ITUIUTABA & IPIACU & 1 & 0 \\
\hline ITUIUTABA & ITUIUTABA & 7 & 1 \\
\hline ITUIUTABA & SANTA VITORIA & 5 & 1 \\
\hline JANAUBA & CATUTI & 0 & 0 \\
\hline JANAUBA & ESPINOSA & 1 & 0 \\
\hline JANAUBA & GAMELEIRAS & 0 & 0 \\
\hline JANAUBA & JAIBA & 6 & 1 \\
\hline JANAUBA & JANAUBA & 10 & 2 \\
\hline JANAUBA & MAMONAS & 0 & 0 \\
\hline JANAUBA & MATO VERDE & 0 & 0 \\
\hline JANAUBA & MONTE AZUL & 0 & 0 \\
\hline JANAUBA & MONTEZUMA & 0 & 0 \\
\hline JANAUBA & NOVA PORTEIRINHA & 1 & 0 \\
\hline JANAUBA & PAI PEDRO & 1 & 0 \\
\hline JANAUBA & PORTEIRINHA & 2 & 0 \\
\hline JANAUBA & RIACHO DOS MACHADOS & 0 & 0 \\
\hline JANAUBA & RIO PARDO DE MINAS & 4 & 0 \\
\hline JANAUBA & SANTO ANTONIO DO RETIRO & 0 & 0 \\
\hline JANAUBA & SERRANOPOLIS DE MINAS & 0 & 0 \\
\hline JANAUBA & VERDELANDIA & 0 & 0 \\
\hline JANUARIA & BONITO DE MINAS & 4 & 0 \\
\hline JANUARIA & CHAPADA GAUCHA & 0 & 0 \\
\hline JANUARIA & CONEGO MARINHO & 3 & 0 \\
\hline JANUARIA & IBIRACATU & 1 & 0 \\
\hline JANUARIA & ICARAI DE MINAS & 2 & 0 \\
\hline JANUARIA & ITACARAMBI & 1 & 0 \\
\hline
\end{tabular}




\begin{tabular}{|c|c|c|c|}
\hline JANUARIA & JANUARIA & 6 & 1 \\
\hline JANUARIA & JUVENILIA & 1 & 0 \\
\hline JANUARIA & MANGA & 2 & 0 \\
\hline JANUARIA & MATIAS CARDOSO & 3 & 0 \\
\hline JANUARIA & MIRAVANIA & 0 & 0 \\
\hline JANUARIA & MONTALVANIA & 2 & 0 \\
\hline JANUARIA & PEDRAS DE MARIA DA CRUZ & 6 & 1 \\
\hline JANUARIA & PINTOPOLIS & 1 & 0 \\
\hline JANUARIA & SAO FRANCISCO & 7 & 1 \\
\hline JANUARIA & SAO JOAO DAS MISSOES & 2 & 0 \\
\hline JANUARIA & UBAI & 1 & 0 \\
\hline JANUARIA & URUCUIA & 0 & 0 \\
\hline JANUARIA & VARZELANDIA & 0 & 0 \\
\hline JUIZ DE FORA & ARANTINA & 0 & 0 \\
\hline JUIZ DE FORA & BELMIRO BRAGA & 1 & 0 \\
\hline JUIZ DE FORA & BICAS & 0 & 0 \\
\hline JUIZ DE FORA & BOM JARDIM DE MINAS & 1 & 0 \\
\hline JUIZ DE FORA & CHACARA & 0 & 0 \\
\hline JUIZ DE FORA & CHIADOR & 1 & 0 \\
\hline JUIZ DE FORA & CORONEL PACHECO & 0 & 0 \\
\hline JUIZ DE FORA & DESCOBERTO & 0 & 0 \\
\hline JUIZ DE FORA & EWBANK DA CAMARA & 1 & 0 \\
\hline JUIZ DE FORA & GOIANA & 1 & 0 \\
\hline JUIZ DE FORA & GUARARA & 0 & 0 \\
\hline JUIZ DE FORA & JUIZ DE FORA & 10 & 2 \\
\hline JUIZ DE FORA & LIMA DUARTE & 1 & 0 \\
\hline JUIZ DE FORA & MAR DE ESPANHA & 0 & 0 \\
\hline JUIZ DE FORA & MARIPA DE MINAS & 0 & 0 \\
\hline JUIZ DE FORA & MATIAS BARBOSA & 3 & 0 \\
\hline JUIZ DE FORA & OLARIA & 0 & 0 \\
\hline JUIZ DE FORA & PEDRO TEIXEIRA & 1 & 0 \\
\hline JUIZ DE FORA & PEQUERI & 0 & 0 \\
\hline JUIZ DE FORA & PIAU & 0 & 0 \\
\hline JUIZ DE FORA & RIO NOVO & 0 & 0 \\
\hline JUIZ DE FORA & RIO PRETO & 0 & 0 \\
\hline JUIZ DE FORA & ROCHEDO DE MINAS & 0 & 0 \\
\hline JUIZ DE FORA & SANTA BARBARA DO MONTE VERDE & 0 & 0 \\
\hline JUIZ DE FORA & SANTA RITA DE JACUTINGA & 0 & 0 \\
\hline JUIZ DE FORA & SANTANA DO DESERTO & 1 & 0 \\
\hline JUIZ DE FORA & SANTOS DUMONT & 5 & 1 \\
\hline JUIZ DE FORA & SAO JOAO NEPOMUCENO & 0 & 0 \\
\hline JUIZ DE FORA & SENADOR CORTES & 0 & 0 \\
\hline JUIZ DE FORA & SIMAO PEREIRA & 0 & 0 \\
\hline LEOPOLDINA & ALEM PARAIBA & 0 & 0 \\
\hline LEOPOLDINA & ARGIRITA & 0 & 0 \\
\hline
\end{tabular}




\begin{tabular}{|c|c|c|c|}
\hline LEOPOLDINA & CATAGUASES & 0 & 0 \\
\hline LEOPOLDINA & ESTRELA DALVA & 0 & 0 \\
\hline LEOPOLDINA & ITAMARATI DE MINAS & 0 & 0 \\
\hline LEOPOLDINA & LEOPOLDINA & 0 & 0 \\
\hline LEOPOLDINA & PIRAPETINGA & 1 & 0 \\
\hline LEOPOLDINA & RECREIO & 1 & 0 \\
\hline LEOPOLDINA & SANTO ANTONIO DO AVENTUREIRO & 0 & 0 \\
\hline LEOPOLDINA & VOLTA GRANDE & 0 & 0 \\
\hline MANHUAÇU & ALTO JEQUITIBA & 0 & 0 \\
\hline MANHUAÇU & CAPUTIRA & 0 & 0 \\
\hline MANHUAÇU & CHALE & 1 & 0 \\
\hline MANHUAÇU & CONCEICAO DE IPANEMA & 0 & 0 \\
\hline MANHUAÇU & DURANDE & 0 & 0 \\
\hline MANHUAÇU & LAJINHA & 4 & 0 \\
\hline MANHUAÇU & LUISBURGO & 0 & 0 \\
\hline MANHUAÇU & MANHUACU & 11 & 2 \\
\hline MANHUAÇU & MANHUMIRIM & 1 & 0 \\
\hline MANHUAÇU & MARTINS SOARES & 1 & 0 \\
\hline MANHUAÇU & MATIPO & 3 & 0 \\
\hline MANHUAÇU & MUTUM & 3 & 0 \\
\hline MANHUAÇU & REDUTO & 1 & 0 \\
\hline MANHUAÇU & SANTA MARGARIDA & 1 & 0 \\
\hline MANHUAÇU & SANTANA DO MANHUACU & 1 & 0 \\
\hline MANHUAÇU & SAO JOAO DO MANHUACU & 0 & 0 \\
\hline MANHUAÇU & SAO JOSE DO MANTIMENTO & 2 & 0 \\
\hline MANHUAÇU & SIMONESIA & 1 & 0 \\
\hline METROPOLITANA A & BARAO DE COCAIS & 0 & 0 \\
\hline METROPOLITANA A & BELO HORIZONTE & 33 & 7 \\
\hline METROPOLITANA A & BELO VALE & 0 & 0 \\
\hline METROPOLITANA A & BOM JESUS DO AMPARO & 1 & 0 \\
\hline METROPOLITANA A & BONFIM & 0 & 0 \\
\hline METROPOLITANA A & BRUMADINHO & 0 & 0 \\
\hline METROPOLITANA A & CAETE & 2 & 0 \\
\hline METROPOLITANA A & CATAS ALTAS & 3 & 0 \\
\hline METROPOLITANA A & CRUCILANDIA & 0 & 0 \\
\hline METROPOLITANA A & MOEDA & 0 & 0 \\
\hline METROPOLITANA A & NOVA LIMA & 3 & 0 \\
\hline METROPOLITANA A & NOVA UNIAO & 0 & 0 \\
\hline METROPOLITANA A & PIEDADE DOS GERAIS & 0 & 0 \\
\hline METROPOLITANA A & RAPOSOS & 0 & 0 \\
\hline METROPOLITANA A & RIO ACIMA & 0 & 0 \\
\hline METROPOLITANA A & RIO MANSO & 0 & 0 \\
\hline METROPOLITANA A & SABARA & 6 & 1 \\
\hline METROPOLITANA A & SANTA BARBARA & 1 & 0 \\
\hline METROPOLITANA B & BELO HORIZONTE & 23 & 5 \\
\hline
\end{tabular}




\begin{tabular}{|c|c|c|c|}
\hline METROPOLITANA B & BETIM & 9 & 2 \\
\hline METROPOLITANA B & CONTAGEM & 19 & 4 \\
\hline METROPOLITANA B & ESMERALDAS & 7 & 1 \\
\hline METROPOLITANA B & IBIRITE & 9 & 2 \\
\hline METROPOLITANA B & IGARAPE & 7 & 1 \\
\hline METROPOLITANA B & JUATUBA & 2 & 0 \\
\hline METROPOLITANA B & MARIO CAMPOS & 3 & 0 \\
\hline METROPOLITANA B & MATEUS LEME & 1 & 0 \\
\hline METROPOLITANA B & SAO JOAQUIM DE BICAS & 2 & 0 \\
\hline METROPOLITANA B & SARZEDO & 11 & 2 \\
\hline METROPOLITANA C & BELO HORIZONTE & 17 & 3 \\
\hline METROPOLITANA C & CONFINS & 0 & 0 \\
\hline METROPOLITANA C & JABOTICATUBAS & 0 & 0 \\
\hline METROPOLITANA C & LAGOA SANTA & 7 & 1 \\
\hline METROPOLITANA C & MORRO DO PILAR & 0 & 0 \\
\hline METROPOLITANA C & PEDRO LEOPOLDO & 0 & 0 \\
\hline METROPOLITANA C & RIBEIRAO DAS NEVES & 42 & 10 \\
\hline METROPOLITANA C & SANTA LUZIA & 14 & 3 \\
\hline METROPOLITANA C & SANTANA DO RIACHO & 1 & 0 \\
\hline METROPOLITANA C & SAO JOSE DA LAPA & 1 & 0 \\
\hline METROPOLITANA C & TAQUARACU DE MINAS & 0 & 0 \\
\hline METROPOLITANA C & VESPASIANO & 7 & 1 \\
\hline MONTE CARMELO & ABADIA DOS DOURADOS & 0 & 0 \\
\hline MONTE CARMELO & CASCALHO RICO & 0 & 0 \\
\hline MONTE CARMELO & COROMANDEL & 3 & 0 \\
\hline MONTE CARMELO & DOURADOQUARA & 0 & 0 \\
\hline MONTE CARMELO & ESTRELA DO SUL & 0 & 0 \\
\hline MONTE CARMELO & GRUPIARA & 0 & 0 \\
\hline MONTE CARMELO & MONTE CARMELO & 3 & 0 \\
\hline MONTE CARMELO & ROMARIA & 0 & 0 \\
\hline MONTES CLAROS & BOCAIUVA & 0 & 0 \\
\hline MONTES CLAROS & BOTUMIRIM & 0 & 0 \\
\hline MONTES CLAROS & BRASILIA DE MINAS & 0 & 0 \\
\hline MONTES CLAROS & CAMPO AZUL & 0 & 0 \\
\hline MONTES CLAROS & CAPITAO ENEAS & 6 & 1 \\
\hline MONTES CLAROS & CLARO DOS POCOES & 0 & 0 \\
\hline MONTES CLAROS & CORACAO DE JESUS & 2 & 0 \\
\hline MONTES CLAROS & CRISTALIA & 2 & 0 \\
\hline MONTES CLAROS & ENGENHEIRO NAVARRO & 0 & 0 \\
\hline MONTES CLAROS & FRANCISCO DUMONT & 0 & 0 \\
\hline MONTES CLAROS & FRANCISCO SA & 6 & 1 \\
\hline MONTES CLAROS & GLAUCILANDIA & 0 & 0 \\
\hline MONTES CLAROS & GRAO MOGOL & 3 & 0 \\
\hline MONTES CLAROS & GUARACIAMA & 1 & 0 \\
\hline MONTES CLAROS & ITACAMBIRA & 0 & 0 \\
\hline
\end{tabular}




\begin{tabular}{|c|c|c|c|}
\hline MONTES CLAROS & JAPONVAR & 2 & 0 \\
\hline MONTES CLAROS & JOSENOPOLIS & 0 & 0 \\
\hline MONTES CLAROS & JURAMENTO & 1 & 0 \\
\hline MONTES CLAROS & LONTRA & 0 & 0 \\
\hline MONTES CLAROS & LUISLANDIA & 0 & 0 \\
\hline MONTES CLAROS & MIRABELA & 0 & 0 \\
\hline MONTES CLAROS & MONTES CLAROS & 9 & 2 \\
\hline MONTES CLAROS & OLHOS-D AGUA & 0 & 0 \\
\hline MONTES CLAROS & PADRE CARVALHO & 1 & 0 \\
\hline MONTES CLAROS & PATIS & 0 & 0 \\
\hline MONTES CLAROS & SAO JOAO DA LAGOA & 1 & 0 \\
\hline MONTES CLAROS & SAO JOAO DA PONTE & 2 & 0 \\
\hline MONTES CLAROS & SAO JOAO DO PACUI & 0 & 0 \\
\hline MONTES CLAROS & SAO JOAO DO PARAISO & 1 & 0 \\
\hline MONTES CLAROS & VARGEM GRANDE DO RIO PARDO & 2 & 0 \\
\hline MURIAÉ & ANTONIO PRADO DE MINAS & 0 & 0 \\
\hline MURIAÉ & BARAO DE MONTE ALTO & 0 & 0 \\
\hline MURIAÉ & EUGENOPOLIS & 0 & 0 \\
\hline MURIAÉ & LARANJAL & 0 & 0 \\
\hline MURIAÉ & MIRADOURO & 1 & 0 \\
\hline MURIAÉ & MIRAI & 0 & 0 \\
\hline MURIAÉ & MURIAE & 2 & 0 \\
\hline MURIAÉ & PALMA & 0 & 0 \\
\hline MURIAÉ & PATROCINIO DO MURIAE & 0 & 0 \\
\hline MURIAÉ & ROSARIO DA LIMEIRA & 0 & 0 \\
\hline MURIAÉ & SANTANA DE CATAGUASES & 0 & 0 \\
\hline MURIAÉ & SAO FRANCISCO DO GLORIA & 0 & 0 \\
\hline MURIAÉ & SAO SEBASTIAO DA VARGEM ALEGRE & 0 & 0 \\
\hline MURIAÉ & VIEIRAS & 1 & 0 \\
\hline NOVA ERA & BELA VISTA DE MINAS & 1 & 0 \\
\hline NOVA ERA & DIONISIO & 0 & 0 \\
\hline NOVA ERA & FERROS & 3 & 0 \\
\hline NOVA ERA & ITABIRA & 2 & 0 \\
\hline NOVA ERA & ITAMBE DO MATO DENTRO & 0 & 0 \\
\hline NOVA ERA & JOAO MONLEVADE & 0 & 0 \\
\hline NOVA ERA & NOVA ERA & 0 & 0 \\
\hline NOVA ERA & PASSABEM & 3 & 0 \\
\hline NOVA ERA & RIO PIRACICABA & 0 & 0 \\
\hline NOVA ERA & SANTA MARIA DE ITABIRA & 0 & 0 \\
\hline NOVA ERA & SANTO ANTONIO DO RIO ABAIXO & 1 & 0 \\
\hline NOVA ERA & SAO DOMINGOS DO PRATA & 2 & 0 \\
\hline NOVA ERA & SAO GONCALO DO RIO ABAIXO & 0 & 0 \\
\hline NOVA ERA & SAO JOSE DO GOIABAL & 1 & 0 \\
\hline NOVA ERA & SAO SEBASTIAO DO RIO PRETO & 0 & 0 \\
\hline OURO PRETO & ACAIACA & 3 & 0 \\
\hline
\end{tabular}




\begin{tabular}{|c|c|c|c|}
\hline OURO PRETO & DIOGO DE VASCONCELOS & 2 & 0 \\
\hline OURO PRETO & ITABIRITO & 9 & 2 \\
\hline OURO PRETO & MARIANA & 5 & 1 \\
\hline OURO PRETO & OURO PRETO & 9 & 2 \\
\hline PARA DE MINAS & ABAETE & 1 & 0 \\
\hline PARA DE MINAS & BIQUINHAS & 0 & 0 \\
\hline PARA DE MINAS & BOM DESPACHO & 0 & 0 \\
\hline PARA DE MINAS & CEDRO DO ABAETE & 0 & 0 \\
\hline PARA DE MINAS & CONCEICAO DO PARA & 0 & 0 \\
\hline PARA DE MINAS & DORES DO INDAIA & 0 & 0 \\
\hline PARA DE MINAS & ESTRELA DO INDAIA & 0 & 0 \\
\hline PARA DE MINAS & FLORESTAL & 2 & 0 \\
\hline PARA DE MINAS & IGARATINGA & 0 & 0 \\
\hline PARA DE MINAS & LEANDRO FERREIRA & 2 & 0 \\
\hline PARA DE MINAS & MARTINHO CAMPOS & 1 & 0 \\
\hline PARA DE MINAS & MORADA NOVA DE MINAS & 0 & 0 \\
\hline PARA DE MINAS & ONCA DE PITANGUI & 1 & 0 \\
\hline PARA DE MINAS & PAINEIRAS & 0 & 0 \\
\hline PARA DE MINAS & PARA DE MINAS & 9 & 2 \\
\hline PARA DE MINAS & PEQUI & 0 & 0 \\
\hline PARA DE MINAS & PITANGUI & 3 & 0 \\
\hline PARA DE MINAS & QUARTEL GERAL & 0 & 0 \\
\hline PARA DE MINAS & SAO JOSE DA VARGINHA & 0 & 0 \\
\hline PARA DE MINAS & SERRA DA SAUDADE & 0 & 0 \\
\hline PARACATU & BRASILANDIA DE MINAS & 0 & 0 \\
\hline PARACATU & GUARDA-MOR & 0 & 0 \\
\hline PARACATU & JOAO PINHEIRO & 3 & 0 \\
\hline PARACATU & PARACATU & 7 & 1 \\
\hline PARACATU & VAZANTE & 1 & 0 \\
\hline PASSOS & ALPINOPOLIS & 0 & 0 \\
\hline PASSOS & BOM JESUS DA PENHA & 0 & 0 \\
\hline PASSOS & CAPITOLIO & 3 & 0 \\
\hline PASSOS & CARMO DO RIO CLARO & 1 & 0 \\
\hline PASSOS & CORREGO FUNDO & 0 & 0 \\
\hline PASSOS & DELFINOPOLIS & 3 & 0 \\
\hline PASSOS & DORESOPOLIS & 0 & 0 \\
\hline PASSOS & FORMIGA & 3 & 0 \\
\hline PASSOS & FORTALEZA DE MINAS & 1 & 0 \\
\hline PASSOS & PASSOS & 2 & 0 \\
\hline PASSOS & PIMENTA & 0 & 0 \\
\hline PASSOS & PIUMHI & 0 & 0 \\
\hline PASSOS & SAO JOAO BATISTA DO GLORIA & 1 & 0 \\
\hline PASSOS & SAO JOSE DA BARRA & 1 & 0 \\
\hline PASSOS & SAO ROQUE DE MINAS & 3 & 0 \\
\hline PASSOS & VARGEM BONITA & 0 & 0 \\
\hline
\end{tabular}




\begin{tabular}{|c|c|c|c|}
\hline PATOS DE MINAS & ARAPUA & 0 & 0 \\
\hline PATOS DE MINAS & CARMO DO PARANAIBA & 2 & 0 \\
\hline PATOS DE MINAS & LAGAMAR & 1 & 0 \\
\hline PATOS DE MINAS & LAGOA FORMOSA & 2 & 0 \\
\hline PATOS DE MINAS & LAGOA GRANDE & 0 & 0 \\
\hline PATOS DE MINAS & MATUTINA & 1 & 0 \\
\hline PATOS DE MINAS & PATOS DE MINAS & 7 & 1 \\
\hline PATOS DE MINAS & PRESIDENTE OLEGARIO & 0 & 0 \\
\hline PATOS DE MINAS & RIO PARANAIBA & 0 & 0 \\
\hline PATOS DE MINAS & SANTA ROSA DA SERRA & 0 & 0 \\
\hline PATOS DE MINAS & SAO GONCALO DO ABAETE & 1 & 0 \\
\hline PATOS DE MINAS & SAO GOTARDO & 6 & 1 \\
\hline PATOS DE MINAS & TIROS & 0 & 0 \\
\hline PATOS DE MINAS & VARJAO DE MINAS & 0 & 0 \\
\hline PATROCÍNIO & CRUZEIRO DA FORTALEZA & 0 & 0 \\
\hline PATROCÍNIO & GUIMARANIA & 0 & 0 \\
\hline PATROCÍNIO & IBIA & 1 & 0 \\
\hline PATROCÍNIO & IRAI DE MINAS & 0 & 0 \\
\hline PATROCÍNIO & PATROCINIO & 2 & 0 \\
\hline PATROCÍNIO & PERDIZES & 2 & 0 \\
\hline PATROCÍNIO & SERRA DO SALITRE & 0 & 0 \\
\hline PIRAPORA & BURITIZEIRO & 5 & 1 \\
\hline PIRAPORA & IBIAI & 1 & 0 \\
\hline PIRAPORA & JEQUITAI & 1 & 0 \\
\hline PIRAPORA & LAGOA DOS PATOS & 0 & 0 \\
\hline PIRAPORA & PIRAPORA & 1 & 0 \\
\hline PIRAPORA & PONTO CHIQUE & 0 & 0 \\
\hline PIRAPORA & SANTA FE DE MINAS & 0 & 0 \\
\hline PIRAPORA & SAO ROMAO & 3 & 0 \\
\hline PIRAPORA & VARZEA DA PALMA & 0 & 0 \\
\hline POÇOS DE CALDAS & ALTEROSA & 0 & 0 \\
\hline POÇOS DE CALDAS & ANDRADAS & 6 & 1 \\
\hline POÇOS DE CALDAS & AREADO & 2 & 0 \\
\hline POÇOS DE CALDAS & BANDEIRA DO SUL & 0 & 0 \\
\hline POÇOS DE CALDAS & BOTELHOS & 3 & 0 \\
\hline POÇOS DE CALDAS & CABO VERDE & 1 & 0 \\
\hline POÇOS DE CALDAS & CALDAS & 3 & 0 \\
\hline POÇOS DE CALDAS & CAMPESTRE & 2 & 0 \\
\hline POÇOS DE CALDAS & CONCEICAO DA APARECIDA & 1 & 0 \\
\hline POÇOS DE CALDAS & DIVISA NOVA & 0 & 0 \\
\hline POÇOS DE CALDAS & IBITIURA DE MINAS & 0 & 0 \\
\hline POÇOS DE CALDAS & MONTE BELO & 0 & 0 \\
\hline POÇOS DE CALDAS & MUZAMBINHO & 3 & 0 \\
\hline POÇOS DE CALDAS & NOVA RESENDE & 2 & 0 \\
\hline POÇOS DE CALDAS & POCOS DE CALDAS & 5 & 1 \\
\hline
\end{tabular}




\begin{tabular}{|c|c|c|c|}
\hline POÇOS DE CALDAS & SANTA RITA DE CALDAS & 1 & 0 \\
\hline POÇOS DE CALDAS & SERRANIA & 0 & 0 \\
\hline PONTE NOVA & ABRE CAMPO & 1 & 0 \\
\hline PONTE NOVA & ALVINOPOLIS & 0 & 0 \\
\hline PONTE NOVA & AMPARO DO SERRA & 0 & 0 \\
\hline PONTE NOVA & ARAPONGA & 1 & 0 \\
\hline PONTE NOVA & BARRA LONGA & 0 & 0 \\
\hline PONTE NOVA & CAJURI & 0 & 0 \\
\hline PONTE NOVA & CANAA & 3 & 0 \\
\hline PONTE NOVA & DOM SILVERIO & 0 & 0 \\
\hline PONTE NOVA & GUARACIABA & 1 & 0 \\
\hline PONTE NOVA & JEQUERI & 2 & 0 \\
\hline PONTE NOVA & ORATORIOS & 0 & 0 \\
\hline PONTE NOVA & PEDRA BONITA & 2 & 0 \\
\hline PONTE NOVA & PEDRA DO ANTA & 0 & 0 \\
\hline PONTE NOVA & PIEDADE DE PONTE NOVA & 1 & 0 \\
\hline PONTE NOVA & PONTE NOVA & 1 & 0 \\
\hline PONTE NOVA & PORTO FIRME & 1 & 0 \\
\hline PONTE NOVA & RAUL SOARES & 2 & 0 \\
\hline PONTE NOVA & RIO CASCA & 0 & 0 \\
\hline PONTE NOVA & RIO DOCE & 0 & 0 \\
\hline PONTE NOVA & SANTA CRUZ DO ESCALVADO & 0 & 0 \\
\hline PONTE NOVA & SANTO ANTONIO DO GRAMA & 0 & 0 \\
\hline PONTE NOVA & SAO MIGUEL DO ANTA & 0 & 0 \\
\hline PONTE NOVA & SAO PEDRO DOS FERROS & 0 & 0 \\
\hline PONTE NOVA & SEM-PEIXE & 0 & 0 \\
\hline PONTE NOVA & SERICITA & 1 & 0 \\
\hline PONTE NOVA & TEIXEIRAS & 0 & 0 \\
\hline PONTE NOVA & URUCANIA & 2 & 0 \\
\hline PONTE NOVA & VERMELHO NOVO & 0 & 0 \\
\hline PONTE NOVA & VICOSA & 4 & 0 \\
\hline POUSO ALEGRE & ALBERTINA & 0 & 0 \\
\hline POUSO ALEGRE & BOM REPOUSO & 0 & 0 \\
\hline POUSO ALEGRE & BORDA DA MATA & 1 & 0 \\
\hline POUSO ALEGRE & BUENO BRANDAO & 2 & 0 \\
\hline POUSO ALEGRE & CACHOEIRA DE MINAS & 0 & 0 \\
\hline POUSO ALEGRE & CAMANDUCAIA & 5 & 1 \\
\hline POUSO ALEGRE & CAMBUI & 4 & 0 \\
\hline POUSO ALEGRE & CAREACU & 2 & 0 \\
\hline POUSO ALEGRE & CONGONHAL & 1 & 0 \\
\hline POUSO ALEGRE & CORREGO DO BOM JESUS & 1 & 0 \\
\hline POUSO ALEGRE & ESPIRITO SANTO DO DOURADO & 0 & 0 \\
\hline POUSO ALEGRE & ESTIVA & 0 & 0 \\
\hline POUSO ALEGRE & EXTREMA & 1 & 0 \\
\hline POUSO ALEGRE & HELIODORA & 2 & 0 \\
\hline
\end{tabular}




\begin{tabular}{|c|c|c|c|}
\hline POUSO ALEGRE & INCONFIDENTES & 1 & 0 \\
\hline POUSO ALEGRE & IPUIUNA & 0 & 0 \\
\hline POUSO ALEGRE & ITAPEVA & 3 & 0 \\
\hline POUSO ALEGRE & JACUTINGA & 1 & 0 \\
\hline POUSO ALEGRE & MONTE SIAO & 4 & 0 \\
\hline POUSO ALEGRE & MUNHOZ & 0 & 0 \\
\hline POUSO ALEGRE & OURO FINO & 3 & 0 \\
\hline POUSO ALEGRE & POUSO ALEGRE & 15 & 3 \\
\hline POUSO ALEGRE & SANTA RITA DO SAPUCAI & 8 & 1 \\
\hline POUSO ALEGRE & SAO JOAO DA MATA & 0 & 0 \\
\hline POUSO ALEGRE & SAO SEBASTIAO DA BELA VISTA & 0 & 0 \\
\hline POUSO ALEGRE & SENADOR AMARAL & 1 & 0 \\
\hline POUSO ALEGRE & SENADOR JOSE BENTO & 1 & 0 \\
\hline POUSO ALEGRE & SILVIANOPOLIS & 0 & 0 \\
\hline POUSO ALEGRE & TOCOS DO MOJI & 0 & 0 \\
\hline POUSO ALEGRE & TOLEDO & 0 & 0 \\
\hline SÃO JOÃO DEL REI & BOM SUCESSO & 0 & 0 \\
\hline SÃO JOÃO DEL REI & CARRANCAS & 0 & 0 \\
\hline SÃO JOÃO DEL REI & CONCEICAO DA BARRA DE MINAS & 0 & 0 \\
\hline SÃO JOÃO DEL REI & CORONEL XAVIER CHAVES & 0 & 0 \\
\hline SÃO JOÃO DEL REI & DORES DE CAMPOS & 0 & 0 \\
\hline SÃO JOÃO DEL REI & IBITURUNA & 1 & 0 \\
\hline SÃO JOÃO DEL REI & IJACI & 1 & 0 \\
\hline SÃO JOÃO DEL REI & INGAI & 0 & 0 \\
\hline SÃO JOÃO DEL REI & ITUMIRIM & 0 & 0 \\
\hline SÃO JOÃO DEL REI & ITUTINGA & 0 & 0 \\
\hline SÃO JOÃO DEL REI & LAGOA DOURADA & 1 & 0 \\
\hline SÃO JOÃO DEL REI & NAZARENO & 0 & 0 \\
\hline SÃO JOÃO DEL REI & PRADOS & 1 & 0 \\
\hline SÃO JOÃO DEL REI & RESENDE COSTA & 2 & 0 \\
\hline SÃO JOÃO DEL REI & RITAPOLIS & 0 & 0 \\
\hline SÃO JOÃO DEL REI & SANTA CRUZ DE MINAS & 0 & 0 \\
\hline SÃO JOÃO DEL REI & SAO JOAO DEL REI & 13 & 3 \\
\hline SÃO JOÃO DEL REI & SAO TIAGO & 1 & 0 \\
\hline SÃO JOÃO DEL REI & TIRADENTES & 0 & 0 \\
\hline SÃO SEBASTIÃO DO PARAÍSO & ARCEBURGO & 0 & 0 \\
\hline SÃO SEBASTIÃO DO PARAÍSO & CAPETINGA & 0 & 0 \\
\hline SÃO SEBASTIÃO DO PARAÍSO & CASSIA & 1 & 0 \\
\hline SÃO SEBASTIÃO DO PARAÍSO & CLARAVAL & 0 & 0 \\
\hline SÃO SEBASTIÃO DO PARAÍSO & GUARANESIA & 0 & 0 \\
\hline SÃO SEBASTIÃO DO PARAÍSO & GUAXUPE & 0 & 0 \\
\hline SÃO SEBASTIÃO DO PARAÍSO & IBIRACI & 0 & 0 \\
\hline SÃO SEBASTIÃO DO PARAÍSO & ITAMOGI & 0 & 0 \\
\hline SÃO SEBASTIÃO DO PARAÍSO & ITAU DE MINAS & 0 & 0 \\
\hline SÃO SEBASTIÃO DO PARAÍSO & JACUI & 0 & 0 \\
\hline
\end{tabular}




\begin{tabular}{|c|c|c|c|}
\hline SÃO SEBASTIÃO DO PARAÍSO & JURUAIA & 0 & 0 \\
\hline SÃO SEBASTIÃO DO PARAÍSO & MONTE SANTO DE MINAS & 0 & 0 \\
\hline SÃO SEBASTIÃO DO PARAÍSO & PRATAPOLIS & 0 & 0 \\
\hline SÃO SEBASTIÃO DO PARAÍSO & SAO PEDRO DA UNIAO & 0 & 0 \\
\hline SÃO SEBASTIÃO DO PARAÍSO & SAO SEBASTIAO DO PARAISO & 1 & 0 \\
\hline SÃO SEBASTIÃO DO PARAÍSO & SAO TOMAS DE AQUINO & 0 & 0 \\
\hline SETE LAGOAS & ARACAI & 0 & 0 \\
\hline SETE LAGOAS & BALDIM & 1 & 0 \\
\hline SETE LAGOAS & CACHOEIRA DA PRATA & 0 & 0 \\
\hline SETE LAGOAS & CAETANOPOLIS & 0 & 0 \\
\hline SETE LAGOAS & CAPIM BRANCO & 2 & 0 \\
\hline SETE LAGOAS & CORDISBURGO & 1 & 0 \\
\hline SETE LAGOAS & FORTUNA DE MINAS & 0 & 0 \\
\hline SETE LAGOAS & FUNILANDIA & 0 & 0 \\
\hline SETE LAGOAS & INHAUMA & 0 & 0 \\
\hline SETE LAGOAS & JEQUITIBA & 0 & 0 \\
\hline SETE LAGOAS & MARAVILHAS & 0 & 0 \\
\hline SETE LAGOAS & MATOZINHOS & 0 & 0 \\
\hline SETE LAGOAS & PAPAGAIOS & 1 & 0 \\
\hline SETE LAGOAS & PARAOPEBA & 6 & 1 \\
\hline SETE LAGOAS & POMPEU & 0 & 0 \\
\hline SETE LAGOAS & PRUDENTE DE MORAIS & 1 & 0 \\
\hline SETE LAGOAS & SANTANA DE PIRAPAMA & 0 & 0 \\
\hline SETE LAGOAS & SETE LAGOAS & 8 & 1 \\
\hline TEOFILO OTONI & AGUAS FORMOSAS & 4 & 0 \\
\hline TEOFILO OTONI & ATALEIA & 1 & 0 \\
\hline TEOFILO OTONI & BERTOPOLIS & 3 & 0 \\
\hline TEOFILO OTONI & CAMPANARIO & 1 & 0 \\
\hline TEOFILO OTONI & CARAI & 1 & 0 \\
\hline TEOFILO OTONI & CARLOS CHAGAS & 0 & 0 \\
\hline TEOFILO OTONI & CATUJI & 0 & 0 \\
\hline TEOFILO OTONI & CRISOLITA & 4 & 0 \\
\hline TEOFILO OTONI & FRANCISCOPOLIS & 3 & 0 \\
\hline TEOFILO OTONI & FREI GASPAR & 2 & 0 \\
\hline TEOFILO OTONI & FRONTEIRA DOS VALES & 0 & 0 \\
\hline TEOFILO OTONI & ITAIPE & 2 & 0 \\
\hline TEOFILO OTONI & ITAMBACURI & 0 & 0 \\
\hline TEOFILO OTONI & JAMPRUCA & 0 & 0 \\
\hline TEOFILO OTONI & LADAINHA & 0 & 0 \\
\hline TEOFILO OTONI & MACHACALIS & 0 & 0 \\
\hline TEOFILO OTONI & MALACACHETA & 2 & 0 \\
\hline TEOFILO OTONI & NANUQUE & 0 & 0 \\
\hline TEOFILO OTONI & NOVO CRUZEIRO & 2 & 0 \\
\hline TEOFILO OTONI & NOVO ORIENTE DE MINAS & 3 & 0 \\
\hline TEOFILO OTONI & OURO VERDE DE MINAS & 0 & 0 \\
\hline
\end{tabular}




\begin{tabular}{|c|c|c|c|}
\hline TEOFILO OTONI & PADRE PARAISO & 1 & 0 \\
\hline TEOFILO OTONI & PAVAO & 0 & 0 \\
\hline TEOFILO OTONI & PESCADOR & 0 & 0 \\
\hline TEOFILO OTONI & PONTO DOS VOLANTES & 1 & 0 \\
\hline TEOFILO OTONI & POTE & 2 & 0 \\
\hline TEOFILO OTONI & SANTA HELENA DE MINAS & 1 & 0 \\
\hline TEOFILO OTONI & SERRA DOS AIMORES & 2 & 0 \\
\hline TEOFILO OTONI & SETUBINHA & 0 & 0 \\
\hline TEOFILO OTONI & TEOFILO OTONI & 5 & 1 \\
\hline TEOFILO OTONI & UMBURATIBA & 0 & 0 \\
\hline UBÁ & ASTOLFO DUTRA & 2 & 0 \\
\hline UBÁ & BRAS PIRES & 0 & 0 \\
\hline UBÁ & COIMBRA & 1 & 0 \\
\hline UBÁ & DIVINESIA & 0 & 0 \\
\hline UBÁ & DONA EUZEBIA & 0 & 0 \\
\hline UBÁ & DORES DO TURVO & 0 & 0 \\
\hline UBÁ & ERVALIA & 0 & 0 \\
\hline UBÁ & GUARANI & 1 & 0 \\
\hline UBÁ & GUIDOVAL & 0 & 0 \\
\hline UBÁ & GUIRICEMA & 0 & 0 \\
\hline UBÁ & PAULA CANDIDO & 1 & 0 \\
\hline UBÁ & PIRAUBA & 0 & 0 \\
\hline UBÁ & PRESIDENTE BERNARDES & 0 & 0 \\
\hline UBÁ & RIO POMBA & 0 & 0 \\
\hline UBÁ & RODEIRO & 1 & 0 \\
\hline UBÁ & SAO GERALDO & 0 & 0 \\
\hline UBÁ & SENADOR FIRMINO & 0 & 0 \\
\hline UBÁ & SILVEIRANIA & 1 & 0 \\
\hline UBÁ & TABULEIRO & 0 & 0 \\
\hline UBÁ & TOCANTINS & 0 & 0 \\
\hline UBÁ & UBA & 2 & 0 \\
\hline UBÁ & VISCONDE DO RIO BRANCO & 0 & 0 \\
\hline UBERABA & AGUA COMPRIDA & 0 & 0 \\
\hline UBERABA & ARAXA & 4 & 0 \\
\hline UBERABA & CAMPO FLORIDO & 0 & 0 \\
\hline UBERABA & CAMPOS ALTOS & 1 & 0 \\
\hline UBERABA & CARNEIRINHO & 2 & 0 \\
\hline UBERABA & COMENDADOR GOMES & 1 & 0 \\
\hline UBERABA & CONCEICAO DAS ALAGOAS & 4 & 0 \\
\hline UBERABA & CONQUISTA & 0 & 0 \\
\hline UBERABA & DELTA & 3 & 0 \\
\hline UBERABA & FRONTEIRA & 2 & 0 \\
\hline UBERABA & FRUTAL & 2 & 0 \\
\hline UBERABA & ITAPAGIPE & 4 & 0 \\
\hline UBERABA & ITURAMA & 3 & 0 \\
\hline
\end{tabular}




\begin{tabular}{|c|c|c|c|}
\hline UBERABA & LIMEIRA DO OESTE & 1 & 0 \\
\hline UBERABA & PEDRINOPOLIS & 0 & 0 \\
\hline UBERABA & PIRAJUBA & 0 & 0 \\
\hline UBERABA & PLANURA & 0 & 0 \\
\hline UBERABA & PRATINHA & 0 & 0 \\
\hline UBERABA & SACRAMENTO & 0 & 0 \\
\hline UBERABA & SANTA JULIANA & 3 & 0 \\
\hline UBERABA & SAO FRANCISCO DE SALES & 0 & 0 \\
\hline UBERABA & TAPIRA & 0 & 0 \\
\hline UBERABA & UBERABA & 16 & 3 \\
\hline UBERABA & UNIAO DE MINAS & 0 & 0 \\
\hline UBERABA & VERISSIMO & 0 & 0 \\
\hline UBERLANDIA & ARAGUARI & 6 & 1 \\
\hline UBERLANDIA & ARAPORA & 0 & 0 \\
\hline UBERLANDIA & CAMPINA VERDE & 0 & 0 \\
\hline UBERLANDIA & INDIANOPOLIS & 1 & 0 \\
\hline UBERLANDIA & MONTE ALEGRE DE MINAS & 1 & 0 \\
\hline UBERLANDIA & NOVA PONTE & 0 & 0 \\
\hline UBERLANDIA & PRATA & 1 & 0 \\
\hline UBERLANDIA & TUPACIGUARA & 4 & 0 \\
\hline UBERLANDIA & UBERLANDIA & 42 & 10 \\
\hline UNAI & ARINOS & 3 & 0 \\
\hline UNAI & BONFINOPOLIS DE MINAS & 0 & 0 \\
\hline UNAI & BURITIS & 1 & 0 \\
\hline UNAI & CABECEIRA GRANDE & 1 & 0 \\
\hline UNAI & DOM BOSCO & 1 & 0 \\
\hline UNAI & FORMOSO & 2 & 0 \\
\hline UNAI & NATALANDIA & 0 & 0 \\
\hline UNAI & RIACHINHO & 1 & 0 \\
\hline UNAI & UNAI & 6 & 1 \\
\hline UNAI & URUANA DE MINAS & 0 & 0 \\
\hline VARGINHA & ALFENAS & 13 & 3 \\
\hline VARGINHA & BOA ESPERANCA & 3 & 0 \\
\hline VARGINHA & CAMBUQUIRA & 0 & 0 \\
\hline VARGINHA & CAMPANHA & 1 & 0 \\
\hline VARGINHA & CAMPO DO MEIO & 0 & 0 \\
\hline VARGINHA & CAMPOS GERAIS & 0 & 0 \\
\hline VARGINHA & CARMO DA CACHOEIRA & 0 & 0 \\
\hline VARGINHA & CARVALHOPOLIS & 0 & 0 \\
\hline VARGINHA & COQUEIRAL & 0 & 0 \\
\hline VARGINHA & CORDISLANDIA & 0 & 0 \\
\hline VARGINHA & ELOI MENDES & 1 & 0 \\
\hline VARGINHA & FAMA & 1 & 0 \\
\hline VARGINHA & GUAPE & 0 & 0 \\
\hline VARGINHA & ILICINEA & 0 & 0 \\
\hline
\end{tabular}




\begin{tabular}{|l|l|c|c|}
\hline VARGINHA & LAMBARI & 0 & 0 \\
\hline VARGINHA & LUMINARIAS & 0 & 0 \\
\hline VARGINHA & MACHADO & 0 & 0 \\
\hline VARGINHA & MONSENHOR PAULO & 0 & 0 \\
\hline VARGINHA & NEPOMUCENO & 0 & 0 \\
\hline VARGINHA & PARAGUACU & 0 & 0 \\
\hline VARGINHA & POCO FUNDO & 0 & 0 \\
\hline VARGINHA & SANTANA DA VARGEM & 0 & 0 \\
\hline VARGINHA & SAO BENTO ABADE & 0 & 0 \\
\hline VARGINHA & SAO GONCALO DO SAPUCAI & 4 & 0 \\
\hline VARGINHA & TRES CORACOES & 4 & 0 \\
\hline VARGINHA & TRES PONTAS & 0 & 1 \\
\hline VARGINHA & TURVOLANDIA & 7 & $\mathbf{1 1 8}$ \\
\hline VARGINHA & VARGINHA & $\mathbf{1 1 7 9}$ & 0 \\
\hline Total geral & & & 0 \\
\hline
\end{tabular}

CARGO: PROFESSOR DE EDUCAÇÃO BÁSICA - PEB - MATEMÁTICA

\begin{tabular}{|c|c|c|c|}
\hline S R E & MUNICIPIO & $\begin{array}{l}\text { TOTAL DE } \\
\text { VAGAS }\end{array}$ & $\begin{array}{c}\text { VAGAS } \\
\text { RESERVADAS - } \\
\text { PORTADORES DE } \\
\text { DEFICIÊNCIA } \\
\end{array}$ \\
\hline ALMENARA & AGUAS VERMELHAS & 0 & 0 \\
\hline ALMENARA & ALMENARA & 0 & 0 \\
\hline ALMENARA & BANDEIRA & 0 & 0 \\
\hline ALMENARA & CACHOEIRA DE PAJEU & 0 & 0 \\
\hline ALMENARA & CURRAL DE DENTRO & 0 & 0 \\
\hline ALMENARA & DIVISA ALEGRE & 0 & 0 \\
\hline ALMENARA & DIVISOPOLIS & 0 & 0 \\
\hline ALMENARA & FELISBURGO & 2 & 0 \\
\hline ALMENARA & JACINTO & 1 & 0 \\
\hline ALMENARA & JEQUITINHONHA & 2 & 0 \\
\hline ALMENARA & JOAIMA & 0 & 0 \\
\hline ALMENARA & JORDANIA & 1 & 0 \\
\hline ALMENARA & MATA VERDE & 0 & 0 \\
\hline ALMENARA & MONTE FORMOSO & 0 & 0 \\
\hline ALMENARA & PALMOPOLIS & 0 & 0 \\
\hline ALMENARA & PEDRA AZUL & 1 & 0 \\
\hline ALMENARA & RIO DO PRADO & 0 & 0 \\
\hline ALMENARA & RUBIM & 0 & 0 \\
\hline ALMENARA & SALTO DA DIVISA & 1 & 0 \\
\hline ALMENARA & SANTA MARIA DO SALTO & 0 & 0 \\
\hline ALMENARA & SANTO ANTONIO DO JACINTO & 1 & 0 \\
\hline ARACUAI & ARACUAI & 5 & 1 \\
\hline ARACUAI & BERILO & 2 & 0 \\
\hline ARACUAI & BERIZAL & 0 & 0 \\
\hline ARACUAI & CHAPADA DO NORTE & 5 & 1 \\
\hline
\end{tabular}




\begin{tabular}{|c|c|c|c|}
\hline ARACUAI & COMERCINHO & 0 & 0 \\
\hline ARACUAI & CORONEL MURTA & 0 & 0 \\
\hline ARACUAI & FRANCISCO BADARO & 1 & 0 \\
\hline ARACUAI & FRUTA DE LEITE & 0 & 0 \\
\hline ARACUAI & INDAIABIRA & 0 & 0 \\
\hline ARACUAI & ITAOBIM & 1 & 0 \\
\hline ARACUAI & ITINGA & 2 & 0 \\
\hline ARACUAI & JENIPAPO DE MINAS & 2 & 0 \\
\hline ARACUAI & JOSE GONCALVES DE MINAS & 0 & 0 \\
\hline ARACUAI & MEDINA & 2 & 0 \\
\hline ARACUAI & NINHEIRA & 5 & 1 \\
\hline ARACUAI & NOVORIZONTE & 1 & 0 \\
\hline ARACUAI & RUBELITA & 0 & 0 \\
\hline ARACUAI & SALINAS & 2 & 0 \\
\hline ARACUAI & SANTA CRUZ DE SALINAS & 0 & 0 \\
\hline ARACUAI & TAIOBEIRAS & 3 & 0 \\
\hline ARACUAI & VIRGEM DA LAPA & 5 & 1 \\
\hline BARBACENA & ALFREDO VASCONCELOS & 2 & 0 \\
\hline BARBACENA & ALTO RIO DOCE & 1 & 0 \\
\hline BARBACENA & ANDRELANDIA & 2 & 0 \\
\hline BARBACENA & ANTONIO CARLOS & 1 & 0 \\
\hline BARBACENA & ARACITABA & 1 & 0 \\
\hline BARBACENA & BARBACENA & 6 & 1 \\
\hline BARBACENA & BARROSO & 0 & 0 \\
\hline BARBACENA & BIAS FORTES & 1 & 0 \\
\hline BARBACENA & CAPELA NOVA & 0 & 0 \\
\hline BARBACENA & CARANDAI & 0 & 0 \\
\hline BARBACENA & CIPOTANEA & 0 & 0 \\
\hline BARBACENA & DESTERRO DO MELO & 0 & 0 \\
\hline BARBACENA & IBERTIOGA & 0 & 0 \\
\hline BARBACENA & MADRE DE DEUS DE MINAS & 0 & 0 \\
\hline BARBACENA & MERCES & 0 & 0 \\
\hline BARBACENA & OLIVEIRA FORTES & 1 & 0 \\
\hline BARBACENA & PAIVA & 0 & 0 \\
\hline BARBACENA & PIEDADE DO RIO GRANDE & 0 & 0 \\
\hline BARBACENA & RESSAQUINHA & 0 & 0 \\
\hline BARBACENA & SANTA BARBARA DO TUGURIO & 0 & 0 \\
\hline BARBACENA & SANTA RITA DO IBITIPOCA & 0 & 0 \\
\hline BARBACENA & SANTANA DO GARAMBEU & 0 & 0 \\
\hline BARBACENA & SAO VICENTE DE MINAS & 0 & 0 \\
\hline BARBACENA & SENHORA DOS REMEDIOS & 0 & 0 \\
\hline CAMPO BELO & AGUANIL & 2 & 0 \\
\hline CAMPO BELO & CAMACHO & 1 & 0 \\
\hline CAMPO BELO & CAMPO BELO & 4 & 0 \\
\hline CAMPO BELO & CANA VERDE & 1 & 0 \\
\hline
\end{tabular}




\begin{tabular}{|c|c|c|c|}
\hline CAMPO BELO & CANDEIAS & 2 & 0 \\
\hline CAMPO BELO & CRISTAIS & 0 & 0 \\
\hline CAMPO BELO & LAVRAS & 2 & 0 \\
\hline CAMPO BELO & PERDOES & 1 & 0 \\
\hline CAMPO BELO & RIBEIRAO VERMELHO & 0 & 0 \\
\hline CAMPO BELO & SANTANA DO JACARE & 0 & 0 \\
\hline CAMPO BELO & SANTO ANTONIO DO AMPARO & 2 & 0 \\
\hline CAMPO BELO & SAO FRANCISCO DE PAULA & 0 & 0 \\
\hline CARANGOLA & ALTO CAPARAO & 2 & 0 \\
\hline CARANGOLA & CAIANA & 1 & 0 \\
\hline CARANGOLA & CAPARAO & 1 & 0 \\
\hline CARANGOLA & CARANGOLA & 4 & 0 \\
\hline CARANGOLA & DIVINO & 3 & 0 \\
\hline CARANGOLA & ESPERA FELIZ & 1 & 0 \\
\hline CARANGOLA & FARIA LEMOS & 0 & 0 \\
\hline CARANGOLA & FERVEDOURO & 5 & 1 \\
\hline CARANGOLA & ORIZANIA & 0 & 0 \\
\hline CARANGOLA & PEDRA DOURADA & 0 & 0 \\
\hline CARANGOLA & TOMBOS & 1 & 0 \\
\hline CARATINGA & ALVARENGA & 1 & 0 \\
\hline CARATINGA & BOM JESUS DO GALHO & 0 & 0 \\
\hline CARATINGA & BUGRE & 1 & 0 \\
\hline CARATINGA & CARATINGA & 8 & 2 \\
\hline CARATINGA & CORREGO NOVO & 1 & 0 \\
\hline CARATINGA & DOM CAVATI & 0 & 0 \\
\hline CARATINGA & ENTRE FOLHAS & 1 & 0 \\
\hline CARATINGA & IAPU & 1 & 0 \\
\hline CARATINGA & IMBE DE MINAS & 2 & 0 \\
\hline CARATINGA & INHAPIM & 0 & 0 \\
\hline CARATINGA & IPABA & 0 & 0 \\
\hline CARATINGA & IPANEMA & 0 & 0 \\
\hline CARATINGA & PIEDADE DE CARATINGA & 3 & 0 \\
\hline CARATINGA & PINGO D AGUA & 0 & 0 \\
\hline CARATINGA & POCRANE & 1 & 0 \\
\hline CARATINGA & SANTA BARBARA DO LESTE & 1 & 0 \\
\hline CARATINGA & SANTA RITA DE MINAS & 0 & 0 \\
\hline CARATINGA & SAO DOMINGOS DAS DORES & 1 & 0 \\
\hline CARATINGA & SAO JOAO DO ORIENTE & 1 & 0 \\
\hline CARATINGA & SAO SEBASTIAO DO ANTA & 1 & 0 \\
\hline CARATINGA & TAPARUBA & 0 & 0 \\
\hline CARATINGA & TARUMIRIM & 1 & 0 \\
\hline CARATINGA & UBAPORANGA & 1 & 0 \\
\hline CARATINGA & VARGEM ALEGRE & 0 & 0 \\
\hline CAXAMBU & AIURUOCA & 3 & 0 \\
\hline CAXAMBU & ALAGOA & 0 & 0 \\
\hline
\end{tabular}




\begin{tabular}{|c|c|c|c|}
\hline CAXAMBU & BAEPENDI & 1 & 0 \\
\hline CAXAMBU & BOCAINA DE MINAS & 0 & 0 \\
\hline CAXAMBU & CARVALHOS & 0 & 0 \\
\hline CAXAMBU & CAXAMBU & 0 & 0 \\
\hline CAXAMBU & CONCEICAO DO RIO VERDE & 0 & 0 \\
\hline CAXAMBU & CRUZILIA & 1 & 0 \\
\hline CAXAMBU & ITAMONTE & 0 & 0 \\
\hline CAXAMBU & ITANHANDU & 0 & 0 \\
\hline CAXAMBU & JESUANIA & 1 & 0 \\
\hline CAXAMBU & LIBERDADE & 1 & 0 \\
\hline CAXAMBU & MINDURI & 0 & 0 \\
\hline CAXAMBU & OLIMPIO NORONHA & 0 & 0 \\
\hline CAXAMBU & PASSA QUATRO & 3 & 0 \\
\hline CAXAMBU & PASSA VINTE & 0 & 0 \\
\hline CAXAMBU & POUSO ALTO & 1 & 0 \\
\hline CAXAMBU & SAO LOURENCO & 3 & 0 \\
\hline CAXAMBU & SAO SEBASTIAO DO RIO VERDE & 0 & 0 \\
\hline CAXAMBU & SAO TOME DAS LETRAS & 0 & 0 \\
\hline CAXAMBU & SERITINGA & 0 & 0 \\
\hline CAXAMBU & SERRANOS & 1 & 0 \\
\hline CAXAMBU & SOLEDADE DE MINAS & 0 & 0 \\
\hline CEL. FABRICIANO & ANTONIO DIAS & 0 & 0 \\
\hline CEL. FABRICIANO & BELO ORIENTE & 1 & 0 \\
\hline CEL. FABRICIANO & BRAUNAS & 1 & 0 \\
\hline CEL. FABRICIANO & CORONEL FABRICIANO & 5 & 1 \\
\hline CEL. FABRICIANO & IPATINGA & 3 & 0 \\
\hline CEL. FABRICIANO & JAGUARAÇU & 0 & 0 \\
\hline CEL. FABRICIANO & JOANESIA & 2 & 0 \\
\hline CEL. FABRICIANO & MARLIERIA & 1 & 0 \\
\hline CEL. FABRICIANO & MESQUITA & 2 & 0 \\
\hline CEL. FABRICIANO & SANTANA DO PARAISO & 2 & 0 \\
\hline CEL. FABRICIANO & TIMOTEO & 2 & 0 \\
\hline CONSELHEIRO LAFAIETE & CARANAIBA & 0 & 0 \\
\hline CONSELHEIRO LAFAIETE & CASA GRANDE & 0 & 0 \\
\hline CONSELHEIRO LAFAIETE & CATAS ALTAS DA NORUEGA & 0 & 0 \\
\hline CONSELHEIRO LAFAIETE & CONGONHAS & 0 & 0 \\
\hline CONSELHEIRO LAFAIETE & CONSELHEIRO LAFAIETE & 1 & 0 \\
\hline CONSELHEIRO LAFAIETE & CRISTIANO OTONI & 0 & 0 \\
\hline CONSELHEIRO LAFAIETE & DESTERRO DE ENTRE RIOS & 0 & 0 \\
\hline CONSELHEIRO LAFAIETE & ENTRE RIOS DE MINAS & 1 & 0 \\
\hline CONSELHEIRO LAFAIETE & ITAVERAVA & 0 & 0 \\
\hline CONSELHEIRO LAFAIETE & JECEABA & 0 & 0 \\
\hline CONSELHEIRO LAFAIETE & LAMIM & 1 & 0 \\
\hline CONSELHEIRO LAFAIETE & OURO BRANCO & 0 & 0 \\
\hline CONSELHEIRO LAFAIETE & PIRANGA & 2 & 0 \\
\hline
\end{tabular}




\begin{tabular}{|c|c|c|c|}
\hline CONSELHEIRO LAFAIETE & QUELUZITO & 1 & 0 \\
\hline CONSELHEIRO LAFAIETE & RIO ESPERA & 1 & 0 \\
\hline CONSELHEIRO LAFAIETE & SANTANA DOS MONTES & 1 & 0 \\
\hline CONSELHEIRO LAFAIETE & SAO BRAS DO SUACUI & 1 & 0 \\
\hline CONSELHEIRO LAFAIETE & SENHORA DE OLIVEIRA & 0 & 0 \\
\hline CURVELO & AUGUSTO DE LIMA & 0 & 0 \\
\hline CURVELO & BUENOPOLIS & 0 & 0 \\
\hline CURVELO & CORINTO & 5 & 1 \\
\hline CURVELO & CURVELO & 6 & 1 \\
\hline CURVELO & FELIXLANDIA & 0 & 0 \\
\hline CURVELO & INIMUTABA & 0 & 0 \\
\hline CURVELO & JOAQUIM FELICIO & 0 & 0 \\
\hline CURVELO & LASSANCE & 2 & 0 \\
\hline CURVELO & MORRO DA GARCA & 1 & 0 \\
\hline CURVELO & PRESIDENTE JUSCELINO & 0 & 0 \\
\hline CURVELO & SANTO HIPOLITO & 2 & 0 \\
\hline CURVELO & TRES MARIAS & 2 & 0 \\
\hline DIAMANTINA & ALVORADA DE MINAS & 2 & 0 \\
\hline DIAMANTINA & ANGELANDIA & 2 & 0 \\
\hline DIAMANTINA & ARICANDUVA & 1 & 0 \\
\hline DIAMANTINA & CAPELINHA & 8 & 2 \\
\hline DIAMANTINA & CARBONITA & 0 & 0 \\
\hline DIAMANTINA & CONCEICAO DO MATO DENTRO & 0 & 0 \\
\hline DIAMANTINA & CONGONHAS DO NORTE & 2 & 0 \\
\hline DIAMANTINA & COUTO DE MAGALHAES DE MINAS & 0 & 0 \\
\hline DIAMANTINA & DATAS & 1 & 0 \\
\hline DIAMANTINA & DIAMANTINA & 2 & 0 \\
\hline DIAMANTINA & FELICIO DOS SANTOS & 0 & 0 \\
\hline DIAMANTINA & GOUVEA & 3 & 0 \\
\hline DIAMANTINA & ITAMARANDIBA & 5 & 1 \\
\hline DIAMANTINA & LEME DO PRADO & 0 & 0 \\
\hline DIAMANTINA & MINAS NOVAS & 6 & 1 \\
\hline DIAMANTINA & MONJOLOS & 0 & 0 \\
\hline DIAMANTINA & PRESIDENTE KUBITSCHEK & 0 & 0 \\
\hline DIAMANTINA & RIO VERMELHO & 2 & 0 \\
\hline DIAMANTINA & SANTO ANTONIO DO ITAMBE & 0 & 0 \\
\hline DIAMANTINA & SAO GONCALO DO RIO PRETO & 0 & 0 \\
\hline DIAMANTINA & SENADOR MODESTINO GONCALVES & 0 & 0 \\
\hline DIAMANTINA & SERRA AZUL DE MINAS & 0 & 0 \\
\hline DIAMANTINA & SERRO & 7 & 1 \\
\hline DIAMANTINA & TURMALINA & 2 & 0 \\
\hline DIAMANTINA & VEREDINHA & 0 & 0 \\
\hline DIVINÓPOLIS & ARAUJOS & 0 & 0 \\
\hline DIVINÓPOLIS & ARCOS & 3 & 0 \\
\hline DIVINÓPOLIS & BAMBUI & 0 & 0 \\
\hline
\end{tabular}




\begin{tabular}{|c|c|c|c|}
\hline DIVINÓPOLIS & CARMO DA MATA & 1 & 0 \\
\hline DIVINÓPOLIS & CARMO DO CAJURU & 1 & 0 \\
\hline DIVINÓPOLIS & CARMOPOLIS DE MINAS & 0 & 0 \\
\hline DIVINÓPOLIS & CLAUDIO & 4 & 0 \\
\hline DIVINÓPOLIS & CORREGO DANTA & 0 & 0 \\
\hline DIVINÓPOLIS & DIVINOPOLIS & 12 & 2 \\
\hline DIVINÓPOLIS & IGUATAMA & 0 & 0 \\
\hline DIVINÓPOLIS & ITAGUARA & 0 & 0 \\
\hline DIVINÓPOLIS & ITAPECERICA & 0 & 0 \\
\hline DIVINÓPOLIS & ITATIAIUCU & 0 & 0 \\
\hline DIVINÓPOLIS & ITAUNA & 10 & 2 \\
\hline DIVINÓPOLIS & JAPARAIBA & 0 & 0 \\
\hline DIVINÓPOLIS & LAGOA DA PRATA & 3 & 0 \\
\hline DIVINÓPOLIS & LUZ & 0 & 0 \\
\hline DIVINÓPOLIS & MEDEIROS & 0 & 0 \\
\hline DIVINÓPOLIS & MOEMA & 0 & 0 \\
\hline DIVINÓPOLIS & NOVA SERRANA & 6 & 1 \\
\hline DIVINÓPOLIS & OLIVEIRA & 0 & 0 \\
\hline DIVINÓPOLIS & PAINS & 0 & 0 \\
\hline DIVINÓPOLIS & PASSA TEMPO & 0 & 0 \\
\hline DIVINÓPOLIS & PEDRA DO INDAIA & 0 & 0 \\
\hline DIVINÓPOLIS & PERDIGAO & 2 & 0 \\
\hline DIVINÓPOLIS & PIRACEMA & 0 & 0 \\
\hline DIVINÓPOLIS & SANTO ANTONIO DO MONTE & 2 & 0 \\
\hline DIVINÓPOLIS & SAO GONCALO DO PARA & 1 & 0 \\
\hline DIVINÓPOLIS & SAO SEBASTIAO DO OESTE & 0 & 0 \\
\hline DIVINÓPOLIS & TAPIRAI & 0 & 0 \\
\hline GOVERNADOR VALADARES & ACUCENA & 2 & 0 \\
\hline GOVERNADOR VALADARES & AIMORES & 1 & 0 \\
\hline GOVERNADOR VALADARES & ALPERCATA & 0 & 0 \\
\hline GOVERNADOR VALADARES & CAPITAO ANDRADE & 1 & 0 \\
\hline GOVERNADOR VALADARES & CENTRAL DE MINAS & 1 & 0 \\
\hline GOVERNADOR VALADARES & CONSELHEIRO PENA & 3 & 0 \\
\hline GOVERNADOR VALADARES & COROACI & 2 & 0 \\
\hline GOVERNADOR VALADARES & CUPARAQUE & 0 & 0 \\
\hline GOVERNADOR VALADARES & DIVINO DAS LARANJEIRAS & 0 & 0 \\
\hline GOVERNADOR VALADARES & ENGENHEIRO CALDAS & 1 & 0 \\
\hline GOVERNADOR VALADARES & FERNANDES TOURINHO & 1 & 0 \\
\hline GOVERNADOR VALADARES & FREI INOCENCIO & 0 & 0 \\
\hline GOVERNADOR VALADARES & GALILEIA & 0 & 0 \\
\hline GOVERNADOR VALADARES & GOIABEIRA & 0 & 0 \\
\hline GOVERNADOR VALADARES & GOVERNADOR VALADARES & 21 & 4 \\
\hline GOVERNADOR VALADARES & ITABIRINHA & 2 & 0 \\
\hline GOVERNADOR VALADARES & ITANHOMI & 3 & 0 \\
\hline GOVERNADOR VALADARES & ITUETA & 0 & 0 \\
\hline
\end{tabular}




\begin{tabular}{|c|c|c|c|}
\hline GOVERNADOR VALADARES & MANTENA & 2 & 0 \\
\hline GOVERNADOR VALADARES & MARILAC & 1 & 0 \\
\hline GOVERNADOR VALADARES & MATHIAS LOBATO & 0 & 0 \\
\hline GOVERNADOR VALADARES & MENDES PIMENTEL & 0 & 0 \\
\hline GOVERNADOR VALADARES & NACIP RAYDAN & 0 & 0 \\
\hline GOVERNADOR VALADARES & NAQUE & 0 & 0 \\
\hline GOVERNADOR VALADARES & NOVA BELEM & 0 & 0 \\
\hline GOVERNADOR VALADARES & NOVA MODICA & 0 & 0 \\
\hline GOVERNADOR VALADARES & PERIQUITO & 0 & 0 \\
\hline GOVERNADOR VALADARES & RESPLENDOR & 0 & 0 \\
\hline GOVERNADOR VALADARES & SANTA EFIGENIA DE MINAS & 0 & 0 \\
\hline GOVERNADOR VALADARES & SANTA RITA DO ITUETO & 1 & 0 \\
\hline GOVERNADOR VALADARES & SAO FELIX DE MINAS & 1 & 0 \\
\hline GOVERNADOR VALADARES & SAO GERALDO DA PIEDADE & 0 & 0 \\
\hline GOVERNADOR VALADARES & SAO GERALDO DO BAIXIO & 0 & 0 \\
\hline GOVERNADOR VALADARES & SAO JOAO DO MANTENINHA & 0 & 0 \\
\hline GOVERNADOR VALADARES & SAO JOSE DA SAFIRA & 1 & 0 \\
\hline GOVERNADOR VALADARES & SAO JOSE DO DIVINO & 1 & 0 \\
\hline GOVERNADOR VALADARES & SARDOA & 0 & 0 \\
\hline GOVERNADOR VALADARES & SOBRALIA & 0 & 0 \\
\hline GOVERNADOR VALADARES & TUMIRITINGA & 0 & 0 \\
\hline GOVERNADOR VALADARES & VIRGOLANDIA & 0 & 0 \\
\hline GUANHÃES & AGUA BOA & 5 & 1 \\
\hline GUANHÃES & CANTAGALO & 1 & 0 \\
\hline GUANHÃES & CARMESIA & 1 & 0 \\
\hline GUANHÃES & COLUNA & 2 & 0 \\
\hline GUANHÃES & DIVINOLANDIA DE MINAS & 0 & 0 \\
\hline GUANHÃES & DOM JOAQUIM & 1 & 0 \\
\hline GUANHÃES & DORES DE GUANHAES & 1 & 0 \\
\hline GUANHÃES & FREI LAGONEGRO & 0 & 0 \\
\hline GUANHÃES & GONZAGA & 1 & 0 \\
\hline GUANHÃES & GUANHAES & 4 & 0 \\
\hline GUANHÃES & JOSE RAYDAN & 0 & 0 \\
\hline GUANHÃES & MATERLANDIA & 1 & 0 \\
\hline GUANHÃES & PAULISTAS & 1 & 0 \\
\hline GUANHÃES & PECANHA & 3 & 0 \\
\hline GUANHÃES & SABINOPOLIS & 4 & 0 \\
\hline GUANHÃES & SANTA MARIA DO SUACUI & 1 & 0 \\
\hline GUANHÃES & SAO JOAO EVANGELISTA & 2 & 0 \\
\hline GUANHÃES & SAO JOSE DO JACURI & 0 & 0 \\
\hline GUANHÃES & SAO PEDRO DO SUACUI & 0 & 0 \\
\hline GUANHÃES & SAO SEBASTIAO DO MARANHAO & 1 & 0 \\
\hline GUANHÃES & SENHORA DO PORTO & 1 & 0 \\
\hline GUANHÃES & VIRGINOPOLIS & 1 & 0 \\
\hline ITAJUBÁ & BRASOPOLIS & 3 & 0 \\
\hline
\end{tabular}




\begin{tabular}{|c|c|c|c|}
\hline ITAJUBÁ & CARMO DE MINAS & 0 & 0 \\
\hline ITAJUBÁ & CONCEICAO DAS PEDRAS & 0 & 0 \\
\hline ITAJUBÁ & CONCEICAO DOS OUROS & 0 & 0 \\
\hline ITAJUBÁ & CONSOLACAO & 0 & 0 \\
\hline ITAJUBÁ & CRISTINA & 1 & 0 \\
\hline ITAJUBÁ & DELFIM MOREIRA & 0 & 0 \\
\hline ITAJUBÁ & DOM VICOSO & 0 & 0 \\
\hline ITAJUBÁ & GONCALVES & 1 & 0 \\
\hline ITAJUBÁ & ITAJUBA & 3 & 0 \\
\hline ITAJUBÁ & MARIA DA FE & 0 & 0 \\
\hline ITAJUBÁ & MARMELOPOLIS & 0 & 0 \\
\hline ITAJUBÁ & NATERCIA & 0 & 0 \\
\hline ITAJUBÁ & PARAISOPOLIS & 1 & 0 \\
\hline ITAJUBÁ & PEDRALVA & 2 & 0 \\
\hline ITAJUBÁ & PIRANGUCU & 1 & 0 \\
\hline ITAJUBÁ & PIRANGUINHO & 0 & 0 \\
\hline ITAJUBÁ & SAO JOSE DO ALEGRE & 1 & 0 \\
\hline ITAJUBÁ & SAPUCAI-MIRIM & 4 & 0 \\
\hline ITAJUBÁ & VIRGINIA & 2 & 0 \\
\hline ITAJUBÁ & WENCESLAU BRAZ & 1 & 0 \\
\hline ITUIUTABA & CACHOEIRA DOURADA & 0 & 0 \\
\hline ITUIUTABA & CANAPOLIS & 1 & 0 \\
\hline ITUIUTABA & CAPINOPOLIS & 0 & 0 \\
\hline ITUIUTABA & CENTRALINA & 0 & 0 \\
\hline ITUIUTABA & GURINHATA & 0 & 0 \\
\hline ITUIUTABA & IPIACU & 1 & 0 \\
\hline ITUIUTABA & ITUIUTABA & 11 & 2 \\
\hline ITUIUTABA & SANTA VITORIA & 2 & 0 \\
\hline JANAUBA & CATUTI & 1 & 0 \\
\hline JANAUBA & ESPINOSA & 1 & 0 \\
\hline JANAUBA & GAMELEIRAS & 1 & 0 \\
\hline JANAUBA & JAIBA & 1 & 0 \\
\hline JANAUBA & JANAUBA & 9 & 2 \\
\hline JANAUBA & MAMONAS & 1 & 0 \\
\hline JANAUBA & MATO VERDE & 1 & 0 \\
\hline JANAUBA & MONTE AZUL & 0 & 0 \\
\hline JANAUBA & MONTEZUMA & 2 & 0 \\
\hline JANAUBA & NOVA PORTEIRINHA & 2 & 0 \\
\hline JANAUBA & PAI PEDRO & 1 & 0 \\
\hline JANAUBA & PORTEIRINHA & 1 & 0 \\
\hline JANAUBA & RIACHO DOS MACHADOS & 0 & 0 \\
\hline JANAUBA & RIO PARDO DE MINAS & 5 & 1 \\
\hline JANAUBA & SANTO ANTONIO DO RETIRO & 1 & 0 \\
\hline JANAUBA & SERRANOPOLIS DE MINAS & 0 & 0 \\
\hline JANAUBA & VERDELANDIA & 0 & 0 \\
\hline
\end{tabular}




\begin{tabular}{|c|c|c|c|}
\hline JANUARIA & BONITO DE MINAS & 3 & 0 \\
\hline JANUARIA & CHAPADA GAUCHA & 2 & 0 \\
\hline JANUARIA & CONEGO MARINHO & 2 & 0 \\
\hline JANUARIA & IBIRACATU & 1 & 0 \\
\hline JANUARIA & ICARAI DE MINAS & 5 & 1 \\
\hline JANUARIA & ITACARAMBI & 4 & 0 \\
\hline JANUARIA & JANUARIA & 11 & 2 \\
\hline JANUARIA & JUVENILIA & 1 & 0 \\
\hline JANUARIA & MANGA & 3 & 0 \\
\hline JANUARIA & MATIAS CARDOSO & 4 & 0 \\
\hline JANUARIA & MIRAVANIA & 0 & 0 \\
\hline JANUARIA & MONTALVANIA & 0 & 0 \\
\hline JANUARIA & PEDRAS DE MARIA DA CRUZ & 4 & 0 \\
\hline JANUARIA & PINTOPOLIS & 0 & 0 \\
\hline JANUARIA & SAO FRANCISCO & 12 & 2 \\
\hline JANUARIA & SAO JOAO DAS MISSOES & 0 & 0 \\
\hline JANUARIA & UBAI & 0 & 0 \\
\hline JANUARIA & URUCUIA & 0 & 0 \\
\hline JANUARIA & VARZELANDIA & 1 & 0 \\
\hline JUIZ DE FORA & ARANTINA & 0 & 0 \\
\hline JUIZ DE FORA & BELMIRO BRAGA & 0 & 0 \\
\hline JUIZ DE FORA & BICAS & 0 & 0 \\
\hline JUIZ DE FORA & BOM JARDIM DE MINAS & 1 & 0 \\
\hline JUIZ DE FORA & CHACARA & 0 & 0 \\
\hline JUIZ DE FORA & CHIADOR & 0 & 0 \\
\hline JUIZ DE FORA & CORONEL PACHECO & 0 & 0 \\
\hline JUIZ DE FORA & DESCOBERTO & 3 & 0 \\
\hline JUIZ DE FORA & EWBANK DA CAMARA & 0 & 0 \\
\hline JUIZ DE FORA & GOIANA & 0 & 0 \\
\hline JUIZ DE FORA & GUARARA & 0 & 0 \\
\hline JUIZ DE FORA & JUIZ DE FORA & 33 & 4 \\
\hline JUIZ DE FORA & LIMA DUARTE & 4 & 0 \\
\hline JUIZ DE FORA & MAR DE ESPANHA & 1 & 0 \\
\hline JUIZ DE FORA & MARIPA DE MINAS & 0 & 0 \\
\hline JUIZ DE FORA & MATIAS BARBOSA & 1 & 0 \\
\hline JUIZ DE FORA & OLARIA & 0 & 0 \\
\hline JUIZ DE FORA & PEDRO TEIXEIRA & 1 & 0 \\
\hline JUIZ DE FORA & PEQUERI & 0 & 0 \\
\hline JUIZ DE FORA & PIAU & 0 & 0 \\
\hline JUIZ DE FORA & RIO NOVO & 0 & 0 \\
\hline JUIZ DE FORA & RIO PRETO & 0 & 0 \\
\hline JUIZ DE FORA & ROCHEDO DE MINAS & 0 & 0 \\
\hline JUIZ DE FORA & SANTA BARBARA DO MONTE VERDE & 0 & 0 \\
\hline JUIZ DE FORA & SANTA RITA DE JACUTINGA & 0 & 0 \\
\hline JUIZ DE FORA & SANTANA DO DESERTO & 0 & 0 \\
\hline
\end{tabular}




\begin{tabular}{|c|c|c|c|}
\hline JUIZ DE FORA & SANTOS DUMONT & 0 & 0 \\
\hline JUIZ DE FORA & SAO JOAO NEPOMUCENO & 0 & 0 \\
\hline JUIZ DE FORA & SENADOR CORTES & 0 & 0 \\
\hline JUIZ DE FORA & SIMAO PEREIRA & 0 & 0 \\
\hline LEOPOLDINA & ALEM PARAIBA & 1 & 0 \\
\hline LEOPOLDINA & ARGIRITA & 0 & 0 \\
\hline LEOPOLDINA & CATAGUASES & 1 & 0 \\
\hline LEOPOLDINA & ESTRELA DALVA & 0 & 0 \\
\hline LEOPOLDINA & ITAMARATI DE MINAS & 0 & 0 \\
\hline LEOPOLDINA & LEOPOLDINA & 1 & 0 \\
\hline LEOPOLDINA & PIRAPETINGA & 0 & 0 \\
\hline LEOPOLDINA & RECREIO & 0 & 0 \\
\hline LEOPOLDINA & SANTO ANTONIO DO AVENTUREIRO & 1 & 0 \\
\hline LEOPOLDINA & VOLTA GRANDE & 0 & 0 \\
\hline MANHUAÇU & ALTO JEQUITIBA & 1 & 0 \\
\hline MANHUAÇU & CAPUTIRA & 0 & 0 \\
\hline MANHUAÇU & CHALE & 2 & 0 \\
\hline MANHUAÇU & CONCEICAO DE IPANEMA & 0 & 0 \\
\hline MANHUAÇU & DURANDE & 2 & 0 \\
\hline MANHUAÇU & LAJINHA & 2 & 0 \\
\hline MANHUAÇU & LUISBURGO & 0 & 0 \\
\hline MANHUAÇU & MANHUACU & 4 & 0 \\
\hline MANHUAÇU & MANHUMIRIM & 1 & 0 \\
\hline MANHUAÇU & MARTINS SOARES & 0 & 0 \\
\hline MANHUAÇU & MATIPO & 0 & 0 \\
\hline MANHUAÇU & MUTUM & 4 & 0 \\
\hline MANHUAÇU & REDUTO & 0 & 0 \\
\hline MANHUAÇU & SANTA MARGARIDA & 0 & 0 \\
\hline MANHUAÇU & SANTANA DO MANHUACU & 2 & 0 \\
\hline MANHUAÇU & SAO JOAO DO MANHUACU & 0 & 0 \\
\hline MANHUAÇU & SAO JOSE DO MANTIMENTO & 0 & 0 \\
\hline MANHUAÇU & SIMONESIA & 1 & 0 \\
\hline METROPOLITANA A & BARAO DE COCAIS & 0 & 0 \\
\hline METROPOLITANA A & BELO HORIZONTE & 44 & 6 \\
\hline METROPOLITANA A & BELO VALE & 0 & 0 \\
\hline METROPOLITANA A & BOM JESUS DO AMPARO & 0 & 0 \\
\hline METROPOLITANA A & BONFIM & 1 & 0 \\
\hline METROPOLITANA A & BRUMADINHO & 0 & 0 \\
\hline METROPOLITANA A & CAETE & 5 & 1 \\
\hline METROPOLITANA A & CATAS ALTAS & 1 & 0 \\
\hline METROPOLITANA A & CRUCILANDIA & 0 & 0 \\
\hline METROPOLITANA A & MOEDA & 0 & 0 \\
\hline METROPOLITANA A & NOVA LIMA & 3 & 0 \\
\hline METROPOLITANA A & NOVA UNIAO & 0 & 0 \\
\hline METROPOLITANA A & PIEDADE DOS GERAIS & 1 & 0 \\
\hline
\end{tabular}




\begin{tabular}{|c|c|c|c|}
\hline METROPOLITANA A & RAPOSOS & 0 & 0 \\
\hline METROPOLITANA A & RIO ACIMA & 0 & 0 \\
\hline METROPOLITANA A & RIO MANSO & 0 & 0 \\
\hline METROPOLITANA A & SABARA & 10 & 2 \\
\hline METROPOLITANA A & SANTA BARBARA & 3 & 0 \\
\hline METROPOLITANA B & BELO HORIZONTE & 46 & 6 \\
\hline METROPOLITANA B & BETIM & 28 & 4 \\
\hline METROPOLITANA B & CONTAGEM & 40 & 5 \\
\hline METROPOLITANA B & ESMERALDAS & 4 & 0 \\
\hline METROPOLITANA B & IBIRITE & 11 & 2 \\
\hline METROPOLITANA B & IGARAPE & 4 & 0 \\
\hline METROPOLITANA B & JUATUBA & 3 & 0 \\
\hline METROPOLITANA B & MARIO CAMPOS & 0 & 0 \\
\hline METROPOLITANA B & MATEUS LEME & 5 & 1 \\
\hline METROPOLITANA B & SAO JOAQUIM DE BICAS & 1 & 0 \\
\hline METROPOLITANA B & SARZEDO & 2 & 0 \\
\hline METROPOLITANA C & BELO HORIZONTE & 54 & 10 \\
\hline METROPOLITANA C & CONFINS & 1 & 0 \\
\hline METROPOLITANA C & JABOTICATUBAS & 3 & 0 \\
\hline METROPOLITANA C & LAGOA SANTA & 3 & 0 \\
\hline METROPOLITANA C & MORRO DO PILAR & 0 & 0 \\
\hline METROPOLITANA C & PEDRO LEOPOLDO & 1 & 0 \\
\hline METROPOLITANA C & RIBEIRAO DAS NEVES & 60 & 11 \\
\hline METROPOLITANA C & SANTA LUZIA & 21 & 4 \\
\hline METROPOLITANA C & SANTANA DO RIACHO & 0 & 0 \\
\hline METROPOLITANA C & SAO JOSE DA LAPA & 2 & 0 \\
\hline METROPOLITANA C & TAQUARACU DE MINAS & 1 & 0 \\
\hline METROPOLITANA C & VESPASIANO & 7 & 1 \\
\hline MONTE CARMELO & ABADIA DOS DOURADOS & 0 & 0 \\
\hline MONTE CARMELO & CASCALHO RICO & 1 & 0 \\
\hline MONTE CARMELO & COROMANDEL & 3 & 0 \\
\hline MONTE CARMELO & DOURADOQUARA & 0 & 0 \\
\hline MONTE CARMELO & ESTRELA DO SUL & 1 & 0 \\
\hline MONTE CARMELO & GRUPIARA & 0 & 0 \\
\hline MONTE CARMELO & MONTE CARMELO & 2 & 0 \\
\hline MONTE CARMELO & ROMARIA & 0 & 0 \\
\hline MONTES CLAROS & BOCAIUVA & 0 & 0 \\
\hline MONTES CLAROS & BOTUMIRIM & 2 & 0 \\
\hline MONTES CLAROS & BRASILIA DE MINAS & 1 & 0 \\
\hline MONTES CLAROS & CAMPO AZUL & 0 & 0 \\
\hline MONTES CLAROS & CAPITAO ENEAS & 2 & 0 \\
\hline MONTES CLAROS & CLARO DOS POCOES & 1 & 0 \\
\hline MONTES CLAROS & CORACAO DE JESUS & 0 & 0 \\
\hline MONTES CLAROS & CRISTALIA & 1 & 0 \\
\hline MONTES CLAROS & ENGENHEIRO NAVARRO & 0 & 0 \\
\hline
\end{tabular}




\begin{tabular}{|c|c|c|c|}
\hline MONTES CLAROS & FRANCISCO DUMONT & 0 & 0 \\
\hline MONTES CLAROS & FRANCISCO SA & 4 & 0 \\
\hline MONTES CLAROS & GLAUCILANDIA & 3 & 0 \\
\hline MONTES CLAROS & GRAO MOGOL & 3 & 0 \\
\hline MONTES CLAROS & GUARACIAMA & 0 & 0 \\
\hline MONTES CLAROS & ITACAMBIRA & 1 & 0 \\
\hline MONTES CLAROS & JAPONVAR & 0 & 0 \\
\hline MONTES CLAROS & JOSENOPOLIS & 1 & 0 \\
\hline MONTES CLAROS & JURAMENTO & 2 & 0 \\
\hline MONTES CLAROS & LONTRA & 0 & 0 \\
\hline MONTES CLAROS & LUISLANDIA & 0 & 0 \\
\hline MONTES CLAROS & MIRABELA & 2 & 0 \\
\hline MONTES CLAROS & MONTES CLAROS & 9 & 2 \\
\hline MONTES CLAROS & OLHOS-D AGUA & 1 & 0 \\
\hline MONTES CLAROS & PADRE CARVALHO & 1 & 0 \\
\hline MONTES CLAROS & PATIS & 0 & 0 \\
\hline MONTES CLAROS & SAO JOAO DA LAGOA & 1 & 0 \\
\hline MONTES CLAROS & SAO JOAO DA PONTE & 3 & 0 \\
\hline MONTES CLAROS & SAO JOAO DO PACUI & 0 & 0 \\
\hline MONTES CLAROS & SAO JOAO DO PARAISO & 1 & 0 \\
\hline MONTES CLAROS & VARGEM GRANDE DO RIO PARDO & 0 & 0 \\
\hline MURIAÉ & ANTONIO PRADO DE MINAS & 0 & 0 \\
\hline MURIAÉ & BARAO DE MONTE ALTO & 1 & 0 \\
\hline MURIAÉ & EUGENOPOLIS & 0 & 0 \\
\hline MURIAÉ & LARANJAL & 0 & 0 \\
\hline MURIAÉ & MIRADOURO & 1 & 0 \\
\hline MURIAÉ & MIRAI & 0 & 0 \\
\hline MURIAÉ & MURIAE & 2 & 0 \\
\hline MURIAÉ & PALMA & 0 & 0 \\
\hline MURIAÉ & PATROCINIO DO MURIAE & 0 & 0 \\
\hline MURIAÉ & ROSARIO DA LIMEIRA & 0 & 0 \\
\hline MURIAÉ & SANTANA DE CATAGUASES & 1 & 0 \\
\hline MURIAÉ & SAO FRANCISCO DO GLORIA & 0 & 0 \\
\hline MURIAÉ & SAO SEBASTIAO DA VARGEM ALEGRE & 1 & 0 \\
\hline MURIAÉ & VIEIRAS & 1 & 0 \\
\hline NOVA ERA & BELA VISTA DE MINAS & 3 & 0 \\
\hline NOVA ERA & DIONISIO & 0 & 0 \\
\hline NOVA ERA & FERROS & 1 & 0 \\
\hline NOVA ERA & ITABIRA & 5 & 1 \\
\hline NOVA ERA & ITAMBE DO MATO DENTRO & 0 & 0 \\
\hline NOVA ERA & JOAO MONLEVADE & 2 & 0 \\
\hline NOVA ERA & NOVA ERA & 0 & 0 \\
\hline NOVA ERA & PASSABEM & 0 & 0 \\
\hline NOVA ERA & RIO PIRACICABA & 0 & 0 \\
\hline NOVA ERA & SANTA MARIA DE ITABIRA & 3 & 0 \\
\hline
\end{tabular}




\begin{tabular}{|c|c|c|c|}
\hline NOVA ERA & SANTO ANTONIO DO RIO ABAIXO & 0 & 0 \\
\hline NOVA ERA & SAO DOMINGOS DO PRATA & 4 & 0 \\
\hline NOVA ERA & SAO GONCALO DO RIO ABAIXO & 1 & 0 \\
\hline NOVA ERA & SAO JOSE DO GOIABAL & 0 & 0 \\
\hline NOVA ERA & SAO SEBASTIAO DO RIO PRETO & 1 & 0 \\
\hline OURO PRETO & ACAIACA & 1 & 0 \\
\hline OURO PRETO & DIOGO DE VASCONCELOS & 0 & 0 \\
\hline OURO PRETO & ITABIRITO & 10 & 2 \\
\hline OURO PRETO & MARIANA & 11 & 2 \\
\hline OURO PRETO & OURO PRETO & 11 & 2 \\
\hline PARA DE MINAS & ABAETE & 3 & 0 \\
\hline PARA DE MINAS & BIQUINHAS & 0 & 0 \\
\hline PARA DE MINAS & BOM DESPACHO & 0 & 0 \\
\hline PARA DE MINAS & CEDRO DO ABAETE & 0 & 0 \\
\hline PARA DE MINAS & CONCEICAO DO PARA & 0 & 0 \\
\hline PARA DE MINAS & DORES DO INDAIA & 0 & 0 \\
\hline PARA DE MINAS & ESTRELA DO INDAIA & 1 & 0 \\
\hline PARA DE MINAS & FLORESTAL & 6 & 1 \\
\hline PARA DE MINAS & IGARATINGA & 1 & 0 \\
\hline PARA DE MINAS & LEANDRO FERREIRA & 1 & 0 \\
\hline PARA DE MINAS & MARTINHO CAMPOS & 2 & 0 \\
\hline PARA DE MINAS & MORADA NOVA DE MINAS & 0 & 0 \\
\hline PARA DE MINAS & ONCA DE PITANGUI & 0 & 0 \\
\hline PARA DE MINAS & PAINEIRAS & 0 & 0 \\
\hline PARA DE MINAS & PARA DE MINAS & 4 & 0 \\
\hline PARA DE MINAS & PEQUI & 0 & 0 \\
\hline PARA DE MINAS & PITANGUI & 2 & 0 \\
\hline PARA DE MINAS & QUARTEL GERAL & 0 & 0 \\
\hline PARA DE MINAS & SAO JOSE DA VARGINHA & 0 & 0 \\
\hline PARA DE MINAS & SERRA DA SAUDADE & 0 & 0 \\
\hline PARACATU & BRASILANDIA DE MINAS & 1 & 0 \\
\hline PARACATU & GUARDA-MOR & 0 & 0 \\
\hline PARACATU & JOAO PINHEIRO & 4 & 0 \\
\hline PARACATU & PARACATU & 10 & 2 \\
\hline PARACATU & VAZANTE & 1 & 0 \\
\hline PASSOS & ALPINOPOLIS & 1 & 0 \\
\hline PASSOS & BOM JESUS DA PENHA & 0 & 0 \\
\hline PASSOS & CAPITOLIO & 2 & 0 \\
\hline PASSOS & CARMO DO RIO CLARO & 2 & 0 \\
\hline PASSOS & CORREGO FUNDO & 0 & 0 \\
\hline PASSOS & DELFINOPOLIS & 2 & 0 \\
\hline PASSOS & DORESOPOLIS & 0 & 0 \\
\hline PASSOS & FORMIGA & 3 & 0 \\
\hline PASSOS & FORTALEZA DE MINAS & 0 & 0 \\
\hline PASSOS & PASSOS & 2 & 0 \\
\hline
\end{tabular}




\begin{tabular}{|c|c|c|c|}
\hline PASSOS & PIMENTA & 0 & 0 \\
\hline PASSOS & PIUMHI & 1 & 0 \\
\hline PASSOS & SAO JOAO BATISTA DO GLORIA & 1 & 0 \\
\hline PASSOS & SAO JOSE DA BARRA & 1 & 0 \\
\hline PASSOS & SAO ROQUE DE MINAS & 4 & 0 \\
\hline PASSOS & VARGEM BONITA & 0 & 0 \\
\hline PATOS DE MINAS & ARAPUA & 0 & 0 \\
\hline PATOS DE MINAS & CARMO DO PARANAIBA & 4 & 0 \\
\hline PATOS DE MINAS & LAGAMAR & 0 & 0 \\
\hline PATOS DE MINAS & LAGOA FORMOSA & 1 & 0 \\
\hline PATOS DE MINAS & LAGOA GRANDE & 1 & 0 \\
\hline PATOS DE MINAS & MATUTINA & 0 & 0 \\
\hline PATOS DE MINAS & PATOS DE MINAS & 13 & 3 \\
\hline PATOS DE MINAS & PRESIDENTE OLEGARIO & 0 & 0 \\
\hline PATOS DE MINAS & RIO PARANAIBA & 0 & 0 \\
\hline PATOS DE MINAS & SANTA ROSA DA SERRA & 0 & 0 \\
\hline PATOS DE MINAS & SAO GONCALO DO ABAETE & 0 & 0 \\
\hline PATOS DE MINAS & SAO GOTARDO & 6 & 1 \\
\hline PATOS DE MINAS & TIROS & 0 & 0 \\
\hline PATOS DE MINAS & VARJAO DE MINAS & 0 & 0 \\
\hline PATROCÍNIO & CRUZEIRO DA FORTALEZA & 0 & 0 \\
\hline PATROCÍNIO & GUIMARANIA & 0 & 0 \\
\hline PATROCÍNIO & IBIA & 1 & 0 \\
\hline PATROCÍNIO & IRAI DE MINAS & 0 & 0 \\
\hline PATROCÍNIO & PATROCINIO & 5 & 1 \\
\hline PATROCÍNIO & PERDIZES & 2 & 0 \\
\hline PATROCÍNIO & SERRA DO SALITRE & 0 & 0 \\
\hline PIRAPORA & BURITIZEIRO & 8 & 2 \\
\hline PIRAPORA & IBIAI & 1 & 0 \\
\hline PIRAPORA & JEQUITAI & 0 & 0 \\
\hline PIRAPORA & LAGOA DOS PATOS & 0 & 0 \\
\hline PIRAPORA & PIRAPORA & 5 & 1 \\
\hline PIRAPORA & PONTO CHIQUE & 1 & 0 \\
\hline PIRAPORA & SANTA FE DE MINAS & 0 & 0 \\
\hline PIRAPORA & SAO ROMAO & 2 & 0 \\
\hline PIRAPORA & VARZEA DA PALMA & 0 & 0 \\
\hline POÇOS DE CALDAS & ALTEROSA & 0 & 0 \\
\hline POÇOS DE CALDAS & ANDRADAS & 3 & 0 \\
\hline POÇOS DE CALDAS & AREADO & 2 & 0 \\
\hline POÇOS DE CALDAS & BANDEIRA DO SUL & 1 & 0 \\
\hline POÇOS DE CALDAS & BOTELHOS & 4 & 0 \\
\hline POÇOS DE CALDAS & CABO VERDE & 2 & 0 \\
\hline POÇOS DE CALDAS & CALDAS & 1 & 0 \\
\hline POÇOS DE CALDAS & CAMPESTRE & 1 & 0 \\
\hline POÇOS DE CALDAS & CONCEICAO DA APARECIDA & 0 & 0 \\
\hline
\end{tabular}




\begin{tabular}{|c|c|c|c|}
\hline POÇOS DE CALDAS & DIVISA NOVA & 0 & 0 \\
\hline POÇOS DE CALDAS & IBITIURA DE MINAS & 1 & 0 \\
\hline POÇOS DE CALDAS & MONTE BELO & 1 & 0 \\
\hline POÇOS DE CALDAS & MUZAMBINHO & 2 & 0 \\
\hline POÇOS DE CALDAS & NOVA RESENDE & 0 & 0 \\
\hline POÇOS DE CALDAS & POCOS DE CALDAS & 9 & 2 \\
\hline POÇOS DE CALDAS & SANTA RITA DE CALDAS & 1 & 0 \\
\hline POÇOS DE CALDAS & SERRANIA & 1 & 0 \\
\hline PONTE NOVA & ABRE CAMPO & 2 & 0 \\
\hline PONTE NOVA & ALVINOPOLIS & 0 & 0 \\
\hline PONTE NOVA & AMPARO DO SERRA & 1 & 0 \\
\hline PONTE NOVA & ARAPONGA & 1 & 0 \\
\hline PONTE NOVA & BARRA LONGA & 1 & 0 \\
\hline PONTE NOVA & CAJURI & 0 & 0 \\
\hline PONTE NOVA & CANAA & 0 & 0 \\
\hline PONTE NOVA & DOM SILVERIO & 0 & 0 \\
\hline PONTE NOVA & GUARACIABA & 0 & 0 \\
\hline PONTE NOVA & JEQUERI & 1 & 0 \\
\hline PONTE NOVA & ORATORIOS & 0 & 0 \\
\hline PONTE NOVA & PEDRA BONITA & 2 & 0 \\
\hline PONTE NOVA & PEDRA DO ANTA & 0 & 0 \\
\hline PONTE NOVA & PIEDADE DE PONTE NOVA & 0 & 0 \\
\hline PONTE NOVA & PONTE NOVA & 3 & 0 \\
\hline PONTE NOVA & PORTO FIRME & 1 & 0 \\
\hline PONTE NOVA & RAUL SOARES & 0 & 0 \\
\hline PONTE NOVA & RIO CASCA & 1 & 0 \\
\hline PONTE NOVA & RIO DOCE & 0 & 0 \\
\hline PONTE NOVA & SANTA CRUZ DO ESCALVADO & 0 & 0 \\
\hline PONTE NOVA & SANTO ANTONIO DO GRAMA & 1 & 0 \\
\hline PONTE NOVA & SAO MIGUEL DO ANTA & 1 & 0 \\
\hline PONTE NOVA & SAO PEDRO DOS FERROS & 0 & 0 \\
\hline PONTE NOVA & SEM-PEIXE & 0 & 0 \\
\hline PONTE NOVA & SERICITA & 0 & 0 \\
\hline PONTE NOVA & TEIXEIRAS & 2 & 0 \\
\hline PONTE NOVA & URUCANIA & 0 & 0 \\
\hline PONTE NOVA & VERMELHO NOVO & 0 & 0 \\
\hline PONTE NOVA & VICOSA & 10 & 2 \\
\hline POUSO ALEGRE & ALBERTINA & 1 & 0 \\
\hline POUSO ALEGRE & BOM REPOUSO & 0 & 0 \\
\hline POUSO ALEGRE & BORDA DA MATA & 2 & 0 \\
\hline POUSO ALEGRE & BUENO BRANDAO & 0 & 0 \\
\hline POUSO ALEGRE & CACHOEIRA DE MINAS & 2 & 0 \\
\hline POUSO ALEGRE & CAMANDUCAIA & 5 & 1 \\
\hline POUSO ALEGRE & CAMBUI & 4 & 0 \\
\hline POUSO ALEGRE & CAREACU & 1 & 0 \\
\hline
\end{tabular}




\begin{tabular}{|c|c|c|c|}
\hline POUSO ALEGRE & CONGONHAL & 1 & 0 \\
\hline POUSO ALEGRE & CORREGO DO BOM JESUS & 1 & 0 \\
\hline POUSO ALEGRE & ESPIRITO SANTO DO DOURADO & 0 & 0 \\
\hline POUSO ALEGRE & ESTIVA & 1 & 0 \\
\hline POUSO ALEGRE & EXTREMA & 3 & 0 \\
\hline POUSO ALEGRE & HELIODORA & 2 & 0 \\
\hline POUSO ALEGRE & INCONFIDENTES & 2 & 0 \\
\hline POUSO ALEGRE & IPUIUNA & 0 & 0 \\
\hline POUSO ALEGRE & ITAPEVA & 3 & 0 \\
\hline POUSO ALEGRE & JACUTINGA & 0 & 0 \\
\hline POUSO ALEGRE & MONTE SIAO & 3 & 0 \\
\hline POUSO ALEGRE & MUNHOZ & 0 & 0 \\
\hline POUSO ALEGRE & OURO FINO & 2 & 0 \\
\hline POUSO ALEGRE & POUSO ALEGRE & 11 & 2 \\
\hline POUSO ALEGRE & SANTA RITA DO SAPUCAI & 6 & 1 \\
\hline POUSO ALEGRE & SAO JOAO DA MATA & 0 & 0 \\
\hline POUSO ALEGRE & SAO SEBASTIAO DA BELA VISTA & 0 & 0 \\
\hline POUSO ALEGRE & SENADOR AMARAL & 2 & 0 \\
\hline POUSO ALEGRE & SENADOR JOSE BENTO & 0 & 0 \\
\hline POUSO ALEGRE & SILVIANOPOLIS & 1 & 0 \\
\hline POUSO ALEGRE & TOCOS DO MOJI & 0 & 0 \\
\hline POUSO ALEGRE & TOLEDO & 2 & 0 \\
\hline SÃO JOÃO DEL REI & BOM SUCESSO & 1 & 0 \\
\hline SÃO JOÃO DEL REI & CARRANCAS & 0 & 0 \\
\hline SÃO JOÃO DEL REI & CONCEICAO DA BARRA DE MINAS & 1 & 0 \\
\hline SÃO JOÃO DEL REI & CORONEL XAVIER CHAVES & 0 & 0 \\
\hline SÃO JOÃO DEL REI & DORES DE CAMPOS & 0 & 0 \\
\hline SÃO JOÃO DEL REI & IBITURUNA & 0 & 0 \\
\hline SÃO JOÃO DEL REI & IJACI & 1 & 0 \\
\hline SÃO JOÃO DEL REI & INGAI & 1 & 0 \\
\hline SÃO JOÃO DEL REI & ITUMIRIM & 0 & 0 \\
\hline SÃO JOÃO DEL REI & ITUTINGA & 0 & 0 \\
\hline SÃO JOÃO DEL REI & LAGOA DOURADA & 0 & 0 \\
\hline SÃO JOÃO DEL REI & NAZARENO & 1 & 0 \\
\hline SÃO JOÃO DEL REI & PRADOS & 2 & 0 \\
\hline SÃO JOÃO DEL REI & RESENDE COSTA & 2 & 0 \\
\hline SÃO JOÃO DEL REI & RITAPOLIS & 0 & 0 \\
\hline SÃO JOÃO DEL REI & SANTA CRUZ DE MINAS & 0 & 0 \\
\hline SÃO JOÃO DEL REI & SAO JOAO DEL REI & 10 & 2 \\
\hline SÃO JOÃO DEL REI & SAO TIAGO & 1 & 0 \\
\hline SÃO JOÃO DEL REI & TIRADENTES & 1 & 0 \\
\hline SÃO SEBASTIÃO DO PARAÍSO & ARCEBURGO & 0 & 0 \\
\hline SÃO SEBASTIÃO DO PARAÍSO & CAPETINGA & 0 & 0 \\
\hline SÃO SEBASTIÃO DO PARAÍSO & CASSIA & 1 & 0 \\
\hline SÃO SEBASTIÃO DO PARAÍSO & CLARAVAL & 0 & 0 \\
\hline
\end{tabular}




\begin{tabular}{|c|c|c|c|}
\hline SÃO SEBASTIÃO DO PARAÍSO & GUARANESIA & 0 & 0 \\
\hline SÃO SEBASTIÃO DO PARAÍSO & GUAXUPE & 1 & 0 \\
\hline SÃO SEBASTIÃO DO PARAÍSO & IBIRACI & 0 & 0 \\
\hline SÃO SEBASTIÃO DO PARAÍSO & ITAMOGI & 2 & 0 \\
\hline SÃO SEBASTIÃO DO PARAÍSO & ITAU DE MINAS & 0 & 0 \\
\hline SÃO SEBASTIÃO DO PARAÍSO & JACUI & 0 & 0 \\
\hline SÃO SEBASTIÃO DO PARAÍSO & JURUAIA & 2 & 0 \\
\hline SÃO SEBASTIÃO DO PARAÍSO & MONTE SANTO DE MINAS & 2 & 0 \\
\hline SÃO SEBASTIÃO DO PARAÍSO & PRATAPOLIS & 0 & 0 \\
\hline SÃO SEBASTIÃO DO PARAÍSO & SAO PEDRO DA UNIAO & 0 & 0 \\
\hline SÃO SEBASTIÃO DO PARAÍSO & SAO SEBASTIAO DO PARAISO & 6 & 1 \\
\hline SÃO SEBASTIÃO DO PARAÍSO & SAO TOMAS DE AQUINO & 2 & 0 \\
\hline SETE LAGOAS & ARACAI & 0 & 0 \\
\hline SETE LAGOAS & BALDIM & 2 & 0 \\
\hline SETE LAGOAS & CACHOEIRA DA PRATA & 0 & 0 \\
\hline SETE LAGOAS & CAETANOPOLIS & 1 & 0 \\
\hline SETE LAGOAS & CAPIM BRANCO & 1 & 0 \\
\hline SETE LAGOAS & CORDISBURGO & 2 & 0 \\
\hline SETE LAGOAS & FORTUNA DE MINAS & 1 & 0 \\
\hline SETE LAGOAS & FUNILANDIA & 0 & 0 \\
\hline SETE LAGOAS & INHAUMA & 0 & 0 \\
\hline SETE LAGOAS & JEQUITIBA & 0 & 0 \\
\hline SETE LAGOAS & MARAVILHAS & 0 & 0 \\
\hline SETE LAGOAS & MATOZINHOS & 0 & 0 \\
\hline SETE LAGOAS & PAPAGAIOS & 2 & 0 \\
\hline SETE LAGOAS & PARAOPEBA & 0 & 0 \\
\hline SETE LAGOAS & POMPEU & 1 & 0 \\
\hline SETE LAGOAS & PRUDENTE DE MORAIS & 4 & 0 \\
\hline SETE LAGOAS & SANTANA DE PIRAPAMA & 0 & 0 \\
\hline SETE LAGOAS & SETE LAGOAS & 7 & 1 \\
\hline TEOFILO OTONI & AGUAS FORMOSAS & 4 & 0 \\
\hline TEOFILO OTONI & ATALEIA & 1 & 0 \\
\hline TEOFILO OTONI & BERTOPOLIS & 1 & 0 \\
\hline TEOFILO OTONI & CAMPANARIO & 0 & 0 \\
\hline TEOFILO OTONI & CARAI & 2 & 0 \\
\hline TEOFILO OTONI & CARLOS CHAGAS & 1 & 0 \\
\hline TEOFILO OTONI & CATUJI & 0 & 0 \\
\hline TEOFILO OTONI & CRISOLITA & 1 & 0 \\
\hline TEOFILO OTONI & FRANCISCOPOLIS & 0 & 0 \\
\hline TEOFILO OTONI & FREI GASPAR & 1 & 0 \\
\hline TEOFILO OTONI & FRONTEIRA DOS VALES & 0 & 0 \\
\hline TEOFILO OTONI & ITAIPE & 0 & 0 \\
\hline TEOFILO OTONI & ITAMBACURI & 0 & 0 \\
\hline TEOFILO OTONI & JAMPRUCA & 0 & 0 \\
\hline TEOFILO OTONI & LADAINHA & 1 & 0 \\
\hline
\end{tabular}




\begin{tabular}{|c|c|c|c|}
\hline TEOFILO OTONI & MACHACALIS & 1 & 0 \\
\hline TEOFILO OTONI & MALACACHETA & 0 & 0 \\
\hline TEOFILO OTONI & NANUQUE & 2 & 0 \\
\hline TEOFILO OTONI & NOVO CRUZEIRO & 1 & 0 \\
\hline TEOFILO OTONI & NOVO ORIENTE DE MINAS & 5 & 1 \\
\hline TEOFILO OTONI & OURO VERDE DE MINAS & 2 & 0 \\
\hline TEOFILO OTONI & PADRE PARAISO & 3 & 0 \\
\hline TEOFILO OTONI & PAVAO & 1 & 0 \\
\hline TEOFILO OTONI & PESCADOR & 0 & 0 \\
\hline TEOFILO OTONI & PONTO DOS VOLANTES & 0 & 0 \\
\hline TEOFILO OTONI & POTE & 1 & 0 \\
\hline TEOFILO OTONI & SANTA HELENA DE MINAS & 1 & 0 \\
\hline TEOFILO OTONI & SERRA DOS AIMORES & 1 & 0 \\
\hline TEOFILO OTONI & SETUBINHA & 1 & 0 \\
\hline TEOFILO OTONI & TEOFILO OTONI & 10 & 2 \\
\hline TEOFILO OTONI & UMBURATIBA & 0 & 0 \\
\hline UBÁ & ASTOLFO DUTRA & 0 & 0 \\
\hline UBÁ & BRAS PIRES & 0 & 0 \\
\hline UBÁ & COIMBRA & 1 & 0 \\
\hline UBÁ & DIVINESIA & 0 & 0 \\
\hline UBÁ & DONA EUZEBIA & 0 & 0 \\
\hline UBÁ & DORES DO TURVO & 0 & 0 \\
\hline UBÁ & ERVALIA & 1 & 0 \\
\hline UBÁ & GUARANI & 0 & 0 \\
\hline UBÁ & GUIDOVAL & 0 & 0 \\
\hline UBÁ & GUIRICEMA & 0 & 0 \\
\hline UBÁ & PAULA CANDIDO & 1 & 0 \\
\hline UBÁ & PIRAUBA & 0 & 0 \\
\hline UBÁ & PRESIDENTE BERNARDES & 0 & 0 \\
\hline UBÁ & RIO POMBA & 1 & 0 \\
\hline UBÁ & RODEIRO & 0 & 0 \\
\hline UBÁ & SAO GERALDO & 1 & 0 \\
\hline UBÁ & SENADOR FIRMINO & 0 & 0 \\
\hline UBÁ & SILVEIRANIA & 0 & 0 \\
\hline UBÁ & TABULEIRO & 0 & 0 \\
\hline UBÁ & TOCANTINS & 1 & 0 \\
\hline UBÁ & UBA & 7 & 1 \\
\hline UBÁ & VISCONDE DO RIO BRANCO & 1 & 0 \\
\hline UBERABA & AGUA COMPRIDA & 1 & 0 \\
\hline UBERABA & ARAXA & 3 & 0 \\
\hline UBERABA & CAMPO FLORIDO & 0 & 0 \\
\hline UBERABA & CAMPOS ALTOS & 0 & 0 \\
\hline UBERABA & CARNEIRINHO & 2 & 0 \\
\hline UBERABA & COMENDADOR GOMES & 1 & 0 \\
\hline UBERABA & CONCEICAO DAS ALAGOAS & 4 & 0 \\
\hline
\end{tabular}




\begin{tabular}{|c|c|c|c|}
\hline UBERABA & CONQUISTA & 0 & 0 \\
\hline UBERABA & DELTA & 0 & 0 \\
\hline UBERABA & FRONTEIRA & 0 & 0 \\
\hline UBERABA & FRUTAL & 2 & 0 \\
\hline UBERABA & ITAPAGIPE & 1 & 0 \\
\hline UBERABA & ITURAMA & 1 & 0 \\
\hline UBERABA & LIMEIRA DO OESTE & 0 & 0 \\
\hline UBERABA & PEDRINOPOLIS & 0 & 0 \\
\hline UBERABA & PIRAJUBA & 1 & 0 \\
\hline UBERABA & PLANURA & 2 & 0 \\
\hline UBERABA & PRATINHA & 0 & 0 \\
\hline UBERABA & SACRAMENTO & 1 & 0 \\
\hline UBERABA & SANTA JULIANA & 2 & 0 \\
\hline UBERABA & SAO FRANCISCO DE SALES & 0 & 0 \\
\hline UBERABA & TAPIRA & 0 & 0 \\
\hline UBERABA & UBERABA & 18 & 4 \\
\hline UBERABA & UNIAO DE MINAS & 0 & 0 \\
\hline UBERABA & VERISSIMO & 0 & 0 \\
\hline UBERLANDIA & ARAGUARI & 8 & 2 \\
\hline UBERLANDIA & ARAPORA & 0 & 0 \\
\hline UBERLANDIA & CAMPINA VERDE & 3 & 0 \\
\hline UBERLANDIA & INDIANOPOLIS & 3 & 0 \\
\hline UBERLANDIA & MONTE ALEGRE DE MINAS & 0 & 0 \\
\hline UBERLANDIA & NOVA PONTE & 0 & 0 \\
\hline UBERLANDIA & PRATA & 5 & 1 \\
\hline UBERLANDIA & TUPACIGUARA & 3 & 0 \\
\hline UBERLANDIA & UBERLANDIA & 54 & 10 \\
\hline UNAI & ARINOS & 3 & 0 \\
\hline UNAI & BONFINOPOLIS DE MINAS & 0 & 0 \\
\hline UNAI & BURITIS & 0 & 0 \\
\hline UNAI & CABECEIRA GRANDE & 0 & 0 \\
\hline UNAI & DOM BOSCO & 0 & 0 \\
\hline UNAI & FORMOSO & 1 & 0 \\
\hline UNAI & NATALANDIA & 0 & 0 \\
\hline UNAI & RIACHINHO & 2 & 0 \\
\hline UNAI & UNAI & 5 & 1 \\
\hline UNAI & URUANA DE MINAS & 1 & 0 \\
\hline VARGINHA & ALFENAS & 3 & 0 \\
\hline VARGINHA & BOA ESPERANCA & 0 & 0 \\
\hline VARGINHA & CAMBUQUIRA & 0 & 0 \\
\hline VARGINHA & CAMPANHA & 1 & 0 \\
\hline VARGINHA & CAMPO DO MEIO & 0 & 0 \\
\hline VARGINHA & CAMPOS GERAIS & 0 & 0 \\
\hline VARGINHA & CARMO DA CACHOEIRA & 1 & 0 \\
\hline VARGINHA & CARVALHOPOLIS & 0 & 0 \\
\hline
\end{tabular}




\begin{tabular}{|c|c|c|c|}
\hline VARGINHA & COQUEIRAL & 0 & 0 \\
\hline VARGINHA & CORDISLANDIA & 0 & 0 \\
\hline VARGINHA & ELOI MENDES & 0 & 0 \\
\hline VARGINHA & FAMA & 0 & 0 \\
\hline VARGINHA & GUAPE & 0 & 0 \\
\hline VARGINHA & ILICINEA & 0 & 0 \\
\hline VARGINHA & LAMBARI & 1 & 0 \\
\hline VARGINHA & LUMINARIAS & 0 & 0 \\
\hline VARGINHA & MACHADO & 1 & 0 \\
\hline VARGINHA & MONSENHOR PAULO & 1 & 0 \\
\hline VARGINHA & NEPOMUCENO & 1 & 0 \\
\hline VARGINHA & PARAGUACU & 1 & 0 \\
\hline VARGINHA & POCO FUNDO & 2 & 0 \\
\hline VARGINHA & SANTANA DA VARGEM & 0 & 0 \\
\hline VARGINHA & SAO BENTO ABADE & 0 & 0 \\
\hline VARGINHA & SAO GONCALO DO SAPUCAI & 1 & 0 \\
\hline VARGINHA & TRES CORACOES & 4 & 0 \\
\hline VARGINHA & TRES PONTAS & 1 & 0 \\
\hline VARGINHA & TURVOLANDIA & 0 & 0 \\
\hline VARGINHA & VARGINHA & 6 & 1 \\
\hline Total geral & & 1476 & 148 \\
\hline
\end{tabular}

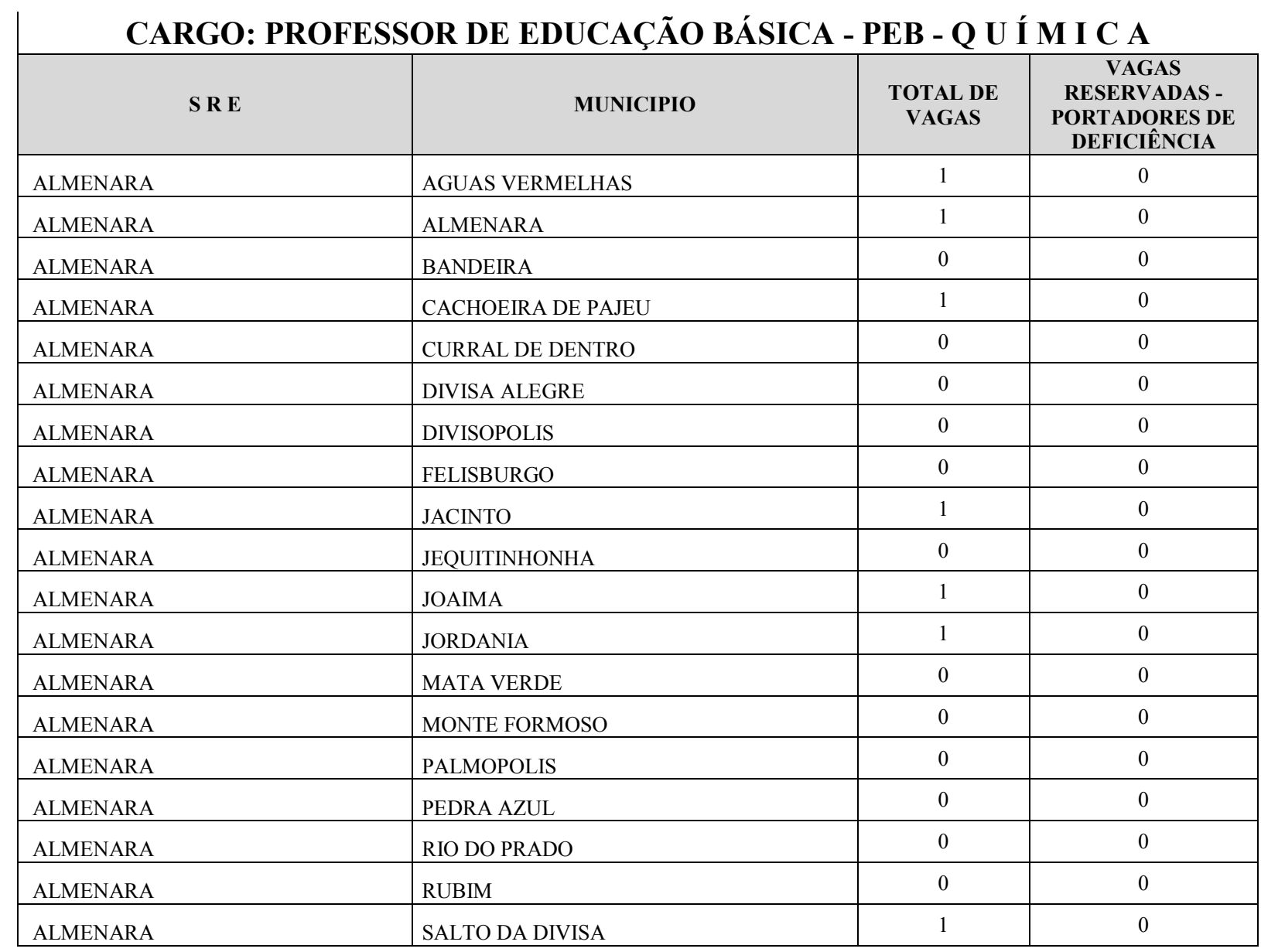




\begin{tabular}{|c|c|c|c|}
\hline ALMENARA & SANTA MARIA DO SALTO & 1 & 0 \\
\hline ALMENARA & SANTO ANTONIO DO JACINTO & 0 & 0 \\
\hline ARACUAI & ARACUAI & 2 & 0 \\
\hline ARACUAI & BERILO & 2 & 0 \\
\hline ARACUAI & BERIZAL & 0 & 0 \\
\hline ARACUAI & CHAPADA DO NORTE & 3 & 0 \\
\hline ARACUAI & COMERCINHO & 0 & 0 \\
\hline ARACUAI & CORONEL MURTA & 1 & 0 \\
\hline ARACUAI & FRANCISCO BADARO & 1 & 0 \\
\hline ARACUAI & FRUTA DE LEITE & 0 & 0 \\
\hline ARACUAI & INDAIABIRA & 0 & 0 \\
\hline ARACUAI & ITAOBIM & 0 & 0 \\
\hline ARACUAI & ITINGA & 1 & 0 \\
\hline ARACUAI & JENIPAPO DE MINAS & 0 & 0 \\
\hline ARACUAI & JOSE GONCALVES DE MINAS & 0 & 0 \\
\hline ARACUAI & MEDINA & 2 & 0 \\
\hline ARACUAI & NINHEIRA & 2 & 0 \\
\hline ARACUAI & NOVORIZONTE & 0 & 0 \\
\hline ARACUAI & RUBELITA & 0 & 0 \\
\hline ARACUAI & SALINAS & 3 & 0 \\
\hline ARACUAI & SANTA CRUZ DE SALINAS & 1 & 0 \\
\hline ARACUAI & TAIOBEIRAS & 2 & 0 \\
\hline ARACUAI & VIRGEM DA LAPA & 0 & 0 \\
\hline BARBACENA & ALFREDO VASCONCELOS & 1 & 0 \\
\hline BARBACENA & ALTO RIO DOCE & 0 & 0 \\
\hline BARBACENA & ANDRELANDIA & 0 & 0 \\
\hline BARBACENA & ANTONIO CARLOS & 1 & 0 \\
\hline BARBACENA & ARACITABA & 0 & 0 \\
\hline BARBACENA & BARBACENA & 5 & 2 \\
\hline BARBACENA & BARROSO & 0 & 0 \\
\hline BARBACENA & BIAS FORTES & 0 & 0 \\
\hline BARBACENA & CAPELA NOVA & 0 & 0 \\
\hline BARBACENA & CARANDAI & 0 & 0 \\
\hline BARBACENA & CIPOTANEA & 0 & 0 \\
\hline BARBACENA & DESTERRO DO MELO & 0 & 0 \\
\hline BARBACENA & IBERTIOGA & 0 & 0 \\
\hline BARBACENA & MADRE DE DEUS DE MINAS & 0 & 0 \\
\hline BARBACENA & MERCES & 0 & 0 \\
\hline BARBACENA & OLIVEIRA FORTES & 0 & 0 \\
\hline BARBACENA & PAIVA & 1 & 0 \\
\hline BARBACENA & PIEDADE DO RIO GRANDE & 0 & 0 \\
\hline BARBACENA & RESSAQUINHA & 0 & 0 \\
\hline BARBACENA & SANTA BARBARA DO TUGURIO & 0 & 0 \\
\hline BARBACENA & SANTA RITA DO IBITIPOCA & 0 & 0 \\
\hline BARBACENA & SANTANA DO GARAMBEU & 0 & 0 \\
\hline
\end{tabular}




\begin{tabular}{|c|c|c|c|}
\hline BARBACENA & SAO VICENTE DE MINAS & 1 & 0 \\
\hline BARBACENA & SENHORA DOS REMEDIOS & 0 & 0 \\
\hline CAMPO BELO & AGUANIL & 0 & 0 \\
\hline CAMPO BELO & CAMACHO & 0 & 0 \\
\hline CAMPO BELO & CAMPO BELO & 1 & 0 \\
\hline CAMPO BELO & CANA VERDE & 0 & 0 \\
\hline CAMPO BELO & CANDEIAS & 0 & 0 \\
\hline CAMPO BELO & CRISTAIS & 1 & 0 \\
\hline CAMPO BELO & LAVRAS & 2 & 0 \\
\hline CAMPO BELO & PERDOES & 1 & 0 \\
\hline CAMPO BELO & RIBEIRAO VERMELHO & 0 & 0 \\
\hline CAMPO BELO & SANTANA DO JACARE & 0 & 0 \\
\hline CAMPO BELO & SANTO ANTONIO DO AMPARO & 0 & 0 \\
\hline CAMPO BELO & SAO FRANCISCO DE PAULA & 0 & 0 \\
\hline CARANGOLA & ALTO CAPARAO & 0 & 0 \\
\hline CARANGOLA & CAIANA & 0 & 0 \\
\hline CARANGOLA & CAPARAO & 0 & 0 \\
\hline CARANGOLA & CARANGOLA & 3 & 0 \\
\hline CARANGOLA & DIVINO & 1 & 0 \\
\hline CARANGOLA & ESPERA FELIZ & 2 & 0 \\
\hline CARANGOLA & FARIA LEMOS & 1 & 0 \\
\hline CARANGOLA & FERVEDOURO & 1 & 0 \\
\hline CARANGOLA & ORIZANIA & 0 & 0 \\
\hline CARANGOLA & PEDRA DOURADA & 0 & 0 \\
\hline CARANGOLA & TOMBOS & 1 & 0 \\
\hline CARATINGA & ALVARENGA & 0 & 0 \\
\hline CARATINGA & BOM JESUS DO GALHO & 0 & 0 \\
\hline CARATINGA & BUGRE & 0 & 0 \\
\hline CARATINGA & CARATINGA & 5 & 2 \\
\hline CARATINGA & CORREGO NOVO & 0 & 0 \\
\hline CARATINGA & DOM CAVATI & 0 & 0 \\
\hline CARATINGA & ENTRE FOLHAS & 1 & 0 \\
\hline CARATINGA & IAPU & 1 & 0 \\
\hline CARATINGA & IMBE DE MINAS & 0 & 0 \\
\hline CARATINGA & INHAPIM & 3 & 0 \\
\hline CARATINGA & IPABA & 0 & 0 \\
\hline CARATINGA & IPANEMA & 1 & 0 \\
\hline CARATINGA & PIEDADE DE CARATINGA & 0 & 0 \\
\hline CARATINGA & PINGO D AGUA & 1 & 0 \\
\hline CARATINGA & POCRANE & 1 & 0 \\
\hline CARATINGA & SANTA BARBARA DO LESTE & 0 & 0 \\
\hline CARATINGA & SANTA RITA DE MINAS & 0 & 0 \\
\hline CARATINGA & SAO DOMINGOS DAS DORES & 0 & 0 \\
\hline CARATINGA & SAO JOAO DO ORIENTE & 0 & 0 \\
\hline CARATINGA & SAO SEBASTIAO DO ANTA & 0 & 0 \\
\hline
\end{tabular}




\begin{tabular}{|c|c|c|c|}
\hline CARATINGA & TAPARUBA & 0 & 0 \\
\hline CARATINGA & TARUMIRIM & 3 & 0 \\
\hline CARATINGA & UBAPORANGA & 1 & 0 \\
\hline CARATINGA & VARGEM ALEGRE & 1 & 0 \\
\hline CAXAMBU & AIURUOCA & 1 & 0 \\
\hline CAXAMBU & ALAGOA & 0 & 0 \\
\hline CAXAMBU & BAEPENDI & 0 & 0 \\
\hline CAXAMBU & BOCAINA DE MINAS & 1 & 0 \\
\hline CAXAMBU & CARVALHOS & 0 & 0 \\
\hline CAXAMBU & CAXAMBU & 1 & 0 \\
\hline CAXAMBU & CONCEICAO DO RIO VERDE & 0 & 0 \\
\hline CAXAMBU & CRUZILIA & 0 & 0 \\
\hline CAXAMBU & ITAMONTE & 0 & 0 \\
\hline CAXAMBU & ITANHANDU & 0 & 0 \\
\hline CAXAMBU & JESUANIA & 0 & 0 \\
\hline CAXAMBU & LIBERDADE & 0 & 0 \\
\hline CAXAMBU & MINDURI & 0 & 0 \\
\hline CAXAMBU & OLIMPIO NORONHA & 0 & 0 \\
\hline CAXAMBU & PASSA QUATRO & 1 & 0 \\
\hline CAXAMBU & PASSA VINTE & 0 & 0 \\
\hline CAXAMBU & POUSO ALTO & 1 & 0 \\
\hline CAXAMBU & SAO LOURENCO & 1 & 0 \\
\hline CAXAMBU & SAO SEBASTIAO DO RIO VERDE & 0 & 0 \\
\hline CAXAMBU & SAO TOME DAS LETRAS & 0 & 0 \\
\hline CAXAMBU & SERITINGA & 0 & 0 \\
\hline CAXAMBU & SERRANOS & 1 & 0 \\
\hline CAXAMBU & SOLEDADE DE MINAS & 0 & 0 \\
\hline CORONEL FABRICIANO & ANTONIO DIAS & 0 & 0 \\
\hline CORONEL FABRICIANO & BELO ORIENTE & 1 & 0 \\
\hline CORONEL FABRICIANO & BRAUNAS & 0 & 0 \\
\hline CORONEL FABRICIANO & CORONEL FABRICIANO & 5 & 2 \\
\hline CORONEL FABRICIANO & IPATINGA & 4 & 0 \\
\hline CORONEL FABRICIANO & JAGUARAÇU & 0 & 0 \\
\hline CORONEL FABRICIANO & JOANESIA & 0 & 0 \\
\hline CORONEL FABRICIANO & MARLIERIA & 0 & 0 \\
\hline CORONEL FABRICIANO & MESQUITA & 0 & 0 \\
\hline CORONEL FABRICIANO & SANTANA DO PARAISO & 1 & 0 \\
\hline CORONEL FABRICIANO & TIMOTEO & 2 & 0 \\
\hline CONSELHEIRO LAFAIETE & CARANAIBA & 0 & 0 \\
\hline CONSELHEIRO LAFAIETE & CASA GRANDE & 1 & 0 \\
\hline CONSELHEIRO LAFAIETE & CATAS ALTAS DA NORUEGA & 0 & 0 \\
\hline CONSELHEIRO LAFAIETE & CONGONHAS & 0 & 0 \\
\hline CONSELHEIRO LAFAIETE & CONSELHEIRO LAFAIETE & 3 & 0 \\
\hline CONSELHEIRO LAFAIETE & CRISTIANO OTONI & 0 & 0 \\
\hline CONSELHEIRO LAFAIETE & DESTERRO DE ENTRE RIOS & 0 & 0 \\
\hline
\end{tabular}




\begin{tabular}{|c|c|c|c|}
\hline CONSELHEIRO LAFAIETE & ENTRE RIOS DE MINAS & 1 & 0 \\
\hline CONSELHEIRO LAFAIETE & ITAVERAVA & 0 & 0 \\
\hline CONSELHEIRO LAFAIETE & JECEABA & 0 & 0 \\
\hline CONSELHEIRO LAFAIETE & LAMIM & 0 & 0 \\
\hline CONSELHEIRO LAFAIETE & OURO BRANCO & 0 & 0 \\
\hline CONSELHEIRO LAFAIETE & PIRANGA & 3 & 0 \\
\hline CONSELHEIRO LAFAIETE & QUELUZITO & 1 & 0 \\
\hline CONSELHEIRO LAFAIETE & RIO ESPERA & 0 & 0 \\
\hline CONSELHEIRO LAFAIETE & SANTANA DOS MONTES & 0 & 0 \\
\hline CONSELHEIRO LAFAIETE & SAO BRAS DO SUACUI & 0 & 0 \\
\hline CONSELHEIRO LAFAIETE & SENHORA DE OLIVEIRA & 1 & 0 \\
\hline CURVELO & AUGUSTO DE LIMA & 0 & 0 \\
\hline CURVELO & BUENOPOLIS & 0 & 0 \\
\hline CURVELO & CORINTO & 1 & 0 \\
\hline CURVELO & CURVELO & 3 & 0 \\
\hline CURVELO & FELIXLANDIA & 1 & 0 \\
\hline CURVELO & INIMUTABA & 2 & 0 \\
\hline CURVELO & JOAQUIM FELICIO & 0 & 0 \\
\hline CURVELO & LASSANCE & 0 & 0 \\
\hline CURVELO & MORRO DA GARCA & 0 & 0 \\
\hline CURVELO & PRESIDENTE JUSCELINO & 0 & 0 \\
\hline CURVELO & SANTO HIPOLITO & 1 & 0 \\
\hline CURVELO & TRES MARIAS & 1 & 0 \\
\hline DIAMANTINA & ALVORADA DE MINAS & 0 & 0 \\
\hline DIAMANTINA & ANGELANDIA & 0 & 0 \\
\hline DIAMANTINA & ARICANDUVA & 2 & 0 \\
\hline DIAMANTINA & CAPELINHA & 3 & 0 \\
\hline DIAMANTINA & CARBONITA & 0 & 0 \\
\hline DIAMANTINA & CONCEICAO DO MATO DENTRO & 2 & 0 \\
\hline DIAMANTINA & CONGONHAS DO NORTE & 0 & 0 \\
\hline DIAMANTINA & COUTO DE MAGALHAES DE MINAS & 1 & 0 \\
\hline DIAMANTINA & DATAS & 1 & 0 \\
\hline DIAMANTINA & DIAMANTINA & 1 & 0 \\
\hline DIAMANTINA & FELICIO DOS SANTOS & 1 & 0 \\
\hline DIAMANTINA & GOUVEA & 3 & 0 \\
\hline DIAMANTINA & ITAMARANDIBA & 6 & 2 \\
\hline DIAMANTINA & LEME DO PRADO & 0 & 0 \\
\hline DIAMANTINA & MINAS NOVAS & 2 & 0 \\
\hline DIAMANTINA & MONJOLOS & 0 & 0 \\
\hline DIAMANTINA & PRESIDENTE KUBITSCHEK & 0 & 0 \\
\hline DIAMANTINA & RIO VERMELHO & 3 & 0 \\
\hline DIAMANTINA & SANTO ANTONIO DO ITAMBE & 1 & 0 \\
\hline DIAMANTINA & SAO GONCALO DO RIO PRETO & 0 & 0 \\
\hline DIAMANTINA & SENADOR MODESTINO GONCALVES & 0 & 0 \\
\hline DIAMANTINA & SERRA AZUL DE MINAS & 0 & 0 \\
\hline
\end{tabular}




\begin{tabular}{|c|c|c|c|}
\hline DIAMANTINA & SERRO & 2 & 0 \\
\hline DIAMANTINA & TURMALINA & 0 & 0 \\
\hline DIAMANTINA & VEREDINHA & 0 & 0 \\
\hline DIVINÓPOLIS & ARAUJOS & 0 & 0 \\
\hline DIVINÓPOLIS & ARCOS & 0 & 0 \\
\hline DIVINÓPOLIS & BAMBUI & 3 & 0 \\
\hline DIVINÓPOLIS & CARMO DA MATA & 0 & 0 \\
\hline DIVINÓPOLIS & CARMO DO CAJURU & 0 & 0 \\
\hline DIVINÓPOLIS & CARMOPOLIS DE MINAS & 0 & 0 \\
\hline DIVINÓPOLIS & CLAUDIO & 0 & 0 \\
\hline DIVINÓPOLIS & CORREGO DANTA & 1 & 0 \\
\hline DIVINÓPOLIS & DIVINOPOLIS & 6 & 2 \\
\hline DIVINÓPOLIS & IGUATAMA & 1 & 0 \\
\hline DIVINÓPOLIS & ITAGUARA & 0 & 0 \\
\hline DIVINÓPOLIS & ITAPECERICA & 1 & 0 \\
\hline DIVINÓPOLIS & ITATIAIUCU & 1 & 0 \\
\hline DIVINÓPOLIS & ITAUNA & 1 & 0 \\
\hline DIVINÓPOLIS & JAPARAIBA & 0 & 0 \\
\hline DIVINÓPOLIS & LAGOA DA PRATA & 3 & 0 \\
\hline DIVINÓPOLIS & LUZ & 0 & 0 \\
\hline DIVINÓPOLIS & MEDEIROS & 0 & 0 \\
\hline DIVINÓPOLIS & MOEMA & 0 & 0 \\
\hline DIVINÓPOLIS & NOVA SERRANA & 2 & 0 \\
\hline DIVINÓPOLIS & OLIVEIRA & 1 & 0 \\
\hline DIVINÓPOLIS & PAINS & 0 & 0 \\
\hline DIVINÓPOLIS & PASSA TEMPO & 0 & 0 \\
\hline DIVINÓPOLIS & PEDRA DO INDAIA & 0 & 0 \\
\hline DIVINÓPOLIS & PERDIGAO & 1 & 0 \\
\hline DIVINÓPOLIS & PIRACEMA & 0 & 0 \\
\hline DIVINÓPOLIS & SANTO ANTONIO DO MONTE & 1 & 0 \\
\hline DIVINÓPOLIS & SAO GONCALO DO PARA & 1 & 0 \\
\hline DIVINÓPOLIS & SAO SEBASTIAO DO OESTE & 0 & 0 \\
\hline DIVINÓPOLIS & TAPIRAI & 1 & 0 \\
\hline GOVERNADOR VALADARES & ACUCENA & 1 & 0 \\
\hline GOVERNADOR VALADARES & AIMORES & 2 & 0 \\
\hline GOVERNADOR VALADARES & ALPERCATA & 0 & 0 \\
\hline GOVERNADOR VALADARES & CAPITAO ANDRADE & 0 & 0 \\
\hline GOVERNADOR VALADARES & CENTRAL DE MINAS & 2 & 0 \\
\hline GOVERNADOR VALADARES & CONSELHEIRO PENA & 1 & 0 \\
\hline GOVERNADOR VALADARES & COROACI & 0 & 0 \\
\hline GOVERNADOR VALADARES & CUPARAQUE & 1 & 0 \\
\hline GOVERNADOR VALADARES & DIVINO DAS LARANJEIRAS & 0 & 0 \\
\hline GOVERNADOR VALADARES & ENGENHEIRO CALDAS & 0 & 0 \\
\hline GOVERNADOR VALADARES & FERNANDES TOURINHO & 1 & 0 \\
\hline GOVERNADOR VALADARES & FREI INOCENCIO & 1 & 0 \\
\hline
\end{tabular}




\begin{tabular}{|c|c|c|c|}
\hline GOVERNADOR VALADARES & GALILEIA & 0 & 0 \\
\hline GOVERNADOR VALADARES & GOIABEIRA & 0 & 0 \\
\hline GOVERNADOR VALADARES & GOVERNADOR VALADARES & 8 & 2 \\
\hline GOVERNADOR VALADARES & ITABIRINHA & 0 & 0 \\
\hline GOVERNADOR VALADARES & ITANHOMI & 2 & 0 \\
\hline GOVERNADOR VALADARES & ITUETA & 1 & 0 \\
\hline GOVERNADOR VALADARES & MANTENA & 1 & 0 \\
\hline GOVERNADOR VALADARES & MARILAC & 0 & 0 \\
\hline GOVERNADOR VALADARES & MATHIAS LOBATO & 0 & 0 \\
\hline GOVERNADOR VALADARES & MENDES PIMENTEL & 0 & 0 \\
\hline GOVERNADOR VALADARES & NACIP RAYDAN & 0 & 0 \\
\hline GOVERNADOR VALADARES & NAQUE & 1 & 0 \\
\hline GOVERNADOR VALADARES & NOVA BELEM & 1 & 0 \\
\hline GOVERNADOR VALADARES & NOVA MODICA & 0 & 0 \\
\hline GOVERNADOR VALADARES & PERIQUITO & 0 & 0 \\
\hline GOVERNADOR VALADARES & RESPLENDOR & 1 & 0 \\
\hline GOVERNADOR VALADARES & SANTA EFIGENIA DE MINAS & 0 & 0 \\
\hline GOVERNADOR VALADARES & SANTA RITA DO ITUETO & 0 & 0 \\
\hline GOVERNADOR VALADARES & SAO FELIX DE MINAS & 0 & 0 \\
\hline GOVERNADOR VALADARES & SAO GERALDO DA PIEDADE & 0 & 0 \\
\hline GOVERNADOR VALADARES & SAO GERALDO DO BAIXIO & 0 & 0 \\
\hline GOVERNADOR VALADARES & SAO JOAO DO MANTENINHA & 1 & 0 \\
\hline GOVERNADOR VALADARES & SAO JOSE DA SAFIRA & 0 & 0 \\
\hline GOVERNADOR VALADARES & SAO JOSE DO DIVINO & 0 & 0 \\
\hline GOVERNADOR VALADARES & SARDOA & 0 & 0 \\
\hline GOVERNADOR VALADARES & SOBRALIA & 0 & 0 \\
\hline GOVERNADOR VALADARES & TUMIRITINGA & 0 & 0 \\
\hline GOVERNADOR VALADARES & VIRGOLANDIA & 0 & 0 \\
\hline GUANHÃES & AGUA BOA & 2 & 0 \\
\hline GUANHÃES & CANTAGALO & 0 & 0 \\
\hline GUANHÃES & CARMESIA & 0 & 0 \\
\hline GUANHÃES & COLUNA & 0 & 0 \\
\hline GUANHÃES & DIVINOLANDIA DE MINAS & 1 & 0 \\
\hline GUANHÃES & DOM JOAQUIM & 1 & 0 \\
\hline GUANHÃES & DORES DE GUANHAES & 0 & 0 \\
\hline GUANHÃES & FREI LAGONEGRO & 0 & 0 \\
\hline GUANHÃES & GONZAGA & 0 & 0 \\
\hline GUANHÃES & GUANHAES & 6 & 2 \\
\hline GUANHÃES & JOSE RAYDAN & 0 & 0 \\
\hline GUANHÃES & MATERLANDIA & 1 & 0 \\
\hline GUANHÃES & PAULISTAS & 0 & 0 \\
\hline GUANHÃES & PECANHA & 1 & 0 \\
\hline GUANHÃES & SABINOPOLIS & 1 & 0 \\
\hline GUANHÃES & SANTA MARIA DO SUACUI & 3 & 0 \\
\hline GUANHÃES & SAO JOAO EVANGELISTA & 1 & 0 \\
\hline
\end{tabular}




\begin{tabular}{|c|c|c|c|}
\hline GUANHÃES & SAO JOSE DO JACURI & 1 & 0 \\
\hline GUANHÃES & SAO PEDRO DO SUACUI & 1 & 0 \\
\hline GUANHÃES & SAO SEBASTIAO DO MARANHAO & 2 & 0 \\
\hline GUANHÃES & SENHORA DO PORTO & 0 & 0 \\
\hline GUANHÃES & VIRGINOPOLIS & 0 & 0 \\
\hline ITAJUBÁ & BRASOPOLIS & 0 & 0 \\
\hline ITAJUBÁ & CARMO DE MINAS & 2 & 0 \\
\hline ITAJUBÁ & CONCEICAO DAS PEDRAS & 1 & 0 \\
\hline ITAJUBÁ & CONCEICAO DOS OUROS & 0 & 0 \\
\hline ITAJUBÁ & CONSOLACAO & 1 & 0 \\
\hline ITAJUBÁ & CRISTINA & 0 & 0 \\
\hline ITAJUBÁ & DELFIM MOREIRA & 1 & 0 \\
\hline ITAJUBÁ & DOM VICOSO & 1 & 0 \\
\hline ITAJUBÁ & GONCALVES & 0 & 0 \\
\hline ITAJUBÁ & ITAJUBA & 2 & 0 \\
\hline ITAJUBÁ & MARIA DA FE & 2 & 0 \\
\hline ITAJUBÁ & MARMELOPOLIS & 0 & 0 \\
\hline ITAJUBÁ & NATERCIA & 0 & 0 \\
\hline ITAJUBÁ & PARAISOPOLIS & 0 & 0 \\
\hline ITAJUBÁ & PEDRALVA & 2 & 0 \\
\hline ITAJUBÁ & PIRANGUCU & 0 & 0 \\
\hline ITAJUBÁ & PIRANGUINHO & 0 & 0 \\
\hline ITAJUBÁ & SAO JOSE DO ALEGRE & 1 & 0 \\
\hline ITAJUBÁ & SAPUCAI-MIRIM & 0 & 0 \\
\hline ITAJUBÁ & VIRGINIA & 1 & 0 \\
\hline ITAJUBÁ & WENCESLAU BRAZ & 0 & 0 \\
\hline ITUIUTABA & CACHOEIRA DOURADA & 0 & 0 \\
\hline ITUIUTABA & CANAPOLIS & 0 & 0 \\
\hline ITUIUTABA & CAPINOPOLIS & 1 & 0 \\
\hline ITUIUTABA & CENTRALINA & 0 & 0 \\
\hline ITUIUTABA & GURINHATA & 0 & 0 \\
\hline ITUIUTABA & IPIACU & 0 & 0 \\
\hline ITUIUTABA & ITUIUTABA & 1 & 0 \\
\hline ITUIUTABA & SANTA VITORIA & 3 & 0 \\
\hline JANAUBA & CATUTI & 0 & 0 \\
\hline JANAUBA & ESPINOSA & 1 & 0 \\
\hline JANAUBA & GAMELEIRAS & 2 & 0 \\
\hline JANAUBA & JAIBA & 1 & 0 \\
\hline JANAUBA & JANAUBA & 7 & 2 \\
\hline JANAUBA & MAMONAS & 0 & 0 \\
\hline JANAUBA & MATO VERDE & 2 & 0 \\
\hline JANAUBA & MONTE AZUL & 0 & 0 \\
\hline JANAUBA & MONTEZUMA & 1 & 0 \\
\hline JANAUBA & NOVA PORTEIRINHA & 1 & 0 \\
\hline JANAUBA & PAI PEDRO & 1 & 0 \\
\hline
\end{tabular}




\begin{tabular}{|c|c|c|c|}
\hline JANAUBA & PORTEIRINHA & 4 & 0 \\
\hline JANAUBA & RIACHO DOS MACHADOS & 0 & 0 \\
\hline JANAUBA & RIO PARDO DE MINAS & 2 & 0 \\
\hline JANAUBA & SANTO ANTONIO DO RETIRO & 0 & 0 \\
\hline JANAUBA & SERRANOPOLIS DE MINAS & 0 & 0 \\
\hline JANAUBA & VERDELANDIA & 0 & 0 \\
\hline JANUARIA & BONITO DE MINAS & 1 & 0 \\
\hline JANUARIA & CHAPADA GAUCHA & 2 & 0 \\
\hline JANUARIA & CONEGO MARINHO & 2 & 0 \\
\hline JANUARIA & IBIRACATU & 0 & 0 \\
\hline JANUARIA & ICARAI DE MINAS & 4 & 0 \\
\hline JANUARIA & ITACARAMBI & 1 & 0 \\
\hline JANUARIA & JANUARIA & 3 & 0 \\
\hline JANUARIA & JUVENILIA & 1 & 0 \\
\hline JANUARIA & MANGA & 1 & 0 \\
\hline JANUARIA & MATIAS CARDOSO & 1 & 0 \\
\hline JANUARIA & MIRAVANIA & 0 & 0 \\
\hline JANUARIA & MONTALVANIA & 1 & 0 \\
\hline JANUARIA & PEDRAS DE MARIA DA CRUZ & 2 & 0 \\
\hline JANUARIA & PINTOPOLIS & 1 & 0 \\
\hline JANUARIA & SAO FRANCISCO & 4 & 0 \\
\hline JANUARIA & SAO JOAO DAS MISSOES & 1 & 0 \\
\hline JANUARIA & UBAI & 0 & 0 \\
\hline JANUARIA & URUCUIA & 0 & 0 \\
\hline JANUARIA & VARZELANDIA & 0 & 0 \\
\hline JUIZ DE FORA & ARANTINA & 0 & 0 \\
\hline JUIZ DE FORA & BELMIRO BRAGA & 1 & 0 \\
\hline JUIZ DE FORA & BICAS & 0 & 0 \\
\hline JUIZ DE FORA & BOM JARDIM DE MINAS & 1 & 0 \\
\hline JUIZ DE FORA & CHACARA & 0 & 0 \\
\hline JUIZ DE FORA & CHIADOR & 0 & 0 \\
\hline JUIZ DE FORA & CORONEL PACHECO & 0 & 0 \\
\hline JUIZ DE FORA & DESCOBERTO & 0 & 0 \\
\hline JUIZ DE FORA & EWBANK DA CAMARA & 1 & 0 \\
\hline JUIZ DE FORA & GOIANA & 1 & 0 \\
\hline JUIZ DE FORA & GUARARA & 1 & 0 \\
\hline JUIZ DE FORA & JUIZ DE FORA & 16 & 3 \\
\hline JUIZ DE FORA & LIMA DUARTE & 1 & 0 \\
\hline JUIZ DE FORA & MAR DE ESPANHA & 0 & 0 \\
\hline JUIZ DE FORA & MARIPA DE MINAS & 0 & 0 \\
\hline JUIZ DE FORA & MATIAS BARBOSA & 0 & 0 \\
\hline JUIZ DE FORA & OLARIA & 0 & 0 \\
\hline JUIZ DE FORA & PEDRO TEIXEIRA & 1 & 0 \\
\hline JUIZ DE FORA & PEQUERI & 1 & 0 \\
\hline JUIZ DE FORA & PIAU & 0 & 0 \\
\hline
\end{tabular}




\begin{tabular}{|c|c|c|c|}
\hline JUIZ DE FORA & RIO NOVO & 0 & 0 \\
\hline JUIZ DE FORA & RIO PRETO & 0 & 0 \\
\hline JUIZ DE FORA & ROCHEDO DE MINAS & 1 & 0 \\
\hline JUIZ DE FORA & SANTA BARBARA DO MONTE VERDE & 0 & 0 \\
\hline JUIZ DE FORA & SANTA RITA DE JACUTINGA & 0 & 0 \\
\hline JUIZ DE FORA & SANTANA DO DESERTO & 0 & 0 \\
\hline JUIZ DE FORA & SANTOS DUMONT & 2 & 0 \\
\hline JUIZ DE FORA & SAO JOAO NEPOMUCENO & 1 & 0 \\
\hline JUIZ DE FORA & SENADOR CORTES & 1 & 0 \\
\hline JUIZ DE FORA & SIMAO PEREIRA & 0 & 0 \\
\hline LEOPOLDINA & ALEM PARAIBA & 0 & 0 \\
\hline LEOPOLDINA & ARGIRITA & 0 & 0 \\
\hline LEOPOLDINA & CATAGUASES & 1 & 0 \\
\hline LEOPOLDINA & ESTRELA DALVA & 1 & 0 \\
\hline LEOPOLDINA & ITAMARATI DE MINAS & 0 & 0 \\
\hline LEOPOLDINA & LEOPOLDINA & 0 & 0 \\
\hline LEOPOLDINA & PIRAPETINGA & 0 & 0 \\
\hline LEOPOLDINA & RECREIO & 0 & 0 \\
\hline LEOPOLDINA & SANTO ANTONIO DO AVENTUREIRO & 1 & 0 \\
\hline LEOPOLDINA & VOLTA GRANDE & 0 & 0 \\
\hline MANHUAÇU & ALTO JEQUITIBA & 1 & 0 \\
\hline MANHUAÇU & CAPUTIRA & 1 & 0 \\
\hline MANHUAÇU & CHALE & 0 & 0 \\
\hline MANHUAÇU & CONCEICAO DE IPANEMA & 0 & 0 \\
\hline MANHUAÇU & DURANDE & 1 & 0 \\
\hline MANHUAÇU & LAJINHA & 2 & 0 \\
\hline MANHUAÇU & LUISBURGO & 0 & 0 \\
\hline MANHUAÇU & MANHUACU & 3 & 0 \\
\hline MANHUAÇU & MANHUMIRIM & 2 & 0 \\
\hline MANHUAÇU & MARTINS SOARES & 0 & 0 \\
\hline MANHUAÇU & MATIPO & 0 & 0 \\
\hline MANHUAÇU & MUTUM & 1 & 0 \\
\hline MANHUAÇU & REDUTO & 0 & 0 \\
\hline MANHUAÇU & SANTA MARGARIDA & 1 & 0 \\
\hline MANHUAÇU & SANTANA DO MANHUACU & 1 & 0 \\
\hline MANHUAÇU & SAO JOAO DO MANHUACU & 0 & 0 \\
\hline MANHUAÇU & SAO JOSE DO MANTIMENTO & 1 & 0 \\
\hline MANHUAÇU & SIMONESIA & 1 & 0 \\
\hline METROPOLITANA A & BARAO DE COCAIS & 0 & 0 \\
\hline METROPOLITANA A & BELO HORIZONTE & 19 & 3 \\
\hline METROPOLITANA A & BELO VALE & 1 & 0 \\
\hline METROPOLITANA A & BOM JESUS DO AMPARO & 0 & 0 \\
\hline METROPOLITANA A & BONFIM & 0 & 0 \\
\hline METROPOLITANA A & BRUMADINHO & 2 & 0 \\
\hline METROPOLITANA A & CAETE & 2 & 0 \\
\hline
\end{tabular}




\begin{tabular}{|c|c|c|c|}
\hline METROPOLITANA A & CATAS ALTAS & 0 & 0 \\
\hline METROPOLITANA A & CRUCILANDIA & 0 & 0 \\
\hline METROPOLITANA A & MOEDA & 0 & 0 \\
\hline METROPOLITANA A & NOVA LIMA & 5 & 2 \\
\hline METROPOLITANA A & NOVA UNIAO & 0 & 0 \\
\hline METROPOLITANA A & PIEDADE DOS GERAIS & 0 & 0 \\
\hline METROPOLITANA A & RAPOSOS & 2 & 0 \\
\hline METROPOLITANA A & RIO ACIMA & 0 & 0 \\
\hline METROPOLITANA A & RIO MANSO & 0 & 0 \\
\hline METROPOLITANA A & SABARA & 3 & 0 \\
\hline METROPOLITANA A & SANTA BARBARA & 3 & 0 \\
\hline METROPOLITANA B & BELO HORIZONTE & 16 & 3 \\
\hline METROPOLITANA B & BETIM & 24 & 7 \\
\hline METROPOLITANA B & CONTAGEM & 25 & 7 \\
\hline METROPOLITANA B & ESMERALDAS & 3 & 0 \\
\hline METROPOLITANA B & IBIRITE & 2 & 0 \\
\hline METROPOLITANA B & IGARAPE & 2 & 0 \\
\hline METROPOLITANA B & JUATUBA & 1 & 0 \\
\hline METROPOLITANA B & MARIO CAMPOS & 3 & 0 \\
\hline METROPOLITANA B & MATEUS LEME & 1 & 0 \\
\hline METROPOLITANA B & SAO JOAQUIM DE BICAS & 0 & 0 \\
\hline METROPOLITANA B & SARZEDO & 2 & 0 \\
\hline METROPOLITANA C & BELO HORIZONTE & 30 & 7 \\
\hline METROPOLITANA C & CONFINS & 1 & 0 \\
\hline METROPOLITANA C & JABOTICATUBAS & 1 & 0 \\
\hline METROPOLITANA C & LAGOA SANTA & 2 & 0 \\
\hline METROPOLITANA C & MORRO DO PILAR & 0 & 0 \\
\hline METROPOLITANA C & PEDRO LEOPOLDO & 4 & 0 \\
\hline METROPOLITANA C & RIBEIRAO DAS NEVES & 19 & 3 \\
\hline METROPOLITANA C & SANTA LUZIA & 11 & 2 \\
\hline METROPOLITANA C & SANTANA DO RIACHO & 0 & 0 \\
\hline METROPOLITANA C & SAO JOSE DA LAPA & 2 & 0 \\
\hline METROPOLITANA C & TAQUARACU DE MINAS & 0 & 0 \\
\hline METROPOLITANA C & VESPASIANO & 6 & 2 \\
\hline MONTE CARMELO & ABADIA DOS DOURADOS & 0 & 0 \\
\hline MONTE CARMELO & CASCALHO RICO & 1 & 0 \\
\hline MONTE CARMELO & COROMANDEL & 3 & 0 \\
\hline MONTE CARMELO & DOURADOQUARA & 0 & 0 \\
\hline MONTE CARMELO & ESTRELA DO SUL & 1 & 0 \\
\hline MONTE CARMELO & GRUPIARA & 0 & 0 \\
\hline MONTE CARMELO & MONTE CARMELO & 2 & 0 \\
\hline MONTE CARMELO & ROMARIA & 0 & 0 \\
\hline MONTES CLAROS & BOCAIUVA & 1 & 0 \\
\hline MONTES CLAROS & BOTUMIRIM & 1 & 0 \\
\hline MONTES CLAROS & BRASILIA DE MINAS & 0 & 0 \\
\hline
\end{tabular}




\begin{tabular}{|c|c|c|c|}
\hline MONTES CLAROS & CAMPO AZUL & 0 & 0 \\
\hline MONTES CLAROS & CAPITAO ENEAS & 0 & 0 \\
\hline MONTES CLAROS & CLARO DOS POCOES & 0 & 0 \\
\hline MONTES CLAROS & CORACAO DE JESUS & 3 & 0 \\
\hline MONTES CLAROS & CRISTALIA & 2 & 0 \\
\hline MONTES CLAROS & ENGENHEIRO NAVARRO & 0 & 0 \\
\hline MONTES CLAROS & FRANCISCO DUMONT & 0 & 0 \\
\hline MONTES CLAROS & FRANCISCO AS & 2 & 0 \\
\hline MONTES CLAROS & GLAUCILANDIA & 1 & 0 \\
\hline MONTES CLAROS & GRAO MOGOL & 0 & 0 \\
\hline MONTES CLAROS & GUARACIAMA & 1 & 0 \\
\hline MONTES CLAROS & ITACAMBIRA & 1 & 0 \\
\hline MONTES CLAROS & JAPONVAR & 1 & 0 \\
\hline MONTES CLAROS & JOSENOPOLIS & 1 & 0 \\
\hline MONTES CLAROS & JURAMENTO & 0 & 0 \\
\hline MONTES CLAROS & LONTRA & 0 & 0 \\
\hline MONTES CLAROS & LUISLANDIA & 0 & 0 \\
\hline MONTES CLAROS & MIRABELA & 1 & 0 \\
\hline MONTES CLAROS & MONTES CLAROS & 12 & 2 \\
\hline MONTES CLAROS & OLHOS-D AGUA & 0 & 0 \\
\hline MONTES CLAROS & PADRE CARVALHO & 1 & 0 \\
\hline MONTES CLAROS & PATIS & 0 & 0 \\
\hline MONTES CLAROS & SAO JOAO DA LAGOA & 1 & 0 \\
\hline MONTES CLAROS & SAO JOAO DA PONTE & 3 & 0 \\
\hline MONTES CLAROS & SAO JOAO DO PACUI & 0 & 0 \\
\hline MONTES CLAROS & SAO JOAO DO PARAISO & 1 & 0 \\
\hline MONTES CLAROS & VARGEM GRANDE DO RIO PARDO & 0 & 0 \\
\hline MURIAÉ & ANTONIO PRADO DE MINAS & 1 & 0 \\
\hline MURIAÉ & BARAO DE MONTE ALTO & 0 & 0 \\
\hline MURIAÉ & EUGENOPOLIS & 1 & 0 \\
\hline MURIAÉ & LARANJAL & 0 & 0 \\
\hline MURIAÉ & MIRADOURO & 0 & 0 \\
\hline MURIAÉ & MIRAI & 0 & 0 \\
\hline MURIAÉ & MURIAE & 1 & 0 \\
\hline MURIAÉ & PALMA & 0 & 0 \\
\hline MURIAÉ & PATROCINIO DO MURIAE & 0 & 0 \\
\hline MURIAÉ & ROSARIO DA LIMEIRA & 0 & 0 \\
\hline MURIAÉ & SANTANA DE CATAGUASES & 0 & 0 \\
\hline MURIAÉ & SAO FRANCISCO DO GLORIA & 0 & 0 \\
\hline MURIAÉ & SAO SEBASTIAO DA VARGEM ALEGRE & 1 & 0 \\
\hline MURIAÉ & VIEIRAS & 0 & 0 \\
\hline NOVA ERA & BELA VISTA DE MINAS & 1 & 0 \\
\hline NOVA ERA & DIONISIO & 0 & 0 \\
\hline NOVA ERA & FERROS & 0 & 0 \\
\hline NOVA ERA & ITABIRA & 0 & 0 \\
\hline
\end{tabular}




\begin{tabular}{|c|c|c|c|}
\hline NOVA ERA & ITAMBE DO MATO DENTRO & 0 & 0 \\
\hline NOVA ERA & JOAO MONLEVADE & 2 & 0 \\
\hline NOVA ERA & NOVA ERA & 1 & 0 \\
\hline NOVA ERA & PASSABEM & 0 & 0 \\
\hline NOVA ERA & RIO PIRACICABA & 0 & 0 \\
\hline NOVA ERA & SANTA MARIA DE ITABIRA & 0 & 0 \\
\hline NOVA ERA & SANTO ANTONIO DO RIO ABAIXO & 0 & 0 \\
\hline NOVA ERA & SAO DOMINGOS DO PRATA & 1 & 0 \\
\hline NOVA ERA & SAO GONCALO DO RIO ABAIXO & 0 & 0 \\
\hline NOVA ERA & SAO JOSE DO GOIABAL & 0 & 0 \\
\hline NOVA ERA & SAO SEBASTIAO DO RIO PRETO & 0 & 0 \\
\hline OURO PRETO & ACAIACA & 0 & 0 \\
\hline OURO PRETO & DIOGO DE VASCONCELOS & 1 & 0 \\
\hline OURO PRETO & ITABIRITO & 4 & 0 \\
\hline OURO PRETO & MARIANA & 2 & 0 \\
\hline OURO PRETO & OURO PRETO & 3 & 0 \\
\hline PARA DE MINAS & ABAETE & 1 & 0 \\
\hline PARA DE MINAS & BIQUINHAS & 0 & 0 \\
\hline PARA DE MINAS & BOM DESPACHO & 0 & 0 \\
\hline PARA DE MINAS & CEDRO DO ABAETE & 0 & 0 \\
\hline PARA DE MINAS & CONCEICAO DO PARA & 0 & 0 \\
\hline PARA DE MINAS & DORES DO INDAIA & 1 & 0 \\
\hline PARA DE MINAS & ESTRELA DO INDAIA & 0 & 0 \\
\hline PARA DE MINAS & FLORESTAL & 2 & 0 \\
\hline PARA DE MINAS & IGARATINGA & 1 & 0 \\
\hline PARA DE MINAS & LEANDRO FERREIRA & 1 & 0 \\
\hline PARA DE MINAS & MARTINHO CAMPOS & 0 & 0 \\
\hline PARA DE MINAS & MORADA NOVA DE MINAS & 0 & 0 \\
\hline PARA DE MINAS & ONCA DE PITANGUI & 0 & 0 \\
\hline PARA DE MINAS & PAINEIRAS & 1 & 0 \\
\hline PARA DE MINAS & PARA DE MINAS & 5 & 2 \\
\hline PARA DE MINAS & PEQUI & 0 & 0 \\
\hline PARA DE MINAS & PITANGUI & 2 & 0 \\
\hline PARA DE MINAS & QUARTEL GERAL & 0 & 0 \\
\hline PARA DE MINAS & SAO JOSE DA VARGINHA & 0 & 0 \\
\hline PARA DE MINAS & SERRA DA SAUDADE & 0 & 0 \\
\hline PARACATU & BRASILANDIA DE MINAS & 1 & 0 \\
\hline PARACATU & GUARDA-MOR & 0 & 0 \\
\hline PARACATU & JOAO PINHEIRO & 1 & 0 \\
\hline PARACATU & PARACATU & 5 & 2 \\
\hline PARACATU & VAZANTE & 1 & 0 \\
\hline PASSOS & ALPINOPOLIS & 2 & 0 \\
\hline PASSOS & BOM JESUS DA PENHA & 1 & 0 \\
\hline PASSOS & CAPITOLIO & 0 & 0 \\
\hline PASSOS & CARMO DO RIO CLARO & 0 & 0 \\
\hline
\end{tabular}




\begin{tabular}{|c|c|c|c|}
\hline PASSOS & CORREGO FUNDO & 0 & 0 \\
\hline PASSOS & DELFINOPOLIS & 0 & 0 \\
\hline PASSOS & DORESOPOLIS & 1 & 0 \\
\hline PASSOS & FORMIGA & 0 & 0 \\
\hline PASSOS & FORTALEZA DE MINAS & 0 & 0 \\
\hline PASSOS & PASSOS & 4 & 0 \\
\hline PASSOS & PIMENTA & 0 & 0 \\
\hline PASSOS & PIUMHI & 0 & 0 \\
\hline PASSOS & SAO JOAO BATISTA DO GLORIA & 1 & 0 \\
\hline PASSOS & SAO JOSE DA BARRA & 0 & 0 \\
\hline PASSOS & SAO ROQUE DE MINAS & 4 & 0 \\
\hline PASSOS & VARGEM BONITA & 0 & 0 \\
\hline PATOS DE MINAS & ARAPUA & 1 & 0 \\
\hline PATOS DE MINAS & CARMO DO PARANAIBA & 2 & 0 \\
\hline PATOS DE MINAS & LAGAMAR & 0 & 0 \\
\hline PATOS DE MINAS & LAGOA FORMOSA & 0 & 0 \\
\hline PATOS DE MINAS & LAGOA GRANDE & 1 & 0 \\
\hline PATOS DE MINAS & MATUTINA & 0 & 0 \\
\hline PATOS DE MINAS & PATOS DE MINAS & 6 & 2 \\
\hline PATOS DE MINAS & PRESIDENTE OLEGARIO & 3 & 0 \\
\hline PATOS DE MINAS & RIO PARANAIBA & 0 & 0 \\
\hline PATOS DE MINAS & SANTA ROSA DA SERRA & 1 & 0 \\
\hline PATOS DE MINAS & SAO GONCALO DO ABAETE & 0 & 0 \\
\hline PATOS DE MINAS & SAO GOTARDO & 2 & 0 \\
\hline PATOS DE MINAS & TIROS & 0 & 0 \\
\hline PATOS DE MINAS & VARJAO DE MINAS & 0 & 0 \\
\hline PATROCÍNIO & CRUZEIRO DA FORTALEZA & 0 & 0 \\
\hline PATROCÍNIO & GUIMARANIA & 0 & 0 \\
\hline PATROCÍNIO & IBIA & 0 & 0 \\
\hline PATROCÍNIO & IRAI DE MINAS & 0 & 0 \\
\hline PATROCÍNIO & PATROCINIO & 4 & 0 \\
\hline PATROCÍNIO & PERDIZES & 1 & 0 \\
\hline PATROCÍNIO & SERRA DO SALITRE & 0 & 0 \\
\hline PIRAPORA & BURITIZEIRO & 1 & 0 \\
\hline PIRAPORA & IBIAI & 1 & 0 \\
\hline PIRAPORA & JEQUITAI & 1 & 0 \\
\hline PIRAPORA & LAGOA DOS PATOS & 1 & 0 \\
\hline PIRAPORA & PIRAPORA & 3 & 0 \\
\hline PIRAPORA & PONTO CHIQUE & 0 & 0 \\
\hline PIRAPORA & SANTA FE DE MINAS & 0 & 0 \\
\hline PIRAPORA & SAO ROMAO & 1 & 0 \\
\hline PIRAPORA & VARZEA DA PALMA & 0 & 0 \\
\hline POÇOS DE CALDAS & ALTEROSA & 0 & 0 \\
\hline POÇOS DE CALDAS & ANDRADAS & 0 & 0 \\
\hline POÇOS DE CALDAS & AREADO & 0 & 0 \\
\hline
\end{tabular}




\begin{tabular}{|c|c|c|c|}
\hline POÇOS DE CALDAS & BANDEIRA DO SUL & 0 & 0 \\
\hline POÇOS DE CALDAS & BOTELHOS & 1 & 0 \\
\hline POÇOS DE CALDAS & CABO VERDE & 0 & 0 \\
\hline POÇOS DE CALDAS & CALDAS & 0 & 0 \\
\hline POÇOS DE CALDAS & CAMPESTRE & 0 & 0 \\
\hline POÇOS DE CALDAS & CONCEICAO DA APARECIDA & 1 & 0 \\
\hline POÇOS DE CALDAS & DIVISA NOVA & 1 & 0 \\
\hline POÇOS DE CALDAS & IBITIURA DE MINAS & 0 & 0 \\
\hline POÇOS DE CALDAS & MONTE BELO & 0 & 0 \\
\hline POÇOS DE CALDAS & MUZAMBINHO & 0 & 0 \\
\hline POÇOS DE CALDAS & NOVA RESENDE & 0 & 0 \\
\hline POÇOS DE CALDAS & POCOS DE CALDAS & 4 & 0 \\
\hline POÇOS DE CALDAS & SANTA RITA DE CALDAS & 0 & 0 \\
\hline POÇOS DE CALDAS & SERRANIA & 0 & 0 \\
\hline PONTE NOVA & ABRE CAMPO & 1 & 0 \\
\hline PONTE NOVA & ALVINOPOLIS & 1 & 0 \\
\hline PONTE NOVA & AMPARO DO SERRA & 1 & 0 \\
\hline PONTE NOVA & ARAPONGA & 0 & 0 \\
\hline PONTE NOVA & BARRA LONGA & 0 & 0 \\
\hline PONTE NOVA & CAJURI & 0 & 0 \\
\hline PONTE NOVA & CANAA & 1 & 0 \\
\hline PONTE NOVA & DOM SILVERIO & 1 & 0 \\
\hline PONTE NOVA & GUARACIABA & 0 & 0 \\
\hline PONTE NOVA & JEQUERI & 0 & 0 \\
\hline PONTE NOVA & ORATORIOS & 0 & 0 \\
\hline PONTE NOVA & PEDRA BONITA & 0 & 0 \\
\hline PONTE NOVA & PEDRA DO ANTA & 0 & 0 \\
\hline PONTE NOVA & PIEDADE DE PONTE NOVA & 0 & 0 \\
\hline PONTE NOVA & PONTE NOVA & 0 & 0 \\
\hline PONTE NOVA & PORTO FIRME & 2 & 0 \\
\hline PONTE NOVA & RAUL SOARES & 2 & 0 \\
\hline PONTE NOVA & RIO CASCA & 0 & 0 \\
\hline PONTE NOVA & RIO DOCE & 0 & 0 \\
\hline PONTE NOVA & SANTA CRUZ DO ESCALVADO & 0 & 0 \\
\hline PONTE NOVA & SANTO ANTONIO DO GRAMA & 0 & 0 \\
\hline PONTE NOVA & SAO MIGUEL DO ANTA & 1 & 0 \\
\hline PONTE NOVA & SAO PEDRO DOS FERROS & 0 & 0 \\
\hline PONTE NOVA & SEM-PEIXE & 1 & 0 \\
\hline PONTE NOVA & SERICITA & 0 & 0 \\
\hline PONTE NOVA & TEIXEIRAS & 1 & 0 \\
\hline PONTE NOVA & URUCANIA & 1 & 0 \\
\hline PONTE NOVA & VERMELHO NOVO & 0 & 0 \\
\hline PONTE NOVA & VICOSA & 1 & 0 \\
\hline POUSO ALEGRE & ALBERTINA & 0 & 0 \\
\hline POUSO ALEGRE & BOM REPOUSO & 0 & 0 \\
\hline
\end{tabular}




\begin{tabular}{|c|c|c|c|}
\hline POUSO ALEGRE & BORDA DA MATA & 0 & 0 \\
\hline POUSO ALEGRE & BUENO BRANDAO & 0 & 0 \\
\hline POUSO ALEGRE & CACHOEIRA DE MINAS & 1 & 0 \\
\hline POUSO ALEGRE & CAMANDUCAIA & 2 & 0 \\
\hline POUSO ALEGRE & CAMBUI & 4 & 0 \\
\hline POUSO ALEGRE & CAREACU & 0 & 0 \\
\hline POUSO ALEGRE & CONGONHAL & 0 & 0 \\
\hline POUSO ALEGRE & CORREGO DO BOM JESUS & 0 & 0 \\
\hline POUSO ALEGRE & ESPIRITO SANTO DO DOURADO & 0 & 0 \\
\hline POUSO ALEGRE & ESTIVA & 0 & 0 \\
\hline POUSO ALEGRE & EXTREMA & 2 & 0 \\
\hline POUSO ALEGRE & HELIODORA & 0 & 0 \\
\hline POUSO ALEGRE & INCONFIDENTES & 0 & 0 \\
\hline POUSO ALEGRE & IPUIUNA & 0 & 0 \\
\hline POUSO ALEGRE & ITAPEVA & 1 & 0 \\
\hline POUSO ALEGRE & JACUTINGA & 0 & 0 \\
\hline POUSO ALEGRE & MONTE SIAO & 1 & 0 \\
\hline POUSO ALEGRE & MUNHOZ & 0 & 0 \\
\hline POUSO ALEGRE & OURO FINO & 1 & 0 \\
\hline POUSO ALEGRE & POUSO ALEGRE & 5 & 2 \\
\hline POUSO ALEGRE & SANTA RITA DO SAPUCAI & 0 & 0 \\
\hline POUSO ALEGRE & SAO JOAO DA MATA & 0 & 0 \\
\hline POUSO ALEGRE & SAO SEBASTIAO DA BELA VISTA & 0 & 0 \\
\hline POUSO ALEGRE & SENADOR AMARAL & 0 & 0 \\
\hline POUSO ALEGRE & SENADOR JOSE BENTO & 0 & 0 \\
\hline POUSO ALEGRE & SILVIANOPOLIS & 0 & 0 \\
\hline POUSO ALEGRE & TOCOS DO MOJI & 0 & 0 \\
\hline POUSO ALEGRE & TOLEDO & 0 & 0 \\
\hline SÃO JOÃO DEL REI & BOM SUCESSO & 1 & 0 \\
\hline SÃO JOÃO DEL REI & CARRANCAS & 0 & 0 \\
\hline SÃO JOÃO DEL REI & CONCEICAO DA BARRA DE MINAS & 0 & 0 \\
\hline SÃO JOÃO DEL REI & CORONEL XAVIER CHAVES & 0 & 0 \\
\hline SÃO JOÃO DEL REI & DORES DE CAMPOS & 0 & 0 \\
\hline SÃO JOÃO DEL REI & IBITURUNA & 0 & 0 \\
\hline SÃO JOÃO DEL REI & IJACI & 0 & 0 \\
\hline SÃO JOÃO DEL REI & INGAI & 0 & 0 \\
\hline SÃO JOÃO DEL REI & ITUMIRIM & 0 & 0 \\
\hline SÃO JOÃO DEL REI & ITUTINGA & 0 & 0 \\
\hline SÃO JOÃO DEL REI & LAGOA DOURADA & 0 & 0 \\
\hline SÃO JOÃO DEL REI & NAZARENO & 1 & 0 \\
\hline SÃO JOÃO DEL REI & PRADOS & 0 & 0 \\
\hline SÃO JOÃO DEL REI & RESENDE COSTA & 0 & 0 \\
\hline SÃO JOÃO DEL REI & RITAPOLIS & 0 & 0 \\
\hline SÃO JOÃO DEL REI & SANTA CRUZ DE MINAS & 0 & 0 \\
\hline SÃO JOÃO DEL REI & SAO JOAO DEL REI & 0 & 0 \\
\hline
\end{tabular}




\begin{tabular}{|c|c|c|c|}
\hline SÃO JOÃO DEL REI & SAO TIAGO & 0 & 0 \\
\hline SÃO JOÃO DEL REI & TIRADENTES & 0 & 0 \\
\hline SÃO SEBASTIÃO DO PARAÍSO & ARCEBURGO & 0 & 0 \\
\hline SÃO SEBASTIÃO DO PARAÍSO & CAPETINGA & 0 & 0 \\
\hline SÃO SEBASTIÃO DO PARAÍSO & CASSIA & 0 & 0 \\
\hline SÃO SEBASTIÃO DO PARAÍSO & CLARAVAL & 0 & 0 \\
\hline SÃO SEBASTIÃO DO PARAÍSO & GUARANESIA & 1 & 0 \\
\hline SÃO SEBASTIÃO DO PARAÍSO & GUAXUPE & 2 & 0 \\
\hline SÃO SEBASTIÃO DO PARAÍSO & IBIRACI & 0 & 0 \\
\hline SÃO SEBASTIÃO DO PARAÍSO & ITAMOGI & 0 & 0 \\
\hline SÃO SEBASTIÃO DO PARAÍSO & ITAU DE MINAS & 0 & 0 \\
\hline SÃO SEBASTIÃO DO PARAÍSO & JACUI & 0 & 0 \\
\hline SÃO SEBASTIÃO DO PARAÍSO & JURUAIA & 0 & 0 \\
\hline SÃO SEBASTIÃO DO PARAÍSO & MONTE SANTO DE MINAS & 1 & 0 \\
\hline SÃO SEBASTIÃO DO PARAÍSO & PRATAPOLIS & 0 & 0 \\
\hline SÃO SEBASTIÃO DO PARAÍSO & SAO PEDRO DA UNIAO & 0 & 0 \\
\hline SÃO SEBASTIÃO DO PARAÍSO & SAO SEBASTIAO DO PARAISO & 1 & 0 \\
\hline SÃO SEBASTIÃO DO PARAÍSO & SAO TOMAS DE AQUINO & 1 & 0 \\
\hline SETE LAGOAS & ARACAI & 0 & 0 \\
\hline SETE LAGOAS & BALDIM & 1 & 0 \\
\hline SETE LAGOAS & CACHOEIRA DA PRATA & 0 & 0 \\
\hline SETE LAGOAS & CAETANOPOLIS & 0 & 0 \\
\hline SETE LAGOAS & CAPIM BRANCO & 0 & 0 \\
\hline SETE LAGOAS & CORDISBURGO & 0 & 0 \\
\hline SETE LAGOAS & FORTUNA DE MINAS & 0 & 0 \\
\hline SETE LAGOAS & FUNILANDIA & 0 & 0 \\
\hline SETE LAGOAS & INHAUMA & 1 & 0 \\
\hline SETE LAGOAS & JEQUITIBA & 0 & 0 \\
\hline SETE LAGOAS & MARAVILHAS & 1 & 0 \\
\hline SETE LAGOAS & MATOZINHOS & 0 & 0 \\
\hline SETE LAGOAS & PAPAGAIOS & 2 & 0 \\
\hline SETE LAGOAS & PARAOPEBA & 0 & 0 \\
\hline SETE LAGOAS & POMPEU & 3 & 0 \\
\hline SETE LAGOAS & PRUDENTE DE MORAIS & 1 & 0 \\
\hline SETE LAGOAS & SANTANA DE PIRAPAMA & 0 & 0 \\
\hline SETE LAGOAS & SETE LAGOAS & 6 & 2 \\
\hline TEOFILO OTONI & AGUAS FORMOSAS & 1 & 0 \\
\hline TEOFILO OTONI & ATALEIA & 0 & 0 \\
\hline TEOFILO OTONI & BERTOPOLIS & 2 & 0 \\
\hline TEOFILO OTONI & CAMPANARIO & 0 & 0 \\
\hline TEOFILO OTONI & CARAI & 1 & 0 \\
\hline TEOFILO OTONI & CARLOS CHAGAS & 2 & 0 \\
\hline TEOFILO OTONI & CATUJI & 0 & 0 \\
\hline TEOFILO OTONI & CRISOLITA & 0 & 0 \\
\hline TEOFILO OTONI & FRANCISCOPOLIS & 1 & 0 \\
\hline
\end{tabular}




\begin{tabular}{|c|c|c|c|}
\hline TEOFILO OTONI & FREI GASPAR & 0 & 0 \\
\hline TEOFILO OTONI & FRONTEIRA DOS VALES & 0 & 0 \\
\hline TEOFILO OTONI & ITAIPE & 1 & 0 \\
\hline TEOFILO OTONI & ITAMBACURI & 0 & 0 \\
\hline TEOFILO OTONI & JAMPRUCA & 0 & 0 \\
\hline TEOFILO OTONI & LADAINHA & 2 & 0 \\
\hline TEOFILO OTONI & MACHACALIS & 0 & 0 \\
\hline TEOFILO OTONI & MALACACHETA & 5 & 2 \\
\hline TEOFILO OTONI & NANUQUE & 0 & 0 \\
\hline TEOFILO OTONI & NOVO CRUZEIRO & 6 & 2 \\
\hline TEOFILO OTONI & NOVO ORIENTE DE MINAS & 2 & 0 \\
\hline TEOFILO OTONI & OURO VERDE DE MINAS & 1 & 0 \\
\hline TEOFILO OTONI & PADRE PARAISO & 2 & 0 \\
\hline TEOFILO OTONI & PAVAO & 0 & 0 \\
\hline TEOFILO OTONI & PESCADOR & 0 & 0 \\
\hline TEOFILO OTONI & PONTO DOS VOLANTES & 1 & 0 \\
\hline TEOFILO OTONI & POTE & 3 & 0 \\
\hline TEOFILO OTONI & SANTA HELENA DE MINAS & 1 & 0 \\
\hline TEOFILO OTONI & SERRA DOS AIMORES & 1 & 0 \\
\hline TEOFILO OTONI & SETUBINHA & 0 & 0 \\
\hline TEOFILO OTONI & TEOFILO OTONI & 8 & 2 \\
\hline TEOFILO OTONI & UMBURATIBA & 1 & 0 \\
\hline UBÁ & ASTOLFO DUTRA & 1 & 0 \\
\hline UBÁ & BRAS PIRES & 0 & 0 \\
\hline UBÁ & COIMBRA & 2 & 0 \\
\hline UBÁ & DIVINESIA & 0 & 0 \\
\hline UBÁ & DONA EUZEBIA & 0 & 0 \\
\hline UBÁ & DORES DO TURVO & 0 & 0 \\
\hline UBÁ & ERVALIA & 0 & 0 \\
\hline UBÁ & GUARANI & 0 & 0 \\
\hline UBÁ & GUIDOVAL & 1 & 0 \\
\hline UBÁ & GUIRICEMA & 0 & 0 \\
\hline UBÁ & PAULA CANDIDO & 2 & 0 \\
\hline UBÁ & PIRAUBA & 0 & 0 \\
\hline UBÁ & PRESIDENTE BERNARDES & 0 & 0 \\
\hline UBÁ & RIO POMBA & 0 & 0 \\
\hline UBÁ & RODEIRO & 0 & 0 \\
\hline UBÁ & SAO GERALDO & 1 & 0 \\
\hline UBÁ & SENADOR FIRMINO & 0 & 0 \\
\hline UBÁ & SILVEIRANIA & 0 & 0 \\
\hline UBÁ & TABULEIRO & 0 & 0 \\
\hline UBÁ & TOCANTINS & 0 & 0 \\
\hline UBÁ & UBA & 3 & 0 \\
\hline UBÁ & VISCONDE DO RIO BRANCO & 1 & 0 \\
\hline UBERABA & AGUA COMPRIDA & 1 & 0 \\
\hline
\end{tabular}




\begin{tabular}{|c|c|c|c|}
\hline UBERABA & ARAXA & 3 & 0 \\
\hline UBERABA & CAMPO FLORIDO & 1 & 0 \\
\hline UBERABA & CAMPOS ALTOS & 0 & 0 \\
\hline UBERABA & CARNEIRINHO & 1 & 0 \\
\hline UBERABA & COMENDADOR GOMES & 0 & 0 \\
\hline UBERABA & CONCEICAO DAS ALAGOAS & 0 & 0 \\
\hline UBERABA & CONQUISTA & 0 & 0 \\
\hline UBERABA & DELTA & 0 & 0 \\
\hline UBERABA & FRONTEIRA & 0 & 0 \\
\hline UBERABA & FRUTAL & 1 & 0 \\
\hline UBERABA & ITAPAGIPE & 2 & 0 \\
\hline UBERABA & ITURAMA & 0 & 0 \\
\hline UBERABA & LIMEIRA DO OESTE & 0 & 0 \\
\hline UBERABA & PEDRINOPOLIS & 0 & 0 \\
\hline UBERABA & PIRAJUBA & 0 & 0 \\
\hline UBERABA & PLANURA & 0 & 0 \\
\hline UBERABA & PRATINHA & 0 & 0 \\
\hline UBERABA & SACRAMENTO & 2 & 0 \\
\hline UBERABA & SANTA JULIANA & 0 & 0 \\
\hline UBERABA & SAO FRANCISCO DE SALES & 0 & 0 \\
\hline UBERABA & TAPIRA & 1 & 0 \\
\hline UBERABA & UBERABA & 5 & 2 \\
\hline UBERABA & UNIAO DE MINAS & 0 & 0 \\
\hline UBERABA & VERISSIMO & 0 & 0 \\
\hline UBERLANDIA & ARAGUARI & 2 & 0 \\
\hline UBERLANDIA & ARAPORA & 0 & 0 \\
\hline UBERLANDIA & CAMPINA VERDE & 2 & 0 \\
\hline UBERLANDIA & INDIANOPOLIS & 0 & 0 \\
\hline UBERLANDIA & MONTE ALEGRE DE MINAS & 0 & 0 \\
\hline UBERLANDIA & NOVA PONTE & 0 & 0 \\
\hline UBERLANDIA & PRATA & 0 & 0 \\
\hline UBERLANDIA & TUPACIGUARA & 3 & 0 \\
\hline UBERLANDIA & UBERLANDIA & 16 & 3 \\
\hline UNAI & ARINOS & 3 & 0 \\
\hline UNAI & BONFINOPOLIS DE MINAS & 0 & 0 \\
\hline UNAI & BURITIS & 1 & 0 \\
\hline UNAI & CABECEIRA GRANDE & 0 & 0 \\
\hline UNAI & DOM BOSCO & 1 & 0 \\
\hline UNAI & FORMOSO & 1 & 0 \\
\hline UNAI & NATALANDIA & 0 & 0 \\
\hline UNAI & RIACHINHO & 0 & 0 \\
\hline UNAI & UNAI & 7 & 2 \\
\hline UNAI & URUANA DE MINAS & 0 & 0 \\
\hline VARGINHA & ALFENAS & 2 & 0 \\
\hline VARGINHA & BOA ESPERANCA & 1 & 0 \\
\hline
\end{tabular}




\begin{tabular}{|c|c|c|c|}
\hline VARGINHA & CAMBUQUIRA & 0 & 0 \\
\hline VARGINHA & CAMPANHA & 0 & 0 \\
\hline VARGINHA & CAMPO DO MEIO & 1 & 0 \\
\hline VARGINHA & CAMPOS GERAIS & 2 & 0 \\
\hline VARGINHA & CARMO DA CACHOEIRA & 0 & 0 \\
\hline VARGINHA & CARVALHOPOLIS & 0 & 0 \\
\hline VARGINHA & COQUEIRAL & 0 & 0 \\
\hline VARGINHA & CORDISLANDIA & 0 & 0 \\
\hline VARGINHA & ELOI MENDES & 0 & 0 \\
\hline VARGINHA & FAMA & 0 & 0 \\
\hline VARGINHA & GUAPE & 0 & 0 \\
\hline VARGINHA & ILICINEA & 0 & 0 \\
\hline VARGINHA & LAMBARI & 0 & 0 \\
\hline VARGINHA & LUMINARIAS & 0 & 0 \\
\hline VARGINHA & MACHADO & 0 & 0 \\
\hline VARGINHA & MONSENHOR PAULO & 0 & 0 \\
\hline VARGINHA & NEPOMUCENO & 0 & 0 \\
\hline VARGINHA & PARAGUACU & 1 & 0 \\
\hline VARGINHA & POCO FUNDO & 0 & 0 \\
\hline VARGINHA & SANTANA DA VARGEM & 0 & 0 \\
\hline VARGINHA & SAO BENTO ABADE & 0 & 0 \\
\hline VARGINHA & SAO GONCALO DO SAPUCAI & 0 & 0 \\
\hline VARGINHA & TRES CORACOES & 1 & 0 \\
\hline VARGINHA & TRES PONTAS & 1 & 0 \\
\hline VARGINHA & TURVOLANDIA & 1 & 0 \\
\hline VARGINHA & VARGINHA & 5 & 2 \\
\hline Total geral & & 815 & 82 \\
\hline
\end{tabular}

CARGO: PROFESSOR DE EDUCAÇÃO BÁSICA - PEB - S O C I O L O G I A

\begin{tabular}{|l|l|c|c|}
\hline \multicolumn{1}{|c|}{ S R E } & \multicolumn{1}{|c|}{ MUNICIPIO } & \multicolumn{1}{c|}{$\begin{array}{c}\text { VAGAS } \\
\text { TOTAL DE } \\
\text { VAGAS } \\
\text { RESERVADAS - } \\
\text { PORTADORES DE } \\
\text { DEFICIENCIA }\end{array}$} \\
\hline ALMENARA & AGUAS VERMELHAS & 1 & 0 \\
\hline ALMENARA & ALMENARA & 0 & 0 \\
\hline ALMENARA & BANDEIRA & 0 & 0 \\
\hline ALMENARA & CACHOEIRA DE PAJEU & 0 & 0 \\
\hline ALMENARA & CURRAL DE DENTRO & 0 & 0 \\
\hline ALMENARA & DIVISA ALEGRE & 0 & 0 \\
\hline ALMENARA & DIVISOPOLIS & 0 & 0 \\
\hline ALMENARA & FELISBURGO & 0 & 0 \\
\hline ALMENARA & JACINTO & 2 & 0 \\
\hline ALMENARA & JEQUITINHONHA & 0 & 0 \\
\hline ALMENARA & JOAIMA & 0 & 0 \\
\hline ALMENARA & JORDANIA & 0 & 0 \\
\hline ALMENARA & MATA VERDE & & 0 \\
\hline
\end{tabular}




\begin{tabular}{|c|c|c|c|}
\hline ALMENARA & MONTE FORMOSO & 0 & 0 \\
\hline ALMENARA & PALMOPOLIS & 0 & 0 \\
\hline ALMENARA & PEDRA AZUL & 0 & 0 \\
\hline ALMENARA & RIO DO PRADO & 0 & 0 \\
\hline ALMENARA & RUBIM & 0 & 0 \\
\hline ALMENARA & SALTO DA DIVISA & 1 & 0 \\
\hline ALMENARA & SANTA MARIA DO SALTO & 0 & 0 \\
\hline ALMENARA & SANTO ANTONIO DO JACINTO & 0 & 0 \\
\hline ARACUAI & ARACUAI & 0 & 0 \\
\hline ARACUAI & BERILO & 1 & 0 \\
\hline ARACUAI & BERIZAL & 2 & 0 \\
\hline ARACUAI & CHAPADA DO NORTE & 1 & 0 \\
\hline ARACUAI & COMERCINHO & 0 & 0 \\
\hline ARACUAI & CORONEL MURTA & 0 & 0 \\
\hline ARACUAI & FRANCISCO BADARO & 0 & 0 \\
\hline ARACUAI & FRUTA DE LEITE & 0 & 0 \\
\hline ARACUAI & INDAIABIRA & 0 & 0 \\
\hline ARACUAI & ITAOBIM & 1 & 0 \\
\hline ARACUAI & ITINGA & 1 & 0 \\
\hline ARACUAI & JENIPAPO DE MINAS & 1 & 0 \\
\hline ARACUAI & JOSE GONCALVES DE MINAS & 0 & 0 \\
\hline ARACUAI & MEDINA & 0 & 0 \\
\hline ARACUAI & NINHEIRA & 0 & 0 \\
\hline ARACUAI & NOVORIZONTE & 1 & 0 \\
\hline ARACUAI & RUBELITA & 0 & 0 \\
\hline ARACUAI & SALINAS & 3 & 0 \\
\hline ARACUAI & SANTA CRUZ DE SALINAS & 0 & 0 \\
\hline ARACUAI & TAIOBEIRAS & 2 & 0 \\
\hline ARACUAI & VIRGEM DA LAPA & 1 & 0 \\
\hline BARBACENA & ALFREDO VASCONCELOS & 0 & 0 \\
\hline BARBACENA & ALTO RIO DOCE & 0 & 0 \\
\hline BARBACENA & ANDRELANDIA & 0 & 0 \\
\hline BARBACENA & ANTONIO CARLOS & 1 & 0 \\
\hline BARBACENA & ARACITABA & 0 & 0 \\
\hline BARBACENA & BARBACENA & 4 & 0 \\
\hline BARBACENA & BARROSO & 1 & 0 \\
\hline BARBACENA & BIAS FORTES & 0 & 0 \\
\hline BARBACENA & CAPELA NOVA & 0 & 0 \\
\hline BARBACENA & CARANDAI & 0 & 0 \\
\hline BARBACENA & CIPOTANEA & 0 & 0 \\
\hline BARBACENA & DESTERRO DO MELO & 0 & 0 \\
\hline BARBACENA & IBERTIOGA & 0 & 0 \\
\hline BARBACENA & MADRE DE DEUS DE MINAS & 0 & 0 \\
\hline BARBACENA & MERCES & 0 & 0 \\
\hline BARBACENA & OLIVEIRA FORTES & 0 & 0 \\
\hline
\end{tabular}




\begin{tabular}{|c|c|c|c|}
\hline BARBACENA & PAIVA & 0 & 0 \\
\hline BARBACENA & PIEDADE DO RIO GRANDE & 0 & 0 \\
\hline BARBACENA & RESSAQUINHA & 0 & 0 \\
\hline BARBACENA & SANTA BARBARA DO TUGURIO & 0 & 0 \\
\hline BARBACENA & SANTA RITA DO IBITIPOCA & 1 & 0 \\
\hline BARBACENA & SANTANA DO GARAMBEU & 0 & 0 \\
\hline BARBACENA & SAO VICENTE DE MINAS & 0 & 0 \\
\hline BARBACENA & SENHORA DOS REMEDIOS & 0 & 0 \\
\hline CAMPO BELO & AGUANIL & 0 & 0 \\
\hline CAMPO BELO & CAMACHO & 0 & 0 \\
\hline CAMPO BELO & CAMPO BELO & 0 & 0 \\
\hline CAMPO BELO & CANA VERDE & 0 & 0 \\
\hline CAMPO BELO & CANDEIAS & 1 & 0 \\
\hline CAMPO BELO & CRISTAIS & 1 & 0 \\
\hline CAMPO BELO & LAVRAS & 3 & 0 \\
\hline CAMPO BELO & PERDOES & 0 & 0 \\
\hline CAMPO BELO & RIBEIRAO VERMELHO & 0 & 0 \\
\hline CAMPO BELO & SANTANA DO JACARE & 0 & 0 \\
\hline CAMPO BELO & SANTO ANTONIO DO AMPARO & 0 & 0 \\
\hline CAMPO BELO & SAO FRANCISCO DE PAULA & 0 & 0 \\
\hline CARANGOLA & ALTO CAPARAO & 0 & 0 \\
\hline CARANGOLA & CAIANA & 0 & 0 \\
\hline CARANGOLA & CAPARAO & 0 & 0 \\
\hline CARANGOLA & CARANGOLA & 0 & 0 \\
\hline CARANGOLA & DIVINO & 1 & 0 \\
\hline CARANGOLA & ESPERA FELIZ & 1 & 0 \\
\hline CARANGOLA & FARIA LEMOS & 0 & 0 \\
\hline CARANGOLA & FERVEDOURO & 0 & 0 \\
\hline CARANGOLA & ORIZANIA & 0 & 0 \\
\hline CARANGOLA & PEDRA DOURADA & 0 & 0 \\
\hline CARANGOLA & TOMBOS & 0 & 0 \\
\hline CARATINGA & ALVARENGA & 0 & 0 \\
\hline CARATINGA & BOM JESUS DO GALHO & 0 & 0 \\
\hline CARATINGA & BUGRE & 0 & 0 \\
\hline CARATINGA & CARATINGA & 2 & 0 \\
\hline CARATINGA & CORREGO NOVO & 0 & 0 \\
\hline CARATINGA & DOM CAVATI & 0 & 0 \\
\hline CARATINGA & ENTRE FOLHAS & 0 & 0 \\
\hline CARATINGA & IAPU & 1 & 0 \\
\hline CARATINGA & IMBE DE MINAS & 0 & 0 \\
\hline CARATINGA & INHAPIM & 1 & 0 \\
\hline CARATINGA & IPABA & 1 & 0 \\
\hline CARATINGA & IPANEMA & 1 & 0 \\
\hline CARATINGA & PIEDADE DE CARATINGA & 0 & 0 \\
\hline CARATINGA & PINGO D AGUA & 0 & 0 \\
\hline
\end{tabular}




\begin{tabular}{|c|c|c|c|}
\hline CARATINGA & POCRANE & 0 & 0 \\
\hline CARATINGA & SANTA BARBARA DO LESTE & 0 & 0 \\
\hline CARATINGA & SANTA RITA DE MINAS & 1 & 0 \\
\hline CARATINGA & SAO DOMINGOS DAS DORES & 0 & 0 \\
\hline CARATINGA & SAO JOAO DO ORIENTE & 0 & 0 \\
\hline CARATINGA & SAO SEBASTIAO DO ANTA & 0 & 0 \\
\hline CARATINGA & TAPARUBA & 0 & 0 \\
\hline CARATINGA & TARUMIRIM & 0 & 0 \\
\hline CARATINGA & UBAPORANGA & 0 & 0 \\
\hline CARATINGA & VARGEM ALEGRE & 0 & 0 \\
\hline CAXAMBU & AIURUOCA & 0 & 0 \\
\hline CAXAMBU & ALAGOA & 1 & 0 \\
\hline CAXAMBU & BAEPENDI & 1 & 0 \\
\hline CAXAMBU & BOCAINA DE MINAS & 1 & 0 \\
\hline CAXAMBU & CARVALHOS & 0 & 0 \\
\hline CAXAMBU & CAXAMBU & 0 & 0 \\
\hline CAXAMBU & CONCEICAO DO RIO VERDE & 0 & 0 \\
\hline CAXAMBU & CRUZILIA & 1 & 0 \\
\hline CAXAMBU & ITAMONTE & 0 & 0 \\
\hline CAXAMBU & ITANHANDU & 0 & 0 \\
\hline CAXAMBU & JESUANIA & 0 & 0 \\
\hline CAXAMBU & LIBERDADE & 0 & 0 \\
\hline CAXAMBU & MINDURI & 0 & 0 \\
\hline CAXAMBU & OLIMPIO NORONHA & 0 & 0 \\
\hline CAXAMBU & PASSA QUATRO & 0 & 0 \\
\hline CAXAMBU & PASSA VINTE & 0 & 0 \\
\hline CAXAMBU & POUSO ALTO & 0 & 0 \\
\hline CAXAMBU & SAO LOURENCO & 2 & 0 \\
\hline CAXAMBU & SAO SEBASTIAO DO RIO VERDE & 0 & 0 \\
\hline CAXAMBU & SAO TOME DAS LETRAS & 0 & 0 \\
\hline CAXAMBU & SERITINGA & 0 & 0 \\
\hline CAXAMBU & SERRANOS & 0 & 0 \\
\hline CAXAMBU & SOLEDADE DE MINAS & 0 & 0 \\
\hline CORONEL FABRICIANO & ANTONIO DIAS & 0 & 0 \\
\hline CORONEL FABRICIANO & BELO ORIENTE & 1 & 0 \\
\hline CORONEL FABRICIANO & BRAUNAS & 0 & 0 \\
\hline CORONEL FABRICIANO & CORONEL FABRICIANO & 2 & 0 \\
\hline CORONEL FABRICIANO & IPATINGA & 3 & 0 \\
\hline CORONEL FABRICIANO & JAGUARAÇU & 0 & 0 \\
\hline CORONEL FABRICIANO & JOANESIA & 0 & 0 \\
\hline CORONEL FABRICIANO & MARLIERIA & 0 & 0 \\
\hline CORONEL FABRICIANO & MESQUITA & 0 & 0 \\
\hline CORONEL FABRICIANO & SANTANA DO PARAISO & 1 & 0 \\
\hline CORONEL FABRICIANO & TIMOTEO & 1 & 0 \\
\hline CONSELHEIRO LAFAIETE & CARANAIBA & 0 & 0 \\
\hline
\end{tabular}




\begin{tabular}{|c|c|c|c|}
\hline CONSELHEIRO LAFAIETE & CASA GRANDE & 0 & 0 \\
\hline CONSELHEIRO LAFAIETE & CATAS ALTAS DA NORUEGA & 0 & 0 \\
\hline CONSELHEIRO LAFAIETE & CONGONHAS & 1 & 0 \\
\hline CONSELHEIRO LAFAIETE & CONSELHEIRO LAFAIETE & 0 & 0 \\
\hline CONSELHEIRO LAFAIETE & CRISTIANO OTONI & 0 & 0 \\
\hline CONSELHEIRO LAFAIETE & DESTERRO DE ENTRE RIOS & 0 & 0 \\
\hline CONSELHEIRO LAFAIETE & ENTRE RIOS DE MINAS & 2 & 0 \\
\hline CONSELHEIRO LAFAIETE & ITAVERAVA & 0 & 0 \\
\hline CONSELHEIRO LAFAIETE & JECEABA & 0 & 0 \\
\hline CONSELHEIRO LAFAIETE & LAMIM & 1 & 0 \\
\hline CONSELHEIRO LAFAIETE & OURO BRANCO & 0 & 0 \\
\hline CONSELHEIRO LAFAIETE & PIRANGA & 2 & 0 \\
\hline CONSELHEIRO LAFAIETE & QUELUZITO & 0 & 0 \\
\hline CONSELHEIRO LAFAIETE & RIO ESPERA & 0 & 0 \\
\hline CONSELHEIRO LAFAIETE & SANTANA DOS MONTES & 0 & 0 \\
\hline CONSELHEIRO LAFAIETE & SAO BRAS DO SUACUI & 0 & 0 \\
\hline CONSELHEIRO LAFAIETE & SENHORA DE OLIVEIRA & 0 & 0 \\
\hline CURVELO & AUGUSTO DE LIMA & 0 & 0 \\
\hline CURVELO & BUENOPOLIS & 1 & 0 \\
\hline CURVELO & CORINTO & 1 & 0 \\
\hline CURVELO & CURVELO & 4 & 0 \\
\hline CURVELO & FELIXLANDIA & 0 & 0 \\
\hline CURVELO & INIMUTABA & 1 & 0 \\
\hline CURVELO & JOAQUIM FELICIO & 0 & 0 \\
\hline CURVELO & LASSANCE & 0 & 0 \\
\hline CURVELO & MORRO DA GARCA & 1 & 0 \\
\hline CURVELO & PRESIDENTE JUSCELINO & 0 & 0 \\
\hline CURVELO & SANTO HIPOLITO & 1 & 0 \\
\hline CURVELO & TRES MARIAS & 1 & 0 \\
\hline DIAMANTINA & ALVORADA DE MINAS & 0 & 0 \\
\hline DIAMANTINA & ANGELANDIA & 0 & 0 \\
\hline DIAMANTINA & ARICANDUVA & 1 & 0 \\
\hline DIAMANTINA & CAPELINHA & 3 & 0 \\
\hline DIAMANTINA & CARBONITA & 0 & 0 \\
\hline DIAMANTINA & CONCEICAO DO MATO DENTRO & 0 & 0 \\
\hline DIAMANTINA & CONGONHAS DO NORTE & 1 & 0 \\
\hline DIAMANTINA & COUTO DE MAGALHAES DE MINAS & 0 & 0 \\
\hline DIAMANTINA & DATAS & 0 & 0 \\
\hline DIAMANTINA & DIAMANTINA & 3 & 0 \\
\hline DIAMANTINA & FELICIO DOS SANTOS & 0 & 0 \\
\hline DIAMANTINA & GOUVEA & 1 & 0 \\
\hline DIAMANTINA & ITAMARANDIBA & 3 & 0 \\
\hline DIAMANTINA & LEME DO PRADO & 0 & 0 \\
\hline DIAMANTINA & MINAS NOVAS & 2 & 0 \\
\hline DIAMANTINA & MONJOLOS & 0 & 0 \\
\hline
\end{tabular}




\begin{tabular}{|c|c|c|c|}
\hline DIAMANTINA & PRESIDENTE KUBITSCHEK & 0 & 0 \\
\hline DIAMANTINA & RIO VERMELHO & 0 & 0 \\
\hline DIAMANTINA & SANTO ANTONIO DO ITAMBE & 1 & 0 \\
\hline DIAMANTINA & SAO GONCALO DO RIO PRETO & 0 & 0 \\
\hline DIAMANTINA & SENADOR MODESTINO GONCALVES & 0 & 0 \\
\hline DIAMANTINA & SERRA AZUL DE MINAS & 0 & 0 \\
\hline DIAMANTINA & SERRO & 2 & 0 \\
\hline DIAMANTINA & TURMALINA & 1 & 0 \\
\hline DIAMANTINA & VEREDINHA & 0 & 0 \\
\hline DIVINÓPOLIS & ARAUJOS & 0 & 0 \\
\hline DIVINÓPOLIS & ARCOS & 0 & 0 \\
\hline DIVINÓPOLIS & BAMBUI & 2 & 0 \\
\hline DIVINÓPOLIS & CARMO DA MATA & 0 & 0 \\
\hline DIVINÓPOLIS & CARMO DO CAJURU & 1 & 0 \\
\hline DIVINÓPOLIS & CARMOPOLIS DE MINAS & 0 & 0 \\
\hline DIVINÓPOLIS & CLAUDIO & 1 & 0 \\
\hline DIVINÓPOLIS & CORREGO DANTA & 0 & 0 \\
\hline DIVINÓPOLIS & DIVINOPOLIS & 7 & 2 \\
\hline DIVINÓPOLIS & IGUATAMA & 0 & 0 \\
\hline DIVINÓPOLIS & ITAGUARA & 0 & 0 \\
\hline DIVINÓPOLIS & ITAPECERICA & 0 & 0 \\
\hline DIVINÓPOLIS & ITATIAIUCU & 0 & 0 \\
\hline DIVINÓPOLIS & ITAUNA & 1 & 0 \\
\hline DIVINÓPOLIS & JAPARAIBA & 0 & 0 \\
\hline DIVINÓPOLIS & LAGOA DA PRATA & 2 & 0 \\
\hline DIVINÓPOLIS & LUZ & 0 & 0 \\
\hline DIVINÓPOLIS & MEDEIROS & 0 & 0 \\
\hline DIVINÓPOLIS & MOEMA & 0 & 0 \\
\hline DIVINÓPOLIS & NOVA SERRANA & 5 & 2 \\
\hline DIVINÓPOLIS & OLIVEIRA & 0 & 0 \\
\hline DIVINÓPOLIS & PAINS & 0 & 0 \\
\hline DIVINÓPOLIS & PASSA TEMPO & 0 & 0 \\
\hline DIVINÓPOLIS & PEDRA DO INDAIA & 0 & 0 \\
\hline DIVINÓPOLIS & PERDIGAO & 0 & 0 \\
\hline DIVINÓPOLIS & PIRACEMA & 0 & 0 \\
\hline DIVINÓPOLIS & SANTO ANTONIO DO MONTE & 1 & 0 \\
\hline DIVINÓPOLIS & SAO GONCALO DO PARA & 0 & 0 \\
\hline DIVINÓPOLIS & SAO SEBASTIAO DO OESTE & 0 & 0 \\
\hline DIVINÓPOLIS & TAPIRAI & 0 & 0 \\
\hline GOVERNADOR VALADARES & ACUCENA & 0 & 0 \\
\hline GOVERNADOR VALADARES & AIMORES & 0 & 0 \\
\hline GOVERNADOR VALADARES & ALPERCATA & 0 & 0 \\
\hline GOVERNADOR VALADARES & CAPITAO ANDRADE & 1 & 0 \\
\hline GOVERNADOR VALADARES & CENTRAL DE MINAS & 1 & 0 \\
\hline GOVERNADOR VALADARES & CONSELHEIRO PENA & 1 & 0 \\
\hline
\end{tabular}




\begin{tabular}{|c|c|c|c|}
\hline GOVERNADOR VALADARES & COROACI & 0 & 0 \\
\hline GOVERNADOR VALADARES & CUPARAQUE & 0 & 0 \\
\hline GOVERNADOR VALADARES & DIVINO DAS LARANJEIRAS & 0 & 0 \\
\hline GOVERNADOR VALADARES & ENGENHEIRO CALDAS & 0 & 0 \\
\hline GOVERNADOR VALADARES & FERNANDES TOURINHO & 0 & 0 \\
\hline GOVERNADOR VALADARES & FREI INOCENCIO & 1 & 0 \\
\hline GOVERNADOR VALADARES & GALILEIA & 0 & 0 \\
\hline GOVERNADOR VALADARES & GOIABEIRA & 0 & 0 \\
\hline GOVERNADOR VALADARES & GOVERNADOR VALADARES & 9 & 2 \\
\hline GOVERNADOR VALADARES & ITABIRINHA & 0 & 0 \\
\hline GOVERNADOR VALADARES & ITANHOMI & 0 & 0 \\
\hline GOVERNADOR VALADARES & ITUETA & 0 & 0 \\
\hline GOVERNADOR VALADARES & MANTENA & 1 & 0 \\
\hline GOVERNADOR VALADARES & MARILAC & 1 & 0 \\
\hline GOVERNADOR VALADARES & MATHIAS LOBATO & 0 & 0 \\
\hline GOVERNADOR VALADARES & MENDES PIMENTEL & 1 & 0 \\
\hline GOVERNADOR VALADARES & NACIP RAYDAN & 0 & 0 \\
\hline GOVERNADOR VALADARES & NAQUE & 0 & 0 \\
\hline GOVERNADOR VALADARES & NOVA BELEM & 0 & 0 \\
\hline GOVERNADOR VALADARES & NOVA MODICA & 0 & 0 \\
\hline GOVERNADOR VALADARES & PERIQUITO & 0 & 0 \\
\hline GOVERNADOR VALADARES & RESPLENDOR & 0 & 0 \\
\hline GOVERNADOR VALADARES & SANTA EFIGENIA DE MINAS & 0 & 0 \\
\hline GOVERNADOR VALADARES & SANTA RITA DO ITUETO & 0 & 0 \\
\hline GOVERNADOR VALADARES & SAO FELIX DE MINAS & 0 & 0 \\
\hline GOVERNADOR VALADARES & SAO GERALDO DA PIEDADE & 0 & 0 \\
\hline GOVERNADOR VALADARES & SAO GERALDO DO BAIXIO & 0 & 0 \\
\hline GOVERNADOR VALADARES & SAO JOAO DO MANTENINHA & 0 & 0 \\
\hline GOVERNADOR VALADARES & SAO JOSE DA SAFIRA & 0 & 0 \\
\hline GOVERNADOR VALADARES & SAO JOSE DO DIVINO & 1 & 0 \\
\hline GOVERNADOR VALADARES & SARDOA & 1 & 0 \\
\hline GOVERNADOR VALADARES & SOBRALIA & 0 & 0 \\
\hline GOVERNADOR VALADARES & TUMIRITINGA & 0 & 0 \\
\hline GOVERNADOR VALADARES & VIRGOLANDIA & 0 & 0 \\
\hline GUANHÃES & AGUA BOA & 0 & 0 \\
\hline GUANHÃES & CANTAGALO & 0 & 0 \\
\hline GUANHÃES & CARMESIA & 0 & 0 \\
\hline GUANHÃES & COLUNA & 0 & 0 \\
\hline GUANHÃES & DIVINOLANDIA DE MINAS & 0 & 0 \\
\hline GUANHÃES & DOM JOAQUIM & 1 & 0 \\
\hline GUANHÃES & DORES DE GUANHAES & 0 & 0 \\
\hline GUANHÃES & FREI LAGONEGRO & 0 & 0 \\
\hline GUANHÃES & GONZAGA & 0 & 0 \\
\hline GUANHÃES & GUANHAES & 1 & 0 \\
\hline GUANHÃES & JOSE RAYDAN & 1 & 0 \\
\hline
\end{tabular}




\begin{tabular}{|c|c|c|c|}
\hline GUANHÃES & MATERLANDIA & 0 & 0 \\
\hline GUANHÃES & PAULISTAS & 0 & 0 \\
\hline GUANHÃES & PECANHA & 0 & 0 \\
\hline GUANHÃES & SABINOPOLIS & 1 & 0 \\
\hline GUANHÃES & SANTA MARIA DO SUACUI & 0 & 0 \\
\hline GUANHÃES & SAO JOAO EVANGELISTA & 0 & 0 \\
\hline GUANHÃES & SAO JOSE DO JACURI & 0 & 0 \\
\hline GUANHÃES & SAO PEDRO DO SUACUI & 0 & 0 \\
\hline GUANHÃES & SAO SEBASTIAO DO MARANHAO & 0 & 0 \\
\hline GUANHÃES & SENHORA DO PORTO & 0 & 0 \\
\hline GUANHÃES & VIRGINOPOLIS & 0 & 0 \\
\hline ITAJUBÁ & BRASOPOLIS & 1 & 0 \\
\hline ITAJUBÁ & CARMO DE MINAS & 1 & 0 \\
\hline ITAJUBÁ & CONCEICAO DAS PEDRAS & 0 & 0 \\
\hline ITAJUBÁ & CONCEICAO DOS OUROS & 0 & 0 \\
\hline ITAJUBÁ & CONSOLACAO & 0 & 0 \\
\hline ITAJUBÁ & CRISTINA & 0 & 0 \\
\hline ITAJUBÁ & DELFIM MOREIRA & 0 & 0 \\
\hline ITAJUBÁ & DOM VICOSO & 0 & 0 \\
\hline ITAJUBÁ & GONCALVES & 1 & 0 \\
\hline ITAJUBÁ & ITAJUBA & 0 & 0 \\
\hline ITAJUBÁ & MARIA DA FE & 0 & 0 \\
\hline ITAJUBÁ & MARMELOPOLIS & 0 & 0 \\
\hline ITAJUBÁ & NATERCIA & 0 & 0 \\
\hline ITAJUBÁ & PARAISOPOLIS & 0 & 0 \\
\hline ITAJUBÁ & PEDRALVA & 0 & 0 \\
\hline ITAJUBÁ & PIRANGUCU & 0 & 0 \\
\hline ITAJUBÁ & PIRANGUINHO & 0 & 0 \\
\hline ITAJUBÁ & SAO JOSE DO ALEGRE & 0 & 0 \\
\hline ITAJUBÁ & SAPUCAI-MIRIM & 1 & 0 \\
\hline ITAJUBÁ & VIRGINIA & 0 & 0 \\
\hline ITAJUBÁ & WENCESLAU BRAZ & 0 & 0 \\
\hline ITUIUTABA & CACHOEIRA DOURADA & 0 & 0 \\
\hline ITUIUTABA & CANAPOLIS & 0 & 0 \\
\hline ITUIUTABA & CAPINOPOLIS & 0 & 0 \\
\hline ITUIUTABA & CENTRALINA & 0 & 0 \\
\hline ITUIUTABA & GURINHATA & 0 & 0 \\
\hline ITUIUTABA & IPIACU & 0 & 0 \\
\hline ITUIUTABA & ITUIUTABA & 6 & 2 \\
\hline ITUIUTABA & SANTA VITORIA & 0 & 0 \\
\hline JANAUBA & CATUTI & 0 & 0 \\
\hline JANAUBA & ESPINOSA & 0 & 0 \\
\hline JANAUBA & GAMELEIRAS & 0 & 0 \\
\hline JANAUBA & JAIBA & 1 & 0 \\
\hline JANAUBA & JANAUBA & 3 & 0 \\
\hline
\end{tabular}




\begin{tabular}{|c|c|c|c|}
\hline JANAUBA & MAMONAS & 1 & 0 \\
\hline JANAUBA & MATO VERDE & 0 & 0 \\
\hline JANAUBA & MONTE AZUL & 0 & 0 \\
\hline JANAUBA & MONTEZUMA & 0 & 0 \\
\hline JANAUBA & NOVA PORTEIRINHA & 0 & 0 \\
\hline JANAUBA & PAI PEDRO & 0 & 0 \\
\hline JANAUBA & PORTEIRINHA & 2 & 0 \\
\hline JANAUBA & RIACHO DOS MACHADOS & 0 & 0 \\
\hline JANAUBA & RIO PARDO DE MINAS & 3 & 0 \\
\hline JANAUBA & SANTO ANTONIO DO RETIRO & 0 & 0 \\
\hline JANAUBA & SERRANOPOLIS DE MINAS & 0 & 0 \\
\hline JANAUBA & VERDELANDIA & 1 & 0 \\
\hline JANUARIA & BONITO DE MINAS & 1 & 0 \\
\hline JANUARIA & CHAPADA GAUCHA & 1 & 0 \\
\hline JANUARIA & CONEGO MARINHO & 0 & 0 \\
\hline JANUARIA & IBIRACATU & 1 & 0 \\
\hline JANUARIA & ICARAI DE MINAS & 0 & 0 \\
\hline JANUARIA & ITACARAMBI & 0 & 0 \\
\hline JANUARIA & JANUARIA & 2 & 0 \\
\hline JANUARIA & JUVENILIA & 0 & 0 \\
\hline JANUARIA & MANGA & 0 & 0 \\
\hline JANUARIA & MATIAS CARDOSO & 0 & 0 \\
\hline JANUARIA & MIRAVANIA & 0 & 0 \\
\hline JANUARIA & MONTALVANIA & 0 & 0 \\
\hline JANUARIA & PEDRAS DE MARIA DA CRUZ & 0 & 0 \\
\hline JANUARIA & PINTOPOLIS & 0 & 0 \\
\hline JANUARIA & SAO FRANCISCO & 1 & 0 \\
\hline JANUARIA & SAO JOAO DAS MISSOES & 0 & 0 \\
\hline JANUARIA & UBAI & 0 & 0 \\
\hline JANUARIA & URUCUIA & 0 & 0 \\
\hline JANUARIA & VARZELANDIA & 0 & 0 \\
\hline JUIZ DE FORA & ARANTINA & 0 & 0 \\
\hline JUIZ DE FORA & BELMIRO BRAGA & 0 & 0 \\
\hline JUIZ DE FORA & BICAS & 0 & 0 \\
\hline JUIZ DE FORA & BOM JARDIM DE MINAS & 0 & 0 \\
\hline JUIZ DE FORA & CHACARA & 0 & 0 \\
\hline JUIZ DE FORA & CHIADOR & 0 & 0 \\
\hline JUIZ DE FORA & CORONEL PACHECO & 0 & 0 \\
\hline JUIZ DE FORA & DESCOBERTO & 0 & 0 \\
\hline JUIZ DE FORA & EWBANK DA CAMARA & 1 & 0 \\
\hline JUIZ DE FORA & GOIANA & 0 & 0 \\
\hline JUIZ DE FORA & GUARARA & 0 & 0 \\
\hline JUIZ DE FORA & JUIZ DE FORA & 10 & 3 \\
\hline JUIZ DE FORA & LIMA DUARTE & 1 & 0 \\
\hline JUIZ DE FORA & MAR DE ESPANHA & 0 & 0 \\
\hline
\end{tabular}




\begin{tabular}{|c|c|c|c|}
\hline JUIZ DE FORA & MARIPA DE MINAS & 0 & 0 \\
\hline JUIZ DE FORA & MATIAS BARBOSA & 1 & 0 \\
\hline JUIZ DE FORA & OLARIA & 0 & 0 \\
\hline JUIZ DE FORA & PEDRO TEIXEIRA & 0 & 0 \\
\hline JUIZ DE FORA & PEQUERI & 1 & 0 \\
\hline JUIZ DE FORA & PIAU & 0 & 0 \\
\hline JUIZ DE FORA & RIO NOVO & 0 & 0 \\
\hline JUIZ DE FORA & RIO PRETO & 0 & 0 \\
\hline JUIZ DE FORA & ROCHEDO DE MINAS & 0 & 0 \\
\hline JUIZ DE FORA & SANTA BARBARA DO MONTE VERDE & 1 & 0 \\
\hline JUIZ DE FORA & SANTA RITA DE JACUTINGA & 0 & 0 \\
\hline JUIZ DE FORA & SANTANA DO DESERTO & 0 & 0 \\
\hline JUIZ DE FORA & SANTOS DUMONT & 0 & 0 \\
\hline JUIZ DE FORA & SAO JOAO NEPOMUCENO & 0 & 0 \\
\hline JUIZ DE FORA & SENADOR CORTES & 0 & 0 \\
\hline JUIZ DE FORA & SIMAO PEREIRA & 0 & 0 \\
\hline LEOPOLDINA & ALEM PARAIBA & 0 & 0 \\
\hline LEOPOLDINA & ARGIRITA & 0 & 0 \\
\hline LEOPOLDINA & CATAGUASES & 2 & 0 \\
\hline LEOPOLDINA & ESTRELA DALVA & 0 & 0 \\
\hline LEOPOLDINA & ITAMARATI DE MINAS & 0 & 0 \\
\hline LEOPOLDINA & LEOPOLDINA & 0 & 0 \\
\hline LEOPOLDINA & PIRAPETINGA & 0 & 0 \\
\hline LEOPOLDINA & RECREIO & 0 & 0 \\
\hline LEOPOLDINA & SANTO ANTONIO DO AVENTUREIRO & 0 & 0 \\
\hline LEOPOLDINA & VOLTA GRANDE & 0 & 0 \\
\hline MANHUAÇU & ALTO JEQUITIBA & 0 & 0 \\
\hline MANHUAÇU & CAPUTIRA & 0 & 0 \\
\hline MANHUAÇU & CHALE & 0 & 0 \\
\hline MANHUAÇU & CONCEICAO DE IPANEMA & 0 & 0 \\
\hline MANHUAÇU & DURANDE & 0 & 0 \\
\hline MANHUAÇU & LAJINHA & 0 & 0 \\
\hline MANHUAÇU & LUISBURGO & 0 & 0 \\
\hline MANHUAÇU & MANHUACU & 2 & 0 \\
\hline MANHUAÇU & MANHUMIRIM & 1 & 0 \\
\hline MANHUAÇU & MARTINS SOARES & 0 & 0 \\
\hline MANHUAÇU & MATIPO & 1 & 0 \\
\hline MANHUAÇU & MUTUM & 0 & 0 \\
\hline MANHUAÇU & REDUTO & 0 & 0 \\
\hline MANHUAÇU & SANTA MARGARIDA & 1 & 0 \\
\hline MANHUAÇU & SANTANA DO MANHUACU & 1 & 0 \\
\hline MANHUAÇU & SAO JOAO DO MANHUACU & 0 & 0 \\
\hline MANHUAÇU & SAO JOSE DO MANTIMENTO & 0 & 0 \\
\hline MANHUAÇU & SIMONESIA & 0 & 0 \\
\hline METROPOLITANA A & BARAO DE COCAIS & 1 & 0 \\
\hline
\end{tabular}




\begin{tabular}{|c|c|c|c|}
\hline METROPOLITANA A & BELO HORIZONTE & 27 & 5 \\
\hline METROPOLITANA A & BELO VALE & 0 & 0 \\
\hline METROPOLITANA A & BOM JESUS DO AMPARO & 1 & 0 \\
\hline METROPOLITANA A & BONFIM & 1 & 0 \\
\hline METROPOLITANA A & BRUMADINHO & 0 & 0 \\
\hline METROPOLITANA A & CAETE & 1 & 0 \\
\hline METROPOLITANA A & CATAS ALTAS & 0 & 0 \\
\hline METROPOLITANA A & CRUCILANDIA & 0 & 0 \\
\hline METROPOLITANA A & MOEDA & 0 & 0 \\
\hline METROPOLITANA A & NOVA LIMA & 0 & 0 \\
\hline METROPOLITANA A & NOVA UNIAO & 0 & 0 \\
\hline METROPOLITANA A & PIEDADE DOS GERAIS & 1 & 0 \\
\hline METROPOLITANA A & RAPOSOS & 1 & 0 \\
\hline METROPOLITANA A & RIO ACIMA & 0 & 0 \\
\hline METROPOLITANA A & RIO MANSO & 0 & 0 \\
\hline METROPOLITANA A & SABARA & 5 & 2 \\
\hline METROPOLITANA A & SANTA BARBARA & 0 & 0 \\
\hline METROPOLITANA B & BELO HORIZONTE & 28 & 5 \\
\hline METROPOLITANA B & BETIM & 14 & 3 \\
\hline METROPOLITANA B & CONTAGEM & 25 & 5 \\
\hline METROPOLITANA B & ESMERALDAS & 0 & 0 \\
\hline METROPOLITANA B & IBIRITE & 7 & 2 \\
\hline METROPOLITANA B & IGARAPE & 1 & 0 \\
\hline METROPOLITANA B & JUATUBA & 2 & 0 \\
\hline METROPOLITANA B & MARIO CAMPOS & 0 & 0 \\
\hline METROPOLITANA B & MATEUS LEME & 0 & 0 \\
\hline METROPOLITANA B & SAO JOAQUIM DE BICAS & 0 & 0 \\
\hline METROPOLITANA B & SARZEDO & 1 & 0 \\
\hline METROPOLITANA C & BELO HORIZONTE & 25 & 5 \\
\hline METROPOLITANA C & CONFINS & 1 & 0 \\
\hline METROPOLITANA C & JABOTICATUBAS & 0 & 0 \\
\hline METROPOLITANA C & LAGOA SANTA & 1 & 0 \\
\hline METROPOLITANA C & MORRO DO PILAR & 0 & 0 \\
\hline METROPOLITANA C & PEDRO LEOPOLDO & 1 & 0 \\
\hline METROPOLITANA C & RIBEIRAO DAS NEVES & 15 & 3 \\
\hline METROPOLITANA C & SANTA LUZIA & 4 & 0 \\
\hline METROPOLITANA C & SANTANA DO RIACHO & 0 & 0 \\
\hline METROPOLITANA C & SAO JOSE DA LAPA & 1 & 0 \\
\hline METROPOLITANA C & TAQUARACU DE MINAS & 0 & 0 \\
\hline METROPOLITANA C & VESPASIANO & 1 & 0 \\
\hline MONTE CARMELO & ABADIA DOS DOURADOS & 0 & 0 \\
\hline MONTE CARMELO & CASCALHO RICO & 0 & 0 \\
\hline MONTE CARMELO & COROMANDEL & 1 & 0 \\
\hline MONTE CARMELO & DOURADOQUARA & 0 & 0 \\
\hline MONTE CARMELO & ESTRELA DO SUL & 0 & 0 \\
\hline
\end{tabular}




\begin{tabular}{|c|c|c|c|}
\hline MONTE CARMELO & GRUPIARA & 0 & 0 \\
\hline MONTE CARMELO & MONTE CARMELO & 2 & 0 \\
\hline MONTE CARMELO & ROMARIA & 0 & 0 \\
\hline MONTES CLAROS & BOCAIUVA & 0 & 0 \\
\hline MONTES CLAROS & BOTUMIRIM & 1 & 0 \\
\hline MONTES CLAROS & BRASILIA DE MINAS & 0 & 0 \\
\hline MONTES CLAROS & CAMPO AZUL & 0 & 0 \\
\hline MONTES CLAROS & CAPITAO ENEAS & 0 & 0 \\
\hline MONTES CLAROS & CLARO DOS POCOES & 0 & 0 \\
\hline MONTES CLAROS & CORACAO DE JESUS & 1 & 0 \\
\hline MONTES CLAROS & CRISTALIA & 0 & 0 \\
\hline MONTES CLAROS & ENGENHEIRO NAVARRO & 0 & 0 \\
\hline MONTES CLAROS & FRANCISCO DUMONT & 0 & 0 \\
\hline MONTES CLAROS & FRANCISCO SA & 2 & 0 \\
\hline MONTES CLAROS & GLAUCILANDIA & 0 & 0 \\
\hline MONTES CLAROS & GRAO MOGOL & 2 & 0 \\
\hline MONTES CLAROS & GUARACIAMA & 0 & 0 \\
\hline MONTES CLAROS & ITACAMBIRA & 0 & 0 \\
\hline MONTES CLAROS & JAPONVAR & 0 & 0 \\
\hline MONTES CLAROS & JOSENOPOLIS & 0 & 0 \\
\hline MONTES CLAROS & JURAMENTO & 1 & 0 \\
\hline MONTES CLAROS & LONTRA & 0 & 0 \\
\hline MONTES CLAROS & LUISLANDIA & 0 & 0 \\
\hline MONTES CLAROS & MIRABELA & 0 & 0 \\
\hline MONTES CLAROS & MONTES CLAROS & 3 & 0 \\
\hline MONTES CLAROS & OLHOS-D AGUA & 0 & 0 \\
\hline MONTES CLAROS & PADRE CARVALHO & 0 & 0 \\
\hline MONTES CLAROS & PATIS & 1 & 0 \\
\hline MONTES CLAROS & SAO JOAO DA LAGOA & 0 & 0 \\
\hline MONTES CLAROS & SAO JOAO DA PONTE & 2 & 0 \\
\hline MONTES CLAROS & SAO JOAO DO PACUI & 0 & 0 \\
\hline MONTES CLAROS & SAO JOAO DO PARAISO & 0 & 0 \\
\hline MONTES CLAROS & VARGEM GRANDE DO RIO PARDO & 0 & 0 \\
\hline MURIAÉ & ANTONIO PRADO DE MINAS & 0 & 0 \\
\hline MURIAÉ & BARAO DE MONTE ALTO & 0 & 0 \\
\hline MURIAÉ & EUGENOPOLIS & 0 & 0 \\
\hline MURIAÉ & LARANJAL & 0 & 0 \\
\hline MURIAÉ & MIRADOURO & 0 & 0 \\
\hline MURIAÉ & MIRAI & 1 & 0 \\
\hline MURIAÉ & MURIAE & 0 & 0 \\
\hline MURIAÉ & PALMA & 1 & 0 \\
\hline MURIAÉ & PATROCINIO DO MURIAE & 1 & 0 \\
\hline MURIAÉ & ROSARIO DA LIMEIRA & 0 & 0 \\
\hline MURIAÉ & SANTANA DE CATAGUASES & 0 & 0 \\
\hline MURIAÉ & SAO FRANCISCO DO GLORIA & 0 & 0 \\
\hline
\end{tabular}




\begin{tabular}{|c|c|c|c|}
\hline MURIAÉ & SAO SEBASTIAO DA VARGEM ALEGRE & 0 & 0 \\
\hline MURIAÉ & VIEIRAS & 0 & 0 \\
\hline NOVA ERA & BELA VISTA DE MINAS & 0 & 0 \\
\hline NOVA ERA & DIONISIO & 0 & 0 \\
\hline NOVA ERA & FERROS & 0 & 0 \\
\hline NOVA ERA & ITABIRA & 5 & 2 \\
\hline NOVA ERA & ITAMBE DO MATO DENTRO & 1 & 0 \\
\hline NOVA ERA & JOAO MONLEVADE & 2 & 0 \\
\hline NOVA ERA & NOVA ERA & 0 & 0 \\
\hline NOVA ERA & PASSABEM & 0 & 0 \\
\hline NOVA ERA & RIO PIRACICABA & 0 & 0 \\
\hline NOVA ERA & SANTA MARIA DE ITABIRA & 0 & 0 \\
\hline NOVA ERA & SANTO ANTONIO DO RIO ABAIXO & 0 & 0 \\
\hline NOVA ERA & SAO DOMINGOS DO PRATA & 1 & 0 \\
\hline NOVA ERA & SAO GONCALO DO RIO ABAIXO & 1 & 0 \\
\hline NOVA ERA & SAO JOSE DO GOIABAL & 0 & 0 \\
\hline NOVA ERA & SAO SEBASTIAO DO RIO PRETO & 0 & 0 \\
\hline OURO PRETO & ACAIACA & 0 & 0 \\
\hline OURO PRETO & DIOGO DE VASCONCELOS & 1 & 0 \\
\hline OURO PRETO & ITABIRITO & 3 & 0 \\
\hline OURO PRETO & MARIANA & 4 & 0 \\
\hline OURO PRETO & OURO PRETO & 7 & 2 \\
\hline PARA DE MINAS & ABAETE & 1 & 0 \\
\hline PARA DE MINAS & BIQUINHAS & 1 & 0 \\
\hline PARA DE MINAS & BOM DESPACHO & 0 & 0 \\
\hline PARA DE MINAS & CEDRO DO ABAETE & 0 & 0 \\
\hline PARA DE MINAS & CONCEICAO DO PARA & 0 & 0 \\
\hline PARA DE MINAS & DORES DO INDAIA & 0 & 0 \\
\hline PARA DE MINAS & ESTRELA DO INDAIA & 0 & 0 \\
\hline PARA DE MINAS & FLORESTAL & 1 & 0 \\
\hline PARA DE MINAS & IGARATINGA & 1 & 0 \\
\hline PARA DE MINAS & LEANDRO FERREIRA & 1 & 0 \\
\hline PARA DE MINAS & MARTINHO CAMPOS & 0 & 0 \\
\hline PARA DE MINAS & MORADA NOVA DE MINAS & 0 & 0 \\
\hline PARA DE MINAS & ONCA DE PITANGUI & 0 & 0 \\
\hline PARA DE MINAS & PAINEIRAS & 0 & 0 \\
\hline PARA DE MINAS & PARA DE MINAS & 3 & 0 \\
\hline PARA DE MINAS & PEQUI & 0 & 0 \\
\hline PARA DE MINAS & PITANGUI & 2 & 0 \\
\hline PARA DE MINAS & QUARTEL GERAL & 0 & 0 \\
\hline PARA DE MINAS & SAO JOSE DA VARGINHA & 0 & 0 \\
\hline PARA DE MINAS & SERRA DA SAUDADE & 0 & 0 \\
\hline PARACATU & BRASILANDIA DE MINAS & 0 & 0 \\
\hline PARACATU & GUARDA-MOR & 0 & 0 \\
\hline PARACATU & JOAO PINHEIRO & 1 & 0 \\
\hline
\end{tabular}




\begin{tabular}{|c|c|c|c|}
\hline PARACATU & PARACATU & 5 & 2 \\
\hline PARACATU & VAZANTE & 0 & 0 \\
\hline PASSOS & ALPINOPOLIS & 0 & 0 \\
\hline PASSOS & BOM JESUS DA PENHA & 0 & 0 \\
\hline PASSOS & CAPITOLIO & 0 & 0 \\
\hline PASSOS & CARMO DO RIO CLARO & 1 & 0 \\
\hline PASSOS & CORREGO FUNDO & 0 & 0 \\
\hline PASSOS & DELFINOPOLIS & 0 & 0 \\
\hline PASSOS & DORESOPOLIS & 0 & 0 \\
\hline PASSOS & FORMIGA & 1 & 0 \\
\hline PASSOS & FORTALEZA DE MINAS & 1 & 0 \\
\hline PASSOS & PASSOS & 0 & 0 \\
\hline PASSOS & PIMENTA & 1 & 0 \\
\hline PASSOS & PIUMHI & 0 & 0 \\
\hline PASSOS & SAO JOAO BATISTA DO GLORIA & 0 & 0 \\
\hline PASSOS & SAO JOSE DA BARRA & 0 & 0 \\
\hline PASSOS & SAO ROQUE DE MINAS & 1 & 0 \\
\hline PASSOS & VARGEM BONITA & 0 & 0 \\
\hline PATOS DE MINAS & ARAPUA & 0 & 0 \\
\hline PATOS DE MINAS & CARMO DO PARANAIBA & 1 & 0 \\
\hline PATOS DE MINAS & LAGAMAR & 0 & 0 \\
\hline PATOS DE MINAS & LAGOA FORMOSA & 0 & 0 \\
\hline PATOS DE MINAS & LAGOA GRANDE & 0 & 0 \\
\hline PATOS DE MINAS & MATUTINA & 0 & 0 \\
\hline PATOS DE MINAS & PATOS DE MINAS & 3 & 0 \\
\hline PATOS DE MINAS & PRESIDENTE OLEGARIO & 1 & 0 \\
\hline PATOS DE MINAS & RIO PARANAIBA & 1 & 0 \\
\hline PATOS DE MINAS & SANTA ROSA DA SERRA & 0 & 0 \\
\hline PATOS DE MINAS & SAO GONCALO DO ABAETE & 0 & 0 \\
\hline PATOS DE MINAS & SAO GOTARDO & 2 & 0 \\
\hline PATOS DE MINAS & TIROS & 0 & 0 \\
\hline PATOS DE MINAS & VARJAO DE MINAS & 1 & 0 \\
\hline PATROCÍNIO & CRUZEIRO DA FORTALEZA & 0 & 0 \\
\hline PATROCÍNIO & GUIMARANIA & 0 & 0 \\
\hline PATROCÍNIO & IBIA & 0 & 0 \\
\hline PATROCÍNIO & IRAI DE MINAS & 0 & 0 \\
\hline PATROCÍNIO & PATROCINIO & 1 & 0 \\
\hline PATROCÍNIO & PERDIZES & 1 & 0 \\
\hline PATROCÍNIO & SERRA DO SALITRE & 0 & 0 \\
\hline PIRAPORA & BURITIZEIRO & 3 & 0 \\
\hline PIRAPORA & IBIAI & 0 & 0 \\
\hline PIRAPORA & JEQUITAI & 0 & 0 \\
\hline PIRAPORA & LAGOA DOS PATOS & 0 & 0 \\
\hline PIRAPORA & PIRAPORA & 1 & 0 \\
\hline PIRAPORA & PONTO CHIQUE & 1 & 0 \\
\hline
\end{tabular}




\begin{tabular}{|c|c|c|c|}
\hline PIRAPORA & SANTA FE DE MINAS & 0 & 0 \\
\hline PIRAPORA & SAO ROMAO & 1 & 0 \\
\hline PIRAPORA & VARZEA DA PALMA & 1 & 0 \\
\hline POÇOS DE CALDAS & ALTEROSA & 0 & 0 \\
\hline POÇOS DE CALDAS & ANDRADAS & 1 & 0 \\
\hline POÇOS DE CALDAS & AREADO & 1 & 0 \\
\hline POÇOS DE CALDAS & BANDEIRA DO SUL & 0 & 0 \\
\hline POÇOS DE CALDAS & BOTELHOS & 1 & 0 \\
\hline POÇOS DE CALDAS & CABO VERDE & 0 & 0 \\
\hline POÇOS DE CALDAS & CALDAS & 0 & 0 \\
\hline POÇOS DE CALDAS & CAMPESTRE & 0 & 0 \\
\hline POÇOS DE CALDAS & CONCEICAO DA APARECIDA & 0 & 0 \\
\hline POÇOS DE CALDAS & DIVISA NOVA & 0 & 0 \\
\hline POÇOS DE CALDAS & IBITIURA DE MINAS & 0 & 0 \\
\hline POÇOS DE CALDAS & MONTE BELO & 0 & 0 \\
\hline POÇOS DE CALDAS & MUZAMBINHO & 0 & 0 \\
\hline POÇOS DE CALDAS & NOVA RESENDE & 1 & 0 \\
\hline POÇOS DE CALDAS & POCOS DE CALDAS & 6 & 2 \\
\hline POÇOS DE CALDAS & SANTA RITA DE CALDAS & 0 & 0 \\
\hline POÇOS DE CALDAS & SERRANIA & 0 & 0 \\
\hline PONTE NOVA & ABRE CAMPO & 0 & 0 \\
\hline PONTE NOVA & ALVINOPOLIS & 0 & 0 \\
\hline PONTE NOVA & AMPARO DO SERRA & 1 & 0 \\
\hline PONTE NOVA & ARAPONGA & 1 & 0 \\
\hline PONTE NOVA & BARRA LONGA & 0 & 0 \\
\hline PONTE NOVA & CAJURI & 0 & 0 \\
\hline PONTE NOVA & CANAA & 0 & 0 \\
\hline PONTE NOVA & DOM SILVERIO & 0 & 0 \\
\hline PONTE NOVA & GUARACIABA & 0 & 0 \\
\hline PONTE NOVA & JEQUERI & 0 & 0 \\
\hline PONTE NOVA & ORATORIOS & 0 & 0 \\
\hline PONTE NOVA & PEDRA BONITA & 1 & 0 \\
\hline PONTE NOVA & PEDRA DO ANTA & 0 & 0 \\
\hline PONTE NOVA & PIEDADE DE PONTE NOVA & 0 & 0 \\
\hline PONTE NOVA & PONTE NOVA & 1 & 0 \\
\hline PONTE NOVA & PORTO FIRME & 0 & 0 \\
\hline PONTE NOVA & RAUL SOARES & 0 & 0 \\
\hline PONTE NOVA & RIO CASCA & 1 & 0 \\
\hline PONTE NOVA & RIO DOCE & 1 & 0 \\
\hline PONTE NOVA & SANTA CRUZ DO ESCALVADO & 0 & 0 \\
\hline PONTE NOVA & SANTO ANTONIO DO GRAMA & 0 & 0 \\
\hline PONTE NOVA & SAO MIGUEL DO ANTA & 0 & 0 \\
\hline PONTE NOVA & SAO PEDRO DOS FERROS & 0 & 0 \\
\hline PONTE NOVA & SEM-PEIXE & 0 & 0 \\
\hline PONTE NOVA & SERICITA & 0 & 0 \\
\hline
\end{tabular}




\begin{tabular}{|c|c|c|c|}
\hline PONTE NOVA & TEIXEIRAS & 0 & 0 \\
\hline PONTE NOVA & URUCANIA & 1 & 0 \\
\hline PONTE NOVA & VERMELHO NOVO & 0 & 0 \\
\hline PONTE NOVA & VICOSA & 2 & 0 \\
\hline POUSO ALEGRE & ALBERTINA & 1 & 0 \\
\hline POUSO ALEGRE & BOM REPOUSO & 0 & 0 \\
\hline POUSO ALEGRE & BORDA DA MATA & 0 & 0 \\
\hline POUSO ALEGRE & BUENO BRANDAO & 1 & 0 \\
\hline POUSO ALEGRE & CACHOEIRA DE MINAS & 1 & 0 \\
\hline POUSO ALEGRE & CAMANDUCAIA & 3 & 0 \\
\hline POUSO ALEGRE & CAMBUI & 2 & 0 \\
\hline POUSO ALEGRE & CAREACU & 0 & 0 \\
\hline POUSO ALEGRE & CONGONHAL & 0 & 0 \\
\hline POUSO ALEGRE & CORREGO DO BOM JESUS & 0 & 0 \\
\hline POUSO ALEGRE & ESPIRITO SANTO DO DOURADO & 1 & 0 \\
\hline POUSO ALEGRE & ESTIVA & 0 & 0 \\
\hline POUSO ALEGRE & EXTREMA & 1 & 0 \\
\hline POUSO ALEGRE & HELIODORA & 0 & 0 \\
\hline POUSO ALEGRE & INCONFIDENTES & 1 & 0 \\
\hline POUSO ALEGRE & IPUIUNA & 0 & 0 \\
\hline POUSO ALEGRE & ITAPEVA & 1 & 0 \\
\hline POUSO ALEGRE & JACUTINGA & 0 & 0 \\
\hline POUSO ALEGRE & MONTE SIAO & 1 & 0 \\
\hline POUSO ALEGRE & MUNHOZ & 0 & 0 \\
\hline POUSO ALEGRE & OURO FINO & 1 & 0 \\
\hline POUSO ALEGRE & POUSO ALEGRE & 6 & 2 \\
\hline POUSO ALEGRE & SANTA RITA DO SAPUCAI & 2 & 0 \\
\hline POUSO ALEGRE & SAO JOAO DA MATA & 0 & 0 \\
\hline POUSO ALEGRE & SAO SEBASTIAO DA BELA VISTA & 0 & 0 \\
\hline POUSO ALEGRE & SENADOR AMARAL & 0 & 0 \\
\hline POUSO ALEGRE & SENADOR JOSE BENTO & 0 & 0 \\
\hline POUSO ALEGRE & SILVIANOPOLIS & 0 & 0 \\
\hline POUSO ALEGRE & TOCOS DO MOJI & 0 & 0 \\
\hline POUSO ALEGRE & TOLEDO & 0 & 0 \\
\hline SÃO JOÃO DEL REI & BOM SUCESSO & 0 & 0 \\
\hline SÃO JOÃO DEL REI & CARRANCAS & 0 & 0 \\
\hline SÃO JOÃO DEL REI & CONCEICAO DA BARRA DE MINAS & 0 & 0 \\
\hline SÃO JOÃO DEL REI & CORONEL XAVIER CHAVES & 0 & 0 \\
\hline SÃO JOÃO DEL REI & DORES DE CAMPOS & 0 & 0 \\
\hline SÃO JOÃO DEL REI & IBITURUNA & 1 & 0 \\
\hline SÃO JOÃO DEL REI & IJACI & 0 & 0 \\
\hline SÃO JOÃO DEL REI & INGAI & 0 & 0 \\
\hline SÃO JOÃO DEL REI & ITUMIRIM & 0 & 0 \\
\hline SÃO JOÃO DEL REI & ITUTINGA & 1 & 0 \\
\hline SÃO JOÃO DEL REI & LAGOA DOURADA & 0 & 0 \\
\hline
\end{tabular}




\begin{tabular}{|c|c|c|c|}
\hline SÃO JOÃO DEL REI & NAZARENO & 0 & 0 \\
\hline SÃO JOÃO DEL REI & PRADOS & 1 & 0 \\
\hline SÃO JOÃO DEL REI & RESENDE COSTA & 0 & 0 \\
\hline SÃO JOÃO DEL REI & RITAPOLIS & 0 & 0 \\
\hline SÃO JOÃO DEL REI & SANTA CRUZ DE MINAS & 0 & 0 \\
\hline SÃO JOÃO DEL REI & SAO JOAO DEL REI & 1 & 0 \\
\hline SÃO JOÃO DEL REI & SAO TIAGO & 0 & 0 \\
\hline SÃO JOÃO DEL REI & TIRADENTES & 0 & 0 \\
\hline SÃO SEBASTIÃO DO PARAÍSO & ARCEBURGO & 0 & 0 \\
\hline SÃO SEBASTIÃO DO PARAÍSO & CAPETINGA & 0 & 0 \\
\hline SÃO SEBASTIÃO DO PARAÍSO & CASSIA & 0 & 0 \\
\hline SÃO SEBASTIÃO DO PARAÍSO & CLARAVAL & 0 & 0 \\
\hline SÃO SEBASTIÃO DO PARAÍSO & GUARANESIA & 0 & 0 \\
\hline SÃO SEBASTIÃO DO PARAÍSO & GUAXUPE & 0 & 0 \\
\hline SÃO SEBASTIÃO DO PARAÍSO & IBIRACI & 0 & 0 \\
\hline SÃO SEBASTIÃO DO PARAÍSO & ITAMOGI & 1 & 0 \\
\hline SÃO SEBASTIÃO DO PARAÍSO & ITAU DE MINAS & 0 & 0 \\
\hline SÃO SEBASTIÃO DO PARAÍSO & JACUI & 0 & 0 \\
\hline SÃO SEBASTIÃO DO PARAÍSO & JURUAIA & 0 & 0 \\
\hline SÃO SEBASTIÃO DO PARAÍSO & MONTE SANTO DE MINAS & 0 & 0 \\
\hline SÃO SEBASTIÃO DO PARAÍSO & PRATAPOLIS & 0 & 0 \\
\hline SÃO SEBASTIÃO DO PARAÍSO & SAO PEDRO DA UNIAO & 0 & 0 \\
\hline SÃO SEBASTIÃO DO PARAÍSO & SAO SEBASTIAO DO PARAISO & 3 & 0 \\
\hline SÃO SEBASTIÃO DO PARAÍSO & SAO TOMAS DE AQUINO & 0 & 0 \\
\hline SETE LAGOAS & ARACAI & 0 & 0 \\
\hline SETE LAGOAS & BALDIM & 1 & 0 \\
\hline SETE LAGOAS & CACHOEIRA DA PRATA & 0 & 0 \\
\hline SETE LAGOAS & CAETANOPOLIS & 0 & 0 \\
\hline SETE LAGOAS & CAPIM BRANCO & 0 & 0 \\
\hline SETE LAGOAS & CORDISBURGO & 0 & 0 \\
\hline SETE LAGOAS & FORTUNA DE MINAS & 0 & 0 \\
\hline SETE LAGOAS & FUNILANDIA & 0 & 0 \\
\hline SETE LAGOAS & INHAUMA & 0 & 0 \\
\hline SETE LAGOAS & JEQUITIBA & 0 & 0 \\
\hline SETE LAGOAS & MARAVILHAS & 0 & 0 \\
\hline SETE LAGOAS & MATOZINHOS & 1 & 0 \\
\hline SETE LAGOAS & PAPAGAIOS & 0 & 0 \\
\hline SETE LAGOAS & PARAOPEBA & 1 & 0 \\
\hline SETE LAGOAS & POMPEU & 0 & 0 \\
\hline SETE LAGOAS & PRUDENTE DE MORAIS & 0 & 0 \\
\hline SETE LAGOAS & SANTANA DE PIRAPAMA & 0 & 0 \\
\hline SETE LAGOAS & SETE LAGOAS & 4 & 0 \\
\hline TEOFILO OTONI & AGUAS FORMOSAS & 1 & 0 \\
\hline TEOFILO OTONI & ATALEIA & 0 & 0 \\
\hline TEOFILO OTONI & BERTOPOLIS & 0 & 0 \\
\hline
\end{tabular}




\begin{tabular}{|c|c|c|c|}
\hline TEOFILO OTONI & CAMPANARIO & 0 & 0 \\
\hline TEOFILO OTONI & CARAI & 1 & 0 \\
\hline TEOFILO OTONI & CARLOS CHAGAS & 1 & 0 \\
\hline TEOFILO OTONI & CATUJI & 0 & 0 \\
\hline TEOFILO OTONI & CRISOLITA & 0 & 0 \\
\hline TEOFILO OTONI & FRANCISCOPOLIS & 1 & 0 \\
\hline TEOFILO OTONI & FREI GASPAR & 0 & 0 \\
\hline TEOFILO OTONI & FRONTEIRA DOS VALES & 0 & 0 \\
\hline TEOFILO OTONI & ITAIPE & 1 & 0 \\
\hline TEOFILO OTONI & ITAMBACURI & 0 & 0 \\
\hline TEOFILO OTONI & JAMPRUCA & 0 & 0 \\
\hline TEOFILO OTONI & LADAINHA & 1 & 0 \\
\hline TEOFILO OTONI & MACHACALIS & 0 & 0 \\
\hline TEOFILO OTONI & MALACACHETA & 3 & 0 \\
\hline TEOFILO OTONI & NANUQUE & 0 & 0 \\
\hline TEOFILO OTONI & NOVO CRUZEIRO & 3 & 0 \\
\hline TEOFILO OTONI & NOVO ORIENTE DE MINAS & 0 & 0 \\
\hline TEOFILO OTONI & OURO VERDE DE MINAS & 0 & 0 \\
\hline TEOFILO OTONI & PADRE PARAISO & 0 & 0 \\
\hline TEOFILO OTONI & PAVAO & 1 & 0 \\
\hline TEOFILO OTONI & PESCADOR & 1 & 0 \\
\hline TEOFILO OTONI & PONTO DOS VOLANTES & 0 & 0 \\
\hline TEOFILO OTONI & POTE & 0 & 0 \\
\hline TEOFILO OTONI & SANTA HELENA DE MINAS & 0 & 0 \\
\hline TEOFILO OTONI & SERRA DOS AIMORES & 0 & 0 \\
\hline TEOFILO OTONI & SETUBINHA & 0 & 0 \\
\hline TEOFILO OTONI & TEOFILO OTONI & 2 & 0 \\
\hline TEOFILO OTONI & UMBURATIBA & 0 & 0 \\
\hline UBÁ & ASTOLFO DUTRA & 0 & 0 \\
\hline UBÁ & BRAS PIRES & 0 & 0 \\
\hline UBÁ & COIMBRA & 1 & 0 \\
\hline UBÁ & DIVINESIA & 0 & 0 \\
\hline UBÁ & DONA EUZEBIA & 0 & 0 \\
\hline UBÁ & DORES DO TURVO & 0 & 0 \\
\hline UBÁ & ERVALIA & 0 & 0 \\
\hline UBÁ & GUARANI & 0 & 0 \\
\hline UBÁ & GUIDOVAL & 0 & 0 \\
\hline UBÁ & GUIRICEMA & 0 & 0 \\
\hline UBÁ & PAULA CANDIDO & 1 & 0 \\
\hline UBÁ & PIRAUBA & 0 & 0 \\
\hline UBÁ & PRESIDENTE BERNARDES & 0 & 0 \\
\hline UBÁ & RIO POMBA & 0 & 0 \\
\hline UBÁ & RODEIRO & 1 & 0 \\
\hline UBÁ & SAO GERALDO & 0 & 0 \\
\hline UBÁ & SENADOR FIRMINO & 0 & 0 \\
\hline
\end{tabular}




\begin{tabular}{|c|c|c|c|}
\hline UBÁ & SILVEIRANIA & 0 & 0 \\
\hline UBÁ & TABULEIRO & 0 & 0 \\
\hline UBÁ & TOCANTINS & 0 & 0 \\
\hline UBÁ & UBA & 4 & 0 \\
\hline UBÁ & VISCONDE DO RIO BRANCO & 0 & 0 \\
\hline UBERABA & AGUA COMPRIDA & 0 & 0 \\
\hline UBERABA & ARAXA & 2 & 0 \\
\hline UBERABA & CAMPO FLORIDO & 0 & 0 \\
\hline UBERABA & CAMPOS ALTOS & 0 & 0 \\
\hline UBERABA & CARNEIRINHO & 1 & 0 \\
\hline UBERABA & COMENDADOR GOMES & 0 & 0 \\
\hline UBERABA & CONCEICAO DAS ALAGOAS & 1 & 0 \\
\hline UBERABA & CONQUISTA & 0 & 0 \\
\hline UBERABA & DELTA & 0 & 0 \\
\hline UBERABA & FRONTEIRA & 0 & 0 \\
\hline UBERABA & FRUTAL & 1 & 0 \\
\hline UBERABA & ITAPAGIPE & 1 & 0 \\
\hline UBERABA & ITURAMA & 1 & 0 \\
\hline UBERABA & LIMEIRA DO OESTE & 1 & 0 \\
\hline UBERABA & PEDRINOPOLIS & 0 & 0 \\
\hline UBERABA & PIRAJUBA & 0 & 0 \\
\hline UBERABA & PLANURA & 0 & 0 \\
\hline UBERABA & PRATINHA & 0 & 0 \\
\hline UBERABA & SACRAMENTO & 0 & 0 \\
\hline UBERABA & SANTA JULIANA & 1 & 0 \\
\hline UBERABA & SAO FRANCISCO DE SALES & 0 & 0 \\
\hline UBERABA & TAPIRA & 0 & 0 \\
\hline UBERABA & UBERABA & 8 & 2 \\
\hline UBERABA & UNIAO DE MINAS & 0 & 0 \\
\hline UBERABA & VERISSIMO & 0 & 0 \\
\hline UBERLANDIA & ARAGUARI & 4 & 0 \\
\hline UBERLANDIA & ARAPORA & 0 & 0 \\
\hline UBERLANDIA & CAMPINA VERDE & 1 & 0 \\
\hline UBERLANDIA & INDIANOPOLIS & 0 & 0 \\
\hline UBERLANDIA & MONTE ALEGRE DE MINAS & 0 & 0 \\
\hline UBERLANDIA & NOVA PONTE & 0 & 0 \\
\hline UBERLANDIA & PRATA & 0 & 0 \\
\hline UBERLANDIA & TUPACIGUARA & 1 & 0 \\
\hline UBERLANDIA & UBERLANDIA & 23 & 5 \\
\hline UNAI & ARINOS & 0 & 0 \\
\hline UNAI & BONFINOPOLIS DE MINAS & 0 & 0 \\
\hline UNAI & BURITIS & 1 & 0 \\
\hline UNAI & CABECEIRA GRANDE & 0 & 0 \\
\hline UNAI & DOM BOSCO & 0 & 0 \\
\hline UNAI & FORMOSO & 0 & 0 \\
\hline
\end{tabular}




\begin{tabular}{|c|c|c|c|}
\hline UNAI & NATALANDIA & 0 & 0 \\
\hline UNAI & RIACHINHO & 1 & 0 \\
\hline UNAI & UNAI & 4 & 0 \\
\hline UNAI & URUANA DE MINAS & 1 & 0 \\
\hline VARGINHA & ALFENAS & 4 & 0 \\
\hline VARGINHA & BOA ESPERANCA & 1 & 0 \\
\hline VARGINHA & CAMBUQUIRA & 1 & 0 \\
\hline VARGINHA & CAMPANHA & 0 & 0 \\
\hline VARGINHA & CAMPO DO MEIO & 0 & 0 \\
\hline VARGINHA & CAMPOS GERAIS & 0 & 0 \\
\hline VARGINHA & CARMO DA CACHOEIRA & 0 & 0 \\
\hline VARGINHA & CARVALHOPOLIS & 1 & 0 \\
\hline VARGINHA & COQUEIRAL & 1 & 0 \\
\hline VARGINHA & CORDISLANDIA & 0 & 0 \\
\hline VARGINHA & ELOI MENDES & 2 & 0 \\
\hline VARGINHA & FAMA & 0 & 0 \\
\hline VARGINHA & GUAPE & 0 & 0 \\
\hline VARGINHA & ILICINEA & 0 & 0 \\
\hline VARGINHA & LAMBARI & 1 & 0 \\
\hline VARGINHA & LUMINARIAS & 1 & 0 \\
\hline VARGINHA & MACHADO & 0 & 0 \\
\hline VARGINHA & MONSENHOR PAULO & 0 & 0 \\
\hline VARGINHA & NEPOMUCENO & 0 & 0 \\
\hline VARGINHA & PARAGUACU & 0 & 0 \\
\hline VARGINHA & POCO FUNDO & 0 & 0 \\
\hline VARGINHA & SANTANA DA VARGEM & 0 & 0 \\
\hline VARGINHA & SAO BENTO ABADE & 0 & 0 \\
\hline VARGINHA & SAO GONCALO DO SAPUCAI & 1 & 0 \\
\hline VARGINHA & TRES CORACOES & 1 & 0 \\
\hline VARGINHA & TRES PONTAS & 1 & 0 \\
\hline VARGINHA & TURVOLANDIA & 0 & 0 \\
\hline VARGINHA & VARGINHA & 3 & 0 \\
\hline Total geral & & 577 & 58 \\
\hline
\end{tabular}




\section{ANEXO III \\ ATRIBUIÇÕES DOS CARGOS \\ (observado o Anexo II da Lei no ${ }^{0}$ 15.293/2004)}

\section{a) Assistente Técnico de Educação Básica - ATB Nível I Grau A:}

- exercer suas atividades em unidade escolar, participando do processo que envolve o planejamento, a elaboração, a execução e a avaliação do plano de desenvolvimento pedagógico e institucional da escola;

- organizar e manter atualizados cadastros, arquivos, fichários, livros e outros instrumentos de escrituração da escola, relativos aos registros funcionais dos servidores e à vida escolar dos alunos;

- organizar e manter atualizado o sistema de informações legais e regulamentares de interesse da escola;

- redigir ofícios, exposições de motivos, atas e outros expedientes;

- coletar, apurar, selecionar, registrar e consolidar dados para a elaboração de informações estatísticas;

- realizar trabalhos de digitação e mecanografia;

- realizar trabalhos de protocolização, preparo, seleção, classificação, registro e arquivamento de documentos e formulários;

- atender, orientar e encaminhar o público;

- auxiliar na organização, manutenção e atendimento em biblioteca escolar e sala de multimeios;

- auxiliar no cuidado e na distribuição de material esportivo, de laboratórios, de oficinas pedagógicas e outros sob sua guarda;

- exercer outras atividades integrantes do plano de desenvolvimento pedagógico e institucional da escola, previstas no regulamento desta lei e no regimento escolar.

\section{b) Assistente Técnico Educacional - ATE Nível I Grau A:}

- exercer suas atividades na Unidade Central da SEE e nas Superintendências Regionais de Ensino da SEE, participando do processo que envolve o planejamento, a elaboração, a execução e a avaliação do plano de desenvolvimento pedagógico e institucional;

- organizar e manter atualizados cadastros, arquivos, fichários, livros e outros instrumentos de escrituração da escola, relativos aos registros funcionais dos servidores;

- organizar e manter atualizado o sistema de informações legais e regulamentares de interesse da SEE;

- redigir ofícios, exposições de motivos, atas e outros expedientes;

- coletar, apurar, selecionar, registrar e consolidar dados para elaboração de informações estatísticas;

- realizar trabalhos de digitação e mecanografia;

- realizar trabalhos de protocolização, preparo, seleção, classificação, registro e arquivamento de documentos e formulários;

- atender, orientar e encaminhar a clientela;

- auxiliar na organização, manutenção e atendimento em biblioteca e sala de multimeios; 
- exercer outras atividades integrantes do plano de desenvolvimento pedagógico e institucional da SEE.

c) Analista Educacional - ANE Nível I Grau A:

- exercer atividade profissional específica em nível superior de escolaridade nos setores pedagógico e administrativo no campo da educação, na Unidade Central da SEE e nas Superintendências Regionais de Ensino;

- elaborar, analisar e avaliar planos, programas e projetos pedagógicos;

- coordenar, acompanhar, avaliar e redirecionar a execução de propostas educacionais;

- elaborar normas, instruções e orientações para aplicação da legislação relativa a programas e currículos escolares e à administração de pessoal, material, patrimônio e serviços;

- elaborar, executar e acompanhar projetos de capacitação de pessoal e treinamentos operacionais nos vários âmbitos de atuação;

- proporcionar assistência técnica na elaboração de instrumentos de avaliação do processo educacional;

- elaborar programas, provas e material instrucional para o Ensino Fundamental e Médio;

- realizar pesquisas e estudos que subsidiem a proposta de políticas, diretrizes e normas educacionais;

- participar da elaboração de planejamentos ou propostas anuais de atividades do setor ou órgão em que atua;

- organizar e produzir dados e informações educacionais;

- elaborar a proposta de reforma, ampliação ou construção da rede física de atendimento e acompanhar a sua execução;

- realizar trabalhos de escrituração contábil, cálculo de custos, perícia, previsão, levantamento, análise e revisão de balanços e demonstrativos, execução orçamentária e movimentação de contas financeiras e patrimoniais;

- emitir pareceres e relatórios sobre assuntos financeiros e contábeis.

\section{d) Analista Educacional - ANE Nível I Grau A - Inspeção Escolar:}

- exercer a inspeção escolar, que compreende:

1- orientação, assistência e controle do processo administrativo das escolas e, na forma do regulamento, do seu processo pedagógico;

2- orientação da organização dos processos de criação, autorização de funcionamento, reconhecimento e registro de escolas, no âmbito de sua área de atuação;

3- garantia de regularidade do funcionamento das escolas, em todos os aspectos;

4- responsabilidade pelo fluxo correto e regular de informações entre as escolas, os órgãos regionais e o órgão central da SEE;

- exercer outras atividades compatíveis com a natureza do cargo, previstas na regulamentação aplicável e de acordo com a política pública educacional.

e) Especialista em Educação Básica - EEB Nível I Grau A - Orientação Educacional ou Supervisão Pedagógica: 
- exercer em unidade escolar a supervisão do processo didático como elemento articulador no planejamento, no acompanhamento, no controle e na avaliação das atividades pedagógicas, conforme o plano de desenvolvimento pedagógico e institucional da unidade escolar;

- atuar como elemento articulador das relações interpessoais internas e externas da escola que envolvam os profissionais, os alunos e seus pais e a comunidade;

- planejar, executar e coordenar cursos, atividades e programas internos de capacitação profissional e treinamento em serviço;

- participar da elaboração do calendário escolar;

- participar das atividades do Conselho de Classe ou coordená-las;

- exercer, em trabalho individual ou em grupo, a orientação, o aconselhamento e o encaminhamento de alunos em sua formação geral e na sondagem de suas aptidões específicas;

- atuar como elemento articulador das relações internas na escola e externas com as famílias dos alunos, comunidade e entidades de apoio psicopedagógicos e como ordenador das influências que incidam sobre a formação do educando;

- exercer atividades de apoio à docência;

- exercer outras atividades integrantes do plano de desenvolvimento pedagógico e institucional da escola, previstas no regulamento desta lei e no regimento escolar.

\section{f) Professor de Educação Básica - PEB Nível I Grau A - Todas as Áreas de Atuação:}

- exercer a docência na educação básica, em unidade escolar, responsabilizando-se pela regência de turmas ou de aulas, pela orientação de aprendizagem na educação de jovens e adultos, pela docência em laboratório de ensino, em sala de recursos didáticos e em oficina pedagógica;

- participar do processo que envolve planejamento, elaboração, execução, controle e avaliação do projeto político-pedagógico e do plano de desenvolvimento pedagógico e institucional da escola;

- participar da elaboração do calendário escolar;

- exercer atividade de coordenação pedagógica de área de conhecimento específico, nos termos do regulamento;

- atuar na elaboração e na implementação de projetos educativos ou, como docente, em projeto de formação continuada de educadores, na forma do regulamento;

- participar da elaboração e da implementação de projetos e atividades de articulação e integração da escola com as famílias dos educandos e com a comunidade escolar;

- participar de cursos, atividades e programas de capacitação profissional, quando convocado ou convidado;

- acompanhar e avaliar sistematicamente seus alunos durante o processo de ensinoaprendizagem;

- realizar avaliações periódicas dos cursos ministrados e das atividades realizadas;

- promover e participar de atividades complementares ao processo da sua formação profissional;

- exercer outras atribuições integrantes do plano de desenvolvimento pedagógico e institucional da escola, previstas no regulamento desta lei e no regimento escolar. 
ANEXO IV

MUNICIIPIOS QUE COMPÕEM AS SUPERINTENDÊNCIAS REGIONAIS DE ENSINO E MUNICÍPIOS DE REALIZAÇÃO DAS PROVAS

\begin{tabular}{|c|c|c|}
\hline \multicolumn{3}{|c|}{ SECRETARIA DE ESTADO DE EDUCAÇÃO - CONCURSO PÚBLICO - EDITAL Nº1/20 } \\
\hline SRE & MUNICÍPIOS & MUNICÍPIO DE PROVA \\
\hline \multirow{21}{*}{ SRE ALMENARA } & AGUAS VERMELHAS & \multirow{21}{*}{ ALMENARA } \\
\hline & ALMENARA & \\
\hline & BANDEIRA & \\
\hline & CACHOEIRA DE PAJEU & \\
\hline & CURRAL DE DENTRO & \\
\hline & DIVISA ALEGRE & \\
\hline & DIVISOPOLIS & \\
\hline & FELISBURGO & \\
\hline & JACINTO & \\
\hline & JEQUITINHONHA & \\
\hline & JOAIMA & \\
\hline & JORDANIA & \\
\hline & MATA VERDE & \\
\hline & MONTE FORMOSO & \\
\hline & PALMOPOLIS & \\
\hline & PEDRA AZUL & \\
\hline & RIO DO PRADO & \\
\hline & RUBIM & \\
\hline & SALTO DA DIVISA & \\
\hline & SANTA MARIA DO SALTO & \\
\hline & SANTO ANTONIO DO JACINTO & \\
\hline \multirow{16}{*}{ SRE ARAÇUAI } & ARACUAI & \multirow{16}{*}{ ARAÇUAÍ } \\
\hline & BERILO & \\
\hline & BERIZAL & \\
\hline & CHAPADA DO NORTE & \\
\hline & COMERCINHO & \\
\hline & CORONEL MURTA & \\
\hline & FRANCISCO BADARO & \\
\hline & FRUTA DE LEITE & \\
\hline & INDAIABIRA & \\
\hline & ITAOBIM & \\
\hline & ITINGA & \\
\hline & JENIPAPO DE MINAS & \\
\hline & JOSE GONCALVES DE MINAS & \\
\hline & MEDINA & \\
\hline & NINHEIRA & \\
\hline & NOVORIZONTE & \\
\hline
\end{tabular}




\begin{tabular}{|c|c|c|}
\hline & RUBELITA & \\
\hline & SALINAS & \\
\hline & SANTA CRUZ DE SALINAS & \\
\hline & TAIOBEIRAS & \\
\hline & VIRGEM DA LAPA & \\
\hline \multirow{24}{*}{ SRE BARBACENA } & ALFREDO VASCONCELOS & \multirow{24}{*}{ BARBACENA } \\
\hline & ALTO RIO DOCE & \\
\hline & ANDRELANDIA & \\
\hline & ANTONIO CARLOS & \\
\hline & ARACITABA & \\
\hline & BARBACENA & \\
\hline & BARROSO & \\
\hline & BIAS FORTES & \\
\hline & CAPELA NOVA & \\
\hline & CARANDAI & \\
\hline & CIPOTANEA & \\
\hline & DESTERRO DO MELO & \\
\hline & IBERTIOGA & \\
\hline & MADRE DE DEUS DE MINAS & \\
\hline & MERCES & \\
\hline & OLIVEIRA FORTES & \\
\hline & PAIVA & \\
\hline & PIEDADE DO RIO GRANDE & \\
\hline & RESSAQUINHA & \\
\hline & SANTA BARBARA DO TUGURIO & \\
\hline & SANTA RITA DO IBITIPOCA & \\
\hline & SANTANA DO GARAMBEU & \\
\hline & SAO VICENTE DE MINAS & \\
\hline & SENHORA DOS REMEDIOS & \\
\hline \multirow{12}{*}{$\begin{array}{c}\text { SRE CAMPO } \\
\text { BELO }\end{array}$} & AGUANIL & \multirow{12}{*}{ CAMPO BELO } \\
\hline & CAMACHO & \\
\hline & CAMPO BELO & \\
\hline & CANA VERDE & \\
\hline & CANDEIAS & \\
\hline & CRISTAIS & \\
\hline & LAVRAS & \\
\hline & PERDOES & \\
\hline & RIBEIRAO VERMELHO & \\
\hline & SANTANA DO JACARE & \\
\hline & SANTO ANTONIO DO AMPARO & \\
\hline & SAO FRANCISCO DE PAULA & \\
\hline \multirow{4}{*}{ SRE CARANGOLA } & ALTO CAPARAO & \multirow{4}{*}{ CARANGOLA } \\
\hline & CAIANA & \\
\hline & CAPARAO & \\
\hline & CARANGOLA & \\
\hline
\end{tabular}




\begin{tabular}{|c|c|c|}
\hline & DIVINO & \\
\hline & ESPERA FELIZ & \\
\hline & FARIA LEMOS & \\
\hline & FERVEDOURO & \\
\hline & ORIZANIA & \\
\hline & PEDRA DOURADA & \\
\hline & TOMBOS & \\
\hline \multirow{24}{*}{ SRE CARATINGA } & ALVARENGA & \multirow{24}{*}{ CARATINGA } \\
\hline & BOM JESUS DO GALHO & \\
\hline & BUGRE & \\
\hline & CARATINGA & \\
\hline & CORREGO NOVO & \\
\hline & DOM CAVATI & \\
\hline & ENTRE FOLHAS & \\
\hline & IAPU & \\
\hline & IMBE DE MINAS & \\
\hline & INHAPIM & \\
\hline & IPABA & \\
\hline & IPANEMA & \\
\hline & PIEDADE DE CARATINGA & \\
\hline & PINGO D AGUA & \\
\hline & POCRANE & \\
\hline & SANTA BARBARA DO LESTE & \\
\hline & SANTA RITA DE MINAS & \\
\hline & SAO DOMINGOS DAS DORES & \\
\hline & SAO JOAO DO ORIENTE & \\
\hline & SAO SEBASTIAO DO ANTA & \\
\hline & TAPARUBA & \\
\hline & TARUMIRIM & \\
\hline & UBAPORANGA & \\
\hline & VARGEM ALEGRE & \\
\hline \multirow{14}{*}{ SRE CAXAMBU } & AIURUOCA & \multirow{14}{*}{ CAXAMBU } \\
\hline & ALAGOA & \\
\hline & BAEPENDI & \\
\hline & BOCAINA DE MINAS & \\
\hline & CARVALHOS & \\
\hline & CAXAMBU & \\
\hline & CONCEICAO DO RIO VERDE & \\
\hline & CRUZILIA & \\
\hline & ITAMONTE & \\
\hline & ITANHANDU & \\
\hline & JESUANIA & \\
\hline & LIBERDADE & \\
\hline & MINDURI & \\
\hline & OLIMPIO NORONHA & \\
\hline
\end{tabular}




\begin{tabular}{|c|c|c|}
\hline & PASSA QUATRO & \\
\hline & PASSA VINTE & \\
\hline & POUSO ALTO & \\
\hline & SAO LOURENCO & \\
\hline & SAO SEBASTIAO DO RIO VERDE & \\
\hline & SAO TOME DAS LETRAS & \\
\hline & SERITINGA & \\
\hline & SERRANOS & \\
\hline & SOLEDADE DE MINAS & \\
\hline \multirow{11}{*}{$\begin{array}{c}\text { SRE CORONEL } \\
\text { FABRICIANO }\end{array}$} & ANTONIO DIAS & \multirow{11}{*}{ CORONEL FABRICIANO } \\
\hline & BELO ORIENTE & \\
\hline & BRAUNAS & \\
\hline & CORONEL FABRICIANO & \\
\hline & IPATINGA & \\
\hline & JAGUARAÇU & \\
\hline & JOANESIA & \\
\hline & MARLIERIA & \\
\hline & MESQUITA & \\
\hline & SANTANA DO PARAISO & \\
\hline & TIMOTEO & \\
\hline \multirow{18}{*}{$\begin{array}{c}\text { SRE } \\
\text { CONSELHEIRO } \\
\text { LAFAIETE }\end{array}$} & CARANAIBA & \multirow{18}{*}{ CONSELHEIRO LAFAIETE } \\
\hline & CASA GRANDE & \\
\hline & CATAS ALTAS DA NORUEGA & \\
\hline & CONGONHAS & \\
\hline & CONSELHEIRO LAFAIETE & \\
\hline & CRISTIANO OTONI & \\
\hline & DESTERRO DE ENTRE RIOS & \\
\hline & ENTRE RIOS DE MINAS & \\
\hline & ITAVERAVA & \\
\hline & JECEABA & \\
\hline & LAMIM & \\
\hline & OURO BRANCO & \\
\hline & PIRANGA & \\
\hline & QUELUZITO & \\
\hline & RIO ESPERA & \\
\hline & SANTANA DOS MONTES & \\
\hline & SAO BRAS DO SUACUI & \\
\hline & SENHORA DE OLIVEIRA & \\
\hline \multirow{7}{*}{ SRE CURVELO } & AUGUSTO DE LIMA & \multirow{7}{*}{ CURVELO } \\
\hline & BUENOPOLIS & \\
\hline & CORINTO & \\
\hline & CURVELO & \\
\hline & FELIXLANDIA & \\
\hline & INIMUTABA & \\
\hline & JOAQUIM FELICIO & \\
\hline
\end{tabular}




\begin{tabular}{|c|c|c|}
\hline & LASSANCE & \\
\hline & MORRO DA GARCA & \\
\hline & PRESIDENTE JUSCELINO & \\
\hline & SANTO HIPOLITO & \\
\hline & TRES MARIAS & \\
\hline \multirow{25}{*}{$\begin{array}{c}\text { SRE } \\
\text { DIAMANTINA }\end{array}$} & ALVORADA DE MINAS & \multirow{25}{*}{ DIAMANTINA } \\
\hline & ANGELANDIA & \\
\hline & ARICANDUVA & \\
\hline & CAPELINHA & \\
\hline & CARBONITA & \\
\hline & CONCEICAO DO MATO DENTRO & \\
\hline & CONGONHAS DO NORTE & \\
\hline & COUTO DE MAGALHAES DE MINAS & \\
\hline & DATAS & \\
\hline & DIAMANTINA & \\
\hline & FELICIO DOS SANTOS & \\
\hline & GOUVEA & \\
\hline & ITAMARANDIBA & \\
\hline & LEME DO PRADO & \\
\hline & MINAS NOVAS & \\
\hline & MONJOLOS & \\
\hline & PRESIDENTE KUBITSCHEK & \\
\hline & RIO VERMELHO & \\
\hline & SANTO ANTONIO DO ITAMBE & \\
\hline & SAO GONCALO DO RIO PRETO & \\
\hline & SENADOR MODESTINO GONCALVES & \\
\hline & SERRA AZUL DE MINAS & \\
\hline & SERRO & \\
\hline & TURMALINA & \\
\hline & VEREDINHA & \\
\hline \multirow{15}{*}{$\begin{array}{c}\text { SRE } \\
\text { DIVINÓPOLIS }\end{array}$} & ARAUJOS & \multirow{15}{*}{ DIVINÓPOLIS } \\
\hline & ARCOS & \\
\hline & BAMBUI & \\
\hline & CARMO DA MATA & \\
\hline & CARMO DO CAJURU & \\
\hline & CARMOPOLIS DE MINAS & \\
\hline & CLAUDIO & \\
\hline & CORREGO DANTA & \\
\hline & DIVINOPOLIS & \\
\hline & IGUATAMA & \\
\hline & ITAGUARA & \\
\hline & ITAPECERICA & \\
\hline & ITATIAIUCU & \\
\hline & ITAUNA & \\
\hline & JAPARAIBA & \\
\hline
\end{tabular}




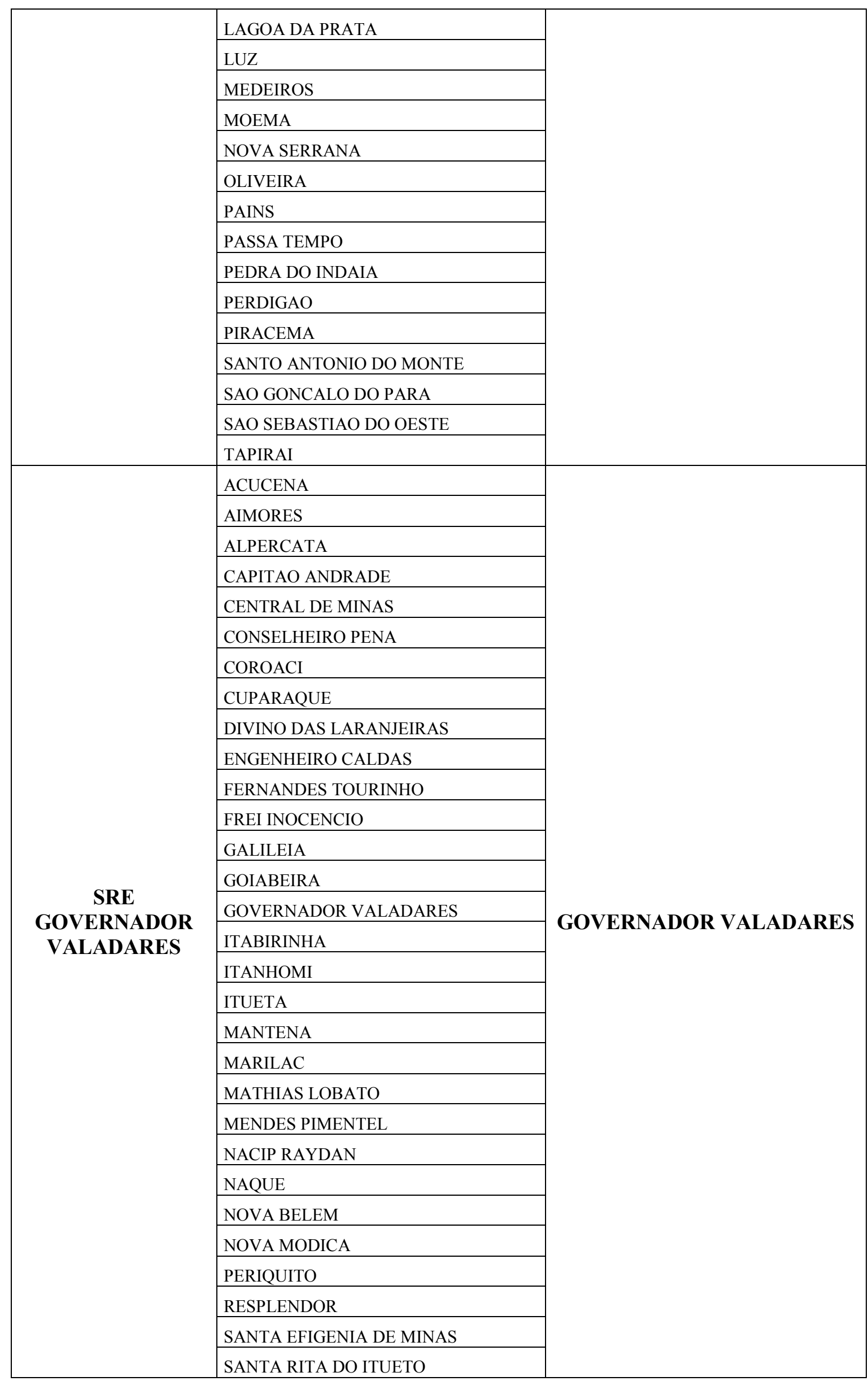




\begin{tabular}{|c|c|c|}
\hline & SAO FELIX DE MINAS & \\
\hline & SAO GERALDO DA PIEDADE & \\
\hline & SAO GERALDO DO BAIXIO & \\
\hline & SAO JOAO DO MANTENINHA & \\
\hline & SAO JOSE DA SAFIRA & \\
\hline & SAO JOSE DO DIVINO & \\
\hline & SARDOA & \\
\hline & SOBRALIA & \\
\hline & TUMIRITINGA & \\
\hline & VIRGOLANDIA & \\
\hline \multirow{22}{*}{ SRE GUANHÃES } & AGUA BOA & \multirow{22}{*}{ GUANHÃES } \\
\hline & CANTAGALO & \\
\hline & CARMESIA & \\
\hline & COLUNA & \\
\hline & DIVINOLANDIA DE MINAS & \\
\hline & DOM JOAQUIM & \\
\hline & DORES DE GUANHAES & \\
\hline & FREI LAGONEGRO & \\
\hline & GONZAGA & \\
\hline & GUANHAES & \\
\hline & JOSE RAYDAN & \\
\hline & MATERLANDIA & \\
\hline & PAULISTAS & \\
\hline & PECANHA & \\
\hline & SABINOPOLIS & \\
\hline & SANTA MARIA DO SUACUI & \\
\hline & SAO JOAO EVANGELISTA & \\
\hline & SAO JOSE DO JACURI & \\
\hline & SAO PEDRO DO SUACUI & \\
\hline & SAO SEBASTIAO DO MARANHAO & \\
\hline & SENHORA DO PORTO & \\
\hline & VIRGINOPOLIS & \\
\hline \multirow{13}{*}{ SRE ITAJUBÁ } & BRASOPOLIS & \multirow{13}{*}{ ITAJUBÁ } \\
\hline & CARMO DE MINAS & \\
\hline & CONCEICAO DAS PEDRAS & \\
\hline & CONCEICAO DOS OUROS & \\
\hline & CONSOLACAO & \\
\hline & CRISTINA & \\
\hline & DELFIM MOREIRA & \\
\hline & DOM VICOSO & \\
\hline & GONCALVES & \\
\hline & ITAJUBA & \\
\hline & MARIA DA FE & \\
\hline & MARMELOPOLIS & \\
\hline & NATERCIA & \\
\hline
\end{tabular}




\begin{tabular}{|c|c|c|}
\hline & PARAISOPOLIS & \\
\hline & PEDRALVA & \\
\hline & PIRANGUCU & \\
\hline & PIRANGUINHO & \\
\hline & SAO JOSE DO ALEGRE & \\
\hline & SAPUCAI-MIRIM & \\
\hline & VIRGINIA & \\
\hline & WENCESLAU BRAZ & \\
\hline \multirow{8}{*}{ SRE ITUIUTABA } & CACHOEIRA DOURADA & \multirow{8}{*}{ ITUIUTABA } \\
\hline & CANAPOLIS & \\
\hline & CAPINOPOLIS & \\
\hline & CENTRALINA & \\
\hline & GURINHATA & \\
\hline & IPIACU & \\
\hline & ITUIUTABA & \\
\hline & SANTA VITORIA & \\
\hline \multirow{17}{*}{ SRE JANAÚBA } & CATUTI & \multirow{17}{*}{ JANAUBA } \\
\hline & ESPINOSA & \\
\hline & GAMELEIRAS & \\
\hline & JAIBA & \\
\hline & JANAUBA & \\
\hline & MAMONAS & \\
\hline & MATO VERDE & \\
\hline & MONTE AZUL & \\
\hline & MONTEZUMA & \\
\hline & NOVA PORTEIRINHA & \\
\hline & PAI PEDRO & \\
\hline & PORTEIRINHA & \\
\hline & RIACHO DOS MACHADOS & \\
\hline & RIO PARDO DE MINAS & \\
\hline & SANTO ANTONIO DO RETIRO & \\
\hline & SERRANOPOLIS DE MINAS & \\
\hline & VERDELANDIA & \\
\hline \multirow{12}{*}{ SRE JANUÁRIA } & BONITO DE MINAS & \multirow{12}{*}{ JANUARIA } \\
\hline & CHAPADA GAUCHA & \\
\hline & CONEGO MARINHO & \\
\hline & IBIRACATU & \\
\hline & ICARAI DE MINAS & \\
\hline & ITACARAMBI & \\
\hline & JANUARIA & \\
\hline & JUVENILIA & \\
\hline & MANGA & \\
\hline & MATIAS CARDOSO & \\
\hline & MIRAVANIA & \\
\hline & MONTALVANIA & \\
\hline
\end{tabular}




\begin{tabular}{|c|c|c|}
\hline & PEDRAS DE MARIA DA CRUZ & \\
\hline & PINTOPOLIS & \\
\hline & SAO FRANCISCO & \\
\hline & SAO JOAO DAS MISSOES & \\
\hline & UBAI & \\
\hline & URUCUIA & \\
\hline & VARZELANDIA & \\
\hline \multirow{30}{*}{$\begin{array}{c}\text { SRE JUIZ DE } \\
\text { FORA }\end{array}$} & ARANTINA & \multirow{30}{*}{ JUIZ DE FORA } \\
\hline & BELMIRO BRAGA & \\
\hline & BICAS & \\
\hline & BOM JARDIM DE MINAS & \\
\hline & CHACARA & \\
\hline & CHIADOR & \\
\hline & CORONEL PACHECO & \\
\hline & DESCOBERTO & \\
\hline & EWBANK DA CAMARA & \\
\hline & GOIANA & \\
\hline & GUARARA & \\
\hline & JUIZ DE FORA & \\
\hline & LIMA DUARTE & \\
\hline & MAR DE ESPANHA & \\
\hline & MARIPA DE MINAS & \\
\hline & MATIAS BARBOSA & \\
\hline & OLARIA & \\
\hline & PEDRO TEIXEIRA & \\
\hline & PEQUERI & \\
\hline & PIAU & \\
\hline & RIO NOVO & \\
\hline & RIO PRETO & \\
\hline & ROCHEDO DE MINAS & \\
\hline & SANTA BARBARA DO MONTE VERDE & \\
\hline & SANTA RITA DE JACUTINGA & \\
\hline & SANTANA DO DESERTO & \\
\hline & SANTOS DUMONT & \\
\hline & SAO JOAO NEPOMUCENO & \\
\hline & SENADOR CORTES & \\
\hline & SIMAO PEREIRA & \\
\hline \multirow{8}{*}{$\begin{array}{c}\text { SRE } \\
\text { LEOPOLDINA }\end{array}$} & ALEM PARAIBA & \multirow{8}{*}{ LEOPOLDINA } \\
\hline & ARGIRITA & \\
\hline & CATAGUASES & \\
\hline & ESTRELA DALVA & \\
\hline & ITAMARATI DE MINAS & \\
\hline & LEOPOLDINA & \\
\hline & PIRAPETINGA & \\
\hline & RECREIO & \\
\hline
\end{tabular}




\begin{tabular}{|c|c|c|}
\hline & SANTO ANTONIO DO AVENTUREIRO & \\
\hline & VOLTA GRANDE & \\
\hline \multirow{18}{*}{ SRE MANHUAÇU } & ALTO JEQUITIBA & \multirow{18}{*}{ MANHUAÇU } \\
\hline & CAPUTIRA & \\
\hline & CHALE & \\
\hline & CONCEICAO DE IPANEMA & \\
\hline & DURANDE & \\
\hline & LAJINHA & \\
\hline & LUISBURGO & \\
\hline & MANHUACU & \\
\hline & MANHUMIRIM & \\
\hline & MARTINS SOARES & \\
\hline & MATIPO & \\
\hline & MUTUM & \\
\hline & REDUTO & \\
\hline & SANTA MARGARIDA & \\
\hline & SANTANA DO MANHUACU & \\
\hline & SAO JOAO DO MANHUACU & \\
\hline & SAO JOSE DO MANTIMENTO & \\
\hline & SIMONESIA & \\
\hline \multirow{18}{*}{$\begin{array}{c}\text { SRE } \\
\text { METROPOLITAN } \\
\text { A A }\end{array}$} & BELO HORIZONTE & \multirow{18}{*}{ BELO HORIZONTE } \\
\hline & BARAO DE COCAIS & \\
\hline & BELO VALE & \\
\hline & BOM JESUS DO AMPARO & \\
\hline & BONFIM & \\
\hline & BRUMADINHO & \\
\hline & CAETE & \\
\hline & CATAS ALTAS & \\
\hline & CRUCILANDIA & \\
\hline & MOEDA & \\
\hline & NOVA LIMA & \\
\hline & NOVA UNIAO & \\
\hline & PIEDADE DOS GERAIS & \\
\hline & RAPOSOS & \\
\hline & RIO ACIMA & \\
\hline & RIO MANSO & \\
\hline & SABARA & \\
\hline & SANTA BARBARA & \\
\hline \multirow{7}{*}{$\begin{array}{c}\text { SRE } \\
\text { METROPOLITAN } \\
\text { A B }\end{array}$} & BELO HORIZONTE & \multirow{7}{*}{ BELO HORIZONTE } \\
\hline & BETIM & \\
\hline & CONTAGEM & \\
\hline & ESMERALDAS & \\
\hline & IBIRITE & \\
\hline & IGARAPE & \\
\hline & JUATUBA & \\
\hline
\end{tabular}




\begin{tabular}{|c|c|c|}
\hline & MARIO CAMPOS & \\
\hline & MATEUS LEME & \\
\hline & SAO JOAQUIM DE BICAS & \\
\hline & SARZEDO & \\
\hline \multirow{12}{*}{$\begin{array}{c}\text { SRE } \\
\text { METROPOLITAN } \\
\text { A C }\end{array}$} & BELO HORIZONTE & \multirow{12}{*}{ BELO HORIZONTE } \\
\hline & CONFINS & \\
\hline & JABOTICATUBAS & \\
\hline & LAGOA SANTA & \\
\hline & MORRO DO PILAR & \\
\hline & PEDRO LEOPOLDO & \\
\hline & RIBEIRAO DAS NEVES & \\
\hline & SANTA LUZIA & \\
\hline & SANTANA DO RIACHO & \\
\hline & SAO JOSE DA LAPA & \\
\hline & TAQUARACU DE MINAS & \\
\hline & VESPASIANO & \\
\hline \multirow{8}{*}{$\begin{array}{l}\text { SRE MONTE } \\
\text { CARMELO }\end{array}$} & ABADIA DOS DOURADOS & \multirow{8}{*}{ MONTE CARMELO } \\
\hline & CASCALHO RICO & \\
\hline & COROMANDEL & \\
\hline & DOURADOQUARA & \\
\hline & ESTRELA DO SUL & \\
\hline & GRUPIARA & \\
\hline & MONTE CARMELO & \\
\hline & ROMARIA & \\
\hline \multirow{21}{*}{$\begin{array}{l}\text { SRE MONTES } \\
\text { CLAROS }\end{array}$} & BOCAIUVA & \multirow{21}{*}{ MONTES CLAROS } \\
\hline & BOTUMIRIM & \\
\hline & BRASILIA DE MINAS & \\
\hline & CAMPO AZUL & \\
\hline & CAPITAO ENEAS & \\
\hline & CLARO DOS POCOES & \\
\hline & CORACAO DE JESUS & \\
\hline & CRISTALIA & \\
\hline & ENGENHEIRO NAVARRO & \\
\hline & FRANCISCO DUMONT & \\
\hline & FRANCISCO AS & \\
\hline & GLAUCILANDIA & \\
\hline & GRAO MOGOL & \\
\hline & GUARACIAMA & \\
\hline & ITACAMBIRA & \\
\hline & JAPONVAR & \\
\hline & JOSENOPOLIS & \\
\hline & JURAMENTO & \\
\hline & LONTRA & \\
\hline & LUISLANDIA & \\
\hline & MIRABELA & \\
\hline
\end{tabular}




\begin{tabular}{|c|c|c|}
\hline & MONTES CLAROS & \\
\hline & OLHOS-D AGUA & \\
\hline & PADRE CARVALHO & \\
\hline & PATIS & \\
\hline & SAO JOAO DA LAGOA & \\
\hline & SAO JOAO DA PONTE & \\
\hline & SAO JOAO DO PACUI & \\
\hline & SAO JOAO DO PARAISO & \\
\hline & VARGEM GRANDE DO RIO PARDO & \\
\hline \multirow{14}{*}{ SRE MURIAÉ } & ANTONIO PRADO DE MINAS & \multirow{14}{*}{ MURIAÉ } \\
\hline & BARAO DE MONTE ALTO & \\
\hline & EUGENOPOLIS & \\
\hline & LARANJAL & \\
\hline & MIRADOURO & \\
\hline & MIRAI & \\
\hline & MURIAE & \\
\hline & PALMA & \\
\hline & PATROCINIO DO MURIAE & \\
\hline & ROSARIO DA LIMEIRA & \\
\hline & SANTANA DE CATAGUASES & \\
\hline & SAO FRANCISCO DO GLORIA & \\
\hline & $\begin{array}{l}\text { SAO SEBASTIAO DA VARGEM } \\
\text { ALEGRE }\end{array}$ & \\
\hline & VIEIRAS & \\
\hline \multirow{15}{*}{ SRE NOVA ERA } & BELA VISTA DE MINAS & \multirow{15}{*}{ NOVA ERA } \\
\hline & DIONISIO & \\
\hline & FERROS & \\
\hline & ITABIRA & \\
\hline & ITAMBE DO MATO DENTRO & \\
\hline & JOAO MONLEVADE & \\
\hline & NOVA ERA & \\
\hline & PASSABEM & \\
\hline & RIO PIRACICABA & \\
\hline & SANTA MARIA DE ITABIRA & \\
\hline & SANTO ANTONIO DO RIO ABAIXO & \\
\hline & SAO DOMINGOS DO PRATA & \\
\hline & SAO GONCALO DO RIO ABAIXO & \\
\hline & SAO JOSE DO GOIABAL & \\
\hline & SAO SEBASTIAO DO RIO PRETO & \\
\hline \multirow{5}{*}{$\begin{array}{l}\text { SRE OURO } \\
\text { PRETO }\end{array}$} & ACAIACA & \multirow{5}{*}{ OURO PRETO } \\
\hline & DIOGO DE VASCONCELOS & \\
\hline & ITABIRITO & \\
\hline & MARIANA & \\
\hline & OURO PRETO & \\
\hline SRE PARÁ DE & ABAETE & PARA DE MINAS \\
\hline
\end{tabular}




\begin{tabular}{|c|c|c|}
\hline & BIQUINHAS & \\
\hline & BOM DESPACHO & \\
\hline & CEDRO DO ABAETE & \\
\hline & CONCEICAO DO PARA & \\
\hline & DORES DO INDAIA & \\
\hline & ESTRELA DO INDAIA & \\
\hline & FLORESTAL & \\
\hline & IGARATINGA & \\
\hline & LEANDRO FERREIRA & \\
\hline & MARTINHO CAMPOS & \\
\hline & MORADA NOVA DE MINAS & \\
\hline & ONCA DE PITANGUI & \\
\hline & PAINEIRAS & \\
\hline & PARA DE MINAS & \\
\hline & PEQUI & \\
\hline & PITANGUI & \\
\hline & QUARTEL GERAL & \\
\hline & SAO JOSE DA VARGINHA & \\
\hline & SERRA DA SAUDADE & \\
\hline \multirow{5}{*}{ SRE PARACATU } & BRASILANDIA DE MINAS & \multirow{5}{*}{ PARACATU } \\
\hline & GUARDA-MOR & \\
\hline & JOAO PINHEIRO & \\
\hline & PARACATU & \\
\hline & VAZANTE & \\
\hline \multirow{16}{*}{ SRE PASSOS } & ALPINOPOLIS & \multirow{16}{*}{ PASSOS } \\
\hline & BOM JESUS DA PENHA & \\
\hline & CAPITOLIO & \\
\hline & CARMO DO RIO CLARO & \\
\hline & CORREGO FUNDO & \\
\hline & DELFINOPOLIS & \\
\hline & DORESOPOLIS & \\
\hline & FORMIGA & \\
\hline & FORTALEZA DE MINAS & \\
\hline & PASSOS & \\
\hline & PIMENTA & \\
\hline & PIUMHI & \\
\hline & SAO JOAO BATISTA DO GLORIA & \\
\hline & SAO JOSE DA BARRA & \\
\hline & SAO ROQUE DE MINAS & \\
\hline & VARGEM BONITA & \\
\hline \multirow{5}{*}{$\begin{array}{c}\text { SRE PATOS DE } \\
\text { MINAS }\end{array}$} & ARAPUA & \multirow{5}{*}{ PATOS DE MINAS } \\
\hline & CARMO DO PARANAIBA & \\
\hline & LAGAMAR & \\
\hline & LAGOA FORMOSA & \\
\hline & LAGOA GRANDE & \\
\hline
\end{tabular}




\begin{tabular}{|c|c|c|}
\hline & MATUTINA & \\
\hline & PATOS DE MINAS & \\
\hline & PRESIDENTE OLEGARIO & \\
\hline & RIO PARANAIBA & \\
\hline & SANTA ROSA DA SERRA & \\
\hline & SAO GONCALO DO ABAETE & \\
\hline & SAO GOTARDO & \\
\hline & TIROS & \\
\hline & VARJAO DE MINAS & \\
\hline \multirow{7}{*}{ SRE PATROCÍNIO } & CRUZEIRO DA FORTALEZA & \multirow{7}{*}{ PATROCÍNIO } \\
\hline & GUIMARANIA & \\
\hline & IBIA & \\
\hline & IRAI DE MINAS & \\
\hline & PATROCINIO & \\
\hline & PERDIZES & \\
\hline & SERRA DO SALITRE & \\
\hline \multirow{9}{*}{ SRE PIRAPORA } & BURITIZEIRO & \multirow{9}{*}{ PIRAPORA } \\
\hline & IBIAI & \\
\hline & JEQUITAI & \\
\hline & LAGOA DOS PATOS & \\
\hline & PIRAPORA & \\
\hline & PONTO CHIQUE & \\
\hline & SANTA FE DE MINAS & \\
\hline & SAO ROMAO & \\
\hline & VARZEA DA PALMA & \\
\hline \multirow{17}{*}{$\begin{array}{l}\text { SRE POÇOS DE } \\
\text { CALDAS }\end{array}$} & ALTEROSA & \multirow{17}{*}{ POÇOS DE CALDAS } \\
\hline & ANDRADAS & \\
\hline & AREADO & \\
\hline & BANDEIRA DO SUL & \\
\hline & BOTELHOS & \\
\hline & CABO VERDE & \\
\hline & CALDAS & \\
\hline & CAMPESTRE & \\
\hline & CONCEICAO DA APARECIDA & \\
\hline & DIVISA NOVA & \\
\hline & IBITIURA DE MINAS & \\
\hline & MONTE BELO & \\
\hline & MUZAMBINHO & \\
\hline & NOVA RESENDE & \\
\hline & POCOS DE CALDAS & \\
\hline & SANTA RITA DE CALDAS & \\
\hline & SERRANIA & \\
\hline \multirow{3}{*}{ SRE PONTE NOVA } & ABRE CAMPO & \multirow{3}{*}{ PONTE NOVA } \\
\hline & ALVINOPOLIS & \\
\hline & AMPARO DO SERRA & \\
\hline
\end{tabular}




\begin{tabular}{|c|c|c|}
\hline & ARAPONGA & \\
\hline & BARRA LONGA & \\
\hline & CAJURI & \\
\hline & CANAA & \\
\hline & DOM SILVERIO & \\
\hline & GUARACIABA & \\
\hline & JEQUERI & \\
\hline & ORATORIOS & \\
\hline & PEDRA BONITA & \\
\hline & PEDRA DO ANTA & \\
\hline & PIEDADE DE PONTE NOVA & \\
\hline & PONTE NOVA & \\
\hline & PORTO FIRME & \\
\hline & RAUL SOARES & \\
\hline & RIO CASCA & \\
\hline & RIO DOCE & \\
\hline & SANTA CRUZ DO ESCALVADO & \\
\hline & SANTO ANTONIO DO GRAMA & \\
\hline & SAO MIGUEL DO ANTA & \\
\hline & SAO PEDRO DOS FERROS & \\
\hline & SEM-PEIXE & \\
\hline & SERICITA & \\
\hline & TEIXEIRAS & \\
\hline & URUCANIA & \\
\hline & VERMELHO NOVO & \\
\hline & VICOSA & \\
\hline \multirow{19}{*}{$\begin{array}{l}\text { SRE POUSO } \\
\text { ALEGRE }\end{array}$} & ALBERTINA & \multirow{19}{*}{ POUSO ALEGRE } \\
\hline & BOM REPOUSO & \\
\hline & BORDA DA MATA & \\
\hline & BUENO BRANDAO & \\
\hline & CACHOEIRA DE MINAS & \\
\hline & CAMANDUCAIA & \\
\hline & CAMBUI & \\
\hline & CAREACU & \\
\hline & CONGONHAL & \\
\hline & CORREGO DO BOM JESUS & \\
\hline & ESPIRITO SANTO DO DOURADO & \\
\hline & ESTIVA & \\
\hline & EXTREMA & \\
\hline & HELIODORA & \\
\hline & INCONFIDENTES & \\
\hline & IPUIUNA & \\
\hline & ITAPEVA & \\
\hline & JACUTINGA & \\
\hline & MONTE SIAO & \\
\hline
\end{tabular}




\begin{tabular}{|c|c|c|}
\hline & MUNHOZ & \\
\hline & OURO FINO & \\
\hline & POUSO ALEGRE & \\
\hline & SANTA RITA DO SAPUCAI & \\
\hline & SAO JOAO DA MATA & \\
\hline & SAO SEBASTIAO DA BELA VISTA & \\
\hline & SENADOR AMARAL & \\
\hline & SENADOR JOSE BENTO & \\
\hline & SILVIANOPOLIS & \\
\hline & TOCOS DO MOJI & \\
\hline & TOLEDO & \\
\hline \multirow{19}{*}{$\begin{array}{l}\text { SRE SÃO JOÃO } \\
\text { DEL REI }\end{array}$} & BOM SUCESSO & \multirow{19}{*}{ SÃO JOÃO DEL REI } \\
\hline & CARRANCAS & \\
\hline & CONCEICAO DA BARRA DE MINAS & \\
\hline & CORONEL XAVIER CHAVES & \\
\hline & DORES DE CAMPOS & \\
\hline & IBITURUNA & \\
\hline & IJACI & \\
\hline & INGAI & \\
\hline & ITUMIRIM & \\
\hline & ITUTINGA & \\
\hline & LAGOA DOURADA & \\
\hline & NAZARENO & \\
\hline & PRADOS & \\
\hline & RESENDE COSTA & \\
\hline & RITAPOLIS & \\
\hline & SANTA CRUZ DE MINAS & \\
\hline & SAO JOAO DEL REI & \\
\hline & SAO TIAGO & \\
\hline & TIRADENTES & \\
\hline \multirow{15}{*}{$\begin{array}{c}\text { SRE SÃO } \\
\text { SEBASTIÃO DO } \\
\text { PARAÍSO }\end{array}$} & ARCEBURGO & \multirow{15}{*}{$\begin{array}{c}\text { SÃO SEBASTIÃO DO } \\
\text { PARAÍSO }\end{array}$} \\
\hline & CAPETINGA & \\
\hline & CASSIA & \\
\hline & CLARAVAL & \\
\hline & GUARANESIA & \\
\hline & GUAXUPE & \\
\hline & IBIRACI & \\
\hline & ITAMOGI & \\
\hline & ITAU DE MINAS & \\
\hline & JACUI & \\
\hline & JURUAIA & \\
\hline & MONTE SANTO DE MINAS & \\
\hline & PRATAPOLIS & \\
\hline & SAO PEDRO DA UNIAO & \\
\hline & SAO SEBASTIAO DO PARAISO & \\
\hline
\end{tabular}




\begin{tabular}{|c|c|c|}
\hline & SAO TOMAS DE AQUINO & \\
\hline \multirow{18}{*}{$\begin{array}{l}\text { SRE SETE } \\
\text { LAGOAS }\end{array}$} & ARACAI & \multirow{18}{*}{ SETE LAGOAS } \\
\hline & BALDIM & \\
\hline & CACHOEIRA DA PRATA & \\
\hline & CAETANOPOLIS & \\
\hline & CAPIM BRANCO & \\
\hline & CORDISBURGO & \\
\hline & FORTUNA DE MINAS & \\
\hline & FUNILANDIA & \\
\hline & INHAUMA & \\
\hline & JEQUITIBA & \\
\hline & MARAVILHAS & \\
\hline & MATOZINHOS & \\
\hline & PAPAGAIOS & \\
\hline & PARAOPEBA & \\
\hline & POMPEU & \\
\hline & PRUDENTE DE MORAIS & \\
\hline & SANTANA DE PIRAPAMA & \\
\hline & SETE LAGOAS & \\
\hline \multirow{26}{*}{$\begin{array}{c}\text { SRE TEÓFILO } \\
\text { OTONI }\end{array}$} & AGUAS FORMOSAS & \multirow{26}{*}{ TEOFILO OTONI } \\
\hline & ATALEIA & \\
\hline & BERTOPOLIS & \\
\hline & CAMPANARIO & \\
\hline & CARAI & \\
\hline & CARLOS CHAGAS & \\
\hline & CATUJI & \\
\hline & CRISOLITA & \\
\hline & FRANCISCOPOLIS & \\
\hline & FREI GASPAR & \\
\hline & FRONTEIRA DOS VALES & \\
\hline & ITAIPE & \\
\hline & ITAMBACURI & \\
\hline & JAMPRUCA & \\
\hline & LADAINHA & \\
\hline & MACHACALIS & \\
\hline & MALACACHETA & \\
\hline & NANUQUE & \\
\hline & NOVO CRUZEIRO & \\
\hline & NOVO ORIENTE DE MINAS & \\
\hline & OURO VERDE DE MINAS & \\
\hline & PADRE PARAISO & \\
\hline & PAVAO & \\
\hline & PESCADOR & \\
\hline & PONTO DOS VOLANTES & \\
\hline & POTE & \\
\hline
\end{tabular}




\begin{tabular}{|c|c|c|}
\hline & SANTA HELENA DE MINAS & \\
\hline & SERRA DOS AIMORES & \\
\hline & SETUBINHA & \\
\hline & TEOFILO OTONI & \\
\hline & UMBURATIBA & \\
\hline \multirow{22}{*}{ SRE UBÁ } & ASTOLFO DUTRA & \multirow{22}{*}{ UBÁ } \\
\hline & BRAS PIRES & \\
\hline & COIMBRA & \\
\hline & DIVINESIA & \\
\hline & DONA EUZEBIA & \\
\hline & DORES DO TURVO & \\
\hline & ERVALIA & \\
\hline & GUARANI & \\
\hline & GUIDOVAL & \\
\hline & GUIRICEMA & \\
\hline & PAULA CANDIDO & \\
\hline & PIRAUBA & \\
\hline & PRESIDENTE BERNARDES & \\
\hline & RIO POMBA & \\
\hline & RODEIRO & \\
\hline & SAO GERALDO & \\
\hline & SENADOR FIRMINO & \\
\hline & SILVEIRANIA & \\
\hline & TABULEIRO & \\
\hline & TOCANTINS & \\
\hline & UBA & \\
\hline & VISCONDE DO RIO BRANCO & \\
\hline \multirow{18}{*}{ SRE UBERABA } & AGUA COMPRIDA & \multirow{18}{*}{ UBERABA } \\
\hline & ARAXA & \\
\hline & CAMPO FLORIDO & \\
\hline & CAMPOS ALTOS & \\
\hline & CARNEIRINHO & \\
\hline & COMENDADOR GOMES & \\
\hline & CONCEICAO DAS ALAGOAS & \\
\hline & CONQUISTA & \\
\hline & DELTA & \\
\hline & FRONTEIRA & \\
\hline & FRUTAL & \\
\hline & ITAPAGIPE & \\
\hline & ITURAMA & \\
\hline & LIMEIRA DO OESTE & \\
\hline & PEDRINOPOLIS & \\
\hline & PIRAJUBA & \\
\hline & PLANURA & \\
\hline & PRATINHA & \\
\hline
\end{tabular}




\begin{tabular}{|c|c|c|}
\hline & SACRAMENTO & \\
\hline & SANTA JULIANA & \\
\hline & SAO FRANCISCO DE SALES & \\
\hline & TAPIRA & \\
\hline & UBERABA & \\
\hline & UNIAO DE MINAS & \\
\hline & VERISSIMO & \\
\hline \multirow{9}{*}{$\begin{array}{c}\text { SRE } \\
\text { UBERLÂNDIA }\end{array}$} & ARAGUARI & \multirow{9}{*}{ UBERLANDIA } \\
\hline & ARAPORA & \\
\hline & CAMPINA VERDE & \\
\hline & INDIANOPOLIS & \\
\hline & MONTE ALEGRE DE MINAS & \\
\hline & NOVA PONTE & \\
\hline & PRATA & \\
\hline & TUPACIGUARA & \\
\hline & UBERLANDIA & \\
\hline \multirow{10}{*}{ SRE UNAI } & ARINOS & \multirow{10}{*}{ UNAI } \\
\hline & BONFINÓPOLIS DE MINAS & \\
\hline & BURITIS & \\
\hline & CABECEIRA GRANDE & \\
\hline & DOM BOSCO & \\
\hline & FORMOSO & \\
\hline & NATHALANDIA & \\
\hline & RIACHINHO & \\
\hline & UNAI & \\
\hline & URUANA DE MINAS & \\
\hline \multirow{19}{*}{ SRE VARGINHA } & ALFENAS & \multirow{19}{*}{ VARGINHA } \\
\hline & BOA ESPERANCA & \\
\hline & CAMBUQUIRA & \\
\hline & CAMPANHA & \\
\hline & CAMPO DO MEIO & \\
\hline & CAMPOS GERAIS & \\
\hline & CARMO DA CACHOEIRA & \\
\hline & CARVALHOPOLIS & \\
\hline & COQUEIRAL & \\
\hline & CORDISLANDIA & \\
\hline & ELOI MENDES & \\
\hline & FAMA & \\
\hline & GUAPE & \\
\hline & ILICINEA & \\
\hline & LAMBARI & \\
\hline & LUMINARIAS & \\
\hline & MACHADO & \\
\hline & MONSENHOR PAULO & \\
\hline & NEPOMUCENO & \\
\hline
\end{tabular}




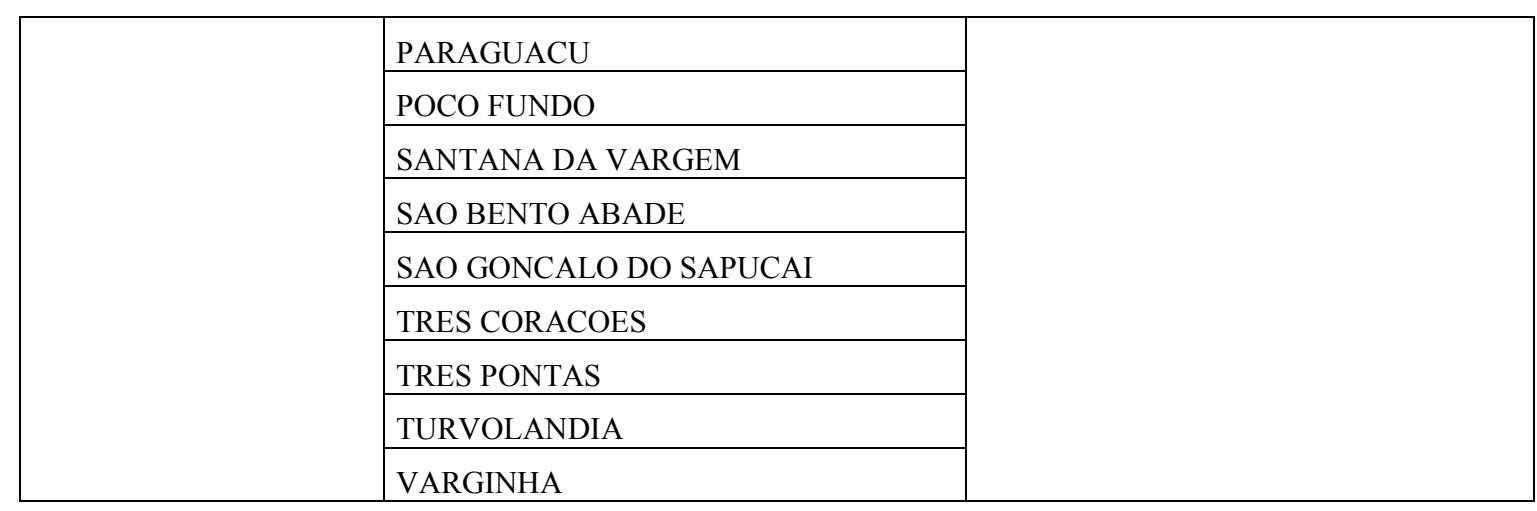


ANEXO V

REFERÊNCIAS DE ESTUDO

\begin{tabular}{|c|c|c|c|}
\hline \multicolumn{4}{|c|}{ NIVEL MÉDIO } \\
\hline CARGO & \multicolumn{3}{|c|}{ CONTEÚDO DA PROVA } \\
\hline & \multicolumn{2}{|c|}{ CONHECIMENTOS GERAIS } & \multirow{2}{*}{$\begin{array}{l}\text { CONHECIMENTOS } \\
\text { ESPECÍFICOS }\end{array}$} \\
\hline & PORTUGUÊS & MATEMÁTICA & \\
\hline $\begin{array}{c}\text { Assistente } \\
\text { Técnico } \\
\text { Educacional - } \\
\text { ATE } \\
\text { e } \\
\text { Assistente } \\
\text { Técnico de } \\
\text { Educação } \\
\text { Básica - ATB }\end{array}$ & $\begin{array}{l}\text { I - Procedimentos de Leitura } \\
\text { Localizar uma informação apresentada pelo texto e identificar seu sentido } \\
\text { global. } \\
\text { Saber o sentido de uma palavra ou expressão, por meio da construção de } \\
\text { inferências, além perceber a intenção de um autor e distinguir entre um fato e } \\
\text { uma opinião. } \\
\text { II - Compreensão do texto: implicações do suporte, do gênero e/ou do } \\
\text { enunciador. } \\
\text { Interpretar textos que associam linguagem verbal e não verbal ou } \\
\text { simplesmente textos não verbais. } \\
\text { Reconhecer diversos gêneros textuais. } \\
\text { III - Relação entre textos } \\
\text { Reconhecer posições distintas entre duas ou mais opiniões relativas ao } \\
\text { mesmo fato ou ao mesmo tema. } \\
\text { Reconhecer diferentes formas de abordar uma informação ao comparar textos } \\
\text { que tratam do mesmo tema. } \\
\text { IV - Coerência e coesão no processamento do texto } \\
\text { Reconhecer relações lógico-discursivas presentes no texto, marcadas por } \\
\text { conjunções, adverbios etc. } \\
\text { Estabelecer relações entre elementos e partes do texto considerando: } \\
\text { causa/conseqüência, mecanismos de concordância verbal e nominal } \\
\text { repetições ou substituições que contribuem para sua continuidade. } \\
\text { Identificar a tese do texto e estabelecer suas relações com os argumentos de } \\
\text { sustentação. } \\
\text { Diferenciar as partes principais e secundárias em um texto. } \\
\text { V - Relações entre recursos expressivos e efeitos de sentido } \\
\text { Identificar efeitos e ironia ou humor nos textos. } \\
\text { Reconhecer efeito de sentido decorrente da escolha de palavras ou } \\
\text { expressões, do uso de pontuação e outras notações, de recursos ortográficos e } \\
\text { morfossintáticos. } \\
\text { VI - Variação linguística } \\
\text { Identificar marcas linguísticas que evidenciam o locutor e o interlocutor de } \\
\text { um texto. }\end{array}$ & $\begin{array}{l}\text { I - Espaço e Forma } \\
\text { Localizar objetos em representações do espaço. } \\
\text { Identificar figuras geométricas e suas propriedades. } \\
\text { Reconhecer transformações no plano. } \\
\text { Aplicar relações e propriedades. } \\
\text { II - Grandezas e Medidas } \\
\text { Utilizar sistemas de medidas. } \\
\text { Medir grandezas. } \\
\text { Estimar e comparar grandezas. } \\
\text { III - Números e Operações } \\
\text { Conhecer e utilizar números. } \\
\text { Realizar e aplicar operações. } \\
\text { IV - Tratamento da Informação } \\
\text { Ler, utilizar e interpretar informações apresentadas em tabelas e } \\
\text { gráficos. }\end{array}$ & $\begin{array}{l}\text { - Lei no 9394/96 (lei de } \\
\text { Diretrizes e Bases da Educação } \\
\text { - LDB - atualizada). } \\
\text { - Noções Gerais de Informática. } \\
\text { - Direitos da criança e do } \\
\text { adolescente. } \\
\text { - Ética na administração pública. } \\
\text { - Direitos da mulher. } \\
\text { - Estatuto do Idoso. } \\
\text {-Educação inclusiva } \\
\text { (afrodescendentes, pessoas } \\
\text { portadoras de deficiência, } \\
\text { indígenas). } \\
\text { - Analfabetismo e escolarização } \\
\text { - Ofício, ata, exposição de } \\
\text { motivos, minuta. } \\
\text {-Arquivo, fichário, cadastro. } \\
\text { - }\end{array}$ \\
\hline
\end{tabular}




\begin{tabular}{|c|c|c|}
\hline \multicolumn{3}{|c|}{ NIVEL SUPERIOR } \\
\hline CARGO & CONTEÚDO DA PROVA: CONHECII & IENTOS GERAIS \\
\hline & PORTUGUÊS & MATEMÁTICA \\
\hline $\begin{array}{c}\text { Analista Educacional - } \\
\text { ANE, } \\
\text { Analista } \\
\text { Educacional/Inspeção } \\
\text { Escolar - ANE/IE, } \\
\text { Especialista em } \\
\text { Educação Básica/ } \\
\text { Orientação Educacional } \\
\text { - EEB/OE, } \\
\text { Especialista em } \\
\text { Educação Básica/ } \\
\text { Supervisão Pedagógica } \\
\text { - EEB/SP } \\
\text { e } \\
\text { Professor de Educação } \\
\text { Básica - PEB }\end{array}$ & $\begin{array}{l}\text { I - Procedimentos de Leitura } \\
\text { Localizar uma informação apresentada pelo texto e identificar seu sentido global. } \\
\text { Saber o sentido de uma palavra ou expressão, por meio da construção de inferências, além } \\
\text { perceber a intenção de um autor e distinguir entre um fato e uma opinião. } \\
\text { II - Compreensão do texto: implicações do suporte, do gênero e/ou do enunciador. } \\
\text { Interpretar textos que associam linguagem verbal e não verbal ou simplesmente textos não } \\
\text { verbais. } \\
\text { Reconhecer diversos gêneros textuais, identificando a função desses textos na sociedade. } \\
\text { III - Relação entre textos } \\
\text { Reconhecer posições distintas entre duas ou mais opiniões relativas ao mesmo fato ou ao } \\
\text { mesmo tema. } \\
\text { Reconhecer diferentes formas de abordar uma informação ao comparar textos que tratam do } \\
\text { mesmo tema. } \\
\text { IV - Coerência e coesão no processamento do texto } \\
\text { Reconhecer relações lógico-discursivas presentes no texto, marcadas por conjunções, advérbios } \\
\text { etc. } \\
\text { Estabelecer relações entre elementos e partes do texto considerando: causa/consequência, } \\
\text { mecanismos de concordância verbal e nominal repetições ou substituições que contribuem para } \\
\text { sua continuidade. } \\
\text { Identificar a tese do texto e estabelecer suas relações com os argumentos de sustentação. } \\
\text { Diferenciar as partes principais e secundárias em um texto. } \\
\text { V - Relações entre recursos expressivos e efeitos de sentido. } \\
\text { Identificar efeitos e ironia ou humor nos textos. } \\
\text { Reconhecer efeito de sentido decorrente da escolha de palavras ou expressões, do uso de } \\
\text { pontuação e outras notações, de recursos ortográficos e morfossintáticos. } \\
\text { VI - Variação linguística } \\
\text { Identificar marcas linguísticas que evidenciam o locutor e o interlocutor de um texto. }\end{array}$ & $\begin{array}{l}\text { I - Espaço e Forma } \\
\text { Localizar objetos em representações do espaço. } \\
\text { Identificar figuras geométricas e suas propriedades. } \\
\text { Reconhecer transformações no plano. } \\
\text { Aplicar relações e propriedades. } \\
\text { II - Grandezas e Medidas. } \\
\text { Utilizar sistemas de medidas. } \\
\text { Medir grandezas. } \\
\text { Estimar e comparar grandezas. } \\
\text { III - Números, Operações e Álgebra } \\
\text { Conhecer e utilizar números. } \\
\text { Realizar e aplicar operações. } \\
\text { Utilizar procedimentos algébricos. } \\
\text { IV - Tratamento da Informação } \\
\text { Ler, utilizar e interpretar informações apresentadas em tabelas e } \\
\text { gráficos. } \\
\text { Utilizar procedimentos de combinatória e probabilidade. }\end{array}$ \\
\hline
\end{tabular}

\section{NIVEL SUPERIOR}




\begin{tabular}{|c|c|}
\hline CARGO & CONTEÚDO DA PROVA: CONHECIMENTOS ESPECÍFICOS \\
\hline Analista Educacional - ANE & $\begin{array}{l}\text { - Noções gerais de informática. } \\
\text { - Constituição Federal de } 1988 \text { - Título I, Título II, Título III, Título VIII - Capítulo III, Seção I. } \\
\text { - Lei no } 869 / 1952 \text { - Estatuto dos Funcionários Públicos Civis do Estado de Minas Gerais. } \\
\text { - Lei n } \text { n }^{\circ} \text { 15.293/2004 - Carreiras dos Profissionais de Educação Básica do Estado. } \\
\text { - Lei 18.975/2010 - Fixa o subsídio das carreiras do Grupo de Atividades de Educação Básica do Poder Executivo Estadual e do pessoal civil da Polícia } \\
\text { Militar do Estado de Minas Gerais. } \\
\text { - Estatuto da Criança e do Adolescente } \\
\text { - Direitos da mulher. } \\
\text { - Estatuto do Idoso. } \\
\text { - Educação inclusiva (afrodescendentes, pessoas portadoras de deficiência, indígenas). } \\
\text { - Analfabetismo e escolarização. }\end{array}$ \\
\hline $\begin{array}{l}\text { Analista Educacional/ Inspeção } \\
\quad \text { Escolar - ANE / IE }\end{array}$ & $\begin{array}{l}\text { - Padrões de Competências de Diretor de Escola*. } \\
\text { - Noções gerais de informática. } \\
\text { - Constituição Federal de } 1988 \text { - Título I, Título II, Título III, Título VIII - Capítulo III, Seção I. } \\
\text { - Lei no } 869 / 1952 \text { - Estatuto dos Funcionários Públicos Civis do Estado de Minas Gerais. } \\
\text { - Lei n } \text { n }^{\circ} \text { 15.293/2004 - Carreiras dos Profissionais de Educação Básica do Estado. } \\
\text { - Lei 18.975/2010 - Fixa o subsídio das carreiras do Grupo de Atividades de Educação Básica do Poder Executivo Estadual e do pessoal civil da Polícia } \\
\text { Militar do Estado de Minas Gerais. } \\
\text { - Estatuto da Criança e do Adolescente } \\
\text { Parecer CNE/CBE 07/2010 - Diretrizes Curriculares Nacionais Gerais para a Educação Básica. } \\
\text { - Direitos da mulher. } \\
\text { - Estatuto do Idoso. } \\
\text { - Educação inclusiva (afrodescendentes, pessoas portadoras de deficiência, indígenas). } \\
\text { - Analfabetismo e escolarização. }\end{array}$ \\
\hline $\begin{array}{l}\text { Especialista em Educação } \\
\text { Básica Orientação Educacional } \\
- \text { EEB/OE }\end{array}$ & $\begin{array}{l}\text { - Padrões Profissionais de Competência para o Professor dos Ciclos de Alfabetização e Complementar/Anos Iniciais do Ensino Fundamental do Sistema } \\
\text { Educacional de Minas Gerais*. } \\
\text { - Noções gerais de informática. }\end{array}$ \\
\hline $\begin{array}{l}\text { Especialista em } r \text { Educação } \\
\text { Básica Supervisão } \\
\text { - EEB/SP }\end{array}$ & $\begin{array}{l}\text { - Padrões Profissionais de Competência para o Professor dos Ciclos de Alfabetização e Complementar/Anos Iniciais do Ensino Fundamental do Sistema } \\
\text { Educacional de Minas Gerais*. } \\
\text { - Noções gerais de informática. }\end{array}$ \\
\hline $\begin{array}{l}\text { Professor em Educação Básica } \\
\text { - PEB - Anos Iniciais do } \\
\text { Ensino Fundamental }\end{array}$ & $\begin{array}{l}\text { - Proposta Curricular - CBC* (Conteúdo Básico Comum -- Fundamental - Ciclos/Ciclo da Alfabetização). } \\
\text { - Padrões Profissionais para o Professor dos Ciclos de Alfabetização e Complementar/Anos Iniciais do Ensino Fundamental do Sistema Educacional de } \\
\text { Minas Gerais*. }\end{array}$ \\
\hline $\begin{array}{l}\text { Professor em Educação Básica } \\
\text { - PEB - Arte/Artes }\end{array}$ & $\begin{array}{l}\text { Proposta Curricular - } \mathrm{CBC}^{*} \text { (Conteúdo Básico Comum) e Orientações Pedagógicas da SEE/MG para o ensino de Arte/Artes*. Conhecimento do } \\
\text { conteúdo relacionado à área de ensino. }\end{array}$ \\
\hline
\end{tabular}




\begin{tabular}{|c|c|}
\hline $\begin{array}{l}\text { Professor em Educação Básica } \\
\text { - PEB - Biologia }\end{array}$ & $\begin{array}{l}\text { Proposta Curricular - CBC* (Conteúdo Básico Comum) e Orientações Pedagógicas da SEE/MG para o ensino de Biologia*. Conhecimento } \\
\text { conteúdo relacionado à área de ensino. }\end{array}$ \\
\hline $\begin{array}{l}\text { Professor em Educação Básica } \\
\text { - PEB - Educação Física }\end{array}$ & $\begin{array}{l}\text { Proposta Curricular - CBC* (Conteúdo Básico Comum - Ensino Fundamental e Médio) e Orientações Pedagógicas da SEE/MG* para o ensino de } \\
\text { Educação Física (Ensino Fundamental e Médio). Conhecimento do conteúdo relacionado à área de ensino. }\end{array}$ \\
\hline $\begin{array}{l}\text { Professor em Educação Básica } \\
\text { - PEB - Filosofia }\end{array}$ & $\begin{array}{l}\text { Proposta Curricular - CBC* (Conteúdo Básico Comum) e Orientações Pedagógicas da SEE/MG para o ensino de Filosofia*. Conhecimento do conteúdo } \\
\text { relacionado à área de ensino. }\end{array}$ \\
\hline $\begin{array}{l}\text { Professor em Educação Básica } \\
\text { - PEB - Física }\end{array}$ & $\begin{array}{l}\text { Proposta Curricular - CBC* (Conteúdo Básico Comum) e Orientações Pedagógicas da SEE/MG para o ensino de Física*. Conhecimento do conteúdo } \\
\text { relacionado à área de ensino. }\end{array}$ \\
\hline $\begin{array}{l}\text { Professor em Educação Básica } \\
\text { - PEB - Geografia }\end{array}$ & $\begin{array}{l}\text { Proposta Curricular - CBC* (Conteúdo Básico Comum -- Ensino Fundamental e Médio) e Orientações Pedagógicas da SEE/MG para o ensino de } \\
\text { Geografia* (Ensino Fundamental e Médio). Conhecimento do conteúdo relacionado à área de ensino. }\end{array}$ \\
\hline $\begin{array}{l}\text { Professor em Educação Básica } \\
\text { - PEB - História }\end{array}$ & $\begin{array}{l}\text { Proposta Curricular - CBC* (Conteúdo Básico Comum -- Ensino Fundamental e Médio) e Orientações Pedagógicas da SEE/MG para o ensino de } \\
\text { História* (Ensino Fundamental e Médio). Conhecimento do conteúdo relacionado à área de ensino }\end{array}$ \\
\hline $\begin{array}{l}\text { Professor em Educação Básica } \\
\text { - PEB - Língua Estrangeira } \\
\text { Moderna: Espanhol }\end{array}$ & $\begin{array}{l}\text { Proposta Curricular-CBC* (Conteúdo Básico Comum -- Ensino Fundamental e Médio) e Orientações Pedagógicas da SEE/MG para o ensino de Língua } \\
\text { Estrangeira -- Espanhol* (Ensino Fundamental e Médio). Conhecimento do conteúdo relacionado à área de ensino. }\end{array}$ \\
\hline $\begin{array}{l}\text { Professor em Educação Básica } \\
\text { - PEB - Língua Estrangeira } \\
\text { Moderna: Inglês }\end{array}$ & $\begin{array}{l}\text { Proposta Curricular - } \mathrm{CBC}^{*} \text { (Conteúdo Básico Comum -- Ensino Fundamental e Médio) e Orientações Pedagógicas da SEE/MG para o ensino de Língua } \\
\text { Estrangeira -- Inglês* (Ensino Fundamental e Médio). Conhecimento do conteúdo relacionado à área de ensino. }\end{array}$ \\
\hline $\begin{array}{l}\text { Professor em Educação Básica } \\
\text { - PEB - Língua Portuguesa }\end{array}$ & $\begin{array}{l}\text { Proposta Curricular - CBC* (Conteúdo Básico Comum - Ensino Fundamental e Médio) e Orientações Pedagógicas da SEE/MG para o ensino de Língua } \\
\text { Portuguesa* (Ensino Fundamental e Médio). Conhecimento do conteúdo relacionado à área de ensino. }\end{array}$ \\
\hline $\begin{array}{l}\text { Professor em Educação Básica } \\
\text { - PEB - Matemática }\end{array}$ & $\begin{array}{l}\text { Proposta Curricular - CBC* (Conteúdo Básico Comum -- Ensino Fundamental e Médio) e Orientações Pedagógicas da SEE/MG para o ensino de } \\
\text { Matemática* (Ensino Fundamental e Médio). Conhecimento do conteúdo relacionado à área de ensino. }\end{array}$ \\
\hline $\begin{array}{l}\text { Professor em Educação Básica } \\
\text { - PEB - Química }\end{array}$ & $\begin{array}{l}\text { Proposta Curricular - CBC* (Conteúdo Básico Comum) e Orientações Pedagógicas da SEE/MG para o ensino de Química*. Conhecimento do conteúdo } \\
\text { relacionado à área de ensino. }\end{array}$ \\
\hline $\begin{array}{l}\text { Professor em Educação Básica } \\
\text { - PEB - Sociologia }\end{array}$ & $\begin{array}{l}\text { Proposta Curricular - } \mathrm{CBC}^{*} \text { (Conteúdo Básico Comum) e Orientações Pedagógicas da SEE/MG para o ensino de Sociologia*. Conhecimento do conteúdo } \\
\text { relacionado à área de ensino. }\end{array}$ \\
\hline
\end{tabular}

* O conteúdo destacado está disponível na Internet, na página do Centro de Referência Virtual do Professor: http://crv.educacao.mg.gov.br 


\section{ANEXO VI \\ TÍTULOS}

a) Os títulos de formação acadêmica receberão pontuação conforme especificações contidas na tabela a seguir:

CARREIRAS: Professor de Educação Básica - PEB I A, Analista Educacional - ANE I A, Analista Educacional / Inspeção Escolar - ANE/IE I A, Especialista em Educação Básica - EEB I A - Orientador Educacional e Supervisor Pedagógico

\begin{tabular}{|c|c|c|c|c|}
\hline DISCRIMINAÇÃO & $\begin{array}{l}\text { QUANTIDADE } \\
\text { MÁXIMA }\end{array}$ & $\begin{array}{c}\text { VALOR } \\
\text { UNITÁRIO }\end{array}$ & $\begin{array}{l}\text { VALOR } \\
\text { MÁXIMO }\end{array}$ & COMPROVANTE \\
\hline Especialização & 1,0 & 1,0 & 1,0 & $\begin{array}{l}\text { Certificado, em qualquer área do } \\
\text { conhecimento, acompanhado do } \\
\text { histórico escolar ou certidão/declaração } \\
\text { de conclusão de curso acompanhada do } \\
\text { histórico escolar, concluído em } \\
\text { Instituição de Ensino Superior que possua } \\
\text { programa de pós-graduação stricto sensu } \\
\text { (Mestrado e Doutorado) com avaliação da } \\
\text { CAPES superior a } 3 \text { (três) pontos. }\end{array}$ \\
\hline Mestrado & 1,0 & 2,0 & 2,0 & $\begin{array}{l}\text { Diploma de mestrado, em qualquer área } \\
\text { do conhecimento, acompanhado do } \\
\text { histórico escolar ou certidão/declaração } \\
\text { de conclusão do curso, acompanhada do } \\
\text { histórico escolar e ata da defesa da } \\
\text { dissertação, acompanhada de declaração } \\
\text { do coordenador do curso. } \\
\text { Para curso realizado no exterior, ver item } \\
9.21 \text { deste Edital. }\end{array}$ \\
\hline Doutorado & 1,0 & 3,0 & 3,0 & $\begin{array}{l}\text { Diploma de doutorado, em qualquer } \\
\text { área do conhecimento, acompanhado do } \\
\text { histórico escolar ou certidão/declaração } \\
\text { de conclusão do curso, acompanhada do } \\
\text { histórico escolar e ata da defesa da tese, } \\
\text { acompanhada de declaração do } \\
\text { coordenador do curso. } \\
\text { Para curso realizado no exterior, ver item } \\
9.21 \text { deste Edital. }\end{array}$ \\
\hline
\end{tabular}

CARREIRAS: Assistente Técnico Educacional - ATE I A e Assistente Técnico em Educação Básica - ATB I A.

\begin{tabular}{|l|c|c|c|c|}
\hline DISCRIMINAÇÃO & $\begin{array}{c}\text { QUANTIDADE } \\
\text { MÁXIMA }\end{array}$ & $\begin{array}{c}\text { VALOR } \\
\text { UNITÁRIO }\end{array}$ & $\begin{array}{c}\text { VALOR } \\
\text { MÁXIMO }\end{array}$ & COMPROVANTE \\
\hline Curso Superior & 1,0 & 1,0 & 1,0 & $\begin{array}{l}\text { Diploma de curso superior em } \\
\text { qualquer área de conhecimento. }\end{array}$ \\
\hline
\end{tabular}

b) Os títulos de tempo de serviço receberão pontuação conforme especificações contidas na tabela a seguir: 


\begin{tabular}{|c|c|c|c|c|}
\hline \multicolumn{1}{|c|}{ CARREIRA: Professor de Educação Básica - PEB I A } \\
\hline DISCRIMINAÇÃo & $\begin{array}{c}\text { VALOR } \\
\text { UNITÁRIO }\end{array}$ & $\begin{array}{c}\text { QUANTIDA } \\
\text { DE MÁXIMA }\end{array}$ & $\begin{array}{c}\text { VALOR } \\
\text { MÁXIM } \\
\text { O }\end{array}$ & COMPROVANTE \\
\hline $\begin{array}{l}\text { Tempo de efetivo exercício de } \\
\text { atividades correspondentes ao } \\
\text { cargo e área de atuação para a qual } \\
\text { se inscreveu em estabelecimentos } \\
\text { privados ou públicos (federais, } \\
\text { estaduais, municipais). }\end{array}$ & 0,025 (por mês) & 120 meses & 3,0 & $\begin{array}{c}\text { Atestado de tempo de } \\
\text { serviço expedido conforme } \\
\text { modelo contido no item b.1 } \\
\text { deste Anexo. }\end{array}$ \\
\hline
\end{tabular}

b.1) Modelo de Atestado para comprovação de tempo de serviço:

TIMBRE / CARIMBO DA ESCOLA OU ENTIDADE EDUCACIONAL

Ato de Reconhecimento / Autorização: DO

(no caso de escola particular)

\section{ATESTADO DE TEMPO DE SERVIÇO NA ÁREA DOCENTE}

Atesto, sob as penas da Lei, para fins de pontuação por tempo de serviço no Concurso Público para provimento efetivo do cargo de Professor de Educação Básica - PEB I - A do quadro de pessoal da Secretaria de Estado de Educação, que o (a) Sr. (a) [NOME DO COMPLETO DO CANDIDATO], R.G. $n^{\circ}$ [NÚMERO DA CARTEIRA DE IDENTIDADE], expedido por [ÓRGÃO EXPEDIDOR DA CARTEIRA DE IDENTIDADE], inscrito no CPF sob o n. ${ }^{\circ}$ [NÚMERO DO CPF DO CANDIDATO] nascido (a) em , exerceu nesta Escola/ Entidade Educacional o cargo/função/emprego de [DESCREVER O CARGO E ÁREA DE ATUAĊ̃̃O] no período de a $1-1$ contando com: meses de Tempo de Serviço.

Tempo de exercício efetivo em estabelecimento:

FEDERAL ESTADUAL MUNICIPAL PARTICULAR 


\section{(1) \\ ESTADO DO PARANÁ \\ Secretaria de Estado da Administração e da Previdência \\ Departamento de Recursos Humanos}

\section{EDITAL № 017/2013}

A DIRETORA DO DEPARTAMENTO DE RECURSOS HUMANOS DA SECRETARIA DE ESTADO DA ADMINISTRAÇÃO E DA PREVIDÊNCIA - SEAP, no uso de suas atribuições legais, bem como atendendo aos termos do Decreto Estadual ํㅜ 7.116, de 28/01/2013, e considerando a autorização governamental exarada nos Protocolos 11.187.793-9 e 11.187.792-0, torna público o presente Edital, que estabelece as instruções especiais para a realização do Concurso Público de Provas e Títulos para provimento no cargo de Professor, nas disciplinas da matriz curricular e pedagogo, do Quadro Próprio do Magistério - QPM, da Secretaria de Estado da Educação - SEED, especificadas no Anexo I do presente Edital.

\section{DAS DISPOSIÇÕES PRELIMINARES}

1.1. O Concurso Público será regido pelas regras estabelecidas no presente Edital e executado mediante Provas de Conhecimentos, Prova de Didática e Prova de Títulos pela Associação Paranaense de Cultura, mantenedora da Pontifícia Universidade Católica do Paraná, e destina-se a selecionar candidatos para provimento no Cargo de Professor, conforme detalhamento constante do item 2 deste Edital.

1.2. O Concurso Público consistirá da avaliação de conhecimentos mediante a aplicação de Prova de Conhecimentos, de caráter eliminatório e classificatório, de Prova Didática, de caráter eliminatório e classificatório, de Prova de Títulos, de caráter classificatório, e de Avaliação Médica, de caráter eliminatório, todo processo em conformidade com o estabelecido neste Edital.

1.3. A inscrição no Concurso Público implicará a aceitação tácita das normas estabelecidas neste Edital e em outros que forem publicados durante a realização do Concurso Público, cujas regras, normas e critérios os candidatos são obrigados a cumprir.

1.4. É de exclusiva responsabilidade do candidato inscrito acompanhar a publicação ou divulgação dos atos concernentes ao Concurso Público divulgados na internet, no endereço eletrônico www.pucpr.br/concursos link Concurso do Estado do Paraná, menu Edital e no Diário Oficial do Estado do Paraná - Suplemento de Concursos Públicos - www.dioe.pr.gov.br, obrigando-se a manter atualizado o endereço informado no ato da inscrição para fins de eventual contato com o candidato, conforme especificado no subitem 17.12 deste Edital.

1.5. As Provas de Conhecimentos serão realizadas em 14 (quatorze) municípios polos, conforme estabelecido no Anexo II deste Edital, no dia 19 de maio de 2013, na forma prevista neste Edital, em locais a serem divulgados por meio do Ensalamento.

1.6. O prazo de validade do Concurso será de 1 (um) ano contado a partir da data de publicação da Homologação do resultado final, por ato do Titular da Secretaria de Estado da Administração e da Previdência, no Diário Oficial do Estado do Paraná - Suplemento de Concursos Públicos - www.dioe.pr.gov.br, prorrogável por uma única vez, por igual período, a critério da Administração Pública Estadual.

1.7. Poderá ser atribuído atendimento especial para a realização da prova de conhecimentos ao candidato que o solicitar, durante o período de inscrições, desde que justificada a necessidade desse tratamento especial. A solicitação deverá ser efetuada no ato da inscrição, na forma e prazo determinados neste Edital, conforme orienta o subitem 5.15, e poderá ser atendida, de acordo com critérios de viabilidade e de razoabilidade, mediante apreciação da Coordenação do Concurso.

1.8. Este Edital será passível de impugnação, por escrito e no prazo de 5 (cinco) dias a contar da sua publicação, via protocolo junto ao Departamento de Recursos Humanos da Secretaria da Administração e da Previdência - SEAP, sito na rua Jacy Loureiro de Campos s/n Centro Cívico - 80530-140, Curitiba - Paraná.

1.8.1 Cabe ao interessado informar especificamente o(s) item(s) objeto de impugnação, bem como a respectiva motivação.

1.9. A publicação do resultado final do Concurso Público será feita em três listas, quando couber, pelo Núcleo Regional de Educação (NRE)/ disciplinas da matriz curricular e pedagogo, em ordem decrescente de pontos, sendo a primeira uma lista geral contendo a pontuação de todos os candidatos, inclusive a das pessoas com deficiência e dos afrodescendentes, a segunda uma lista com a pontuação das pessoas com deficiência, e a terceira uma lista com a pontuação dos candidatos afrodescendentes.

1.10. Para fins de pontuação em todas as provas previstas neste edital serão consideradas 2 (duas) casas decimais. 


\section{ESTADO DO PARANÁ}

Secretaria de Estado da Administração e da Previdência

Departamento de Recursos Humanos

\section{DO CARGO, FUNÇÃO, NATUREZA DO VÍNCULO FUNCIONAL, REGIME PREVIDENCIÁRIO, № DE VAGAS, ESCOLARIDADE MÍNIMA EXIGIDA, REQUISITOS, CARGA HORÁRIA, REMUNERAÇÃO, TAXA DE INSCRIÇÃO E DESCRIÇÃO DAS ATIVIDADES.}

2.1. Os requisitos/escolaridade previstos no quadro a seguir deverão ser preenchidos até a data da posse do candidato, devendo ser comprovados por meio de documentação oficial.

2.2. O requisito de escolaridade deverá estar devidamente legalizado junto aos órgãos educacionais competentes.

\begin{tabular}{|c|c|}
\hline \multicolumn{2}{|l|}{ Cargo: PROFESSOR } \\
\hline № de Vagas & Conforme estipulado no Anexo I deste Edital. \\
\hline Requisito/escolaridade & $\begin{array}{l}\text { MATRIZ CURRICULAR: Licenciatura Plena na disciplina de inscrição. } \\
\text { PEDAGOGO: Licenciatura em Pedagogia. }\end{array}$ \\
\hline Carga Horária & 20 horas semanais. \\
\hline Remuneração & $\begin{array}{l}\mathrm{R} \$ 1.044,94 \text { (um mil e quarenta e quatro reais e noventa e quatro centavos) e } \mathrm{R} \$ \\
304,00 \text { (trezentos e quatro reais) de Auxílio Transporte. }\end{array}$ \\
\hline Taxa de inscrição & $\begin{array}{l}\mathrm{R} \$ 60,00 \text { (sessenta reais) por inscrição, sendo permitido no máximo } 2 \text { (duas) } \\
\text { inscrições. }\end{array}$ \\
\hline Condições & $\begin{array}{l}\text { O candidato poderá optar fazer uma ou duas inscrições nas disciplinas da matriz } \\
\text { curricular; ou uma inscrição de pedagogo; ou uma inscrição de pedagogo e mais } \\
\text { uma inscrição nas disciplinas da matriz curricular, desde que para o mesmo NRE. }\end{array}$ \\
\hline Etapa & $\begin{array}{l}\text { Prova de Conhecimentos (objetiva e redação), Prova Didática, Prova de Títulos e } \\
\text { Avaliação Médica. }\end{array}$ \\
\hline
\end{tabular}

2.3. Descrição do cargo professor das disciplinas da matriz curricular: Docência na Educação Básica, incluindo, entre outras, as seguintes atribuições: participar na elaboração da proposta pedagógica da escola; elaborar e cumprir plano de trabalho segundo a proposta pedagógica da escola; zelar pela aprendizagem dos alunos; estabelecer e implementar estratégias de recuperação para os alunos de menor rendimento; ministrar os dias letivos e as horas-aula estabelecidas; participar integralmente dos períodos dedicados ao planejamento, à avaliação e ao desenvolvimento profissional; colaborar com as atividades de articulação com as famílias e a comunidade; desincumbir-se das demais tarefas indispensáveis ao atingimento dos fins educacionais da escola e do processo de ensino-aprendizagem.

2.3.1 Descrição do cargo professor - pedagogo: Atividades de Suporte Pedagógico direto à docência na Educação Básica, voltadas para planejamento, administração, supervisão e orientação educacional, incluindo, entre outras, as seguintes atribuições: coordenar a elaboração e execução da proposta pedagógica da escola; administrar o pessoal e os recursos materiais e financeiros da escola, tendo em vista o atingimento de seus objetivos pedagógicos; assegurar o cumprimento dos dias letivos e horas-aula estabelecidas; zelar pelo cumprimento do plano de trabalho dos docentes; prover meios para a recuperação dos alunos de menor rendimento; promover a articulação com as famílias e a comunidade, criando processos de integração da sociedade com a escola; informar os pais ou responsáveis sobre a frequência e o rendimento dos alunos, bem como sobre a execução da proposta pedagógica da escola; coordenar, no âmbito da escola, as atividades de planejamento, avaliação e desenvolvimento profissional; acompanhar e orientar o processo de desenvolvimento dos estudantes, em colaboração com os docentes e as famílias; elaborar estudos, levantamentos qualitativos e quantitativos indispensáveis ao desenvolvimento do sistema ou rede de ensino ou da escola; elaborar, implementar, acompanhar e avaliar planos, programas e projetos voltados para o desenvolvimento do sistema e/ou rede de ensino e da escola, em relação a aspectos pedagógicos, administrativos, financeiros, de pessoal e de recursos materiais; acompanhar e supervisionar o funcionamento das escolas, zelando pelo cumprimento da legislação e normas educacionais e pelo padrão de qualidade de ensino.

2.4. REGIME JURÍDICO: Estatutário, com direitos, vantagens, obrigações e atribuições especificadas na Lei Estadual $n^{\circ}$ 6.174, de 16 de novembro de 1970 (Estatuto dos Funcionários Civis do Paraná), nas Leis

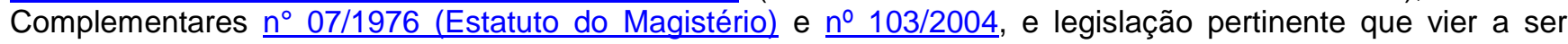
aplicada.

2.5. REGIME PREVIDENCIÁRIO: Regime Próprio de Previdência Social - RPPS. 


\section{递 \\ ESTADO DO PARANÁ \\ Secretaria de Estado da Administração e da Previdência \\ Departamento de Recursos Humanos \\ 3. DA RESERVA DE VAGAS PARA PESSOAS COM DEFICIÊNCIA}

3.1 À pessoa com deficiência, amparada pelo artigo 37, inciso VIII da Constituição Federal, pela Lei Estadual ํㅜ 13.456, de 11 de janeiro de 2002, e pela Lei Estadual ํㅜ 15.139, de 31 de maio de 2006, fica reservado 0 percentual de $5 \%$ (cinco por cento) das vagas autorizadas e ofertadas.

3.2 Quando a aplicação do percentual de reserva às pessoas com deficiência resultar em número fracionado, este será elevado até o primeiro número inteiro subsequente.

3.3 O percentual de vagas reservado neste Edital às pessoas com deficiência será observado ao longo do período de validade do Concurso Público, inclusive em relação às vagas que surgirem ou que forem criadas, desde que o quantitativo de vagas assim permita.

3.4 São consideradas pessoas com deficiência aquelas que se enquadram nas categorias discriminadas na Lei Estadual no 15.139/2006 e na Lei Estadual oㅜ 16.945/2011.

3.5 Para a inscrição como pessoa com deficiência o candidato deverá observar, no momento da inscrição, os procedimentos específicos previstos no subitem 6.1 deste Edital, assecuratórios de tratamento especial a esse grupo, caso contrário não concorrerá às vagas reservadas, mas automaticamente às vagas de ampla concorrência, nem terá direito às prerrogativas asseguradas neste Edital.

3.6 Só serão homologadas as inscrições, na reserva para pessoas com deficiência, dos candidatos que atenderem ao disposto no subitem 6.3 e nas Leis Estaduais 꿋 15.139/2006 e 16.945/2011.

3.7 O candidato inscrito como pessoa com deficiência que não tiver confirmada essa condição, perderá o direito às vagas reservadas aos candidatos desse grupo, passando a integrar apenas o grupo de candidatos que pleiteiam as vagas destinadas à ampla concorrência.

3.8 O candidato com deficiência participará no Concurso Público em igualdade de condições com os demais candidatos no que concerne ao conteúdo das provas, aos critérios de aprovação, ao horário, à data, ao local de aplicação da prova e à pontuação mínima exigida para aprovação.

3.9 Após a nomeação e posse, durante o estágio probatório, será avaliada a compatibilidade entre a sua deficiência e o desempenho das atribuições do cargo/função.

3.10 O candidato que for nomeado na condição de pessoa com deficiência não poderá arguir ou utilizar essa condição para pleitear ou justificar mudança de função e assistência de terceiros no ambiente de trabalho e para o desempenho das atribuições do cargo/função.

3.11 $\mathrm{Na}$ inexistência de candidatos inscritos ou aprovados para as vagas destinadas às pessoas com deficiência, as vagas serão ocupadas pelos demais candidatos classificados e habilitados na lista geral, observada a ordem geral de classificação.

3.12 O candidato que se inscrever como pessoa com deficiência concorrerá, além das vagas reservadas por força de lei, também às vagas de ampla concorrência.

\section{DA RESERVA DE VAGAS PARA AFRODESCENDENTES}

4.1 Ao candidato afrodescendente, amparado pela Lei Estadual $n^{\circ} 14.274 / 2003$, é reservado 10\% (dez por cento) das vagas, dentro do prazo de validade do Concurso Público, para o cargo estabelecido no anexo I deste Edital, devendo o candidato observar, no ato da inscrição, além das condições gerais estabelecidas neste Edital, também as condições especiais previstas neste item, para que possa fazer uso das prerrogativas disciplinadas em lei e neste Edital.

4.2 Quando o número de vagas reservadas aos afrodescendentes resultar em fração igual ou superior a 0,5 (zero vírgula cinco), arredondar-se-á para o número inteiro superior ou para o número inteiro inferior, quando resultar em fração menor que 0,5 (zero vírgula cinco). 


\section{ESTADO DO PARANÁ \\ Secretaria de Estado da Administração e da Previdência \\ Departamento de Recursos Humanos}

4.3 Para efeitos do previsto neste Edital, considera-se afrodescendente aquele que assim se declarar expressamente, no ato da inscrição, identificando-se como de cor preta ou parda, a raça etnia negra, conforme

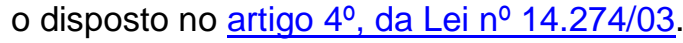

4.4 O candidato afrodescendente participará do concurso em igualdade de condições com os demais candidatos no que concerne às exigências estabelecidas neste Edital, conforme previsto no artigo $2^{\circ}$ da Lei Estadual no 14.274/03.

4.5 Detectada falsidade na declaração a que se refere este Edital, sujeitar-se-á o candidato à anulação da inscrição no concurso e de todos os efeitos daí decorrentes, e, se já nomeado, à pena de demissão, assegurada em qualquer hipótese, a ampla defesa ao contraditório.

4.6 O candidato que se inscrever como afrodescendente concorrerá, além das vagas reservadas por força de lei, também às vagas de ampla concorrência.

4.7 $\mathrm{Na}$ hipótese de não existirem candidatos inscritos ou aprovados para as vagas reservadas aos afrodescendentes, as vagas respectivas e remanescentes serão destinadas aos demais candidatos aprovados na lista geral, observada a ordem geral de classificação.

\section{DOS PROCEDIMENTOS PARA A INSCRIÇÃO E O PAGAMENTO DA TAXA DE INSCRIÇÃO}

5.1 A inscrição poderá ser efetuada a partir das $10 \mathrm{~h}$ do dia 25 de fevereiro de 2013 até às $12 \mathrm{~h}$ do dia 09 de abril de 2013, somente via internet, no endereço eletrônico www.pucpr.br/concursos link Concurso do Estado do Paraná, menu Inscrição, onde o formulário de inscrição deverá ser devidamente preenchido e conferido pelo candidato. A impressão do boleto bancário estará disponível até $12 \mathrm{~h}$, do dia 09 de abril de 2013 e o pagamento deverá ser efetuado até o dia 09 de abril de 2013 até o final do expediente do sistema bancário.

5.2 O valor da taxa de inscrição é de $\mathrm{R} \$ 60,00$ (sessenta reais) por inscrição, cujo pagamento deverá ser efetuado até o dia 09 de abril de 2013, em qualquer agência bancária ou rede credenciada, até o final expediente do sistema bancário, mediante a apresentação do boleto.

5.3 O candidato poderá optar por fazer uma ou duas inscrições nas disciplinas da matriz curricular; ou uma inscrição de pedagogo; ou uma inscrição de pedagogo e mais uma inscrição nas disciplinas da matriz curricular desde que seja no mesmo NRE. No caso de duas inscrições haverá emissão de 2 (dois) boletos no valor de $R \$$ 60,00 (sessenta reais) cada.

5.4 O candidato poderá alterar sua opção de inscrição ou local de Prova, independentemente do pagamento da taxa de inscrição, mediante o cancelamento da inscrição anteriormente realizada. No caso de já ter sido realizado o pagamento da taxa de inscrição, não haverá a devolução total ou parcial do valor pago. O candidato deverá fazer novo processo de inscrição e pagamento.

5.5 A inscrição somente será efetivada e confirmada com o correspondente pagamento da taxa de inscrição. Apenas o agendamento do pagamento no sistema bancário não é suficiente para efetivação da inscrição, não se responsabilizando a Secretaria de Estado da Administração e da Previdência - SEAP, nem a Pontifícia Universidade Católica do Paraná, pelo não recebimento da confirmação bancária do recolhimento do valor da taxa de inscrição.

5.6 No ato da inscrição, o candidato deverá ainda assinalar o local para realização das provas, independentemente do NRE de escolha da vaga, indicando um, entre os 14 (quatorze) municípios sede de prova, conforme estabelecido no Anexo II deste Edital.

5.7 Antes de efetuar o recolhimento da taxa de inscrição, o candidato deve inteirar-se das regras deste Edital e certificar-se de que preenche ou preencherá, até a data da posse, todos os requisitos exigidos para a investidura no cargo. Não haverá a devolução da taxa de inscrição após a sua efetivação, quaisquer que sejam os motivos inclusive o não comparecimento a quaisquer Provas.

5.8 Não haverá isenção, parcial ou total, do valor da taxa de inscrição, exceto aos candidatos que se enquadrarem no disposto no item 7 do presente Edital.

5.9 É vedada a inscrição condicional e/ou fora de prazo.

5.10 A qualquer tempo poderá ser anulada a inscrição, as provas e a nomeação, por meio de processo administrativo devidamente instaurado, ouvido o candidato, o que pode ocorrer inclusive após a homologação do resultado final do Concurso Público, desde que verificada a prática de qualquer ilegalidade pelo candidato, 


\section{ESTADO DO PARANÁ \\ Secretaria de Estado da Administração e da Previdência \\ Departamento de Recursos Humanos}

tais como: falsidade nas declarações e/ou quaisquer irregularidades nas provas e/ou nos documentos apresentados, entre outras.

5.11 Ao efetuar a inscrição, o candidato assume o compromisso que aceita as condições estabelecidas no presente Edital e nos demais que vierem a ser publicados durante a realização das etapas do Concurso Público.

5.12 A relação preliminar dos candidatos inscritos será divulgada no dia 15 de abril de 2013, no endereço eletrônico www.pucpr.br/concursos, link concurso do Estado do Paraná, menu Resultados. O candidato cujo nome não constar da relação preliminar de inscritos poderá interpor recurso dirigido à Comissão do Concurso, somente via sistema (menu Recursos), no prazo de 2 (dois) dias úteis, contado da data da divulgação da referida relação, enviando imediatamente o boleto bancário e o comprovante de pagamento digitalizado (escaneado) pelo mesmo sistema.

5.13 Na hipótese de dados cadastrais digitados incorretamente, no ato da inscrição, o candidato deverá acessar novamente o link de inscrição, digitar seu CPF e alterar os dados, exceto nos casos de mudança de opção de inscrição (NRE/disciplina da matriz curricular ou pedagogo) ou de local de prova, em que deverá ser observado o disposto no item 5.4 .

5.14 A candidata que tiver necessidade de amamentar durante a realização deverá levar um acompanhante, maior de idade, que ficará em local reservado e que será o responsável pelos cuidados e pela guarda da criança.

5.14.1 A candidata que não levar acompanhante não realizará a prova.

5.14.2 A criança não poderá permanecer com a candidata na sala de prova.

5.14.3 O tempo de amamentação não será acrescentado ao tempo total de realização da prova.

5.15 O candidato que necessitar de atendimento especial no dia da Prova deverá solicitá-lo, no ato da inscrição, em campo especifico.

5.16 Os locais de realização das provas, bem como a consulta de Ensalamento, serão divulgados no endereço eletrônico www.pucpr.br/concursos, link Concurso do Estado do Paraná, menu Ensalamento, a partir das $17 \mathrm{~h}$ do dia 13 de maio de 2013.

5.17 O candidato deverá imprimir o comprovante de ensalamento a partir das $17 \mathrm{~h}$ do dia 13 de maio de 2013, no endereço eletrônico www.pucpr.br/concursos, link Concurso do Estado do Paraná, menu Ensalamento, no qual estará indicado o local, o horário e o endereço de realização da prova, sendo de exclusiva responsabilidade do candidato a sua obtenção.

5.18 A homologação das inscrições será publicada, mediante edital específico no dia 18 de abril de 2013, às 17h, no endereço eletrônico www.pucpr.br/concursos, link Concurso do Estado do Paraná, menu Publicações, e no Diário Oficial do Estado do Paraná - Suplemento de Concursos Públicos - www.dioe.pr.gov.br, em 3 (três) listas, quando couber.

5.19 A Pontifícia Universidade Católica do Paraná não se responsabilizará por inscrições não recebidas, em decorrência de ordem técnica, falhas de comunicação, congestionamento de linhas de comunicação, bem como de outros fatores que impossibilitem a transferência de dados.

\section{DOS PROCEDIMENTOS PARA INSCRIÇÃO APLICÁVEIS ÀS PESSOAS COM DEFICIÊNCIA}

6.1 Antes de efetuar a inscrição, o candidato com deficiência deverá avaliar se a deficiência apresentada permite o exercício da atividade profissional, conforme as atribuições do cargo especificadas no subitem 2.3 deste Edital.

6.2 O candidato com deficiência, conforme estabelecido no item 3.4, deverá declarar essa condição ao efetivar sua inscrição, no período de 25 de fevereiro de 2013 até o dia 09 de abril de 2013, enviar, por meio de SEDEX, com A.R. (Aviso de Recebimento) à Pontifícia Universidade Católica do Paraná, Núcleo de Processos Seletivos e Concursos, na Rua Imaculada Conceição no 1155, Bairro Prado Velho, Curitiba Paraná, CEP 80215.901, o laudo médico atestando a espécie e o grau ou nível de deficiência, sendo de caráter obrigatório o código correspondente da Classificação Internacional de Doença - CID X, bem como a provável causa da deficiência. 


\section{ESTADO DO PARANÁ \\ Secretaria de Estado da Administração e da Previdência Departamento de Recursos Humanos}

6.3 O candidato com deficiência deverá solicitar exclusivamente no ato de inscrição, prova ampliada, com ou sem a presença de ledor, ou outro tratamento diferenciado justificando essa necessidade.

6.3.1 Para o candidato cego a prova de redação será realizada exclusivamente em Braile. Neste caso o candidato deverá portar o REGLETE e a PUNÇÃO.

6.4 O candidato com deficiência poderá solicitar no ato da inscrição tempo adicional de no máximo uma hora para a realização das provas. No período de 25 de fevereiro de 2013 até às $12 \mathrm{~h}$ do dia 09 abril de 2013 deverá encaminhar via sistema digitalizado (escaneado) justificativa acompanhada de parecer emitido por especialista na área de sua deficiência.

6.5 O candidato com deficiência que não fizer a solicitação de acordo com o disposto nos subitens 6.3 e 6.4 , não receberá atendimento diferenciado.

6.6 A solicitação de quaisquer condições especiais para a realização da prova de conhecimentos será atendida obedecendo a critério de legalidade, viabilidade e de razoabilidade, mediante apreciação da Comissão Organizadora deste Concurso Público.

6.7 Para inscrição como pessoa com deficiência, o candidato deverá observar, no momento da inscrição, os procedimentos específicos previstos no item 6 e subitens deste Edital, assecuratórios de tratamento especial a esse grupo, caso contrário não concorrerá às vagas reservadas, mas automaticamente às vagas de ampla concorrência, nem terá direito às prerrogativas asseguradas neste Edital às pessoas com deficiência, não cabendo a interposição de recurso nesta hipótese.

6.8 O resultado das inscrições dos candidatos que se declararam com deficiência será divulgado no dia 22 de abril de 2013 após às 17h, no endereço eletrônico: www.pucpr.br/concursos, link Concurso do Estado do Paraná, menu Publicações, e no Diário Oficial do Estado www.dioe.pr.gov.br.

\section{DA ISENÇÃO DO PAGAMENTO DA TAXA DE INSCRIÇÃO}

7.1 Haverá isenção do valor total da taxa de inscrição para o candidato que, cumulativamente:

a) estiver inscrito no Cadastro Único para Programas Sociais do Governo Federal - Cadúnico, de que trata o Decreto $\mathrm{n}^{\circ} \mathbf{6 . 1 3 5}$, de 26 de junho de 2007; e

b) for membro de família de baixa renda, nos termos do Decreto ํㅜ 6.135, de 2007.

7.2 Para estar inscrito no Cadastro Único é necessário que o candidato tenha efetuado o cadastramento junto ao órgão gestor do Cadastro Único do município em que reside.

7.3 O cadastro e o respectivo Número de Inclusão Social - NIS - do candidato deverão estar devidamente identificados e confirmados na base de dados do CadÚnico até a data da sua inscrição no concurso.

7.4 É da inteira responsabilidade do candidato procurar o órgão gestor do CadÚnico do seu município para a atualização do seu cadastro na base de dados.

7.5 Para a realização do pedido de isenção do pagamento da respectiva taxa de inscrição, o candidato deverá indicar no ato da inscrição o número do NIS e a autodeclaração de que está cadastrado junto ao órgão gestor, além do NIS atribuído pelo CadÚnico do Governo Federal, e os seguintes dados: nome completo, sem abreviações; data de nascimento; sexo; número do documento de identidade; data de emissão do documento de identidade; sigla do órgão emissor do documento de identidade; número do CPF; nome completo da mãe.

7.6 O candidato solicitante da isenção da taxa de inscrição deverá firmar declaração, no Requerimento de Isenção, de que atende à condição estabelecida na letra "b" do subitem 7.1.

7.7 Os dados informados pelo candidato, no ato da inscrição, deverão ser exatamente iguais aos que foram declarados ao Órgão Gestor do Cadúnico.

7.8 Não serão analisados os pedidos de isenção sem a indicação do número correto do NIS e, ainda, aqueles que não contenham as informações suficientes e corretas para a identificação do candidato na base de dados do Órgão Gestor do CadÚnico ou que não atendam ao estabelecido no presente item.

7.9 O pedido de isenção poderá ser efetuado no período compreendido entre as $10 \mathrm{~h}$ do dia 25 de fevereiro de 2013 e às 23h59min do dia 06 de março de 2013.

7.10 As informações prestadas no Requerimento de Isenção, referentes à isenção do pagamento da taxa de 


\section{ESTADO DO PARANÁ \\ Secretaria de Estado da Administração e da Previdência \\ Departamento de Recursos Humanos}

inscrição, serão de inteira responsabilidade do candidato.

7.11 A PUCPR consultará o órgão gestor do CadÚnico para verificar a veracidade das informações prestadas pelo candidato.

7.12 A declaração falsa sujeitará o candidato às sanções previstas em lei, aplicando-se, ainda, o disposto no parágrafo único do art. 10 do Decreto Federal № 83.936, de 6 de setembro de 1979.

7.13 Serão desconsiderados os pedidos de isenção de pagamento da taxa de inscrição do candidato que omitir, prestar informações equivocadas ou inverídicas.

7.14 Será desconsiderado o pedido de isenção do pagamento da taxa de inscrição do candidato que já tenha efetuado o pagamento da taxa de inscrição.

7.15 Não serão analisados pedidos de isenção do pagamento da taxa de inscrição para candidatos que não preencham as condições para sua concessão, seja qual for o motivo alegado.

7.16 A relação dos candidatos com pedidos de isenção deferidos ou indeferidos será disponibilizada na internet, no endereço eletrônico www.pucpr.br/concursos, link Concurso do Estado do Paraná, Menu Resultado, no dia 22 de março de 2013.

7.17 O candidato cujo pedido de isenção do pagamento da taxa de inscrição tenha sido indeferido poderá apresentar recurso contra o indeferimento no período de 2 (dois) dias úteis após a divulgação de que trata o subitem 7.16, via internet, no endereço eletrônico www.pucpr.br/concursos, link Concurso do Estado do Paraná, Menu Recursos, anexar, digitalizado (escaneado) comprovante oficial de inscrição no CadÚnico.

7.18 O resultado da análise de eventuais recursos apresentados será dado a conhecer, via internet, no endereço eletrônico www.pucpr.br/concursos, link Concurso do Estado do Paraná Menu Recursos, no dia 27 de março de 2013.

7.19 Os candidatos cujos pedidos de isenção do pagamento da taxa de inscrição forem indeferidos deverão, para efetivar sua inscrição no concurso, acessar o endereço eletrônico www.pucpr.br/concusos, link Concurso do Estado do Paraná, menu Inscrição, reimprimir o respectivo boleto bancário até às $12 \mathrm{~h}$ do dia 09 de abril de 2013 e efetuar o pagamento da taxa de inscrição até o final do sistema bancário.

7.20 Os candidatos a que se refere o subitem 7.19 que não efetuarem o pagamento da taxa de inscrição, dentro do prazo estipulado, serão automaticamente excluídos do concurso.

\section{DA PROVA DE CONHECIMENTOS}

8.1 A prova de conhecimentos compreenderá 2 (duas) etapas, a saber:

- Fase 1 - prova de conhecimentos contendo 40 questões objetivas de múltipla escolha (A, B, C, D, E);

- Fase 2 - redação dissertativo-argumentativa.

8.1.1 Fase 1: Será aplicada prova de conhecimentos, de caráter eliminatório e classificatório, abrangendo 10 questões de conhecimento comum (3 informática, 4 atualidades e 3 do Estatuto da Criança e do Adolescente), 20 questões de Conhecimentos Específicos da Disciplina, 10 questões de conhecimento de Fundamentos da Educação, conforme o conteúdo programático constante do Anexo III deste Edital.

\begin{tabular}{|c|c|c|}
\hline \multirow{2}{*}{ PROVA } & $\begin{array}{c}\text { № DE } \\
\text { QUESTÕES }\end{array}$ & ÁREAS DE CONHECIMENTO \\
\hline \multirow{2}{*}{ FASE I } & 10 & Conhecimento Comum \\
\cline { 2 - 3 } & 20 & Conhecimento Específico \\
\cline { 2 - 3 } & 10 & Fundamentos da Educação \\
\hline Total de Questões & $\mathbf{4 0}$ & \multicolumn{2}{|c}{} \\
\hline
\end{tabular}

8.1.2. O candidato com duas inscrições homologadas, conforme previsto no subitem 5.3 , além das 40 questões descritas no subitem 8.1.1, deverá responder às 20 questões de Conhecimentos Específicos correspondentes à segunda inscrição.

8.1.3. Na prova de conhecimentos cada resposta correta valerá 0,25 (vinte e cinco centésimos) pontos, totalizando 10 (dez) pontos.

8.1.4 Somente serão corrigidas as redações (Fase 2) dos candidatos que obtiverem número de acertos igual 


\section{ESTADO DO PARANÁ \\ Secretaria de Estado da Administração e da Previdência \\ Departamento de Recursos Humanos}

ou superior a 24 (vinte e quatro) acertos do total de questões na Prova de Conhecimentos. Além disso, o candidato deverá obter, no mínimo, 12 (doze) acertos na área de Conhecimentos Específicos, no mínimo 4 (quatro) acertos na área de Fundamentos da Educação e 3 (três) acertos em Conhecimento Comum. Serão automaticamente excluídos do Concurso Público os candidatos que não atingirem o número de acertos mínimos previsto neste subitem.

8.2. Fase 2: Será exigido uma redação dissertativo-argumentativa, na modalidade padrão formal da Língua Portuguesa, com no mínimo 15 (quinze) e no máximo 20 (vinte) linhas sobre um determinado tema.

8.2.1. Para a correção das redações serão observados os seguintes critérios:

1- Adequação à proposta:

a) O texto não é cópia integral dos textos de apoio (coletânea);

b) O texto mantém-se dentro do tema proposto;

c) O texto apresenta-se como dissertativo-argumentativo, conforme subitem 8.2.;

d) O texto obedece ao número mínimo de 15 (quinze) e máximo de 20 (vinte) linhas, conforme subitem 8.2.

2- Conteúdo do texto;

a) Progressão (grau de informatividade) e coerência;

b) Qualidade do conteúdo: capacidade do candidato para selecionar, relacionar, organizar e interpretar fatos, informações, opiniões e argumentos, incluindo o bom uso da coletânea, em defesa de um ponto de vista, demonstrando conhecimento dos mecanismos linguístico-discursivos necessários para a construção do seu texto.

3- Linguagem:

a) Coesão: uso adequado e expressivo dos recursos linguísticos como atividade de composição textual;

b) Norma padrão: domínio da norma padrão formal da Língua Portuguesa.

4- Critérios para anulação da redação:

a) Reprodução total dos textos de apoio (coletânea);

b) Fuga total do tema;

c) Não se tratar de um texto dissertativo-argumentativo;

d) Não obedecer ao número mínimo de 15 (quinze) e máximo de 20 (vinte) linhas.

8.2.2. A prova de redação corresponde ao total de 10 (dez) pontos.

8.3. Para obter aprovação na Prova de Conhecimentos, além do estabelecido no item 8.1.4, o candidato deverá alcançar o mínimo de 6 (seis) pontos na redação.

8.4. A nota da Prova de Conhecimentos será a média aritmética das pontuações obtidas nas fases 1 e 2 .

8.5. A pontuação final obtida pelos candidatos aprovados nas fases 1 e 2 será publicada em ordem decrescente de acordo com o número de pontos obtidos na Prova de Conhecimentos, com observância do disposto nos subitens 8.1.4 e 8.3 deste Edital. A divulgação será feita mediante publicação, em edital específico, no endereço eletrônico www.pucpr.br/concursos, link Concurso Público do Estado do Paraná, menu resultado e no Diário Oficial do Estado do Paraná - Suplemento de Concursos Públicos - www.dioe.pr.gov.br.

8.6. A Prova de Conhecimentos será aplicada no dia 19 de maio de 2013, com início às $14 \mathrm{~h}$, nos locais a serem divulgados no Ensalamento dos candidatos, observado o horário oficial de Brasília-DF.

8.7. O candidato deverá comparecer ao local designado para a realização da prova, com antecedência de 1 (uma) hora, obrigatoriamente munido de lápis, borracha e caneta esferográfica transparente com tinta preta ou azul, Comprovante de Ensalamento e documento de identificação original. Os acessos aos locais de provas serão abertos às $12 \mathrm{~h} 30$ e fechados impreterivelmente às $13 \mathrm{~h} 30$, ficando impedido de ingressar o candidato que chegar ao local de prova após o horário estipulado, independentemente do motivo, ainda que por força maior 


\section{ESTADO DO PARANÁ \\ Secretaria de Estado da Administração e da Previdência Departamento de Recursos Humanos}

e/ou caso fortuito.

8.8. A lista com a indicação dos locais de prova estará disponível na página da Pontifícia Universidade Católica do Paraná, no endereço eletrônico www.pucpr.br/concursos, link Concurso do Estado do Paraná, Menu Ensalamento, a partir das $17 \mathrm{~h}$ do dia 13 de maio de 2013.

8.9. O ingresso na sala de prova somente será permitido ao candidato munido de 1 (um) dos documentos abaixo discriminados, apresentando forma legível e em via original:

I - Cédula de Identidade Civil (RG);

II - Carteira de identidade fornecida por órgão ou conselho de representação de classe;

III - Carteira Nacional de Habilitação, válida e com fotografia, na forma da Lei nº 9.503/97 - Código de Trânsito Brasileiro;

IV - Passaporte brasileiro válido;

V - Carteira Profissional de trabalho com foto;

VI - Certificado de Reservista com foto;

VII - Carteira de Identificação das Forças Armadas (Aeronáutica, Exército ou Marinha);

VIII - Carteira de Identidade de Estrangeiros emitida no Brasil.

8.10. Não serão aceitos como documentos de identificação para ingresso na sala de prova: CPF, Certidão de Nascimento, Título Eleitoral, Carteira Nacional de Habilitação sem foto, Carteira de Estudante, carteira funcional sem valor de identidade, documentos ilegíveis, não identificáveis e/ou danificados.

8.11. Não será aceita cópia de documento de identificação, ainda que autenticada, nem protocolo de documento de identificação.

8.12. Caso o candidato esteja impossibilitado de apresentar, no dia de realização da prova, documentos originais de identificação previstos no subitem 8.9 por motivo de roubo, furto ou extravio, deverá apresentar documento que ateste o registro da ocorrência em órgão policial, expedido, no máximo, há 30 (trinta) dias da realização da prova, sob pena de ficar impedido de realizar a prova.

8.13. Não será aplicada a Prova de Conhecimentos, em qualquer hipótese, em local ou data ou em horário diferente dos prescritos neste Edital e no Ensalamento do candidato.

8.14. Não será permitida, durante a realização da prova, a comunicação entre os candidatos, nem a utilização de máquinas calculadoras e/ou similares, livros, anotações, réguas de cálculo, impressos ou qualquer outro material de consulta. O descumprimento da presente prescrição implicará a eliminação do candidato, caracterizando-se como tentativa de fraude.

8.15. Não será permitido, no dia da realização da prova, o uso de aparelhos eletrônicos (bip, telefone celular, smartphone, walkman, agenda eletrônica, notebook, palmtop, tablet, receptor, gravador e similares), óculos escuros e relógios que possam comprometer a segurança do Concurso. Caso o candidato porte qualquer um desses objetos deverá desligá-lo(s) ou retirar a bateria e colocá-lo(s) dentro de uma embalagem plástica fornecida pela Comissão Organizadora que será deixada sob a carteira e/ou deverá guardar em local que impeça sua acessibilidade. O descumprimento da presente prescrição implicará a eliminação do candidato, caracterizando-se como tentativa de fraude.

8.16. Não será permitida, durante a realização da Prova Conhecimento, a utilização de gorros, bonés e demais acessórios que impeçam a visibilidade das orelhas. Esses objetos deverão ser guardados pelos candidatos em local que impeça sua acessibilidade. O descumprimento da presente prescrição implicará a eliminação do candidato, caracterizando-se como tentativa de fraude.

8.17. É proibido o porte de arma de fogo e/ou arma branca durante a realização das provas, exceto para os candidatos que, por força da atividade que exerçam e da legislação, tenham autorização para tal. Neste caso, os candidatos deverão procurar a Comissão Organizadora do Concurso, que instruirá o desmuniciamento da arma antes do início das provas.

8.18. A SEAP e a Pontifícia Universidade Católica do Paraná não se responsabilizarão por perdas ou extravios de objetos ou de equipamentos eletrônicos ocorridos durante a realização das provas, nem por danos neles causados. 


\section{ESTADO DO PARANÁ \\ Secretaria de Estado da Administração e da Previdência \\ Departamento de Recursos Humanos}

8.19. O não comparecimento do candidato à Prova implicará sua eliminação do Concurso.

8.20. A duração da Prova de Conhecimentos será de 4 (quatro) horas, com o acréscimo de 1 (uma) hora para os candidatos com duas inscrições homologadas. Para ambos os casos, está incluído o tempo para o preenchimento do Cartão-Resposta/Redação.

8.21. O controle do tempo de aplicação da prova e as informações a respeito do tempo transcorrido durante a realização da prova serão feitos pelos fiscais de sala.

8.22. É de responsabilidade do candidato comparecer ao local de prova com a antecedência necessária para início da realização da Prova de Conhecimentos, bem como observar o tempo destinado à realização da prova.

8.23. As respostas às questões objetivas serão transcritas para o Cartão-Resposta com caneta esferográfica transparente com tinta preta ou azul, devendo o candidato assinalar uma única resposta para cada questão.

8.24. As respostas às questões da Prova de Conhecimentos lançadas no Cartão-Resposta serão corrigidas por meio de processamento eletrônico.

8.25. Não serão computadas questões não assinaladas ou que contenham mais de uma resposta, emenda ou rasura.

8.26. O candidato é responsável pelo correto preenchimento do Cartão-Resposta/Redação e por sua conservação e integridade, pois não haverá substituição do cartão, salvo em caso de defeito de impressão.

8.27. O candidato somente poderá retirar-se da sala de prova após 1 (uma) hora do início da Prova de Conhecimentos, devendo, antes de retirar-se, assinar a lista de presença e entregar aos aplicadores o CartãoResposta da prova Objetiva e da Redação.

8.28. Ao final do tempo destinado à realização da prova, em cada sala, é obrigatória a saída simultânea dos três últimos candidatos, que deverão assinar a ata de encerramento da aplicação da prova.

8.29. Durante a realização da prova não será permitido ao candidato ausentar-se da sala, a não ser em caso especial e desde que acompanhado por um componente da equipe de aplicação da prova.

8.30. O candidato que desacatar ou desrespeitar os fiscais ou responsáveis pela aplicação da prova, bem como aquele que descumprir as demais condições estabelecidas neste item será excluído do Concurso.

8.31. Todos os candidatos aprovados na Prova de Conhecimentos serão convocados por edital específico para a Prova Didática.

\section{DA PROVA DIDÁTICA - MATRIZ CURRICULAR}

9.1. Consistirá na apresentação, pelo candidato aprovado e classificado na prova de conhecimentos, de um plano de aula, de sua autoria, relacionado à área de conhecimento da disciplina de inscrição, no qual constará o planejamento do desenvolvimento de atividades de ensino de modo a promover as condições para a efetivação do processo ensino e aprendizagem.

9.1.1. O plano de aula deverá versar sobre um dos temas estabelecidos no Anexo IV do presente Edital, observada a disciplina de inscrição, e considerar os anos finais do Ensino Fundamental e/ou Ensino Médio.

9.2 O candidato deverá, ainda, ministrar aula para uma banca composta por 2 (dois) avaliadores, sendo 1 (um) professor da disciplina de inscrição e 1 (um) pedagogo. A exposição será filmada e gravada em áudio e vídeo e não poderá exceder o tempo máximo de 20 minutos.

9.2.1. A pontuação final da Prova Didática será a média aritmética das 2 (duas) avaliações.

9.2.1.1 A pontuação final será definida conforme critérios estabelecidos em edital específico.

9.2.2. Constatada a divergência de $20 \%$ (vinte) ou mais entre as duas pontuações, haverá uma terceira avaliação da prova filmada, a ser realizada (não presencialmente) por um professor especialista da disciplina de inscrição do candidato. Neste caso a pontuação final será a média aritmética das três avaliações.

9.3. Para a realização da prova didática, o candidato deverá apresentar, no ato, 2 (duas) vias do plano de aula sobre o tema a ser ministrado, de igual teor, datadas e assinadas, conforme modelo a ser apresentado em edital específico, para os anos finais do Ensino Fundamental e/ou Ensino Médio.

9.4. Caso o candidato esteja concorrendo em duas disciplinas, deverá apresentar um plano de aula para 


\section{ESTADO DO PARANÁ \\ Secretaria de Estado da Administração e da Previdência \\ Departamento de Recursos Humanos}

cada disciplina de opção de inscrição, observado o cronograma estabelecido em edital específico de convocação.

9.5. A Prova Didática tem caráter eliminatório e classificatório de acordo com a pontuação obtida.

9.6. O candidato que não apresentar, no ato, o plano de aula não poderá ministrar a aula e será eliminado do concurso.

9.7. Para a Prova Didática estarão disponíveis os seguintes recursos: quadro de giz, giz e apagador.

9.8. Poderão ser levados, para realização da Prova Didática, pela pessoa inscrita, outros materiais didáticos que se considerar necessários.

9.9. Objetivando dar igual tratamento aos candidatos, será vedada a utilização dos seguintes recursos para a realização da prova didática: equipamentos de áudio, vídeo, informática e eletrônicos, retroprojetor, projetor de slides e data show.

9.10. Durante a simulação, a Banca Examinadora não poderá ser solicitada a interagir.

9.11. Serão aprovados os candidatos que obtiverem a pontuação igual ou superior a 6,00 (seis) pontos.

9.12. A Banca Examinadora registrará sua avaliação em formulário próprio no término da aula. A Banca Examinadora não está autorizada a fornecer o resultado da prova aos candidatos.

9.13. A relação com o resultado da Prova Didática será publicada em Edital específico, no endereço eletrônico www.pucpr.br/concursos, link Concurso do Estado do Paraná, menu Resultado.

9.14. É proibido o porte de arma de fogo/arma branca durante a realização das provas, exceto para os candidatos que, por força da atividade que exerçam e da legislação, tenham autorização para tal. Neste caso, os candidatos deverão procurar a Comissão Organizadora do Concurso, que instruirá o desmuniciamento da arma antes do início das provas.

\section{DA PROVA DIDÁTICA - PEDAGOGO}

10.1 Consistirá na apresentação, pelo candidato aprovado e classificado na Prova de Conhecimentos, de um plano de ação, de sua autoria, relacionado à área pedagógica, o qual constará de um plano de ação sobre uma situação problema.

10.1.1 O plano de ação deverá versar sobre um dos temas estabelecidos no Anexo IV do presente Edital, e considerar os anos finais do Ensino Fundamental e/ou Ensino Médio.

10.2 O candidato deverá, ainda, fazer exposição do seu plano de ação para uma banca composta por 2 avaliadores, sendo 1 (um) pedagogo e 1 (um) professor. A exposição será filmada e gravada em áudio e vídeo e não poderá exceder o tempo máximo de 20 minutos.

10.2.1 A pontuação final da Prova Didática será a média aritmética das 2 (duas) avaliações.

10.2.1.1 A pontuação final será definida conforme critérios estabelecidos em edital específico.

10.2.2 Constatada a divergência de $20 \%$ (vinte) ou mais entre as duas pontuações, haverá uma terceira avaliação da prova filmada, a ser realizada (não presencialmente) por um professor especialista da disciplina de inscrição do candidato. Neste caso a pontuação final será a média aritmética das três avaliações.

10.3 Para a realização da Prova Didática, o candidato deverá apresentar, no ato, 2 (duas) vias do plano de ação sobre o tema a ser apresentado, de igual teor, datadas e assinadas, conforme modelo a ser apresentado em edital específico, para os anos finais do Ensino Fundamental e/ou Ensino Médio.

10.4 Caso o candidato esteja concorrendo em duas inscrições, pedagogia e disciplina da matriz curricular, deverá apresentar um plano de ação e um plano de aula, respectivamente, observado o cronograma estabelecido em edital especifico de convocação.

10.5 A Prova Didática tem caráter eliminatório e classificatório de acordo com a pontuação obtida. 


\section{ESTADO DO PARANÁ \\ Secretaria de Estado da Administração e da Previdência Departamento de Recursos Humanos}

10.6 O candidato que não apresentar, no ato, o plano de ação não poderá realizar a respectiva exposição e será eliminado do concurso.

10.7 Para a Prova Didática estarão disponíveis os seguintes recursos: quadro de giz, giz e apagador.

10.8 Poderão ser levados, para realização da Prova Didática, pela pessoa inscrita, outros materiais didáticos que considere necessários.

10.9 Objetivando dar igual tratamento aos candidatos, será vedada a utilização dos seguintes recursos para a realização da prova didática: equipamentos de áudio, vídeo, informática e eletrônicos, retroprojetor, projetor de slides e data show.

10.10 Durante a simulação, a Banca Examinadora não poderá ser solicitada a interagir.

10.11 Serão aprovados os candidatos que obtiverem a pontuação igual ou superior a 6,00 (seis) pontos.

10.12 A Banca Examinadora registrará sua avaliação em formulário próprio no término da exposição. A Banca Examinadora não está autorizada a fornecer o resultado da prova aos candidatos.

10.13 A relação com o resultado da prova didática será publicada em Edital específico, no endereço eletrônico www.pucpr.br/concursos, link Concurso do Estado do Paraná, menu Resultado.

10.14 É proibido o porte de arma de fogo/arma branca durante a realização das provas, exceto para os candidatos que, por força da atividade que exerçam e da legislação, tenham autorização para tal. Neste caso, os candidatos deverão procurar a Comissão Organizadora do Concurso, que instruirá o desmuniciamento da arma antes do início das provas.

\section{DA PROVA DE TÍTULOS}

11.1. A Prova de Títulos terá caráter classificatório e somente serão analisados os Títulos dos candidatos aprovados na Prova de Conhecimentos e na Prova Didática.

11.2. Os títulos de todos os candidatos aprovados na Prova de Conhecimentos e na Prova Didática, conforme subitem 11.5 deste Edital, deverão ser digitalizados (escaneados) e anexados via internet, endereço eletrônico www.pucpr.br/concursos, link Concurso do Estado do Paraná, menu Prova de Títulos, conforme edital especifico.

11.3. Os candidatos eliminados na Prova Didática, ou seja, aqueles que não atenderem aos critérios estabelecidos no subitem 9.11 para o cargo de professor da matriz curricular e subitem 10.11 para o cargo de pedagogo, não terão seus títulos analisados e pontuados.

11.4. A Prova de Títulos valerá, no máximo, 20 (vinte) pontos. 


\section{ESTADO DO PARANÁ \\ Secretaria de Estado da Administração e da Previdência \\ Departamento de Recursos Humanos}

11.5. Serão computados pontos na Prova de Títulos aos candidatos aprovados na Prova Didática e que comprovarem possuir quaisquer dos seguintes títulos:

\begin{tabular}{|l|c|c|}
\hline \multicolumn{1}{|c|}{ Títulos } & Pontos & Máximo \\
\hline $\begin{array}{l}\text { D) Diploma ou Ata de Defesa de Tese, devidamente homologada, de curso de pós- } \\
\text { graduação, em nível de doutorado - título de Doutor, de acordo com as exigências legais } \\
\text { específicas no período de realização do respectivo curso. }\end{array}$ & 4,5 & 4,5 \\
\hline $\begin{array}{l}\text { b) Diploma ou Ata de Defesa de Dissertação, devidamente homologada, de curso de } \\
\text { pós-graduação, em nível de mestrado - título de Mestre, de acordo com as exigências } \\
\text { legais específicas no período de realização do respectivo curso. }\end{array}$ & 4 & 4 \\
\hline $\begin{array}{l}\text { c) Certificado ou Certidão de conclusão de curso de Especialização, em nível de pós- } \\
\text { graduação - lato sensu, acompanhada de Histórico, de acordo com as exigências legais } \\
\text { específicas no período de realização do respectivo curso. }\end{array}$ & 3 & 3 \\
\hline $\begin{array}{l}\text { d) Outro curso de Licenciatura Plena e/ou Habilitação, de curso de Licenciatura Plena, } \\
\text { desde que não seja aquele/a utilizado/a para o ingresso no cargo. }\end{array}$ & 2,5 & 2,5 \\
\hline $\begin{array}{l}\text { e) Cursos de Extensão, Cursos de Aperfeiçoamento, Cursos de Atualização } \\
\text { Multidisciplinar, PIBID*, PIBI** devidamente certificados por Instituições de Ensino } \\
\text { Superior, com a carga horária mínima de 40 horas por certificado, frequência e e } \\
\text { aproveitamento. }\end{array}$ & $\begin{array}{c}0,01 \text { por } \\
\text { cursada }\end{array}$ & 2 \\
\hline $\begin{array}{l}\text { d) Experiência profissional, devidamente comprovada, em magistério em qualquer nível } \\
\text { ou modalidade de educação, em estabelecimento de ensino da rede particular ou pública, } \\
\text { a partir de 01/01/1992. }\end{array}$ & $\begin{array}{c}0,2 \text { por } \\
\text { ano } \\
\text { completo }\end{array}$ & 4 \\
\hline
\end{tabular}

*Programa Institucional de Bolsa de Iniciação à Docência.

** Programa Institucional de Bolsas de Iniciação Científica.

11.6. Para a Prova de Títulos serão considerados como títulos hábeis à pontuação somente os relacionados no quadro de títulos e na forma estabelecida neste Edital.

11.7. Somente os títulos que atenderem aos requisitos do Edital serão avaliados.

11.8. Para a Prova de Títulos somente serão aceitas cópias digitalizadas (escaneadas) dos documentos originais, legíveis e em bom estado de conservação.

11.9. A comprovação dos títulos de que trata a letra "d" do subitem 11.5 se dará mediante apresentação de cópia digitalizada (escaneada) de Carteira de Trabalho e Previdência Social (página de identificação do portador e página(s) do registro de emprego) ou, no caso de contratado pelo Poder Público, mediante apresentação de Declarações, Certidões, Portarias, Contratos e outros documentos que comprovem a experiência profissional, devendo constar expressamente a função de Professor ou Docente e/ou Pedagogo, emitida pelo setor competente.

11.9.1 Caso o documento utilizado para a comprovação da experiência profissional informe função diversa da de Professor ou Docente e/ou Pedagogo, o candidato deverá providenciar junto ao contratante uma declaração complementar na qual fique comprovada a função de Professor ou Docente e/ou Pedagogo.

11.9.2 No caso de experiência junto ao Poder Público, deverá constar o documento comprobatório deverá constar expressamente o tempo em dia(s), mês(es) e ano(s).

11.9.3 Para efeito de contagem do tempo de experiência profissional a data limite será 09 de abril de 2013 (data final das inscrições).

- Será considerado o somatório do tempo de serviço descartando-se as frações de meses e de dias.

- Serão desconsiderados os documentos que não atenderem aos subitens anteriores.

- Os candidatos com duas inscrições deverão apresentar a titulação correspondente a cada inscrição. 


\section{ESTADO DO PARANÁ \\ Secretaria de Estado da Administração e da Previdência Departamento de Recursos Humanos}

11.10. Não será computado, como experiência profissional, o tempo de estágio profissional supervisionado ou monitorado e tempos de serviço paralelo.

11.11. Receberá pontuação 0 (zero) na Prova de Títulos o candidato que não enviar os documentos na forma, no prazo estipulados neste Edital e em Edital específico de Convocação. $O$ candidato que receber pontuação 0 (zero) na Prova de Títulos não será eliminado do Concurso Público, mantendo esta pontuação, juntamente com a nota da Prova de Conhecimentos e Didática, para cálculo da classificação final.

11.12. Não serão admitidos, sob qualquer hipótese, títulos encaminhados via postal, fax, meio eletrônico (email) ou anexados em protocolos de recursos administrativos.

11.13. O resultado da pontuação da Prova de Títulos, por ordem decrescente de pontuação, será divulgado mediante edital especifico e publicado no endereço eletrônico www.pucpr.br/concusos, link Concurso do Estado do Paraná, Menu Resultado, www.dioe.pr.gov.br e no Diário Oficial do Estado do Paraná - Suplemento de Concursos Públicos do Estado.

11.14. A conclusão de cursos de pós-graduação stricto sensu deverá ser comprovada com apresentação de Diploma de Doutor ou Mestre ou com a Ata de Defesa de Tese ou Dissertação, respectivamente, devidamente homologado(a) e convalidado(a) de acordo com as determinações legais à época de realização do referido curso.

11.15. A conclusão de cursos de pós-graduação lato sensu, deverá ser comprovada com a apresentação de Certificado ou Certidão de conclusão de curso de Especialização, em nível de pós-graduação, acompanhado de Histórico, de acordo com as determinações legais à época de realização do referido curso.

11.16. Todos os documentos apresentados para a Prova de Títulos expedidos no exterior deverão estar devidamente traduzidos para a Língua Portuguesa por tradutor juramentado.

\section{DOS RECURSOS}

12.1. Caberá recurso após a divulgação dos resultados provisórios nas seguintes etapas do Concurso:

\subsubsection{Quanto à Prova de Conhecimentos - Fase 1:}

a) No dia 20 de maio de 2013, às $12 \mathrm{~h}$, serão divulgados a Prova de Conhecimentos e o gabarito oficial provisório das questões objetivas, no endereço eletrônico www.pucpr.br/concursos, link Concurso do Estado do Paraná, menu Resultado;

b) A partir da divulgação do gabarito provisório da Prova de Conhecimentos, o candidato terá o prazo de 2 (dois) dias úteis para interpor recurso, utilizando-se do formulário específico que estará disponível no endereço eletrônico www.pucpr.br/concursos, link Concurso do Estado do Paraná, menu Recursos;

c) Os recursos da prova de conhecimentos serão apreciados pela Pontifícia Universidade Católica do Paraná, que os julgará em até 12 (doze) dias úteis. O resultado dos recursos da Prova de Conhecimentos será dado a conhecer ao candidato individualmente via sistema, no endereço eletrônico www.pucpr.br/concursos, link Concurso do Estado do Paraná, menu Resultado;

d) Os pontos relativos às questões objetivas que, porventura, forem anuladas serão atribuídos a todos os candidatos que se submeteram à respectiva prova. Se houver retificação de alternativa $(A, B, C, D, E)$ divulgada pelo gabarito provisório como sendo a correta, os efeitos decorrentes serão aplicados a todos os candidatos, independentemente de terem ou não recorrido. O resultado da Prova de Conhecimentos será computado com base no gabarito oficial definitivo publicado no endereço eletrônico www.pucpr.br/concursos, link Concurso do Estado do Paraná, menu Resultado;

e) Não serão admitidos recursos relativos ao preenchimento incompleto, rasurado, equivocado, em duplicidade ou incorreto do Cartão-Resposta.

f) Não cabe pedido de reconsideração ou de revisão de resultado de recurso.

\subsubsection{Quanto à Prova de Conhecimentos - Fase 2:}

a) Serão divulgados, em edital específico, a pontuação da prova de da Prova de Conhecimentos - Fase 2, no endereço eletrônico www.pucpr.br/concursos, link Concurso do Estado do Paraná, menu Resultado;

b) A partir da divulgação da pontuação da Prova de Conhecimentos - Fase 2, o candidato poderá acessar seu 


\section{ESTADO DO PARANÁ \\ Secretaria de Estado da Administração e da Previdência \\ Departamento de Recursos Humanos}

desempenho individual na prova através do endereço eletrônico www.pucpr.br/concursos, link Concursos do Estado do Paraná, menu Resultado.

c) No prazo de 2 (dois) dias úteis, contados a partir da divulgação da pontuação da Prova de Conhecimentos Fase 2, o candidato poderá interpor recurso, utilizando-se do formulário específico que estará disponível no endereço eletrônico www.pucpr.br/concursos, link Concurso do Estado do Paraná, menu Recursos;

d) Os recursos da Prova de Conhecimentos - Fase 2 serão apreciados pela Pontifícia Universidade Católica do Paraná, que os julgará em até 15 (quinze) dias úteis;

e) O resultado dos recursos da Prova da Prova de Conhecimentos - Fase 2 será dado a conhecer mediante publicação no endereço eletrônico www.pucpr.br/concursos, link Concurso do Estado do Paraná, menu Resultado;

f) Os recursos que não estiverem redigidos em formulário específico ou tiverem sido interpostos fora do prazo não serão admitidos nem analisados;

g) Os candidatos que interpuserem recursos não serão comunicados individualmente do resultado dos mesmos, o qual ficará disponível no endereço eletrônico www.pucpr.br/concursos, link Concurso do Estado do Paraná, menu Recursos, pelo prazo de 2 (dois) dias úteis a contar da data de publicação da resposta ao recurso;

h) Não cabe pedido de reconsideração ou de revisão de resultado de recurso.

\subsubsection{Quanto à Prova Didática:}

a) Serão divulgados, em edital específico, a pontuação da Prova Didática, no endereço eletrônico www.pucpr.br/concursos, link Concurso do Estado do Paraná, menu Resultado;

b) A partir da divulgação da pontuação da Prova Didática, o candidato poderá acessar seu desempenho individual na prova através do endereço eletrônico www.pucpr.br/concursos, link Concursos do Estado do Paraná, menu Resultado.

c) No prazo de 2 (dois) dias úteis, contados a partir da divulgação da pontuação da Prova Didática, o candidato poderá interpor recurso, utilizando-se do formulário específico que estará disponível no endereço eletrônico www.pucpr.br/concursos, link Concurso do Estado do Paraná, menu Recursos;

d) Os recursos da Prova Didática serão apreciados pela Pontifícia Universidade Católica do Paraná, que os julgará em até 15 (quize) dias úteis;

e) O resultado dos recursos da Prova Didática será dado a conhecer mediante publicação no endereço eletrônico www.pucpr.br/concursos, link Concurso do Estado do Paraná, menu Resultado;

f) Os recursos que não estiverem redigidos em formulário específico ou tiverem sido interpostos fora do prazo não serão admitidos nem analisados.

g) Os candidatos que interpuserem recursos não serão comunicados individualmente do resultado dos mesmos, o qual ficará disponível no endereço eletrônico www.pucpr.br/concursos, link Concurso do Estado do Paraná, menu Recursos, pelo prazo de 2 (dois) dias úteis a contar da data de publicação da resposta ao recurso;

h) Não cabe pedido de reconsideração ou de revisão de resultado de recurso.

\subsubsection{Quanto à Prova de Títulos:}

a) A partir da divulgação da pontuação obtida na Prova de Títulos, o candidato poderá, no prazo de 2 (dois) dias úteis, interpor recurso, mediante requerimento em formulário específico que estará disponível no endereço eletrônico www.pucpr.br/concursos, link Concurso do Estado do Paraná, menu Resultado;

b) Os recursos da Prova de Títulos serão apreciados pela Pontifícia Universidade Católica do Paraná, que os julgará em até 10 (dez) dias úteis. O resultado dos recursos da Prova de Títulos será dado a conhecer mediante publicação no endereço eletrônico www.pucpr.br/concursos, link Concurso do Estado do Paraná, menu Resultado. 


\section{ESTADO DO PARANÁ \\ Secretaria de Estado da Administração e da Previdência Departamento de Recursos Humanos}

c) Os recursos da Prova de Títulos serão apreciados pela Pontifícia Universidade Católica do Paraná, que os julgará em até 11 (onze) dias úteis;

d) O resultado dos recursos da Prova de Títulos será dado a conhecer mediante publicação no endereço eletrônico www.pucpr.br/concursos, link Concurso do Estado do Paraná, menu Recursos.

e) Os recursos que não estiverem redigidos em formulário específico ou tiverem sido interpostos fora do prazo não serão admitidos nem analisados.

f) Os candidatos que interpuserem recursos não serão comunicados individualmente do resultado dos mesmos, o qual ficará disponível no endereço eletrônico www.pucpr.br/concursos, link Concurso do Estado do Paraná, menu Recursos, pelo prazo de 2 (dois) dias úteis a contar da data de publicação da resposta ao recurso.

g) Não cabe pedido de reconsideração ou de revisão de resultado de recurso.

\section{DA CLASSIFICAÇÃO FINAL NO CONCURSO PÚBLICO}

13.1 A classificação final dos candidatos será publicada após decididos os recursos, mediante edital específico, conforme previsto no subitem 12 deste Edital e publicado no endereço eletrônico do Diário Oficial do Estado www.dioe.pr.gov.br e no endereço eletrônico da Pontifica Universidade Católica do Paraná, www.pucpr.br/concursos, link Concurso do Estado do Paraná, menu Resultado, servindo como atestado de aprovação, e será ordenada de acordo com os valores decrescentes das pontuações finais, por NRE, disciplina e nome, em 3 (três) listas, quando couber.

13.2 A classificação final no Concurso Público será baseada na pontuação final obtida:

\begin{tabular}{|c|c|}
\hline CARGO & PONTUAÇÃO FINAL \\
\hline PROFESSOR & PF $=(5 x \mathrm{PC}+3 \times \mathrm{PD})+\mathrm{PT}$ \\
\hline
\end{tabular}

em que: PF: Pontuação Final; PC: Pontuação obtida na Prova de Conhecimentos (subitem 8.4); PD: Pontuação obtida na Prova Didática; PT: Pontuação obtida na Prova de Títulos.

13.3 Ocorrendo empate na pontuação final obtida pelos candidatos nas provas serão adotados os seguintes critérios de desempate, sucessivamente:
a) maior idade, dentre os candidatos com idade igual ou superior a 60 (sessenta) anos, até o último dia de inscrição neste Concurso Público, conforme Art. 27, Parágrafo único, do Estatuto do Idoso;
b) maior pontuação nas questões de Conhecimentos Específicos;
c) maior pontuação na Prova Didática;
d) maior pontuação nas questões de Fundamentos da Educação;
e) maior pontuação na Prova de Conhecimentos - Fase 2 (redação dissertativo-argumentativa);
f) maior pontuação nas questões de Conhecimentos Gerais - Fase 1;
g) maior idade, excetuando-se o critério definido na letra "a".

\section{DA AVALIAÇÃO MÉDICA}

14.1 Anteriormente à nomeação, os candidatos aprovados e classificados no Concurso Público serão convocados por edital específico, no endereço eletrônico www.pucpr.br/concursos, link Concurso do Estado do Paraná, menu Avaliação Médica, para se submeterem à Avaliação Médica, de caráter eliminatório, conforme estipulado em legislação vigente.

14.2 A Avaliação Médica abrangerá exames laboratoriais e clínicos, a serem especificados no Edital de Convocação específico.

14.3 A realização dos exames laboratoriais e outros exames exigidos, bem como avaliações clínicas especializadas, conforme estipulados em edital específico, ocorrerá às expensas do candidato, exceto a avaliação clínica, que será de responsabilidade da SEAP.

14.4 O local de realização da Avaliação Clínica será estabelecido em Edital próprio de Convocação, podendo ser diferente da cidade de realização das Provas de Conhecimentos e Didática.

14.5 Para a Avaliação Clínica o candidato deverá apresentar-se munido de documento de identidade original, 


\section{ESTADO DO PARANÁ \\ Secretaria de Estado da Administração e da Previdência Departamento de Recursos Humanos}

devendo assinar lista de presença.

14.6 Compete à Divisão de Medicina e Saúde Ocupacional - DIMS/SEAP - a homologação do resultado da Avaliação Médica.

14.7 Será considerado apto pela DIMS/SEAP o candidato que não apresentar quaisquer alterações patológicas que o contraindiquem ao desempenho do cargo/função para o qual se inscreveu.

\section{DOS REQUISITOS EXIGIDOS PARA A INVESTIDURA, POSSE E EXERCíCIO NO CARGO.}

15.1 Para a investidura no cargo:

a) ter no mínimo 18 anos;

b) ter nacionalidade brasileira ou portuguesa e, em caso de nacionalidade portuguesa, estar amparado pelo estatuto de igualdade entre brasileiros e portugueses, com reconhecimento do gozo de direitos políticos

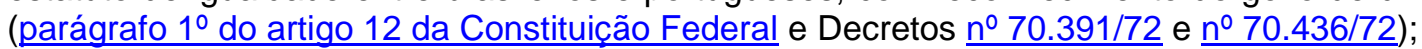

c) estar em dia com as obrigações eleitorais;

d) possuir Certificado de Reservista ou de dispensa de incorporação, se do sexo masculino;

e) comprovar o nível de escolaridade exigido para o exercício do cargo, na data da posse;

f) apresentar boa saúde;

g) ter boa conduta;

h) não possuir acúmulo de cargos na forma prevista na legislação, e

i) cumprir as determinações deste Edital.

15.2 Para a posse no cargo, deverá o candidato apresentar os seguintes documentos originais e fotocópias:

a) Declaração dos bens, direitos e valores que constituem o seu patrimônio, nos termos do art. 103, da Constituição Estadual do Paraná, em prazo determinado em edital, antes da posse, sob pena de esta não se efetivar;

b) Declarar, em formulário próprio, que não exerce outro cargo, emprego ou função pública, nos termos do art. 37, incisos XVI e XVII da Constituição da República Federativa do Brasil;

c) Declarar, por escrito, que não tenha sido demitido em consequência de aplicação de pena disciplinar, do serviço público federal, estadual, distrital ou municipal, nos últimos cinco anos, contados de forma retroativa da data da nomeação, nem que tenha perdido o cargo em razão de ordem judicial transitada em julgado a ser cumprida ou em cumprimento;

d) certidão negativa emitida por distribuidores ou cartórios criminais e Varas de Execução Pena(se houver) das cidades nas quais o candidato tenha residido/domiciliado nos últimos 5 (cinco) anos, expedida no máximo nos últimos 180 (cento e oitenta) dias antes da posse.

e) certidão negativa eleitoral dos respectivos domicílios eleitorais nos últimos 2 (dois) anos;

f) certificado de reservista do serviço militar;

g) diploma de conclusão de curso de graduação superior registrado pelo Ministério da Educação e Cultura (MEC) ou certificado de colação de grau acompanhado de histórico escolar;

h) Título de Eleitor.

15.3 Para a posse no cargo, o candidato deverá ainda apresentar os documentos originais pontuados na Prova de Títulos.

15.4 Para o exercício do cargo, apresentar os seguintes documentos originais e fotocópias:

a) Carteira de identidade;

b) Documento que informe o número do cadastro de pessoa física - CPF;

c) Documento que informe o número do PIS-PASEP, se já for cadastrado;

d) Certidão de nascimento dos filhos menores;

e) Comprovante de endereço atual;

f) Certidão de casamento;

g) Ficha cadastral preenchida.

15.5 A não apresentação dos documentos comprobatórios ou a falta de comprovação de qualquer dos requisitos exigidos para a posse no cargo, especificados neste Edital, impedirá a posse do candidato automática e consequentemente, tornada sem efeito a nomeação, sem prejuízo das sanções penais aplicáveis.

15.6 Verificada a falsidade nos documentos apresentados será o candidato eliminado do Concurso Público, 


\section{ESTADO DO PARANÁ \\ Secretaria de Estado da Administração e da Previdência \\ Departamento de Recursos Humanos}

com nulidade da aprovação ou da classificação e dos efeitos decorrentes, sem prejuízo das sanções penais aplicáveis.

15.7 O candidato aprovado que tiver completado 70 (setenta) anos de idade antes da data designada para investidura no cargo, não poderá ser empossado, conforme inciso II, do § 1ำ do artigo 35 , da Constituição do Estado do Paraná.

\section{DO APROVEITAMENTO}

16.1. Os candidatos serão aproveitados de acordo com a classificação final, ressalvado o atendimento do percentual legal de $5 \%$ (cinco por cento) para pessoas com deficiência, de acordo com os subitem 3 deste Edital, e de 10\% (dez por cento) para afrodescendentes, de acordo com os subitem 4.

16.2. O candidato nomeado ficará lotado no NRE de inscrição no concurso e a lotação em estabelecimento de ensino ou município se dará somente através do concurso de remoção.

16.3 A relação dos municípios que integram cada NRE consta no anexo $\mathrm{V}$ deste edital.

\section{DAS DISPOSIÇÕES FINAIS}

17.1. Caberá à Secretaria de Estado da Administração e da Previdência - SEAP - homologar o resultado final do Concurso Público, dentro de 30 (trinta) dias, contados da publicação da classificação final.

17.2. A posse no cargo estará condicionada à apresentação da documentação comprobatória dos requisitos para investidura e ao atendimento das demais condições constitucionais, legais, regulamentares previstas neste Edital.

17.3. Todos os atos oficiais referentes ao Concurso Público, normatizados por este Edital, serão divulgados no Diário Oficial do Estado do Paraná - Suplemento de Concursos Públicos - www.dioe.pr.gov.br e no endereço eletrônico www.pucpr.br/concursos, link Concurso do Estado do Paraná, com antecedência mínima de 5 (cinco) dias úteis.

17.4. Será excluído do Concurso Público, por ato do DRH/SEAP, o candidato que prestar declaração falsa ou inexata, em qualquer documento, ou usar de meios ilícitos durante o Concurso. Na hipótese de já ter sido nomeado será tornado sem efeito, na forma da lei, o respectivo ato de nomeação, sem prejuízo das sanções penais cabíveis.

17.5. As despesas decorrentes da participação no Concurso Público e aquelas decorrentes de deslocamento ou mudança de domicílio para a investidura no cargo correrão às expensas do candidato.

17.6. Todos os prazos fixados neste Edital correrão a partir das datas de suas publicações, excluindo-se o dia da publicação e incluindo-se o dia do vencimento.

17.7. O descumprimento de quaisquer das instruções deste Edital implicará a eliminação do candidato do Concurso Público.

17.8. Não serão fornecidos atestados, certificados ou certidões relativos à classificação ou pontuações de candidatos, valendo para tal fim os resultados publicados nos editais pelo endereço www.pucpr.br/concursos, link Concurso do Estado do Paraná e no Diário Oficial do Estado do Paraná - Suplemento de Concursos Públicos - www.dioe.pr.gov.br.

17.9. Não haverá segunda chamada para nenhuma prova, fase ou etapa do Concurso, resultando a ausência do candidato, por qualquer motivo, inclusive moléstia, acidente ou outro fato, na eliminação automática do Concurso.

17.10 Não será aplicada a Prova de Conhecimentos, ou procedida qualquer outra prova, em qualquer hipótese, em local ou data ou em horário diferente dos prescritos neste Edital, em editais específicos referentes às fases deste Concurso e no Ensalamento do candidato.

17.11. O candidato poderá obter informações referentes ao Concurso Público junto PUCPR pelo site www.pucpr.br/concursos, link Concurso do Estado do Paraná, Menu Candidato.

17.12. O candidato aprovado e classificado no Concurso Público obriga-se a manter atualizado o seu endereço junto à PUCPR, por meio do endereço eletrônico www.pucpr.br/concursos, link Concurso do Estado do Paraná, 


\section{ESTADO DO PARANÁ \\ Secretaria de Estado da Administração e da Previdência \\ Departamento de Recursos Humanos}

até a data da homologação do resultado final do Concurso Público. Após, o endereço deverá ser mantido atualizado, pelo candidato, junto ao Departamento de Recursos Humanos da Secretaria de Administração e da Previdência - DRH/SEAP, sito à rua Jacy Loureiro de Campos, S/N, 2ํAㄱar - Centro Cívico - CEP 80.530140, Curitiba / PR, através de correspondência, para a hipótese do referido órgão julgar necessário o contato individual.

17.13. Fazendo uso da prerrogativa prevista no subitem 17.12 deste Edital, a PUCPR e a SEAP não se responsabilizarão por eventuais prejuízos decorrentes de:

a) Endereço não atualizado;

b) Endereço de difícil acesso;

c) Correspondência devolvida pela ECT por razões de informação de endereço errado do candidato;

d) Correspondência recebida por terceiros.

17.14. Os casos omissos serão resolvidos pelo Departamento de Recursos Humanos da Secretaria de Estado da Administração e da Previdência - DRH/SEAP.

Curitiba, 18 de fevereiro de 2013.

Sandra Regina Sellucio Marques

Diretora do Departamento de Recursos Humanos 


\section{ESTADO DO PARANÁ \\ Secretaria de Estado da Administração e da Previdência \\ Departamento de Recursos Humanos}

\section{ANEXO I DO EDITAL № 17/2013 - DISTRIBUIÇÃO DE VAGAS}

\begin{tabular}{|c|c|c|c|c|c|c|c|c|c|c|c|c|c|c|c|c|c|}
\hline \multicolumn{18}{|c|}{$\begin{array}{l}\text { DISTRIBUIÇÃO DE VAGAS POR NÚCLEO REGIONAL DE EDUCAÇÃO } \\
\text { AMPLA CONCORRÊNCIA }\end{array}$} \\
\hline & NRE & 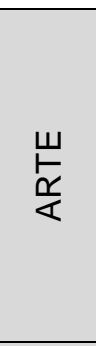 & 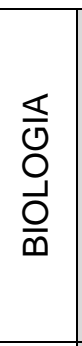 & 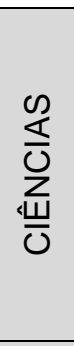 & 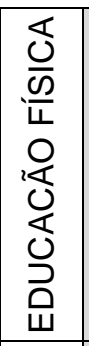 & 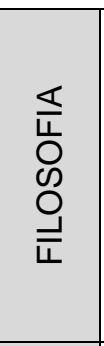 & $\frac{\frac{\pi}{O}}{\frac{\mathscr{S}}{4}}$ & 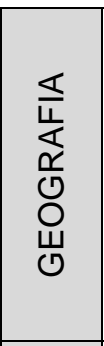 & 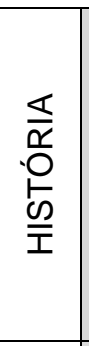 & 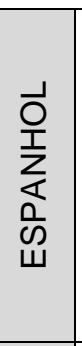 & 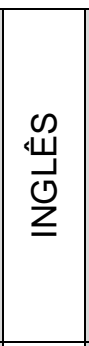 & 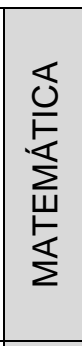 & 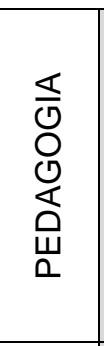 & 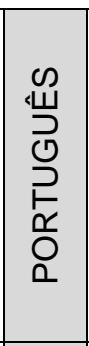 & 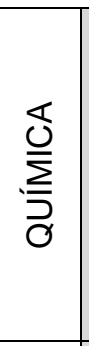 & 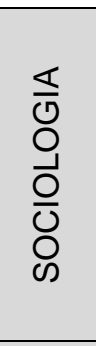 & $\begin{array}{l}\frac{1}{\leftarrow} \\
\stackrel{0}{\circ}\end{array}$ \\
\hline 1 & APUCARANA & 60 & 8 & 2 & 2 & 46 & 12 & 2 & 3 & 4 & 3 & 1 & 48 & 6 & 1 & 57 & 255 \\
\hline 2 & ÁREA METROP. NORTE & 172 & 12 & 71 & 19 & 46 & 63 & 179 & 8 & 34 & 80 & 171 & 122 & 9 & 57 & 100 & 1143 \\
\hline 3 & ÁREA METROP. SUL & 144 & 5 & 89 & 13 & 78 & 88 & 193 & 0 & 31 & 75 & 171 & 81 & 24 & 69 & 114 & 1175 \\
\hline 4 & ASSIS CHATEAUBRIAND & 18 & 2 & 3 & 2 & 12 & 4 & 2 & 17 & 1 & 2 & 1 & 11 & 6 & 4 & 15 & 100 \\
\hline 5 & CAMPO MOURÃO & 34 & 12 & 3 & 12 & 46 & 21 & 0 & 32 & 11 & 2 & 1 & 22 & 6 & 6 & 49 & 257 \\
\hline 6 & CASCAVEL & 122 & 5 & 3 & 23 & 47 & 54 & 69 & 3 & 20 & 26 & 0 & 46 & 6 & 18 & 77 & 519 \\
\hline 7 & CIANORTE & 27 & 3 & 2 & 6 & 20 & 8 & 0 & 1 & 5 & 4 & 1 & 16 & 1 & 2 & 25 & 121 \\
\hline 8 & CORNÉLIO PROCÓPIO & 43 & 4 & 2 & 4 & 37 & 4 & 12 & 15 & 11 & 6 & 1 & 0 & 1 & 2 & 40 & 182 \\
\hline 9 & CURITIBA & 34 & 13 & 27 & 6 & 122 & 68 & 81 & 2 & 15 & 119 & 1 & 63 & 20 & 3 & 220 & 794 \\
\hline 10 & DOIS VIZINHOS & 19 & 2 & 3 & 4 & 7 & 2 & 0 & 4 & 4 & 2 & 1 & 16 & 6 & 2 & 10 & 82 \\
\hline 11 & FOZ DO IGUAÇU & 117 & 6 & 6 & 8 & 66 & 43 & 21 & 22 & 15 & 57 & 27 & 53 & 1 & 25 & 73 & 540 \\
\hline 12 & FRANCISCO BELTRÃO & 44 & 4 & 4 & 22 & 39 & 5 & 17 & 60 & 11 & 42 & 1 & 68 & 17 & 2 & 46 & 382 \\
\hline 13 & GOIOERÊ & 29 & 2 & 2 & 3 & 22 & 5 & 0 & 9 & 10 & 1 & 1 & 14 & 1 & 3 & 22 & 124 \\
\hline 14 & GUARAPUAVA & 90 & 12 & 18 & 37 & 29 & 12 & 13 & 26 & 15 & 21 & 2 & 80 & 37 & 16 & 46 & 54 \\
\hline 32 & IBAITI & 8 & 2 & 2 & 2 & 18 & 6 & 34 & 2 & 4 & 0 & 1 & 3 & 1 & 2 & 18 & 103 \\
\hline 15 & IRATI & 72 & 10 & 12 & 20 & 29 & 15 & 28 & 16 & 13 & 15 & 5 & 54 & 22 & 12 & 37 & 360 \\
\hline 16 & IVAIPORÃ & 46 & 4 & 0 & 5 & 31 & 15 & 2 & 12 & 8 & 5 & 0 & 21 & 1 & 6 & 30 & 186 \\
\hline 17 & JACAREZINHO & 3 & 4 & 2 & 0 & 30 & 2 & 19 & 0 & 5 & 1 & 0 & 0 & 0 & 1 & 36 & 103 \\
\hline 31 & LARANJEIRAS DO SUL & 66 & 20 & 15 & 21 & 34 & 15 & 36 & 35 & 27 & 19 & 21 & 21 & 34 & 4 & 38 & 406 \\
\hline 20 & LOANDA & 26 & 5 & 2 & 2 & 13 & 9 & 2 & 10 & 2 & 2 & 1 & 9 & 1 & 3 & 17 & 104 \\
\hline 18 & LONDRINA & 50 & 19 & 47 & 20 & 74 & 29 & 61 & 47 & 10 & 65 & 44 & 63 & 12 & 2 & 71 & 614 \\
\hline 19 & MARINGÁ & 94 & 12 & 13 & 13 & 67 & 9 & 9 & 15 & 12 & 30 & 1 & 23 & 1 & 6 & 98 & 403 \\
\hline 21 & PARANAGUÁ & 86 & 18 & 38 & 5 & 42 & 35 & 70 & 2 & 11 & 20 & 6 & 32 & 6 & 30 & 47 & 448 \\
\hline 22 & PARANAVAÍ & 32 & 8 & 4 & 4 & 31 & 15 & 20 & 12 & 2 & 1 & 1 & 20 & 9 & 6 & 32 & 197 \\
\hline 23 & PATO BRANCO & 73 & 8 & 4 & 1 & 25 & 6 & 22 & 4 & 13 & 11 & 2 & 0 & 9 & 2 & 46 & 226 \\
\hline 24 & PITANGA & 26 & 2 & 2 & 4 & 18 & 4 & 1 & 3 & 10 & 2 & 1 & 12 & 2 & 4 & 22 & 113 \\
\hline 25 & PONTA GROSSA & 187 & 19 & 46 & 27 & 84 & 15 & 47 & 17 & 3 & 64 & 26 & 74 & 53 & 18 & 100 & 780 \\
\hline 26 & TELÊMACO BORBA & 64 & 12 & 19 & 34 & 35 & 8 & 39 & 30 & 15 & 16 & 39 & 8 & 20 & 25 & 33 & 397 \\
\hline 27 & TOLEDO & 87 & 4 & 17 & 2 & 36 & 21 & 9 & 0 & 13 & 21 & 0 & 51 & 1 & 2 & 54 & 318 \\
\hline 28 & UMUARAMA & 63 & 8 & 9 & 2 & 36 & 27 & 20 & 2 & 3 & 20 & 1 & 16 & 1 & 6 & 43 & 257 \\
\hline 29 & UNIÃO DA VITÓRIA & 63 & 2 & 0 & 4 & 31 & 25 & 2 & 1 & 3 & 2 & 0 & 30 & 2 & 3 & 30 & 198 \\
\hline 30 & WENCESLAU BRAZ & 29 & 6 & 6 & 27 & 23 & 17 & 43 & 2 & 6 & 12 & 2 & 25 & 2 & 12 & 23 & 235 \\
\hline & Total Geral & 2028 & 253 & 473 & 354 & 1274 & 662 & 1053 & 412 & 347 & 746 & 531 & 1102 & 318 & 354 & 1669 & 11576 \\
\hline
\end{tabular}




\section{ESTADO DO PARANÁ}

\section{Secretaria de Estado da Administração e da Previdência Departamento de Recursos Humanos}

\begin{tabular}{|c|c|c|c|c|c|c|c|c|c|c|c|c|c|c|c|c|c|}
\hline \multicolumn{18}{|c|}{$\begin{array}{c}\text { DISTRIBUIÇÃO DE VAGAS POR NÚCLEO REGIONAL DE EDUCAÇÃO } \\
\text { PCD - PESSOA COM DEFICIÊNCIA }\end{array}$} \\
\hline & NRE & 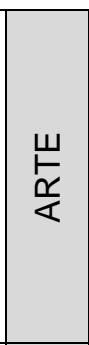 & $\begin{array}{l}\frac{\square}{0} \\
0 \\
\text { O } \\
\frac{0}{0}\end{array}$ & $\frac{0}{\frac{0}{\Delta}}$ & 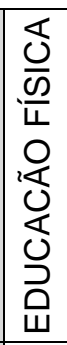 & 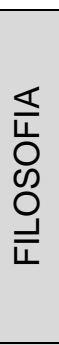 & $\frac{\frac{\delta}{D}}{\frac{D}{L}}$ & 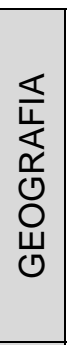 & 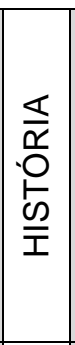 & 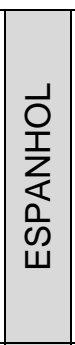 & 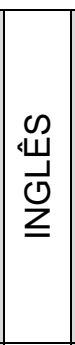 & 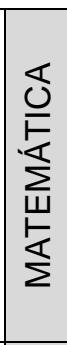 & 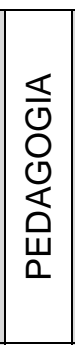 & 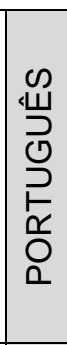 & 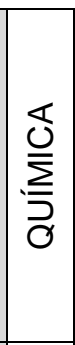 & 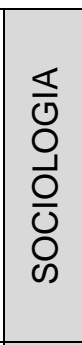 & $\begin{array}{l}\frac{1}{\leqslant} \\
\stackrel{0}{0} \\
\vdash\end{array}$ \\
\hline 1 & APUCARANA & 4 & 1 & 0 & 0 & 3 & 1 & 0 & 0 & 0 & 0 & 0 & 3 & 1 & 0 & 4 & 17 \\
\hline 2 & ÁREA METROP. NORTE & 11 & 1 & 5 & 2 & 3 & 4 & 11 & 1 & 3 & 5 & 11 & 8 & 1 & 4 & 6 & 76 \\
\hline 3 & ÁREA METROP. SUL & 9 & 1 & 6 & 1 & 5 & 6 & 12 & 0 & 2 & 5 & 11 & 5 & 2 & 5 & 7 & 77 \\
\hline 4 & ASSIS CHATEAUBRIAI & 2 & 0 & 0 & 0 & 1 & 0 & 0 & 1 & 0 & 0 & 0 & 1 & 1 & 0 & 1 & 7 \\
\hline 5 & CAMPO MOURÃO & 2 & 1 & 0 & 1 & 3 & 2 & 0 & 2 & 1 & 0 & 0 & 2 & 1 & 1 & 3 & 19 \\
\hline 6 & CASCAVEL & 8 & 1 & 0 & 2 & 3 & 4 & 5 & 0 & 2 & 2 & 0 & 3 & 1 & 2 & 5 & 38 \\
\hline 7 & CIANORTE & 2 & 0 & 0 & 1 & 2 & 1 & 0 & 0 & 1 & 0 & 0 & 1 & 0 & 0 & 2 & 10 \\
\hline 8 & CORNÉLIO PROCÓPIO & 3 & 1 & 0 & 0 & 2 & 0 & 1 & 1 & 1 & 1 & 0 & 0 & 0 & 0 & 3 & 13 \\
\hline 9 & CURITIBA & 2 & 1 & 2 & 1 & 8 & 4 & 5 & 0 & 1 & 7 & 0 & 4 & 2 & 0 & 13 & 50 \\
\hline 10 & DOIS VIZINHOS & 2 & 0 & 0 & 0 & 1 & 0 & 0 & 0 & 0 & 0 & 0 & 1 & 1 & 0 & 1 & 6 \\
\hline 11 & FOZ D & 7 & 1 & 1 & 1 & 4 & 3 & 2 & 2 & 1 & 4 & 2 & 4 & 0 & 2 & 5 & 39 \\
\hline 12 & FRAI & 3 & 1 & 1 & 2 & 3 & 1 & 1 & 4 & 1 & 3 & 0 & 4 & 1 & 0 & 3 & 28 \\
\hline 13 & GOIOERÊ & 2 & 0 & 0 & 0 & 2 & 1 & 0 & 1 & 1 & 0 & 0 & 1 & 0 & 0 & 2 & 10 \\
\hline 14 & GUARAPUAVA & 6 & 1 & 2 & 3 & 2 & 1 & 1 & 2 & 1 & 2 & 0 & 5 & 3 & 1 & 3 & 33 \\
\hline 32 & IBAITI & 1 & 0 & 0 & 0 & 2 & 1 & 2 & 0 & 0 & 0 & 0 & 1 & 0 & 0 & 2 & 9 \\
\hline 15 & IRATI & 5 & 1 & 1 & 2 & 2 & 1 & 2 & 1 & 1 & 1 & 1 & 4 & 2 & 1 & 3 & 28 \\
\hline 16 & IVAIPORÃ & 3 & 0 & 0 & 1 & 2 & 1 & 0 & 1 & 1 & 1 & 0 & 2 & 0 & 1 & 2 & 15 \\
\hline 17 & JAC & 0 & 0 & 0 & 0 & 2 & 0 & 2 & 0 & 1 & 0 & 0 & 0 & 0 & 0 & 3 & 8 \\
\hline 31 & LARANJEI & 4 & 2 & 1 & 2 & 2 & 1 & 3 & 3 & 2 & 2 & 2 & 2 & 3 & 0 & 3 & 32 \\
\hline 20 & LOANDA & 2 & 0 & 0 & 0 & 1 & 1 & 0 & 1 & 0 & 0 & 0 & 1 & 0 & 0 & 1 & 7 \\
\hline 18 & LONDRINA & 3 & 2 & 3 & 2 & 5 & 2 & 4 & 3 & 1 & 4 & 3 & 4 & 1 & 0 & 5 & 42 \\
\hline 19 & MARINGÁ & 6 & 1 & 1 & 1 & 4 & 1 & 1 & 1 & 1 & 2 & 0 & 2 & 0 & 1 & 6 & 28 \\
\hline 21 & PARANAGUÁ & 6 & 2 & 3 & 1 & 3 & 3 & 5 & 0 & 1 & 2 & 1 & 2 & 1 & 2 & 3 & 35 \\
\hline 22 & PARANAVAÍ & 2 & 1 & 0 & 0 & 2 & 1 & 2 & 1 & 0 & 0 & 0 & 2 & 1 & 1 & 2 & 15 \\
\hline 23 & PATO & 5 & 1 & 1 & 0 & 2 & 1 & 2 & 0 & 1 & 1 & 0 & 0 & 1 & 0 & 3 & 18 \\
\hline 24 & PITANGA & 2 & 0 & 0 & 0 & 2 & 0 & 0 & 0 & 1 & 0 & 0 & 1 & 0 & 1 & 2 & 9 \\
\hline 25 & PONTA GROSSA & 11 & 2 & 3 & 2 & 5 & 1 & 3 & 1 & 1 & 4 & 2 & 5 & 4 & 2 & 6 & 52 \\
\hline 26 & TELÊMACO BORBA & 4 & 1 & 2 & 2 & 2 & 1 & 3 & 2 & 1 & 1 & 3 & 1 & 2 & 2 & 2 & 29 \\
\hline 27 & TOLEDO & 6 & 0 & 1 & 0 & 3 & 2 & 1 & 0 & 1 & 2 & 0 & 4 & 0 & 0 & 4 & 24 \\
\hline 28 & UMUARAMA & 4 & 1 & 1 & 0 & 3 & 2 & 2 & 0 & 0 & 2 & 0 & 1 & 0 & 1 & 3 & 20 \\
\hline 29 & UNIÃO DA VITÓRIA & 4 & 0 & 0 & 1 & 2 & 2 & 0 & 0 & 1 & 0 & 0 & 2 & 0 & 0 & 2 & 14 \\
\hline 30 & WENCESLAU BRAZ & 2 & 1 & 1 & 2 & 2 & 1 & 3 & 0 & 1 & 1 & 0 & 2 & 0 & 1 & 2 & 19 \\
\hline & Total Geral & 133 & 25 & 35 & 30 & 88 & 50 & 73 & 28 & 30 & 52 & 36 & 78 & 29 & 28 & 112 & 827 \\
\hline
\end{tabular}




\section{ESTADO DO PARANÁ}

\section{Secretaria de Estado da Administração e da Previdência Departamento de Recursos Humanos}

\begin{tabular}{|c|c|c|c|c|c|c|c|c|c|c|c|c|c|c|c|c|c|}
\hline \multicolumn{18}{|c|}{$\begin{array}{l}\text { DISTRIBUIÇÃO DE VAGAS POR NÚCLEO REGIONAL DE EDUCAÇÃO } \\
\text { AFRODESCENDENTE }\end{array}$} \\
\hline & NRE & 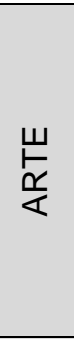 & 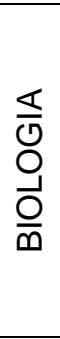 & 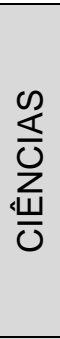 & 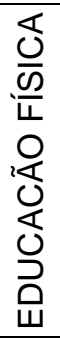 & 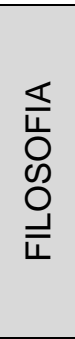 & $\frac{\mathbb{U}}{\frac{D}{L}}$ & 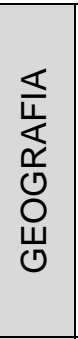 & 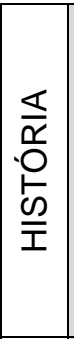 & 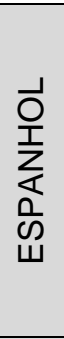 & 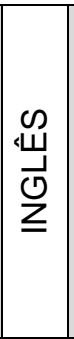 & 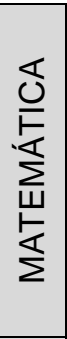 & 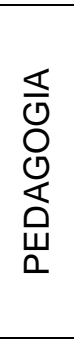 & 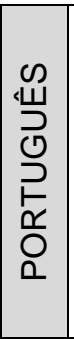 & 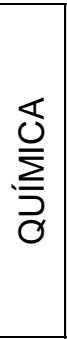 & 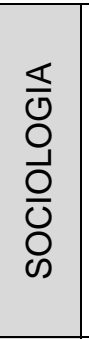 & $\begin{array}{l}\underset{\leftarrow}{\mathbb{E}} \\
\stackrel{0}{\circ}\end{array}$ \\
\hline 1 & APUCARANA & 7 & 1 & 0 & 0 & 5 & 2 & 0 & 0 & 0 & 0 & 0 & 6 & 1 & 0 & 7 & 29 \\
\hline 2 & ÁREA METROP. NORTE & 20 & 1 & 8 & 2 & 5 & 7 & 21 & 1 & 4 & 10 & 20 & 15 & 1 & 7 & 12 & 134 \\
\hline 3 & ÁREA METROP. SUL & 17 & 1 & 11 & 2 & 9 & 10 & 23 & 0 & 4 & 9 & 20 & 10 & 3 & 8 & 14 & 141 \\
\hline 4 & ASSIS CHATEAUBRIAND & 2 & 0 & 0 & 0 & 1 & 0 & 0 & 2 & 0 & 0 & 0 & 1 & 1 & 0 & 2 & 9 \\
\hline 5 & CAMPO MOURÃO & 4 & 2 & 0 & 1 & 5 & 3 & 0 & 4 & 1 & 0 & 0 & 3 & 1 & 1 & 6 & 31 \\
\hline 6 & CASCAVEL & 14 & 1 & 0 & 3 & 6 & 6 & 8 & 0 & 2 & 3 & 0 & 6 & 1 & 2 & 9 & 61 \\
\hline 7 & CIANORTE & 3 & 0 & 0 & 1 & 3 & 1 & 0 & 0 & 1 & 0 & 0 & 2 & 0 & 0 & 3 & 14 \\
\hline 8 & CORNÉLIO PROCÓPIO & 5 & 1 & 0 & 0 & 4 & 0 & 1 & 2 & 1 & 1 & 0 & 0 & 0 & 0 & 5 & 20 \\
\hline 9 & CURITIBA & 4 & 2 & 3 & 1 & 15 & 8 & 10 & 0 & 2 & 14 & 0 & 7 & 2 & 0 & 26 & 94 \\
\hline 10 & DOIS VIZINHOS & 2 & 0 & 0 & 0 & 1 & 0 & 0 & 0 & 0 & 0 & 0 & 2 & 1 & 0 & 1 & 7 \\
\hline 11 & FOZ DO IGUAÇU & 14 & 1 & 1 & 1 & 8 & 5 & 3 & 3 & 2 & 7 & 3 & 6 & 0 & 3 & 9 & 66 \\
\hline 12 & FRANCISCO BELTRÃO & 5 & 1 & 1 & 3 & 5 & 1 & 2 & 7 & 1 & 5 & 0 & 8 & 2 & 0 & 5 & 46 \\
\hline 13 & GOIOERE & 3 & 0 & 0 & 0 & 3 & 1 & 0 & 1 & 1 & 0 & 0 & 2 & 0 & 0 & 3 & 14 \\
\hline 14 & GUARA & 11 & 1 & 2 & 4 & 4 & 1 & 2 & 3 & 2 & 3 & 0 & 9 & 5 & 2 & 5 & 54 \\
\hline 32 & IBAITI & 1 & 0 & 0 & 0 & 2 & 1 & 4 & 0 & 0 & 0 & 0 & 1 & 0 & 0 & 2 & 11 \\
\hline 15 & RATI & 9 & 1 & 1 & 2 & 4 & 2 & 4 & 2 & 2 & 2 & 1 & 6 & 3 & 2 & 4 & 45 \\
\hline 16 & IVAIPORÃ & 6 & 0 & 0 & 1 & 4 & 2 & 0 & 1 & 1 & 1 & 0 & 3 & 0 & 1 & 4 & 24 \\
\hline 17 & JACAREZINHO & 0 & 0 & 0 & 0 & 4 & 0 & 2 & 0 & 1 & 0 & 0 & 0 & 0 & 0 & 4 & 11 \\
\hline 31 & IRAS DO SUL & 8 & 2 & 2 & 3 & 4 & 2 & 4 & 4 & 3 & 2 & 3 & 3 & 4 & 0 & 5 & 49 \\
\hline 20 & LOANDA & 3 & 1 & 0 & 0 & 2 & 1 & 0 & 1 & 0 & 0 & 0 & 1 & 0 & 0 & 2 & 11 \\
\hline 18 & LONDRINA & 6 & 2 & 6 & 2 & 9 & 3 & 7 & 6 & 1 & 8 & 5 & 7 & 2 & 0 & 8 & 72 \\
\hline 19 & MARINGÁ & 11 & 1 & 2 & 2 & 8 & 1 & 1 & 2 & 1 & 4 & 0 & 3 & 0 & 1 & 12 & 49 \\
\hline 21 & PARANAGUÁ & 10 & 2 & 5 & 1 & 5 & 4 & 8 & 0 & 1 & 3 & 1 & 4 & 1 & 4 & 6 & 55 \\
\hline 22 & PARANAVAÍ & 4 & 1 & 0 & 0 & 4 & 2 & 2 & 1 & 0 & 0 & 0 & 2 & 1 & 1 & 4 & 22 \\
\hline 23 & PATO BRANCO & 9 & 1 & 1 & 0 & 3 & 1 & 3 & 0 & 2 & 1 & 0 & 0 & 1 & 0 & 5 & 27 \\
\hline 24 & PITANGA & 3 & 0 & 0 & 0 & 2 & 0 & 0 & 0 & 1 & 0 & 0 & 2 & 0 & 1 & 3 & 12 \\
\hline 25 & PONTA GROSSA & 22 & 2 & 5 & 3 & 10 & 2 & 6 & 2 & 1 & 8 & 3 & 9 & 6 & 2 & 12 & 93 \\
\hline 26 & TELÊMACO BORBA & 8 & 2 & 2 & 4 & 4 & 1 & 5 & 4 & 2 & 2 & 5 & 1 & 2 & 3 & 4 & 49 \\
\hline 27 & TOLEDO & 10 & 0 & 2 & 0 & 4 & 3 & 1 & 0 & 2 & 3 & 0 & 6 & 0 & 0 & 6 & 37 \\
\hline 28 & UMUARAMA & 8 & 1 & 1 & 0 & 4 & 3 & 2 & 0 & 0 & 2 & 0 & 2 & 0 & 1 & 5 & 29 \\
\hline 29 & UNIÃO DA VITÓRIA & 7 & 0 & 0 & 1 & 4 & 3 & 0 & 0 & 1 & 0 & 0 & 4 & 0 & 0 & 4 & 24 \\
\hline 30 & WENCESLAU BRAZ & 4 & 1 & 1 & 3 & 3 & 2 & 5 & 0 & 1 & 1 & 0 & 3 & 0 & 1 & 3 & 28 \\
\hline & Total Geral & 240 & 29 & 54 & 40 & 154 & 78 & 124 & 46 & 41 & 89 & 61 & 134 & 38 & 40 & 200 & 1368 \\
\hline
\end{tabular}




\section{ESTADO DO PARANÁ}

Secretaria de Estado da Administração e da Previdência

Departamento de Recursos Humanos

ANEXO II DO EDITAL № 17/2013 - RELAÇÃO DE NÚCLEOS REGIONAIS SEDE DE PROVA

\begin{tabular}{|l|l|}
\hline NÚCLEO SEDE DE PROVA & NÚCLEOS DE INSCRIÇÃO \\
\hline CAMPO MOURÃO & IVAIPORÃ \\
& PITANGA \\
& CAMPO MOURÃO \\
\hline CASCAVEL & ASSIS CHATEAUBRIAND \\
& $\begin{array}{l}\text { TOLEDO } \\
\text { CASCAVEL }\end{array}$ \\
\hline CURITIBA & ÁREA METROPOLITANA NORTE \\
& ÁREA METROPOLITANA SUL \\
FURITIBA
\end{tabular}




\title{
递 \\ ESTADO DO PARANÁ \\ Secretaria de Estado da Administração e da Previdência \\ Departamento de Recursos Humanos
}

\section{ANEXO III DO EDITAL № 17/2013 - PROGRAMA}

\author{
ATUALIDADES \\ Tópicos relevantes e atuais em diversas áreas, tais como: segurança, transportes, política, economia, \\ sociedade, educação, saúde, cultura, tecnologia, energia, relações internacionais, desenvolvimento sustentável \\ e ecologia, suas inter-relações e suas vinculações históricas.

\section{INFORMÁTICA} \\ Conceitos e modos de utilização de aplicativos para edição de textos, planilhas, apresentações didáticas em \\ mídias e Internet. Conceitos de organização e de gerenciamento de informações, arquivos, pastas e programas.

\section{FUNDAMENTOS DA EDUCAÇÃO - DISCIPLINAS DOS ANOS FINAIS DO ENSINO FUNDAMENTAL E ENSINO MÉDIO}

1. Tendências e concepções pedagógicas; 1.1 A educação e suas relações socioeconômicas

políticas e culturais; 1.2 As relações entre educação, trabalho e cidadania; 1.3 Inclusão educacional e diversidade; 1.4 Função social da escola. 2. Estrutura educacional brasileira; 2.1 Sistema educacional brasileiro: níveis e modalidades de ensino; 2.2 Legislação: Lei no 9394/96 LDBEN, Lei oㅜ 8.069/90 ECA, Lei no 10639/03 História e cultura afro-brasileira e africana 2.3 As Diretrizes Curriculares Nacionais e Estadual para a educação básica. 3. Elementos da prática pedagógica; 3.1Organização da escola e instâncias colegiadas; 3.2 Saberes escolares, método didático, avaliação escolar, recursos didáticos e o uso de novas tecnologias da informação e comunicação na educação. 3.3 Projeto Político-Pedagógico da escola. 3.4 Gestão Democrática.

ARTE - CONHECIMENTOS ESPECÍFICOS: Histórico da Disciplina no Brasil e Estado do Paraná: a história do ensino de Arte no Brasil. Fundamentos teóricos da Arte (Música, Dança, Teatro e Artes Visuais). Influência estrangeira e sua incorporação ao ensino brasileiro: período colonial e império; da primeira república até 1960. A lei no 5692/71 e sua vigência na escola pública. Os movimentos dos anos 80 .O Currículo Básico para as Escolas Públicas do Paraná (1992). As Diretrizes Curriculares Orientadoras da Educação Básica para a Rede Estadual de Ensino (DCEs) - Arte. Fundamentação Teórica: teorias críticas da arte que têm como ponto de referência o materialismo histórico dialético. Filosofia da Arte. Sociologia da Arte: função social da arte. Psicologia da Arte. Cultura popular, erudita, Indústria Cultural e as novas tecnologias na arte contemporânea. Interpretações da arte na sociedade: arte como ideologia, arte como forma de conhecimento, arte como trabalho criador. Conteúdos Estruturantes: Elementos Formais. Composição. Movimentos e períodos. ARTES VISUAIS. ELEMENTOS FORMAIS: linha, forma, superfície, volume, luz, cor, textura. COMPOSIÇÃO: bidimensional, tridimensional, figurativo, abstrato, cânones clássicos, composição cromática, perspectiva, planos, profundidade, semelhanças, contrastes, ritmo visual, simetria, proporção, técnica: pintura, fotografia, desenho, gravura, pontilhismo, grafitti, escultura, arquitetura, audiovisual. Gêneros: retrato, natureza morta, paisagem. MOVIMENTOS E PERÍODOS: Arte na pré-história, arte no antigo Egito, arte greco-romana, arte medieval, arte românica e gótica, renascimento, barroco, romantismo, realismo, impressionismo, expressionismo, cubismo, abstracionismo, dadaísmo, surrealismo, pop art, arte contemporânea, arte brasileira, arte paranaense, indústria cultural, arte latino-americana, arte brasileira, arte afro-brasileira, arte africana e indígena. DANÇA. ELEMENTOS FORMAIS: movimento corporal, tempo, espaço. COMPOSIÇÃO: peso, salto e queda, fluxo, eixo, giro, movimentos articulares, aceleração e desaceleração, ponto de apoio, rolamento, lento, médio e rápido, níveis, deslocamento, direções, planos, coreografia, rotação, formação. Gêneros: étnica, popular, salão. Técnica: Improvisação. MOVIMENTOS E PERÍODOS: dança circular, dança oriental, dança clássica, dança moderna, dança contemporânea, hip-hop, indústria cultural, dança indígena. TEATRO. ELEMENTOS FORMAIS: personagem: expressões corporais, vocais, gestuais e faciais, ação, espaço. COMPOSIÇÃO: representação, texto dramático, cenografia, roteiro, sonoplastia, iluminação, figurino, adereços, máscara, caracterização e maquiagem. Gêneros: tragédia, comédia, drama, épico, de rua. Técnicas: teatro direto e indireto, improvisação, monólogo, jogos teatrais, direção, produção. MOVIMENTOS E PERÍODOS: Teatro Greco-romano, Teatro Renascentista, teatro do oprimido, teatro dialético, teatro pobre, teatro do absurdo, teatro engajado, teatro brasileiro, teatro paranaense, teatro popular. MÚSICA. ENSINO FUNDAMENTAL E MEDIO. CONTEÚDOS ESTRUTURANTES. Conteúdos básicos específicos de música, para as séries do ensino fundamental e médio. 1. ELEMENTOS FORMAIS: altura; duração; timbre; intensidade; densidade. 2. COMPOSIÇÃO: elementos da música: ritmo, melodia, harmonia, escalas: modal, tonal, diatônicas, pentatônicas, cromáticas. Gêneros musicais: erudito, clássico, popular brasileira, étnico, folclórico, pop, rock. Técnicas: improvisação, vocal, instrumental, eletrônica e mista 3. MOVIMENTOS E PERíODOS. 
Música Popular Brasileira, Indústria Cultural, Engajada, Vanguarda, Ocidental Oriental, Tropicália, Jovem Guarda, Africana, Latino-Americana, Paranaense, Contemporânea.

BIOLOGIA - CONHECIMENTOS ESPECíFICOS: Concepções de ciência e de método na construção histórica do conhecimento biológico; concepção contemporânea de ciência como atividade humana; concepções sobre o fenômeno Vida em diferentes contextos históricos e socioculturais, conforme as Diretrizes Curriculares Orientadoras da Educação Básica para a Rede Estadual de Ensino de Biologia (DCEs) - Biologia. História da disciplina no Brasil. Classificação dos seres vivos: critérios taxonômicos e filogenéticos. Sistemas biológicos: anatomia, morfologia e fisiologia. Mecanismos de desenvolvimento embriológico; embriologia comparada dos diferentes seres vivos; histórico e evolução das observações celulares; mecanismos celulares biofísicos e bioquímicos. Teorias evolutivas; teorias sobre o surgimento dos primeiros seres vivos; estratégias de adaptação e sobrevivência dos seres vivos ao longo do processo evolutivo. Formas de transmissão das características hereditárias e o papel do ambiente; diversidade dos seres vivos e diferentes níveis de organização; dinâmica dos ecossistemas: relações entre os seres vivos e estes com o ambiente. Organismos geneticamente modificados. Biotecnologia e bioética.

CIÊNCIAS - CONHECIMENTOS ESPECÍFICOS: Concepções de ciência e de método científico; concepção contemporânea de ciência como atividade humana. História da Ciência e a popularização do conhecimento científico em diferentes contextos históricos e socioculturais, conforme as Diretrizes Curriculares Orientadoras da Educação Básica para a Rede Estadual de Ensino (DCEs) - Ciências. o Ensino de Ciências e a história da disciplina de Ciências no currículo das escolas brasileiras; formação de conceitos científicos e a aprendizagem significativa no Ensino de Ciências; as relações entre a Ciência, a Tecnologia e a Sociedade. Conhecimentos sobre Astronomia: dentre eles sobre o universo, o sistema solar, os movimentos celestes e terrestres, os astros, a origem e a evolução do universo, a gravitação universal. Matéria: constituição e propriedades da matéria. Sistemas Biológicos: dentre eles sobre os níveis de organização dos seres vivos, os mecanismos celulares, morfologia e fisiologia dos seres vivos, embriologia comparada, mecanismos de herança genética. Energia: as formas de energia, bem como sobre a conservação, a conversão e a transmissão de energia. Biodiversidade: dentre eles a organização dos seres vivos, a sistemática, os ecossistemas, as interações ecológicas, as teorias da origem da vida e a evolução dos seres vivos.

EDUCAÇÃO FÍSICA - CONHECIMENTOS ESPECÍFICOS: Concepção e conteúdos, conforme as Diretrizes Curriculares Orientadoras da Educação Básica para a Rede Estadual de Ensino (DCEs) - Educação Física. Dimensão Histórica da Educação Física. Fundamentos Teóricos Metodológicos da Educação Física. Cultura Corporal. Os conteúdos a serem desenvolvidos são esporte, lutas, dança, ginástica, jogos e brincadeiras. Esses são os saberes de grande amplitude e de tradição da disciplina. Esses conteúdos não são vistos de forma fragmentada, mas podem sofrer um processo de ressignificação ao longo da história. Esporte: coletivos, individuais e radicais. Lutas: de aproximação, que mantém a distância, com instrumento mediador, capoeira. Dança: folclóricas, de salão, de rua, criativas e circulares. Ginástica: artística/olímpica, rítmica, de condicionamento físico, circense, geral. Jogos e Brincadeiras: jogos cooperativos, de tabuleiro, dramáticos, brincadeiras e cantigas de roda, jogos e brincadeiras populares.

FILOSOFIA - CONHECIMENTOS ESPECÍ́FICOS: Dimensões históricas do ensino de Filosofia no Brasil e no Paraná. Fundamentos teórico-metodológicos do ensino de Filosofia. Conteúdos estruturantes e conteúdos básicos conforme Diretrizes Curriculares Orientadoras da Educação Básica para a Rede Estadual de Ensino (DCEs)- Filosofia: Mito e Filosofia: Saber mítico; Saber filosófico; Relação Mito e Filosofia. Atualidade do mito. O que é Filosofia? Teoria do Conhecimento: possibilidade do conhecimento. As formas de conhecimento. O problema da verdade. A questão do método. Conhecimento e lógica. Ética: ética e moral. Pluralidade ética. Ética e violência. Razão, desejo e vontade. Liberdade: autonomia do sujeito e necessidade das normas. Filosofia Política: Relações entre comunidade e poder. Liberdade e igualdade política. Política e Ideologia. Esfera pública e privada. Filosofia da Ciência: Concepções de ciência. A questão do método científico. Contribuições e limites da ciência. Ciência e ideologia. Ciência e ética. Estética: Natureza da arte. Filosofia e arte. Categorias estéticas - feio, belo, sublime, trágico, cômico, grotesco, gosto etc. Estética e sociedade.

FíSICA - CONHECIMENTOS ESPECÍFICOS: Concepção da disciplina de Física em conformidade com as Diretrizes Curriculares Orientadoras da Educação Básica para a Rede Estadual de Ensino (DCEs) - Física. Medidas físicas e unidades. Análise dimensional. Ordens de grandeza. Movimento de translação e o conceito de partícula. As leis de Newton. Dinâmica da partícula. Aplicações das leis de Newton. Forças de atrito. Forças 


\section{(1) \\ ESTADO DO PARANÁ \\ Secretaria de Estado da Administração e da Previdência \\ Departamento de Recursos Humanos}

no movimento circular. Observações inerciais e não inerciais. Limitações da Mecânica Clássica. Conservação da energia. Trabalho de uma força. Teorema do trabalho-energia cinética. Forças conservativas. Energia potencial elástica e energia potencial gravitacional. Conservação da energia mecânica. Forças não conservativas. Conservação da energia. Potência. Conservação do momento linear e colisões. Centro de massa. Movimento do centro de massa. Momento linear de um sistema de partículas. Princípio da conservação do momento linear. Impulso de uma força. Colisões. Os modelos geocêntrico do universo: Eudoxo, Ptolomeu e Brahe. O Modelo copernicano. Galileu e a teoria copernicana. A estrutura do universo kepleriano. Newton e gravitação universal. Introdução à relatividade restrita. Movimento Harmônico Simples (MHS). Energia no MHS. Movimento ondulatório simples. Ondas Harmônicas: na corda e sonoras. Reflexão. Refração. Difração. Efeito Doppler. Superposição de ondas. Ondas estacionárias. Densidade. Pressão. Empuxo. Equação de Bernoulli. Equilíbrio térmico. Escalas de temperatura. Termometria. Gases ideais. Capacidade calorífica. Mudanças de fase de agregação. Primeira lei da termodinâmica. Energia interna. Trabalho e diagrama P-V. Expansão quaseestática de um gás. Segunda lei da termodinâmica. Máquinas térmicas. Refrigeradores. Enunciados de Kelvin. Enunciado de Clausius. A máquina de Carnot. Irreversibilidade e desordem. Entropia de gás ideal. Variações de entropia. Carga Elétrica. Lei de Coulomb. Condutores e isolantes. Campo Elétrico. Campo elétrico de carga puntual. Campo elétrico de distribuições de cargas elétricas. Linhas de força. Lei de Gauss. Potencial. Trabalho em campo elétrico. Diferença de potencial. Superfícies equipotenciais. Capacitores. Capacitância. Capacitor de placas paralelas. Associação de capacitores. Energia de um campo elétrico. Corrente Elétrica. Lei de Ohm. Resistência elétrica. Associação de resistores. Energia e potência. Força eletromotriz. Equação de circuito. Associação de f.e.m. Leis de Kirchoff. Campo magnético de uma corrente elétrica. Linhas de força. Fluxo magnético e indução magnética. Campo magnético de uma espira. Lei de Ampère. Campo magnético de um solenóide. Forças magnéticas em cargas elétricas. Forças magnéticas em correntes elétricas. Geração de Força Eletromotriz. Lei de Faraday. Lei de Lenz. Geração de f.e.m. em condutores. Propriedades magnéticas da matéria. Meios paramagnéticos e diamagnéticos. Ferromagnetismo. Espectro eletromagnético. Produção de uma onda por uma antena de dipolo (qualitativo). Propriedades da Luz. Velocidade da luz. Propagação da luz. Princípio de Huygens. Reflexão e refração. Polarização da luz. Interferência e Difração da Luz. Interferência em duas fendas estreitas. Interferência em duas ou mais fendas igualmente espaçadas. Difração por fenda simples. Interferência e difração em duas fendas. Difração de Fraunhofer e difração de Fresnel. Experiência de Michelson-Morley. Postulados da relatividade restrita. Transformações de Lorentz. Sincronismo e simultaneidade. Paradoxo dos gêmeos. Transformação de velocidades. Momento linear e energia relativística. Origens da Física Quântica. Radiação do corpo negro e a constante de Planck. Efeito fotoelétrico. Espectros atômicos. Modelo atômico de Bohr. Comprimento de ondas de de Broglie e ondas de matéria. Princípio da incerteza Heisenberg . Dualidade onda-partícula.

GEOGRAFIA - CONHECIMENTOS ESPECÍFICOS: As concepções teóricas da ciência geográfica. O objeto de estudo da Geografia. Conceitos Geográficos: Paisagem; Região; Território; Lugar; Sociedade; Natureza e Rede. Processo de urbanização e industrialização. O espaço agrário mundial e brasileiro. As desigualdades socioeconômicas na configuração espacial. A circulação de mercadorias, pessoas, informações e capitais. O processo de globalização. As relações de poder e domínio sobre os territórios. Dinâmica da natureza e as questões ambientais. Os domínios morfoclimáticos brasileiros. A relação Sociedade-Natureza. População: Fatores do crescimento populacional; Crescimento vegetativo; Mortalidade infantil e expectativa de vida no mundo; Teorias demográficas; Movimentos migratórios. Linguagem Cartográfica. Espaço Paranaense: economia, política, questões socioambientais e formação populacional. O ensino de Geografia de acordo com as Diretrizes Curriculares Orientadoras da Educação Básica para a Rede Estadual de Ensino (DCEs) Geografia.

HISTÓRIA - CONHECIMENTOS ESPECÍFICOS: Dimensão Histórica da disciplina: História da disciplina de 1970 à 2008. Estudos Sociais - LDB 5692/71; Currículo Básico do Estado do Paraná e Reestruturação do Ensino do Segundo Grau no Paraná (1990); LDBEN 9394/96 e Diretrizes Curriculares Orientadoras da Educação Básica para a Rede Estadual de Ensino (DCEs) - História. Fundamentos teóricos: Nova História, Nova História Cultural e Nova Esquerda Inglesa. Conceitos Históricos: a) Epistemológicos: tempo, sujeitos, processo histórico, evidência histórica (memória, patrimônio, produção de dados), explicação histórica, narrativa histórica e consciência histórica; b) Específicos: Nova História - mentalidades; Nova História Cultural representação, prática cultural, apropriação cultural, circularidade cultural; Nova Esquerda Inglesa - experiência histórica, hegemonia, cultura comum. Conteúdos estruturantes: Relações de Trabalho, Relações de Poder e Relações Culturais. Conteúdos básicos conforme as Diretrizes Curriculares Orientadoras da Educação Básica para a Rede Estadual de Ensino (DCEs) - História. 


\title{
ESTADO DO PARANÁ \\ Secretaria de Estado da Administração e da Previdência \\ Departamento de Recursos Humanos
}

\begin{abstract}
LÍNGUAS ESTRANGEIRAS MODERNAS - INGLESA E ESPANHOLA - CONHECIMENTOS ESPECÍFICOS: Conteúdos relacionados à prática do professor e ao ensino da língua: Teorias sobre aquisição de linguagem. Concepções teóricas do ensino e aprendizagem de língua estrangeira moderna. Concepções de linguagem e implicações no ensino de língua estrangeira moderna. As abordagens e o contexto sócio-histórico: implicações no ensino de Língua Estrangeira Moderna. A natureza sócio-interacional da linguagem. Função social e educacional do ensino de língua estrangeira moderna na escola pública. Linguagem e sociedade (introdução a questões relativas à língua, poder, identidade e cultura). Análise critica do discurso (desenvolvimento de conhecimento sobre o papel da linguagem nas relações sócio-educacionais). $O$ conhecimento sistêmico, de mundo e da organização textual e o processo de ensinar e aprender língua estrangeira. Dimensão histórica do ensino de língua estrangeira no Brasil e no Paraná. Fundamentos teóricometodológicos do ensino de Língua Estrangeira Moderna e Conteúdo Estruturante de acordo com as Diretrizes Curriculares Orientadoras para a Educação Básica da rede Estadual (DCEs) - LEM. Gêneros textuais, suportes textuais e domínios discursivos. Conteúdos relacionados aos conhecimentos da língua, leitura e compreensão textual: gêneros textuais, suportes textuais e domínios discursivos; Compreensão e Interpretação de diferentes gêneros textuais: as características da situação de produção, a construção composicional do gênero e os fatores linguístico-discursivos. Análise Linguística: o texto (verbal e não verbal) como unidade privilegiada na análise/reflexão da língua(gem), os efeitos de sentido provocados pelos elementos linguísticos, a norma padrão e as outras variedades linguísticas.
\end{abstract}

LÍNGUA PORTUGUESA - CONHECIMENTOS ESPECÍFICOS: Concepção da disciplina em conformidade com as Diretrizes Curriculares Orientadoras da Educação Básica para a Rede Estadual de Ensino (DCEs) - Língua Portuguesa; a história da Disciplina Língua Portuguesa; Concepção de língua/linguagem como processo de interação: conceitos básicos de dialogismo, polifonia, alteridade, discurso, enunciado, enunciação, texto, gêneros discursivos. Oralidade: concepção, gêneros orais, oralidade e ensino de língua, particularidades do texto oral. Leitura: concepção, gêneros, papel do leitor, diferentes objetivos da leitura, formação do leitor crítico, intertextualidade, inferências. Escrita: produção de texto na escola, papel do interlocutor, contexto de produção, gêneros da escrita, fatores linguísticos e discursivos da escrita, o trabalho de análise e revisão de reescrita de textos. Análise Linguística: o texto (oral e escrito) como unidade privilegiada na análise/reflexão da língua(gem), os efeitos de sentido provocados pelos elementos linguísticos, a norma padrão e as outras variedades linguísticas. Literatura:

História da literatura Brasileira e História da Literatura Portuguesa. Literatura e ensino; o tratamento estético do texto literário e os efeitos de sentidos.

MATEMÁTICA - CONHECIMENTOS ESPECÍFICOS: Concepção da disciplina de Matemática em conformidade com as Diretrizes Curriculares Orientadoras da Educação Básica para a Rede Estadual de Ensino (DCEs) Matemática. Dimensão Histórica da Disciplina de Matemática; Educação Matemática e suas relações entre o processo de ensino, aprendizagem e conhecimento matemático; Tendências em Educação Matemática (resolução de problemas, modelagem, etnomatemática, história da matemática e mídias tecnológicas); Conjuntos Numéricos; Equações; Polinômios; Sistema de Medidas; Proporcionalidade; Matrizes; Determinantes; Sistemas Lineares; Geometria Plana; Geometria Espacial; Geometria Analítica; Tópicos da Geometria não-euclidiana; Função Afim; Função Quadrática; Função Exponencial; Função Logarítmica; Função Trigonométrica; Função Modular; Progressão Aritmética; Progressão Geométrica; Análise Combinatória; Estatística; Matemática Financeira; Binômio de Newton.

QUÍMICA - CONHECIMENTOS ESPECÍFICOS: Dimensão histórica da disciplina: contribuições da alquimia; fatos marcantes da história do conhecimento químico e suas inter-relações de natureza econômica, política e social. Ensino de Química: constituição da Química como disciplinar escolar; as reformas de ensino e suas implicações no ensino de Química no Brasil. Fundamentos teórico-metodológicos: construção e reconstrução de significados dos conceitos científicos a partir do contato com o objeto de estudo da química - matéria e suas transformações; abordagem experimental; contextualização; superação do método tradicional de ensino. Conteúdos estruturantes: Química sintética - síntese de novos produtos e novos materiais. Matéria e sua natureza - estudo dos aspectos microscópicos dos materiais para compreensão dos aspectos macroscópicos ; Biogeoquímica- interações existentes entre hidrosfera, litosfera e atmosfera. Conteúdos básicos conforme as Diretrizes Curriculares Orientadoras da Educação Básica para a Rede Estadual de Ensino (DCEs) - Química.

SOCIOLOGIA - CONHECIMENTOS ESPECÍFICOS: Dimensão histórica da Disciplina de Sociologia, Fundamentação Teórico-Metodológica, Conteúdos Estruturantes e básicos conforme as Diretrizes Curriculares Orientadoras da Educação Básica para a Rede Estadual de Ensino (DCEs) - Sociologia. Processo de 


\section{ESTADO DO PARANÁ \\ Secretaria de Estado da Administração e da Previdência Departamento de Recursos Humanos}

Socialização e as Instituições Sociais: Processo de Socialização; Instituições sociais, Familiares; Escolares; Religiosas. Instituições de Reinserção (prisões, manicômios, educandários, asilos,etc). Cultura e Indústria Cultural: Desenvolvimento antropológico do conceito de cultura e sua contribuição na análise das diferentes sociedades; Diversidade cultural; Identidade; Meios de comunicação de massa; Sociedade de consumo; Indústria cultural; Questões de gênero; Culturas afro-brasileira e africanas; Culturas indígenas. Trabalho, Produção e Classes Sociais: Conceito de trabalho e o trabalho nas diferentes sociedades; Desigualdades sociais: estamentos, castas,classes sociais; Organização do trabalho nas sociedades capitalistas e suas contradições; Globalização e Neoliberalismo; Relações de trabalho;Trabalho no Brasil. Poder, Política e Ideologia: Formação e desenvolvimento do Estado moderno; Democracia, autoritarismo, totalitarismo; Estado no Brasil; Conceitos de Poder; Conceitos de Ideologia; Conceitos de Dominação e Legitimidade; As expressões da violência nas sociedades contemporâneas. Direitos, Cidadania e Movimentos Sociais: Direitos: civis, políticos e sociais; Direitos Humanos Conceito de cidadania; Movimentos Sociais; Movimentos Sociais no Brasil; A questão ambiental e os movimentos ambientais; A questão das ONG's.

\section{CONHECIMENTOS ESPECÍFICOS - PROFESSOR PEDAGOGO:}

História da Educação Brasileira e as relações entre escola, estado e sociedade. Políticas públicas da Educação no Brasil. Fundamentos e concepções de gestão e diferentes formas de estruturação na organização da escola. Gestão e instâncias colegiadas na unidade escolar; estrutura, funcionamento e organização. Formação do Pedagogo no Brasil. O financiamento da educação. Educação e Pedagogia: bases filosóficas, sociológicas, psicológicas, antropológicas e políticas de educação. A Pedagogia: seu objeto, campo de conhecimento e de trabalho; as correntes pedagógicas. A relação entre educação/cultura/ética e cidadania. Concepções e teorias curriculares. O Projeto Político Pedagógico - Papel e função da escola: concepções e diferentes formas de organização do conhecimento e do tempo nos currículos escolares. A didática e as diferentes formas de organizar o ensino. Formação continuada do professor. Escola, violência e cidadania. Organização do trabalho pedagógico na escola: o pedagogo como educador e mediador no ambiente de trabalho. 


\title{
ESTADO DO PARANÁ \\ Secretaria de Estado da Administração e da Previdência \\ Departamento de Recursos Humanos
}

ANEXO IV DO EDITAL № 17/2013 - Temas para Concurso - Prova Didática

\author{
Arte \\ a) Arte Contemporânea. \\ b) Dança nas aulas de arte. \\ c) O audiovisual nas aulas de arte. \\ d) Teatro nas aulas de arte. \\ e) Música nas aulas de arte.
}

\section{Biologia}

a) Classificação dos seres vivos: critérios taxionômicos e filogenéticos.

b) Teorias sobre a origem da vida e a evolução das espécies.

c) Interferência humana na Terra: questões ambientais, vida social e saúde humana.

d) Hereditariedade, reprodução e desenvolvimento embriológico da espécie humana.

e) Biotecnologia, bioética e manipulação da vida.

\section{Ciências}
a) Astronomia: da origem e evolução do universo aos movimentos terrestres e celestes.
b) Do átomo ao universo: constituição, propriedades e ciclo da matéria.
c) A conservação da energia e o ambiente: dos recursos à conversão e eficiência energética.
d) Níveis de organização da vida: relações emergentes entre mecanismos celulares, organismos e biodiversidade.
e) Diversidade de espécies na biosfera: ecossistemas, interações ecológicas, dinâmica de populações e teorias evolutivas.

\section{Educação Física}

a) O esporte como um fenômeno social.

b) Jogos e brincadeiras.

c) Atividade física e saúde.

d) Lutas.

e) Danças.

\section{Filosofia}
a) Filosofia: origem e conceitos.
b) A política em Platão e Aristóteles.
c) A questão do conhecimento em Descartes.
d) O conceito de esclarecimento em Adorno e Horkheimer.
e) Epistemologias contemporâneas.

\section{Física}

a) Mecânica newtoniana.

b) Eletricidade.

c) Eletromagnetismo.

d) Termodinâmica.

e) Física Moderna e Contemporânea.

\section{Geografia}

a) População brasileira: suas manifestações socioespaciais e sua diversidade cultural.

b) Formação e crescimento das cidades, a dinâmica dos espaços urbanos e a urbanização.

c) O Espaço rural brasileiro e suas contradições.

d) A dinâmica da natureza e sua alteração pelo emprego de tecnologias da exploração e produção.

e) Espaço em rede: produção, transporte e comunicação na atual configuração territorial.

\section{História}

a) O mundo feudal europeu dos séculos XI ao XIV.

b) O sistema escravista na América portuguesa e Brasil imperial: a relação Brasil, Portugal e África.

c) A formação do trabalho assalariado urbanização e industrialização na Europa e no Brasil nos séculos XVIII a XX. 


\section{ESTADO DO PARANÁ \\ Secretaria de Estado da Administração e da Previdência \\ Departamento de Recursos Humanos}

d) A formação dos Estados nacionais: as revoluções políticas e sociais nos séculos XIX e XX.

e) Os movimentos sociais no Brasil no século XX: a resistência contra a Ditadura civil-militar brasileira e a luta pela redemocratização.

\section{LEM Espanhol}

a) Variação Linguística na Língua Espanhola.

b) Gêneros Textuais em língua espanhola: as características da situação de produção, a construção composicional do gênero e os fatores linguístico-discursivos.

c) Os tempos verbais em língua espanhola, contextualizados sob a perspectiva discursiva da língua.

d) Coesão e coerência textuais: os marcadores de discurso em língua espanhola.

e) A diversidade linguística e cultural a partir da língua espanhola.

\section{LEM Inglês}

a) Os gêneros discursivos, seus elementos composicionais e suas esferas de circulação.

b) Funções das classes gramaticais contextualizadas nos textos sob a perspectiva discursiva da língua.

c) A Língua Inglesa e o léxico: escolhas lexicais adequadas à construção do sentido dos enunciados e ao gênero selecionado.

d) Coesão e coerência textuais: marcadores de discurso.

e) A diversidade linguística e cultural.

\section{Língua Portuguesa}

a) Leitura: exploração das possibilidades didáticas para a leitura de um ou mais textos.

b) Escrita: proposição de produção textual de determinado gênero, de forma que abranja seu tema, estilo e forma composicional.

c) Oralidade: exploração das marcas linguísticas próprias de determinado gênero oral, considerando-se a situação de comunicação e os interlocutores.

d) Literatura: exploração de um gênero literário (conto, romance, poema etc.), tendo como pressuposto teórico a Estética da Recepção.

e) Análise linguística: exploração de determinado(s) elemento(s) linguístico(s) de um gênero textual/discursivo.

\section{Matemática}

a) Números e álgebra.

b) Geometrias.

c) Funções.

d) Grandezas e medidas.

e) Tratamento da informação.

Esses itens deverão ser estudados considerando-se as tendências metodológicas do campo da Educação Matemática, a saber:

- Resolução de Problemas

- Modelagem Matemática

- Investigação Matemática

- História da Matemática

- Mídias Tecnológicas

- Jogos

\section{Química}
a) Matéria.
b) Ligação química.
c) Funções químicas.
d) Velocidade das reações.
e) Equilíbrio químico.

\section{Sociologia}

a) Contexto do surgimento do pensamento social e o objeto de estudo da Sociologia.

b) Indústria Cultural e Cultura de Massa e as influências nas relações sociais.

c) O mundo do trabalho e suas contradições na sociedade capitalista. 


\section{ESTADO DO PARANÁ \\ Secretaria de Estado da Administração e da Previdência \\ Departamento de Recursos Humanos}

d) Processo de formação do Estado Moderno e relações de poder a partir das teorias clássicas.

e) Princípios norteadores dos Movimentos Sociais Contemporâneos no Brasil.

\section{Pedagogia}

a) Organização e elementos do Plano de Trabalho Docente (PTD).

b) O Papel dos colegiados escolares: conselho escolar.

c) O papel dos colegiados escolares: conselho de classe.

d) Avaliação escolar.

e) A concepção disciplinar do currículo. 


\section{ESTADO DO PARANÁ}

\section{Secretaria de Estado da Administração e da Previdência}

Departamento de Recursos Humanos

\section{ANEXO V DO EDITAL № 17/2013 - Municípios que integram cada NRE}

\begin{tabular}{|c|c|c|}
\hline COD. NRE & NRE & MUNICÍPIO \\
\hline 1 & APUCARANA & APUCARANA \\
\hline 1 & APUCARANA & ARAPONGAS \\
\hline 1 & APUCARANA & BOM SUCESSO \\
\hline 1 & APUCARANA & BORRAZOPOLIS \\
\hline 1 & APUCARANA & CALIFORNIA \\
\hline 1 & APUCARANA & CAMBIRA \\
\hline 1 & APUCARANA & CRUZMALTINA \\
\hline 1 & APUCARANA & FAXINAL \\
\hline 1 & APUCARANA & JANDAIA DO SUL \\
\hline 1 & APUCARANA & KALORE \\
\hline 1 & APUCARANA & $\begin{array}{l}\text { MARILANDIA DO } \\
\text { SUL }\end{array}$ \\
\hline 1 & APUCARANA & MARUMBI \\
\hline 1 & APUCARANA & MAUA DA SERRA \\
\hline 1 & APUCARANA & $\begin{array}{l}\text { NOVO } \\
\text { ITACOLOMI }\end{array}$ \\
\hline 1 & APUCARANA & RIO BOM \\
\hline 1 & APUCARANA & SABAUDIA \\
\hline 2 & AM NORTE & ADRIANOPOLIS \\
\hline 2 & AM NORTE & $\begin{array}{l}\text { ALMIRANTE } \\
\text { TAMANDARE }\end{array}$ \\
\hline 2 & AM NORTE & $\begin{array}{l}\text { BOCAIUVA DO } \\
\text { SUL }\end{array}$ \\
\hline 2 & AM NORTE & $\begin{array}{c}\text { CAMPINA } \\
\text { GRANDE DO SUL }\end{array}$ \\
\hline 2 & AM NORTE & CAMPO MAGRO \\
\hline 2 & AM NORTE & CERRO AZUL \\
\hline 2 & AM NORTE & COLOMBO \\
\hline 2 & AM NORTE & $\begin{array}{l}\text { DOUTOR } \\
\text { ULYSSES }\end{array}$ \\
\hline 2 & AM NORTE & ITAPERUCU \\
\hline 2 & AM NORTE & PINHAIS \\
\hline 2 & AM NORTE & PIRAQUARA \\
\hline 2 & AM NORTE & $\begin{array}{l}\text { QUATRO } \\
\text { BARRAS } \\
\end{array}$ \\
\hline 2 & AM NORTE & $\begin{array}{l}\text { RIO BRANCO DO } \\
\text { SUL }\end{array}$ \\
\hline 2 & AM NORTE & $\begin{array}{l}\text { TUNAS DO } \\
\text { PARANA }\end{array}$ \\
\hline 3 & AM SUL & AGUDOS DO SUL \\
\hline 3 & AM SUL & ARAUCARIA \\
\hline 3 & AM SUL & BALSA NOVA \\
\hline 3 & AM SUL & $\begin{array}{l}\text { CAMPO DO } \\
\text { TENENTE }\end{array}$ \\
\hline 3 & AM SUL & CAMPO LARGO \\
\hline 3 & AM SUL & CONTENDA \\
\hline 3 & AM SUL & $\begin{array}{l}\text { FAZENDA RIO } \\
\text { GRANDE }\end{array}$ \\
\hline 3 & AM SUL & LAPA \\
\hline 3 & AM SUL & MANDIRITUBA \\
\hline 3 & AM SUL & PIEN \\
\hline 3 & AM SUL & QUITANDINHA \\
\hline 3 & AM SUL & RIO NEGRO \\
\hline 3 & AM SUL & $\begin{array}{l}\text { SAO JOSE DOS } \\
\text { PINHAIS }\end{array}$ \\
\hline 3 & AM SUL & TIJUCAS DO SUL \\
\hline 4 & ASSIS CHATEAUBRIAND & $\begin{array}{l}\text { ASSIS } \\
\text { CHATEAUBRIAND }\end{array}$ \\
\hline 4 & ASSIS CHATEAUBRIAND & $\begin{array}{l}\text { BRASILANDIA } \\
\text { DO SUL }\end{array}$ \\
\hline
\end{tabular}

\begin{tabular}{|c|c|c|}
\hline 4 & ASSIS CHATEAUBRIAND & $\begin{array}{l}\text { FORMOSA DO } \\
\text { OESTE } \\
\end{array}$ \\
\hline 4 & ASSIS CHATEAUBRIAND & $\begin{array}{l}\text { IRACEMA DO } \\
\text { OESTE }\end{array}$ \\
\hline 4 & ASSIS CHATEAUBRIAND & JESUITAS \\
\hline 4 & ASSIS CHATEAUBRIAND & NOVA AURORA \\
\hline 4 & ASSIS CHATEAUBRIAND & TUPASSI \\
\hline 5 & CAMPO MOURÃO & $\begin{array}{l}\text { ALTAMIRA DO } \\
\text { PARANA }\end{array}$ \\
\hline 5 & CAMPO MOURÃO & ARARUNA \\
\hline 5 & CAMPO MOURÃO & $\begin{array}{l}\text { BARBOSA } \\
\text { FERRAZ }\end{array}$ \\
\hline 5 & CAMPO MOURÃO & $\begin{array}{l}\text { CAMPINA DA } \\
\text { LAGOA }\end{array}$ \\
\hline 5 & CAMPO MOURÃO & CAMPO MOURAO \\
\hline 5 & CAMPO MOURÃO & $\begin{array}{l}\text { CORUMBATAI } \\
\text { DO SUL }\end{array}$ \\
\hline 5 & CAMPO MOURÃO & $\begin{array}{l}\text { ENGENHEIRO } \\
\text { BELTRAO }\end{array}$ \\
\hline 5 & CAMPO MOURÃO & FAROL \\
\hline 5 & CAMPO MOURÃO & FENIX \\
\hline 5 & CAMPO MOURÃO & IRETAMA \\
\hline 5 & CAMPO MOURÃO & LUIZIANA \\
\hline 5 & CAMPO MOURÃO & MAMBORE \\
\hline 5 & CAMPO MOURÃO & NOVA CANTU \\
\hline 5 & CAMPO MOURÃO & PEABIRU \\
\hline 5 & CAMPO MOURÃO & QUINTA DO SOL \\
\hline 5 & CAMPO MOURÃO & RONCADOR \\
\hline 6 & CASCAVEL & ANAHY \\
\hline 6 & CASCAVEL & $\begin{array}{l}\text { BOA VISTA DA } \\
\text { APARECIDA } \\
\end{array}$ \\
\hline 6 & CASCAVEL & BRAGANEY \\
\hline 6 & CASCAVEL & CAFELANDIA \\
\hline 6 & CASCAVEL & CAMPO BONITO \\
\hline 6 & CASCAVEL & $\begin{array}{l}\text { CAPITAO } \\
\text { LEONIDAS } \\
\text { MARQUES }\end{array}$ \\
\hline 6 & CASCAVEL & CASCAVEL \\
\hline 6 & CASCAVEL & CATANDUVAS \\
\hline 6 & CASCAVEL & CEU AZUL \\
\hline 6 & CASCAVEL & CORBELIA \\
\hline 6 & CASCAVEL & GUARANIACU \\
\hline 6 & CASCAVEL & IBEMA \\
\hline 6 & CASCAVEL & IGUATU \\
\hline 6 & CASCAVEL & LINDOESTE \\
\hline 6 & CASCAVEL & SANTA LUCIA \\
\hline 6 & CASCAVEL & $\begin{array}{l}\text { SANTA TEREZA } \\
\text { DO OESTE }\end{array}$ \\
\hline 6 & CASCAVEL & $\begin{array}{l}\text { TRES BARRAS } \\
\text { DO PARANA }\end{array}$ \\
\hline 6 & CASCAVEL & $\begin{array}{l}\text { VERA CRUZ DO } \\
\text { OESTE }\end{array}$ \\
\hline 7 & CIANORTE & CIANORTE \\
\hline 7 & CIANORTE & CIDADE GAUCHA \\
\hline 7 & CIANORTE & GUAPOREMA \\
\hline 7 & CIANORTE & INDIANOPOLIS \\
\hline 7 & CIANORTE & JAPURA \\
\hline 7 & CIANORTE & JUSSARA \\
\hline 7 & CIANORTE & RONDON \\
\hline 7 & CIANORTE & $\begin{array}{l}\text { SAO MANOEL DO } \\
\text { PARANA }\end{array}$ \\
\hline
\end{tabular}




\section{ESTADO DO PARANÁ \\ Secretaria de Estado da Administração e da Previdência Departamento de Recursos Humanos}

\begin{tabular}{|c|c|c|}
\hline 7 & CIANORTE & SAO TOME \\
\hline 7 & CIANORTE & TAPEJARA \\
\hline 7 & CIANORTE & TERRA BOA \\
\hline 7 & CIANORTE & $\begin{array}{l}\text { TUNEIRAS DO } \\
\text { OESTE }\end{array}$ \\
\hline 8 & CORNÉLIO PROCÓPIO & ASSAI \\
\hline 8 & CORNÉLIO PROCÓPIO & BANDEIRANTES \\
\hline 8 & CORNÉLIO PROCÓPIO & CONGONHINHAS \\
\hline 8 & CORNÉLIO PROCÓPIO & $\begin{array}{l}\text { CORNELIO } \\
\text { PROCOPIO }\end{array}$ \\
\hline 8 & CORNÉLIO PROCÓPIO & ITAMBARACA \\
\hline 8 & CORNÉLIO PROCÓPIO & JATAIZINHO \\
\hline 8 & CORNÉLIO PROCÓPIO & LEOPOLIS \\
\hline 8 & CORNÉLIO PROCÓPIO & $\begin{array}{l}\text { NOVA AMERICA } \\
\text { DA COLINA }\end{array}$ \\
\hline 8 & CORNÉLIO PROCÓPIO & NOVA FATIMA \\
\hline 8 & CORNÉLIO PROCÓPIO & $\begin{array}{l}\text { NOVA SANTA } \\
\text { BARBARA }\end{array}$ \\
\hline 8 & CORNÉLIO PROCÓPIO & RANCHO ALEGRE \\
\hline 8 & CORNÉLIO PROCÓPIO & SANTA AMELIA \\
\hline 8 & CORNÉLIO PROCÓPIO & $\begin{array}{l}\text { SANTA CECILIA } \\
\text { DO PAVAO }\end{array}$ \\
\hline 8 & CORNÉLIO PROCÓPIO & SANTA MARIANA \\
\hline 8 & CORNÉLIO PROCÓPIO & $\begin{array}{l}\text { SANTO ANTONIO } \\
\text { DO PARAISO }\end{array}$ \\
\hline 8 & CORNÉLIO PROCÓPIO & $\begin{array}{l}\text { SAO JERONIMO } \\
\text { DA SERRA }\end{array}$ \\
\hline 8 & CORNÉLIO PROCÓPIO & $\begin{array}{l}\text { SAO SEBASTIAO } \\
\text { DA AMOREIRA }\end{array}$ \\
\hline 8 & CORNÉLIO PROCÓPIO & SERTANEJA \\
\hline 8 & CORNÉLIO PROCÓPIO & URAI \\
\hline 9 & CURITIBA & CURITIBA \\
\hline 10 & DOIS VIZINHOS & $\begin{array}{l}\text { BOA ESPERANCA } \\
\text { DO IGUACU }\end{array}$ \\
\hline 10 & DOIS VIZINHOS & $\begin{array}{l}\text { CRUZEIRO DO } \\
\text { IGUACU }\end{array}$ \\
\hline 10 & DOIS VIZINHOS & DOIS VIZINHOS \\
\hline 10 & DOIS VIZINHOS & $\begin{array}{l}\text { NOVA } \\
\text { ESPERANCA DO } \\
\text { SUDOESTE }\end{array}$ \\
\hline 10 & DOIS VIZINHOS & $\begin{array}{l}\text { NOVA PRATA DO } \\
\text { IGUACU }\end{array}$ \\
\hline 10 & DOIS VIZINHOS & $\begin{array}{l}\text { SALTO DO } \\
\text { LONTRA }\end{array}$ \\
\hline 10 & DOIS VIZINHOS & $\begin{array}{l}\text { SAO JORGE DO } \\
\text { OESTE }\end{array}$ \\
\hline 11 & FOZ DO IGUAÇU & FOZ DO IGUACU \\
\hline 11 & FOZ DO IGUAÇU & ITAIPULANDIA \\
\hline 11 & FOZ DO IGUAÇU & MATELANDIA \\
\hline 11 & FOZ DO IGUAÇU & MEDIANEIRA \\
\hline 11 & FOZ DO IGUAÇU & MISSAL \\
\hline 11 & FOZ DO IGUAÇU & RAMILANDIA \\
\hline 11 & FOZ DO IGUAÇU & $\begin{array}{l}\text { SANTA } \\
\text { TEREZINHA DE } \\
\text { ITAIPU }\end{array}$ \\
\hline 11 & FOZ DO IGUAÇU & $\begin{array}{l}\text { SAO MIGUEL DO } \\
\text { IGUACU }\end{array}$ \\
\hline 11 & FOZ DO IGUAÇU & $\begin{array}{l}\text { SERRANOPOLIS } \\
\text { DO IGUACU }\end{array}$ \\
\hline 12 & FRANCISCO BELTRÃO & AMPERE \\
\hline 12 & FRANCISCO BELTRÃO & BARRACAO \\
\hline 12 & FRANCISCO BELTRÃO & $\begin{array}{l}\text { BELA VISTA DA } \\
\text { CAROBA }\end{array}$ \\
\hline 12 & FRANCISCO BELTRÃO & BOM JESUS DO \\
\hline
\end{tabular}

\begin{tabular}{|c|c|c|}
\hline & & SUL \\
\hline 12 & FRANCISCO BELTRÃO & CAPANEMA \\
\hline 12 & FRANCISCO BELTRÃO & $\begin{array}{l}\text { ENEAS } \\
\text { MARQUES }\end{array}$ \\
\hline 12 & FRANCISCO BELTRÃO & $\begin{array}{l}\text { FLOR DA SERRA } \\
\text { DO SUL }\end{array}$ \\
\hline 12 & FRANCISCO BELTRÃO & $\begin{array}{l}\text { FRANCISCO } \\
\text { BELTRAO } \\
\end{array}$ \\
\hline 12 & FRANCISCO BELTRÃO & MANFRINOPOLIS \\
\hline 12 & FRANCISCO BELTRÃO & MARMELEIRO \\
\hline 12 & FRANCISCO BELTRÃO & $\begin{array}{l}\text { PEROLA DO } \\
\text { OESTE }\end{array}$ \\
\hline 12 & FRANCISCO BELTRÃO & $\begin{array}{l}\text { PINHAL DE SAO } \\
\text { BENTO }\end{array}$ \\
\hline 12 & FRANCISCO BELTRÃO & PLANALTO \\
\hline 12 & FRANCISCO BELTRÃO & PRANCHITA \\
\hline 12 & FRANCISCO BELTRÃO & REALEZA \\
\hline 12 & FRANCISCO BELTRÃO & RENASCENCA \\
\hline 12 & FRANCISCO BELTRÃO & SALGADO FILHO \\
\hline 12 & FRANCISCO BELTRÃO & $\begin{array}{l}\text { SANTA IZABEL } \\
\text { DO OESTE }\end{array}$ \\
\hline 12 & FRANCISCO BELTRÃO & $\begin{array}{l}\text { SANTO ANTONIO } \\
\text { DO SUDOESTE }\end{array}$ \\
\hline 12 & FRANCISCO BELTRÃO & VERE \\
\hline 13 & GOIOERÊ & BOA ESPERANCA \\
\hline 13 & GOIOERE & GOIOERE \\
\hline 13 & GOIOERÊ & JANIOPOLIS \\
\hline 13 & GOIOERÊ & JURANDA \\
\hline 13 & GOIOERÊ & MARILUZ \\
\hline 13 & GOIOERÊ & MOREIRA SALES \\
\hline 13 & GOIOERÊ & $\begin{array}{l}\text { QUARTO } \\
\text { CENTENARIO }\end{array}$ \\
\hline 13 & GOIOERÊ & $\begin{array}{l}\text { RANCHO ALEGRE } \\
\text { DO OESTE }\end{array}$ \\
\hline 13 & GOIOERÊ & UBIRATA \\
\hline 14 & GUARAPUAVA & $\begin{array}{l}\text { CAMPINA DO } \\
\text { SIMAO }\end{array}$ \\
\hline 14 & GUARAPUAVA & CANDOI \\
\hline 14 & GUARAPUAVA & FOZ DO JORDAO \\
\hline 14 & GUARAPUAVA & GOIOXIM \\
\hline 14 & GUARAPUAVA & GUARAPUAVA \\
\hline 14 & GUARAPUAVA & PINHAO \\
\hline 14 & GUARAPUAVA & $\begin{array}{l}\text { RESERVA DO } \\
\text { IGUACU }\end{array}$ \\
\hline 14 & GUARAPUAVA & TURVO \\
\hline 15 & IRATI & $\begin{array}{l}\text { FERNANDES } \\
\text { PINHEIRO }\end{array}$ \\
\hline 15 & IRATI & GUAMIRANGA \\
\hline 15 & IRATI & $\begin{array}{l}\text { INACIO } \\
\text { MARTINS } \\
\end{array}$ \\
\hline 15 & IRATI & IRATI \\
\hline 15 & IRATI & MALLET \\
\hline 15 & IRATI & PRUDENTOPOLIS \\
\hline 15 & IRATI & REBOUCAS \\
\hline 15 & IRATI & RIO AZUL \\
\hline 15 & IRATI & $\begin{array}{l}\text { TEIXEIRA } \\
\text { SOARES }\end{array}$ \\
\hline 16 & IVAIPORÃ & ARAPUA \\
\hline 16 & IVAIPORÃ & $\begin{array}{l}\text { ARIRANHA DO } \\
\text { IVAI }\end{array}$ \\
\hline 16 & IVAIPORÃ & $\begin{array}{l}\text { CANDIDO DE } \\
\text { ABREU }\end{array}$ \\
\hline 16 & IVAIPORÃ & GODOY \\
\hline
\end{tabular}




\section{ESTADO DO PARANÁ}

\section{Secretaria de Estado da Administração e da Previdência}

Departamento de Recursos Humanos

\begin{tabular}{|c|c|c|}
\hline & & MOREIRA \\
\hline 16 & IVAIPOR $\tilde{A}$ & GRANDES RIOS \\
\hline 16 & IVAIPORÃ & IVAIPORA \\
\hline 16 & IVAIPORÃ & JARDIM ALEGRE \\
\hline 16 & IVAIPORÃ & LIDIANOPOLIS \\
\hline 16 & IVAIPORÃ & LUNARDELLI \\
\hline 16 & IVAIPORÃ & MANOEL RIBAS \\
\hline 16 & IVAIPOR $\tilde{A}$ & $\begin{array}{l}\text { RIO BRANCO DO } \\
\text { IVAI }\end{array}$ \\
\hline 16 & IVAIPORÃ & $\begin{array}{l}\text { ROSARIO DO } \\
\text { IVAI }\end{array}$ \\
\hline 16 & IVAIPORÃ & $\begin{array}{l}\text { SAO JOAO DO } \\
\text { IVAI }\end{array}$ \\
\hline 16 & IVAIPORÃ & $\begin{array}{l}\text { SAO PEDRO DO } \\
\text { IVAI }\end{array}$ \\
\hline 17 & JACAREZINHO & ABATIA \\
\hline 17 & JACAREZINHO & ANDIRA \\
\hline 17 & JACAREZINHO & $\begin{array}{l}\text { BARRA DO } \\
\text { JACARE }\end{array}$ \\
\hline 17 & JACAREZINHO & CAMBARA \\
\hline 17 & JACAREZINHO & CARLOPOLIS \\
\hline 17 & JACAREZINHO & JACAREZINHO \\
\hline 17 & JACAREZINHO & $\begin{array}{l}\text { JOAQUIM } \\
\text { TAVORA } \\
\end{array}$ \\
\hline 17 & JACAREZINHO & JUNDIAI DO SUL \\
\hline 17 & JACAREZINHO & QUATIGUA \\
\hline 17 & JACAREZINHO & $\begin{array}{l}\text { RIBEIRAO } \\
\text { CLARO }\end{array}$ \\
\hline 17 & JACAREZINHO & $\begin{array}{l}\text { RIBEIRAO DO } \\
\text { PINHAL }\end{array}$ \\
\hline 17 & JACAREZINHO & $\begin{array}{l}\text { SANTO ANTONIO } \\
\text { DA PLATINA }\end{array}$ \\
\hline 18 & LONDRINA & $\begin{array}{l}\text { ALVORADA DO } \\
\text { SUL }\end{array}$ \\
\hline 18 & LONDRINA & $\begin{array}{l}\text { BELA VISTA DO } \\
\text { PARAISO }\end{array}$ \\
\hline 18 & LONDRINA & CAFEARA \\
\hline 18 & LONDRINA & CAMBE \\
\hline 18 & LONDRINA & $\begin{array}{l}\text { CENTENARIO DO } \\
\text { SUL }\end{array}$ \\
\hline 18 & LONDRINA & FLORESTOPOLIS \\
\hline 18 & LONDRINA & GUARACI \\
\hline 18 & LONDRINA & IBIPORA \\
\hline 18 & LONDRINA & JAGUAPITA \\
\hline 18 & LONDRINA & LONDRINA \\
\hline 18 & LONDRINA & LUPIONOPOLIS \\
\hline 18 & LONDRINA & MIRASELVA \\
\hline 18 & LONDRINA & PITANGUEIRAS \\
\hline 18 & LONDRINA & PORECATU \\
\hline 18 & LONDRINA & $\begin{array}{l}\text { PRADO } \\
\text { FERREIRA }\end{array}$ \\
\hline 18 & LONDRINA & $\begin{array}{l}\text { PRIMEIRO DE } \\
\text { MAIO }\end{array}$ \\
\hline 18 & LONDRINA & ROLANDIA \\
\hline 18 & LONDRINA & SERTANOPOLIS \\
\hline 18 & LONDRINA & TAMARANA \\
\hline 19 & MARINGÁ & ANGULO \\
\hline 19 & MARINGÁ & ASTORGA \\
\hline 19 & MARINGÁ & ATALAIA \\
\hline 19 & MARINGÁ & COLORADO \\
\hline 19 & MARINGÁ & $\begin{array}{r}\text { DOUTOR } \\
\text { CAMARGO }\end{array}$ \\
\hline 19 & MARINGÁ & FLORAI \\
\hline
\end{tabular}

\begin{tabular}{|c|c|c|}
\hline 19 & MARINGÁ & FLORESTA \\
\hline 19 & MARINGÁ & FLORIDA \\
\hline 19 & MARINGÁ & IGUARACU \\
\hline 19 & MARINGÁ & ITAMBE \\
\hline 19 & MARINGÁ & IVATUBA \\
\hline 19 & MARINGÁ & LOBATO \\
\hline 19 & MARINGÁ & MANDAGUACU \\
\hline 19 & MARINGÁ & MANDAGUARI \\
\hline 19 & MARINGÁ & MARIALVA \\
\hline 19 & MARINGÁ & MARINGA \\
\hline 19 & MARINGÁ & $\begin{array}{l}\text { MUNHOZ DE } \\
\text { MELLO }\end{array}$ \\
\hline 19 & MARINGÁ & $\begin{array}{l}\text { NOSSA } \\
\text { SENHORA DAS } \\
\text { GRACAS }\end{array}$ \\
\hline 19 & MARINGÁ & OURIZONA \\
\hline 19 & MARINGÁ & PAICANDU \\
\hline 19 & MARINGÁ & $\begin{array}{c}\text { PRESIDENTE } \\
\text { CASTELO BRANCO }\end{array}$ \\
\hline 19 & MARINGÁ & SANTA FE \\
\hline 19 & MARINGÁ & SANTO INACIO \\
\hline 19 & MARINGÁ & $\begin{array}{l}\text { SAO JORGE DO } \\
\text { IVAI }\end{array}$ \\
\hline 19 & MARINGÁ & SARANDI \\
\hline 20 & LOANDA & $\begin{array}{l}\text { DIAMANTE DO } \\
\text { NORTE }\end{array}$ \\
\hline 20 & LOANDA & ITAUNA DO SUL \\
\hline 20 & LOANDA & LOANDA \\
\hline 20 & LOANDA & MARILENA \\
\hline 20 & LOANDA & NOVA LONDRINA \\
\hline 20 & LOANDA & $\begin{array}{l}\text { PLANALTINA DO } \\
\text { PARANA }\end{array}$ \\
\hline 20 & LOANDA & PORTO RICO \\
\hline 20 & LOANDA & $\begin{array}{l}\text { QUERENCIA DO } \\
\text { NORTE }\end{array}$ \\
\hline 20 & LOANDA & $\begin{array}{l}\text { SANTA CRUZ DO } \\
\text { MONTE CASTELO }\end{array}$ \\
\hline 20 & LOANDA & $\begin{array}{l}\text { SANTA ISABEL } \\
\text { DO IVAI }\end{array}$ \\
\hline 20 & LOANDA & SANTA MONICA \\
\hline 20 & LOANDA & $\begin{array}{l}\text { SAO PEDRO DO } \\
\text { PARANA }\end{array}$ \\
\hline 21 & PARANAGUÁ & ANTONINA \\
\hline 21 & PARANAGUÁ & GUARAQUECABA \\
\hline 21 & PARANAGUÁ & GUARATUBA \\
\hline 21 & PARANAGUÁ & MATINHOS \\
\hline 21 & PARANAGUÁ & MORRETES \\
\hline 21 & PARANAGUÁ & PARANAGUA \\
\hline 21 & PARANAGUÁ & $\begin{array}{l}\text { PONTAL DO } \\
\text { PARANA }\end{array}$ \\
\hline 22 & PARANAVAÍ & ALTO PARANA \\
\hline 22 & PARANAVAÍ & AMAPORA \\
\hline 22 & PARANAVAÍ & $\begin{array}{l}\text { CRUZEIRO DO } \\
\text { SUL }\end{array}$ \\
\hline 22 & PARANAVAÍ & GUAIRACA \\
\hline 22 & PARANAVAÍ & INAJA \\
\hline 22 & PARANAVAÍ & ITAGUAJE \\
\hline 22 & PARANAVAÍ & JARDIM OLINDA \\
\hline 22 & PARANAVAÍ & MIRADOR \\
\hline 22 & PARANAVAÍ & $\begin{array}{l}\text { NOVA ALIANCA } \\
\text { DO IVAI }\end{array}$ \\
\hline 22 & PARANAVAÍ & $\begin{array}{l}\text { NOVA } \\
\text { ESPERANCA }\end{array}$ \\
\hline
\end{tabular}




\section{ESTADO DO PARANÁ}

\section{Secretaria de Estado da Administração e da Previdência}

Departamento de Recursos Humanos

\begin{tabular}{|c|c|c|}
\hline 22 & PARANAVAÍ & $\begin{array}{l}\text { PARAISO DO } \\
\text { NORTE }\end{array}$ \\
\hline 22 & PARANAVAÍ & PARANACITY \\
\hline 22 & PARANAVAÍ & PARANAPOEMA \\
\hline 22 & PARANAVAÍ & PARANAVAI \\
\hline 22 & PARANAVAÍ & SANTA INES \\
\hline 22 & PARANAVAÍ & $\begin{array}{l}\text { SANTO ANTONIO } \\
\text { DO CAIUA }\end{array}$ \\
\hline 22 & PARANAVAÍ & $\begin{array}{l}\text { SAO CARLOS DO } \\
\text { IVAI }\end{array}$ \\
\hline 22 & PARANAVAÍ & $\begin{array}{l}\text { SAO JOAO DO } \\
\text { CAIUA }\end{array}$ \\
\hline 22 & PARANAVAÍ & TAMBOARA \\
\hline 22 & PARANAVAÍ & TERRA RICA \\
\hline 22 & PARANAVAÍ & UNIFLOR \\
\hline 23 & PATO BRANCO & $\begin{array}{l}\text { BOM SUCESSO } \\
\text { DO SUL }\end{array}$ \\
\hline 23 & PATO BRANCO & CHOPINZINHO \\
\hline 23 & PATO BRANCO & CLEVELANDIA \\
\hline 23 & PATO BRANCO & $\begin{array}{l}\text { CORONEL } \\
\text { DOMINGOS } \\
\text { SOARES }\end{array}$ \\
\hline 23 & PATO BRANCO & $\begin{array}{l}\text { CORONEL } \\
\text { VIVIDA }\end{array}$ \\
\hline 23 & PATO BRANCO & HONORIO SERPA \\
\hline 23 & PATO BRANCO & $\begin{array}{l}\text { ITAPEJARA DO } \\
\text { OESTE }\end{array}$ \\
\hline 23 & PATO BRANCO & MANGUEIRINHA \\
\hline 23 & PATO BRANCO & MARIOPOLIS \\
\hline 23 & PATO BRANCO & PALMAS \\
\hline 23 & PATO BRANCO & PATO BRANCO \\
\hline 23 & PATO BRANCO & SAO JOAO \\
\hline 23 & PATO BRANCO & $\begin{array}{l}\text { SAUDADE DO } \\
\text { IGUACU }\end{array}$ \\
\hline 23 & PATO BRANCO & SULINA \\
\hline 23 & PATO BRANCO & VITORINO \\
\hline 24 & PITANGA & $\begin{array}{l}\text { BOA VENTURA } \\
\text { DE SAO ROQUE }\end{array}$ \\
\hline 24 & PITANGA & LARANJAL \\
\hline 24 & PITANGA & MATO RICO \\
\hline 24 & PITANGA & NOVA TEBAS \\
\hline 24 & PITANGA & PALMITAL \\
\hline 24 & PITANGA & PITANGA \\
\hline 24 & PITANGA & $\begin{array}{l}\text { SANTA MARIA } \\
\text { DO OESTE }\end{array}$ \\
\hline 25 & PONTA GROSSA & CARAMBEI \\
\hline 25 & PONTA GROSSA & CASTRO \\
\hline 25 & PONTA GROSSA & IMBITUVA \\
\hline 25 & PONTA GROSSA & IPIRANGA \\
\hline 25 & PONTA GROSSA & IVAI \\
\hline 25 & PONTA GROSSA & PALMEIRA \\
\hline 25 & PONTA GROSSA & PIRAI DO SUL \\
\hline 25 & PONTA GROSSA & PONTA GROSSA \\
\hline 25 & PONTA GROSSA & $\begin{array}{l}\text { PORTO } \\
\text { AMAZONAS }\end{array}$ \\
\hline 25 & PONTA GROSSA & $\begin{array}{l}\text { SAO JOAO DO } \\
\text { TRIUNFO }\end{array}$ \\
\hline 25 & PONTA GROSSA & TIBAGI \\
\hline 26 & TELÊMACO BORBA & CURIUVA \\
\hline 26 & TELÊMACO BORBA & IMBAU \\
\hline 26 & TELÊMACO BORBA & ORTIGUEIRA \\
\hline 26 & TELÊMACO BORBA & RESERVA \\
\hline 26 & TELÊMACO BORBA & SAPOPEMA \\
\hline
\end{tabular}

\begin{tabular}{|c|c|c|}
\hline 26 & TELÊMACO BORBA & $\begin{array}{l}\text { TELEMACO } \\
\text { BORBA }\end{array}$ \\
\hline 26 & TELÊMACO BORBA & VENTANIA \\
\hline 27 & TOLEDO & $\begin{array}{l}\text { DIAMANTE DO } \\
\text { OESTE }\end{array}$ \\
\hline 27 & TOLEDO & $\begin{array}{l}\text { ENTRE RIOS DO } \\
\text { OESTE }\end{array}$ \\
\hline 27 & TOLEDO & GUAIRA \\
\hline 27 & TOLEDO & $\begin{array}{l}\text { MARECHAL } \\
\text { CANDIDO } \\
\text { RONDON }\end{array}$ \\
\hline 27 & TOLEDO & MARIPA \\
\hline 27 & TOLEDO & MERCEDES \\
\hline 27 & TOLEDO & $\begin{array}{l}\text { NOVA SANTA } \\
\text { ROSA }\end{array}$ \\
\hline 27 & TOLEDO & $\begin{array}{l}\text { OURO VERDE DO } \\
\text { OESTE }\end{array}$ \\
\hline 27 & TOLEDO & PALOTINA \\
\hline 27 & TOLEDO & PATO BRAGADO \\
\hline 27 & TOLEDO & $\begin{array}{l}\text { QUATRO } \\
\text { PONTES }\end{array}$ \\
\hline 27 & TOLEDO & SANTA HELENA \\
\hline 27 & TOLEDO & $\begin{array}{l}\text { SAO JOSE DAS } \\
\text { PALMEIRAS }\end{array}$ \\
\hline 27 & TOLEDO & $\begin{array}{l}\text { SAO PEDRO DO } \\
\text { IGUACU }\end{array}$ \\
\hline 27 & TOLEDO & TERRA ROXA \\
\hline 27 & TOLEDO & TOLEDO \\
\hline 28 & UMUARAMA & ALTO PARAISO \\
\hline 28 & UMUARAMA & ALTO PIQUIRI \\
\hline 28 & UMUARAMA & ALTONIA \\
\hline 28 & UMUARAMA & $\begin{array}{l}\text { CAFEZAL DO } \\
\text { SUL }\end{array}$ \\
\hline 28 & UMUARAMA & $\begin{array}{l}\text { CRUZEIRO DO } \\
\text { OESTE }\end{array}$ \\
\hline 28 & UMUARAMA & DOURADINA \\
\hline 28 & UMUARAMA & $\begin{array}{l}\text { ESPERANCA } \\
\text { NOVA }\end{array}$ \\
\hline 28 & UMUARAMA & $\begin{array}{l}\text { FRANCISCO } \\
\text { ALVES }\end{array}$ \\
\hline 28 & UMUARAMA & ICARAIMA \\
\hline 28 & UMUARAMA & IPORA \\
\hline 28 & UMUARAMA & IVATE \\
\hline 28 & UMUARAMA & MARIA HELENA \\
\hline 28 & UMUARAMA & NOVA OLIMPIA \\
\hline 28 & UMUARAMA & PEROBAL \\
\hline 28 & UMUARAMA & PEROLA \\
\hline 28 & UMUARAMA & $\begin{array}{l}\text { SAO JORGE DO } \\
\text { PATROCINIO }\end{array}$ \\
\hline 28 & UMUARAMA & TAPIRA \\
\hline 28 & UMUARAMA & UMUARAMA \\
\hline 28 & UMUARAMA & XAMBRE \\
\hline 29 & UNIÃO DA VITÓRIA & $\begin{array}{l}\text { ANTONIO } \\
\text { OLINTO }\end{array}$ \\
\hline 29 & UNIÃO DA VITÓRIA & BITURUNA \\
\hline 29 & UNIÃO DA VITÓRIA & CRUZ MACHADO \\
\hline 29 & UNIÃO DA VITÓRIA & $\begin{array}{l}\text { GENERAL } \\
\text { CARNEIRO } \\
\end{array}$ \\
\hline 29 & UNIÃO DA VITÓRIA & PAULA FREITAS \\
\hline 29 & UNIÃO DA VITÓRIA & PAULO FRONTIN \\
\hline 29 & UNIÃO DA VITÓRIA & PORTO VITORIA \\
\hline 29 & UNIÃO DA VITÓRIA & $\begin{array}{l}\text { SAO MATEUS DO } \\
\text { SUL }\end{array}$ \\
\hline
\end{tabular}




\section{ESTADO DO PARANÁ}

Secretaria de Estado da Administração e da Previdência

Departamento de Recursos Humanos

\begin{tabular}{|c|l|l|}
\hline 29 & UNIÃO DA VITÓRIA & $\begin{array}{c}\text { UNIAO DA } \\
\text { VITORIA }\end{array}$ \\
\hline 30 & WENCESLAU BRAZ & ARAPOTI \\
\hline 30 & WENCESLAU BRAZ & JAGUARIAIVA \\
\hline 30 & WENCESLAU BRAZ & $\begin{array}{c}\text { SALTO DO } \\
\text { ITARARE }\end{array}$ \\
\hline 30 & WENCESLAU BRAZ & $\begin{array}{l}\text { SANTANA DO } \\
\text { ITARARE }\end{array}$ \\
\hline 30 & WENCESLAU BRAZ & SAO JOSE DA \\
BOA VISTA
\end{tabular}

\begin{tabular}{|c|l|l|}
\hline 31 & LARANJEIRAS DO SUL & $\begin{array}{c}\text { NOVA } \\
\text { LARANJEIRAS }\end{array}$ \\
\hline 31 & LARANJEIRAS DO SUL & $\begin{array}{c}\text { PORTO } \\
\text { BARREIRO }\end{array}$ \\
\hline 31 & LARANJEIRAS DO SUL & $\begin{array}{c}\text { QUEDAS DO } \\
\text { IGUACU }\end{array}$ \\
\hline 31 & LARANJEIRAS DO SUL & $\begin{array}{c}\text { RIO BONITO DO } \\
\text { IGUACU }\end{array}$ \\
\hline 31 & LARANJEIRAS DO SUL & VIRMOND \\
\hline 32 & IBAITI & $\begin{array}{c}\text { CONSELHEIRO } \\
\text { MAIRINCK }\end{array}$ \\
\hline 32 & IBAITI & FIGUEIRA \\
\hline 32 & IBAITI & GUAPIRAMA \\
\hline 32 & IBAITI & IBAITI \\
\hline 32 & IBAITI & JABOTI \\
\hline 32 & IBAITI & JAPIRA \\
\hline 32 & IBAITI & PINHALAO \\
\hline 32 & IBAITI & SIQUEIRA \\
\hline 32 & IBAITI & TAMPOS \\
\hline
\end{tabular}




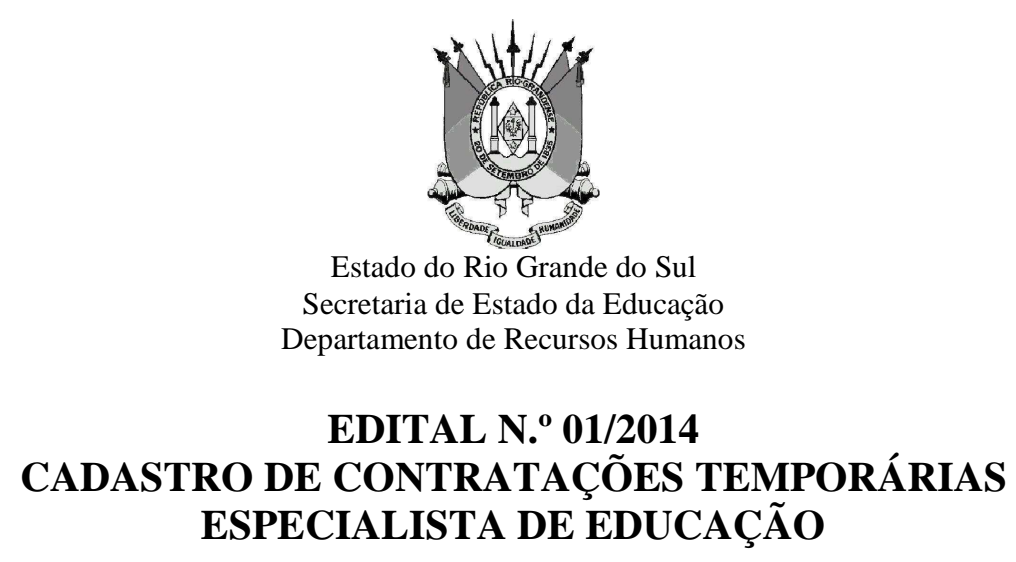

O SECRETÁRIO DE ESTADO DA EDUCAÇÃO, no uso de suas atribuições legais, em conformidade com o inciso IX, do art. 37, da Constituição Federal e inciso IV do art. 19, da Constituição Estadual, disciplinado na Lei Complementar Federal $n^{\circ}$ 101, de 04 de maio de 2000, nos termos da Lei $n^{\circ} 6672$, de 22 de abril de 1974, da Lei Estadual n. ${ }^{\circ} 13.426 / 2010$, de 05/04/2010, regulamentada pelo Decreto Estadual n. ${ }^{\circ} 47.225$ de 13 de maio de 2010, torna público aos interessados que estão abertas nas Coordenadorias Regionais de Educação, para exercício funcional em Estabelecimento de Ensino, as inscrições às contratações temporárias para as funções correspondentes às atribuições dos cargos de Orientador Educacional e de Supervisor Escolar, previstas na Lei 7.132 de 13 de janeiro de 1978, para o ano letivo de 2014, na rede de ensino público estadual e de acordo com as normas deste Edital.

\section{I - DAS NECESSIDADES}

As necessidades a serem providas, em caráter temporário, pelas Coordenadorias Regionais de Educação, são as descritas no anexo único deste Edital.

\section{II - DAS CARACTERÍSTICAS DA FUNÇÃO}

1. Atribuições: de acordo com a descrição da Lei Estadual n. ${ }^{\circ} 7.132$, de 13 de janeiro de 1978, dos Cargos de Orientador Educacional e de Supervisor Escolar;

2. Regime de trabalho de 20 , ou 40 horas semanais, conforme a necessidade da Coordenadoria Regional de Educação, no ato de admissão;

3. Remuneração dos contratos, na forma da Lei, corresponderá ao vencimento do nível 5 (cinco), classe A, da carreira.

\section{III - DAS INSCRIÇÕES E SUAS CONDIÇÕES:}

Os candidatos deverão realizar a inscrição via internet, através do site www.educacao.rs.gov.br ou nas Coordenadorias Regionais de Educação, conforme endereços a seguir relacionados, no período de no período de 22 a 28 de janeiro de 2014, no horário da $9 \mathrm{~h}$ às $11 \mathrm{~h} 30 \mathrm{~min}$ e das $14 \mathrm{~h}$ às $17 \mathrm{~h}$ :

$1^{\text {a }}$ CRE - PORTO ALEGRE

Rua Cabral №. 621 - Bairro Rio Branco

$2^{\mathrm{a}}$ CRE - SÃO LEOPOLDO

Av. João Corrêa, esquina São Joaquim, s/no 
$3^{\text {a }}$ CRE - ESTRELA

R. Cel. Mussrich, 773

4 CRE - CAXIAS DO SUL

Av. Júlio de Castilhos, 4020

$5^{\text {a }}$ CRE - PELOTAS

R. Barão de Butuí, 396

$6^{\text {a }}$ CRE - SANTA CRUZ DO SUL

Rua Ernesto Alves, 887

$7^{\mathrm{a}}$ CRE - PASSO FUNDO

Rua Saldanha Marinho, 478

$8^{\text {a }}$ CRE - SANTA MARIA

Av. Presidente Vargas, 1052

9a CRE - CRUZ ALTA

Rua Pinheiro Machado, 701

10 ${ }^{\text {a }}$ CRE - URUGUAIANA

Rua Duque de Caxias, 2827

11 ${ }^{\text {a }}$ CRE - OSÓRIO

Rua Barão do Rio Branco, 381

12 $2^{\mathrm{a}}$ CRE - GUAÍBA

Rua Dr. Joaquim Ribeiro, 231

13 ${ }^{\text {a }}$ CRE - BAGÉ

Av. Sete de Setembro, 1264

14 ${ }^{\text {a }}$ CRE - SANTO ANGELO

Rua Br. de Santo Ângelo, 832

15 CRE - ERECHIM

Praça da Bandeira, 190 / Centro

$16^{\text {a }}$ CRE - BENTO GONÇALVES

Av. Presidente Costa e Silva, 115

17 ${ }^{\text {a }}$ CRE - SANTA ROSA

Rua Borges de Medeiros, 806

$18^{\text {a }}$ CRE - RIO GRANDE

Rua Fernando Duprat da Silva, 94

$19^{\text {a }}$ CRE - SANTANA DO LIVRAMENTO

Rua Duque de Caxias, 1490

20 ${ }^{\text {a }}$ CRE - PALMEIRA DAS MISSÕES

Av. Independência, 836

21 ${ }^{\text {a }}$ CRE - TRES PASSOS

Av. Borges de Medeiros, 207

$23^{\text {a }}$ CRE - VACARIA

Av. Júlio de Castilhos, 653 
24' CRE - CACHOEIRA DO SUL

Rua Ramiro Barcelos, 2762

25 ${ }^{\text {a }}$ CRE - SOLEDADE

R. Dr. Flores, 152

27 CRE - CANOAS

Av. Inconfidência, 420

28 ${ }^{\text {a }}$ CRE - GRA VATAI

Av. Cel. Fonseca, 627

32 ${ }^{\mathrm{a}}$ CRE - SÃO LUIZ GONZAGA

Rua Venâncio Aires, 2418

35 ${ }^{\mathrm{a}}$ CRE - SÃO BORJA

Av. Presidente Vargas, 2637

$3^{\mathrm{a}}$ CRE - IJUI

Rua XV de Novembro, 498

39' CRE - CARAZINHO

Av. Flores da Cunha, 1082

1 - O candidato poderá inscrever-se em um só município e para uma só função;

2 - O candidato deverá digitar, no Formulário Eletrônico de Inscrição, o número do documento de identidade que tenha fé pública e seu nome conforme consta neste documento, bem como CIC/CPF, endereço, telefone e e-mail;

3 - Após o preenchimento do Formulário Eletrônico de Inscrição, o candidato deverá gerar o documento que será anexado, junto com os comprovantes de titulação, conforme item 6, ao envelope a ser entregue nas Coordenadoria Regionais de Educação ou pelo Correio via SEDEX até o último dia da inscrição. Da documentação, também, fará parte a declaração do candidato aceitando a contratação, devidamente assinada.

4 - A inscrição será considerada aceita quando o candidato proceder à entrega dos documentos comprobatórios com os dados constantes na inscrição;

5 - A entrega da documentação correta é de inteira responsabilidade do candidato.

\subsection{REQUISITOS PARA A INSCRIÇÃO E CONDIÇÕES DE ADMISSÃO}

-ser brasileiro nato ou naturalizado, ou gozar das prerrogativas constantes do artigo 12 da Constituição Federal;

-possuir idade mínima de 18(dezoito) anos completos na data do encerramento das inscrições;

- estar em dia com as obrigações eleitorais;

- não registrar antecedentes criminais, achando-se em pleno gozo de seus direitos civis e políticos;

- estar regularizada a situação com o Serviço Militar (para os candidatos do sexo masculino);

- possuir habilitação conforme art.64, 65 e 67 da Lei 9394/96, de 20 de dezembro de 1996;

-gozar de boa saúde física e mental.

\subsection{DOCUMENTOS NECESSÁRIOS PARA A INSCRIÇÃO}

Deverá ser entregue a cópia reprográfica dos documentos, no envelope, junto com a folha de inscrição impressa conforme item 3.4, bem como os comprovantes dos títulos para classificação. 


\section{IV - DA CLASSIFICAÇÃO}

\section{CRITÉRIOS:}

\section{Orientação Educacional}

*Licenciatura Plena em Pedagogia com habilitação específica em Orientação Educacional, possuidores de diplomas expedidos por estabelecimentos de ensino superior oficiais ou reconhecidos;

*Licenciatura Plena em qualquer disciplina com pós-graduação específica em Orientação Educacional, ministrados por estabelecimentos oficiais ou reconhecidos, devidamente credenciados pelo Conselho Federal de Educação, com estágio específico; *Certificado de Pós-Graduação em Orientação Educacional (mínimo 360horas);

*Certificado de Mestrado em Orientação Educacional (mínimo 360 horas);

*Comprovação de tempo de exercício na função de Orientação Educacional;

*Comprovação de tempo de regência de classe;

*Sorteio público, no caso de empate.

\section{Supervisão Escolar}

*Licenciatura Plena em Pedagogia com habilitação específica em Supervisão Escolar, possuidores de diplomas expedidos por estabelecimentos de ensino oficiais ou reconhecidos;

*Licenciatura Plena em qualquer disciplina com pós-graduação específica em Supervisão Escolar, ministrados por estabelecimentos oficiais ou reconhecidos, com estágio específico;

*Certificado de Pós-Graduação em Supervisão Escolar (mínimo 360 horas);

*Certificado de Mestrado em Supervisão Escolar (mínimo 360 horas);

*Comprovação de tempo de exercício na função de Supervisão Escolar;

*Comprovação de tempo de regência de classe;

*Sorteio público, no caso de empate.

\section{COMISSÃO:}

Para efeito de classificação dos candidatos, segundo os critérios previstos na Lei $\mathrm{n}^{\circ}$ 13.426/2010, será constituída comissão específica designada pelo Titular da Secretaria da Educação.

\section{PONTUAÇÃO}

- A classificação será efetivada através da pontuação dos títulos apresentados pelo candidato;

- Na experiência comprovada para a função será considerado o período comprovado através de atestados atualizados, expedidos pelas escolas de atuação.

\section{DIVULGAÇÃO DA CLASSIFICAÇÃO}

- A classificação, em ordem decrescente a partir da pontuação máxima alcançada individualmente entre os candidatos, no município e Coordenadoria Regional de Educação, será publicada em Edital no Diário Oficial do Estado.

\subsection{CRITÉRIO DE DESEMPATE}

Depois de publicada a classificação dos candidatos, havendo empate, será realizado sorteio público, cujo chamamento será feito por Edital publicado no 
Diário Oficial do Estado, com vinte e quatro horas de antecedência, incluindo o local, horário e especificando os casos de empate por Coordenadoria Regional de Educação.

\subsection{CLASSIFICAÇÃO FINAL}

- Após o desempate através de sorteio público, conforme previsto no item anterior será publicada a classificação final no Diário Oficial do Estado, em Edital que homologará o processo classificatório;

\section{V - DA ADMISSÃO}

1. Obedecida à rigorosa ordem de classificação, a contratação dos especialistas, em caráter temporário, estará subordinada às necessidades de serviço especificadas no Edital;

2. Publicado o ato de admissão no Diário Oficial do Estado, deverá a Coordenadoria Regional de Educação efetuar o chamamento dos candidatos admitidos, mediante divulgação em rádio, jornais e telegrama.

3. Os candidatos admitidos terão o prazo de 72 (setenta e duas) horas, para manifestação, a contar da data do chamamento pela Coordenadoria Regional de Educação.

4. Se o candidato não se apresentar no prazo estabelecido no item anterior, será considerado desistente.

\section{VI - DISPOSIÇÕES GERAIS E FINAIS}

1. Não serão aceitos documentos e/ou títulos fora do ato de inscrição.

2. O Anexo Único é parte integrante deste Edital.

3. Os casos omissos serão resolvidos pela Comissão da Coordenadoria Regional de Educação.

4. O candidato deverá comunicar pessoalmente, e por escrito, à Coordenadoria Regional de Educação, qualquer mudança de endereço residencial. É de inteira responsabilidade do candidato, fornecer de maneira completa, seu endereço.

5. Comprovada, em qualquer tempo, irregularidade ou ilegalidade na obtenção dos títulos apresentados para pontuação, o candidato terá anulada a sua inscrição e os atos dela decorrente.

6. O preenchimento da ficha de inscrição importará no conhecimento das instruções deste Edital e aceitação tácita das condições nele contidas, tais como se acham estabelecidas.

Porto Alegre, 17 de janeiro de 2014.

Jose Clovis de Azevedo

Secretário de Estado da Educação.

Registre-se e publique-se,

Diretor(a) do Departamento Administrativo/SE. 


\section{ANEXO ÚNICO}

\section{ORIENTAÇÃO EDUCACIONAL E SUPERVISÃO ESCOLAR}

$1^{\text {a }}$ CRE

PORTO ALEGRE

$2^{\mathrm{a}}$ CRE

ALTO FELIZ

ARARICA

BARÃO

BOM PRINCÍPIO

BROCHIER

CAMPO BOM

CAPELA DE SANTANA

DOIS IRMÃOS

ESTÂNCIA VELHA

FELIZ

HARMONIA

IGREJINHA

IVOTI

LINDOLFO COLLOR

LINHA NOVA

MARATÁ

MONTENEGRO

MORRO REUTER

NOVA HARTZ

NOVO HAMBURGO

PARECI NOVO

PAROBE

POÇO DAS ANTAS

PORTÃO

PRESIDENTE LUCENA

SALVADOR DO SUL

SANTA MARIA DO HERVAL

SÃO JOSÉ DO HORTENCIO

SÃO JOSÉ DO SUL

SÃO LEOPOLDO

SÃO PEDRO DA SERRA

SÃO SEBASTIÃO DO CAÍ

SÃO VENDELINO

SAPIRANGA

TAQUARA

TRES COROAS

TUPANDI

VALE REAL

\section{$3^{\text {a }}$ CRE}

ANTA GORDA

ARROIO DO MEIO

BOM RETIRO DO SUL

CANUDOS DO VALE

CAPITÃO

COLINAS

COQUEIRO BAIXO

CRUZEIRO DO SUL

DOUTOR RICARDO

ENCANTADO

ESTRELA

FAZENDA VILA NOVA 
FORQUETINHA

IMIGRANTE

LAJEADO

MARQUES DE SOUZA

MUÇUM

NOVA BRESCIA

PAVERAMA

POUSO NOVO

PROGRESSO

PUTINGA

RELVADO

ROCA SALES

SANTA CLARA DO SUL

SERIO

TABAÍ

TAQUARI

TEUTÔNIA

TRAVESSEIRO

VESPASIANO CORREA

WESTFALIA

\section{$4^{\text {a }}$ CRE}

ANTONIO PRADO

CAMBARÁ DO SUL

CANELA

CAXIAS DO SUL

FARROUPILHA

FLORES DA CUNHA

GRAMADO

JAQUIRANA

NOVA PADUA

NOVA PETRÓPOLIS

NOVA ROMA DO SUL

PICADA CAFÉ

SÃO FRANCISCO DE PAULA

SÃO MARCOS

$5^{\mathbf{a}}$ CRE

AMARAL FERRADOR

ARROIO DO PADRE

ARROIO GRANDE

CANGUÇU

CAPÃO DO LEÃO

CERRITO

CRISTAL

HERVAL

JAGUARÃO

MORRO REDONDO

PEDRAS ALTAS

PEDRO OSORIO

PELOTAS

PINHEIRO MACHADO

PIRATINI

SANTANA DA BOA VISTA

SÃO LOURENÇO DO SUL

TURUÇU

$6^{\mathrm{a}}$ CRE

BOQUEIRÃO DO LEÃO

CANDELARIA

ENCRUZILHADA DO SUL

GRAMADO XAVIER

HERVEIRAS

LAGOA BONITA DO SUL 
MATO LEITÃO

PANTANO GRANDE

PASSA SETE

PASSO DO SOBRADO

RIO PARDO

SANTA CRUZ DO SUL

SINIMBU

SOBRADINHO

VALE DO SOL

VALE VERDE

VENÂNCIO AIRES

VERA CRUZ

$7^{\text {a }}$ CRE

AGUA SANTA

CAMARGO

CAPÃO BONITO DO SUL

CASCA

CASEIROS

CIRÍACO

COXILHA

DAVID CANABARRO

ERNESTINA

GENTIL

GRAMADO DOS LOUREIROS

GUAPORÉ

IBIAÇA

IBIRAIARAS

LAGOA VERMELHA

MARAU

MATO CASTELHANO

MULITERNO

NICOLAU VERGUEIRO

NONOAI

PASSO FUNDO

PONTÃO

RIO DOS INDIOS

SANTA CECILIA DO SUL

SANTO ANTONIO DO PALMA

SÃO DOMINGOS DO SUL

SERTÃO

TAPEJARA

UNIÃO DA SERRA

VANINI

VILA LANGARO

VILA MARIA

$8^{\mathrm{a}}$ CRE

CACEQUI

DILERMANDO DE AGUIAR

FAXINAL DO SOTURNO

FORMIGUEIRO

ITAARA

IVORA

JAGUARI

JULIO DE CASTILHOS

MATA

NOVA ESPERANÇA DO SUL

NOVA PALMA

PINHAL GRANDE

QUEVEDOS

SANTA MARIA

SÃO FRANCISCO DE ASSIS

SÃO JOÃO DO POLESINE 
SÃO MARTINHO DA SERRA

SÃO PEDRO DO SUL

SÃO SEPÉ

SÃO VICENTE DO SUL

SILVEIRA MARTINS

TOROPI

VILA NOVA DO SUL

\section{$9^{\text {a }}$ CRE}

BOA VISTA DO CADEADO

BOA VISTA DO INCRA

CRUZ ALTA

FORTALEZA DOS VALOS

IBIRUBÁ

JACUIZINHO

JARI

PEJUÇARA

QUINZE DE NOVEMBRO

SALTO DO JACUI

TUPANCIRETÃ

10 ${ }^{\text {a }}$ CRE

ALEGRETE

BARRA DO QUARAÍ

ITAQUI

MANOEL VIANA

URUGUAIANA

\section{1 ${ }^{\text {a }}$ CRE}

ARROIO DO SAL

BALNEÁRIO PINHAL

CAPÃO DA CANOA

CAPIVARI DO SUL

CARAÁ

CIDREIRA

DOM PEDRO DE ALCÂNTARA

IMBÉ

ITATI

MAMPITUBA

MAQUINÉ

MORRINHOS DO SUL

MOSTARDAS

OSORIO

PALMARES DO SUL

RIOZINHO

ROLANTE

SANTO ANTONIO DA PATRULHA

TAVARES

TERRA DE AREIA

TORRES

TRAMANDAÍ

TRES CACHOEIRAS

TRES FORQUILHAS

XANGRILÁ

12 $2^{\text {a }}$ CRE

ARAMBARÉ ARROIO DOS RATOS

BARÃO DO TRIUNFO

BARRA DO RIBEIRO

BUTIÁ

CAMAQUÃ

CERRO GRANDE DO SUL

CHARQUEADAS 
CHUVISCA

DOM FELICIANO

ELDORADO DO SUL

GENERAL CÃMARA

GUAÍBA

MARIANA PIMENTEL

MINAS DO LEÃO

SÃO JERONIMO

SENTINELA DO SUL

SERTÃO SANTANA

TAPES

13 ${ }^{\text {a }}$ CRE

ACEGUA

BAGÉ

CAÇAPAVA DO SUL

CANDIOTA

DOM PEDRITO

HULHA NEGRA

LAVRAS DO SUL

\section{4 ${ }^{\mathrm{a}} \mathrm{CRE}$}

CERRO LARGO

ENTRE-IJUÍS

EUGENIO DE CASTRO

GUARANI DAS MISSÕES

SALVADOR DAS MISSÕES

SANTO ANGELO

SÃO MIGUEL DAS MISSÕES

SÃO PEDRO DO BUTIÁ

SETE DE SETEMBRO

UBIRETAMA

VITORIA DAS MISSÕES

\section{5 ${ }^{\mathrm{a}}$ CRE}

ARATIBA

AUREA

BARÃO DO COTEGIPE

BARRA DO RIO AZUL

BARRACÃO

BENJAMIN CONSTANT DO SUL

CACIQUE DOBLE

CAMPINAS DO SUL

CARLOS GOMES

CENTENÁRIO

CHARRUA

CRUZALTENSE

ENTRE RIOS DO SUL

EREBANGO

ERECHIM

ERVAL GRANDE

ESTAÇÃO

FAXINALZINHO

FLORIANO PEIXOTO

GAURAMA

GETULIO VARGAS

IPIRANGA DO SUL

ITATIBA DO SUL

JACUTINGA

MACHADINHO

MARCELINO RAMOS

MAXIMILIANO DE ALMEIDA

MARIANO MORO

PAIM FILHO 
PAULO BENTO

PONTE PRETA

QUATRO IRMÃOS

SANANDUVA

SANTO EXPEDITO DO SUL

SÃO JOÃO DA URTIGA

SÃO JOSÉ DO OURO

SÃO VALENTIM

SEVERIANO DE ALMEIDA

TRES ARROIOS

TUPANCI DO SUL

VIADUTOS

16 $^{\text {a }}$ CRE

ANDRE DA ROCHA

BENTO GONÇALVES

BOA VISTA DO SUL

CARLOS BARBOSA

CORONEL PILAR

COTIPOR Ã

DOIS LAJEADOS

FAGUNDES VARELA

GARIBALDI

GUABIJU

MONTAURI

MONTE BELO DO SUL

NOVA ARAÇÁ

NOVA BASSANO

NOVA PRATA

PARAI

PROTASIO ALVES

SANTA TEREZA

SÃO JORGE

SÃO VALENTIM DO SUL

SERAFINA CORREA

VERANÓPOLIS

VILA FLORES

VISTA ALEGRE DO PRATA

17 ${ }^{\text {a }}$ CRE

ALECRIM

ALEGRIA

BOA VISTA DO BURICÁ

CAMPINA DAS MISSÕES

CANDIDO GODOI

DOUTOR MAURÍCIO CARDOSO

GIRUÁ

HORIZONTINA

INDEPENDENCIA

NOVA CANDELARIA

NOVO MACHADO

PORTO LUCENA

PORTO MAUÁ

PORTO VERA CRUZ

SANTA ROSA

SANTO CRISTO

SÃO JOSÉ DO INHACORÁ

SÃO PAULO DAS MISSÕES

SENADOR SALGADO FILHO

TRES DE MAIO

TUCUNDUVA

TUPARENDI 


\section{8 ${ }^{\mathrm{a}}$ CRE}

CHUÍ

RIO GRANDE

SANTA VITORIA DO PALMAR

SÃO JOSÉ DO NORTE

QUARAÍ

19 ${ }^{\text {a }}$ CRE

ROSARIO DO SUL

SANTA MARGARIDA DO SUL

SANTANA DO LIVRAMENTO

SÃO GABRIEL

\section{CRE}

ALPESTRE

AMETISTA DO SUL

BOA VISTA DAS MISSÕES

CAIÇARA

CERRO GRANDE

CRISTAL DO SUL

DOIS IRMÃOS DAS MISSÕES

ERVAL SECO

FREDERICO WESTPHALEN

IRAÍ

JABOTICABA

LAJEADO DO BUGRE

LIBERATO SALZANO

NOVO BARREIRO

NOVO TIRADENTES

PALMEIRA DAS MISSÕES

PALMITINHO

PINHAL

PINHEIRINHO DO VALE

PLANALTO

RODEIO BONITO

SAGRADA FAMILIA

SÃO JOSE DAS MISSÕES

SÃO PEDRO DAS MISSÕES

SEBERI

TAQUARUÇU DO SUL

VICENTE DUTRA

VISTA ALEGRE

\section{1 ${ }^{\text {a }}$ CRE}

BARRA DO GUARITA

BOM PROGRESSO

BRAGA

CAMPO NOVO

CORONEL BICACO

CRISSIUMAL

DERRUBADAS

ESPERANÇA DO SUL

HUMAITÁ

MIRAGUAÍ

REDENTORA

SANTO AUGUSTO

SÃO MARTINHO

SÃO VALÉRIO DO SUL

SEDE NOVA

TENENTE PORTELA

TIRADENTES DO SUL

TRES PASSOS

VISTA GAÚCHA 


\section{$23^{\text {a }}$ CRE}

BOM JESUS

CAMPESTRE DA SERRA

ESMERALDA

IPE

MONTE ALEGRE DOS CAMPOS

MUITOS CAPÕES

PINHAL DA SERRA

SÃO JOSÉ DOS AUSENTES

VACARIA

\section{CRE}

AGUDO

ARROIO DO TIGRE

CACHOEIRA DO SUL

CERRO BRANCO

DONA FRANCISCA

ESTRELA VELHA

IBARAMA

NOVO CABRAIS

PARAISO DO SUL

RESTINGA SECA

SEGREDO

\section{$2^{\mathrm{a}}$ CRE}

ALTO ALEGRE

ARVOREZINHA

BARROS CASSAL

CAMPOS BORGES

ESPUMOSO

FONTOURA XAVIER

IBIRAPUITÃ

ILOPOLIS

ITAPUCA

LAGOA DOS TRES CANTOS

LAGOÃO

MORMACO

NOVA ALVORADA

SÃO JOSE DO HERVAL

SELBACH

SOLEDADE

TAPERA

TUNAS

27 $7^{\mathrm{a}}$ CRE

CANOAS

ESTEIO

NOVA SANTA RITA

SAPUCAIA DO SUL

TRIUNFO

\section{$28^{\text {a }}$ CRE}

ALVORADA

CACHOEIRINHA

GLORINHA

GRAVATAÍ

VIAMÃO

\section{CRE}

BOSSOROCA

CAIBATÉ

DEZESSEIS DE NOVEMBRO 
MATO QUEIMADO

PIRAPO

PORTO XAVIER

ROLADOR

ROQUE GONZALES

SANTO ANTONIO DAS MISSÕES

SÃO LUIZ GONZAGA

SÃO NICOLAU

\section{$3^{\mathrm{a}}$ CRE}

CAPÃO DO CIPÓ

GARRUCHOS

ITACURUBI

MAÇAMBARÁ

SANTIAGO

SÃO BORJA

UNISTALDA

\section{6 $^{\mathrm{a}}$ CRE}

AJURICABA

AUGUSTO PESTANA

BOZANO

CATUIPE

CHIAPETA

CONDOR

CORONEL BARROS

IJUÍ

INHACORÁ

JOIA

NOVA RAMADA

PANAMBI

\section{9 ${ }^{\text {a }}$ CRE}

ALMIRANTE TAMANDARE DO SUL BARRA FUNDA

CARAZINHO

CHAPADA

COLORADO

CONSTANTINA

COQUEIROS DO SUL

ENGENHO VELHO

NÃO ME TOQUE

NOVA BOA VISTA

NOVO XINGU

RONDA ALTA

RONDINHA

SALDANHA MARINHO

SANTA BARBARA DO SUL

SANTO ANTONIO DO PLANALTO

SARANDI

TIO HUGO

TRES PALMEIRAS

TRINDADE DO SUL

VICTOR GRAEFF 


\title{
EDITAL DE CONCURSO PÚBLICO N.006/GDRH/SEAD, DE 10 DE JANEIRO DE 2013.
}

\author{
ATUALIZADO CONFORME RETIFICAÇÕES 01, 02 e 03
}

O Secretário de Estado da Administração do Governo de Rondônia, Senhor RUI VIEIRA DE SOUSA, no uso de suas atribuições legais, conferida pela Lei Complementar n. 327, de 13 de dezembro de 2005, de acordo com os termos do Processo Administrativo n. 01-2201.19200-00/2012/SEAD, torna público que realizará, através da Fundação Professor Carlos Augusto Bittencourt - FUNCAB, Concurso Público para provimento de 1.144 (um mil cento e quarenta e quatro) vagas do cargo de Professor Classe "C", (áreas específicas), pertencentes ao Quadro de Pessoal Efetivo da Secretaria de Estado da Educação de Rondônia, previsto na Lei Complementar n. 680, de 7 de setembro de 2012, publicada no Diário Oficial do Estado de Rondônia n. 2054, de 7 de setembro de 2012 - Caderno Especial, mediante as condições especiais estabelecidas neste Edital e seus Anexos.

\section{DAS DISPOSIÇÕES PRELIMINARES}

1.1. O Concurso Público será regido por este Edital, anexos e eventuais retificações, sendo executado pela Fundação Professor Carlos Augusto Bittencourt - FUNCAB.

1.2. A realização da inscrição implica na concordância do candidato com as regras estabelecidas neste Edital, com renúncia expressa a quaisquer outras.

1.3. O prazo de validade do presente Concurso Público é de 2 (dois) anos, a contar da data da publicação da homologação de seu resultado final, podendo ser prorrogado, uma vez, por igual período, mediante ato do Chefe do Poder Executivo Estadual, conforme dispõe o Artigo 37, inciso III, da Constituição Federal.

1.4. As inscrições para este Concurso Público serão realizadas via Internet, conforme especificado no Item 5.

1.5. Todo o processo de execução deste Concurso Público, com as informações pertinentes, estará disponível no site www.funcab.org.

1.6. Todos os atos oficiais relativos ao Concurso Público serão publicados no Diário Oficial do Estado de Rondônia, na imprensa local e nos sites www.funcab.org e www.rondonia.ro.gov.br. As convocações para posse não serão publicadas no site da FUNCAB.

1.7. O candidato deverá acompanhar as notícias relativas a este Concurso Público nos órgãos de imprensa e sites citados no subitem 1.6, pois, caso ocorram alterações nas normas contidas neste Edital, elas serão neles divulgados.

1.8. Os conteúdos programáticos para todos os cargos/áreas estarão disponíveis no ANEXO VI.

1.9. Os candidatos aprovados que vierem a ingressar no Quadro de Pessoal Efetivo da SEDUC/RO pertencerão ao regime jurídico estatutário e reger-se-ão pelas disposições da Lei Complementar n. 680, de 7 de setembro de 2012, publicada no Diário Oficial do Estado de Rondônia n. 2054, de 7 de setembro de 2012 - Caderno Especial e, no que couber, pelo Estatuto dos Servidores Públicos Civil do Estado de Rondônia, previstos pela Lei Complementar n. 068, de 9 de dezembro de 1992 e suas alterações.

1.10. As atribuições do cargo constam no ANEXO VII.

\section{DAS VAGAS}

2.1. O Concurso Público visa o provimento de 1.144 (um mil cento e quarenta e quatro) vagas do cargo de Professor Classe "C" (áreas específicas), pertencentes ao Quadro de Pessoal Efetivo da Secretaria de Educação do Estado de Rondônia, previsto na Lei Complementar n. 680, de 7 de setembro de 2012, publicada no Diário Oficial do Estado de Rondônia n. 2054, de 7 de setembro de 2012 - Caderno Especial, conforme ANEXO I.

2.2. A escolaridade/habilitação exigida para ingresso será de nível superior na área que concorre, devidamente reconhecida por órgão oficial, mais Registro no Conselho de Classe equivalente para os cargos que couberem, conforme ANEXO I.

2.3. A carga horária de trabalho para todos os servidores será de 40 (quarenta) horas semanais.

2.4. As vagas destinam-se para a lotação em Escolas Públicas Estaduais nas localidades, conforme ANEXO I.

2.5. O valor do vencimento básico será de $\mathrm{R} \$ 1.904,78$ "Anexo I da Lei Complementar n. 680/2012".

2.5.1. A remuneração poderá ser composta de valor superior ao vencimento básico, caso o servidor atenda a dispositivo legalmente constituído.

2.6. Cursos com nomenclaturas diferentes das disponibilizadas no Quadro de Vagas, que possam ter ligação direta com a habilitação exigida para ingresso no cargo, poderão ser submetidos a consultas perante os órgãos competentes, através do setor jurídico da Administração, para verificar da possibilidade de concessão, ou não, de posse.

2.7. O quantitativo de vagas ofertado no presente concurso poderá ser ampliado, considerando a necessidade e o quadro reserva que será constituído por todos aqueles candidatos aprovados fora de número de vagas ofertadas. Para esse fim, tornarse-á necessária a conveniência da administração pública, bem como dotação orçamentária própria disponível para custear os salários dos servidores abrangidos.

\section{DOS REQUISITOS BÁSICOS PARA INVESTIDURA NO CARGO}

3.1. Os requisitos básicos para investidura no cargo são, cumulativamente, os seguintes:

a) Ter sido aprovado no Concurso Público, incluindo-se todas as provas;

b) ser brasileiro ou, em caso de nacionalidade portuguesa, estar amparado pelo estatuto de igualdade entre brasileiros e 
portugueses, com reconhecimento de gozo de direitos políticos, nos termos do parágrafo $1^{\circ}$, artigo 12 , da Constituição Federal;

c) estar quite com as obrigações eleitorais;

d) estar quite com as obrigações militares, para os candidatos do sexo masculino;

e) encontrar-se em pleno gozo de seus direitos políticos e civis;

f) não ter sofrido, no exercício de função pública, penalidade incompatível com nova investidura em cargo público;

g) apresentar escolaridade compatível para o exercício do cargo;

h) estar apto física e mentalmente para o exercício do cargo, incluindo-se os candidatos inscritos na condição de portador de deficiência, atestado pela Junta Médica do Estado de Rondônia, através de Perícia Médica;

i) ter idade mínima de 18 (dezoito) anos;

j) apresentar declaração negativa de antecedentes criminais;

k) certidões fazendárias emitidas pela Secretaria de Estado de Finanças e Tribunal de Contas do Estado de Rondônia;

l) Registro no Conselho de Classe equivalente, para os cargos que couberem;

m) Certidão Negativa do Conselho de Classe equivalente, para os cargos que couberem;

n) cumprir na íntegra as determinações previstas no Edital de abertura do Concurso Público e suas possíveis retificações.

3.2. O candidato, se aprovado, por ocasião da contratação, deverá provar que possui todas as condições para a contratação no cargo/área para o qual foi inscrito, apresentando todos os documentos exigidos pelo presente Edital e outros que lhe forem solicitados, confrontando-se então declaração e documentos, sob pena de perda do direito à vaga.

\section{DAS ETAPAS}

4.1. O presente Concurso Público será composto das seguintes etapas:

1' Etapa:

Prova Objetiva, destinada a todos os cargos/disciplinas, de caráter classificatório e eliminatório.

2a Etapa:

Prova Prática, destinada somente ao cargo de Professor Classe "C" - Libras, de caráter eliminatório;

Prova de Títulos, destinada a todos os cargos/disciplinas, de caráter classificatório.

4.2. Ao final de cada etapa, o resultado será divulgado no site www.funcab.org.

4.3. A Prova Objetiva, será aplicada nas cidades de Ariquemes/RO, Brasília/DF, Cacoal/RO, Cuiabá/MT, Fortaleza/CE, GuajaráMirim/RO, Ji-Paraná/RO, Manaus/AM, Porto Velho/RO, Rio de Janeiro/RJ, Rolim de Moura/RO e Vilhena/RO. A critério da FUNCAB e da SEAD, havendo necessidade, candidatos poderão ser alocados para outras localidades adjacentes aos Municípios de escolha.

4.3.1. A Prova Prática será realizada em Porto Velho.

\section{DAS INSCRIÇÕES}

5.1. Antes de inscrever-se, o candidato deverá tomar conhecimento das normas e condições estabelecidas neste Edital, incluindo seus Anexos, partes integrantes das normas que regem o presente Concurso Público, das quais não poderá alegar desconhecimento em nenhuma hipótese.

5.2. A inscrição no Concurso Público exprime a ciência e tácita aceitação das normas e condições estabelecidas neste Edital.

5.3. As inscrições deverão ser realizadas pela Internet: no site www.funcab.org ou no Posto de Atendimento definido no ANEXO IV, no prazo estabelecido no Cronograma Previsto - ANEXO III.

5.4. O candidato deverá, no ato da inscrição, marcar em campo específico da Ficha de Inscrição On-line uma única opção de cargo/área e localidade da vaga e de local de realização da Prova Objetiva. Depois de efetivada a inscrição, não será aceito pedido de alteração desta opção, quando for o caso.

5.5. O candidato que efetuar mais de uma inscrição terá sua primeira inscrição paga ou isenta automaticamente cancelada, não havendo ressarcimento do valor da inscrição paga, referente à primeira inscrição.

5.5.1. Não sendo possível identificar a última inscrição paga ou isenta, será considerado o número gerado no ato da inscrição, validando-se a última inscrição gerada.

5.6. O valor da inscrição será $\mathbf{R} \mathbf{8 0 , 0 0}$ (oitenta reais).

5.6.1. A importância recolhida relativa à inscrição não será devolvida em hipótese alguma, salvo em caso de cancelamento do Concurso Público, exclusão do cargo oferecido ou em razão de fato atribuível somente à Administração Pública.

5.7. Não será concedida isenção total ou parcial do valor da inscrição, ressalvado o caso de Doadores de Sangue, previsto na Lei Estadual n. 1.134, de 10 de dezembro de 2002, regulamentada pelo Decreto n. 10.709, de 12 de novembro de 2003, publicado no Diário da Oficial do Estado de Rondônia n. 5.353, de 12 de novembro de 2003 ou o candidato inscrito no Cadastro Único para Programas Sociais do Governo Federal (CadÚnico) e for membro de família de baixa renda, ambos nos termos do Decreto Federal n. 6.135, de 26 de junho de 2007.

5.7.1. Roteiro para solicitação da isenção de pagamento do valor da inscrição.

5.7.2. O candidato somente poderá fazer uma solicitação de isenção e uma vez tendo feito a solicitação não será aceito pedido de alteração do cargo.

5.7.2.1. Caso o candidato efetue mais de uma solicitação de isenção, será considerada a última solicitação efetuada. 
5.7.3. Os interessados em obter a isenção do pagamento do valor da inscrição, deverão cumprir um dos critérios constantes nos roteiros abaixo:

\subsubsection{Doadores de Sangue:}

a) acessar o endereço eletrônico www.funcab.org, impreterivelmente, entre os dias previstos para solicitação de isenção, conforme Cronograma Previsto - ANEXO III;

b) preencher a ficha de solicitação de isenção do valor da inscrição on-line;

c) imprimir e assinar a ficha devidamente preenchida;

d) anexar Declaração original emitida pela Fundação de Hematologia e Hemoterapia do Estado de Rondônia - FHEMERON;

e) anexar cópia da Carteira de Identidade, devidamente autenticada em cartório; e

f) ser entregue pessoalmente ou por seu representante legal, portando procuração, no Posto de Atendimento - ANEXO IV, observando o horário de atendimento e nos dias previstos no Cronograma Previsto - ANEXO III ou enviar via SEDEX para o Concurso Público SEDUC - FUNCAB - Caixa Postal n. 99708 - CEP: 24.020-976 - Niterói/RJ, devendo ser notificado à FUNCAB seu envio, através de mensagem encaminhada para o correio eletrônico notificacao@funcab.org ou via fax (21) 26210966, especificando nome completo do candidato, número da Ficha de Inscrição, data de postagem e o número identificador do objeto.

\subsubsection{Hipossuficiência financeira:}

5.7.3.2.1. Não será concedida a isenção do pagamento do valor da inscrição a candidato que não possua o NIS já identificado e confirmado na base de dados do Cadúnico, na data da sua inscrição.

5.7.3.2.2. Para a realização da inscrição com isenção do pagamento do valor da inscrição, o candidato deverá preencher o Formulário de Inscrição, via Internet, no site www.funcab.org, no qual indicará o Número de Identificação Social - NIS atribuído pelo CadÚnico do Governo Federal e firmará declaração de que atende à condição estabelecida no Decreto Federal n. 6.135, de 26 de junho de 2007.

5.7.3.2.3. Não serão analisados os pedidos de isenção sem indicação do número do NIS e, ainda, aqueles que não contenham informações suficientes para a correta identificação do candidato na base de dados do Órgão Gestor do CadÚnico.

5.7.3.2.4. A FUNCAB consultará o órgão gestor do CadÚnico para verificar a veracidade das informações prestadas pelo candidato.

5.7.4. A relação das isenções deferidas e indeferidas será afixada no mural do Posto de Atendimento, bem como disponibilizada no site www.funcab.org, na data prevista no cronograma.

5.7.5. O candidato disporá, unicamente, de 02(dois) dias para contestar o indeferimento, exclusivamente mediante preenchimento de formulário digital, que estará disponível no site www.funcab.org, a partir das $8 \mathrm{~h}$ do primeiro dia até as 23h59min do último dia do prazo previsto no Cronograma, considerando-se o horário local. Após esse período, não serão aceitos pedidos de revisão.

5.7.6. O candidato que tiver seu pedido de isenção indeferido terá que efetuar todos os procedimentos para inscrição descritos nos subitens 5.8 ou $\mathbf{5 . 9}$

5.7.7. O candidato com isenção deferida terá sua inscrição automaticamente efetivada.

5.7.8. As informações prestadas no formulário, bem como a documentação apresentada, serão de inteira responsabilidade do candidato, respondendo este, por qualquer erro ou falsidade.

5.7.9. Não será concedida isenção do pagamento do valor da inscrição ao candidato que:

a) omitir informações e/ou torná-las inverídicas;

b) fraudar e/ou falsificar documentação;

c) pleitear a isenção sem apresentar cópia dos documentos previstos neste item; e

d) não observar o prazo e os horários estabelecidos neste Edital.

5.7.10. Após a entrega do requerimento de isenção e dos documentos comprobatórios, não será permitida a complementação da documentação, nem mesmo através de pedido de revisão e/ou recurso.

5.7.11. Os documentos descritos neste item terão validade somente para este Concurso Público e não serão devolvidos, assim como não serão fornecidas cópias dos mesmos.

5.7.12. Não será aceita solicitação de isenção de pagamento do valor da inscrição via postal, não mencionado neste edital, fax, correio eletrônico ou similar.

5.7.13. Fica reservado à Comissão Coordenadora do Concurso Público da Secretaria de Estado da Administração de Rondônia ou a FUNCAB, o direito de exigir, a seu critério, a apresentação dos documentos originais para conferência.

5.7.14. Sendo constatada, a qualquer tempo, a falsidade de qualquer documentação entregue, será cancelada a inscrição efetivada e anulados todos os atos dela decorrentes, respondendo este, pela falsidade praticada, na forma da lei.

5.7.15. O interessado que não tiver seu pedido de isenção deferido e que não efetuar o pagamento do valor da inscrição na forma e no prazo estabelecido no subitem 5.7.6 estará automaticamente excluído do Concurso Público.

5.7.16. O candidato que tiver a isenção deferida, mas que tenha realizado outra inscrição paga para o mesmo cargo, terá a isenção cancelada.

\subsection{Da inscrição pela Internet}

5.8.1. Para se inscrever pela internet, o candidato deverá acessar o site www.funcab.org, onde consta o Edital, a Ficha de Inscrição via Internet e os procedimentos necessários à efetivação da inscrição. A inscrição pela Internet estará disponível 
durante as 24 horas do dia, ininterruptamente, desde as 10 horas do $1^{\circ}$ dia de inscrição até às $23 \mathrm{~h} 59$ min do último dia de inscrição, conforme estabelecido no Cronograma Previsto - ANEXO III, considerando-se o horário local.

5.8.2. O candidato deverá ler e seguir atentamente as orientações para preenchimento da Ficha de Inscrição via Internet e demais procedimentos, tomando todo o cuidado com a confirmação dos dados preenchidos antes de enviar a inscrição, evitando-se que o botão de rolagem do mouse seja acionado indevidamente e altere os respectivos dados.

5.8.3. Ao efetuar a inscrição via Internet, o candidato deverá imprimir o boleto bancário e efetuar o pagamento do valor da inscrição até a data do seu vencimento. Caso o pagamento não seja efetuado, deverá acessar o site www.funcab.org e emitir a $2^{\text {a }}$ via do boleto bancário, que terá nova data de vencimento. A $2^{\underline{a}}$ via do boleto bancário estará disponível no site para impressão até às 15 horas do último dia de pagamento. A data limite de vencimento do boleto bancário será o primeiro dia útil após o encerramento das inscrições. Após essa data, qualquer pagamento efetuado será desconsiderado.

5.8.4. As inscrições somente serão confirmadas após o banco ratificar o efetivo pagamento do valor da inscrição, que deverá ser feito dentro do prazo estabelecido, em qualquer agência bancária, obrigatoriamente por meio do boleto bancário específico, impresso pelo próprio candidato no momento da inscrição. Não será aceito pagamento feito através de depósito bancário, DOC's ou similares.

5.8.5. O boleto bancário pago, autenticado pelo caixa do banco, deverá estar de posse do candidato durante todo o Certame, para eventual certificação e consulta pelos organizadores.

5.8.6. O Edital e seus Anexos estarão disponíveis no site www.funcab.org para consulta e impressão.

5.8.7. Os candidatos deverão verificar a confirmação de sua inscrição no site www.funcab.org a partir do quinto dia útil após a efetivação do pagamento do boleto bancário.

5.8.8. A confirmação da inscrição deverá ser impressa pelo candidato e guardada consigo juntamente com o canhoto da inscrição autenticado.

5.8.9. O descumprimento de quaisquer das instruções para inscrição via Internet implicará no cancelamento da mesma.

5.8.10. A inscrição via Internet é de inteira responsabilidade do candidato e deve ser feita com antecedência, evitando-se o possível congestionamento de comunicação do site www.funcab.org nos últimos dias de inscrição.

5.8.11. A FUNCAB não será responsável por problemas na inscrição ou emissão de boletos via Internet, motivados por falhas de comunicação ou congestionamento das linhas de comunicação nos últimos dias do período de inscrição, que venham a impossibilitar a transferência e o recebimento de dados.

5.9. Da inscricão no Posto de Atendimento

5.9.1. Para os candidatos que não têm acesso à internet, será disponibilizado, no Posto de Atendimento ANEXO IV, microcomputador para viabilizar a efetivação da inscrição.

5.9.2. Será de responsabilidade exclusiva do candidato efetuar sua inscrição, podendo contar apenas com orientações do atendente do posto. Não será responsabilidade do atendente efetuar a inscrição para o candidato.

5.9.3. Para efetuar a inscrição, o candidato deverá seguir todas as instruções descritas no subitem $\mathbf{5 . 8}$.

5.10. O candidato somente será considerado inscrito neste Concurso Público após ter cumprido todas as instruções descritas no item 5 deste Edital.

5.11. As informações prestadas na solicitação de inscrição serão de inteira responsabilidade do candidato, dispondo a FUNCAB do direito de excluir do Concurso Público aquele que não preencher o formulário de forma completa e correta, ou que preencher com dados de terceiros.

\section{DAS VAGAS RESERVADAS ÀS PESSOAS COM DEFICIÊNCIA}

6.1. As pessoas com deficiência, amparadas pelo inciso VIII do artigo 37, da Constituição Federal, e na forma da Lei n. 515, de 4 de outubro de 1993, poderão concorrer às vagas ofertadas.

6.2. As vagas serão reservadas por cargo e localidade.

6.3. A preferência à contratação obedecerá à seguinte regra:

\begin{tabular}{|c|l|}
\hline $\begin{array}{c}\text { Número de vagas } \\
\text { ofertadas }\end{array}$ & \multicolumn{1}{c|}{ Preferência de Contratação } \\
\hline 1 & Destinada ao candidato que obtiver a maior pontuação geral. \\
\hline 2 & $\begin{array}{l}1 \text { (uma) vaga para o candidato portador de deficiência que obtiver a } 1^{\underline{a}} \text { classificação na referida } \\
\text { condição (lista a parte) e } 1 \text { (uma) vaga para o candidato não portador de deficiência que obtiver a 1ª } \\
\text { classificação. }\end{array}$ \\
\hline
\end{tabular}

6.4. É considerada deficiência toda perda ou anormalidade de uma estrutura ou função psicológica, fisiológica ou anatômica, que gere incapacidade para o desempenho de atividade dentro do padrão considerado normal para o ser humano, conforme previsto em legislação pertinente.

6.5. Ressalvadas as disposições especiais contidas neste Edital, os candidatos com deficiência participarão do Concurso Público em igualdade de condições com os demais candidatos, no que tange ao local de aplicação de prova, ao horário, ao conteúdo, à correção das provas, aos critérios de avaliação e aprovação, à pontuação mínima exigida e a todas as demais normas de regência do Concurso Público.

6.6. Os candidatos com deficiência, aprovados no Concurso Público, terão seus nomes publicados em lista à parte e figurarão também na lista de classificação geral.

6.7. Os candidatos amparados pelo disposto no subitem 6.1 e que declararem sua condição por ocasião da inscrição, caso 
convocados para posse, deverão se submeter à perícia médica realizada pela Junta Médica Oficial do Estado de Rondônia, que terá decisão terminativa sobre a qualificação e aptidão do candidato, observada a compatibilidade da deficiência que possui com as atribuições do cargo.

6.8. Não sendo comprovada a deficiência do candidato, será desconsiderada a sua classificação na listagem de pessoas com deficiência, sendo considerada somente sua classificação na listagem de ampla concorrência.

6.9. No caso de não haver candidatos deficientes aprovados nas provas ou na perícia médica, ou de não haver candidatos aprovados em número suficiente para as vagas reservadas às pessoas com deficiência, as vagas remanescentes serão preenchidas pelos demais candidatos aprovados, observada a ordem de classificação.

6.10. Após a investidura no cargo, a deficiência não poderá ser arguida para justificar o direito a concessão de readaptação ou de aposentadoria por invalidez.

\section{DA INSCRIÇÃO DAS PESSOAS COM DEFICIÊNCIA}

7.1. A inscrição das pessoas com deficiência far-se-á nas formas estabelecidas neste edital, observando-se o que se segue. 7.2. A pessoa com deficiência que pretende concorrer às vagas reservadas deverá, sob as penas da lei, declarar esta condição no campo específico da Ficha de Inscrição On-line.

7.3. O candidato com deficiência que efetuar sua inscrição via Internet deverá, até o último dia de inscrição, entregar o laudo médico ORIGINAL ou cópia autenticada em cartório, atestando claramente a espécie e o grau ou o nível da deficiência, com expressa referência ao código correspondente da Classificação Internacional de Doenças - CID, bem como a provável causa da deficiência, no Posto de Atendimento, observando o horário de atendimento ou enviar via SEDEX para o Concurso Público SEDUC - FUNCAB - Caixa Postal n. 99708 - CEP: 24.020-976 - Niterói/RJ, devendo ser notificado à FUNCAB seu envio, através de mensagem encaminhada para o correio eletrônico notificacao@funcab.org ou via fax (21) 2621-0966, especificando nome completo do candidato, número da Ficha de Inscrição, data de postagem e o número identificador do objeto.

7.4. O candidato com deficiência poderá solicitar condições especiais para a realização das provas, devendo solicitá-las, no campo específico da Ficha de Inscrição On-line, no ato de sua inscrição.

7.4.1. A realização das provas em condições especiais requeridas pelo candidato, conforme disposto no subitem 7.4, ficará sujeita, ainda, à apreciação e deliberação da FUNCAB, observados os critérios de viabilidade e razoabilidade.

7.5. O candidato que não declarar a deficiência conforme estabelecido no subitem 7.2, ou deixar de enviar o laudo médico ORIGINAL ou enviá-lo fora do prazo determinado, perderá a prerrogativa em concorrer às vagas reservadas.

\section{DAS PROVAS ESPECIAIS}

8.1. Caso haja necessidade de condições especiais para se submeter à Prova Objetiva, o candidato deverá solicitá-la no ato da inscrição, no campo específico da Ficha de Inscrição, indicando claramente quais os recursos especiais necessários, arcando o candidato com as consequências de sua omissão.

8.1.1. As provas ampliadas serão exclusivamente elaboradas em fonte tamanho 16.

8.2. A realização da prova em condições especiais ficará sujeita, ainda, à apreciação e deliberação da FUNCAB, observados os critérios de viabilidade e razoabilidade.

8.3. As candidatas lactantes que tiverem necessidade de amamentar durante a realização das provas, além de solicitar atendimento especial para tal fim, deverão levar um acompanhante que ficará em sala reservada para essa finalidade e que será responsável pela guarda da criança, não fazendo jus a prorrogação do tempo, conforme subitem 9.15.

8.3.1. A candidata lactante que comparecer ao local de provas com o lactente e sem acompanhante não realizará as provas.

\section{DAS CONDIÇÕES PARA REALIZAÇÃO DAS ETAPAS}

9.1. As informações sobre os locais e os horários de aplicação das Provas Objetiva e Prática serão disponibilizadas no Posto de Atendimento - ANEXO IV, e no site www.funcab.org com antecedência mínima de 5(cinco) dias da data de sua realização, conforme consta no Cronograma Previsto - ANEXO III.

9.2. Os candidatos deverão acessar e imprimir o Comunicado Oficial de Convocação para Prova (COCP), constando, data, horário e local de realização da Prova Objetiva, disponível no site www.funcab.org

9.2.1. É importante que o candidato tenha em mãos, no dia de realização da prova objetiva, o seu Comunicado Oficial de Convocação para Prova (COCP), para facilitar a localização de sua sala, sendo imprescindível que esteja de posse do documento oficial de identidade conforme especificado nos subitens 9.7 e 9.7.1.

9.2.2. Não será enviada à residência do candidato, comunicação individualizada. O candidato inscrito deverá obter as informações necessárias sobre sua alocação através das formas descritas nos subitens 9.1 e 9.2.

9.3. O candidato é o único responsável pela identificação correta de seu local de realização de provas e pelo comparecimento no horário determinado.

9.4. Os horários das provas referir-se-ão ao horário local.

9.5. Quando da realização da prova objetiva, o candidato deverá, ainda, obrigatoriamente, levar caneta esferográfica de tinta azul ou preta, fabricada em material transparente, não podendo utilizar outro tipo de caneta ou material.

9.5.1. O candidato deverá comparecer para a realização das etapas, portando documento oficial e original de identificação, com antecedência mínima de 1 (uma) hora do horário estabelecido para seu início e/ou fechamento dos portões.

9.6. Não será permitido o ingresso de candidato no local de realização das provas, após o horário fixado para o fechamento dos portões, sendo que a prova objetiva será iniciada 10 (dez) minutos após esse horário. Após o fechamento dos portões, não será 
permitido o acesso de candidatos, em hipótese alguma, mesmo que as provas ainda não tenham sido iniciadas.

9.7. Serão considerados documentos oficiais de identidade:

- Carteiras expedidas pelas Forças Armadas, pelos Corpos de Bombeiros e pelas Polícias Militares;

- Carteiras expedidas pelos órgãos fiscalizadores de exercício profissional (Ordens e Conselhos de Classe) que, por Lei Federal, valem como identidade;

- Certificado de Reservista;

- Passaporte;

- Carteiras Funcionais do Ministério Público e Magistratura;

- Carteiras expedidas por órgão público que, por Lei Federal, valem como identidade;

- Carteira Nacional de Habilitação (somente modelo com foto).

9.7.1. Não serão aceitos como documento de identidade:

- Certidão de nascimento ou Casamento;

- CPF;

- Títulos eleitorais;

- Carteiras de Motorista (modelo sem foto);

- Carteiras de Estudante;

- Carteiras Funcionais sem valor de identidade;

- Documentos ilegíveis, não identificáveis e/ou danificados.

9.7.1.1. O documento deverá estar em perfeitas condições, de forma a permitir, com clareza, a identificação do candidato (foto e assinatura).

9.7.2. Caso o candidato esteja impossibilitado de apresentar, no dia de realização das Etapas, documento de identidade original, por motivo de perda, roubo ou furto, deverá apresentar documento que ateste o registro da ocorrência em órgão policial, expedido há, no máximo, 30 (trinta) dias. Na ocasião será submetido à identificação especial, compreendendo coletas de assinaturas em formulário próprio para fins de Exame Grafotécnico e coleta de digital.

9.8. A identificação especial será exigida, também, ao candidato cujo documento de identificação apresente dúvidas relativas à fisionomia ou à assinatura do portador.

9.9. O documento de identidade deverá ser apresentado ao Fiscal de Sala, antes do acesso à sala de prova.

9.9.1. Não será permitido, em hipótese alguma, o ingresso nas salas de realização das provas de candidatos sem documento oficial e original de identidade nem mesmo sob a alegação de estar aguardando que alguém o traga.

9.10. Não será permitida a permanência de candidatos que já tenham terminado as etapas no local de realização das mesmas. Ao terminarem, os candidatos deverão se retirar imediatamente do local, não sendo possível nem mesmo a utilização dos banheiros e bebedouros.

9.10.1. É vedada a permanência de acompanhantes no local das provas, ressalvado o contido no subitem 8.3.

9.11. As etapas acontecerão em dias, horários e locais indicados nas publicações oficiais e no COCP. Não haverá, sob pretexto algum, segunda chamada, nem justificação de falta, sendo considerado eliminado do Concurso Público o candidato que faltar a prova objetiva. Não haverá aplicação de prova fora do horário, data e locais pré-determinados.

9.12. Será realizada coleta de digital de todos os candidatos, em qualquer etapa, a critério da FUNCAB e da Secretaria de Estado da Administração - SEAD, objetivando a realização de exame datiloscópico, com a confrontação dos candidatos que venham a ser convocados para nomeação.

9.13. Poderá ser utilizado detector de metais nos locais de realização das Etapas.

9.14. O candidato não poderá ausentar-se da sala de realização da Prova Objetiva após assinatura da Lista de Presença e recebimento de seu Cartão de Respostas até o início efetivo da prova e, após este momento, somente acompanhado por Fiscal. Portanto, é importante que o candidato utilize banheiros e bebedouros, se necessitar, antes de sua entrada na sala.

9.15. Não haverá, por qualquer motivo, prorrogação do tempo previsto para aplicação das provas em virtude de afastamento do candidato.

9.16. Será automaticamente eliminado do Concurso Público, o candidato que durante a realização das etapas:

a) for descortês com qualquer membro da equipe encarregada pela realização das etapas;

b) for responsável por falsa identificação pessoal;

c) utilizar ou tentar utilizar meios fraudulentos para obter aprovação;

d) ausentar-se do recinto da prova ou do teste sem permissão;

e) deixar de assinar lista de presença;

f) fizer, em qualquer documento, declaração falsa ou inexata;

g) perturbar, de qualquer modo, a ordem dos trabalhos;

h) não permitir a coleta da impressão digital ou o uso do detector de metais;

i) não atender às determinações deste Edital.

9.16.1. Será automaticamente eliminado do Concurso Público o candidato que, durante a realização da prova objetiva, além de descumprir as determinações acima, também:

a) for surpreendido em comunicação com outro candidato;

b) não devolver o Cartão de Respostas ao término da prova objetiva, antes de sair da sala;

c) ausentar-se do local da prova antes de decorridos 60 (sessenta) minutos do início da mesma; 
d) for surpreendido portando celular durante a realização da prova. Celulares deverão ser desligados, retiradas as baterias, e guardados dentro do envelope fornecido pela FUNCAB ao entrar em sala e mantido lacrado e dentro da sala até a saída definitiva do local da realização da prova;

e) não atender ao critério da alínea acima e for surpreendido com celular fora do envelope fornecido ou portando o celular no deslocamento ao banheiro/bebedouro ou o telefone celular tocar, estes últimos, mesmo dentro do envelope fornecido pela FUNCAB;

f) for surpreendido em comunicação verbal ou escrita ou de qualquer outra forma;

g) utilizar-se de livros, códigos impressos, máquinas calculadoras e similares ou qualquer tipo de consulta;

h) não devolver o Caderno de Questões, se sair antes do horário determinado no subitem 10.11.

9.17. Não é permitido qualquer tipo de anotação e/ou utilização de papel ou similar, além do Caderno de Questões e do Cartão de Respostas, não sendo permitida, nem mesmo, a anotação de gabarito.

9.17.1. O candidato que for pego com a anotação do gabarito deverá entregar ao fiscal ou se desfazer da mesma, e em caso de recusa será eliminado do certame.

9.18. Após entrar em sala, não será admitida qualquer espécie de consulta ou comunicação entre os candidatos, nem a utilização de livros, códigos, papéis, manuais, impressos ou anotações, agendas eletrônicas ou similares, telefone celular, BIP, walkman, gravador ou similares, máquina de calcular MP3, MP4 ou similares, notebook, palmtop, receptor, máquina fotográfica ou similares, controle de alarme de carro ou qualquer outro receptor de mensagens, nem o uso de relógio digital, óculos escuros ou quaisquer acessórios de chapelaria, tais como: chapéu, bonés, gorro, etc.

9.19. Constatando-se que o candidato utilizou processos ilícitos através de meio eletrônico, estatístico, visual ou grafotécnico, sua prova será anulada e será automaticamente eliminado do Concurso Público.

9.20. É proibido o porte de armas nos locais das provas, não podendo o candidato armado realizar as mesmas.

9.21. É expressamente proibido fumar no local de realização das etapas.

9.22. O tempo total de realização da Prova Objetiva da $1^{a}$ etapa será de $04 \mathrm{~h} 30 \mathrm{~min}$.

9.22.1. O tempo de duração da prova inclui o preenchimento do Cartão de Respostas.

9.23. No dia da realização da Prova Objetiva, na hipótese do nome do candidato não constar nas listagens oficiais relativas aos locais de prova estabelecidos no Edital de Convocação, a FUNCAB procederá a inclusão do candidato, mediante a apresentação do boleto bancário com comprovação de pagamento efetuado dentro do prazo previsto para as inscrições, original e uma cópia, com o preenchimento e assinatura do formulário de Solicitação de Inclusão. A cópia do comprovante será retida pela FUNCAB. O candidato que não levar a cópia terá o comprovante original retido para que possa ser efetivada a sua inclusão.

9.23.1. A inclusão será realizada de forma condicional e será analisada pela FUNCAB, com o intuito de se verificar a pertinência da referida inscrição.

9.23.2. Constatada a improcedência da inscrição, a mesma será automaticamente cancelada sem direito à reclamação, independentemente de qualquer formalidade, considerados nulos todos os atos dela decorrentes.

9.24. Toda e qualquer ocorrência, reclamação ou necessidade de registro, deverá ser imediatamente manifesta ao fiscal ou representante da FUNCAB no local e no dia da realização da etapa, para o registro na folha ou ata de ocorrências e, caso necessário, sejam tomadas as providências cabíveis.

9.24.1. Não serão consideradas e nem analisadas as reclamações que não tenham sido registradas na ocasião.

\section{DA PROVA OBJETIVA}

10.1. A Prova Objetiva terá caráter eliminatório e classificatório e será constituída de questões de múltipla escolha, conforme 0 Quadro de Provas, subitem 10.5 e será realizada no turno matutino.

10.1.1. Cada questão terá 5 (cinco) alternativas, sendo apenas uma correta.

10.2. Cada candidato receberá um Caderno de Questões e um único Cartão de Respostas que não poderá ser rasurado, amassado ou manchado.

10.3. O candidato deverá seguir atentamente as recomendações contidas na capa de seu Caderno de Questões e em seu Cartão de Respostas.

10.4. Antes de iniciar a Prova Objetiva, o candidato deverá transcrever a frase que se encontra na capa do Caderno de Questões para o quadro "Exame Grafotécnico" do Cartão de Respostas.

10.5. A organização da prova, seu detalhamento, número de questões por disciplina e valor das questões encontram-se representados nas tabelas abaixo:

\begin{tabular}{|l|c|c|c|}
\hline \multicolumn{1}{|c|}{ Disciplinas } & $\begin{array}{c}\text { Quantidade de } \\
\text { questões }\end{array}$ & $\begin{array}{c}\text { Valor de cada } \\
\text { questão }\end{array}$ & $\begin{array}{c}\text { Pontuação } \\
\text { Máxima }\end{array}$ \\
\hline - Língua Portuguesa & 10 & 2 & 20 \\
\hline - História e Geografia de Rondônia & 05 & 2 & 10 \\
\hline Conhecimentos Específicos: & 10 & 2 & 20 \\
- Informática Básica & 10 & 2 & 20 \\
- Conhecimentos Pedagógicos & & 2 \\
\hline
\end{tabular}




\begin{tabular}{|l|c|c|c|} 
- Conhecimentos na Área de Formação & 15 & 2 & 30 \\
\hline Totais & $\mathbf{5 0}$ & - & $\mathbf{1 0 0}$ \\
\hline
\end{tabular}

10.6. Será eliminado do presente Concurso Público o candidato que não obtiver, pelo menos, $50 \%$ (cinqüenta por cento) dos pontos da Prova Objetiva.

10.7. O candidato deverá transcrever as respostas da Prova Objetiva para o Cartão de Respostas, que será o único documento válido para correção eletrônica.

10.8. A transcrição das alternativas para o Cartão de Respostas e sua assinatura são obrigatórias e serão de inteira responsabilidade do candidato, que deverá proceder em conformidade com as instruções específicas nele contidas, pois a correção da prova será feita somente nesse documento e por processamento eletrônico. Assim sendo, fica o candidato obrigado, ao receber o Cartão de Respostas, verificar se o número do mesmo corresponde ao seu número de inscrição contido no COCP e na Lista de Presença. Não haverá substituição de Cartão de Respostas.

10.8.1. Por motivo de segurança, poderão ser aplicadas provas de mesmo teor, porém com gabaritos diferenciados, de forma que, caberá ao candidato, conferir se o TIPO DE PROVA constante em seu Cartão de Respostas corresponde a do Caderno de Questões recebido. Caso haja qualquer divergência, o candidato deverá, imediatamente, informar ao Fiscal de Sala e solicitar a correção.

10.9. O candidato deverá marcar, para cada questão, somente uma das opções de resposta. Será considerada errada e atribuída nota 0 (zero) à questão com mais de uma opção marcada, sem opção marcada, com emenda ou rasura.

10.10. O candidato só poderá retirar-se definitivamente do recinto de realização da prova após 1 (uma) hora, contada do seu efetivo início.

10.11. O candidato só poderá levar o próprio exemplar do Caderno de Questões se deixar a sala a partir de 1 (uma) hora para o término do horário da prova.

10.12. Ao final da prova, os 03 (três) últimos candidatos deverão permanecer na sala até que o último candidato termine sua prova, devendo todos assinar a Ata de Fiscalização, atestando a idoneidade da fiscalização da prova, retirando-se da mesma de uma só vez.

10.12.1. No caso de haver candidatos que concluam a prova ao mesmo tempo, sendo um ou dois desses necessários para cumprir o subitem 10.12, a seleção dos candidatos será feita mediante sorteio.

10.13. No dia de realização da prova não serão fornecidas, por qualquer membro da equipe de aplicação e/ou pelas autoridades presentes, informações referentes ao conteúdo da mesma e/ou aos critérios de avaliação.

10.14. Por motivo de segurança, somente é permitido ao candidato fazer qualquer anotação durante a prova no seu Caderno de Questões, devendo ser observado o estabelecido no subitem 9.17.

10.15. Ao terminar a prova, o candidato deverá entregar ao Fiscal, o Caderno de Questões, se ainda não o puder levar, o Cartão de Respostas, bem como todo e qualquer material cedido para a execução da prova.

10.16. O gabarito oficial será disponibilizado no site www.funcab.org no $1^{\circ}$ dia útil após a data de realização da prova, a partir das 12 horas (Horário local), conforme Cronograma Previsto - ANEXO III.

10.17. Os cartões de respostas estarão disponíveis no site www.funcab.org até 15(quinze) dias após a divulgação do resultado da Prova Objetiva.

\section{DA PROVA PRÁTICA DE LIBRAS}

11.1. Para a Prova Prática de LIBRAS serão convocados, em Edital específico, os candidatos aprovados na Prova Objetiva que estejam concorrendo às vagas ao cargo de Professor Classe "C" - Libras, no quantitativo de 10(dez) vezes o número de vagas para o cargo.

11.1.1. A convocação para a Prova Prática de LIBRAS será feita exclusivamente por meio de ato de convocação, a ser publicado no Diário Oficial do Estado de Rondônia e divulgado nos sites www.funcab.org e www.rondonia.ro.gov.br, no Posto de Atendimento - ANEXO IV, na data estabelecida no Cronograma Previsto - ANEXO III.

11.1.2. A Prova Prática será de caráter eliminatório.

11.2. Para efeito de posicionamento, será considerada a ordem decrescente da nota obtida na Prova Objetiva. Em caso de empate na última posição do quantitativo definido acima, todos os empatados nesta posição serão convocados.

11.2.1. Todos os candidatos que concorrem às vagas destinadas às pessoas com deficiência aprovados na Prova Objetiva serão convocados, mesmo que não alcancem posicionamento definido no subitem 11.1.

11.2.2. Os candidatos com deficiência que forem convocados e que não estiverem dentro do posicionamento definido no subitem 11.1, se aprovados no Concurso Público, constarão somente na classificação à parte e estarão concorrendo apenas às vagas destinadas às pessoas com deficiência, não constando na listagem geral, referente às vagas de ampla concorrência.

11.3. A Prova Prática de LIBRAS, de responsabilidade da FUNCAB, será individual, com duração de 15 minutos e consistirá de explanação, pelo candidato, sobre um dos temas constantes no ANEXO V, deste Edital, podendo haver questionamentos, sobre o tema, pela Banca Examinadora.

11.3.1. A Prova Prática de LIBRAS será realizada em data, horário e local a serem definidos no Edital de Convocação Específico.

11.3.2. A prova prática de LIBRAS será filmada para eventual consulta e não será divulgada em hipótese alguma. O candidato que não autorizar a filmagem será eliminado do certame. 
11.4. O tema da Prova Prática de LIBRAS será escolhido por meio de sorteio a ser realizado no momento que antecede a prova, dentre os temas propostos no ANEXO $\mathbf{V}$ deste Edital, sendo aberto somente aos candidatos às vagas ao cargo de Professor Classe "C" - Libras.

11.5. A avaliação dos candidatos, na Prova Prática de LIBRAS, será realizada por Banca Examinadora composta por 3 (três) membros, sendo 02 (dois) profissionais qualificados, com proficiência na Língua Brasileira de Sinais, obtida por meio de exame, promovido pelo MEC, e 01 (um) deficiente auditivo, de responsabilidade da FUNCAB.

11.6. O participante que não observar rigorosamente o horário de início de sua Prova Prática de LIBRAS, previsto no cronograma, será automaticamente eliminado do processo. Cada participante deverá comparecer ao local de prova com pelo menos 1 (uma) hora de antecedência em relação ao horário previsto para o início de sua prova.

11.7. Para participar da Prova Prática de LIBRAS, o candidato deverá apresentar à Banca Examinadora, antes do seu início, documento oficial de identificação, conforme descrito nos subitens 9.7 e 9.7.1.

11.8. O candidato será avaliado na Prova Prática, numa escala compreendida entre 0 e 20 pontos, não sendo a pontuação obtida nesta Prova considerada na classificação final do candidato, de forma que, ao resultado da Prova Prática, será atribuído o conceito Apto ou Inapto.

11.8.1 Será considerado Inapto, o candidato que não obtiver, pelo menos, 50\% (cinqüenta por cento) dos pontos na Prova Prática, observado o quadro abaixo:

\begin{tabular}{|l|c|}
\hline \multicolumn{1}{|c|}{ ITEM } & $\begin{array}{c}\text { PONTUAÇÃO } \\
\text { MÁXIMA }\end{array}$ \\
\hline $\begin{array}{l}\text { Fluência em Libras: vocabulário, classificadores, gramática, uso do espaço e expressão } \\
\text { facial e corporal }\end{array}$ & 9,0 \\
\hline Improvisação/Criatividade & 3,0 \\
\hline Didática/Metodologia de ensino: Contextualização do tema: coesão, coerência. & 4,0 \\
\hline Domínio do conteúdo: conhecimento do conteúdo e utilização adequada do tempo & 4,0 \\
\hline \multicolumn{1}{|c|}{ TOTAL } & $\mathbf{2 0 , 0}$ \\
\hline
\end{tabular}

11.9. As avaliações se darão dentro das normas técnicas, levando-se em consideração a desenvoltura do candidato nas atividades propostas.

11.10. O resultado de cada teste será registrado pelo avaliador na Ficha de Avaliação do Candidato e assinado pelo candidato dando a ciência do resultado no término da Prova.

11.10.1. Em caso de recusa, o documento será assinado pelo avaliador, coordenador e duas testemunhas.

11.11. Não será admitido pedido de revisão ou recurso da Prova Prática posteriormente a sua aplicação, devendo todas as considerações recursais ser declaradas pelo candidato ao tomar ciência de sua nota, para o devido parecer da banca e equipe de coordenação.

11.12. O resultado da Prova Prática será afixado no Posto de Atendimento - ANEXO IV e também disponível no portal www.funcab.org.

\section{DA PROVA DE TÍTULOS}

12.1. Serão convocados para esta etapa os candidatos aprovados na Prova Objetiva no quantitativo de 10(dez) vezes o número de vagas para o cargo.

12.1.1. Somente serão analisadas e divulgadas as notas dos títulos dos candidatos para o cargo de Professor Classe " $C$ " Libras aprovados na Prova Prática.

12.2. Para efeito de posicionamento, será considerada a ordem decrescente da nota obtida na Prova Objetiva. Em caso de empate na última posição do quantitativo definido acima, todos os empatados nesta posição serão convocados.

12.2.1. Todos os candidatos que concorrem às vagas destinadas às pessoas com deficiência aprovados na Prova Objetiva serão convocados, mesmo que não alcancem posicionamento definido no subitem 12.1.

12.2.2. Os candidatos com deficiência que forem convocados e que não estiverem dentro do posicionamento definido no subitem 12.1, se aprovados no Concurso Público, constarão somente na classificação à parte e estarão concorrendo apenas às vagas destinadas às pessoas com deficiência, não constando na listagem geral, referente às vagas de ampla concorrência.

12.3. Os títulos para análise deverão ser entregues, impreterivelmente, no período definido no Cronograma Previsto - ANEXO III, no Posto de Atendimento - ANEXO IV ou encaminhados via SEDEX à FUNCAB - Concurso Público SEDUC, Caixa Postal n. 99708 - CEP: 24.020-976 - Niterói/RJ, devendo ser notificado à FUNCAB seu envio, através de mensagem encaminhada para o correio eletrônico notificacao@funcab.org ou via fax (21) 2621-0966, especificando nome completo do candidato, número da Ficha de Inscrição, data de postagem e o número identificador do objeto.

12.3.1. Deverá ser obedecida a data final do prazo para postagem. Documentos postados fora do prazo serão desconsiderados.

12.4. A Prova de Títulos terá caráter apenas classificatório.

12.5. A convocação para a entrega de Títulos será feita exclusivamente por meio de ato de convocação, a ser publicado no 
Diário Oficial do Estado de Rondônia e divulgado nos sites www.funcab.org e www.rondonia.ro.gov.br, no Posto de Atendimento - ANEXO IV, na data estabelecida no Cronograma Previsto - ANEXO III.

12.6. Os títulos deverão ser apresentados por meio de cópias autenticadas em cartório, anexando formulário próprio para entrega de títulos, disponível no site www.funcab.org, onde o candidato deverá numerar e descrever todos os documentos que estão sendo entregues. Cada documento deverá ser numerado de acordo com o descrito no formulário de títulos. Deverá também anexar declaração de veracidade, conforme modelo constante no ANEXO VIII.

12.6.1. O não encaminhamento da declaração de veracidade ou do formulário para entrega de títulos levará a não análise dos títulos enviados.

12.6.2. Nenhum documento será devolvido ao candidato após sua entrega à FUNCAB.

12.7. Somente serão considerados os títulos obtidos pelos candidatos até a data da entrega dos títulos, e que se enquadrarem nos critérios previstos neste edital e que sejam voltados para a área específica do cargo (Disciplina/Área de Formação).

12.8. Todos os cursos previstos para pontuação na avaliação de títulos deverão estar concluídos.

12.9. Somente serão considerados como documentos comprobatórios diplomas e certificados ou declarações de conclusão do curso, feitos em papel timbrado da instituição, atestando a data de conclusão, a carga horária e a defesa da monografia/dissertação/tese, com aprovação da banca e carimbo da instituição, quando for o caso.

12.10. Serão considerados os seguintes títulos, para efeitos do presente Concurso Público:

\begin{tabular}{|l|c|}
\hline \multicolumn{1}{|c|}{ DISCRIMINAÇÃO } & VALOR POR TíTULO \\
\hline A) Pós-Graduação Stricto Sensu - Doutorado & 4,5 pontos \\
\hline B) Pós-Graduação Stricto Sensu - Mestrado & 3,5 pontos \\
\hline C) Pós-Graduação Lato Sensu (360 horas) reconhecida pelo MEC & 2,0 pontos \\
\hline
\end{tabular}

12.11. A nota final dos títulos, de caráter classificatório, corresponderá à soma dos pontos obtidos pelo candidato, variando de 0 (zero) a 10 (dez) pontos.

12.12. Não será aceito para pontuação os títulos exigidos como requisito do cargo.

12.12.1. O candidato que possua mais de um curso de especialização que seja compatível com o requisito do cargo deverá enviar documentação referente a ambos, um para fim de comprovação do requisito e outro para pontuação. Caso o candidato apresente apenas um título dentre os mencionados, esse será considerado como requisito e não será pontuado.

12.12.2. O candidato deverá indicar no formulário citado no subitem 12.6 qual o título deverá ser considerado como requisito e o que deverá ser pontuado. A não indicação acarretará a não pontuação do título nessa especificação.

12.13. Os cursos de especialização lato sensu deverão ser apresentados por meio de certificados acompanhados do correspondente histórico.

12.13.1. Somente serão aceitas para fins de pontuação, declarações de conclusão dos cursos de especialização lato sensu se o curso for concluído a partir de 01/01/2009, desde que constem do referido documento o histórico do curso com data de conclusão e aprovação de monografia.

12.13.2. Os documentos relacionados a este subitem deverão, obrigatoriamente, enquadrar-se nas exigências das resoluções do Conselho Nacional de Educação (CNE) n. 12/83, n. 03/99, n. 01/01 ou n. 01/07.

12.14. Para os cursos de mestrado e doutorado exigir-se-á o certificado no qual conste a comprovação da defesa e aprovação da dissertação/tese.

12.14.1. Os diplomas de mestrado e doutorado expedidos por universidades estrangeiras somente serão aceitos se reconhecidos por universidades que possuam cursos de pós-graduação reconhecidos e avaliados, na mesma área de conhecimento e em nível equivalente ou superior, conforme legislação que trata da matéria.

12.14.2. Somente serão aceitas para fins de pontuação, declarações de conclusão dos cursos mestrado e doutorado se o curso for concluído a partir de 01/01/2008, desde que constem do referido documento a comprovação da defesa e aprovação da dissertação/tese.

12.15. O resultado da Prova de Títulos será divulgado no site www.funcab.org, na data constante no Cronograma Previsto ANEXO III.

\section{DOS RECURSOS}

13.1. O candidato poderá apresentar recurso, devidamente fundamentado, em relação a qualquer das questões da Prova Objetiva, informando as razões pelas quais discorda do gabarito ou conteúdo da questão.

13.2. O recurso será dirigido à FUNCAB e deverá ser interposto no prazo de até 02(dois) dias úteis após a divulgação do gabarito oficial.

13.2.1. Admitir-se-á para cada candidato um único recurso por questão, o qual deverá ser enviado via formulário específico disponível On-line no site www.funcab.org, que deverá ser integralmente preenchido, sendo necessário o envio de um formulário para cada questão recorrida. O formulário estará disponível a partir das $8 \mathrm{~h}$ do primeiro dia até às $23 \mathrm{~h} 59 \mathrm{~min}$ do último dia do prazo previsto no Cronograma, considerando-se o horário local. 
13.2.2. O formulário preenchido de forma incorreta, com campos em branco ou faltando informações será automaticamente desconsiderado, não sendo encaminhado à Banca Acadêmica para avaliação.

13.3. O recurso deve conter a fundamentação das alegações comprovadas por meio de citação de artigos, amparados pela legislação, itens, páginas de livros, nome dos autores.

13.3.1. Após o julgamento dos recursos interpostos, os pontos correspondentes às questões da Prova Objetiva, porventura anuladas, serão atribuídos a todos os candidatos, indistintamente.

13.4. A Prova Objetiva será corrigida de acordo com o novo gabarito oficial após o resultado dos recursos.

13.5. Será facultado ao candidato solicitar revisão da nota da Prova de Títulos.

13.5.1. O pedido de revisão deverá conter, obrigatoriamente, o nome do candidato, o número de sua inscrição e ser encaminhado à FUNCAB, na data definida no Cronograma Previsto - ANEXO III, no horário compreendido entre 08h00min do primeiro dia até às 18h00min (horário local) do último dia, via formulário disponível no site www.funcab.org.

13.6. Será indeferido liminarmente o recurso ou pedido de revisão que descumprir as determinações constantes neste Edital; for dirigido de forma ofensiva à FUNCAB e/ou à Secretaria de Estado da Administração de Rondônia; for apresentado fora do prazo ou fora de contexto.

13.7. A Banca Examinadora constitui a última instância para recurso ou revisão, sendo soberana em suas decisões, razão porque não caberão recursos adicionais.

13.8. As anulações de questões ou alterações de gabarito ou de notas ou resultados, resultantes das decisões dos recursos ou pedidos de revisão deferidos, serão dados a conhecer, coletivamente, através Internet no site www.funcab.org e afixadas no Posto de Atendimento, nas datas estabelecidas no Cronograma Previsto - ANEXO III.

\section{DA CLASSIFICAÇÃO FINAL DO CONCURSO PÚBLICO}

14.1. A nota final no Concurso Público será a nota final da Prova Objetiva, somada com a nota da Prova de Títulos, sendo para o cargo Professor Classe "C" - Libras, condicionada a aprovação na Prova Prática de LIBRAS.

14.2. No caso de igualdade de pontuação na classificação final, após observância do disposto no parágrafo único, do art. 27 , da Lei n. 10.741, de 01/10/2003 (Estatuto do Idoso), será utilizado o critério de desempate, sucessivamente, conforme a seguir:

a) maior número de pontos na Prova Objetiva, na disciplina de Conhecimentos na Área de Formação;

b) maior número de pontos na Prova Objetiva, na disciplina de Conhecimentos Pedagógicos;

c) maior número de pontos na Prova Objetiva, na disciplina de Língua Portuguesa;

d) maior número de pontos na Prova Objetiva, na disciplina de Informática Básica;

e) persistindo o empate, terá preferência o candidato com mais idade, considerando dia, mês, ano e, se necessário, hora e minuto do nascimento.

\section{DA RECONVOCAÇÃO}

15.1. Poderá ser adotado o sistema de reconvocação para posse de candidato nomeado e não empossado, por cargo, habilitação e localidade para qual se inscreveu, considerando o não preenchimento de vagas previstas neste Edital, depois de todos os candidatos aprovados terem sido nomeados, seguindo os critérios dispostos nos itens seguintes.

15.2. Somente poderá ser reconvocado o candidato nomeado que não apresentou o requisito escolaridade correspondente exigido para a posse, devendo este protocolar requerimento junto à Secretaria de Estado da Administração, dentro do prazo de 60 (sessenta) dias, a contar da data da publicação do ato de sua nomeação, solicitando a reconvocação e ainda ter seu pedido deferido.

15.3. Caso seja deferido o pedido do candidato o seu nome será reconduzido, por cargo, habilitação e localidade, nos quais concorreu no certame, para uma relação à parte.

15.4. A reconvocação dar-se-á com nova nomeação, que obedecerá à ordem rigorosa de classificação obtida no certame.

15.5. A reconvocação somente poderá ocorrer depois de todos os candidatos aprovados, por cargo, habilitação e localidade terem sidos nomeados e, ainda assim, restar vagas que não foram preenchidas.

15.6. O prazo para se proceder com a reconvocação é o mesmo da validade do presente Concurso Público.

\section{DISPOSIÇÕES FINAIS}

16.1. Os candidatos poderão obter informações gerais referentes ao Concurso Público através do site www.funcab.org ou por meio dos telefones (21) 2621-0966 - Rio de Janeiro, (69) 3224-5460, ou pelo e-mail concursos@funcab.org ou no Posto de Atendimento - ANEXO IV.

16.1.1. Não serão dadas por telefone informações a respeito de datas, locais e horários de realização das provas e nem de resultados, gabaritos, notas, classificação, convocações ou outras quaisquer relacionadas aos resultados provisórios ou finais das provas e do Concurso Público. O candidato deverá observar rigorosamente os editais e os comunicados a serem divulgados na forma definida neste Edital.

16.1.2. Quaisquer alterações nas regras fixadas neste Edital somente poderão ser feitas por meio de edital de retificação.

16.1.3. A SEAD, SEDUC e FUNCAB não se responsabilizam por informações de qualquer natureza, divulgados em sites de terceiros.

16.2. É de responsabilidade exclusiva do candidato acompanhar as publicações dos Editais, comunicações, retificações e convocações referentes a este Concurso Público, durante todos o período de validade do mesmo.

16.3. Caso o candidato queira utilizar-se de qualquer direito concedido por legislação pertinente, deverá fazer a solicitação 
somente na Secretaria de Estado da Administração de Rondônia, nos primeiros 10 (dez) dias do início das inscrições, em caso de domingo ou feriado, até o primeiro dia útil seguinte. Este período não será prorrogado em hipótese alguma, não cabendo, portanto, acolhimento de recurso posterior relacionado a este subitem.

16.4. Os resultados finais serão divulgados na Internet nos sites www.funcab.org, publicado no Diário Oficial do Estado de Rondônia e em jornais de maior circulação no Estado de Rondônia.

16.5. O resultado final do Concurso Público será homologado pela Secretaria de Estado da Administração de Rondônia.

16.6. Acarretará a eliminação do candidato do Concurso Público, sem prejuízo das sanções penais cabíveis, a burla ou a tentativa de burla a quaisquer das normas definidas neste Edital e/ou em outros editais relativos ao Concurso Público, nos comunicados e/ou nas instruções constantes de cada prova.

16.7. A Administração reserva-se o direito de proceder às nomeações, em número que atenda ao interesse e às necessidades do serviço, de acordo com a disponibilidade orçamentária e até o número de vagas ofertadas neste Edital, das que vierem a surgir ou forem criadas por lei, dentro do prazo de validade do Concurso Público.

16.8. A convocação para posse será feita por meio de publicação no site www.rondonia.ro.gov.br, Diário Oficial do Estado de Rondônia e Jornal de Circulação no Estado de Rondônia.

16.9. O candidato que não atender à convocação para a apresentação dos requisitos citados no item 3 deste Edital ou que não solicitar a reconvocação(neste caso, no prazo de 60 dias a partir da publicação no Diário Oficial do Estado de Rondônia), será automaticamente excluído do Concurso Público.

16.9.1. Somente será recebido e analisado, pedido de relotação depois de completado o período de estágio probatório de 3 anos.

16.10. A posse dos candidatos aprovados se dará em até 30 (trinta) dias, a contar da data da publicação do Decreto de Nomeação no Diário Oficial do Estado de Rondônia.

16.11. O Professor recém empossado deverá participar de programa de integração da SEDUC e, de programa de formação através da academia do profissional do magistério art. 91 LC 680.

16.12. Não será fornecido ao candidato documento comprobatório de classificação em qualquer etapa do presente Concurso Público, valendo, para esse fim, o resultado final divulgado nas formas previstas no subitem 16.4.

16.13. O candidato deverá manter atualizado o seu endereço junto à FUNCAB, até o encerramento da do Concurso Público sob sua responsabilidade, e, após, junto à Secretaria de Estado da Administração de Rondônia.

16.14. As legislações com entrada em vigor após a data de publicação deste Edital, bem como alterações em dispositivos legais e normativos a ela posteriores, não serão objetos de avaliação nas provas do presente Concurso Público.

16.15. O candidato aprovado no Concurso Público, quando convocado para posse e efetivo exercício do cargo, será submetido a Exame Médico Admissional para avaliação de sua capacidade física e mental, cujo caráter é eliminatório e constitui condição e pré-requisito para que se concretize a posse. Correrá por conta do candidato a realização de todos os exames médicos necessários solicitados no ato de sua convocação.

16.16. As ocorrências não previstas neste Edital serão resolvidas a critério exclusivo e irrecorrível da Comissão do Concurso Público e da FUNCAB e, em última instância administrativa, pela Assessoria Jurídica da Secretaria de Estado da Administração de Rondônia.

16.17. Todos os cursos, requisitos para ingresso, referenciados no ANEXO II deste Edital, deverão ter o reconhecimento e/ou sua devida autorização por órgão oficial competente.

16.18. A Secretaria de Estado da Administração de Rondônia e a FUNCAB não se responsabilizam por quaisquer textos, apostilas, cursos, referentes a este Concurso Público.

16.19. Os documentos produzidos e utilizados pelos candidatos em todas as etapas do Concurso Público são de uso e propriedade exclusivos da Banca Examinadora, sendo terminantemente vedada a sua disponibilização a terceiros ou a devolução ao candidato.

16.20. A FUNCAB e a Secretaria de Estado da Administração de Rondônia reservam-se no direito de promover as correções que se fizerem necessárias, em qualquer fase do presente certame ou posterior ao mesmo, em razão de atos não previstos ou imprevisíveis.

16.21. Os candidatos aprovados que não atingiram a classificação necessária ao número de vagas previstas neste edital, integram o cadastro de reserva.

16.22. A Secretaria de Estado da Administração de Rondônia reserva-se o direito de convidar o candidato aprovado e classificado em outra opção de localidade, obedecendo ao critério de maior pontuação no cargo para suprir vaga/localidade para a qual não houver candidatos aprovados. Não sendo de interesse do candidato, este não será excluído do Concurso Público, assinando, no entanto, um Termo de Desistência da localidade oferecida, permanecendo na mesma classificação até eventual surgimento de vaga na localidade em que foi classificado.

16.22.1. O candidato que aceitar prover vaga em localidade diversa da de sua opção, perderá, automaticamente, o direito de ser convocado para a localidade de opção em que foi classificado.

16.22.2. Os candidatos arcarão com todas as despesas resultantes de seus deslocamentos, bem como as despesas de transporte pessoal, de seus familiares e mobiliários, em caso de aceitação de vaga em outra localidade, que implique em mudança de domicílio.

16.23. As despesas relativas à participação em todas as fases do Concurso correrão a expensas do próprio candidato.

16.24. Integram este Edital, os seguintes Anexos: 
Secretaria de Administraçäo

Palácio Rio Madeira

ANEXO I - Quadro de Vagas;

ANEXO II - Requisito/Escolaridade;

ANEXO III - Cronograma Previsto;

ANEXO IV - Posto de Atendimento;

ANEXO V - Tema da Prova Prática de Libras;

ANEXO VI - Conteúdo Programático;

ANEXO VII - Atribuições do cargo e

ANEXO VIII - Modelo Declaração de Veracidade - Prova de Títulos.

Porto Velho, 10 de janeiro 2013.

RUI VIEIRA DE SOUSA

Secretário de Estado da Administração 
Secretaria de Administraçẩo
RONDÔNIA

- GOVERNO DA COOPERACÃO

ANEXO I - QUADRO DE VAGAS

\begin{tabular}{|c|c|c|c|c|c|c|c|c|c|c|c|c|c|c|c|c|c|c|}
\hline \multirow{6}{*}{ Localidades } & \multicolumn{18}{|c|}{ Professor Classe “C”" } \\
\hline & $\frac{d}{\frac{d}{\frac{1}{4}}}$ & $\frac{\text { 응 }}{\frac{0}{0}}$ & 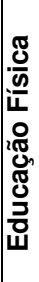 & 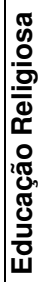 & 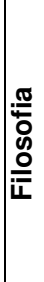 & $\frac{\mathbb{O}}{\frac{0}{n}}$ & 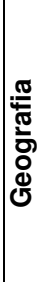 & $\begin{array}{l}\frac{\pi}{2} \\
\frac{0}{0} \\
\frac{0}{\underline{0}} \\
\frac{0}{1}\end{array}$ & 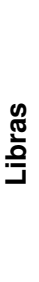 & 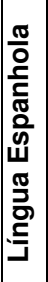 & 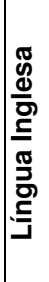 & 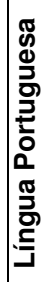 & 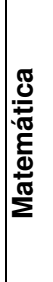 & 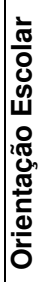 & 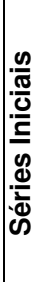 & 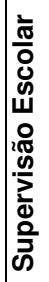 & 趂 & 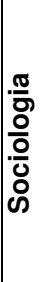 \\
\hline & \multicolumn{18}{|c|}{ ÁREA } \\
\hline & $\mathbf{A}$ & B & $\mathbf{E}$ & $\mathbf{E}$ & $\mathbf{F}$ & $\mathbf{F}$ & $\mathbf{G}$ & $\mathbf{H}$ & $\mathbf{L}$ & $\mathbf{E}$ & I & $\mathbf{P}$ & $\mathbf{M}$ & 0 & $\mathbf{S}$ & $\mathbf{S}$ & $\mathbf{Q}$ & $\mathbf{S}$ \\
\hline & $\mathbf{R}$ & I & D & D & I & I & $\mathbf{E}$ & I & I & $\overline{\mathbf{S}}$ & $\mathbf{N}$ & 0 & $\mathbf{A}$ & $\mathbf{R}$ & I & $\mathbf{U}$ & $\mathbf{U}$ & 0 \\
\hline & $\mathbf{T}$ & 0 & $\mathbf{F}$ & $\mathbf{R}$ & $\mathbf{L}$ & $\mathbf{S}$ & 0 & $\mathbf{S}$ & B & $\mathbf{P}$ & $\mathbf{G}$ & $\mathbf{R}$ & $\mathbf{T}$ & I & $\mathbf{P}$ & $\mathbf{P}$ & I & C \\
\hline Município de Ariquemes & 1 & 1 & 1 & 1 & 1 & 2 & 1 & 1 & 1 & 1 & 1 & 1 & 1 & - & 1 & - & 2 & 1 \\
\hline Município de Alto Paraíso & 1 & 1 & 1 & 1 & 1 & 1 & 1 & 1 & - & 1 & 1 & 1 & 2 & 1 & 1 & 1 & 1 & 1 \\
\hline Município de Rio Crespo & 1 & 1 & 1 & 1 & 1 & 1 & 1 & 1 & - & 1 & 1 & 1 & 2 & 1 & 1 & 1 & 1 & 1 \\
\hline Município de Cacaulândia & 1 & 2 & 1 & 1 & 1 & 1 & 1 & 1 & - & 1 & 1 & 1 & 1 & 1 & 1 & 1 & 1 & 1 \\
\hline Município de Cujubim & 1 & 1 & 1 & 1 & 1 & 1 & 1 & 1 & - & 1 & 1 & 1 & 2 & 1 & 1 & - & 1 & 1 \\
\hline Município de Machadinho do Oeste & 1 & 1 & 1 & 1 & 1 & 1 & 1 & 1 & - & 1 & 1 & 1 & 2 & 1 & 1 & 1 & 1 & 1 \\
\hline Distrito de $5^{\circ} \mathrm{BEC} /$ Machadinho do Oeste & 1 & 1 & 1 & 1 & 1 & 1 & 1 & 1 & - & 1 & 1 & - & 2 & - & 1 & - & 1 & 1 \\
\hline Município de Buritis & 1 & 1 & 1 & 1 & 1 & 1 & 1 & 1 & - & 1 & 1 & 1 & 2 & 1 & 1 & 1 & 1 & 1 \\
\hline Distrito de Jacinópolis/Buritis & 1 & 1 & 1 & 1 & 1 & 1 & 1 & 1 & - & 1 & 1 & 1 & 2 & 1 & - & 1 & 1 & 1 \\
\hline Distrito de Rio Pardo/Buritis & 1 & 1 & 1 & 1 & 1 & 1 & 1 & 1 & - & 1 & 1 & 1 & 2 & 1 & 1 & 1 & 1 & 1 \\
\hline Município de Monte Negro & 1 & 2 & 1 & - & 1 & 1 & 1 & 1 & - & 1 & 1 & 1 & 2 & - & 1 & - & 1 & 1 \\
\hline Município de Campo Novo de Rondônia & - & - & 1 & 1 & 1 & 1 & 1 & 1 & - & 1 & 1 & - & 2 & 1 & 1 & 1 & 1 & 1 \\
\hline Distrito P.A. Rio Branco/Campo Novo de Rondônia & 1 & 1 & 1 & 1 & 1 & 1 & 1 & 1 & - & 1 & 1 & 1 & 2 & 1 & 1 & 1 & 1 & 1 \\
\hline Município de Cacoal & 1 & 2 & 1 & - & 1 & 2 & 1 & 1 & 1 & 1 & 1 & 1 & 1 & - & 1 & - & 1 & 1 \\
\hline Município de Ministro Andreazza & - & - & 1 & - & - & 1 & 1 & - & - & - & 1 & - & 2 & - & - & - & - & - \\
\hline Distrito de Riozinho/Cacoal & - & - & 1 & - & - & 1 & - & - & - & - & - & - & - & - & - & 1 & - & - \\
\hline Município de Espigão do Oeste & - & 1 & 2 & 1 & 1 & 1 & 1 & 1 & - & 1 & 1 & 1 & 2 & - & 1 & - & 2 & 1 \\
\hline Distrito de Boa Vista do Pacarana/Espigão do Oeste & - & - & 1 & - & - & - & - & - & - & - & - & - & 1 & - & - & - & - & - \\
\hline Distrito Setor Seringal/Espigão do Oeste & - & - & 1 & - & - & 1 & - & - & - & - & - & - & - & - & - & - & - & - \\
\hline Município de Cerejeiras & 1 & 1 & 1 & 1 & 1 & 1 & 1 & 1 & 1 & 1 & - & 1 & 1 & 1 & 2 & 1 & 1 & 1 \\
\hline Município de Pimenteiras do Oeste & - & 1 & 1 & - & - & - & 1 & 1 & - & 1 & 1 & 1 & 1 & 1 & - & - & 1 & - \\
\hline Município de Corumbiara & 1 & 1 & 1 & - & - & 1 & - & 1 & - & - & 1 & - & 1 & - & 1 & - & - & 1 \\
\hline Distrito de Rondolândia/Corumbiara & - & 1 & 1 & - & - & - & - & - & - & - & - & - & 1 & 1 & 1 & - & 1 & - \\
\hline Distrito de Guarajus/Corumbiara & - & 1 & 1 & - & - & 1 & - & 1 & - & - & - & - & 1 & 1 & 1 & 1 & 1 & - \\
\hline Distrito de Vitória da União/Corumbiara & - & 1 & 1 & - & - & - & 1 & 1 & - & - & - & - & 1 & 1 & 1 & 1 & 1 & - \\
\hline Distrito de Extrema/Porto Velho & - & 1 & - & - & - & 1 & 1 & 1 & 1 & - & - & 1 & 1 & - & 1 & 1 & 1 & - \\
\hline Distrito de Nova Califórnia/Porto Velho & - & 1 & - & - & - & - & 1 & 1 & - & - & - & - & 1 & 1 & - & 1 & - & - \\
\hline Distrito de Vista Alegre do Abunã/Porto Velho & - & 1 & - & - & - & 1 & - & 1 & - & - & - & 1 & 1 & 1 & - & - & - & - \\
\hline Município de Guajará Mirim & - & 1 & 1 & 1 & 1 & 1 & 1 & 1 & 1 & 1 & 1 & 1 & 2 & 1 & 1 & - & 1 & 1 \\
\hline Município de Nova Mamoré & - & 1 & 1 & 1 & - & 1 & 1 & 1 & - & 1 & 1 & 1 & 2 & 1 & 1 & - & 2 & 1 \\
\hline Distrito do Hiata/Guajará Mirim & - & - & - & - & - & - & - & - & - & - & - & - & 1 & - & 1 & - & - & - \\
\hline Distrito Surpresa/Guajará Mirim & - & 1 & 1 & - & - & - & - & - & - & 1 & 2 & 1 & 1 & 1 & - & 1 & - & - \\
\hline Distrito de Nova Dimensão/Nova Mamoré & 1 & 1 & 1 & 1 & 1 & 1 & 1 & 1 & - & 1 & 1 & - & 1 & - & 1 & - & 1 & 1 \\
\hline Município de Jaru & 1 & 1 & 1 & 1 & 1 & 1 & 1 & 1 & 1 & 1 & 1 & 2 & 1 & 1 & 1 & - & 1 & 1 \\
\hline Distrito de Tarilândia/Jaru & - & 1 & 1 & - & - & - & 1 & 1 & - & 1 & 1 & - & 2 & - & - & 1 & 1 & 1 \\
\hline Distrito de Santa Cruz da Serra/Jaru & - & 1 & - & - & - & - & - & - & - & - & - & - & 1 & 1 & - & - & - & - \\
\hline Distrito de Bom Jesus/Jaru & - & 1 & - & - & - & - & - & 1 & - & 1 & - & 1 & 1 & - & 1 & - & - & - \\
\hline Município de Theobroma & - & 1 & 1 & - & 1 & 1 & 2 & 1 & - & 1 & 1 & 1 & - & 1 & 1 & - & 1 & 1 \\
\hline Município de Governador Jorge Teixeira & - & 1 & 2 & - & 1 & 1 & 1 & 1 & - & - & 1 & 1 & 1 & 1 & - & - & - & - \\
\hline Distrito de Colina Verde/Governador Jorge Teixeira & - & 1 & - & - & - & 1 & - & 1 & - & 1 & 1 & 1 & 1 & 1 & 1 & 1 & 1 & 1 \\
\hline Município de Vale do Anari & - & 2 & 1 & - & 1 & 1 & 1 & 1 & - & 1 & 1 & 2 & 2 & 1 & 1 & 1 & - & - \\
\hline Município de Ji-Paraná & 1 & 1 & 1 & 1 & 1 & 1 & 1 & 1 & 1 & 1 & 1 & 1 & 1 & 1 & 1 & 1 & 1 & 1 \\
\hline Distrito de Nova Londrinha/Ji-Paraná & - & 1 & - & - & - & - & 1 & 1 & - & - & - & - & 1 & - & 1 & 1 & - & - \\
\hline Distrito de Nova Colina/Jí-Paraná & - & - & 1 & - & - & - & - & - & - & - & - & - & 1 & - & 1 & - & - & - \\
\hline Município de Alvorada do Oeste & - & 1 & 1 & - & - & 1 & 1 & 1 & - & 1 & 1 & 1 & 2 & - & 1 & 1 & 1 & 1 \\
\hline Município de Presidente Médici & 1 & 1 & 1 & 1 & - & 1 & 1 & 1 & - & 1 & - & 1 & 2 & 1 & 1 & 1 & 1 & 1 \\
\hline
\end{tabular}


Secretaria de Administraçẩo
RONDÔNIA

- GOVERNO DA COOPERACÃO

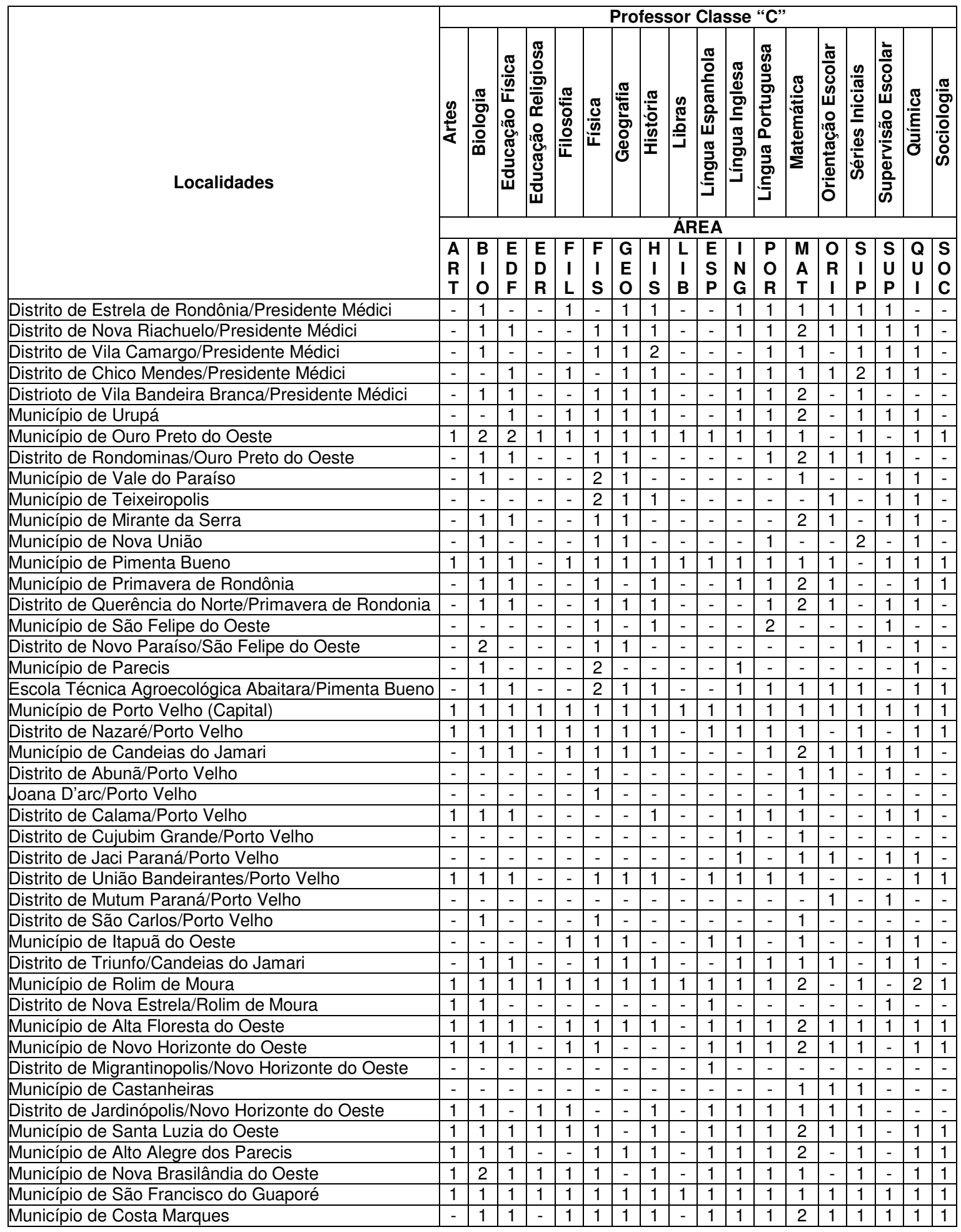


\begin{tabular}{|l|l|l|l|l|l|l|l|l|l|l|l|l|l|l|l|l|l|l|}
\hline Distrito de São Domingos do Guaporé/Costa Marques & - & 1 & 1 & - & - & - & - & - & - & 1 & 1 & 1 & 1 & - & - & - & - & - \\
\hline
\end{tabular} \begin{tabular}{|l|l|l|l|l|l|l|l|l|l|l|l|l|l|l|l|l|}
\hline Distrito de Santo Antônio/São Francisco do Guaporé & - & - & - & - & - & - & 1 & - & - & - & - & - & 1 & - & 1 & - \\
\hline
\end{tabular}

\begin{tabular}{|c|c|c|c|c|c|c|c|c|c|c|c|c|c|c|c|c|c|c|}
\hline \multirow{4}{*}{ Localidades } & \multicolumn{18}{|c|}{ Professor Classe "C" } \\
\hline & 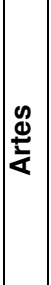 & $\frac{.0}{\frac{0}{8}}$ & 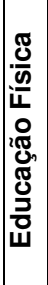 & 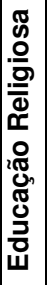 & 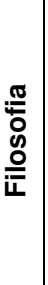 & $\frac{\mathbb{8}}{\frac{8}{4}}$ & 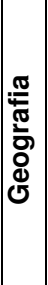 & 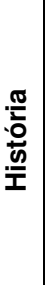 & 恚 & 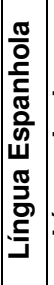 & 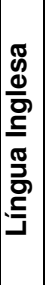 & 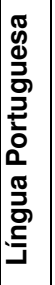 & 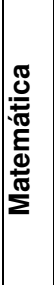 & 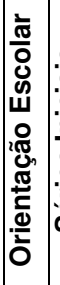 & 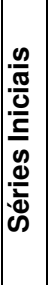 & 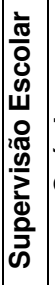 & $\frac{.}{\frac{\delta}{\varepsilon}}$ & $\frac{\frac{\pi}{2}}{\frac{0}{0}}$ \\
\hline & \multicolumn{18}{|c|}{ ÁREA } \\
\hline & \begin{tabular}{l|l|}
$\mathbf{A}$ \\
$\mathbf{R}$ \\
$\mathbf{T}$ \\
\end{tabular} & \begin{tabular}{|l} 
B \\
I \\
0
\end{tabular} & \begin{tabular}{|l} 
E \\
D \\
$F$
\end{tabular} & \begin{tabular}{|l|}
$\mathbf{E}$ \\
$\mathrm{D}$ \\
$\mathbf{R}$ \\
\end{tabular} & \begin{tabular}{|l|}
$F$ \\
$I$ \\
$L$
\end{tabular} & \begin{tabular}{|l|}
$F$ \\
$I$ \\
$S$
\end{tabular} & $\begin{array}{l}\mathbf{G} \\
\mathbf{E} \\
\mathbf{O}\end{array}$ & \begin{tabular}{|l|}
$H$ \\
$\mathbf{I}$ \\
$\mathrm{S}$ \\
\end{tabular} & \begin{tabular}{|l}
$\mathbf{L}$ \\
$\mathbf{I}$ \\
$\mathrm{B}$
\end{tabular} & \begin{tabular}{|l|}
$E$ \\
$S$ \\
$P$ \\
\end{tabular} & \begin{tabular}{l|l|}
$\mathbf{I}$ \\
$\mathbf{N}$ \\
$\mathbf{G}$ \\
\end{tabular} & \begin{tabular}{|l|}
$P$ \\
$O$ \\
$R$ \\
\end{tabular} & \begin{tabular}{|l|}
$\mathbf{M}$ \\
$\mathbf{A}$ \\
$\mathbf{T}$ \\
\end{tabular} & \begin{tabular}{|c|}
$\mathbf{O}$ \\
$\mathrm{R}$ \\
$\mathrm{I}$
\end{tabular} & \begin{tabular}{|l|}
$\mathbf{S}$ \\
$\mathbf{I}$ \\
$\mathbf{P}$ \\
\end{tabular} & \begin{tabular}{|l|}
$\mathbf{S}$ \\
$\mathbf{U}$ \\
$\mathbf{P}$ \\
\end{tabular} & \begin{tabular}{|l|}
$\mathbf{Q}$ \\
$\mathbf{U}$ \\
$\mathbf{I}$
\end{tabular} & $\begin{array}{l}\text { S } \\
0 \\
C\end{array}$ \\
\hline Distrito de Pedras Negras/São Francisco do Guaporé & - & 1 & - & - & - & - & 1 & - & - & 1 & - & - & 1 & - & 1 & - & 1 & - \\
\hline $\begin{array}{l}\text { Distrito de Santana do Guaporé/São Miguel do } \\
\text { Guaporé }\end{array}$ & - & - & - & - & - & - & - & - & - & - & - & - & 1 & - & - & - & - & - \\
\hline Distrito de Forte Príncipe da Beira/Costa Marques & - & 1 & - & - & - & - & 1 & - & - & 1 & - & - & 1 & 1 & 2 & 1 & - & - \\
\hline Município de Seringueiras & 1 & 1 & 1 & 1 & 1 & 1 & 1 & 1 & - & 1 & 1 & 1 & 2 & 1 & 1 & 1 & 1 & 1 \\
\hline Município de São Miguel do Guaporé & 1 & 1 & 1 & 1 & 1 & 2 & 1 & 1 & - & 1 & 1 & 1 & 2 & 1 & 1 & - & 1 & 1 \\
\hline Município de Vilhena & 1 & 2 & 1 & 1 & 1 & 1 & 1 & 1 & 1 & 2 & 1 & 1 & 1 & - & 1 & - & 1 & 1 \\
\hline Município de Chupinguaia & 1 & 1 & 1 & 1 & 1 & 1 & 1 & 1 & - & 1 & 1 & 1 & 2 & 1 & - & 1 & 1 & 1 \\
\hline Distrito de Boa Esperança/Chupinguaia & - & 1 & 1 & - & - & 1 & - & 1 & - & - & - & - & 1 & - & - & 1 & - & - \\
\hline Município de Cabixi & 1 & 2 & 1 & 1 & 1 & 1 & 1 & 1 & - & 1 & 1 & 1 & 2 & 1 & 1 & - & 1 & 1 \\
\hline Distrito de Planalto/Cabixi & - & 1 & 1 & - & - & - & - & - & - & - & - & - & - & - & - & - & - & - \\
\hline Linha 9 - Km 16/Cabixi & - & 1 & 1 & - & - & - & - & - & - & - & - & - & - & - & - & 1 & - & - \\
\hline Município de Colorado do Oeste & 1 & 1 & 2 & 1 & 1 & 1 & 1 & 1 & - & 1 & - & 1 & 2 & - & 1 & - & 2 & 1 \\
\hline TOTAL & 40 & 92 & 77 & 34 & 46 & 82 & 70 & 72 & 13 & 57 & & 68 & 129 & 567 & 70 & 52 & 74 & 48 \\
\hline
\end{tabular}


ANEXO II - REQUISITO/ESCOLARIDADE

\begin{tabular}{|c|c|c|}
\hline Cargo & Área & Requisito/Escolaridade \\
\hline \multirow{14}{*}{ Professor Classe "C" } & Arte & $\begin{array}{l}\text { Diploma de Curso Superior de Licenciatura Plena em Arte ou Diploma de } \\
\text { Bacharel mais Curso de Complementação Pedagógica Específica, oficialmente } \\
\text { reconhecido. }\end{array}$ \\
\hline & Biologia & $\begin{array}{l}\text { Diploma de Curso Superior de Licenciatura Plena em Ciências Biológicas ou } \\
\text { Diploma de Bacharel mais Curso de Complementação Pedagógica Específica, } \\
\text { oficialmente reconhecido. }\end{array}$ \\
\hline & Educação Física & $\begin{array}{l}\text { Diploma de Curso Superior de Licenciatura Plena em Educação Física ou } \\
\text { Diploma de Bacharel mais Curso de Complementação Pedagógica Específica, } \\
\text { oficialmente reconhecido, mais Registro no CREF. }\end{array}$ \\
\hline & $\begin{array}{l}\text { Educação } \\
\text { Religiosa }\end{array}$ & $\begin{array}{l}\text { Diploma de Curso Superior de Licenciatura Plena em Educação Religiosa ou } \\
\text { Diploma de Bacharel mais Curso de Complementação Pedagógica Específica, } \\
\text { oficialmente reconhecido. }\end{array}$ \\
\hline & Filosofia & $\begin{array}{l}\text { Diploma de Curso Superior de Licenciatura Plena em Filosofia ou Diploma de } \\
\text { Bacharel mais Curso de Complementação Pedagógica Específica, oficialmente } \\
\text { reconhecido. }\end{array}$ \\
\hline & Física & $\begin{array}{l}\text { Diploma de Curso Superior de Licenciatura Plena em Física ou Diploma de } \\
\text { Bacharel mais Curso de Complementação Pedagógica Específica, oficialmente } \\
\text { reconhecido. }\end{array}$ \\
\hline & Geografia & $\begin{array}{l}\text { Diploma de Curso Superior de Licenciatura Plena em Geografia ou Diploma de } \\
\text { Bacharel mais Curso de Complementação Pedagógica Específica, oficialmente } \\
\text { reconhecido. }\end{array}$ \\
\hline & História & $\begin{array}{l}\text { Diploma de Curso Superior de Licenciatura Plena em História ou Diploma de } \\
\text { Bacharel mais Curso de Complementação Pedagógica Específica, oficialmente } \\
\text { reconhecido }\end{array}$ \\
\hline & Libras & $\begin{array}{l}\text { Diploma de Curso Superior de Licenciatura Plena em Libras ou Diploma de } \\
\text { Bacharel mais Curso de Complementação Pedagógica Específica, ou ainda } \\
\text { outra Licenciatura Plena mais Curso Especifico em Libras reconhecido pelo } \\
\text { Prolibras, oficialmente reconhecido. }\end{array}$ \\
\hline & Língua Espanhola & $\begin{array}{l}\text { Diploma de Curso Superior de Licenciatura Plena em Letras Espanhol ou } \\
\text { Diploma de Bacharel mais Curso de Complementação Pedagógica Específica } \\
\text { em Língua Espanhola, oficialmente reconhecido. }\end{array}$ \\
\hline & Língua Inglesa & $\begin{array}{l}\text { Diploma de Curso Superior de Licenciatura Plena em Letras Inglês ou } \\
\text { Diploma de Bacharel mais Curso de Complementação Pedagógica Específica, } \\
\text { oficialmente reconhecido. }\end{array}$ \\
\hline & Língua Portuguesa & $\begin{array}{l}\text { Diploma de Curso Superior de Licenciatura Plena em Letras Português ou } \\
\text { Diploma de Bacharel mais Curso de Complementação Pedagógica Específica, } \\
\text { oficialmente reconhecido. }\end{array}$ \\
\hline & Matemática & $\begin{array}{l}\text { Diploma de Curso Superior de Licenciatura Plena em Matemática ou Diploma } \\
\text { de Bacharel mais Curso de Complementação Pedagógica Específica em } \\
\text { Matemática, oficialmente reconhecido. }\end{array}$ \\
\hline & Orientação Escolar & Diploma de Curso Superior de Licenciatura Plena em Pedagogia - Orientação \\
\hline
\end{tabular}




\begin{tabular}{|l|l|l|}
\hline \multirow{2}{*}{ Séries Iniciais } & $\begin{array}{l}\text { Escolar ou Diploma de Bacharel mais Curso de Complementação Pedagógica } \\
\text { Específica, oficialmente reconhecido. }\end{array}$ \\
\cline { 2 - 3 } & $\begin{array}{l}\text { Diploma de Curso Superior de Licenciatura Plena em Pedagogia - Séries } \\
\text { Iniciais, ou Curso Superior em Pedagogia (Resolução 001/MEC), ou Curso } \\
\text { Normal Superior, ou Diploma de Bachare, com Complementação } \\
\text { Pedagógica Específica, oficialmentes reconhecidos. }\end{array}$ \\
\cline { 2 - 3 } Supervisão Escolar & $\begin{array}{l}\text { Diploma de Curso Superior de Licenciatura Plena em Pedagogia - } \\
\text { Supervisão Escolar ou Diploma de Bacharel mais Curso de Complementação } \\
\text { Pedagógica Específica, oficialmente reconhecido. }\end{array}$ \\
\cline { 2 - 3 } Química & $\begin{array}{l}\text { Diploma de Curso Superior de Licenciatura Plena em Química ou Diploma de } \\
\text { Bacharel mais Curso de Complementação Pedagógica Específica, oficialmente } \\
\text { reconhecido. }\end{array}$ \\
\cline { 2 - 3 } & $\begin{array}{l}\text { Diploma de Curso Superior de Licenciatura Plena em Sociologia ou Diploma } \\
\text { de Bacharel mais Curso de Complementação Pedagógica Específica, } \\
\text { oficialmente reconhecido. }\end{array}$ \\
\hline
\end{tabular}

\section{ANEXO III - CRONOGRAMA PREVISTO}

\begin{tabular}{|c|c|}
\hline EVENTOS & DATAS PREVISTAS \\
\hline Solicitação de isenção do valor da inscrição & 15 a $17 / 01 / 2013$ \\
\hline Divulgação das isenções deferidas e indeferidas & 29/01/2013 \\
\hline Recurso contra o indeferimento da isenção & 30 e $31 / 01 / 2013$ \\
\hline Resultado do recurso contra o indeferimento da isenção & $04 / 02 / 2013$ \\
\hline Período de inscrições pela Internet & $15 / 01$ a $07 / 02 / 2013$ \\
\hline Último dia para pagamento do boleto bancário & 08/02/2013 \\
\hline $\begin{array}{l}\text { Divulgação dos locais da Prova Objetiva } \\
\text { Homologação das inscrições }\end{array}$ & 25/02/2013 \\
\hline Realização da Prova Objetiva & 03/03/2013 \\
\hline Divulgação do gabarito da Prova Objetiva (a partir das 12 horas) & 04/03/2013 \\
\hline Período para entrega dos recursos contra a Prova Objetiva & 05 e 06/03/2013 \\
\hline $\begin{array}{l}\text { - Divulgação da resposta aos recursos contra a Prova Objetiva } \\
\text { - Divulgação das notas da Prova Objetiva } \\
\text { - Convocação para entrega dos títulos } \\
\text { - Convocação para Prova Prática para o cargo Professor Classe "C" - Libras }\end{array}$ & 20/03/2013 \\
\hline Prazo para entrega dos Títulos & 20 a $22 / 03 / 2013$ \\
\hline Realização da Prova Prática para o cargo Professor Classe "C" - Libras & $31 / 03 / 2013$ \\
\hline Divulgação do resultado da Prova Prática & 03/04/2013 \\
\hline Divulgação das notas dos Títulos & $08 / 04 / 2013$ \\
\hline Pedido de Revisão da nota dos Títulos & 09 e $10 / 04 / 2013$ \\
\hline $\begin{array}{l}\text { - Divulgação do recurso contra a nota dos títulos } \\
\text { - Divulgação do Resultado final }\end{array}$ & $15 / 04 / 2013$ \\
\hline
\end{tabular}


ANEXO IV - POSTO DE ATENDIMENTO

\begin{tabular}{|c|c|}
\hline LOCAL & FUNCIONAMENTO \\
\hline $\begin{array}{c}\text { Av. Campos Sales, n. 2282 Sala 11 - } \\
\text { Galeria Josefa de Jesus - Centro - Porto Velho/RO }\end{array}$ & $\begin{array}{c}\text { Segunda à sexta-feira } \\
\text { (exceto feriados) } \\
\text { De 08h às 12h e de 14h às 18h } \\
\text { (Horário de Rondônia) }\end{array}$ \\
\hline
\end{tabular}

\section{ANEXO V - TEMA DA PROVA PRÁTICA DE LIBRAS}

1. Português: Comparativos; Advérbios; Numerais; Adjetivos.

2. Matemática: Figuras Geométricas com números e letras; Números inteiros e fracionários; Noções de conjuntos.

3. Ciências e Biologia: Estados físicos da matéria; Temperatura e calor; corpo humano; As partes das plantas; Animais vertebrados; Animais invertebrados.

4. História e Geografia: Descobrimento do Brasil; $O$ processo de industrialização na região norte; Crescimento da população brasileira; Economia de Rondônia na atualidade.

\section{ANEXO VI - CONTEÚDOS PROGRAMÁTICOS}

\section{LÍNGUA PORTUGUESA:}

Compreensão e interpretação de textos. Denotação e conotação. Ortografia: emprego das letras e acentuação gráfica. Classes de palavras e suas flexões. Processo de formação de palavras. Verbos: conjugação, emprego dos tempos, modos e vozes verbais. Concordâncias nominal e verbal. Regências nominal e verbal. Emprego do acento indicativo da crase. Colocação dos pronomes átonos. Emprego dos sinais de pontuação. Semântica: sinonímia, antonímia, homonímia, paronímia, polissemia e figuras de linguagem. Funções sintáticas de termos e de orações. Processos sintáticos: subordinação e coordenação.

\section{HISTÓRIA E GEOGRAFIA DE RONDÔNIA:}

A formação do estado de Rondônia. Povoamento da Bacia Amazônica: período colonial. Capitania de Mato Grosso. Principais ciclos econômicos. Projetos de colonização. Ferrovia Madeira-Mamoré (1 $1^{\text {a }}$ fase e $2^{a}$ fase). Ciclo da borracha ( $1^{\underline{a}}$ fase e $2^{\underline{a}}$ fase). Tratados e limites. Antecedentes da criação do estado. Primeiros núcleos urbanos. Criação dos municípios. Evolução político administrativa. Desenvolvimento econômico. Transportes rodoviário, ferroviário, marítimo e aéreo. População. Movimentos migratórios. Processo de urbanização. Questão indígena. Desenvolvimento sustentável. Relevo. Vegetação. Desmatamento. Hidrografia. Aspectos econômicos. Meso e micro regiões. Problemas ecológicos.

\section{CONHECIMENTOS ESPECÍFICOS:}

\section{INFORMÁTICA BÁSICA}

Ambiente operacional Windows (2008/XP/VISTA/WIN7). Fundamentos do Windows, operações com janelas, ícones, botões, menus, barras de título, barra de menus, barras de ferramentas, área de trabalho, barra de status, barra de formatação e barra de rolagem, trabalho com pastas e arquivos, localização de arquivos e pastas, movimentação e cópia de arquivos, pastas, criação e exclusão de arquivos e pastas, compartilhamentos e áreas de 
transferência; Configurações básicas do Windows: resolução da tela, cores, fontes, impressoras, aparência, segundo plano e protetor de tela; Windows Explorer. Ambiente Intranet, Internet e Extranet. Conceitos básicos e utilização de tecnologias, ferramentas e aplicativos associados. Principais navegadores. Ferramentas de busca e pesquisa. Processador de textos. MS Word 2003/2007/2010 . Conceitos básicos. Criação de documentos. Abrir e salvar documentos. Digitação. Edição de textos. Estilos. Formatação. Tabelas e tabulações. Cabeçalho e rodapé. Configuração de página. Corretor ortográfico. Impressão. Ícones. Atalhos de teclado. Uso dos recursos e ferramentas. Ajuda. Planilha Eletrônica MS Excel 2003/2007/2010. Conceitos básicos. Criação de documentos. Abrir e Salvar documentos. Estilos. Formatação. Fórmulas e funções. Gráficos. Corretor ortográfico. Impressão. Ícones. Atalhos de teclado. Uso dos recursos. Ajuda. Correio eletrônico - Conceitos básicos. Formatos de mensagens. Transmissão e recepção de mensagens. Catálogo de endereços. Arquivos anexados. Uso dos recursos. Ícones. Atalhos de teclado.

\section{CONHECIMENTOS PEDAGÓGICOS}

História da Educação. Filosofia da Educação. Psicologia do desenvolvimento e da aprendizagem. Sociologia da Educação: a democratização da escola, educação e sociedade. Função social da escola. Interdisciplinaridade no Ensino Fundamental: teorias e práticas. Tendências do pensamento pedagógico. Avaliação da aprendizagem escolar. Educação Inclusiva: Fundamentos, Políticas e Práticas Escolares. Bullying. Teoria das Inteligências Múltiplas. Legislação da Educação Básica. Políticas Públicas da Educação Básica. Financiamento e Gestão da Educação. O Projeto Político Pedagógico da Escola. Rotina e gestão em sala de aula. Questões das relações do grupo. Lei ํo 8069/1990 - Estatuto da Criança e do Adolescente. Relação família x escola. Ação pedagógica. Objetivos do ensino fundamental. Brincar e aprender. Aprendendo a aprender. Identificação da população a ser atendida, a atividade econômica, o estilo de vida, a cultura e as tradições. Organização da educação brasileira. Legislação educacional: LDB Lei no 9394/96. Diretrizes Curriculares Nacionais para a Educação das Relações Étnico-Raciais e para o Ensino de História e Cultura Afro-Brasileira e Africana - Resolução no 1, de 17 de junho de 2004, tendo em vista a Lei no 9.131, publicada em 25 de novembro de 1995, e com fundamentação no Parecer CNE/CP 3/2004, de 10 de março de 2004. Interação social. Resolução de problemas. Organização do currículo. Erro e aprendizagem. A construção do conhecimento. Resolução no 04, de 13/07/2010.

\section{CONHECIMENTOS NA ÁREA DE FORMAÇÃO}

\section{PROFESSOR CLASSE “C” - ARTES}

História da arte. Movimentos artísticos. O lúdico na obra de arte. Arte - educação. Psicologia da arte. Processo de criação. Criatividade: conceito, originalidade, criatividade e desenvolvimento, inibição, processo e produto. Percepção: o mundo sonoro, o visual, o tátil. Aspectos formais da Arte: linha, cor, forma, superfície, volume, espaço, tempo, movimento, som, ruído, intensidade, timbre, altura, duração, ritmo, dinâmica. Integração através da arte. Artes Cênicas: história das artes cênicas; papel das artes cênicas no processo educacional, teoria e prática; teatro e jogo, criatividade e imaginação. Artes Plásticas: história geral das artes; história e ensino da arte no Brasil; teoria da arte: arte como produção, conhecimento e expressão; a obra de arte e sua recepção. Artes visuais: elementos de visualidade e suas relações; comunicação na contemporaneidade. Artes visuais e o multiculturalismo. Música: aspectos históricos da música ocidental; elementos estruturais da linguagem musical; tendências educacionais quanto ao ensino da música, na sala de aula; visão interdisciplinar do conhecimento musical. Música e expressão. Dança: história da dança; papel da dança na educação; estrutura e funcionamento do corpo para a dança; proposta triangular: fazer, apreciar, contextualizar. As danças como manifestações culturais. Cultura musical brasileira. Cultura local. Folclore do Brasil. Diretrizes Curriculares Nacionais Gerais para a Educação Básica Parecer CNE/CEB oㅜ 07, de 07 de abril de 2010 e Resolução CNE/CEB ํo 4, de 13 de julho de 2010. Resolução no 07 , de $14 / 12 / 2010$.

\section{PROFESSOR CLASSE "C" - BIOLOGIA}

Meio Ambiente: Terra e Universo: Sistema Solar, origem da Terra, estudo do ar; da água, do solo e dos minerais; O homem como agente transformador do ambiente e os problemas ambientais globais: poluição, efeito estufa, chuva ácida e desmatamento; Vida e Ambiente: origem e evolução dos seres vivos; Seres Vivos: vírus; estudo dos reinos 
Monera, dos Fungos, Protozoários; estudos dos vegetais, classificação, organologia, fisiologia; estudos dos animais, características gerais e classificação; Corpo Humano: noções do corpo humano, anatomia, fisiologia; Noções Básicas de Saúde: viroses, bacterioses, protozooses, verminoses e sua profilaxia; Alimentos: classificação e importância. Doenças transmitidas pelos alimentos; Doenças infecciosas e parasitárias: prevenção e vacinação. AIDS: princípios da doença e formas de prevenção; Sexo e gravidez na adolescência. Conceitos básicos da hereditariedade; Tecnologia e sociedade: avanços tecnológicos e suas relações com a Física e a Química; Física: Fundamentos teóricos da Física: conceitos, leis, relações e princípios básicos; Química: Fundamentos teóricos da Química: conceitos, leis, relações e princípios básicos, interações e transformações químicas, estrutura da matéria, substâncias, misturas e combinações, Noções de funções e reações químicas. Diretrizes Curriculares Nacionais Gerais para a Educação Básica - Parecer CNE/CEB nํ 07, de 07 de abril de 2010 e Resolução CNE/CEB nํ 4, de 13 de julho de 2010. Resolução ํㅡ 07, de 14/12/2010.

\section{PROFESSOR CLASSE “C” - EDUCAÇÃO FÍSICA}

Objetivos e conteúdos da Educação Física em função do nível de desenvolvimento e aprendizagem da criança e do adolescente. Fases do desenvolvimento. Psicomotricidade. Aprendizagem motora e cognitiva. Organização desportiva: torneios, campeonatos, competições, colônia de férias. Didática e Prática de Ensino específica da disciplina. Educação para o lazer. Recreação: conceito e finalidades. Jogo: conceito e valor. Desportos: técnicas fundamentais e regras oficiais. Técnicas e instrumentos de medida e avaliação em Educação Física. Métodos e técnicas da Educação Física. As novas tendências da Educação Física: Educação Física Humanista, Educação Física Progressista e a Cultura Corporal. Jogos Cooperativos. Educação Física Escolar: diferentes abordagens. Fisiologia do exercício. Diretrizes Curriculares Nacionais Gerais para a Educação Básica - Parecer CNE/CEB no 07, de 07 de abril de 2010 e Resolução CNE/CEB no 4, de 13 de julho de 2010. Resolução no 07, de 14/12/2010.

\section{PROFESSOR CLASSE "C" - EDUCAÇÃO RELIGIOSA}

Referencial curricular LDB: Art. 33; substitutivo do art. 33; Lei 9.475 de 22/07/97. Diretrizes curriculares nacionais para o Ensino Fundamental: conhecimento religioso; Ensino Religioso nos ciclos. O Ensino Religioso nas leis de ensino a partir da concepção religiosa; currículo: pressupostos; objetivos; interdisciplinaridade; concepção; correlação da disciplina na área de conhecimento da educação religiosa; metodologia e didática; avaliação. Alteridade, ética e valores no Ensino Religioso. Cultura e Religião: religião e poder; visão religiosa ocidental e oriental; religiosidade versus religião; cultura e tradições religiosas. Pilares da educação: relatório da Comissão Internacional sobre educação - UNESCO - para o século XXI. Caracterização histórica das tradições das grandes religiões (hinduísmo, budismo, judaísmo, cristianismo e islamismo) nos seguintes registros: crenças, livros sagrados, lugares sagrados e de oração, gestos e ritos, festas religiosas, fundadores, organização institucional, valores éticos, símbolos sagrados. Mapa atual das religiões: o mapa mundi e o mapa do Brasil.

\section{PROFESSOR CLASSE "C" - FILOSOFIA}

Do mito à razão: o nascimento da Filosofia na Grécia. O método científico, o senso comum e a filosofia; o problema da demarcação da ciência: Popper x Kuhn. Filosofia e Política. Concepções de ciência: positivismo, neopositivismo, dialética, pragmatismo.Teoria do conhecimento: racionalismo, empirismo; o problema de Gettier. O problema da verdade: correspondência, coerentismo, construtivismo social. O problema mente/corpo. A ideologia: sentidos e funções; a ideologia e a cultura. O pensamento político moderno: Hobbes, Locke, Rousseau, Hegel e Marx. Filosofia e linguagem: jogos de linguagem, atos de fala, ação comunicativa, formações discursivas. O problema da liberdade humana; os valores morais e a ética; metaética; ética e cidadania. O problema de Deus e o mal. Estética: o problema do belo; a arte como conhecimento; as funções da arte. A indústria cultural e a cultura de massa. A Filosofia no Brasil: o problema das filosofias nacionais. Diretrizes Curriculares Nacionais Gerais para a Educação Básica - Parecer CNE/CEB no 07, de 07 de abril de 2010 e Resolução CNE/CEB no 4, de 13 de julho de 2010. Resolução no 07, de 14/12/2010.

\section{PROFESSOR CLASSE “C” - FÍSICA}

Movimento, variações e Conservação; Fenomenologia cotidiana; Variação e Conservação da Quantidade de Movimento; Energia e Potência associadas aos Movimentos; Equilíbrios e Desequilíbrios. Calor, Ambiente e Uso de Energia; Fontes e Trocas de Calor; Tecnologias que usam calor: Motores e Refrigeradores; O Calor na Vida e no Ambiente; Energia: Produção para Uso Social. Som, Imagem e Informação; Fontes Sonoras; Formação e Detecção de Imagens; Gravação e Reprodução de Sons e Imagens; Transmissão de Sons e Imagens. Equipamentos 
Elétricos e Telecomunicações; Aparelhos Elétricos; Motores Elétricos; Geradores; Emissores e Receptores. Matéria e Radiação; Matéria e suas propriedades; Radiações e suas Interações; Energia Nuclear e Radioatividade; Eletrônica e Informática. Universo, Terra e Vida; Terra e Sistema Solar; O Universo e sua Origem; Compreensão Humana do Universo. Novos Paradigmas da Física: Einstein e o Universo Relativístico; Neil Bohr e a Interpretação Quântica da Natureza. Diretrizes Curriculares Nacionais Gerais para a Educação Básica - Parecer CNE/CEB n 07, de 07 de abril de 2010 e Resolução CNE/CEB nํ 4, de 13 de julho de 2010. Resolução no 07, de 14/12/2010.

\section{PROFESSOR CLASSE “C” - GEOGRAFIA}

Atuais concepções teórico-metodológicas da ciência geográfica e das relativas ao ensino e à aprendizagem. Ciências Humanas e suas Tecnologias. Uma nova prática didática na construção do conhecimento geográfico (ensino fundamental). As conexões da Geografia com outras disciplinas, a interdisciplinaridade e a transdisciplinaridade. A linguagem cartográfica: o planeta ao alcance do estudante e aplicações do conhecimento geográfico ao cotidiano escolar.. Formação da superfície da Terra: aspectos geológicos e agentes exógenos. Formação dos solos, tipos e principais problemas ambientais. Climatologia: fatores climáticos e sistemas atmosféricos no Brasil e no mundo. Biogeografia: principais características e problemas dos biomas mundiais e brasileirosA dinâmica demográfica mundial e o patrimônio ambiental: por um conhecimento geográfico sem dramas, mas com uma interpretação pluralista do mundo e do Brasil. Uma nova Globalização ou um novo olhar geográfico sobre o Sistema Mundial? As questões ambientais e a humanidade: seus desafios e necessidades de superação. Os recursos hídricos e energéticos e a inserção do território brasileiro neste contexto. A unificação dos mercados nacionais, as tecnologias e o espaço geográfico. O processo de urbanização mundial e sua espacialização no Brasil. A indústria e seus fatores locacionais. A agricultura e a segurança alimentar no mundo; o agronegócio no Brasil (sua concentração/desconcentração). O sistema mundial: os EUA, a UE (União Europeia) e os países que formam o BRIC (Brasil, Rússia, Índia e China); o Japão na ordem mundial; o Oriente Médio e os conflitos atuais; o sistema sul-americano; a unidade e a diversidade da África; A Oceania Diretrizes Curriculares Nacionais Gerais para a Educação Básica - Parecer CNE/CEB n 07, de 07 de abril de 2010 e Resolução CNE/CEB n 4, de 13 de julho de 2010. Resolução nº 07, de 14/12/2010.

\section{PROFESSOR CLASSE “C” - HISTÓRIA}

Teoria, metodologia e correntes historiográficas. Formação e crise do mundo medieval. Monarquias Nacionais. Renascimento. Expansão marítima e comercial europeia. Mercantilismo. Sistema Colonial. Reforma Protestante e Absolutismo Monárquico. Colonização Portuguesa da América (XVI-XVIII). América Espanhola. Trabalho, escravidão e mercado Atlântico. História do Continente Africano. Revolução Inglesa do século XVII. Revolução Americana. Revolução Industrial. Revolução Francesa. Império Napoleônico. Reação absolutista. As ondas revolucionárias do século XIX. Brasil: de Colônia à Império - processo de emancipação política e formação do Estado Imperial. Movimento Operário. Socialismo e Marxismo. Pós-48: cientificismo, democracia e transformações na estrutura do capitalismo - capitalismo monopolista. Nacionalismo e Estados Nações no século XIX. Imperialismo, Neocolonialismo e $1^{\underline{a}}$ guerra mundial. Brasil: da estabilidade à crise da Monarquia. Proclamação da República. Primeiros anos da República no Brasil. Século XX: a $1^{\underline{a}}$ guerra e seus desdobramentos políticos, econômicos e sociais para a Europa. Revolução Russa. Crise de 29. Totalitarismo. Segunda guerra. O Brasil da República Velha: política oligárquica, movimentos sociais e movimento operário. Crise e Revolução de 30 . Estado Novo. Guerra Fria e a nova expansão do capitalismo. Descolonização afro-asiática: novos rumos. O Novo Oriente Médio. Revoluções do período. Brasil: do Pacto Populista ao Golpe Militar - economia, política, sociedade e cultura do período 1937-1964. Anos 70-90: a crise do império soviético e do leste europeu. A nova crise do capitalismo. O Pós-guerra Fria. Neoliberalismo e globalização da economia. Brasil: da transição para a democracia à atualidade. Diretrizes Curriculares Nacionais Gerais para a Educação Básica - Parecer CNE/CEB n 07 , de 07 de abril de 2010 e Resolução CNE/CEB nº 4, de 13 de julho de 2010. Resolução nº 07, de 14/12/2010.

\section{PROFESSOR CLASSE "C" - LIBRAS}

Introdução: aspectos linguísticos e legais da LIBRAS. A Língua Brasileira de Sinais - LIBRAS: parâmetros fonológicos. Sistematização do léxico da morfologia e da sintaxe com apoio de recursos audio-visuais. Prática da LIBRAS: diálogos contextualizados. Sondagem/diagnóstico em aulas com intérprete de Língua de Sinais para conhecimento da realidade e análise do processo de articulação teoria/prática, nos locais onde realiza as atividades autônomas. Teoria da Interpretação e tradução nas Línguas de Sinais. Mecanismo do uso do espaço na LIBRAS. A ética e o papel do intérprete na sala de aula. Leitura e produção de textos. A legislação e regulamentação da 
profissão Intérprete. As estratégias do uso das expressões faciais e corporais na interpretação. Técnicas de interpretação LIBRAS X Português. Vícios de linguagem e variações linguísticas da interpretação em LIBRAS. As nuances da enunciação em Língua de Sinais - LIBRAS.

\section{PROFESSOR CLASSE “C” - LÍNGUA ESPANHOLA}

Origen, influencias y expansión del español; Interpretación de textos; Gramática contextualizada; El alfabeto; El acento; La división silábica; Saludos y formas de tratamiento; El artículo y las contracciones; El sustantivo (género y número); Sinónimos y antônimos; Heterosemánticos y heterogenéricos; El adjetivo (calificativos y detarminativos); El pronombre (personales y determinantes); Los numerales (ordinales y cardinales); Las preposiciones; Las conjunciones; Los advérbios; El verbo (tiempos y modos); Tipos de frase (afirmativa, negativa, interrogativa, exclamativa); Discurso directo y indirecto; Concordancia nominal y verbal. El español de la América Latina. La regla de eufonía. La literatura española; La literatura Medieval del Cantar de Mio Cid; La literatura renascentista; El Barroco; El Romantismo; El realis y naturalismo; La literatura de la renovación; novela,teatro y lírica.

\section{PROFESSOR CLASSE "C" - LÍNGUA INGLESA}

Estratégias de leitura: identificação de palavras cognatas ou transparentes; inferência de significado; referência pronominal; compreensão geral do texto; reconhecimento de informações específicas; capacidade de análise e síntese; falsos cognatos. Estratégias discursivas: tipo de texto; marcadores de discurso; coerência e elementos de coesão. Aspectos gramaticais: tempos e modos verbais; modais; substantivos, adjetivos, artigos e advérbios; graus comparativo e superlativo; preposições; concordância nominal e verbal; formação de palavras, prefixos e sufixos; conjunções; coordenação e subordinação; 'question tags'; 'relative clauses'; 'conditional sentences'; 'hypothetical and unreal tenses'; 'subjuntive'; 'inversion'; 'passive voice'; 'reported speech'; 'phrasal verbs'; 'collocations'; principais expressões idiomáticas. Noções de métodos e abordagens para o ensino de inglês como língua estrangeira (EFL). Resolução no 07, de 14/12/2010.

\section{PROFESSOR CLASSE "C" - LÍNGUA PORTUGUESA}

Noções de cultura, arte e literatura. O texto literário e o não literário. Aspectos básicos do texto literário: denotação e conotação; principais recursos expressivos. Gêneros literários: lírico, narrativo/épico, dramático. Principais aspectos da versificação. Elementos estruturais da narrativa. Formas narrativas: crônica, conto e romance. Texto: condições de leitura e produção textual: a enunciação. Coesão e coerência textuais. Intertextualidade. Tipologia textual. Modos de organização do discurso: narrativo, descritivo e dissertativo/argumentativo. Semântica: sinonímia, antonímia, homonímia, paronímia, polissemia. Sistema fonológico do português. Sistema ortográfico vigente. Morfossintaxe: classes de palavras. Formação de palavras. Morfologia nominal. Morfologia verbal. Morfologia pronominal. Processos sintáticos: subordinação e coordenação. Constituintes da oração e orações no período. Frase e discurso. Valores semântico-sintáticos dos conectivos. Concordância nominal e verbal. Regência nominal e verbal. Colocação dos termos na frase. Emprego do acento da crase. Normas de pontuação. Diretrizes Curriculares Nacionais Gerais para a Educação Básica - Parecer CNE/CEB no 07, de 07 de abril de 2010 e Resolução CNE/CEB ํㅜ 4, de 13 de julho de 2010. Resolução no 07, de 14/12/2010.

\section{PROFESSOR CLASSE “C” - MATEMÁTICA}

Sistemas de numeração. Conjuntos numéricos. Operações: múltiplos, divisores. Frações. Números decimais. Medidas: área, perímetros, comprimento, capacidade, volume. Simetria. Função de primeiro e segundo grau. Porcentagens, possibilidades e estatísticas. Gráficos. Ângulos. Proporcionalidade. Equações e inequações de primeiro e segundo graus. Sistema de Equações. Polígonos. Funções e relações. Trigonometria no triângulo. Semelhança. Congruência. Teoremas: Tales e Pitágoras. Círculos. Noções de probabilidade. Geometria: figuras geométricas planas: quadrado, retângulo, triângulo, círculo; sólidos geométricos: cubo, paralelepípedo, prisma, cilindro, pirâmide, cone; esfera: cálculo de perímetros, áreas e volumes. Tópicos de matemática financeira: Juros Simples: Cálculo do montante e do Principal - Equivalência de capitais a juros simples. Juros Compostos: Cálculo do Montante e do Principal - Equivalência de capitais a juros compostos. Taxa de juros: Taxa de juros efetiva e nominal - Cálculo da taxa efetiva a partir da taxa nominal - taxas equivalentes em períodos quaisquer. Fatoração. Polinômios (operações). Lógica. Jogos e desafios da matemática. Diretrizes Curriculares Nacionais Gerais para a Educação Básica - Parecer CNE/CEB no 07, de 07 de abril de 2010 e Resolução CNE/CEB no 4, de 13 de julho de 2010. Resolução no 07, de 14/12/2010. 
Secretaria de Administraçẩo

\section{PROFESSOR CLASSE "C” - ORIENTAÇÃO ESCOLAR}

trajetória da Orientação Educacional no Brasil: perspectiva histórico - social - cultural - pedagógica; papel e função do OE no cotidiano escolar. Orientação Educacional e gestão democrática: contexto escolar e contexto social, as relações intra/extra-escolares. Orientação Educacional e o processo de construção do conhecimento na escola: "saber" e "fazer" pedagógico; a organização do trabalho na escola e ação do OE no currículo. Orientação Educacional e as relações de trabalho: abordagens teóricas e considerações críticas. Orientação Profissional numa proposta renovadora. A Lei 9394/96. Diretrizes Curriculares Nacionais Gerais para a Educação Básica - Parecer CNE/CEB no 07, de 07 de abril de 2010 e Resolução CNE/CEB no 4, de 13 de julho de 2010. Resolução no 07, de 14/12/2010. Técnicas de Dinâmica. Processo de avaliação. Relacionamento Interpessoal.

\section{PROFESSOR CLASSE “C” - QUÍMICA}

Classificação periódica dos elementos químicos. Radioatividade. Natureza das emissões radioativas; leis da radioatividade. Fenômenos de fissão nuclear e fusão nuclear. Ligação química. Teoria eletrônica de valência; ligação iônica; ligação covalente; ligação metálica; tipos de fórmula; polaridade das ligações e das moléculas; números de oxidação. Função inorgânica. Conceito; classificação; notação; nomenclatura; conceitos de Arrhenius, Bronsted e Lowry e de Lewis para ácidos e bases. Reação química. Reação química; equação química; tipos de reação química; balanceamento de equação química. Cálculos químicos. Unidade de massa atômica; massas atômica e molecular; Número de vogadro; Mol; massa molar volume molar; cálculos estequiométricos. Soluções. Conceito; classificação; equivalente-grama; tipos de concentração; diluição; volumetria de neutralização. Termoquímica. Energia e calor; entalpia; reações exotérmica e endotérmica; calor de reação em pressão constante e em volume constante; Entalpias de formação das substâncias, de combustão; Lei de Hess. Cinética química. Velocidade de uma reação química; fatores que a influenciam; energia de ativação com ou sem influência de catalisador; lei da ação das massas. Química do carbono. Propriedades fundamentais do átomo de carbono; hibridação; estados de oxidação de carbono; ligação sigma e pi; geometria molecular; classificação do átomo de carbono na cadeia carbônica; notação e nomenclatura dos principais radicais orgânicos. Função orgânica. Conceito; grupamento funcional; fórmulas geral e estrutural; notação e nomenclatura IUPAC das funções orgânicas. Polaridade das moléculas e força intermolecular. Moléculas orgânicas polar e apolar; tipos de força intermolecular; efeitos sobre os pontos de fusão e ebulição nos compostos orgânicos. Acidez e basicidade. Acidez e basicidade de compostos orgânicos. Isomeria. Isomeria plana; isomeria espacial. Intermediário de reação orgânica. Rupturas homolítica e heterolítica; tipo de intermediário. Tipos de mecanismos da reação orgânica. Reação de adição; reação de substituição; reação de eliminação; reação de oxidação; reação de redução; reagentes eletrofílico e radical livre; mecanismo da reação orgânica. Reações de compostos orgânicos. Reação de adição; reação de substituição; reação de eliminação; reação de oxidação. Equilíbrio químico e equilíbrio iônico em soluções aquosas. Reação reversível; equilíbrio químico; constante de equilíbrio; deslocamento de equilíbrio; equilíbrio iônico; ionização da água; ionização dos eletrólitos fracos. Eletroquímica. Potenciais de oxidação e redução; pilhas e acumuladores; eletrólise. Diretrizes Curriculares Nacionais Gerais para a Educação Básica - Parecer CNE/CEB no 07, de 07 de abril de 2010 e Resolução CNE/CEB nํㄴ, de 13 de julho de 2010. Resolução no 07, de 14/12/2010

\section{PROFESSOR CLASSE "C" - SÉRIES INICIAIS}

Abordagem holística dos conteúdos do ensino fundamental, séries iniciais: Alfabetização: concepções de aquisição do conhecimento. Métodos de alfabetização. Letramento e suas implicações para a alfabetização. Alfabetização e enfoque globalizador do conhecimento. Trabalhando com histórias, com livros e revistas, com dramatização, com desenho infantil. (verso, ritmo, canção, sons do corpo, cantigas, parlendas, adivinhas). Imagens. A criança e a aquisição do conceito numérico (numeralização: articulação da linguagem e do cotidiano infantil com a construção de conhecimentos matemáticos). Educação Física, Ciências naturais e alfabetização. Rotina da sala de aula. Brincar e aprender. Jogos, brincadeiras e psicomotricidade. A arte na escola: desenho, teatro, música, pintura. Construção das noções de espaço, tempo e grupo. Língua portuguesa: o processo de aquisição da leitura e da escrita. O texto: apreensão de ideias básicas e acessórias. Interpretação de ideias sugeridas por imagens. Metodologia da linguagem: objetivos do trabalho com a linguagem verbal na escola. Usos, funções e valores sociais da linguagem oral e da escrita. Linguagem: variação linguística; interlocução. O professor, o aluno e o processo de elaboração de textos escritos. Objetivos e expectativas de leitura. Estratégias de processamento de textos. Matemática: a construção dos conceitos matemáticos. Sistema de numeração em diferentes bases. Resolução de problemas. Porcentagem. Operações com números reais. Noções de geometria plana e espacial. Unidades de medidas. Matemática lúdica. Metodologia do ensino de matemática. Ciências: água, ar e solo, características 
físicas, químicas e biológicas e suas relações nos ecossistemas. Sol fontes de energia e processos energéticos vitais na natureza (fotossíntese, quimiossíntese, respiração celular e fermentação). Transformações dos materiais na natureza. Seres vivos: suas relações e interações ambientais (cadeia e teias alimentares; pirâmides ecológicas; relações ecológicas entre os seres vivos). Ciclos biogeoquímicos (da água, do carbono; do nitrogênio e do oxigênio). Meio ambiente. Impactos ambientais manejo e conservação. Lixo. Poluição. Corpo humano: sistemas digestório, respiratório, cardiovascular, excretor, imunológico, endócrino e reprodutor. Vitaminas, sais minerais, proteínas, carboidratos e lipídios. Doenças parasitárias humanas: viroses; bacterioses; protozooses; verminoses. Características gerais e representantes dos vertebrados: peixes cartilaginosos, peixes ósseos, anfíbios, répteis, aves e mamíferos. Características gerais e representantes dos grupos vegetais: briófitas, pteridófitas, gimnospermas e angiospermas. Estudos sociais: Economia e política no Brasil colônia, império e períodos republicanos. Economia e política brasileira na atualidade. Diferentes agentes sociais na história do Brasil. Principais problemas socioeconômicos, desigualdades regionais no Brasil de hoje. Processo histórico da regionalização brasileira. Brasil e estado de Rondônia: principais aspectos geográficos e econômicos. Espaço e tempo. Localização, organização, representação. Tempo físico. Linha de tempo. Mapas e globo terrestre. Diretrizes Curriculares Nacionais Gerais para a Educação Básica - Parecer CNE/CEB no 07, de 07 de abril de 2010 e Resolução CNE/CEB oㅡ 4, de 13 de julho de 2010. Resolução no 07, de 14/12/2010.

\section{PROFESSOR CLASSE "C" - SOCIOLOGIA}

Conceito e importância da Sociologia. Pensamento fundante da Sociologia: E. Durkheim; K. Marx e M. Weber. Conceitos e categorias básicas para a compreensão da vida social: sociabilidade e socialização; Processos Sociais. Estratificação e mobilidade social. Temas especiais: Cultura e Ideologia; Identidade e diversidade cultural; Desenvolvimento; Políticas sociais; Identidades sociais e movimentos populares; O processo histórico da construção das desigualdades sociais na sociedade; Pensamento Sociológico Contemporâneo. Cidadania, diversidade cultural e globalização: identidade no mundo globalizado; identidades nacionais e étnicas; fundamentalismo e nação; violência e desigualdade social; cidade e territórios; direitos, cidadania e democracia no Brasil; política e globalização. Diretrizes Curriculares Nacionais Gerais para a Educação Básica - Parecer CNE/CEB ํo 07, de 07 de abril de 2010 e Resolução CNE/CEB № 4, de 13 de julho de 2010. Resolução no 07, de 14/12/2010

\section{PROFESSOR CLASSE "C" - SUPERVISÃO ESCOLAR}

Conceito e características da supervisão escolar. O Supervisor e a construção do Projeto pedagógico. A supervisão escolar e suas funções: técnica, administrativa e social. Objetivos da Supervisão Escolar. Tipos de Supervisão. Métodos e técnicas de supervisão escolar. Supervisor: um líder e um agente de mudanças. O supervisor como parceiro político-pedagógico do professor. A prática da supervisão escolar: interação com a família e a comunidade, encontros de pais e professores, encontro com professores. Etapas da supervisão escolar: planejamento, acompanhamento, controle. Diretrizes Curriculares Nacionais Gerais para a Educação Básica - Parecer CNE/CEB no 07, de 07 de abril de 2010 e Resolução CNE/CEB no 4, de 13 de julho de 2010. Resolução no 07, de 14/12/2010

\section{ANEXO VII - ATRIBUIÇÕES DO CARGO}

\section{Cargo: Professor Classe "C"}

"Art. 14. São atribuições do Professor em função de docência, preparar e ministrar aulas, avaliar e acompanhar o aproveitamento do corpo discente da Educação Infantil, Fundamental e Médio, no respectivo campo de atuação.

Art. 15. São atribuições do Professor em função de Magistério de natureza pedagógica a direção escolar, a administração, a avaliação, o planejamento, a pesquisa, a orientação, a supervisão, a inspeção, a assistência técnica, o assessoramento em assuntos educacionais, chefia, coordenação, acompanhamento e controle de resultados educacionais e outras similares na área de educação, compreendendo as seguintes especificações:

I - no âmbito escolar:

a) administrar, planejar, organizar, coordenar, controlar e avaliar atividades educacionais junto ao corpo técnico pedagógico, docente e discente, fora da sala de aula, desenvolvidas na unidade escolar;

b) planejar, orientar, acompanhar e avaliar atividades pedagógicas nas unidades escolares, promovendo a 
integração entre as atividades, áreas de estudos e/ou disciplinas que compõem o currículo, bem como o contínuo aperfeiçoamento do processo de ensino/aprendizagem, propondo treinamento e aperfeiçoamento do pessoal, aprimoramento dos recursos de ensino/aprendizagem e melhoria dos currículos; e

c) planejar, acompanhar e avaliar a participação do aluno no processo ensino/aprendizagem envolvendo a comunidade escolar e a família nesse acompanhamento;

II - no âmbito das Coordenadorias Regionais de Educação:

a) inspecionar, supervisionar, orientar, acompanhar e avaliar as atividades das unidades escolares da Educação Infantil, Fundamental e Médio da rede pública estadual, seguindo as

normas do Sistema Estadual de Ensino; e

b) diligenciar a execução de planos, programas, projetos e atividades educacionais, bem como acompanhar e controlar sua execução;

III - no âmbito da administração central do sistema:

a) desenvolver estudos, diagnósticos qualitativos e quantitativos sobre a realidade do Sistema Estadual de Ensino e elaborar programa, planos e projetos de intervenção;

b) propor alternativas à tomada de decisão em relação às necessidades e prioridades da educação;

c) elaborar, avaliar e propor medidas e instrumento de acompanhamento e controle da execução de planos, programas, projetos e atividades educacionais;

d) prestar assistência técnica em assuntos pedagógicos;

e) desempenhar assessoria em assuntos educacionais e outras atividades educacionais que the forem delegadas;

f) responder pela gestão da educação, incluindo o planejamento, acompanhamento, controle e avaliação das ações dos diversos setores que integram a Secretaria de Estado da Educação."

\section{ANEXO VIII \\ DECLARAÇÃO DE VERACIDADE}

$\mathrm{Eu}$, declaro que todas as informações constantes nos documentos entregues para fins de pontuação na etapa de títulos do Concurso Público para provimento de vagas do cargo de Professor Classe "C", (áreas específicas), pertencentes ao Quadro de Pessoal Efetivo da Secretaria de Estado da Educação de Rondônia, são completas, verdadeiras e corretas em todos os detalhes.

Local e data.

Assinatura 